\title{
Catalogue of the Funerary Inscriptions
}

1

Introduction

All the gravestones from a particular cemetery are grouped together. The cemeteries are presented alphabetically. The cemetery abbreviations are listed in Table 1.1 and repeated at the start of each cemetery sequence where their location is also described. Within each cemetery grouping all gravestones are given a sequential reference number comprising the abbreviation of the cemetery name and their unique number, for example ABN1 (Abu Anbra 1), ABN2, ABN3. Every individual gravestone catalogue entry also provides information on: 1 . The co-ordinates of the gravestone (measured with a handheld GPS unit). 2. The maximum dimensions of the gravestone (length, width, and height). 3. The gravestone orientation. 4. A description of the gravestone discussing, where relevant, form, condition, decoration, number of inscribed surfaces, and whether it was excavated. 5 . If the gravestone was inscribed, an Arabic transcription and translation.

The gravestone surfaces were given the codes A to E for the purpose of recording and analysis (Figure 2.1). If a gravestone was oriented following the contemporary ideal, as discussed in Chapter 1, A would be oriented to the West, B to the East, C to the South, D to the North, and E forms the upper surface. All inscribed gravestone surfaces were photographed, but in some instances, particular gravestone surfaces were difficult to photograph adequately for publication because their position in tightly packed cemeteries or shrines meant they could not be easily accessed with a camera. The inscribed surfaces of some gravestones were also fragile which meant it was not possible to scrub them to remove all traces of earth that might be adhering to them. For transcription and translation these difficulties were surmounted by the translators in Bahrain revisiting the gravestones to check their work as necessary. The English translation of The Quran used is by Al-Hilâlî and Khân (1419/1998, Madinah: King Fahd Complex for the Printing of the Holy Quran). The material from the Quran is cited numerically with the Surah followed by the Ayah.

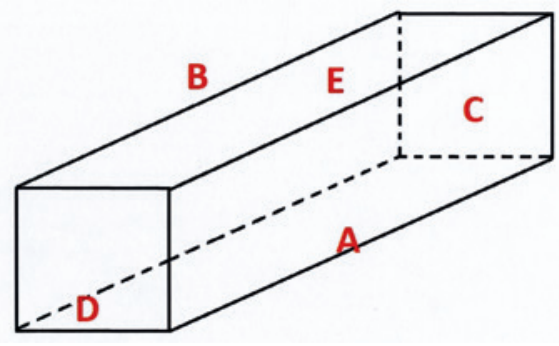

FIGURE 2.1

The lettering system used to record the gravestone surfaces

(C) KONINKLIJKE BRILL NV, LEIDEN, 2019 | DOI:10.1163/9789004383661_003 
Location: Original context not known, possibly a cemetery in the surrounding area. Now kept on a tiled floor area in the Salamya Mosque in A'ali village.

\section{Reference Number: AAL1}

Co-ordinates: $26.16459^{\circ} \mathrm{N} 050.52542^{\circ} \mathrm{E}$

\section{Dimensions:}

Slab 1. $60 \mathrm{~cm}$ length $(\mathrm{l}) \times 24 \mathrm{~cm}$ width $(\mathrm{w}) \times 40.5 \mathrm{~cm}$ height $(\mathrm{h})$

Slab 2. $94 \mathrm{~cm}(\mathrm{l}) \times 28 \mathrm{~cm}(\mathrm{w}) \times 47 \mathrm{~cm}(\mathrm{~h})$

Orientation: Not applicable (NA)

Description: Gravestone formed of two limestone slabs. The inscriptions found on four surfaces are very eroded. Partial remains of a shallow carved pointed niche design on the top surface (E) with additional tracery framing above. The end is broken on one slab and it has some concrete adhering to the top. Eroded unidentifiable raised decoration at the other end. The original orientation is unknown.

\section{Arabic Transcription and Translation:}

A:

- In the Name of Allah, the Most Gracious, the Most Merciful... (35:33)

- Eden Paradise, which they shall enter... (13:23)
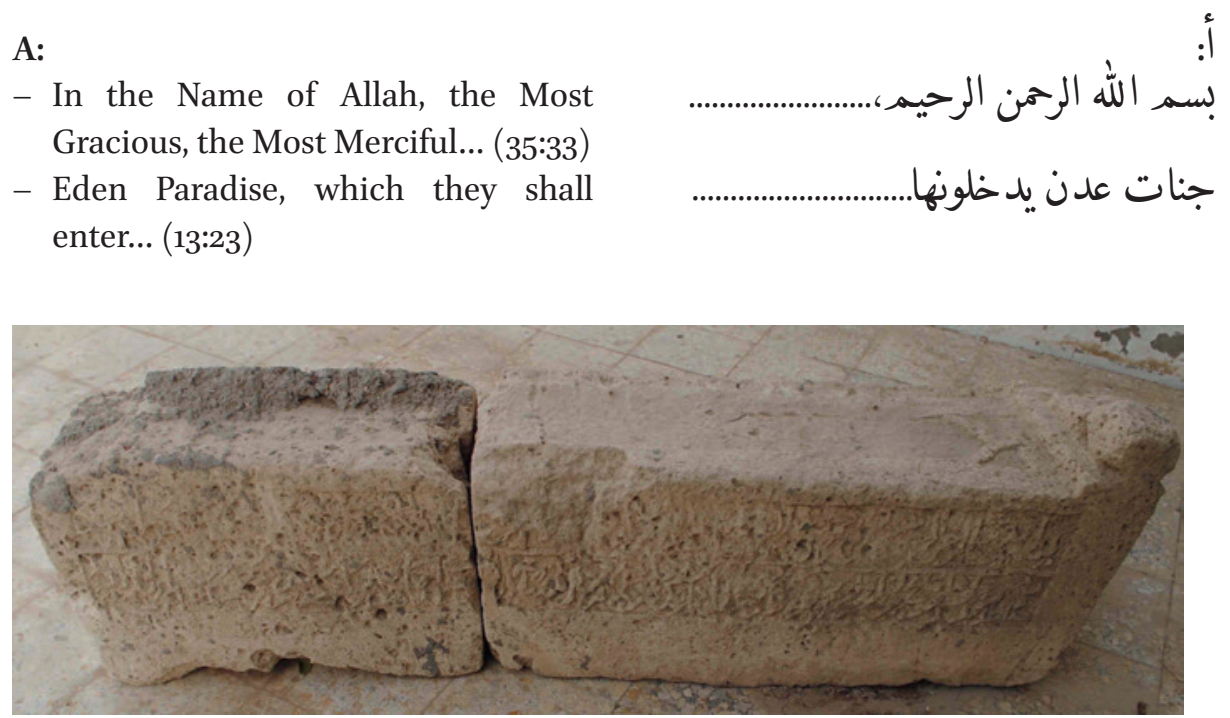

FIGURE 2.2 Surface A, AAL1 
B:

- No carving or inscriptions. لا توي نقش ولا زخارف

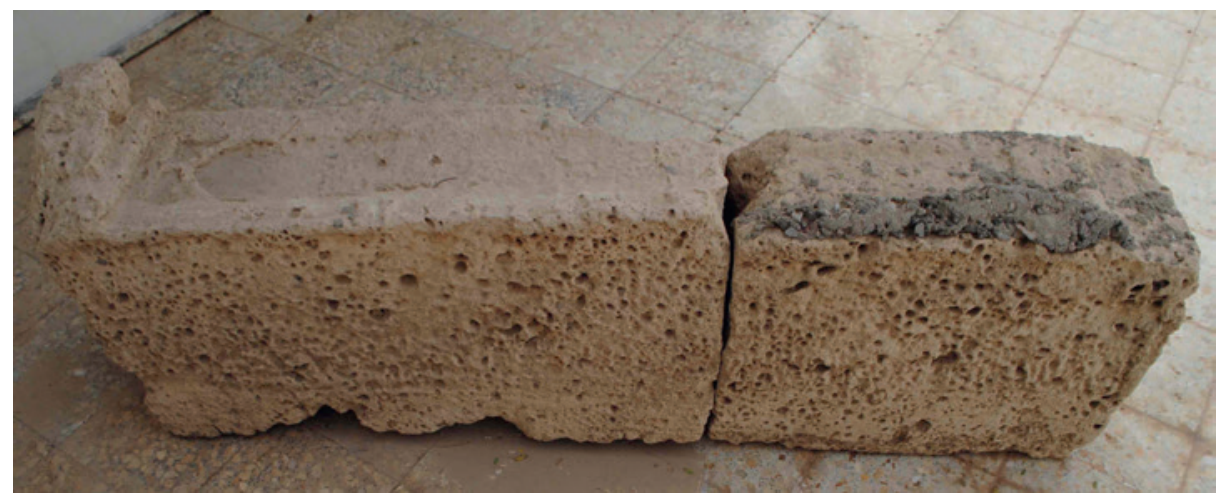

FIGURE 2.3 Surface B, AAL1

C:

- The inscription cannot be read.

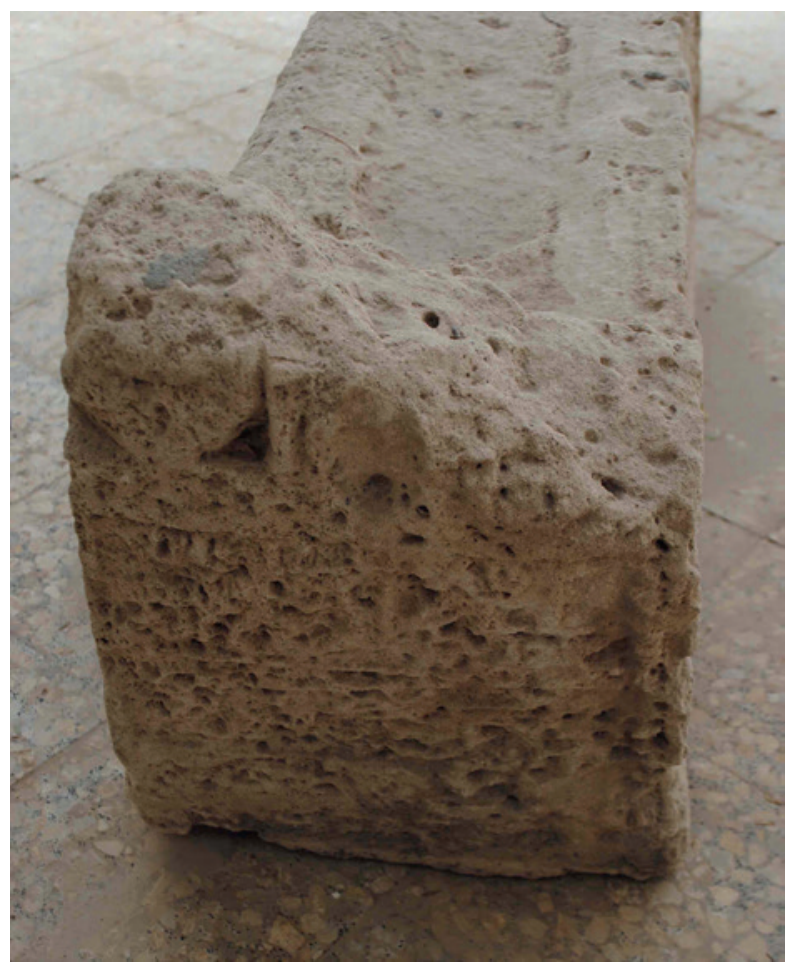

FIGURE 2.4

Surface C, AAL1 
D:

- ...al-Husayni...

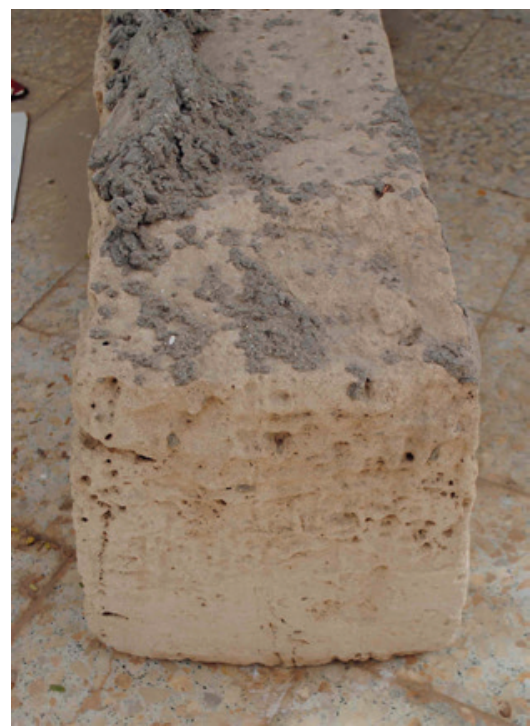

FIGURE 2.5

Surface D, AAL1

E:

- The inscription cannot be read.

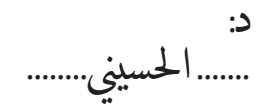

النقش: غير واضح

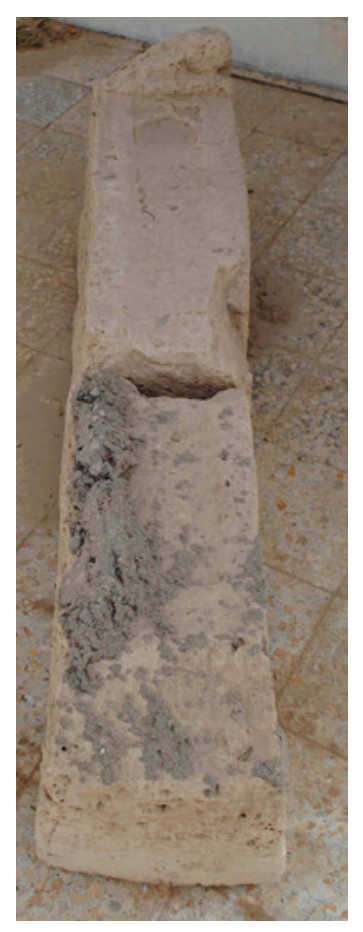

FIGURE 2.6

Surface E, AAL1 
Location: Large unplanned cemetery, it appears that it was originally urban and connected with the former settlement area surrounding the Al-Khamis Mosque, but is now used by the contemporary village community of Bilad al-Qadim. It also contains several Saint's shrines.

\section{Reference Number: ABN1}

Co-ordinates: $26.20939^{\circ} \mathrm{N} 050.55050^{\circ} \mathrm{E}$

Dimensions: $115 \mathrm{~cm}(\mathrm{l}) \times 35.5 \mathrm{~cm}(\mathrm{w}) \times 42 \mathrm{~cm}(\mathrm{~h})$

Orientation: Northwest (NW) to Southeast (SE)

Description: Single limestone slab gravestone in good condition with inscriptions on five surfaces. The raised decoration has been cut off both ends. Shallow rounded pointed niche design on the top surface (E).

\section{Arabic Transcription and Translation:}

A:

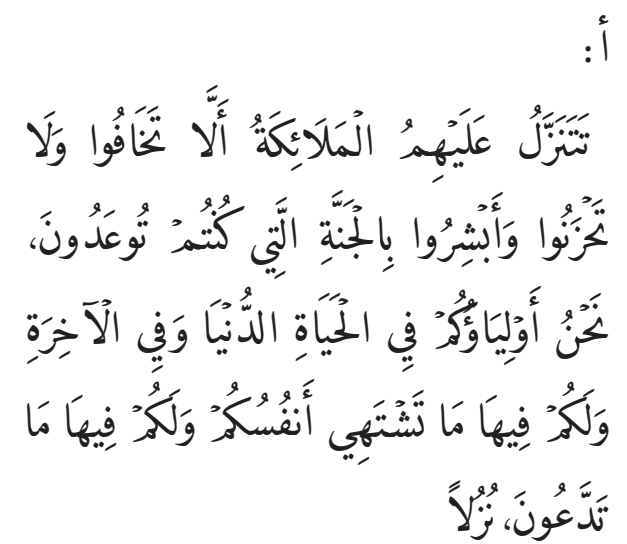

- The angels will descend on them, (saying:) Fear not, nor grieve; But receive the glad tidings of Paradise which you have been promised. We are your friends in the life of this world and in the Hereafter. Therein you shall have all that your souls desire, and all that you ask for, as hospitality (41:30-32)

- From One, the Forgiving, the Most Merciful. Gardens of Eden whose gates will be opened for them. Therein they will recline, therein they will call for fruits in abundance and drinks. And beside them will be maidens of equal age with modest gaze. This is what you are promised on the Day of Reckoning (38:50-53).
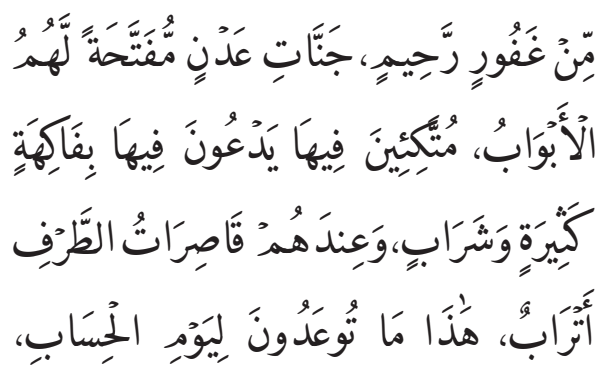

والمالد لله وحله.

Praise be to Allah and to no one else. 


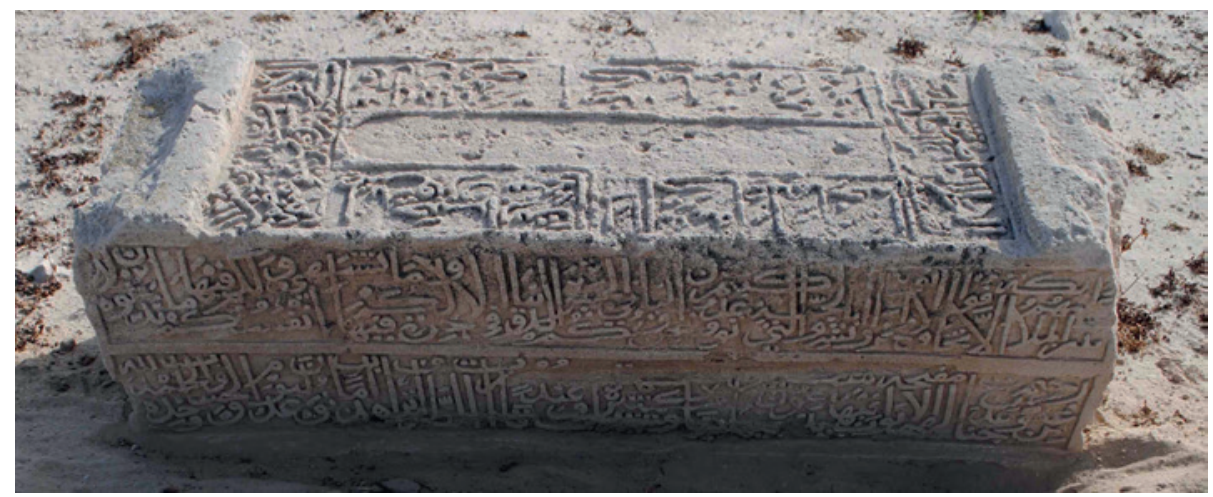

FIGURE 2.7 Surface A, ABN1

B:

- In the Name of Allah, the Most Gracious, the Most Merciful. Allah, there is no other deity but he, the Ever Living, the One Who sustains and protects all that exists. Neither slumber nor sleep overtakes Him. To Him belongs whatever is in the heavens and whatever is on the earth. Who is he that can intercede with Him except by His permission! He knows what happens to them in this world, and what will happen to them in the Hereafter.

- And they will never compass anything of His Knowledge except that which He wills. His Seat extends over the heavens and the earth, and He feels no fatigue in guarding and preserving them. And $\mathrm{He}$ is the Most High, the Most Great (2:255). Allah, the High, the Great has spoken the truth. His Generous Prophet has spoken the truth. Ali, prince of believers, has spoken the truth. Praise be to Allah, Lord of the Worlds.
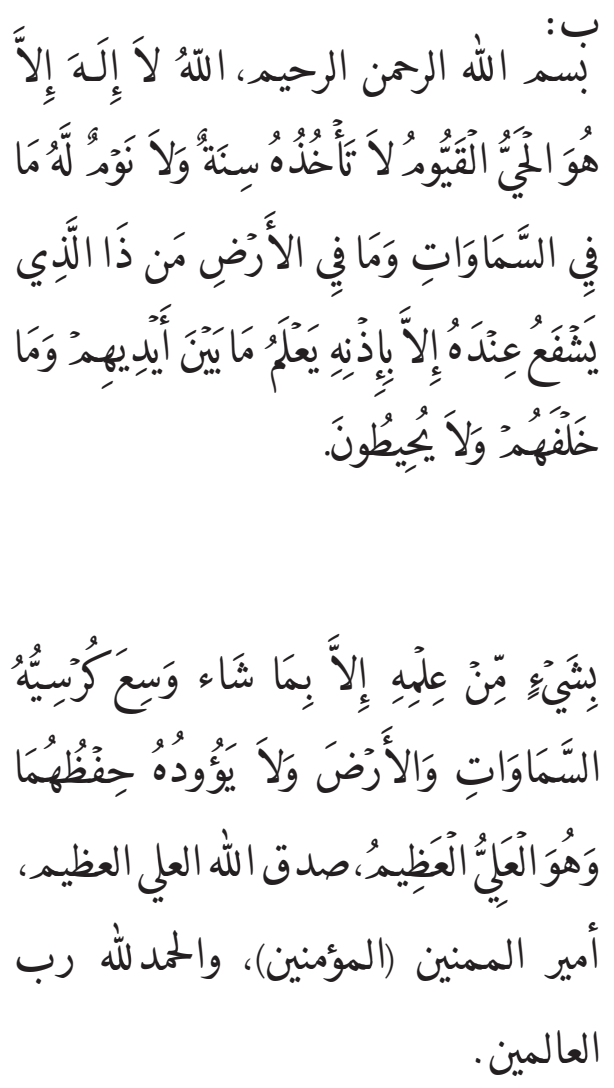


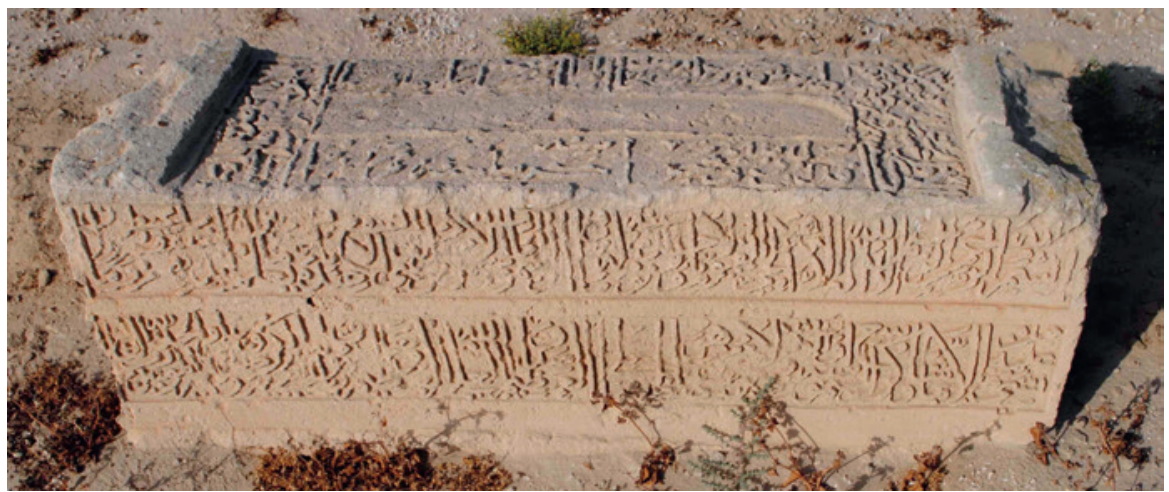

FIGURE 2.8 Surface B, ABN1

C:

- Reading part of the Book of God the راءة جزء من كَب الله العزيز بحاصل Noble One ... Proceeds from ...

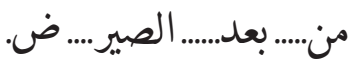

- Six Muhammadi Qirans should be spent on, Sayyid Abdullah Bin Sayyid Naser on Barburah which is located in al-Sahramuw.
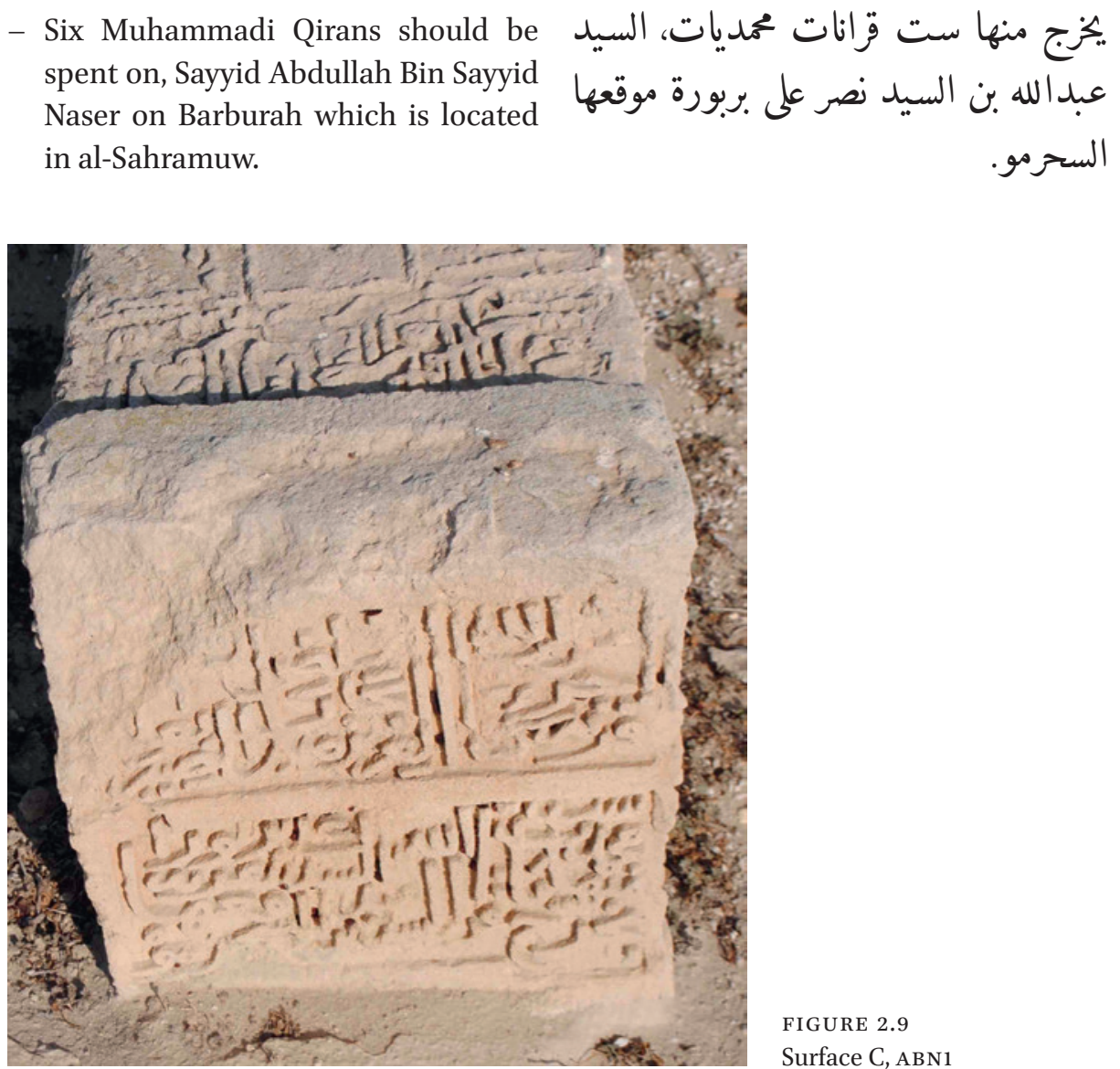

FIGURE 2.9

Surface C, ABN1 
D:

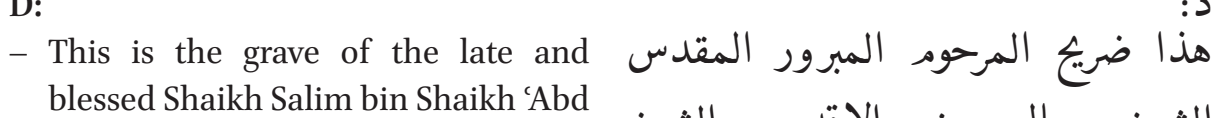
al-Wahhab, who died on fifteenth of Jumada al-Thani, 1103 .

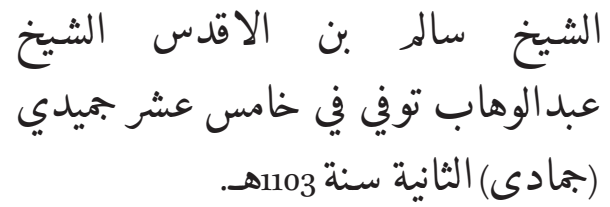

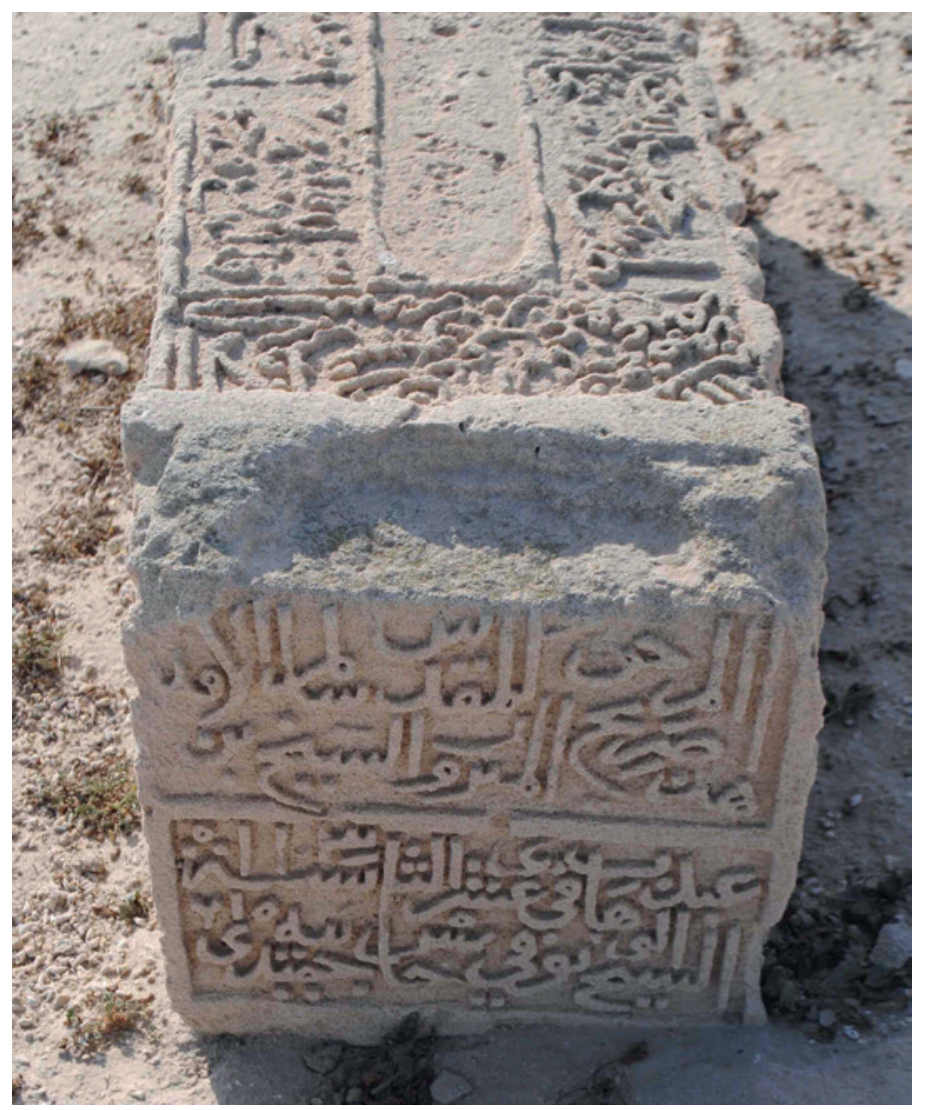

FIGURE 2.10

Surface D, ABN1

E:

- Written by Husayn bin 'Ali bin Zayn al-Din, May Allah forgive them, in Safar 1103.

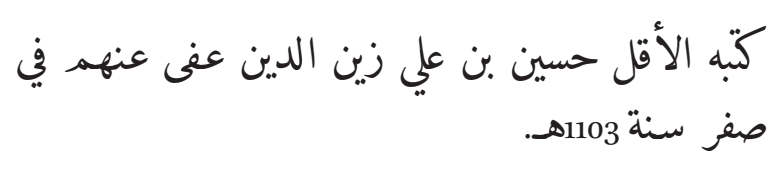

- Oh grave, how good you are طبت يا قبر حيث واريت شيخا سالركاملا عليماخيرا that a knowledgeable, perfect and experienced shaikh was buried in you. 
- My Allah bless his soul and give him paradise and silk as a gen-

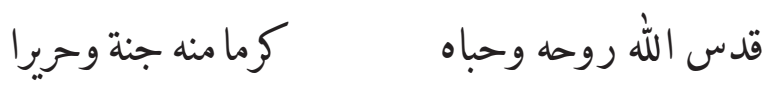
erous gift from Him.

- Engraved by the humble alSayyid Naser bin al-Sayyid Hashim al-Husayni.

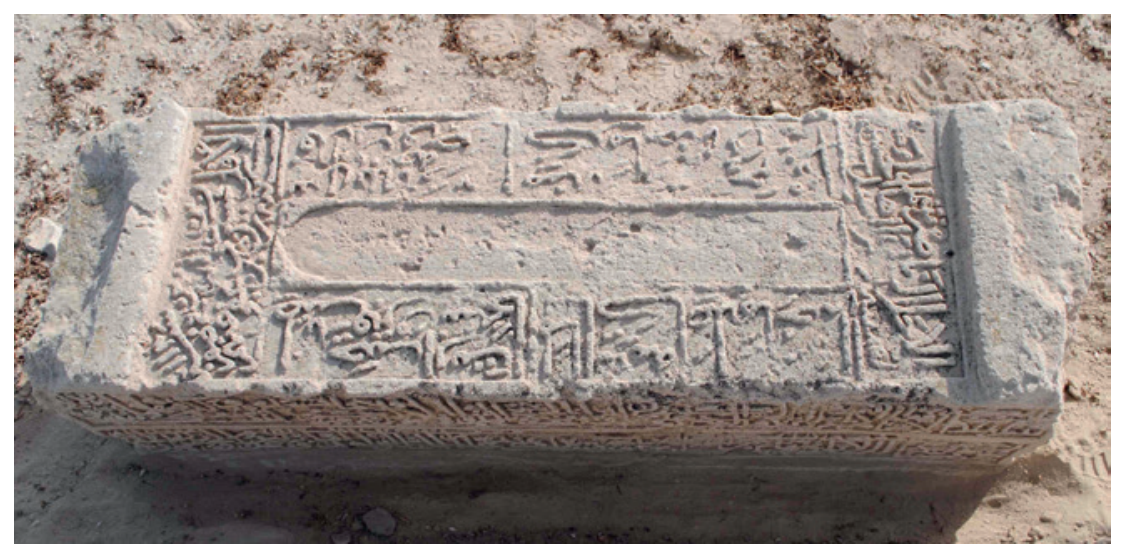

FIGURE 2.11 Surface E, ABN1

\section{Reference Number: ABN2}

Co-ordinates: $26.20974^{\circ} \mathrm{N} 050.55106^{\circ} \mathrm{E}$

\section{Dimensions:}

Slab 1: $80 \mathrm{~cm}(\mathrm{l}) \times 24 \mathrm{~cm}(\mathrm{w}) \times 35 \mathrm{~cm}(\mathrm{~h})$

Slab 2: $22 \mathrm{~cm}(\mathrm{l}) \times 24 \mathrm{~cm}(\mathrm{w}) \times 35 \mathrm{~cm}(\mathrm{~h})$

\section{Orientation: NW-SE}

Description: Single limestone slab gravestone broken into two parts. Hollow interior. Badly eroded. Unidentifiable three element raised decoration at both ends. Partially legible inscriptions on two surfaces.

\section{Arabic Transcription and Translation:}

A:

- With Him except by His permission! He knows what happens to them in this world, and will happen to them in the Hereafter.

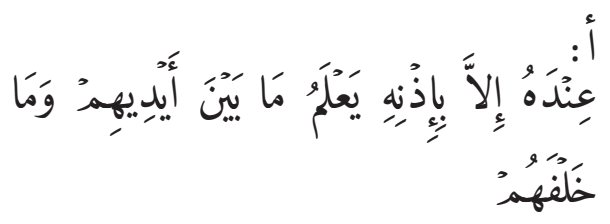


- And they will never compass anything of His Knowledge... (2:255)
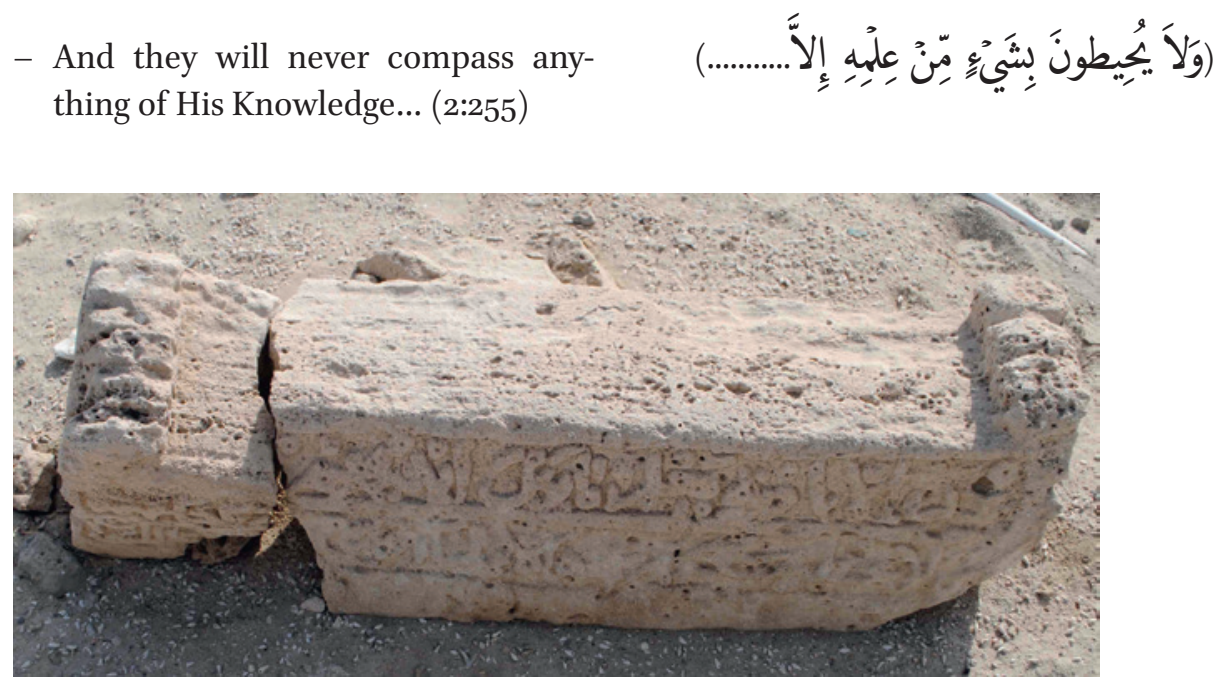

FIGURE 2.12 Surface A, ABN2

B:

- In the Name of Allah, the Most

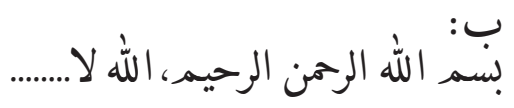
Gracious, the Most Merciful. Allah, none... (2:255)

- ... Who is he that can intercede.

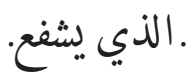

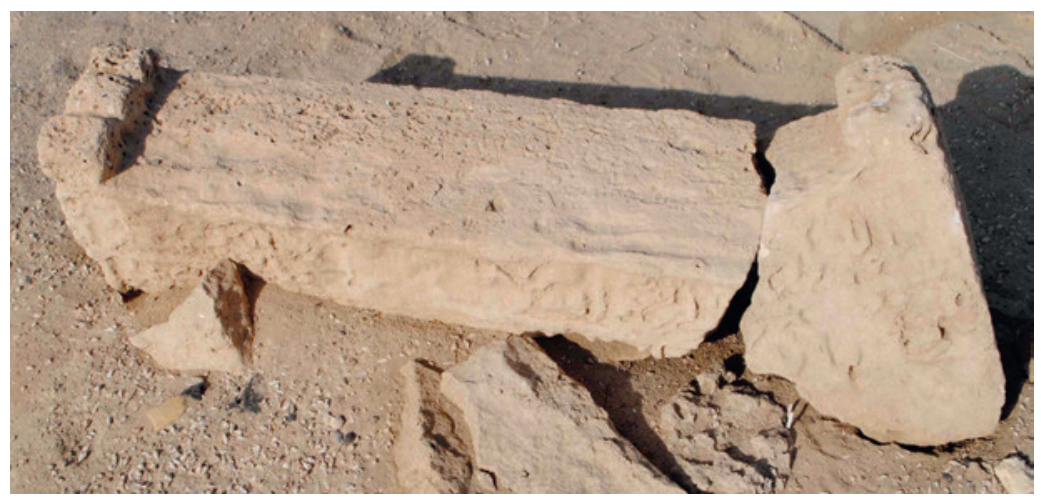

FIGURE 2.13 Surface B, ABN2

C:

- No carving or inscriptions.

لا توجد نقوش أوكّابات

D:

- No carving or inscriptions.

لا توجد نقوش أوكّابات

E:

- No carving or inscriptions.

هـ: لا توجد نقوش أوكّابات 


\section{Reference Number: ABN3}

Co-ordinates: $26.20979^{\circ} \mathrm{N} 050.55109^{\circ} \mathrm{E}$

Dimensions: $140 \mathrm{~cm}(\mathrm{l}) \times 34 \mathrm{~cm}(\mathrm{w}) \times 37 \mathrm{~cm}(\mathrm{~h})$

\section{Orientation: NW-SE}

Description: Single limestone slab gravestone with some patches of erosion and damage. Next to collapsed shrine on top of mound. Raised decoration cut off at both ends. Inscriptions on four surfaces. Shallow carved pointed niche design on top surface $(\mathrm{E})$.

\section{Arabic Transcription and Translation:}

A:

- Verily, those who say: Our Lord is Allah, and then they stand firm, the angels will descend on them, (saying:) Fear not, nor grieve; But receive the glad tidings of Paradise which you have been promised. We have been your friends in the life of this world and in the Hereafter. Therein you shall have all that your souls desire ... which will never finish... (41:30-32)

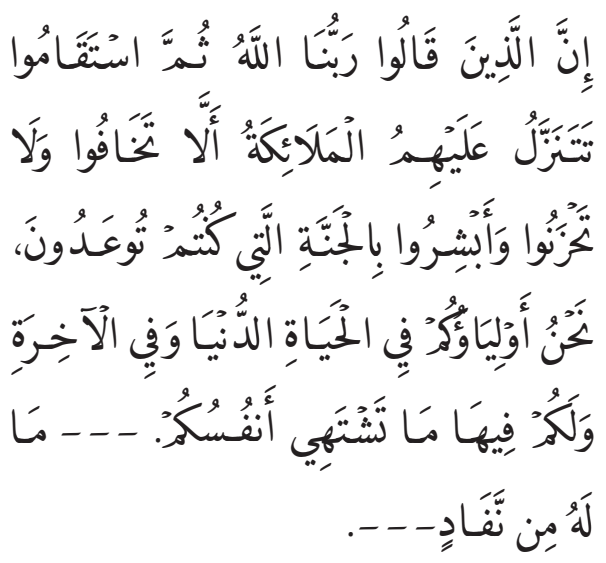

- And all that you ask for, as hospitality from One, the Forgiving, the Most Merciful. Gardens of Eden whose gates will be opened for them. Therein they will recline, therein they will call for fruits in abundance and drinks. And beside them will be maidens of equal age with modest gaze. This is what you are promised on the Day of Reckoning. Verily, this is our Provision... (38:50-54)
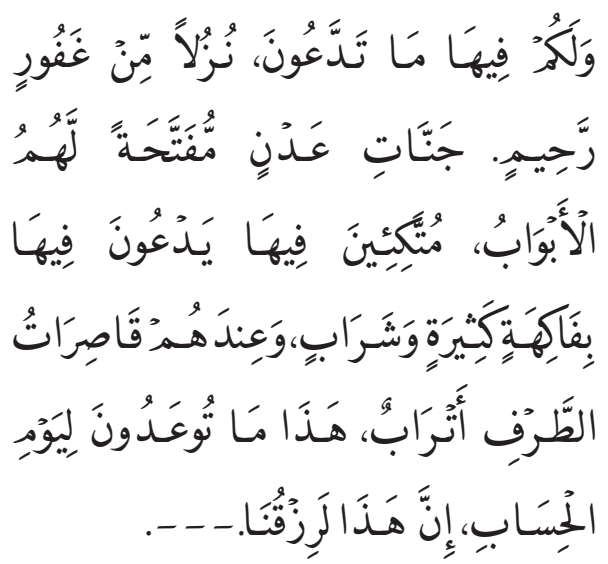


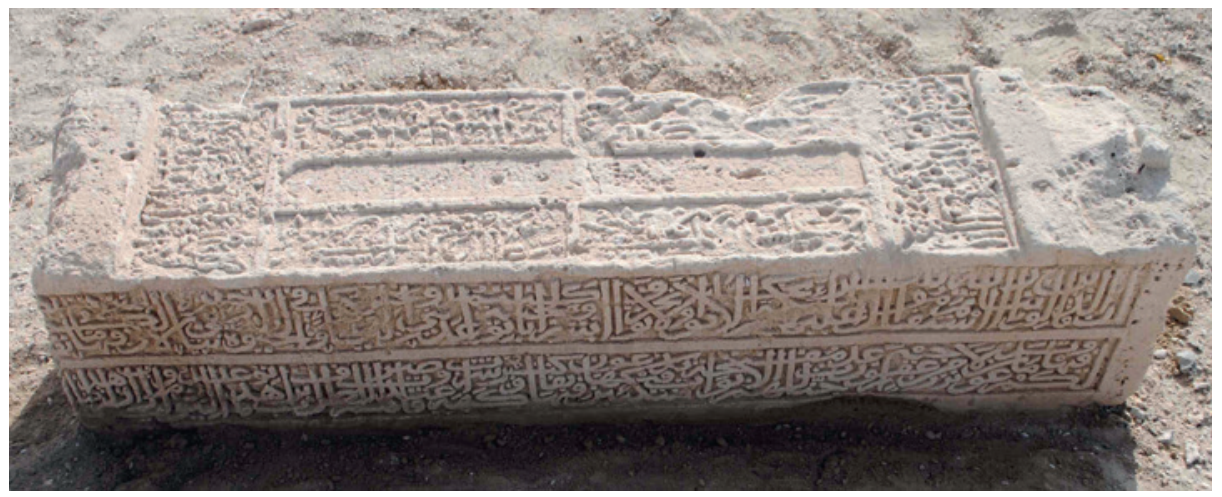

FIGURE 2.14 Surface A, ABN3

B:

- In the Name of Allah, the Most Gracious, the Most Merciful. Allah, none has the right to be worshipped but he, the Ever Living, the One Who sustains and protects all that exists. Neither slumber nor sleep overtakes Him. To Him belongs whatever is in the heavens and whatever is on the earth. Who is he that can intercede with Him except by His permission! He knows ... And they will never compass anything of His Knowledge except that which He wills. His Seat extends over the heavens and the earth, and He feels no fatigue in

- Guarding and preserving them. And He is the Most High, the Most Great. There is no compulsion in religion. Verily, the Right Path has become distinct from the wrong path. Whoever disbelieves in Allah, then has grasped the most trustworthy handhold that will never break. And Allah is All-Hearer All-Knower. Allah is the Guardian of those who believe. He brings them out from darkness into light $\left(2: 255^{-257)}\right.$.

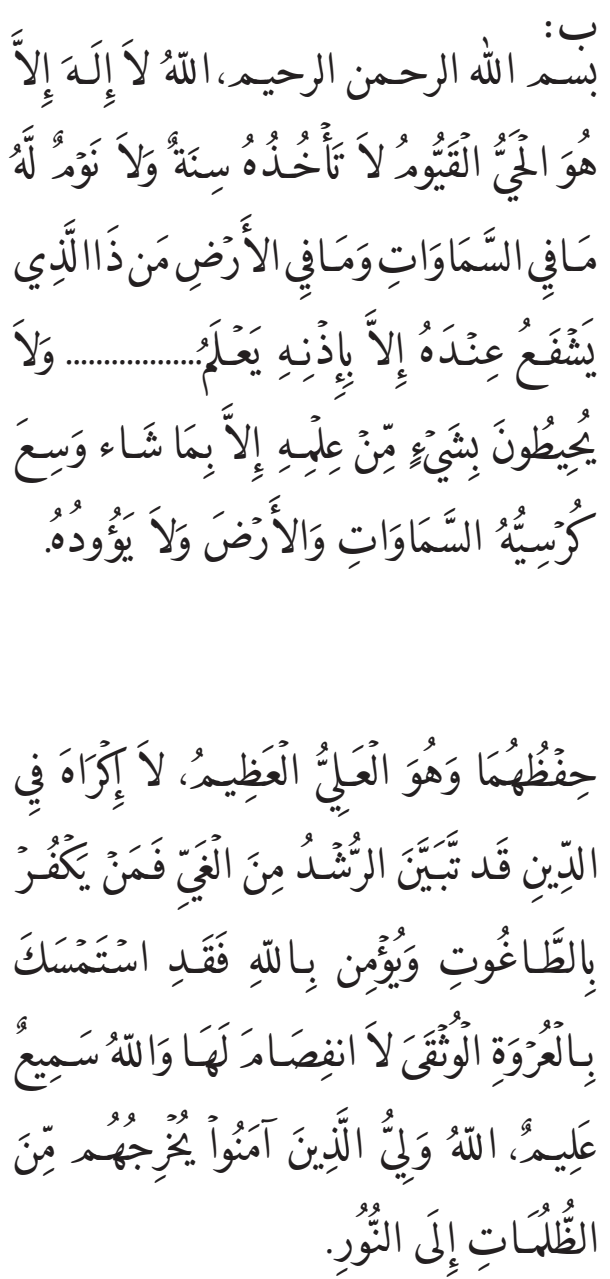




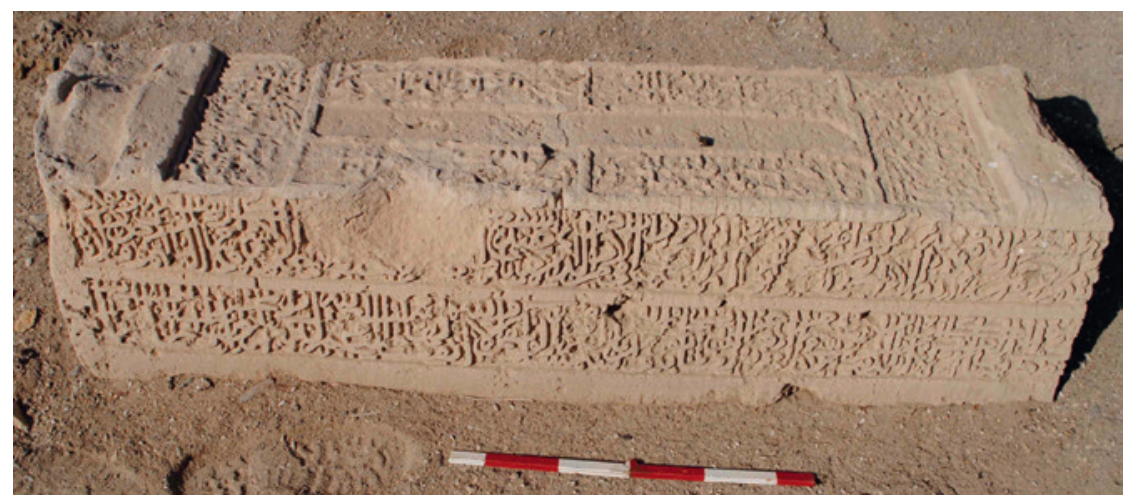

FIGURE 2.15 Surface B, ABN3

C:

- A part of the Book of God the Noble One should be read every day for 15 mann of palm dates.

- From the products of al-Shatba Palm trees ......in Alnaboud .... Located at Sayhat al-Bahrain.
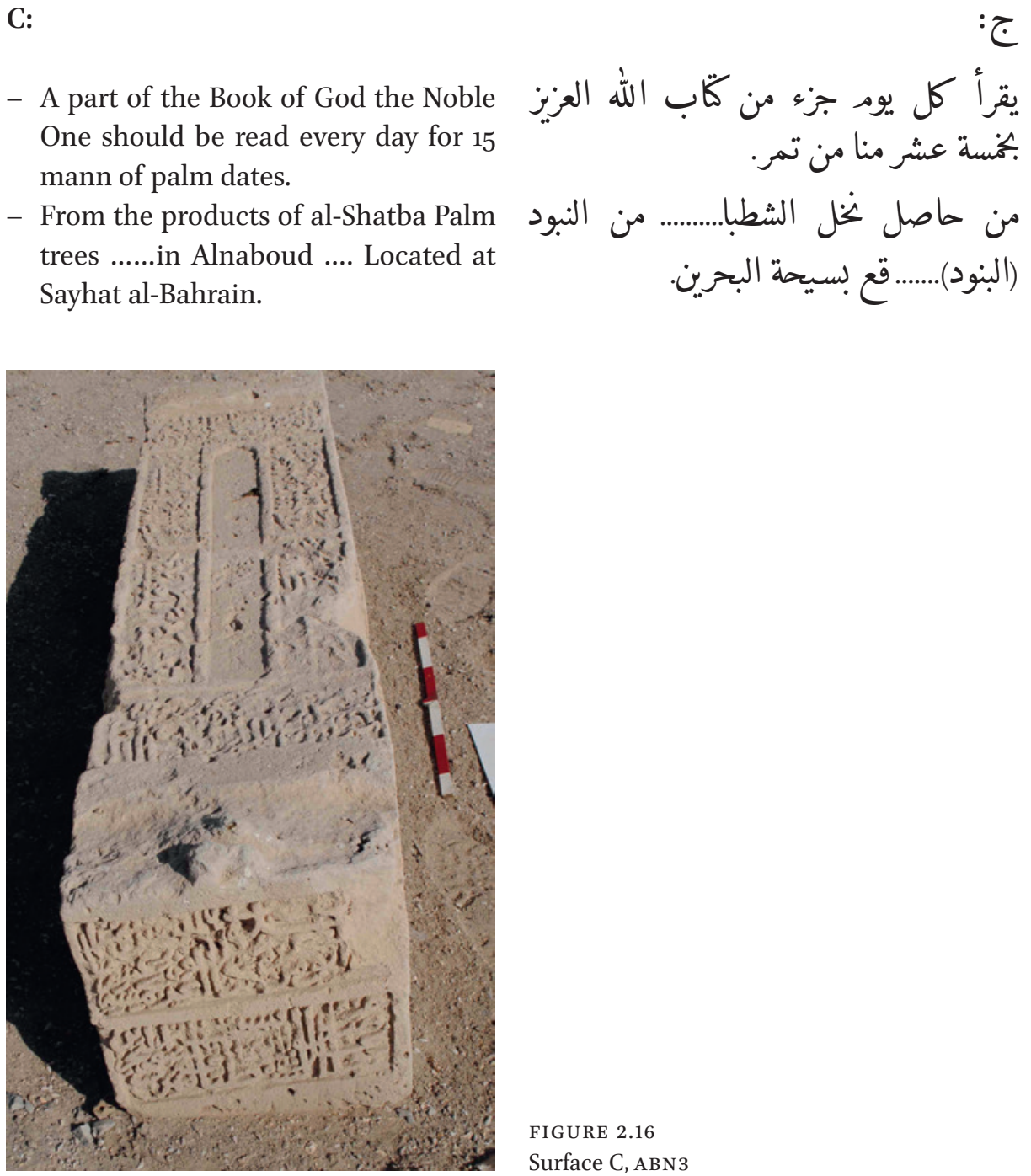

FIGURE 2.16

Surface C, ABN3 
D:

- No carving or inscriptions.
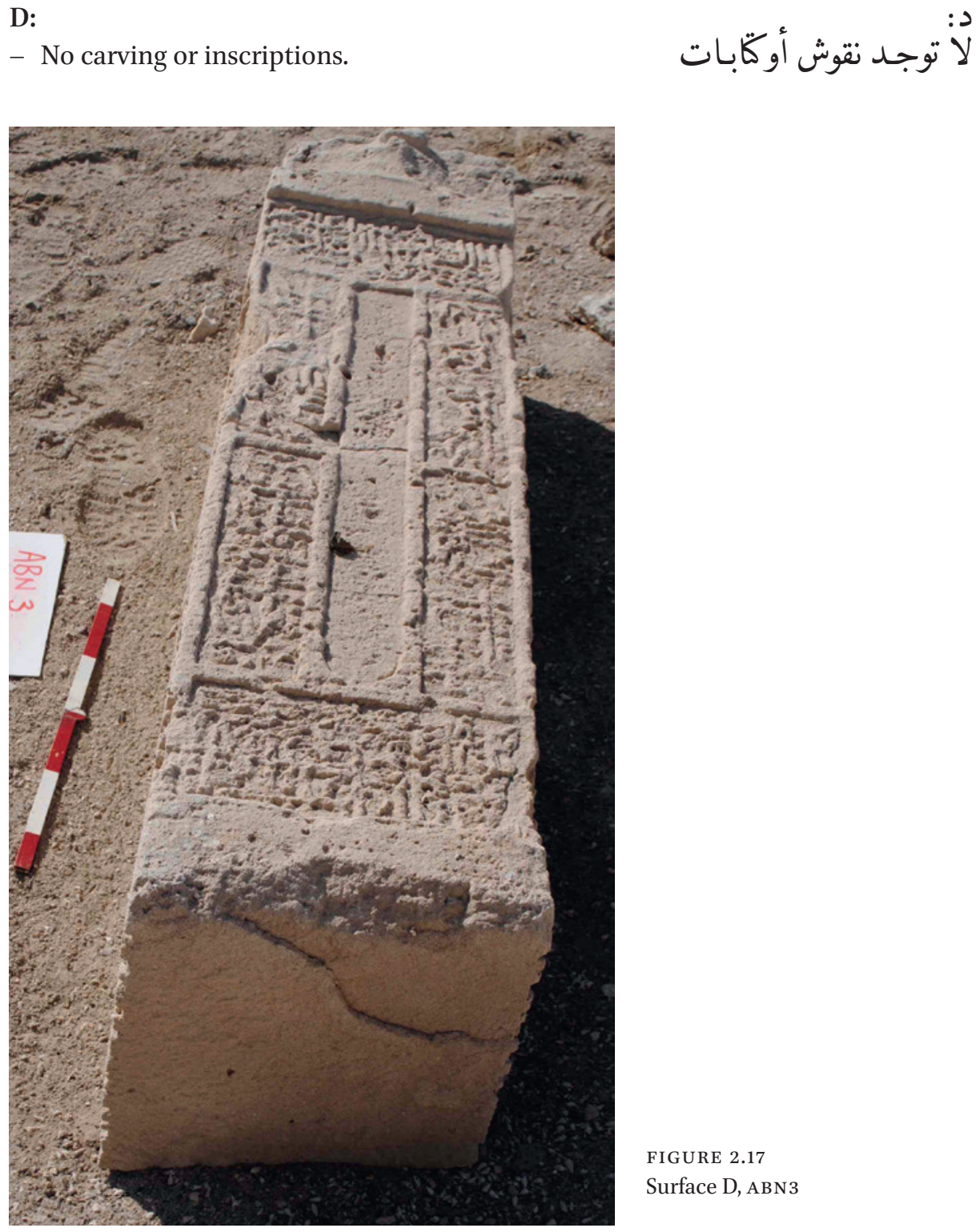

FIGURE 2.17

Surface D, ABN3

E:

- Engraved by...the distinguished ... alSayyid Naser.

- ... gardens ... until buried in the soil ...

- ... He cried for killing of Wahab ... Allah ... The death.

- Written by ...

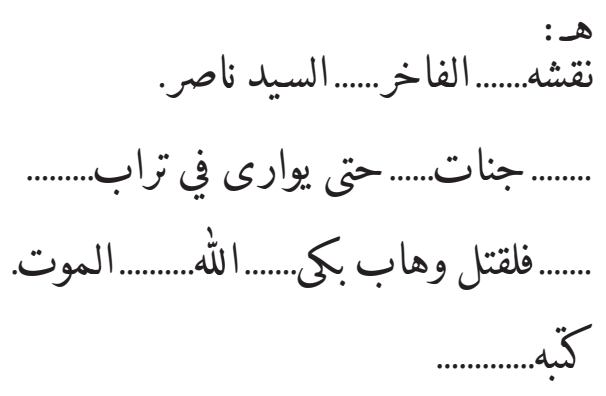




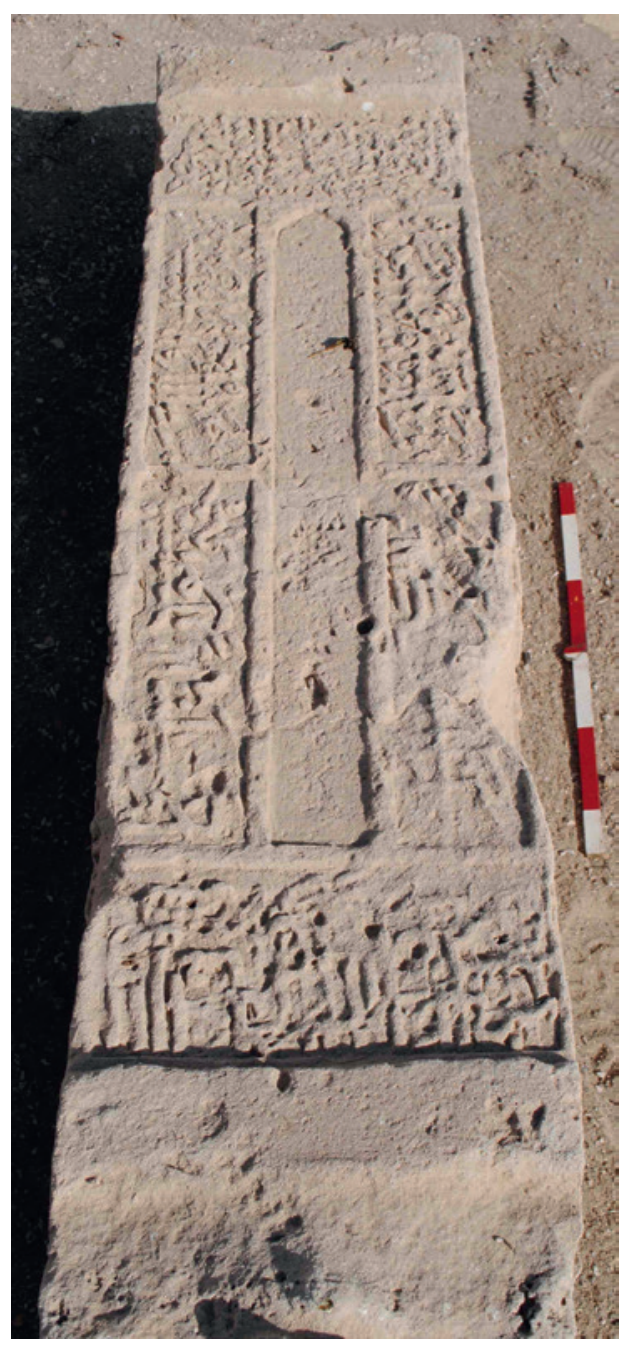

FIGURE 2.18

Surface E, ABN3

\section{Reference Number: ABN4}

Co-ordinates: $26.20484^{\circ} \mathrm{N} 050.55125^{\circ} \mathrm{E}$

Dimensions: $123 \mathrm{~cm}(\mathrm{l}) \times 34 \mathrm{~cm}(\mathrm{w}) \times 34-37 \mathrm{~cm}(\mathrm{~h})$

Orientation: North $(\mathrm{N})$ to South $(\mathrm{S})$

Description: Single limestone slab gravestone in generally good condition but with some damage at the ends on the top surface. Raised decoration cut off at both ends. Next to collapsed shrine, below mound. Shallow carved rectangular rounded niche decoration on top surface. Inscriptions on five surfaces. 
Arabic Transcription and Translation:

A:

- Gardens of Eden whose gates will be opened for them. Therein they will recline, therein they will call for fruits in abundance and drinks. And beside them will be maidens of equal age with modest gaze. This is what you are promised on the Day of Reckoning (38:50-54). Verily, this is our Provision which will never finish. Verily, the dwellers of the Paradise, that Day, will be busy with joyful things. They and their wives will be in pleasant shade, ...on thrones... (36:55-56)

- The angels will descend on them, (saying:) Fear not, nor grieve; But receive the glad tidings of Paradise which you have been promised. We have been your friends in the life of this world and in the Hereafter. Therein you shall have all that your souls desire, and all that you ask for, as hospitality From One, the Forgiving, the Most Merciful (41:3032). My Lord, forgive.

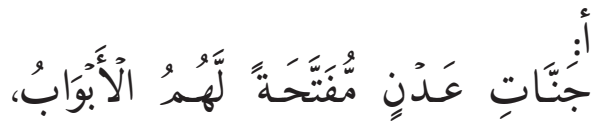
مُ"

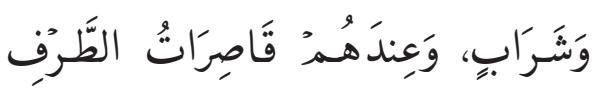

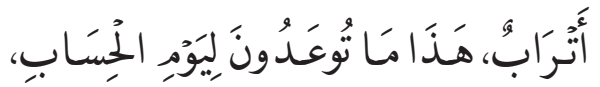

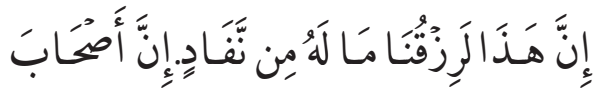

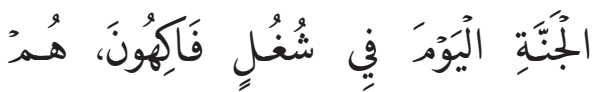

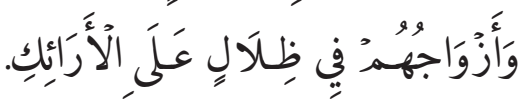

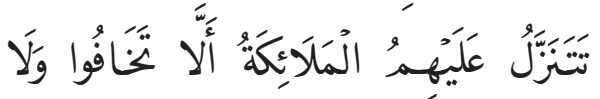

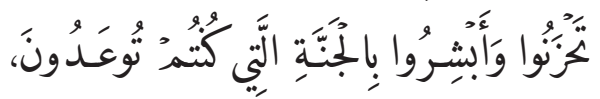

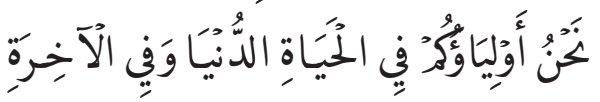

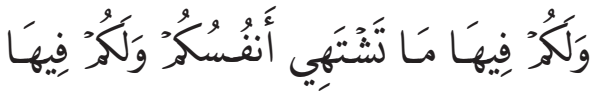

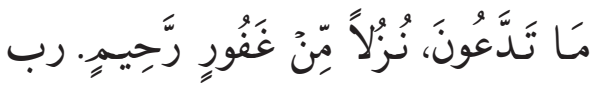

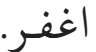

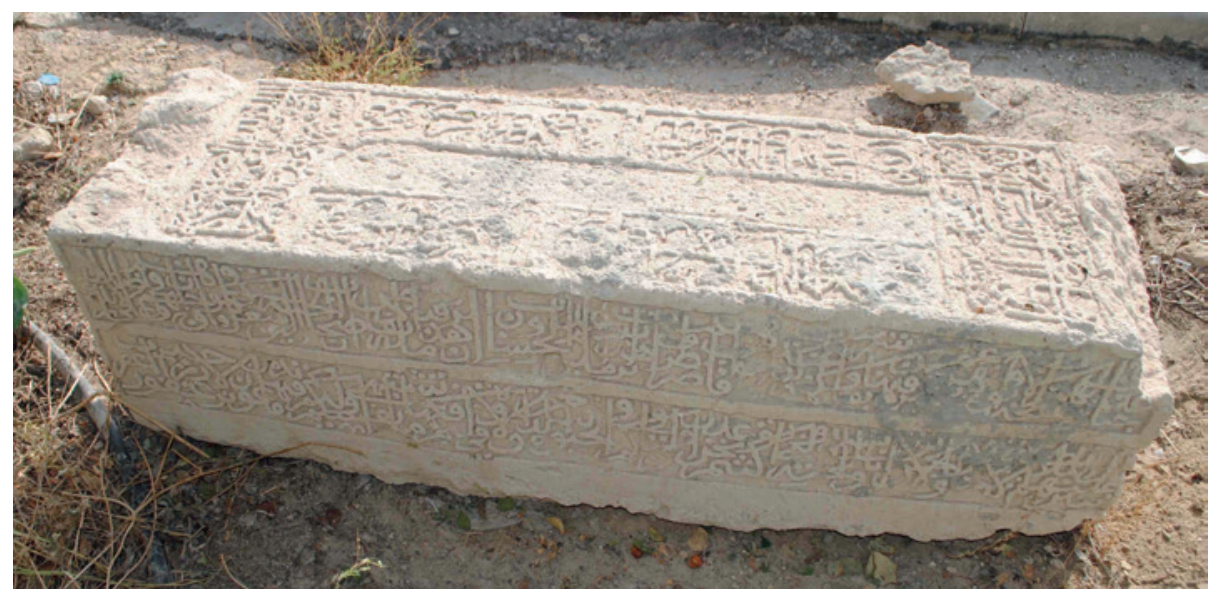

FIGURE 2.19 Surface A, ABN4 
B:

- In the Name of Allah, the Most Gracious, the Most Merciful. Allah, none has the right to be worshipped but he, the Ever Living, the One Who sustains and protects all that exists. Neither slumber nor sleep overtakes Him. To Him belongs whatever is in the heavens and whatever is on the earth. Who is he that can intercede with Him except by His permission!

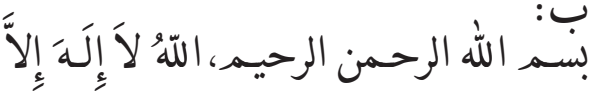

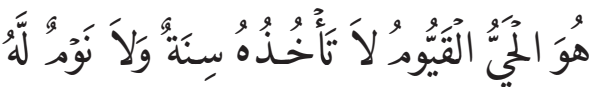

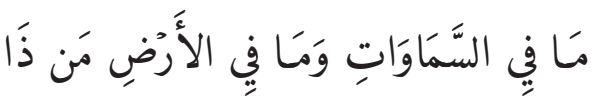

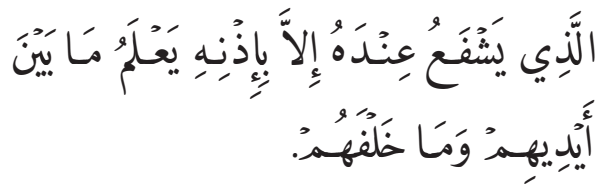
He knows what happens to them in this world, and will happen to them in the Hereafter.

- And they will never compass anything of His Knowledge except that which He wills. His Seat extends over the heavens and the earth, and He feels no fatigue in guarding and preserving them. And He is the Most High, the Most Great. There is no compulsion in religion. Verily, the Right Path has become distinct from the wrong path. Whoever disbelieves in Allah, then has grasped the most trustworthy handhold that will never break. And Allah is All-Hearer AllKnower (2:255-256).
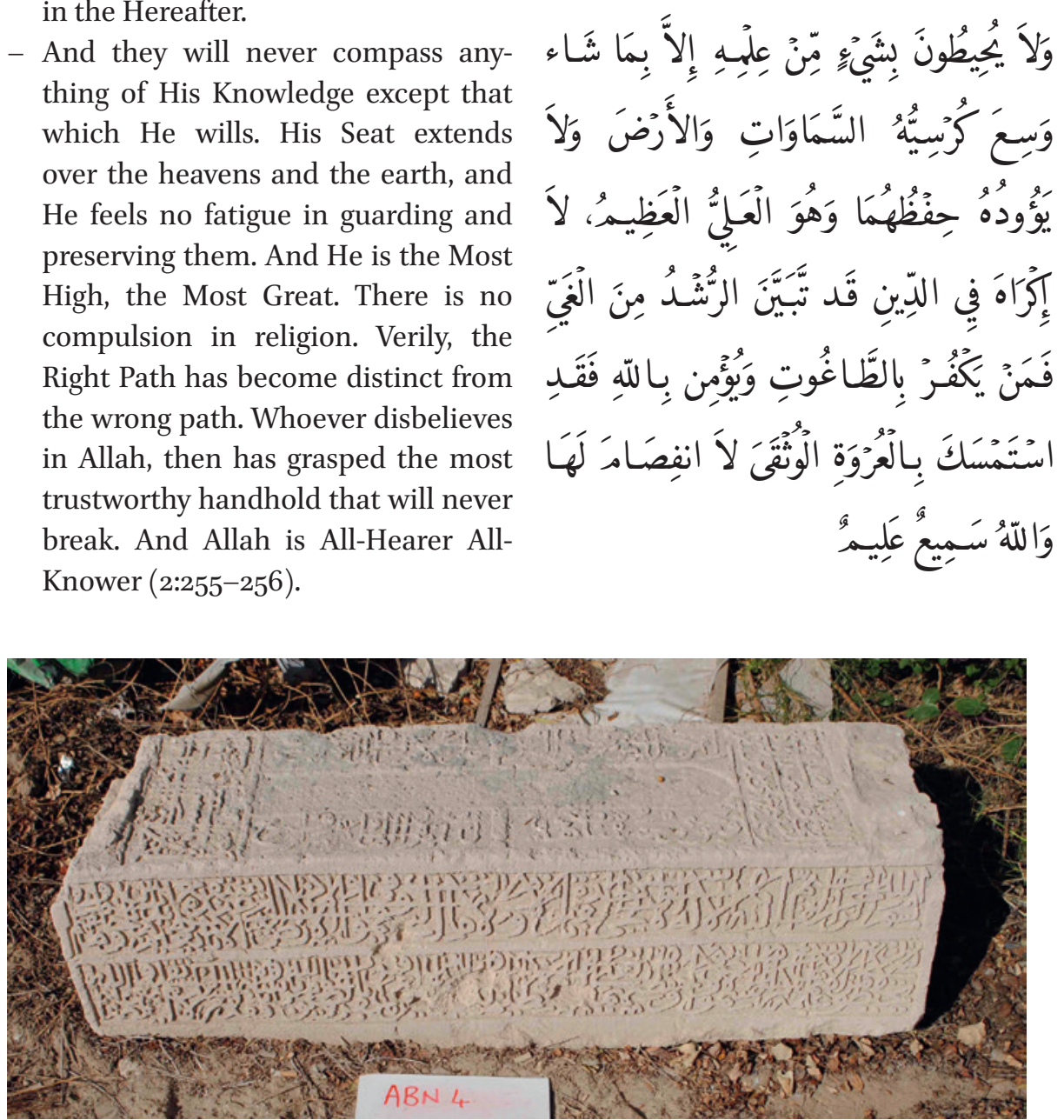

FIGURE $2.20 \quad$ Surface B, ABN4 
C:

- (Reading) ... task ... Day ... From the (قراءة).....وظبفة.... يوم..... من كَّاب الله. Book of God.

ل لكل شهر محدية من حساصل النخل One Muhammadiyyah for every month from the proceed of the palm trees called ... at Mina ...

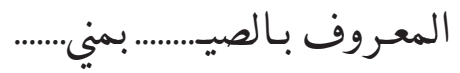

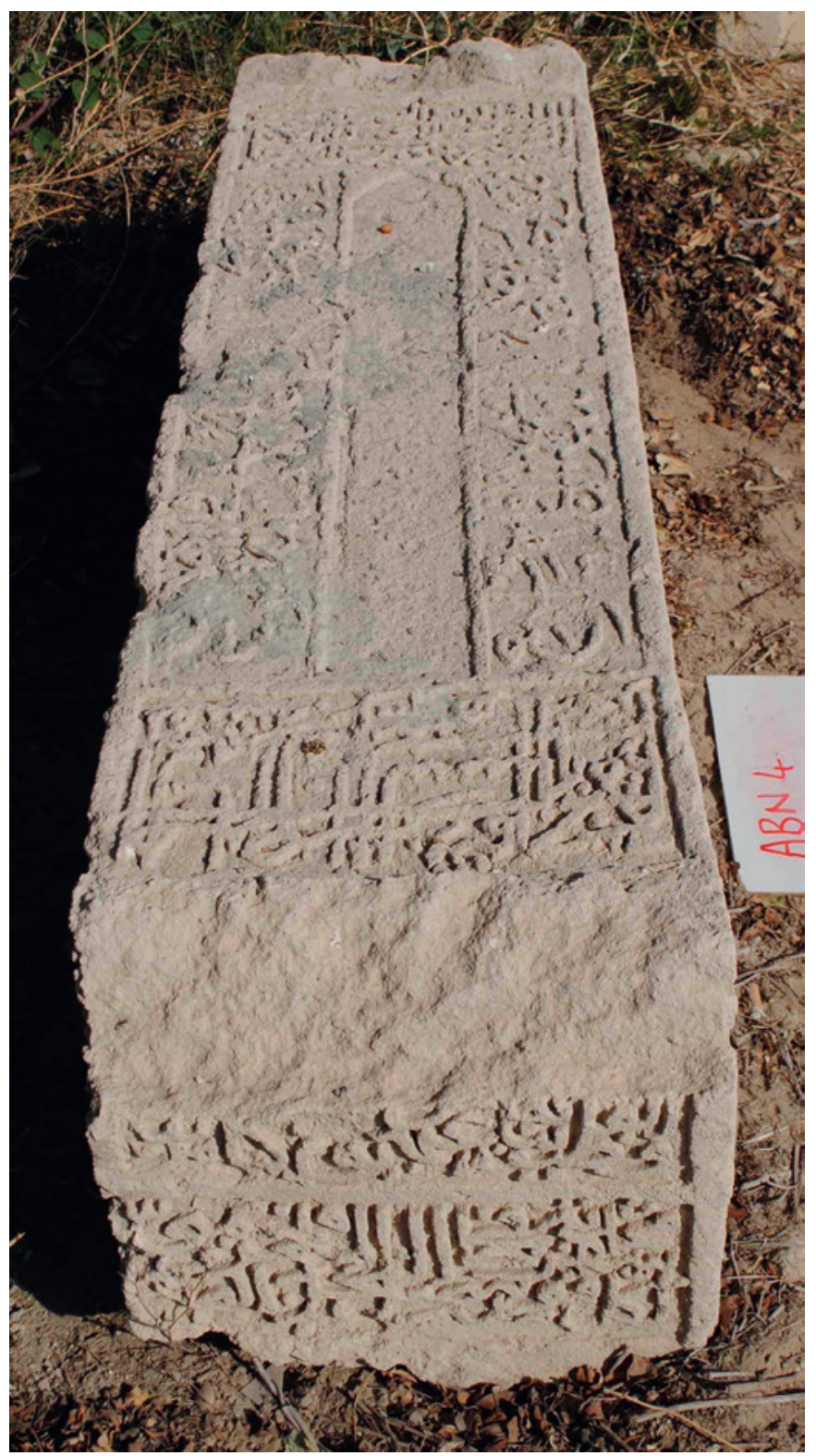


D:

- This is the grave of the chaste Madinah bint Shaikh al-Awah Abdullah bin Ibrahim Al-Mahuzi.

$$
\begin{aligned}
& \text { هذا ضريك المخدرة مدينة بنت الشيخ }
\end{aligned}
$$

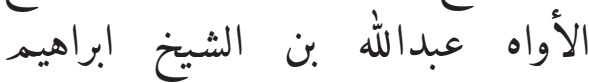

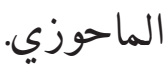

- Her mother is a daughter of al-Sayyid Ja'far, died in nth of Rabic al-Awwal in 1113 .

$$
\begin{aligned}
& \text { المتولدة من بنت السيد جعفر المتوفية }
\end{aligned}
$$

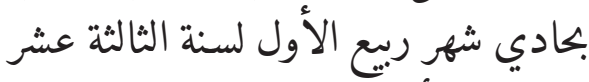

$$
\begin{aligned}
& \text { والمائة و الألف. سكائ. }
\end{aligned}
$$

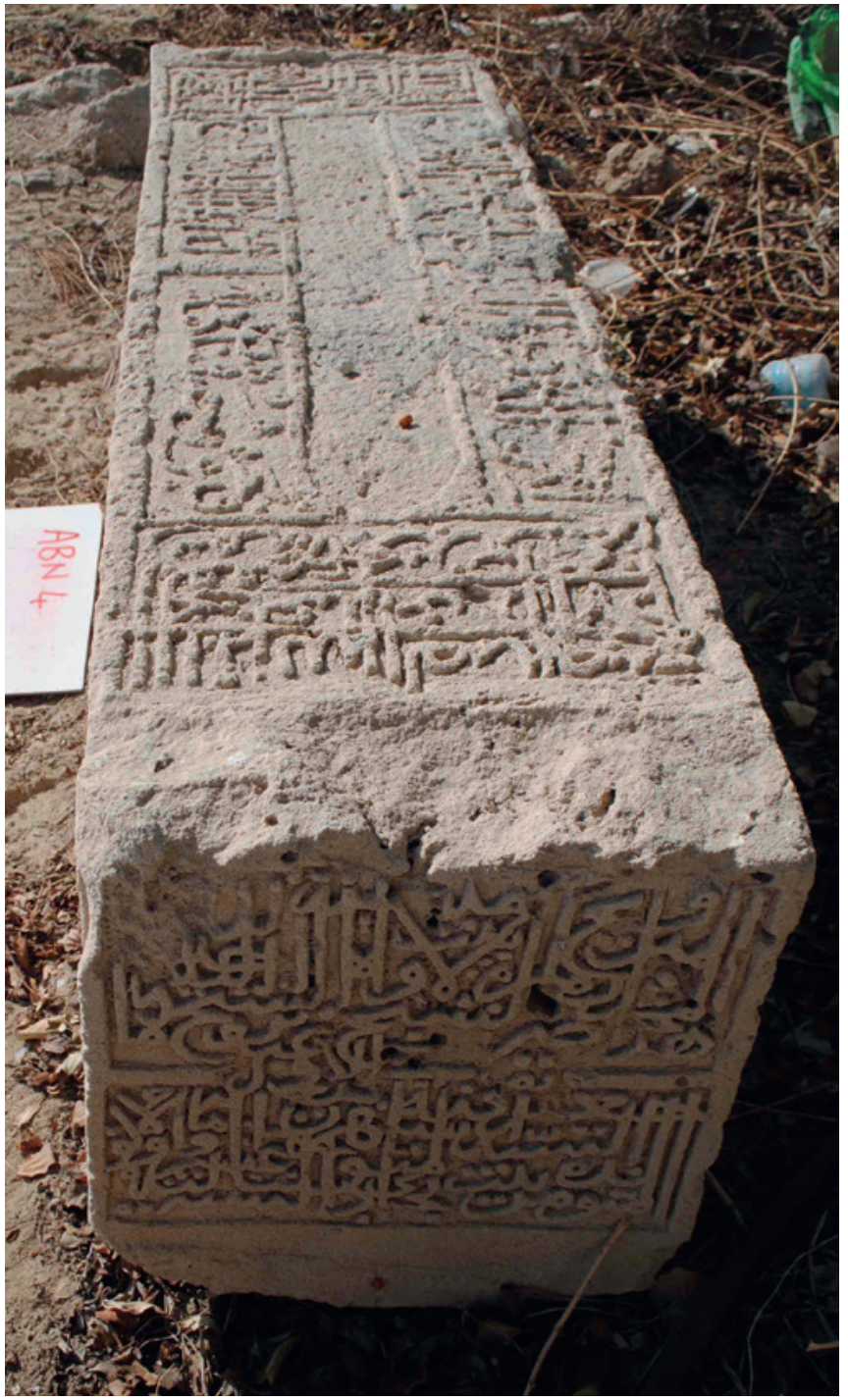


E:

- Written by the one who stands in need of Allah, 'Ali Bin Abdullah Bin 'Abd al-Samad al-Asbai i al-Bahrani.

- Graves, we thought these were illuminated stars ...

- Inscribed by the humble al-Sayyid Naser bin al-Sayyid Hashim alAsba'i al-Bahrani.
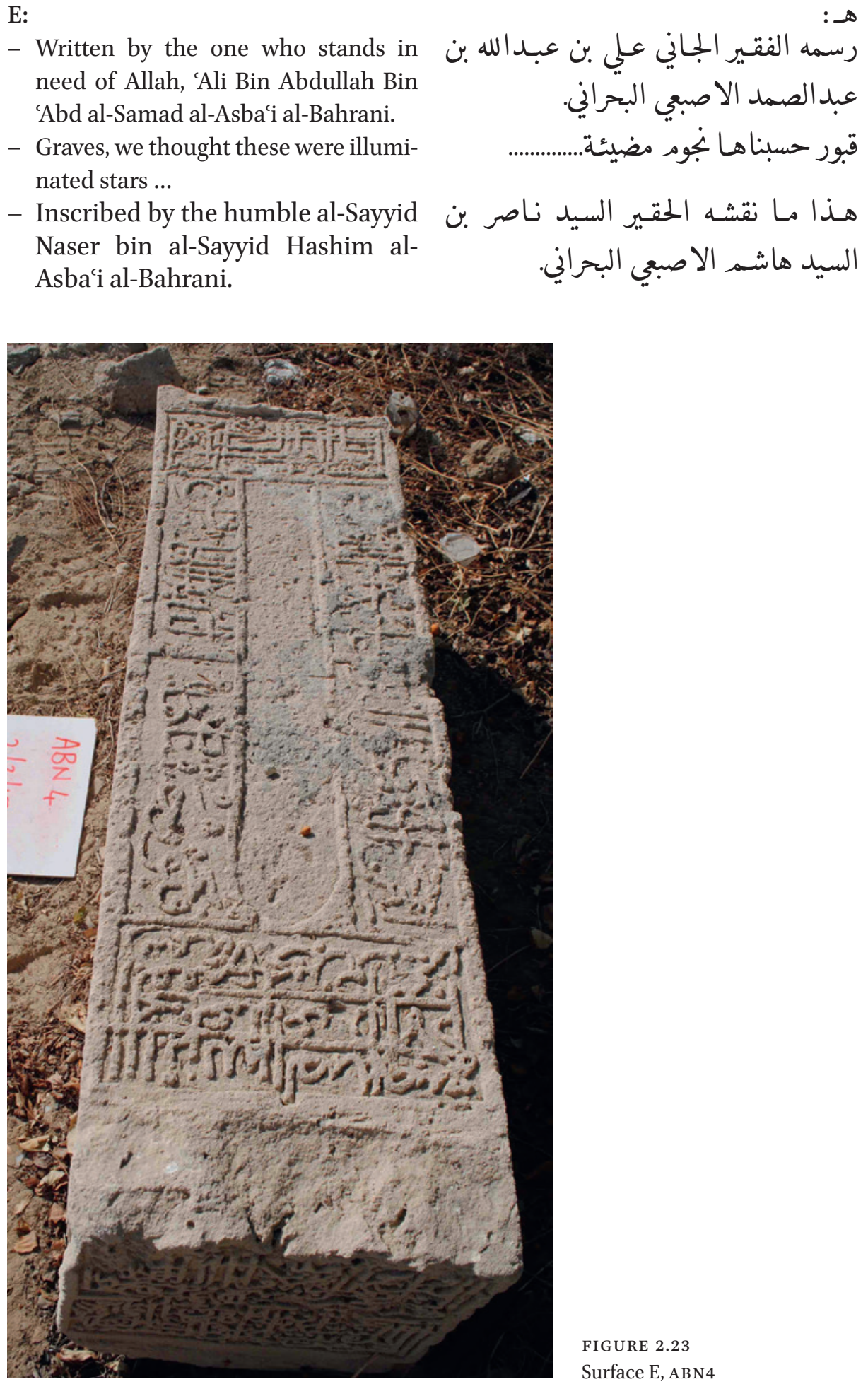

FIGURE 2.23

Surface E, ABN 4 


\section{Reference Number: ABN5}

Co-ordinates: $26.20995^{\circ} \mathrm{N} 050.55146^{\circ} \mathrm{E}$

\section{Dimensions:}

Slab 1: $74.5 \mathrm{~cm}(\mathrm{l}) \times 38.5^{-40} \mathrm{~cm}(\mathrm{w}) \times 34 \mathrm{~cm}(\mathrm{~h})$

Slab 2: $79-80.5 \mathrm{~cm}(\mathrm{l}) \times 38.5 \mathrm{~cm}(\mathrm{w}) \times 34 \mathrm{~cm}(\mathrm{~h})$

\section{Orientation: NW-SE}

Description: Gravestone formed of two solid limestone slabs. In generally good condition. Three element raised decoration at both ends formed of two facetted cubes and a central rounded arch at one end and two facetted cubes and a central cylinder at the other end. The end surfaces ( $C$ and D) are unengraved and the outer surface of the raised decoration on both these sides is incomplete suggesting the gravestone is not fully finished. Shallow carved pointed niche design on the top surface (E). Inscriptions on three surfaces.

\section{Arabic Transcription and Translation:}

A:

- In the Name of Allah, the Most Gracious, the Most Merciful. Verily, those who say: Our Lord is Allah, and then they stand firm, the angels will descend on them, (saying:) Fear not, nor grieve; But receive the glad tidings of Paradise

- Which you have been promised. We have been your friends in the life of this world and in the Hereafter. Therein you shall have all that your souls desire and all that you ask for, as hospitality from One, the Forgiving, the Most Merciful (41:30-32).

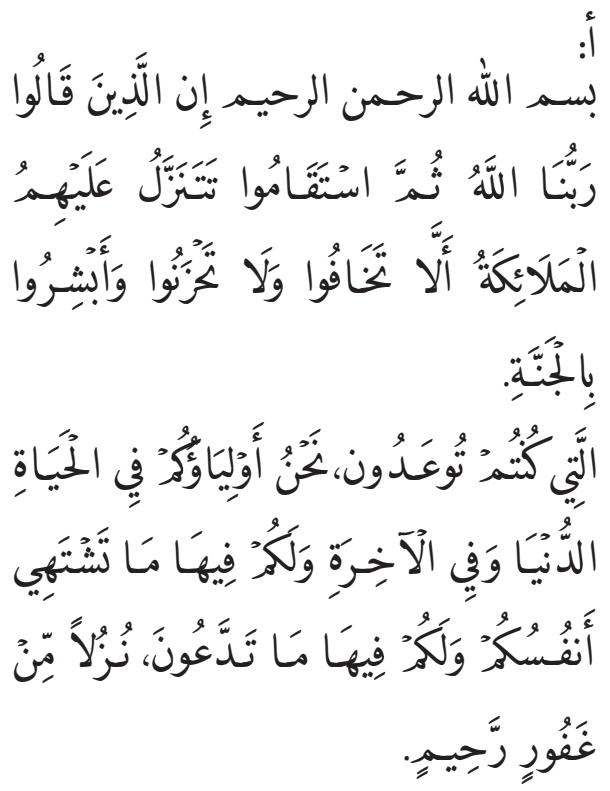




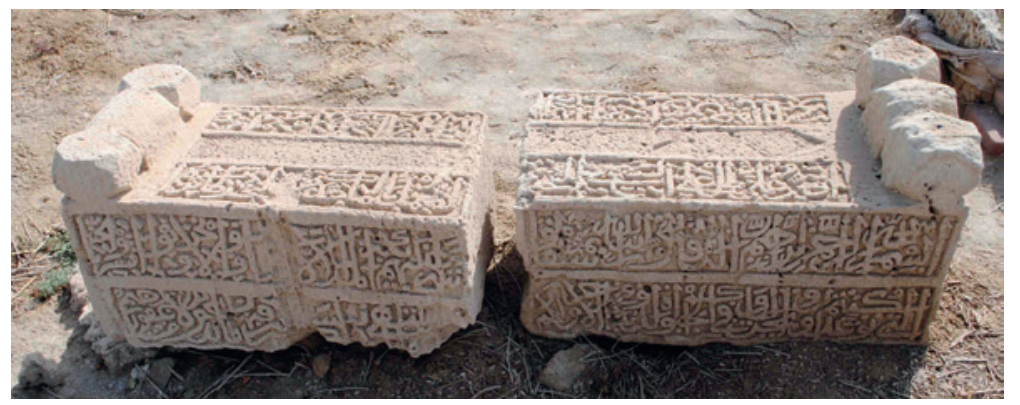

FIGURE 2.24 Surface A, ABN5

B:

- Their sides forsake their beds, to invoke their Lord in fear and hope (32:16). God rest his soul. And give glad tidings to the good doers (22:37). No doubt! Verily, those who believe in Allah they have no fear nor do they grieve.

- These are rewarded with high places because they are patient, and are met therein with greetings and the word of peace and respect. Abiding thereinexcellent it is as an abode, and as a place to rest in (10:62). it will be said to them; peace be on you, a Word from the Most Merciful (36:58). (It will be

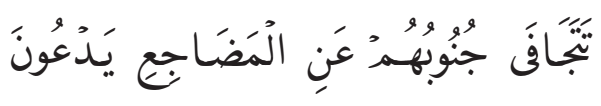

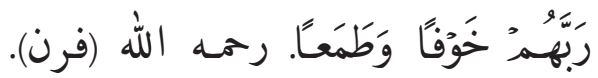

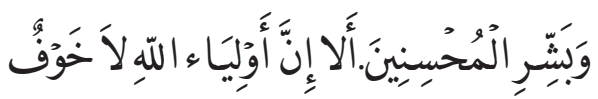

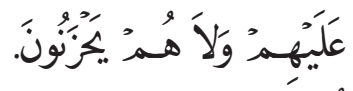

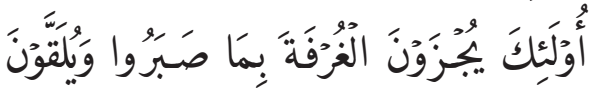

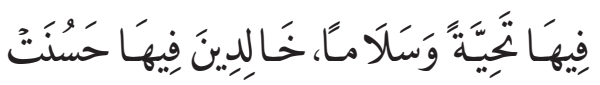

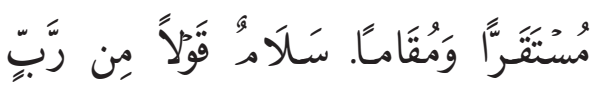

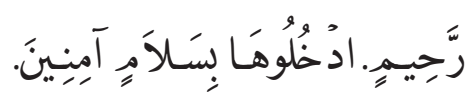
said to them): Enter therein (Paradise), in peace and security (15.46).

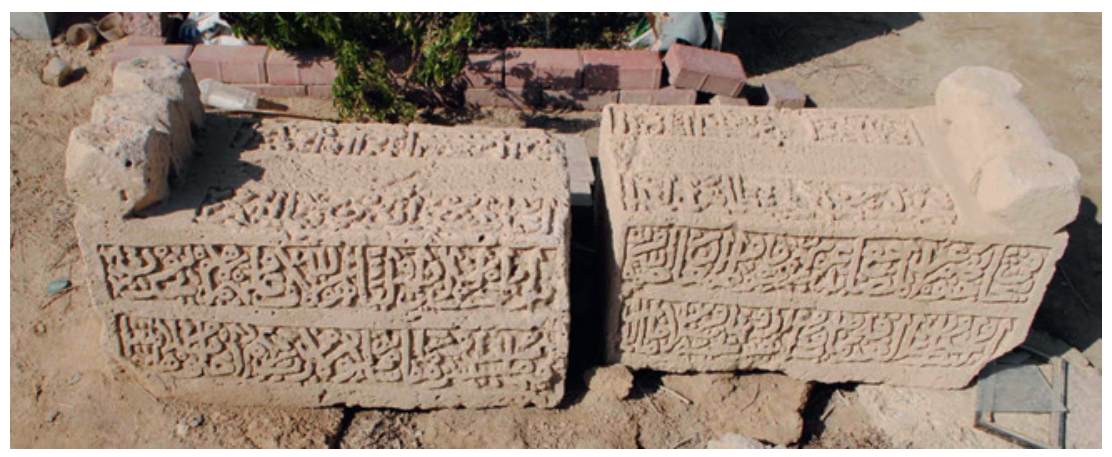

FIGURE 2.25 Surface B, ABN5 
C:

- No carving or inscriptions.

لأ توجد نقوش أوكّابات

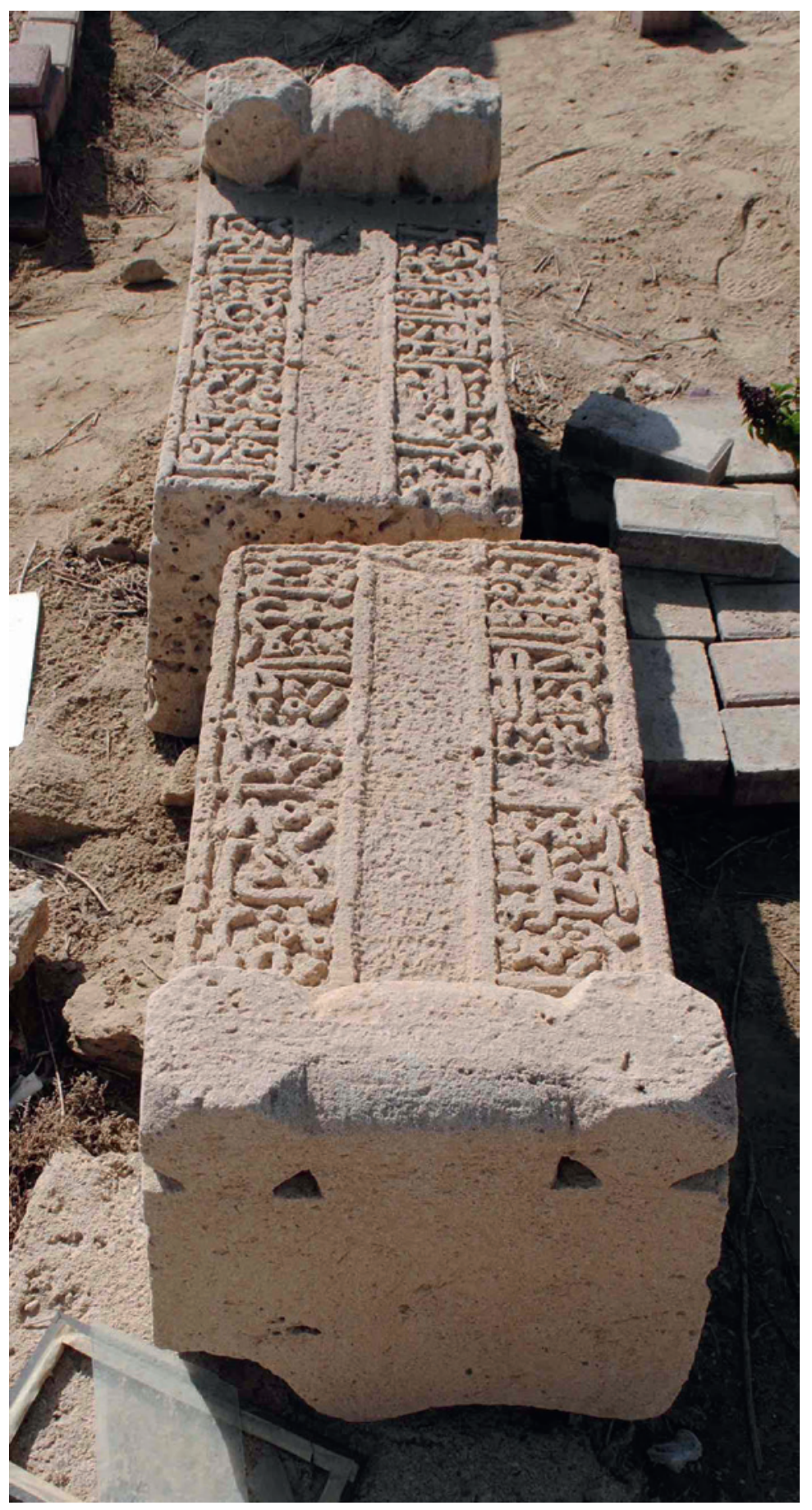

FIGURE 2.26

SURFACE C,ABN5 
D:

- No carving or inscriptions.

لاً توجد نقوش أوكّابات

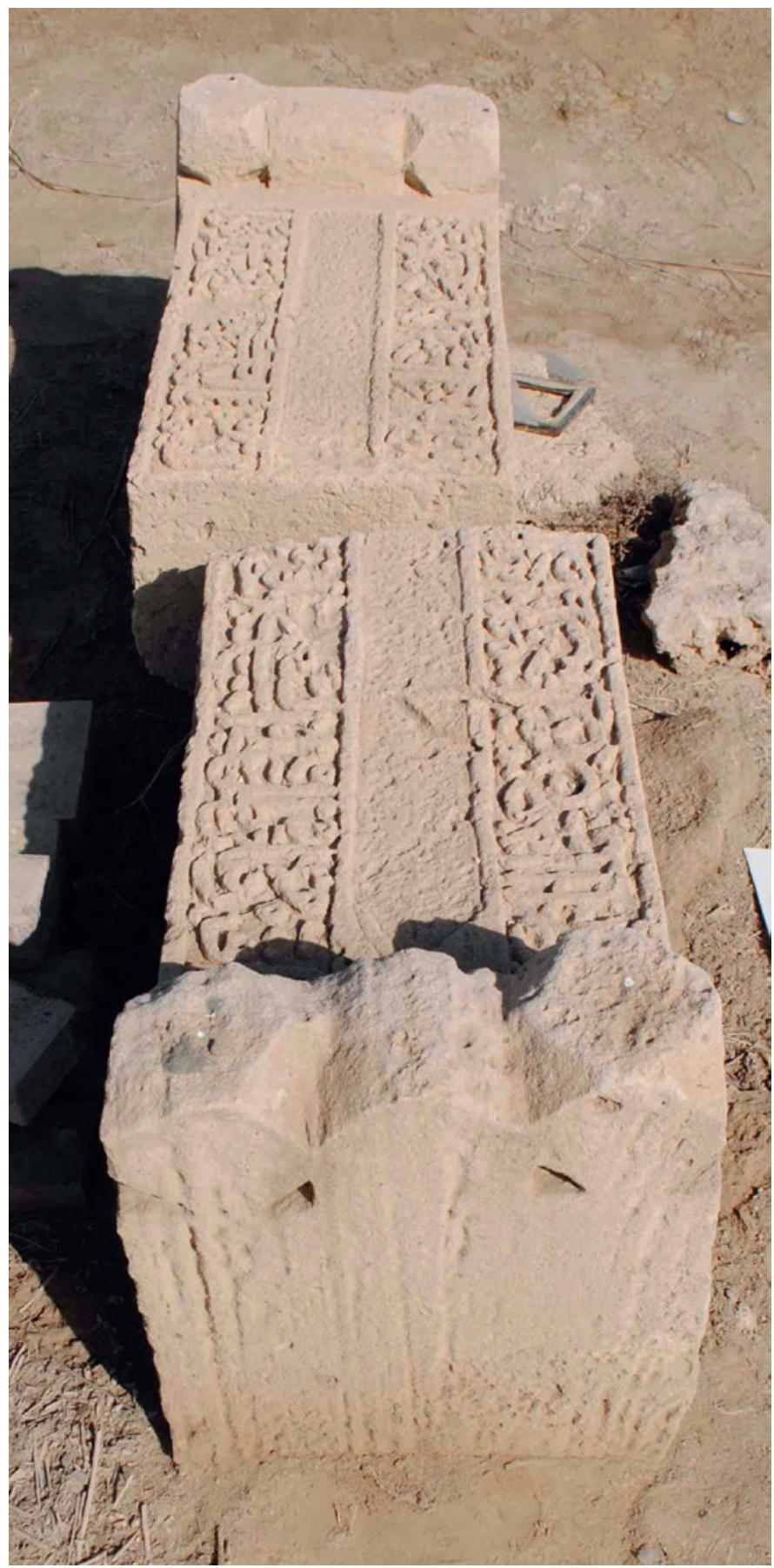

FIGURE 2.27

Surface D, ABN5 
E:

- I am astonished that a man that was like a sea of dew is now placed in two feet of a grave, 707 .

- O 'Ali's grave be proud ... God rest his soul.
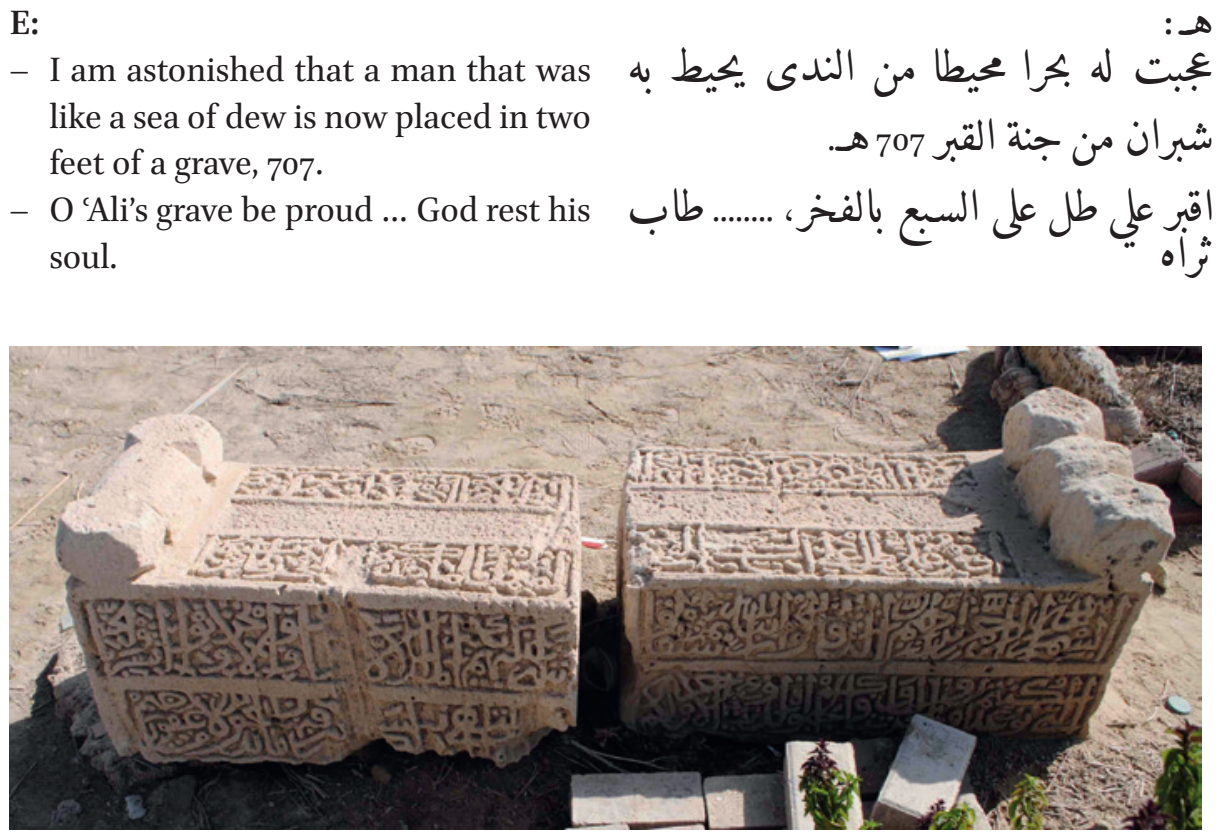

FIGURE 2.28 Surface E, ABN5

\section{Reference Number: ABN6}

Co-ordinates: $26.21051^{\circ} \mathrm{N} 050.55123^{\circ} \mathrm{E}$

Dimensions: $107 \mathrm{~cm}(\mathrm{l}) \times 28 \mathrm{~cm}(\mathrm{w}) \times 42-44 \mathrm{~cm}(\mathrm{~h})$

\section{Orientation: NW-SE}

Description: Single limestone slab gravestone, eroded. Next to collapsed mosque. Three element raised decoration formed of three facetted cubes, the central one thinner, all set on a rectangular plinth at both ends. Inscriptions on five surfaces, two only partially illegible.

\section{Arabic Transcription and Translation:}

A:

- In the Name of Allah, the Most Gracious, the Most Merciful. Verily, those who say: Our Lord is Allah, and then they stand firm, The Angels will descend on them, (saying:) Fear not,

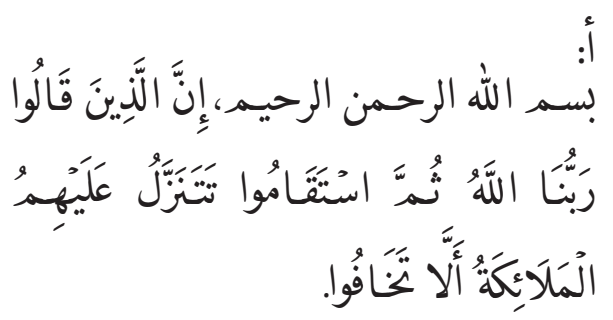


- Nor grieve; But receive the glad tidings of Paradise which you have been promised ... (41:30) the Forgiving, the Most Merciful (41:32).
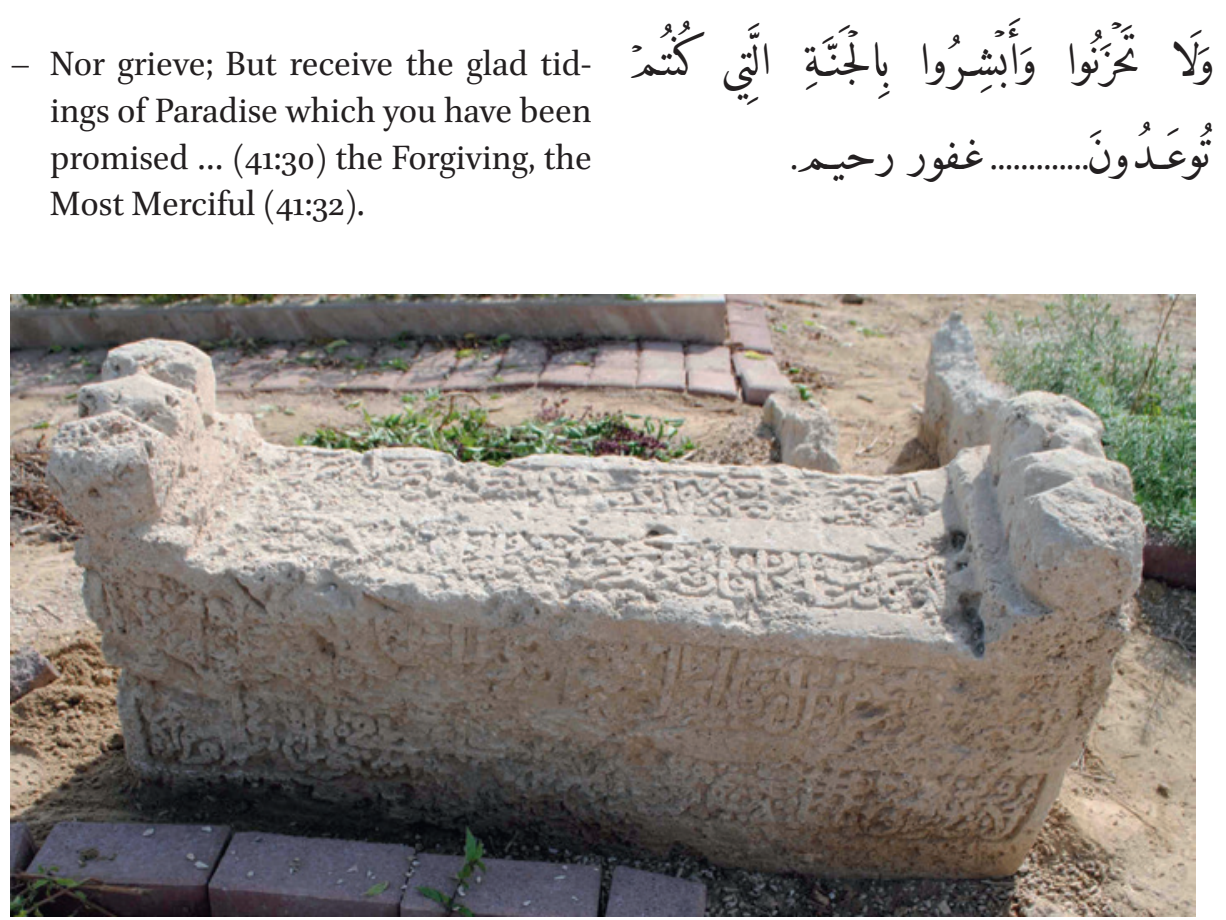

FIGURE 2.29 Surface A, ABN6

B:

- In the Name of Allah, the Most Gracious, the Most Merciful. Their Lord gives them glad tidings of Mercy from Him, and His being pleased and of Gardens for them wherein are everlasting delights. They will dwell therein forever.

- Indeed, Allah has with Him a great reward (9:21-22). Their sides forsake their beds, to invoke their Lord in fear and hope (32:16). Indeed, the mercy of Allah is near to the doers of good $(7: 56)$.

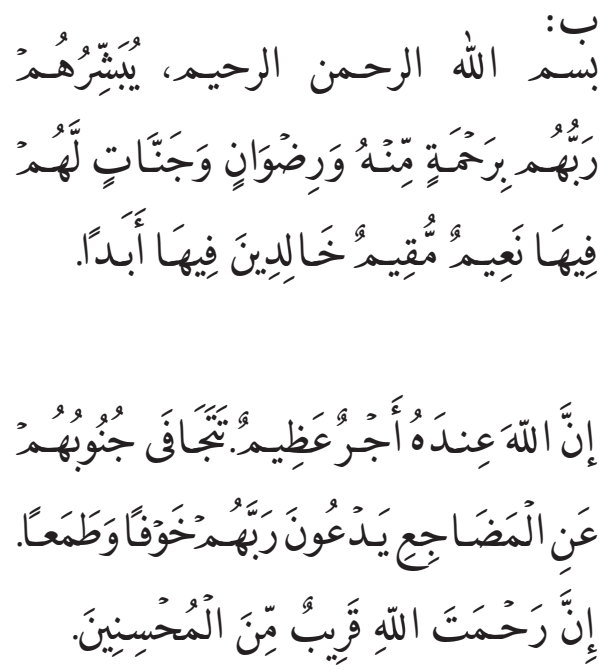




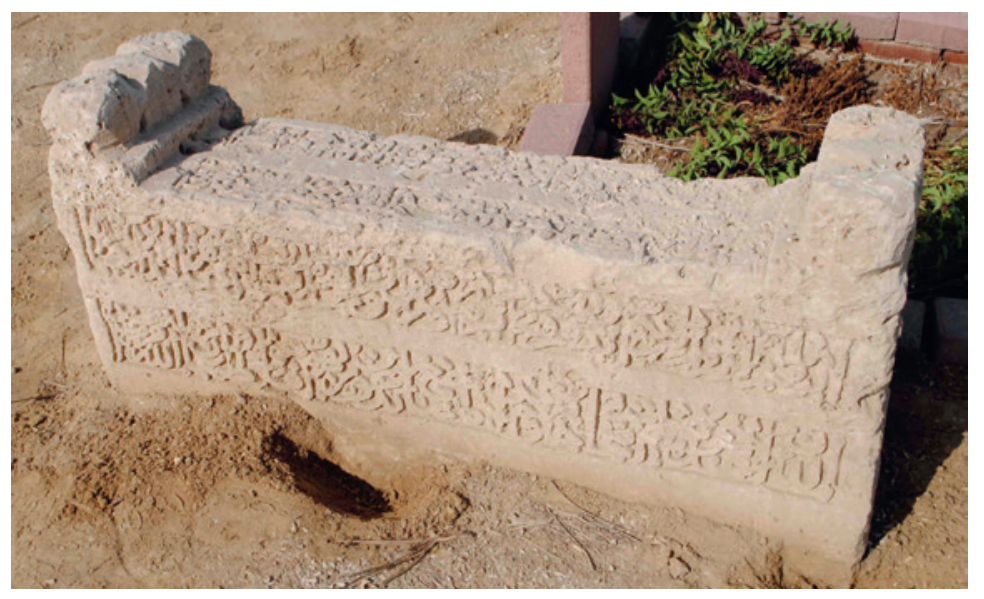

FIGURE 2.30

Surface B, ABN6

C:

- The proceed of ... 6 Qirans ... al-rams ... From ...
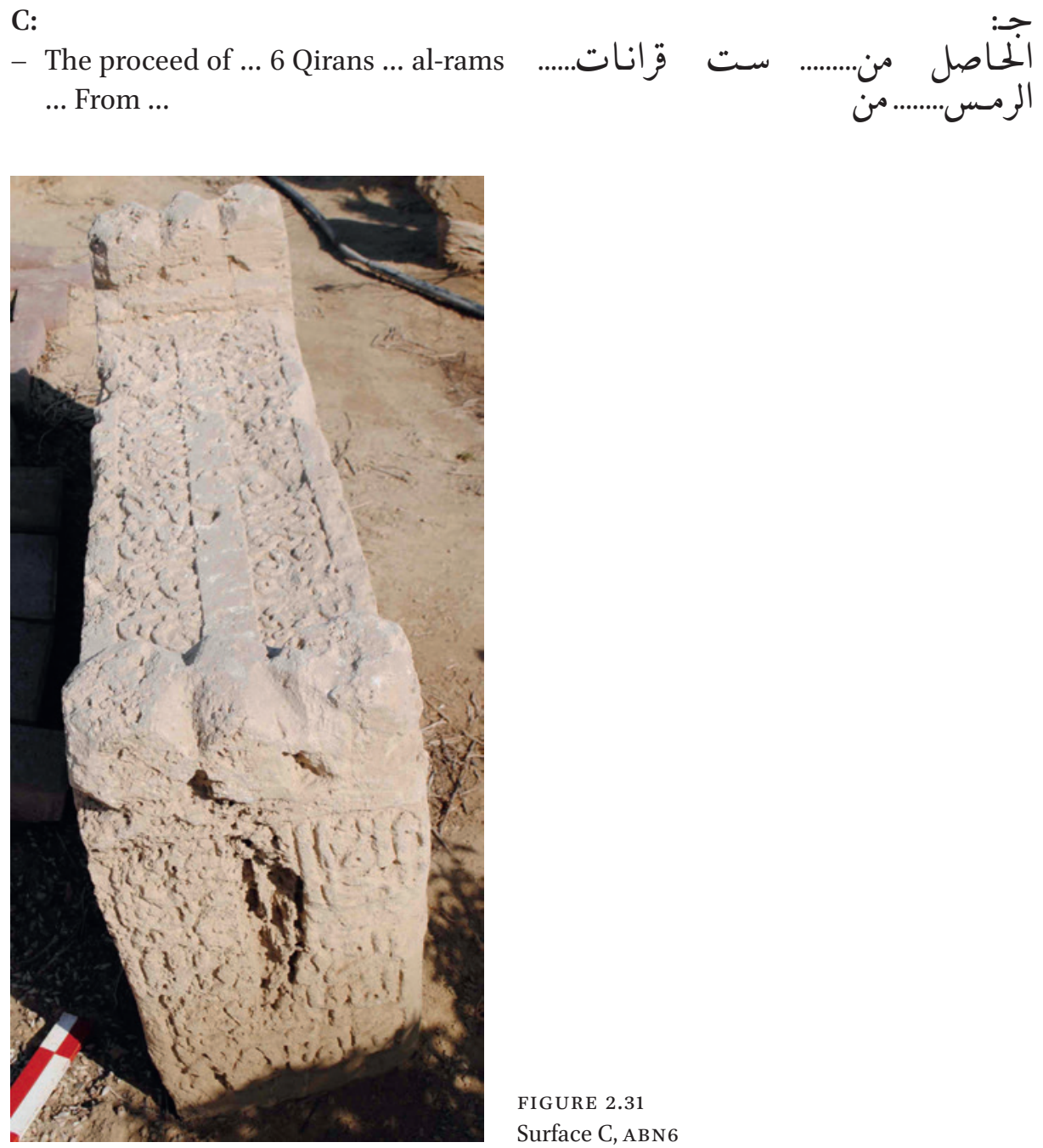

FIGURE 2.31

Surface C, ABN6 
D:

- Year of one thousand and forty-six

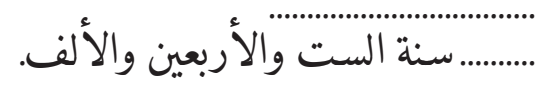

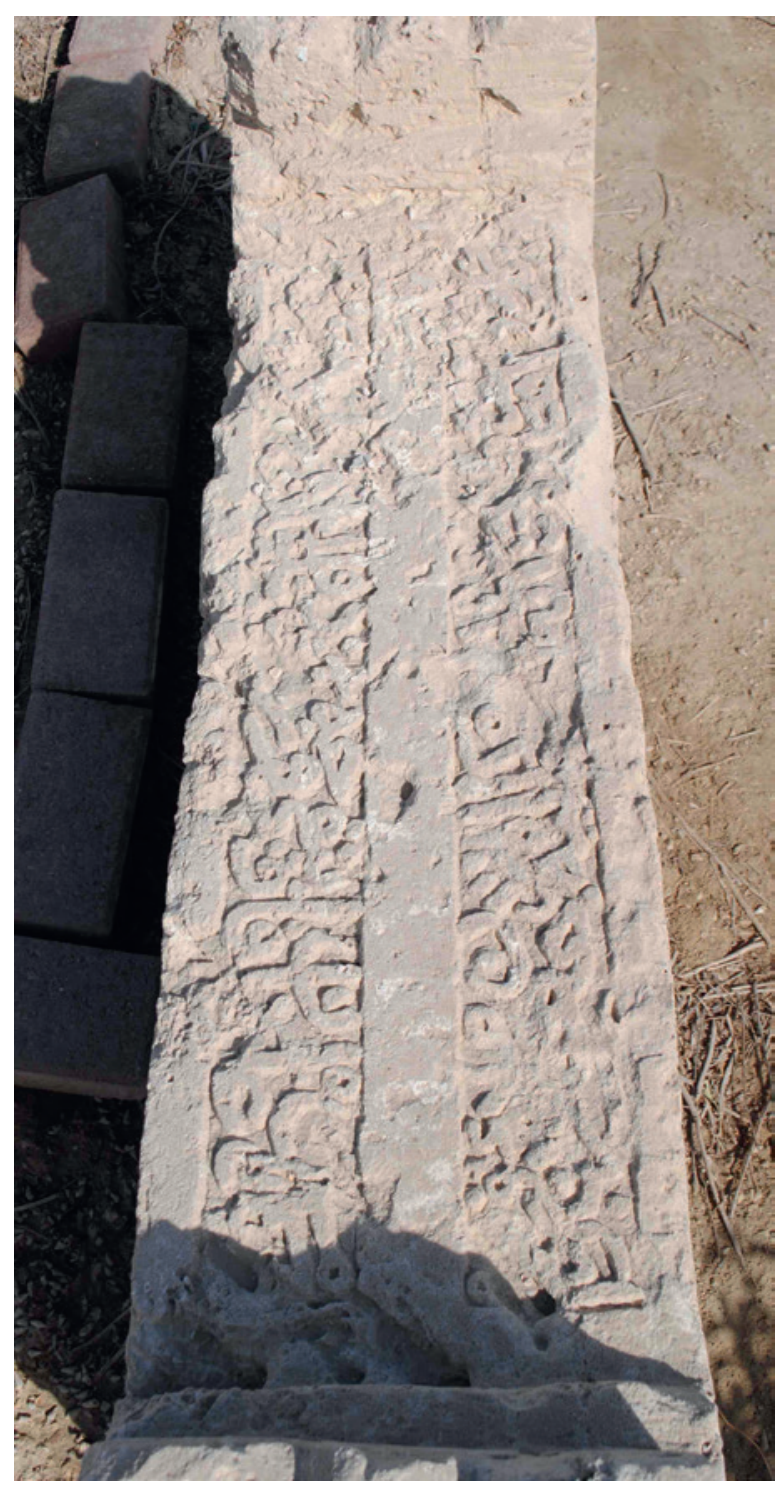

FIGURE 2.32

Surface D, ABN6

E:

- Whatsoever is on the earth will perish. And the Face of your Lord full of Majesty and Honour will remain forever (55:26-27).

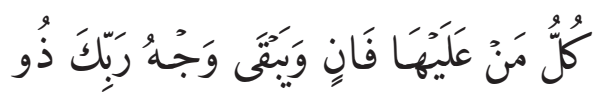

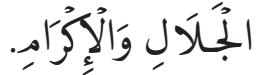


- Everything will perish except His Face. His is the Decision, and to Him all shall be returned. He is a Lord who forgives and he is merciful (28:88).
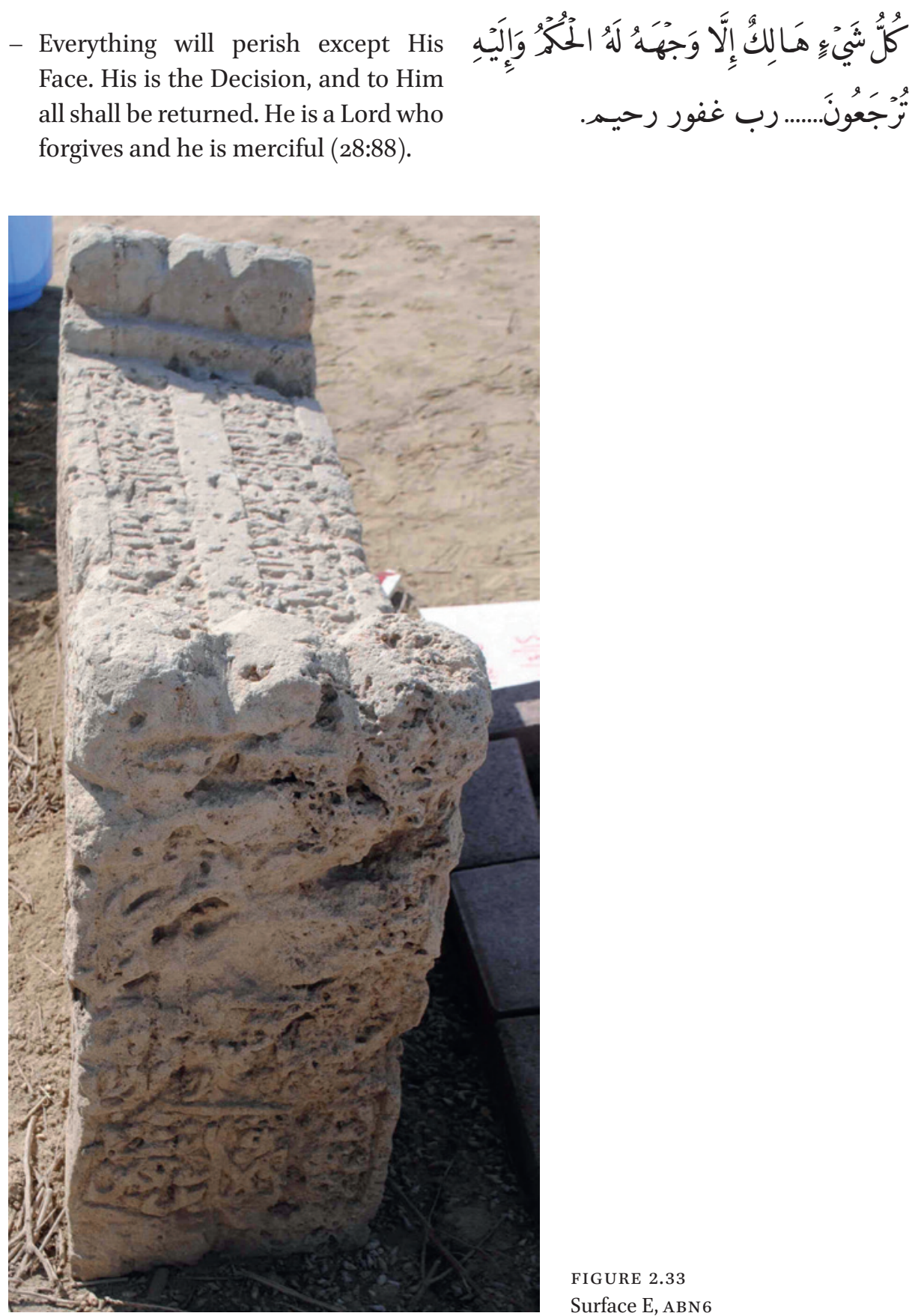

FIGURE 2.33

Surface E, ABN6 
Reference Number: ABN7

Co-ordinates: $26.21059^{\circ} \mathrm{N} 050.55116^{\circ} \mathrm{E}$

Dimensions: $68 \mathrm{~cm}(\mathrm{l}) \times 27 \mathrm{~cm}(\mathrm{w}) \times 37 \mathrm{~cm}(\mathrm{~h})$

Orientation: NW-SE

Description: Short limestone slab, half of a two-slab gravestone. Badly eroded. Traces of shallow carved rectangular panel design on upper surface (E). Possible remains of very eroded unidentifiable raised decoration at one end. Partial inscriptions on two surfaces.

\section{Arabic Transcription and Translation:}

A:

- No carving or inscriptions.
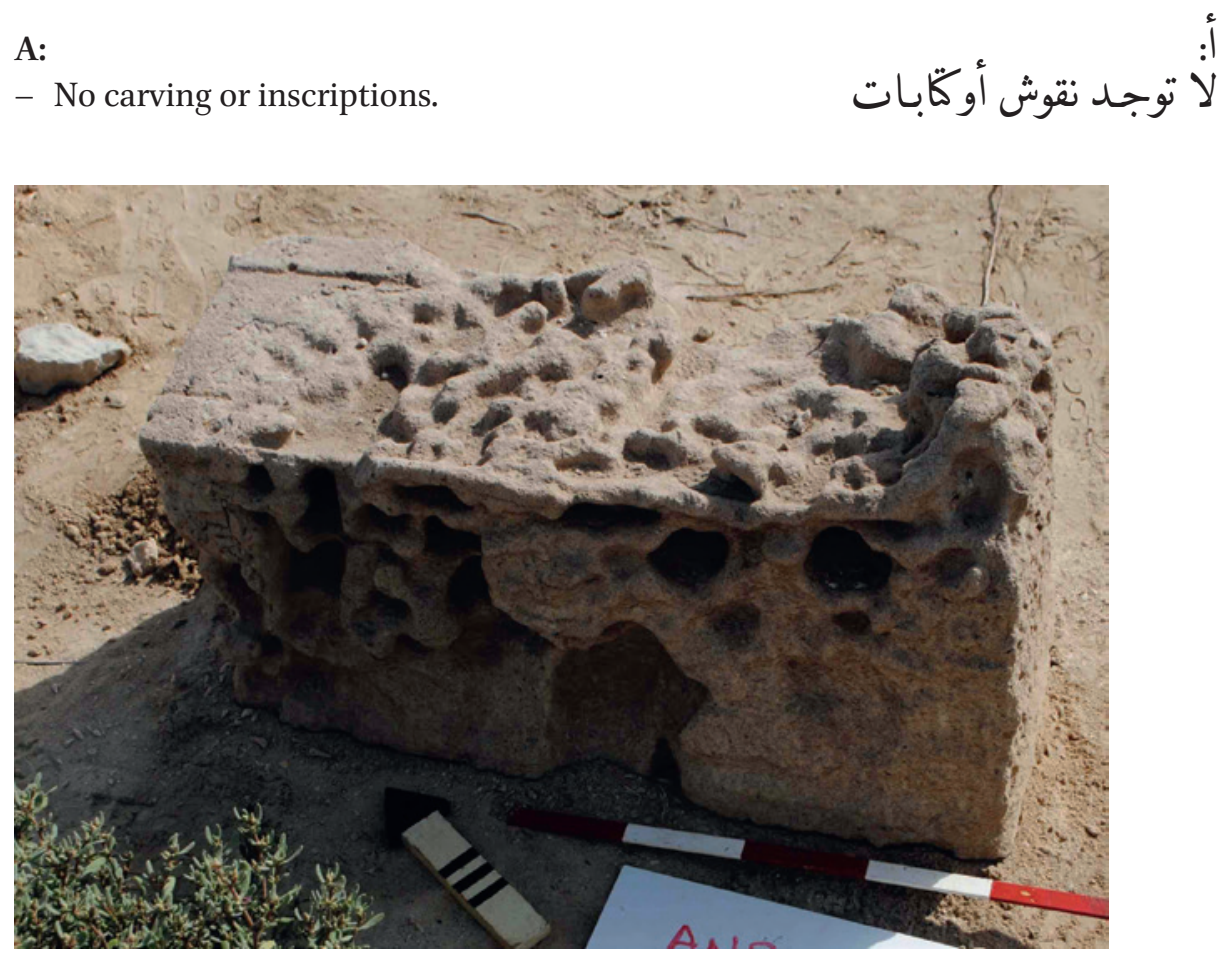

FIGURE 2.34 Surface A, ABN7

B:

- Your sins of the past and the future and ... (48:2)

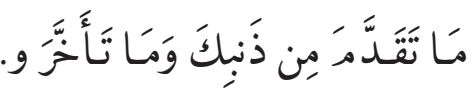

- N ... behind them ... all ...

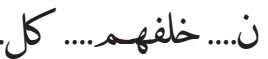




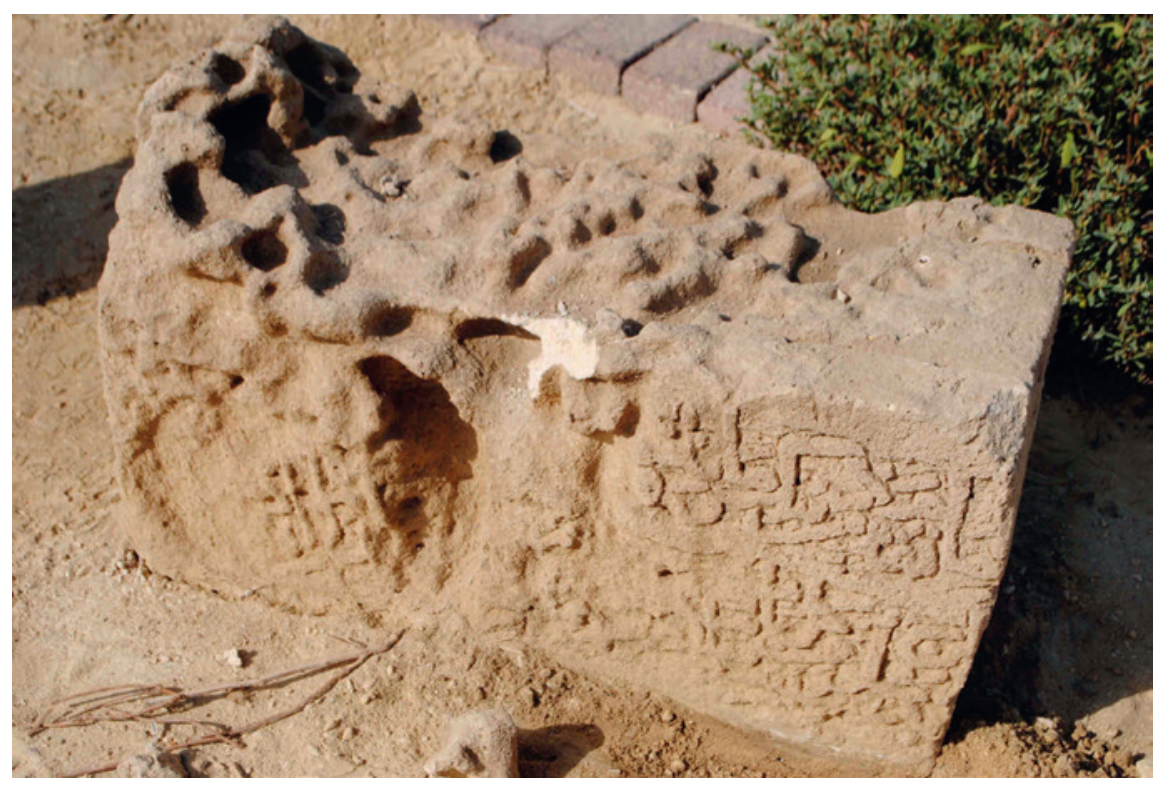

FIGURE 2.35 Surface B, ABN7

C: migration ...

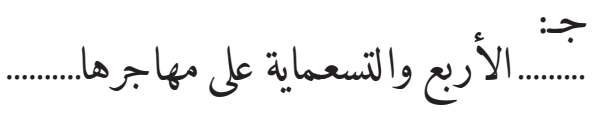

D:

- No carving or inscriptions.

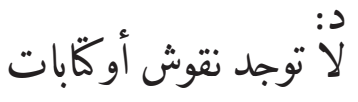

E:

- No carving or inscriptions.

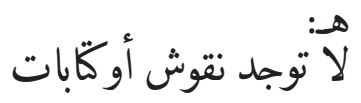

Reference Number: ABN8

Co-ordinates: $26.21054^{\circ} \mathrm{N} 05^{0.55117^{\circ} \mathrm{E}}$

\section{Dimensions:}

Slab 1: $71 \mathrm{~cm}(\mathrm{l}) \times 33 \mathrm{~cm}(\mathrm{w}) \times 33 \mathrm{~cm}(\mathrm{~h})$

Slab 2: $77 \mathrm{~cm}(\mathrm{l}) \times 32 \mathrm{~cm}(\mathrm{w}) \times 33 \mathrm{~cm}(\mathrm{~h})$

Orientation: North north west (NNW) to South south east (SSE) 
Description: Gravestone formed of two limestone slabs. No inscriptions (Figure 2.36). Near collapsed mosque. Cut into shape but left uncarved possibly because the voids in the surface of the stone would have precluded effective carving. Has what appear to be chisel marks on the upper surface (E). Unfinished raised decoration formed of a rectangular block awaiting carving at one end. Three element raised decoration cut into a basic shape of three flattened facetted cubes at the other end.

\section{Arabic Transcription and Translation: No inscriptions}

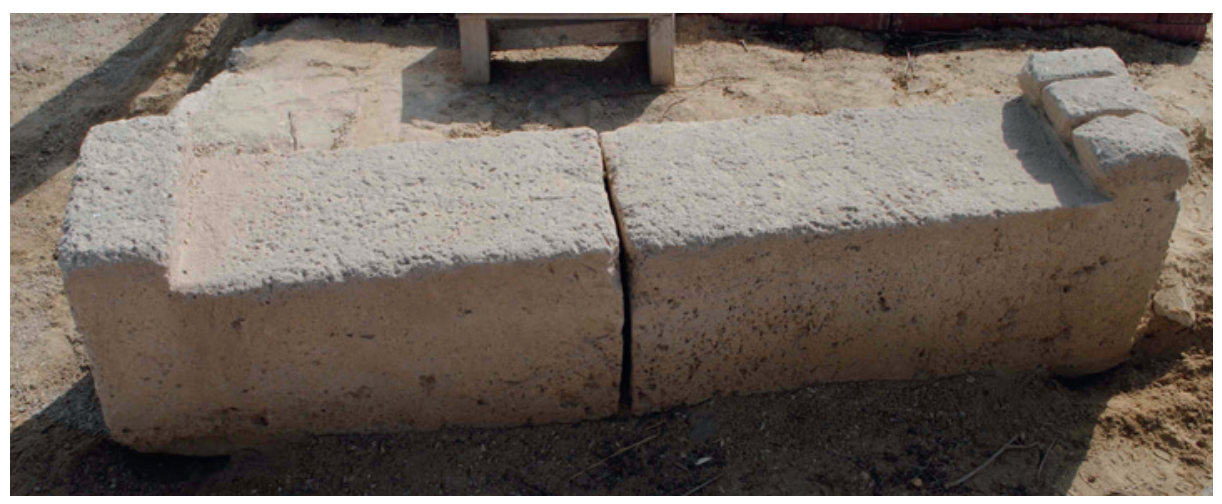

FIGURE 2.36 ABN8

\section{Reference Number: ABN9}

Co-ordinates: $26.21059^{\circ} \mathrm{N} 050.55117^{\circ} \mathrm{E}$

\section{Dimensions:}

Slab 1: $103 \mathrm{~cm}(\mathrm{l}) \times 50 \mathrm{~cm}(\mathrm{w}) \times 48 \mathrm{~cm}(\mathrm{~h})$

Slab 2: $97 \mathrm{~cm}(\mathrm{l}) \times 5^{1} \mathrm{~cm}(\mathrm{w}) \times 48 \mathrm{~cm}(\mathrm{~h})$

\section{Orientation: NW-SE}

Description: Gravestone formed of two limestone slabs. Badly eroded in places. Traces of shallow carved rectangular panel and two circles on upper surface (E) of one of the two slabs. Raised decoration broken or cut off at both ends. Partial inscriptions on four surfaces. Near a collapsed mosque that was excavated and contained ABN47. 


\section{Arabic Transcription and Translation:}

A:

- It is Allah who takes away the souls ...

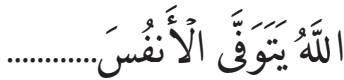
$(39: 42)$

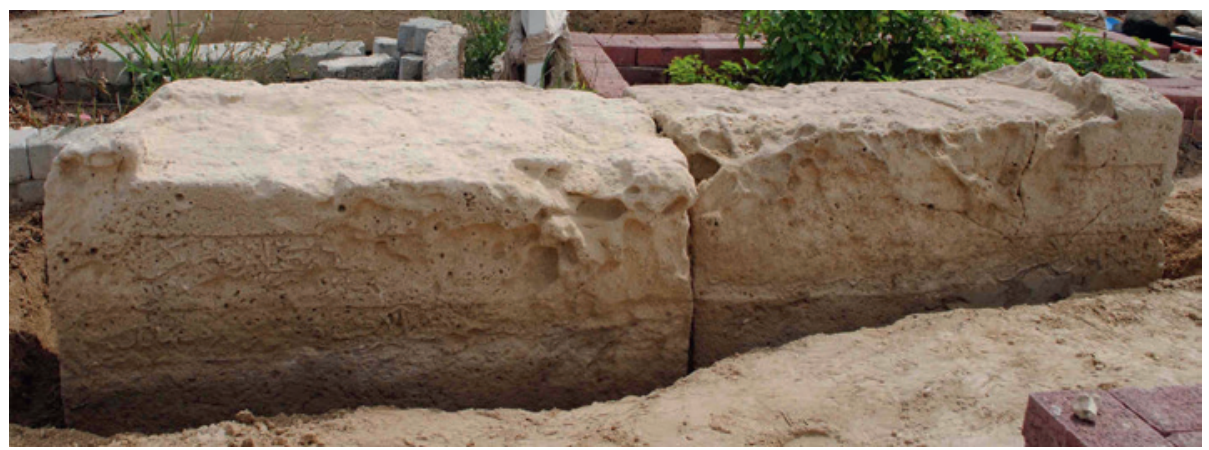

FIGURE 2.37 Surface A, ABN9

B:

- In the Name of Allah, the Most Gracious, the Most Merciful. Their Lord gives them glad tidings of Mercy from Him, and His pleasure and of Gardens for them (9:21).

- Gardens of Eternity. They shall enter them and also those who are righteous from among their fathers, and their wives and their children. And angels shall enter unto them from every gate (13:23).

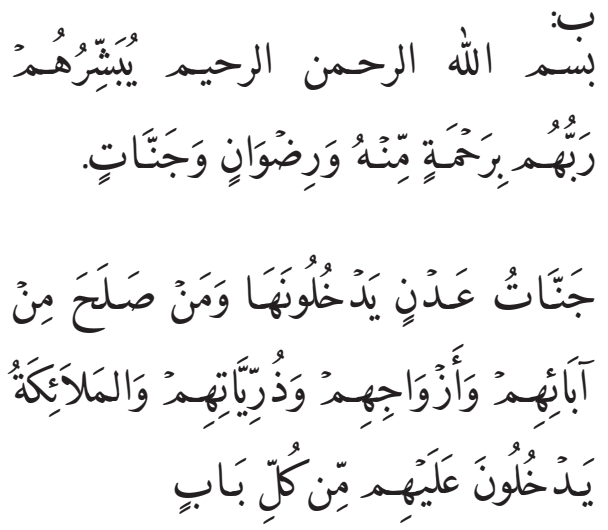




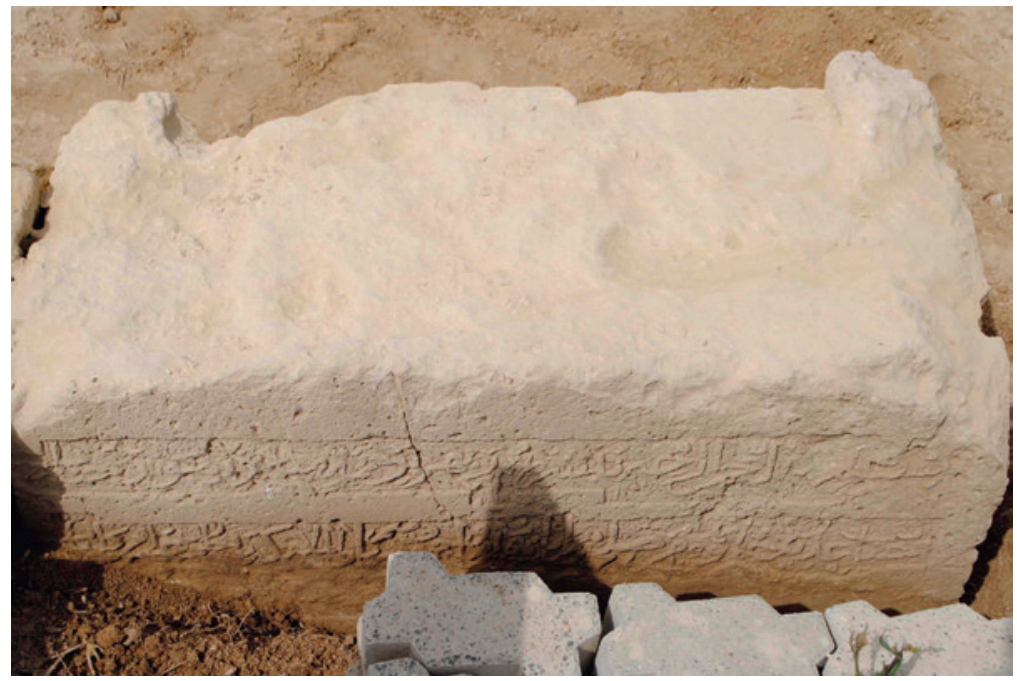

FIGURE 2.38 Surface B, ABN9

$\mathrm{C}:$

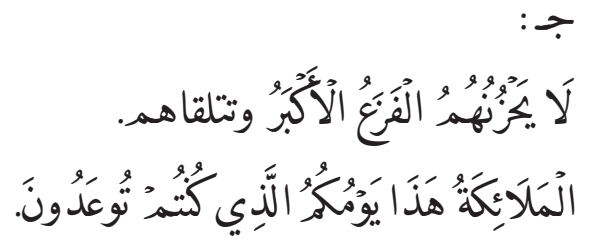

- The greatest terror will not grieve them, and

- The angels will meet them with greeting: this is your Day which you were promised (21:103).

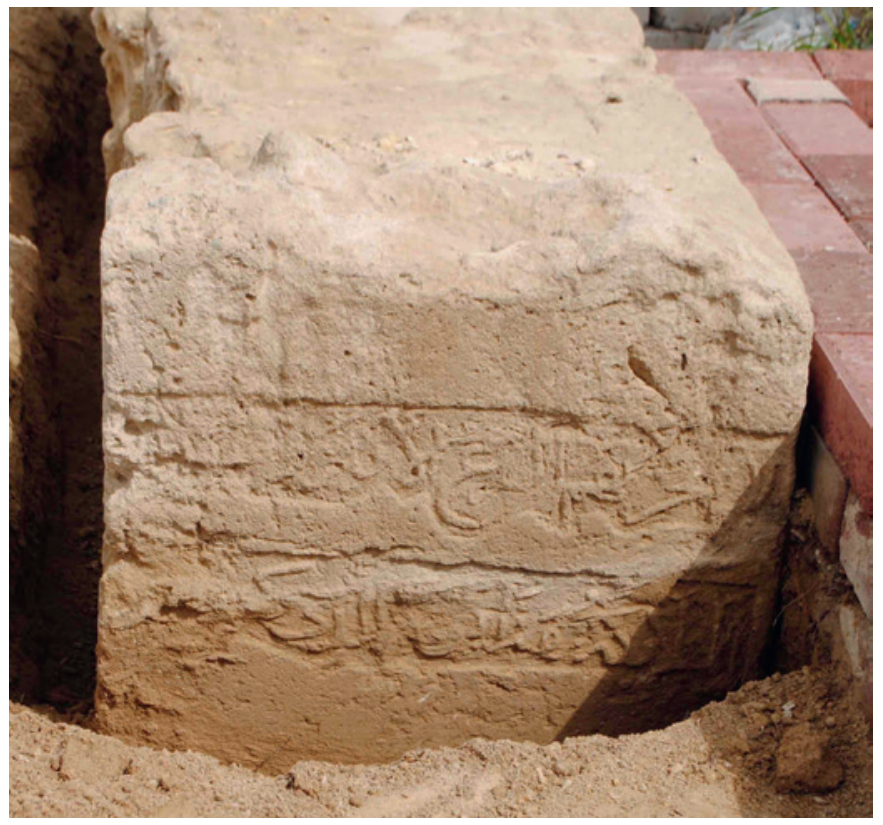


D:

- Grave of the blessed ...

- ... Seven hundred and sixty-five ...

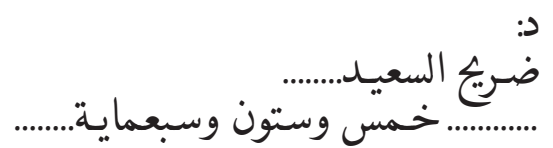

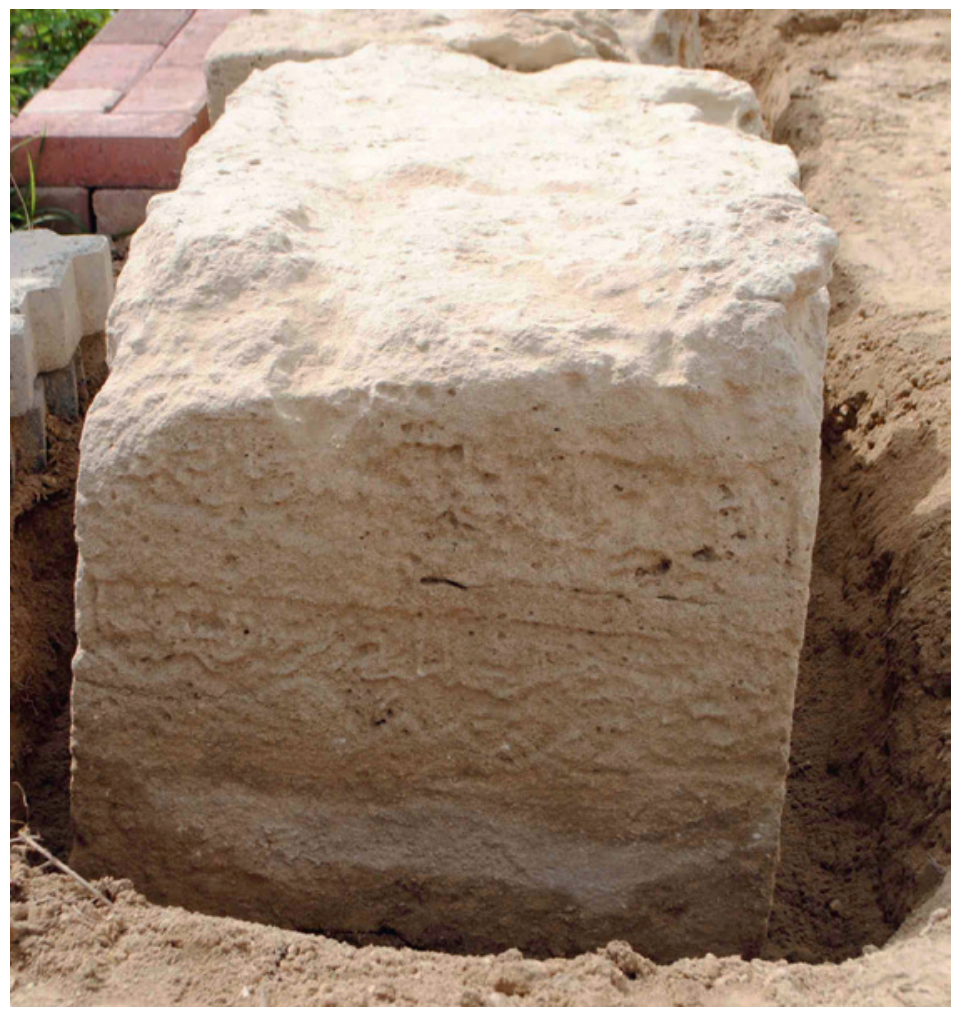

FIGURE 2.40

Surface D, ABN9

E:

- No carving or inscriptions.

لا ته: توجـد نقوش أوكَابـات

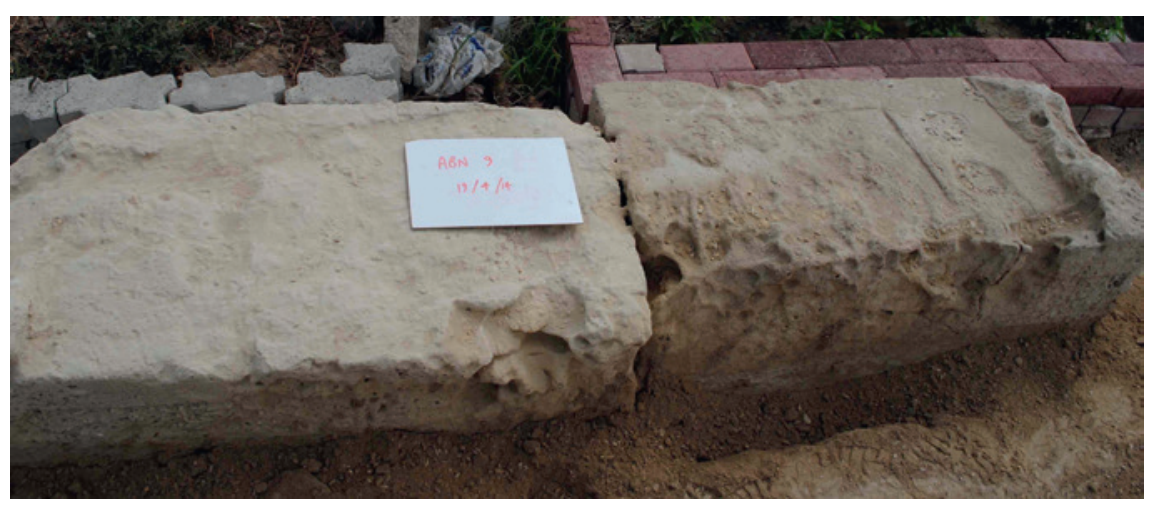

FIGURE 2.41 Surface E, ABN9 
Reference Number: ABN10

Co-ordinates: $26.21059^{\circ} \mathrm{N} 050.55119^{\circ} \mathrm{E}$

\section{Dimensions:}

Slab 1: $105 \mathrm{~cm}(\mathrm{l}) \times 42-43 \mathrm{~cm}(\mathrm{w}) \times 30 \mathrm{~cm}(\mathrm{~h})$

Slab 2: $76 \mathrm{~cm}(\mathrm{l}) \times 42 \mathrm{~cm}(\mathrm{w}) \times 34 \mathrm{~cm}(\mathrm{~h})$

\section{Orientation: NW-SE}

Description: Gravestone formed of two hollow limestone slabs. The smaller stone is more eroded. Inscriptions on three surfaces. Raised decoration on the larger stone has either been eroded or broken off. Rounded top part of shallow carved rounded niche decoration with two circles above niche on the upper surface (E). Found next to a collapsed mosque that was excavated and contained ABN47.

\section{Arabic Transcription and Translation:}

A:

- To dwell therein forever ... God ... (9:21)

- Of Paradise which you have been promised. We have been your friends in the life of this world ...

- And therein you shall have all that you ask for, an entertainment from the Oft-Forgiving, Most Merciful (41:30-32).

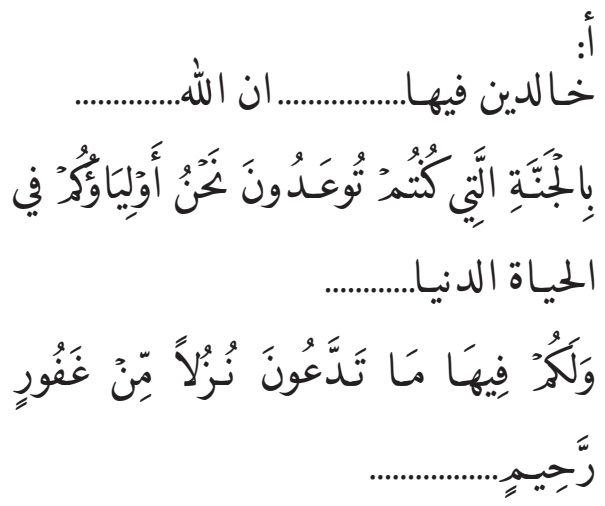

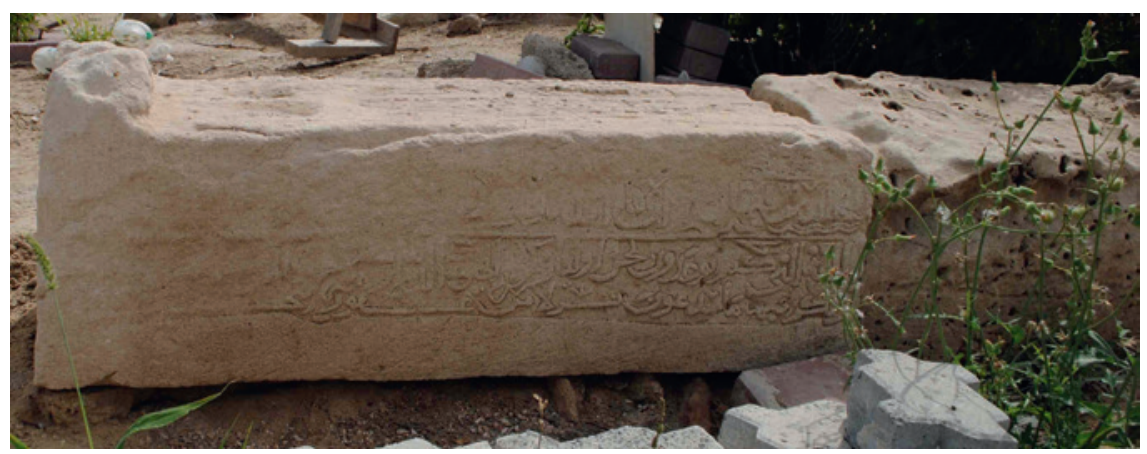

FIGURE 2.42 Surface A, part 1, ABN10 


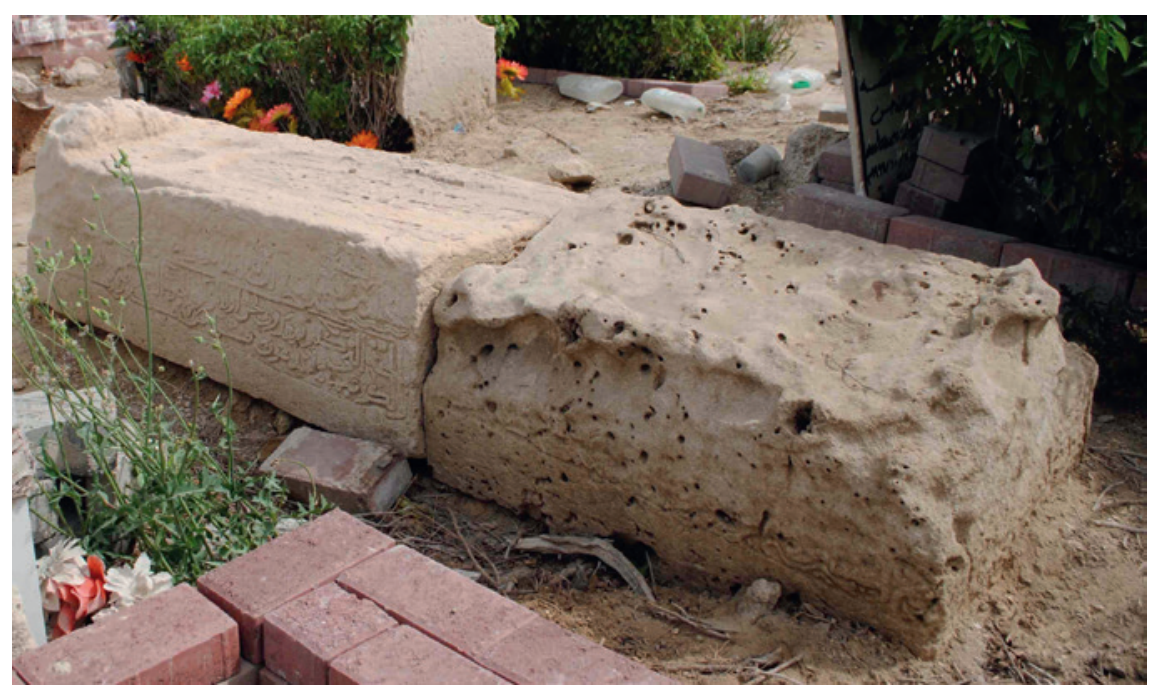

FIGURE 2.43 Surface A, part 2, ABN10

B:

- In the Name of Allah, the Most Gracious, the Most Merciful. Verily, those for whom the good has preceded from Us, they will be removed far therefrom ...

- The greatest terror will not grieve them, and the angels will meet them with greeting: this is your Day which ... (21:101-103)
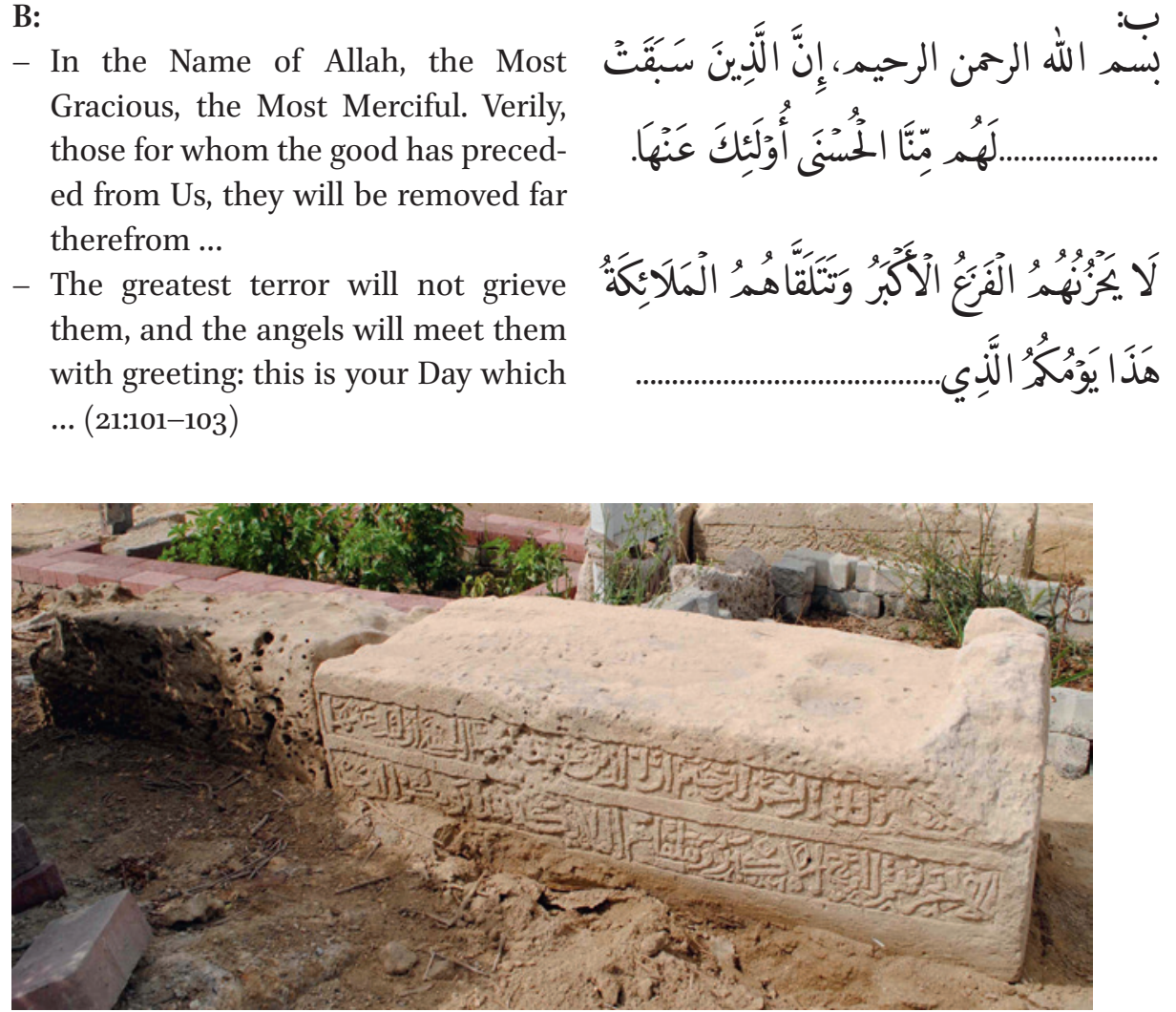

FIGURE 2.44 Surface B, ABN10 
C:

- Very deteriorated, Unable to read.
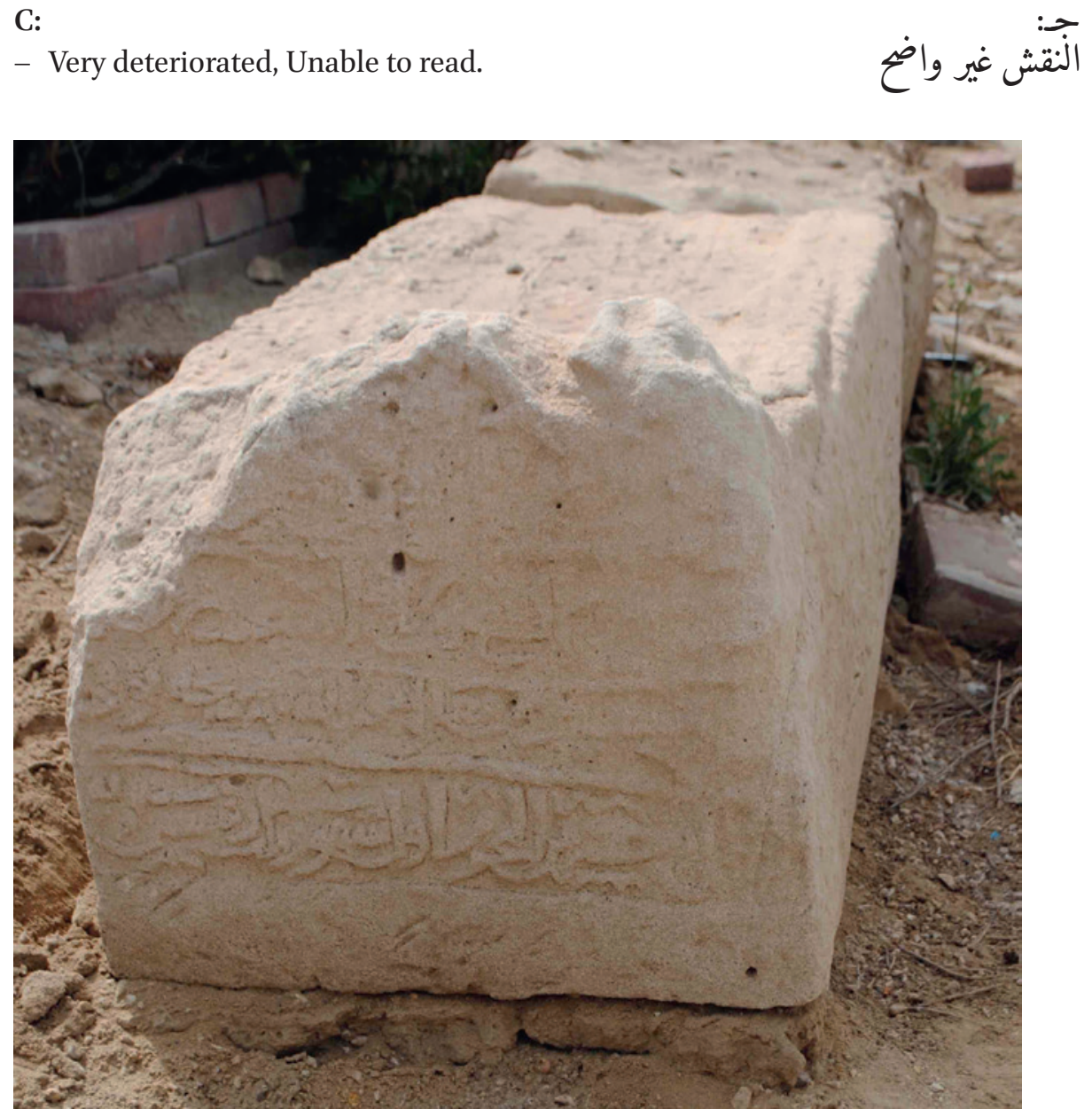

FIGURE 2.45 Surface C, ABN10

D:

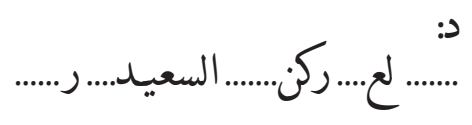

- ... Sacid Bin Macali, God enlighten his shrine, died

- Twenty first of Muharram, the حسادي وعشرين من المحرمر أول شهور first month of seven hundred and forty-six.

سنة سـت واربعـين وسـبعمايـة. 


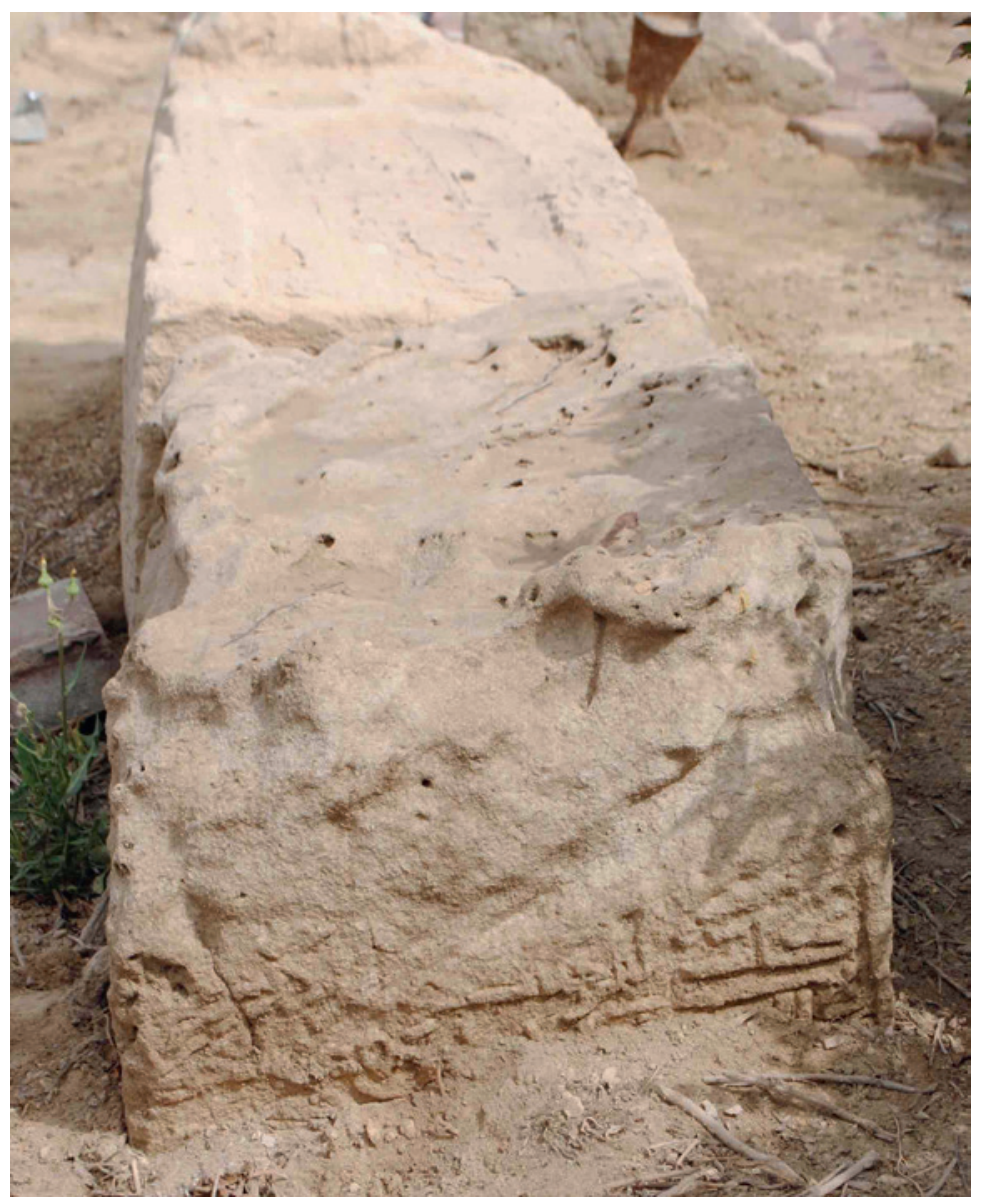

FIGURE 2.46

Surface D, ABN10

E:

- No carving or inscriptions.
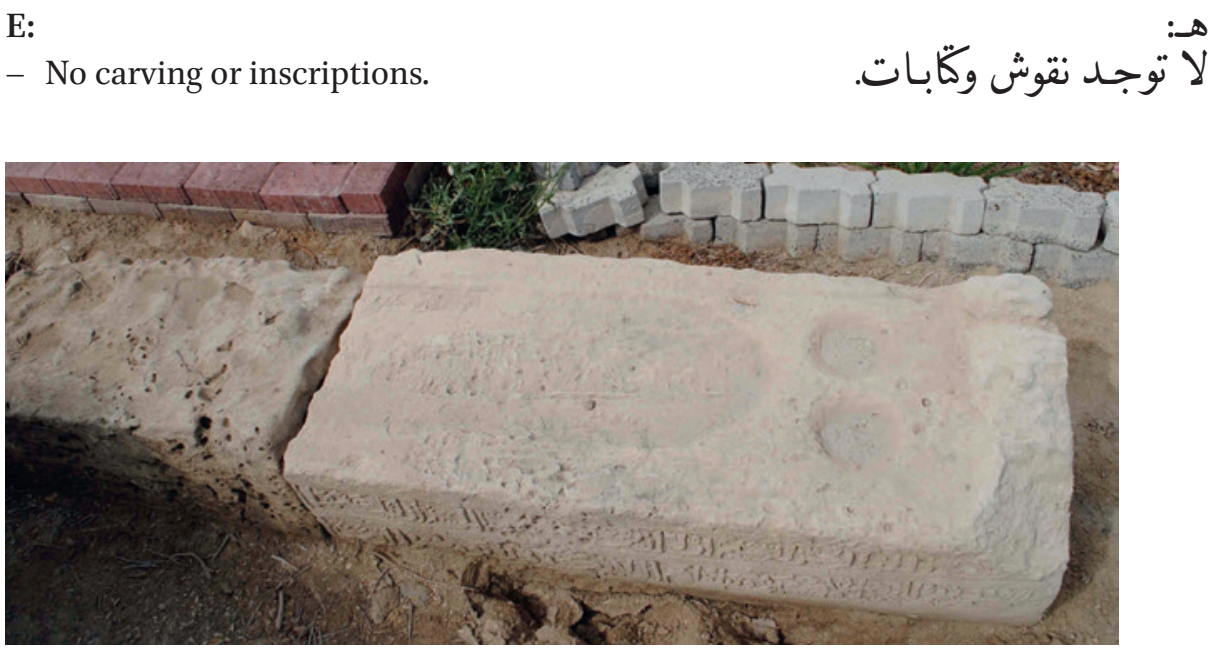

FIGURE 2.47 Surface E, ABN10 
Reference Number: ABN11

Co-ordinates: $26.21056^{\circ} \mathrm{N} 050.55127^{\circ} \mathrm{E}$

\section{Dimensions:}

Slab 1: $109 \mathrm{~cm}(\mathrm{l}) \times 50 \mathrm{~cm}(\mathrm{w}) \times 41 \mathrm{~cm}(\mathrm{~h})$

Slab 2: $82 \mathrm{~cm}(\mathrm{l}) \times 49.5 \mathrm{~cm}(\mathrm{w}) \times 39-40 \mathrm{~cm}(\mathrm{~h})$

\section{Orientation: NNW-SSE}

Description: Gravestone formed of two limestone slabs buried next to a collapsed mosque that was excavated and contained ABN47. Very well carved. Inscriptions on five surfaces, two partly illegible. Mostly in very good condition. Unusually detailed carving on top surface (E) formed of a shallow carved pointed niche design, with two larger circles above and two below, and two smaller circles, seemingly a later addition, within the niche. Three element raised decoration formed of two short collared rounded cylinders with a central rounded arch at one end and a rounded arch at the other end. Flanking the latter are two irregular indentations suggesting there were formerly two other decorative elements that have been removed. Excavated to expose whole gravestone.

\section{Arabic Transcription and Translation:}

A:

- My worshippers! No fear shall be on you this day, nor shall you grieve. Enter paradise, you and your wives, in happiness. Trays of gold and cups will be passed round them.

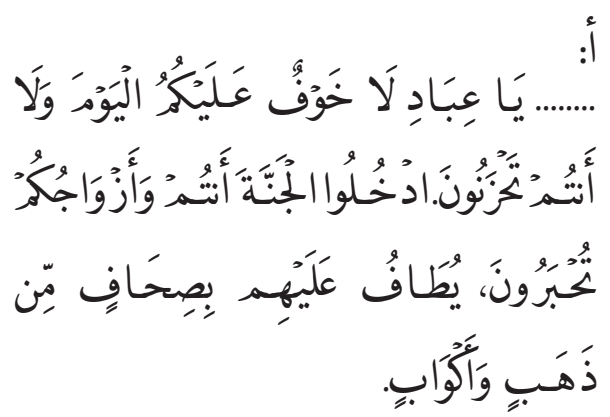

- Therein all that inner-selves could desire, and all that eyes could delight in and you will abide therein forever. Therein for you will be fruits in plenty, of which you will eat (43:68-73).
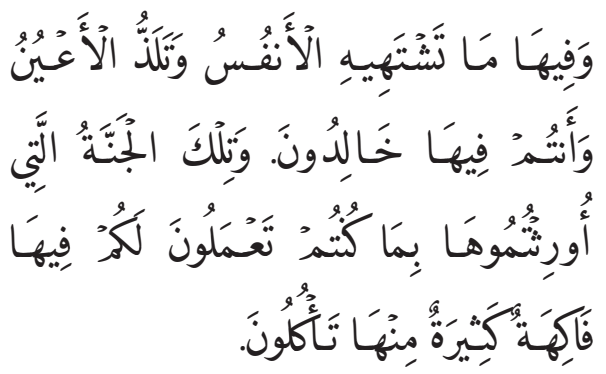


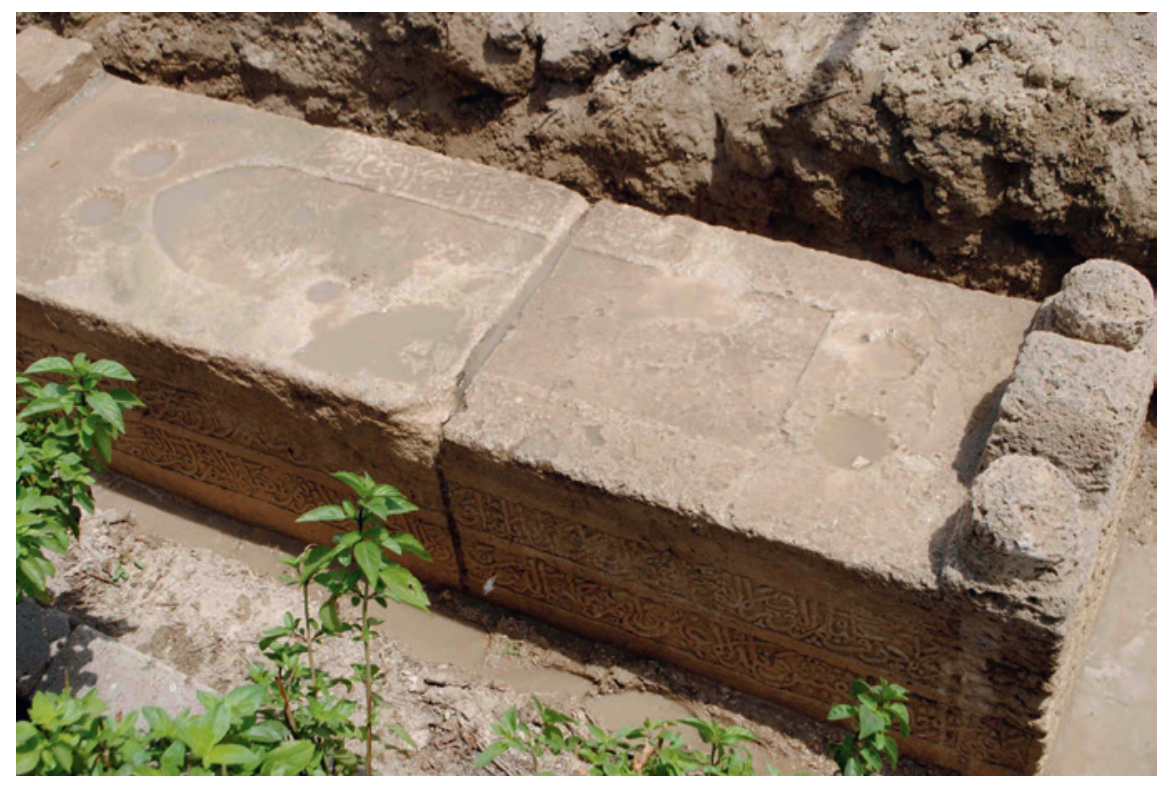

FIGURE 2.48 Surface A, part 1, ABN11

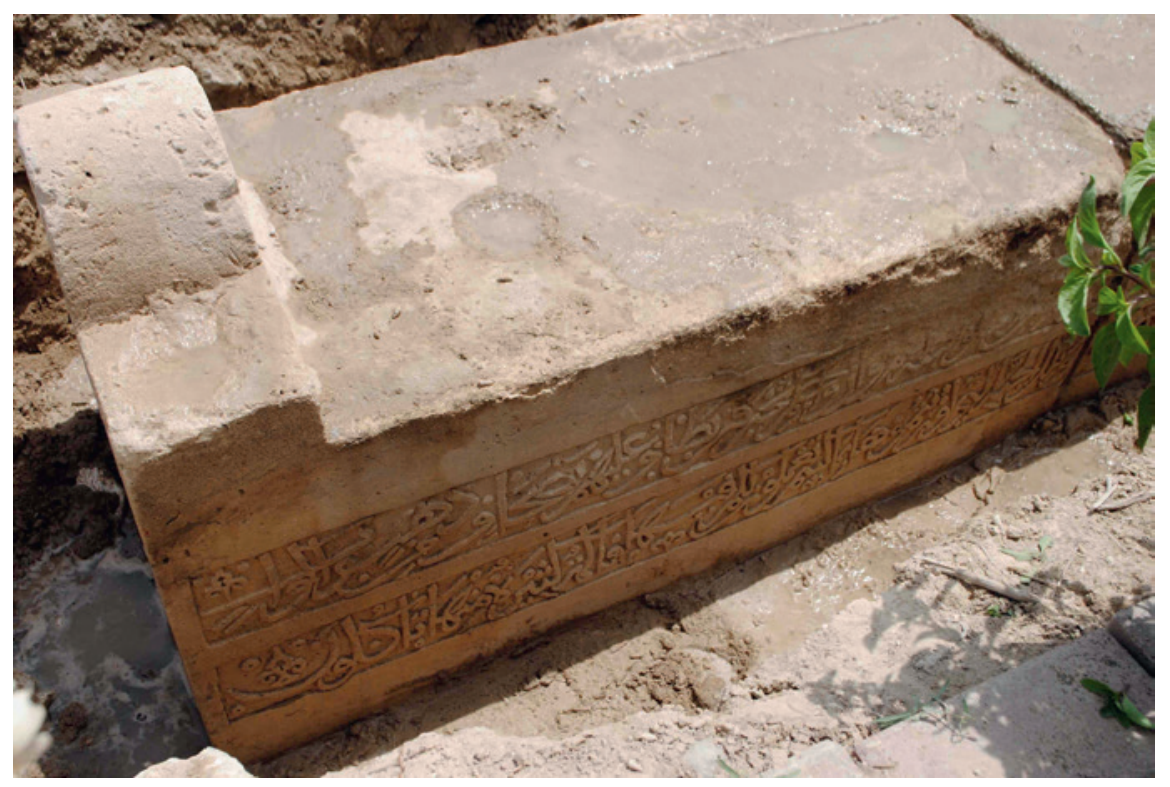

FIGURE 2.49 Surface A, part 2, ABN11 
B:

- In the Name of Allah, the Most Gracious, the Most Merciful. Their Lord gives them glad tidings of Mercy from Him, and His being pleased, and Gardens for them wherein are everlasting delights. They will dwell therein forever. Verily, with Allah is a great reward (9:21-22).

- Eden Paradise, which they shall enter and those who acted righteously from among their fathers, and their wives, and their offspring. And angels shall enter unto them every gate. Peace is upon you for you persevered in patience! Excellent indeed is the final home (13:23-24).

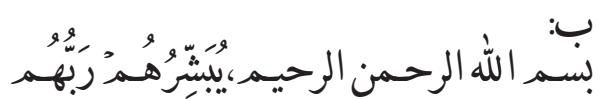
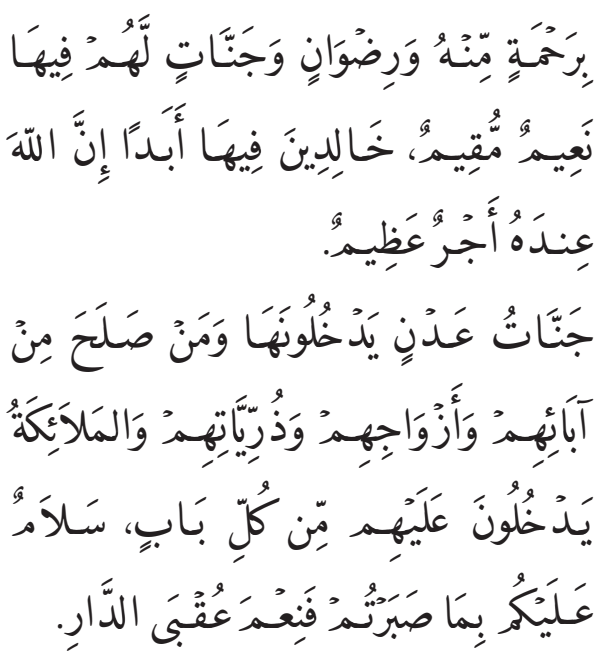

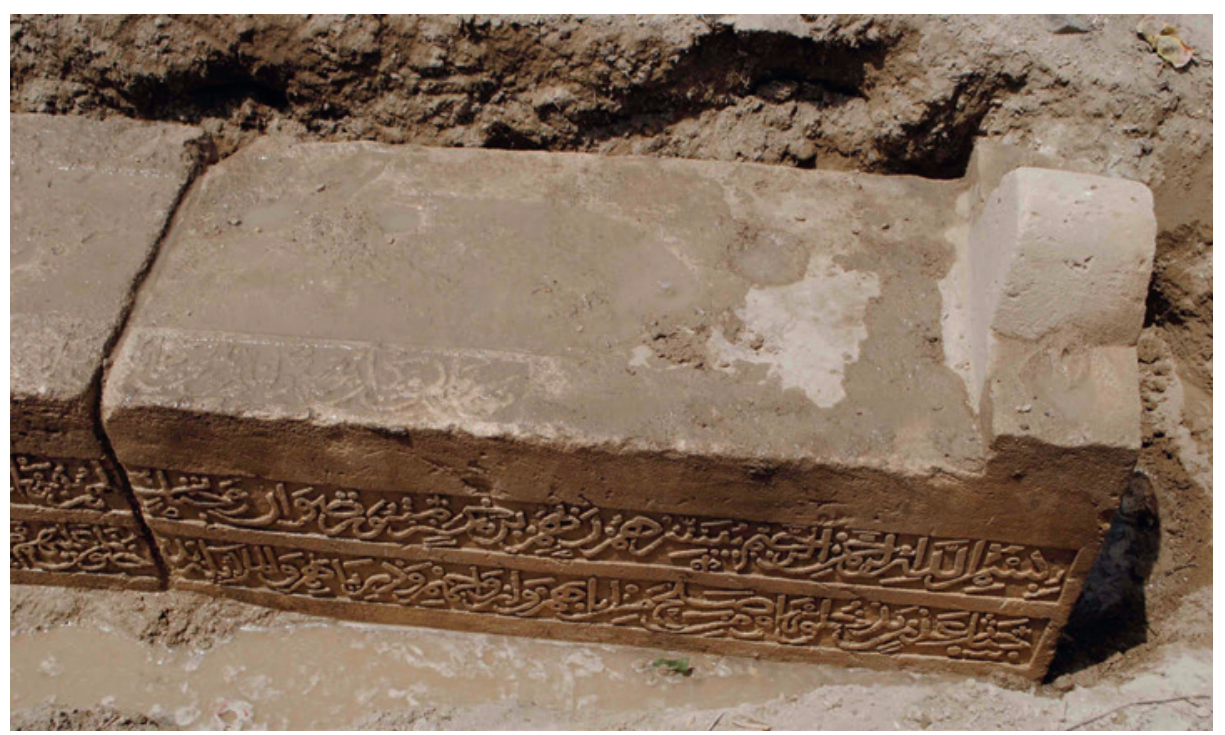

FIGURE 2.50 Surface B, part 1, ABN11 


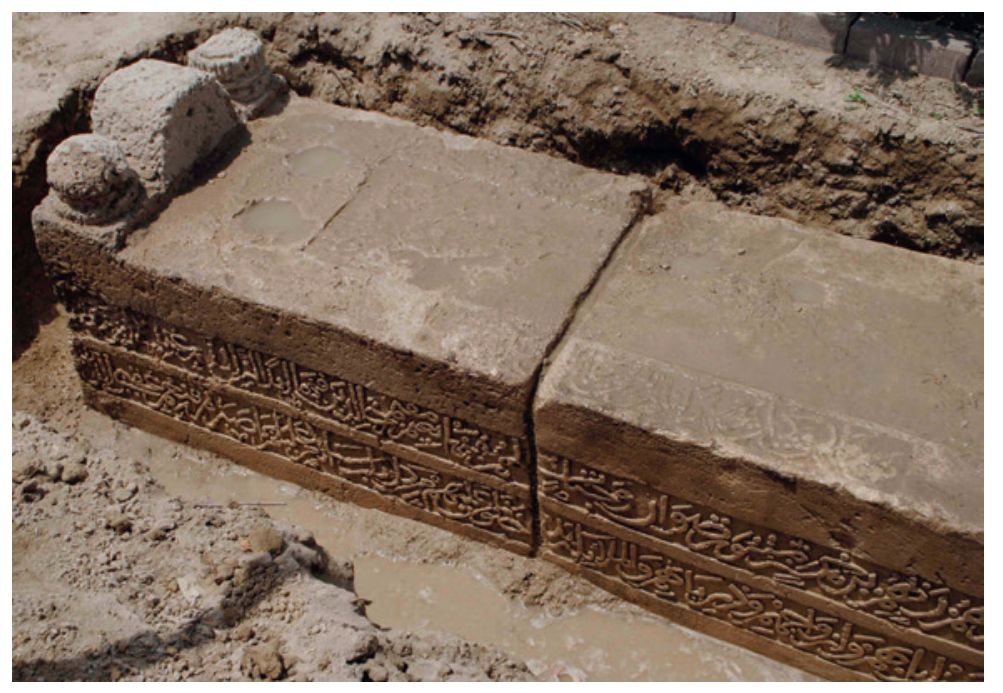

FIGURE 2.51

Surface B,

part 2, ABN11

C:

- Whatsoever is on the earth will perish ... (55:26)

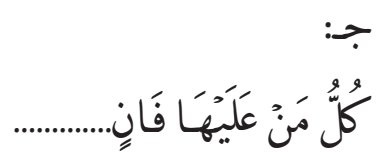

- ... part ... day ... From ... The Great ...
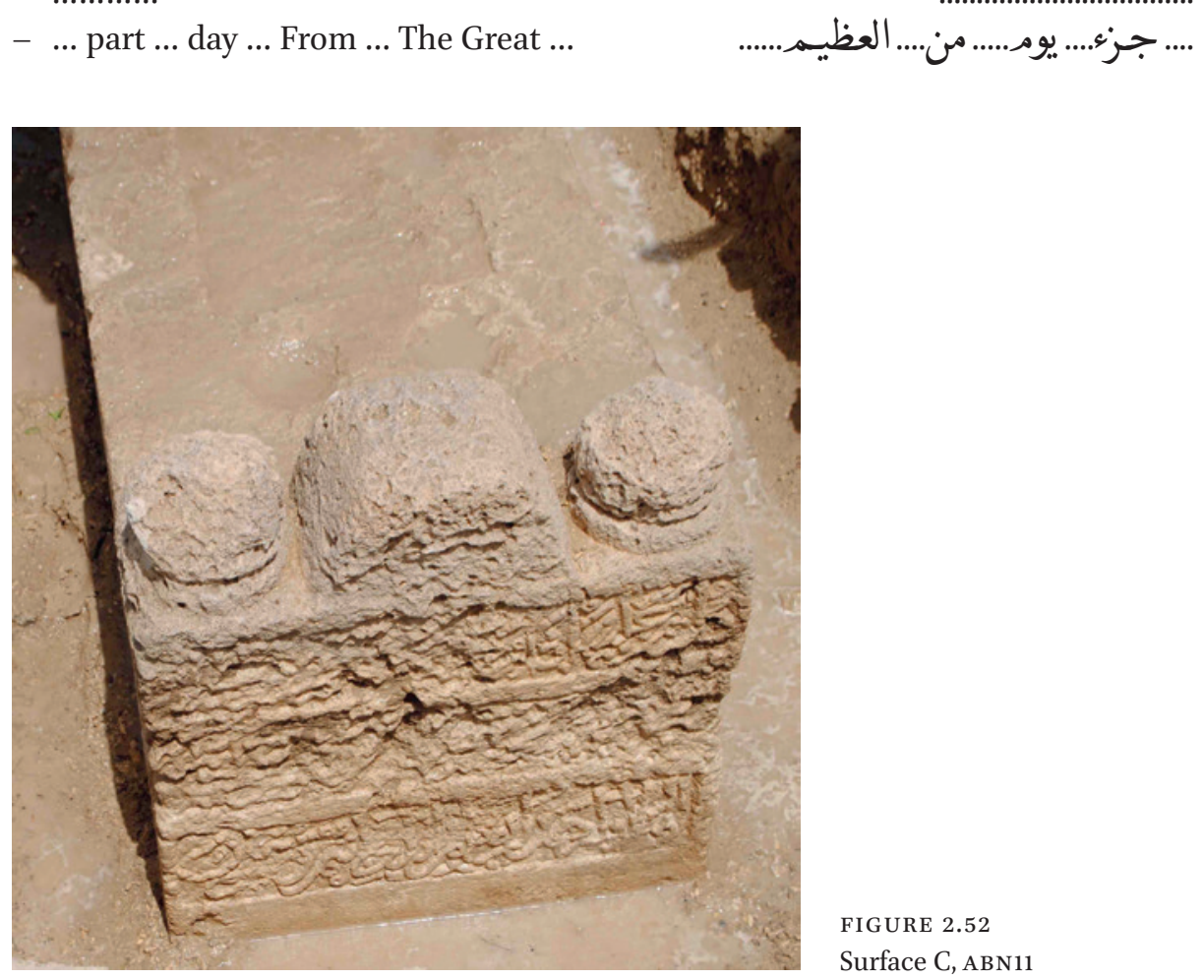

FIGURE 2.52

Surface C, ABN11 
D:

- The blessed late, God enlighten his shrine.

- He lived twenty-four years.

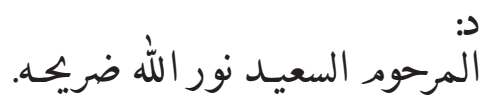

- This is the shrine of the honoured and blessed late.

\section{عـاث اربعـة وعشـرون سنة.}

هذا ضريك الصـدر المعظم المرحوم السعبـد.

- The pride of life and the Day of Reckoning 'Ali the son of the great leader. The pride

زين الدنيا والدين علي .ن المولى المعظم

زن

- Of life and Day of Reckoning Muhammad bin Ahmad Bin Sacid bin Ma'ali.

الد نيـا والدين محمد بن احمـل بن سعيـد بن

- Died in thirteenth of Jumada alakhar, seven hundred and seven.

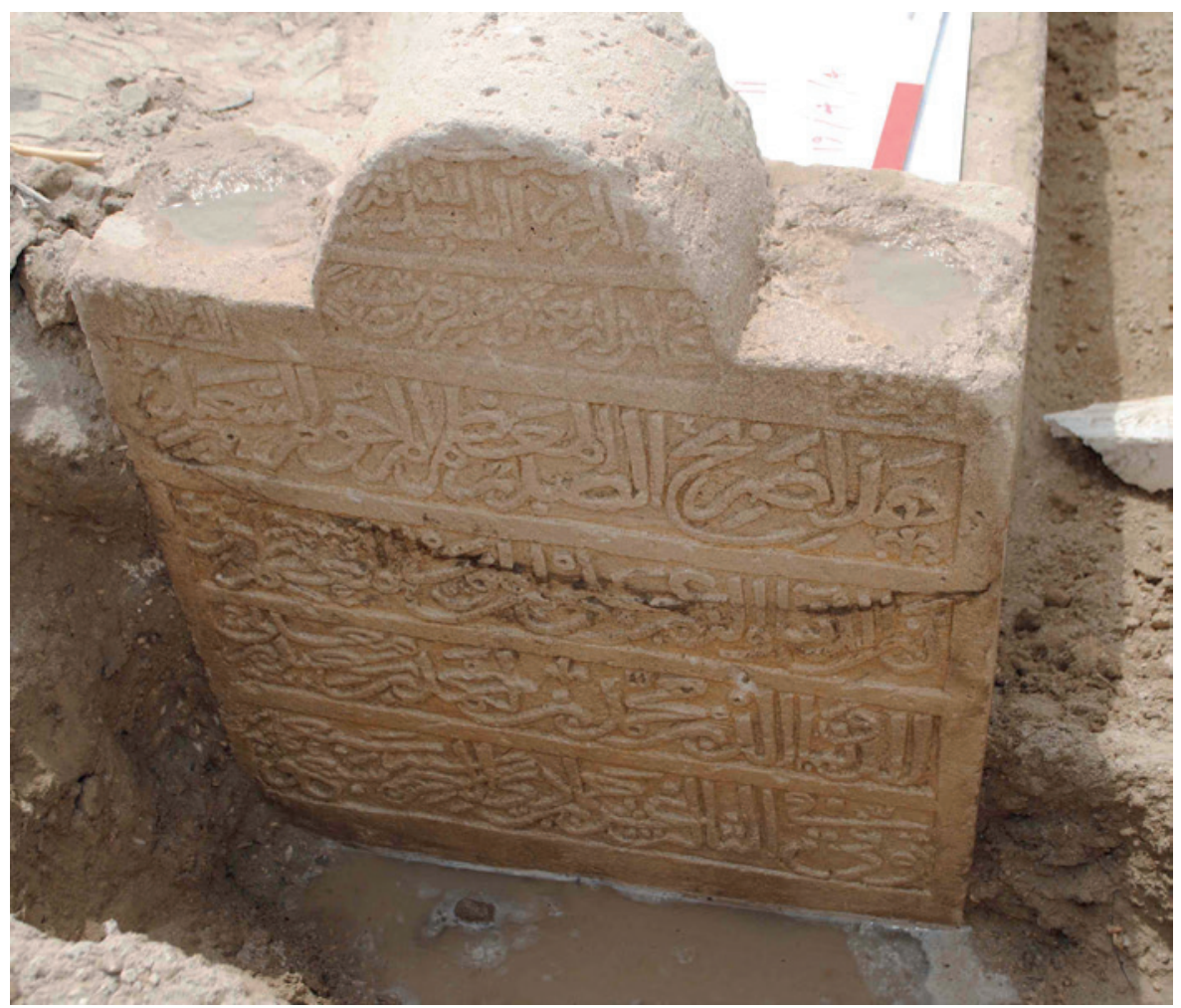

FIGURE 2.53 Surface D, ABN11 
E:

... every Tuesday ... should be read ...
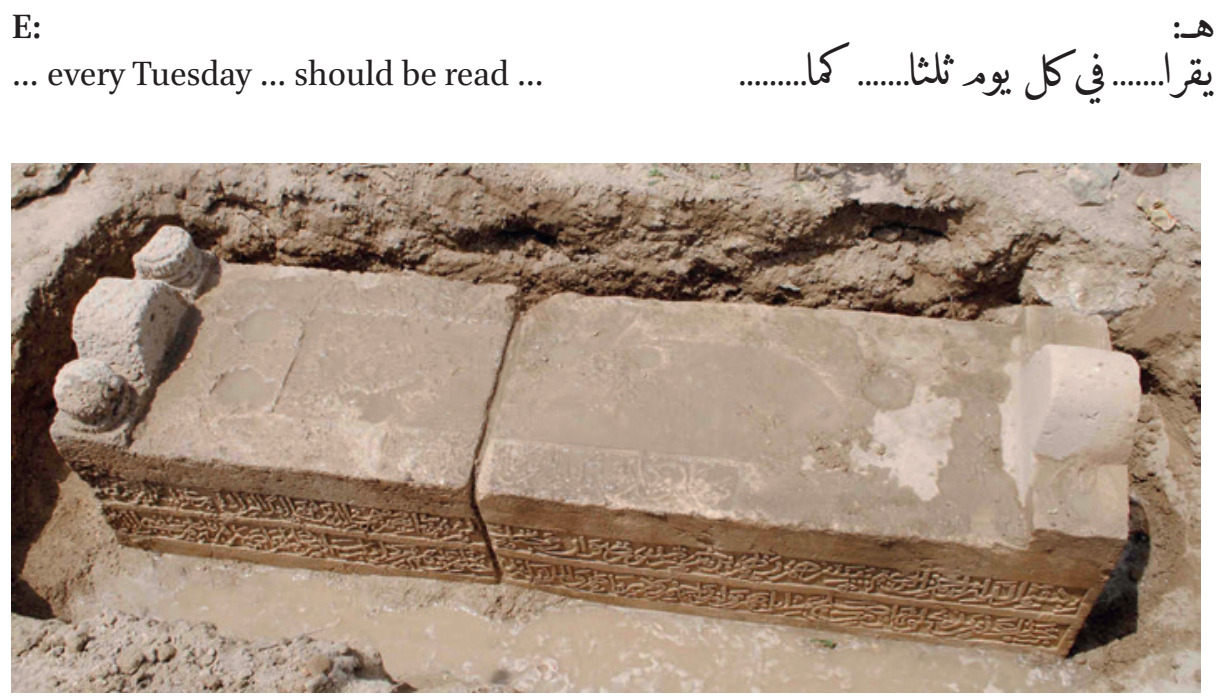

FIGURE 2.54 Surface E, ABN11

\section{Reference Number: ABN12}

Co-ordinates: $26.21063^{\circ} \mathrm{N} 05^{0.55135^{\circ} \mathrm{E}}$

\section{Dimensions:}

Slab 1: $62 \mathrm{~cm}(\mathrm{l}) \times 31 \mathrm{~cm}(\mathrm{w}) \times 36 \mathrm{~cm}(\mathrm{~h})$ Slab 2: $67 \mathrm{~cm}(\mathrm{l}) \times 31 \mathrm{~cm}(\mathrm{w}) \times 33 \mathrm{~cm}(\mathrm{~h})$

\section{Orientation: NW-SE}

Description: Gravestone formed of two limestone slabs. Badly eroded. No inscriptions. Near excavated collapsed mosque containing ABN47. The two blocks were separated and uniquely, indicated the use of a mortise and tenon type joint to join the two slabs of the gravestone (Figure 2.55). Traces of a shallow carved rectangular panel design, probably a niche, on the upper surface (E). Three element eroded raised decoration at each end that appears to be formed of two facetted cubes and a central rounded arch. 


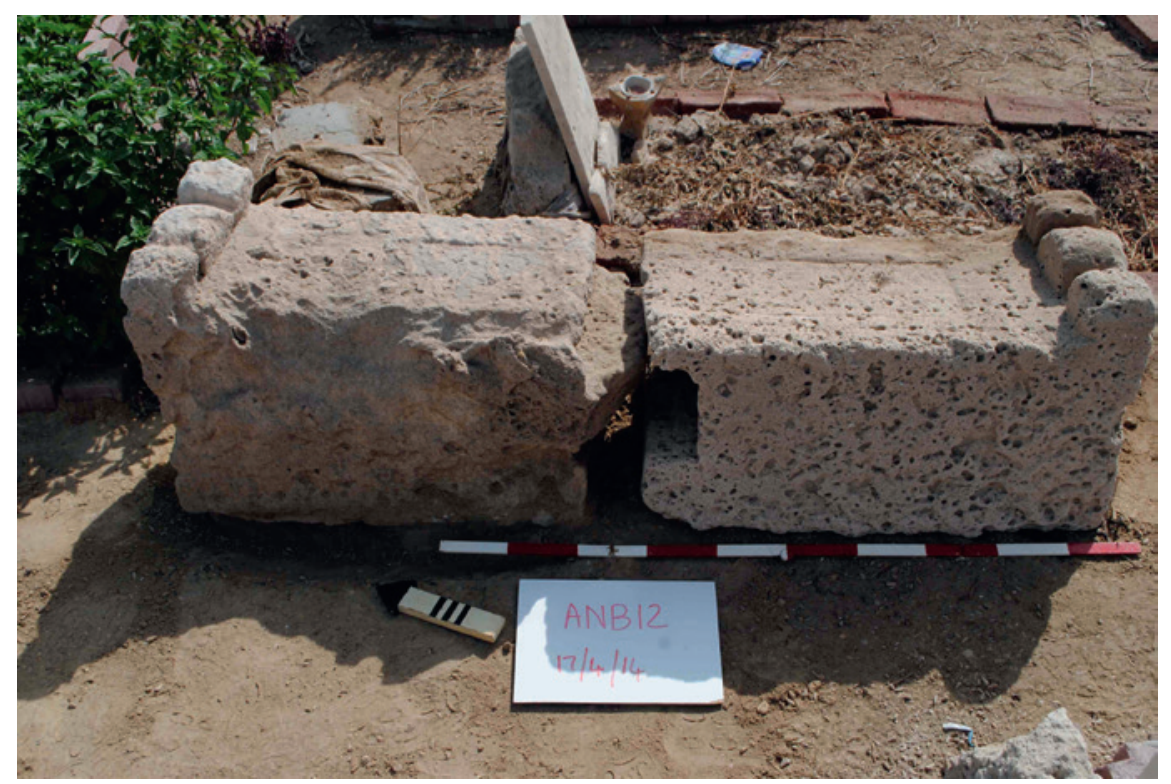

FIGURE $2.55 \quad$ ABN12

Arabic Transcription and Translation: No inscriptions

Reference Number: ABN13

Co-ordinates: $26.21011^{\circ} \mathrm{N} 050.55087^{\circ} \mathrm{E}$

\section{Dimensions:}

Slab 1: $5^{6} \mathrm{~cm}(\mathrm{l}) \times 28 \mathrm{~cm}(\mathrm{w}) \times 31 \mathrm{~cm}(\mathrm{~h})$

Slab 2: $87 \mathrm{~cm}(\mathrm{l}) \times 28-29 \mathrm{~cm}(\mathrm{w}) \times 30 \mathrm{~cm}(\mathrm{~h})$

Orientation: West north west (WNW) to East south east (ESE)

Description: Gravestone formed of two limestone slabs. Gap between the two slabs indicates that they are solid (Figure 2.56). Shallow carved rectangular panel, probably a niche, on the upper surface (E) on one slab, and traces of its continuation on the other slab. Fine but eroded three element raised decoration formed of two decoratively carved facetted cubes with a central rounded arch all set on a rectangular plinth at each end. No inscriptions. 


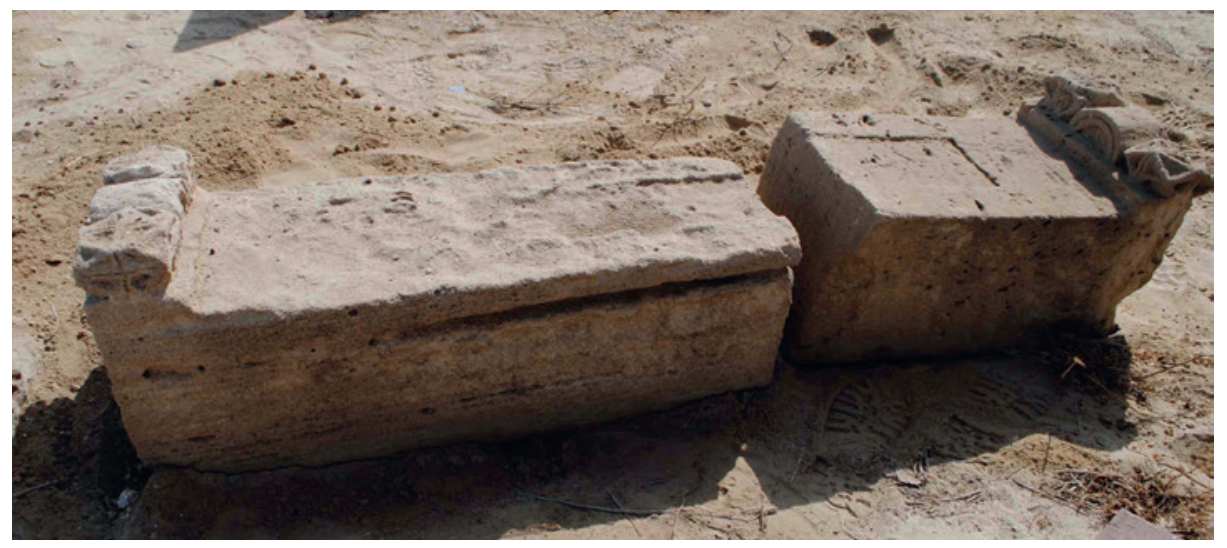

FIGURE 2.56 ABN13

Arabic Transcription and Translation: No inscriptions

\section{Reference Number: ABN14}

Co-ordinates: $26.21013^{\circ} \mathrm{N} 050.55082^{\circ} \mathrm{E}$

Dimensions: $81 \mathrm{~cm}(\mathrm{l}) \times 26-27 \mathrm{~cm}(\mathrm{w}) \times 30 \mathrm{~cm}(\mathrm{~h})$

\section{Orientation: NW-SE}

Description: Single limestone slab gravestone. Half of a double slab gravestone. Badly eroded and appears to have been drilled down one side surface (A). Eroded unidentifiable raised decoration at one end. Partially legible inscriptions on three surfaces.

\section{Arabic Transcription and Translation:}

A:

- The forgiven, the greatest and the blessed late ...

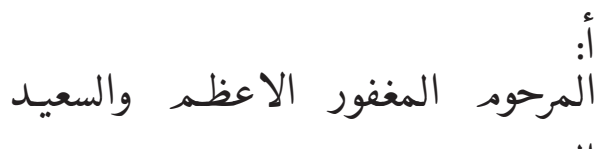

- ... Paradise fair females 'Ali bin Mansur Bin Kamal al-Din ... Safar ... Year four.

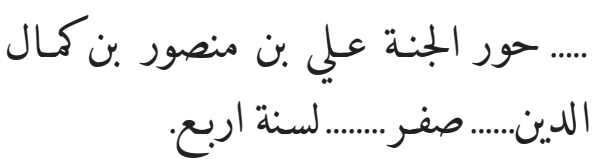




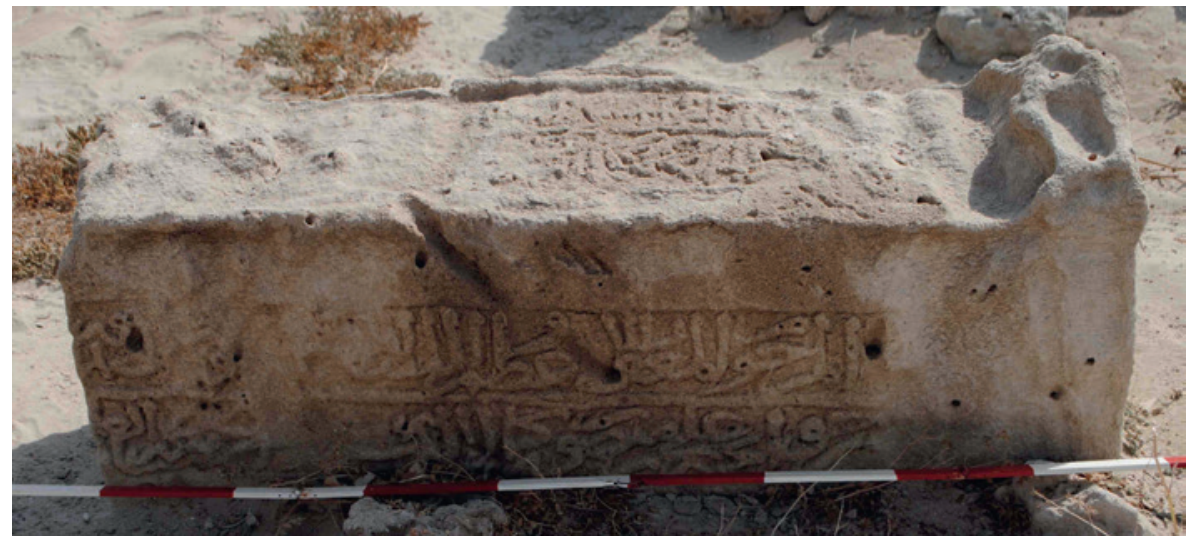

FIGURE 2.57 Surface A, ABN14

B:

- ... praise be to Allah
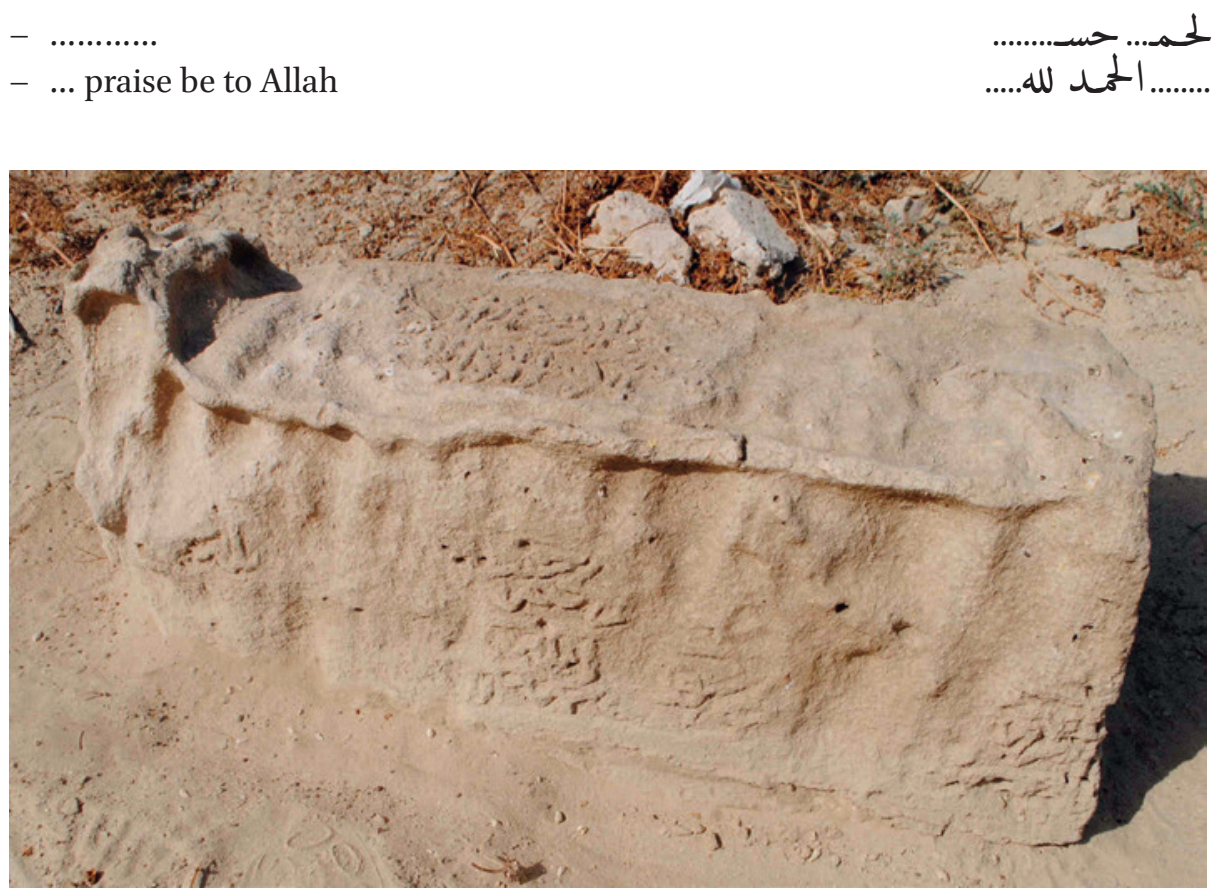

FIGURE 2.58 Surface B, ABN14 
C:

- No carving or inscriptions.

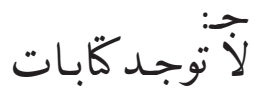

D:

- No carving or inscriptions.

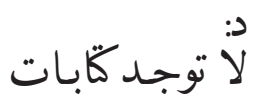

E:

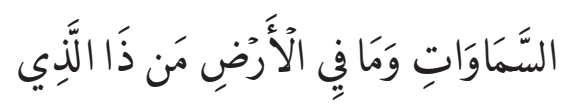
earth. Who is he that ...

- ... His seat extends over the heavens and the earth, and He feels no fatigue ... (2:255)
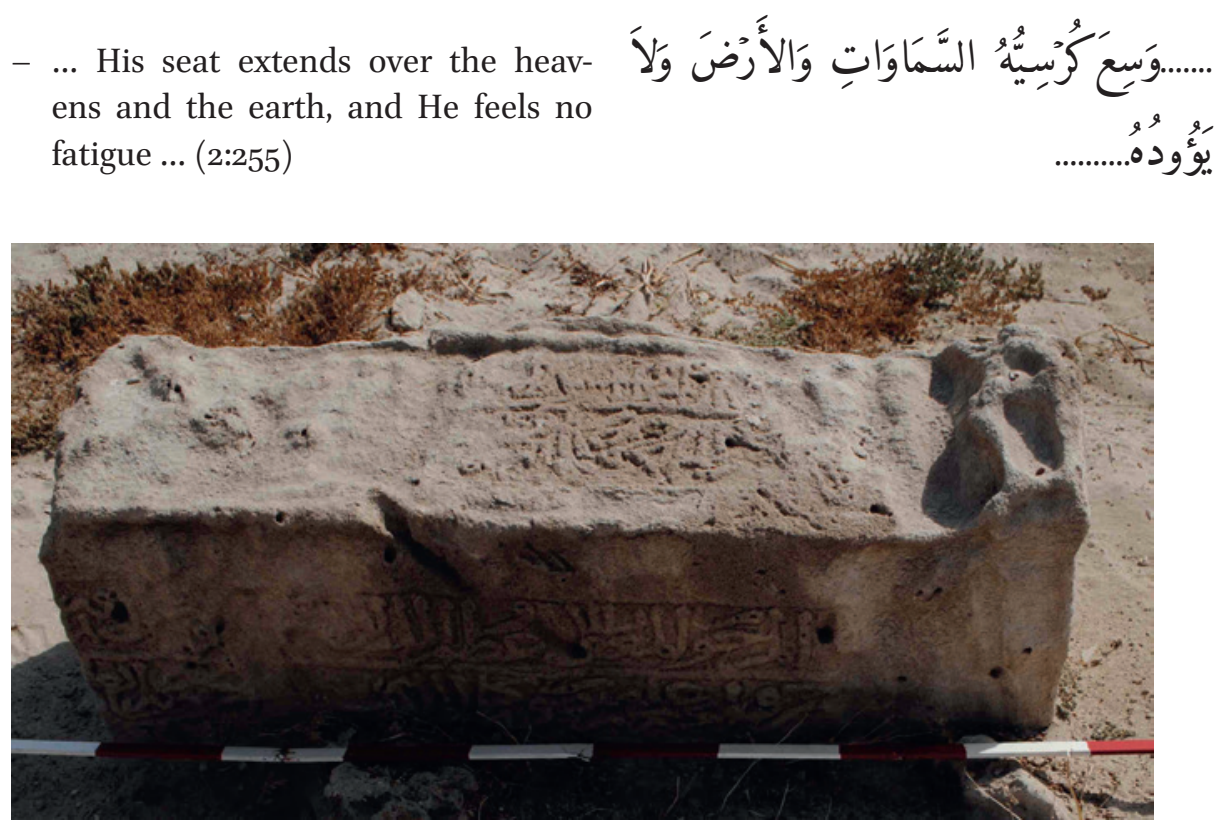

FIGURE 2.59 Surface E, ABN14

\section{Reference Number: ABN15}

Co-ordinates: $26.21071^{\circ} \mathrm{N} 050.55110^{\circ} \mathrm{E}$

Dimensions: $132 \mathrm{~cm}(\mathrm{l}) \times 28.5 \mathrm{~cm}(\mathrm{w}) \times 32 \mathrm{~cm}(\mathrm{~h})$

\section{Orientation: NW-SE}

Description: Single limestone slab gravestone (next to ABN16). Well carved and in good condition. Three element raised decoration formed of two facetted cubes and a central rounded arch all set on a rectangular plinth at each end. Shallow carved pointed niche design on the upper surface (E). Inscriptions on five surfaces. 
Arabic Transcription and Translation:

A:

- In the Name of Allah, the Most Gracious, the Most Merciful. Allah, none has the right to be worshipped but he, the Ever Living, the One Who sustains and protects all that exists. Neither slumber nor sleep overtakes Him. To Him belongs whatever is in the heavens and whatever is on the earth. Who is he that can intercede with Him.

- Except by His permission! He knows what happens to them in this world, and will happen to them in the Hereafter and they will never compass anything of His Knowledge except that which He wills. His Seat extends over the heavens and the earth, and $\mathrm{He}$ feels no fatigue in guarding and preserving them. He is

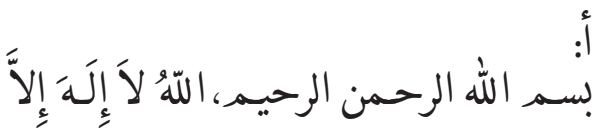

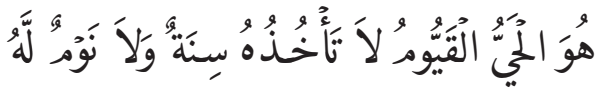

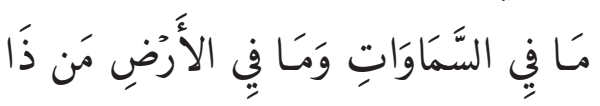

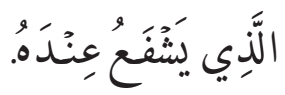
the Most High and the Most Great (2:255). Thanks be to Allah ...
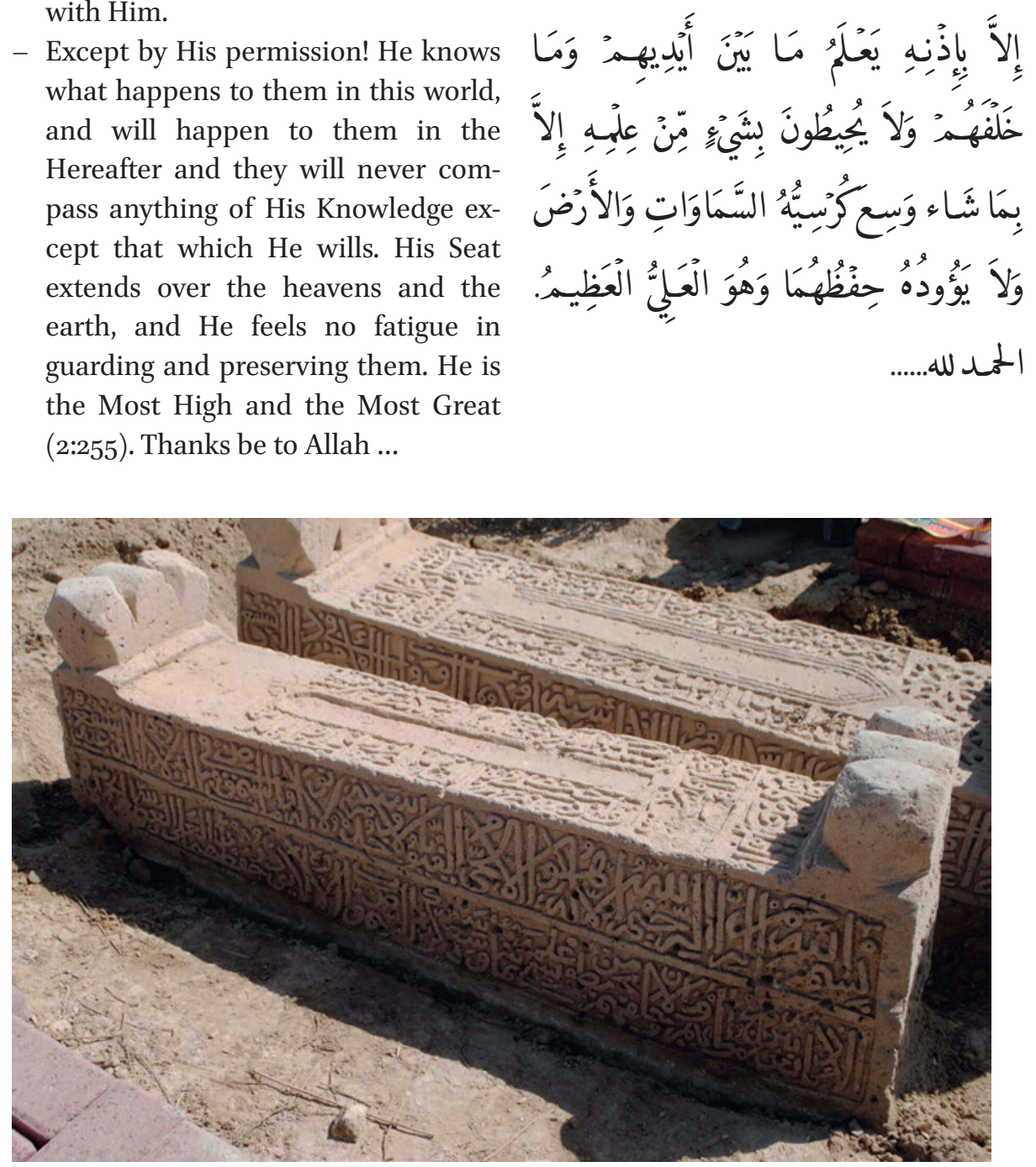

FIGURE 2.60 Surface A, ABN15 
B:

- The angels will descend on them, (saying:) Fear not, nor grieve; But receive the glad tidings of Paradise which you have been promised. We have been your friends in the life of this world and in the Hereafter (41:30-31).

- ... gives them glad tidings ... and His being pleased and of Gardens for them wherein are everlasting delights (9:21).
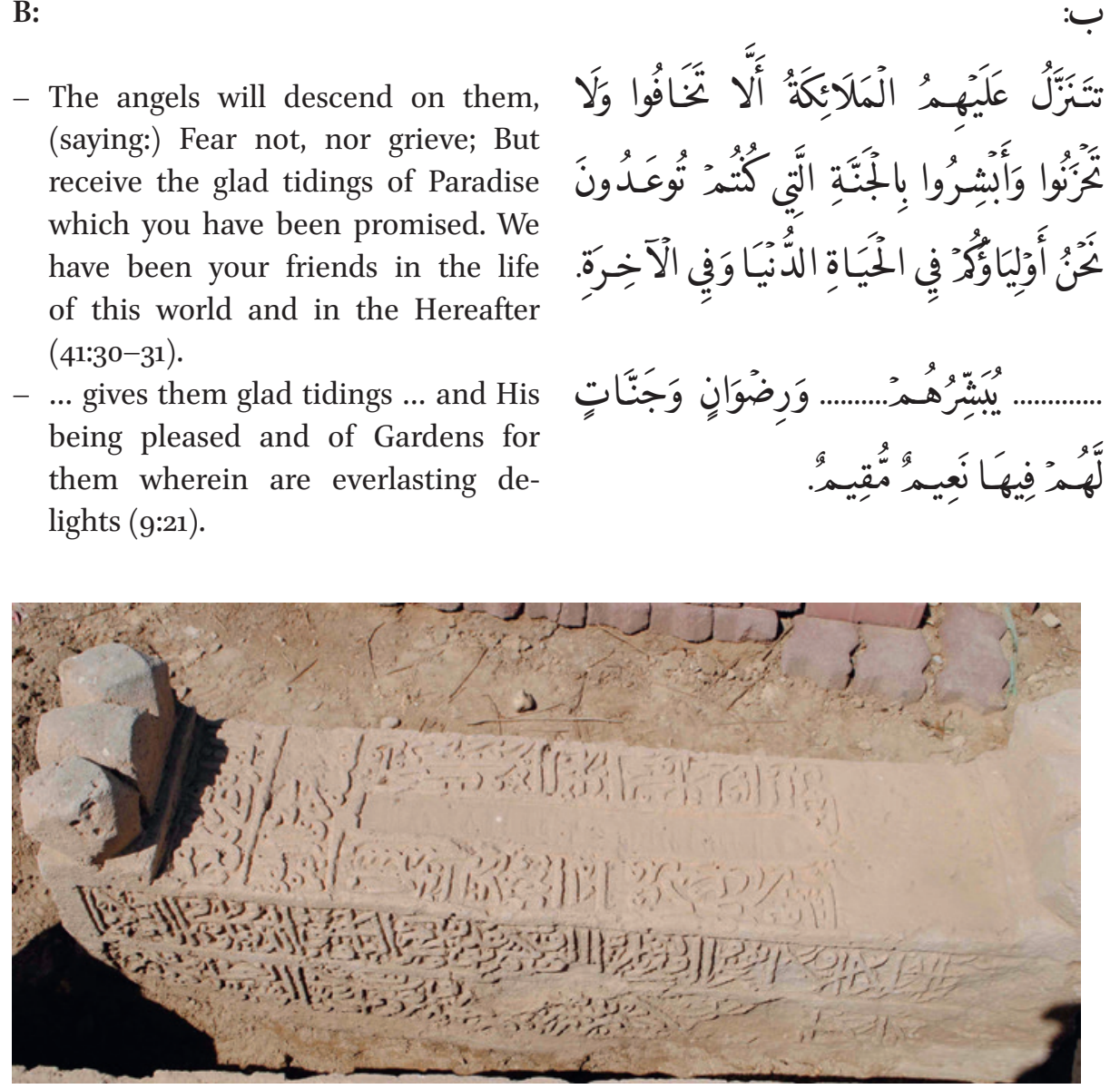

FIGURE 2.61 Surface B, ABN15

C:

- It is the place of the Noble Man.

- The blessed, Hasan bin al-Sayyid Abdullah bin Hasan.

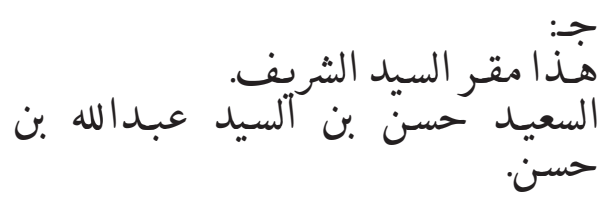




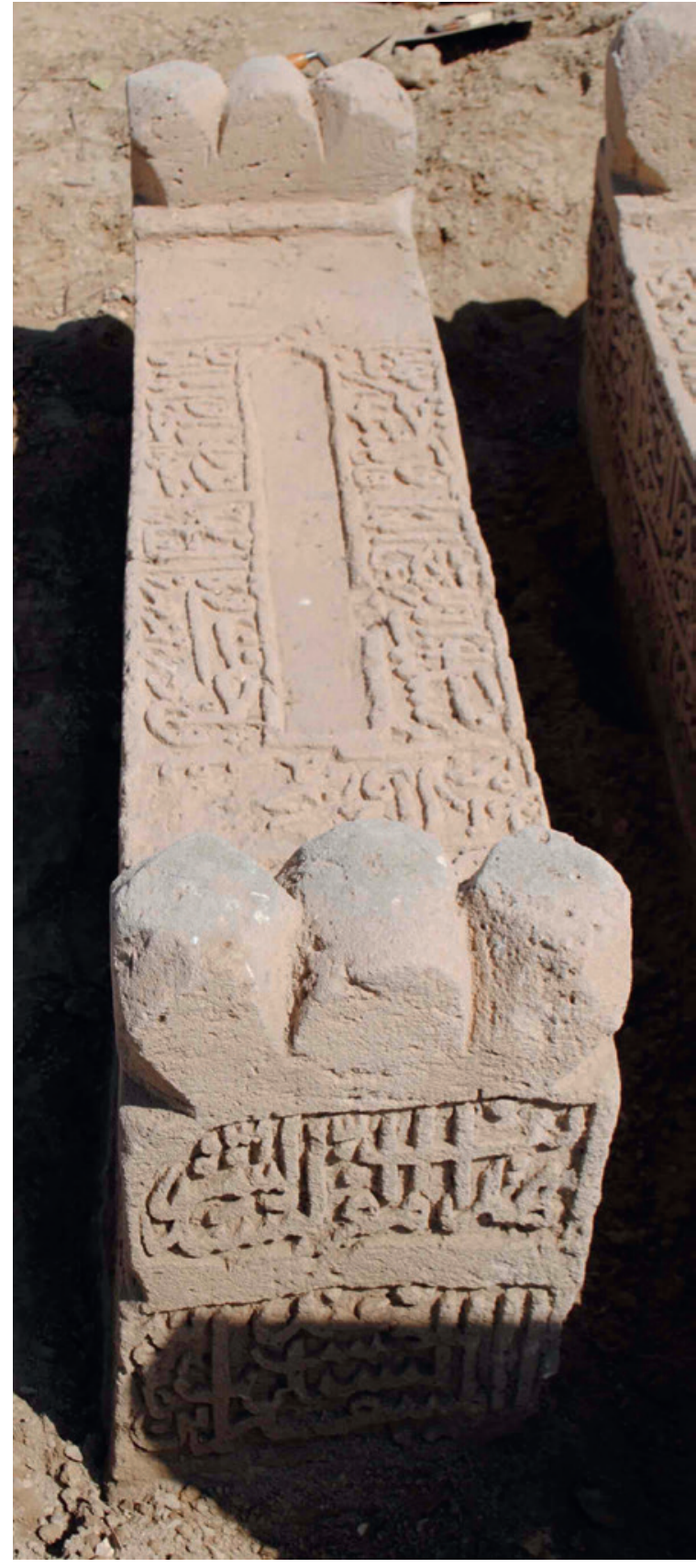

D:

- Died in sixteen

- Of the Rabic al-thani
FIGURE 2.62

Surface C, ABN 15

$$
\text { توفي يوم السادس. }
$$




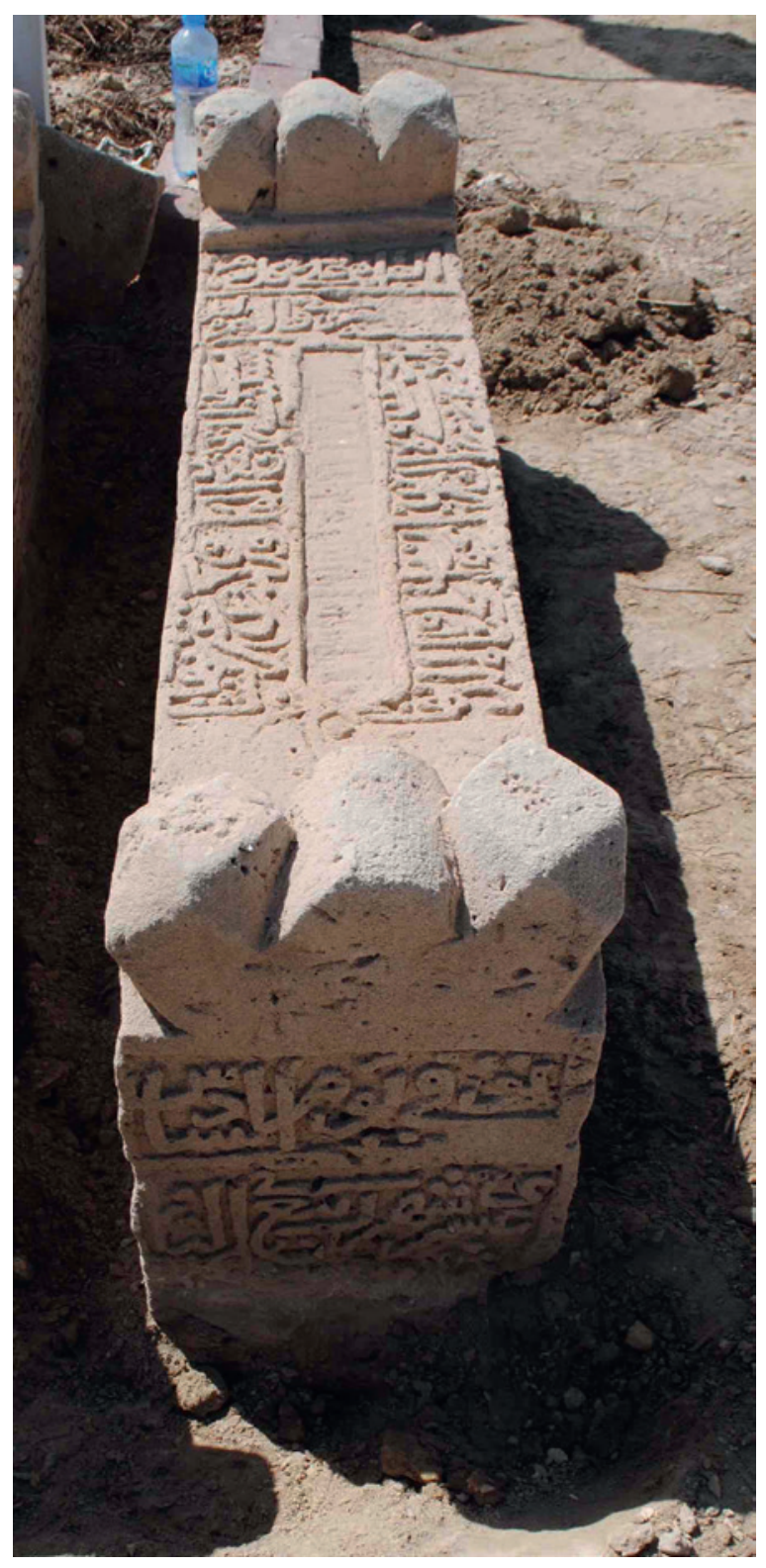

FIGURE 2.63

Surface D, ABN15

E:

- Reading on his grave every day.

هـ: القـراه (القـراءة)على قبره كل .يوم.

- ... its ... part ... in ...

...... نفسـ.... حرزب..... في.... والاجـره لطو.

- You lived in the soil with glad people سكتت التراب مـع الهانــن وقد كتت while you were one of the best youth. 
- And you have been included with the winners of paradise fair females and young servants.
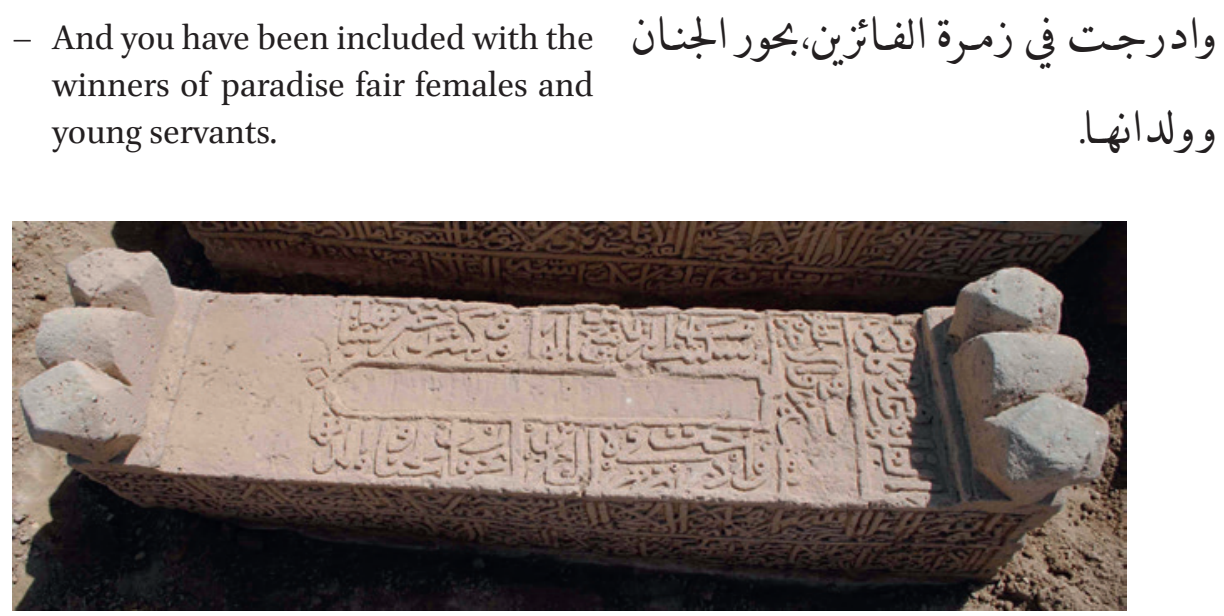

FIGURE 2.64 Surface E, ABN15

Reference Number: ABN16

Co-ordinates: $26.21072^{\circ} \mathrm{N} 050.55110^{\circ} \mathrm{E}$

Dimensions: $15^{2} \mathrm{~cm}(\mathrm{l}) \times 41 \mathrm{~cm}(\mathrm{w}) \times 41 \mathrm{~cm}(\mathrm{~h})$

\section{Orientation: NW-SE}

Description: Single limestone slab gravestone (next to ABN15). Well carved and in good condition. Three element raised decoration formed of two facetted cubes and a central rounded arch all set on a rectangular plinth at each end. Shallow carved pointed niche design on the upper surface (E) with triple lines used to delineate the outline. Inscriptions on five surfaces.

\section{Arabic Transcription and Translation:}

A:

- In the Name of Allah, the Most Gracious, the Most Merciful. Allah, there is no deity but he, the Ever Living, the One Who sustains and protects all that exists. Neither slumber nor sleep overtakes Him. To Him belongs whatever is in the heavens and whatever is on the earth. Who is

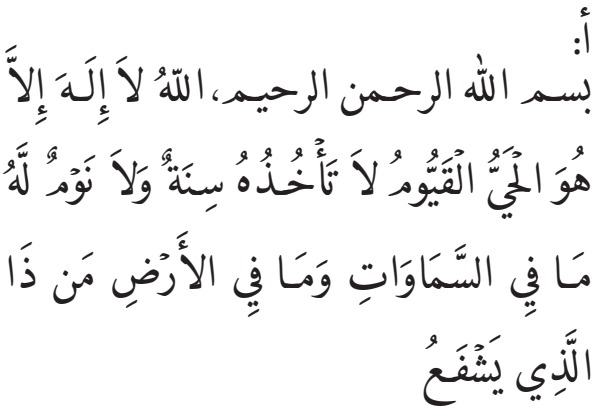
he that can intercede 
- with Him except by His permission! He knows what happens to them in this world, and will happen to them in the Hereafter and they will never compass anything of His Knowledge except that which He wills. His Seat extends over the heavens and the earth, and He feels no fatigue in guard-

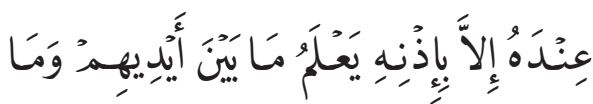

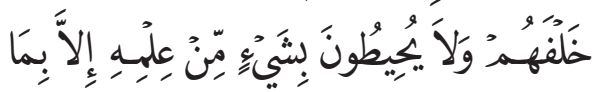

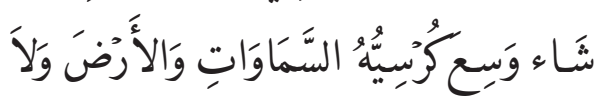

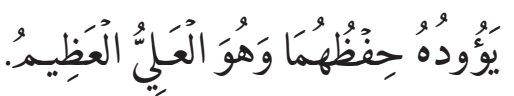
ing and preserving them. And $\mathrm{He}$ is the Most High, the Most Great (2:255).

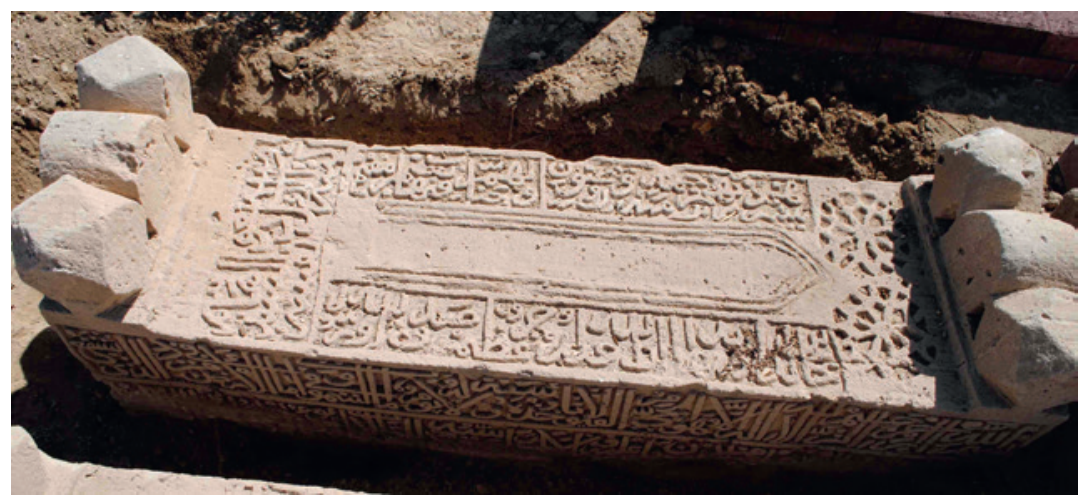

FIGURE 2.65 Surface A, ABN16

B:

- The angels will descend on them, (saying:) Fear not, nor grieve; But receive the glad tidings of Paradise which you have been promised. We have been your friends in the life of this world and in the Hereafter. Therein you shall have

- all that your souls desire and all that you ask for, as hospitality from One, the Forgiving, the Most Merciful (41:3032). Gardens of Eden whose gates will be opened for them. Therein they will recline, therein they will call for fruits in abundance and drinks. And beside them will be maidens of equal age with modest gaze $(38: 50-52)$.

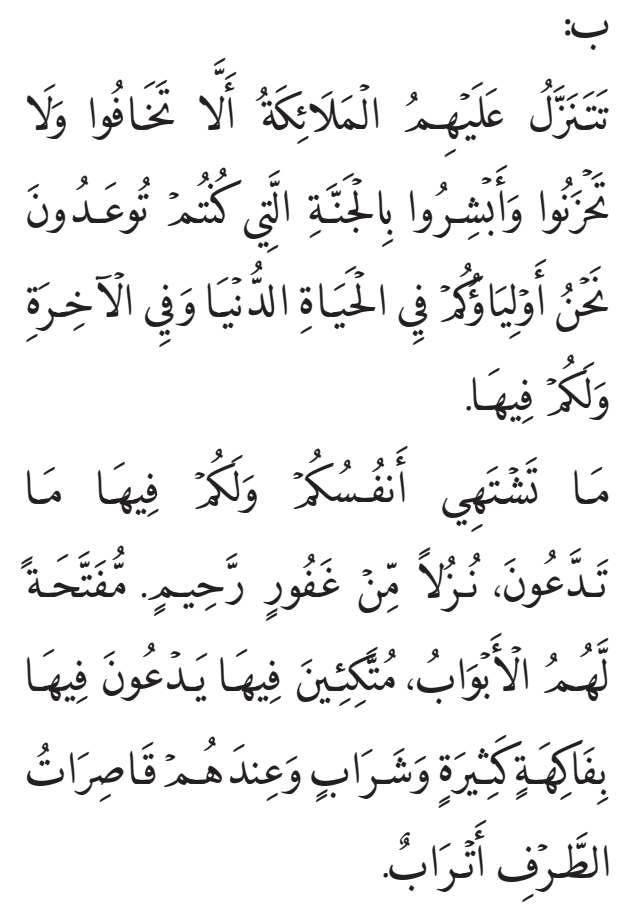




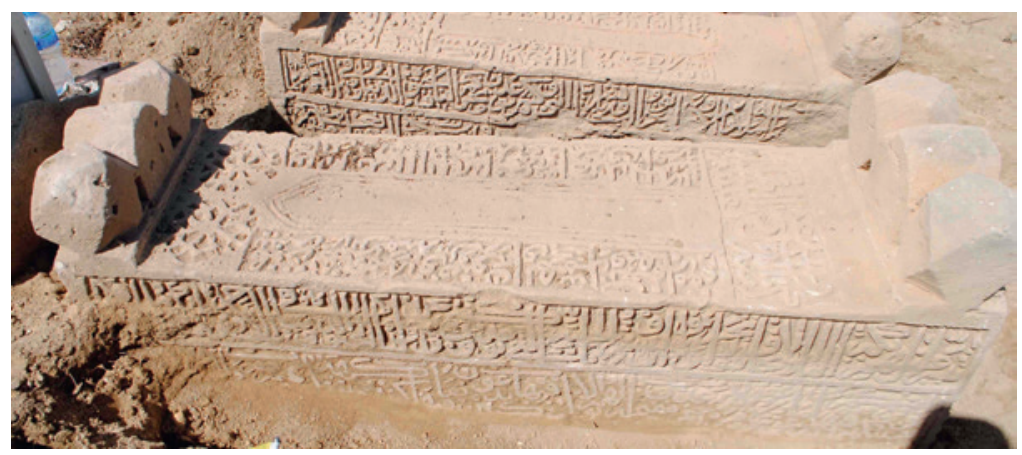

FIGURE 2.66

Surface B,

ABN16

C:

- This is the grave of the noble Hajj Haji

- bin Muhammad bin Husayn bin Naser al-Khutay, May Allah have mercy on him
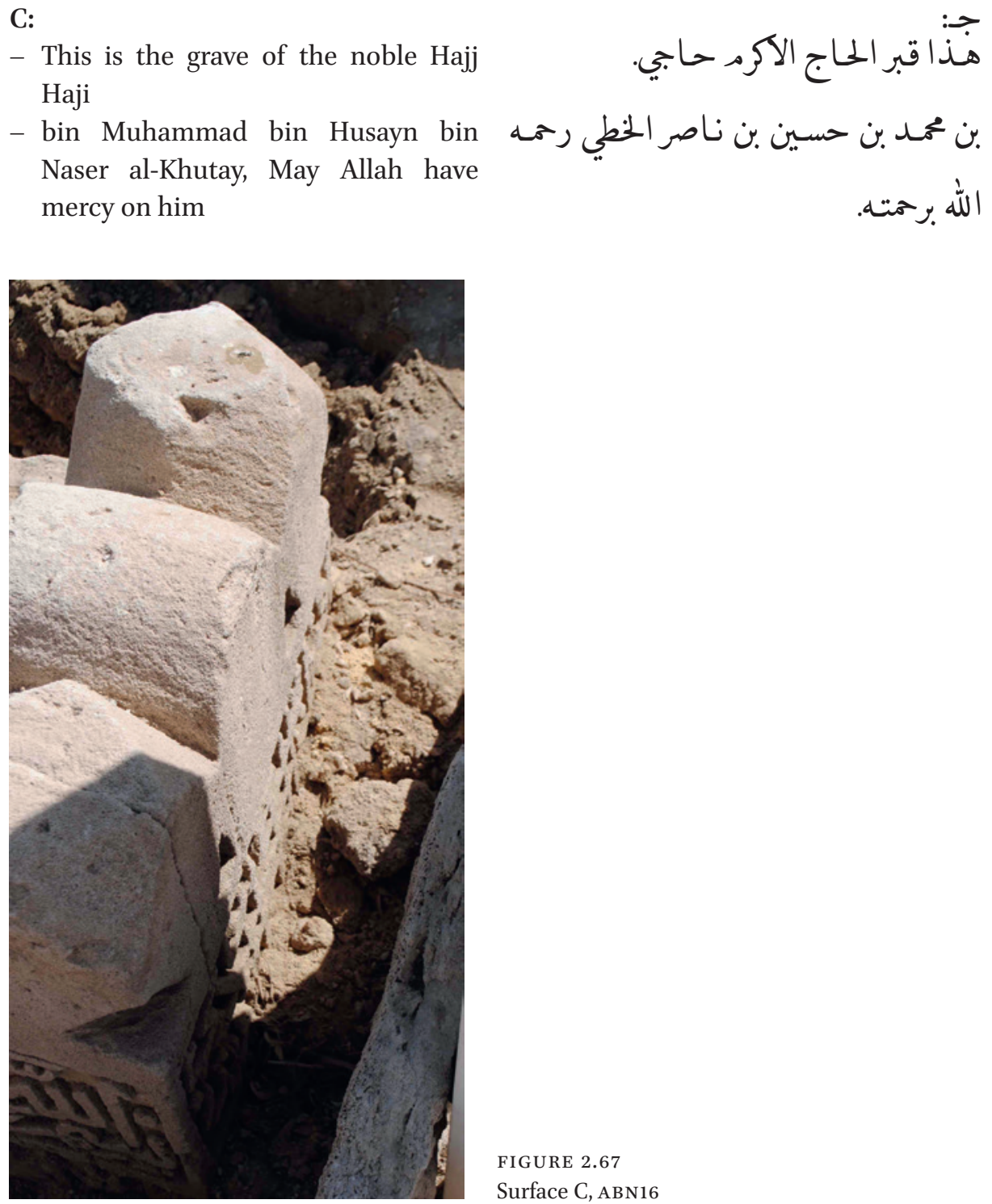

FIGURE 2.67

Surface C, ABN16 
D:

- Died in nineteenth of

$$
\text { دوفئ يوم التاسع عشر من شهر. }
$$
- Rabic al-thani, One thousand and ربيع الثاني من سنة سبع والاربعـن
forty-seven

$$
\text { والالف. }
$$

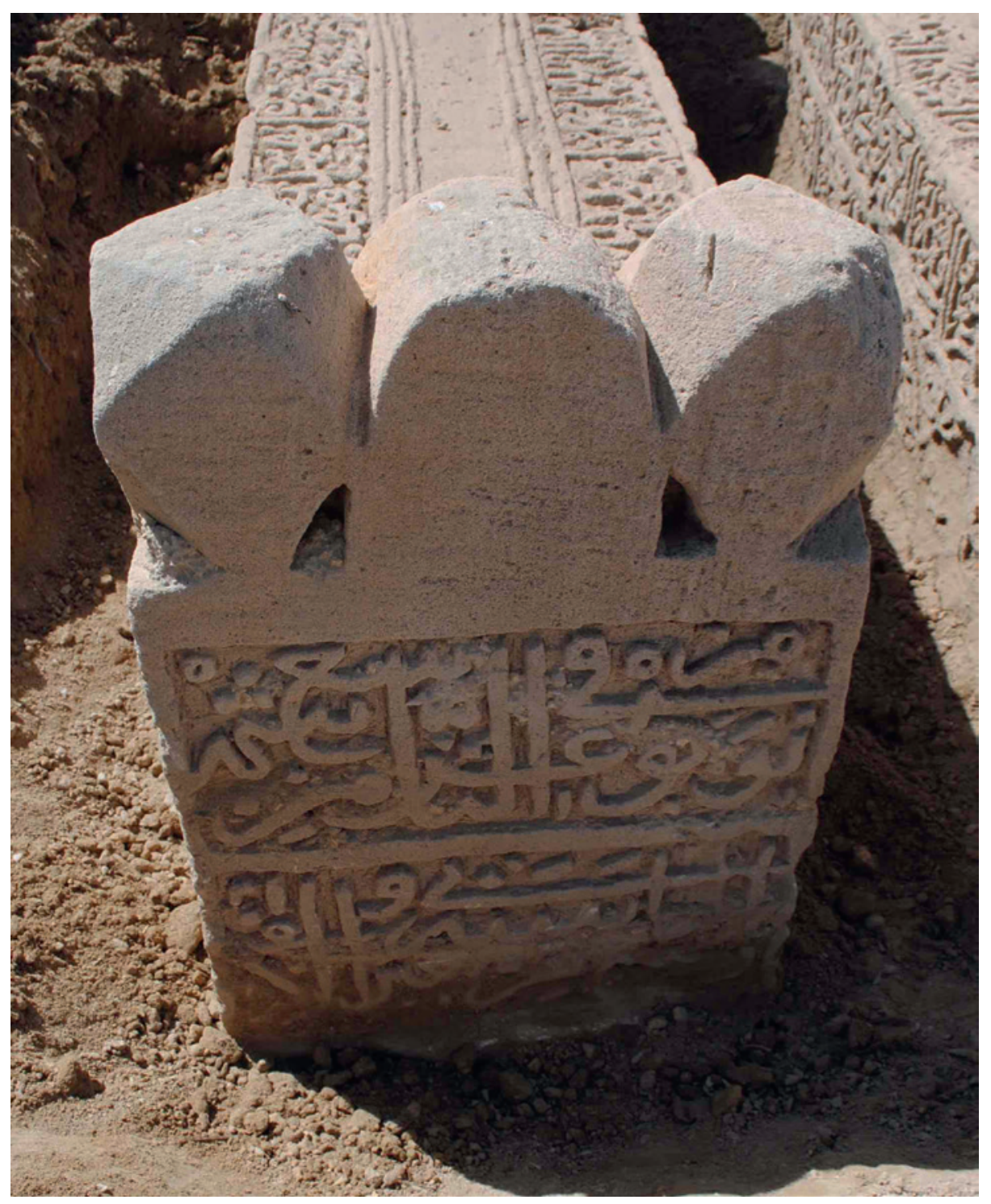

FIGURE 2.68 Surface D, ABN16 
E:

- Written by Sacud and engraved by alSayyid Hashim.

- Their Lord gives the glad tidings of Mercy from Him, and His being pleased, and of Paradise for them wherein are everlasting delights (9:21-22).

- They will dwell therein forever. Verily, with Allah is a great reward. Allah and his messenger have spoken the truth.
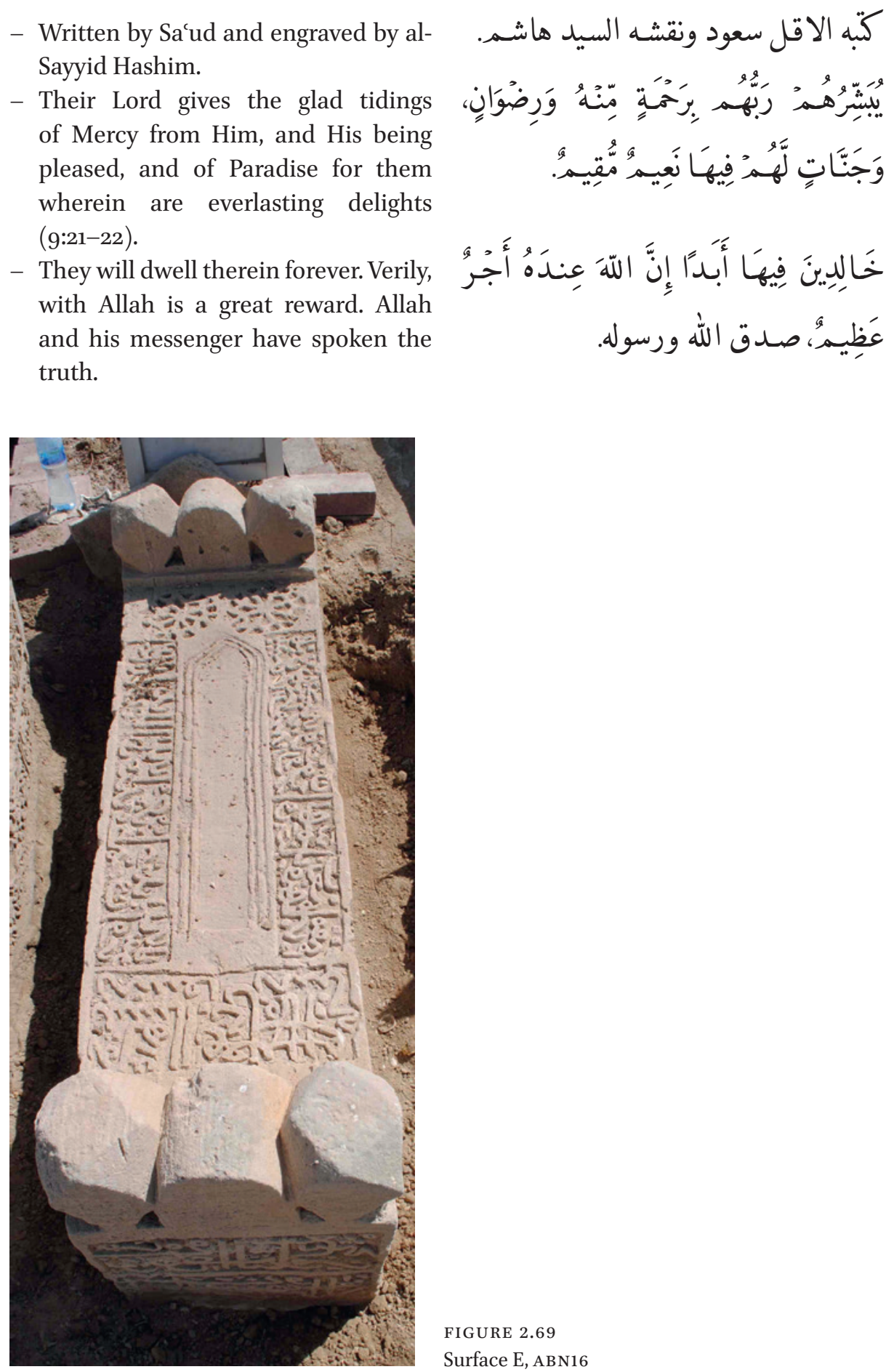

FIGURE 2.69

Surface E, ABN16 


\section{Reference Number: ABN17}

Co-ordinates: $26.21074^{\circ} \mathrm{N} 050.55112^{\circ} \mathrm{E}$

Dimensions: $146 \mathrm{~cm}(\mathrm{l}) \times 35 \cdot 5^{-37} \mathrm{~cm}(\mathrm{w}) \times 46 \mathrm{~cm}(\mathrm{~h})$

\section{Orientation: NNW-SSE}

Description: Single limestone slab gravestone (next to ABN18). No inscriptions. Cut to size and left unfinished (Figure 2.70). The unusual shape is due to the rectangular blocks that would have formed the basis of the raised decoration being half cut off at one end and completely cut off at the other end. Possible saw and chisel marks on the side surfaces (A and B).

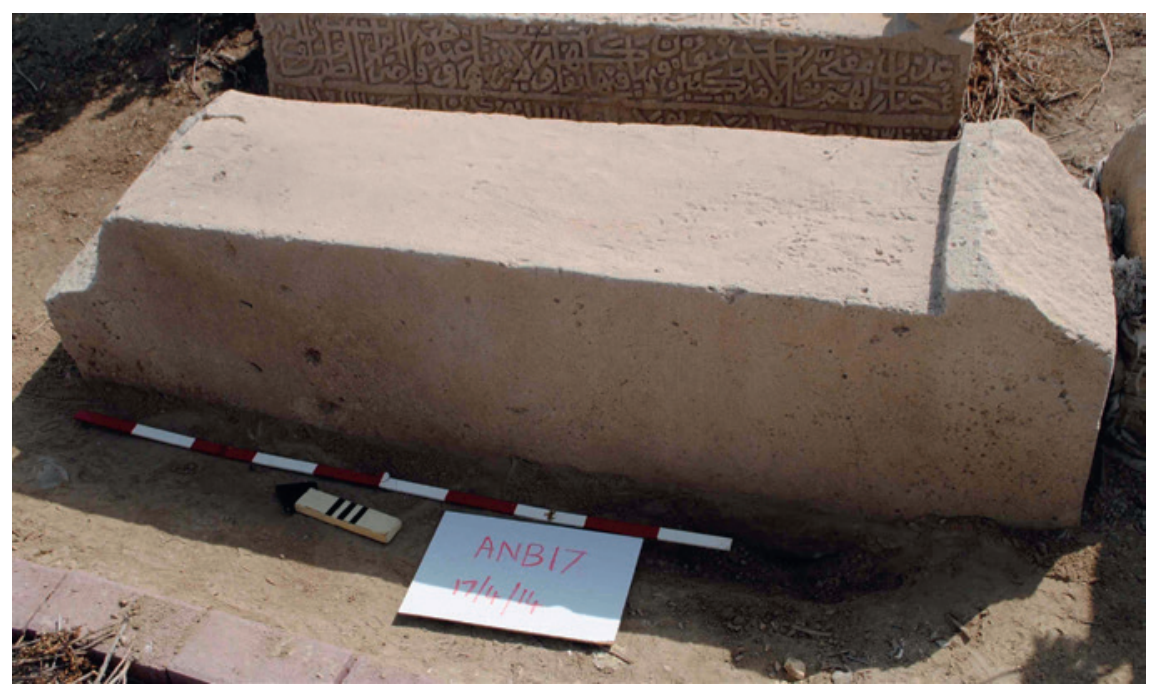

FIGURE 2.70 ABN17

Arabic Transcription and Translation: No inscriptions

Reference Number: ABN18

Co-ordinates: $26.21077^{\circ} \mathrm{N} 050.55112^{\circ} \mathrm{E}$

Dimensions: $130 \mathrm{~cm}(\mathrm{l}) \times 33 \mathrm{~cm}(\mathrm{w}) \times 38.5 \mathrm{~cm}(\mathrm{~h})$

Orientation: NW-SE 
Description: Single limestone slab gravestone. Some erosion on top. Inscriptions on five surfaces. Three element raised decoration at each end formed of two facetted cubes and a central rounded arch all set on a rectangular plinth. Shallow carved pointed niche design on the upper surface (E).

\section{Arabic Transcription and Translation:}

A:

- The Gardens of Eden whose doors will be opened for them. Therein they will recline, therein they will call for fruits in abundance and drinks. And beside them will be chaste females restraining their glances only for their husbands, and of equal ages ... (38:50-52)

- The angels will descend on them, (saying:) 'Fear not, nor grieve; But receive the glad tidings of Paradise which you have been promised. We have been your friends in the life of this world and in the Hereafter

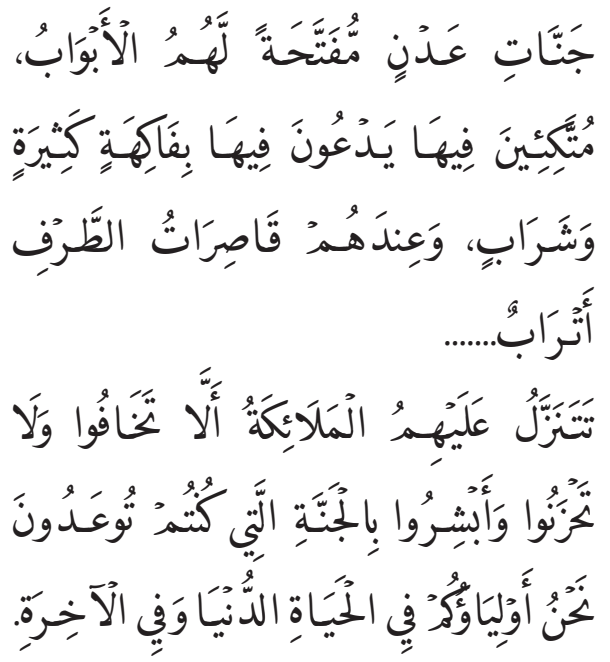
(41:30-31).

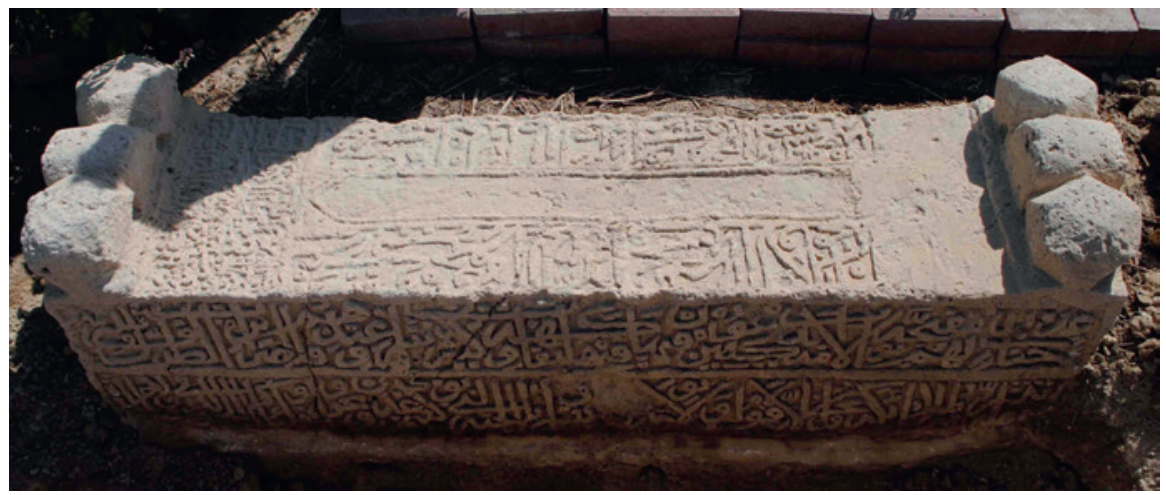

FIGURE 2.71 Surface A, ABN18 
B:

- In the Name of Allah, the Most Gracious, the Most Merciful. Allah, none has the right to be worshipped but he, the Ever Living, the One Who sustains and protects all that exists. Neither slumber nor sleep overtakes Him. To Him belongs whatever is in the heavens and whatever is on the earth.

- Who is he that can intercede with Him except by His permission! He knows what happens to them in this world, and will happen to them in the hereafter and they will never compass anything of His Knowledge except that which He wills. His Seat extends over the heavens and the earth, and He feels no fatigue in guarding and preserving them. And $\mathrm{He}$ is the Most High, the Most Great (2:255).
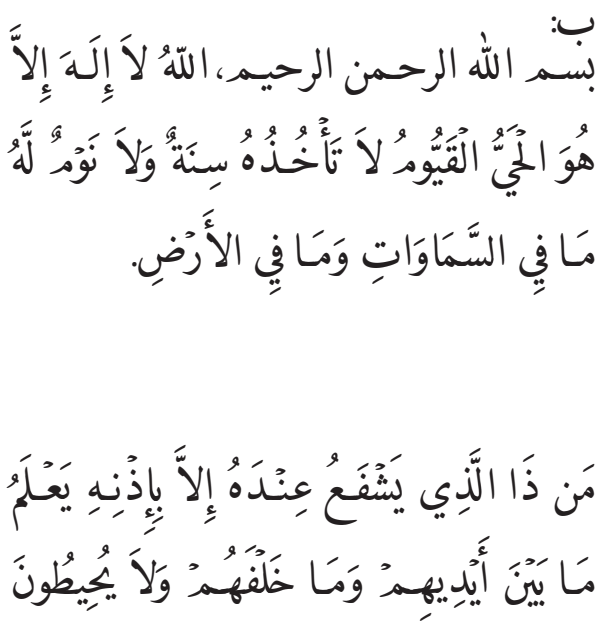

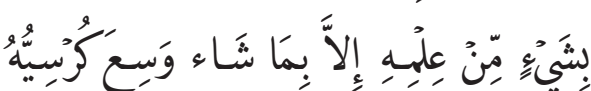

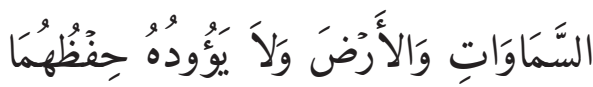

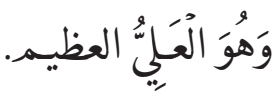

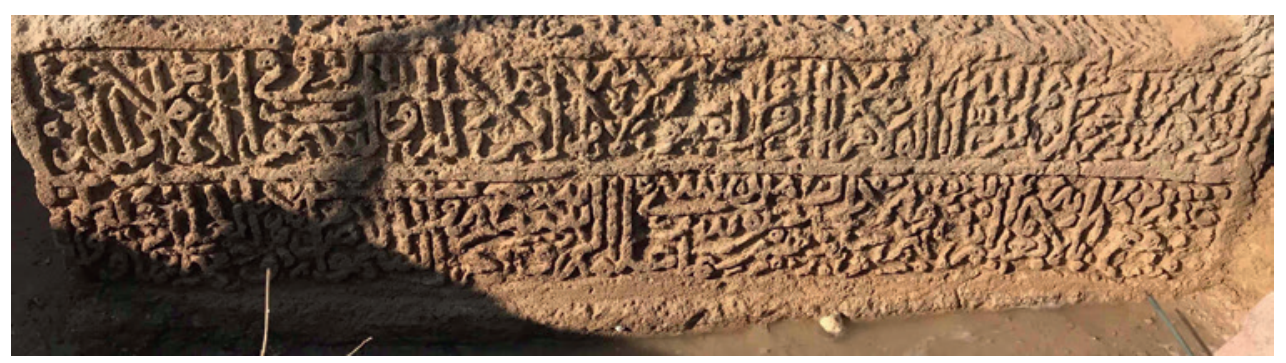

FIGURE 2.72 Surface B, ABN18

C:

- Reading a section on the grave of the Chaste, Maryam the daughter of the Blessed al-Sayyid Majid.

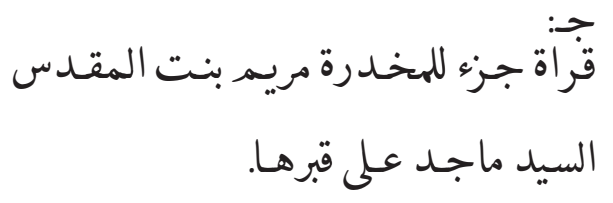

- ... At Sufala Garden in Sitra and half of Almutiaa at Katkan village.

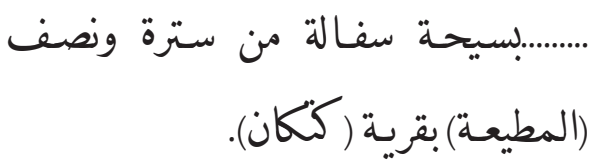

- ... share ... seven ... al-Khawariyah ... ... سهـم... سبعـة... الحواريـة... موقعـه..... located ... 


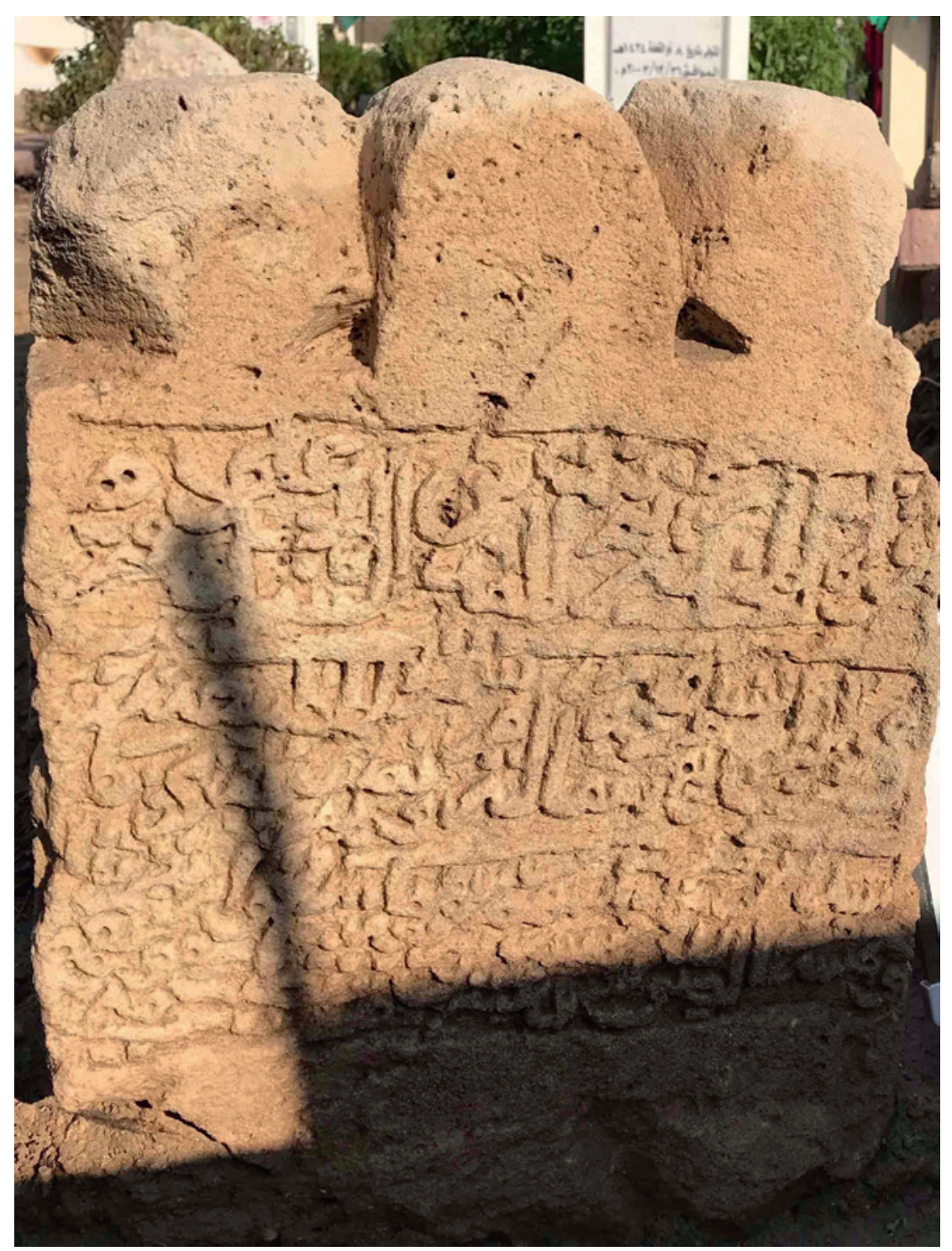

FIGURE 2.73 Surface C, ABN18

D:

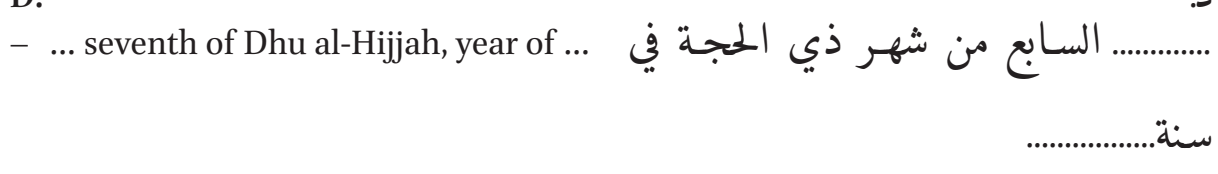

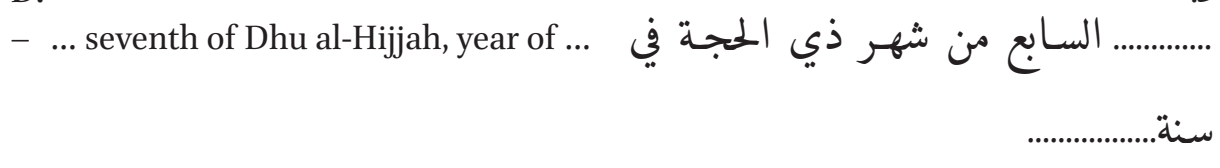

- One thousand and ninety four

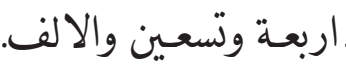




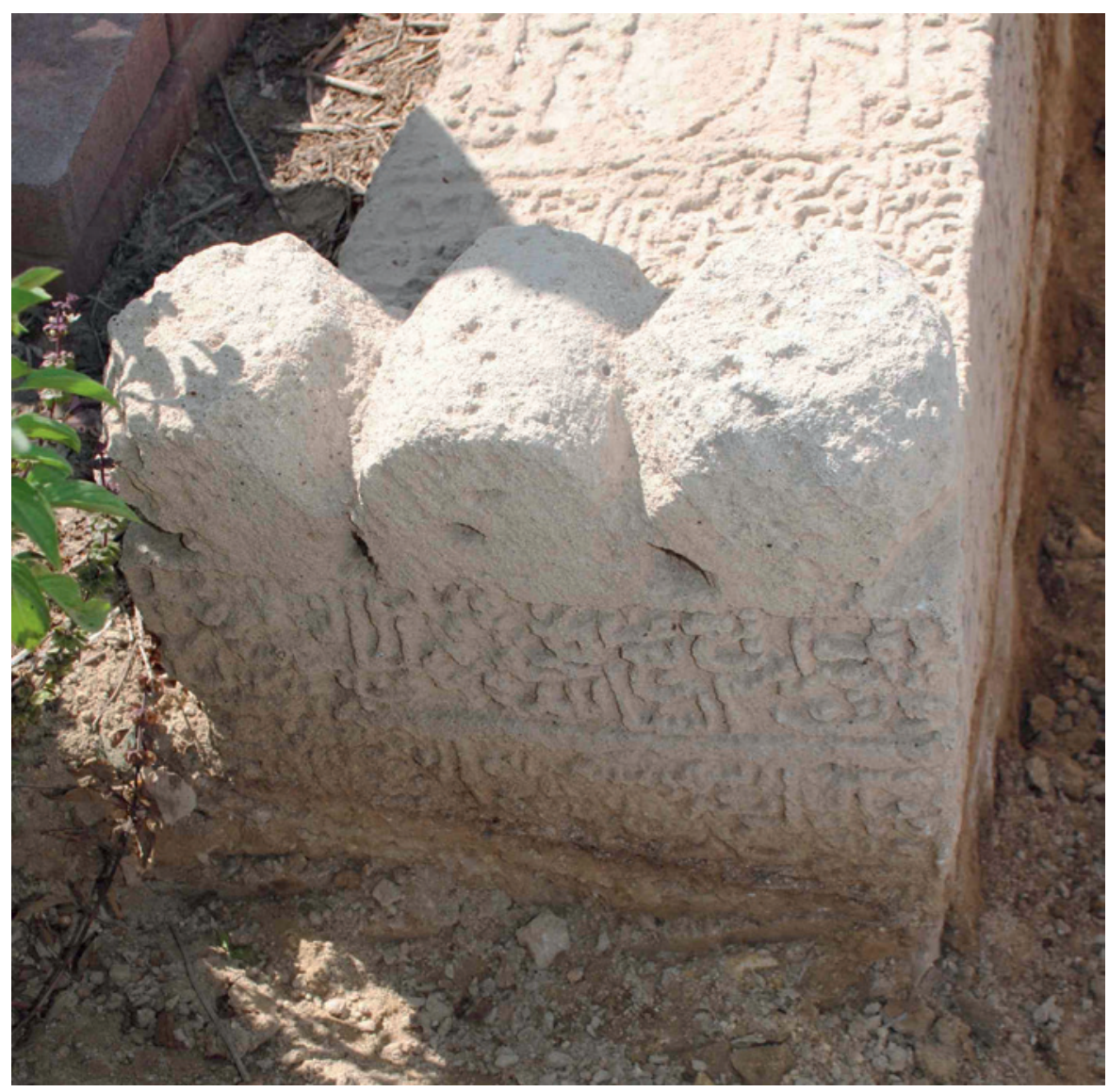

FIGURE 2.74 Surface D, ABN18

E:

- One thousand and ... ten ... shrine ... Al-Sayyid 'Abd al-Ra'uf ...

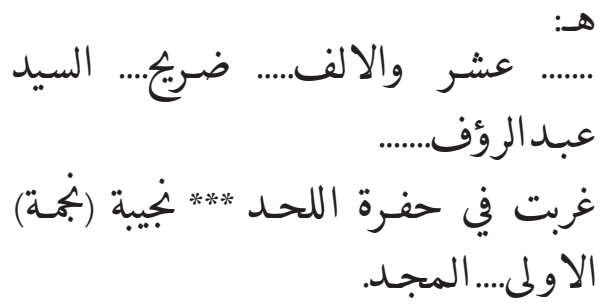

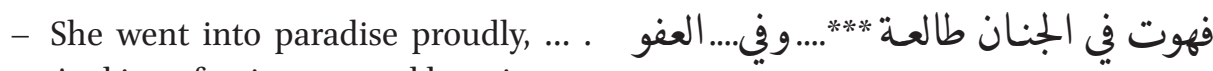
And in ... forgiveness and happiness. 


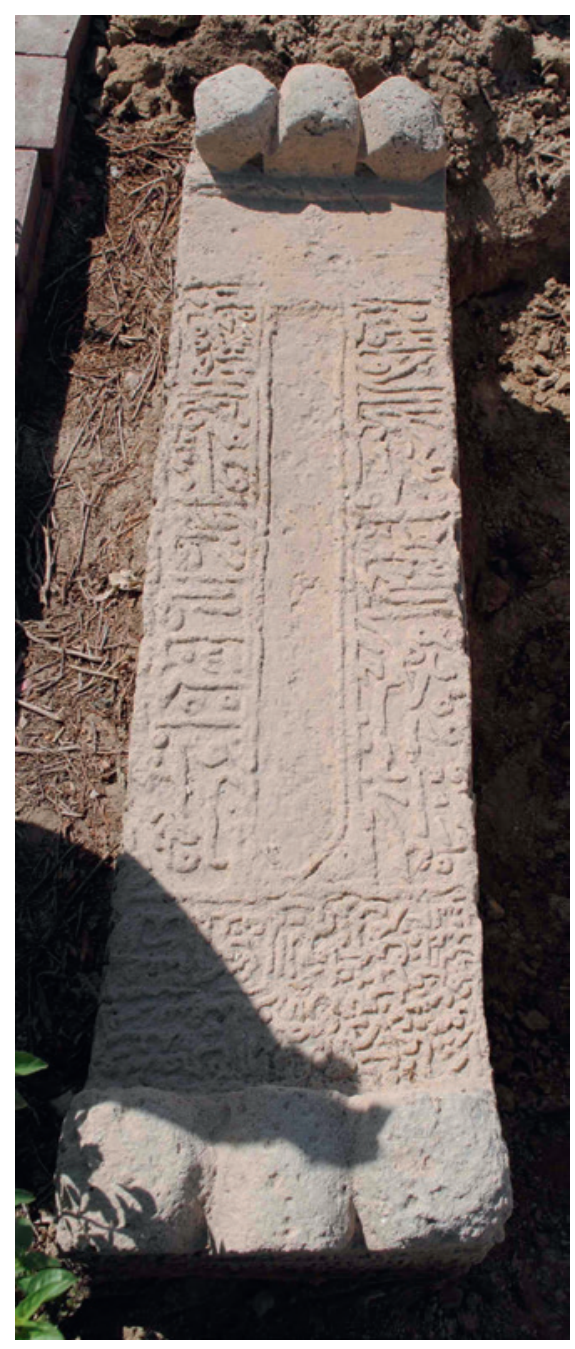

FIGURE 2.75

Surface E, ABN18

Reference Number: ABN19

Co-ordinates: $26.21078^{\circ} \mathrm{N} 050.55109^{\circ} \mathrm{E}$

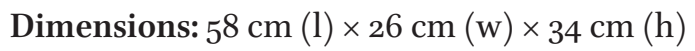

\section{Orientation: NW-SE}

Description: Single solid limestone slab gravestone. Half of a double slab gravestone. Heavily eroded. Part of a shallow carved rectangular design on top surface (E), probably the bottom of a niche design. Three element raised decoration at one end formed of three flattened facetted cubes. Traces of illegible inscription on one surface (B) (Figure 2.76). 


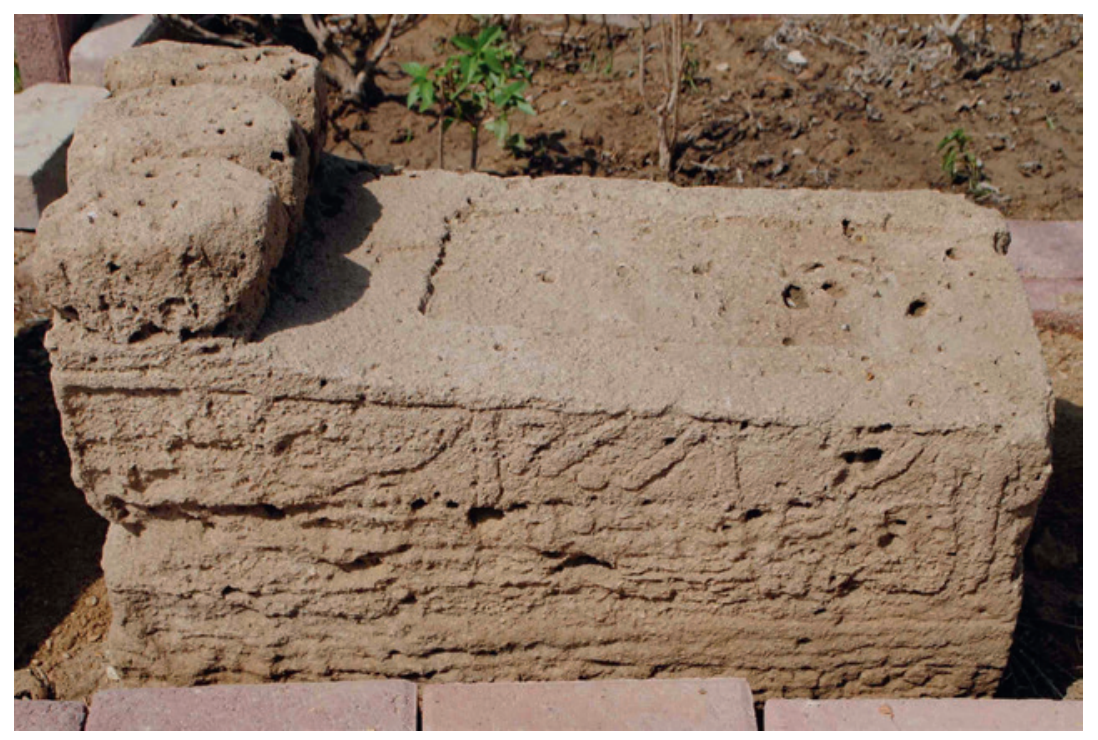

FIGURE 2.76 ABN19

Arabic Transcription and Translation: No legible inscriptions

\section{Reference Number: ABN20}

Co-ordinates: $26.21081^{\circ} \mathrm{N} 050.55109^{\circ} \mathrm{E}$

\section{Dimensions:}

Slab 1: $68 \mathrm{~cm}(\mathrm{l}) \times 26.5^{-28} \mathrm{~cm}(\mathrm{w}) \times 38.5 \mathrm{~cm}(\mathrm{~h})$

Slab 2: $80 \mathrm{~cm}(\mathrm{l}) \times 23 \mathrm{~cm}(\mathrm{w}) \times 33 \mathrm{~cm}(\mathrm{~h})$

\section{Orientation: NW-SE}

Description: Gravestone formed of two limestone slabs. Very eroded in places. Part of a shallow carved rectangular design on top surface (E), probably the bottom of a niche design. Three element raised decoration at one end formed of three flattened facetted cubes. The central one has a carved circle on top. Partly legible inscriptions on two surfaces.

\section{Arabic Transcription and Translation:}

A:

- In the Name of Allah, the Most Gracious, the Most Merciful ...

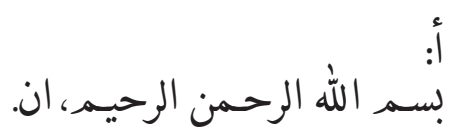




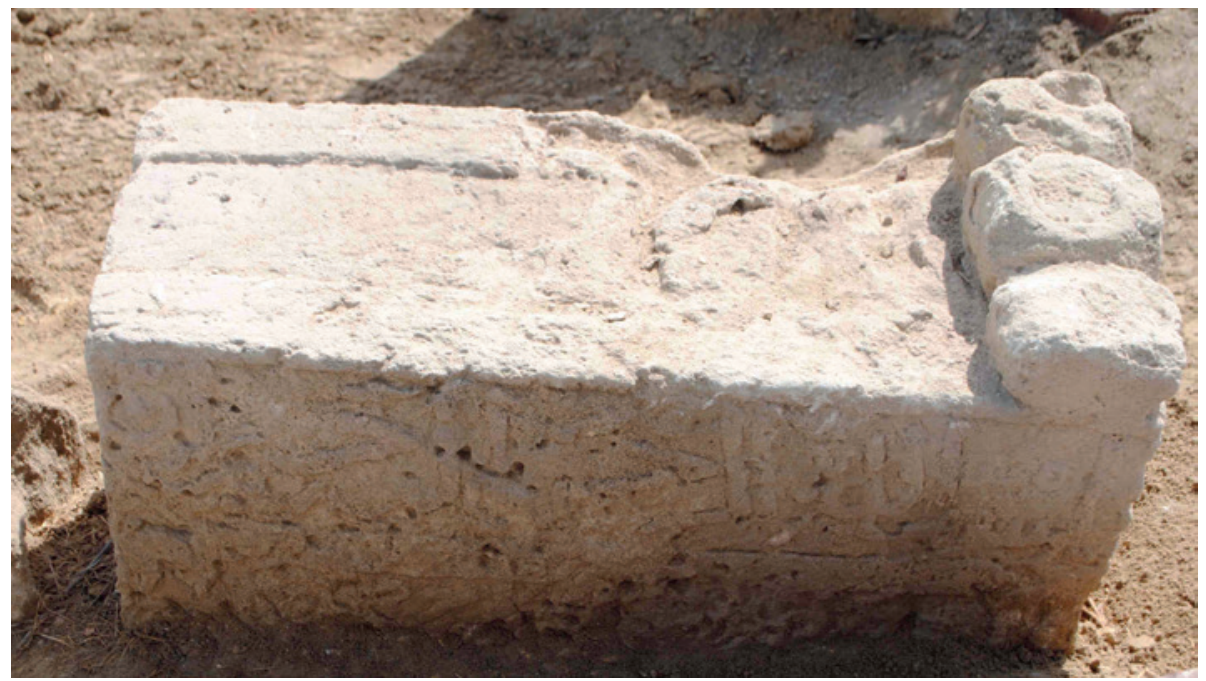

FIGURE 2.77 Surface A, ABN20

B:
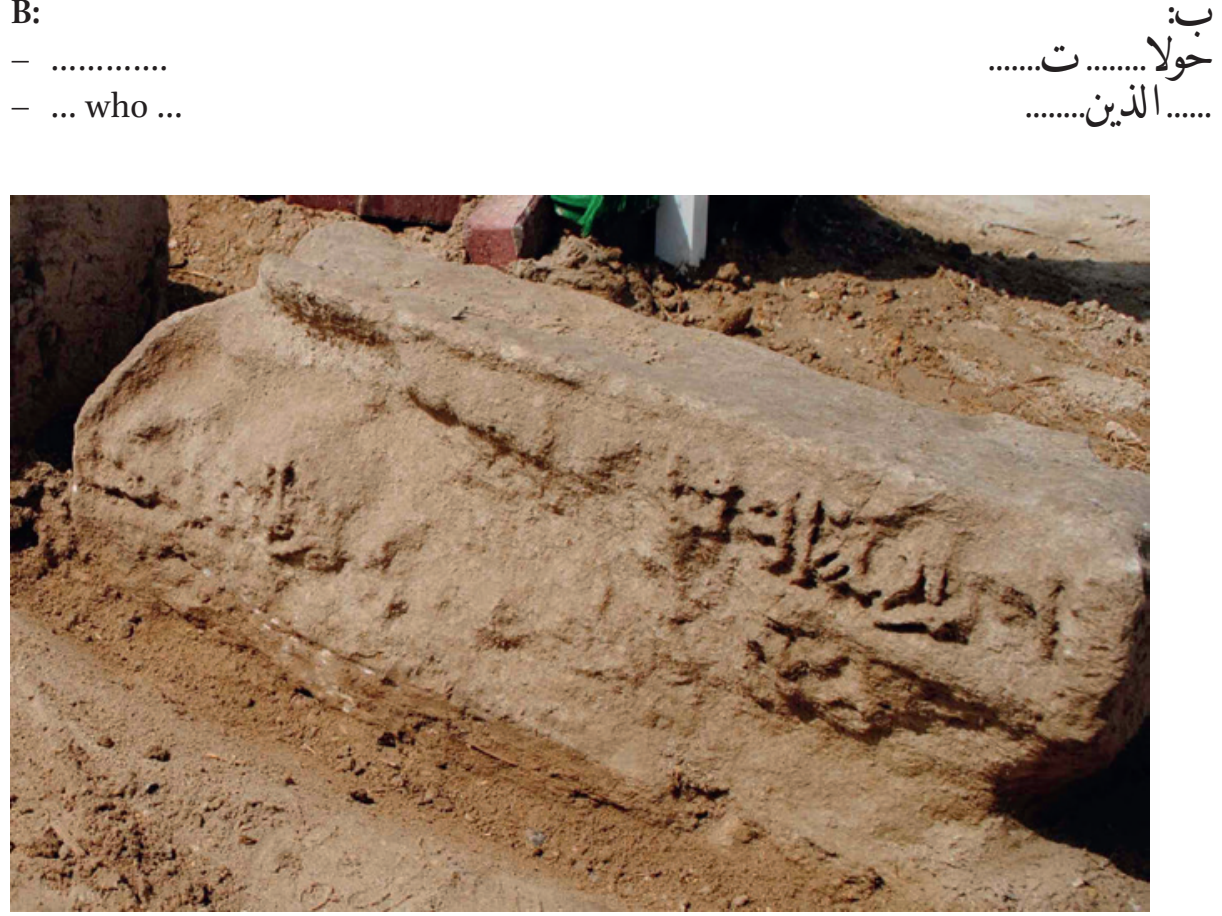

FIGURE 2.78 Surface B, part 1, ABN20 


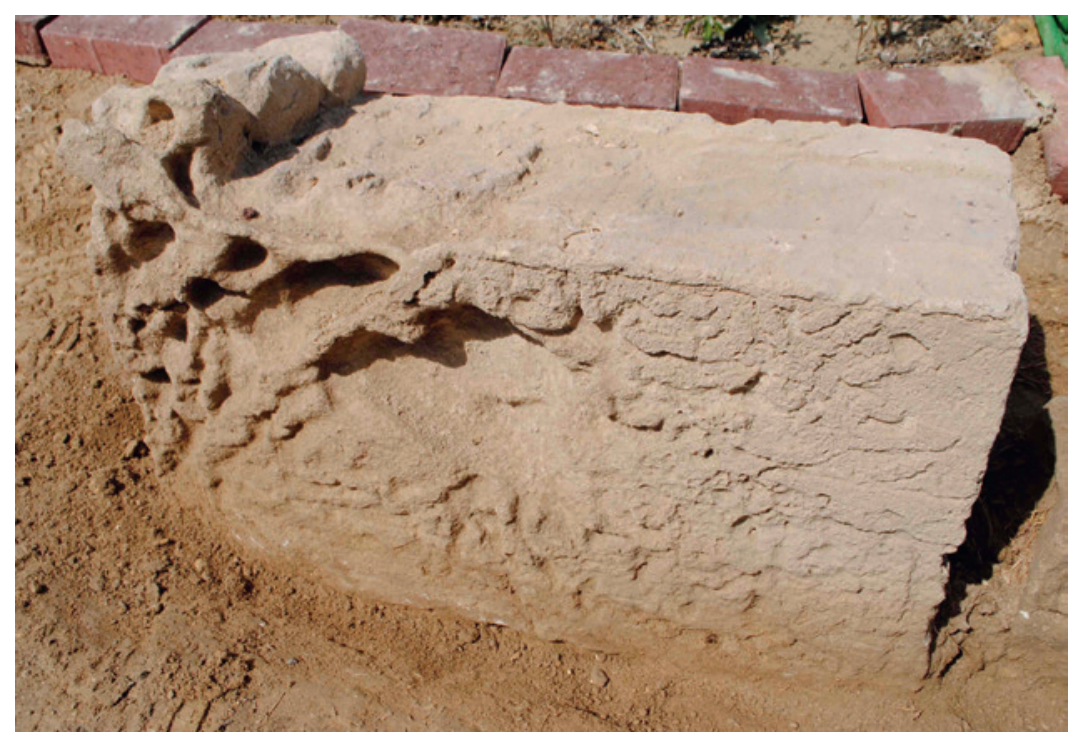

FIGURE 2.79 Surface B, part 2, ABN20

C:

- No carving or inscriptions.

D:

- No carving or inscriptions.

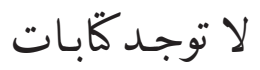

E:

- No carving or inscriptions.

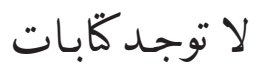

\section{Reference Number: ABN21}

Co-ordinates: $26.21078^{\circ} \mathrm{N} 05^{0.55111^{\circ} \mathrm{E}}$

\section{Dimensions:}

Slab 1: $102 \mathrm{~cm}(\mathrm{l}) \times 49.5 \mathrm{~cm}(\mathrm{w}) \times 29 \mathrm{~cm}(\mathrm{~h})$

Slab 2: $101 \mathrm{~cm}(\mathrm{l}) \times 5^{1} \mathrm{~cm}(\mathrm{w}) \times 31 \mathrm{~cm}(\mathrm{~h})$

\section{Orientation: NW-SE}

Description: Gravestone formed of two limestone slabs. Part of a shallow carved rectangular design on top surface $(\mathrm{E})$ of one slab, probably the bottom of a niche design. Eroded and unidentifiable raised decoration at both ends. Very eroded in places. Illegible inscription on one surface and partially legible inscription on another face. 
Arabic Transcription and Translation:

A:

- Very deteriorated. Unable to read. تموي نقوش متآكلة يصعب قراء تها.

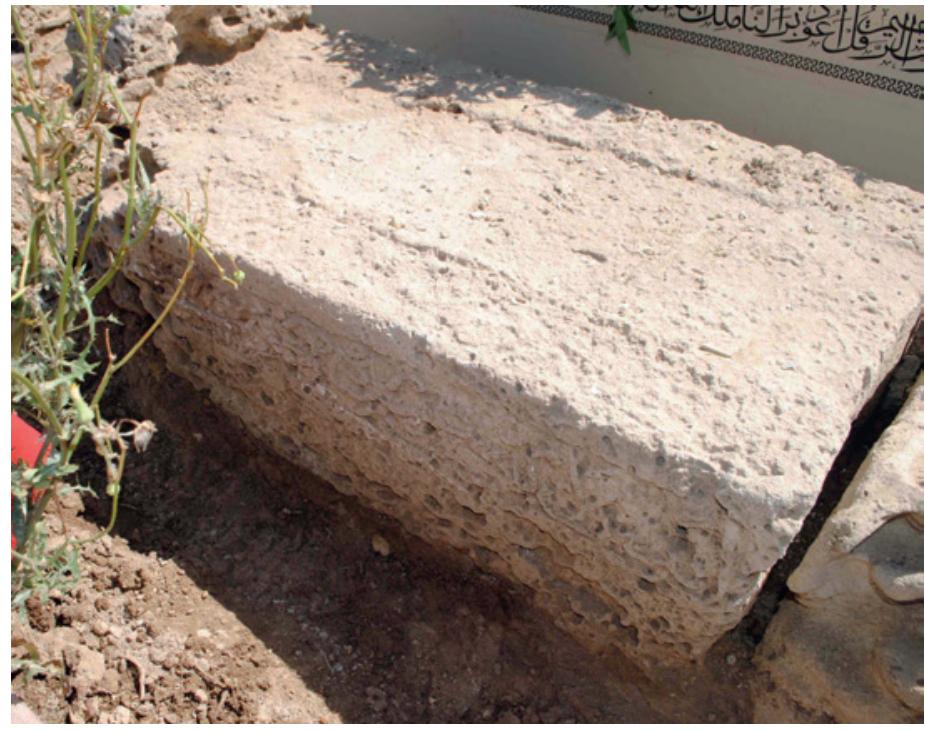

FIGURE 2.80

Surface A, ABN21

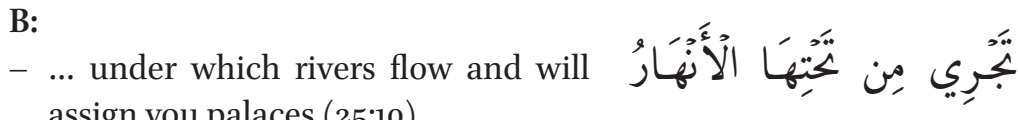
assign you palaces (25:10).

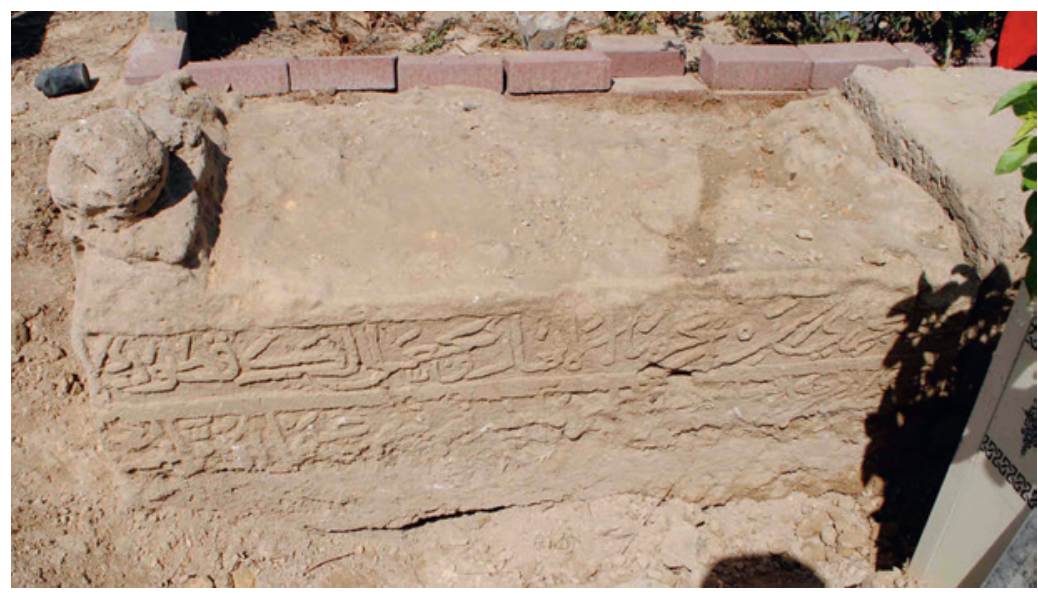

FIGURE 2.81 Surface B, ABN21 
C:

- No legible carving or inscriptions.

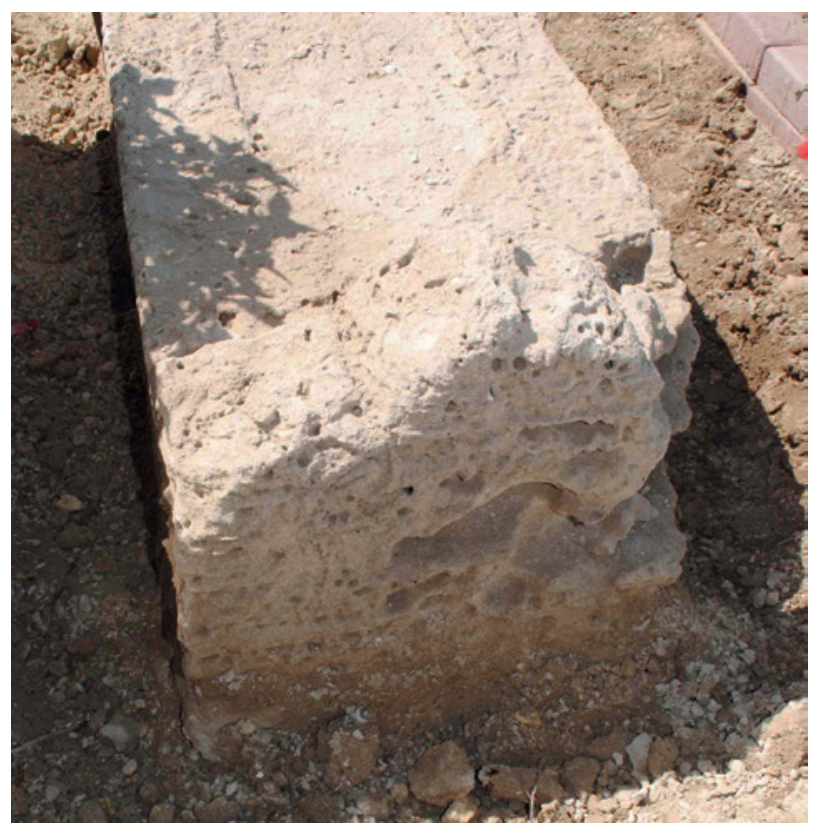

D:

- No legible carving or inscriptions.

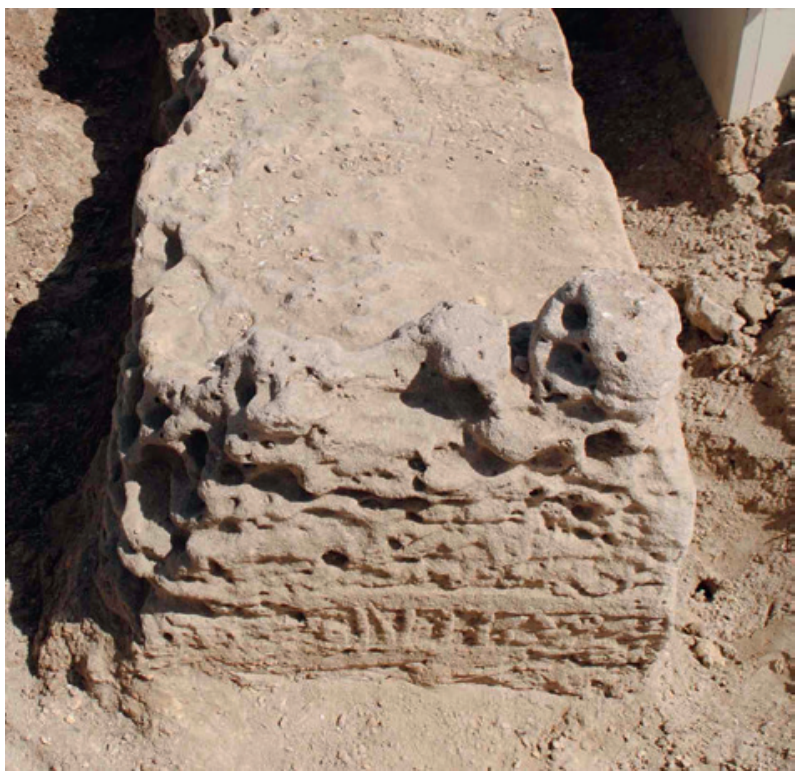

FIGURE 2.82

Surface C, ABN21 
E:

- No carving or inscriptions.

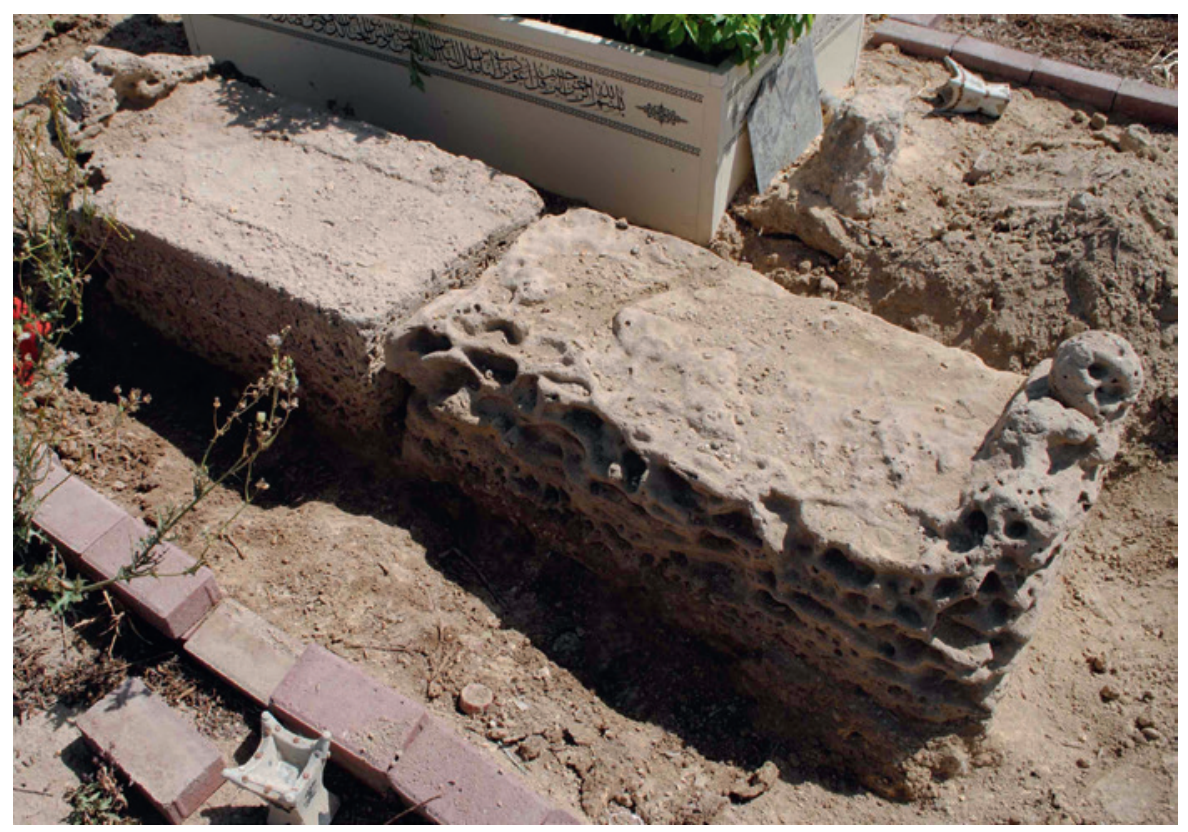

FIGURE 2.84 Surface E, ABN21

Reference Number: ABN22

Co-ordinates: $26.21087^{\circ} \mathrm{N} 05^{0.55112^{\circ} \mathrm{E}}$

\section{Dimensions:}

Slab 1: $66 \mathrm{~cm}(\mathrm{l}) \times 32.5 \mathrm{~cm}(\mathrm{w}) \times 31 \mathrm{~cm}(\mathrm{~h})$

Slab 2: $71 \mathrm{~cm}(\mathrm{l}) \times 32.5 \mathrm{~cm}(\mathrm{w}) \times 32 \mathrm{~cm}(\mathrm{~h})$

\section{Orientation: NNW-SSE}

Description: Gravestone formed of two limestone slabs in generally good condition. Shallow carved pointed niche design on the top surface (E). Three element raised decoration at both ends formed of two facetted cubes and a central rounded arch. Inscriptions on five surfaces, three partly illegible. 


\section{Arabic Transcription and Translation:}

A:

- In the Name of Allah, the Most Gracious, the Most Merciful. Allah, none has the right to be worshipped but he, the Ever Living, the One Who sustains and protects all that exists. Neither slumber nor sleep overtakes Him. To Him belongs whatever is in the heavens and whatever is on the earth. Who is he that can intercede with Him except by His permission! He knows what happens to them in this world, and will happen to them in the hereafter and they will never compass anything of His Knowledge except that which He wills. His Seat extends over the heavens and the earth,

- and He feels no fatigue in guarding and preserving them. And $\mathrm{He}$ is the Most High, the Most Great. There is no compulsion in religion. Verily, the Right Path has become distinct from the wrong path. Whoever disbelieves in Taghut and believes in Allah, then he has grasped the most trustworthy handhold that will never break. And Allah is All-Hearer, All-Knower
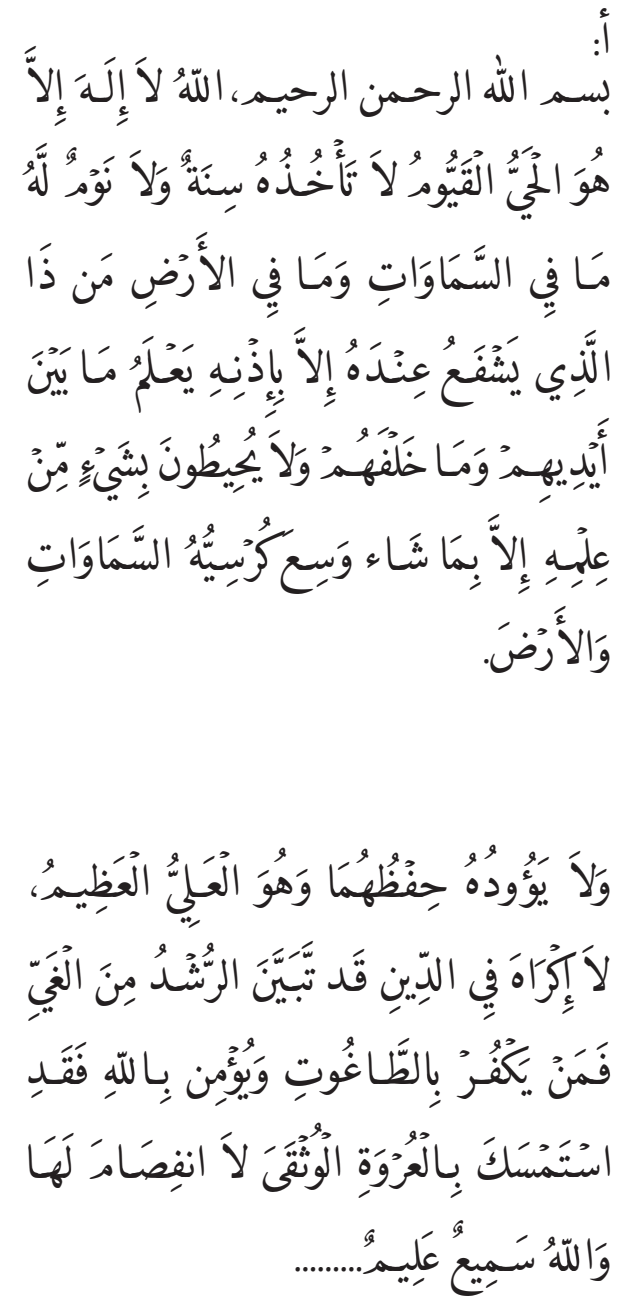
(2:255-256). 


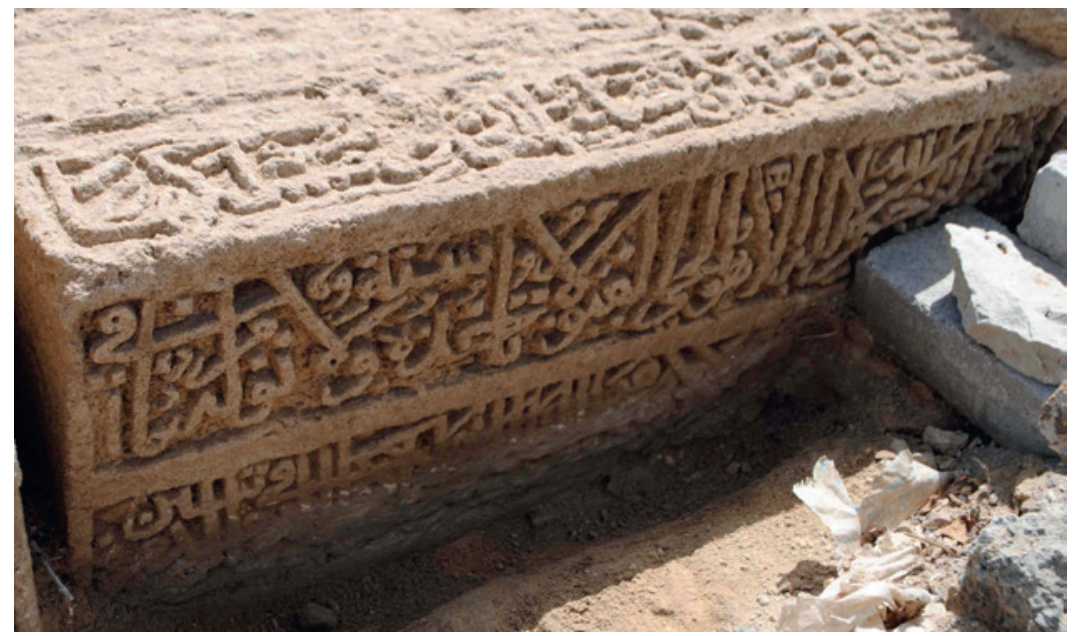

FIGURE 2.85 Surface A, part 1, ABN22

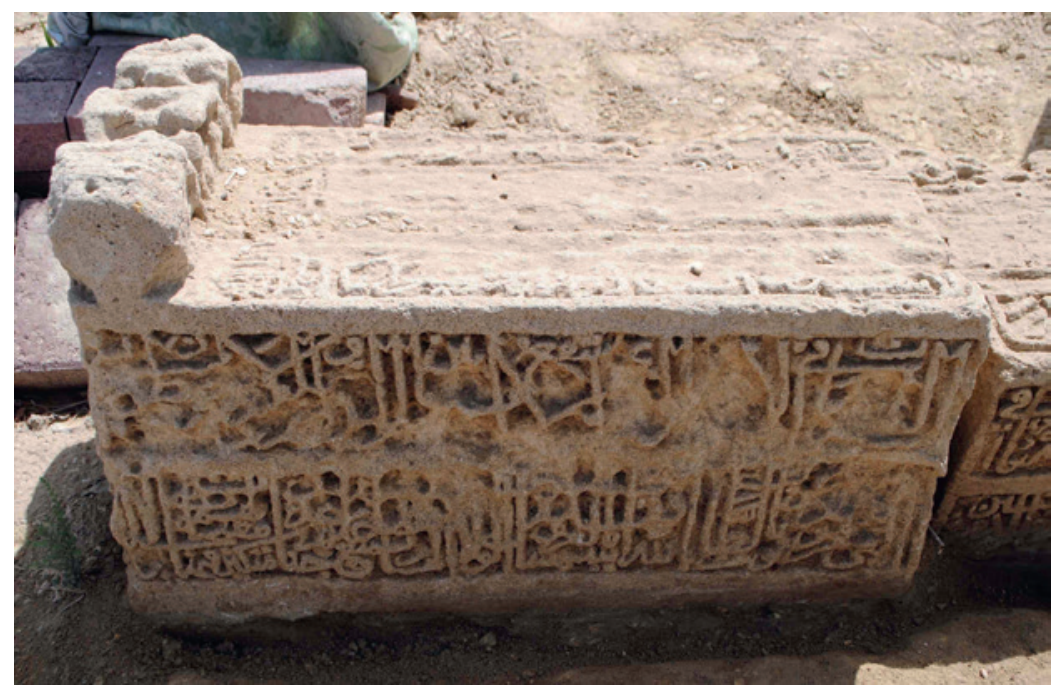

FIGURE 2.86 Surface A, part 2, ABN22

B:

- ... a great reward ... The angels will descend on them, (saying:) 'Fear not, nor grieve; But receive the glad tidings of Paradise which you have been promised (41:30).

- ... therein for you will be fruits in plenty ... shall be met ... (peace) (43:73).

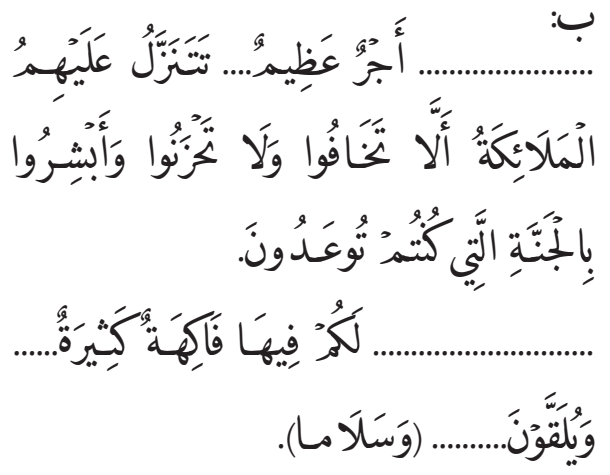




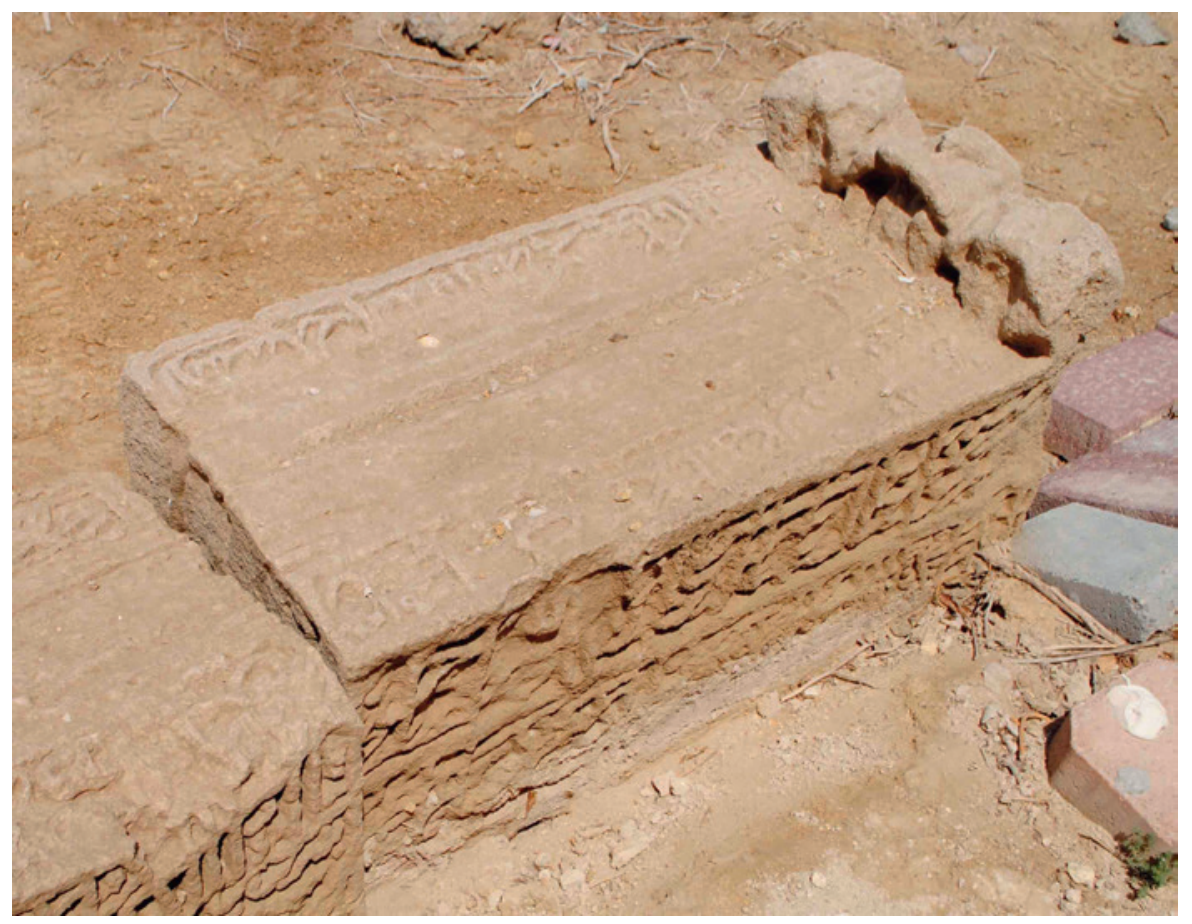

FIGURE 2.87 Surface B, part 1, ABN22

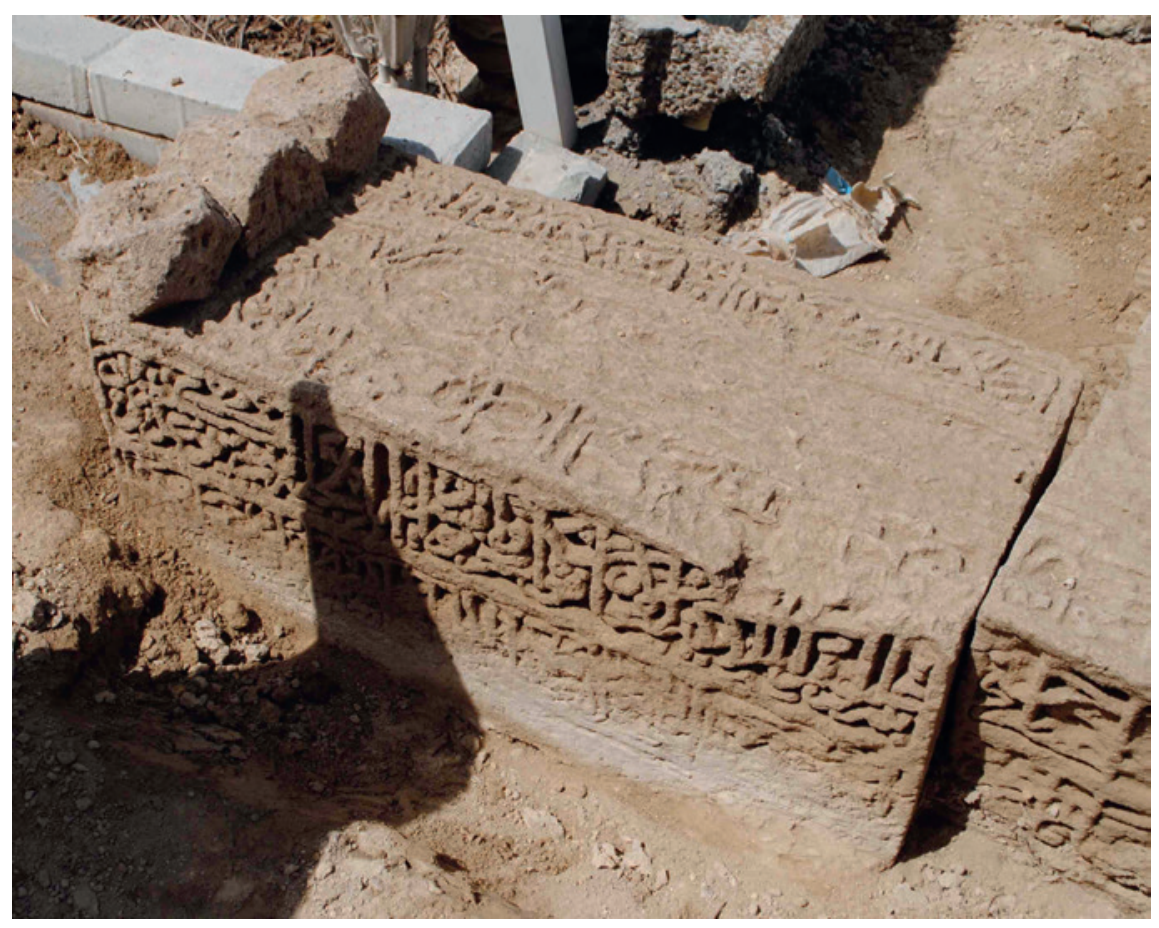

FIGURE 2.88 Surface B, part 2, ABN22 
C:

- I gave you ... rainwater ...

- All kind of happiness ...

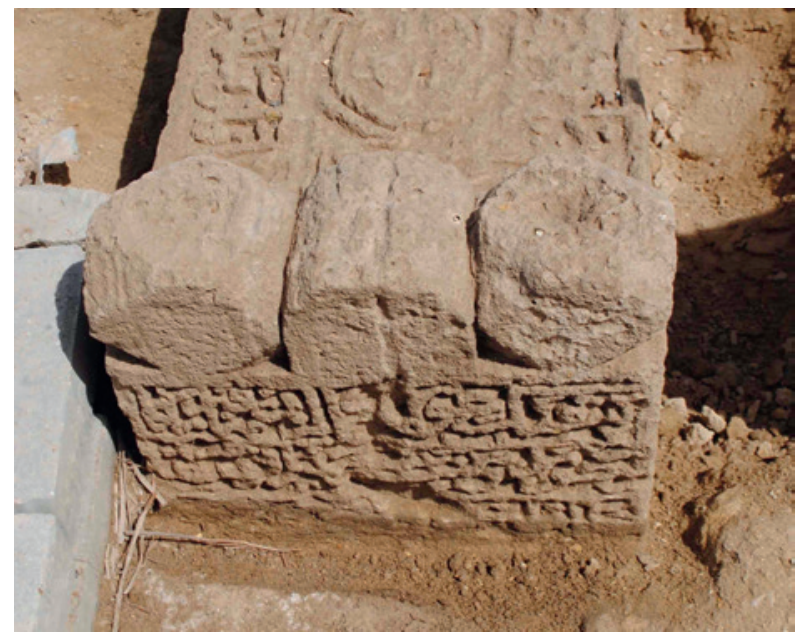

D:

- ... from al-Mustafa ...

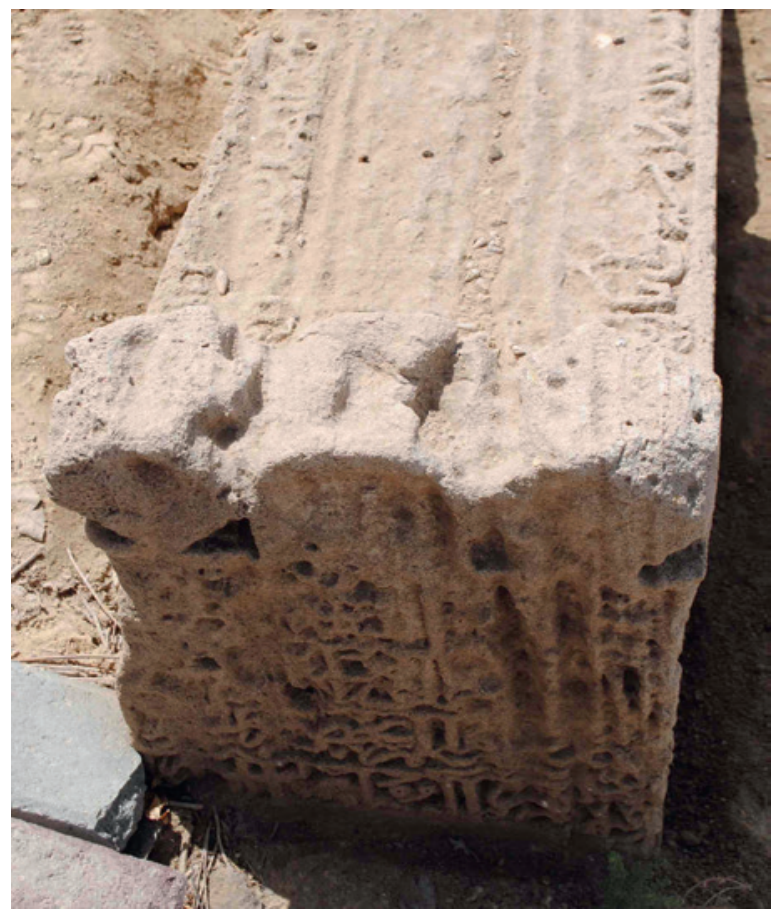

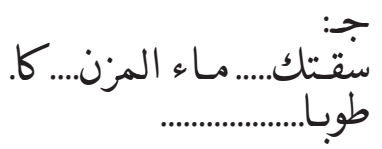

FIGURE 2.89

Surface C, ABN22
FIGURE 2.90

Surface D, ABN22 
E:

- ... al-Sayyid Hashim, forgive ...

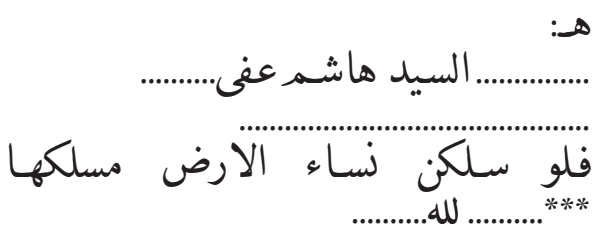

- If the ladies of this world followed her way ... Allah ...

FIGURE 2.91

Surface E,

ABN22

\section{Reference Number: ABN23}

Co-ordinates: $26.21086^{\circ} \mathrm{N} 05^{0.55117^{\circ} \mathrm{E}}$

Dimensions: $179 \mathrm{~cm}(\mathrm{l}) \times 34 \mathrm{~cm}(\mathrm{w}) \times 47 \mathrm{~cm}(\mathrm{~h})$

\section{Orientation: NW-SE}

Description: Single solid limestone slab gravestone (Figure 2.92). Badly eroded. No carving or inscriptions. Next to the exterior wall of the shrine of Shaikh Husayn bin 'Abd al-Samad.

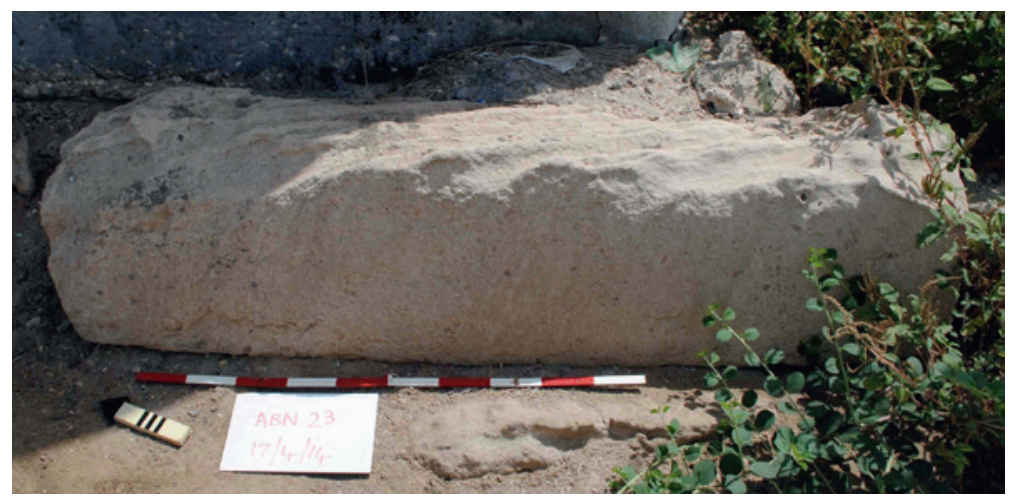

FIGURE 2.92 ABN23

Arabic Transcription and Translation: No inscriptions 
Reference Number: ABN24

Co-ordinates: $26.21087^{\circ} \mathrm{N} 050.55117^{\circ} \mathrm{E}$

Dimensions: $72.5 \mathrm{~cm}(\mathrm{l}) \times 31.5 \mathrm{~cm}(\mathrm{w}) \times 26 \mathrm{~cm}(\mathrm{~h})$

Orientation: NW-SE

Description: Single solid limestone slab gravestone (Figure 2.93). Eroded. No carving or inscriptions. Next to the exterior wall of the shrine of Shaikh Husayn bin 'Abd al-Samad.

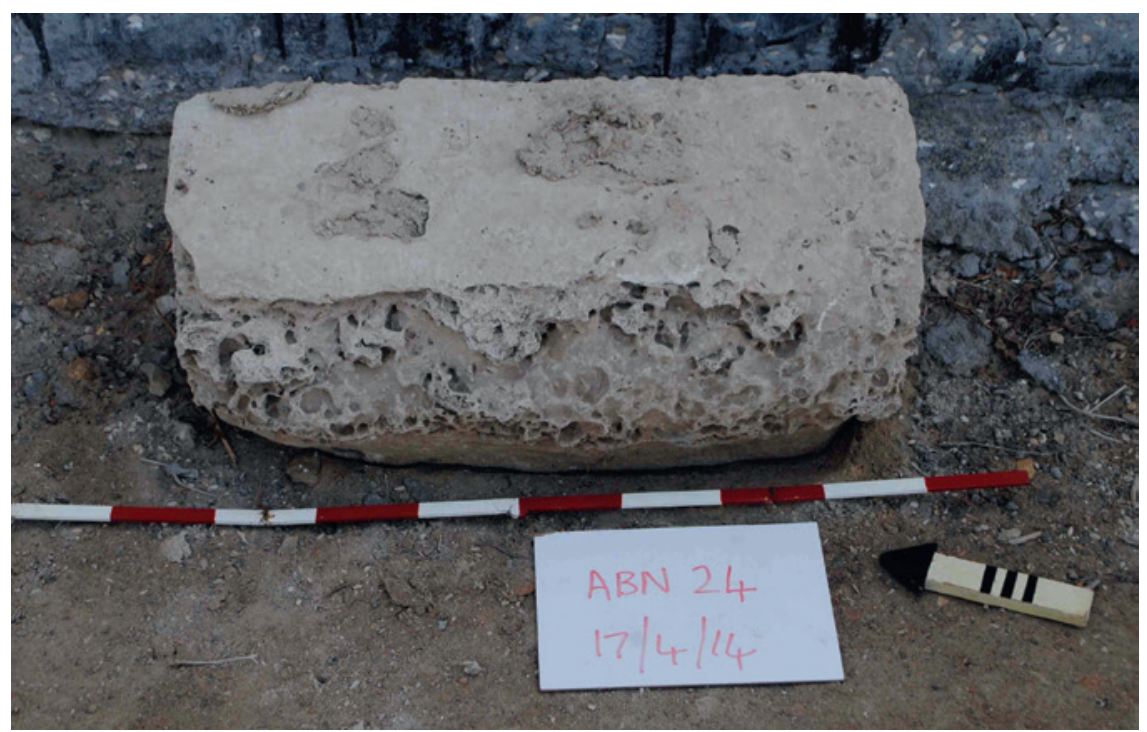

FIGURE 2.93 ABN24

Arabic Transcription and Translation: No inscriptions

Reference Number: ABN25

Co-ordinates: $26.21095^{\circ} \mathrm{N} 05^{0.55111^{\circ} \mathrm{E}}$

Dimensions: $68 \mathrm{~cm}(\mathrm{l}) \times 21.5 \mathrm{~cm}(\mathrm{w}) \times 31.5 \mathrm{~cm}(\mathrm{~h})$

Orientation: West south west (WSW) to East north east (ENE) 
Description: Single solid limestone slab gravestone. Misaligned. One surface and top badly eroded. Eroded and unidentifiable raised decoration at one end. Partly legible inscription on one surface. Rest eroded.

\section{Arabic Transcription and Translation:}

A:

- ... whatever is in the heavens and whatever is on the earth. Who is he that can intercede with Him.

- His Seat extends over the heavens and the earth, and He feels no fatigue in guarding and preserving them. And He is the Most High, the Most Great (2:255).
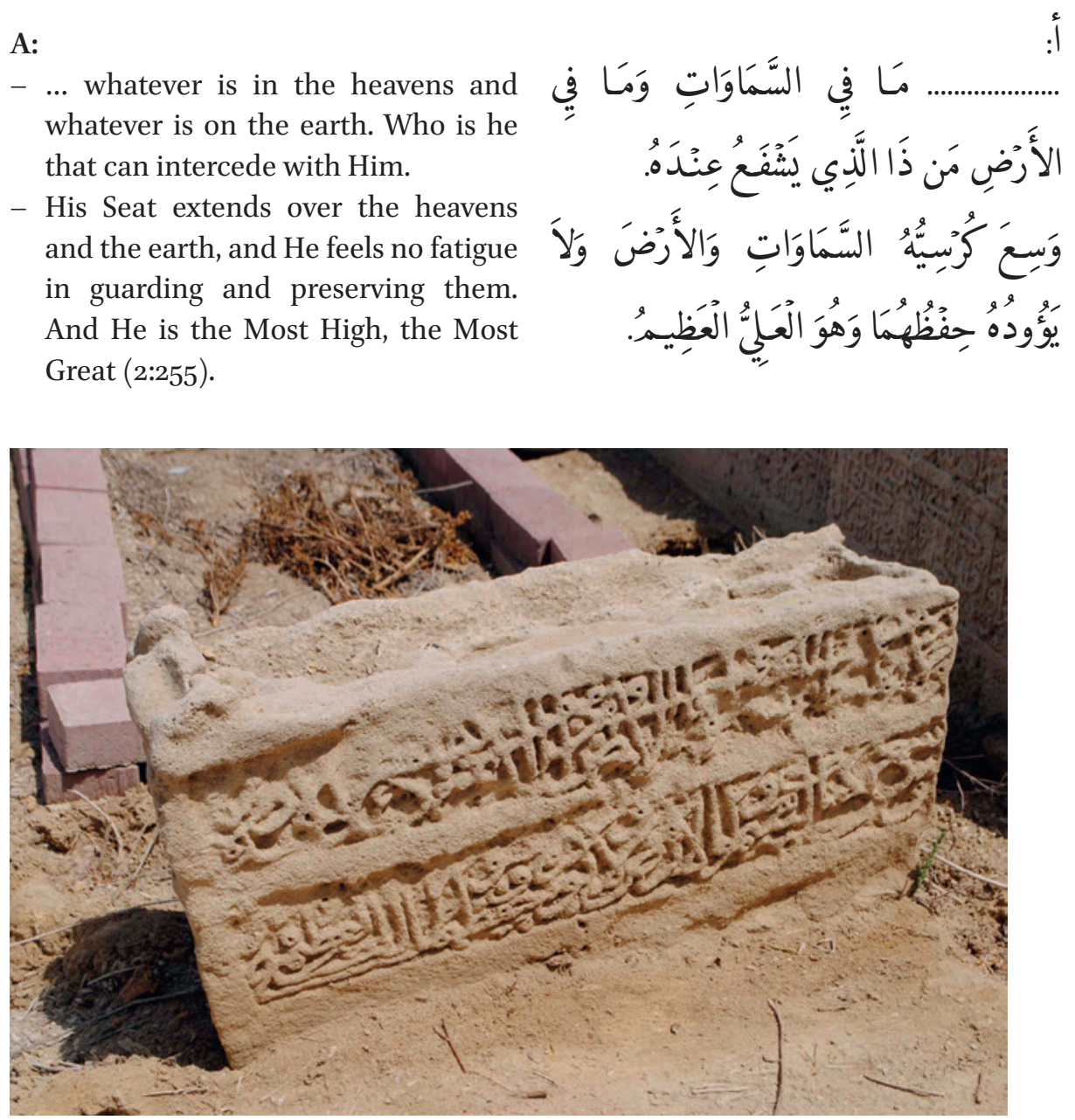

FIGURE 2.94 Surface A, ABN25

B:

- No carving or inscriptions. لا توجـد كَابات 


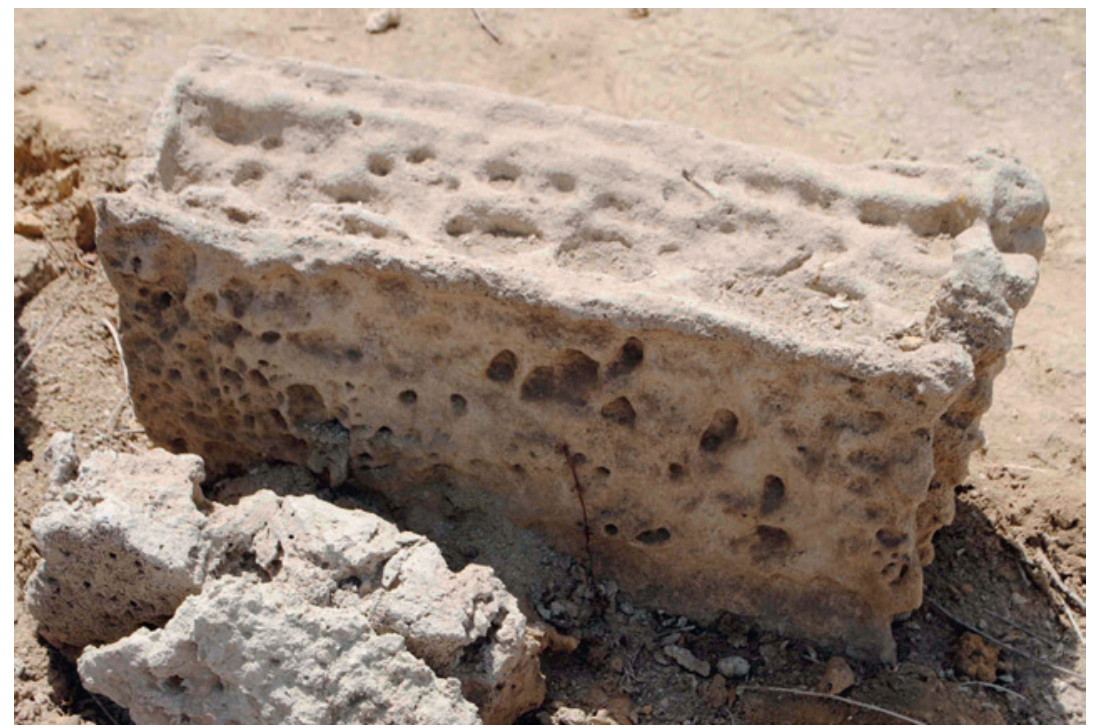

FIGURE 2.95 Surface B, ABN25

C:

- No carving or inscriptions.

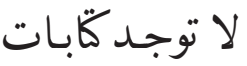

D:

- No carving or inscriptions.

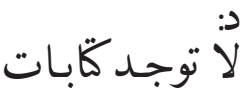

E:

- No carving or inscriptions.

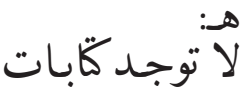

Reference Number: ABN26

Co-ordinates: $26.21095^{\circ} \mathrm{N} 050.55112^{\circ} \mathrm{E}$

\section{Dimensions:}

Slab 1: $82 \mathrm{~cm}(\mathrm{l}) \times 34.5 \mathrm{~cm}(\mathrm{w}) \times 40 \mathrm{~cm}(\mathrm{~h})$

Slab 2: $73 \mathrm{~cm}(\mathrm{l}) \times 35 \mathrm{~cm}(\mathrm{w}) \times 42 \mathrm{~cm}(\mathrm{~h})$

\section{Orientation: NNW-SSE}

Description: Gravestone formed of two limestone slabs in generally good condition. No niche design on surface E. Three element raised decoration at both ends formed of two facetted cubes and a central rounded arch. The raised decoration has not been finished on the reverse of the end surfaces (C and D). One side surface (B) is 
broken, exposing the interior and indicating that both slabs are hollow. Inscriptions on five surfaces.

\section{Arabic Transcription and Translation:}

A:

- Therein they will recline; therein they will call for fruits in abundance and drinks; And beside them will be chaste females restraining their glances only for their husbands, and of equal ages (38:51-52). Their Lord gives them glad tidings of Mercy from Him, and that $\mathrm{He}$ is pleased with them, and of Gardens for them wherein are everlasting delights. They will dwell therein forever. Verily, with Allah is a great reward (9:21-22). The angels will descend on them.

- (saying:) 'Fear not, nor grieve; But receive the glad tidings of Paradise which you have been promised. We have been your friends in the life of this world and in the Hereafter. Therein you shall have all that your souls desire and all that you ask for, as hospitality from One, the Forgiving, the Most Merciful (41:30-32).
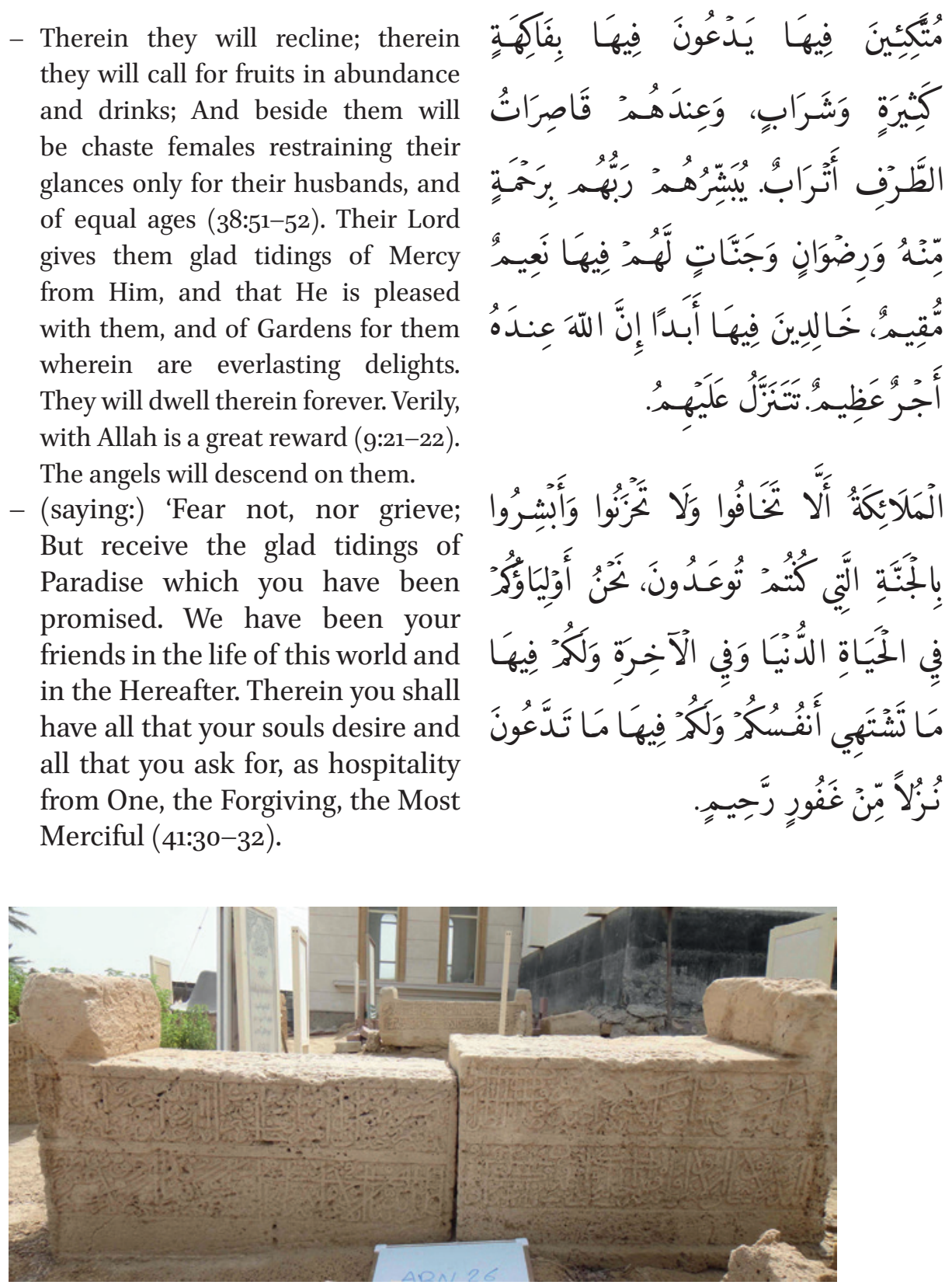

FIGURE 2.96 Surface A, ABN26 
B:

- In the Name of Allah, the Most Gracious, the Most Merciful. Allah, there is no deity but he, the Ever Living, the One Who sustains and protects all that exists. Neither slumber nor sleep overtakes Him. To Him belongs whatever is in the heavens and whatever is on the earth. Who is he that can intercede with Him except by His permission!

- He knows what happens to them in this world, and will happen to them in the Hereafter ... the heavens and the earth, and He feels no fatigue in guarding and preserving them. And He is the Most High, the Most Great (2:255). Eden Gardens, whose doors will be opened (38:50).

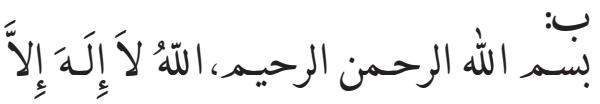

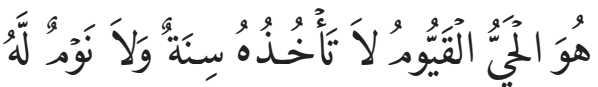

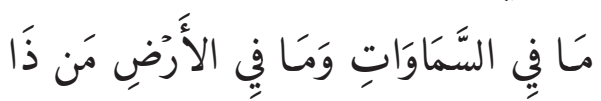

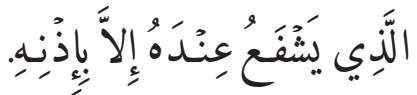

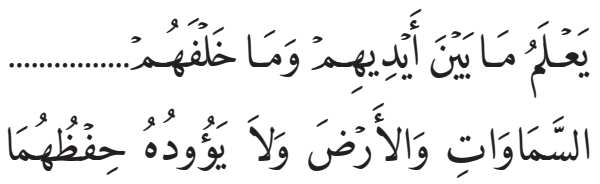

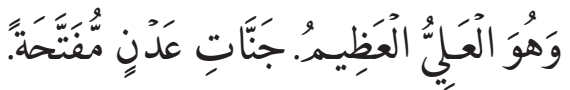

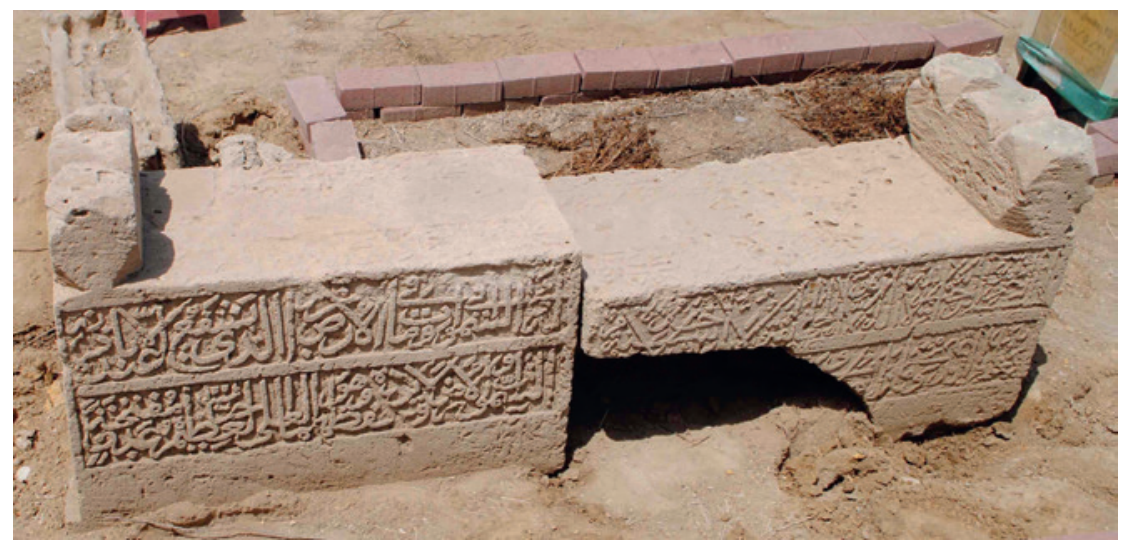

FIGURE 2.97 Surface B, ABN26

C:

- Do you know what this grave includes ... It shelters a pearl ...

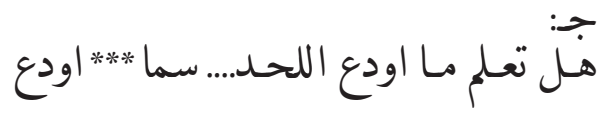
درة...

- Her history is a place of mercy ... her place is in everlasting paradise. 


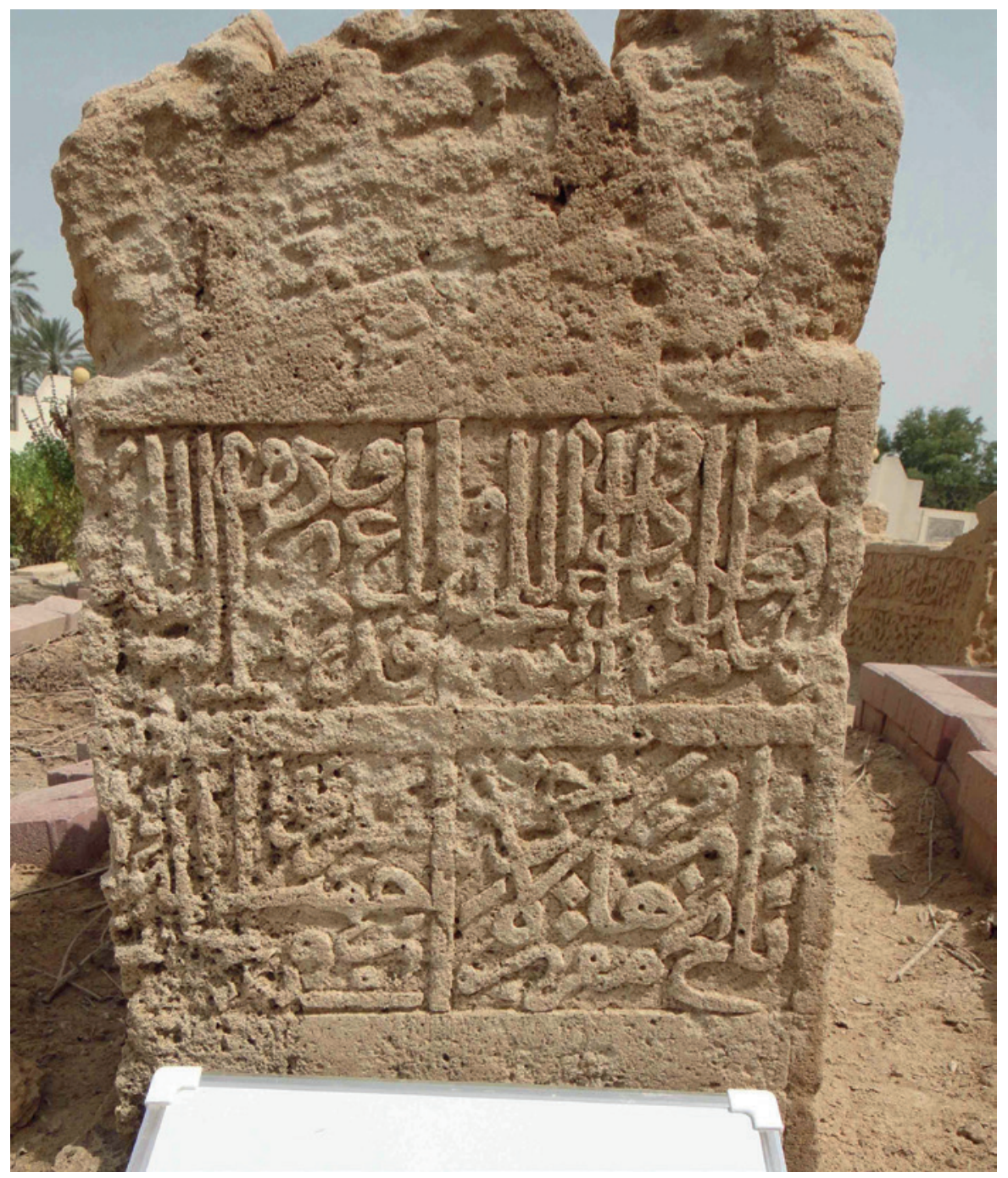

FIGURE 2.98 Surface C, ABN26

D:

- This is the grave of the chaste, knowledgeable and freewoman who always was a pilgrim at the holy house of God.

- And visited the graves of the Prophet and his family. Fatimah bint al-Sayyid 'Ali bin al-Sayyid Husayn bin alSayyid Isa al-Husayni.

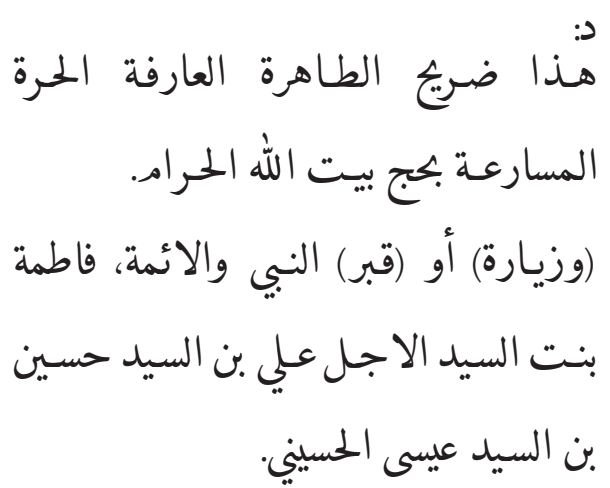




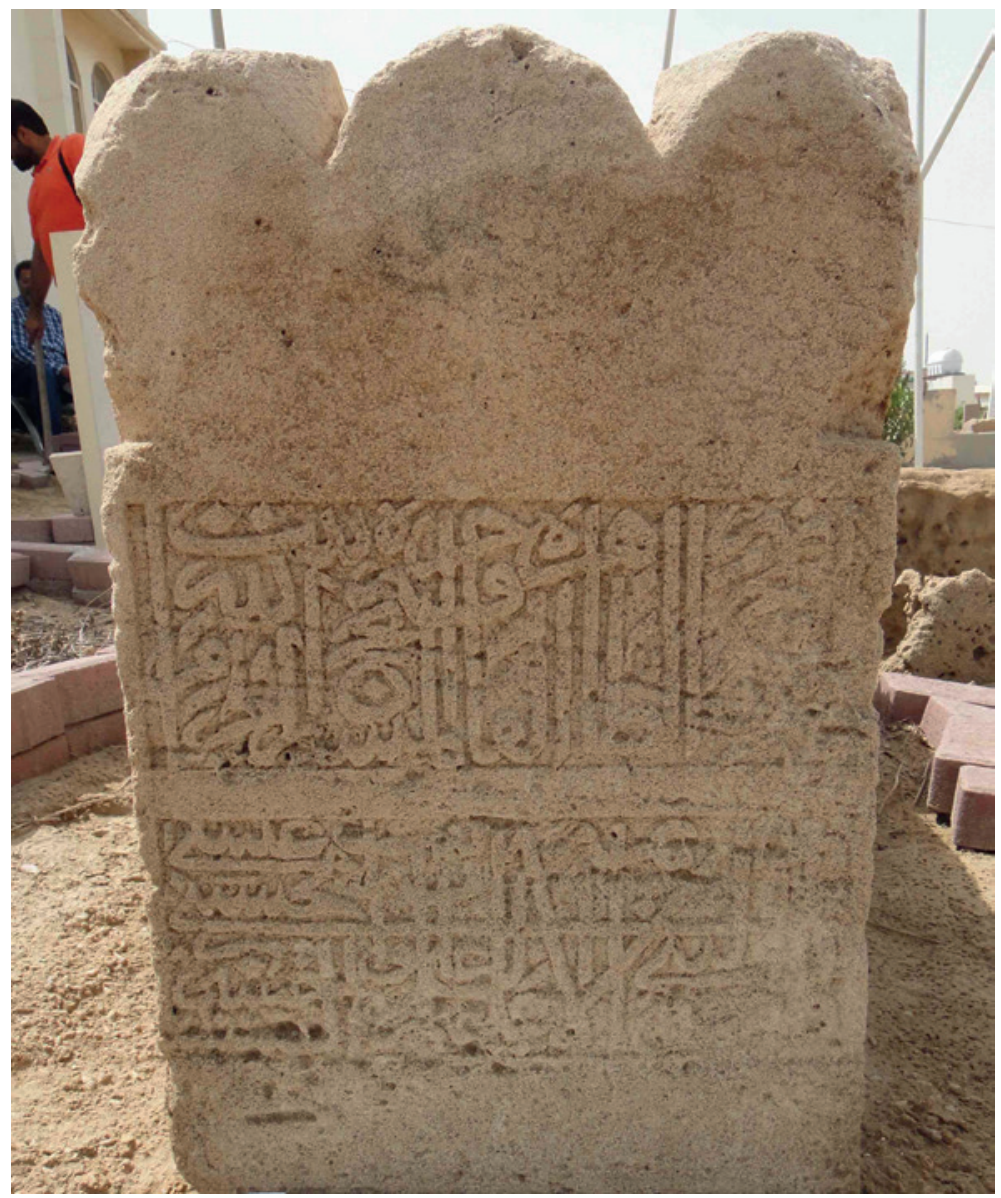

FIGURE 2.99

Surface D, ABN26
E:

- ... the grave is a place ... Allah.

- ... invites ... pearls ... treasure ...

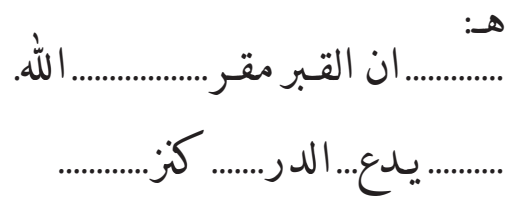

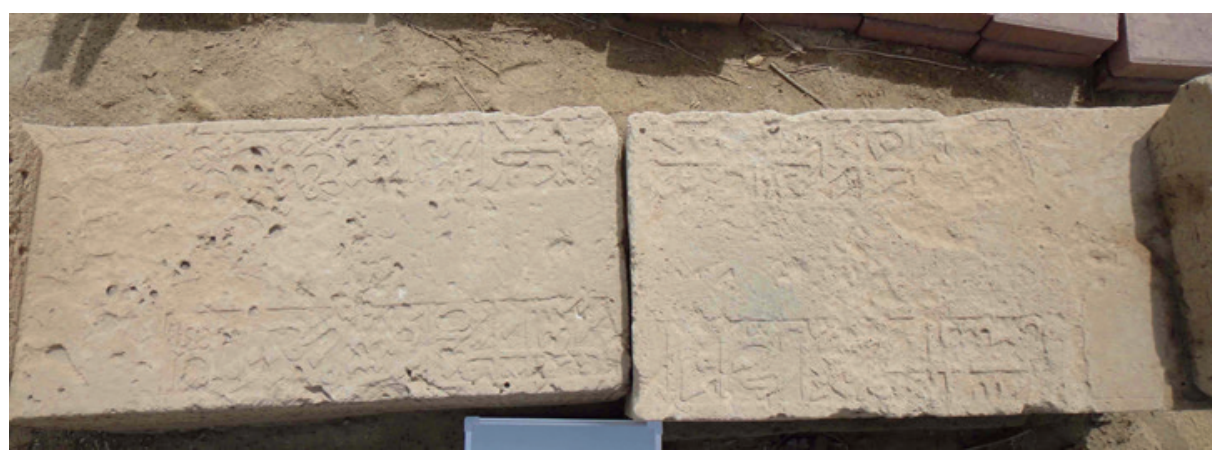

FIGURE 2.100 Surface E, ABN26 


\section{Reference Number: ABN27}

Co-ordinates: $26.21095^{\circ} \mathrm{N} 05^{0.55118^{\circ} \mathrm{E}}$

Dimensions: $139 \mathrm{~cm}(\mathrm{l}) \times 30-32 \mathrm{~cm}(\mathrm{w}) \times 43.5 \mathrm{~cm}(\mathrm{~h})$

\section{Orientation: NNW-SSE}

Description: Single limestone slab gravestone. No niche design on surface E. Rudimentary three element raised decoration at both ends formed of two facetted cubes and a central rounded arch. Deeply carved with large lettering. Next to shrine of Shaikh Husayn bin 'Abd al-Samad. Inscriptions on five surfaces.

\section{Arabic Transcription and Translation:}

A:

- In the Name of Allah, the Most Gracious, the Most Merciful. Allah, none has the right to be worshipped but he, the Ever Living, the One Who sustains and protects all that exists. Neither slumber nor sleep overtakes Him.

- To Him belongs whatever is in the

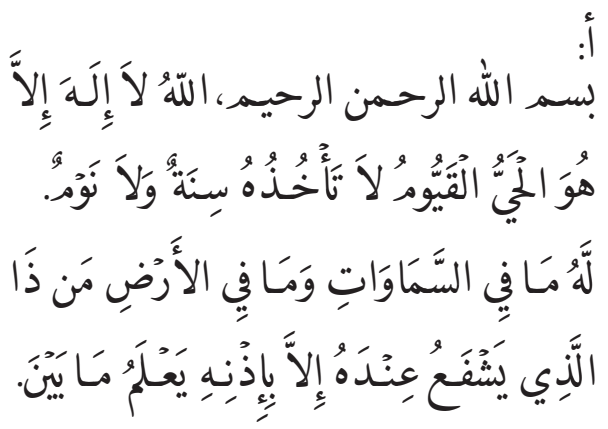
heavens and whatever is on the earth. Who is he that can intercede with Him except by His permission! He knows

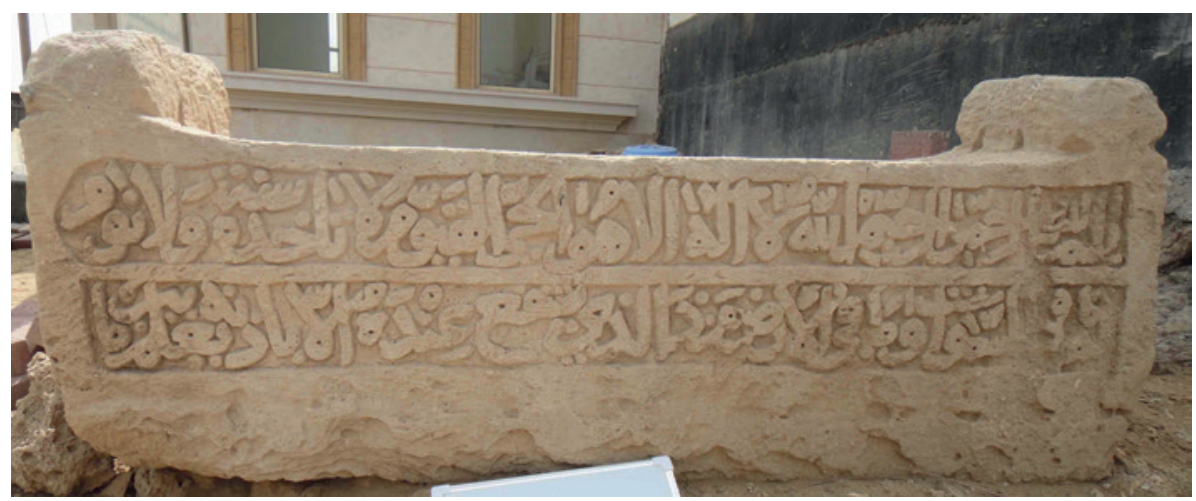

FIGURE 2.101 Surface A, ABN27 
B:

- What happens to them in this world, and will happen to them in the Hereafter and they will never compass anything of His Knowledge except that which He wills. His Seat extends over the heavens and the earth, and He feels no fatigue

- In guarding and preserving them. And He is the Most High, the Most Great. There is no compulsion in religion. Verily, the Right Path has become distinct from the wrong path. Whoever disbelieves in al-Taghut

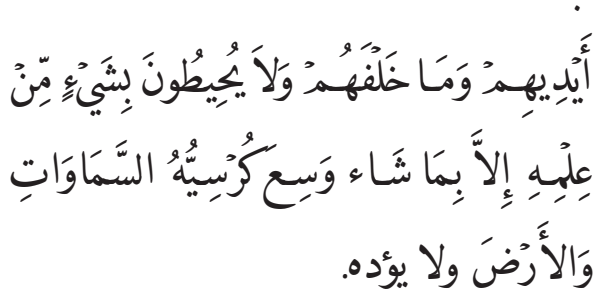

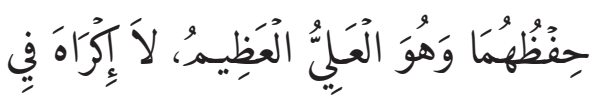

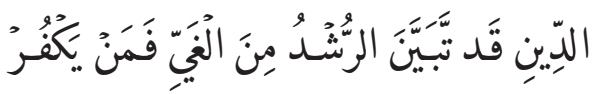
بإلطَّاغُوتُتِ $\left(2: 255^{-256)}\right.$.

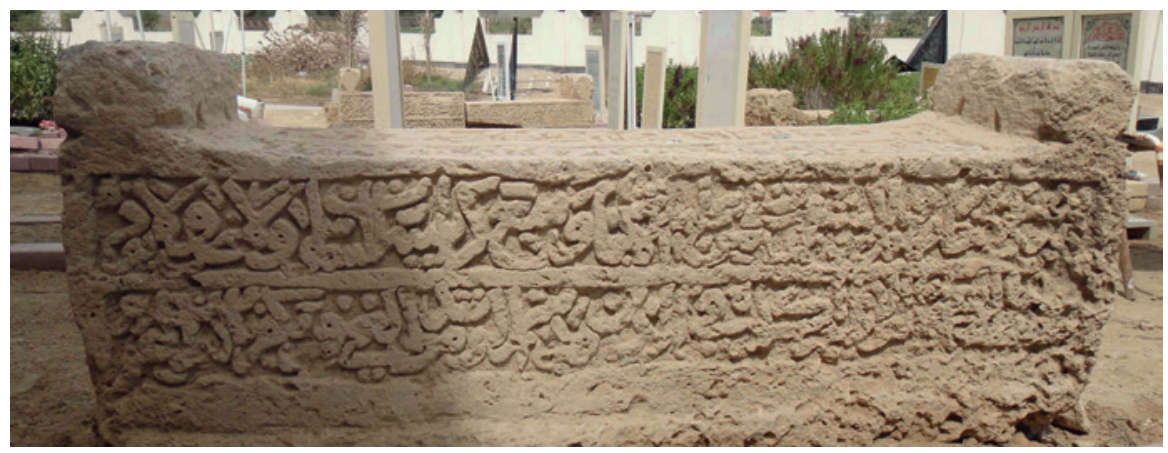

FIGURE 2.102 Surface B, ABN27

C:

- Into light. But as for those who disbelieve.

- their supporters are al-Taghut. they bring them out (2:257).

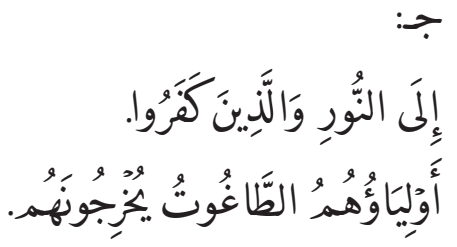




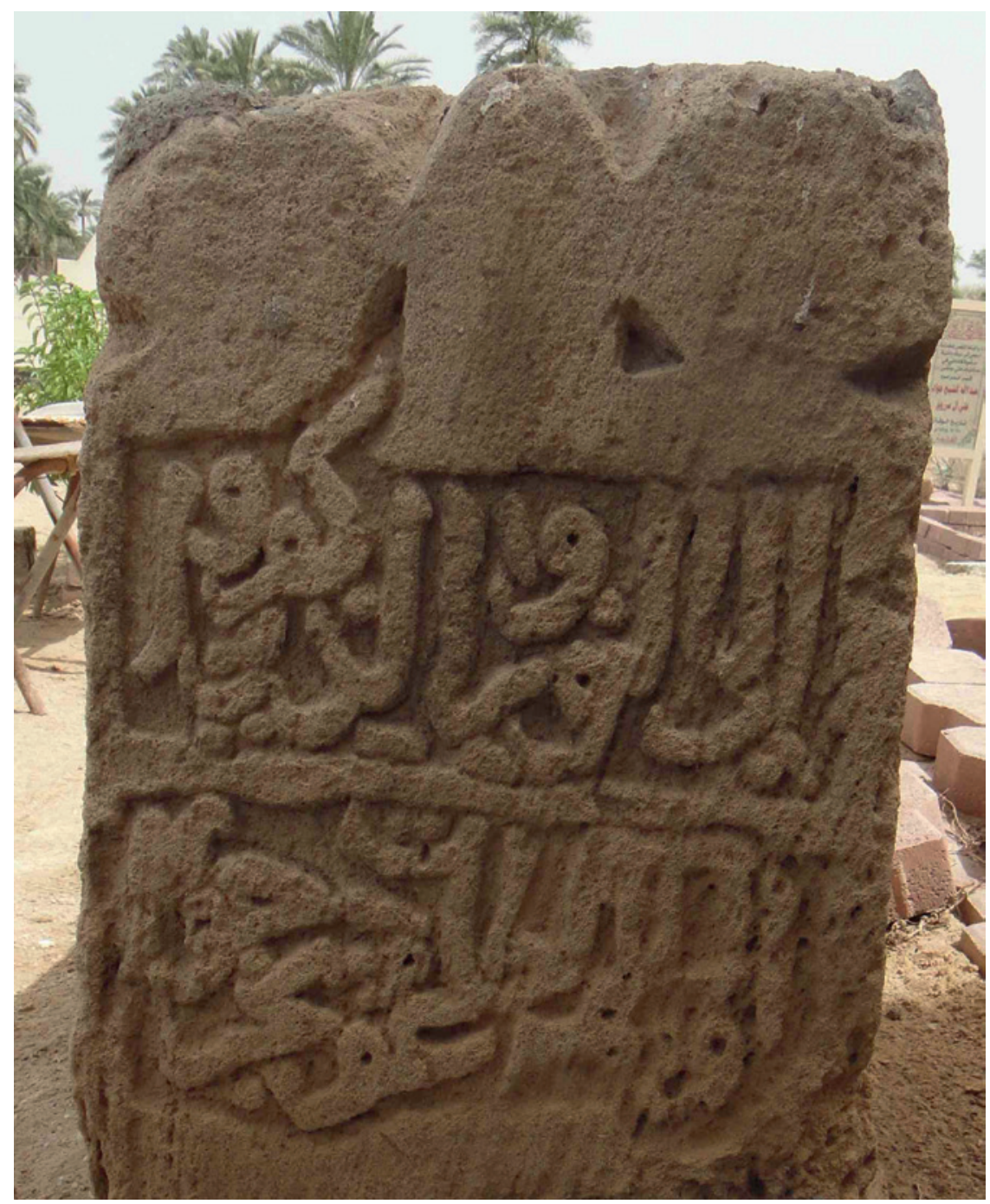

FIGURE 2.103 Surface C, ABN27

D:

- Allah is the Protector of those who believe.

- He brings them out from darkness $(2: 257)$.

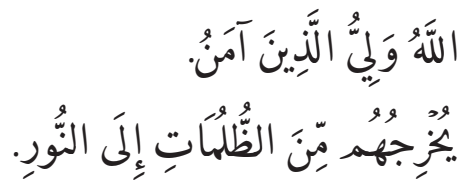

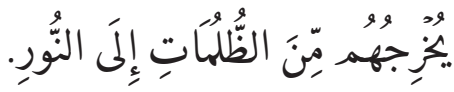




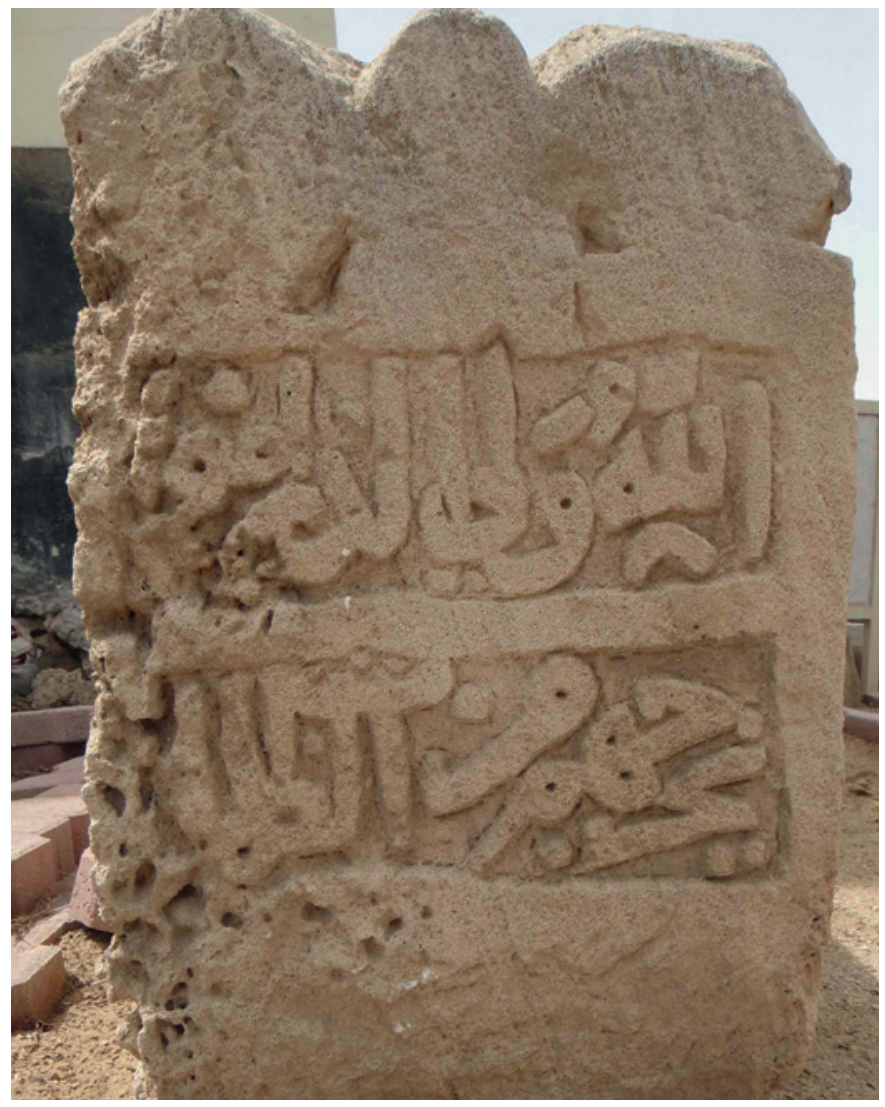

FIGURE 2.104

Surface D, ABN27

E:

- Oh grave, you contain a high mountain, be proud that you embedded a great person such as Ahmad.

هو واحـ شخصا وعن كل الورى، جاهـا people and nobody is similar to him.
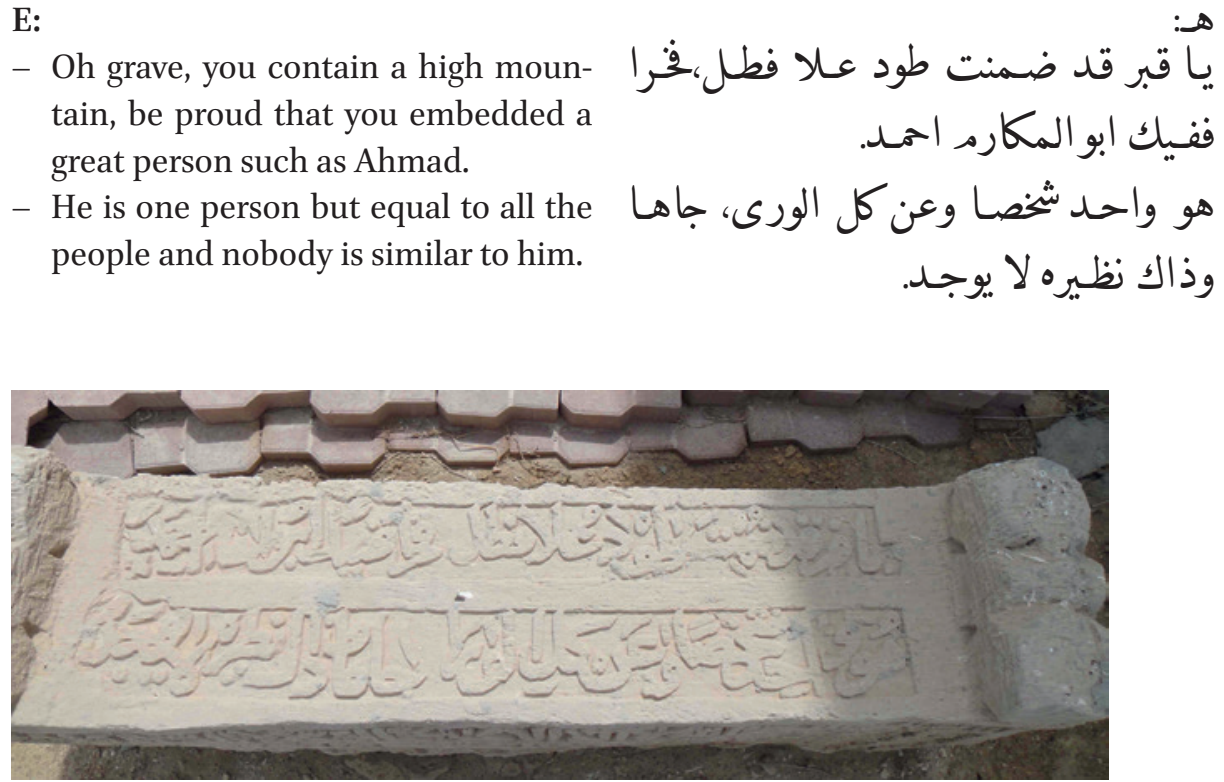

FIGURE 2.105 Surface E, ABN27 
Reference Number: ABN28

Co-ordinates: $26.21095^{\circ} \mathrm{N} 050.55118^{\circ} \mathrm{E}$

Dimensions: $55 \mathrm{~cm}(\mathrm{l}) \times 17-19 \mathrm{~cm}(\mathrm{w}) \times 29 \mathrm{~cm}(\mathrm{~h})$

Orientation: N-S

Description: Small single limestone slab gravestone in very eroded condition (Figure 2.106). Traces of illegible inscriptions on one surface.

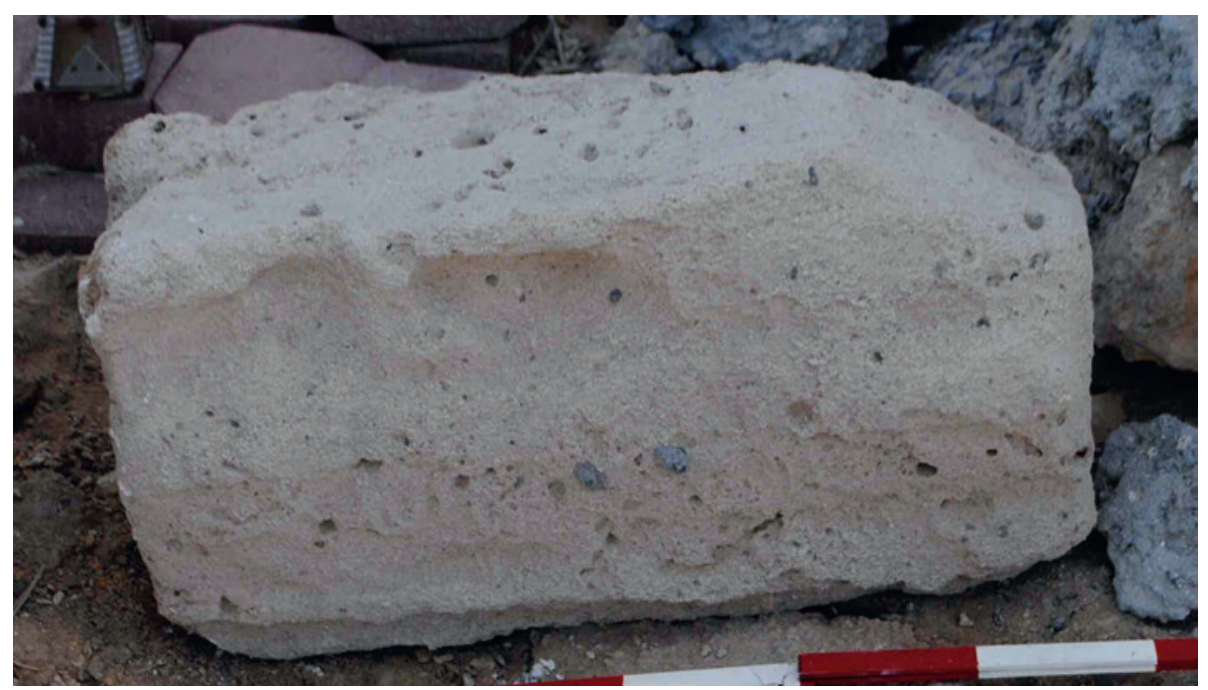

FIGURE 2.106 ABN28

Arabic Transcription and Translation: No legible inscriptions

\section{Reference Number: ABN29}

Co-ordinates: $26.21097^{\circ} \mathrm{N} 050.55114^{\circ} \mathrm{E}$

Dimensions: $147 \mathrm{~cm}(\mathrm{l}) \times 3^{2-}-33 \mathrm{~cm}(\mathrm{w}) \times 41 \mathrm{~cm}(\mathrm{~h})$

\section{Orientation: $\mathrm{N}-\mathrm{S}$}

Description: Single limestone slab gravestone. No niche design on surface E. Three element raised decoration at both ends formed of two facetted cubes with a central thin raised point. Significant erosion on one end surface (C). Inscriptions on four surfaces. 
Arabic Transcription and Translation:

A:

- In the Name of Allah, the Most Gracious, the Most Merciful. Allah, none has the right to be worshipped but he, the Ever Living, the One Who sustains and protects all that exists. Neither slumber nor sleep overtakes Him. To Him belongs whatever is in - ... Who is he that... with Him except by His permission! He knows what happens to them in this world,
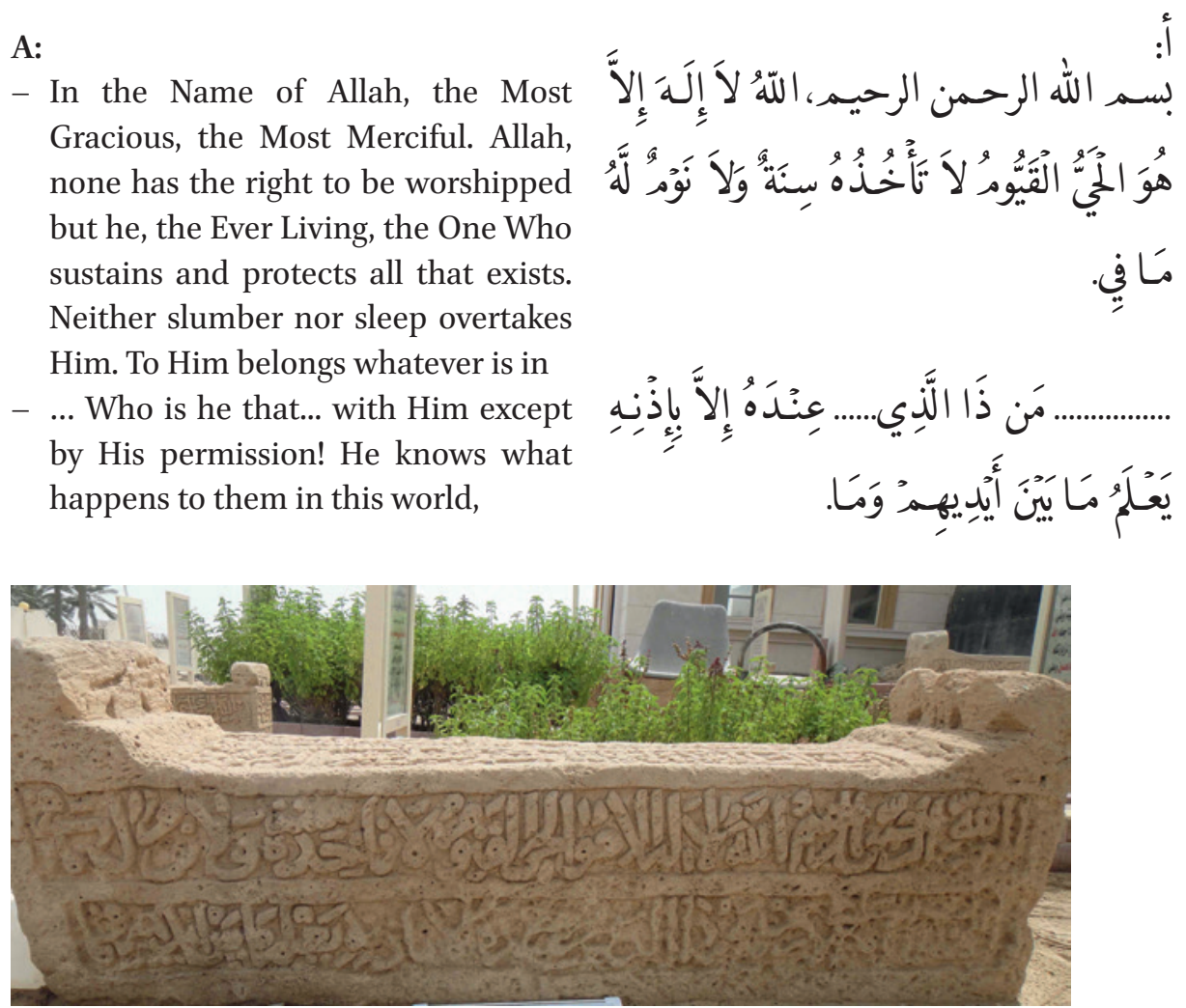

FIGURE 2.107 Surface A, ABN29

B:

- And what will happen to them in the Hereafter and they will never compass anything of His Knowledge except that which He wills. His Seat extends over the heavens and the earth, and He feels no fatigue

- In guarding and preserving them. And $\mathrm{He}$ is the Most High, the Most Great. There is no compulsion in religion. Verily, the Right Path has become distinct from the wrong path. Whoever disbelieves in al-Taghut

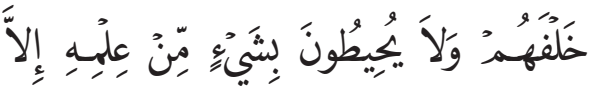

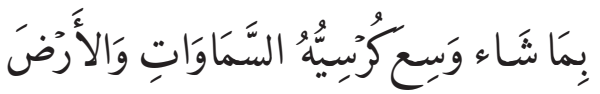
وَلاً يَؤُودهُه.

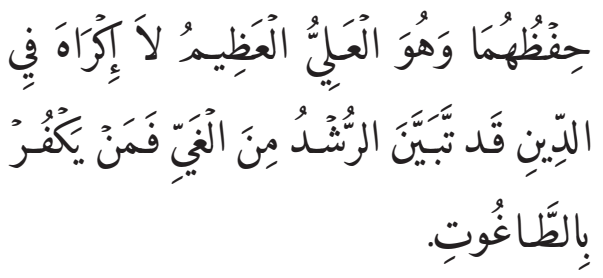
(2:255-256). 


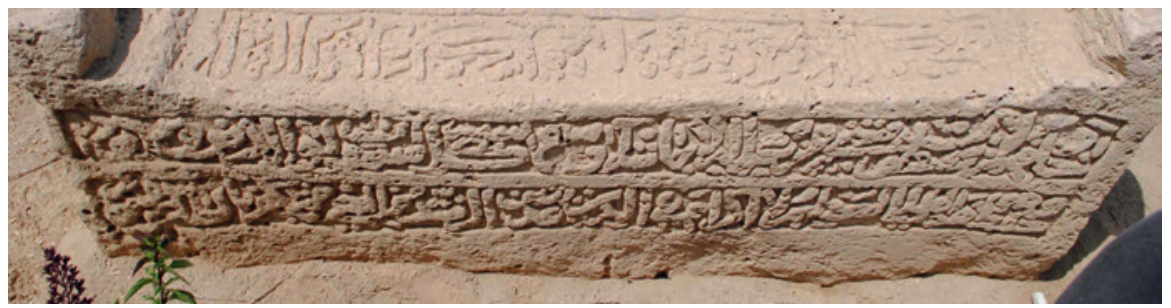

FIGURE 2.108 Surface B, ABN29

C:

- No carving or inscriptions.

$$
\text { لا توجـد عليهـا نقوش }
$$

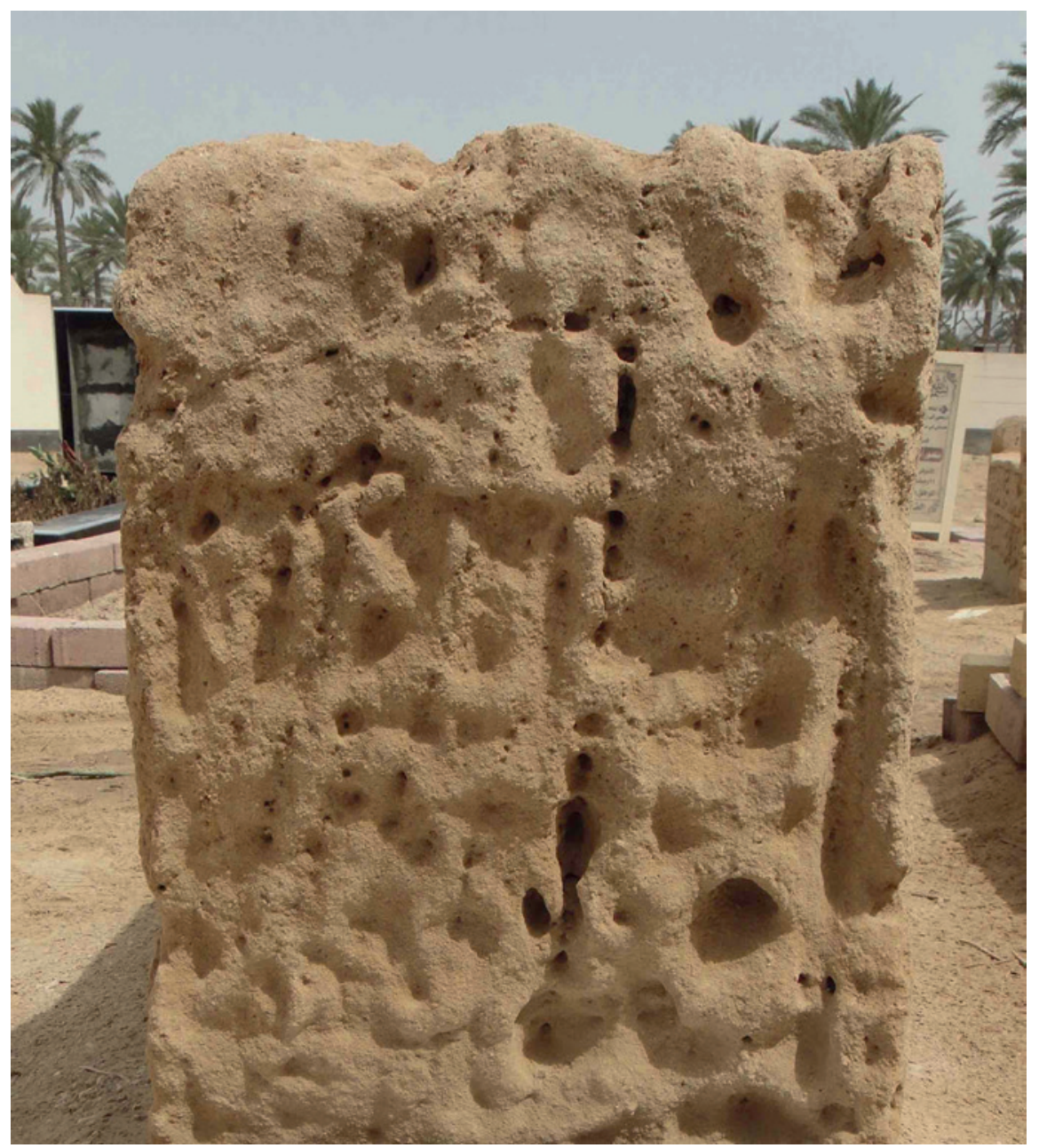

FIGURE 2.109 Surface C, ABN29 
D:

- Allah is the Protector of those who

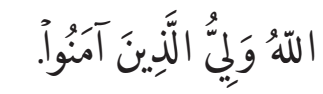
believe.

- He brings them out from darkness (2:257).
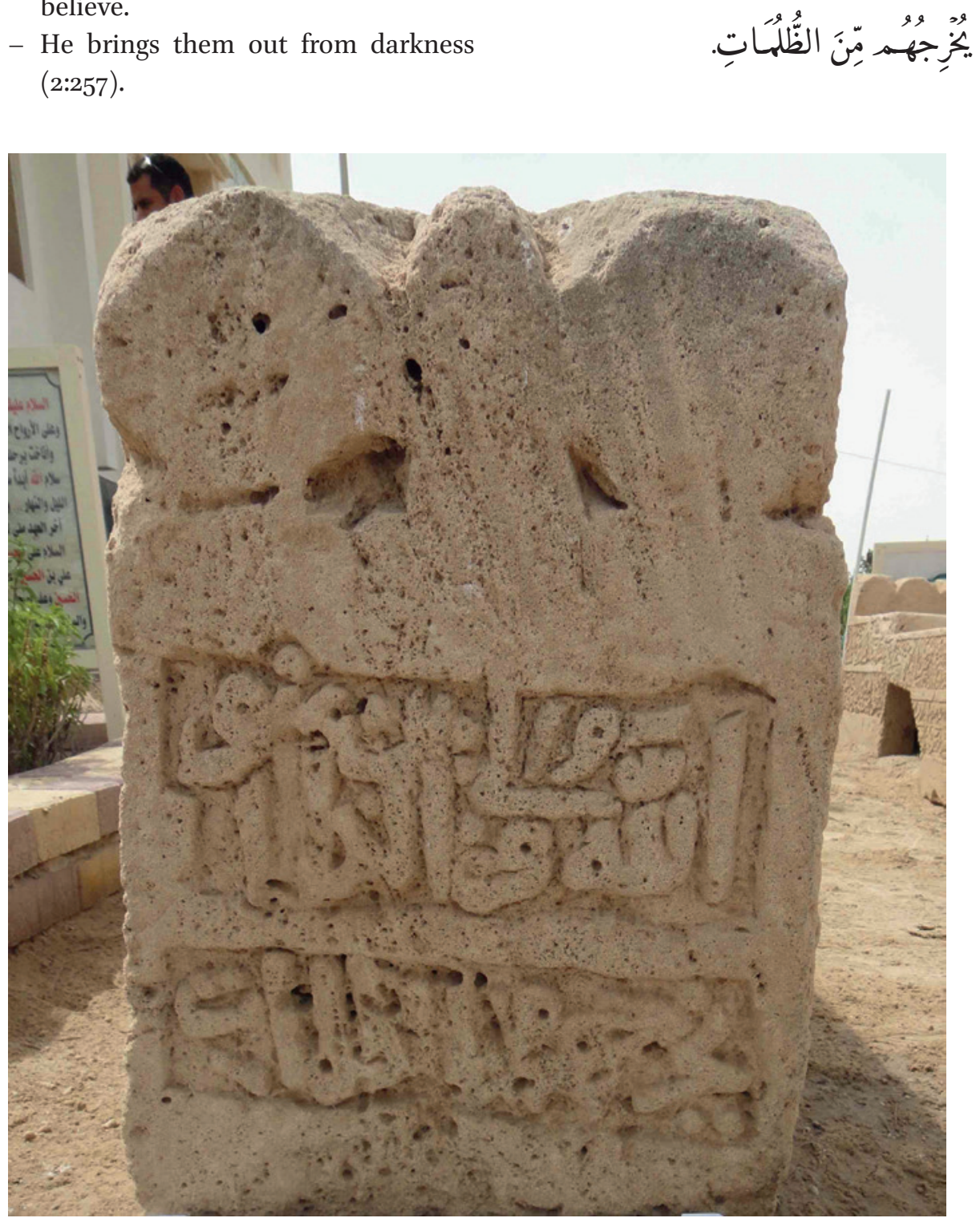

FIGURE 2.110 Surface D, ABN29 
E:

- Oh grave, you should boast to the other graves, because you embedded a person who is a haven for everybody.

- He is the most honourable person socially and in reputation, he is Ja'far bin 'Abd al-Ra'uf.
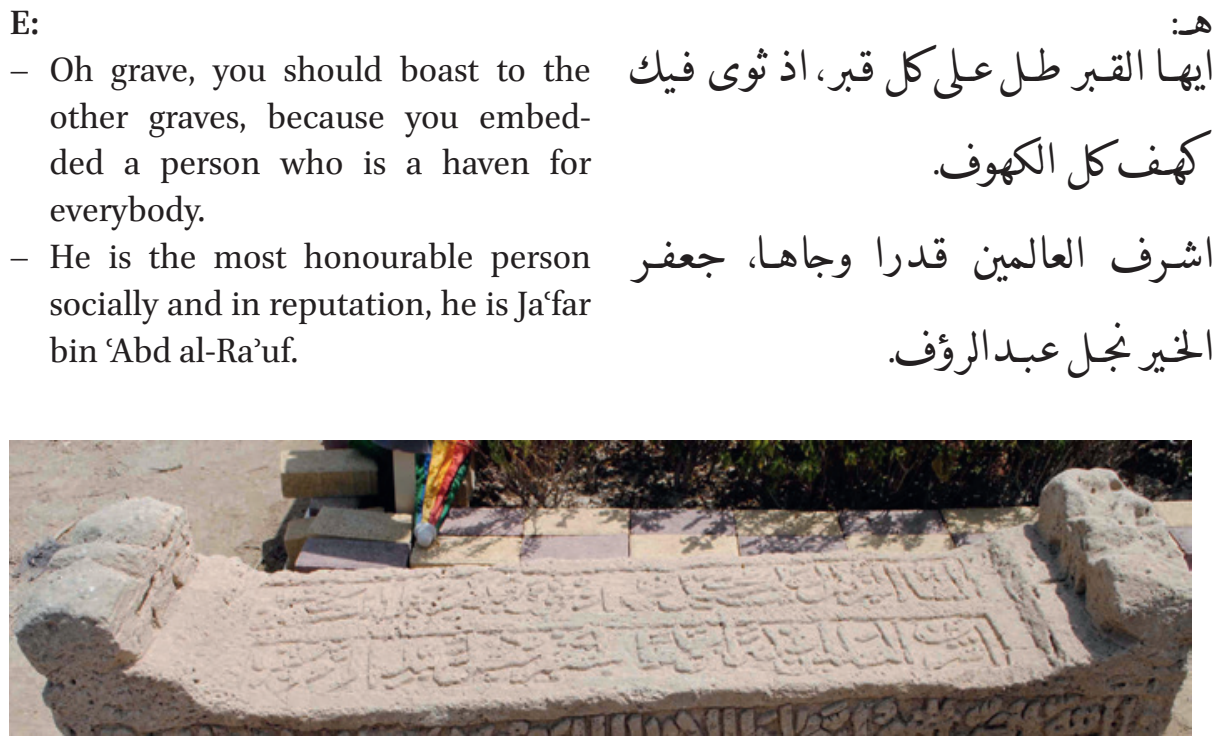

FIGURE 2.111 Surface E, ABN29

\section{Reference Number: ABN30}

Co-ordinates: $26.21099^{\circ} \mathrm{N} 050.55114^{\circ} \mathrm{E}$

Dimensions: $144.5 \mathrm{~cm}(\mathrm{l}) \times 30.5^{-31} \mathrm{~cm}(\mathrm{w}) \times 33 \mathrm{~cm}(\mathrm{~h})$

\section{Orientation: NNW-SSE}

Description: Single limestone slab gravestone. No niche design on surface E. Three element raised decoration at both ends formed of two facetted cubes with a central rounded arch that is wider and flatter at one end. Slight erosion. Deeply carved with large lettering used. Inscriptions on five surfaces.

\section{Arabic Transcription and Translation:}

A:

- And will happen to them in the Hereafter and they will never compass anything of His Knowledge except that which He wills. His Seat

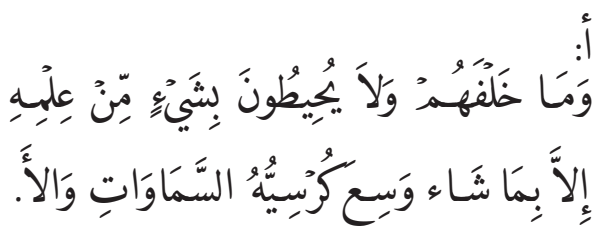
extends over the heavens and 
- The earth and He feels no fatigue in guarding and preserving them. And He is the Most High, the Most Great. There is no compulsion in religion. Verily, the Right Path has become distinct $\left(2: 255^{-256}\right)$.
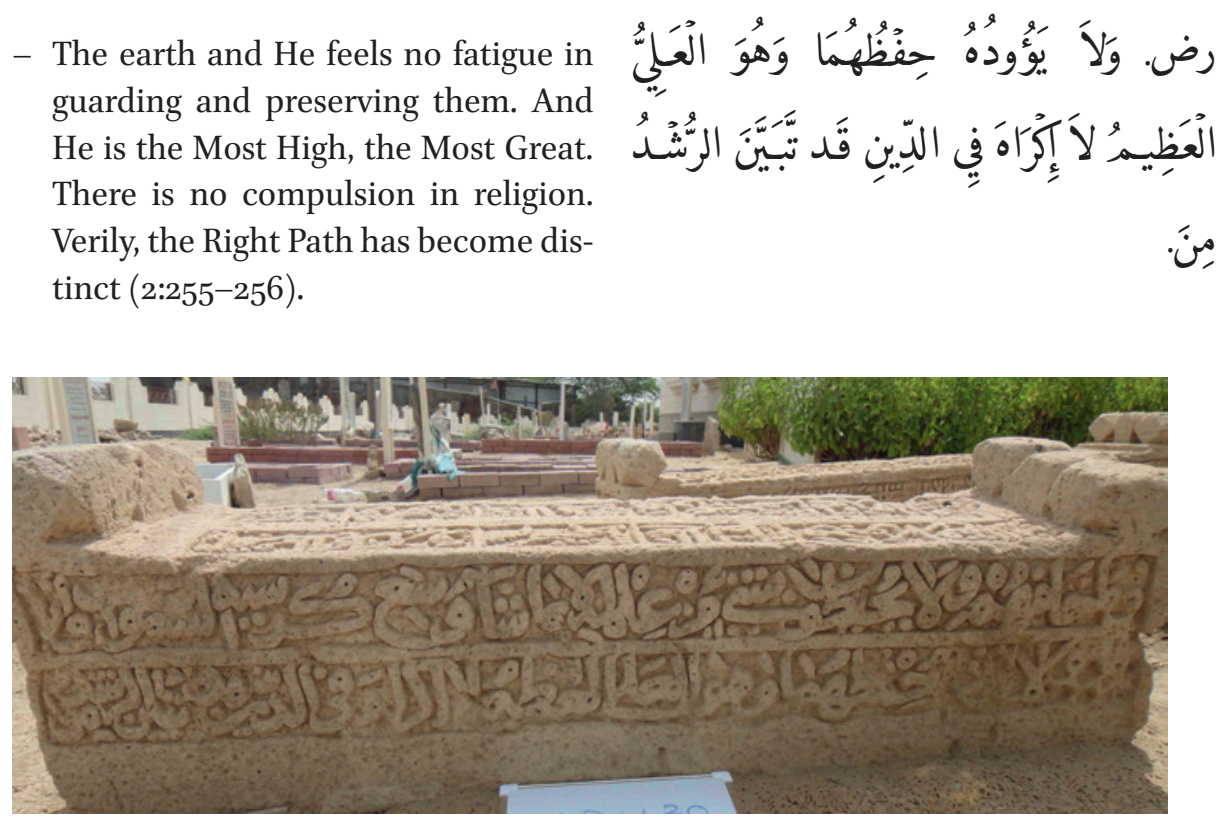

FIGURE 2.112 Surface A, ABN30

B:

- In the Name of Allah, the Most Gracious, the Most Merciful. Allah, none has the right to be worshipped but he, the Ever Living, the One Who sustains and protects all that exists. Neither slumber nor sleep overtakes Him. To Him belongs whatever is in

- the heavens and whatever is on the earth. Who is he that can intercede with Him except by His permission! He knows What happens to them in this world (2:255).

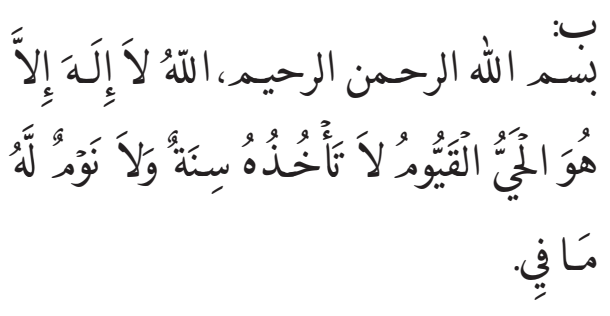

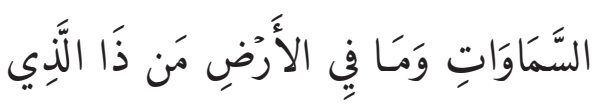

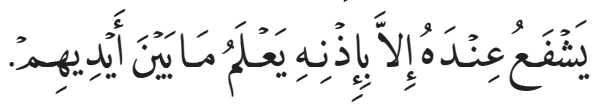

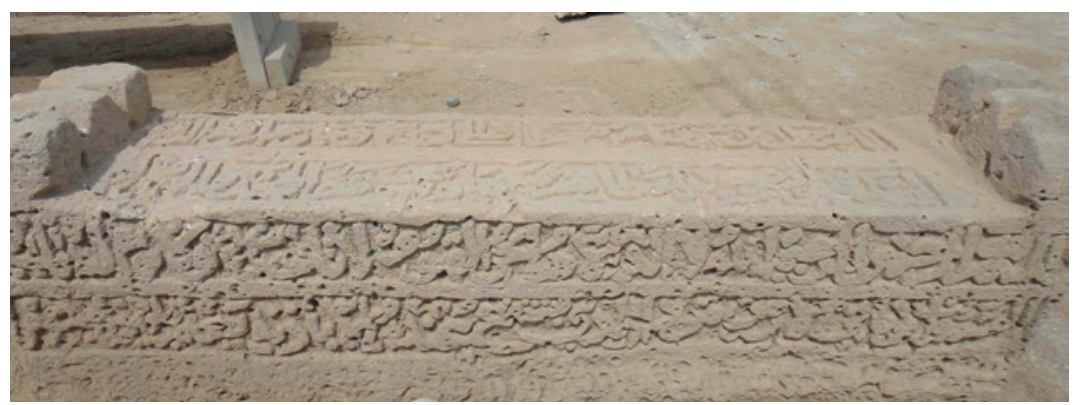

FIGURE 2.113 Surface B, ABN30 
C:

- Allah is the Protector of those who

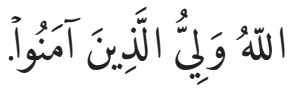
believe (2:257).

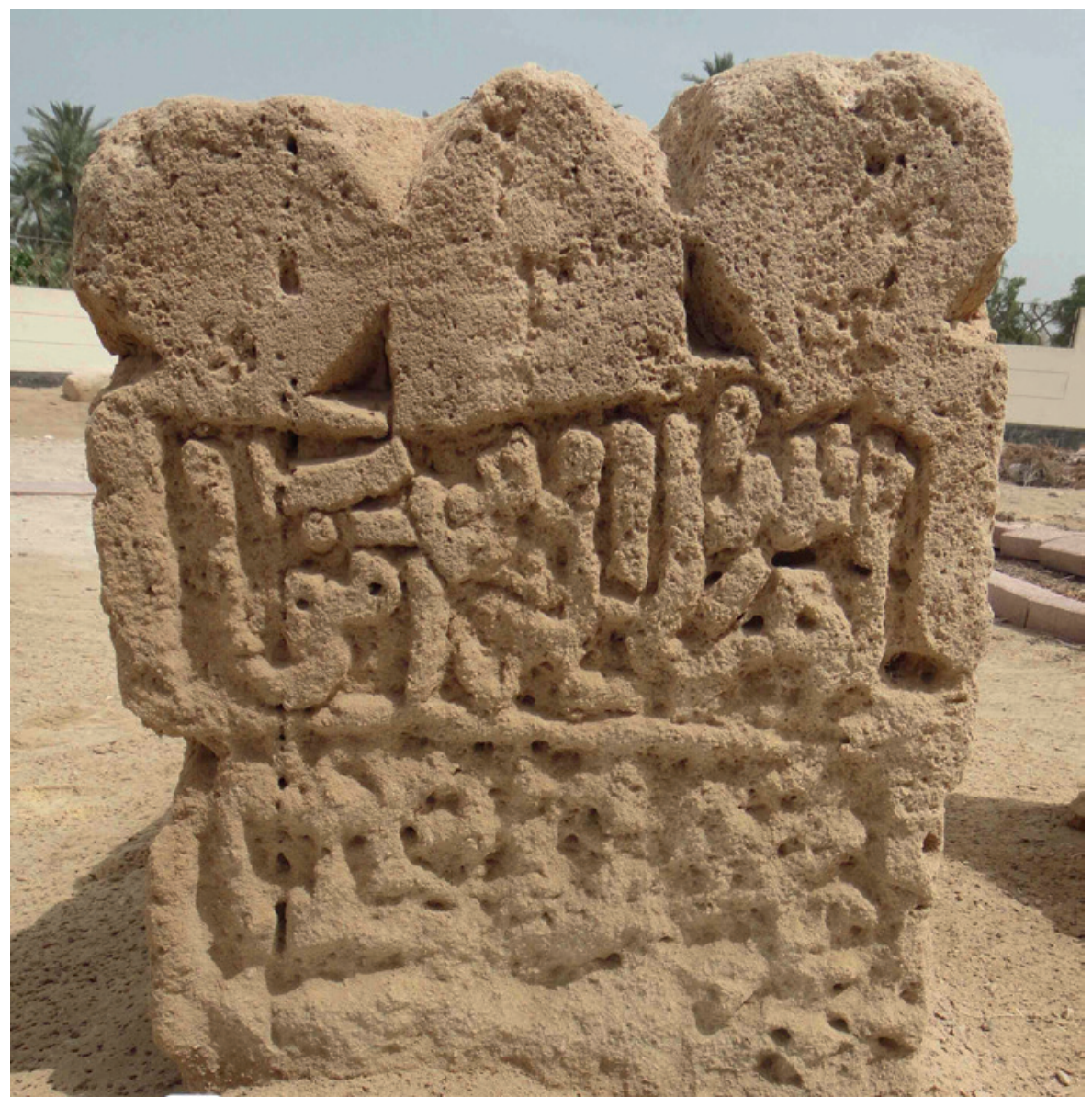

FIGURE 2.114 Surface C, ABN30

D:

- from the wrong path. Whoever disbelieves

- in al-Taghut (2:257).

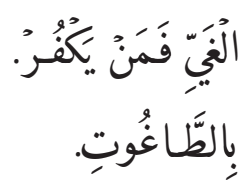




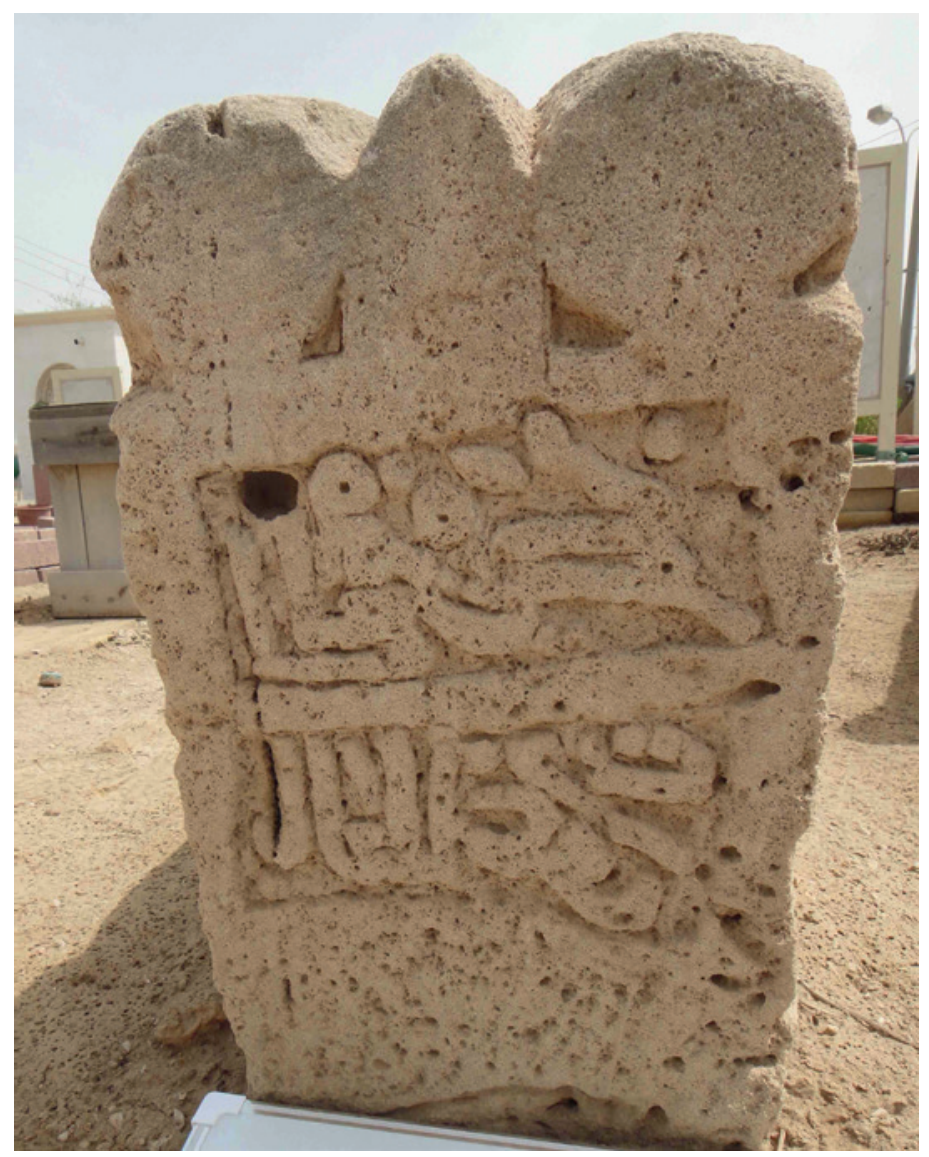

FIGURE 2.115

Surface D, ABN30

E:

- Oh grave, you should boast proudly to other places and get the highest honour

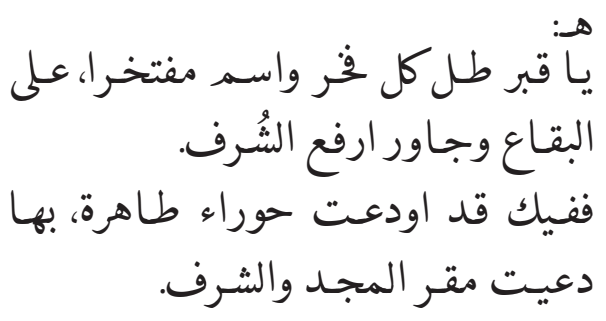

- Because you embedded a chaste woman, and because of her you are a glorious and honoured place.

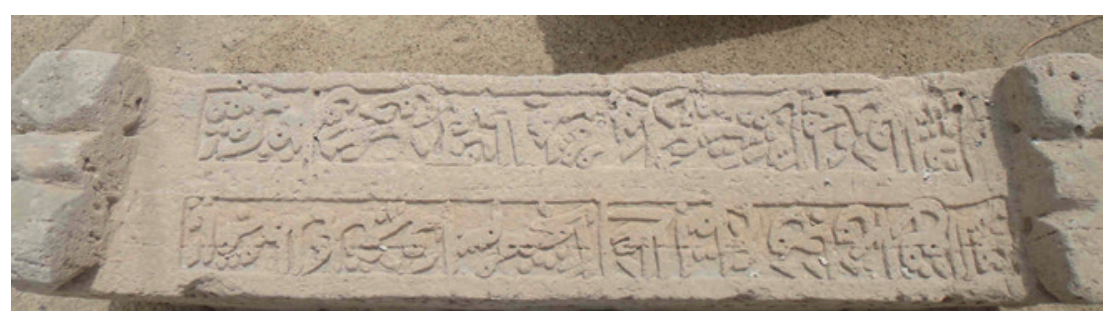

FIGURE 2.116 Surface E, ABN30 


\section{Reference Number: ABN31}

Co-ordinates: $26.21099^{\circ} \mathrm{N} 05^{0.55116^{\circ} \mathrm{E}}$

Dimensions: $142 \mathrm{~cm}(\mathrm{l}) \times 21.5 \mathrm{~cm}(\mathrm{w}) \times 37 \mathrm{~cm}(\mathrm{~h})$

\section{Orientation: NW-SE}

Description: Single limestone slab gravestone in good condition. No niche design on surface E. Three element raised decoration formed of two facetted cubes and a central rounded arch all set on a rectangular plinth at both ends. Inscriptions on five surfaces.

\section{Arabic Transcription and Translation:}

A:

- In the Name of Allah, the Most Gracious, the Most Merciful. Allah, none has the right to be worshipped but he, the Ever Living, the One Who sustains and protects all that exists. Neither slumber nor sleep overtakes Him. To Him belongs whatever is in the heavens and whatever is on the earth. Who is he that can intercede with Him except by His permission!

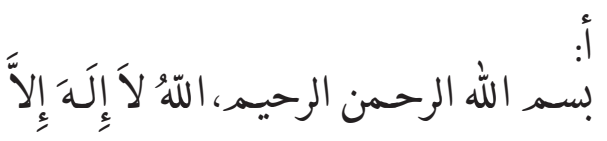

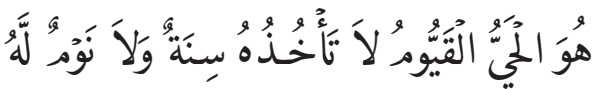

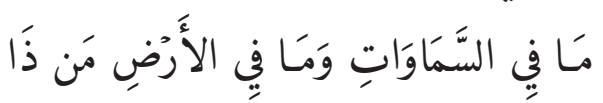

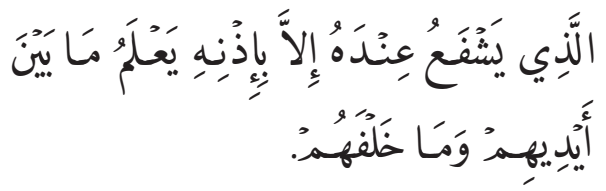
He knows what happens to them in this world, and will happen to them in the Hereafter.

- And they will never compass anything of His Knowledge except that which He wills. His Seat extends over the heavens and the earth, and He feels no fatigue in guarding and preserving them. And $\mathrm{He}$ is the Most High, the Most Great (2:255). Allah, The Most Great, and His prophet

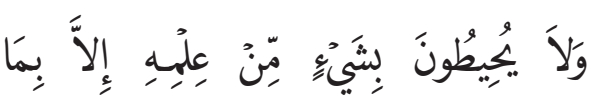

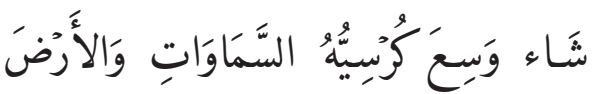
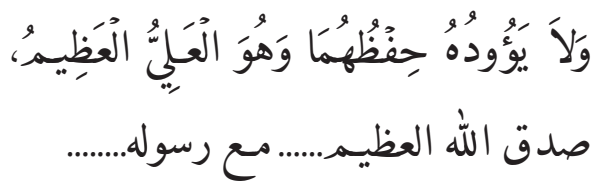
have spoken the truth. 


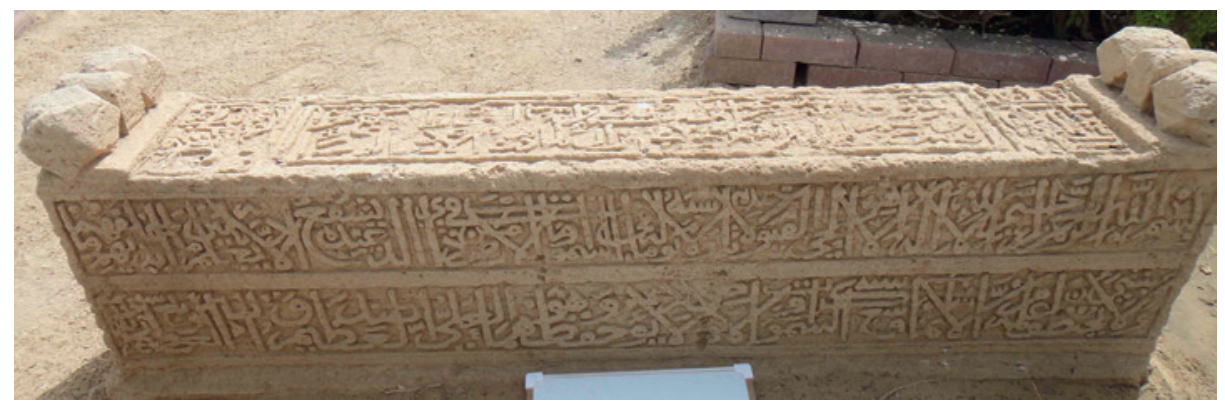

FIGURE 2.117 Surface A, ABN31

B:

- The angels will descend on them, (saying:) Fear not, nor grieve; But receive the glad tidings of Paradise which you have been promised. We have been your friends in the life of this world and in the Hereafter. Therein you shall have all that your souls desire

- And all that you ask for, as hospitality from One, the Forgiving, the Most Merciful (41:30-32). Gardens of Eden whose gates will be opened for them. Therein they will recline, therein they will call for fruits in abundance and drinks. And beside them will be maidens of equal age with modest gaze $\left(38: 50-5^{2}\right)$. Allah, the Most Great, has spoken the truth.
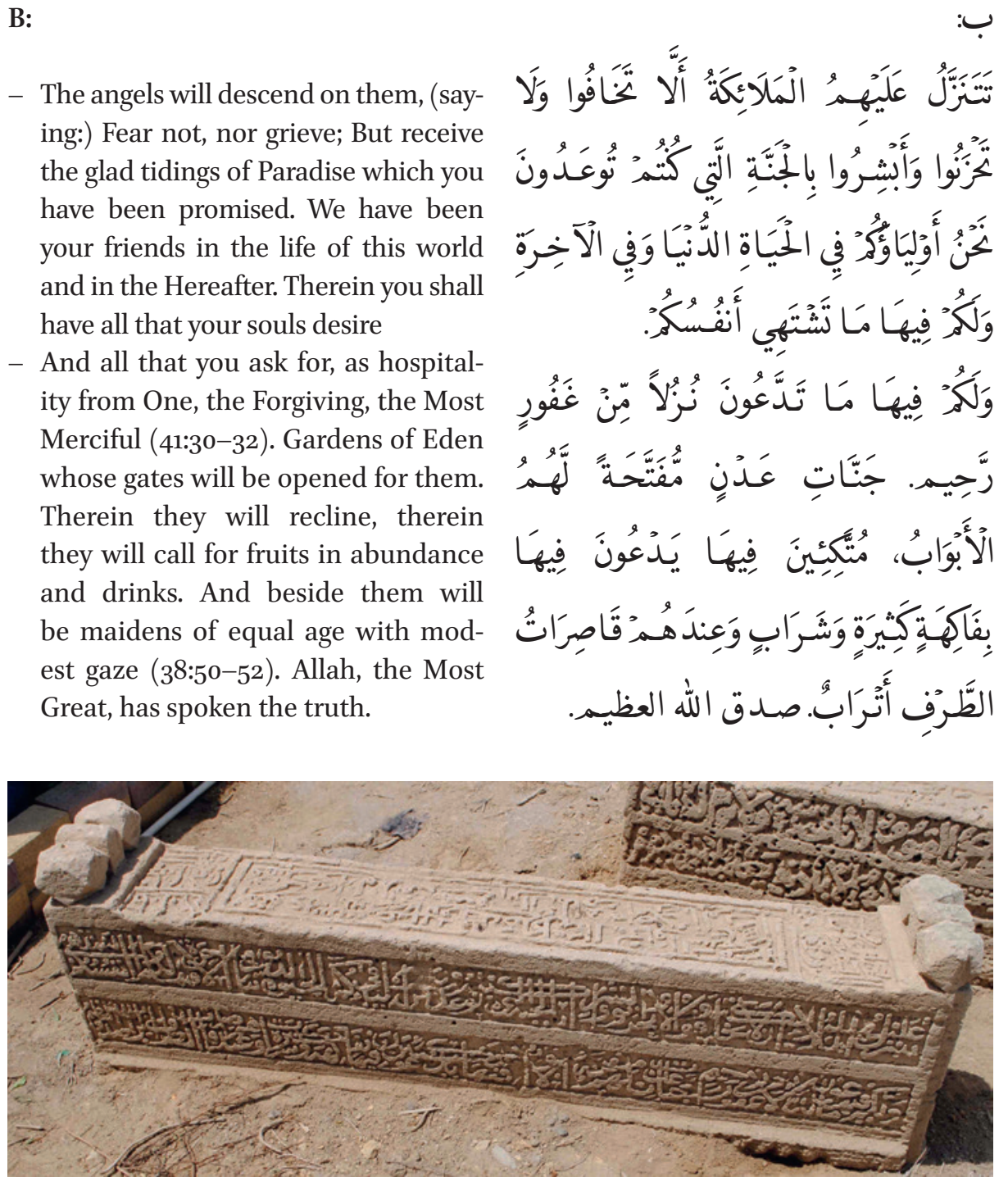

FIGURE 2.118 Surface B, ABN31 
C:

- (Two thirds) and six should be read to her.

- One third on the (palm tree)

$$
\text { جِّـا عليها (ثلثان) وستة. }
$$

(... الثلث على الغل (النخل).

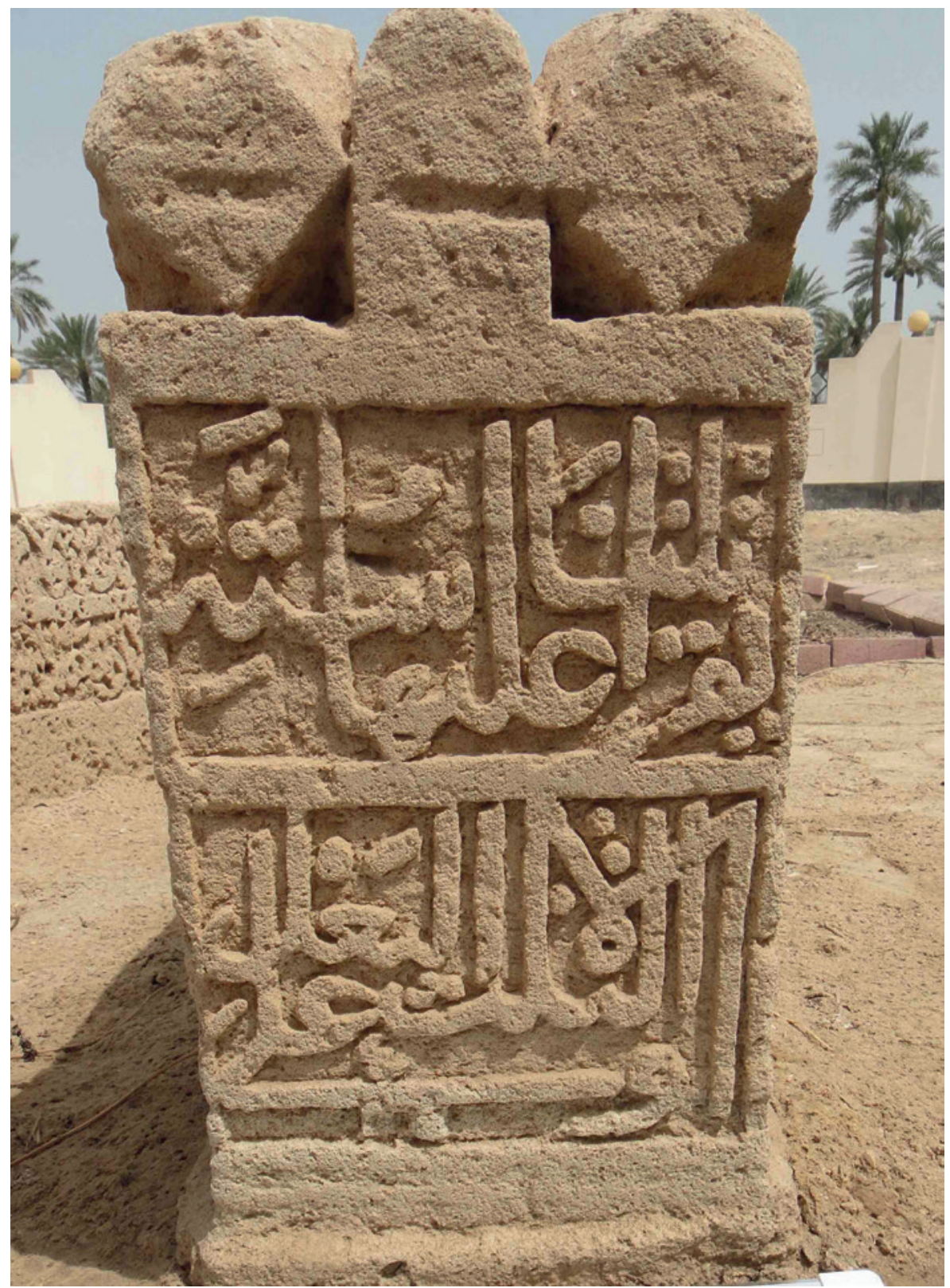

FIGURE 2.119 Surface C, ABN31 
D:

- And half of an eighth which

ونصف اثمان (التمر) الذي.

- On the people of al-Ukul island.

على بنو جزيرة الاكل.

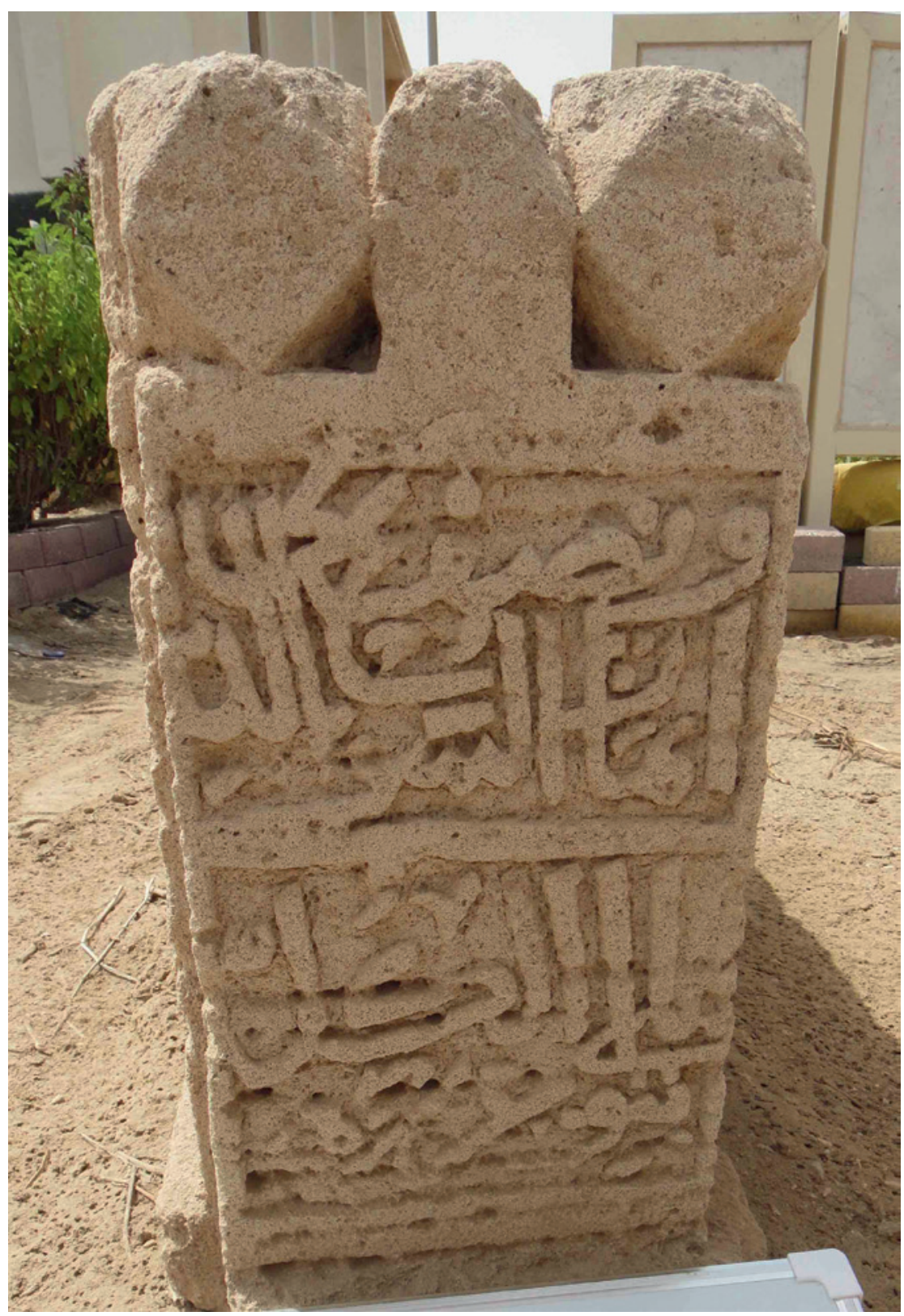

FIGURE 2.120 Surface D, ABN31 
E:

- The chaste, Amirah bint al-Sayyid 'Abd al-Ra'uf died.

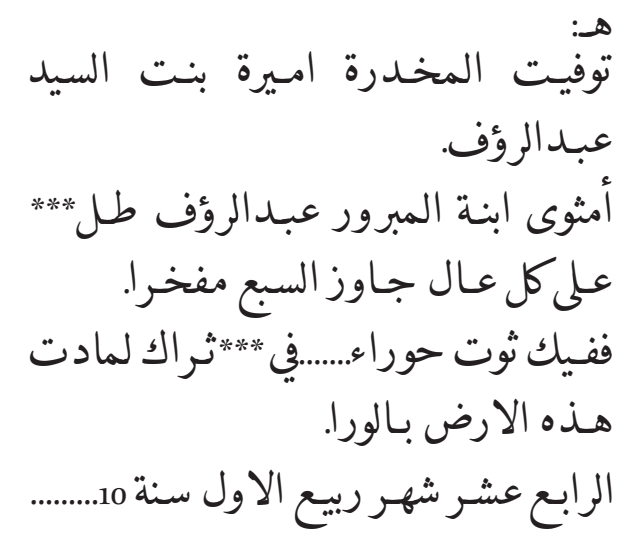

- Oh grave of 'Abd al-Ra'uf's daughter be prouder than others

- Because you embedded Hawra' ... in your soil which without her the earth would shake.

- Fourteenth of Rabic al-awwal, year of $10 \ldots$

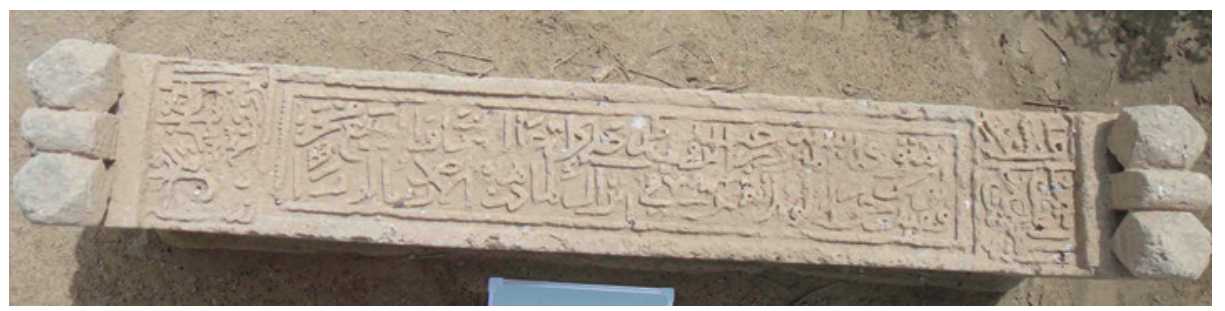

FIGURE 2.121 Surface E, ABN31

\section{Reference Number: ABN32}

Co-ordinates: $26.21098^{\circ} \mathrm{N} 05^{0.55119^{\circ} \mathrm{E}}$

Dimensions: $150 \mathrm{~cm}(\mathrm{l}) \times 33 \mathrm{~cm}(\mathrm{w}) \times 41 \mathrm{~cm}(\mathrm{~h})$

\section{Orientation: NW-SE}

Description: Single limestone slab gravestone in generally good condition. Wellcarved. Some erosion on one side surface (A) and one end surface (D). Shallow carved pointed niche design on top surface (E). Raised decoration cut off at one end and three element raised decoration formed of two facetted cubes and a central rounded arch all set on a rectangular plinth at the other end. Inscriptions on five surfaces. 


\section{Arabic Transcription and Translation:}

A:

- The angels will descend on them ... Therein you shall have all that your souls desire and all that you ask for ... the Forgiving, ... (41:30-32)

- Therein they will recline; therein they will call for fruits in abundance and drinks ... the Day of Reckoning. Verily, this is our Provision which will never finish (38:51-54).
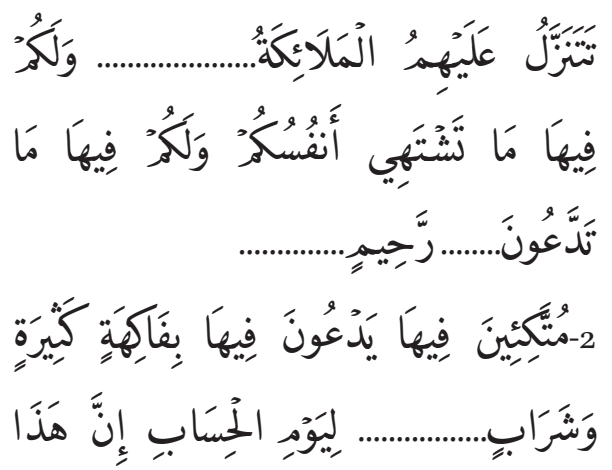

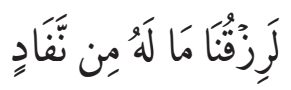

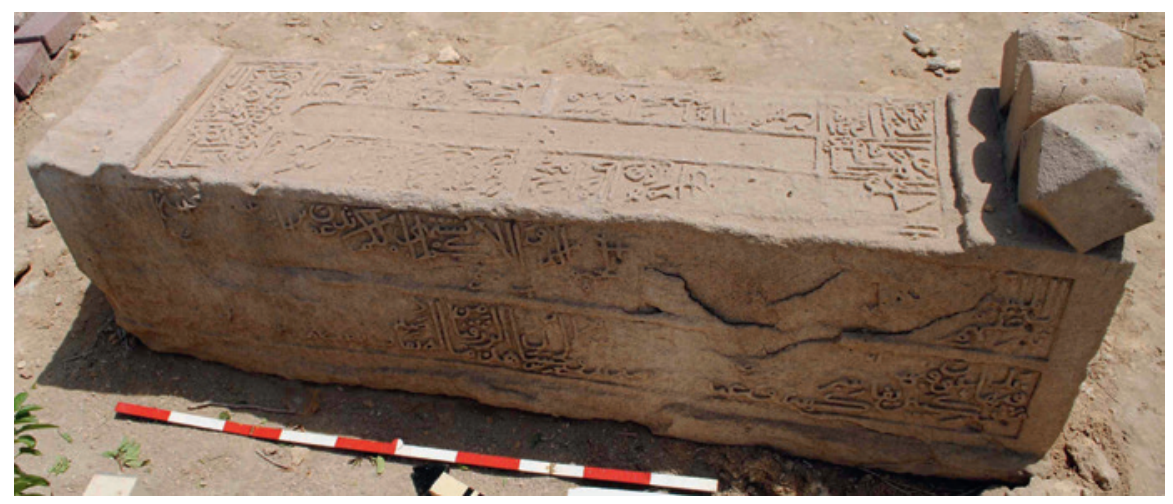

FIGURE 2.122 Surface A, ABN32

B:

- In the Name of Allah, the Most Gracious, the Most Merciful. Allah, none has the right to be worshipped but he, the Ever Living, the One Who sustains and protects all that exists. Neither slumber nor sleep overtakes Him. To Him belongs whatever is in the heavens and whatever is on the earth. Who is he that can intercede with Him except by His permission!

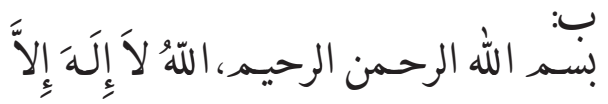

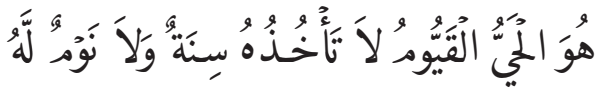

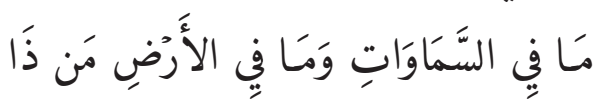

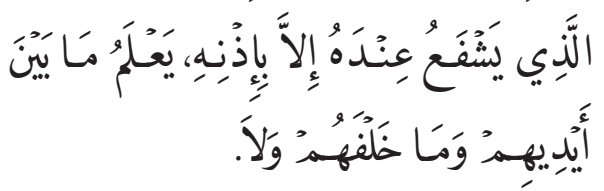
He knows what happens to them in this world, and will happen to them in the Hereafter and they will never 
- Compass anything of His Knowledge except that which He wills. His Seat extends over the heavens and the earth, and He feels no fatigue in guarding and preserving them. And He is the Most High, the Most Great. There is no compulsion in religion. Verily, the Right Path has become distinct from the wrong path. Whoever disbelieves in al-Taghut and believes in Allah, then he has grasped the most trustworthy handhold that will never break. And Allah is All-Hearer, All-Knower (2:255-256).

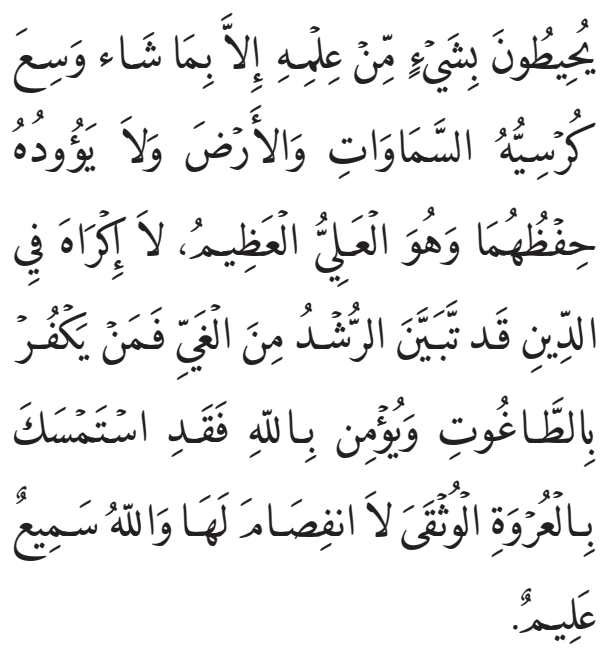

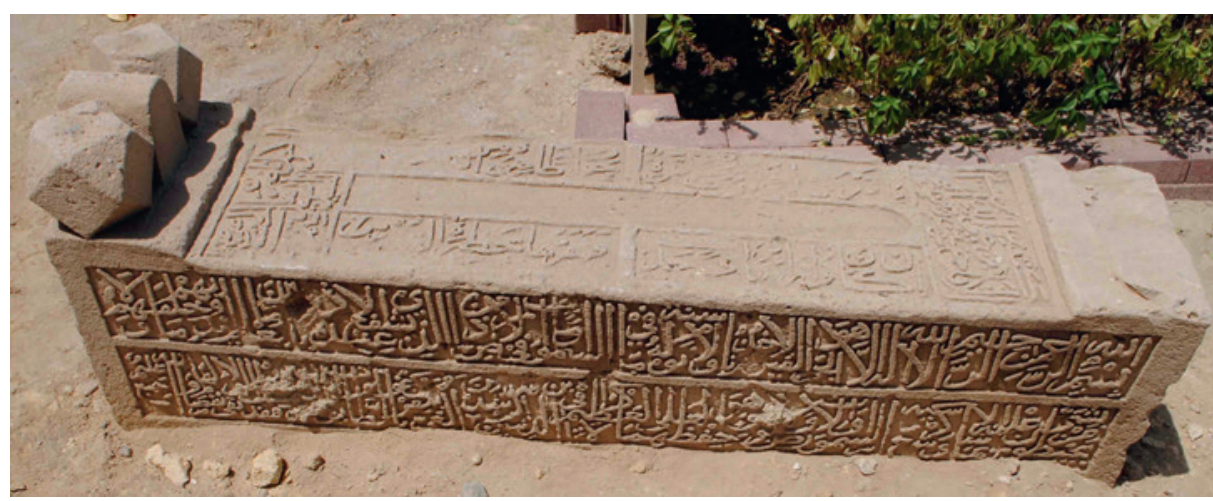

FIGURE 2.123 Surface B, ABN32

C:

- Big baskets, the weight of each one twenty mann from the income. Tributes to develop it from the income of the Abu Naser palm trees which is located in Sitra. The death of the Late Husaynia Bint Jafar in fifteenth of Rabic al-thani, year of one thousand and ninety.

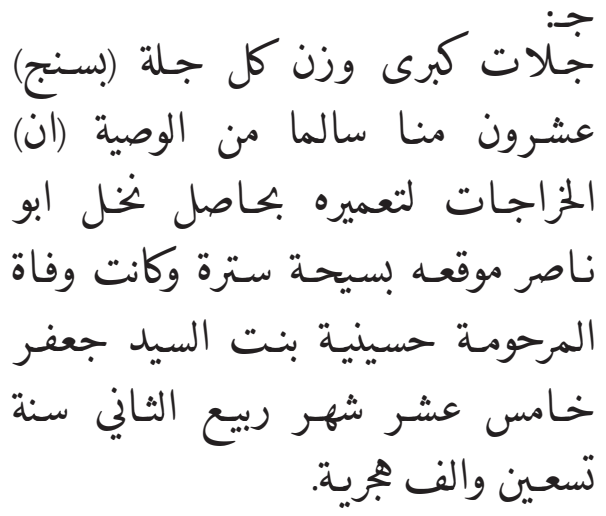




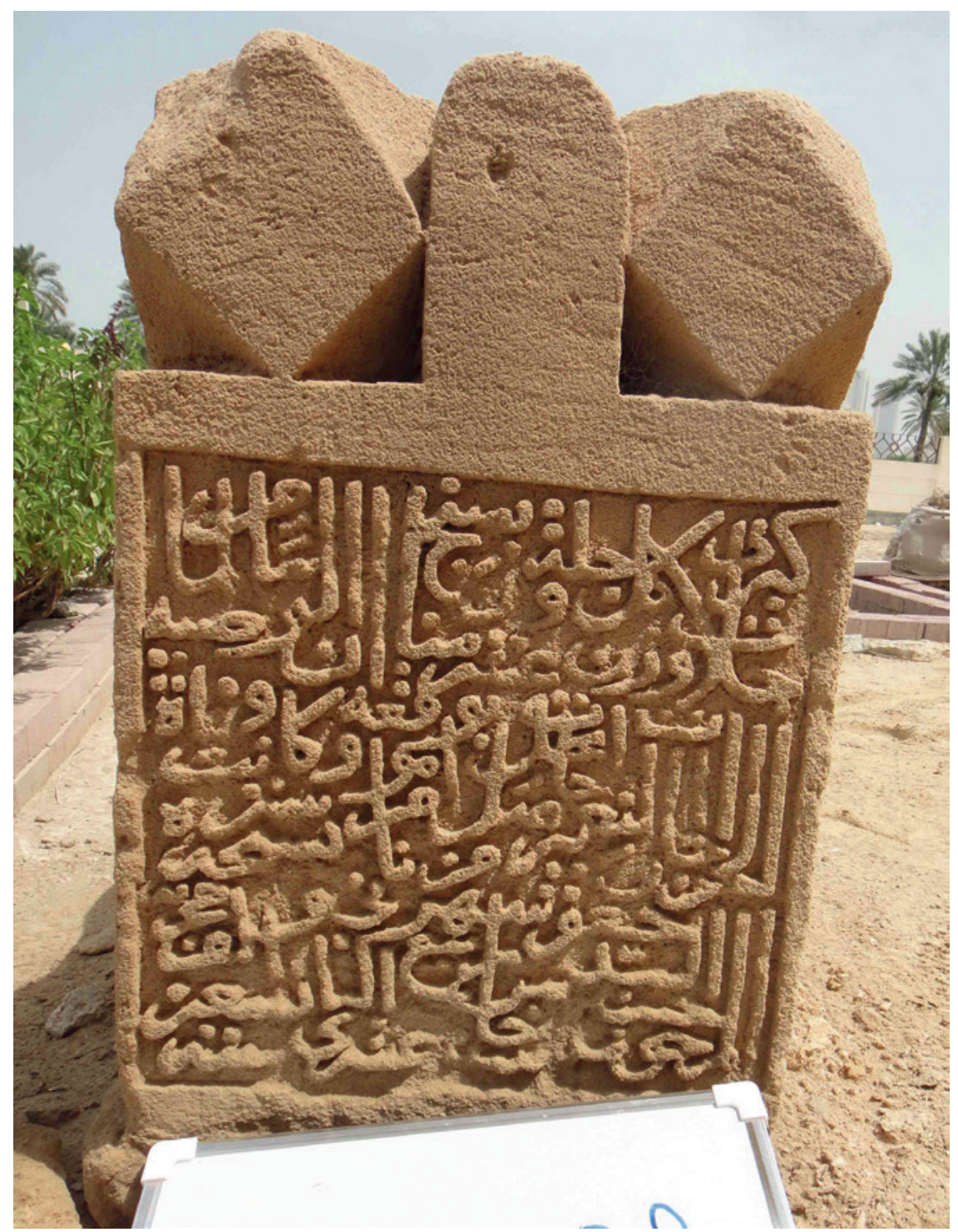

FIGURE 2.124 Surface C, ABN32

D:

- Reading ... on the grave ...

- And on ... bin Husayn ... And should be presented

- ... the believers ...

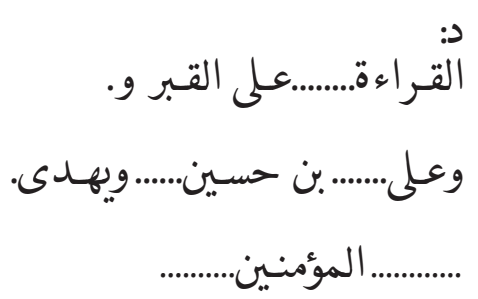




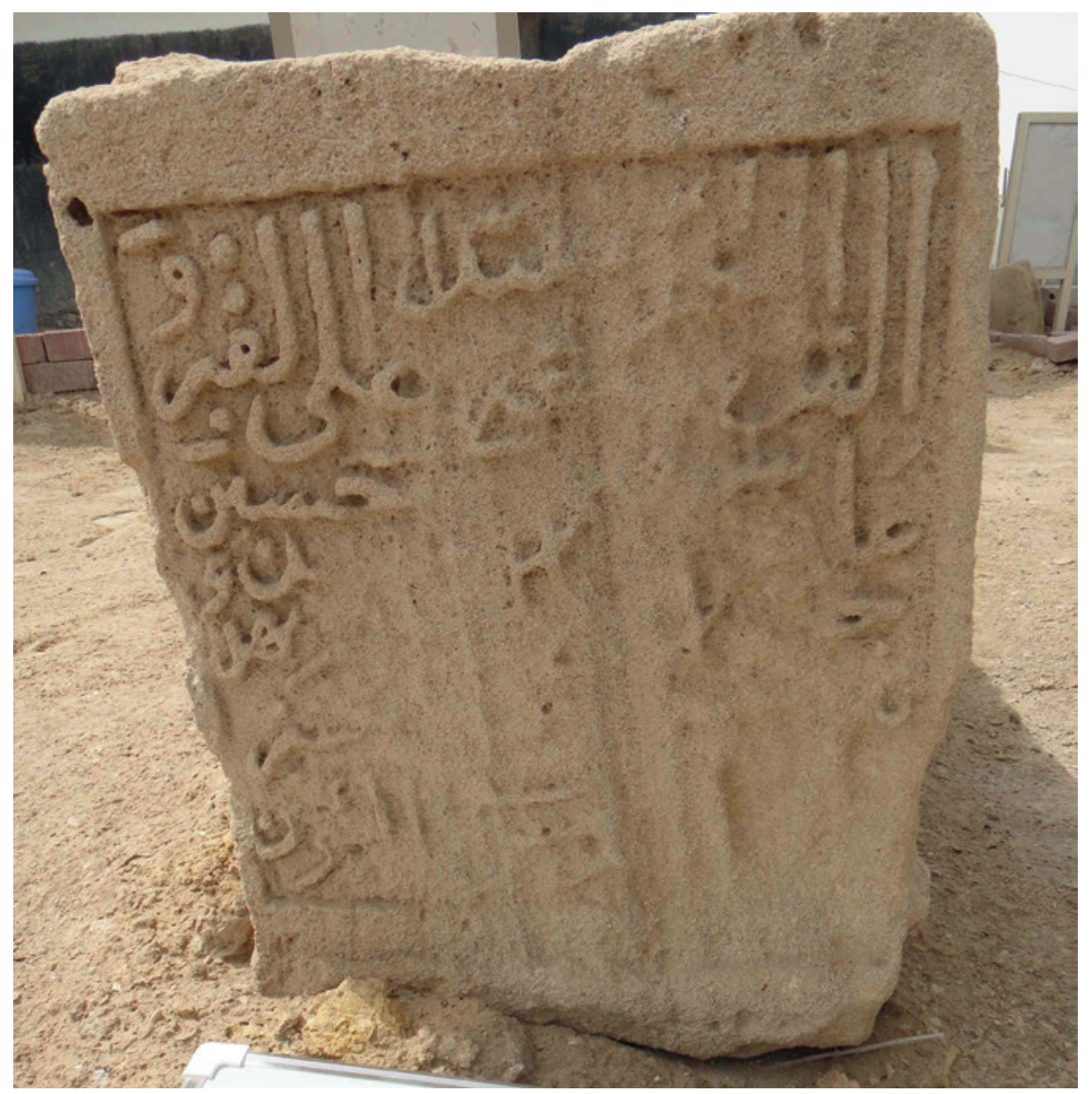

FIGURE 2.125 Surface D, ABN32

E:

كبه الاقل حسين بن علي بن زين الدين Written by Husayn bin 'Ali bin Zayn al-Din al-Bahrani ...

- ... The Great ... al-Sayyid Naser bin alSayyid Hashim al-Husayni, God bless them.

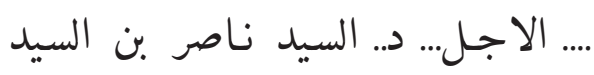

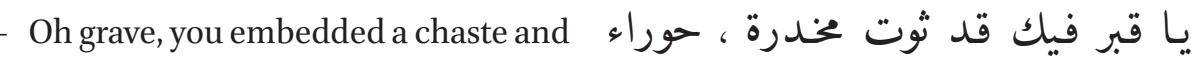
pure woman.

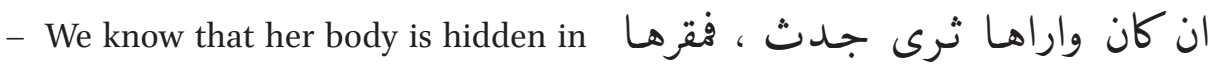
a grave, but in reality, her place is in paradise. 


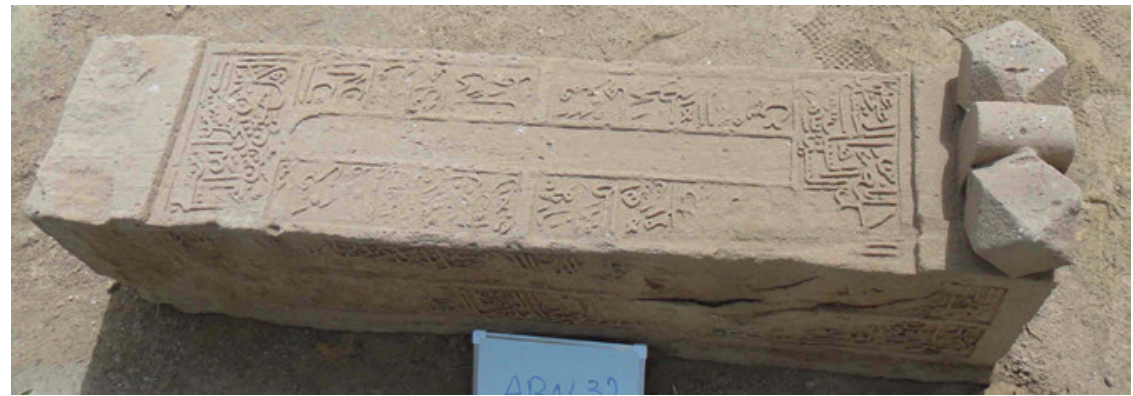

FIGURE 2.126 Surface E, ABN32

\section{Reference Number: ABN33}

Co-ordinates: $26.21111^{\circ} \mathrm{N} 050.55111^{\circ} \mathrm{E}$

Dimensions: Not measured

\section{Orientation: NA}

Description: Single limestone slab gravestone broken into nine fragments. These conjoin to form one hollow incomplete gravestone with inscriptions on two surfaces.

\section{Arabic Transcription and Translation:}

A:

- ... the Most Gracious, the Most Merciful. Allah, none has the right to be worshipped but he, the Ever Living, the One Who sustains and protects all that exists. Neither slumber nor sleep overtakes Him. To Him belongs whatever is in the heavens and whatever is on the earth ...

- And they will never compass anything of His Knowledge except that which He wills. His Seat extends over the heavens and the earth, and He feels no fatigue in guarding and preserving them. And $\mathrm{He}$ is the Most High... (2:255).
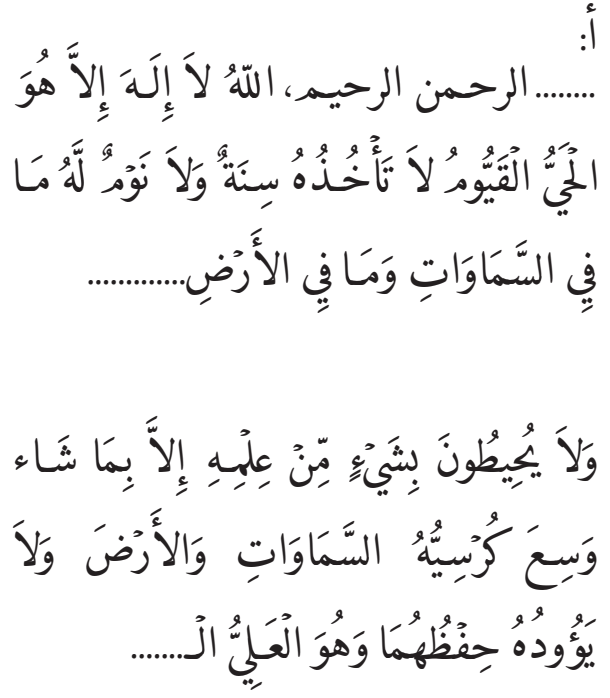


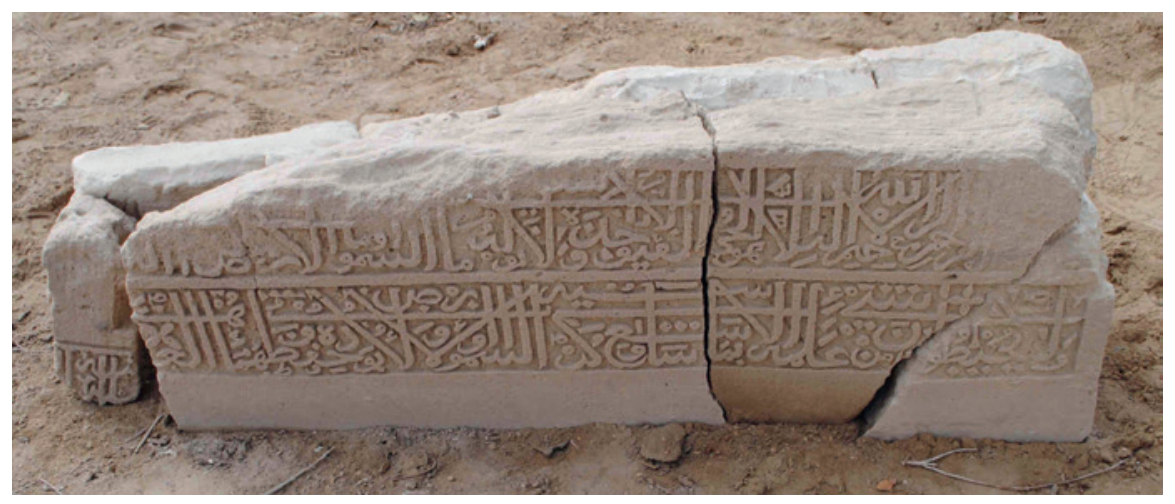

FIGURE 2.127 Surface A, ABN33

B:

- ... Verily, with Allah is a great reward (9:22).

- ... But receive the glad tidings of Paradise which you have been promised. We have been your friends in the life of this world and in the Hereafter. Therein you shall have all that your souls desire and all that you ask for, as hospitality from One, the Forgiving, the Most Merciful (41:30-32).
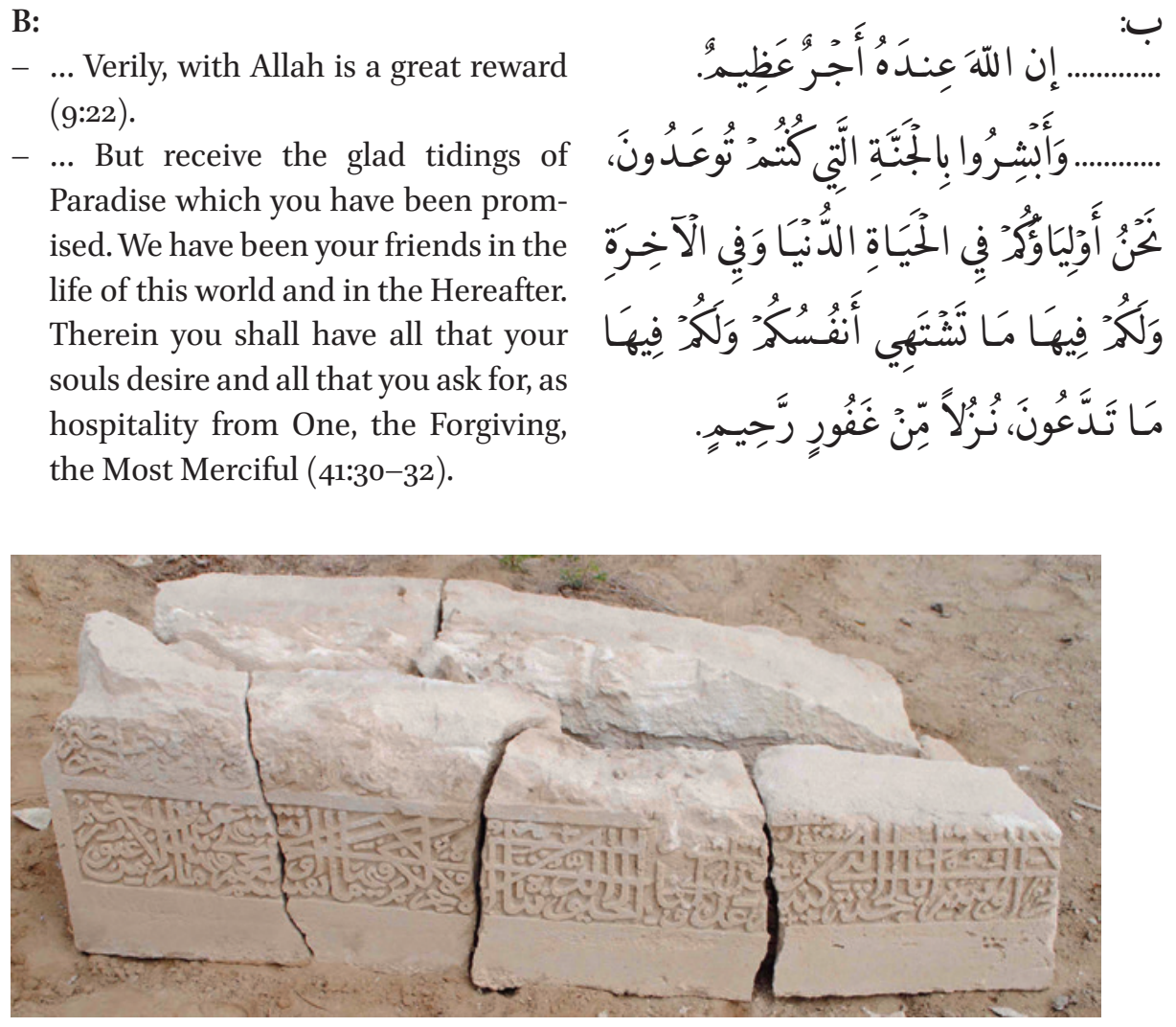

FIGURE 2.128 Surface B, ABN33

C:

- No carving or inscriptions.

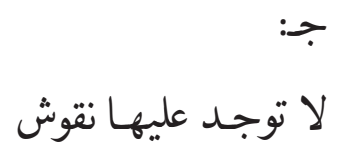


D:

- No carving or inscriptions.

E:

- No carving or inscriptions.

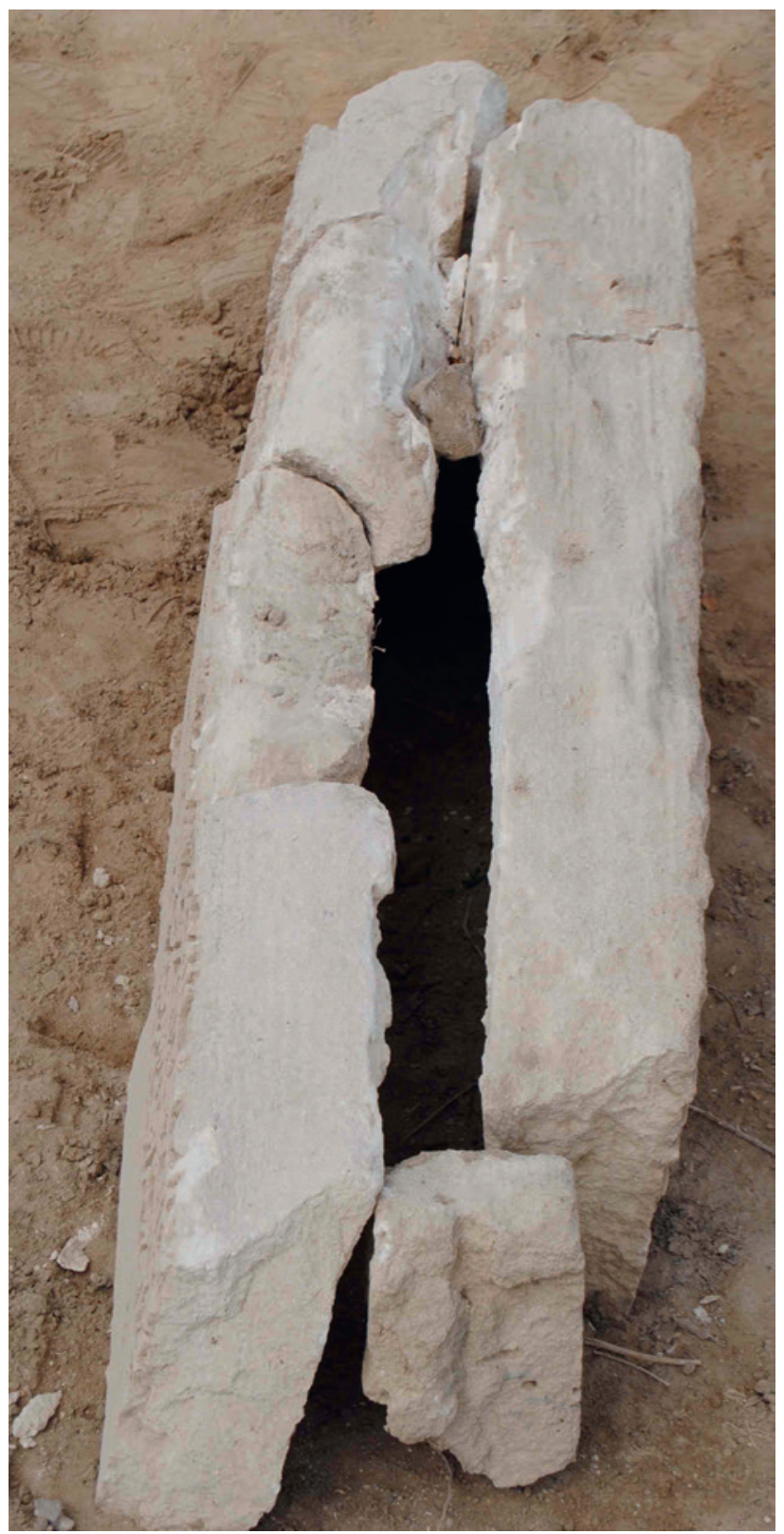

$$
\text { لا توجد عليها نقوش }
$$

لا تهـ: تهـد عليهـا نقوش

FIGURE 2.129

Surface C, ABN33 


\section{Reference Number: ABN34}

Co-ordinates: $26.21086^{\circ} \mathrm{N} 05^{0.55117^{\circ} \mathrm{E}}$

Dimensions: Not measured

\section{Orientation: NA}

Description: Modern white marble gravestone with laser cut black painted lettering. It is included as the individual commemorated by the gravestone died before $1900 \mathrm{CE}$, and because around his shrine many of the original carved limestone gravestones are clustered.

\section{Arabic Transcription and Translation:}

- It is only those who have knowledge among His slaves that fear Allah (35:28).

- Shaikh Husayn bin 'Abd al-Samad, Father of Shaikh Al-Baha'i.

- Born in Lebanon, in 1st of Muhharam, $918 \mathrm{AH}$, Bacalbak. He died in 8th of Rabi` al-awwal, 984, al-Bilad al-Qadim.
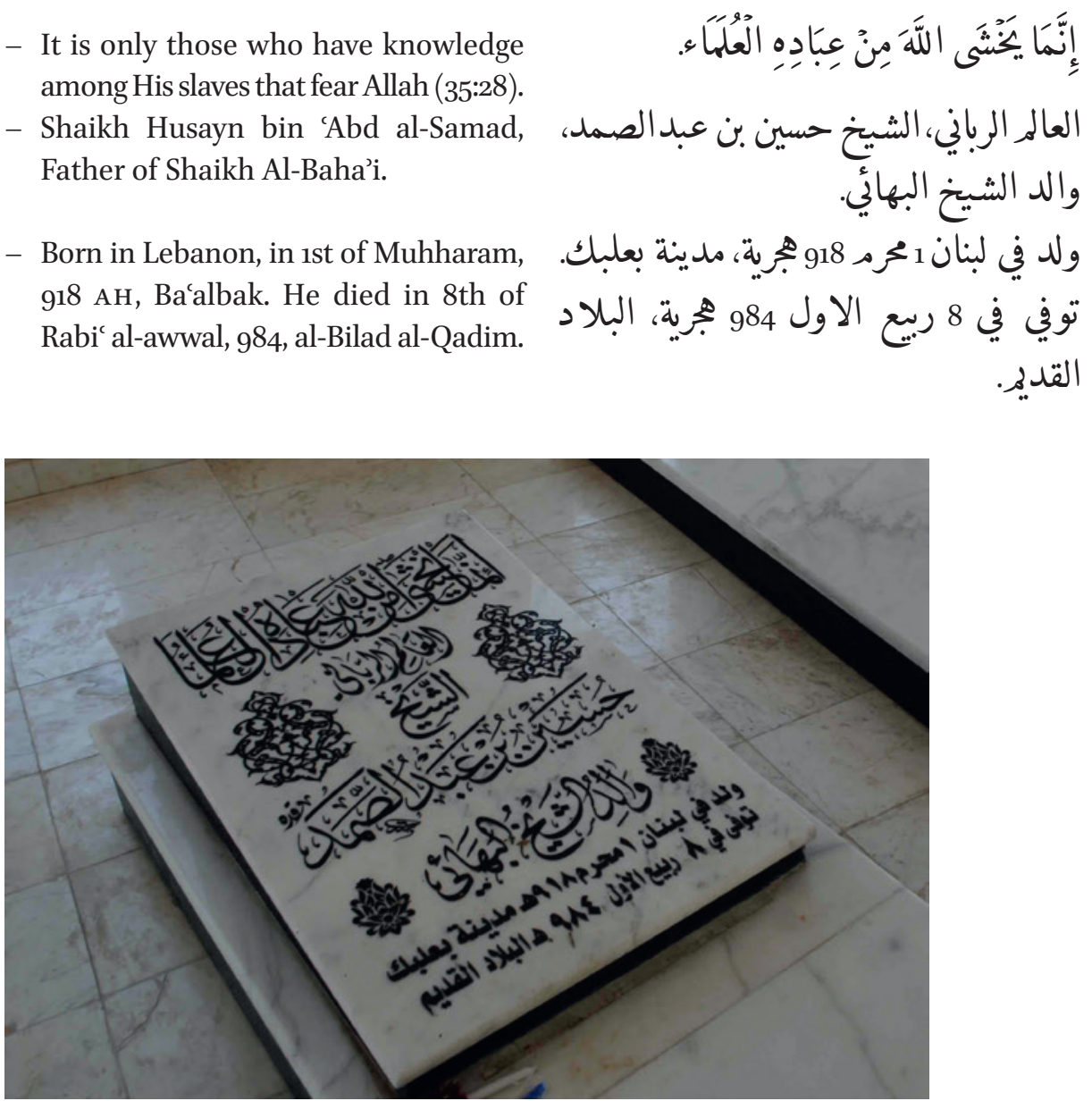

FIGURE 2.130 ABN34 
Reference Number: ABN35

Co-ordinates: $26.21089^{\circ} \mathrm{N} 050.55139^{\circ} \mathrm{E}$

Dimensions: $144 \mathrm{~cm}(\mathrm{l}) \times 33 \mathrm{~cm}(\mathrm{w}) \times 28 \mathrm{~cm}(\mathrm{~h})$

\section{Orientation: N-S}

Description: Single limestone slab gravestone (Figure 2.131). Next to shrine of Shaikh Husayn bin 'Abd al-Samad. The gravestone has been cut to shape but left unfinished. Voids in the stone surface might have precluded further carving. There appear to be chisel marks on the top surface (E) and chisel and saw marks on the side surfaces (A and B). No inscriptions or carving other than rectangular roughed out blocks at each end that would have formed raised decoration if the gravestone was completed.

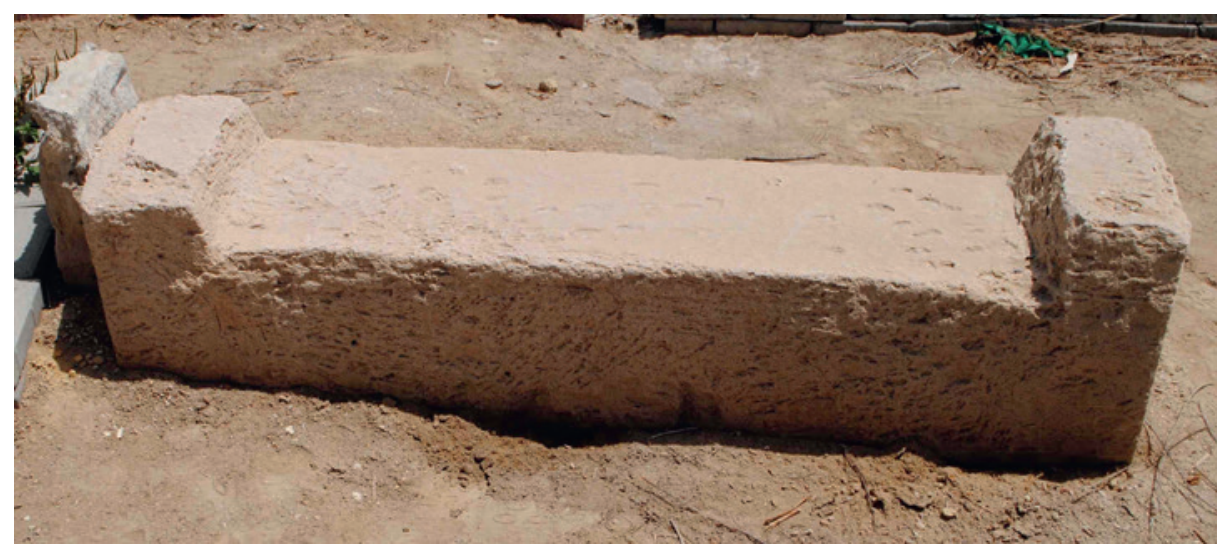

FIGURE 2.131 ABN35

Arabic Transcription and Translation: No inscriptions

Reference Number: ABN36

Co-ordinates: $26.21091^{\circ} \mathrm{N} 050.55143^{\circ} \mathrm{E}$

Dimensions: $154 \mathrm{~cm}(\mathrm{l}) \times 37.5 \mathrm{~cm}(\mathrm{w}) \times 44 \mathrm{~cm}(\mathrm{~h})$

Orientation: NNW-SSE 
Description: Single limestone slab gravestone in good condition. Shallow carved pointed niche design on top surface (E). Three element raised decoration formed of two facetted cubes and central rounded arch all set on a rectangular plinth at both ends. Inscriptions on five surfaces. Partially excavated to expose whole gravestone.

\section{Arabic Transcription and Translation:}

A:

- The angels will descend on them, (saying:) Fear not, nor grieve; But receive the glad tidings of Paradise which you have been promised. We have been your friends in the life of this world and in the Hereafter. Therein you shall have all that your souls desire (41:30-31).

- ... will be opened ... for fruits in abundance and drinks. And beside them will be maidens of equal age with modest gaze $\left(38: 5^{0-52}\right)$. Allah, the Most Great has spoken the truth.
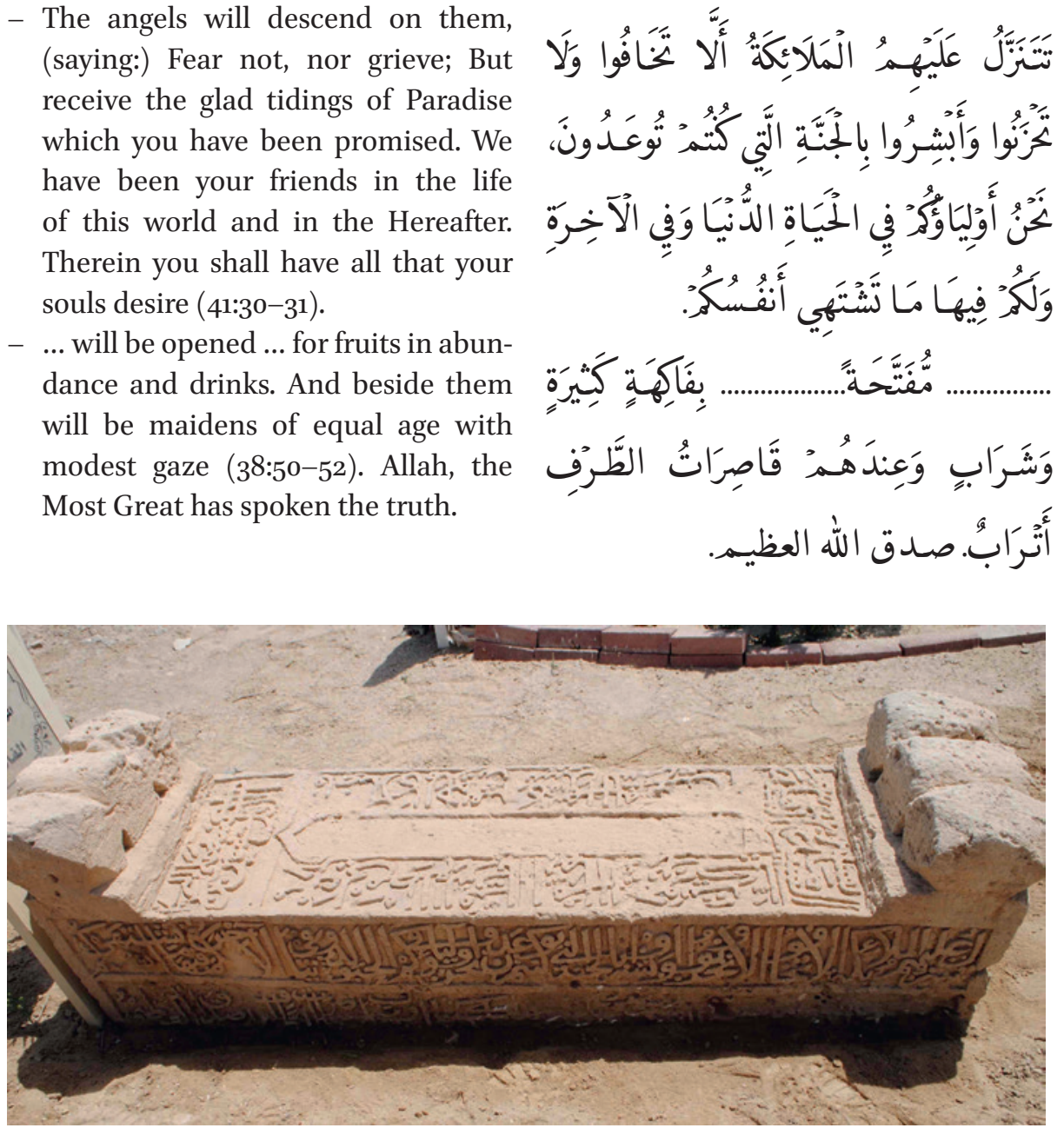

FIGURE 2.132 Surface A, ABN36 
B:

- In the Name of Allah, the Most Gracious, the Most Merciful. Allah, none has the right to be worshipped but he, the Ever Living, the One Who sustains and protects all that exists. Neither slumber nor sleep overtakes Him. To Him belongs whatever is in the heavens and whatever is on the earth. Who is he that can intercede with Him except by His permission! He knows what happens.

- To them in this world, and will happen to them in the Hereafter and they will never compass anything of His Knowledge except that which He wills. His Seat extends over the heavens and the earth, and He feels no fatigue in guarding and preserving them. And He is the Most High, the Most Great. Allah and His Prophet have spoken the truth ... (2:255).

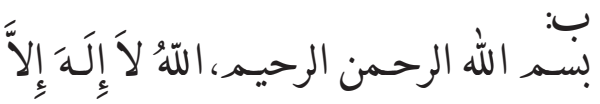

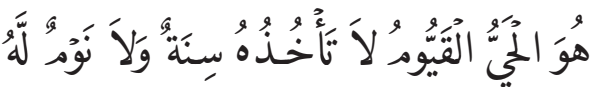
مَا في السَّمَاوَاتِ وَمَا فِي الأَرْضِ مَنْ ذَا

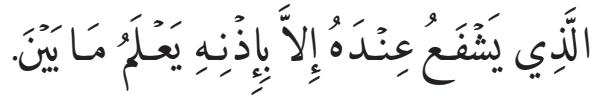

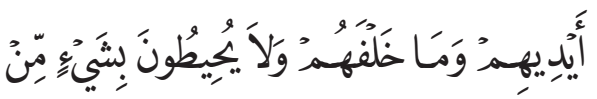

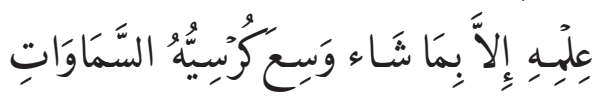

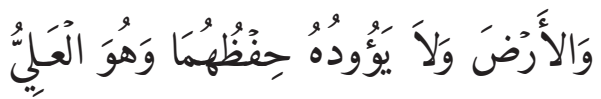
الَُْظِيمُ، صدق الله ورسوله.

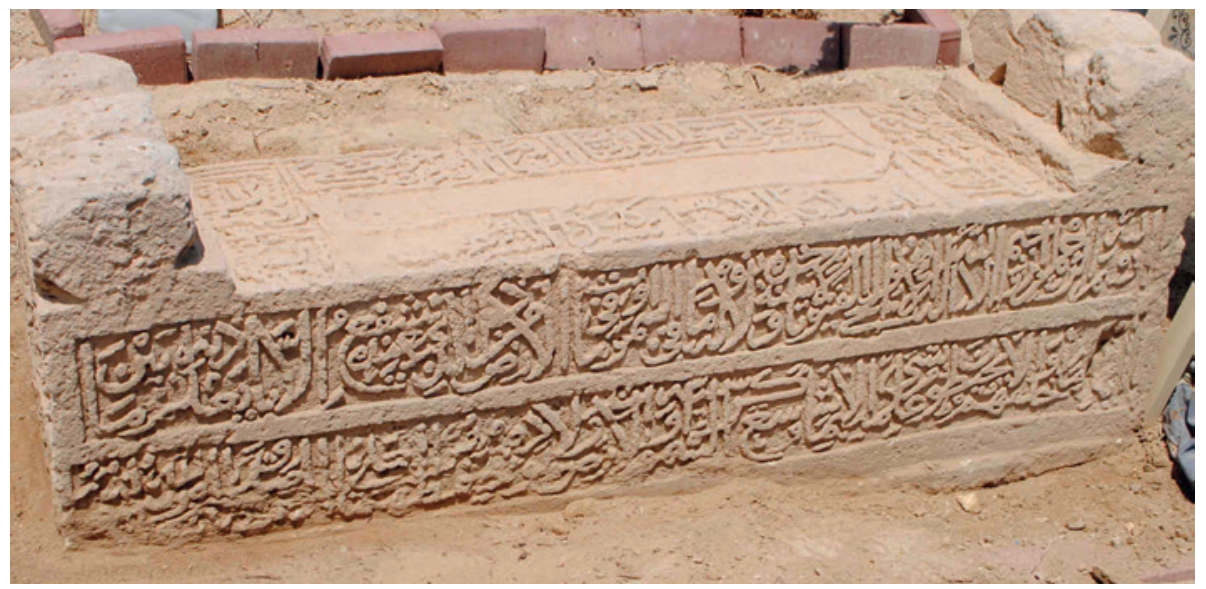

FIGURE 2.133 Surface B, ABN36 
C:

- ... should be read ... for his soul ... And a part on his wife's grave, the daughter of al-Sayyid Majid.

- ... Fruit ... Planting ... from dates crop من الغرس..... of palm gardens ...
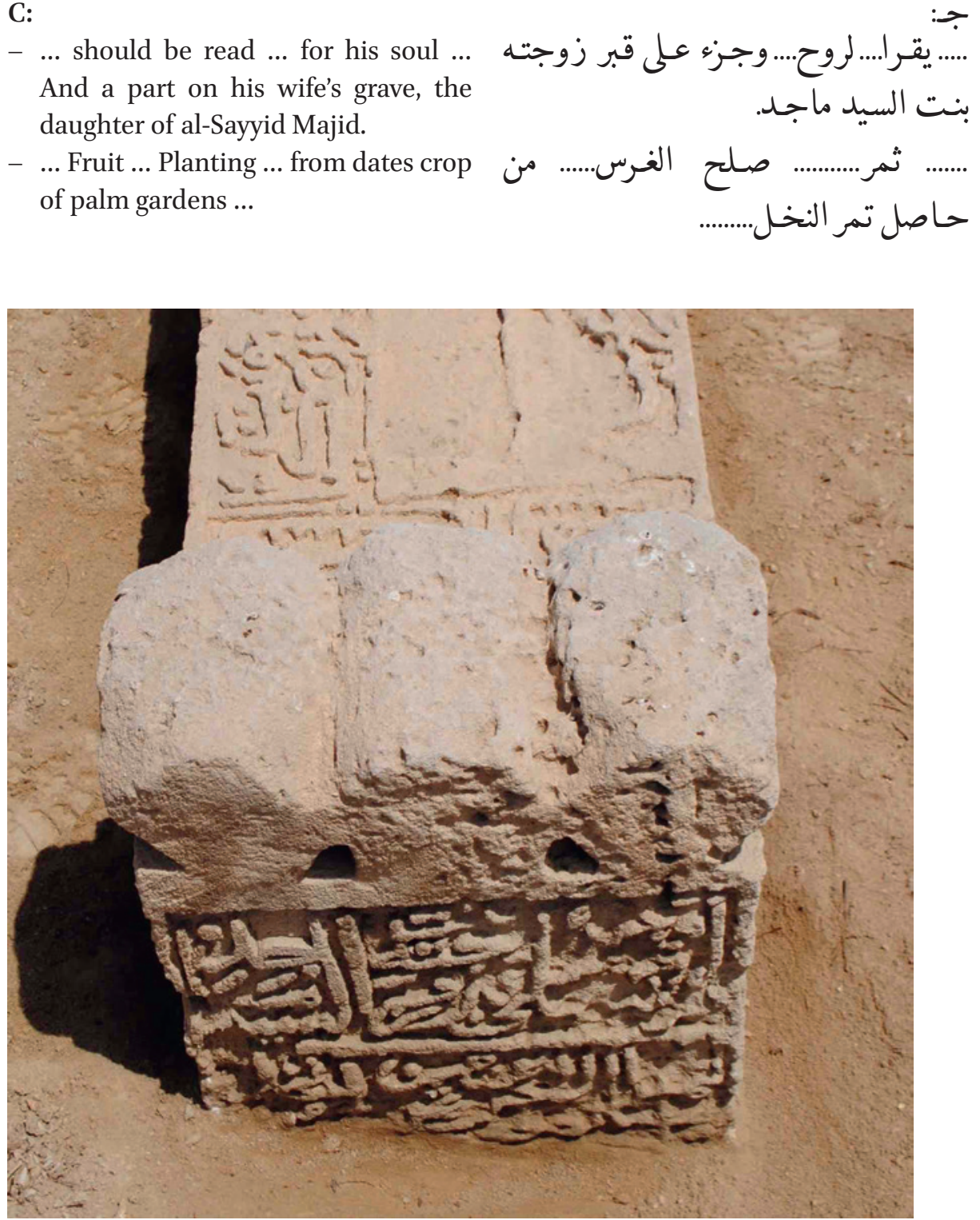

FIGURE 2.134 Surface C, ABN36

D:

- This is the grave of the late...

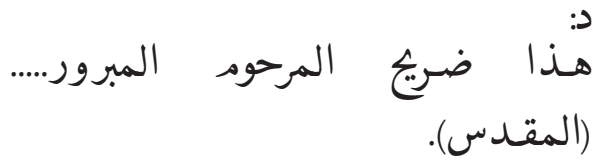

- al-Sayyid 'Ali bin Muhammad Abu السيد عـيل بن السيد محمد ابو شبانة Shabanah al-Husayni 


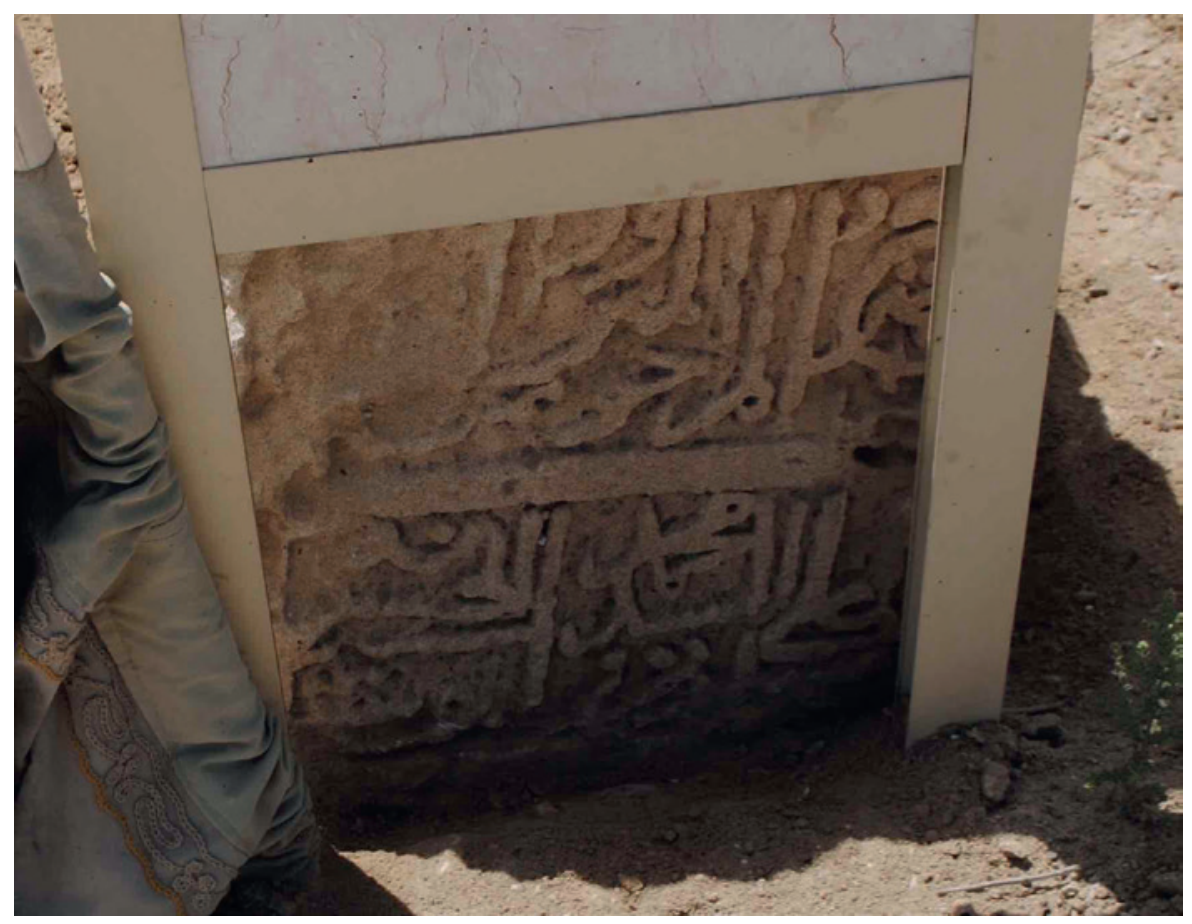

FIGURE 2.135 Surface D, ABN36

E:

- Written by the humble 'Ali bin Husayn al-Bahrani

- Oh grave, you should be equal with the stars in the sky, since you have embedded an innocent man.

- You embedded a faithful and virtuous man.

- Engraved by al-Sayyid Salih bin alSayyid Hashim.

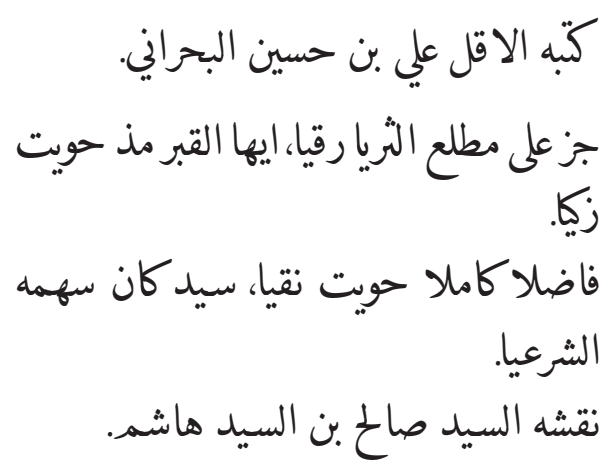




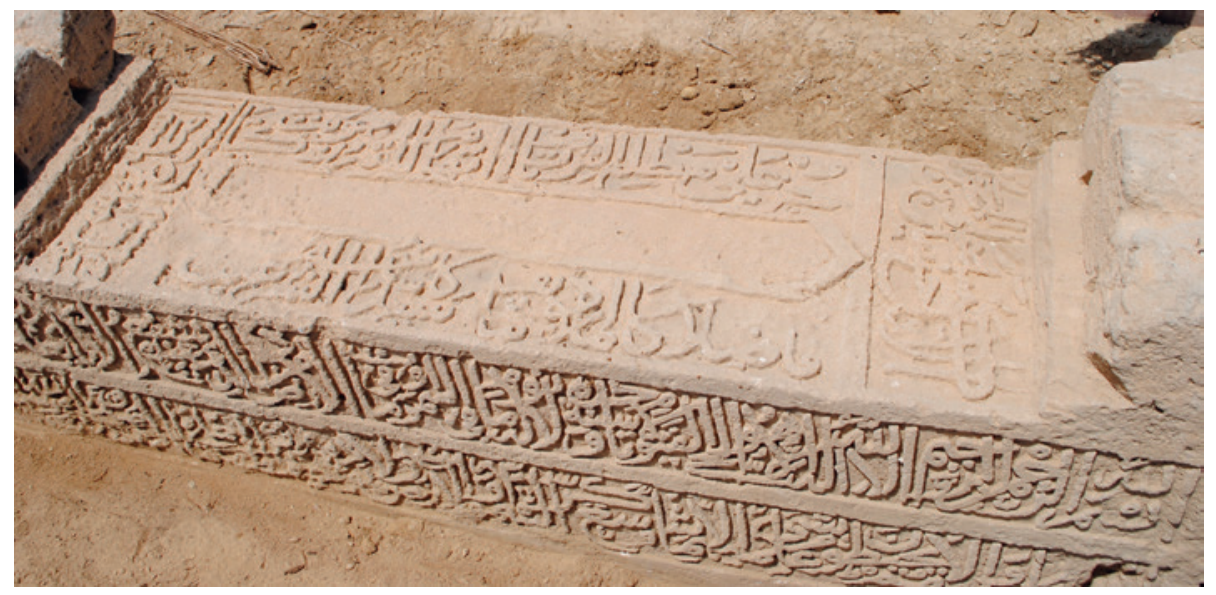

FIGURE 2.136 Surface E, ABN36

\section{Reference Number: ABN37}

Co-ordinates: $26.21079^{\circ} \mathrm{N} 050.55126^{\circ} \mathrm{E}$

Dimensions: $171 \mathrm{~cm}(\mathrm{l}) \times 35 \mathrm{~cm}(\mathrm{w}) \times 44 \mathrm{~cm}(\mathrm{~h})$

\section{Orientation: NW-SE}

Description: Single limestone slab gravestone in generally good condition. Shallow carved pointed niche design on upper surface $(\mathrm{E})$. Three element raised decoration formed of two facetted cubes and central rounded arch all set on a rectangular plinth at both ends. Inscriptions on five surfaces, with two only partially legible.

\section{Arabic Transcription and Translation:}

A:

- Gardens of Eden whose gates will be opened for them. Therein they will recline, therein they will call for fruits in abundance and drinks. And beside them will be maidens of equal age with modest gaze. This is what you are promised on the Day of Reckoning ... (38:50-53)

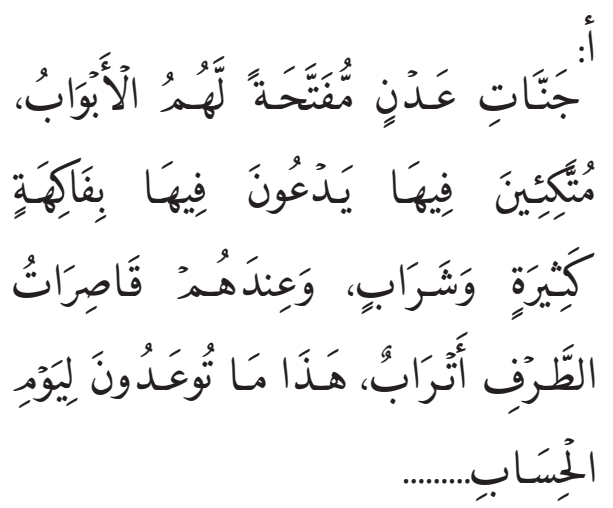




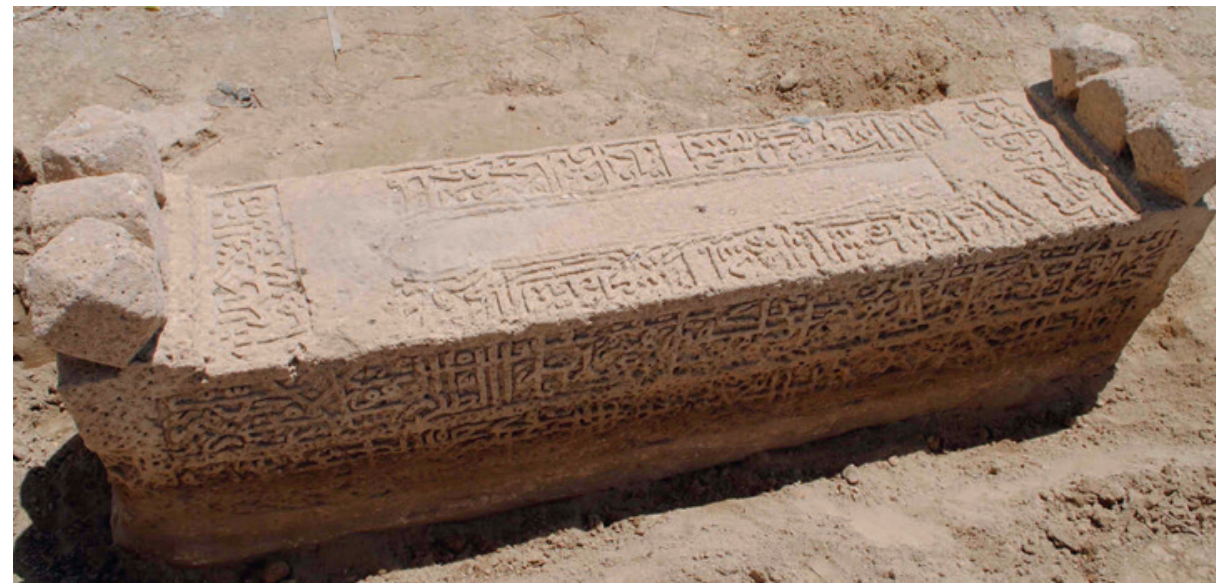

FIGURE 2.137 Surface A, ABN37

B:

- In the Name of Allah, the Most Gracious, the Most Merciful. Allah, none has the right to be worshipped but he, the Ever Living, the One Who sustains and protects all that exists. Neither slumber nor sleep overtakes Him. To Him belongs whatever is in the heavens and whatever is on the earth. Who is he that can intercede with Him.

- Except by His permission! He knows what happens to them in this world, and will happen to them in the Hereafter and they will never compass anything of His Knowledge except that which He wills. His Seat extends over the heavens and the earth, and He feels no fatigue in guarding and preserving them. And He is the Most High, the Most Great (2:255).

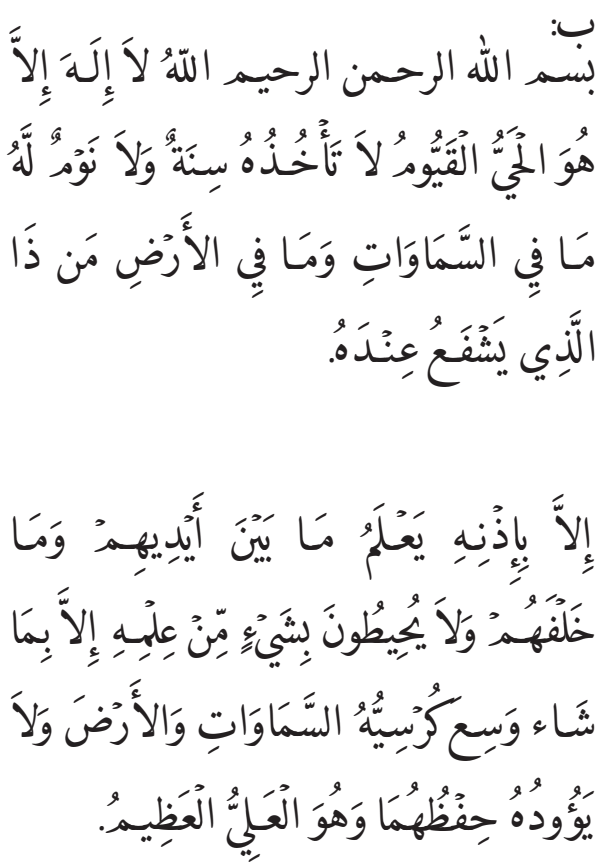




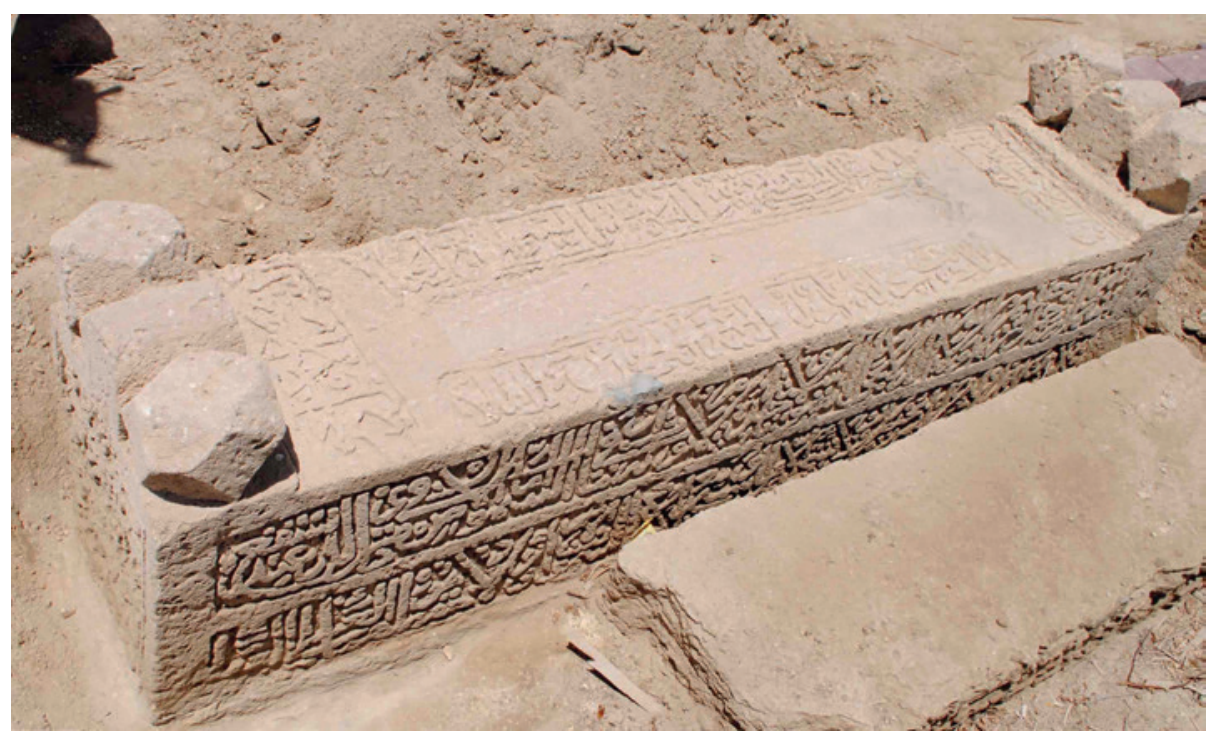

FIGURE 2.138 Surface B, ABN37

C:

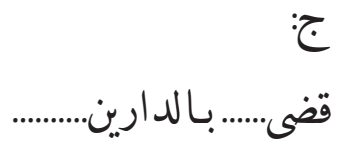

- He spent ... At the life and afterlife ...

قضى.

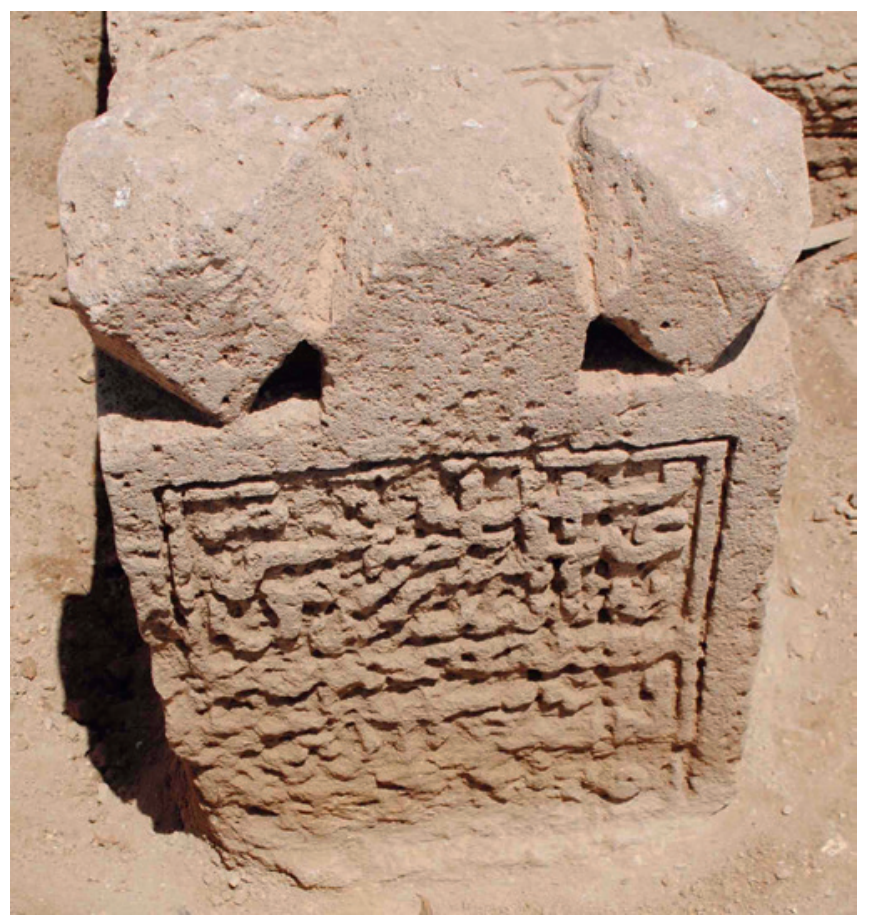

FIGURE 2.139

Surface C, ABN37 
D:

- ... Muharram, year ...
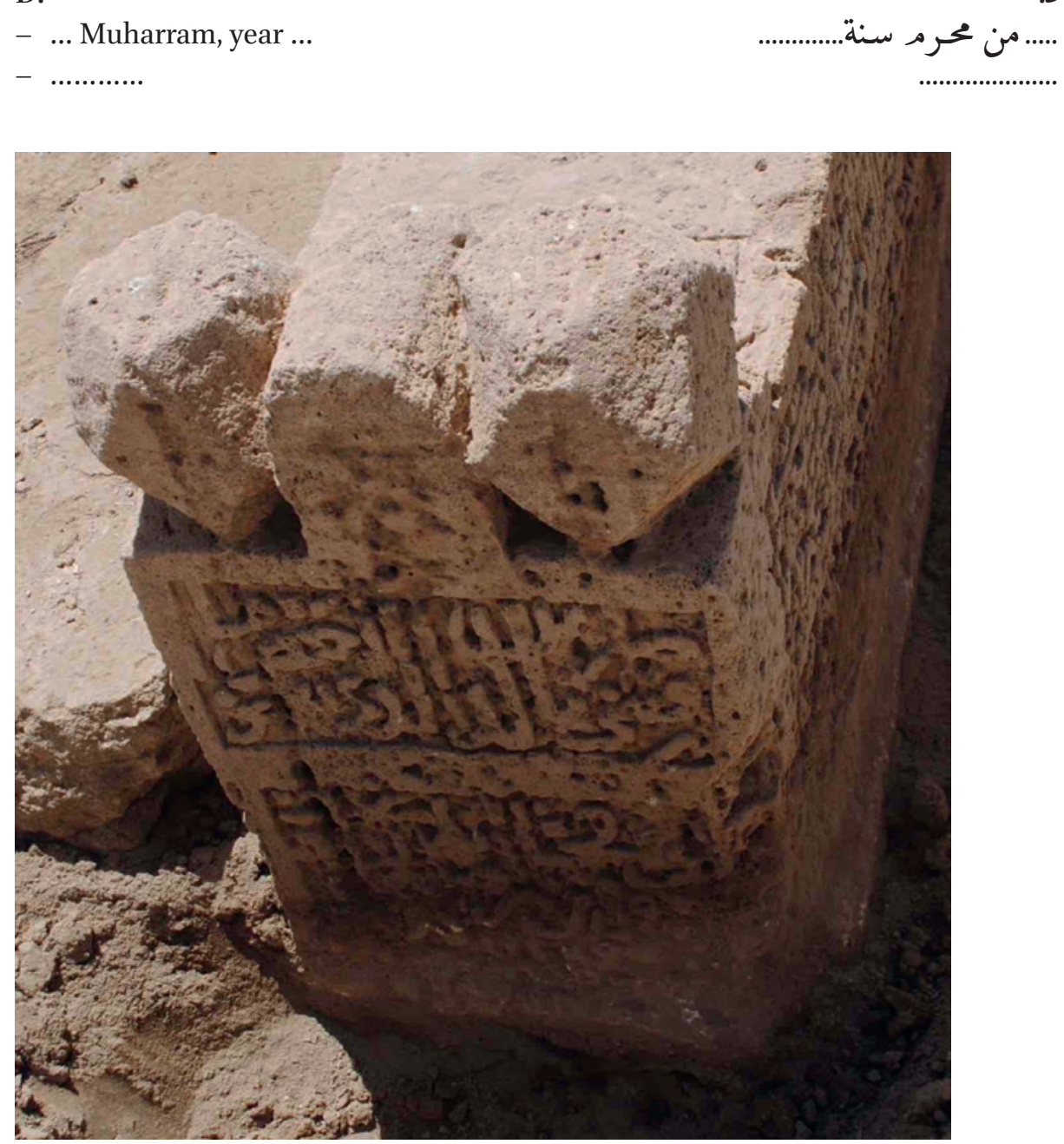

FIGURE 2.140 Surface D, ABN37

E:

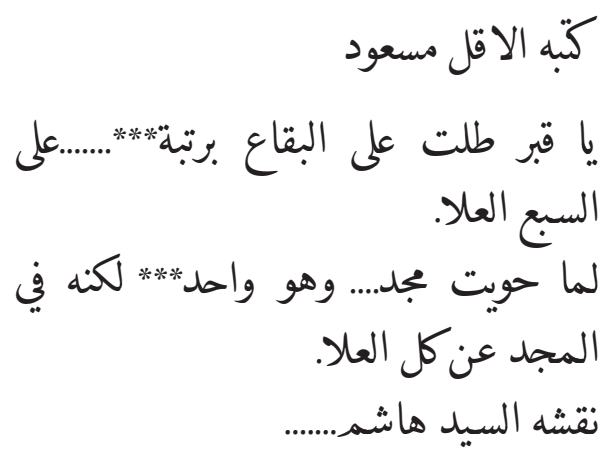

- Written by the humble Mascud

- Engraved by al-Sayyid Hashim. 


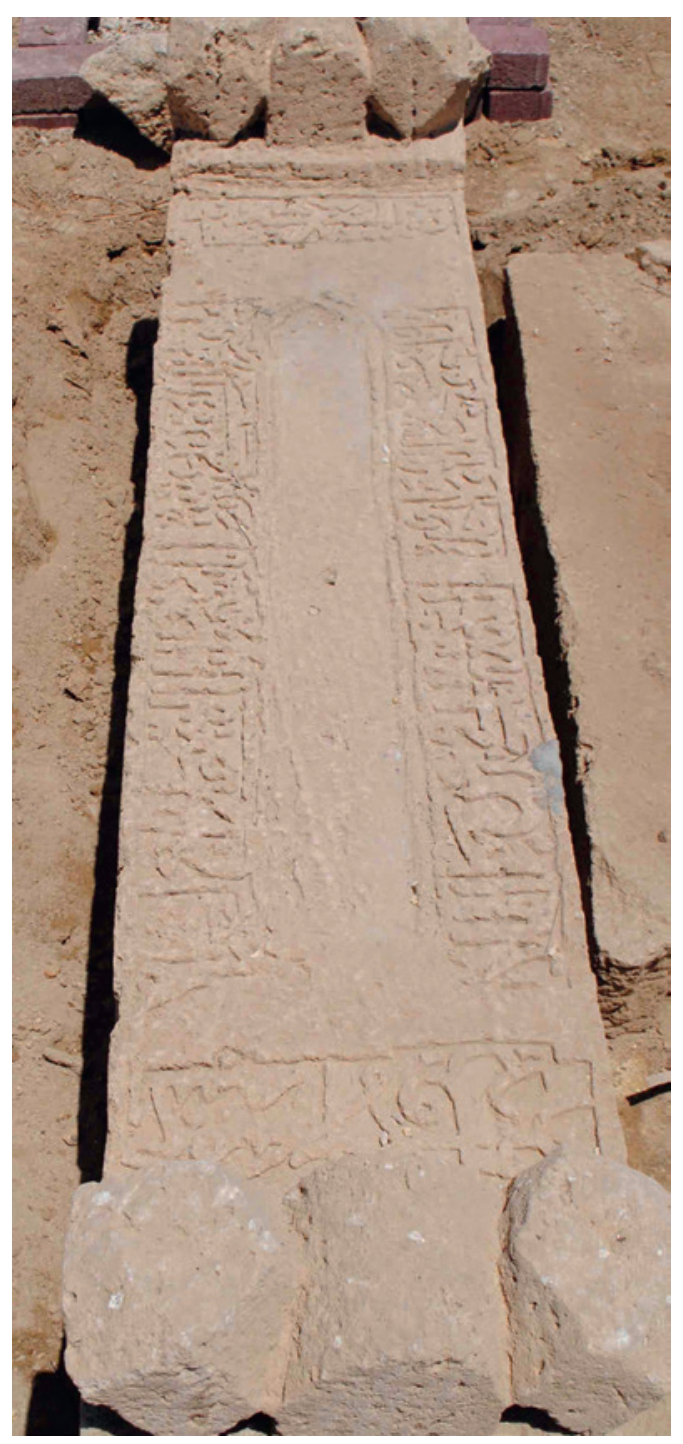

FIGURE 2.141

Surface E, ABN 37

\section{Reference Number: ABN38}

Co-ordinates: $26.21080^{\circ} \mathrm{N} 050.55125^{\circ} \mathrm{E}$

Dimensions: $130 \mathrm{~cm}(\mathrm{l}) \times 25 \mathrm{~cm}(\mathrm{w}) \times 38 \mathrm{~cm}(\mathrm{~h})$

\section{Orientation: NNW-SSE}

Description: Single narrow limestone slab gravestone with some areas of bad erosion and damage. No niche design on surface E. Raised decoration cut off at both ends. Partial inscriptions on two surfaces. 
Arabic Transcription and Translation:

A:

- Very deteriorated. Unable to read

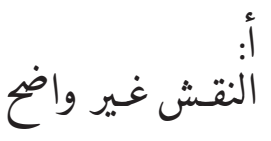

B:

- In the Name of Allah, the Most Gracious, the Most Merciful. Allah, none has the right to be worshipped but he, the Ever Living, the One Who sustains and protects all that exists. Neither slumber nor sleep overtakes Him. To Him belongs whatever is in the heavens and whatever is on the earth. Who is he that

- Except by His permission! He knows what happens to them in this world, and will happen to them in the Hereafter ... (2:255)
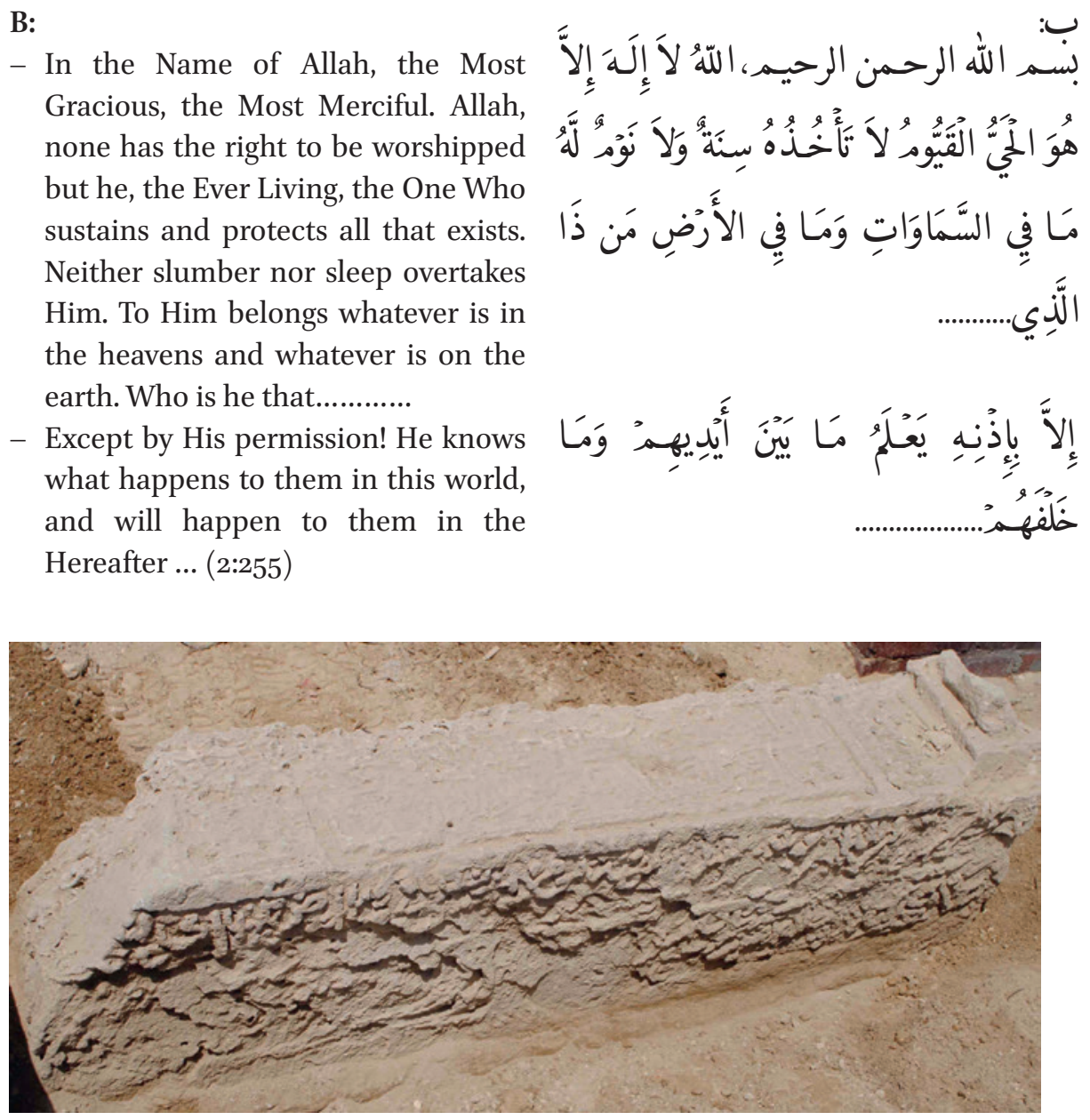

FIGURE 2.142 Surface B, ABN38

C:

- No carving or inscriptions.

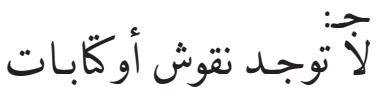

D:

- Very deteriorated. Unable to read.

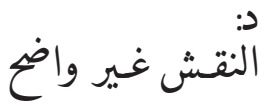


E:

- Engraved by al-Sayyid Hashim

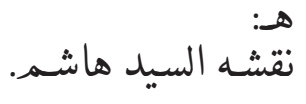

$-\quad \ldots . . . . . .$.

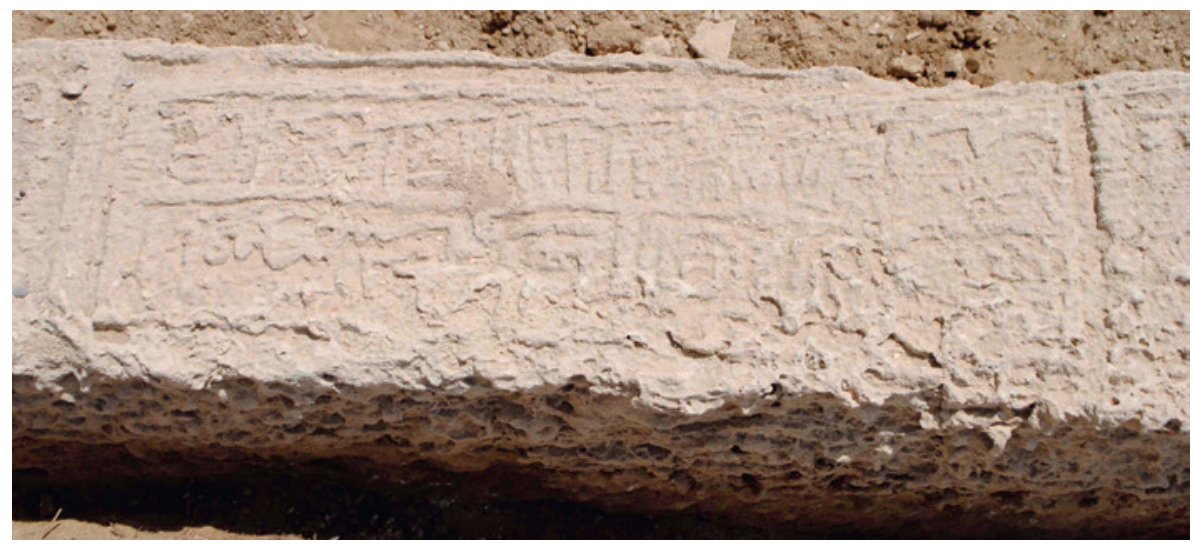

FIGURE 2.143 Surface E, ABN38

\section{Reference Number: ABN39}

Co-ordinates: $26.21082^{\circ} \mathrm{N} 050.55124^{\circ} \mathrm{E}$

Dimensions: $184 \mathrm{~cm}(\mathrm{l}) \times 40 \mathrm{~cm}(\mathrm{w}) \times 25 \mathrm{~cm}(\mathrm{~h})$

\section{Orientation: NNW-SSE}

Description: Single limestone slab gravestone broken into three pieces (Figure 2.144). Very eroded on top but with flat sides suggesting it is unfinished. No inscriptions. Raised decoration cut off at one end and eroded rectangular roughed out block for unfinished raised decoration at the other end.

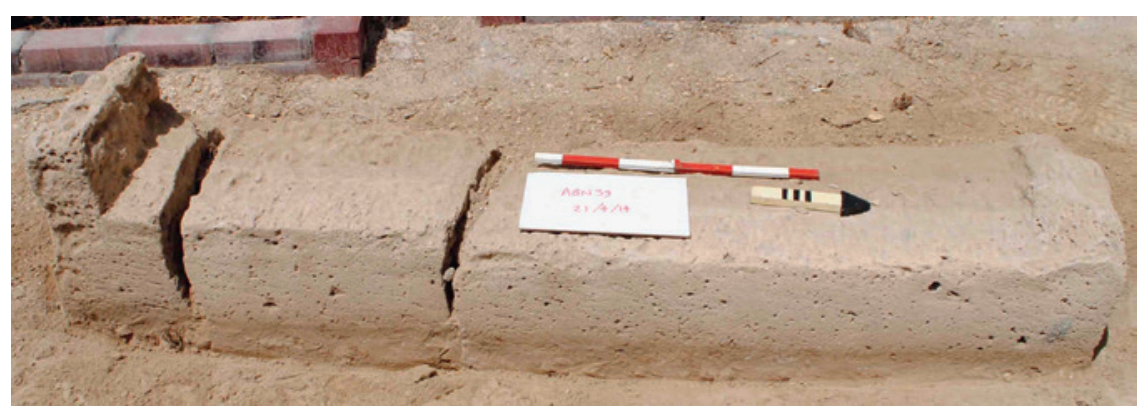

FIGURE 2.144 ABN39

Arabic Transcription and Translation: No inscriptions 
Reference Number: ABN40

Co-ordinates: $26.21077^{\circ} \mathrm{N} 050.55125^{\circ} \mathrm{E}$

Dimensions: $179 \mathrm{~cm}(\mathrm{l}) \times 33 \mathrm{~cm}(\mathrm{w}) \times 26.5 \mathrm{~cm}(\mathrm{~h})$

Orientation: NW-SE

Description: Single limestone slab gravestone. Carving very sharp and well-executed. Shallow carved rounded niche design on the upper surface (E). Three element raised decoration formed of two facetted cubes and a central rounded arch all set on a rectangular plint at both ends, one of which is eroded. Inscriptions on five surfaces.

\section{Arabic Transcription and Translation:}

A:

- They will be served by immortal boys, with cups, and jugs, and a glass from the flowing wine, where from they will get neither any aching of the head, nor any intoxication. And fruit; that they may choose. And the flesh of fowls that they desire. And there will be fair females with wide and lovely eyes, like unto preserved pearls. A reward for what they used to do. No evil vain talk will they hear therein, nor any sinful speech. But only the saying of: Peace! Peace! (56:17-26)

- ... trays of gold and cups, therein all that inner-selves could desire, and all that eyes could delight in and you will abide therein forever. This is the Paradise which you have been made to inherit because of your deeds which you used to do. Therein for you will be fruits in plenty, of which you will eat (43:71-73). Eat and drink with happiness because of what you used to do (52:19).

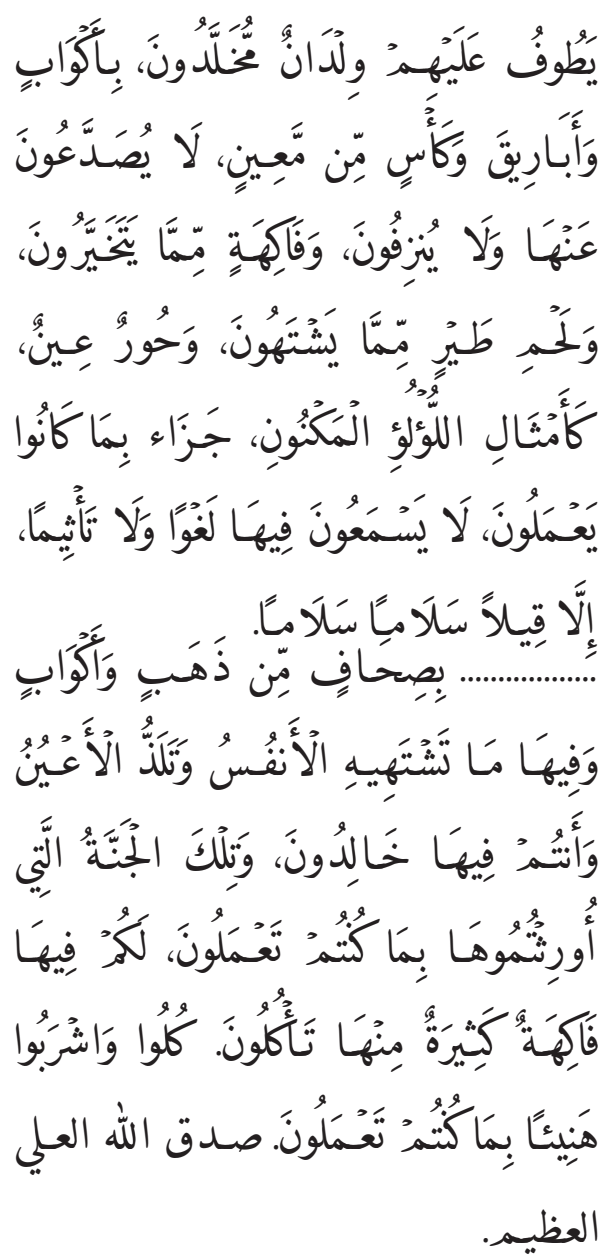




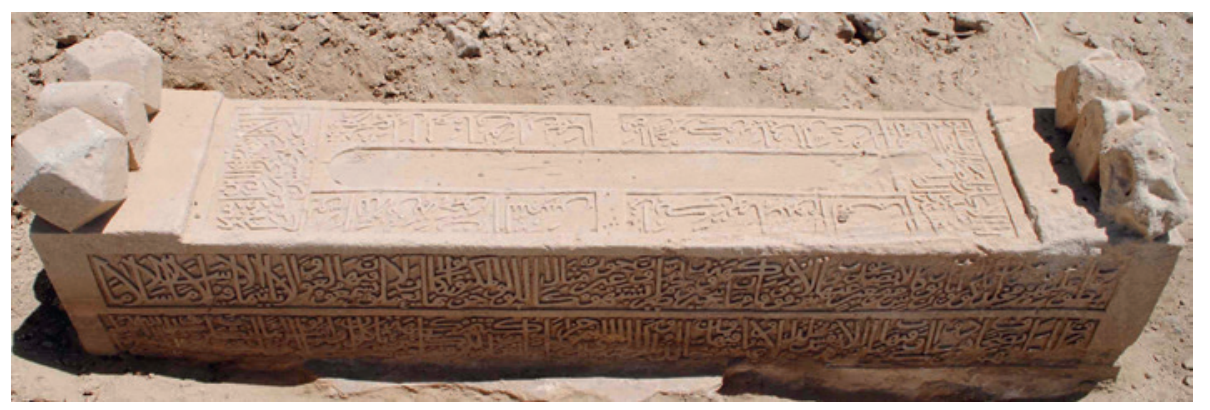

FIGURE 2.145 Surface A, ABN40

B:

- In the Name of Allah, the Most Gracious, the Most Merciful. Allah, none has the right to be worshipped but he, the Ever Living, the One Who sustains and protects all that exists. Neither slumber nor sleep overtakes Him. To Him belongs whatever is in the heavens and whatever is on the earth. Who is he that can intercede with Him except by His permission! He knows what happens to them in this world, and will happen to them in the Hereafter and they will never compass anything of His Knowledge except

- That which He wills. His Seat extends over the heavens and the earth, and He feels no fatigue in guarding and preserving them. And $\mathrm{He}$ is the Most High, the Most Great (2:255). Eden Paradise, whose doors will be opened for them. Therein they will recline, therein they will call for fruits in abundance and drinks, and beside them will be chaste females restraining their glances and of equal ages (38:50-52). Allah, the Most Great has spoken the truth.
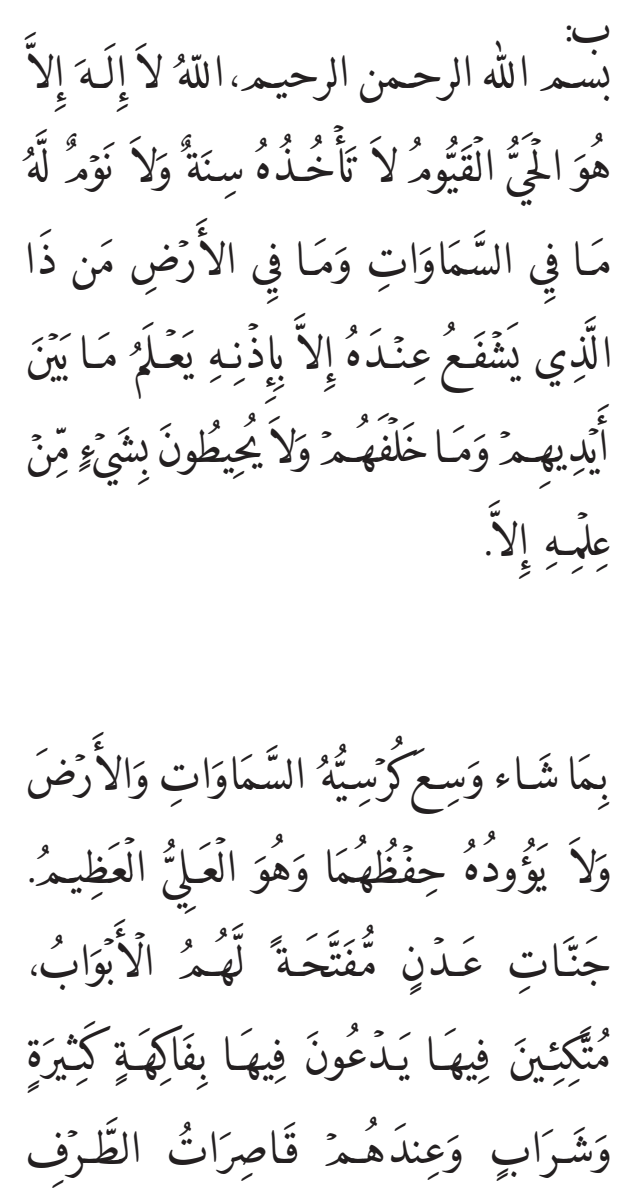

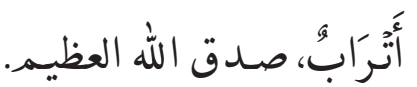




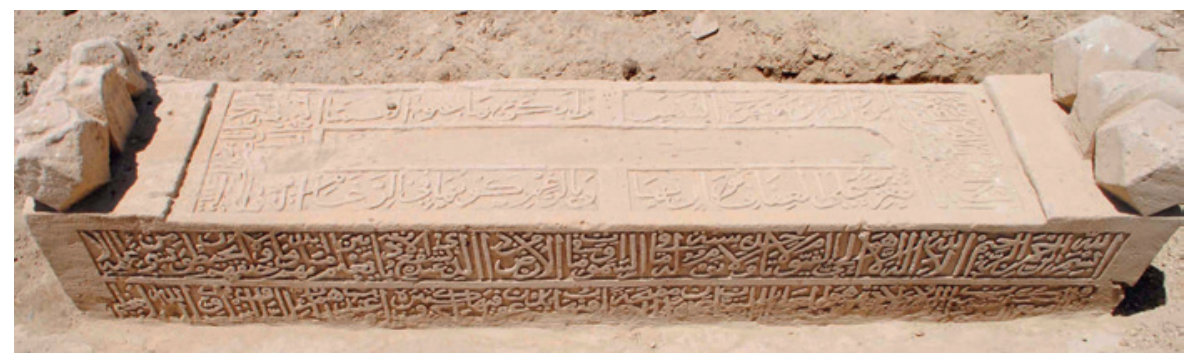

FIGURE 2.146 Surface B, ABN40

C:

القـراة (القـراءة) كل يود جـزأن منكتاب الله العزيز بجلتين سالمة........... من.

- One basket from al-Kharajat garden, half basket from western garden and another half from the eastern and al-Sabkha.

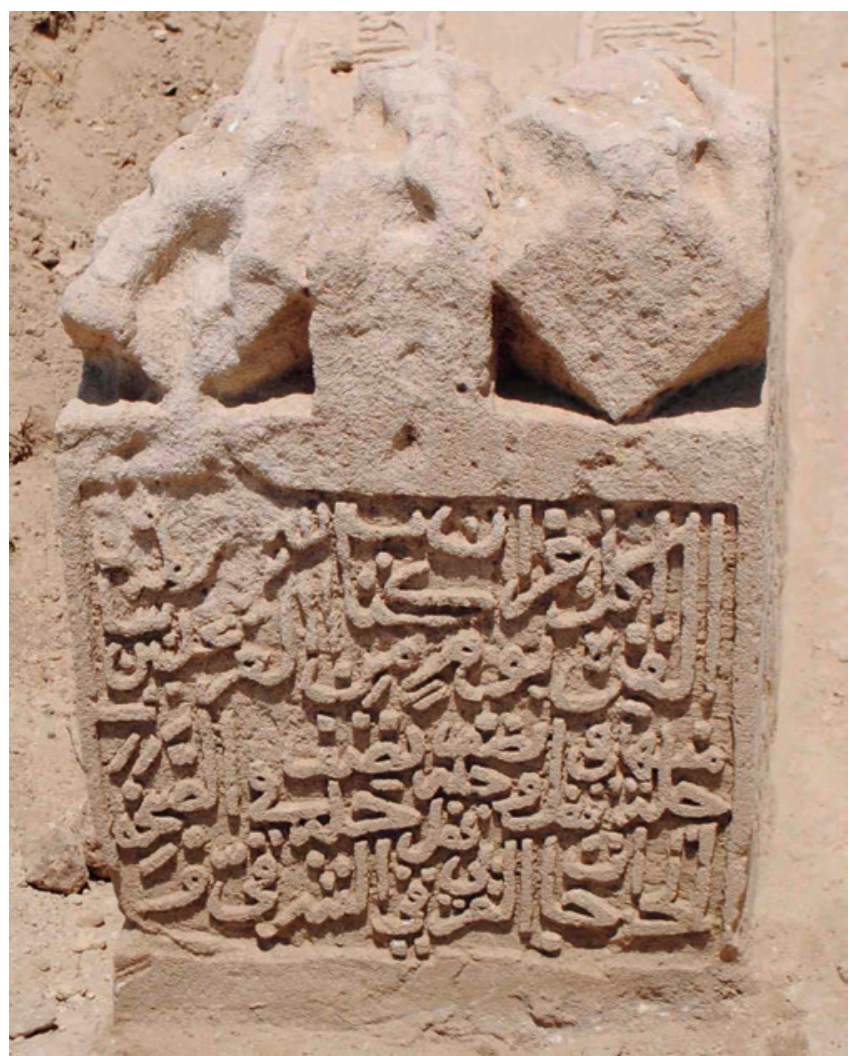

FIGURE 2.147

Surface C, ABN40 
D:

- The death date of the Late Maymunah bint al-Hajj 'Ali bin Muhammad

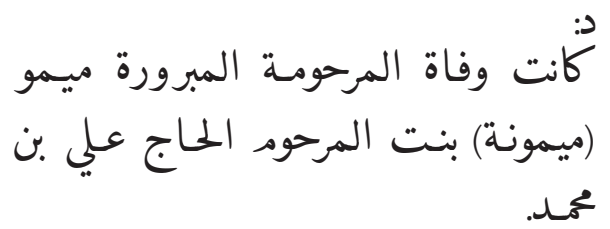

- Al-Manami in ninth of Safar, one thousand and hundred and eight

$$
\begin{aligned}
& \text { المنابي في يوم تـاسع من شهر صفـر سنة } \\
& \text { الثامنـة والمايـة بعـد الالف من الهجرة مرة } \\
& \text { النوبة. }
\end{aligned}
$$

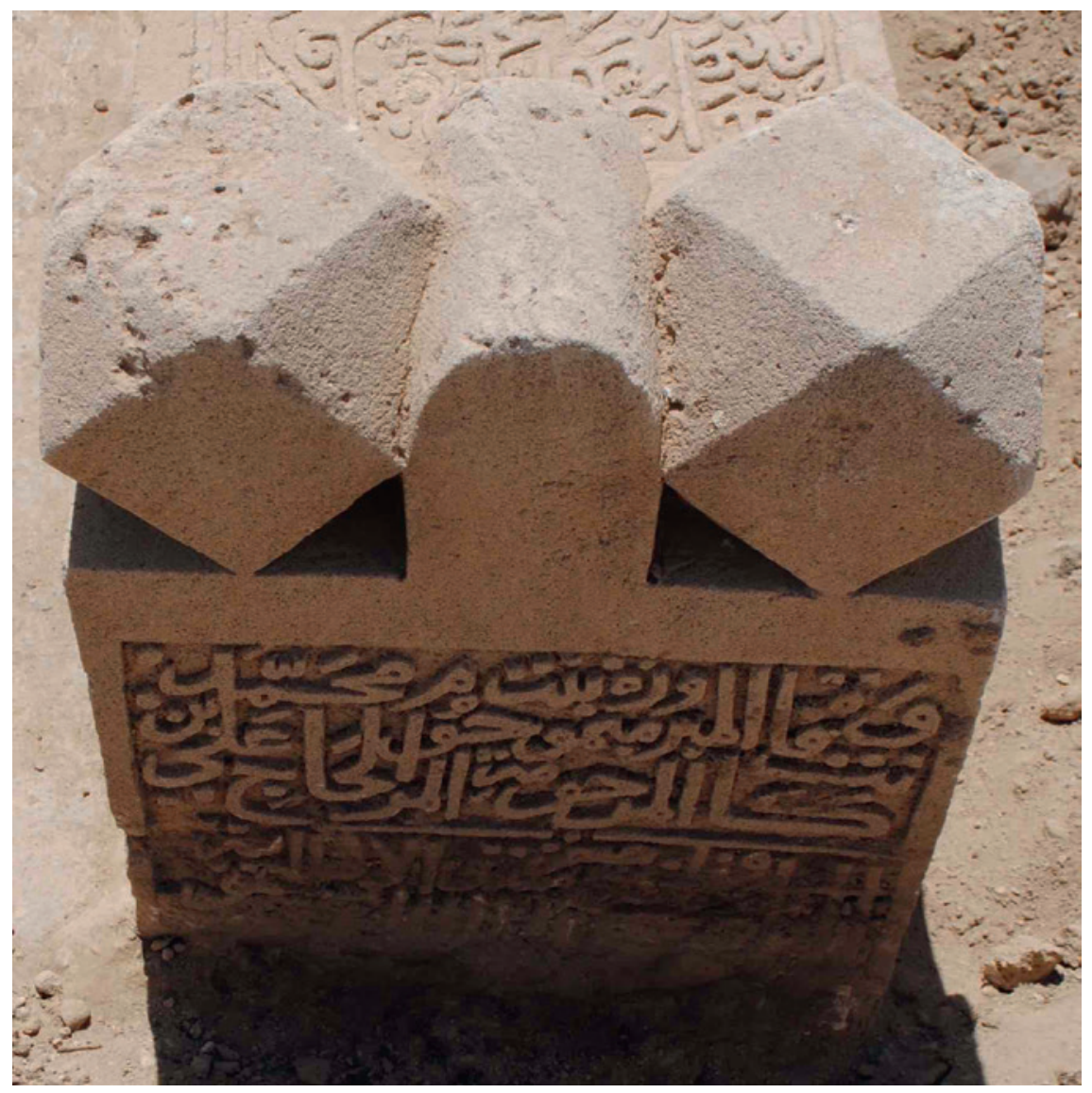

FIGURE 2.148 Surface D, ABN40

E:

- Written by 'Ali bin Husayn bin Zayn كبه الاقل عـي .ن حســن بن زين الدين al-Din, May Allah forgive them 
- May Allah bless a grave embedded a person like the sun, and made the clouds mourning it.

- It is difficult that this chastity disappeared in the soil but unfortunately it has disappeared.

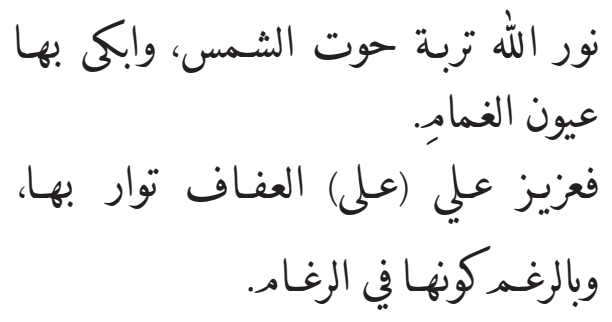

- Engraved by al-Sayyid Naser bin alSayyid ... al-Husayni, God Bless them, in 1110.
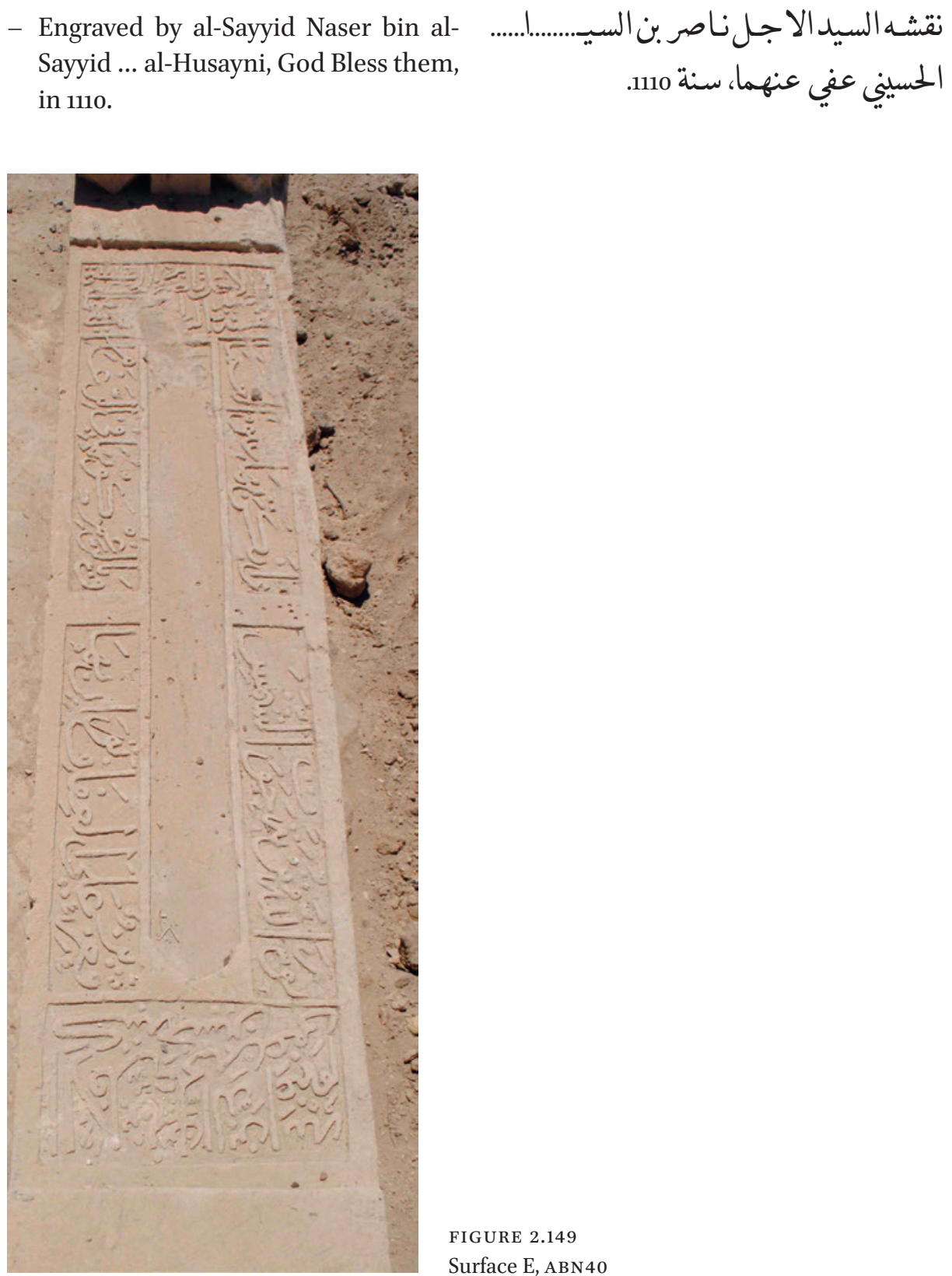


\section{Reference Number: ABN41}

Co-ordinates: $26.21080^{\circ} \mathrm{N} 050.55122^{\circ} \mathrm{E}$

Dimensions: $121 \mathrm{~cm}(\mathrm{l}) \times 33 \mathrm{~cm}(\mathrm{w}) \times 37.5 \mathrm{~cm}(\mathrm{~h})$

\section{Orientation: NNW-SSE}

Description: Single limestone slab gravestone. Some erosion on top surface (E). Shallow carved rounded niche design on top surface (E). Three element raised decoration formed of two facetted cubes and a central rounded arch at both ends. Inscriptions on five surfaces.

\section{Arabic Transcription and Translation:}

A:

- Verily! The pious will be in a place of Security. Among Gardens and springs; dressed in fine silk and also in thick silk, facing each other and we shall marry them to female fair ones with wide, lovely eyes. They will call therein for every kind of fruit in peace and security; they will never taste death therein $(44: 51-56)$.

- The Angels will descend on them, (saying:) Fear not, nor grieve; but receive the glad tidings of Paradise which you have been promised. We have been your friends in the life of this world and in the Hereafter. Therein you shall have all that your souls desire, and all that you ask for (41:30-31).
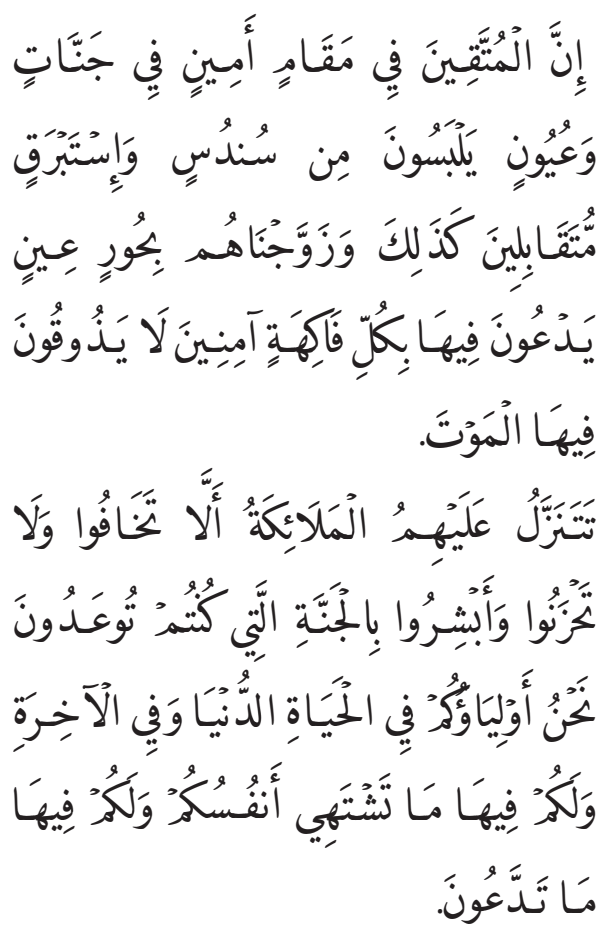


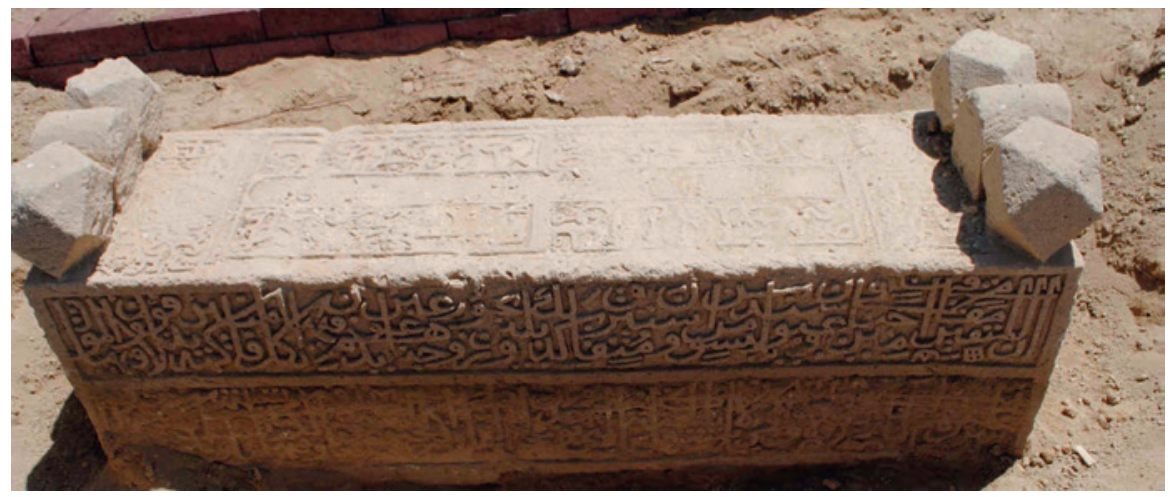

FIGURE 2.150 Surface A, ABN41

B:

- In the Name of Allah, the Most Gracious, the Most Merciful. Allah, none has the right to be worshipped but he, the Ever Living, the One Who sustains and protects all that exists. Neither slumber nor sleep overtakes Him. To Him belongs whatever is in the heavens and whatever is on the earth. Who is he that can intercede with Him

- Except by His permission! He knows what happens to them in this world, and will happen to them in the Hereafter and they will never compass anything of His Knowledge except that which He wills. His Seat extends over the heavens and the earth, and $\mathrm{He}$ feels no fatigue in guarding and preserving them. And He is the Most High, the Most Great (2:255).

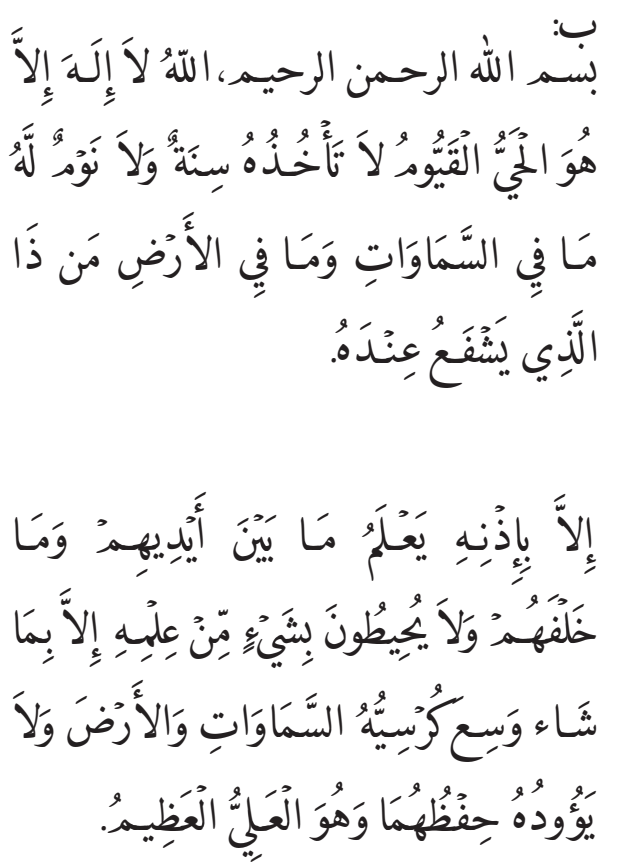




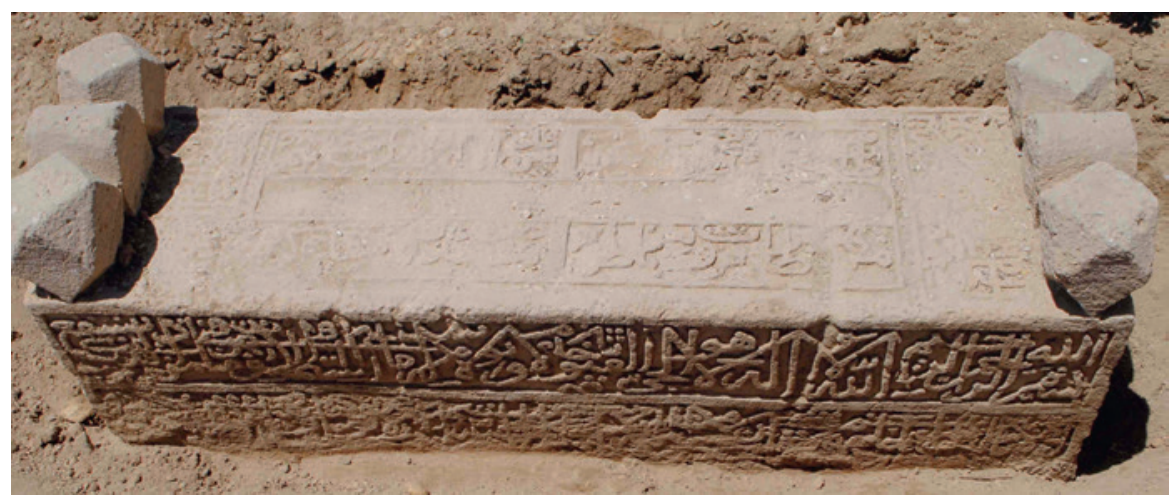

FIGURE 2.151 Surface B, ABN41

C:

- At al-Bahrain land should be given the priority from the other income until

لسّيح البحرين مقدما على غسيره من

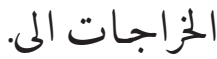

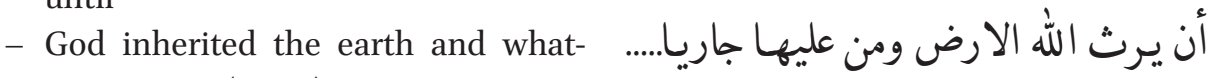
ever on it ... (Mani) ...

......(مني)

- ......chosen......God paradise ... seventh ... year ...

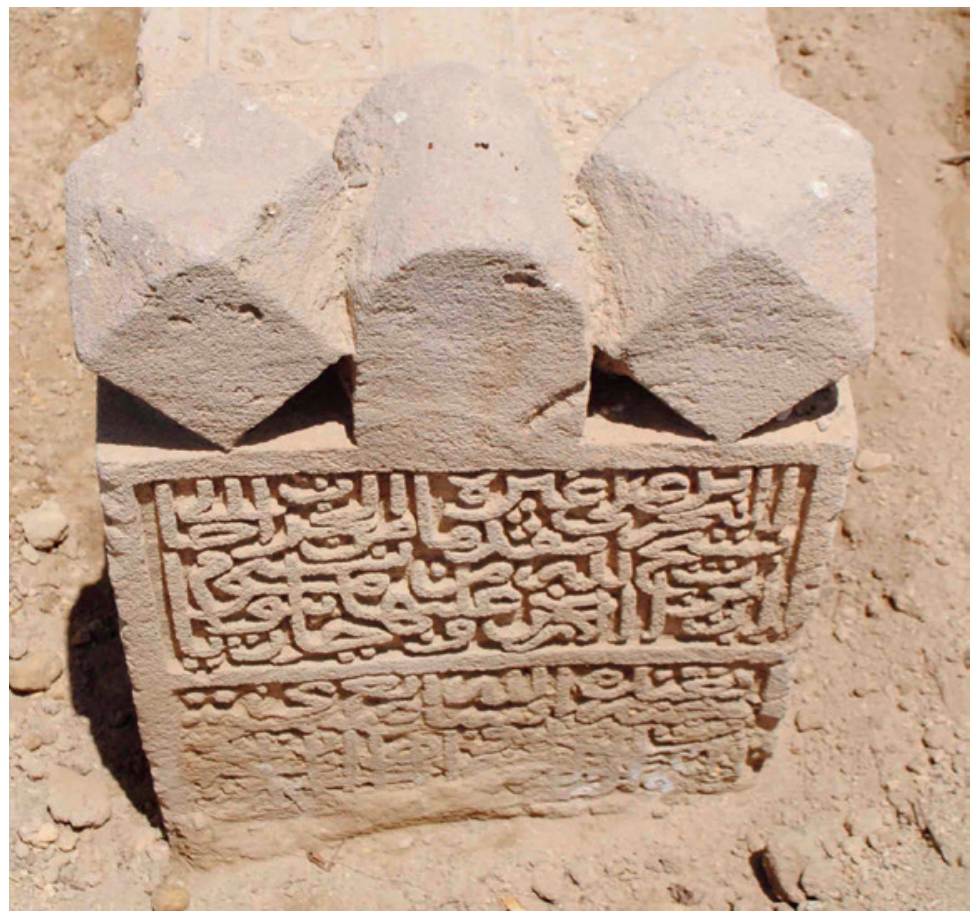


D:

- Fare of reading five parts of the Glorious Book of God everyday on the grave of al-Sayyid 'Abd al-Ra'uf bin al-Sayyid Husayn.
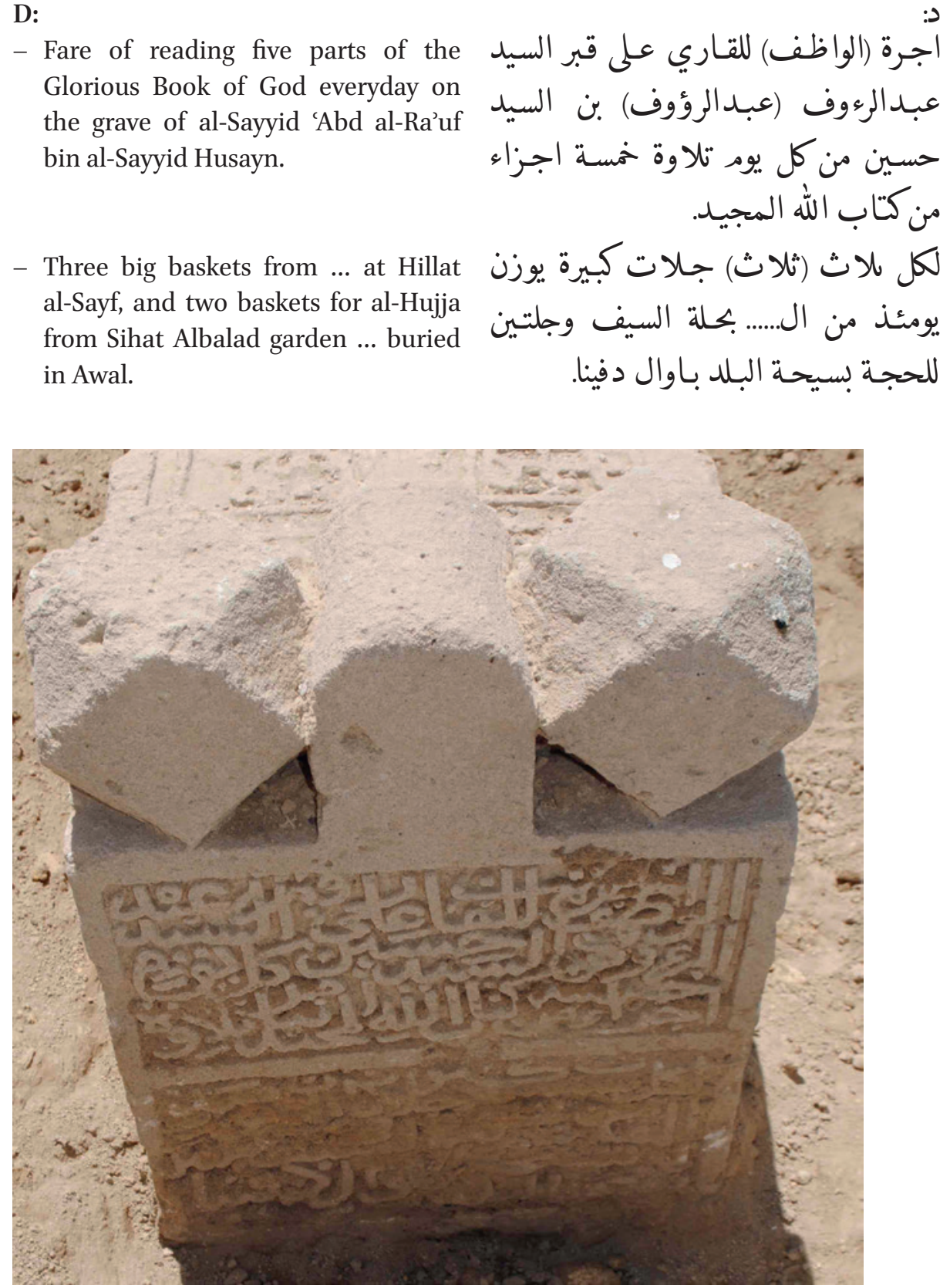

FIGURE 2.153 Surface D, ABN41

E: al-Sayf, and two baskets for al-Hujja from Sihat Albalad garden ... buried in Awal.

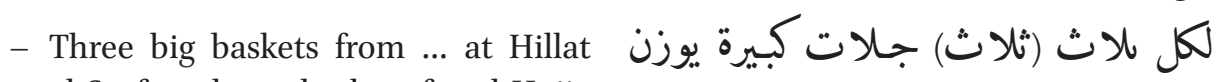
in Awal.

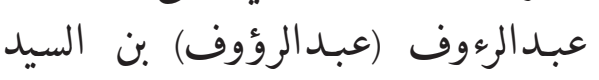
حسـين من كل يوم تلاوة خمسة اجـزاء من كثّاب الله المجيـ. (n) 
- The grave of 'Abd al-Ra'uf is pleasant لاب ثى عبد رؤوف الورى*** من قد since he went to Allah with an innocent heart.

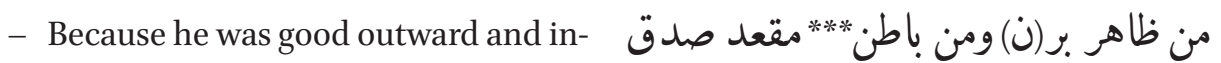
ward, he has got a high status.

-

- Engraved by the skilled, al-Sayyid تقشه الحبر الماهر السيد ناصر بن السيد Naser bin Hashim, May Allah forgive them.

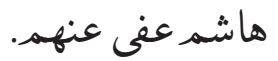

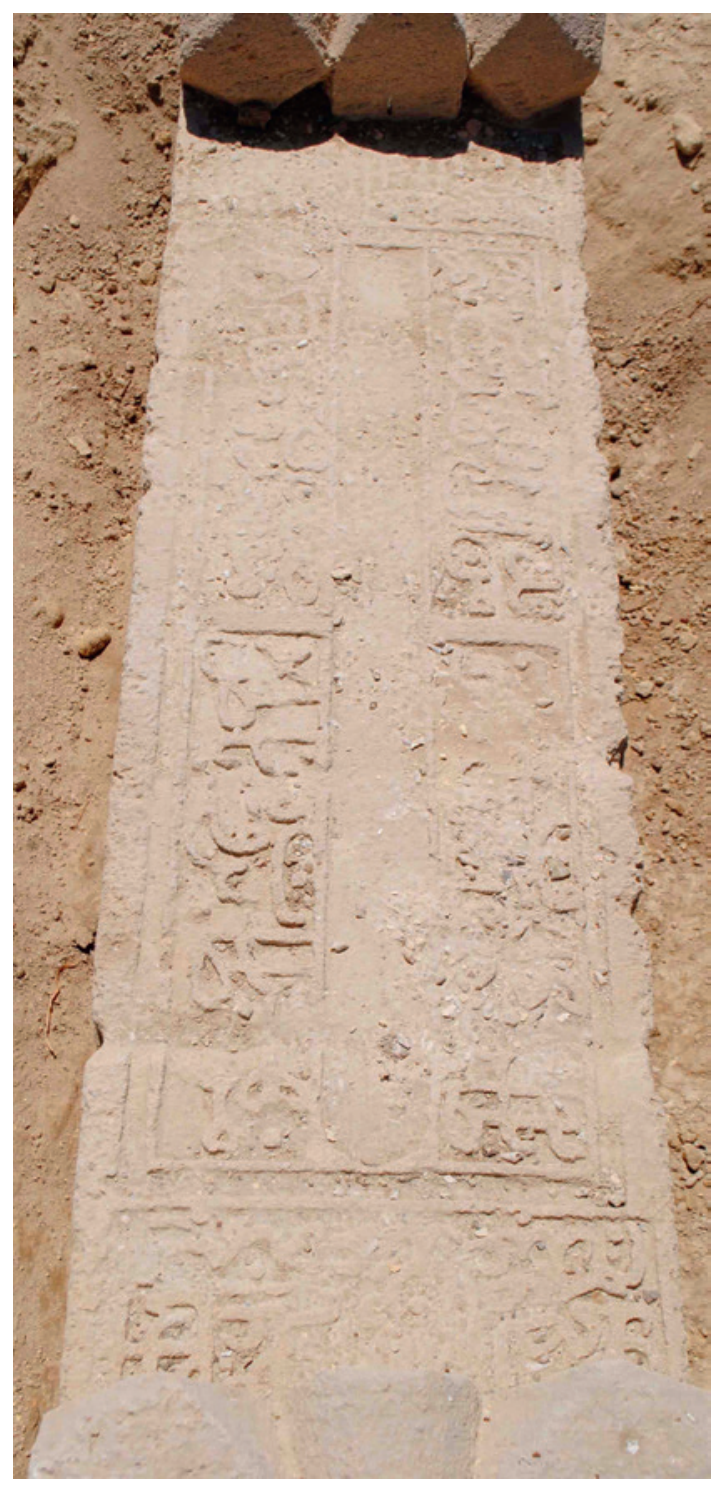

FIGURE 2.154

Surface E, ABN 41 


\section{Reference Number: ABN42}

Co-ordinates: $26.21079^{\circ} \mathrm{N} 050.55122^{\circ} \mathrm{E}$

Dimensions: $127.5 \mathrm{~cm}(\mathrm{l}) \times 18 \mathrm{~cm}(\mathrm{w}) \times 49.5 \mathrm{~cm}(\mathrm{~h})$

\section{Orientation: NW-SE}

Description: Single limestone slab gravestone lying on its side (Figure 2.155). No inscriptions or carving except for raised decoration formed of two facetted cubes and central rounded arch at both ends. The position and the absence of carving or inscriptions suggests the gravestone was cut to shape, partly worked on, and then abandoned for an unknown reason. Partially excavated to expose position.

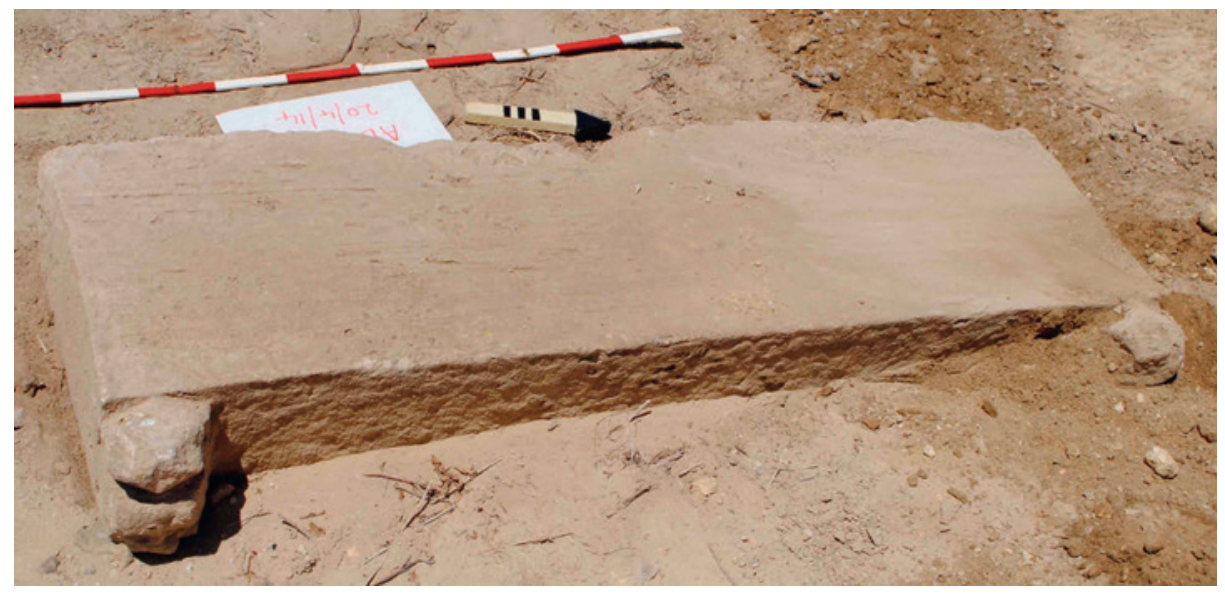

FIGURE 2.155 ABN42

Arabic Transcription and Translation: No inscriptions

Reference Number: ABN43

Co-ordinates: $26.21083^{\circ} \mathrm{N} 050.55120^{\circ} \mathrm{E}$

Dimensions: $88 \mathrm{~cm}(\mathrm{l}) \times 35 \mathrm{~cm}(\mathrm{w}) \times 29 \mathrm{~cm}(\mathrm{~h})$

\section{Orientation: NW-SE}

Description: Single small limestone slab gravestone (Figure 2.156). Badly eroded. No carving or inscriptions. 


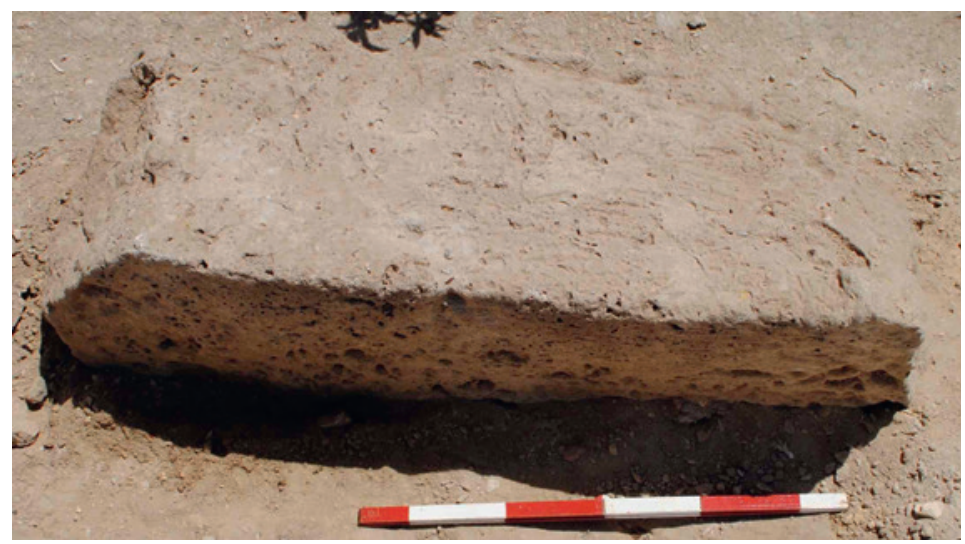

FIGURE 2.156

$\mathrm{ABN} 43$

Arabic Transcription and Translation: No inscriptions

\section{Reference Number: ABN44}

Co-ordinates: $26.21079^{\circ} \mathrm{N} 050.55126^{\circ} \mathrm{E}$

Dimensions: $107 \mathrm{~cm}(\mathrm{l}) \times 35 \mathrm{~cm}(\mathrm{w}) \times 21 \mathrm{~cm}(\mathrm{~h})$

\section{Orientation: NNW-SSE}

Description: Single limestone slab gravestone (Figure 2.157). Significant erosion on one side surface. Next to and given the same co-ordinates as ABN37. Lying on side or upside down. No inscriptions.

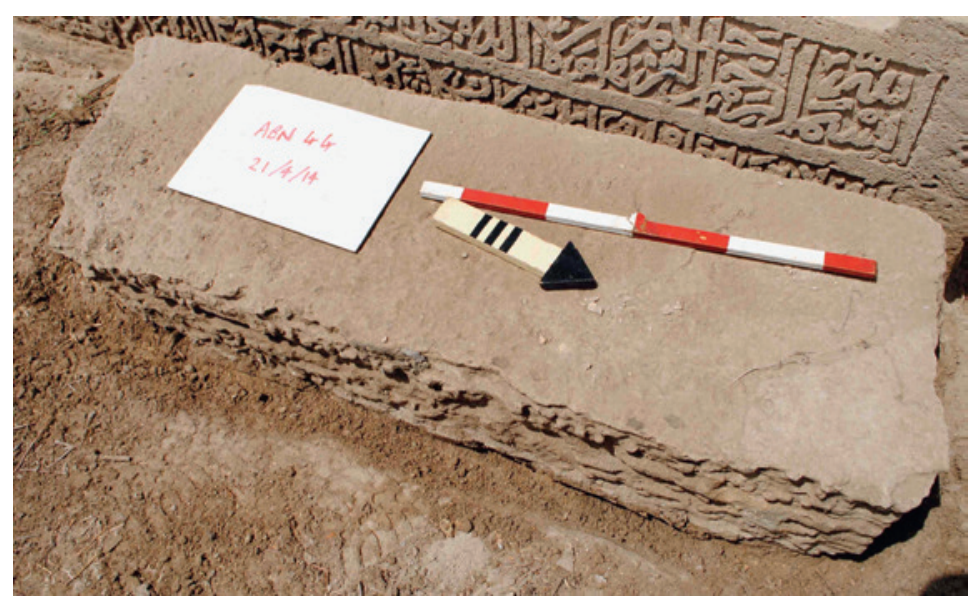

Arabic Transcription and Translation: No inscriptions 
Reference Number: ABN45

Co-ordinates: $26.21074^{\circ} \mathrm{N} 050.55118^{\circ} \mathrm{E}$

Dimensions: $227 \mathrm{~cm}(\mathrm{l}) \times 57 \mathrm{~cm}(\mathrm{w}) \times 45 \mathrm{~cm}(\mathrm{~h})$

\section{Orientation: NW-SE}

Description: Single limestone slab gravestone. Very large. Raised decoration at both ends, three elements formed of two facetted cubes and a central rounded arch all set on a rectangular plinth at one end and a single rounded arch on a rectangular plinth at the other end. Lacks any carving on the top surface (E). Reasonable condition, but with some general erosion. Inscriptions on four surfaces. Excavated to expose complete gravestone.

\section{Arabic Transcription and Translation:}

A:

- No fear shall be on you this day. who believed in Our Ayat and were Muslims, enter Paradise, you and your wives, in happiness (43:68-70).

- Peace be upon you, for you preserved in patience. Excellent indeed is the final home (13:24). Whatsoever is on the earth will perish. And the Face of your Lord full of Majesty and Honour will remain forever $(55: 26-27)$.
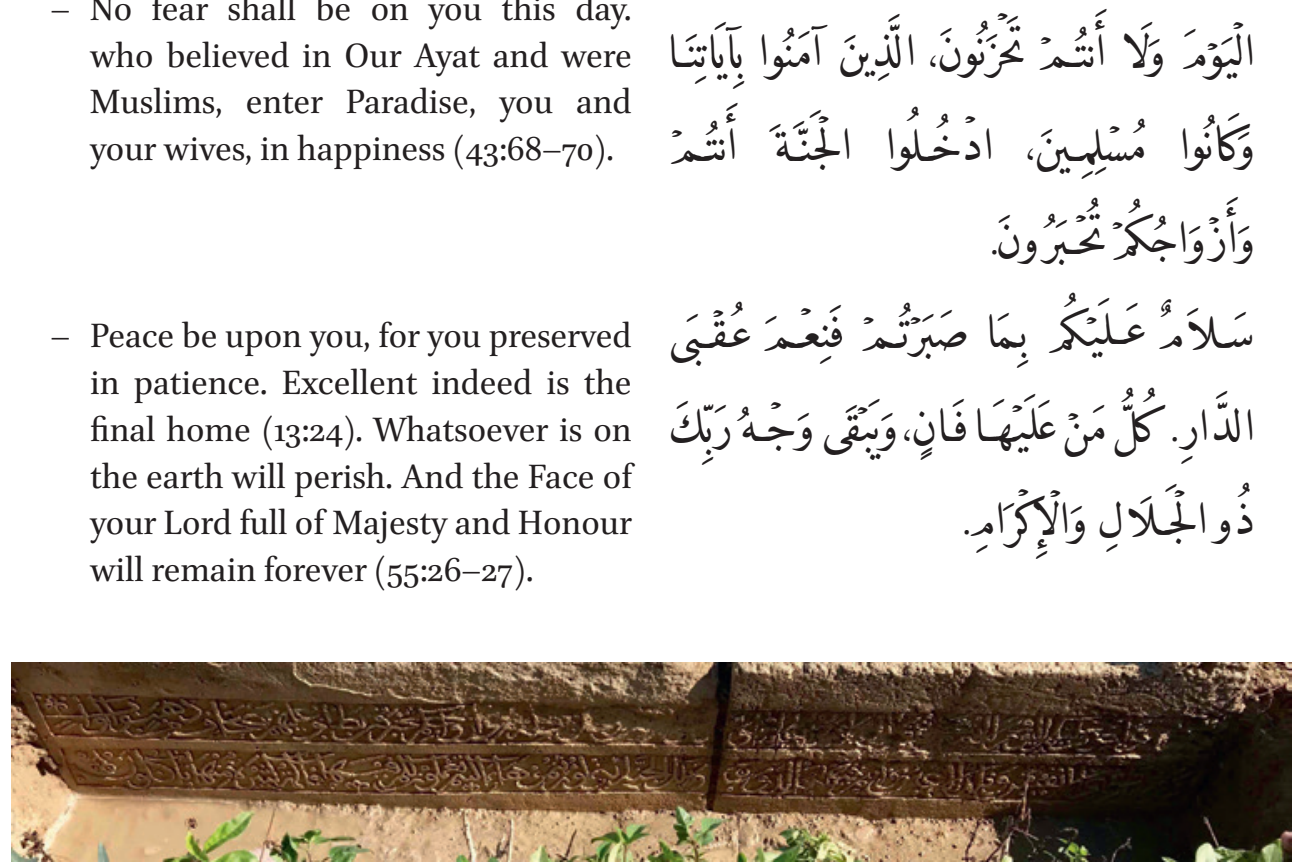

FIGURE 2.158 Surface A, ABN45 
B:

- In the Name of Allah, the Most Gracious, the Most Merciful. Their Lord gives them glad tidings of Mercy from Him, and His pleasure and of Gardens for them. They will dwell therein

- forever. Indeed, Allah has with Him a great reward (9:21-22). They shall enter them and also those who are righteous from among their fathers, and their wives and their children and angels (13:23).
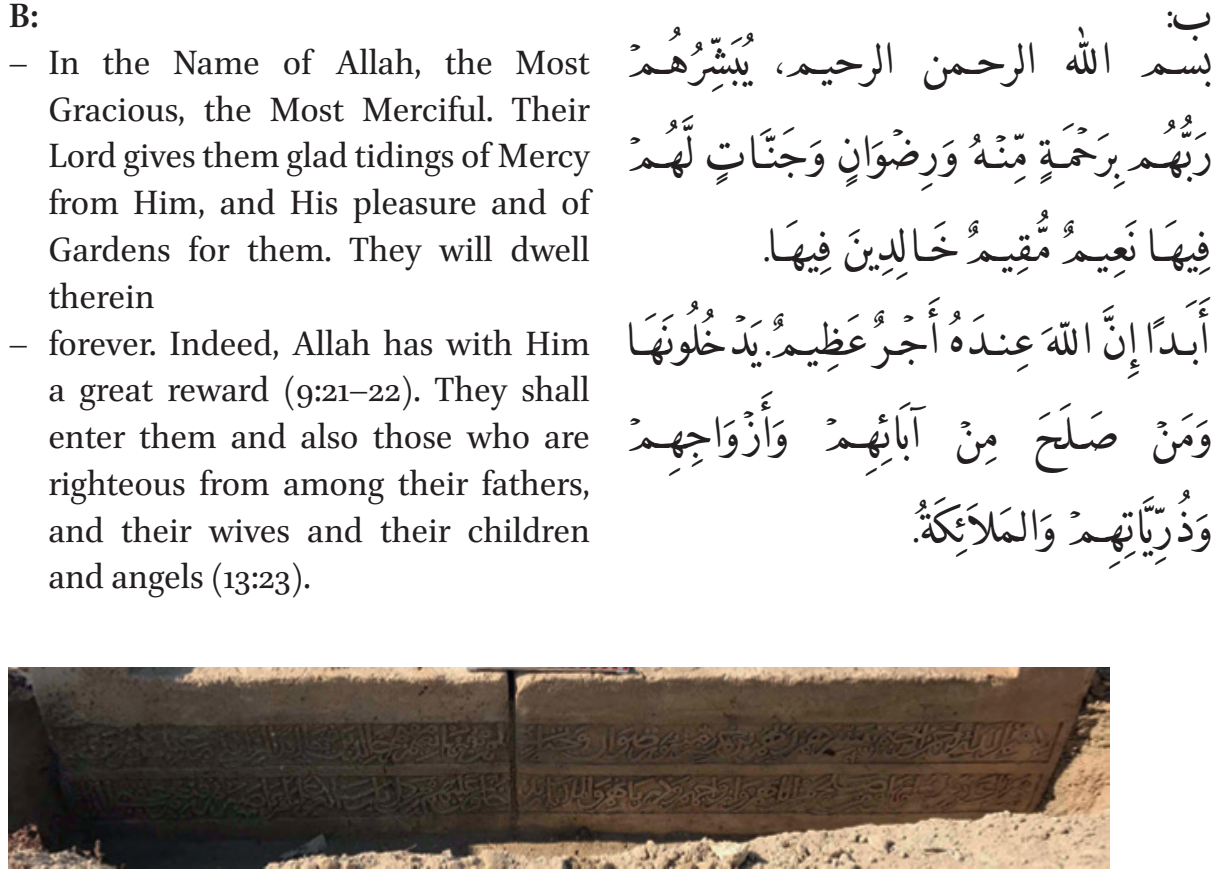

FIGURE 2.159 Surface B, ABN45

C:

- My worshipper! No fear shall be on you (43:68).

- Enter unto them from every gate (13:23).
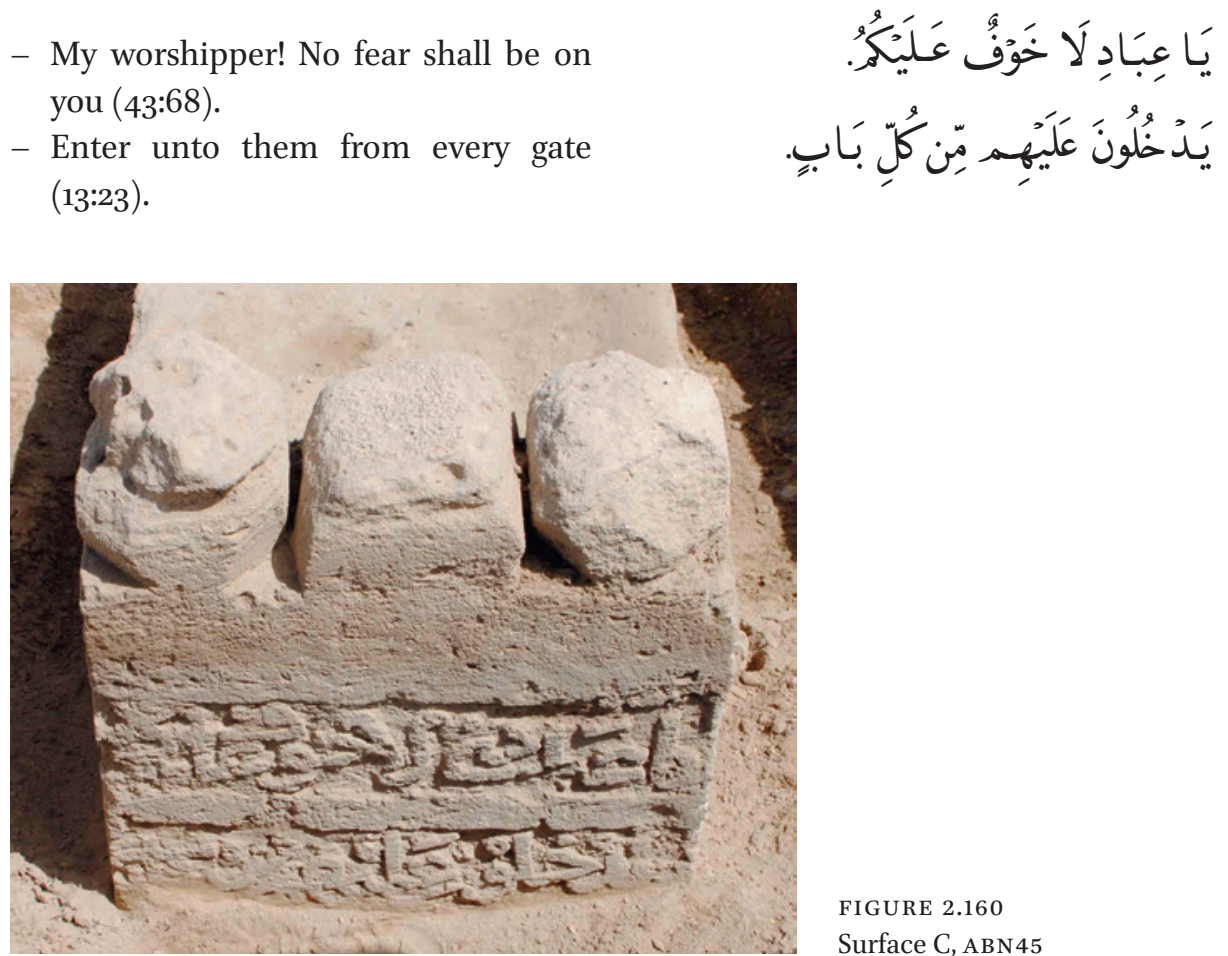
D:

- ... Muhammad bin al-Sacid Said bin Ma'ali.

- He died in nineteenth of

- Safar, year of seven hundred and fifty-four.
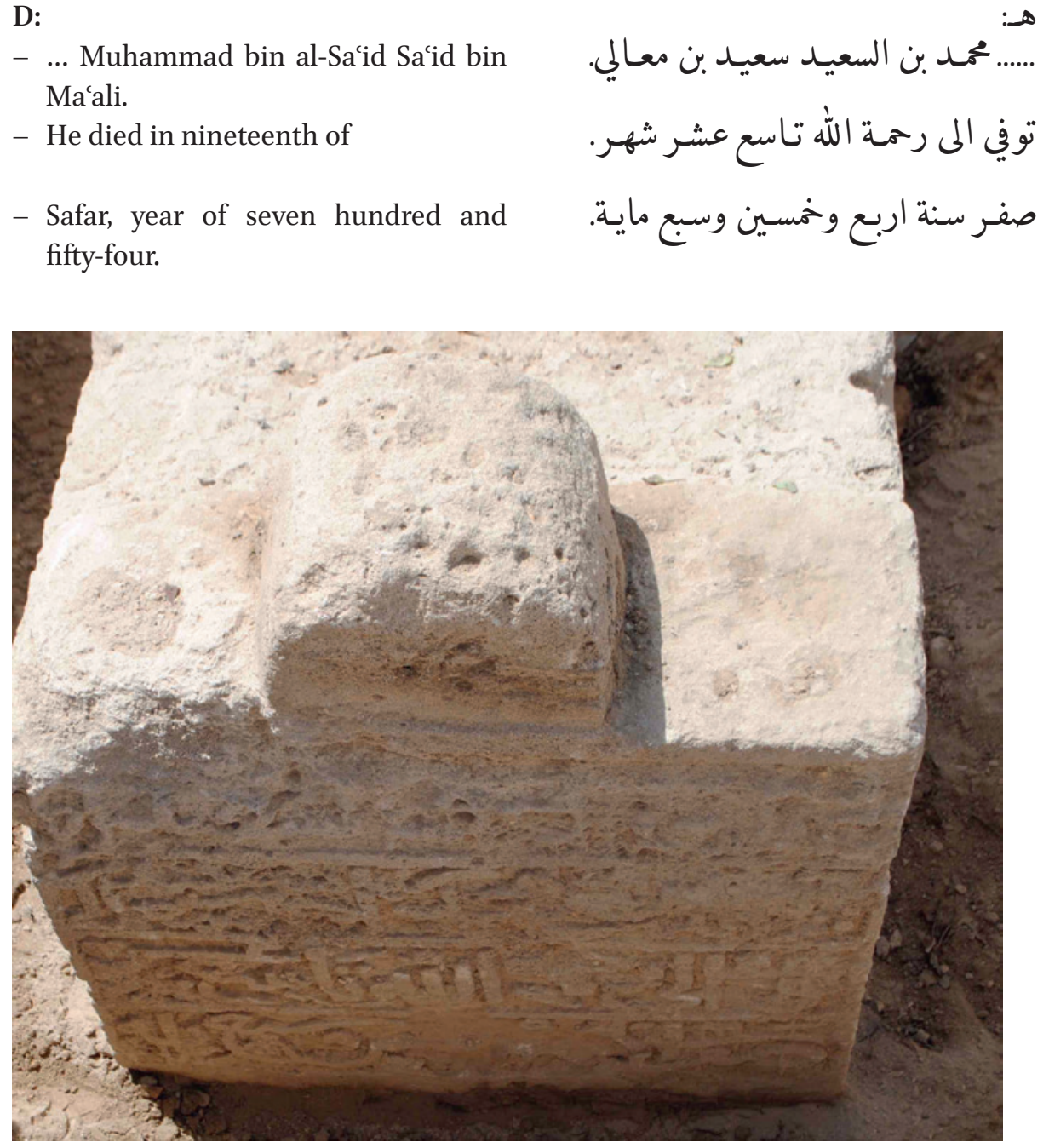

FIGURE 2.161 Surface D, ABN45

E:

- No carving or inscriptions.

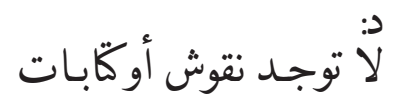




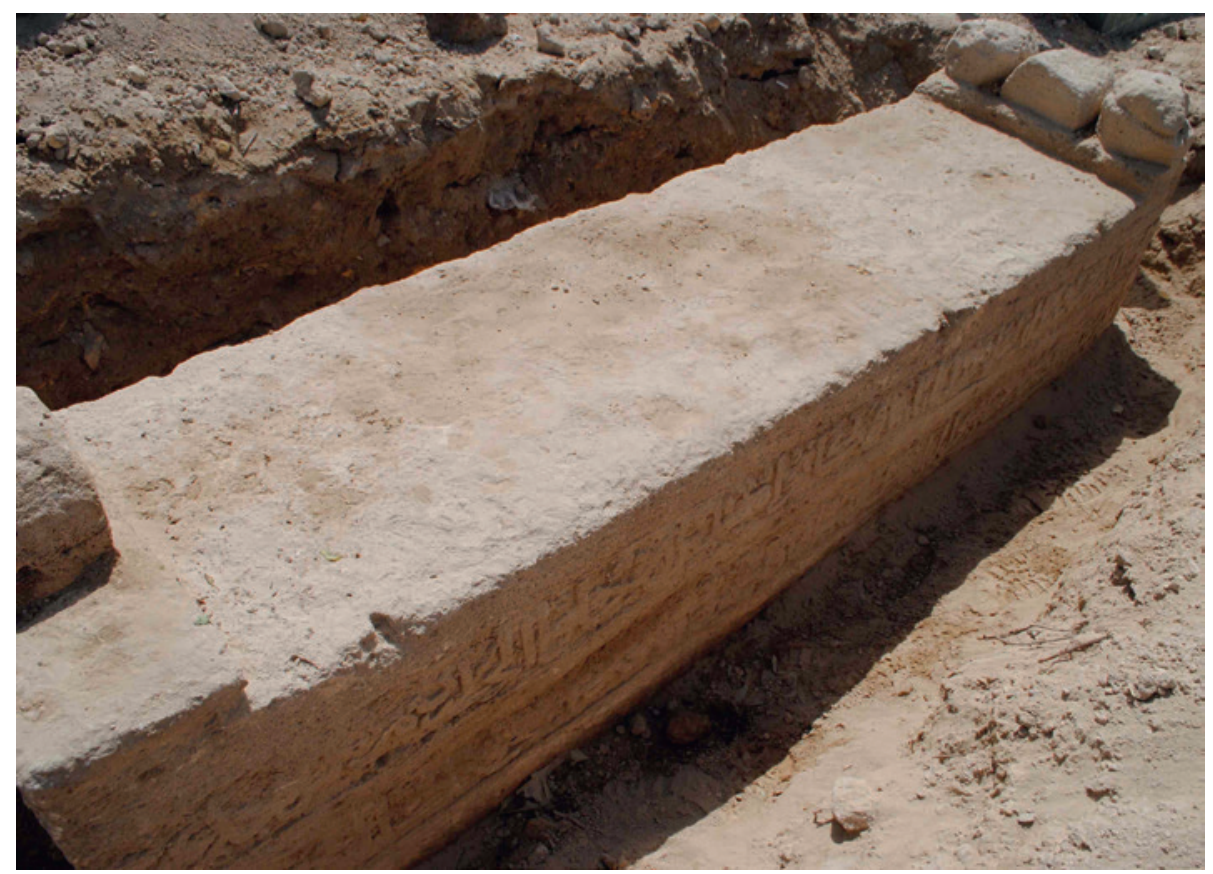

FIGURE 2.162 Surface E, ABN45

\section{Reference Number: ABN46}

Co-ordinates: $26.21070^{\circ} \mathrm{N} 050.55127^{\circ} \mathrm{E}$

Dimensions: $127.5 \mathrm{~cm}(\mathrm{l}) \times 25.5 \mathrm{~cm}(\mathrm{w}) \times 47 \mathrm{~cm}(\mathrm{~h})$

\section{Orientation: N-S}

Description: Single limestone slab gravestone. Found lying on its side in centre of collapsed shrine (Figure 2.163). No inscriptions and a section is split off the top. Series of cup marks on one side surface comprising at least 19 smaller and three larger ones. It is possible that these were made to play the mancala type game. Another identification of a Mancala game board carved onto a gravestone is provided by NOA3. Roughed out rectangular blocks for unfinished raised decoration at both ends. Excavated to expose whole gravestone. 


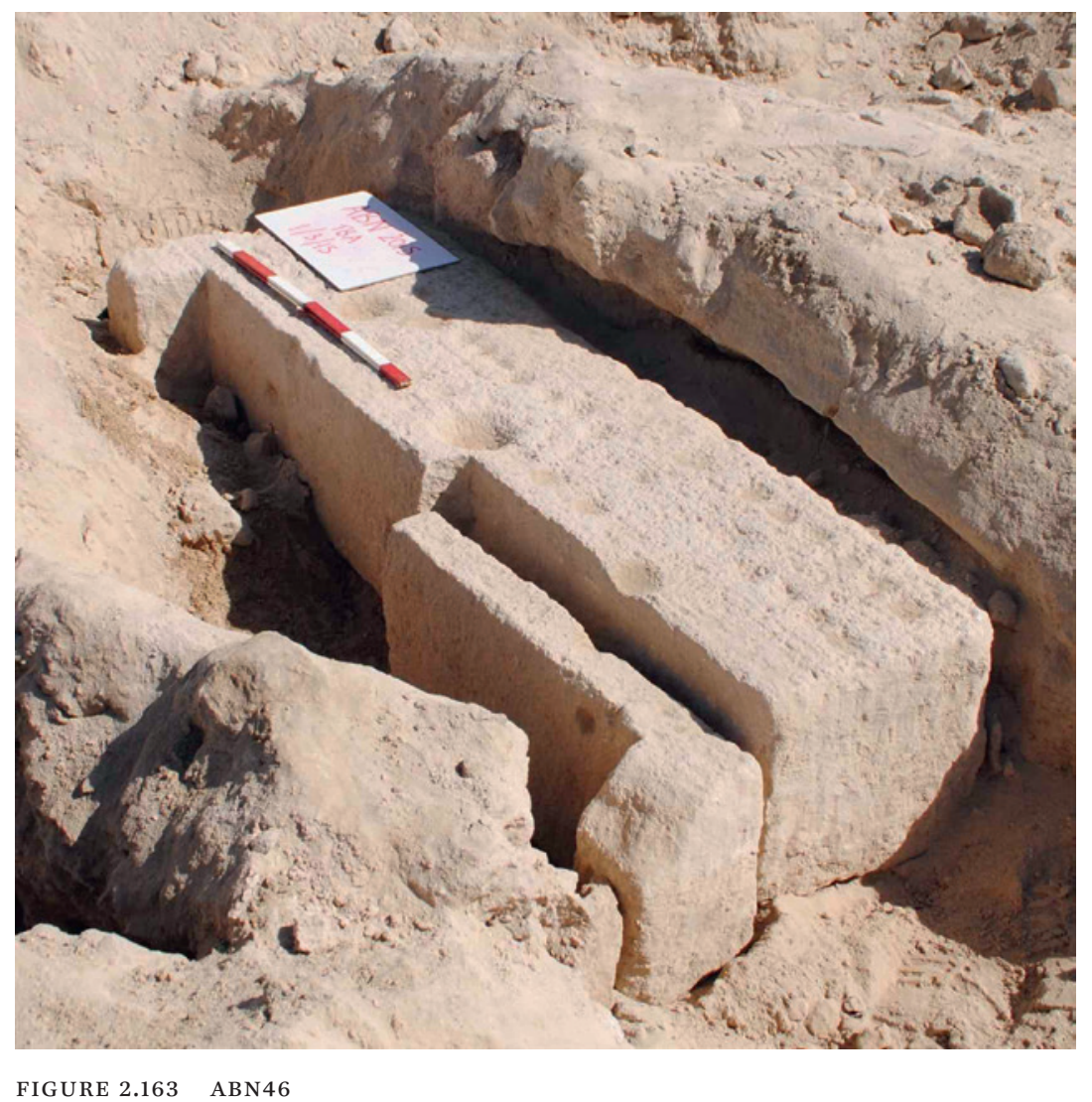

Arabic Transcription and Translation: No inscriptions

Reference Number: ABN47

Co-ordinates: $26.21060^{\circ} \mathrm{N} 050.55135^{\circ} \mathrm{E}$

Dimensions: $160.5 \mathrm{~cm}(\mathrm{l}) \times 37.5 \mathrm{~cm}(\mathrm{w}) \times 57 \mathrm{~cm}(\mathrm{~h})$

Orientation: NW-SE

Description: Single limestone slab gravestone. Elaborate shallow carved rounded niche design with the top of the niche separated by a horizontal bar and the rounded end demarcated with a carved double line. Three element raised decoration formed of two facetted cubes and a central rounded arch at both ends. Generally good condition but with some patches of damage. Surface $C$ has been crudely repaired. Inscriptions on five surfaces. Found within a small collapsed mosque that was excavated. 


\section{Arabic Transcription and Translation:}

A:

- Gardens of Eden whose gates will be opened for them. Therein they will recline, therein they will call for fruits in abundance and drinks. And beside them will be maidens of equal age with modest gaze $(38: 50-52)$... Allah.

- The angels will descend on them, (saying:) Fear not, nor grieve; but receive the glad tidings of Paradise which you have been promised. We have been your friends in the life of this world and in the (41:30-31) ...
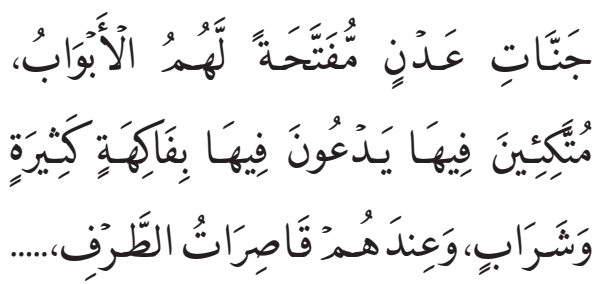

|لّ.

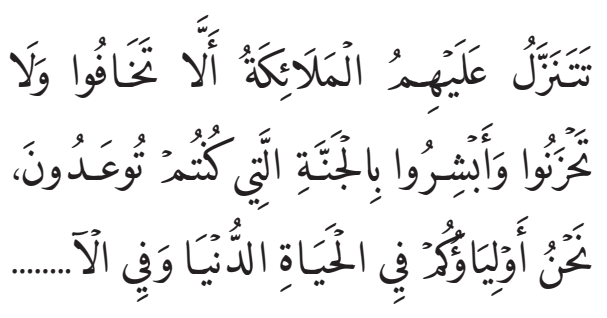

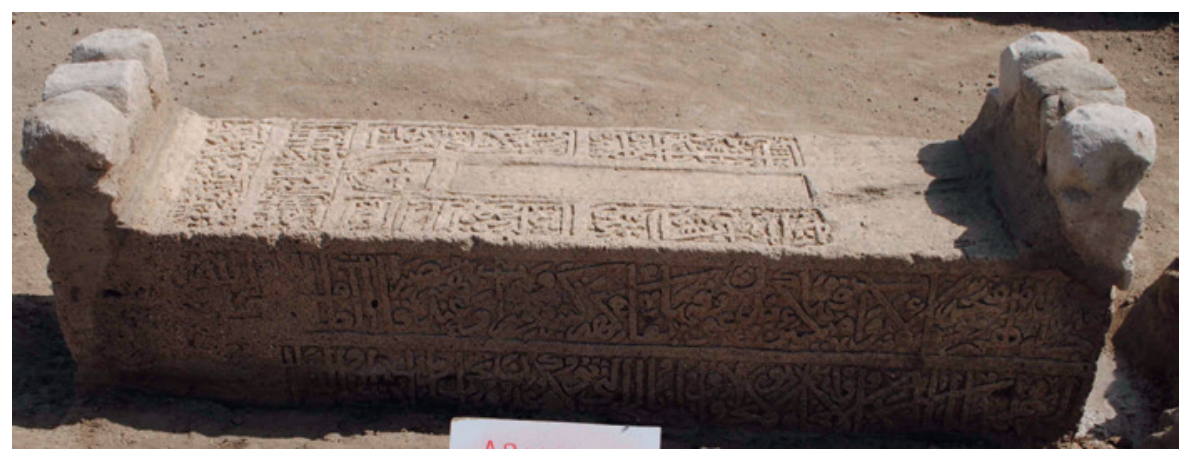

FIGURE 2.164 Surface A, ABN47

B:

- In the Name of Allah, the Most Gracious, the Most Merciful. Allah, none has the right to be worshipped but he, the Ever Living, the One Who sustains and protects all that exists. Neither slumber nor sleep overtakes Him. To Him belongs whatever is in the heavens and whatever is on the earth. Who is he that can intercede

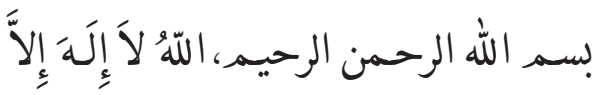

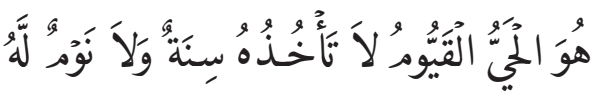

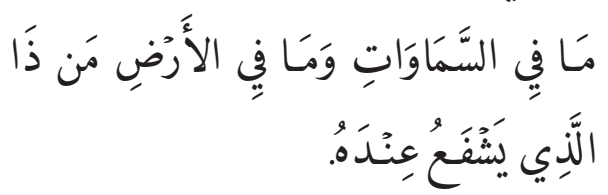
with Him 
- Except ... except that which He wills. His Seat extends over the heavens and the earth, and He feels no fatigue in guarding and preserving them. And He is the Most High, the Most Great (2:255). May peace of Allah be upon Muhammad and his family.
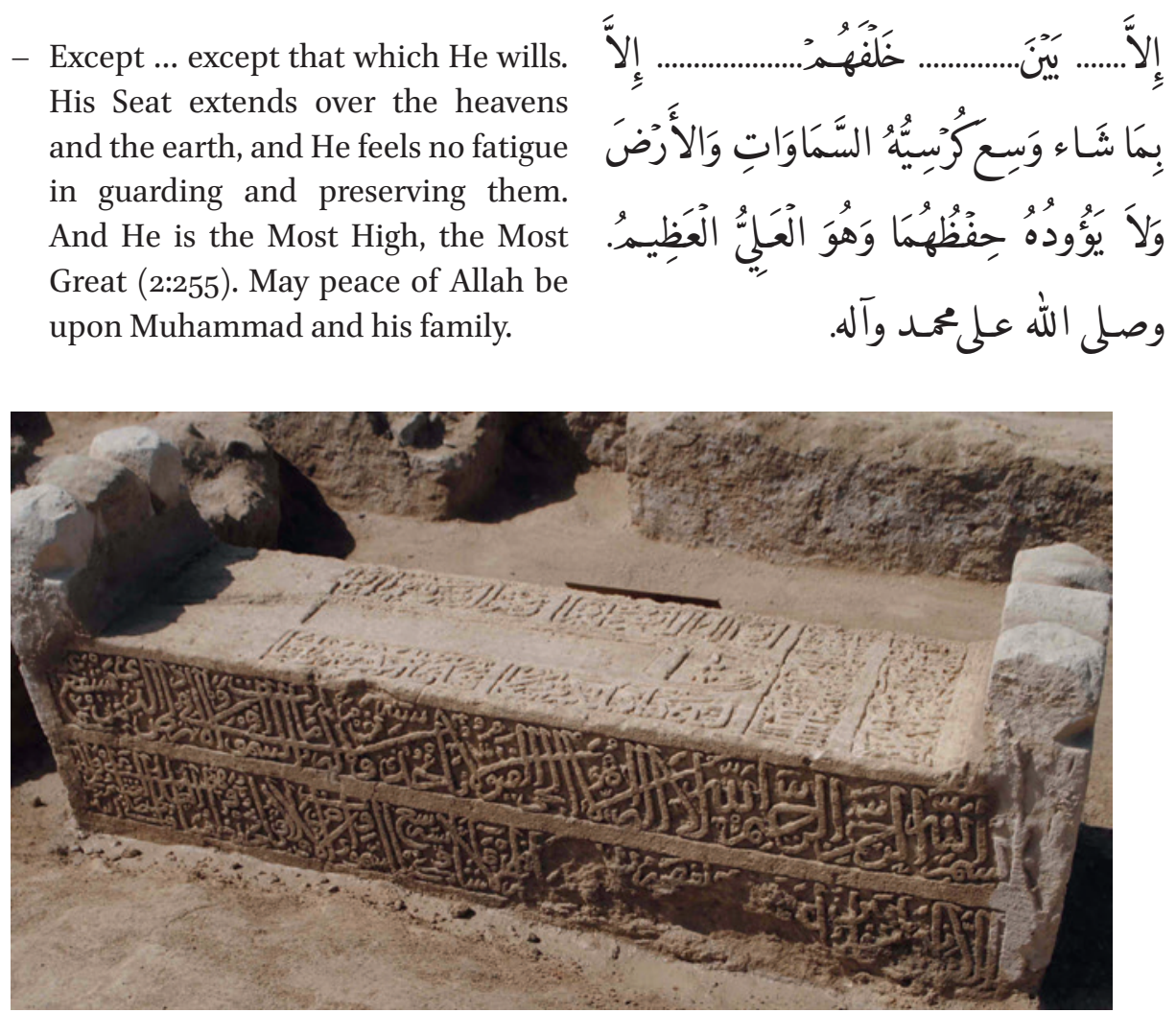

FIGURE 2.165 Surface B, ABN47

C:

- Received ... five ... (years) ... Rabi al-thani.

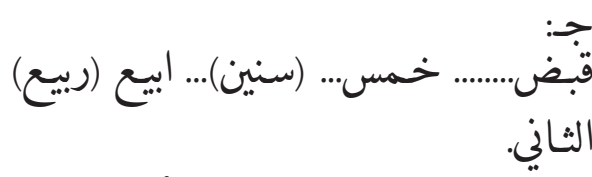

- In the year of one thousand and sixtyseven of Hijra ...

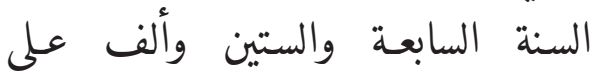

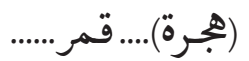

كل مل موم عشـرة اجـزاء من كتّاب الله Powerful everyday, on the ... 


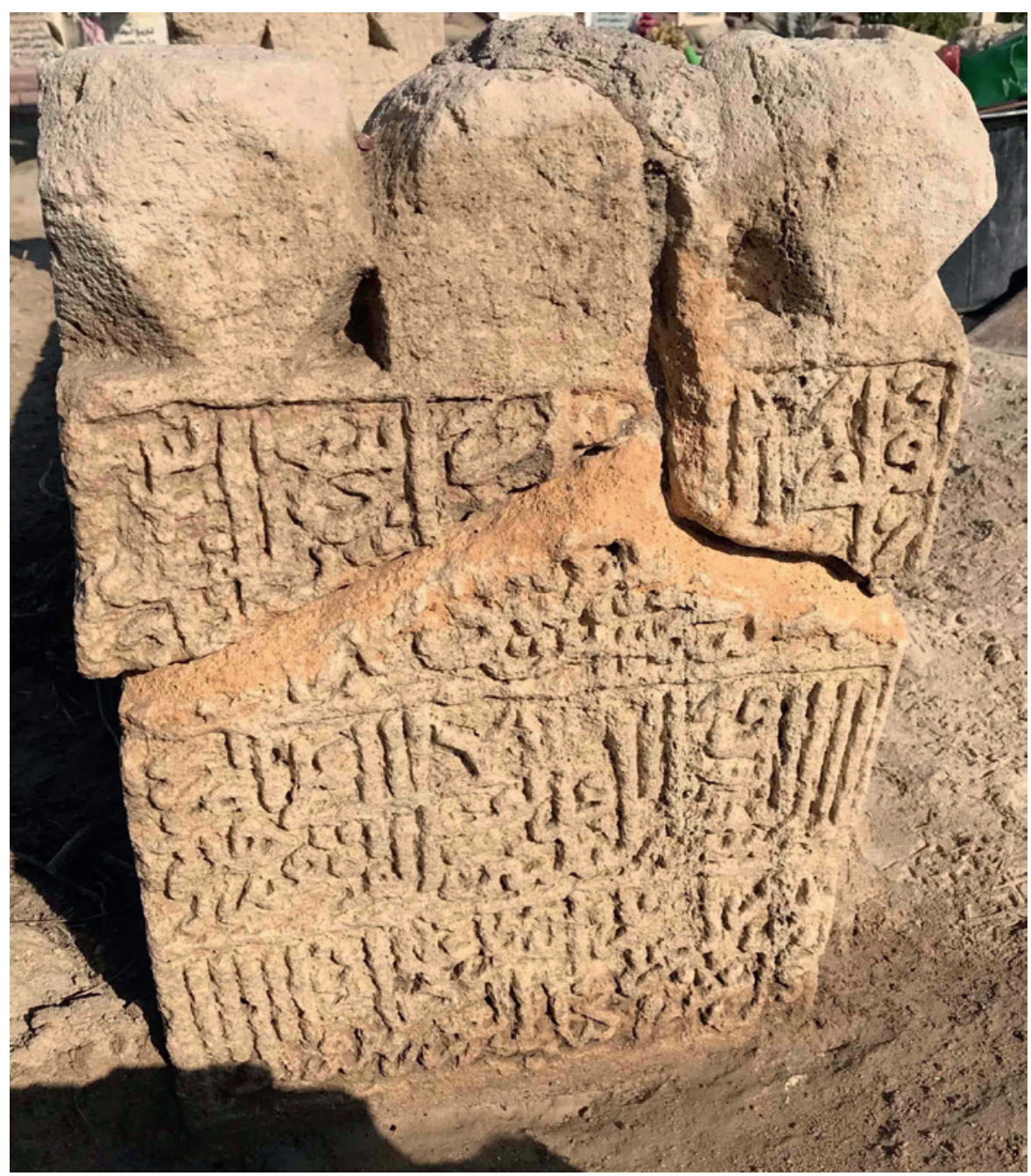

FIGURE 2.166 Surface C, ABN47

D:

- This shrine of ... Al ... al-Bahir ... San.

- ... The holy, Haji.

- Total ... From ... income / crop ...

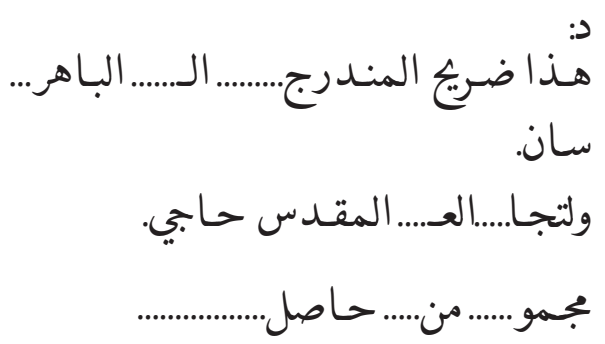




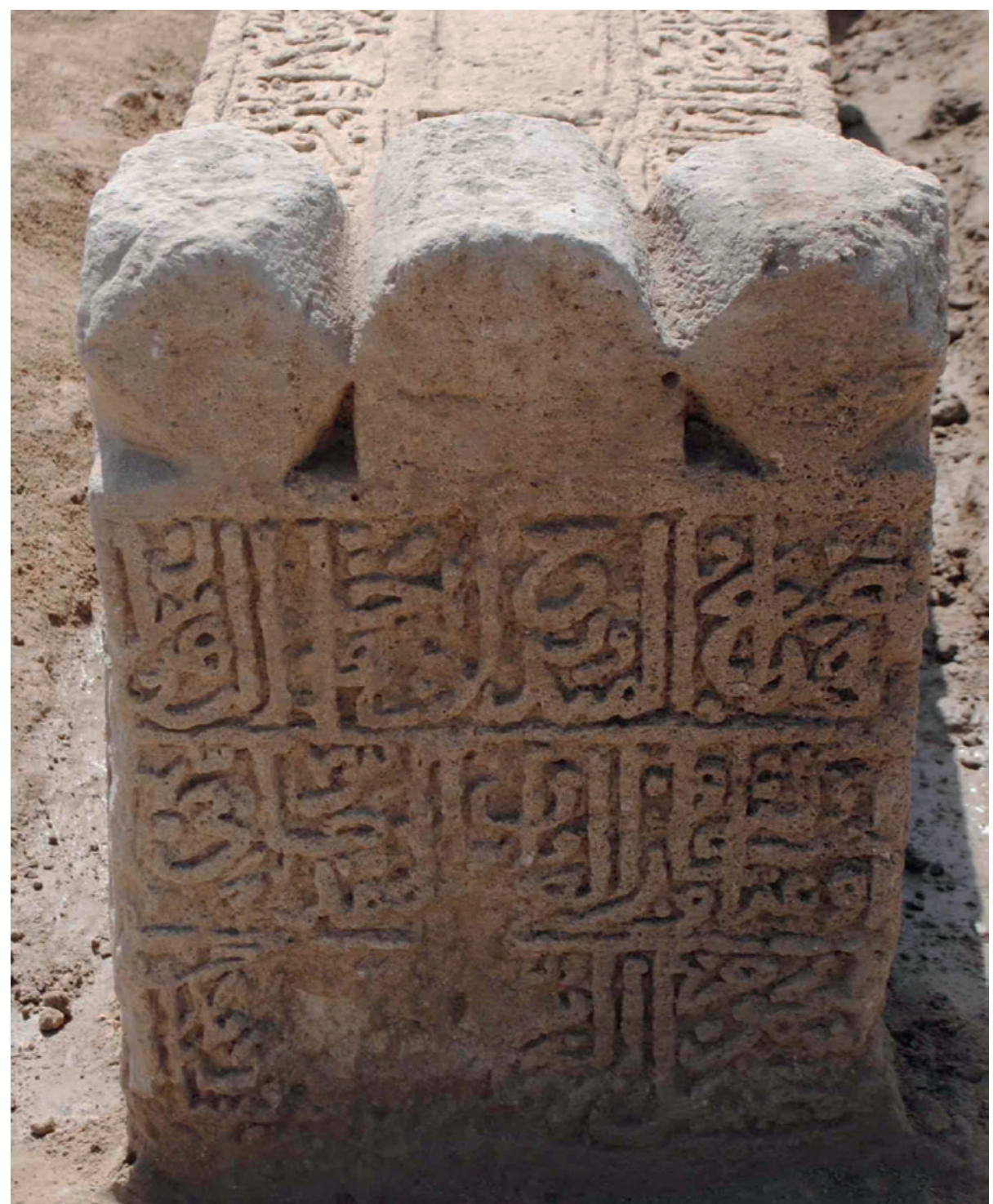

FIGURE 2.167 Surface D, ABN47

E:

كتب الاقل عبد محد بن احد...... الاصبي. Written by the humble Abd Muhammad bin Ahmad ... Al-Asbai $\mathrm{i}$
- The far part ... three hundred from ... with crop ... Al ... eighth.

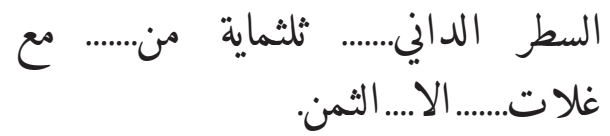


- Nobody can explain my situation more than my grave.
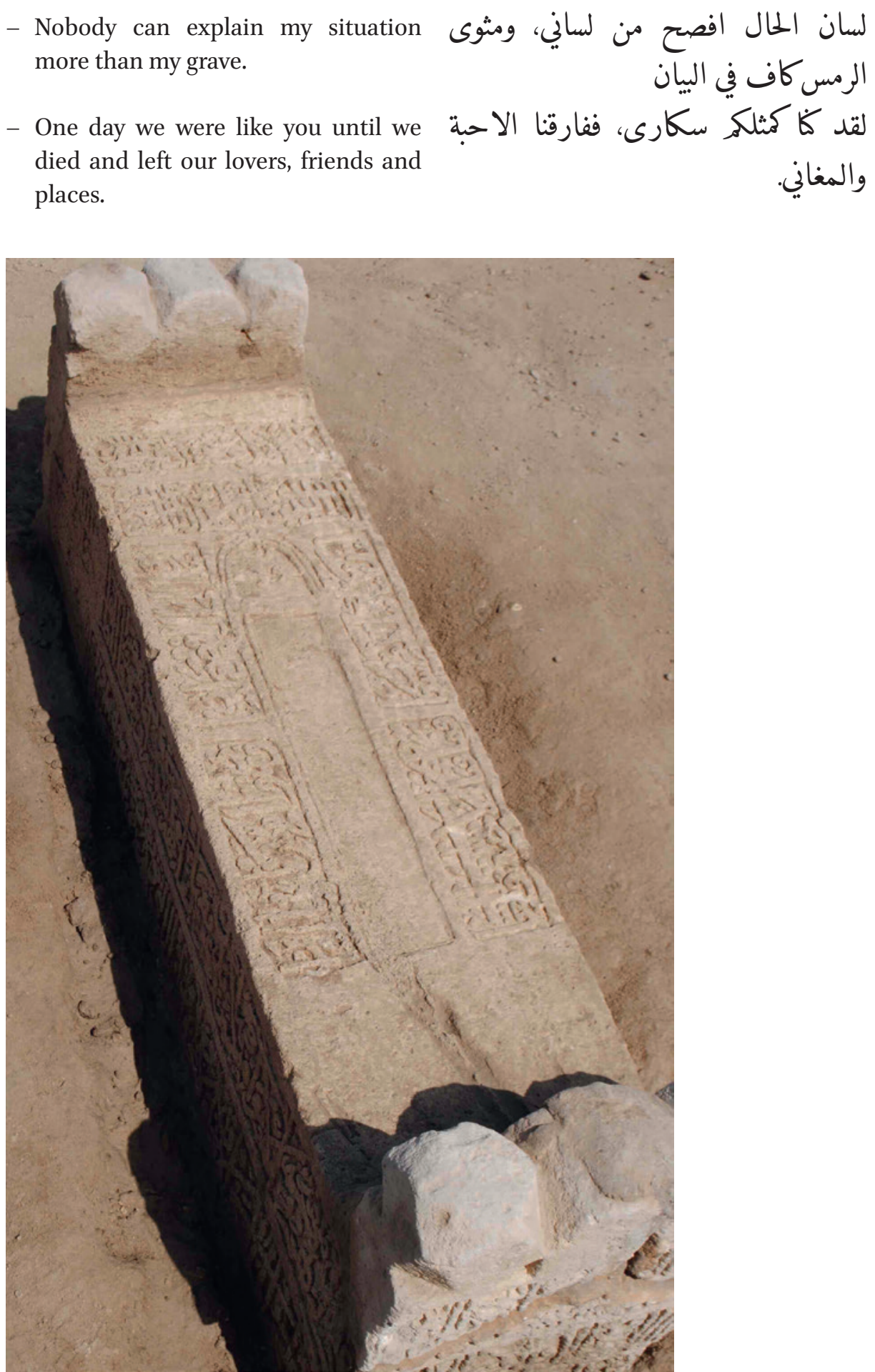

FIGURE 2.168 Surface E, ABN47 
Reference Number: ABN48

Co-ordinates: $26.21080^{\circ} \mathrm{N} 050.55132^{\circ} \mathrm{E}$

\section{Dimensions:}

Slab 1: $98 \mathrm{~cm}(\mathrm{l}) \times 48 \mathrm{~cm}(\mathrm{w}) \times 54 \mathrm{~cm}(\mathrm{~h})$

Slab 2: $98 \mathrm{~cm}(\mathrm{l}) \times 47 \mathrm{~cm}(\mathrm{w}) \times 35 \mathrm{~cm}(\mathrm{~h})$

\section{Orientation: $\mathrm{N}-\mathrm{S}$}

Description: Gravestone formed of two limestone slabs (Figure 2.169). Damaged three element raised decoration formed of, seemingly, two facetted cubes and a central rounded arch at both ends. Illegible inscription on one surface. Traces of shallow carved rectangular niche decoration with a unique demarcated domed end on upper surface (E). Excavated to expose whole gravestone.

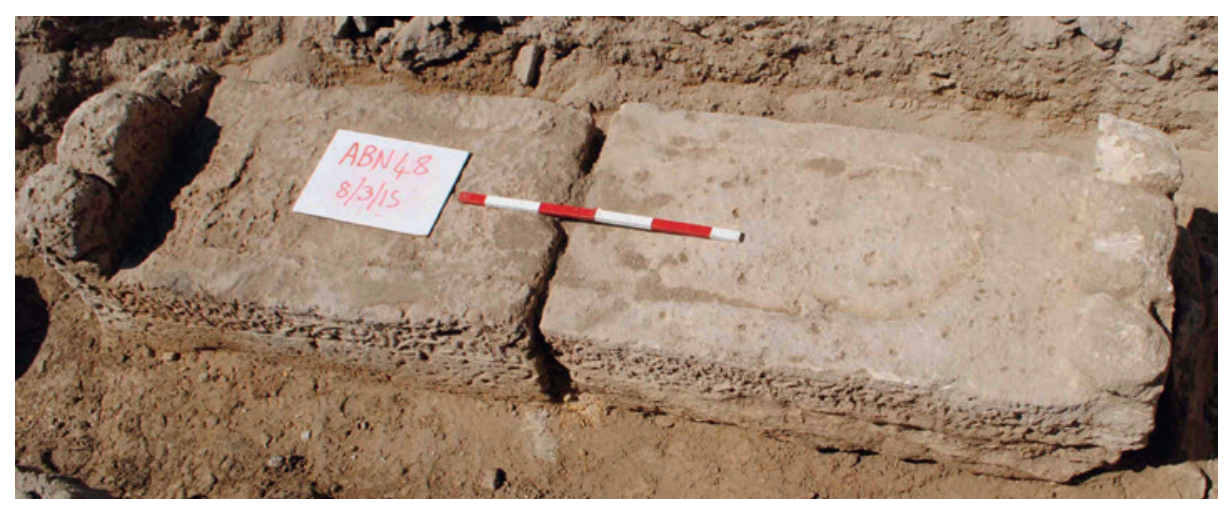

FIGURE 2.169 ABN48

Arabic Transcription and Translation: No legible inscriptions

Reference Number: ABN49

Co-ordinates: $26.21080^{\circ} \mathrm{N} 050.55127^{\circ} \mathrm{E}$

\section{Dimensions:}

Slab 1: $93 \mathrm{~cm}(\mathrm{l}) \times 29 \mathrm{~cm}(\mathrm{w}) \times 49 \mathrm{~cm}(\mathrm{~h})$

Slab 2: $94 \mathrm{~cm}(\mathrm{l}) \times 28 \mathrm{~cm}(\mathrm{w}) \times 45 \mathrm{~cm}(\mathrm{~h})$

Orientation: NW-SE 
Description: Gravestone formed of double limestone slabs. Well preserved inscriptions on five surfaces but with some small areas of damage. Ornate shallow carved pointed niche decoration with elaborate vegetal pattern terminal carved into the upper surface (E). Damaged three element raised decoration formed of two facetted cubes and a central rounded or pointed arch at both ends. The rear of the central arch on the end surfaces $(C$ and $D)$ has inscriptions on it. A roll of brown plastic containing the powdered remains of herbs or a plant-based charm or medicine was found $50 \mathrm{~cm}$ below ground surface in the northern vicinity of the gravestone (Chapter 3). Excavated to expose whole gravestone. This also uncovered the rougher integral plinth of the gravestone that was intended to be below ground.

\section{Arabic Transcription and Translation:}

A:

- The gardens of Eden, which they shall enter and also those who acted righteously from among their fathers, and their wives, and their offspring (13:23) ... immortal boys will go around will wait upon them with cups, and jugs, and a glass of flowing wine. Wherefrom they will get neither any aching of the head ...

- And with fruit that they may choose. And with the flesh of fowls that they desire. And there will be fair females with wide, lovely eyes. Like unto preserved pearls. A reward for what they used to do. No evil vain talk will they hear therein, nor any sinful speech. But only the saying of Salam, Salam. And those on the Right Hand - how will be those on the Right Hand? They will be among thorn less lotetrees. And among banana-trees with fruits piled one above another. And in shade long-extended. And by water flowing constantly (56:17).
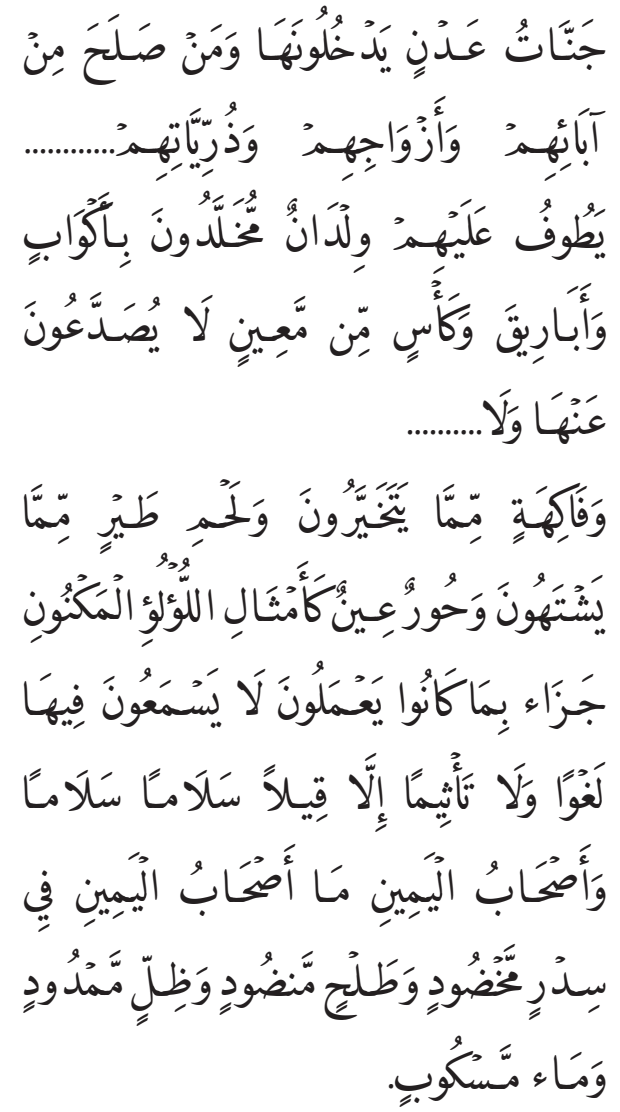


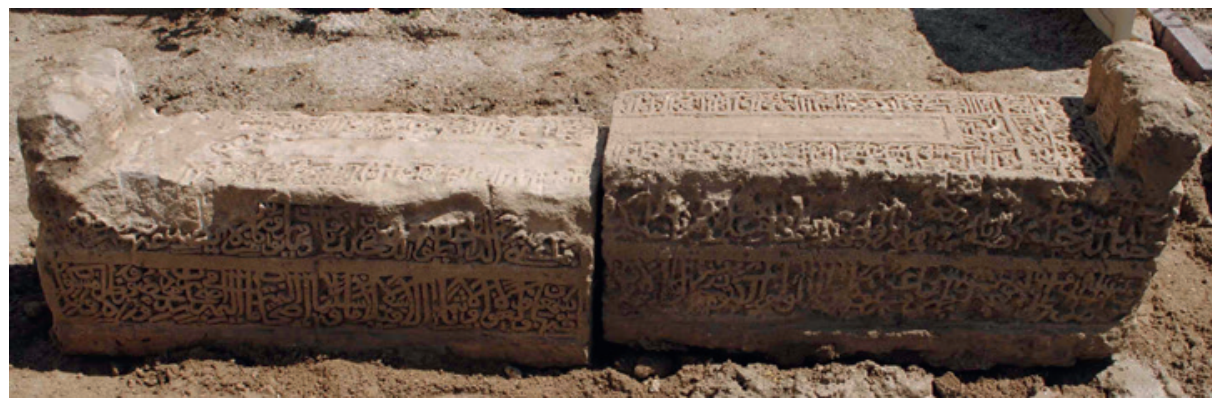

FIGURE 2.170 Surface A, ABN49

B:

- In the Name of Allah, the Most Gracious, the Most Merciful. Allah, none has the right to be worshipped but he, the Ever Living, the One Who sustains and protects all that exists. Neither slumber nor sleep overtakes Him. To Him belongs whatever is in the heavens and whatever is on the earth. Who is he that can intercede with Him except by His permission! He knows what happens to them in this world, and will happen to them in the Hereafter and they will never compass anything of His Knowledge except that which He wills. His Seat extends over the heavens and the earth, and $\mathrm{He}$ feels no fatigue in guarding and preserving them. And He is the Most High,

- The Most Great (2:255). Their Lord gives them glad tidings of Mercy from Him, and His being pleased, and of Gardens (Paradise) for them wherein are everlasting delights (9:21). The angels will descend on them, (saying:) 'Fear not, nor grieve; but receive the glad tidings of Paradise which you have been promised. We have been your friends (41:30-31).
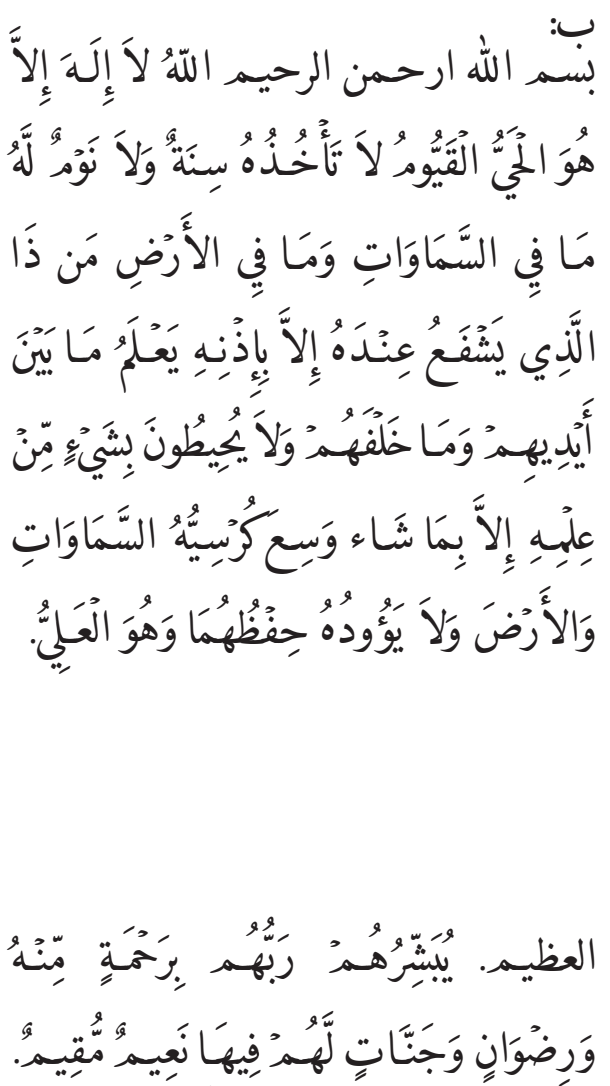

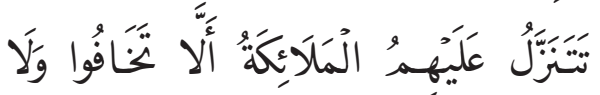

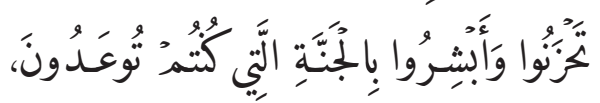

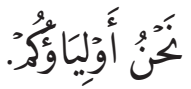




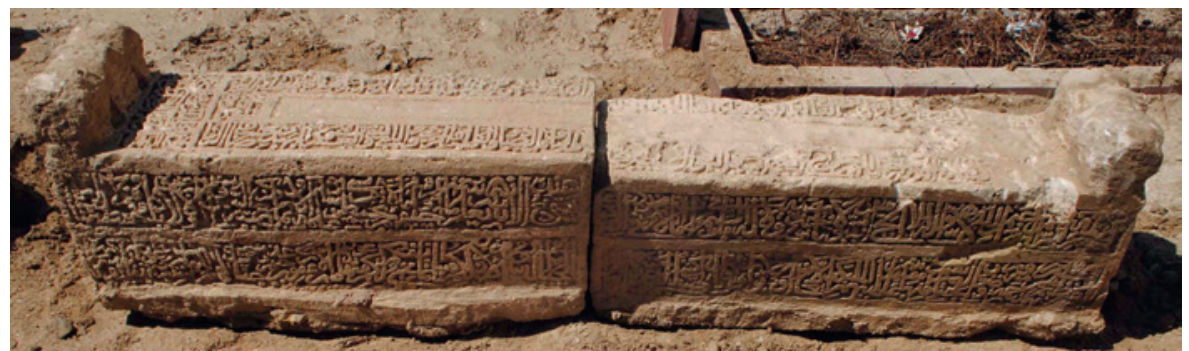

FIGURE 2.171 Surface B, ABN49

C:

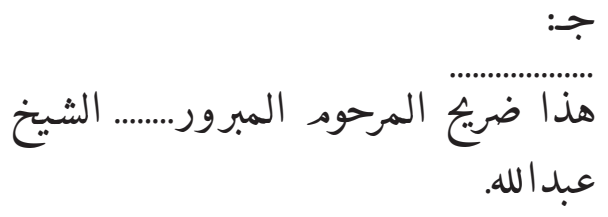

- bin Naser bin Husayn Bin Muqallad. ن ناصر بن حسين .ن مقلد..........

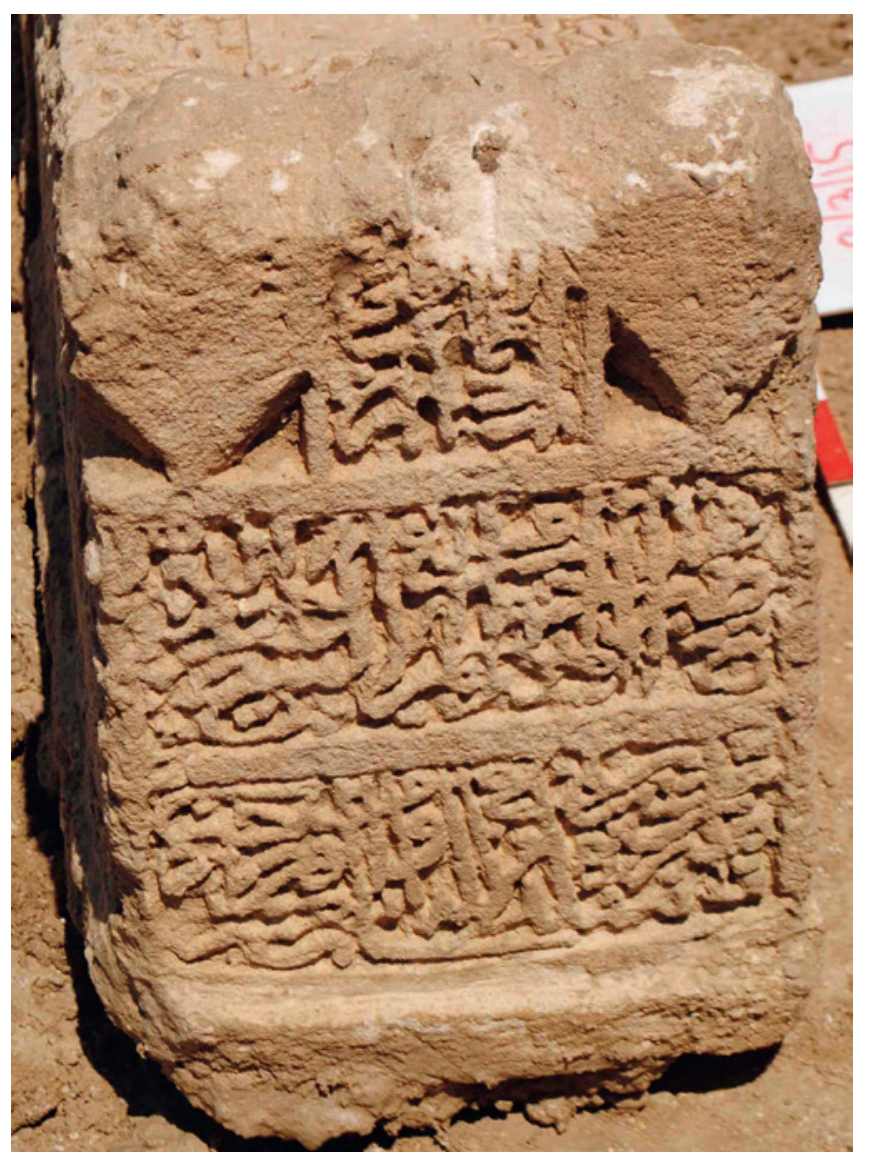

FIGURE 2.172

Surface C, ABN49 
D:

- ... this is...the savant ...

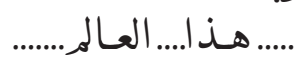

- ... these will be the nearest to Allah, in the Gardens of Delight, a multitude of those will be from the first generation.

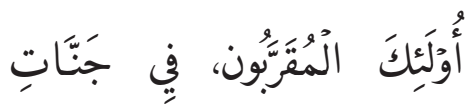

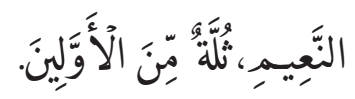

- And a few of those will be from the later generations, they will be on thrones woven with gold and precious stones, reclining thereon face

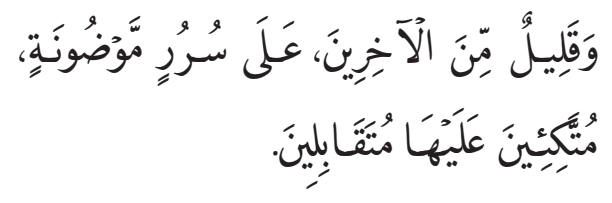
to face $(56: 11-16)$.

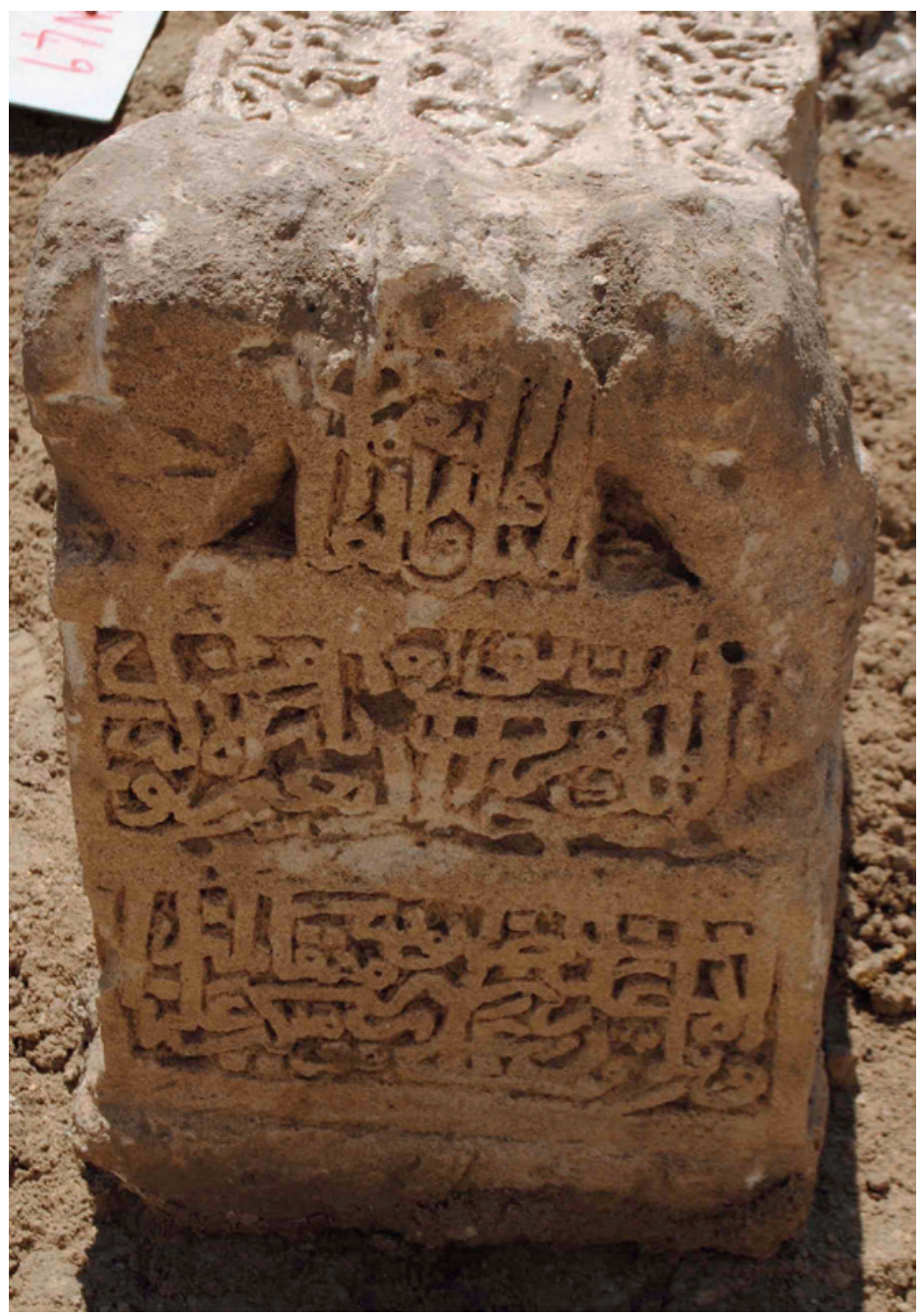


E:

- In the Name of Allah, the Most Gracious, the Most Merciful. Verily! We have sent it down in the night of al-Qadr. And what will make you know what the night of al-Qadr is? The night of Al-Qadr is better than a thousand months. Therein descend the angels and the Spirit by Allah's Permission with all Decrees. Peace! All that night until the appearance of dawn (97:1-5).

- In the Name of Allah, the Most Gracious, the Most Merciful. May the peace of Allah be upon Prophet Muhammad, 'Ali, al-batul, The Grandsons, al-Sajad, al-Baqir, alSadiq, al-Kadhim, al-Rida, al-Taqi, al-Naqi, al-Askari and al-Mahdi Muhammad.

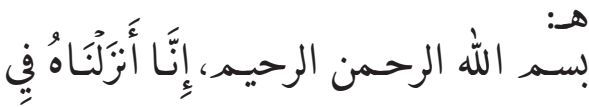

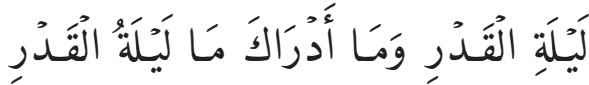

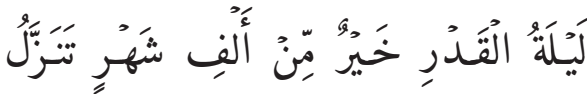

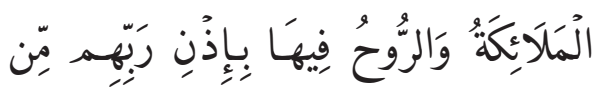

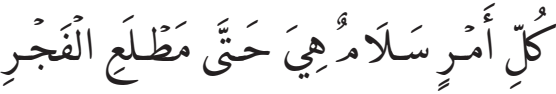

لسـم الله الرحمن الرحيـم، اللهـم صل على محـد النبي وعلي والبتول السبطين والسجاد والبـاقر والصـادق والكاظم والرضى والتقي والنق والنسكي والتئي والمهلدى صاحب الرنان، مُحـ العترة الخـيرة.

- This blessed room is waqf for the great Shaikh, 'Abd Allah bin Naser bin Husayn bin Muqallad.
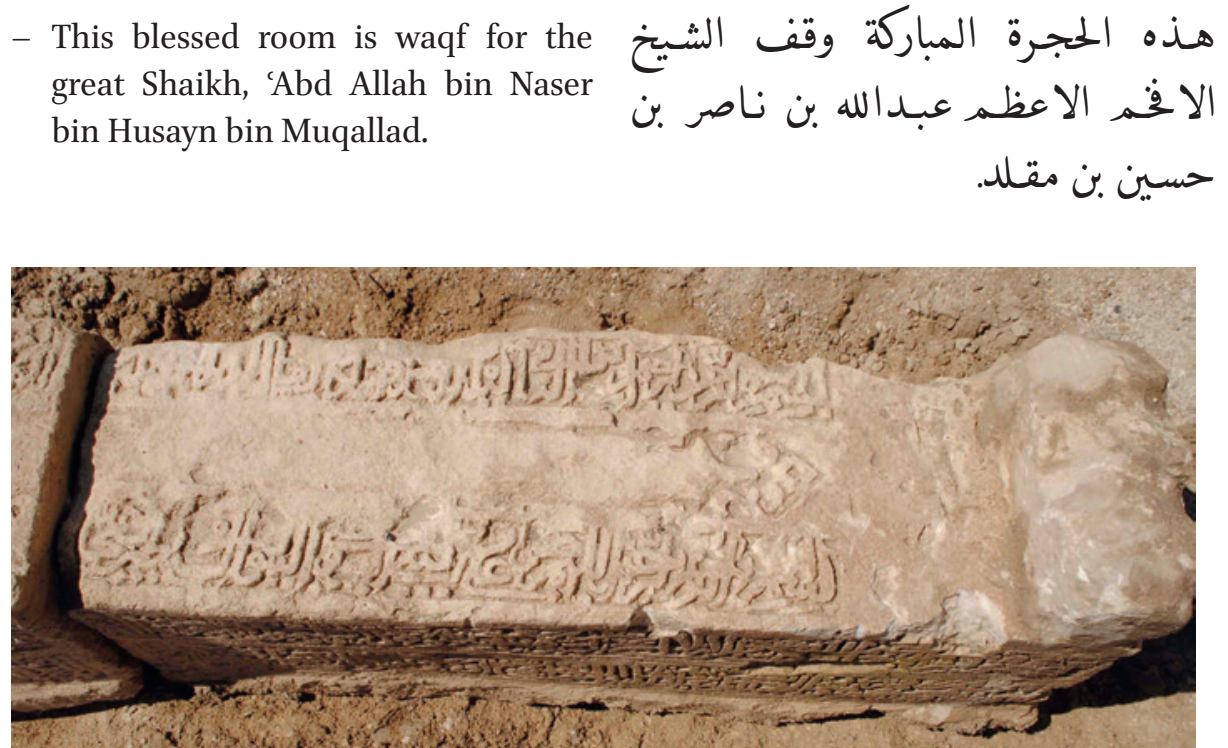

FIGURE 2.174 Surface E, part 1, ABN49 


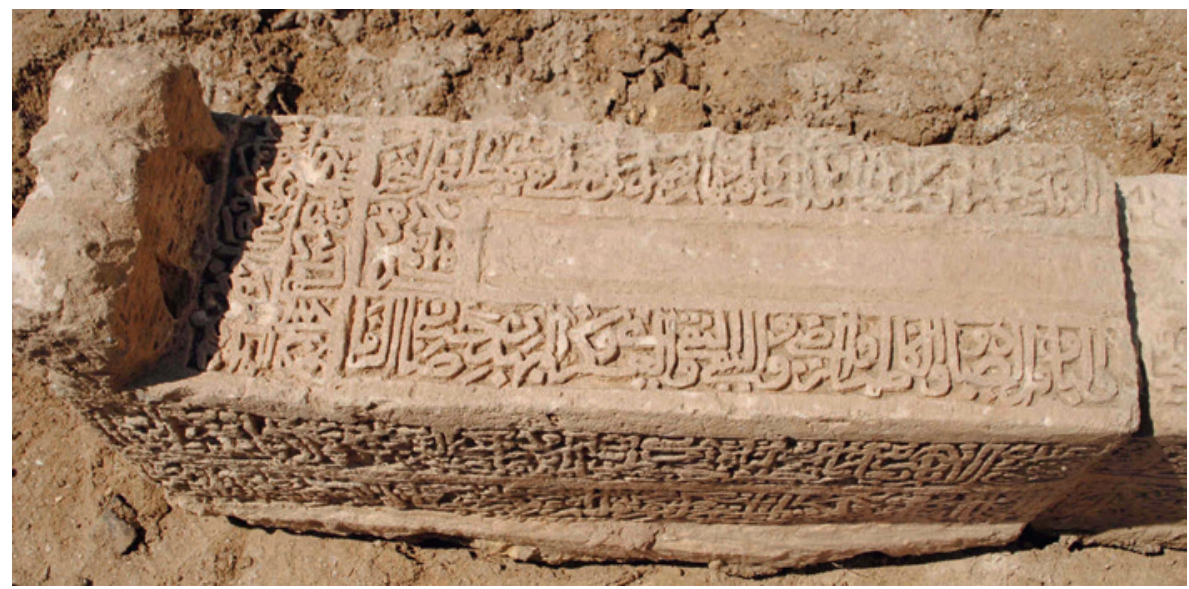

FIGURE 2.175 Surface E, part 2, ABN49

\section{Reference Number: ABN50}

Co-ordinates: $26.21085^{\circ} \mathrm{N} 050.55127^{\circ} \mathrm{E}$

Dimensions: $140 \mathrm{~cm}(\mathrm{l}) \times 30 \mathrm{~cm}(\mathrm{w}) \times 40 \mathrm{~cm}(\mathrm{~h})$

\section{Orientation: N-S}

Description: Single limestone slab gravestone. Significant erosion in places. No niche design on surface E. Three element raised decoration formed of two facetted cubes and a narrow, rounded arch at both ends. Excavated to expose whole gravestone.

\section{Arabic Transcription and Translation:}

A:

- Very deteriorated. It cannot be read.

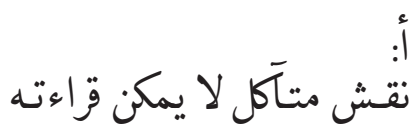

B:

- He is the Ever Living, the One Who sustains and protects all that exists. Neither slumber nor sleep overtakes

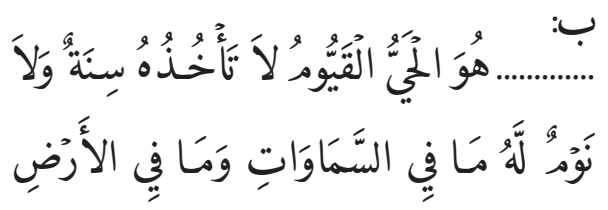


Him. To Him belongs whatever is in the heavens and whatever is on the earth. Who is he that can intercede with Him except by His permission! He knows what happens to them in this world, and will happen to them in the Hereafter and they will never compass anything of His Knowledge except that which He wills. His Seat extends over the heavens and the earth, and He feels no fatigue

- ... and believes in Allah, ... And Allah is All-Hearer, All-Knower. Allah is the Protector of those who believe. He brings them out from darkness into light (2:255-257). God ... has spoken the truth.
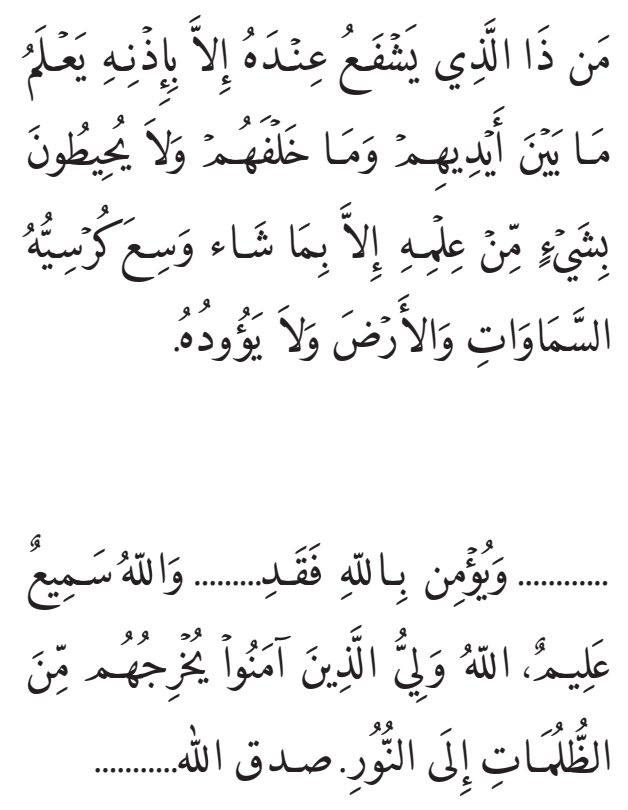

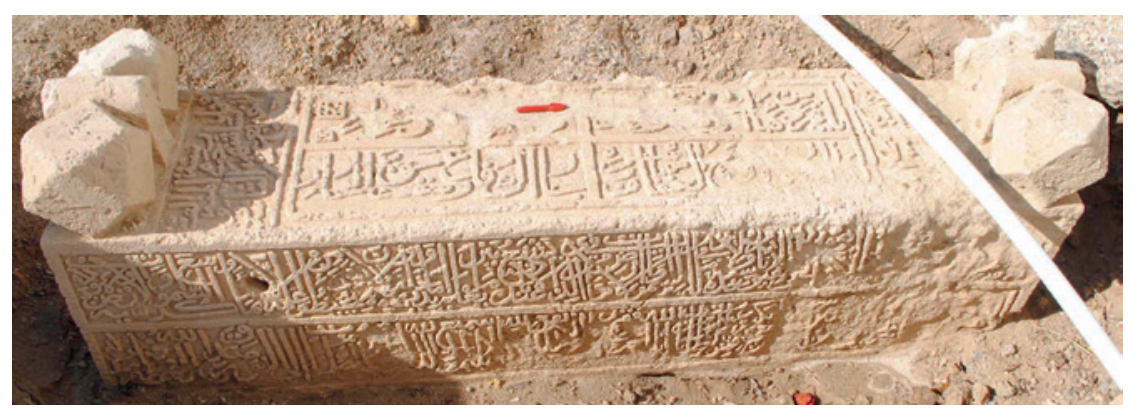

FIGURE 2.176 Surface B, ABN50

C:

- Eight shares from ... garden

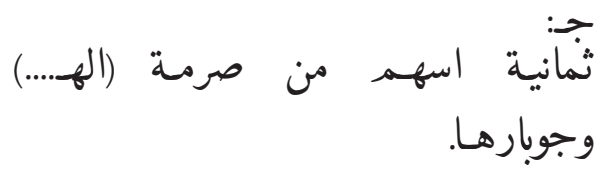

- Located behind Mani, one part is for the night ...

- Big basket by Bahraini weight.

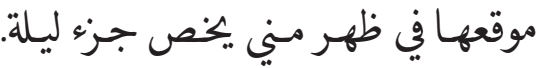

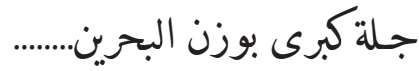




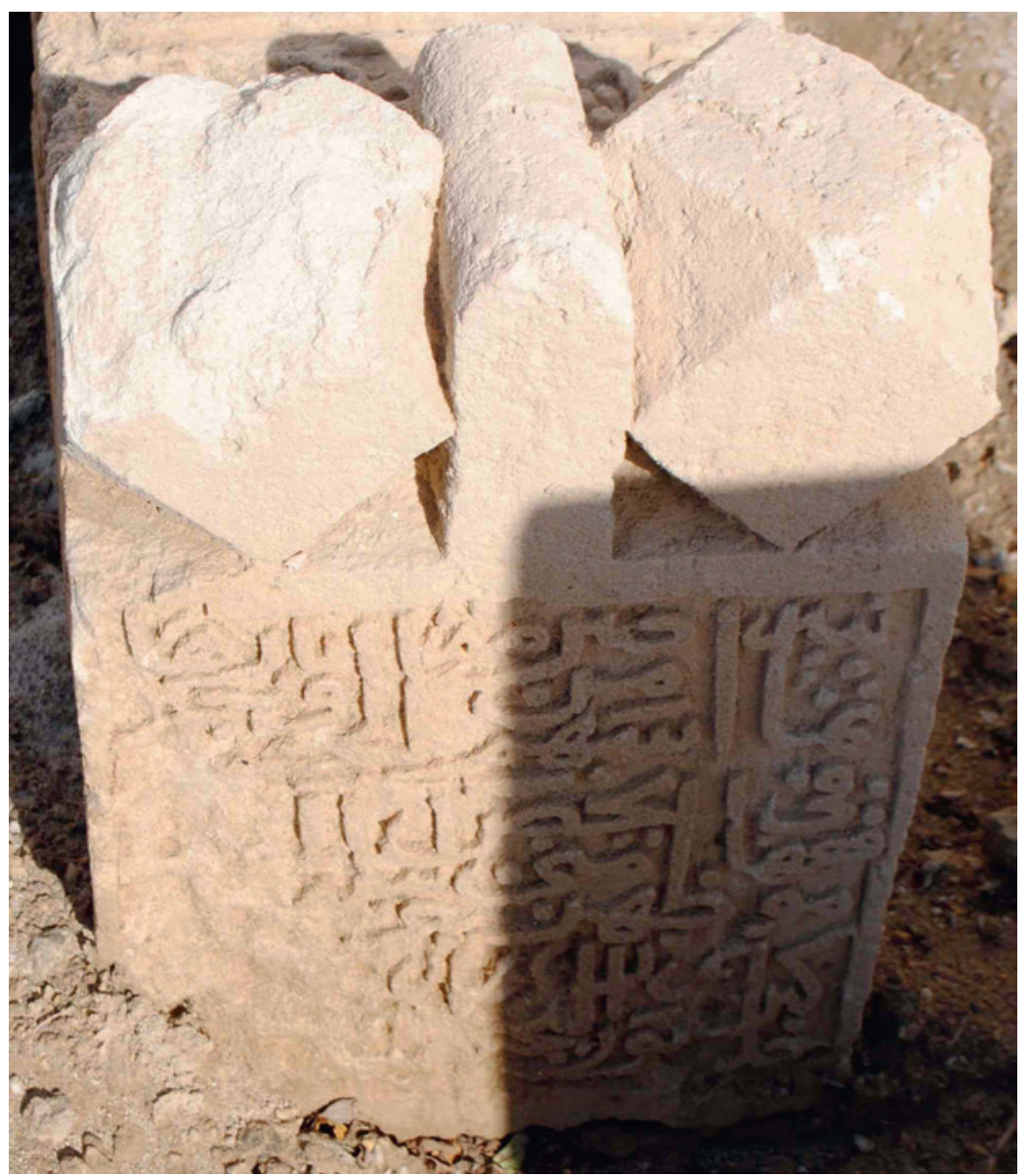

FIGURE 2.177 Surface C, ABN50

D:

- Very deteriorated. It cannot be read.

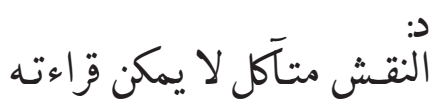

E:

- ... Muhammad, seventeenth of Rajab, year of one thousand, one hundred and two.

- Oh grave ... neighbour

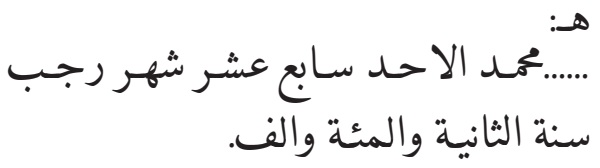

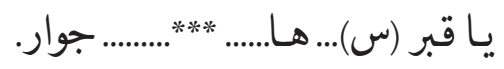

- ... chastity, your neighbour has the neighbourhood rights.

- ... the late ... Bint...the late...

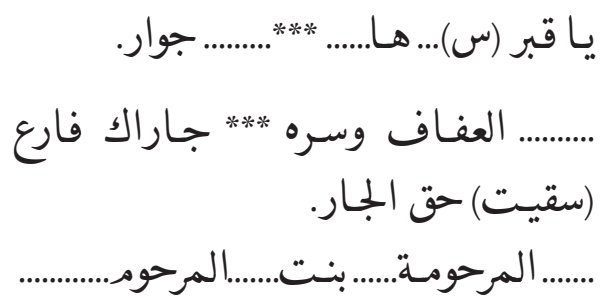



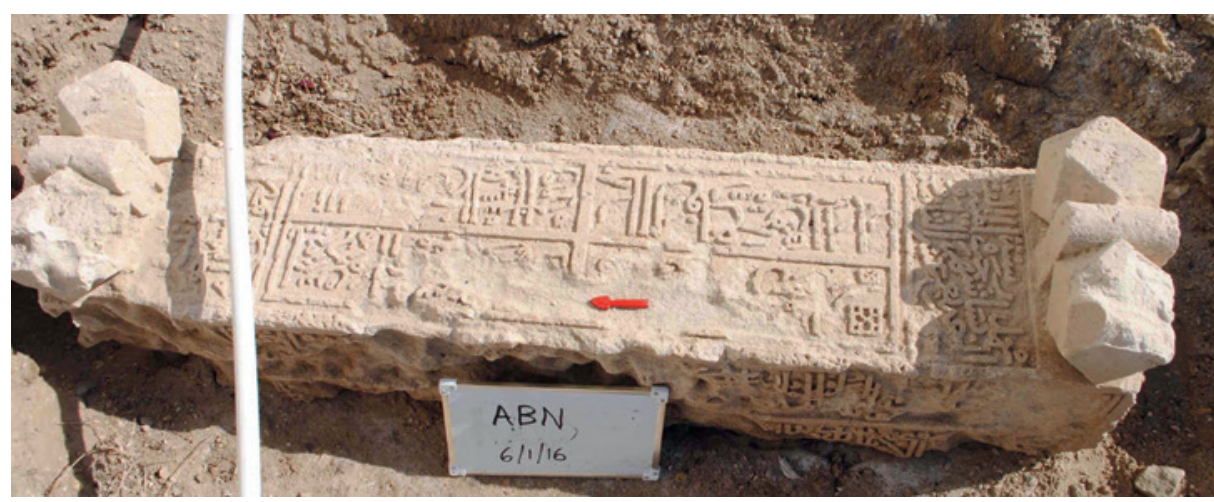

FIGURE 2.178 Surface E, ABN50

4

Abu Saiba (ABS)

Location: Abu Saiba village cemetery

\section{Reference Number: ABS1}

Co-ordinates: $26.21770^{\circ} \mathrm{N} 050.50523^{\circ} \mathrm{E}$

Dimensions: $151 \mathrm{~cm}(\mathrm{l}) \times 30 \mathrm{~cm}(\mathrm{w}) \times 48 \mathrm{~cm}(\mathrm{~h})$

\section{Orientation: NW-SE}

Description: Single limestone slab gravestone enclosed in a glass display case inside a modern cement block shrine structure that was still in the process of construction in 2015. According to local informants the gravestone was found whilst digging new graves along with a pre-Islamic Tylos upright limestone stelae $(41 \mathrm{~cm} \mathrm{[1] \times 29}$ $\mathrm{cm}[\mathrm{w}] \times 11.5 \mathrm{~cm}[\mathrm{depth}])$. The stele is missing its upper figure, assuming one was present, and has two carved columns represented at the side of an upright central rectangular block (cf. Boucharlat and Salles 1989: 130-131; Lombard 1999: 212-215 for parallels). The stele has been transferred to the archaeological store in the Bahrain National Museum. The gravestone has three element raised decoration formed of two facetted cubes and a central rounded arch on a rectangular plinth at both ends. Inscriptions on five surfaces. 
Arabic Transcription and Translation:

A:

- In the Name of Allah, the Most Gracious, the Most Merciful. Allah, none has the right to be worshipped but he, the Ever Living, the One Who sustains and protects all that exists. Neither slumber nor sleep overtakes Him. To Him belongs whatever is in the heavens and whatever is on the earth.

- Who is he that can intercede with Him except by His permission! He knows what happens to them in this world, and will happen to them in the Hereafter and they will never compass anything of His Knowledge except that which He wills. His Seat extends over the heavens and the earth, and He feels no fatigue in guarding and preserving them. And He is the Most High, the Most Great. There is no compulsion in religion. Verily, the Right Path has become distinct from the wrong path. Whoever disbelieves in al-Taghut and believes in Allah, then he has grasped the most trustworthy handhold that will never break. And Allah is AllHearer, All-Knower (2:255-256).

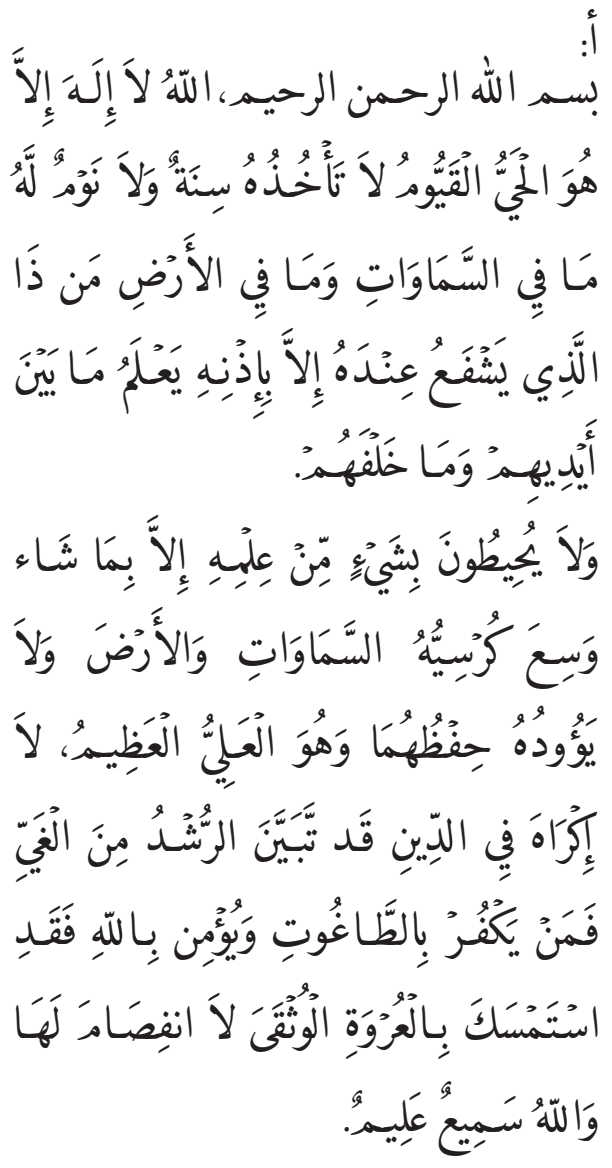

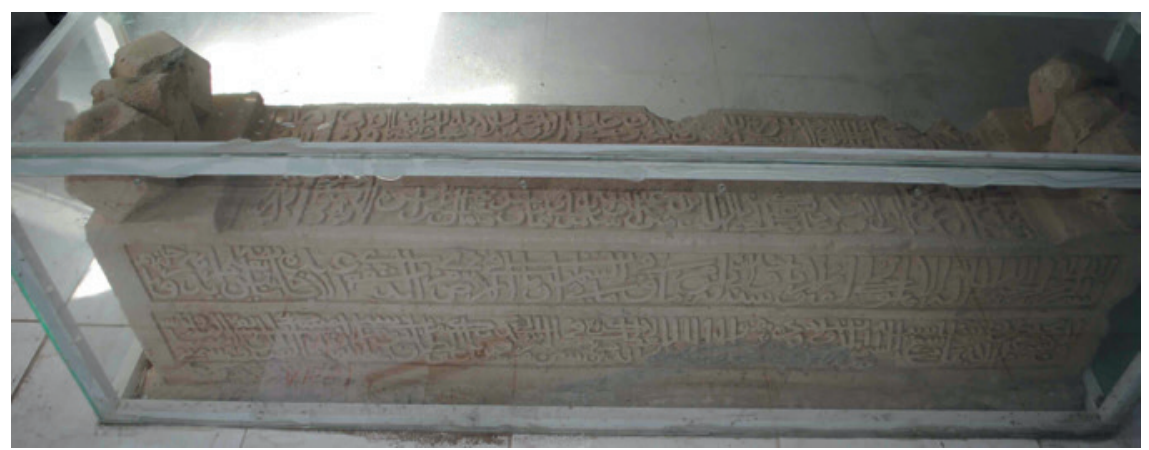

FIGURE 2.179 Surface A, ABS1 
B:

$$
\text { النقش مغطى بزجـاج حساجب }
$$

- Cannot be read because it is covered with glass.

C:
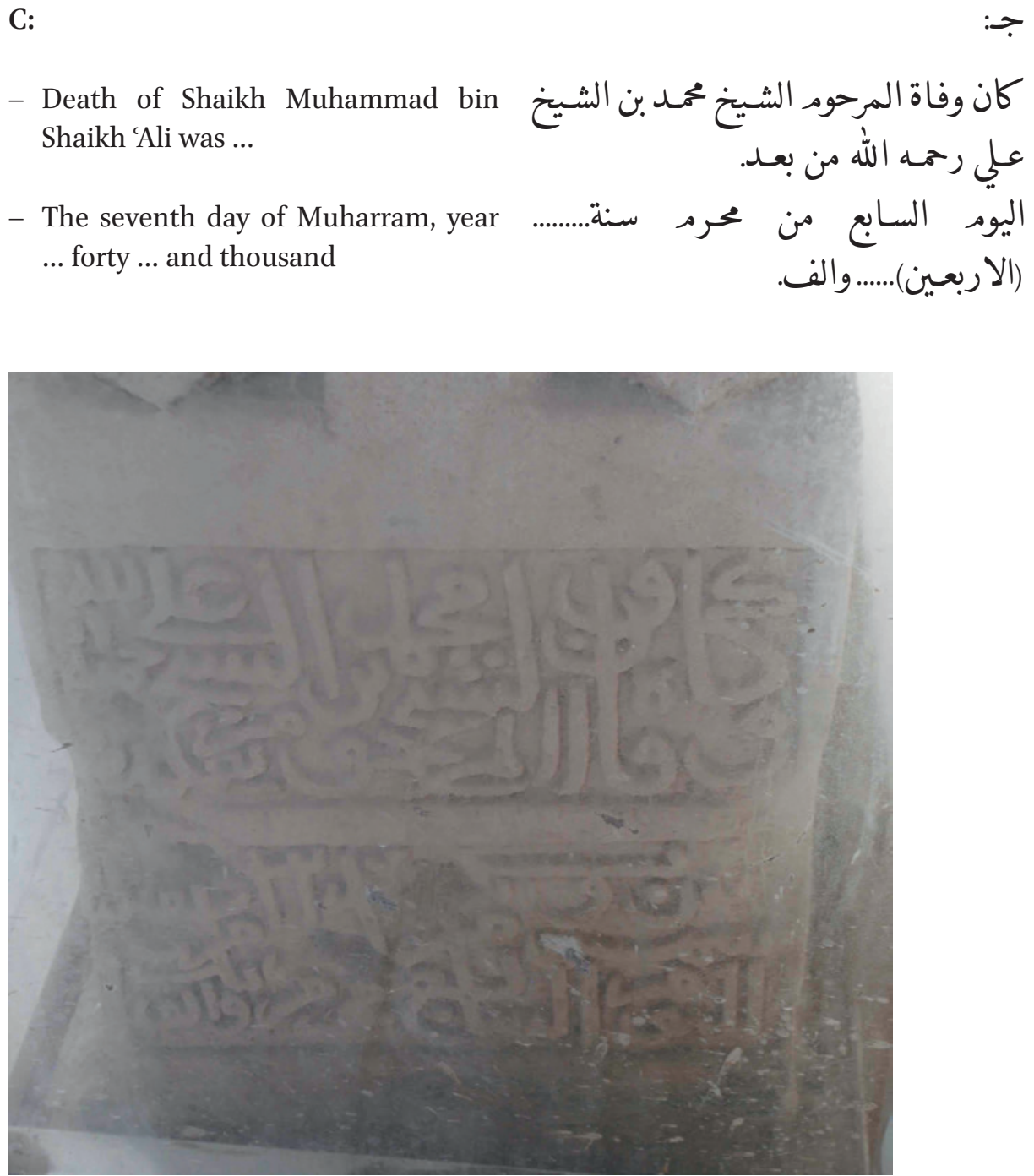

FIGURE 2.180 Surface C, ABS1

D:

- Reading one part every day on the grave of Shaikh Muhammad, and alFatiha, ...

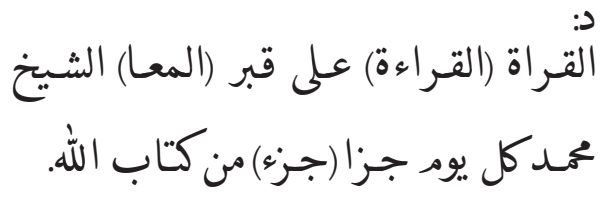

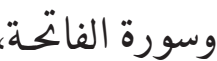




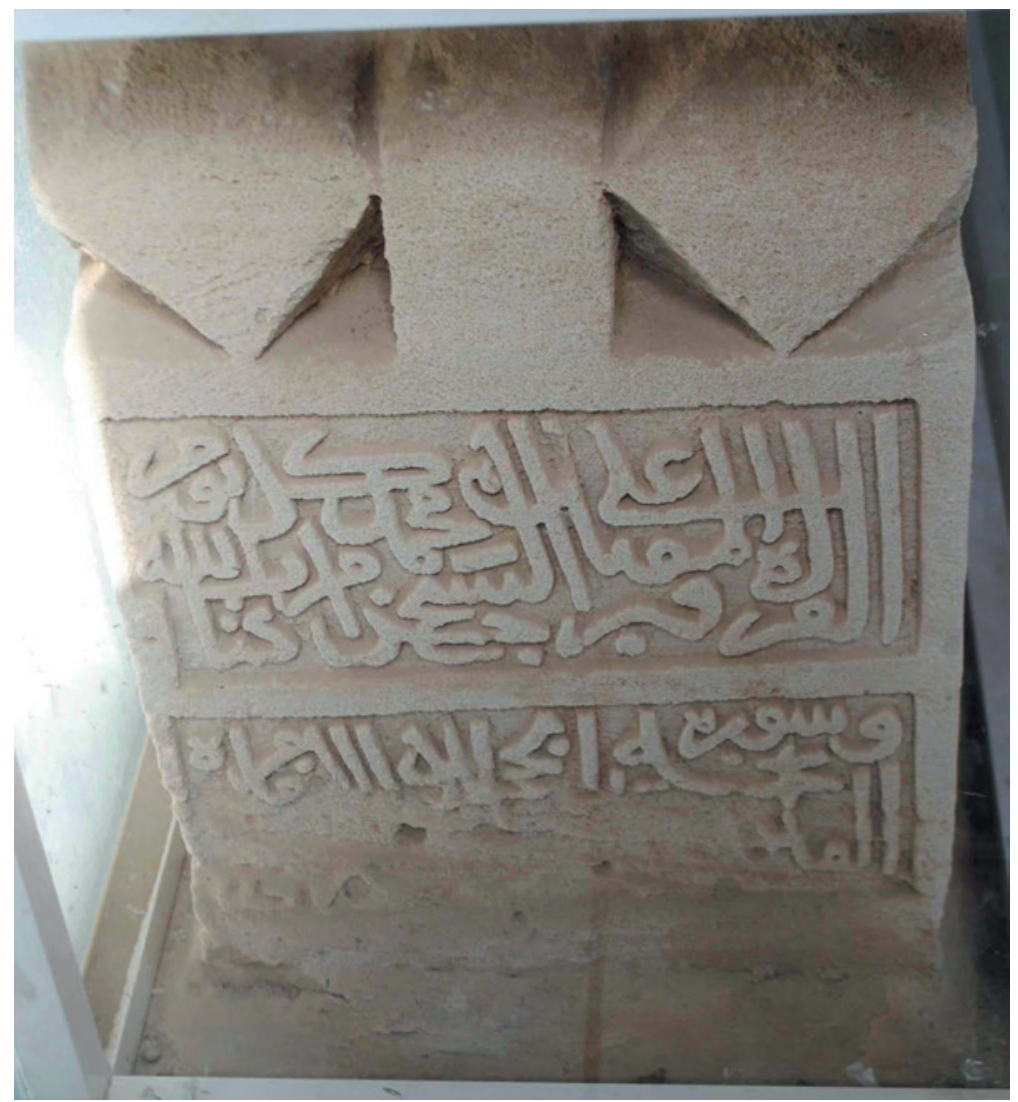

FIGURE 2.181 Surface D, ABS1

E:

- The one, who engraved it, is entreating ... mercy.

- His worshipper and his slave, al-Sayyid Naser.

- The one, who wrote it, is entreating the mercy of his glorious god.

- His worshipper and his needy, 'Abd al-Nabi bin Ahmad

- That home of the Hereafter, We shall assign to those who rebel not against the truth with pride and oppression in the land nor do mischief by committing crimes. And the good end is for the pious (28:83).

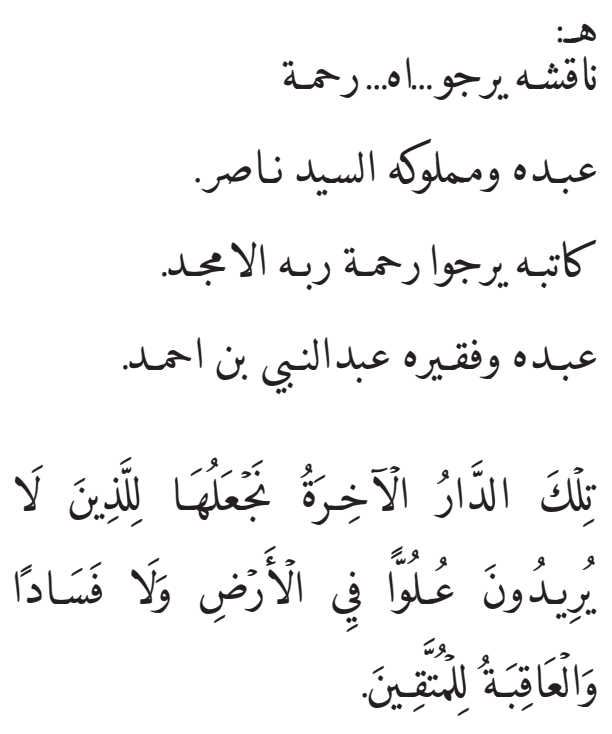


- Allah and also His angels send their Blessings and Mercy on the Prophet. O you who believe! Ask Allah to bless him, and you should greet him with the Islamic way of greeting (33:56). So whosoever does good equal to

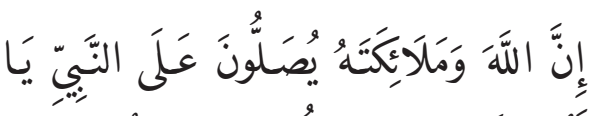

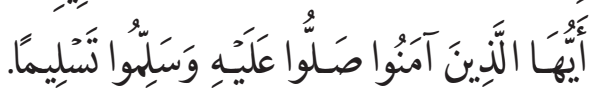

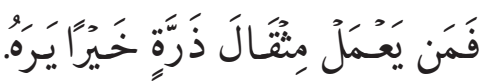
the weight of a small ant shall see it (99:7).

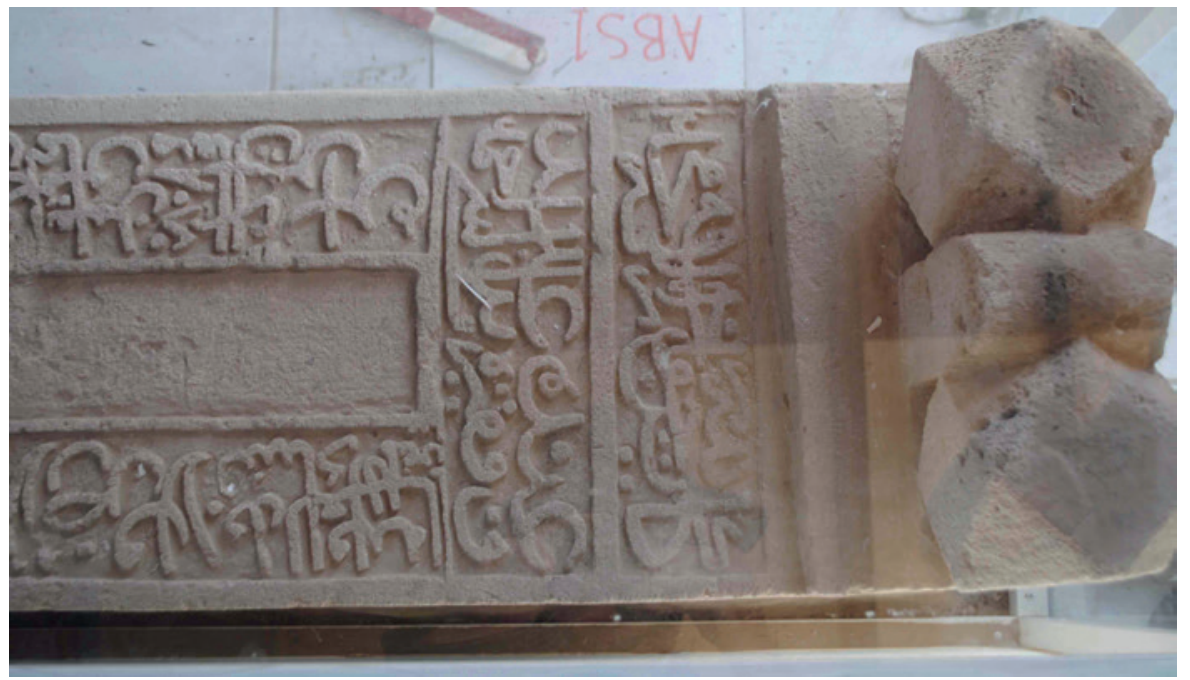

FIGURE 2.182 Surface E, part 1, ABS1

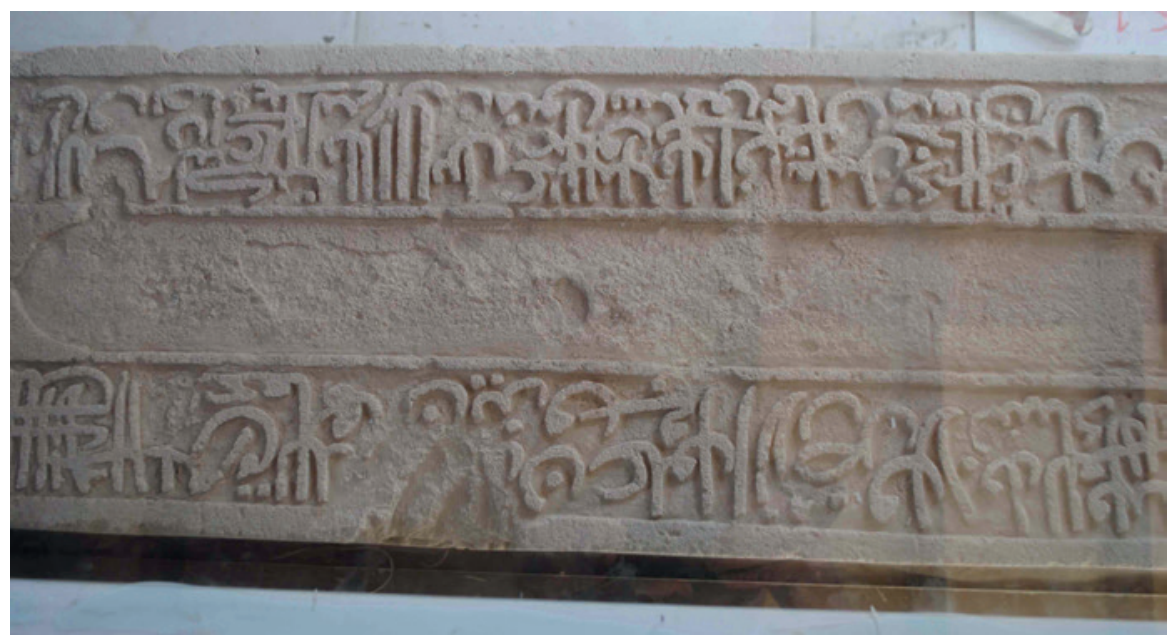

FIGURE 2.183 Surface E, part 2, ABS1 


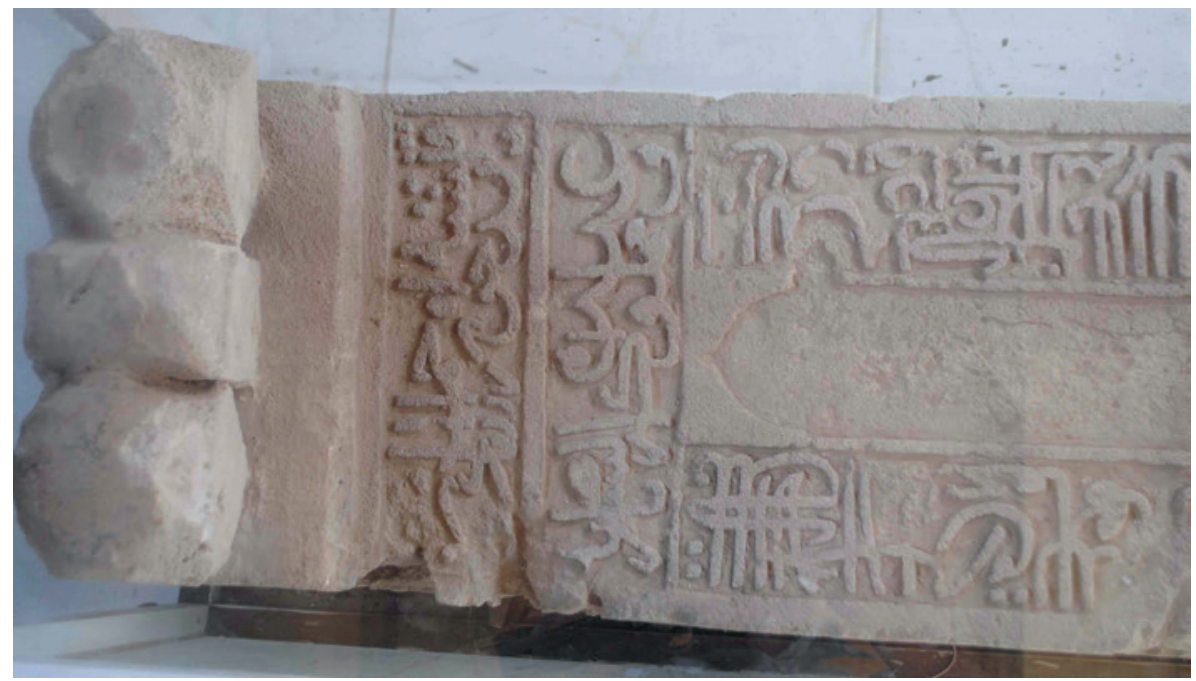

FIGURE 2.184 Surface E, part 3, ABS1

$5 \quad$ Askar (AS K)

Location: Mosque containing a shrine, and associated village cemetery, all no longer in use.

Reference Number: ASK1

Co-ordinates: $26.05656^{\circ} \mathrm{N} 050.61818^{\circ} \mathrm{E}$

Dimensions: Two slabs measured as one unit $-153 \mathrm{~cm}(\mathrm{l}) \times 16 \mathrm{~cm}(\mathrm{w}) \times 49 \mathrm{~cm}(\mathrm{~h})$

Orientation: NNW-SSE

Description: Gravestone formed of two limestone slabs housed within a damaged shrine inside a vandalised mosque complex. The gravestone was set against a hollow cement superstructure ridged on top and filled with rubble. Partially legible inscriptions were found on one visible surface.

\section{Arabic Transcription and Translation:}

- ... The great Shaikh ...

- ... the Shaikhs ... Shams al-Din

- ... (one thousand and sixty-six) ...

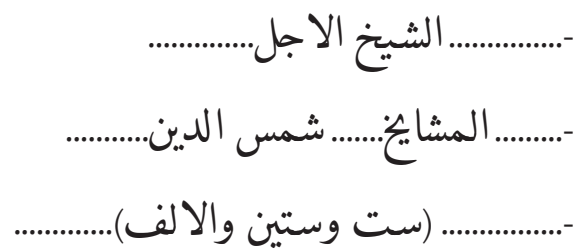




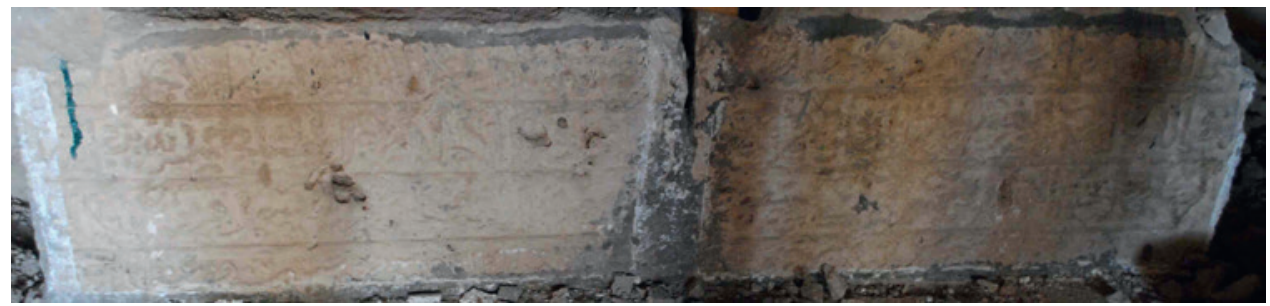

FIGURE 2.185 ASK1

\section{Reference Number: ASK2}

Co-ordinates: $26.05639^{\circ} \mathrm{N} 050.61821^{\circ} \mathrm{E}$

Dimensions: $160 \mathrm{~cm}(\mathrm{l}) \times 57 \mathrm{~cm}(\mathrm{w}) \times 26 \mathrm{~cm}$ maximum surviving height

\section{Orientation: NW-SE}

Description: Partly destroyed gypsum gravestone in cemetery south of mosque and shrine. Scrolling vegetal decoration on four surfaces and partially legible inscription on one surface. The gypsum panels had been constructed around a stone rubble core. Excavated to expose the sides of the gravestone.

\section{Arabic Transcription and Translation:}

- ... There is no God but Allah ...
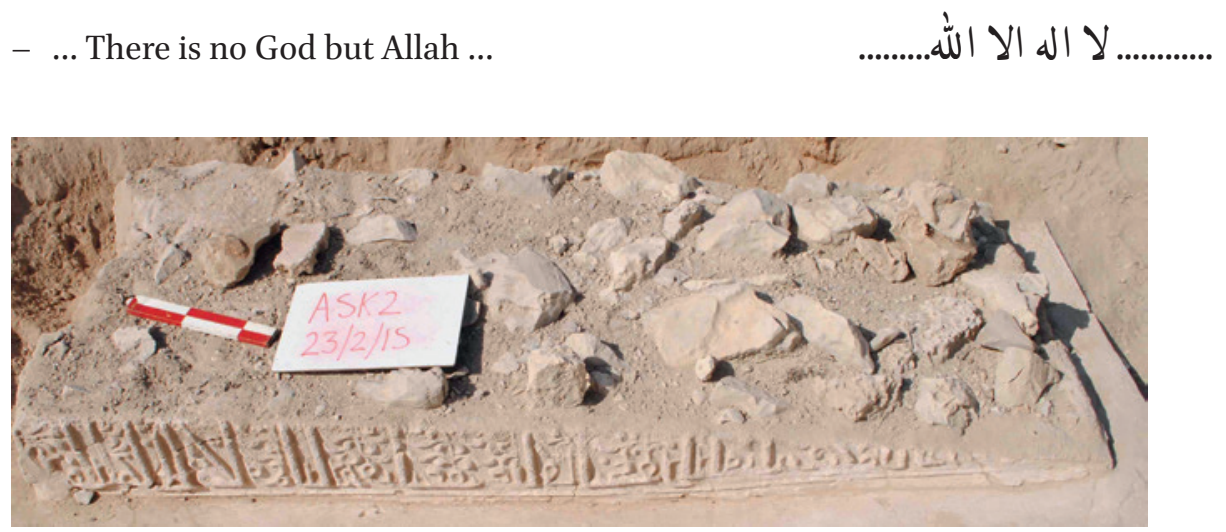

FIGURE 2.186 ASK2

6 Barbar (BAR)

Location: Private house. The gravestone was formerly in the village cemetery in Barbar but was removed for safe keeping by its current custodian who now stores it in his sitting room (majlis). 
Reference Number: BAR1

Co-ordinates: NA

Dimensions: $76 \mathrm{~cm}(\mathrm{l}) \times 29 \mathrm{~cm}(\mathrm{w}) \times 36 \mathrm{~cm}(\mathrm{~h})$

Orientation: NA

Description: Single limestone slab from a double slab gravestone. Generally good condition. Shallow carved rectangular panel on upper surface (E) which was probably part of a niche design. Raised decoration has been cut off one end.

\section{Arabic Transcription and Translation:}

A:

- And Allah is All-Hearer, All-Knower. Allah is the Protector of those who believe. He brings them out from darkness into light. Those ...

- Those are the dwellers of the Fire.

- And they will abide therein forever. Verily, those who say: Our ... Allah $\left(2: 255^{-256)}\right.$.
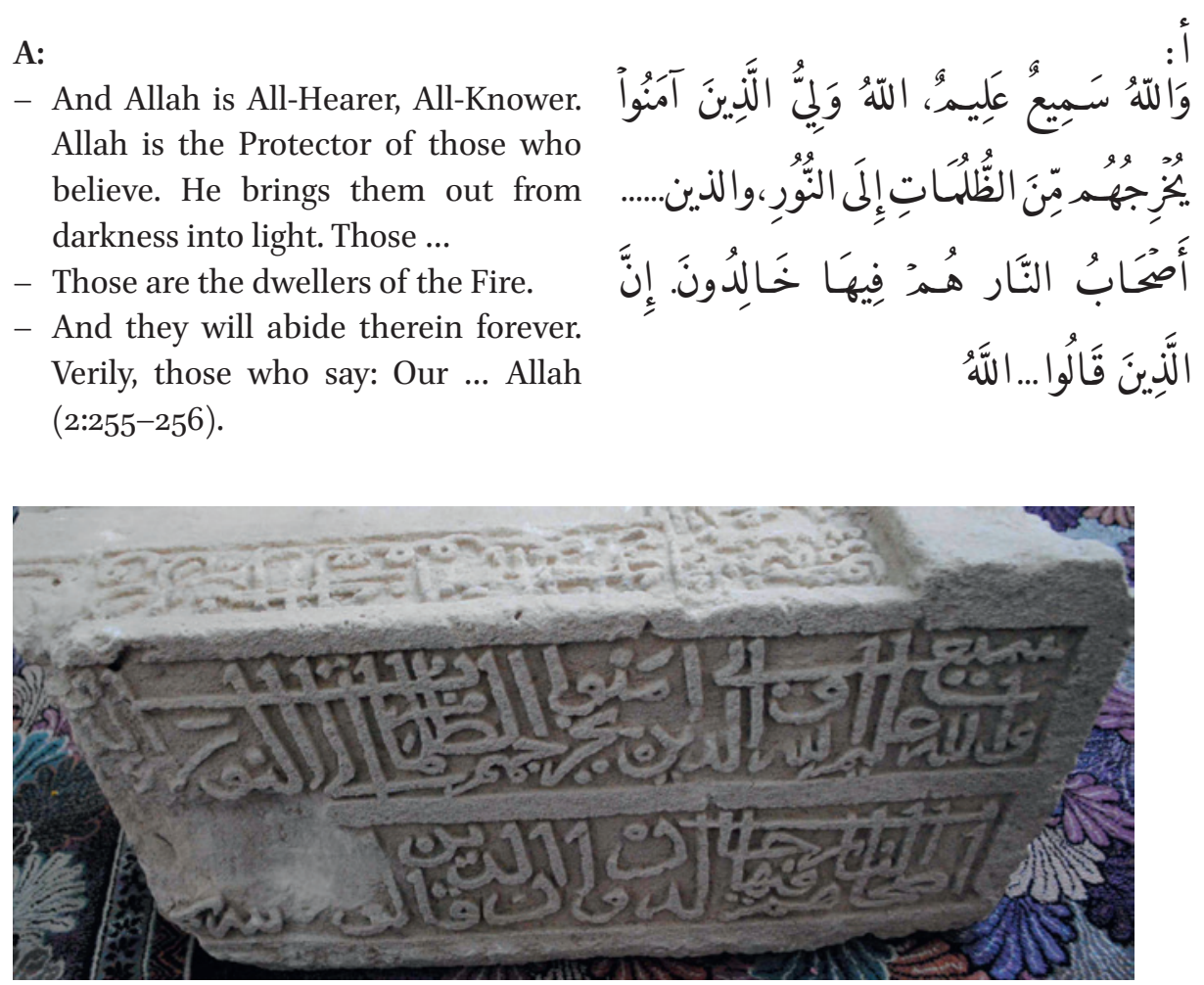

FIGURE 2.187 Surface A, BAR1 
B:

- On the earth. Who is he that can intercede with Him except by His permission! He knows what happens to them in this world, and will happen to them in the Hereafter. And they will never compass anything of His Knowledge except that which $\mathrm{He}$ wills ... extends over ...

- Verily, the Right Path has become distinct from the wrong path. Whoever disbelieves in Allah, then has grasped the most trustworthy handhold that will never break (2:255-256).
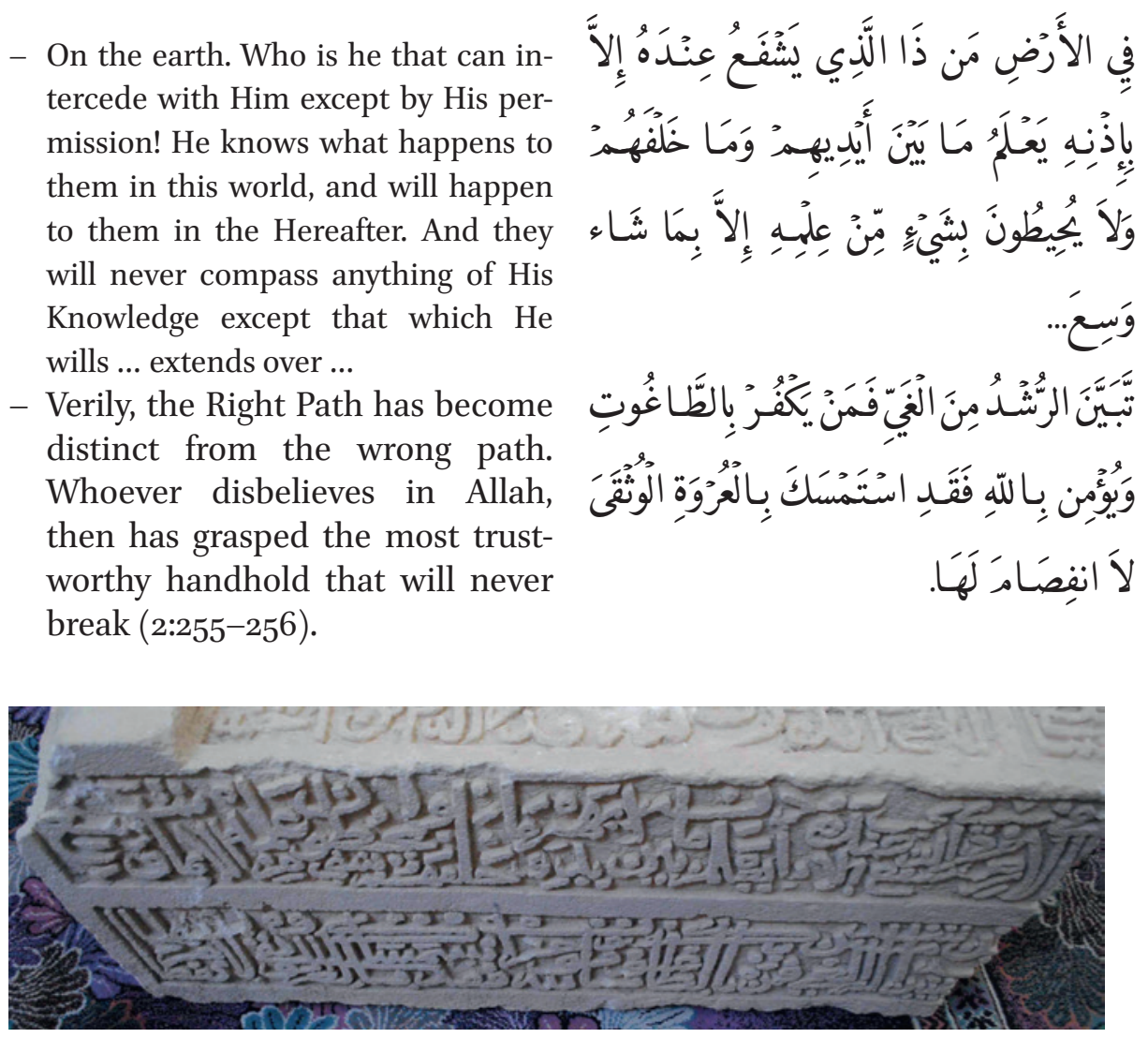

FIGURE 2.188 Surface B, BAR1

C:

- ... Alhaj, two parts every day.

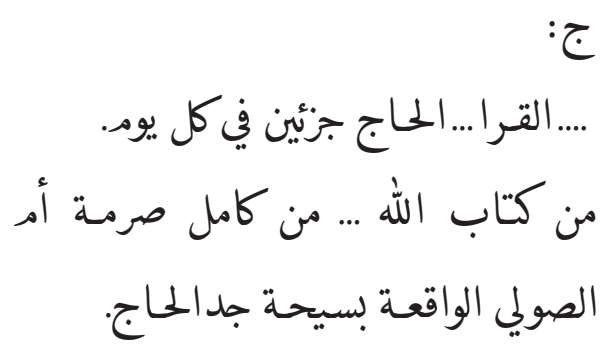

- From The Holy Quran ... all from Um Al-Suli Garden which is located at Jid Alhaj. 


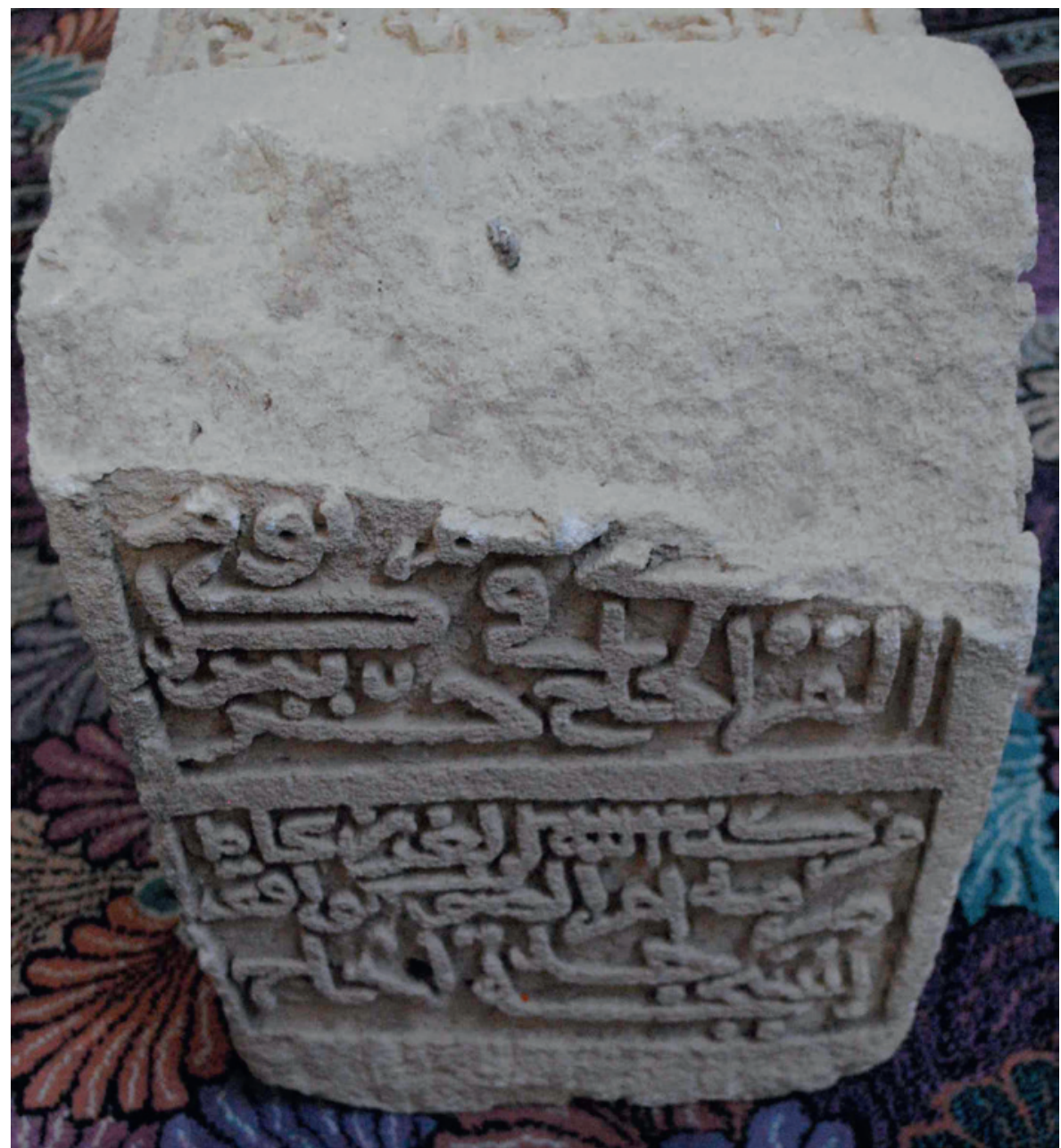

FIGURE 2.189 Surface C, BAR1

D:

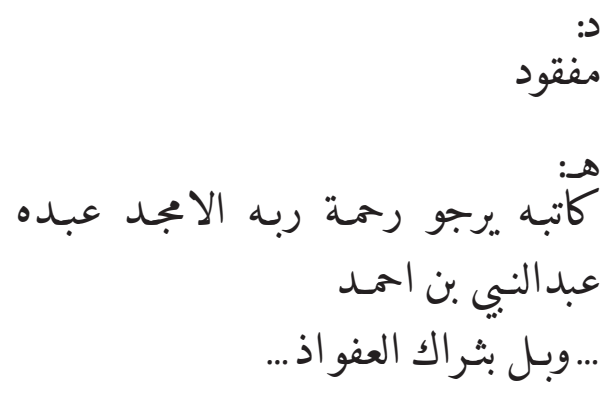

- (The remainder is an incomplete poem which cannot be translated)

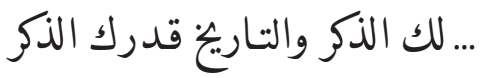




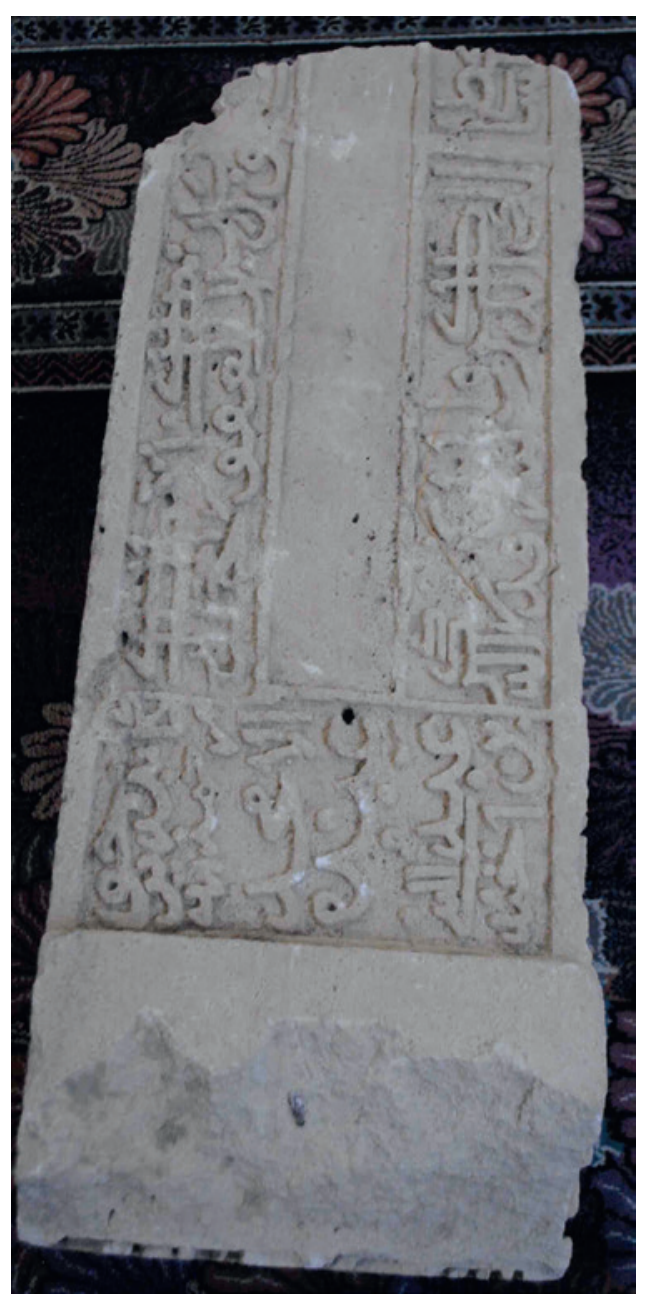

FIGURE 2.190

Surface E, BAR1

\section{$7 \quad$ Beit al-Quran (BEIT)}

Location: On display in the lobby of the private Beit al-Quran Museum in Manama. The original location of the gravestone is not known.

Reference Number: BEIT1

\section{Co-ordinates: NA}

Dimensions: $139 \mathrm{~cm}(\mathrm{l}) \times 28 \mathrm{~cm}(\mathrm{w}) \times 45 \mathrm{~cm}(\mathrm{~h})$

Orientation: NA 
Description: Single limestone slab gravestone in good condition. Shallow carved pointed niche design on upper surface (E). Three element raised decoration formed of two facetted cubes and a central narrow rounded arch all set on a rectangular plinth at both ends. Inscriptions on five surfaces.

\section{Arabic Transcription and Translation:}

A:

- In the Name of Allah, the Most Gracious, the Most Merciful. Allah, none has the right to be worshipped but he, the Ever Living, the One Who sustains and protects all that exists. Neither slumber nor sleep overtakes Him. To Him belongs whatever is in the heavens and whatever is on the earth. Who is he that can intercede with Him except by His permission! He knows what happens to them in this world, and will happen to them in the Hereafter.

- And they will never compass anything of His Knowledge except that which He wills. His Seat extends over the heavens and the earth, and He feels no fatigue in guarding and preserving them. And He is the Most High, the Most Great. There is no compulsion in religion. Verily, the Right Path has become distinct from the wrong path. Whoever disbelieves in al-Taghut and believes in Allah, then he has grasped the most trustworthy handhold (2:255-256).
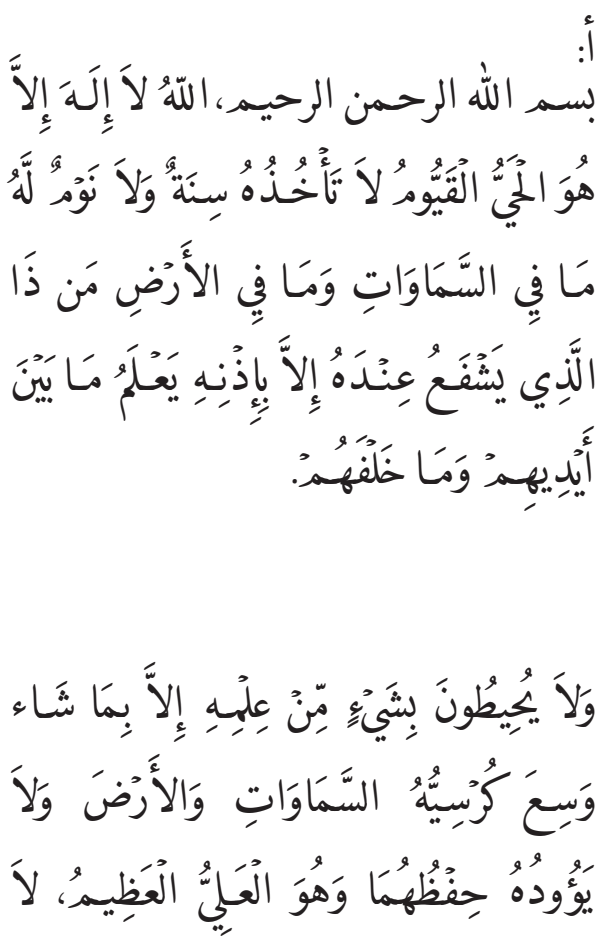

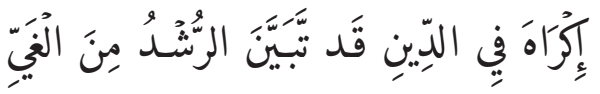

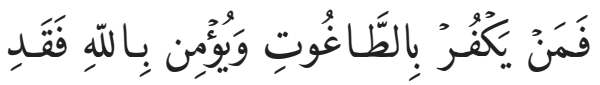

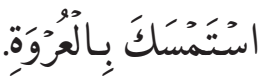

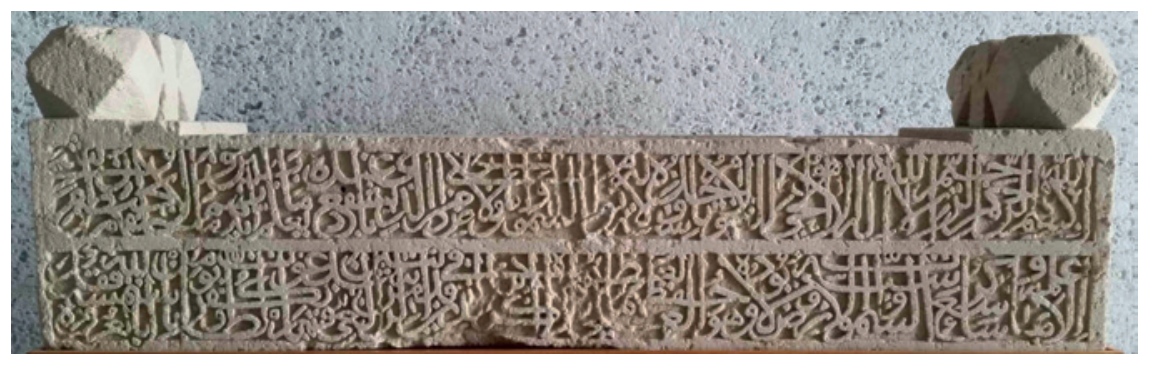

FIGURE 2.191 Surface A, BEIT1 
B:

- That will never break. And Allah is All-Hearer All-Knower (2:255-256). Their Lord gives them glad tidings of Mercy from Him, and that He is pleased with them, and of Gardens for them wherein are everlasting delights. They will dwell therein forever. Verily, with Allah is a great reward (9:21-22). Therein they will recline; therein they will call for fruits in abundance and drinks; And beside them will be chaste

- females (virgins) restraining their glances only for their husbands, and of equal ages. This it is what you are promised for the Day of Reckoning (38:51-53). The Angels will descend on them, saying: Fear not, nor grieve; but receive the glad tidings of Paradise which you have been promised. We have been your friends in the life of this world and in the Hereafter.

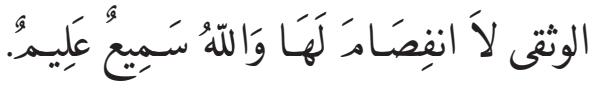

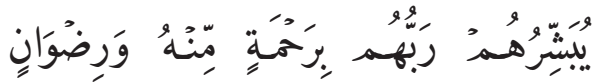

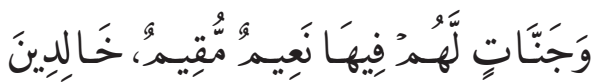

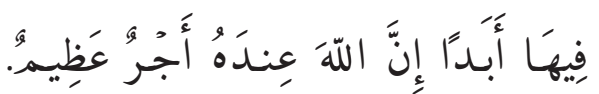

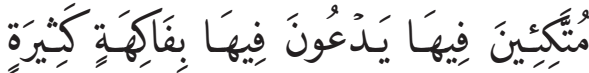

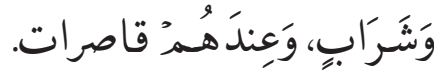

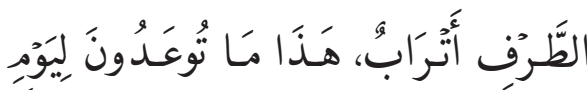

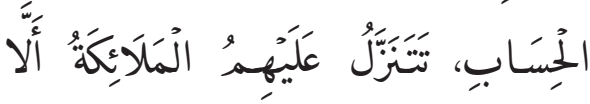

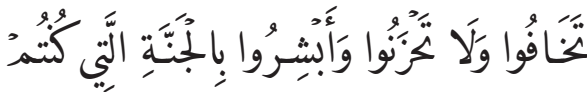

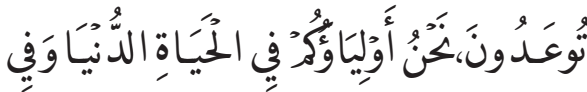

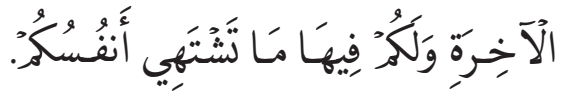
Therein you shall have all that your souls desire (41:30-31).

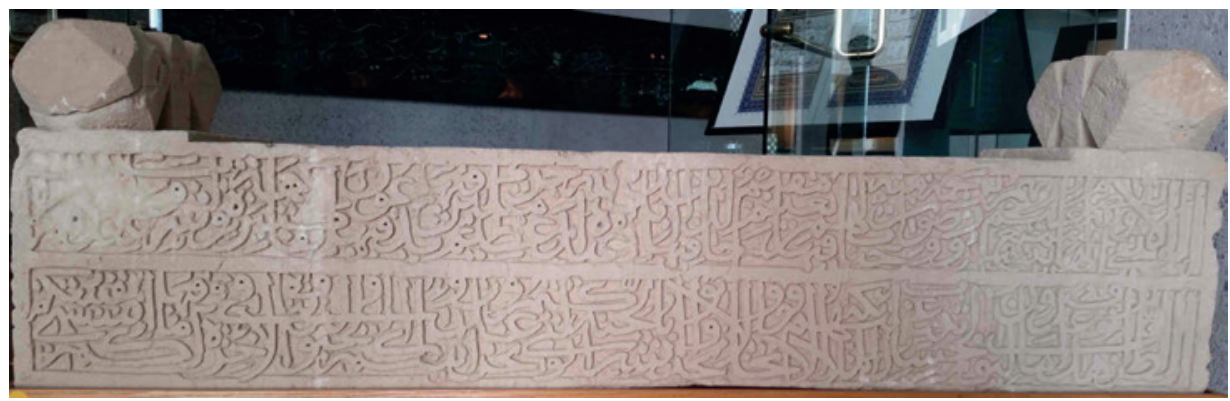

FIGURE 2.192 Surface B, BEIT1

C:

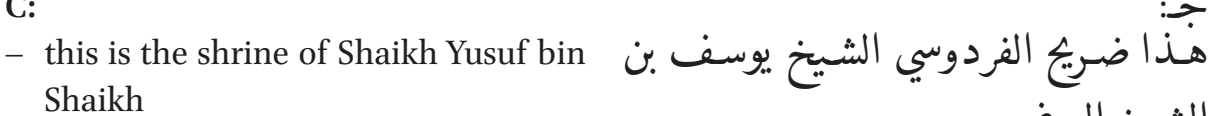




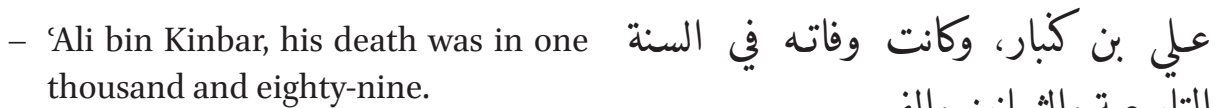

التاسعة والثمانين والف ولف ولن

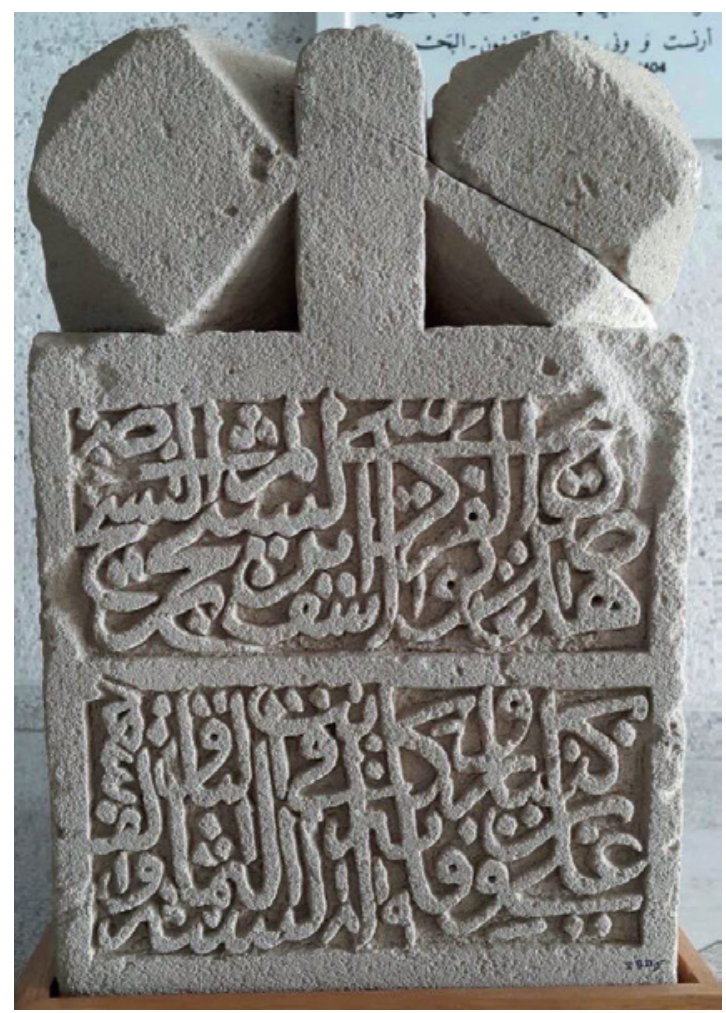

FIGURE 2.193 Surface C, BEIT1

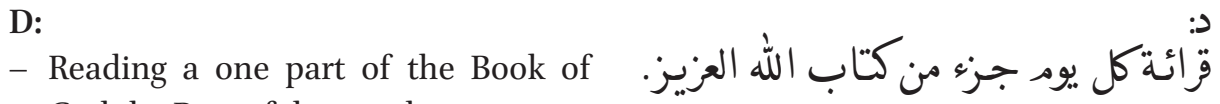
God the Powerful every day.

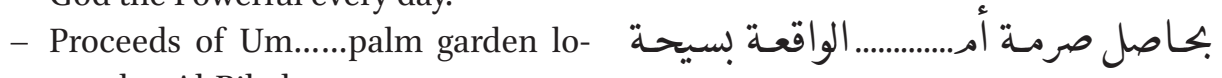
cated at Al-Bilad. 


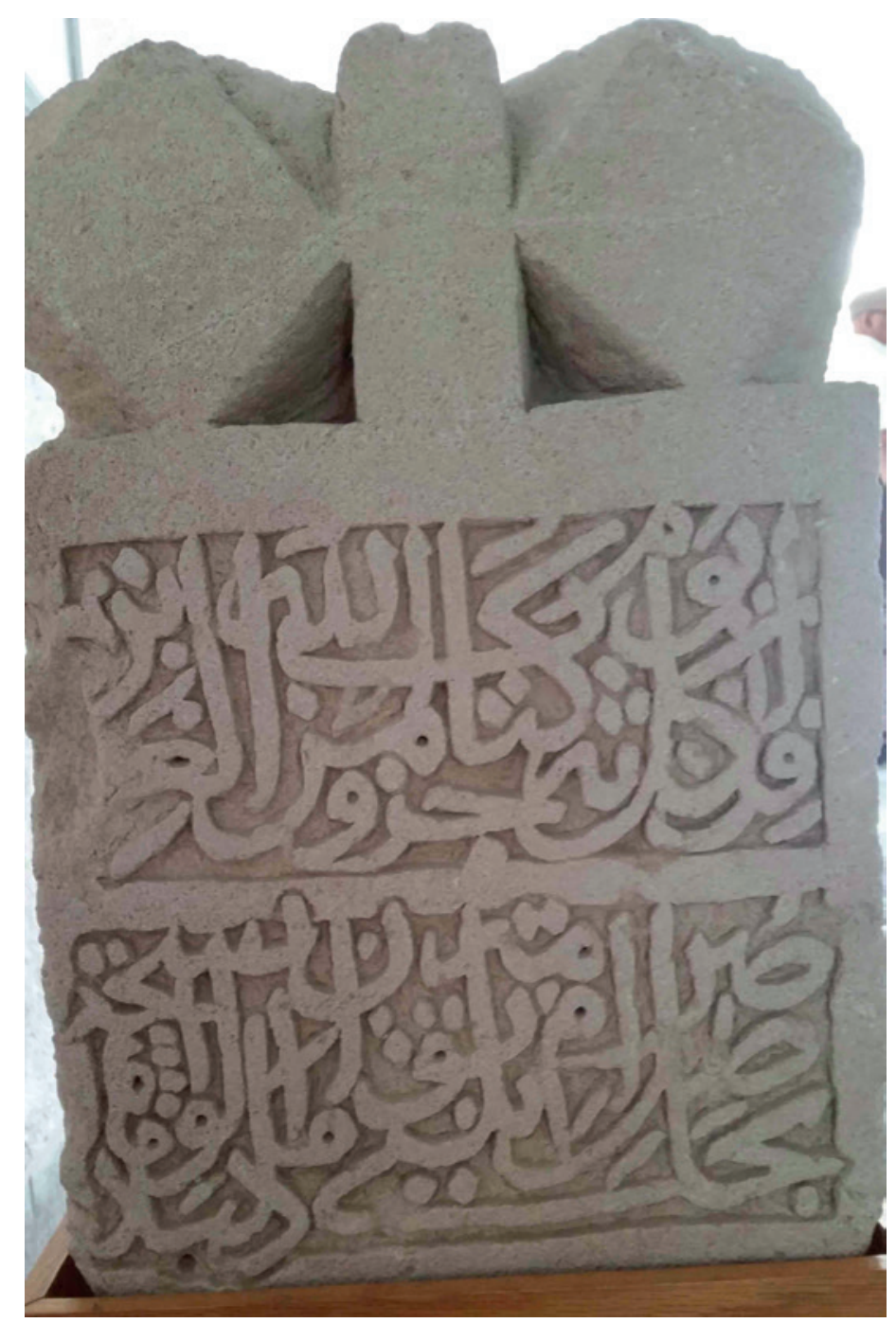

FIGURE 2.194 Surface D, BEIT1

E:

- Engraved by al-Sayyid 'Alawi, son of the good and the pious al-Sayyid Salih.

- Oh grave, you embedded a full moon with a high rank, and famous person.

- You should thank Allah because He gave you a unique thing that He did not give to others

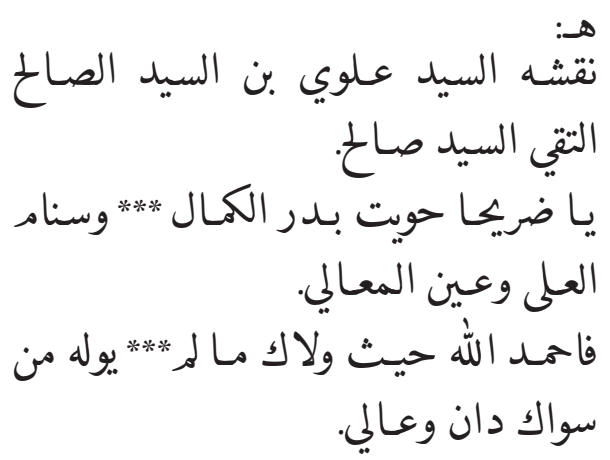


- Written by the humble 'Abd Allah bin 'Ali al-Biladi al-Bahrani.
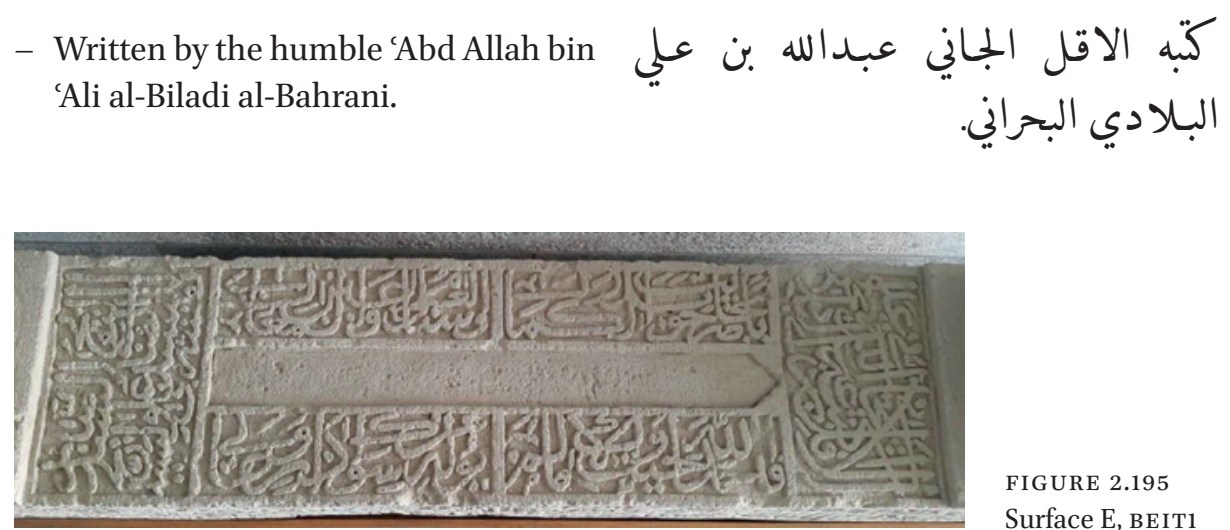

FIGURE 2.195

Surface E, BEIT1

8

Bilad al-Qadim (BAQ)

Location: The road outside the Nasrudin Mosque. The cemetery, if one originally existed, has disappeared under modern development.

\section{Reference Number: BAQ1}

Co-ordinates: $26.20597^{\circ} \mathrm{N} 050.54979^{\circ} \mathrm{E}$

Dimensions: $124 \mathrm{~cm}(\mathrm{l}) \times 26 \mathrm{~cm}(\mathrm{w}) \times 48 \mathrm{~cm}(\mathrm{~h})$

\section{Orientation: NA}

Description: Single limestone slab gravestone with some erosion, modern cement on top, and staining on one side surface (Figure 2.196). The gravestone appears unfinished. It has been cut to size and has no carving or inscriptions other than three element raised decoration formed of two facetted cubes and a central narrow rounded or pointed arch at both ends. Recorded next to the original foundations of the Nasrudin mosque which has been recently rebuilt. The gravestone has been moved from its primary position as the original plaster base setting for the gravestone is next to its current location. 


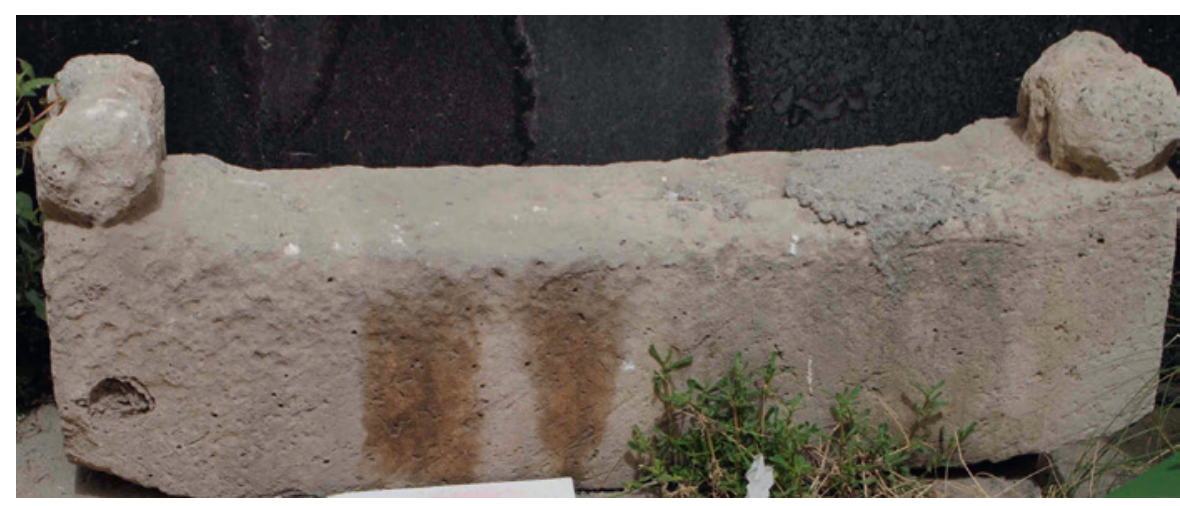

FIGURE 2.196 BAQ1

Arabic Transcription and Translation: No inscriptions

\section{$9 \quad$ Daih (DAI)}

Location: Daih village cemetery. The cemetery contains a mosque but it is not known if it was originally a shrine that developed into a mosque.

\section{Reference Number: DAI1}

Co-ordinates: $26.22513^{\circ} \mathrm{N} 050.53376^{\circ} \mathrm{E}$

Dimensions: $92 \mathrm{~cm}(\mathrm{l}) \times 25.5 \mathrm{~cm}(\mathrm{w}) \times 31.5 \mathrm{~cm}(\mathrm{~h})$

\section{Orientation: NNW-SSE}

Description: Single hollow limestone slab gravestone not in original position. Eroded. Inscriptions on three surfaces. Decorated on top surface (E) with a shallow carved rectangular panel which is not a niche with an engraved circle and two connected triangles above it. Red paint/pigment on the lettering at one end. Found buried under leaves and rubbish in a clump of trees. Now kept in a glass case made by the local community for its display in the cemetery. 


\section{Arabic Transcription and Translation:}

A:

- In the Name of Allah, the Most Gracious, the Most Merciful.
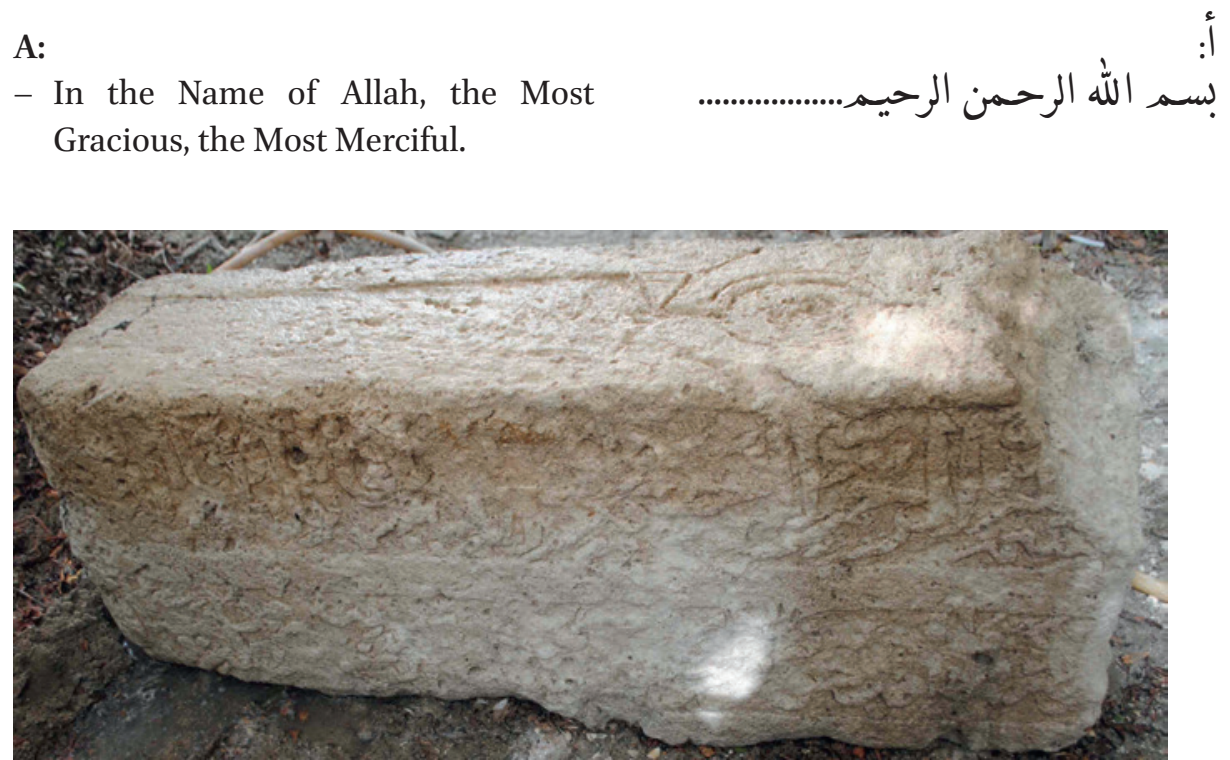

FIGURE 2.197 Surface A, DAI1

B:

- We are your protectors in this world and in the other world, your souls can find in it what they desire ... (41:31)
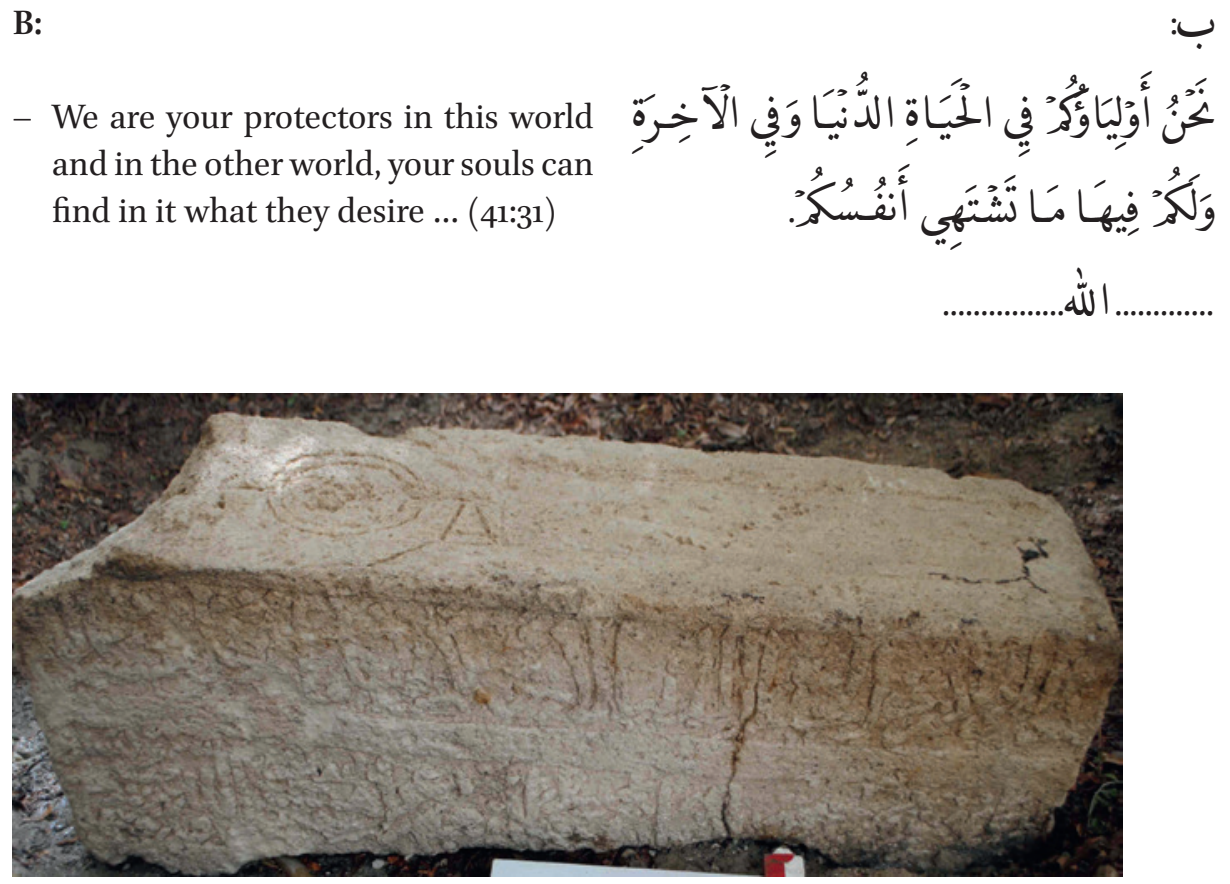

FIGURE 2.198 Surface B, DAI1 
C:

- ... and $650 \ldots$ God ...
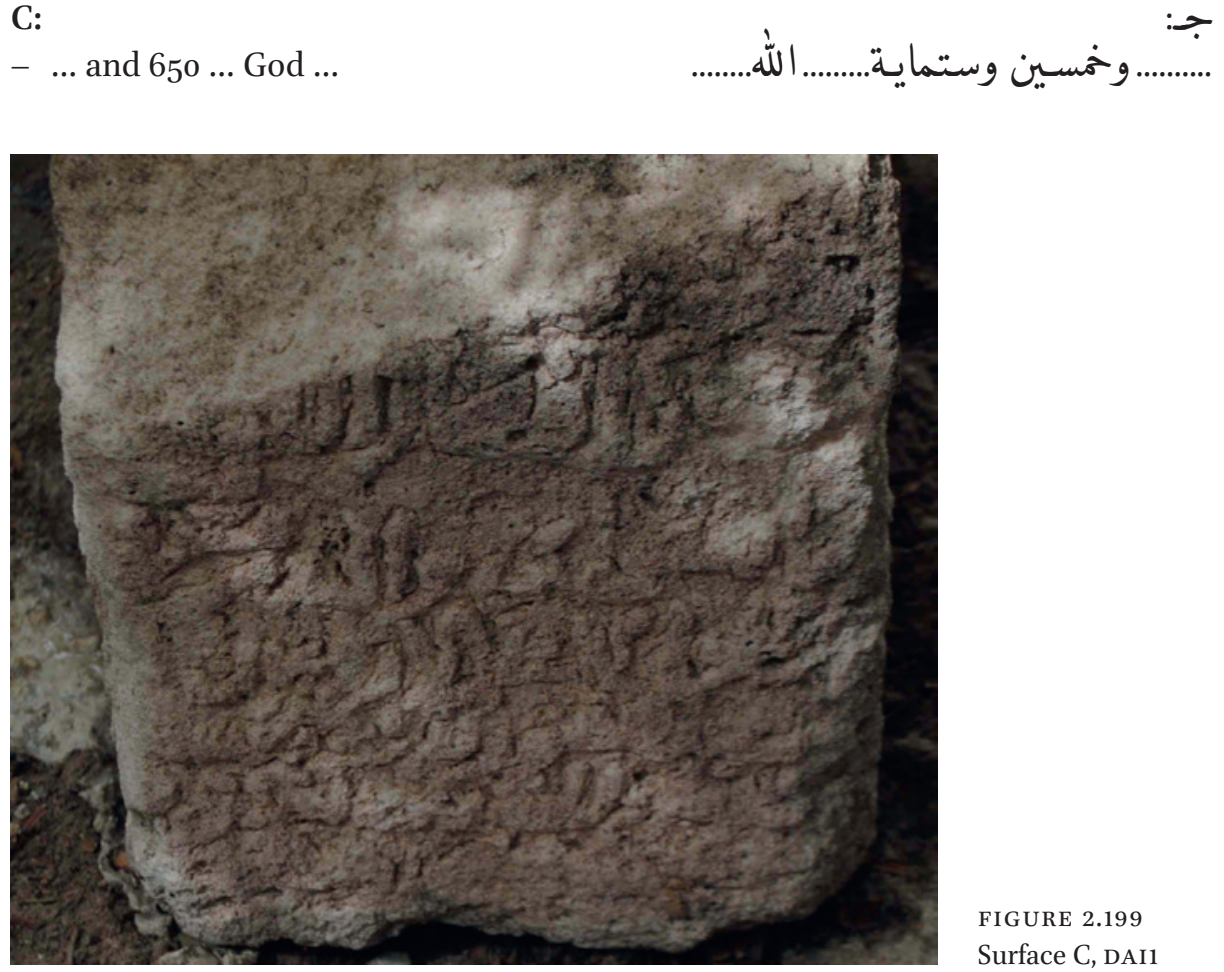

FIGURE 2.199

Surface C, DAI1

D:

- No carving or inscriptions.
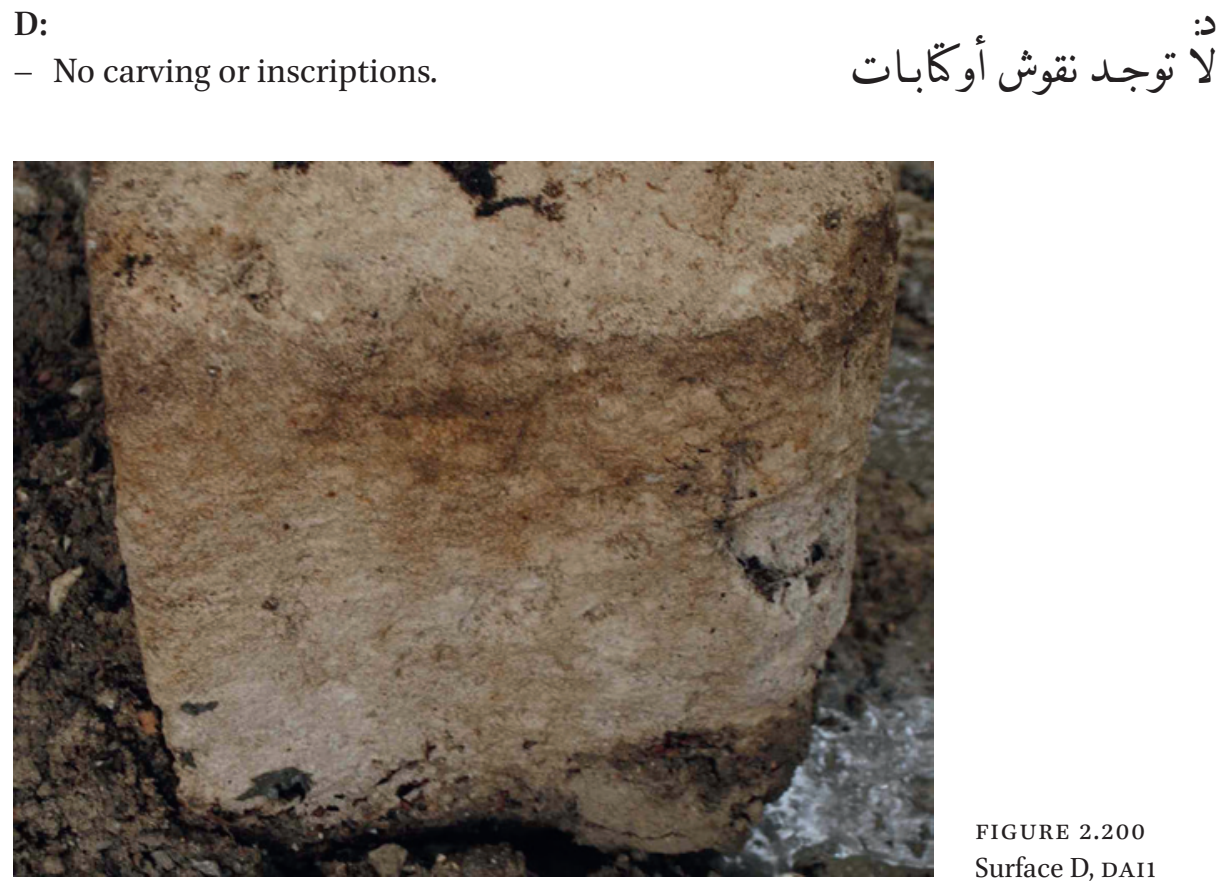

FIGURE 2.200

Surface D, DAI1 
E:

- No carving or inscriptions.
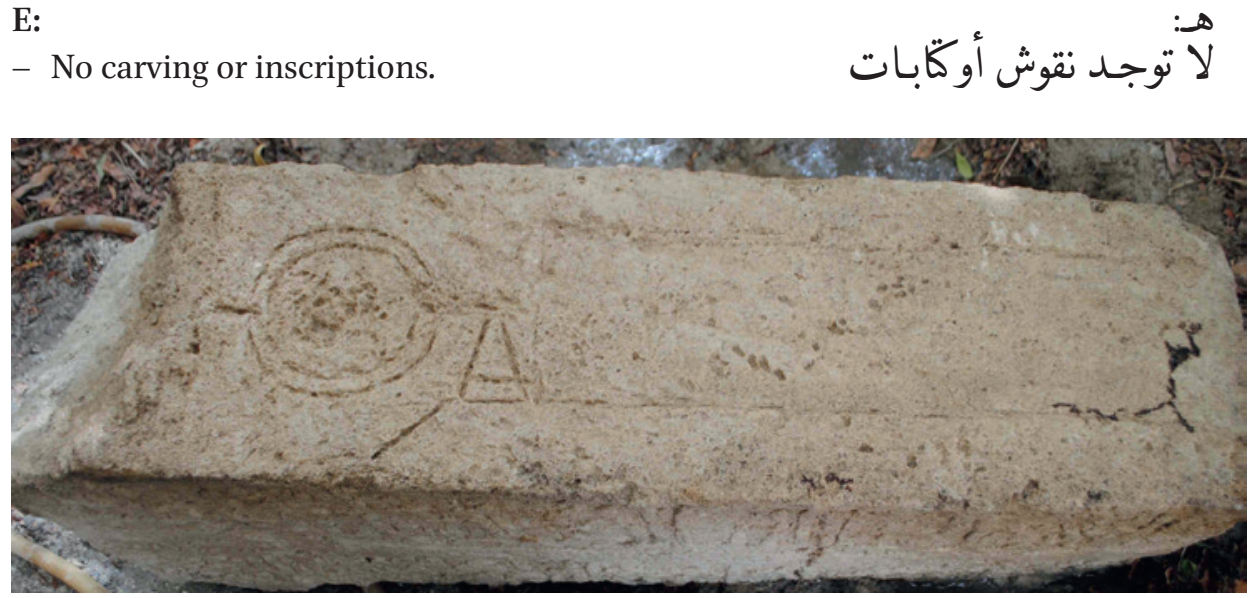

FIGURE 2.201 Surface E, DAI1

10 Hoora (HOO)

Location: Large urban cemetery for the Shi'a population of Manama

\section{Reference Number: HOO1}

Co-ordinates: $26.23116^{\circ} \mathrm{N} 050.58330^{\circ} \mathrm{E}$

Dimensions: $134 \mathrm{~cm}(\mathrm{l}) \times 28 \mathrm{~cm}(\mathrm{w}) \times 47 \mathrm{~cm}(\mathrm{~h})$

\section{Orientation: NNW-SSE}

Description: Single limestone slab gravestone (Figure 2.202). Some erosion. Cut to size and left unfinished possibly because the stone surface is pitted. Roughed out rectangular blocks for unfinished raised decoration at both ends. No inscriptions. Partially excavated to expose the whole gravestone. 


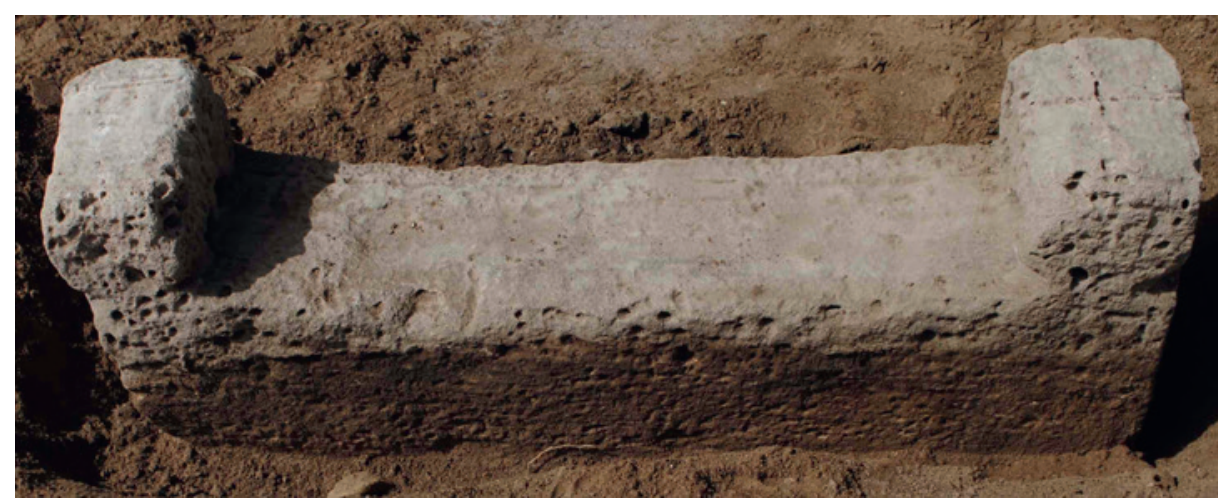

FIGURE $2.202 \quad$ HOO1

Arabic Transcription and Translation: No inscriptions

\section{Reference Number: HOO2}

Co-ordinates: $26.23128^{\circ} \mathrm{N} 050.58313^{\circ} \mathrm{E}$

Dimensions: $84 \mathrm{~cm}(\mathrm{l}) \times 44.5 \mathrm{~cm}(\mathrm{w}) \times 10 \mathrm{~cm}(\mathrm{~h})$

\section{Orientation: NNW-SSE}

Description: Unusually shaped flat single limestone slab gravestone with rounded sides and shoulders leading to a narrower upper section culminating in two carved points on top. Eroded, and with partial inscription in Farsi on one surface. Possibly gravestone is of Iranian origin. Fixed flat onto the ground surface with plaster.

\section{Arabic Transcription and Translation:}

- In 1210.

$$
\text { في سنة 1210. }
$$

- He is the Ever Living.

- And ... The Most Merciful ... The ...

- The eternal houses. 


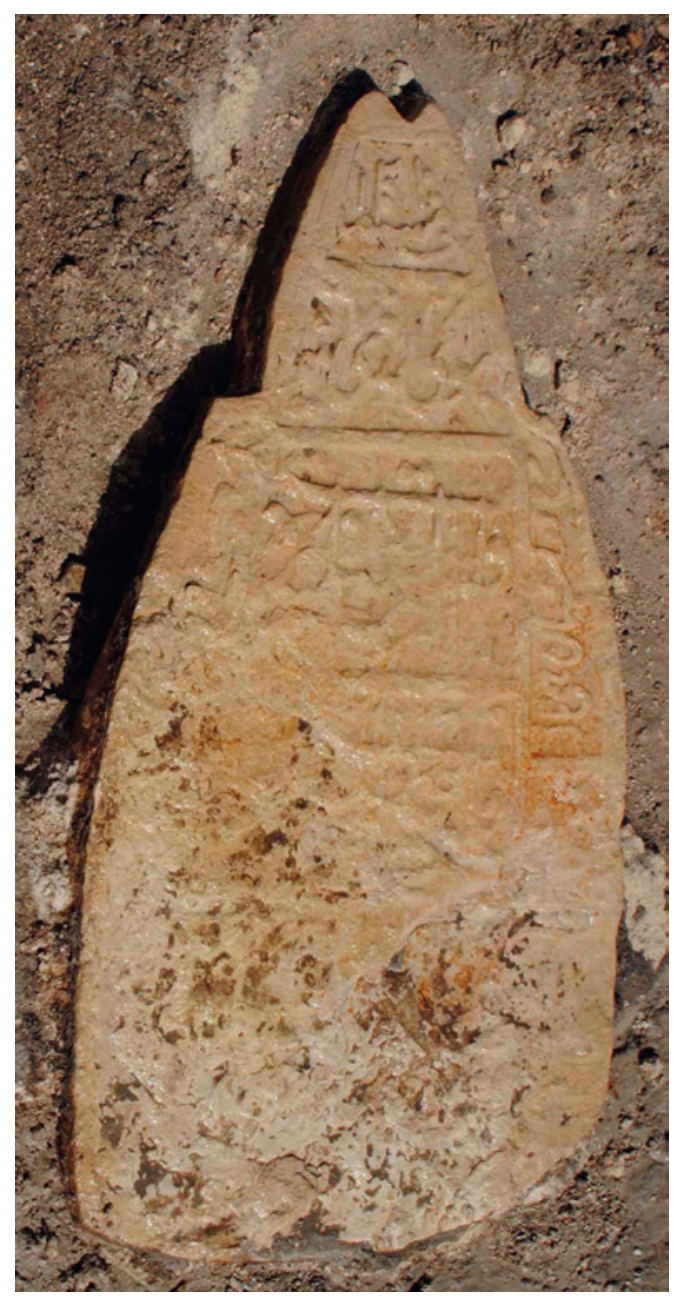

FIGURE 2.203

$\mathrm{HOO} 2$

Reference Number: НоO3

Co-ordinates: $26.23106^{\circ} \mathrm{N} 05^{0.5} 8335^{\circ} \mathrm{E}$

Dimensions: $130 \mathrm{~cm}(\mathrm{l}) \times 24 \mathrm{~cm}(\mathrm{w}) \times 37 \mathrm{~cm}(\mathrm{~h})$

\section{Orientation: N-S}

Description: Narrow single limestone slab gravestone (Figure 2.204). Eroded and roughly cut into shape with rectangular block for unfinished raised decoration at one end. No inscriptions. It seems this gravestone is an early stage roughout that was used as a grave marker but never finished for an unknown reason. Excavated to expose whole gravestone. 


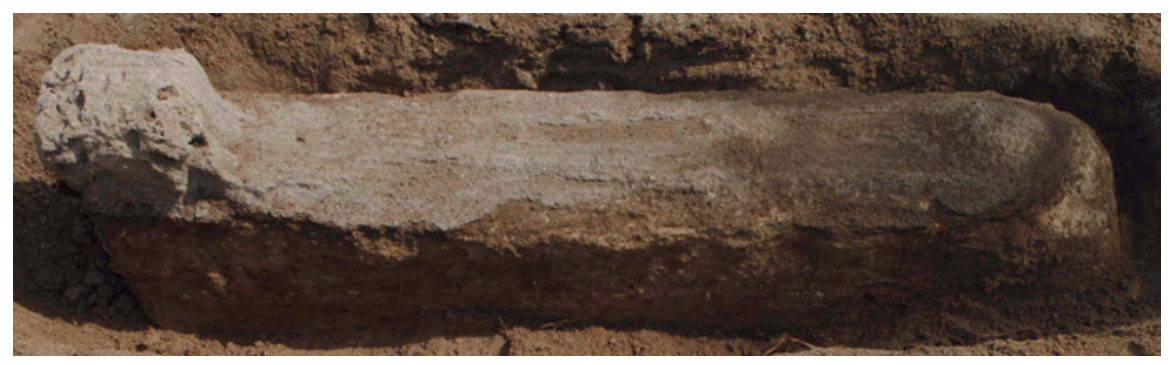

FIGURE $2.204 \quad \mathrm{HOO} 3$

Arabic Transcription and Translation: No inscriptions

\section{Reference Number: HOO4}

Co-ordinates: $26.23107^{\circ} \mathrm{N} 050.5833^{\circ} \mathrm{E}$

Dimensions: $138 \mathrm{~cm}(\mathrm{l}) \times 28.5 \mathrm{~cm}(\mathrm{w}) \times 47 \mathrm{~cm}(\mathrm{~h})$

\section{Orientation: NW-SE}

Description: Single limestone slab gravestone found lying on its side (Figure 2.205). Eroded and roughly cut to size and left unfinished. Roughed out raised decoration formed of what appear to be two facetted cubes and a central rounded arch. At one end a facetted cube can be seen clearly emerging from the stone where it has been left partially unfinished. No inscriptions. Two large cup marks, one carved on the upper surface (E) and another on one side surface, that appear to be intentional but for an unknown purpose.

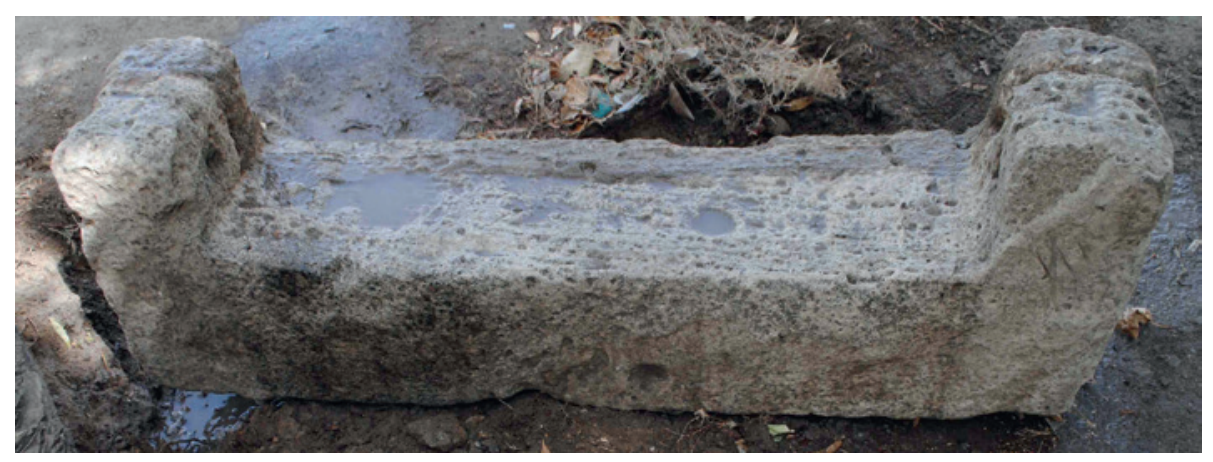

FIGURE 2.205 HOO4

Arabic Transcription and Translation: No inscriptions 
Reference Number: HOO5

Co-ordinates: $26.23124^{\circ} \mathrm{N} 050.58547^{\circ} \mathrm{E}$

Dimensions: $163 \mathrm{~cm}(\mathrm{l}) \times 28.5 \mathrm{~cm}(\mathrm{w}) \times 34 \mathrm{~cm}(\mathrm{~h})$

Orientation: NW-SE

Description: Single limestone slab gravestone. Well carved but with significant erosion in places. Partial shallow carved rectangular panel design on top surface (E), probably a niche. Raised decoration cut or broken off both ends. Inscriptions on five surfaces. Found tilted to the west. Excavated to expose whole gravestone.

\section{Arabic Transcription and Translation:}

A:

- Gardens of Eden, whose doors will be opened for them. Therein they will recline, therein they will call for fruits in abundance and drinks. And beside them will be chaste females restraining their glances and of equal ages $\left(38: 5^{0}-5^{2}\right)$. Their Lord gives them glad tidings of mercy from Him, and of His pleasure, and of Gardens for them wherein are everlasting delights. They will abide therein forever. Verily, with Allah there is a great reward (9:21-22).

- The angels descend upon them, saying: Fear not nor grieve, but receive the glad tidings of the paradise which you have been promised. We have been your friends in the life of this world and are in the Hereafter. Therein you shall have all that your inner-selves desire, and therein you shall have all for which you ask. An entertainment from the Oft-Forgiving, Most Merciful

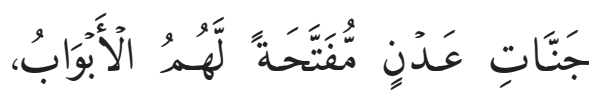

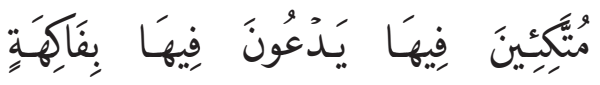

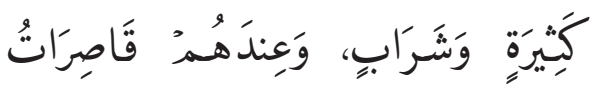

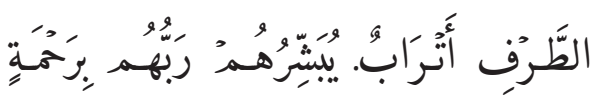

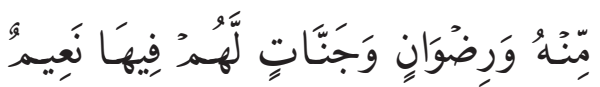

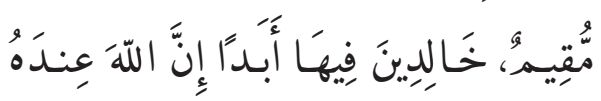

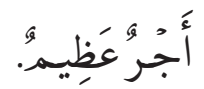

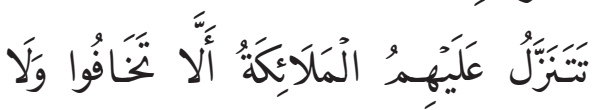

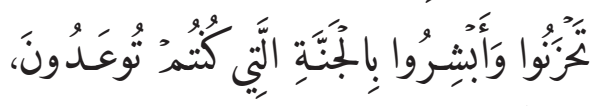

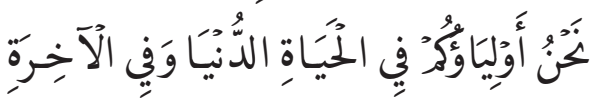
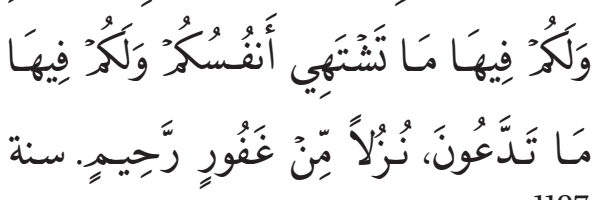
(41:30-32). Year 1107. 


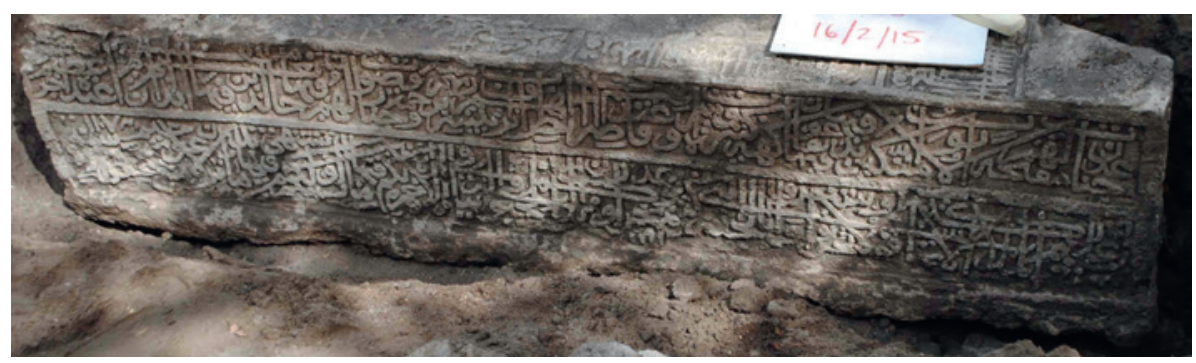

FIGURE 2.206 Surface A, HOO5

B:

- In the Name of Allah, the Most Gracious, the Most Merciful. Allah, none has the right to be worshipped but he, the Ever Living, the One Who sustains and protects all that exists. Neither slumber nor sleep overtakes Him. To Him belongs whatever is in the heavens and whatever is on the earth. Who is he that can intercede with Him except by His permission! He knows what happens to them in this world, and will happen to them in the Hereafter and they will never compass anything of His Knowledge

- Except that which He wills. His Seat extends over the heavens and the earth. And He feels no fatigue in guarding and preserving them. And He is the Most High, the Most Great. There is no compulsion in religion. Verily, the Right Path has become distinct from the wrong path. Whoever disbelieves in al-Taghut and believes in Allah, then he has grasped the most trustworthy handhold (2:255-256).

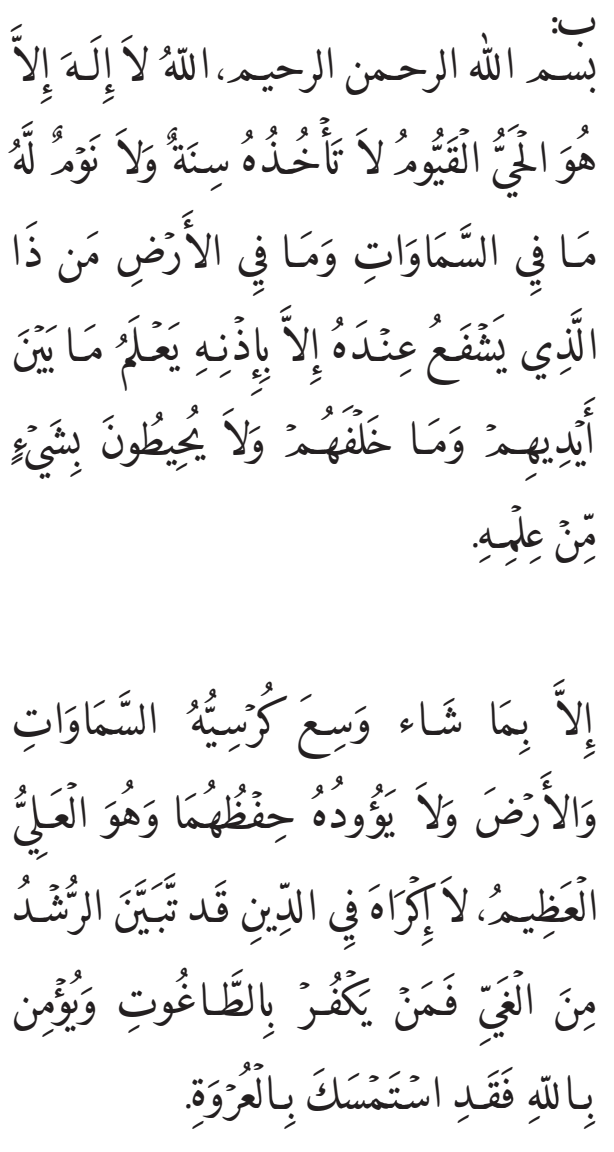

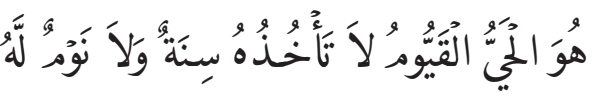

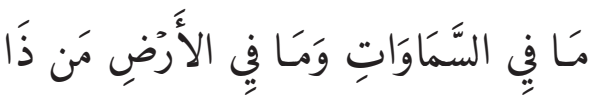

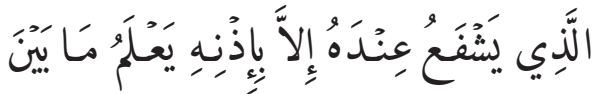

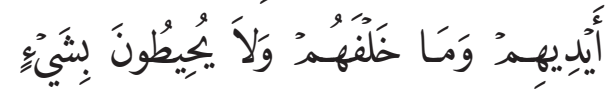
Aje

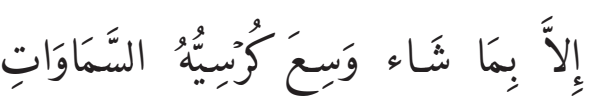

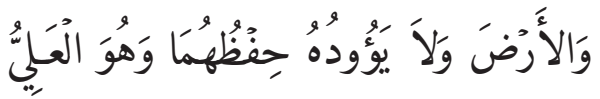

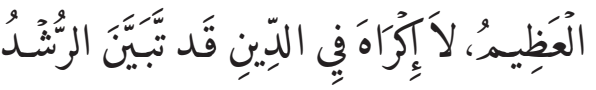




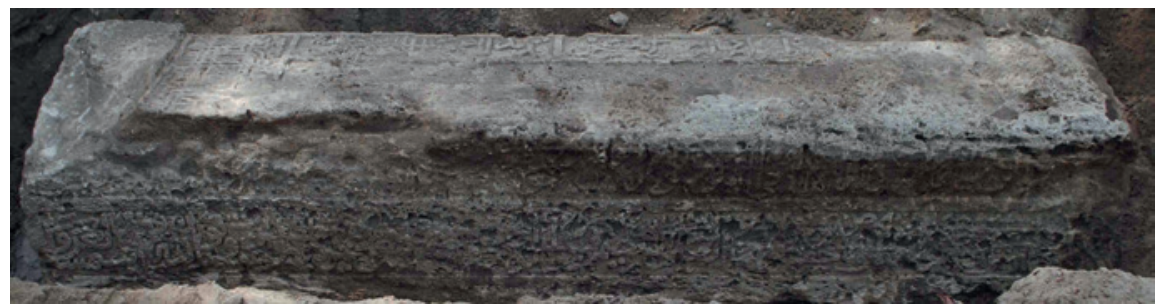

FIGURE 2.207 Surface B, HOO5

C:

كل عاشر ثمانون منًا من هذا this ...

- At Abu Mandah field ...

$$
\begin{aligned}
& \text { (ياخذ) عن (الحـم.... د). } \\
& \text { لسـيح ابو منــدة عـبر ثمره (تمره) (معصور) }
\end{aligned}
$$

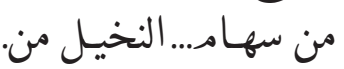

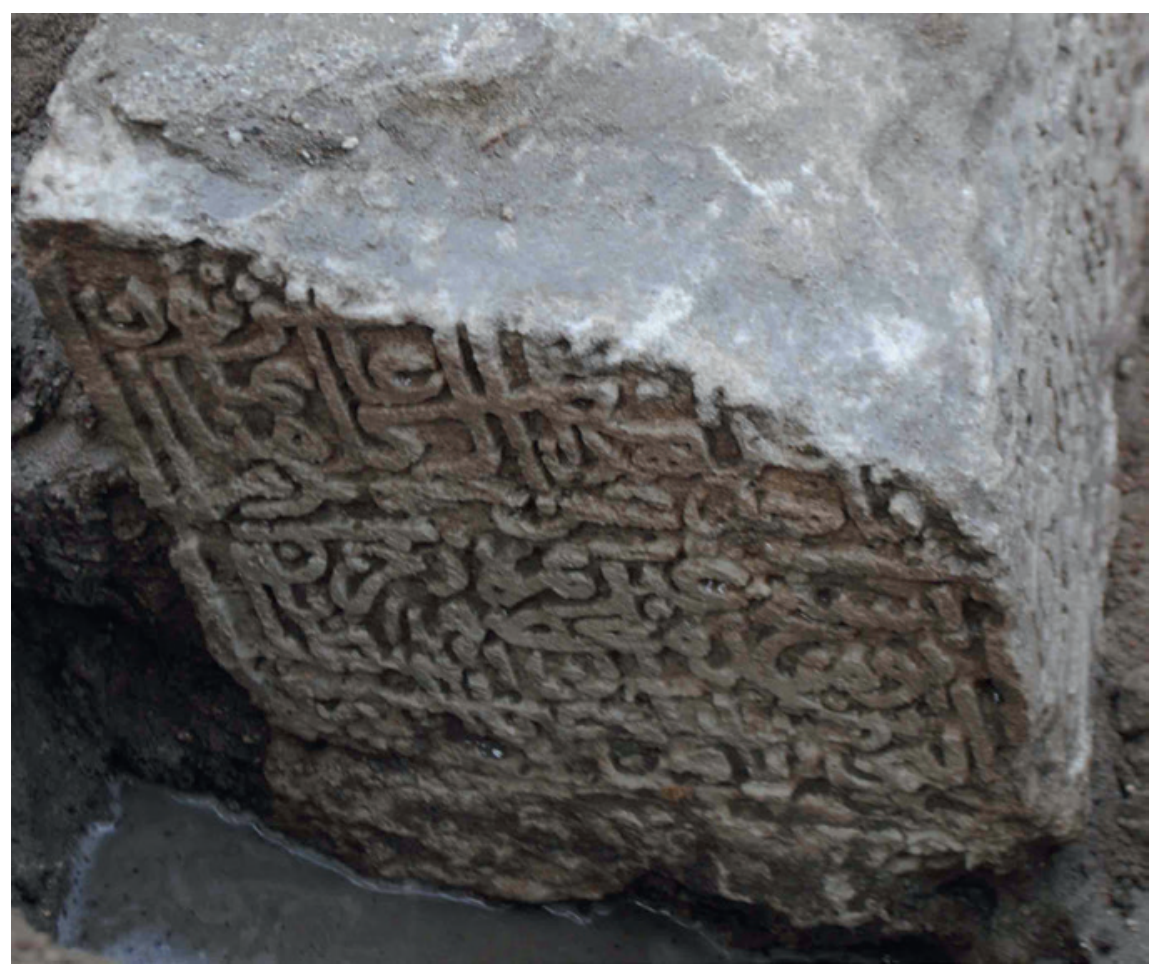

FIGURE 2.208 Surface C, HOO5 
D:

- ... the late ... bint Shaikh ...

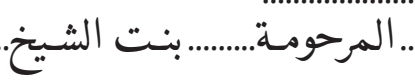

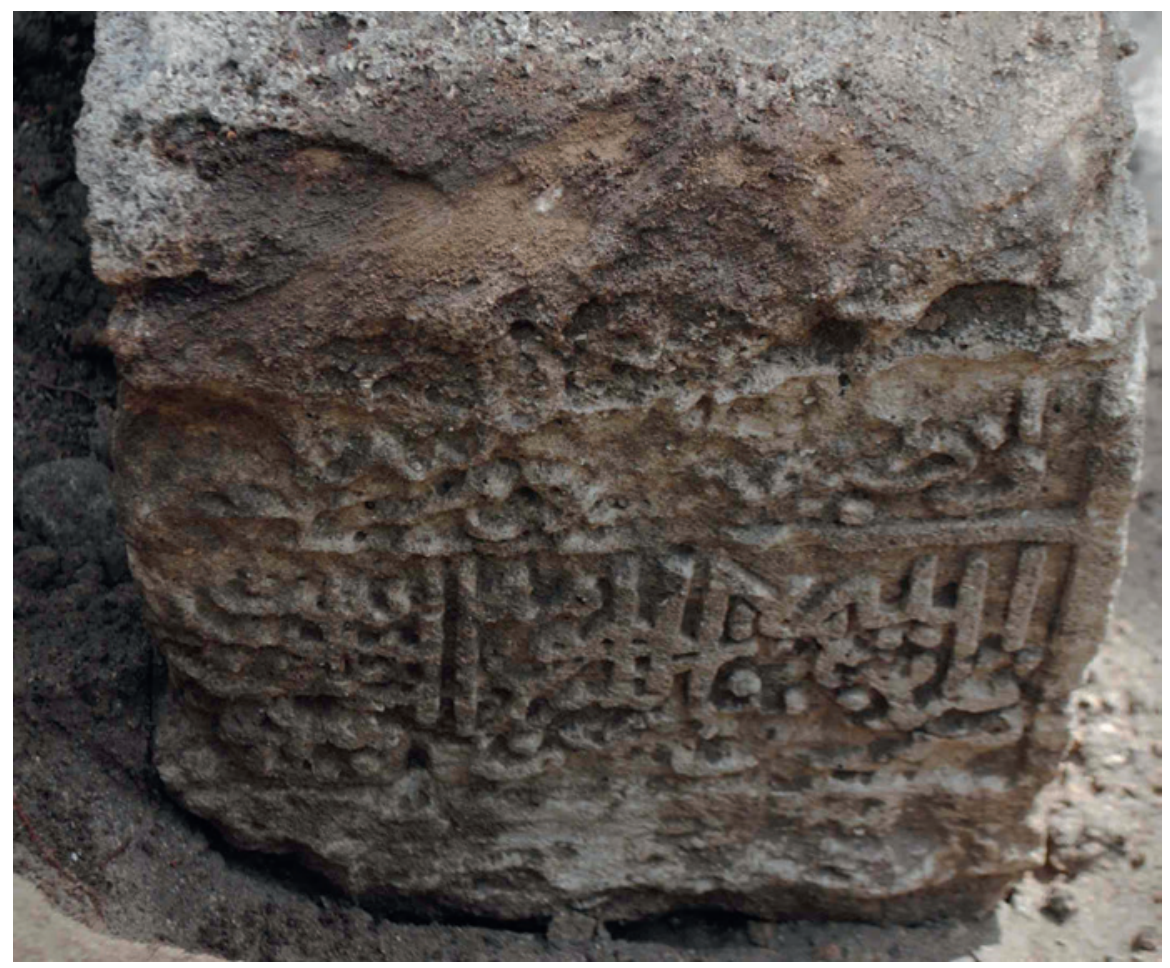

FIGURE 2.209 Surface D, HOO5

E:

- Engraved by al-Sayyid Naser bin alHabr.... al-Sayyid Hashim ...
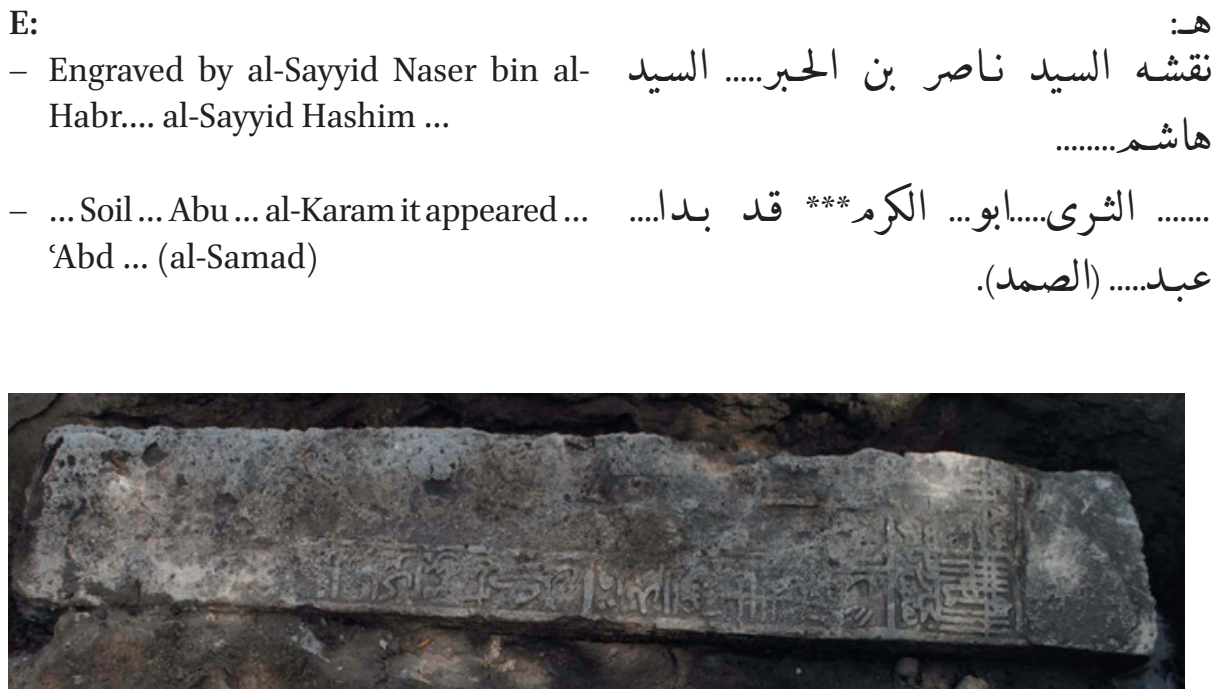

FIGURE 2.210 Surface E, HOO5 
Reference Number: HOO6

Co-ordinates: $26.23070^{\circ} \mathrm{N} 050.58462^{\circ} \mathrm{E}$

Dimensions: $130 \mathrm{~cm}(\mathrm{l}) \times 33 \mathrm{~cm}(\mathrm{w}) \times 30 \mathrm{~cm}(\mathrm{~h})$

Orientation: NW-SE

Description: Single small limestone slab gravestone (Figure 2.211). Very badly eroded. No carving or inscriptions.

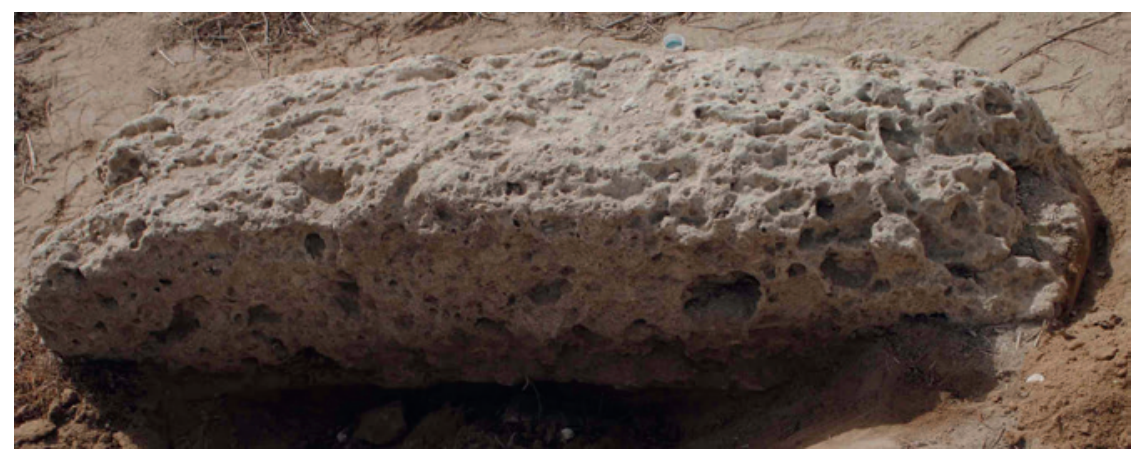

FIGURE 2.211 HOO6

Arabic Transcription and Translation: No inscriptions

Reference Number: $\mathrm{HOO} 7$

Co-ordinates: $26.22981^{\circ} \mathrm{N} 050.58467^{\circ} \mathrm{E}$

Dimensions: $120 \mathrm{~cm}(\mathrm{l}) \times 61 \mathrm{~cm}(\mathrm{w}) \times 6 \mathrm{~cm}(\mathrm{~h})$

Orientation: NW-SE

Description: Flat slab gravestone, possibly made of sandstone (Figure 2.212). Some erosion. Described as of a type bought already inscribed with the name etc. in Iran and the date of death was then added, when required, in Bahrain. Inscription on one surface. 


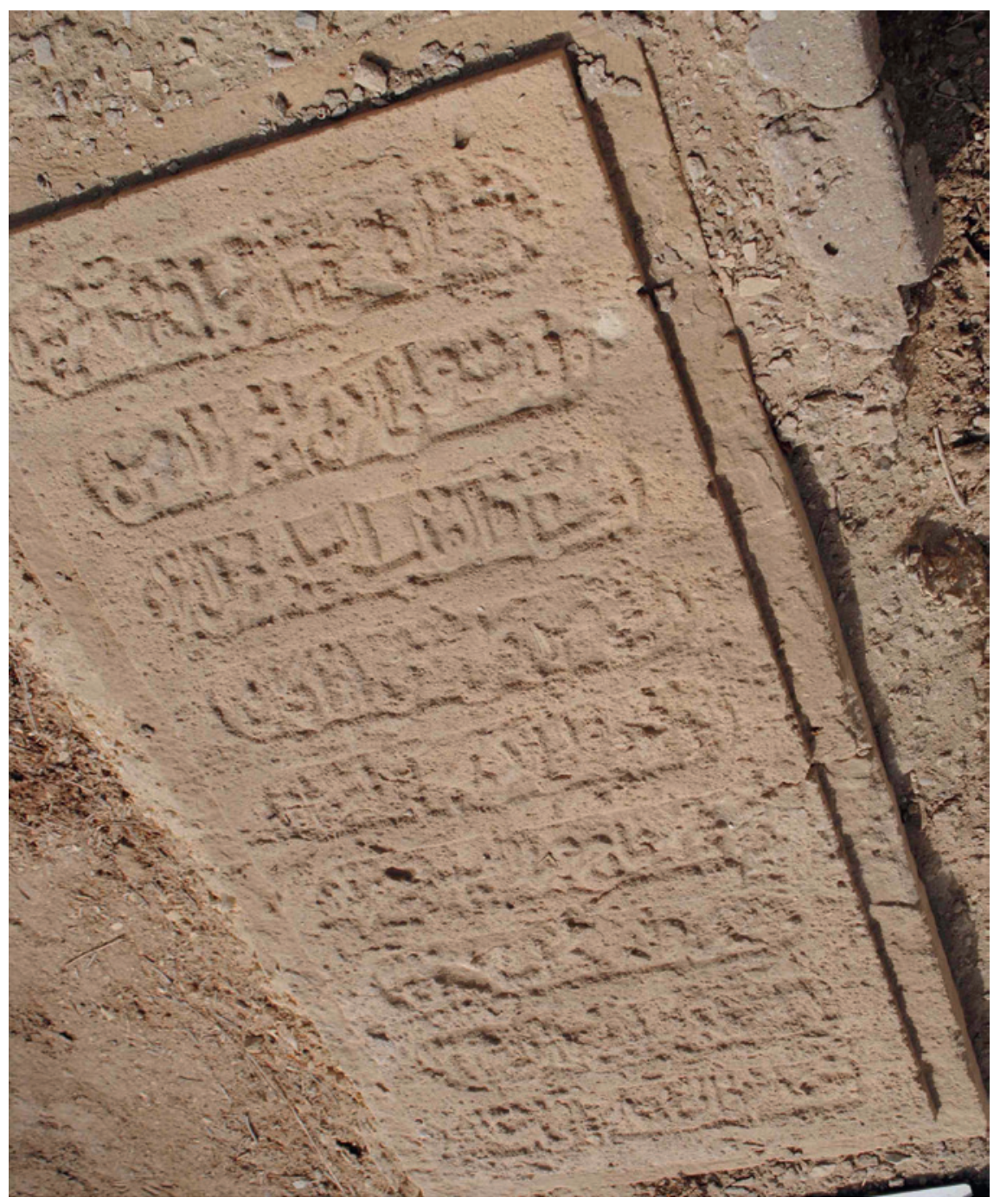

FIGURE 2.212 HOO7

\section{Arabic Transcription and Translation:}

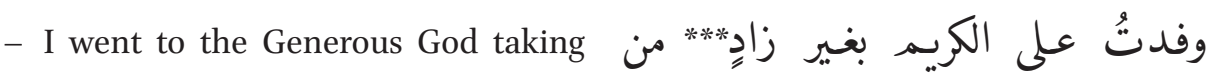
with me only the good works and sweet heart.

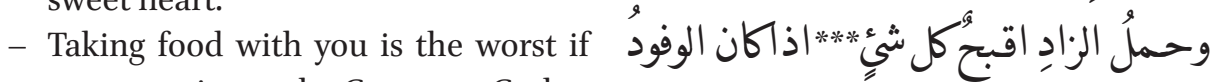
you are going to the Generous God.

- The late, 'Abd al-Hasan Jawad.

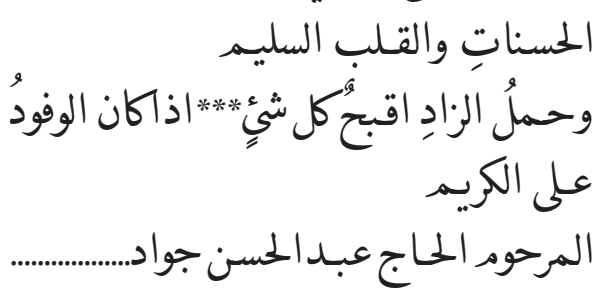


Reference Number: HOO8

Co-ordinates: $26.23061^{\circ} \mathrm{N} 050.5835^{\circ}{ }^{\circ} \mathrm{E}$

Dimensions: $149 \mathrm{~cm}(\mathrm{l}) \times 31 \mathrm{~cm}(\mathrm{w}) \times 45 \mathrm{~cm}(\mathrm{~h})$

\section{Orientation: NNW-SSE}

Description: Single limestone slab gravestone found lying on its side (Figure 2.213). The side that was exposed above the ground surface is eroded. Three element raised decoration formed of two facetted cubes and a central thin slab at both ends. Shallow carved rectangular panel on top surface (E) has been started. No chisel marks evident. No inscriptions. Gravestone was possibly left unfinished as the stone surface was found to be pitted after cutting. Excavated to expose the whole gravestone.

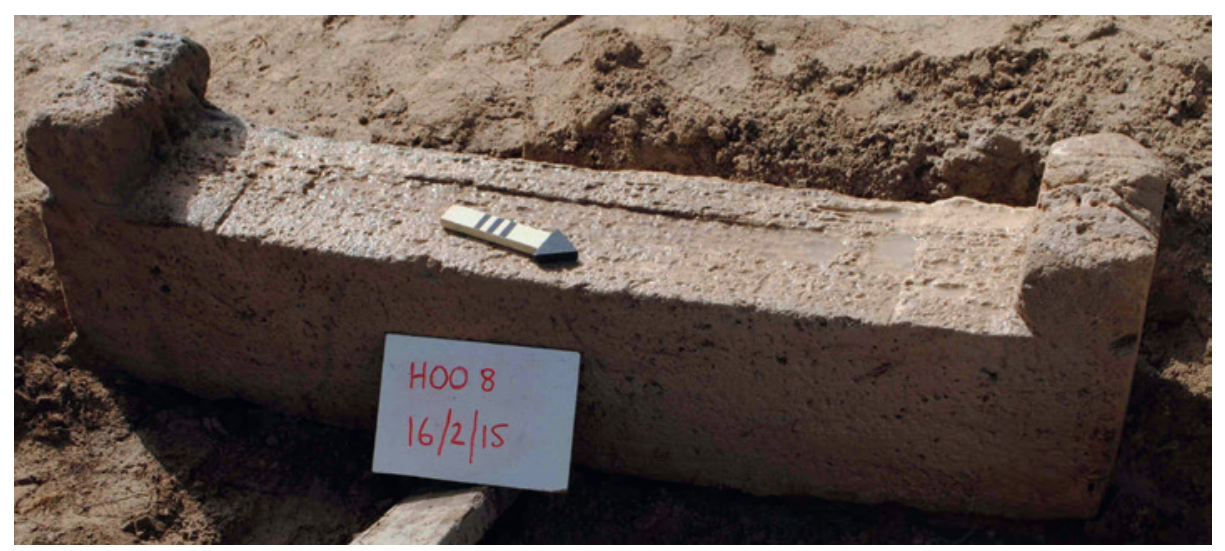

FIGURE 2.213 HOO8

Arabic Transcription and Translation: No inscriptions

Reference Number: HOO9

Co-ordinates: $26.23160^{\circ} \mathrm{N} 050.58337^{\circ} \mathrm{E}$

Dimensions: $80 \mathrm{~cm}(\mathrm{l}) \times 30.5 \mathrm{~cm}(\mathrm{w}) \times 8 \mathrm{~cm}(\mathrm{~h})$

\section{Orientation: NNW-SSE}

Description: Oval flat slab gravestone, possibly made of sandstone (Figure 2.214). Very eroded. Inscribed on one surface. 


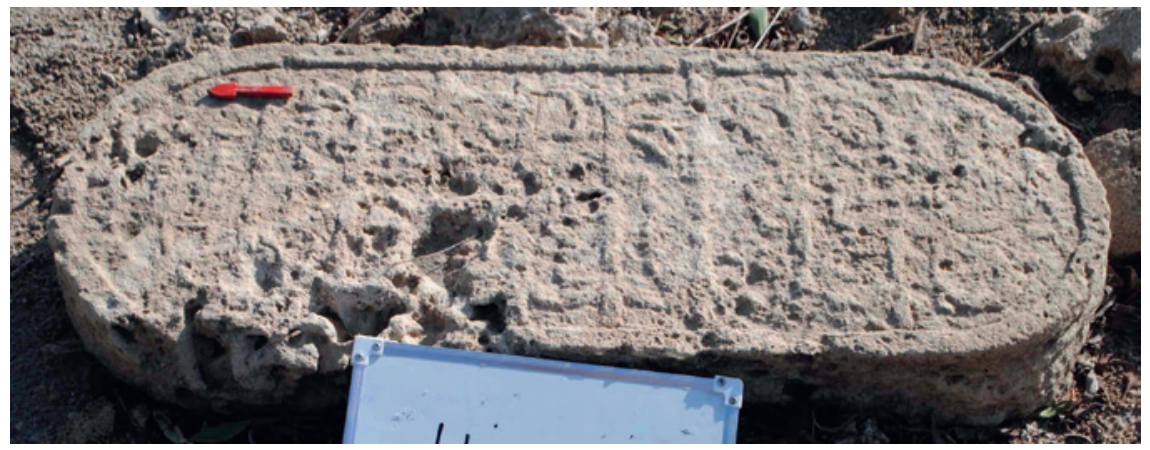

FIGURE $2.214 \quad$ HOO9

Arabic Transcription and Translation: Inscriptions are illegible

\section{Reference Number: HOO10}

Co-ordinates: $26.23140^{\circ} \mathrm{N} 050.58487^{\circ} \mathrm{E}$

Dimensions: $157 \mathrm{~cm}(\mathrm{l}) \times 30 \mathrm{~cm}(\mathrm{w}) \times 50 \mathrm{~cm}(\mathrm{~h})$

\section{Orientation: N-S}

Description: Single limestone slab gravestone (Figure 2.215). Rather than being due to erosion, the bad surface but relatively sharp lines of the different surfaces suggests it was never finished as the limestone was found to be of too poor quality to take inscriptions once the initial shape had been cut. No inscriptions or carving other than rectangular roughed out blocks at each end that would have formed raised decoration if the gravestone was completed.

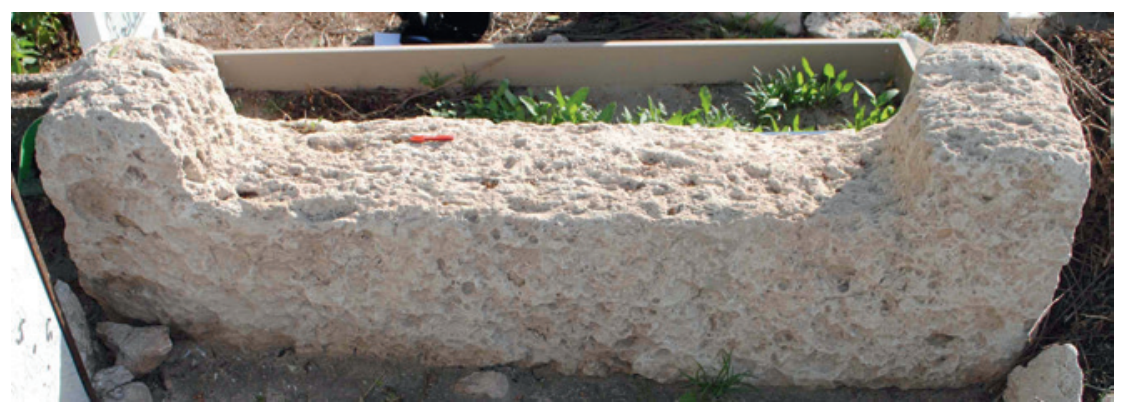

FIGURE 2.215 HOO10

Arabic Transcription and Translation: No inscriptions 
Reference Number: HoO11

Co-ordinates: $26.23141^{\circ} \mathrm{N} 050.58489^{\circ} \mathrm{E}$

Dimensions: $160 \mathrm{~cm}(\mathrm{l}) \times 30.5 \mathrm{~cm}(\mathrm{w}) \times 56 \mathrm{~cm}(\mathrm{~h})$

Orientation: NW-SE

Description: Single limestone slab gravestone (Figure 2.216). It is heavily eroded on one side, but as with Hoo10, the relatively sharp lines of the opposite surface suggest it was never finished as the limestone was found to be of too poor quality to take inscriptions once the initial shape had been cut. No inscriptions or carving other than rectangular roughed out blocks at each end that would have formed raised decoration if the gravestone was completed.

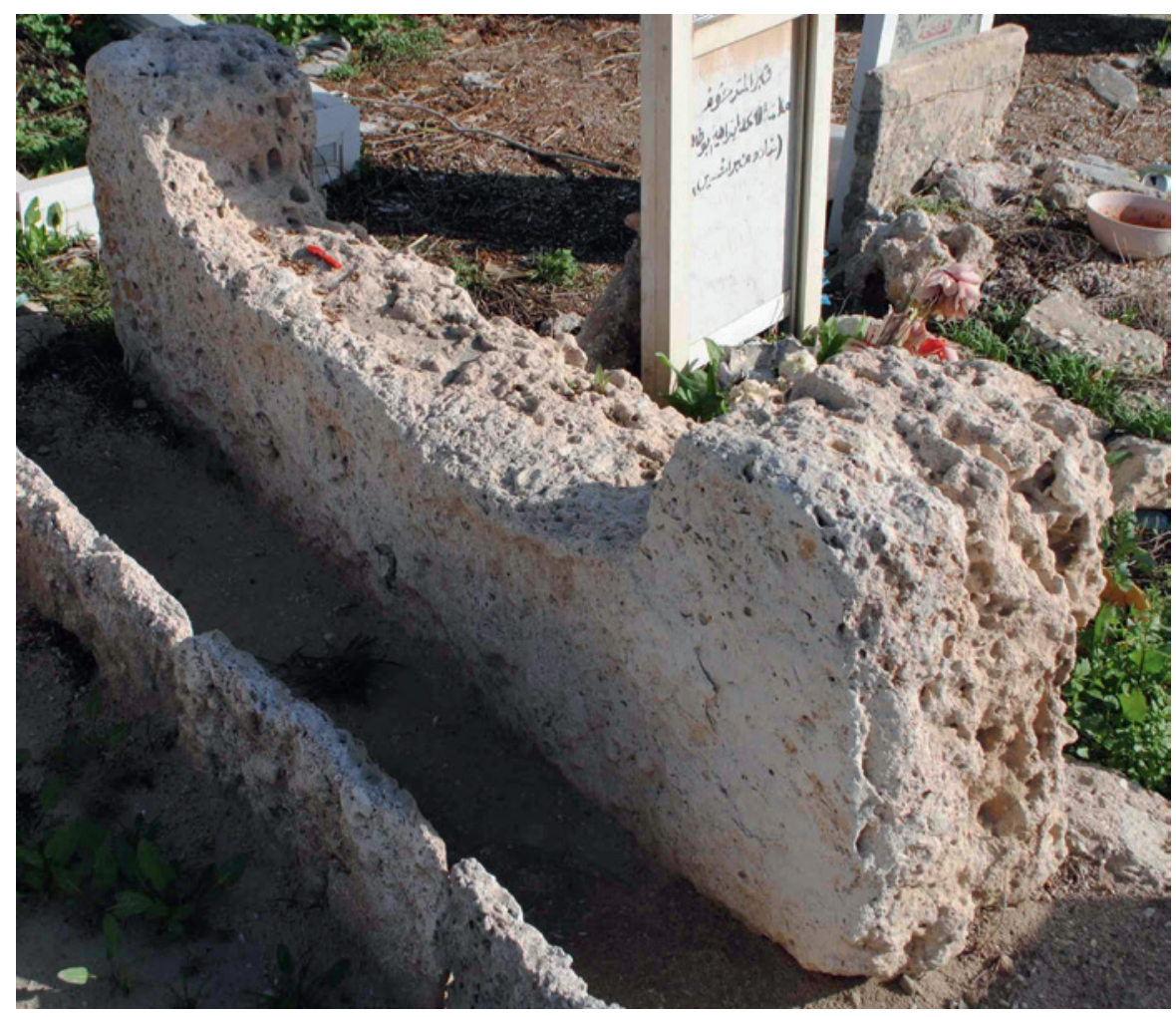

FIGURE $2.216 \quad$ HOO11

Arabic Transcription and Translation: No inscriptions 
Reference Number: HOO12

Co-ordinates: $26.23139^{\circ} \mathrm{N} 050.58508^{\circ} \mathrm{E}$

Dimensions: $170 \mathrm{~cm}(\mathrm{l}) \times 25 \mathrm{~cm}(\mathrm{w}) \times 46 \mathrm{~cm}(\mathrm{~h})$

Orientation: NE-SW

Description: Single limestone slab gravestone found lying on its side (Figure 2.217). Rather than being due to erosion processes, as with HoO10 and HoO11, the relatively sharp lines of the exposed surfaces suggest it was never finished as the limestone was found to be of too poor quality to take inscriptions once the initial shape had been cut. No inscriptions or carving other than roughed out rounded off downward sloping blocks at each end that would have formed raised decoration if the gravestone was completed.

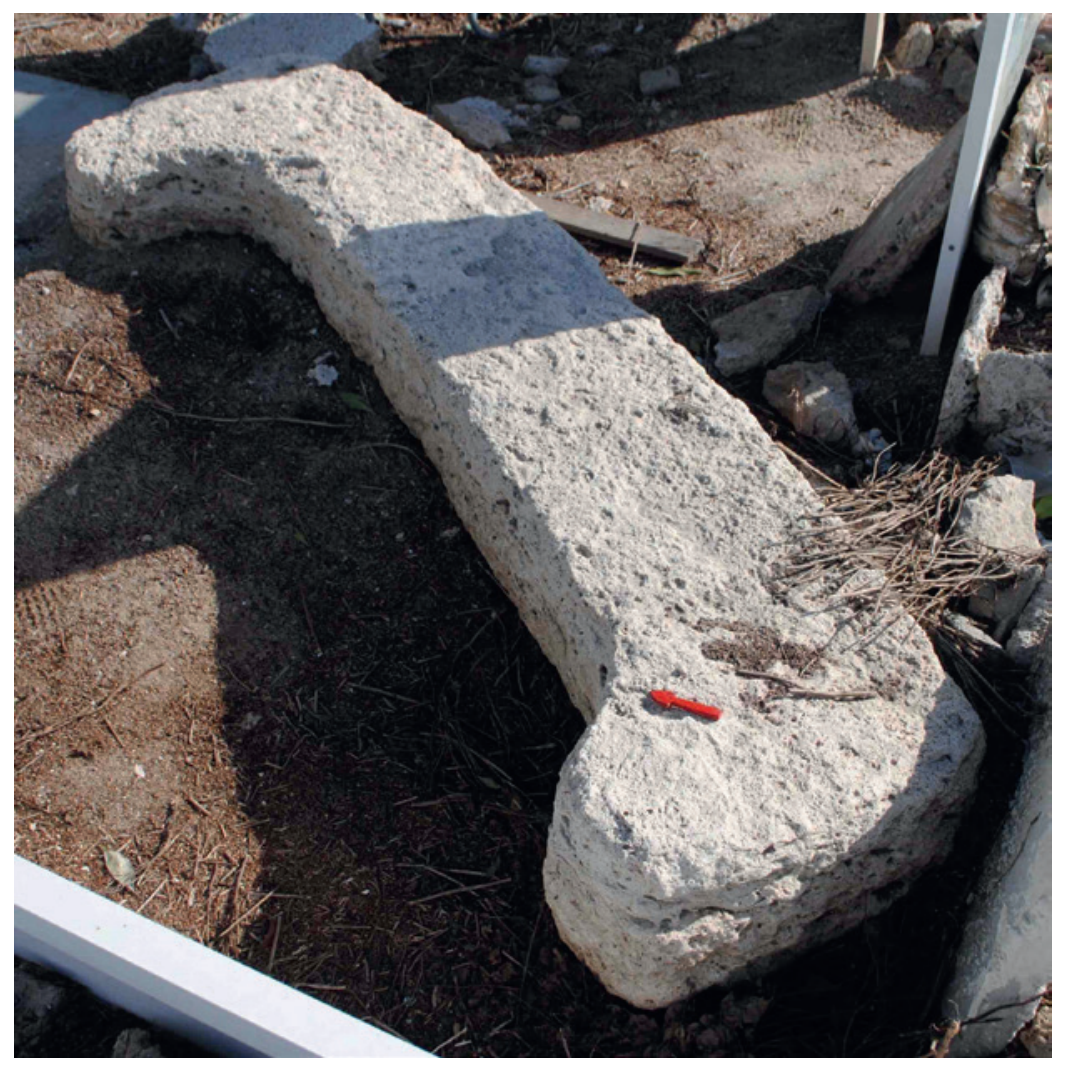

FIGURE $2.217 \quad$ HOO12

Arabic Transcription and Translation: No inscriptions 
11

$$
\text { Hunaniyah (HUN) }
$$

Location: Urban cemetery for Riffa and also used for burial by the Al-Khalifa Royal Family of Bahrain

Reference Number: HUN1

Co-ordinates: $26.12262^{\circ} \mathrm{N} 050.55739^{\circ} \mathrm{E}$

Dimensions: (of total grave) $263 \mathrm{~cm}(\mathrm{l}) \times 143 \mathrm{~cm}(\mathrm{w}) \times 84 \mathrm{~cm}(\mathrm{~h})$

\section{Orientation: NW-SE}

Description: Relatively recent cement tomb with a laser engraved single upright marble slab gravestone. Inscription on one surface.

\section{Arabic Transcription and Translation:}

- Shaikh Salman bin Ahmad al-Khalifa.

- The second ruler of the al-Khalifa family.

- Died in 1236 AH.
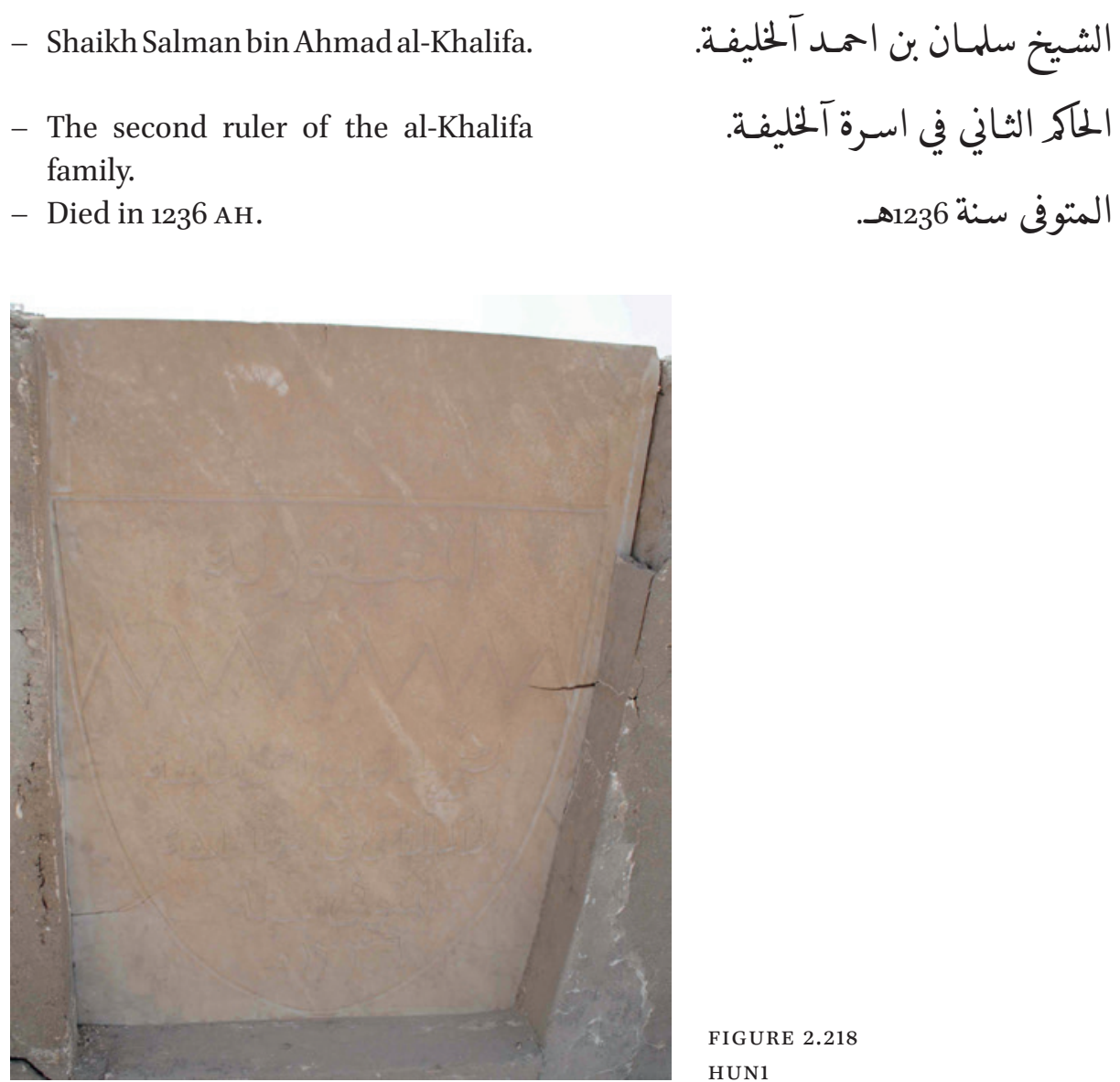
Location: Jebelat Habshi village cemetery

Reference Number: JBH 1

Co-ordinates: $26.21646^{\circ} \mathrm{N} 050.53079^{\circ} \mathrm{E}$

Dimensions: $83.5 \mathrm{~cm}(\mathrm{l}) \times 24 \mathrm{~cm}(\mathrm{w}) \times 39.5 \mathrm{~cm}(\mathrm{~h})$

Orientation: NE-SW

Description: Single hollow limestone slab gravestone. Half of a double slab gravestone. Eroded unidentifiable three element raised decoration at one end. Inscriptions on two surfaces. The letter carving is quite crude and part of a side surface (A) is cut by a vertical intentionally chiselled semi-circular channel.

\section{Arabic Transcription and Translation:}

A:

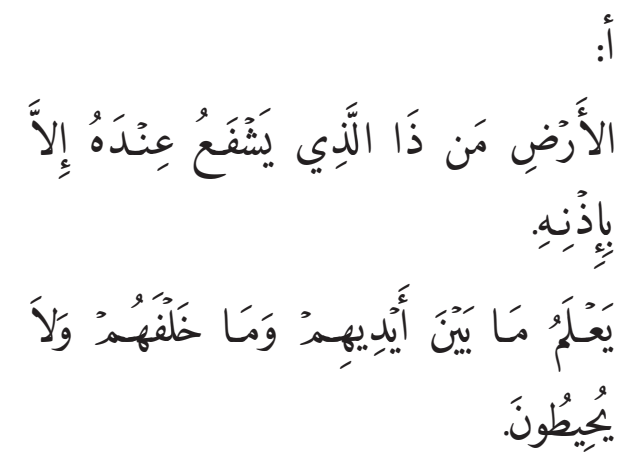

- He knows what happens to them in this world and what will happen to them in the hereafter. And they will never compass (2:255).

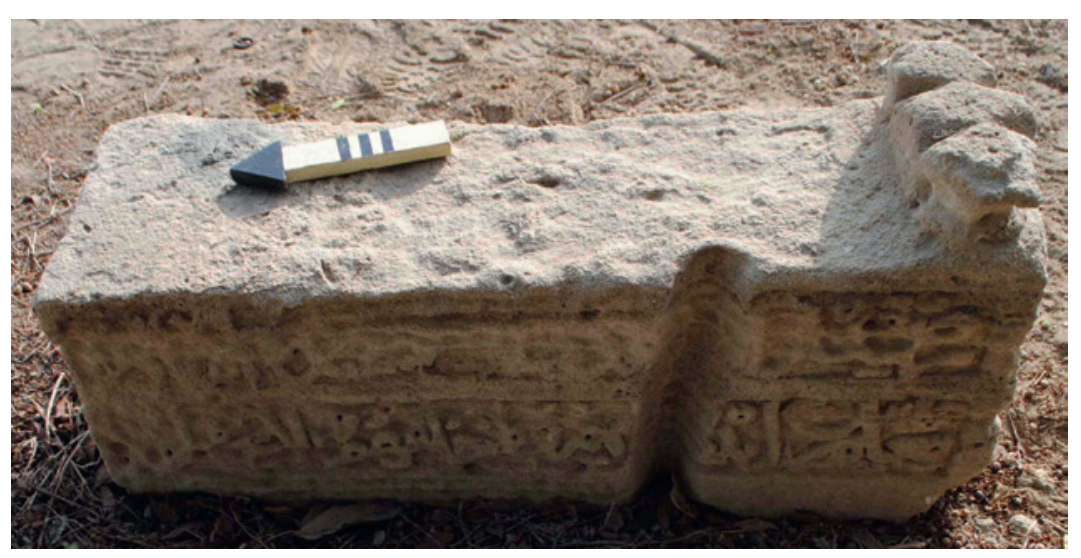

FIGURE 2.219 Surface A, JBH1 
B:

- In the Name of Allah, the Most Gracious, the Most Merciful. Allah, none has the right to be worshipped but He, the Ever Living, the One

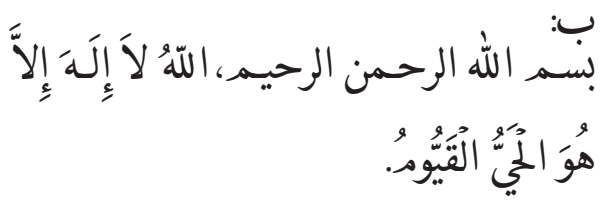
Who sustains and protects all that exists.

- Neither slumber nor sleep overtakes Him. To Him belongs whatever is in the heavens and whatever in (2:255).
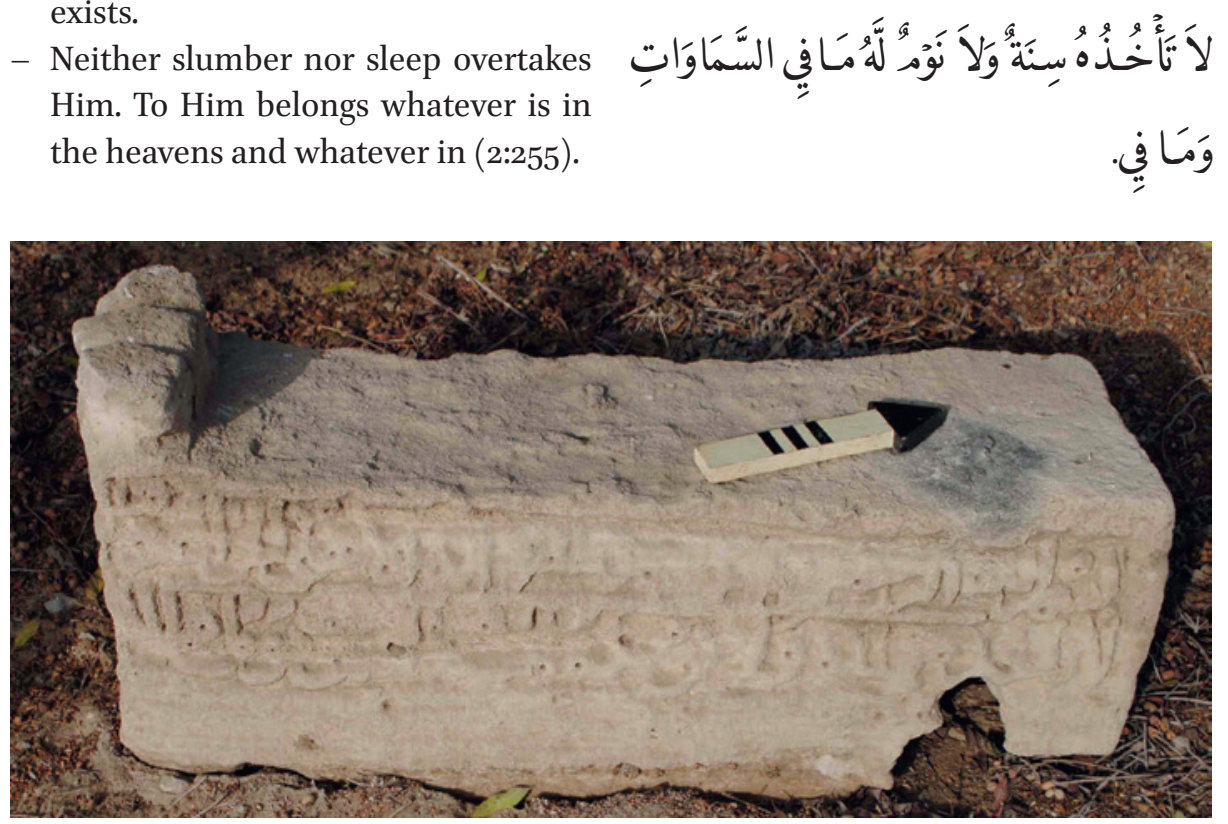

FIGURE 2.220 Surface B, JBH1 
C:

- No carving or inscriptions.

لاذِّوجد نقوش أوكَّبات

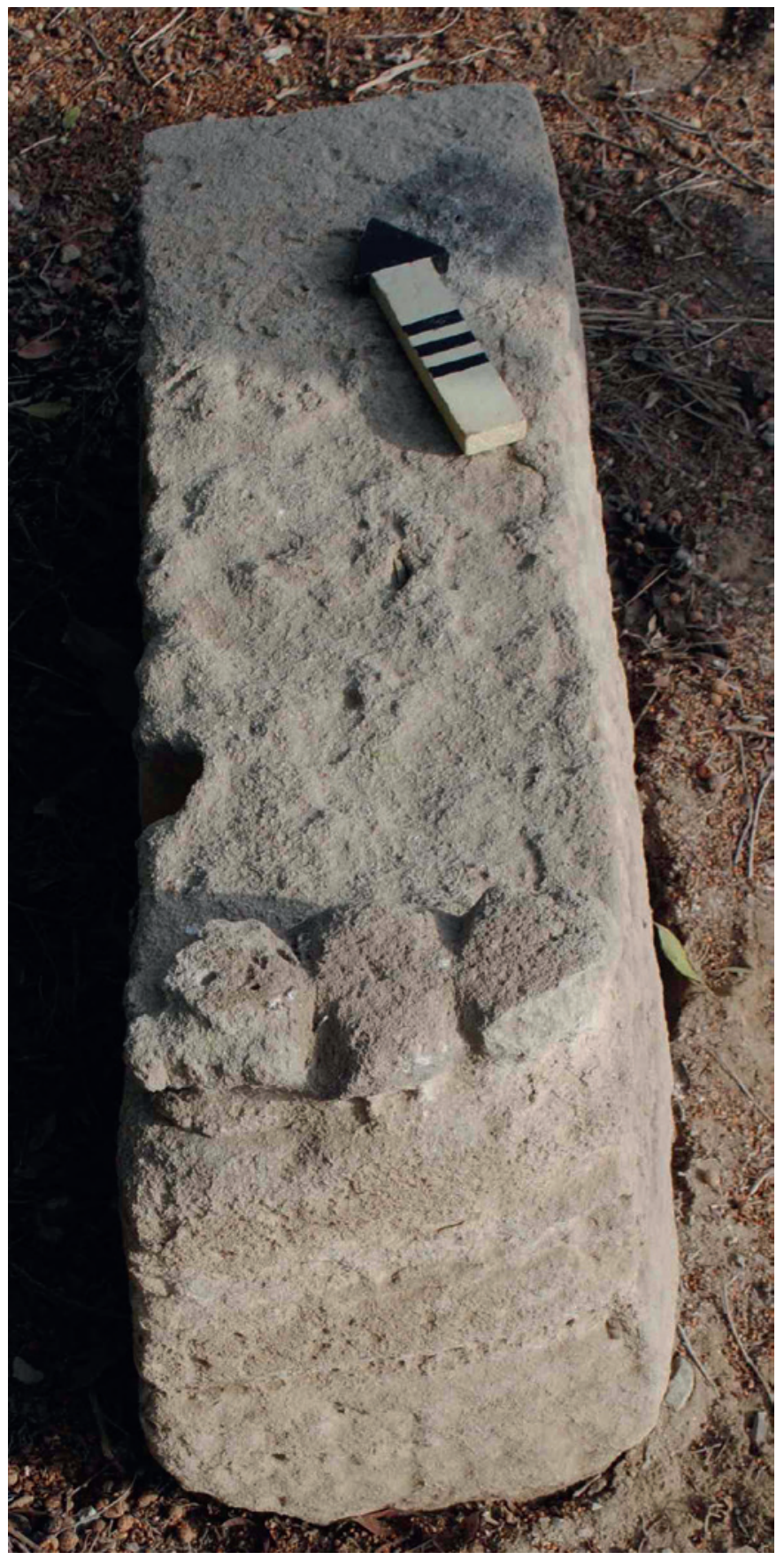

FIGURE 2.221

Surface C, JBH1 
D:

- No carving or inscriptions.

$$
\text { لا توجــ نقوش أوكّابات }
$$

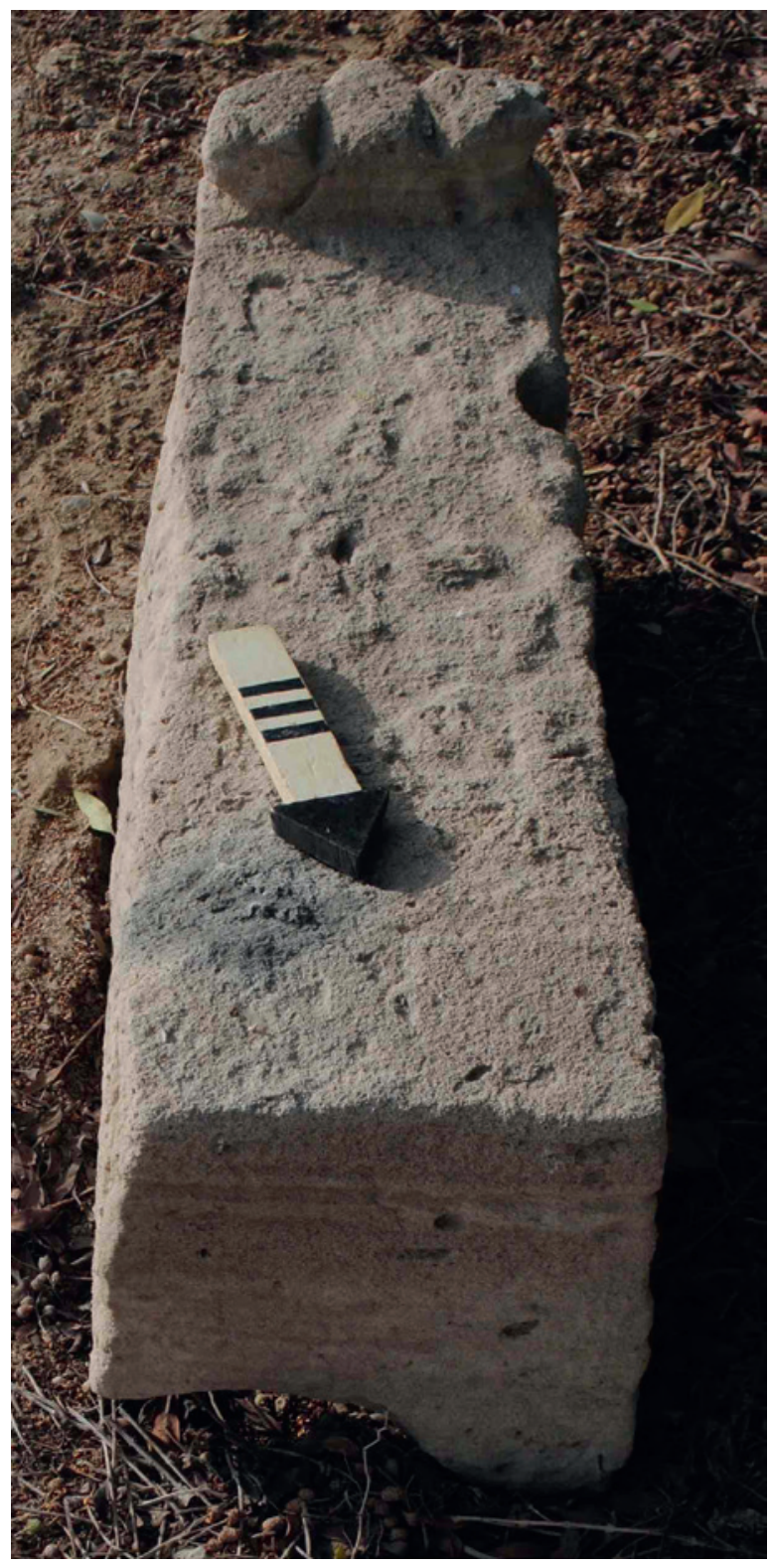

E:

- No carving or inscriptions.
FIGURE 2.222

Surfaces D and E, JBH1

See Figure 2.222 


\section{Reference Number: JBH2}

Co-ordinates: $26.21656^{\circ} \mathrm{N} 050.53088^{\circ} \mathrm{E}$

Dimensions: $150 \mathrm{~cm}(\mathrm{l}) \times 31 \mathrm{~cm}(\mathrm{w}) \times 50 \mathrm{~cm}(\mathrm{~h})$

\section{Orientation: NNW-SSE}

Description: Single limestone slab gravestone (Figure 2.223). No inscriptions. Some erosion on top surface (E) and side surfaces (A and B). Three element raised decoration formed of two facetted cubes and a central rounded arch all set on a rectangular plinth at both ends. The gravestone has been cut to size and left unfinished.

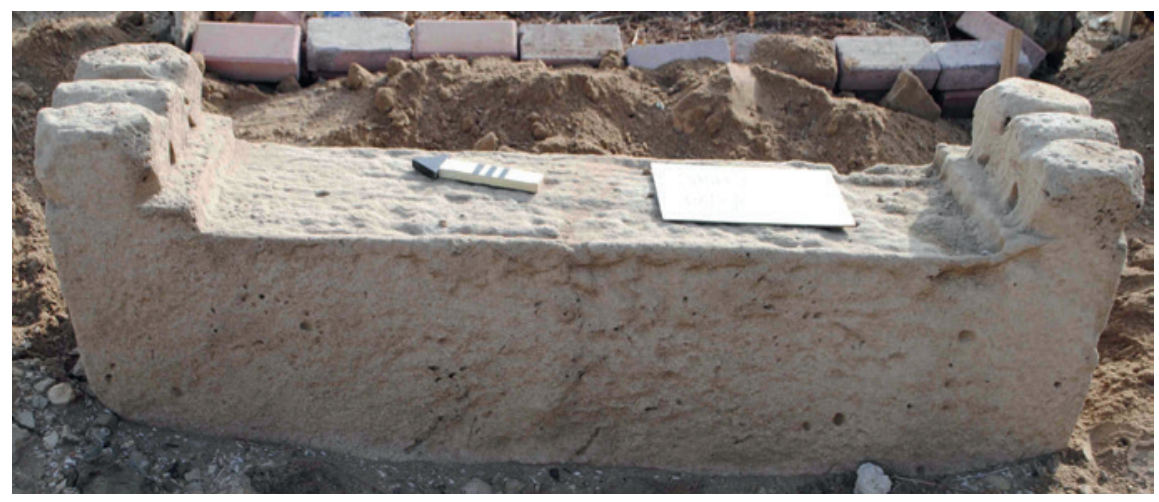

FIGURE 2.223 JBH2

Arabic Transcription and Translation: No inscriptions

Reference Number: JBH3

Co-ordinates: $26.21658^{\circ} \mathrm{N} 050.53093^{\circ} \mathrm{E}$

Dimensions: $142 \mathrm{~cm}(\mathrm{l}) \times 30.5 \mathrm{~cm}(\mathrm{w}) \times 54.5 \mathrm{~cm}(\mathrm{~h})$

\section{Orientation: NW-SE}

Description: Single limestone slab gravestone (Figure 2.224). No inscriptions. Eroded and cement covered three element raised decoration formed of two facetted cubes and a central rounded arch at both ends. The gravestone has been cut to size and left unfinished. 


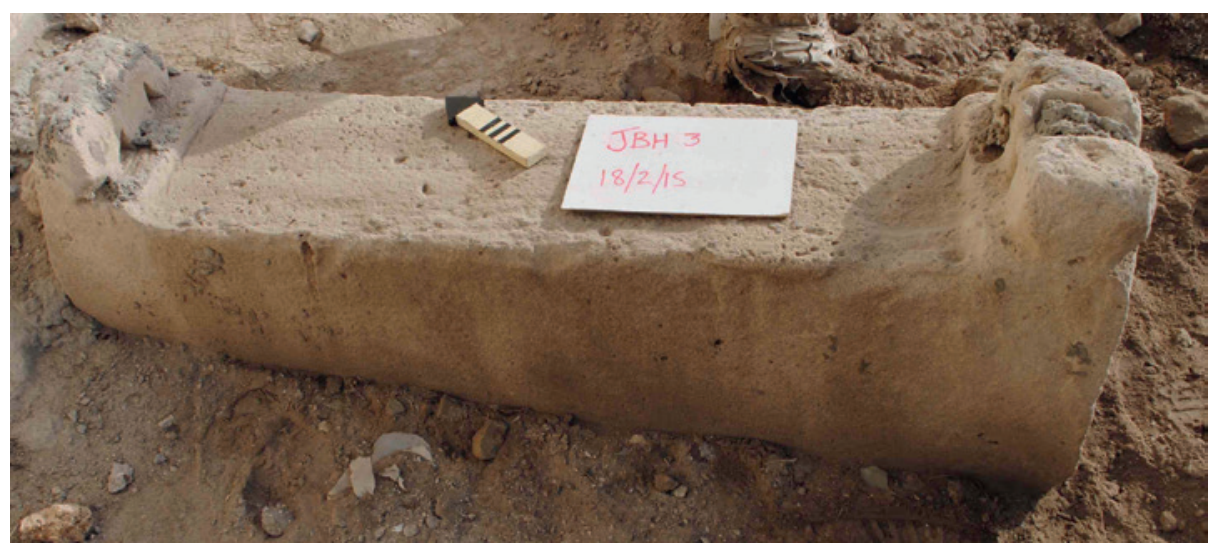

FIGURE 2.224 JBH3

Arabic Transcription and Translation: No inscriptions

Reference Number: JBH4

Co-ordinates: $26.21659^{\circ} \mathrm{N} 050.53098^{\circ} \mathrm{E}$

Dimensions: $75 \mathrm{~cm}(\mathrm{l}) \times 25 \mathrm{~cm}(\mathrm{w}) \times 48.5 \mathrm{~cm}(\mathrm{~h})$

\section{Orientation: NW-SE}

Description: Single hollow limestone slab gravestone, broken in two. Half of a double slab gravestone. Unidentifiable eroded raised decoration at one end. Some erosion on the upper surfaces and has a hole drilled in surface C. Partial inscriptions on three surfaces.

\section{Arabic Transcription and Translation:}

A:

- ... opened ... Therein they will recline, therein they will call for fruits in abundance ... (38:50-51)

- Receive the glad tidings of the paradise which you have been promised. We have been your friends in the life of this world and are in the Hereafter. Therein you shall have all that your inner-selves desire, and therein you shall have all for which you ask (41:30-31).

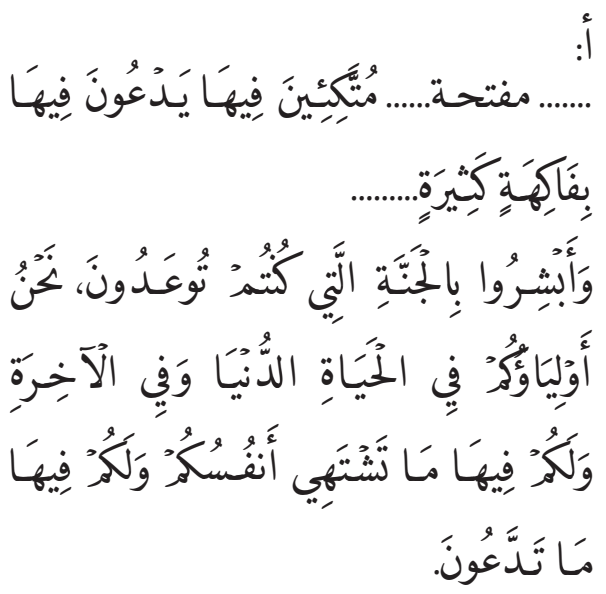




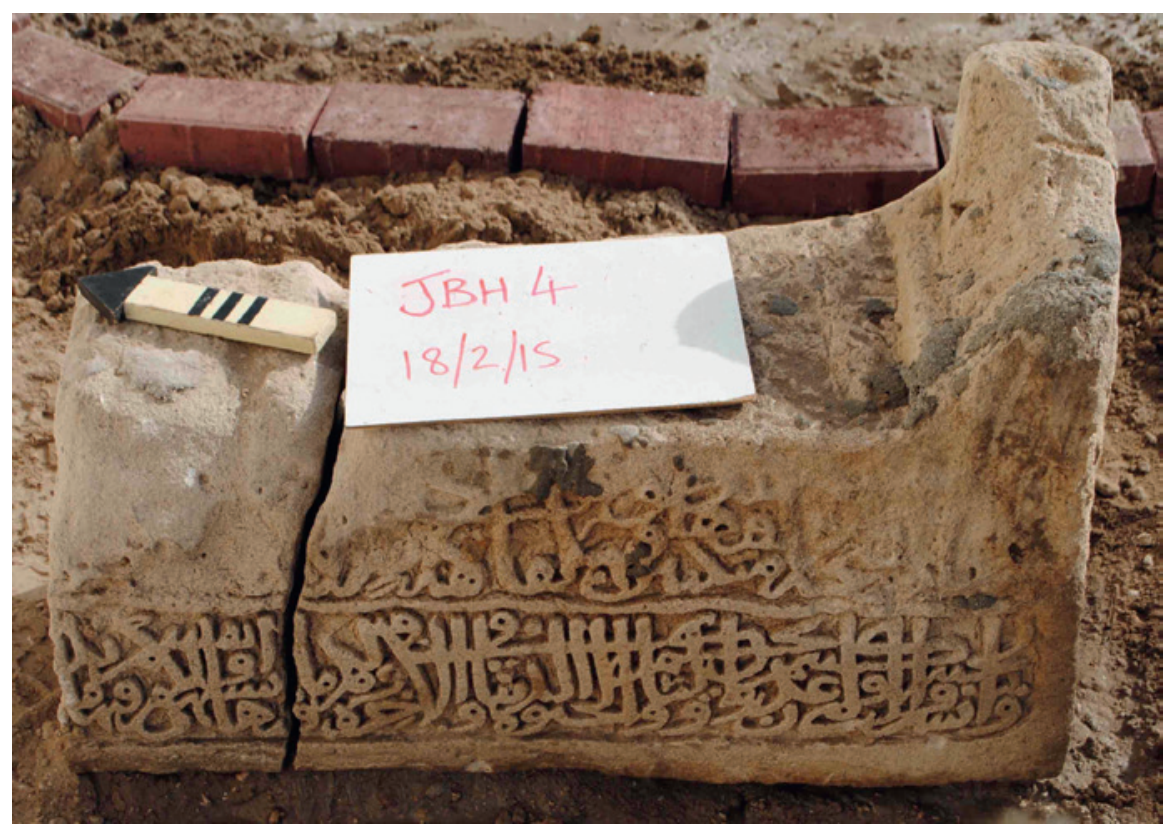

FIGURE 2.225 Surface A, JBH4

B:

- The One Who sustains and protects all that exists. Neither slumber nor sleep overtakes Him. To Him belongs whatever is in the heavens and whatever is on the earth. Who is he that can intercede.

- ... Except that which He wills. His Seat extends over the heavens and the earth. And He feels no fatigue in guarding and preserving them. And He is the Most High, the Most Great (2:255).

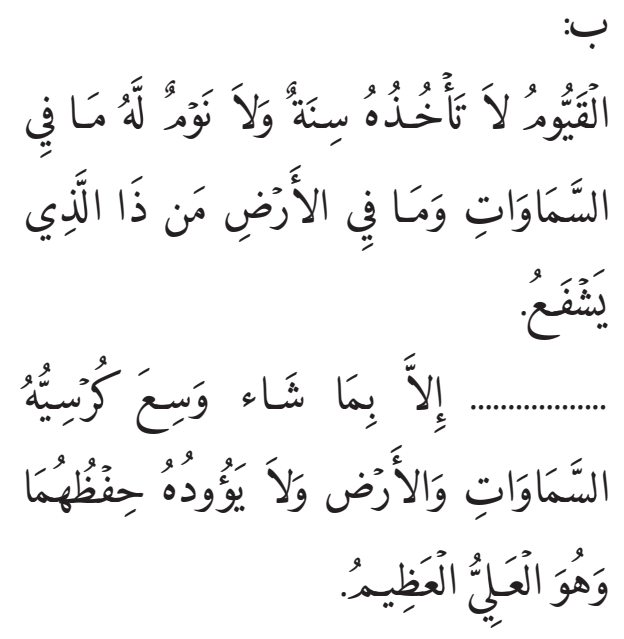




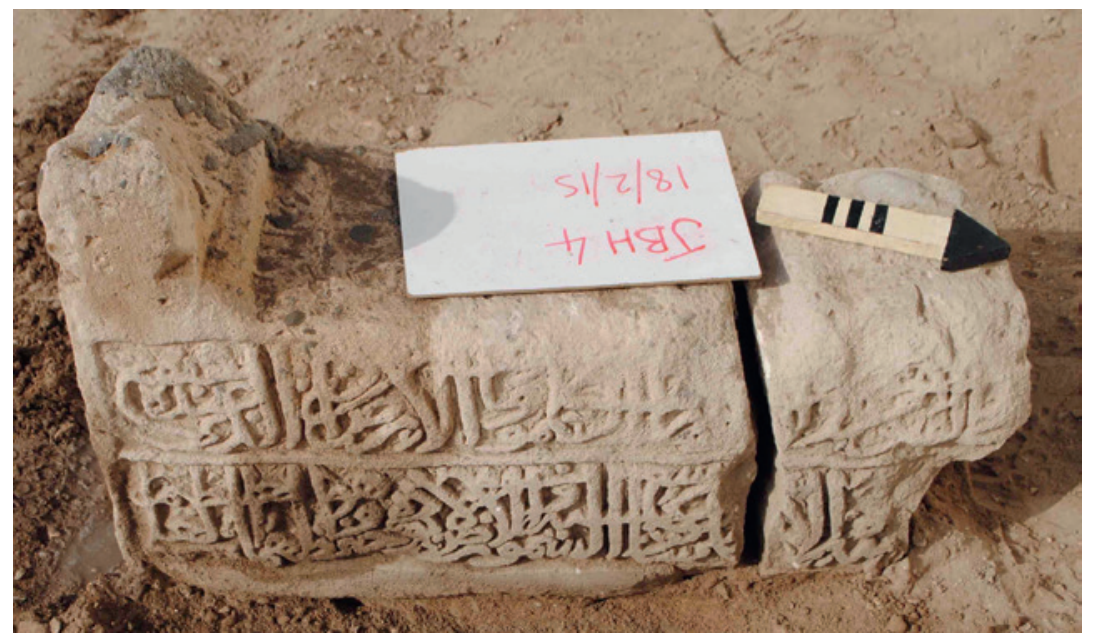

FIGURE 2.226 Surface B, JBH4

C:

- ... Muhammed bin Hassan, engraved by Abdalhussain Alsyed.
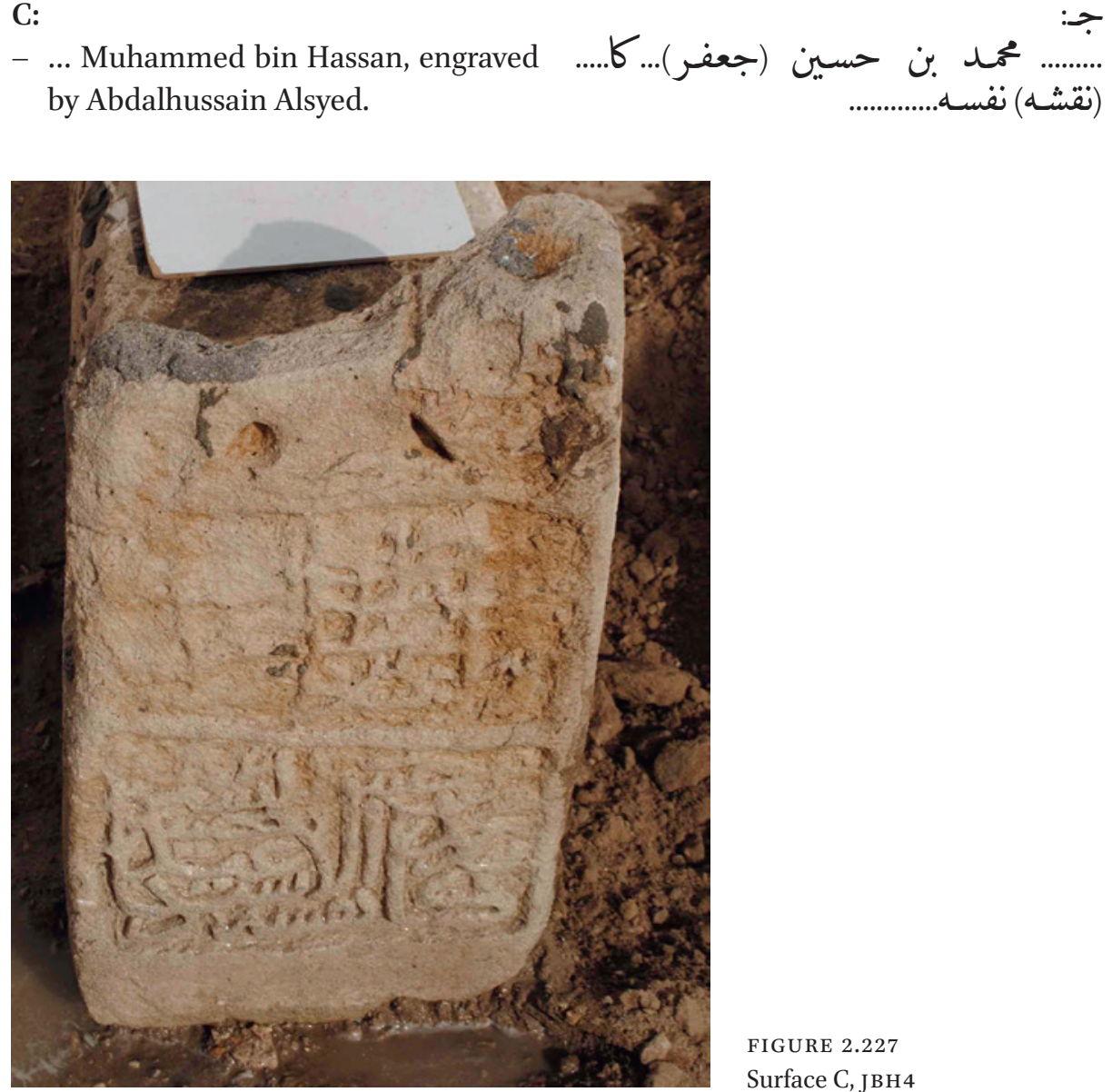
D:

- No carving or inscriptions.

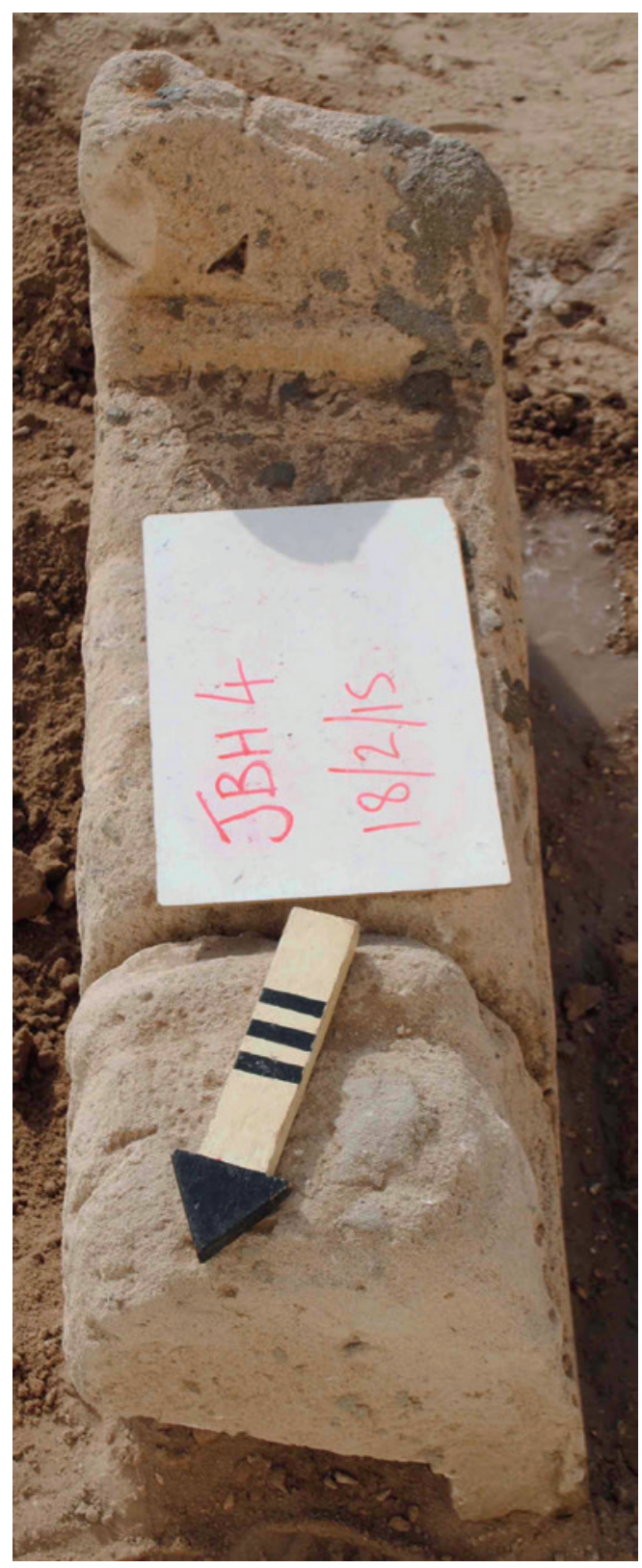

FIGURE 2.228

Surfaces D and E, JBH 4
E:

- No carving or inscriptions. لا توجد نقوش أوكّابات 
Reference Number: JBH5

Co-ordinates: $26.21655^{\circ} \mathrm{N} 050.53094^{\circ} \mathrm{E}$

Dimensions: Hollow fragment $5^{1} \mathrm{~cm}(\mathrm{l}) \times 31.5 \mathrm{~cm}(\mathrm{w}) \times 3^{1} \mathrm{~cm}(\mathrm{~h})$. Inscribed fragment $35 \mathrm{~cm}(\mathrm{l}) \times 21 \mathrm{~cm}(\mathrm{w}) \times 22 \mathrm{~cm}(\mathrm{~h})$

\section{Orientation: NW-SE}

Description: Group of four fragments of limestone gravestone (Figure 2.229). The largest fragment is hollow. One small fragment has a partial inscription.

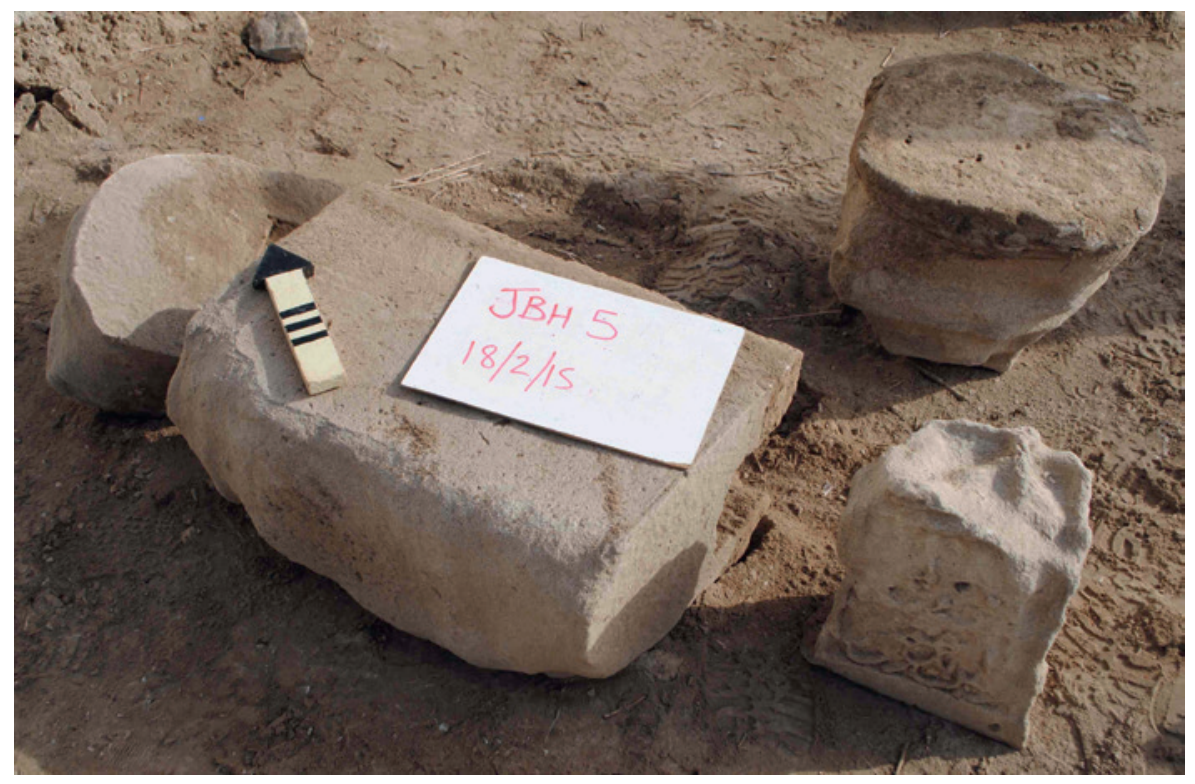

FIGURE 2.229 JBH5

Arabic Transcription and Translation:

Original Surface Unknown

- ... in this world and ... (2:255).<smiles>CN=C=CC(C)C</smiles> 


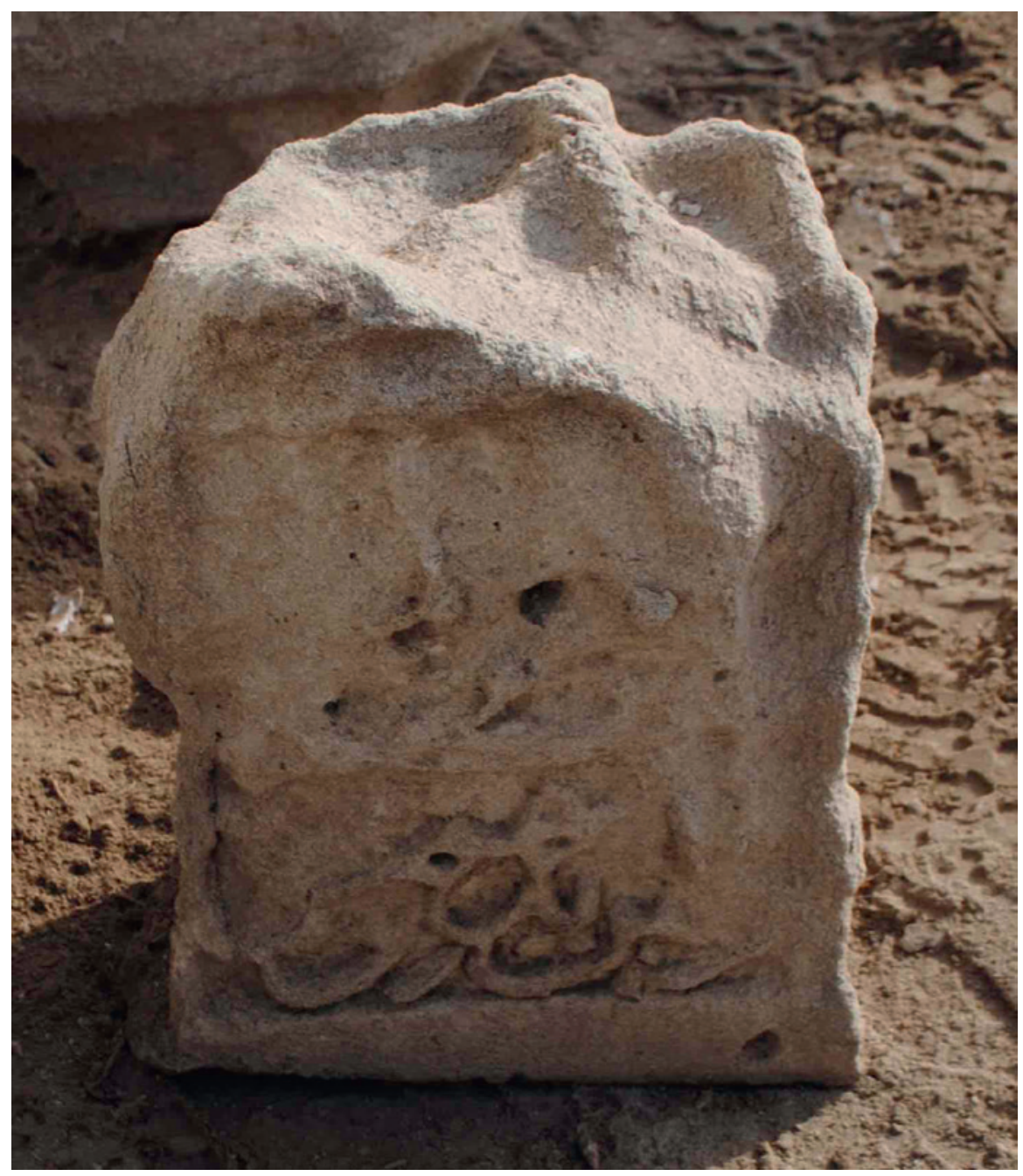

FIGURE 2.230 Partial inscription, JBH5

\section{Reference Number: JBH6}

Co-ordinates: $26.21654^{\circ} \mathrm{N} 050.53095^{\circ} \mathrm{E}$

Dimensions: $102 \mathrm{~cm}(\mathrm{l}) \times 23 \mathrm{~cm}(\mathrm{w}) \times 30 \mathrm{~cm}(\mathrm{~h})$

Orientation: NNW-SSE

Description: Single limestone slab gravestone. Very eroded. Remnants of unidentifiable raised decoration at both ends. Partial inscription on one surface. 
Arabic Transcription and Translation:

A:

- ... their beds, to invoke their Lord in fear ... (32:16).
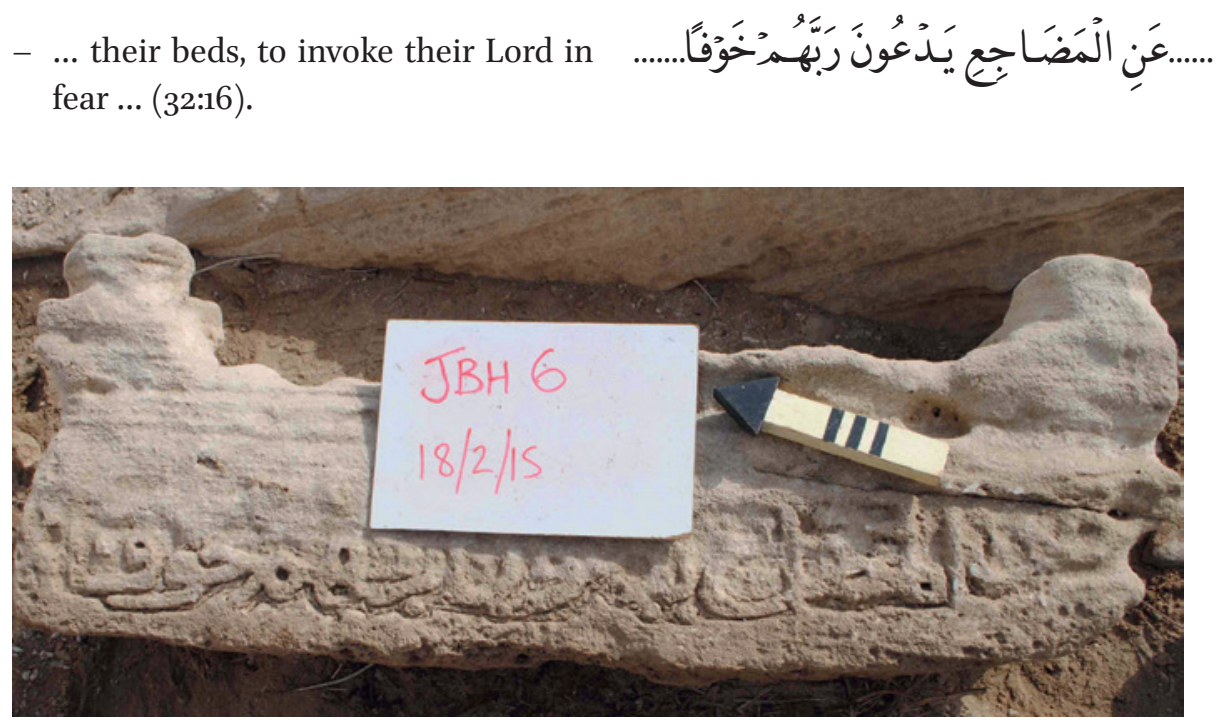

FIGURE 2.231 Surface A, JBH6

B:

- No carving or inscriptions.

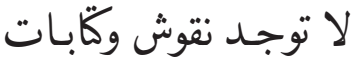

C:

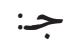

- No carving or inscriptions.

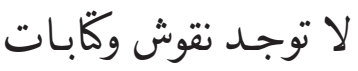

D:

- No carving or inscriptions.

لا تّوجـد نقوش وكَّاتـات

E:

- No carving or inscriptions.

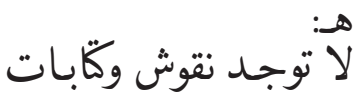




\section{Reference Number: JBH 7}

Co-ordinates: $26.21664^{\circ} \mathrm{N} 050.53097^{\circ} \mathrm{E}$

Dimensions: $163 \mathrm{~cm}(\mathrm{l}) \times 26 \mathrm{~cm}(\mathrm{w}) \times 57 \mathrm{~cm}(\mathrm{~h})$

\section{Orientation: NW-SE}

Description: Single limestone slab gravestone. Three element raised decoration formed of two facetted cubes and a central thin rounded flat slab all set on a rectangular plinth at both ends. The raised decoration is partially broken off at one end and the back of the raised decoration on one end surface (D) has traces of what appears to be rosette carving. Badly eroded in places where above ground. Full inscriptions on two surfaces, and partial inscriptions on two other surfaces. Excavated to expose whole gravestone.

\section{Arabic Transcription and Translation:}

A:
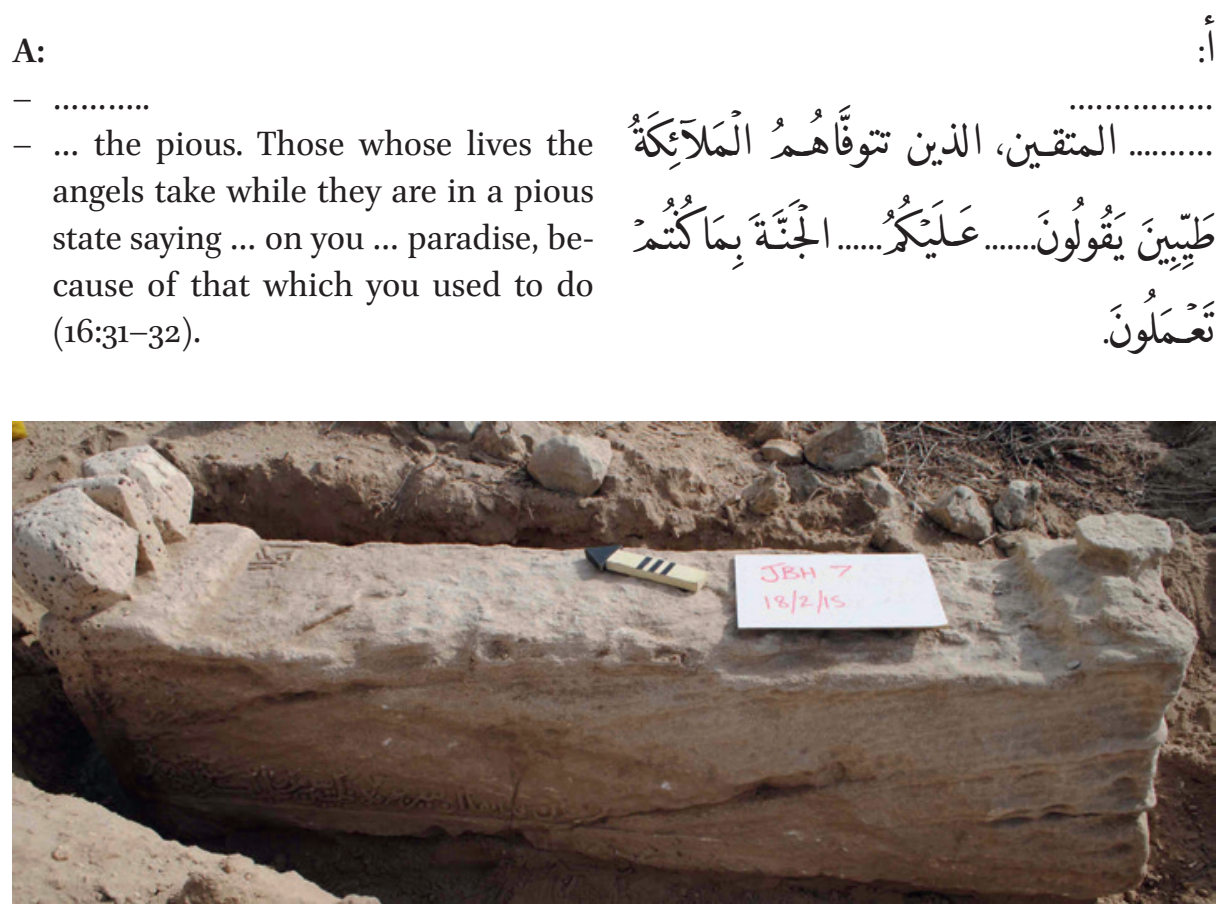

FIGURE 2.232 Surface A, JBH7 
B:

- In the Name of Allah, the Most Gracious, the Most Merciful. Allah, none has the right to be worshipped but he, the Ever Living, the One Who sustains and protects all that exists. Neither slumber nor sleep overtakes Him. To Him belongs whatever is in the heavens and whatever is on the earth. Who is he that can intercede with Him except by His permission! He knows what happens to them in this world, and will happen to them in the Hereafter and they will never compass anything of His Knowledge except that which He wills.

- His Seat extends over the heavens and the earth and He feels no fatigue in guarding and preserving them. And He is the Most High, the Most Great. There is no compulsion in religion. Verily, the Right Path has become distinct from the wrong path. Whoever disbelieves in Taghut and believes in Allah, and then he has grasped the most trustworthy handhold that will never break. And Allah is AllHearer, All-Knower (2:255-256). God Almighty has spoken the truth.
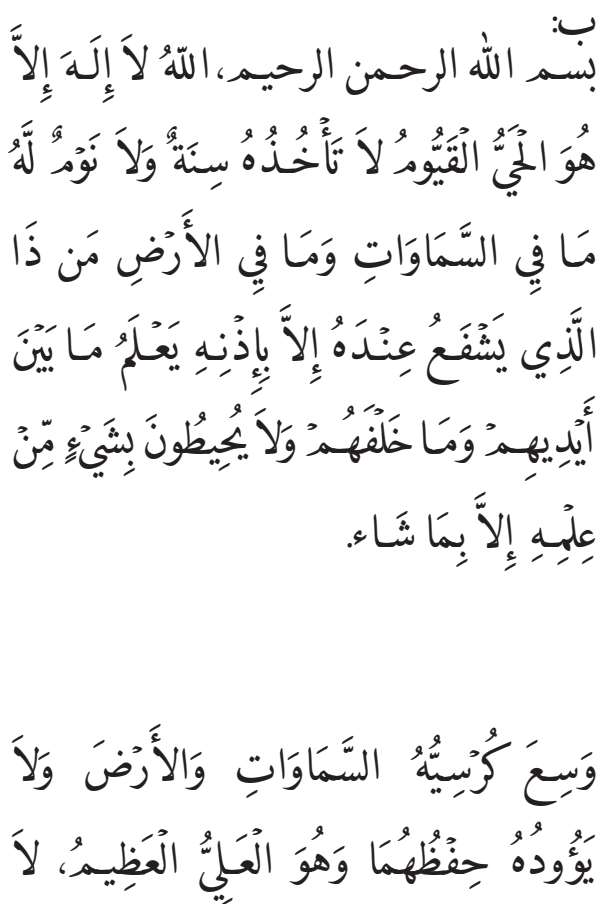

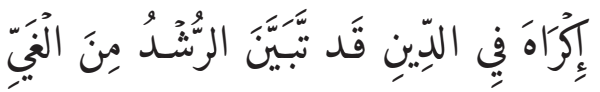

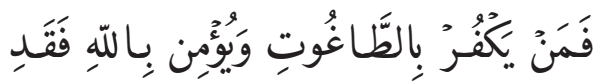

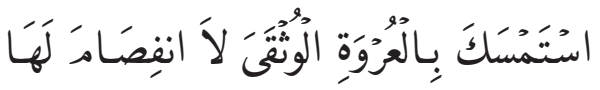
وَاللهُ سَمِيع عَلِيمُ، صـدق الله العلي

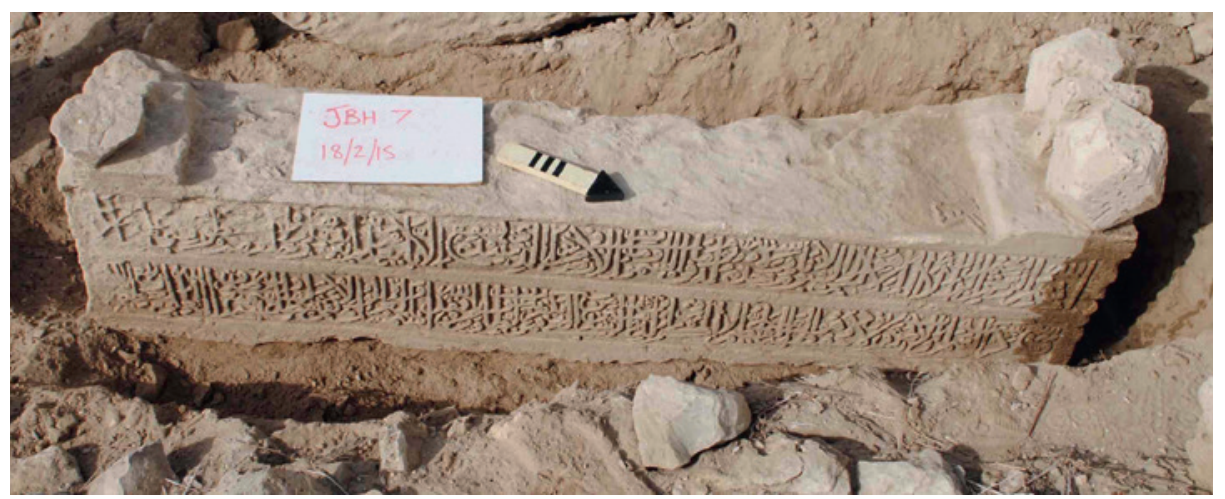

FIGURE 2.233 Surfaces B and E, JBH7 
C:

- No carving or inscriptions.

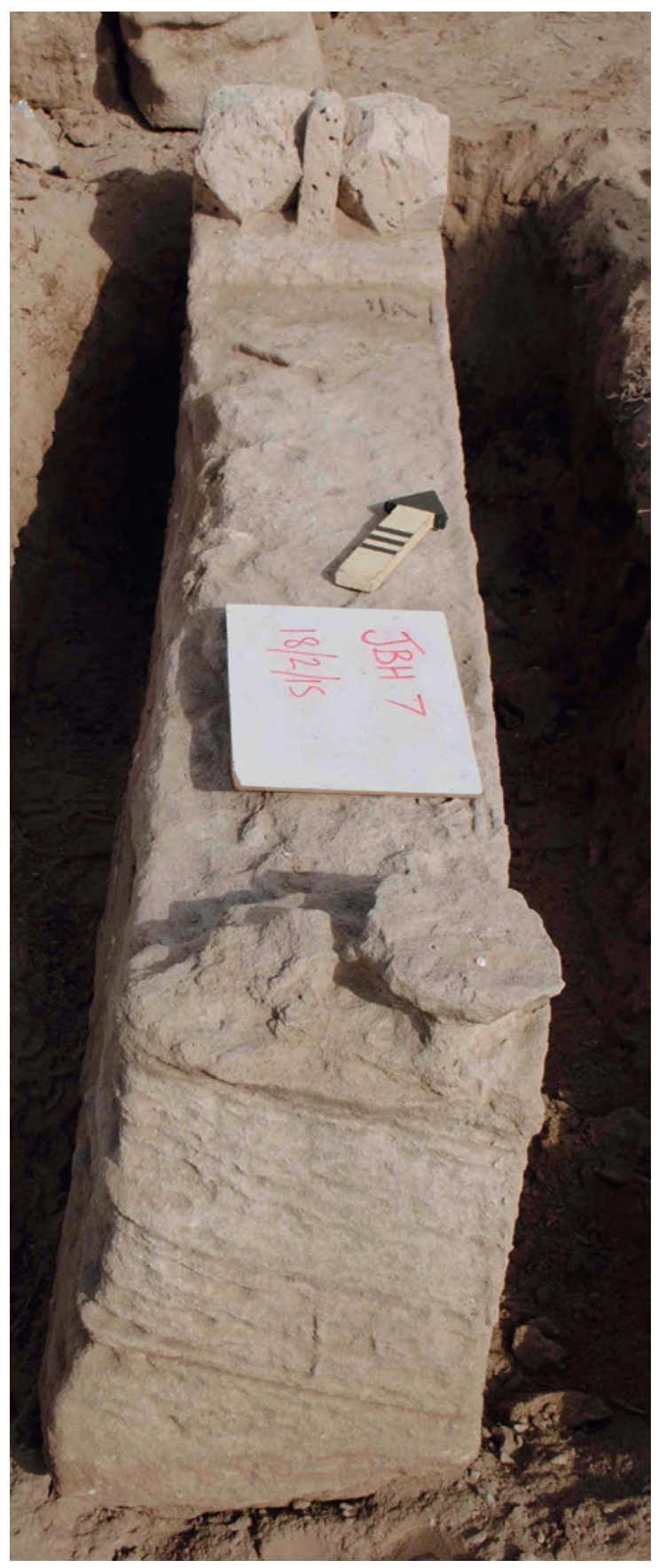

ج

لا توجد نقوش أوكّابات 
D:

- This is the grave of the late, the forgiven, Shaikh 'Ali bin Shaikh Ahmad

- bin 'Abd al-Salam, died in the fifteenth of Rajab, 1098.
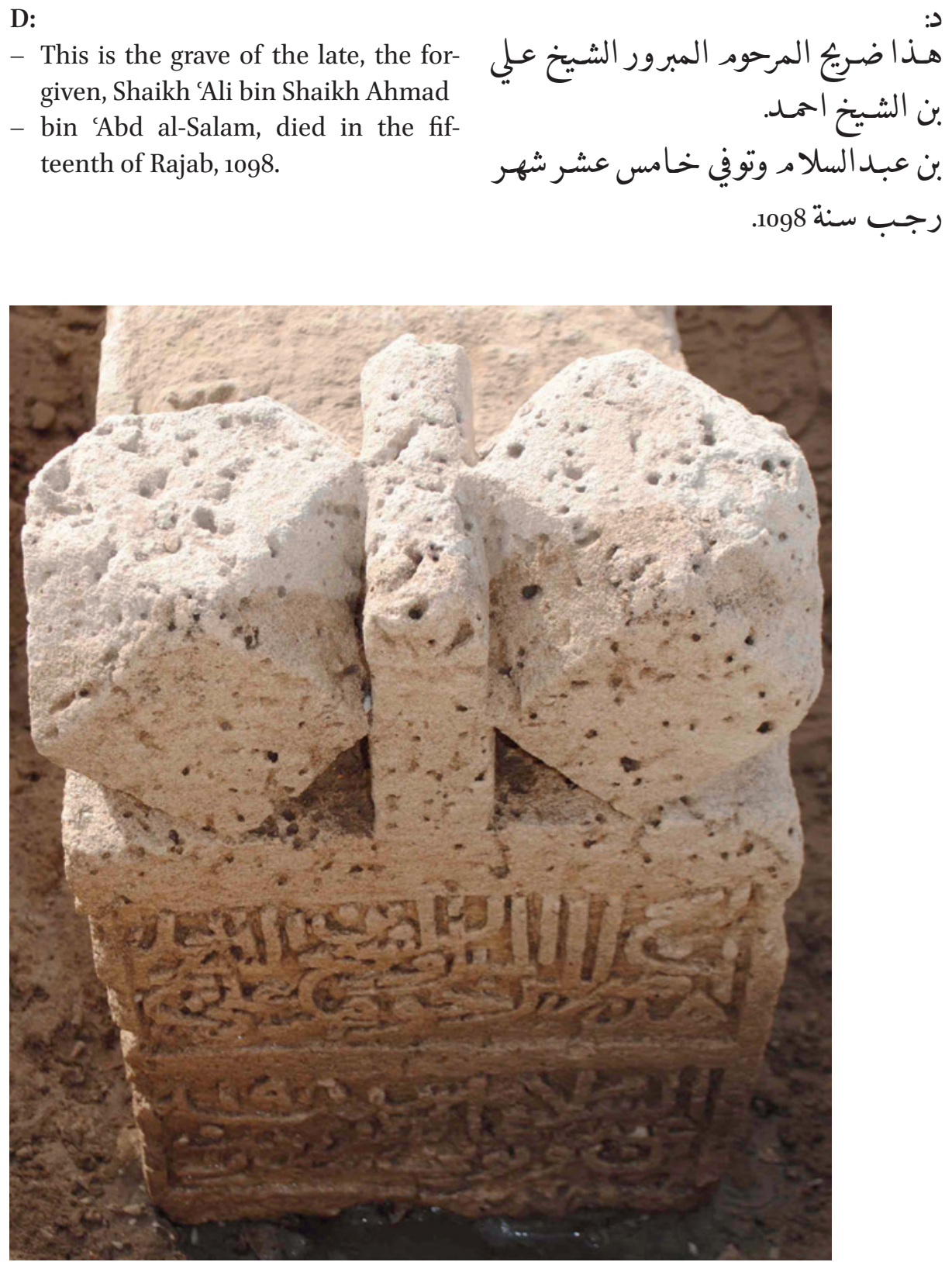

FIGURE 2.235 Surface D, JBH7

E:

- Written by al-Sayyid ...

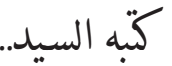

See Figure 2.233 


\section{Reference Number: JBH 8}

Co-ordinates: $26.21653^{\circ} \mathrm{N} 050.53095^{\circ} \mathrm{E}$

Dimensions: $116.5 \mathrm{~cm}(\mathrm{l}) \times 23 \mathrm{~cm}(\mathrm{w}) \times 42 \mathrm{~cm}(\mathrm{~h})$

\section{Orientation: NNW-SSE}

Description: Single hollow limestone slab gravestone. Very eroded on top and on some other areas. Partially legible inscriptions on four surfaces. Unidentifiable raised decoration at both ends. Excavated to expose complete gravestone.

\section{Arabic Transcription and Translation:}

A:

- Eden Paradise, whose doors will be opened for them ... (38:50)

- Grieve not, but receive the glad tidings of the paradise which you have been promised. We have been your friends in the life of this world and are in the Hereafter. Therein you shall have all that your inner-selves desire, and therein you shall have all for which you ask ... (41:30-31) God

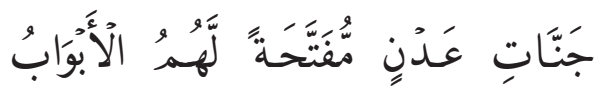

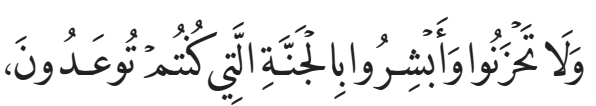

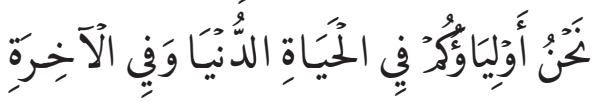
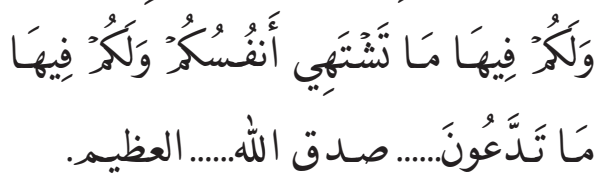
Almighty ... has spoken the truth.

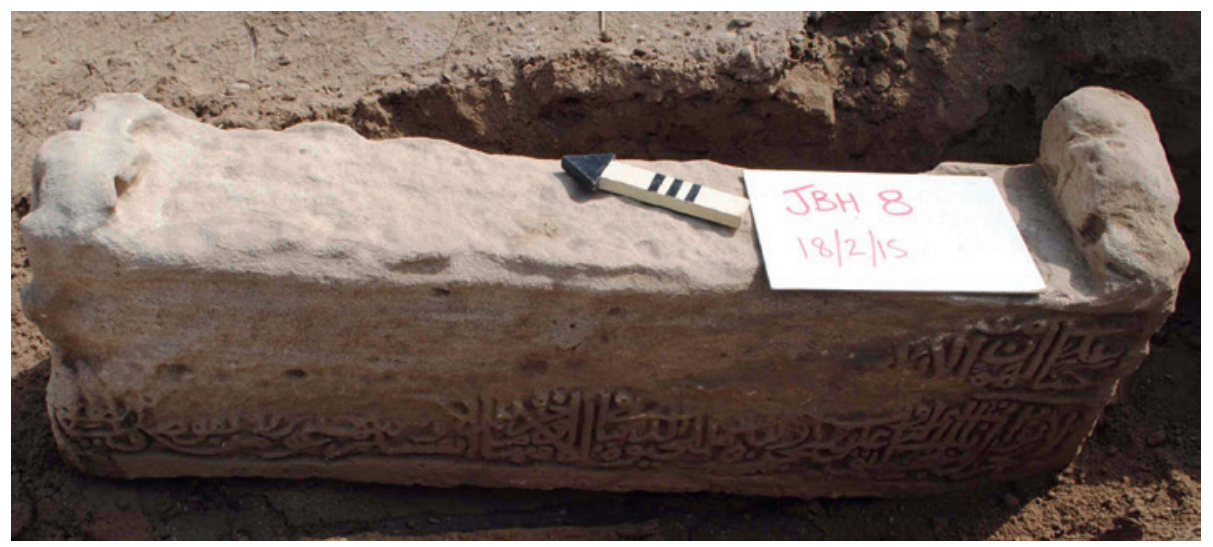

FIGURE 2.236 Surfaces A and E, JBH8 
B:

- In the Name of Allah, the Most Gracious, the Most Merciful. Allah, none has the right to be worshipped but he, the Ever Living, the One Who sustains and protects all that exists. Neither slumber nor sleep overtakes Him. To Him belongs whatever is in the heavens and whatever is on the earth. Who is he that can intercede

- With Him except by His permission! He knows what happens to them in this world, and will happen to them in the Hereafter and they will never compass anything of His Knowledge except that which He wills. His Seat extends over the heavens and the earth and $\mathrm{He}$ feels no fatigue in guarding and preserving them. And $\mathrm{He}$ is the Most High, the Most Great (2:255).

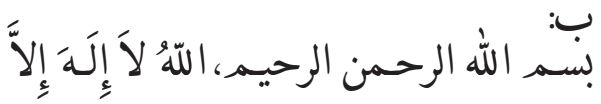

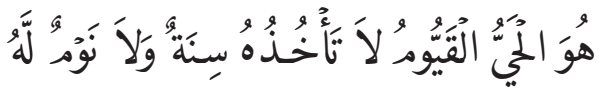

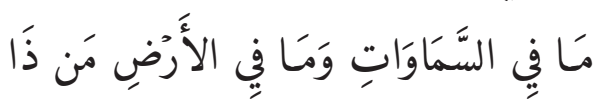

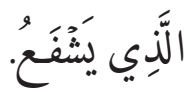

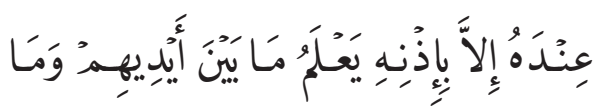

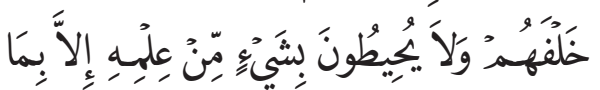

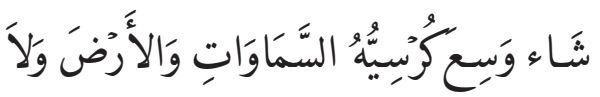

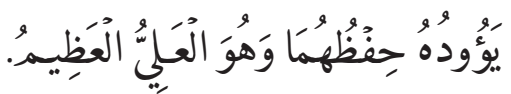

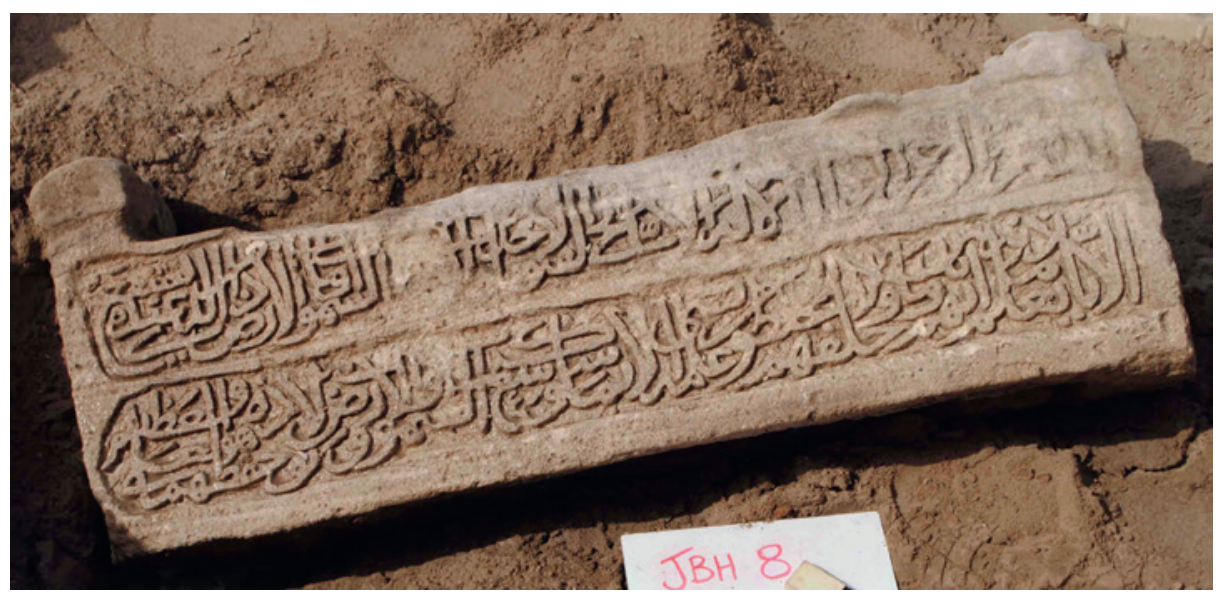

FIGURE 2.237 Surface B, JBH8 
C:

- ... from crop ... from ... at land ...
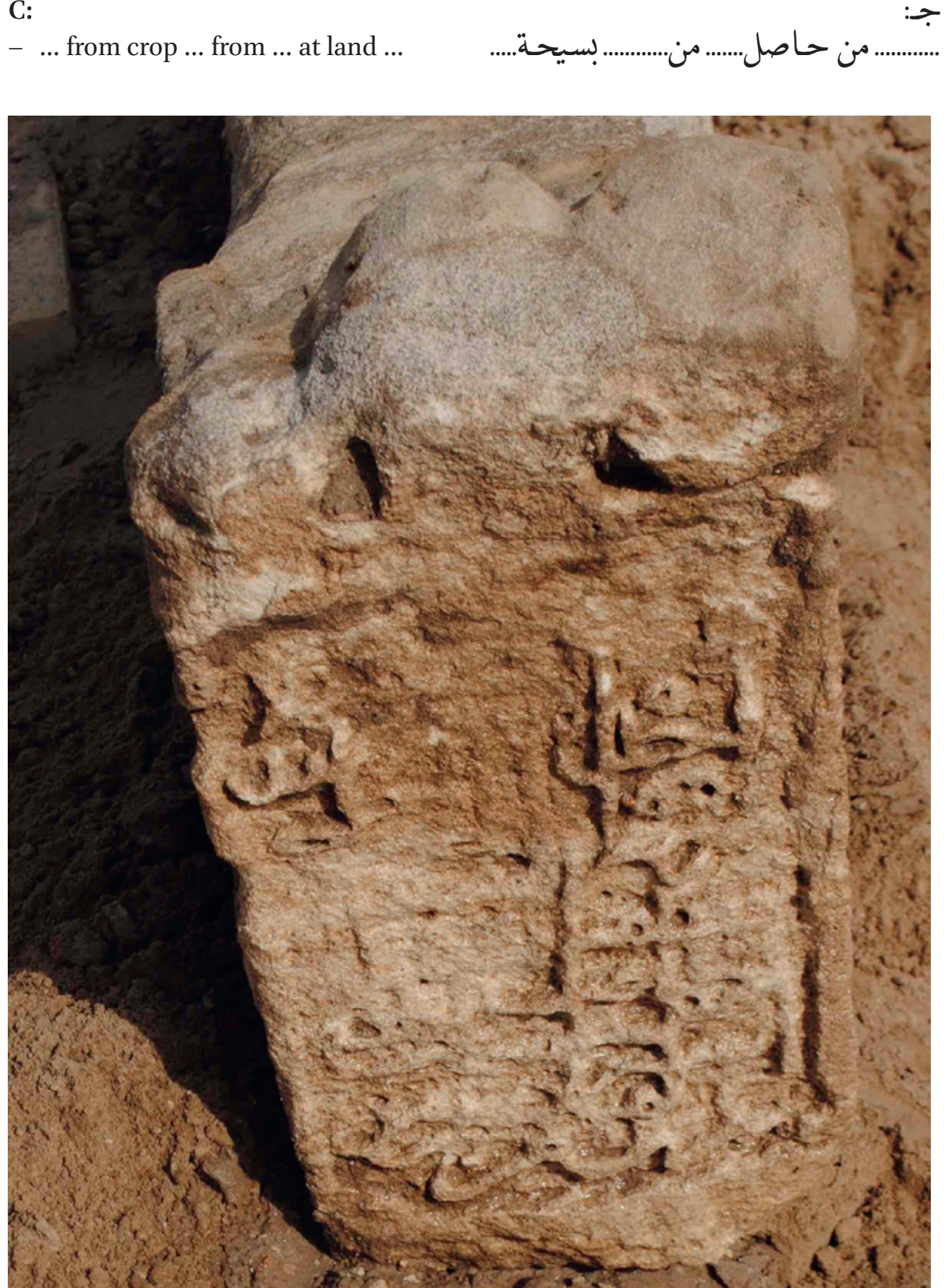

FIGURE 2.238 Surface C, JBH8 
D:

- ... The holy ... Shaikh ... bin Naser ...

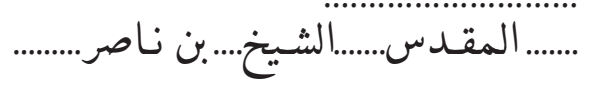

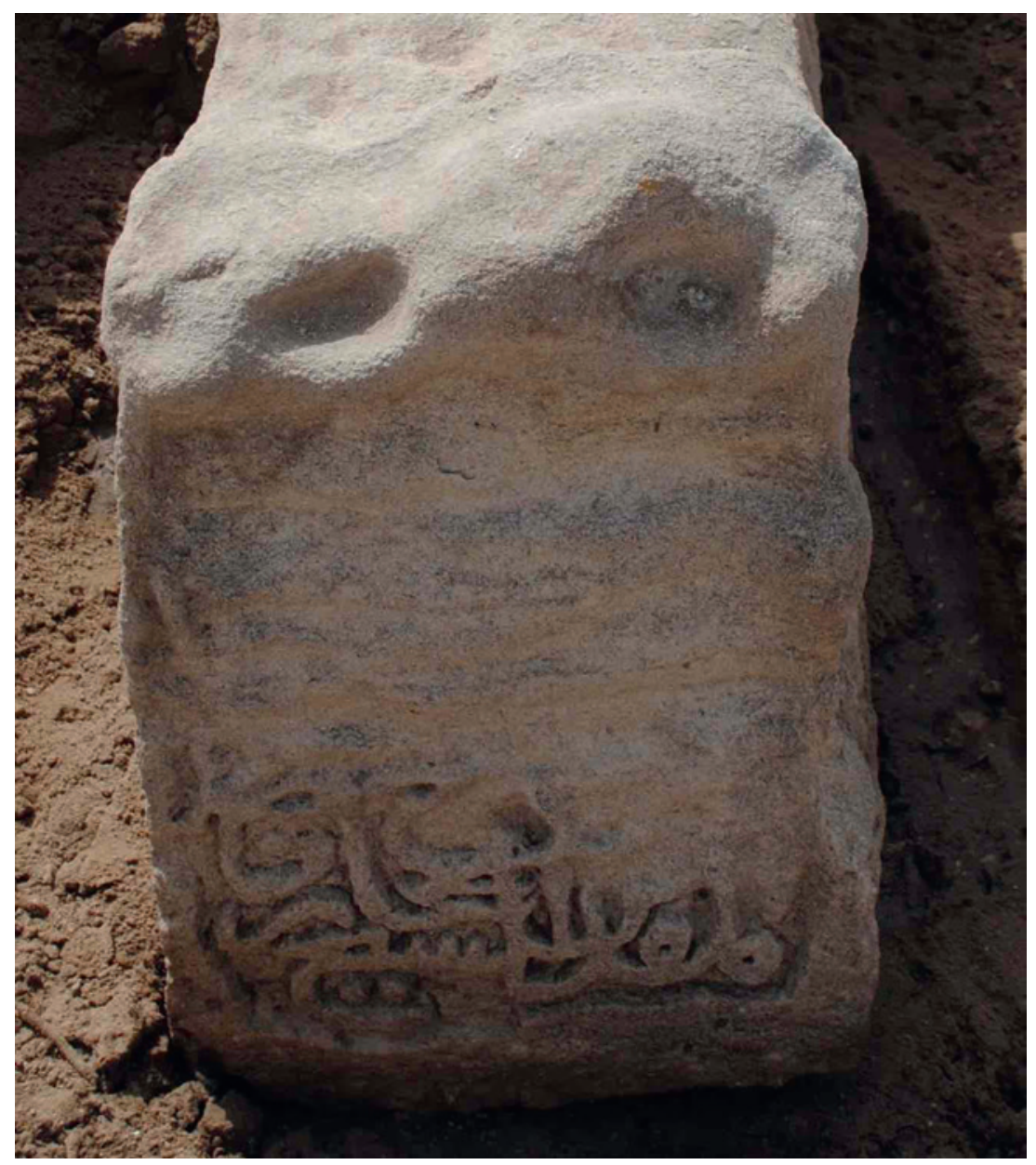

FIGURE 2.239 Surface D, JBH8

E:

- No carving or inscriptions.

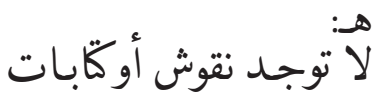

See Figure 2.236 
Reference Number: JBH 9

Co-ordinates: $26.21651^{\circ} \mathrm{N} 050.53094^{\circ} \mathrm{E}$

Dimensions: $66 \mathrm{~cm}(\mathrm{l}) \times 22 \mathrm{~cm}(\mathrm{w}) \times 34.5 \mathrm{~cm}(\mathrm{~h})$

Orientation: NW-SE

Description: Single hollow limestone slab gravestone. Very eroded. Probably once one part of a double slab gravestone. Unidentifiable raised decoration at one end. Partial inscriptions on two surfaces.

\section{Arabic Transcription and Translation:}

A:

- No carving or inscriptions.
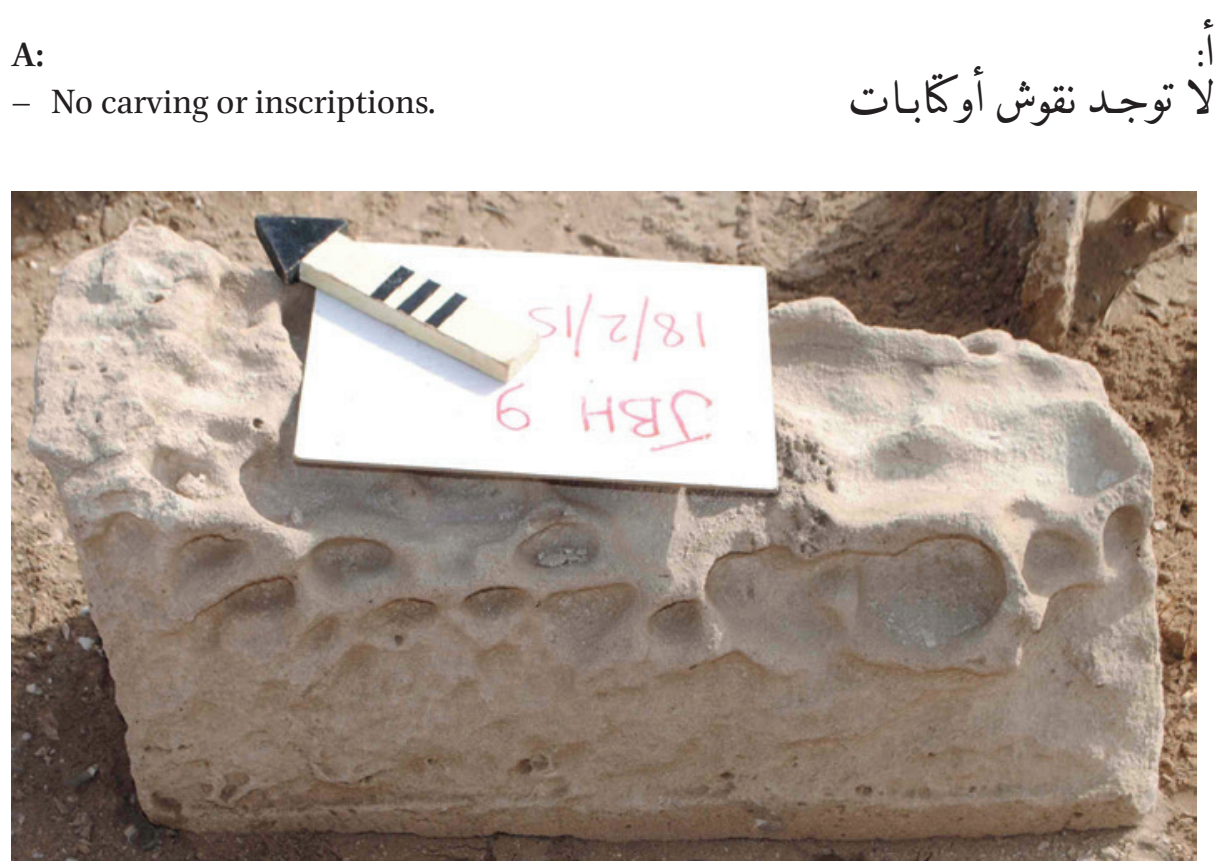

FIGURE 2.240 Surface A, JBH9

B:

$-\ldots$

- ... Allah ...

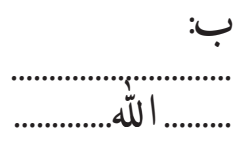




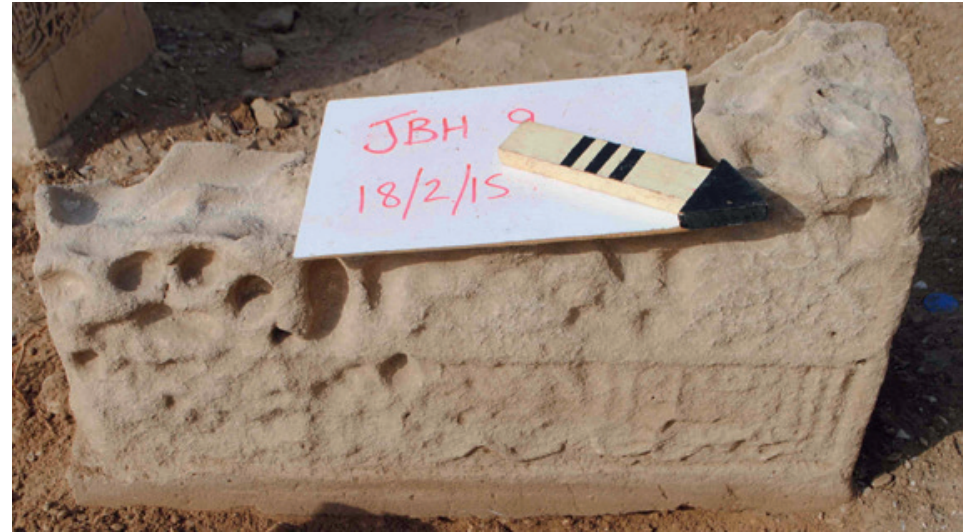

C:

- No carving or inscriptions.

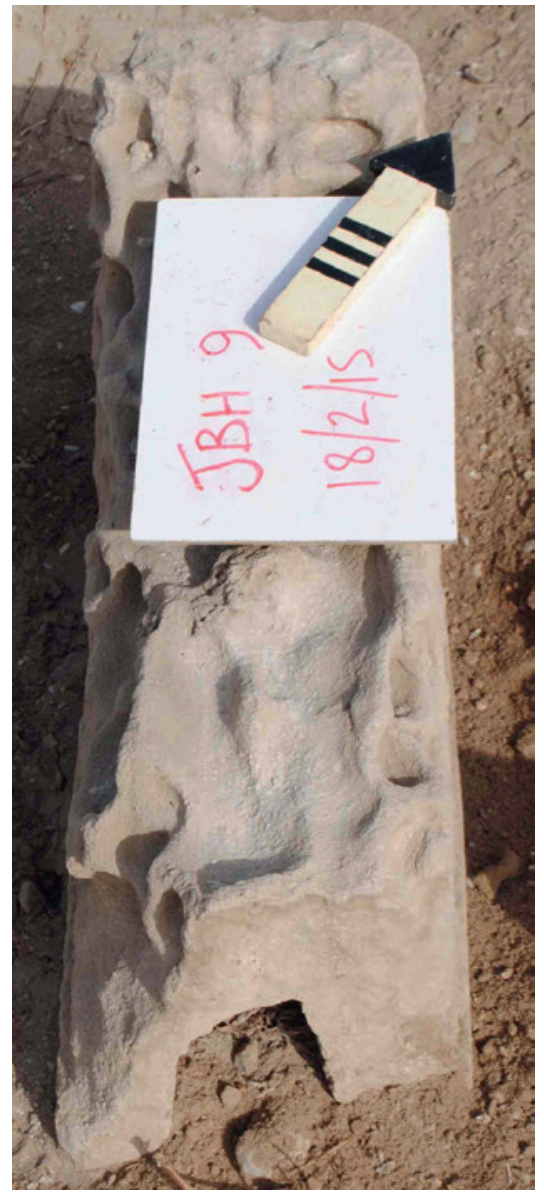

FIGURE 2.242

Surfaces C and E, JвH 9
FIGURE 2.241

Surface B, JBн9 
D:

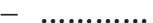

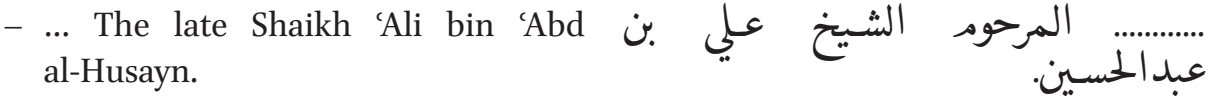

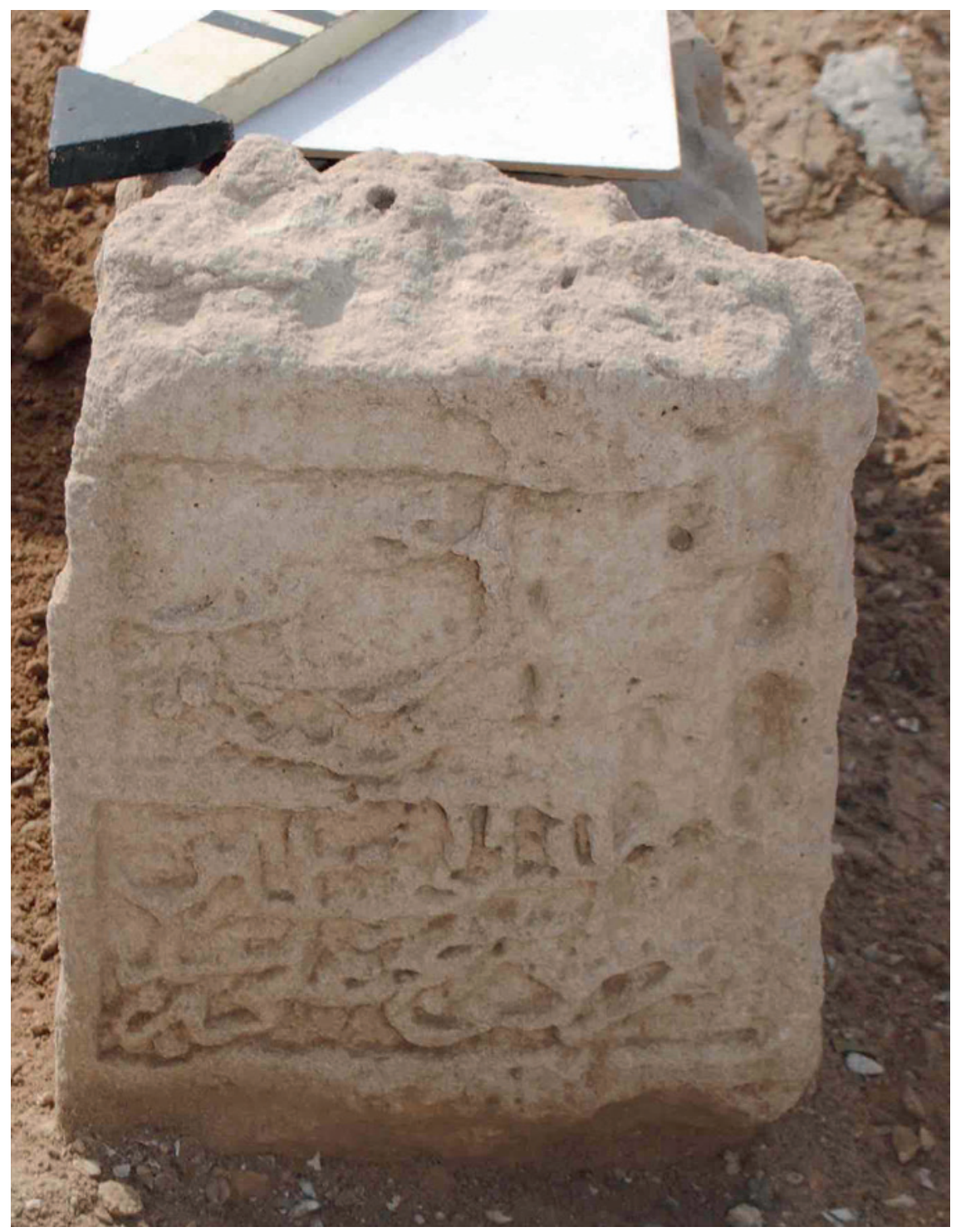

FIGURE 2.243 Surface E, JBH9

E:

- No carving or inscriptions.

لا تهـ: توجـد نقوش أوكابـات

See Figure 2.242 
Reference Number: JBH10

Co-ordinates: $26.21650^{\circ} \mathrm{N} 050.53093^{\circ} \mathrm{E}$

Dimensions: $155 \mathrm{~cm}(\mathrm{l}) \times 31.5 \mathrm{~cm}(\mathrm{w}) \times 55.5 \mathrm{~cm}(\mathrm{~h})$

\section{Orientation: NNW-SSE}

Description: Single limestone slab gravestone. Shallow carved rounded niche design on upper surface (E). Three element raised decoration formed of two facetted cubes and a central thin flat rounded slab all set on a rectangular plinth at both ends. Well-carved inscriptions on five surfaces. The roughly carved base that was designed to be below the ground surface can be seen. In generally good condition but with some patches of erosion.

\section{Arabic Transcription and Translation:}

A:

- The angels descend upon them, saying: Fear not nor grieve, but receive the glad tidings of the paradise which you have been promised. We have been your friends in the life of this world and are in the Hereafter. Therein you shall have all that your inner-selves desire, and therein you shall have all for which you ask. An entertainment from the Oft-Forgiving, Most Merciful (41:30-32). Eden Paradise, whose doors will be opened for them, Therein they will recline, therein they will call for fruits in abundance

- And drinks. And beside them will be chaste females restraining their glances and of equal ages. This is what you are promised for the day of Reckoning. Verily, this is our provision which will never finish (38:5054). Eat and drink comfortably for that which you used to do. They will recline on thrones arranged in ranks. And shall marry them to ... (52:19-20).

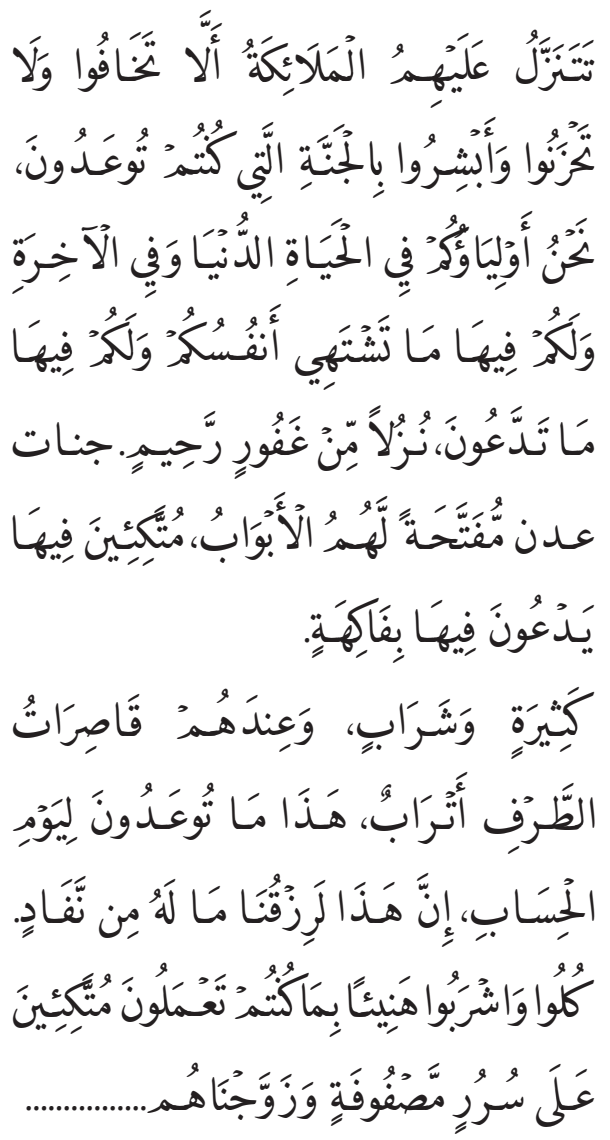




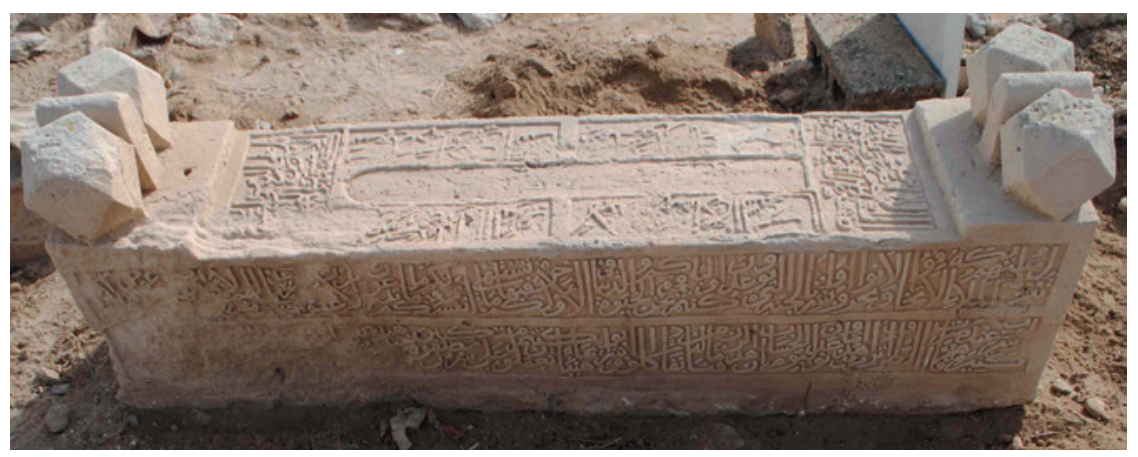

FIGURE 2.244 Surfaces A and E, JBH10

B:

- In the Name of Allah, the Most Gracious, the Most Merciful. Allah, none has the right to be worshipped but he, the Ever Living, the One Who sustains and protects all that exists. Neither slumber nor sleep overtakes Him. To Him belongs whatever is in the heavens and whatever is on the earth. Who is he that can intercede with Him except by His permission! He knows what happens to them in this world, and will happen to them in the Hereafter and they will never compass anything of His Knowledge except that which He wills.

- His Seat extends over the heavens and the earth. And He feels no fatigue in guarding and preserving them. And He is the Most High, the Most Great. There is no compulsion in religion. Verily, the right path has become distinct from the wrong path. Whoever ... (2:255-256).
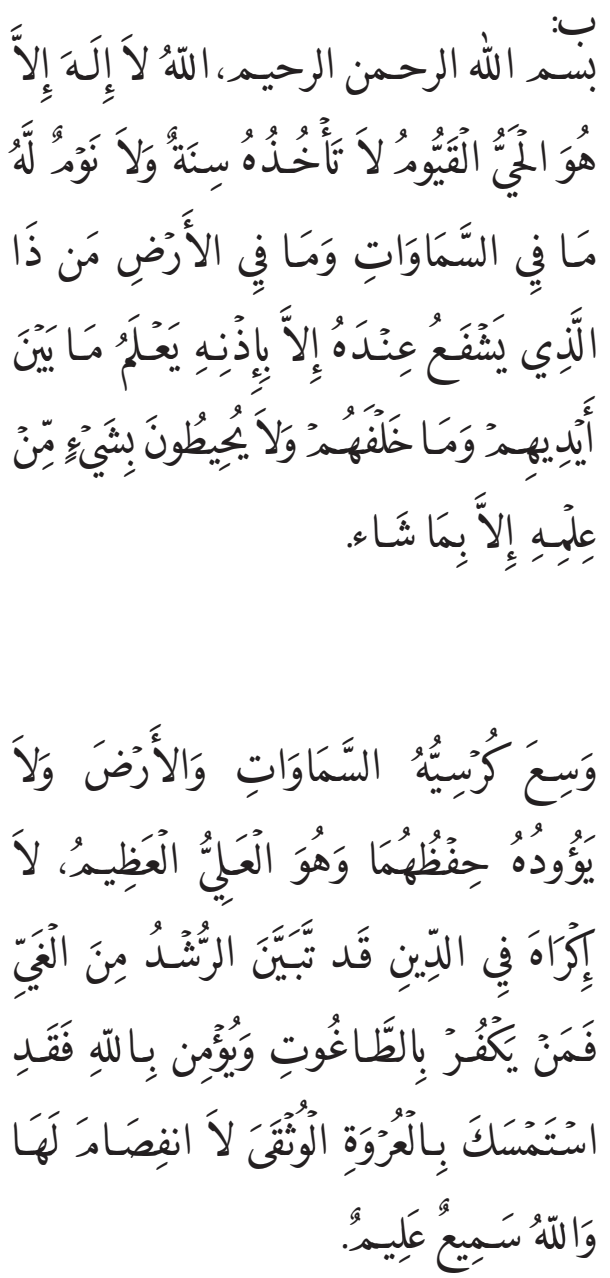


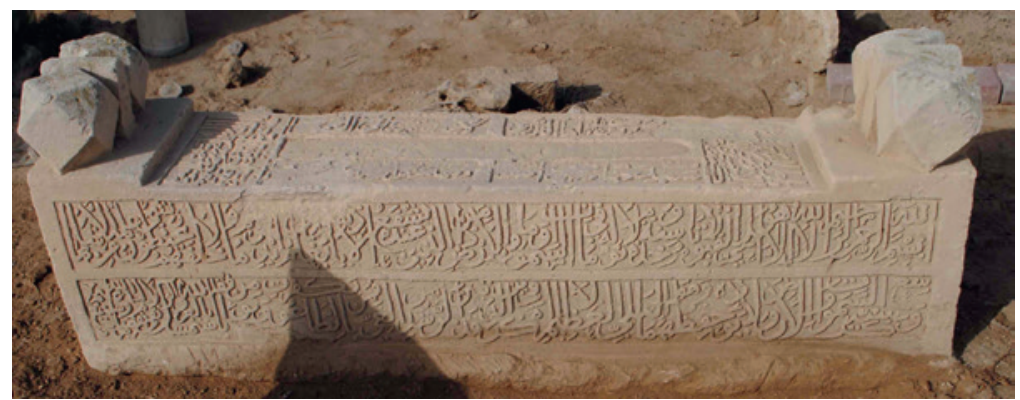

FIGURE 2.245 Surface B, JBH10

C:

- Accomplishment of the Quran...... followed by sixteen muhammadiyyah from the income ... . Baskets ...

- Twenty shares ... completeness ... is ten shares ... Ten shares from zakat ...

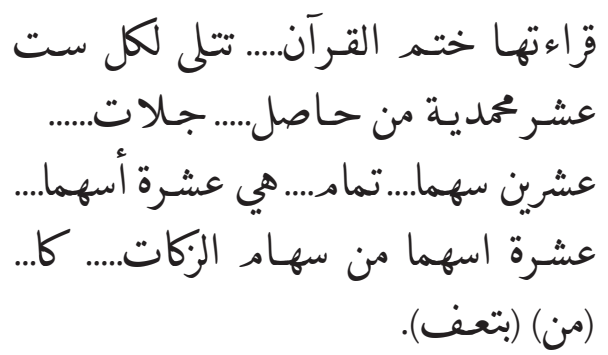

- Engraved by Muhammad Sa'id ...
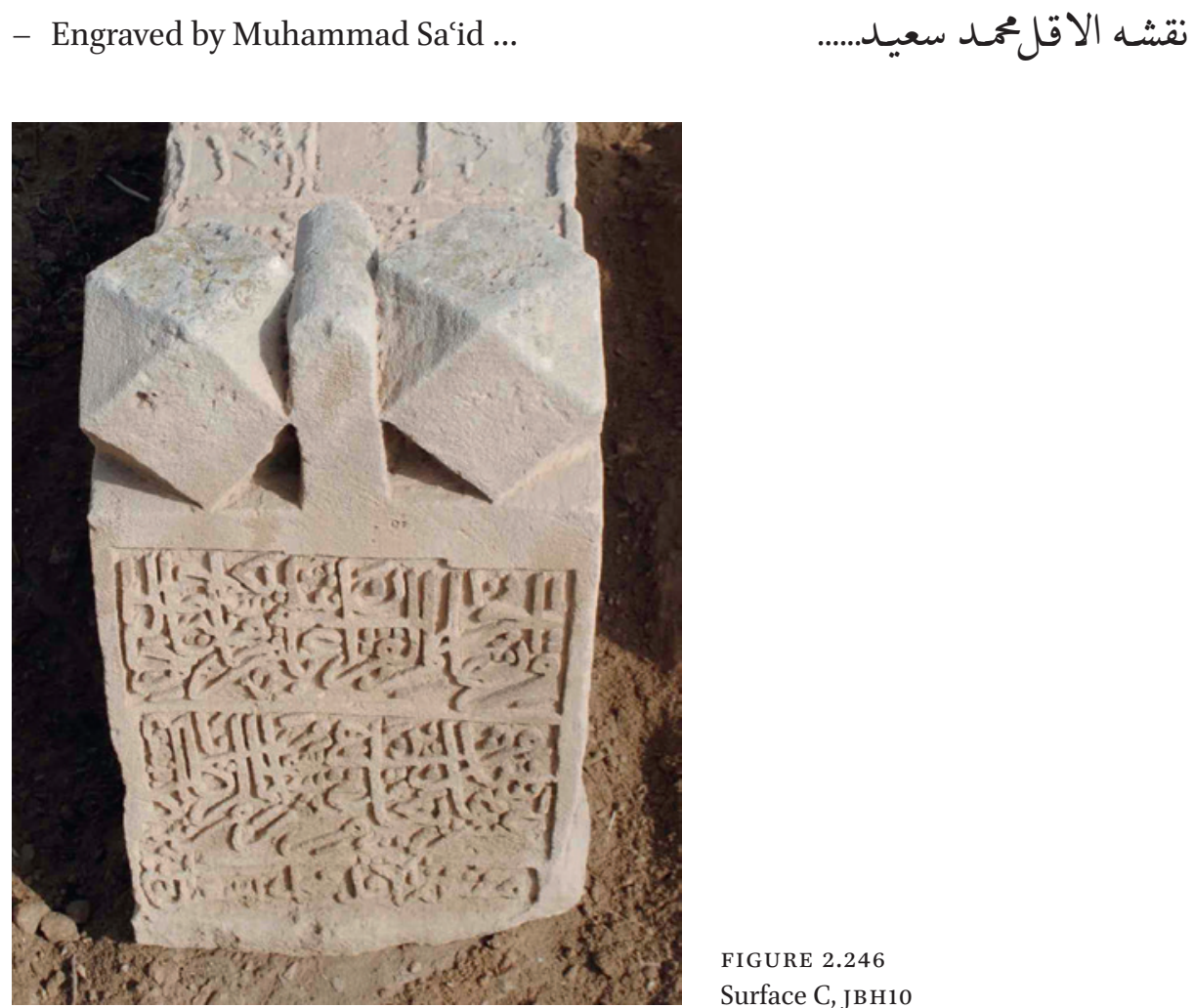
D:

- This is the shrine of the late Hakima (possibly Halima) bint Shaikh 'Ali bin Shaikh Ahmad bin ...

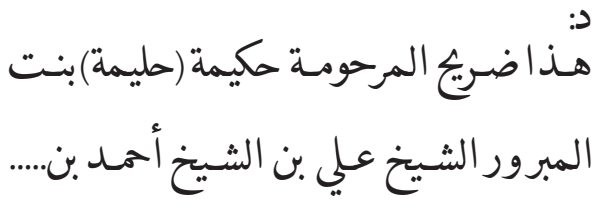

- ... in twelfth of Jumada al-awwal in one thousand and one hundred.

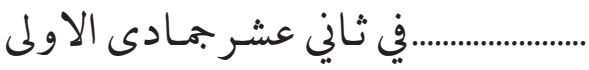

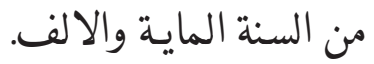

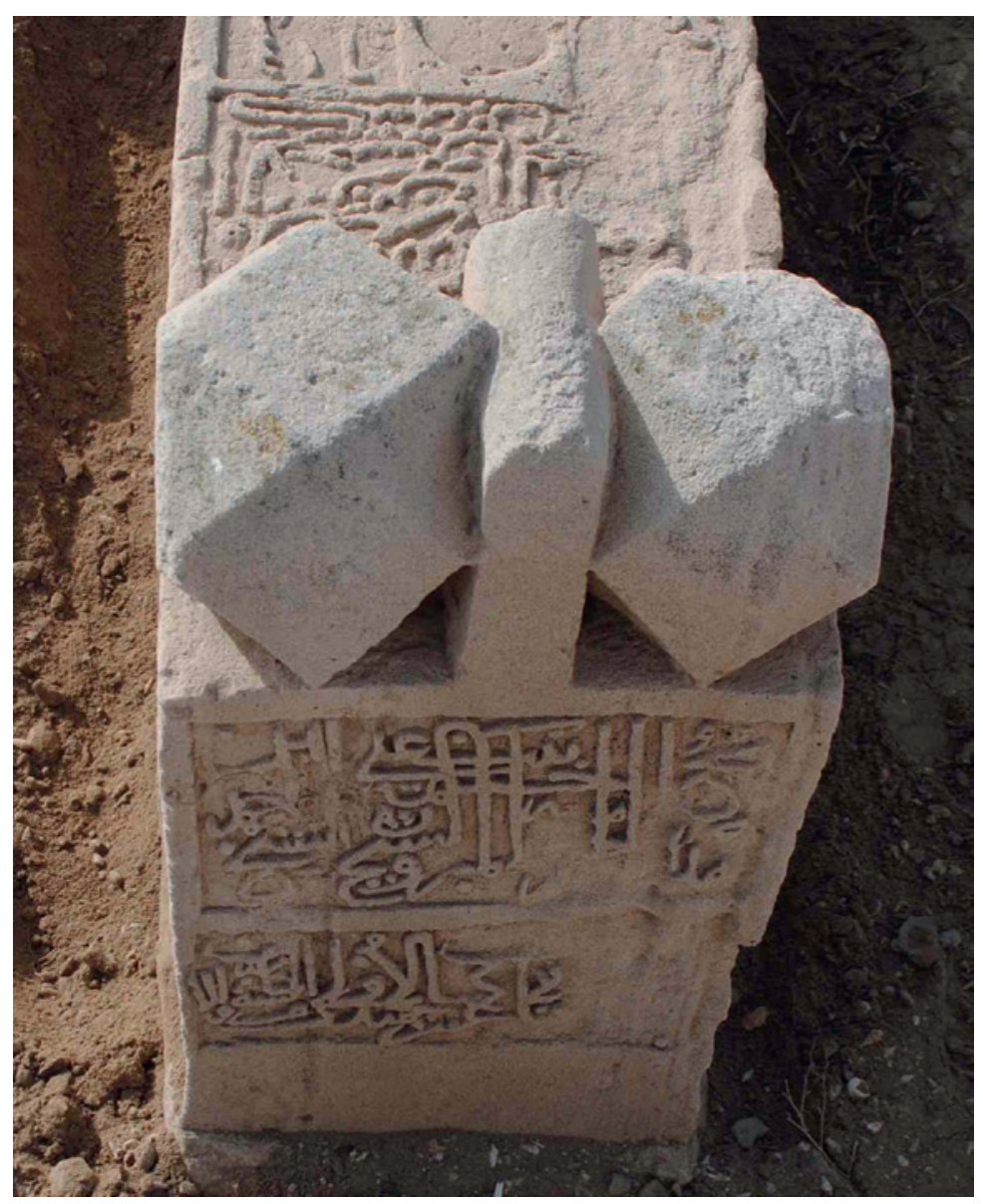

FIGURE 2.247 Surface D, JBH10

E:

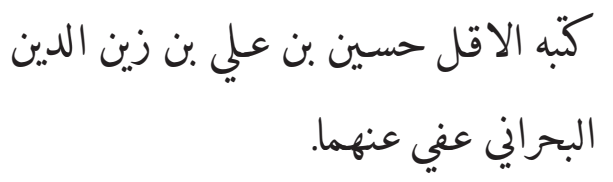
al-Din al-Bahrani, may Allah forgive them. 
- ... Oh how the soil embedded her until the cloud cried on her.

- She has got the happiness of the world and the afterlife, and she went to Allah until Allah showed her ...

- Engraved by al-Sayyid Naser Bin alSayyid Hashim, May Allah forgive them.

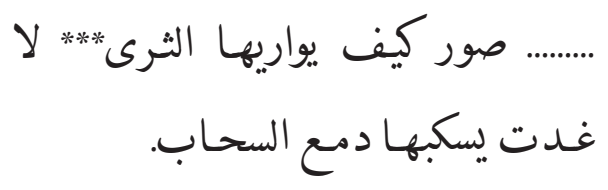

سعدـت دنيـا ودين واتت **** ربها حتى اراه............

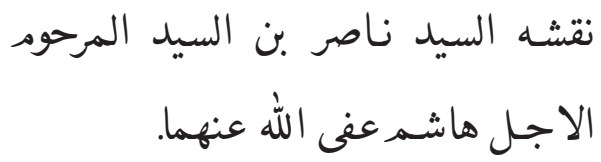

See Figure 2.244

Reference Number: JBH11

Co-ordinates: $26.21654^{\circ} \mathrm{N} 050.53101^{\circ} \mathrm{E}$

Dimensions: $127 \mathrm{~cm}(\mathrm{l}) \times 30 \mathrm{~cm}(\mathrm{w}) \times 41 \mathrm{~cm}(\mathrm{~h})$

\section{Orientation: NW-SE}

Description: Single limestone slab gravestone. Shallow carved pointed niche design on upper surface (E). Eroded unidentifiable probably three element raised decoration at both ends. Double rosettes carved at each end on upper surface (E). Inscriptions on five surfaces. Excavated to expose whole gravestone.

\section{Arabic Transcription and Translation:}

A:

- The heavens and the earth. And He is the Most High, the Most Great (2:255). And those who kept duty to their Lord will be led to Paradise in groups, until,

- When they reach it, and its gates are opened and its keepers say to them: peace be upon you, you have done well, so enter here to abide therein (39:73).
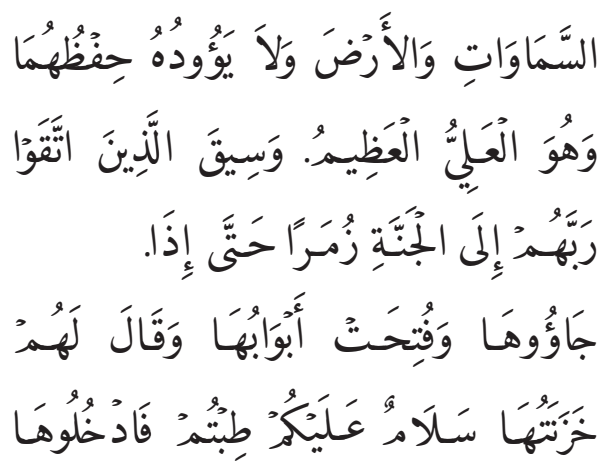

خَالِِ.jِنَ. 


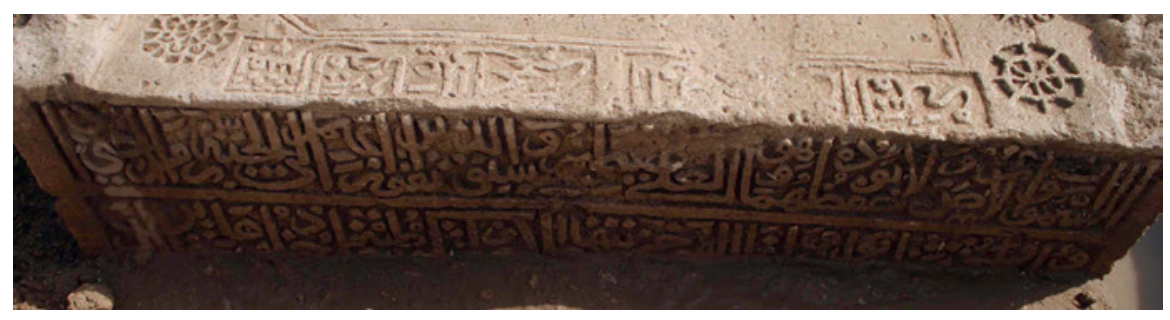

FIGURE 2.248 Surface A, JBH11

B:

- In the Name of Allah, the Most Gracious, the Most Merciful. Allah, none has the right to be worshipped but he, the Ever Living, the One Who sustains and protects all that exists. Neither slumber nor sleep overtakes Him. To Him belongs whatever is in the heavens and whatever is on

- The earth. Who is he that can intercede with Him except by His permission! He knows what happens to them in this world, and will happen to them in the Hereafter and they will never compass anything of His Knowledge except that which $\mathrm{He}$ wills. His Seat extends over (2:255).

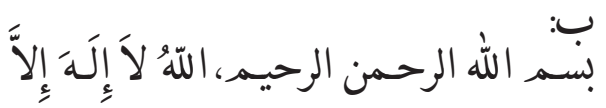

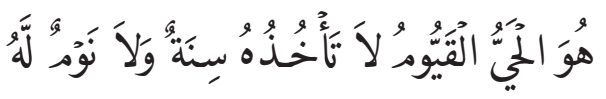

$$
\begin{aligned}
& \text { مَا فِي السَّمَاوَاتِ وَمَا فِي. }
\end{aligned}
$$
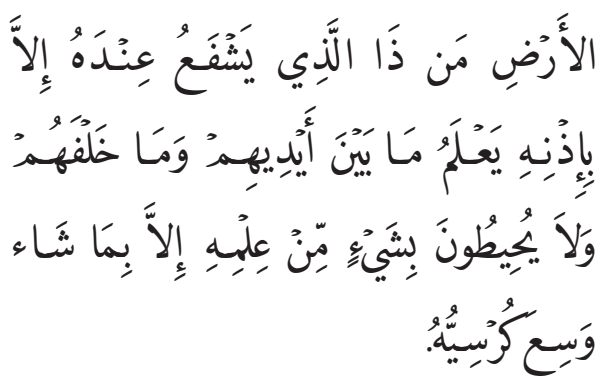

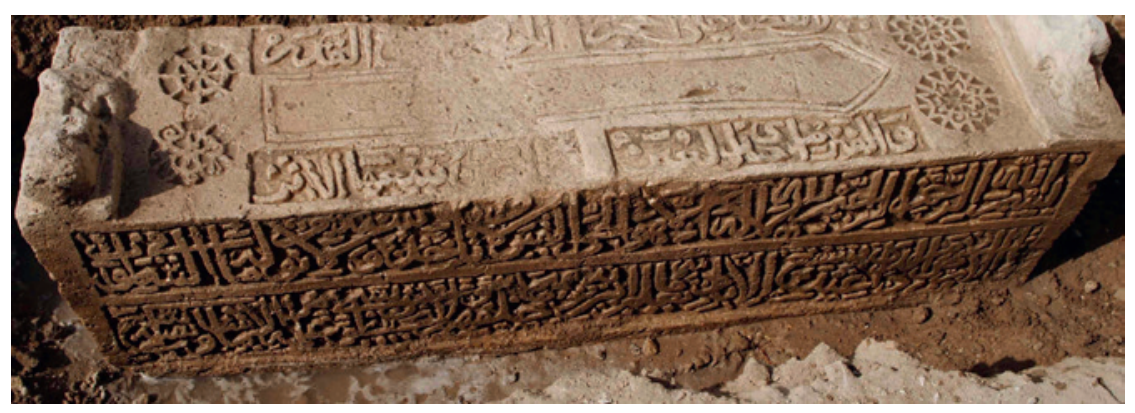

FIGURE 2.249 Surface B, JBH11 
C:

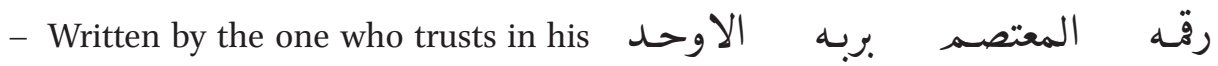
God, 'Abd al-Husayn bin Muhammad.

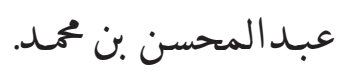

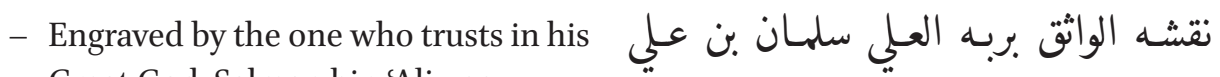
Great God, Salman bin 'Ali, 1007.

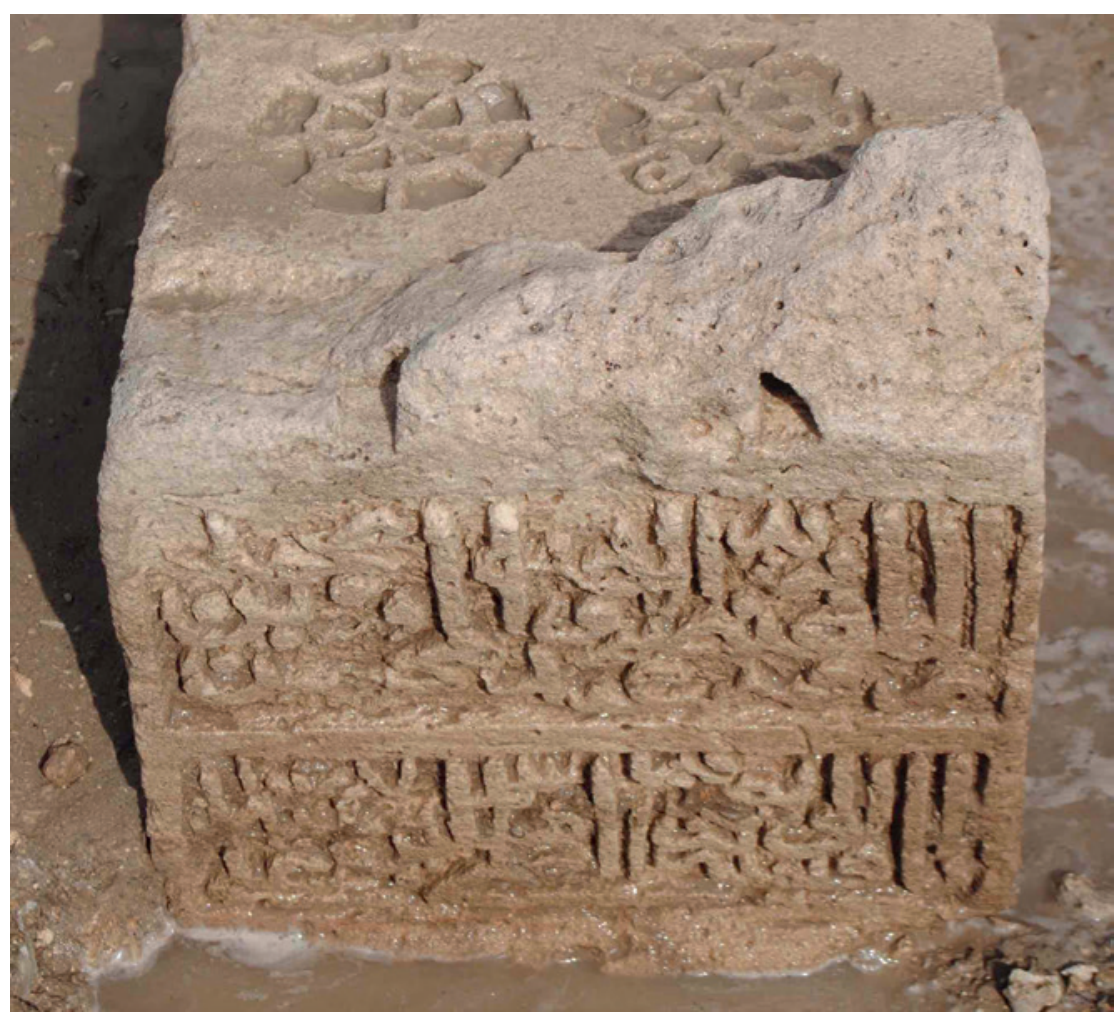

FIGURE 2.250 Surface C, JBH11

D: D:
- The death of the Blissful, 'Abd al- نان اندراج المحبور عبدالسلاه .بن
Salam bin Naser,

- The Truthful, the Beacon, was in الحق المنـار العامر (باقو) لثامنه من شهر eighth of Rabic,

- After one thousand and three of the Prophet's migration.

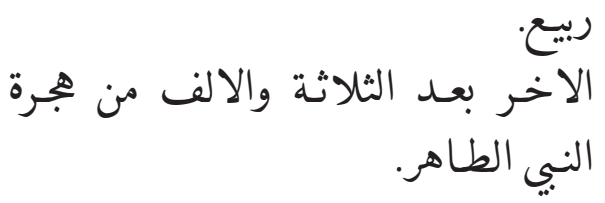




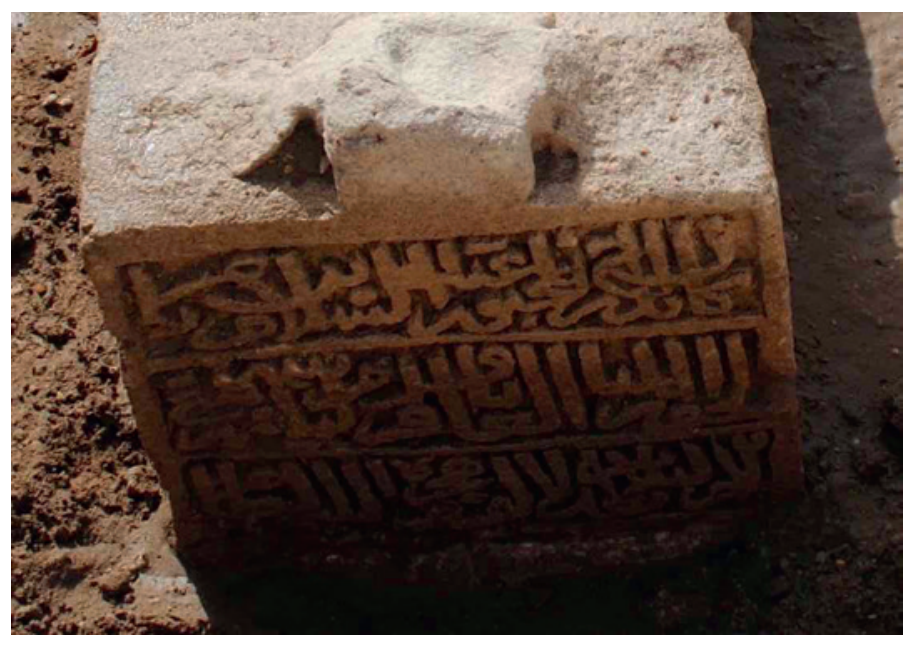

FIGURE 2.251

Surface D, JBH11

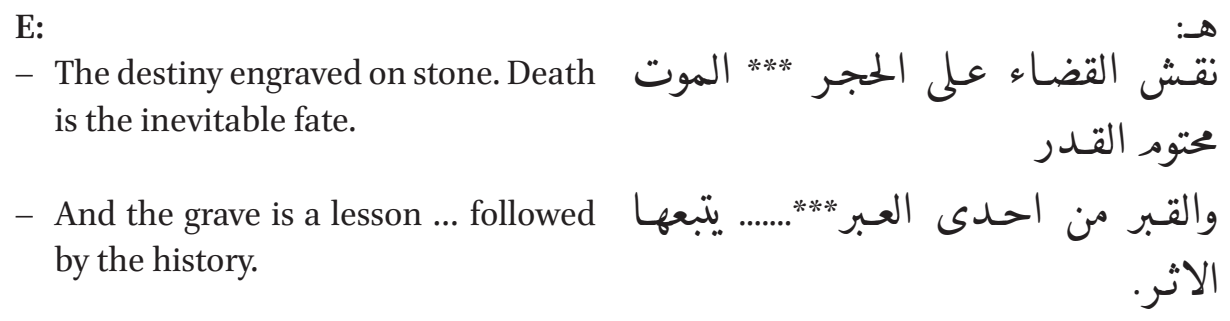

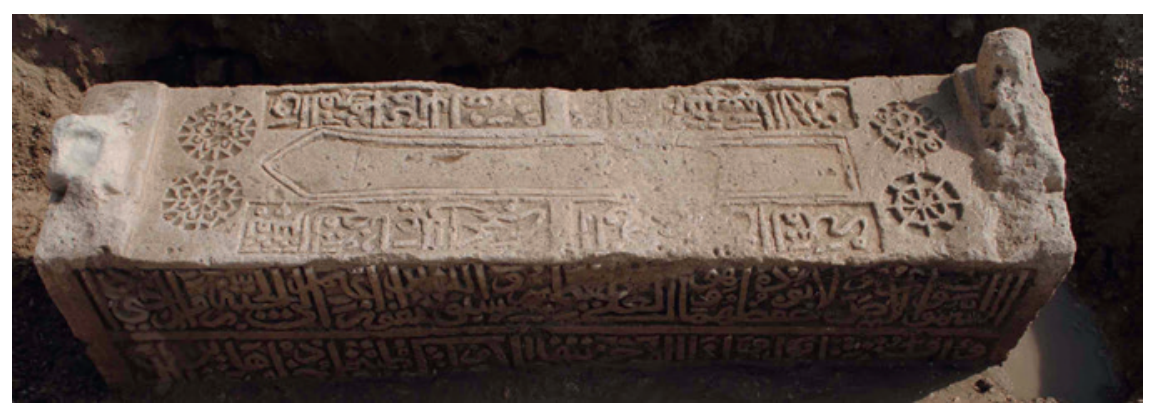

FIGURE 2.252 Surface E, JBH11

Reference Number: JBH12

Co-ordinates: $26.21634^{\circ} \mathrm{N} 050.52946^{\circ} \mathrm{E}$

Dimensions: $151 \mathrm{~cm}(\mathrm{l}) \times 30 \mathrm{~cm}(\mathrm{w}) \times 56 \mathrm{~cm}(\mathrm{~h})$

Orientation: NW-SE 
Description: Single hollow limestone slab gravestone. Found lying on its side and excavated to expose inscriptions on four surfaces, but too fragile to move to record the buried surface (B). Three element raised decoration formed of two facetted cubes and a central thin rounded slab all set on a rectangular plinth at each end. Shallow carved pointed niche design on upper surface $(\mathrm{E})$.

\section{Arabic Transcription and Translation:}

A:

- The angels descend upon them, saying: Fear not nor grieve, but receive the glad tidings of the paradise which you have been promised. We have been your friends in the life of this world and are in the Hereafter. Therein you shall have all that your inner-selves desire, and therein you shall have all for which you ask (41:30-31).

- Eden Paradise, whose doors will be opened for them. Therein they will recline, therein they will call for fruits in abundance and drinks. And beside them will be chaste females restraining their glances and of equal ages. This is what you are promised for the day of Reckoning. Verily, this is our provision which will never finish (38:50-54). God Almighty has spoken

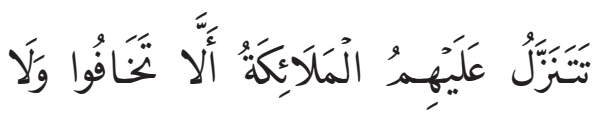

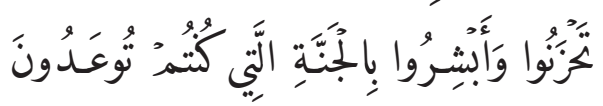

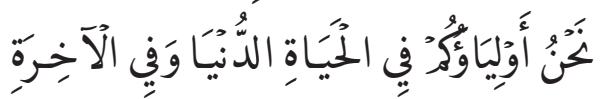

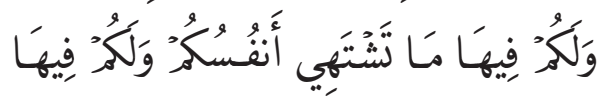

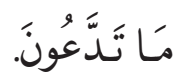

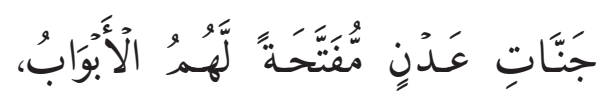

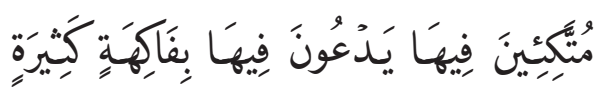
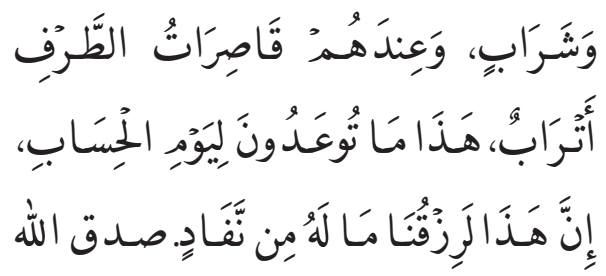
the truth. 


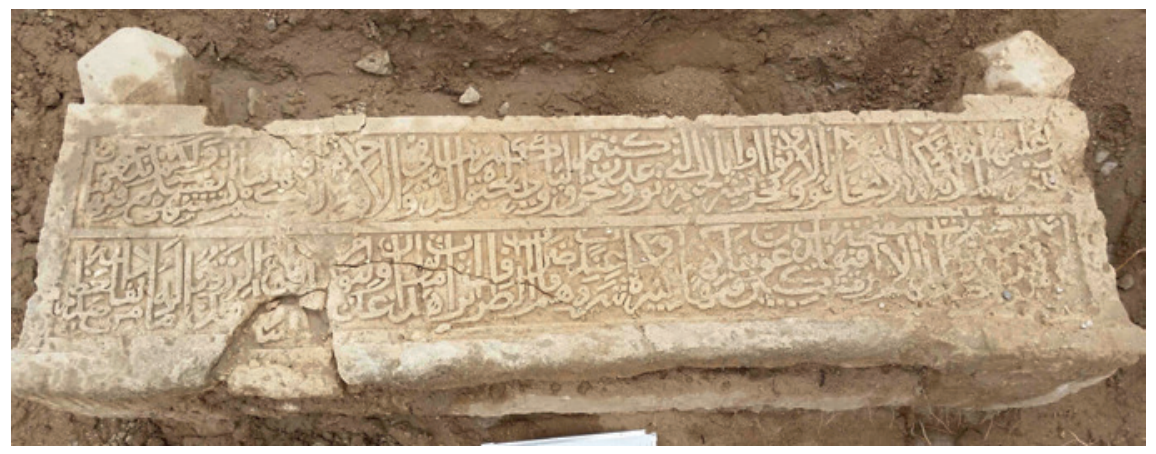

FIGURE 2.253 Surface A, JBH12

B:

- Not able to read.

C: - ... This is ... al-Bahrayn ... Al ...
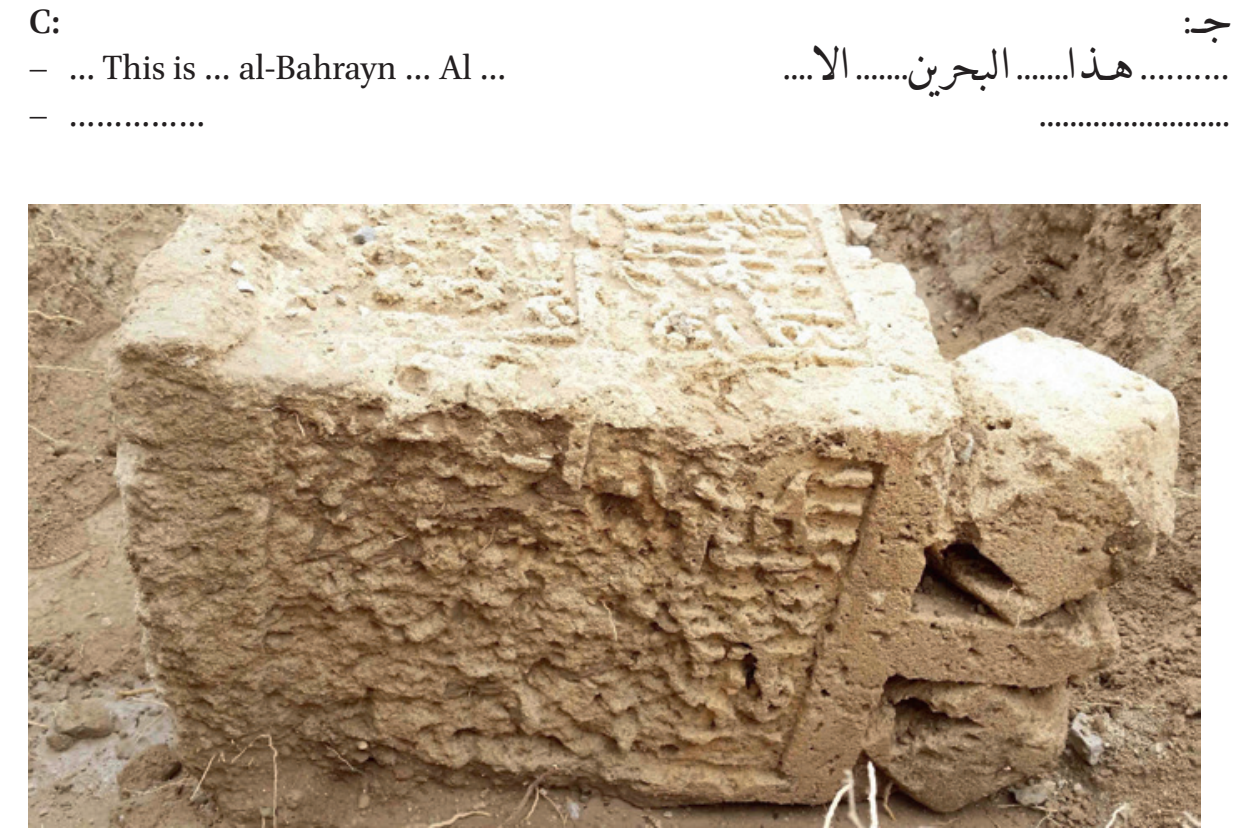

FIGURE 2.254 Surface C, JBH12

D:

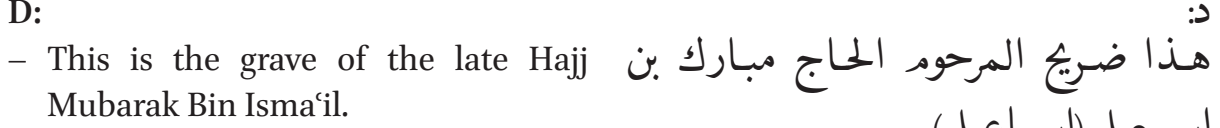

- Died after one thousand and two.

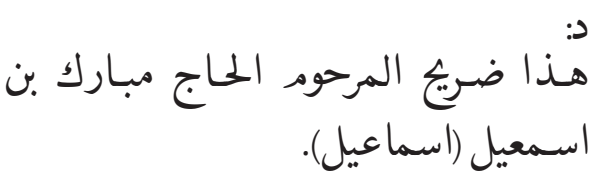

$$
\begin{aligned}
& \text { توفي بعـد سنة اثنـين والالف. }
\end{aligned}
$$




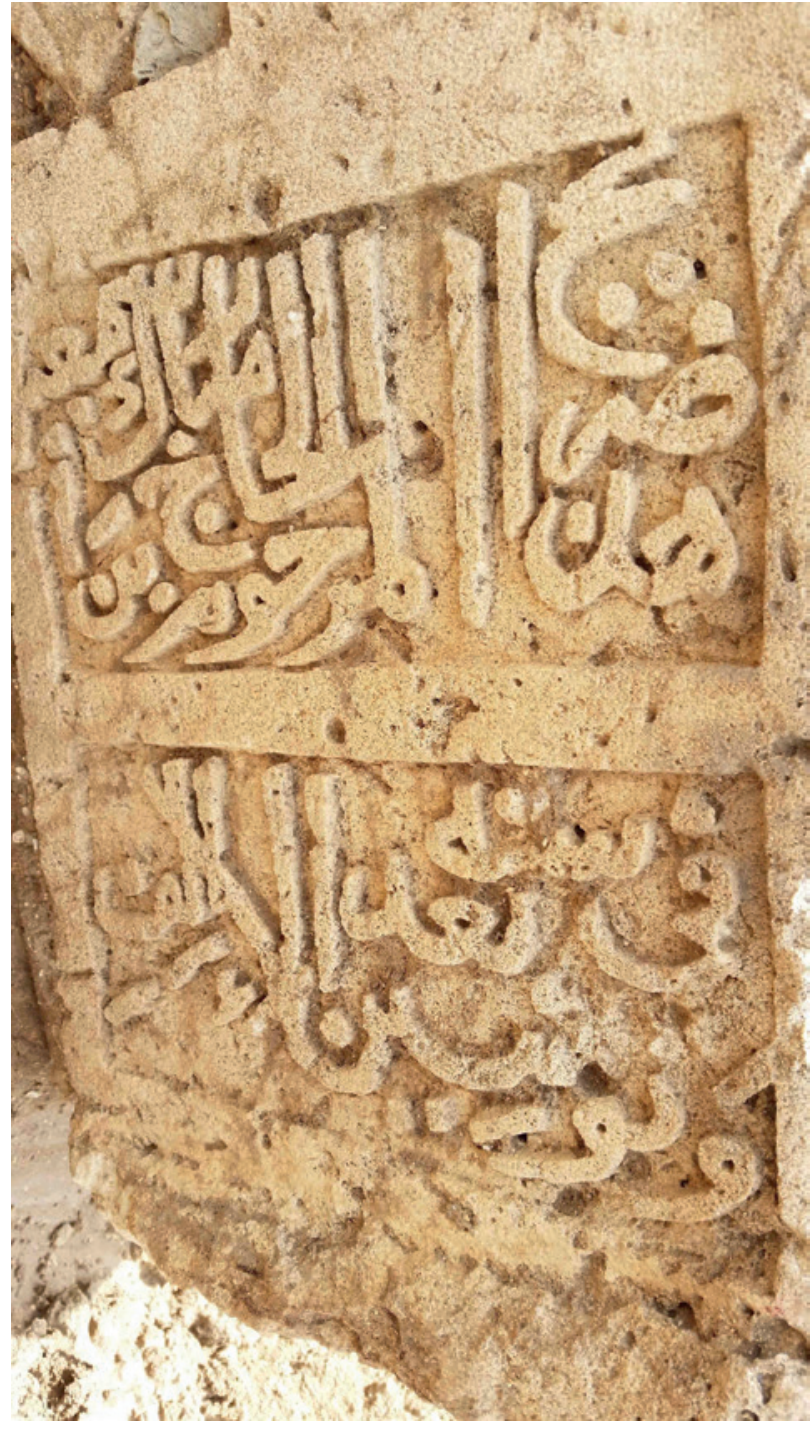

FIGURE 2.255

Surface D, JBH12

E:
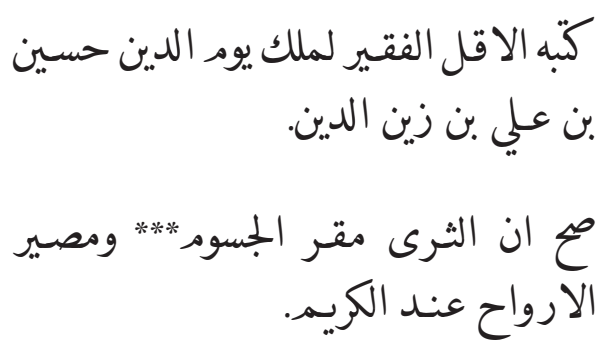
- You are really blessed and a lover of 'Ali, so in the afterlife you will live in happiness.

انت حقا مبارك وموال*** لعلي فاثبت غدا بالنعيـم.

- Engraved by al-Sayyid Naser bin al- نقشه السيد ناصر بن السيد الفـاخر سيد Sayyid Hashim al-Husayni.
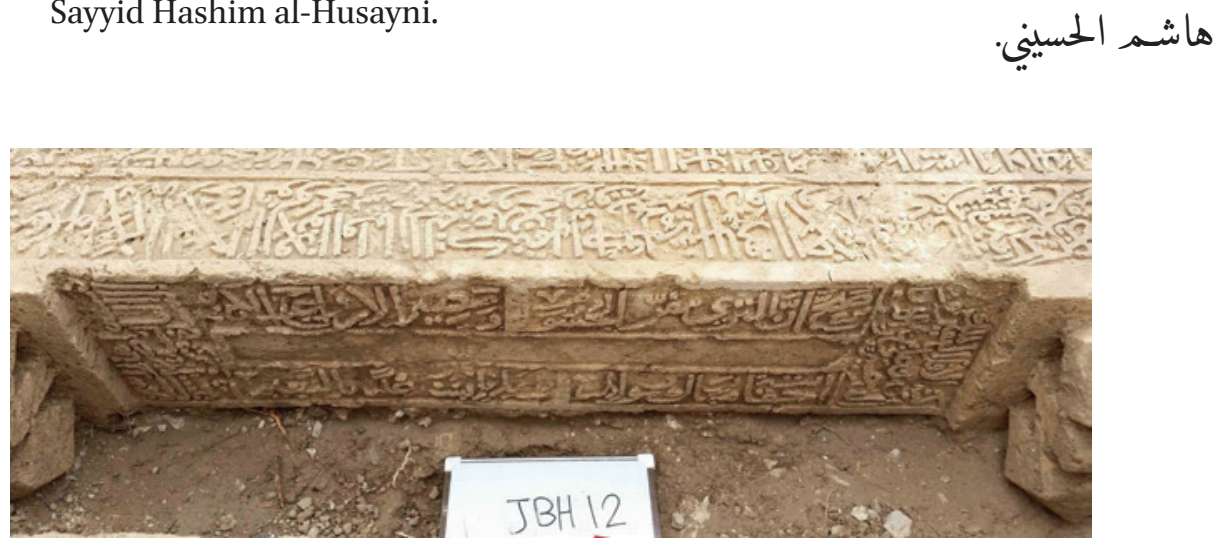

FIGURE 2.256 Surface E, JBH12

\section{Reference Number: JBH13}

Co-ordinates: $26.21656^{\circ} \mathrm{N} 050.53002^{\circ} \mathrm{E}$

Dimensions: $104 \mathrm{~cm}(\mathrm{l}) \times 44 \mathrm{~cm}(\mathrm{w}) \times 23 \mathrm{~cm}(\mathrm{~h})$

\section{Orientation: NNW-SSE}

Description: Single hollow limestone slab gravestone (Figure 2.257). No inscriptions. Excavated to move it from an upside-down position to check for inscriptions.

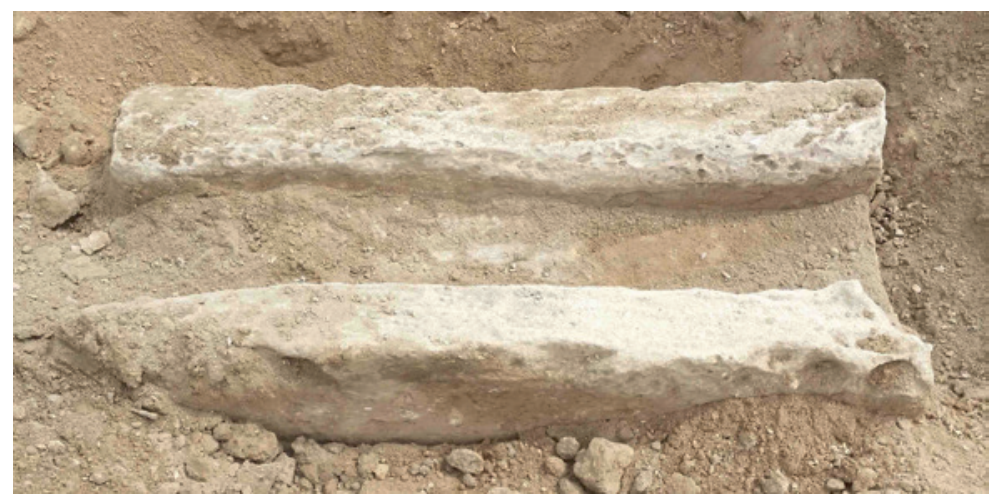

FIGURE $2.257 \quad$ JBH13

Arabic Transcription and Translation: No inscriptions 
13 Jidhafs (JID)

Location: Jidhafs village cemetery

Reference Number: JID1

Co-ordinates: $26.22020^{\circ} \mathrm{N} 050.53889^{\circ} \mathrm{E}$

Dimensions: $122 \mathrm{~cm}(\mathrm{l}) \times 27 \mathrm{~cm}(\mathrm{w}) \times 25.5 \mathrm{~cm}(\mathrm{~h})$

\section{Orientation: NNW-SSE}

Description: Gravestone formed of two limestone slabs measured as one unit because of its poor condition. Very eroded with traces of cement between the two slabs. Partial inscriptions on two surfaces. Excavated to expose gravestone as almost completely buried and tilted on its side.

\section{Arabic Transcription and Translation:}

A:

- In the Name of Allah, the Most Gracious,

- Whatever is on the earth. Who is he that can intercede with Him except by His permission! He knows what happens to them in this world, and will happen to them in the Hereafter and they will never compass anything of His Knowledge except that which He wills. His Seat extends over the heavens and the earth. And He feels
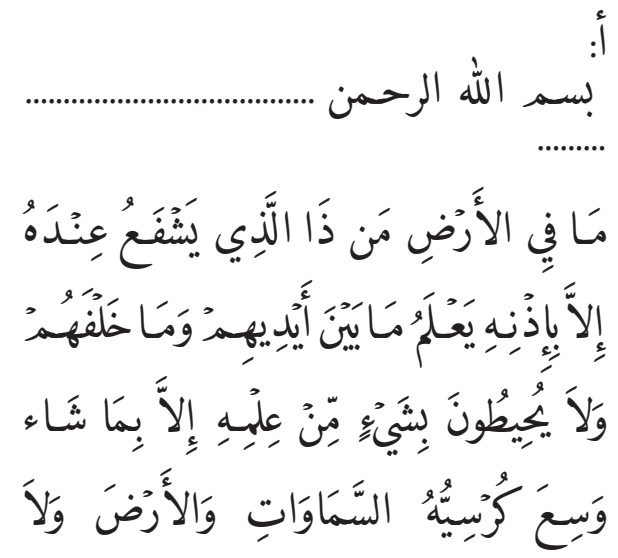
no fatigue in guarding and preserving

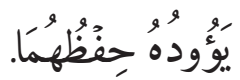
them (2:255). 


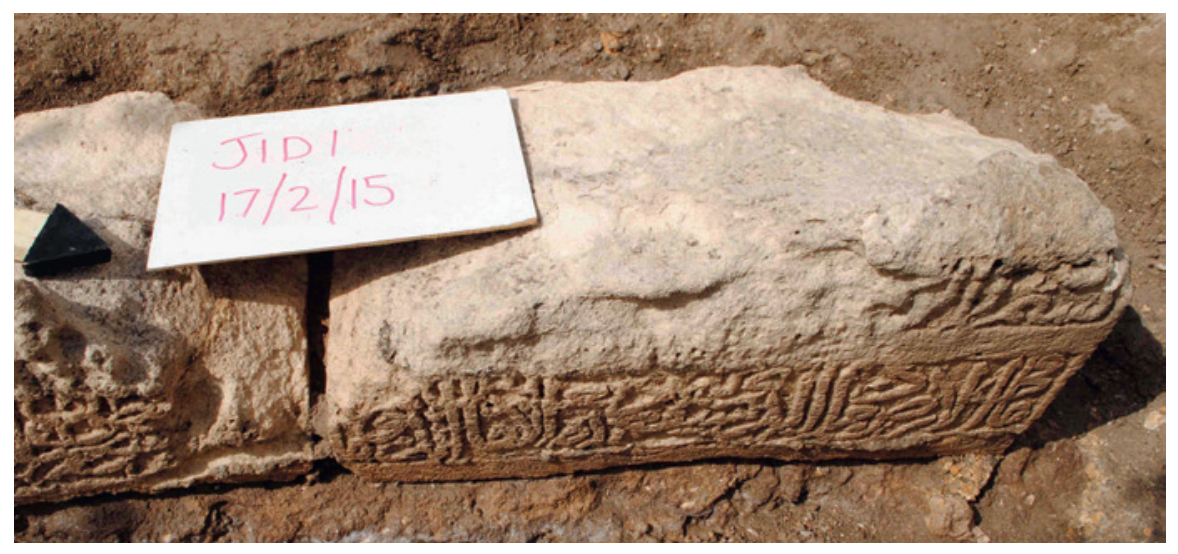

FIGURE 2.258 Surface A, part 1, JID1

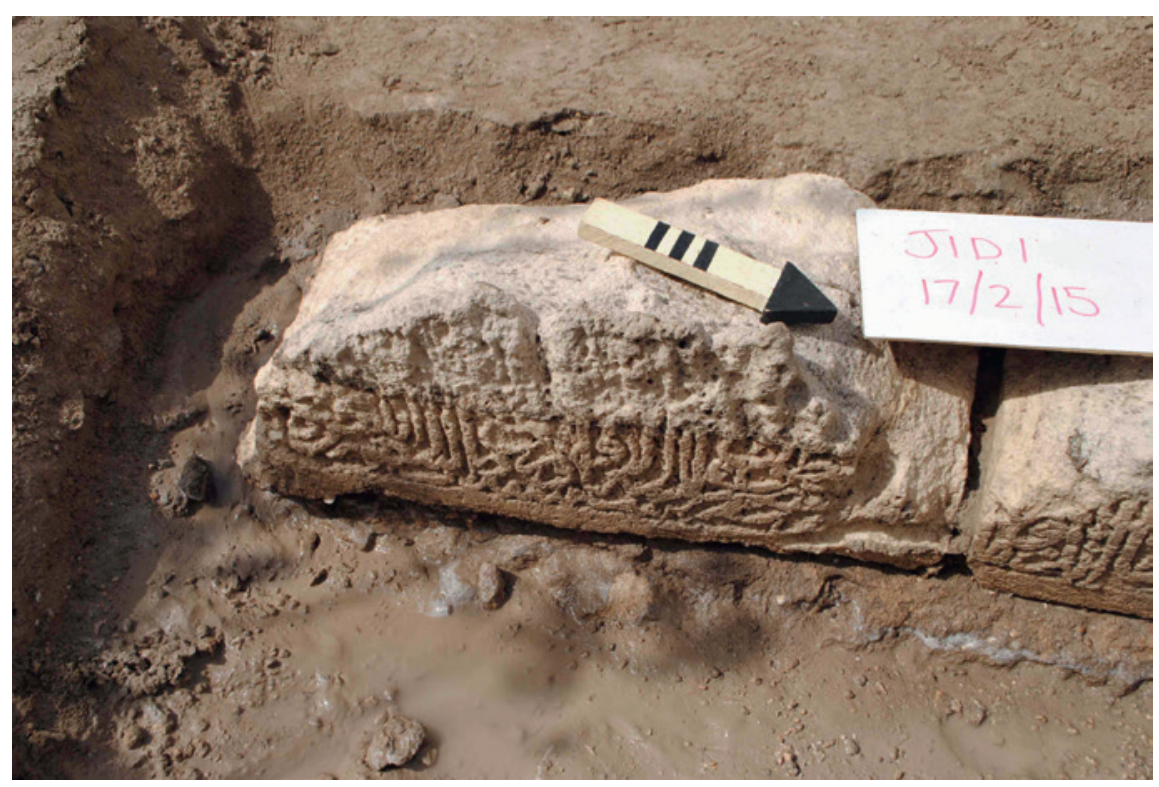

FIGURE 2.259 Surface A, part 2, JID1

B:

- No carving or inscriptions.

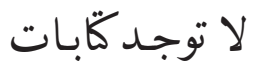


C:

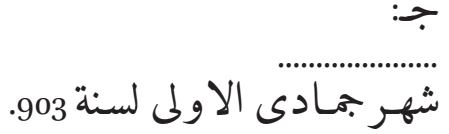

- Month of Jumada II, year 903. شهر جمادى الاولى لسنة 903.

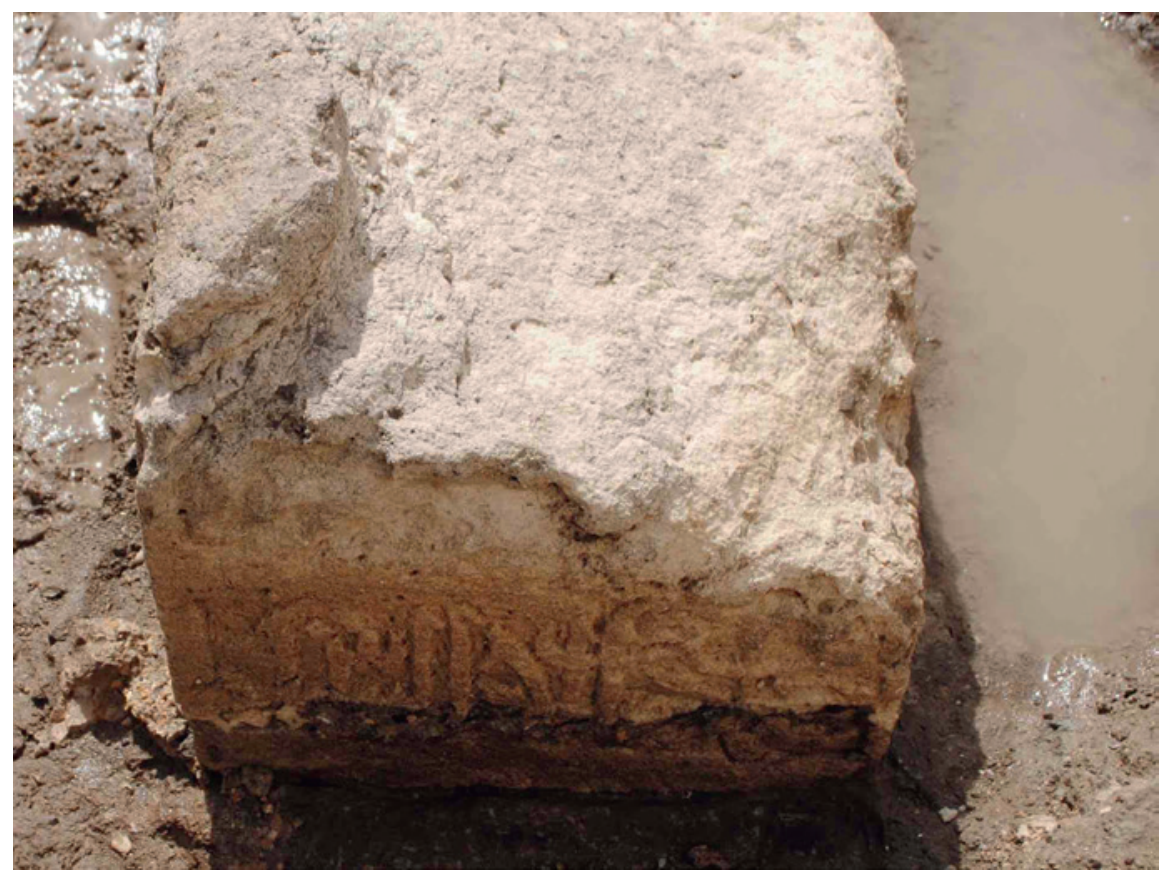

FIGURE 2.260 Surface C, JID1

D:

- No carving or inscriptions.

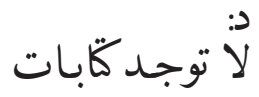

E:

- No carving or inscriptions.

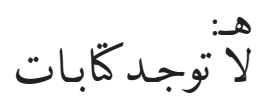

14 Jidhafs al-Imam (JAI)

Location: Jidhafs village cemetery

Reference Number: JAI1

Co-ordinates: $26.21914^{\circ} \mathrm{N} 050.53564^{\circ} \mathrm{E}$

Dimensions: $162 \mathrm{~cm}(\mathrm{l}) \times 23.5 \mathrm{~cm}(\mathrm{w}) \times 54 \mathrm{~cm}(\mathrm{~h})$ 


\section{Orientation: NW-SE}

Description: Single solid limestone slab gravestone (Figure 2.261). No inscriptions. Three element raised decoration formed of two badly carved and mis-shapen facetted cubes and a central rounded arch all set on a rectangular plinth at both ends. The sides are roughly cut and carved with possible chisel marks at one end. The gravestone was possibly left unfinished because of the poor surface quality of the side surfaces. Excavated to expose whole gravestone.

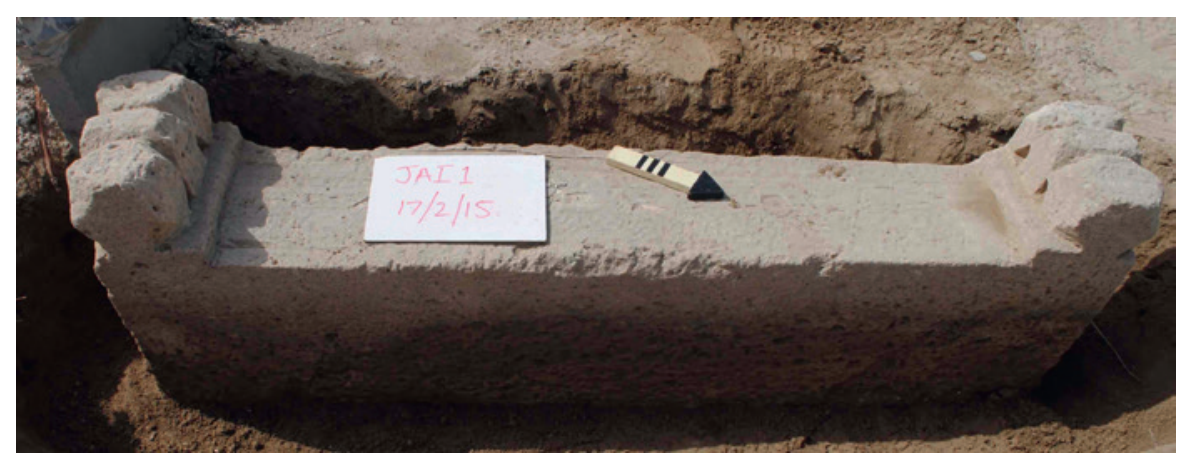

FIGURE 2.261 JAI1

Arabic Transcription and Translation: No inscriptions

\section{Reference Number: JAI2}

Co-ordinates: $26.21891^{\circ} \mathrm{N} 050.53574^{\circ} \mathrm{E}$

Dimensions: $155 \mathrm{~cm}(\mathrm{l}) \times 28.5 \mathrm{~cm}(\mathrm{w}) \times 37 \mathrm{~cm}(\mathrm{~h})$

\section{Orientation: NW-SE}

Description: Single limestone slab gravestone (Figure 2.262). Very badly eroded. No inscriptions. Unidentifiable raised decoration at one end represented by an eroded mis-shapen lump. The gravestone appears to have been re-used or re-appropriated fairly recently, as indicated by the erection of a rectangular boundary around it made from a single course of unmortared cement blocks set upright. 


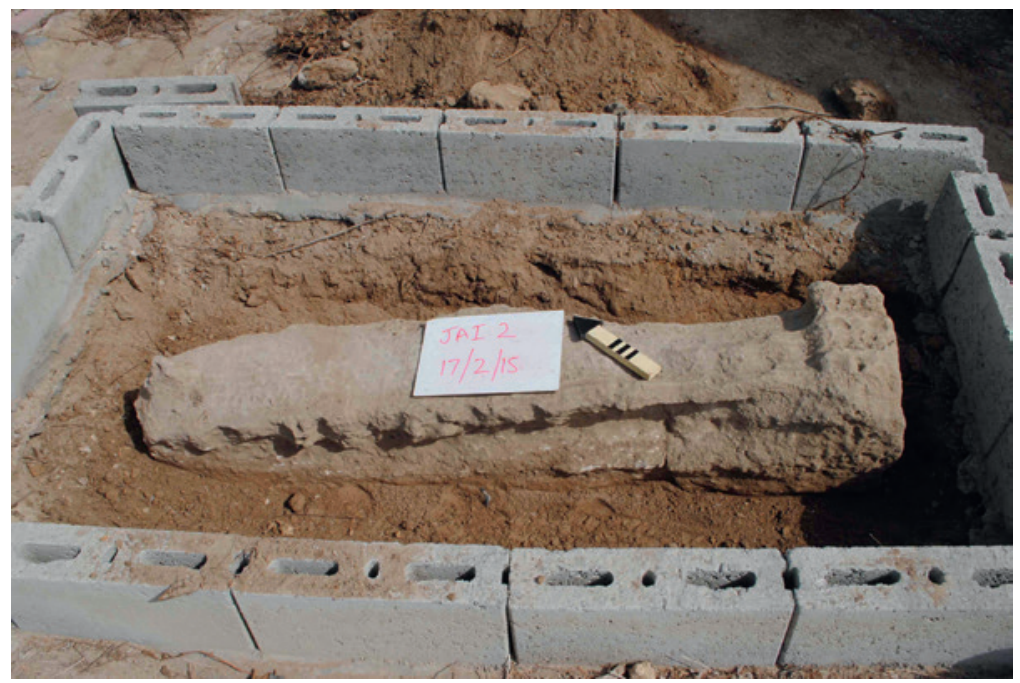

FIGURE 2.262 JAI2

Arabic Transcription and Translation: No inscriptions

Reference Number: JAI3

Co-ordinates: $26.21879^{\circ} \mathrm{N} 050.535^{8} 6^{\circ} \mathrm{E}$

Dimensions: $136 \mathrm{~cm}(\mathrm{l}) \times 30 \mathrm{~cm}(\mathrm{w}) \times 48.5 \mathrm{~cm}(\mathrm{~h})$

\section{Orientation: NNW-SSE}

Description: Single limestone slab gravestone. Very eroded on top and parts of upper surface. Remains of three element unidentifiable raised decoration at one end. Partial inscriptions on four surfaces. Excavated to expose whole gravestone.

\section{Arabic Transcription and Translation:}

A:

- Their Lord gives them glad tidings of Mercy from Him, and His being pleased, and of Gardens for them wherein are everlasting delights. They will dwell therein forever. Verily, with Allah is a great reward (9:21-22). Enter ...

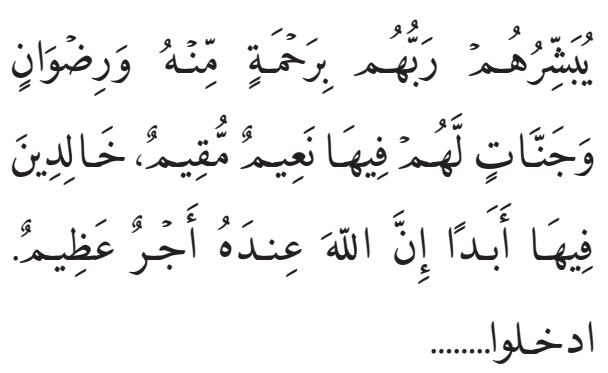




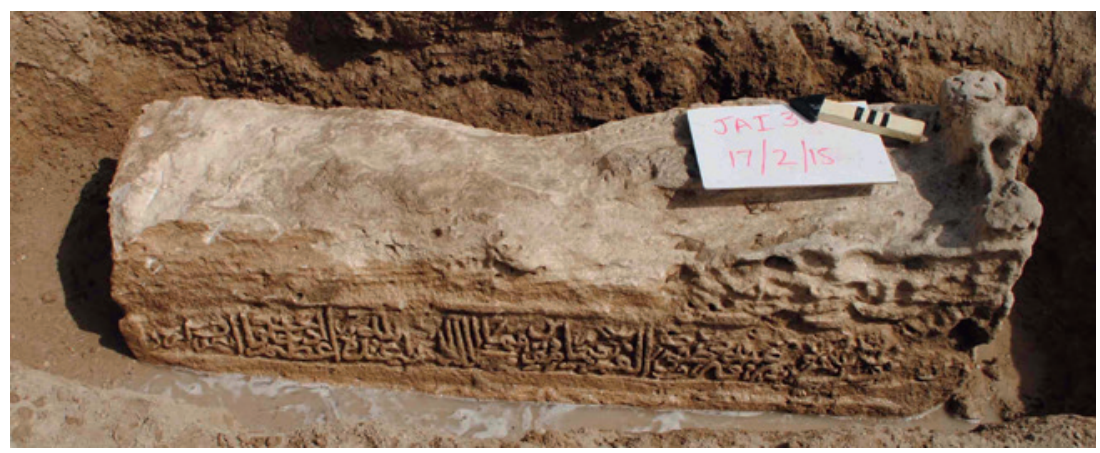

FIGURE 2.263 Surfaces A and E, JAI3

B:

- In the Name of Allah, the Most Gracious, the Most Merciful. Allah, none has the right to be worshipped but he, the Ever Living, the One Who sustains and protects all that exists. Neither slumber nor sleep overtakes Him. To Him belongs whatever is in the heavens and whatever is on the earth. Who is he that can intercede with Him except by His permission! He knows what happens to them in this world, and will happen to them in the Hereafter.

- And they will never compass anything of His Knowledge except that which He wills. His Seat extends over the heavens and the earth. And He feels no fatigue in guarding and preserving them. And He is the Most High, the Most Great (2:255). God's blessings and peace be upon Muhammad and his family.

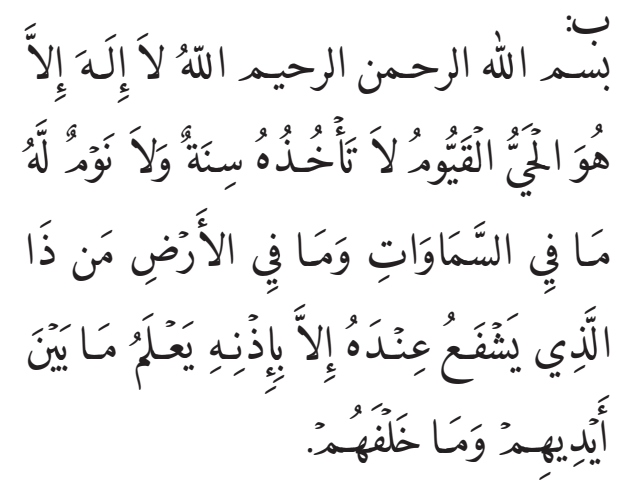

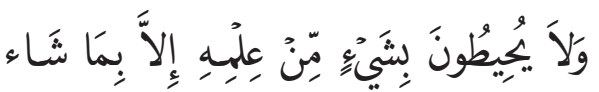

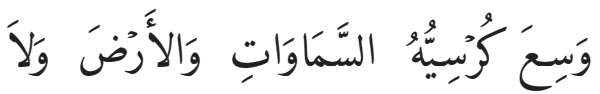

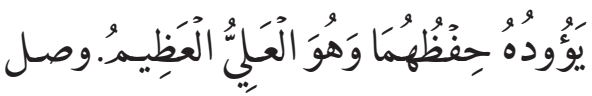
الله عـلى محـد وآله الطاهرين.

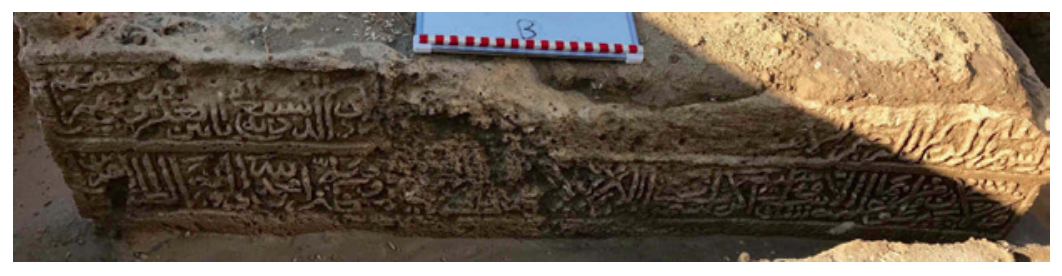

FIGURE 2.264 Surface B, JAI3 
C:

- This is the grave ... Fifteen.

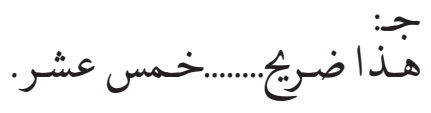

-... Ramadan, year one thousand, رمضان سنة سادسـة والاربعن...... forty-six.

والف.

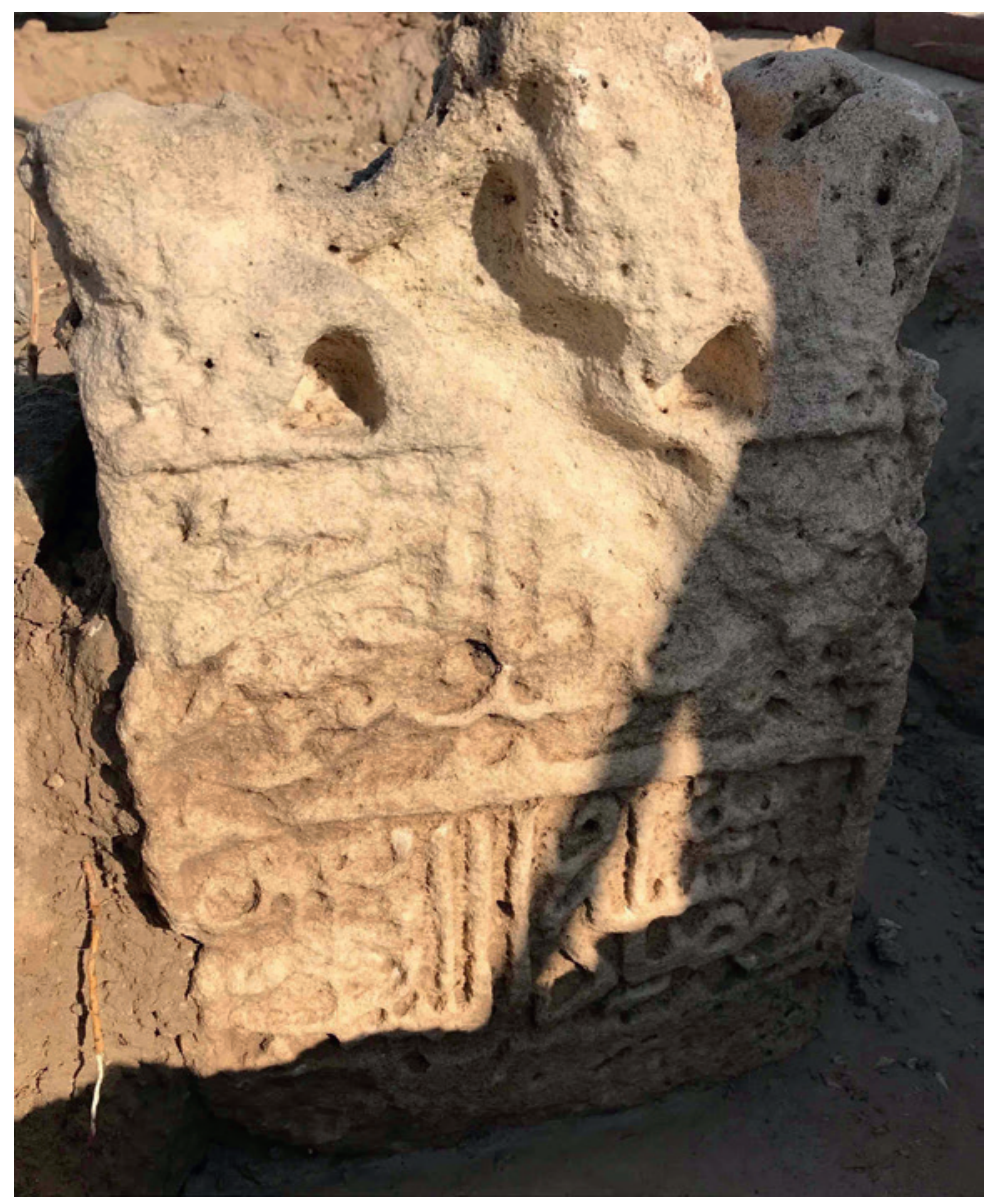

FIGURE 2.265 Surface C, JAI3

D:

- This grave of the late...

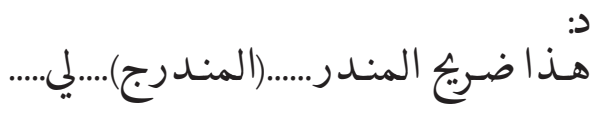

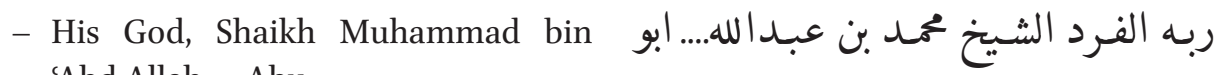
'Abd Allah ... Abu ... 


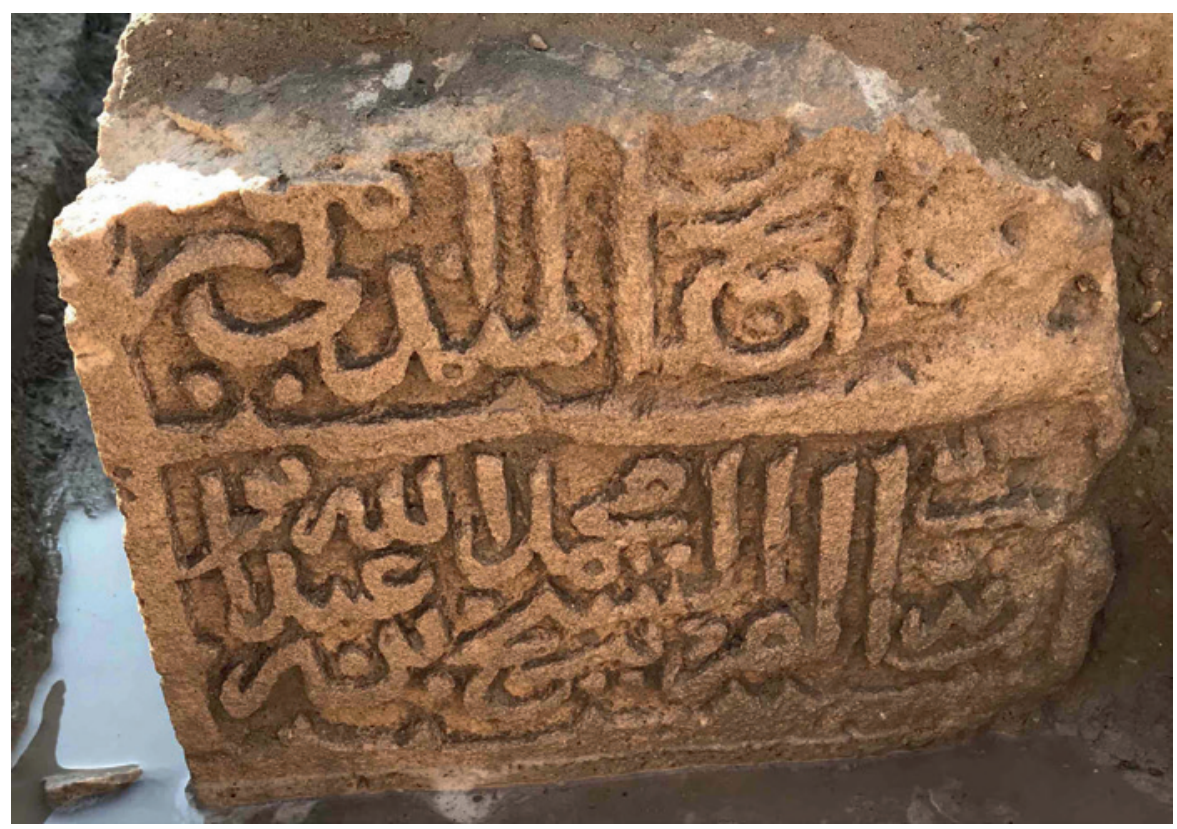

FIGURE 2.266 Surface D, JAI3

E:

- No carving or inscriptions.

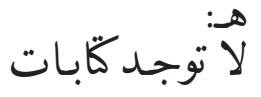

See Figure 2.263

15

\section{Karranah (KAR)}

Location: Karranah village cemetery. Gravestones are only found in one part of the cemetery; the other part of the cemetery is separated as it is bisected by a road where it was around the al-Rabi mosque/shrine. This part of the cemetery is the only one recorded with a pre-Islamic site beneath it. Rescue excavations during 2010-2012 found clay tub burials of Late Dilmun date (c. 1000-400 BC; cf. Lombard 1988: 80 for examples). The al-Rabi mosque/shrine has been extensively rebuilt (Chapter 3) and the graves that surrounded it have now gone, being replaced by recent housing development.

\section{Reference Number: KAR1}

Co-ordinates: $26.22647^{\circ} \mathrm{N} 050.51442^{\circ} \mathrm{E}$ 
Dimensions: Not measured

Orientation: NNW-SSE

Description: Grave covered in concrete (Figure 2.267). Probable inscribed gravestone underneath.

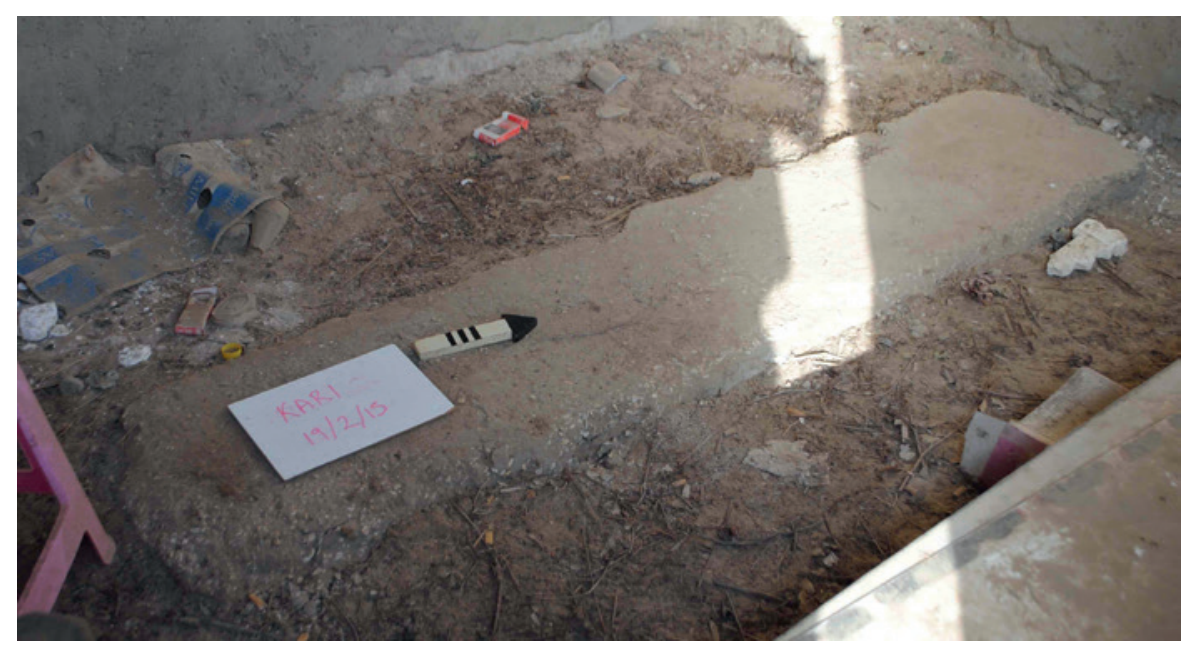

FIGURE 2.267 KAR1

Arabic Transcription and Translation: No Inscriptions

Reference Number: KAR2

Co-ordinates: $26.22675^{\circ} \mathrm{N} 050.51525^{\circ} \mathrm{E}$

\section{Dimensions:}

Slab 1: $62 \mathrm{~cm}(\mathrm{l}) \times 27 \mathrm{~cm}(\mathrm{w}) \times 40 \mathrm{~cm}(\mathrm{~h})$

Slab 2: $72 \mathrm{~cm}(\mathrm{l}) \times 27 \mathrm{~cm}(\mathrm{w}) \times 40 \mathrm{~cm}(\mathrm{~h})$

\section{Orientation: NW-SE}

Description: Gravestone formed of two limestone slabs (Figure 2.268). Eroded unidentifiable raised decoration at one end and partially identifiable 3 -element raised decoration at the other end comprising one facetted cube and two unidentifiable elements on a rectangular plinth. No inscriptions but traces of shallow carved 
pointed niche design on top surface $(\mathrm{E})$. The gravestone had been bedded into the ground with stones. This gravestone, alongside KAR3, was set within the remains of small mosque on a low mound. Small stones marked the former walls and mihrab $(180 \mathrm{~cm} \times 90 \mathrm{~cm})$ of the mosque which covered an area of $\mathrm{c} .8 \mathrm{~m}(\mathrm{l}) \times 6 \mathrm{~m}(\mathrm{w})$. The mihrab contained KAR4. Excavated to expose the whole gravestone.

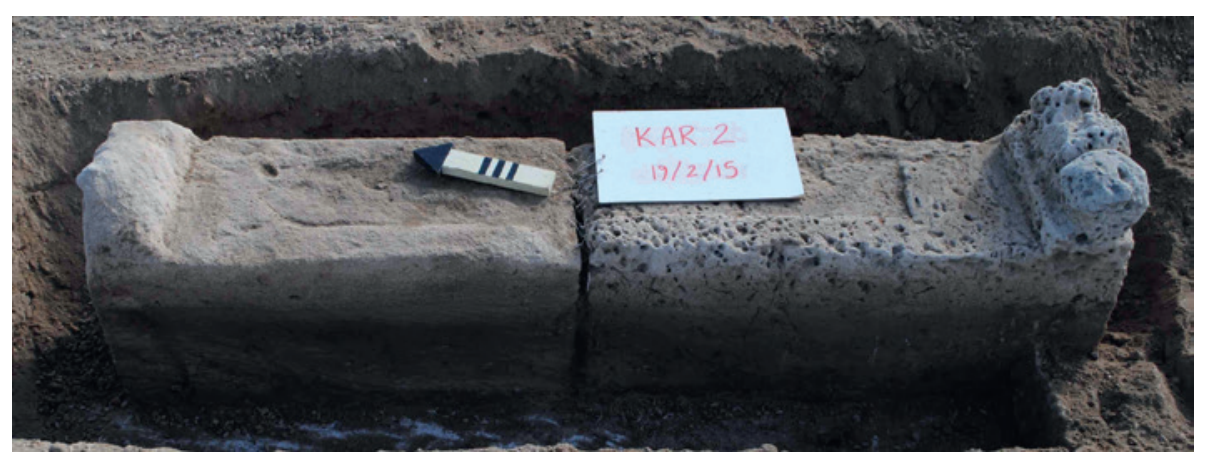

FIGURE 2.268 KAR2

\section{Arabic Transcription and Translation: No inscriptions}

\section{Reference Number: KAR3}

Co-ordinates: $26.22676^{\circ} \mathrm{N} 050.515^{2} 6^{\circ} \mathrm{E}$

\section{Dimensions:}

Slab 1: $72 \mathrm{~cm}(\mathrm{l}) \times 27 \mathrm{~cm}(\mathrm{w}) \times 31 \mathrm{~cm}(\mathrm{~h})$

Slab 2: $59 \mathrm{~cm}(\mathrm{l}) \times 27 \mathrm{~cm}(\mathrm{w}) \times 31 \mathrm{~cm}(\mathrm{~h})$

\section{Orientation: NNW-SSE}

Description: Gravestone formed of two limestone slabs. Eroded unidentifiable raised decoration at both ends. Badly eroded on top and upper parts of all the side and end surfaces where they were above the ground surface. Inscriptions on four surfaces and bottom half of shallow carved rectangular panel design, probably a niche, on upper surface (E). Traces of red paint/pigment on the lettering on two surfaces. Excavated to expose whole gravestone. 


\section{Arabic Transcription and Translation:}

A:

- He knows what happens to them in this world, and will happen to them in the Hereafter and they will never compass anything of His Knowledge

- Except that which He wills. His Seat extends over the heavens and the earth. And He feels no fatigue in guarding and preserving them. And He is the Most High, the Most Great (2:255).
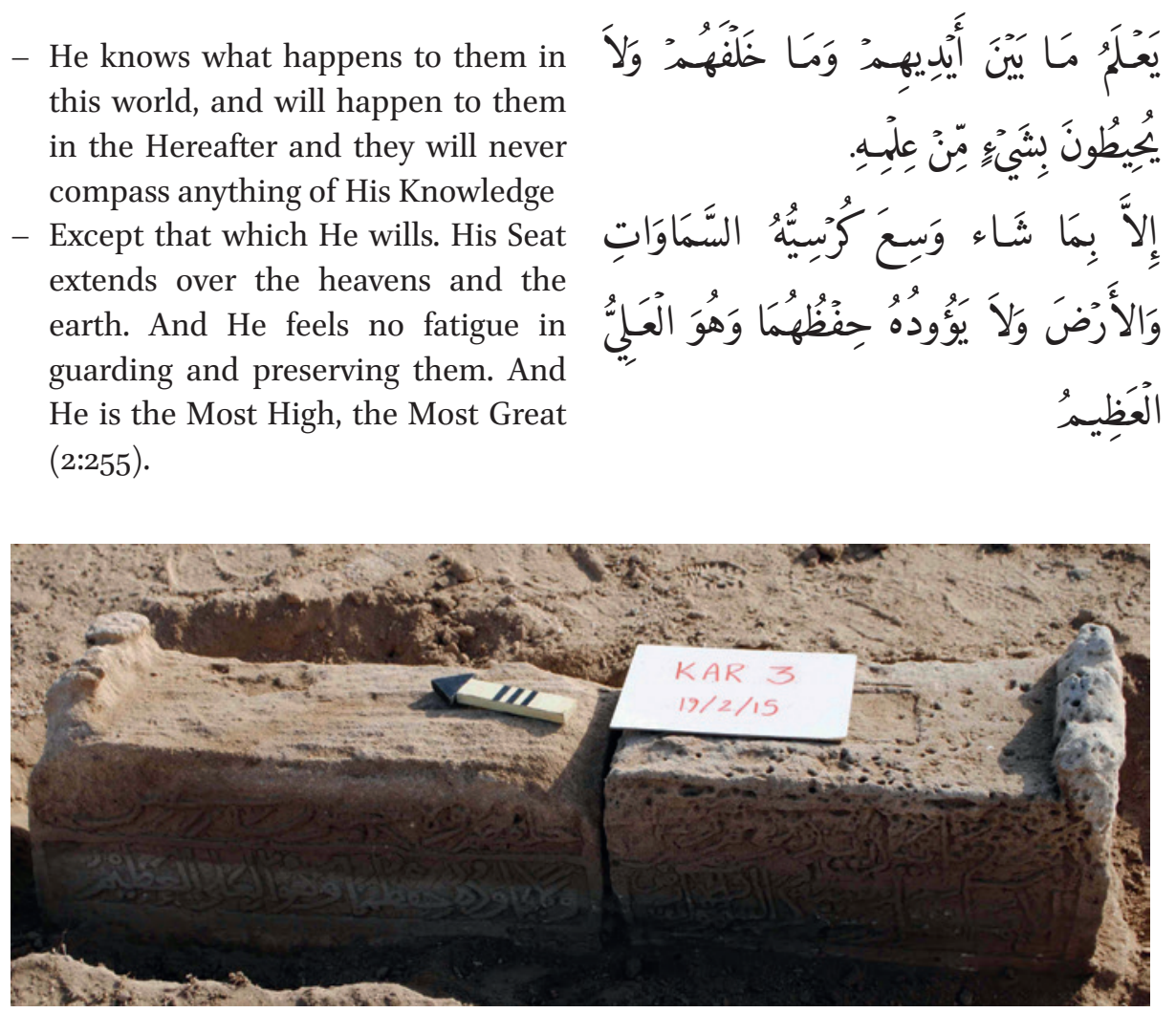

FIGURE 2.269 Surfaces A and E, KAR3

B:

- In the Name of Allah, the Most Gracious, the Most Merciful. Allah, none has the right to be worshipped but he, the Ever Living, the One Who

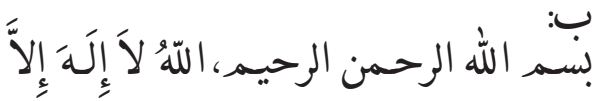

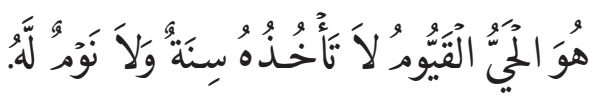
sustains and protects all that exists. Neither slumber nor sleep overtakes Him. To Him belongs

- Whatever is in the heavens and whatever is on the earth. Who is he that can intercede with Him except by His permission! (2:255)

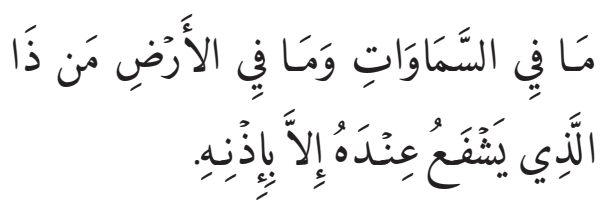




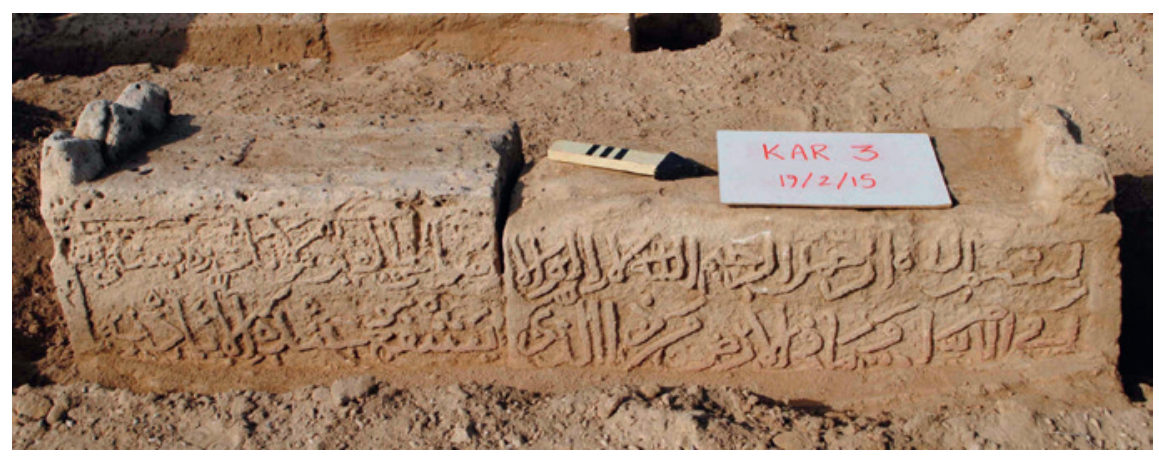

FIGURE 2.270 Surface B, KAR3

C:
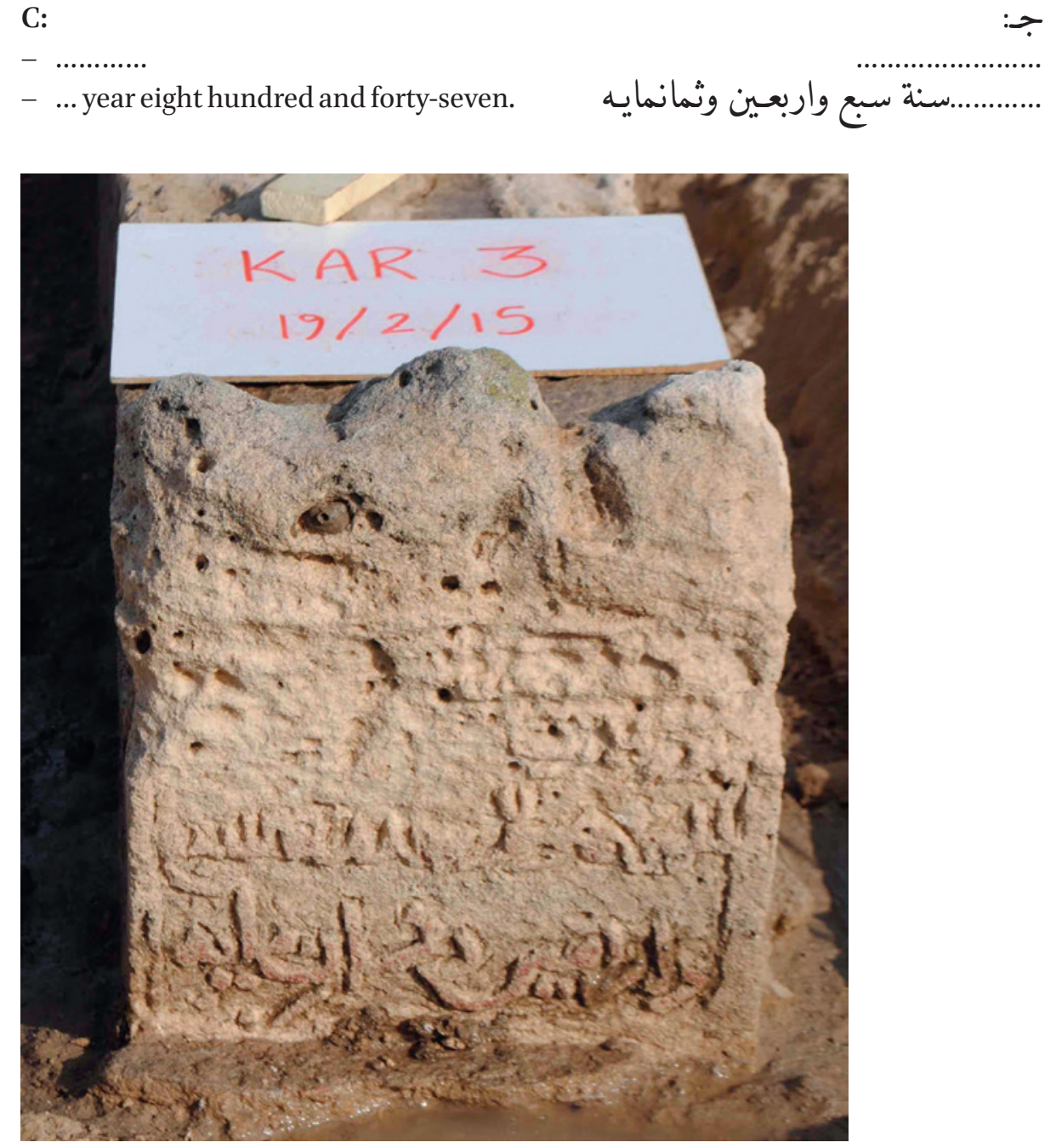

FIGURE 2.271 Surface C, KAR3 
D:

- ... Allah ...

- The chaste lady, Bi Bi Shah Zanan bint Mansur bin 'Ali bin 'Abd al-Amir (al-Naser) Muhammad. May Allah have mercy on her.

$$
\begin{aligned}
& \text { العفيفة الخفرة بي..................... بي شاه زنان بنت } \\
& \text { منصور .ن عِلي .ن الا مــير (النصـير) محــ } \\
& \text {. مرحهم (هـا) اللّ. }
\end{aligned}
$$

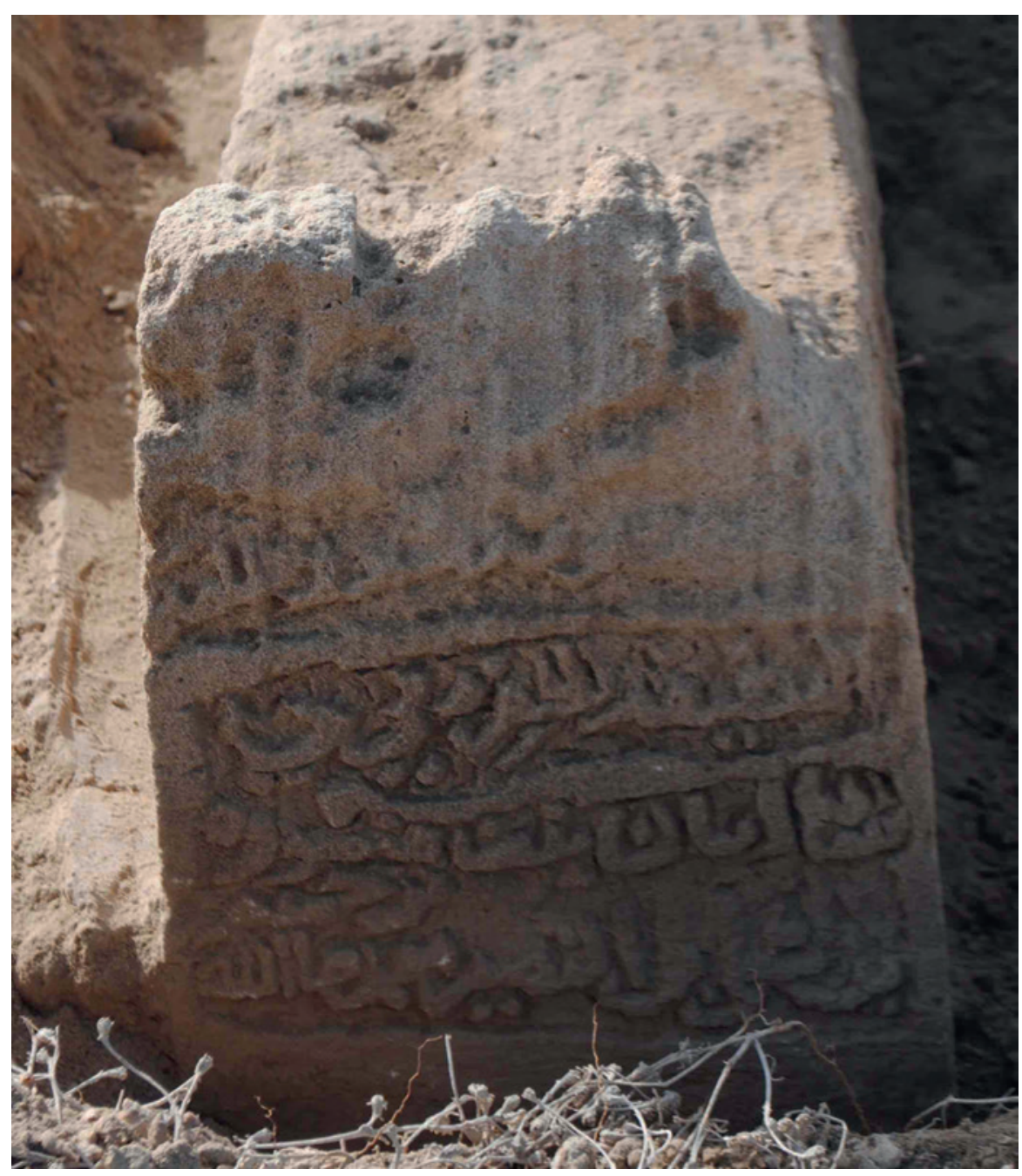

FIGURE 2.272 Surface D. KAR3

E:

- No carving or inscriptions.

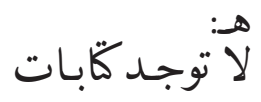

See Figure 2.269 


\section{Reference Number: KAR4}

Co-ordinates: $26.22670^{\circ} \mathrm{N} 050.515^{22}{ }^{\circ} \mathrm{E}$

\section{Dimensions:}

Slab 1: $74 \mathrm{~cm}(\mathrm{l}) \times 49 \mathrm{~cm}(\mathrm{w}) \times 43 \mathrm{~cm}(\mathrm{~h})$

Slab 2: $96 \mathrm{~cm}(\mathrm{l}) \times 48.5 \mathrm{~cm}(\mathrm{w}) \times 36 \mathrm{~cm}(\mathrm{~h})$

\section{Orientation: NNW-SSE}

Description: Gravestone formed of double hollow limestone slabs (Figure 2.273). These were found buried just south of the mihrab in the small mosque that also contained KAR2 and KAR3. Very eroded. Remains of possible unidentifiable raised decoration at one end. No inscriptions. An invocation for magical purposes written on paper was found placed in a small bottle and buried under one of the slabs. It had written on it the words "buried old grave" in Arabic. Excavated to expose whole gravestone.

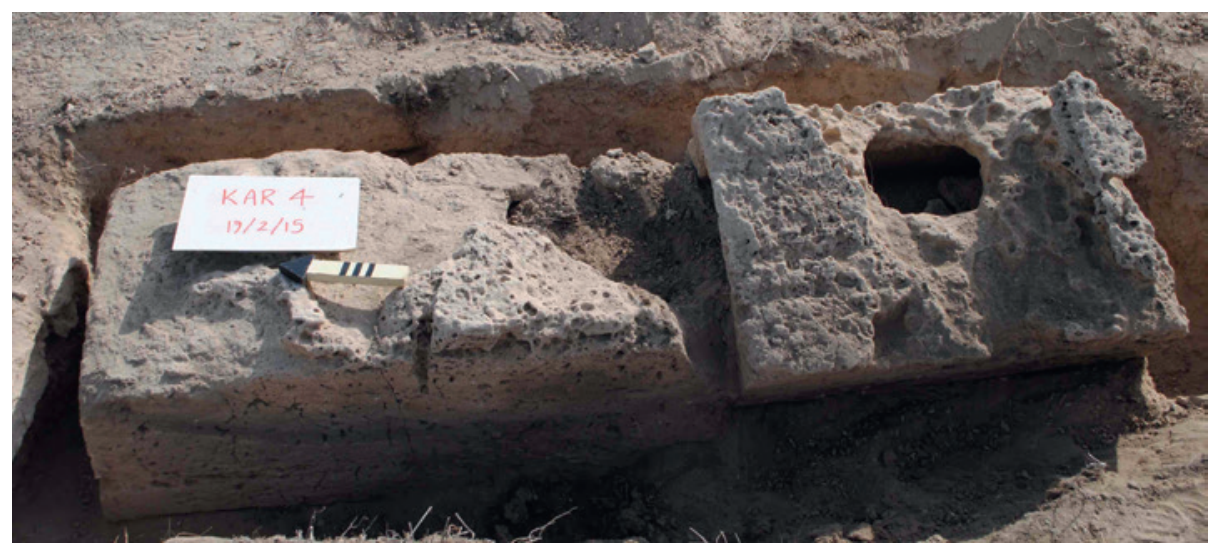

FIGURE $2.273 \quad$ KAR4

Arabic Transcription and Translation: No inscriptions

Reference Number: KAR5

Co-ordinates: $26.22861^{\circ} \mathrm{N} 050.51462^{\circ} \mathrm{E}$ 


\section{Dimensions:}

Slab 1: $99.5 \mathrm{~cm}(\mathrm{l}) \times 40 \mathrm{~cm}(\mathrm{w}) \times 45 \mathrm{~cm}(\mathrm{~h})$

Slab 2: $100 \mathrm{~cm}(\mathrm{l}) \times 42 \mathrm{~cm}(\mathrm{w}) \times 35 \mathrm{~cm}(\mathrm{~h})$

\section{Orientation: $\mathrm{N}-\mathrm{S}$}

Description: Gravestone formed of two limestone slabs set into the floor in the Sheikh Nasser bin Muhammad bin Shaikh Abdullah al-Rabi shrine/mosque. Eroded (due to moisture) inside shrine structure. Modern tile flooring that covered the gravestone was removed to expose it. Eroded and unidentifiable raised rectangular decoration at both ends. Remains of decoration including a carved circle, and shallow carved rounded niche design with an arrow carved within a small rectangle above the rounded end of the niche on the top surface (E). Inscriptions on four surfaces.

\section{Arabic Transcription and Translation:}

A:

- Praise be to Allah. There is no god but Allah. Praise be to Allah. God's blessings upon Muhammad alMustafa, God's blessings upon Ali al-Murtada, God's blessings upon Fatimah al-Zahra', God's blessings upon al-Hasan, God blessings upon al-Husayn, God's blessings upon 'Ali bin al-Husayn, God's blessings upon Muhammad, God's blessings upon Ja'far, God's blessings upon Musa, God's blessings upon 'Ali, God's blessings upon Muhammad, God's blessings upon 'Ali, God's blessings upon al-Hasan al-'Askari, and God's blessings upon al-Hujjah al-Khalaf al-Hadi al-Mahdi. God's blessings upon all of them ...

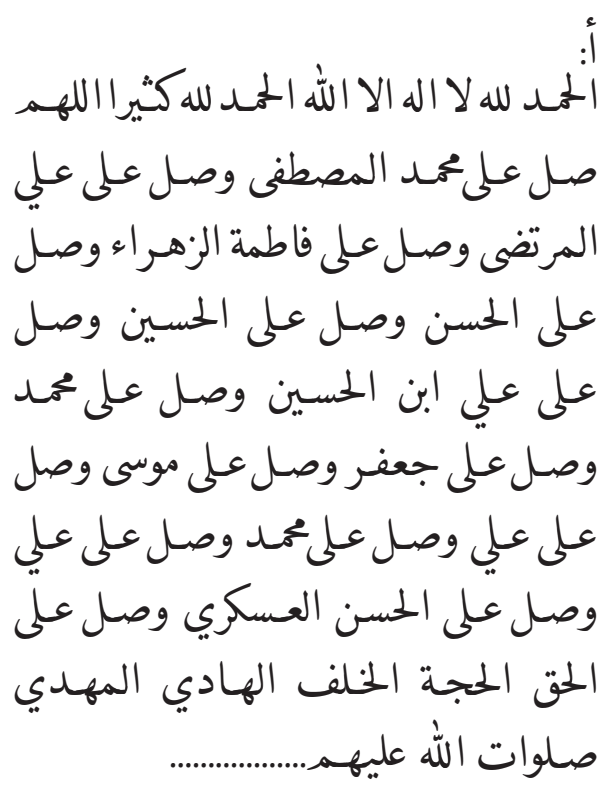


- Verily, We have sent it down in the alQadr night. And what will make you know what the night of al-Qadr night is. The al-Qadr night is better than a thousand months. Therein descend the angels and the Spirit by Allah's Permission with all decrees. There is peace until the appearance of dawn (97:1-5).
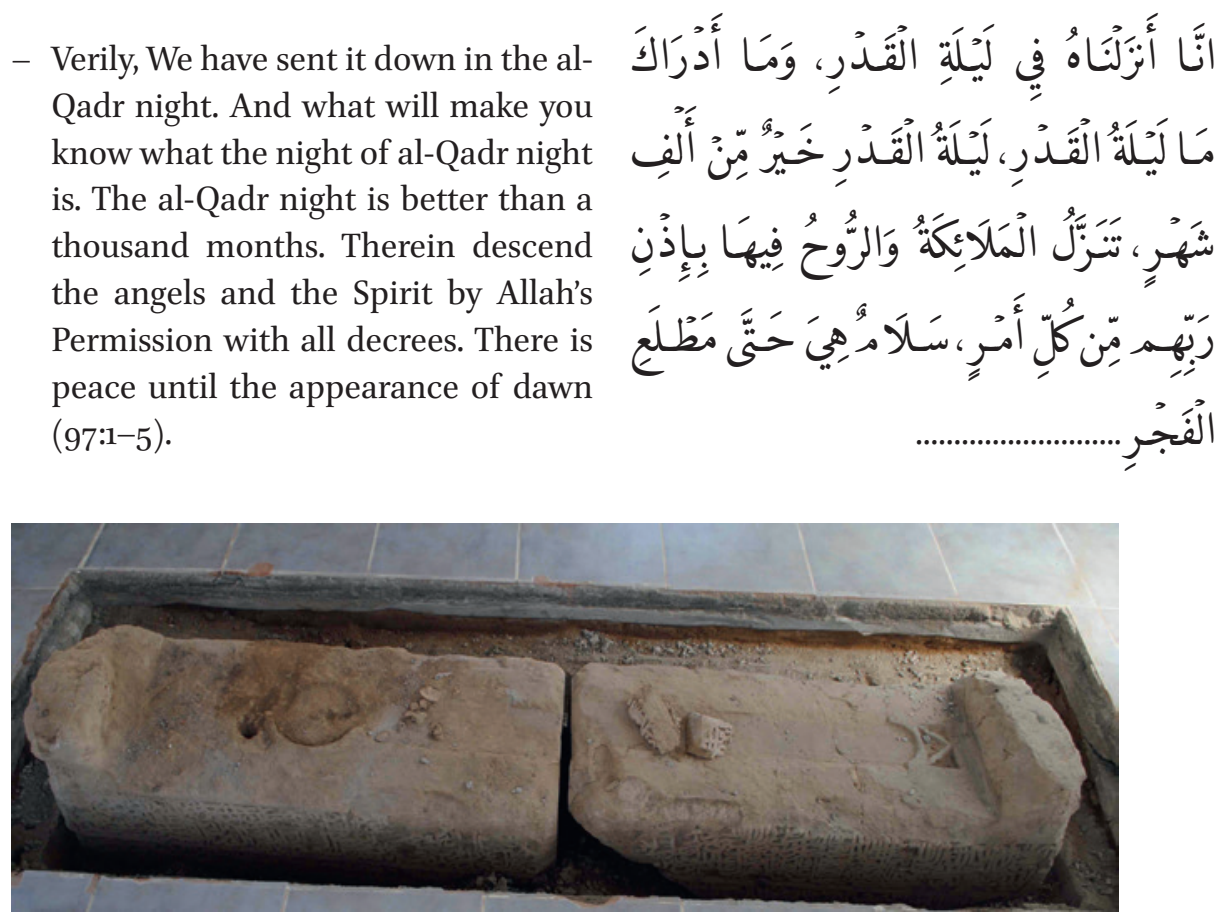

FIGURE 2.274 Surfaces A and E, KAR5

B:

- In the Name of Allah, the Most Gracious, the Most Merciful. Allah, none has the right to be worshipped but he, the Ever Living, the One Who sustains and protects all that exists. Neither slumber nor sleep overtakes Him. To Him belongs whatever is in the heavens and whatever is on the

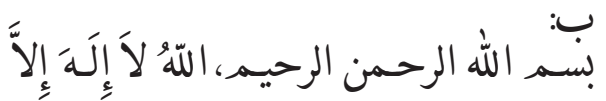

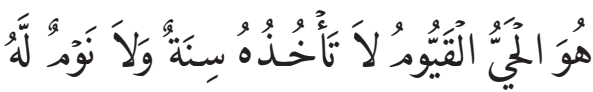

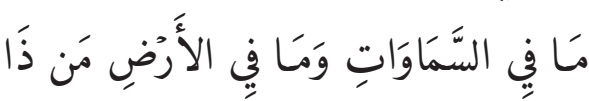

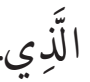
earth. Who is he that ... (2:255)

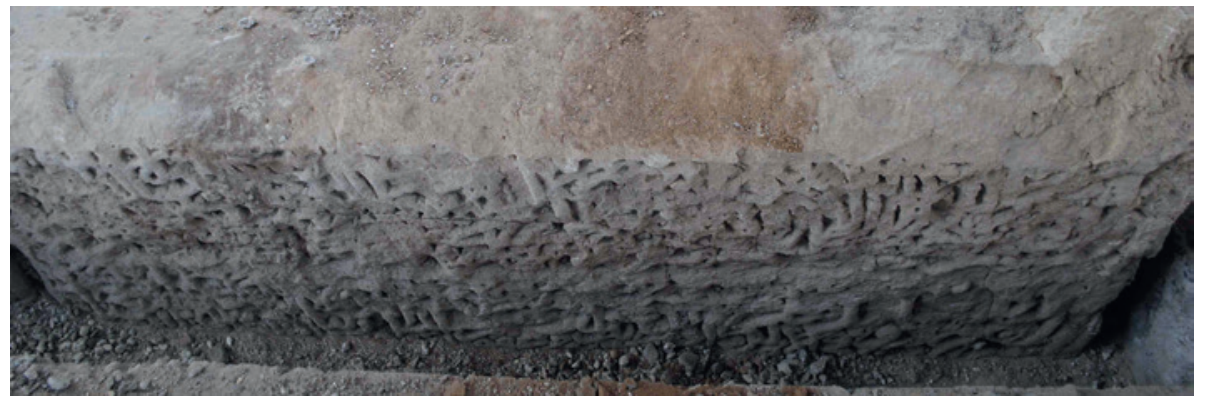

FIGURE 2.275 Surface B, part 1, KAR5 


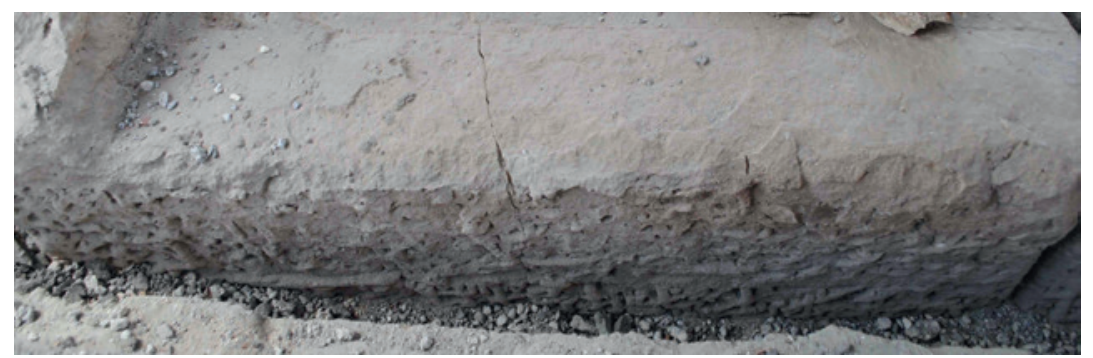

FIGURE 2.276 Surface B, part 2, KAR5

C:

- ....... nine hundred and sixty five ... endowment ... Muhammad ... Naser bin Rabic ... reading of Allah's book, from crop of ...
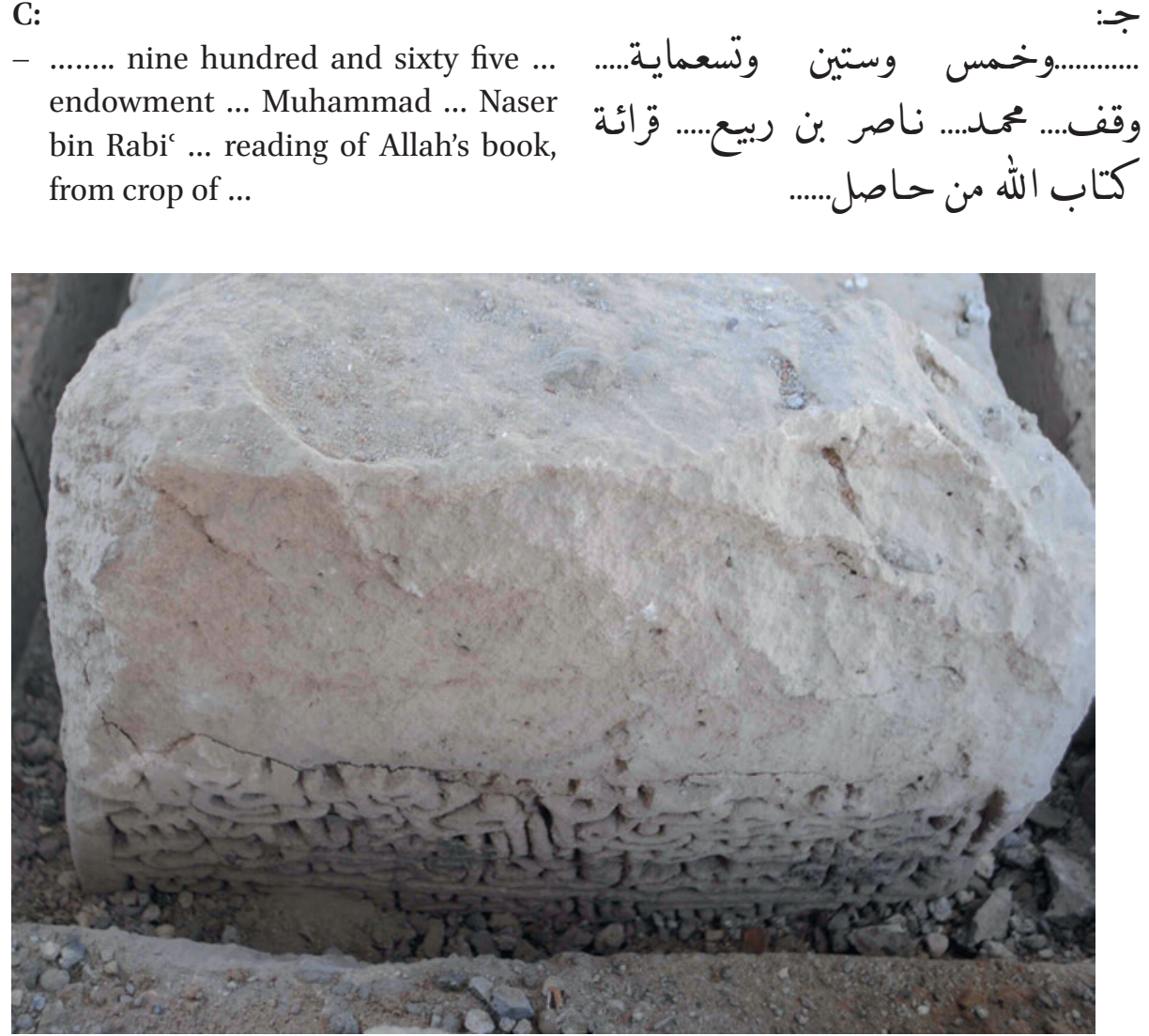

FIGURE 2.277 Surface C, KAR5

D:

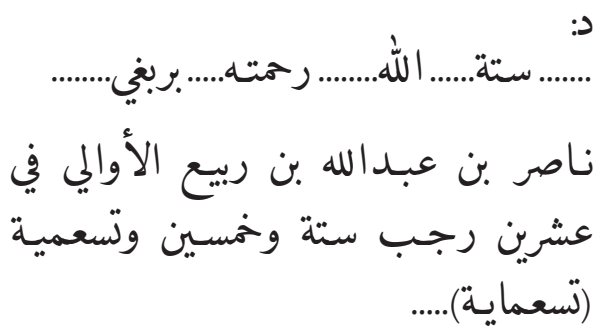




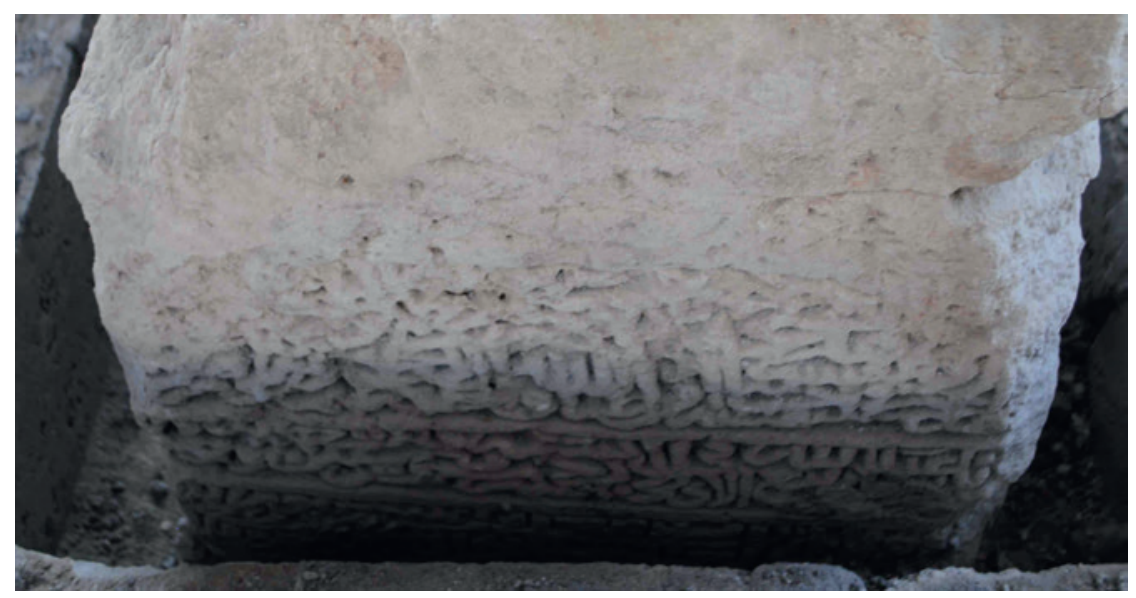

FIGURE 2.278 Surface D, KAR5

E:

- No carving or inscriptions.

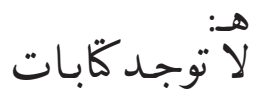

See Figure 2.274

16

\section{Al-Khamis (KHA)}

Location: Archaeological site of former urban cemetery with associated mosque and shrine. The cemetery overlies and cuts down into an earlier phase of residential, commercial, and industrial occupation dated to between the eighth/ninth to fourteenth centuries AD (Insoll et al 2016: 240). Not all the gravestones are in their original positions as some were moved in the 1980 s or earlier as part of restoration work at the site.

\section{Reference Number: KHA1}

Co-ordinates: $26.22861^{\circ} \mathrm{N} 050.51462^{\circ} \mathrm{E}$

Dimensions: $33 \mathrm{~cm}(\mathrm{l}) \times 36 \mathrm{~cm}(\mathrm{w}) \times 47 \mathrm{~cm}(\mathrm{~h})$

\section{Orientation: NA}

Description: Single limestone slab, part of double slab gravestone. Eroded. Not in original position. Eroded three element raised decoration at one end with one facetted cube identifiable. Partial inscriptions on three surfaces.

Previous Publication: Number 21, Kalus (1990: 53). 
Arabic Transcription and Translation:

A:

- In the Name of Allah, the Most Gracious, the Most Merciful. Allah.

- His Seat ... the heavens and the earth (2:255).
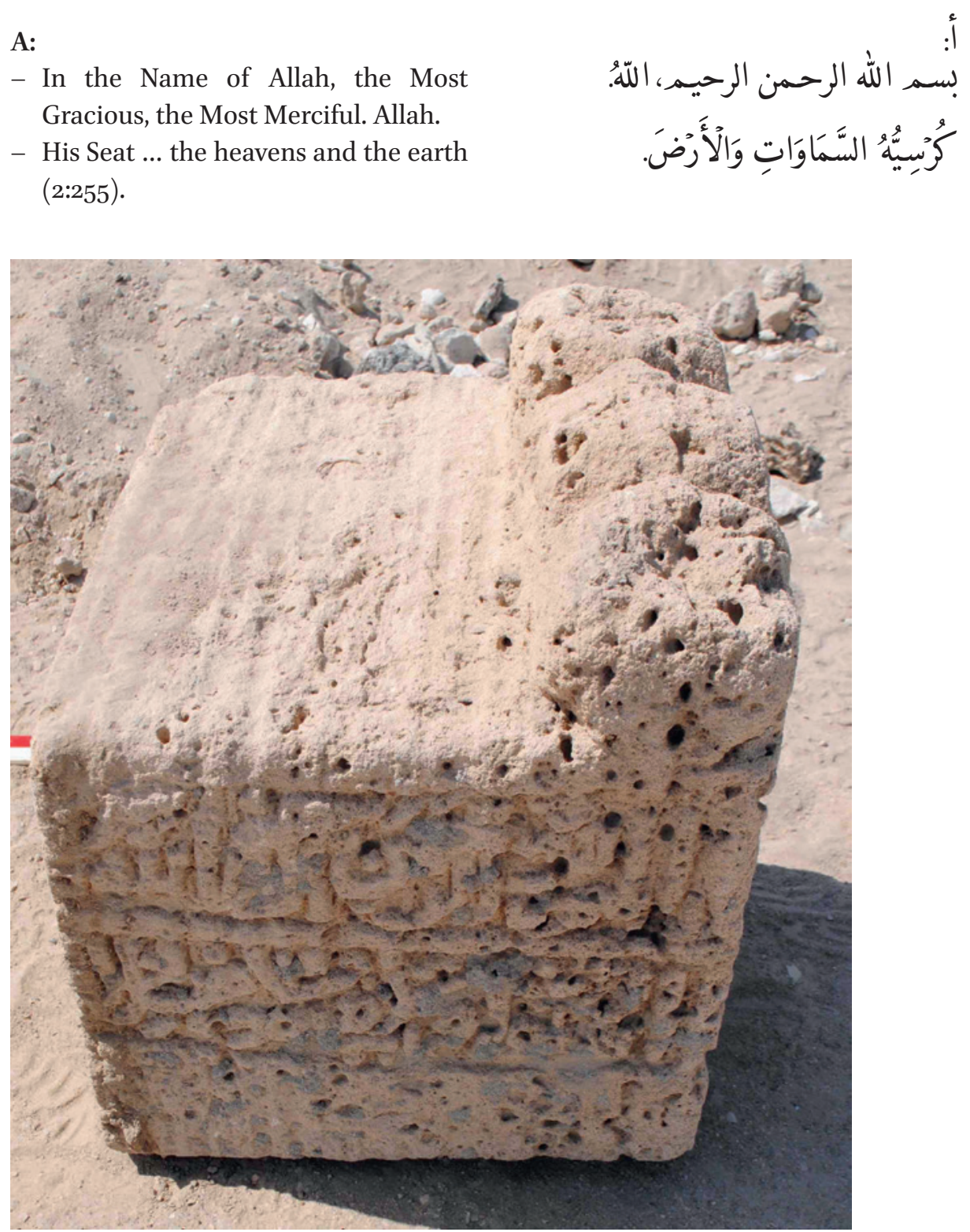

FIGURE 2.279 Surface A, KHA1

B:

- Whoever disbelieves in al-Taghut $(2: 256)$.

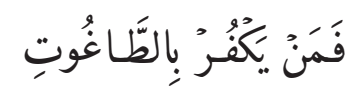




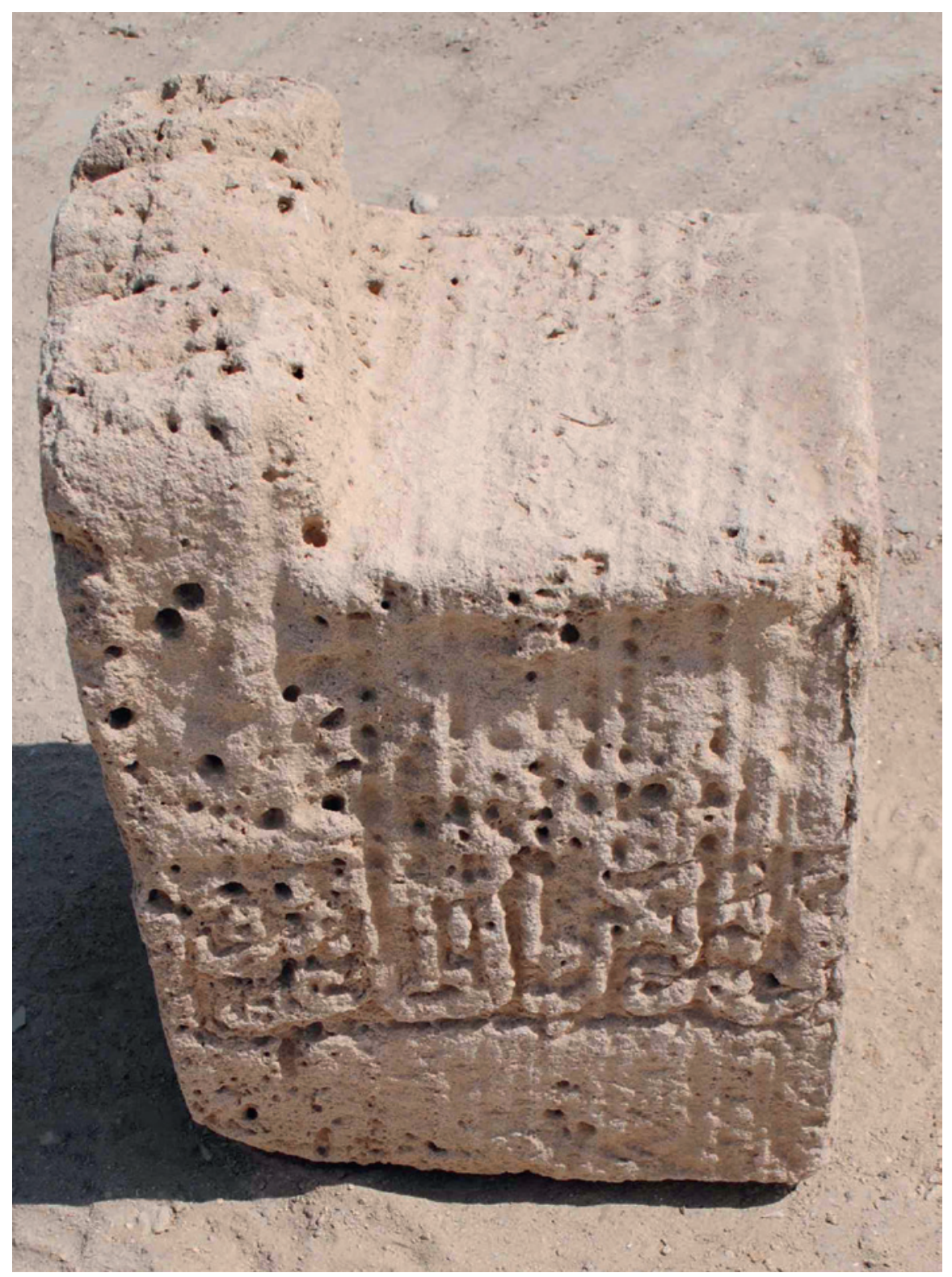

FIGURE 2.280 Surface B, KHA1

C:

- And believes in Allah, then he has grasped.

- The most trustworthy handhold that will never break (2:256).

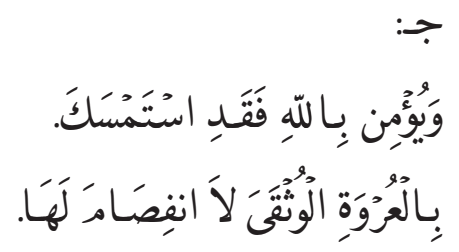




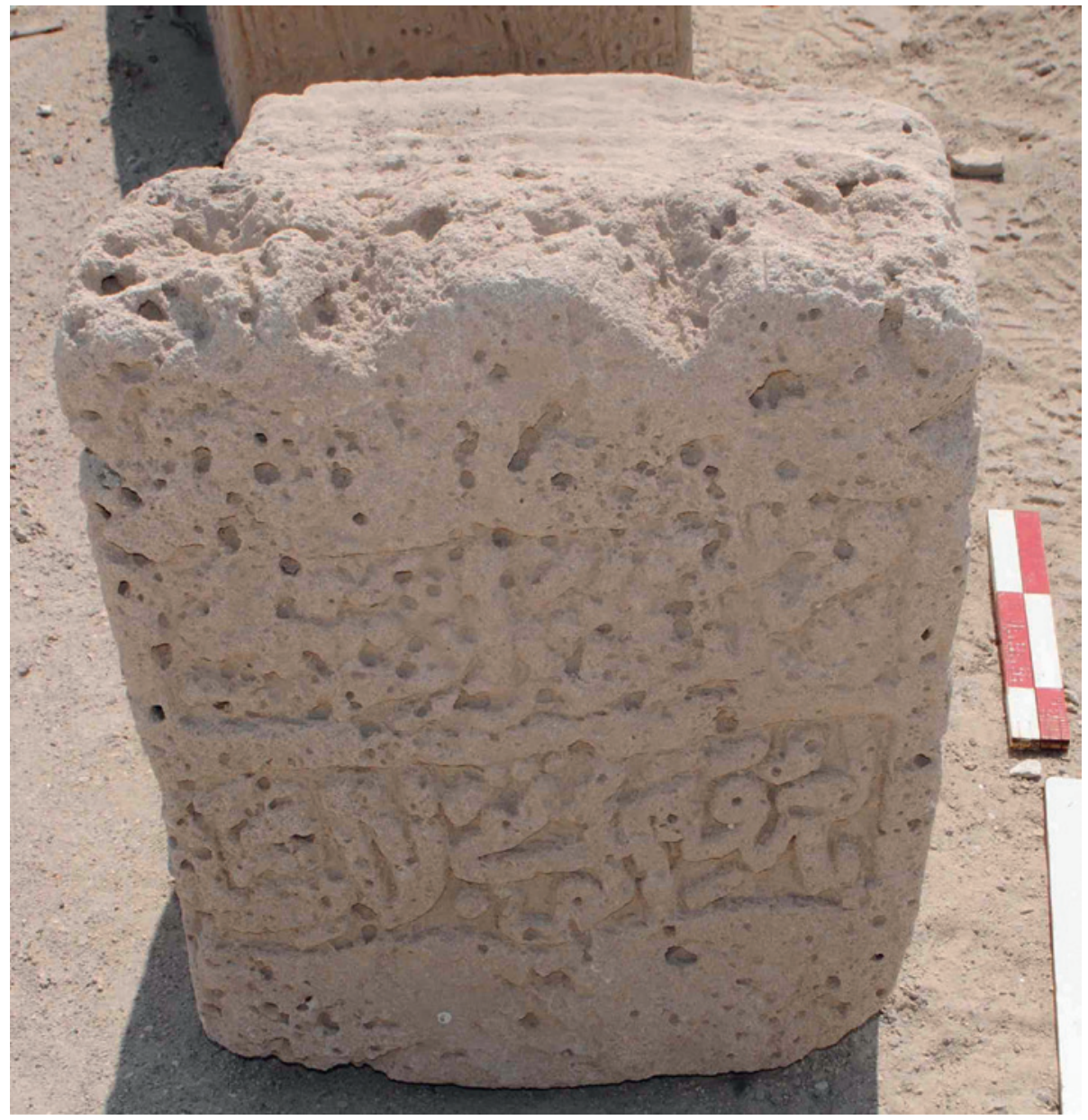

FIGURE 2.281 Surface C, KHA1

D:

- No carving or inscriptions.

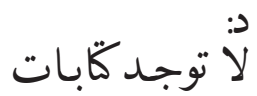

E:

- No carving or inscriptions.

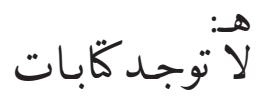

Reference Number: KHA2

Co-ordinates: $26.20849^{\circ} \mathrm{N} 050.54841^{\circ} \mathrm{E}$

Dimensions: $83.5 \mathrm{~cm}(\mathrm{l}) \times 36 \mathrm{~cm}(\mathrm{w}) \times 42 \mathrm{~cm}(\mathrm{~h})$

Orientation: NA 
Description: Single limestone slab gravestone, part of double slab gravestone. Not in original position and not associated with neighbouring stone. Eroded and unidentifiable three element raised decoration at one end. Inscriptions on three surfaces.

Previous Publication: Number S6, Kalus (1995: 137-138).

\section{Arabic Transcription and Translation:}

A:

- Their Lord gives them glad tidings of Mercy from Him, and His being pleased and of Gardens from them wherein are everlasting delights. They will dwell therein forever (9:21-22).

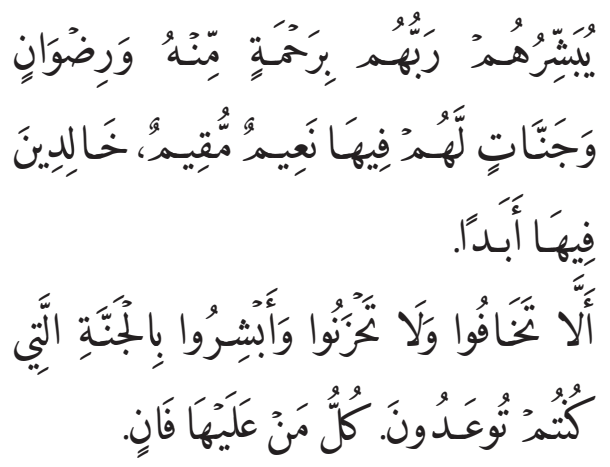

- Fear not, nor grieve; But receive the glad tidings of Paradise which you have been promised (41:30). Whatsoever is on the earth will perish (55:26).

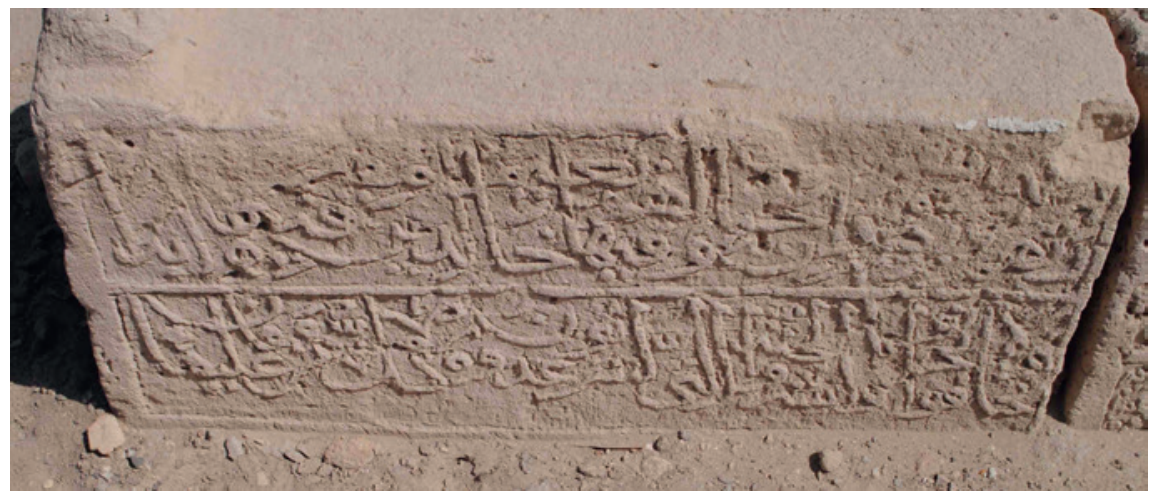

FIGURE 2.282 Surface A, KHA2 
B:

- In the Name of Allah, the Most Gracious, the Most Merciful. Verily, we have given you a manifest victory.

- Straight path. And that Allah may help you with strong help (48:1-3). Gardens of Eden, which they shall enter (13:23).
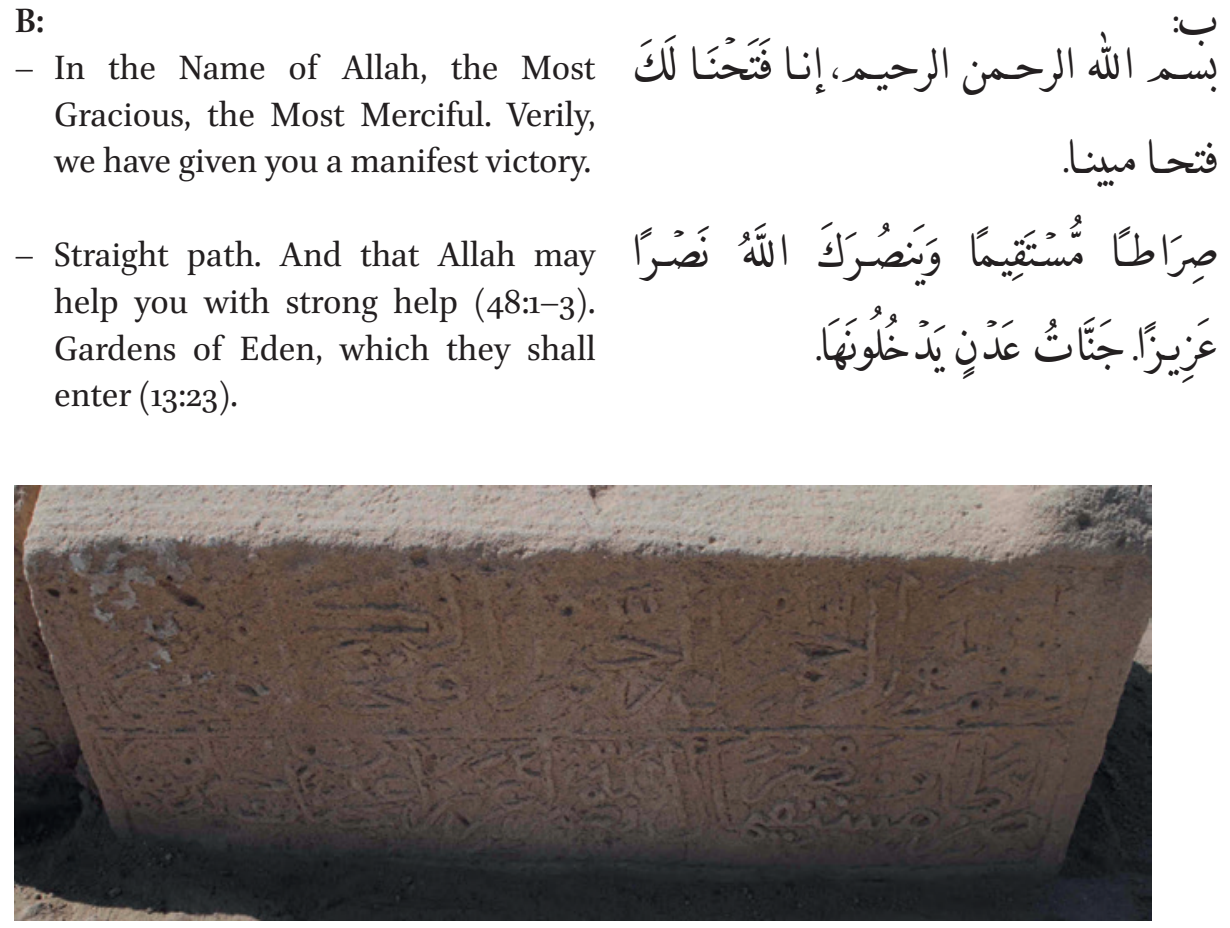

FIGURE 2.283 Surface B, KHA2

C:

- No carving or inscriptions

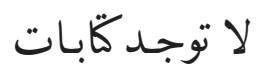

D:

- The blessed late, the example of great masters has died ...

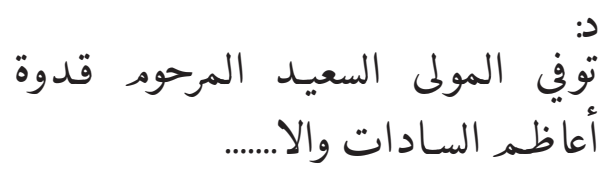

- Glory of the religion, 'Abd al-Aziz bin Ibrahim bin Salih. God rest his soul.

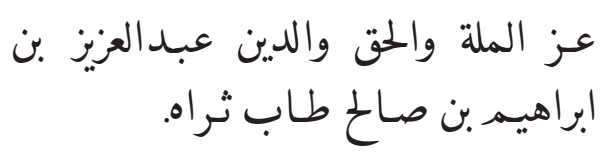




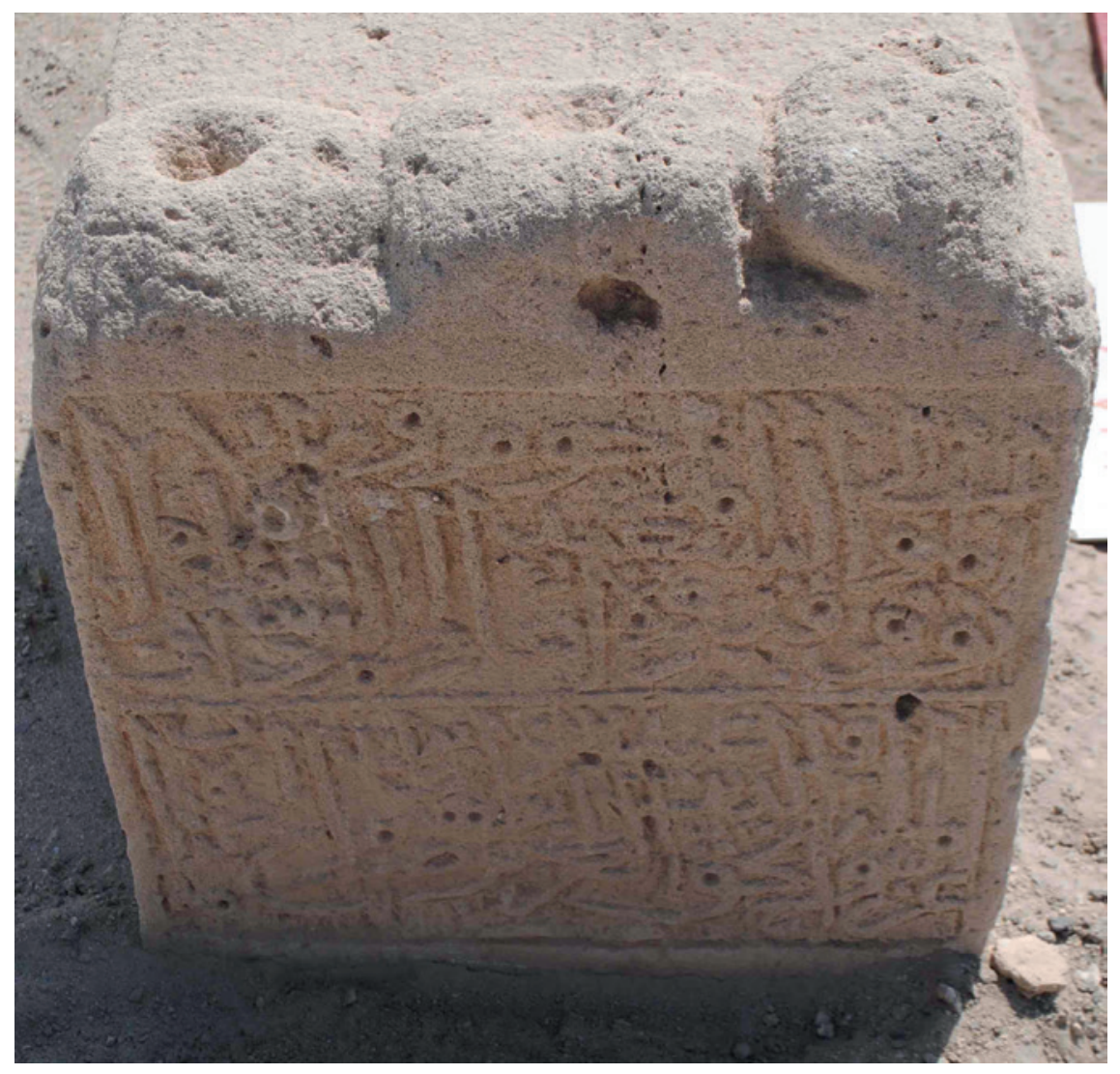

FIGURE 2.284 Surface D, KHA2

E:

- No carving or inscriptions.

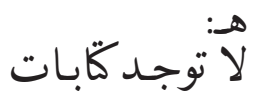

Reference Number: KHA3

Co-ordinates: $26.20847^{\circ} \mathrm{N} 050.54841^{\circ} \mathrm{E}$

Dimensions: $60 \mathrm{~cm}(\mathrm{l}) \times 30.5 \mathrm{~cm}(\mathrm{w}) \times 35 \mathrm{~cm}(\mathrm{~h})$

Orientation: NW-SE

Description: Single limestone slab gravestone, part of double slab gravestone. Not in original position and not associated with neighbouring stone. Inscriptions on two surfaces.

Previous Publication: Number S4, Kalus (1995: 135). 
Arabic Transcription and Translation:

A:

- The late ..., the honoured, the master was ...
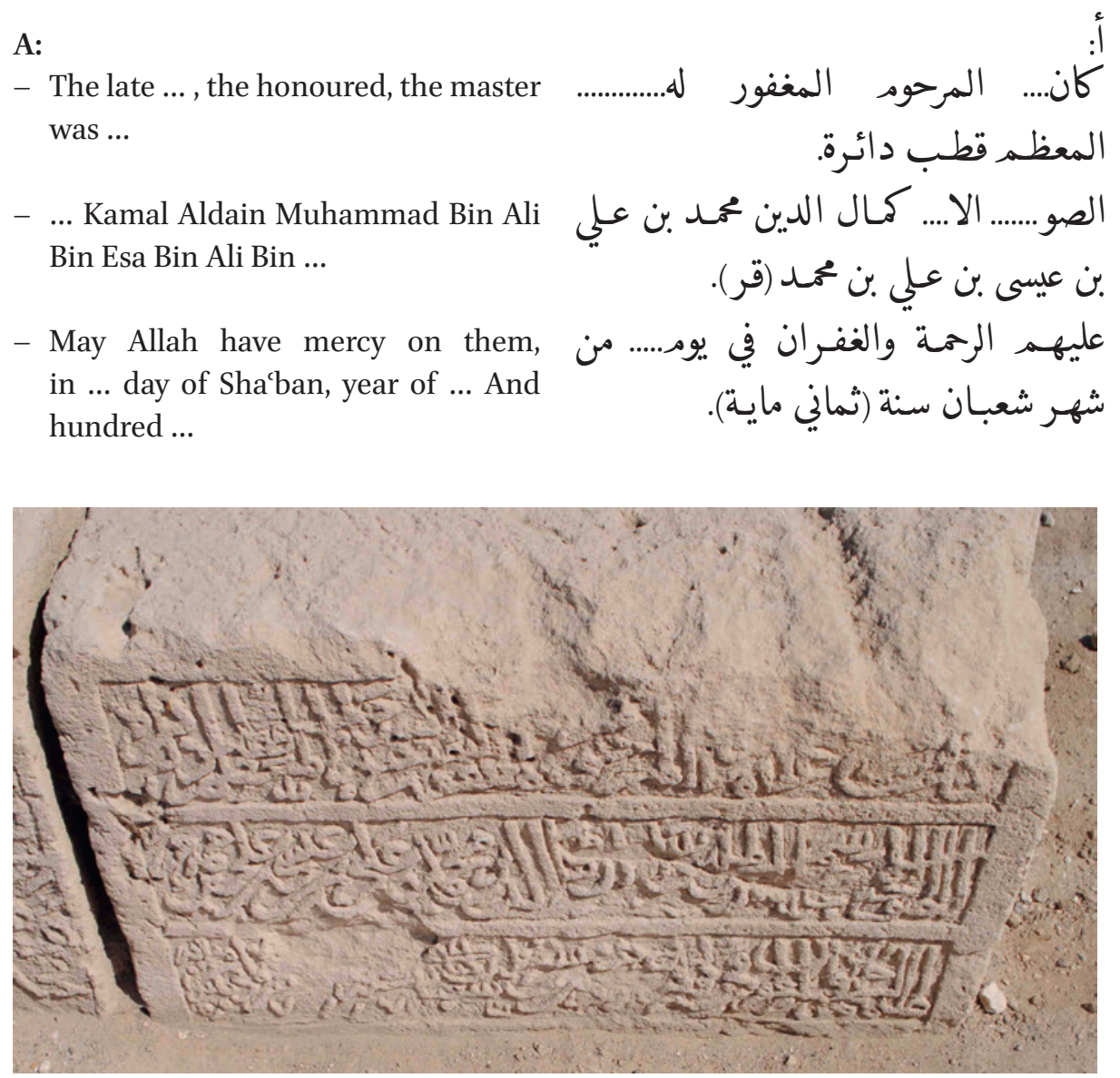

FIGURE 2.285 Surface A, KHA3

B:

- In the Name of Allah, the Most Gracious, the Most Merciful. Verily, we have given you a manifest victory.

- That Allah may forgive you your sins of the past and the future. And complete His favour on you,

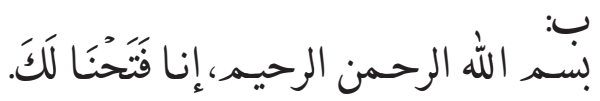

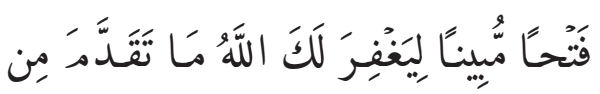

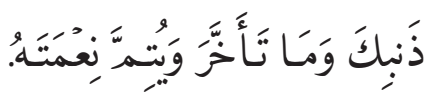

- And guide you on the straight path. And that Allah may help you with strong help (48:1-3).

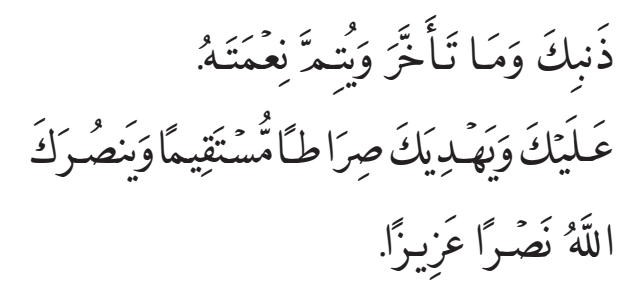




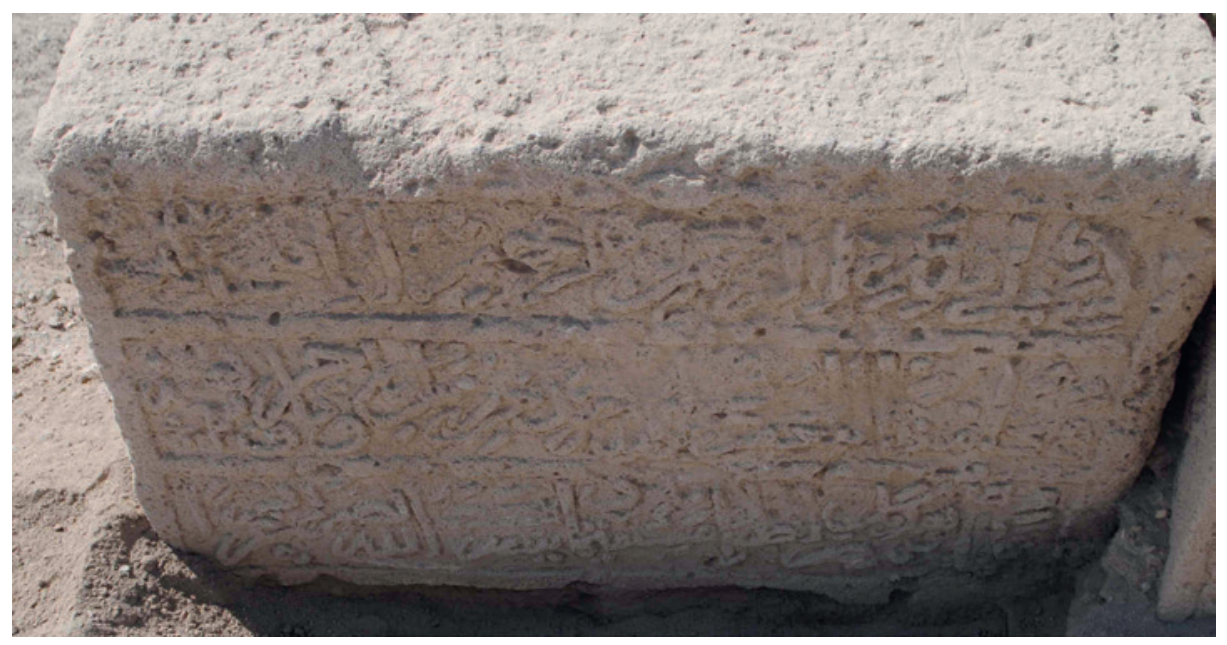

FIGURE 2.286 Surface B, KHA3

C:

- No carving or inscriptions.

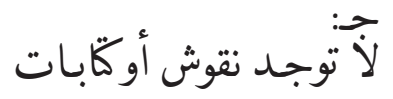

D:

- No carving or inscriptions.

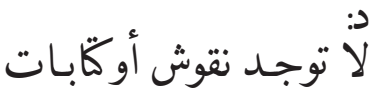

E:

- No carving or inscriptions.

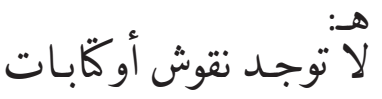

\section{Reference Number: KHA4}

Co-ordinates: $26.20848^{\circ} \mathrm{N} 050.54844^{\circ} \mathrm{E}$

\section{Dimensions:}

Slab 1: $80 \mathrm{~cm}(\mathrm{l}) \times 32 \mathrm{~cm}(\mathrm{w}) \times 48 \mathrm{~cm}(\mathrm{~h})$

Slab 2: $57 \mathrm{~cm}(\mathrm{l}) \times 34 \mathrm{~cm}(\mathrm{w}) \times 33 \mathrm{~cm}(\mathrm{~h})$

\section{Orientation: NNW-SSE}

Description: Gravestone formed of double limestone slabs. Significant erosion in places, particularly where it was exposed above the surface of the shrine mound. Three element raised decoration at one end formed of two facetted cubes and a central rounded arch and eroded unidentifiable raised decoration at the other end. Traces of shallow carved rectangular panel design, probably part of a niche, on the 
top surface (E) of the less eroded slab. Partially legible inscriptions on three surfaces. Excavated to expose associated shrine and whole gravestone.

\section{Arabic Transcription and Translation:}

A:

- ... Muham ... And those ...
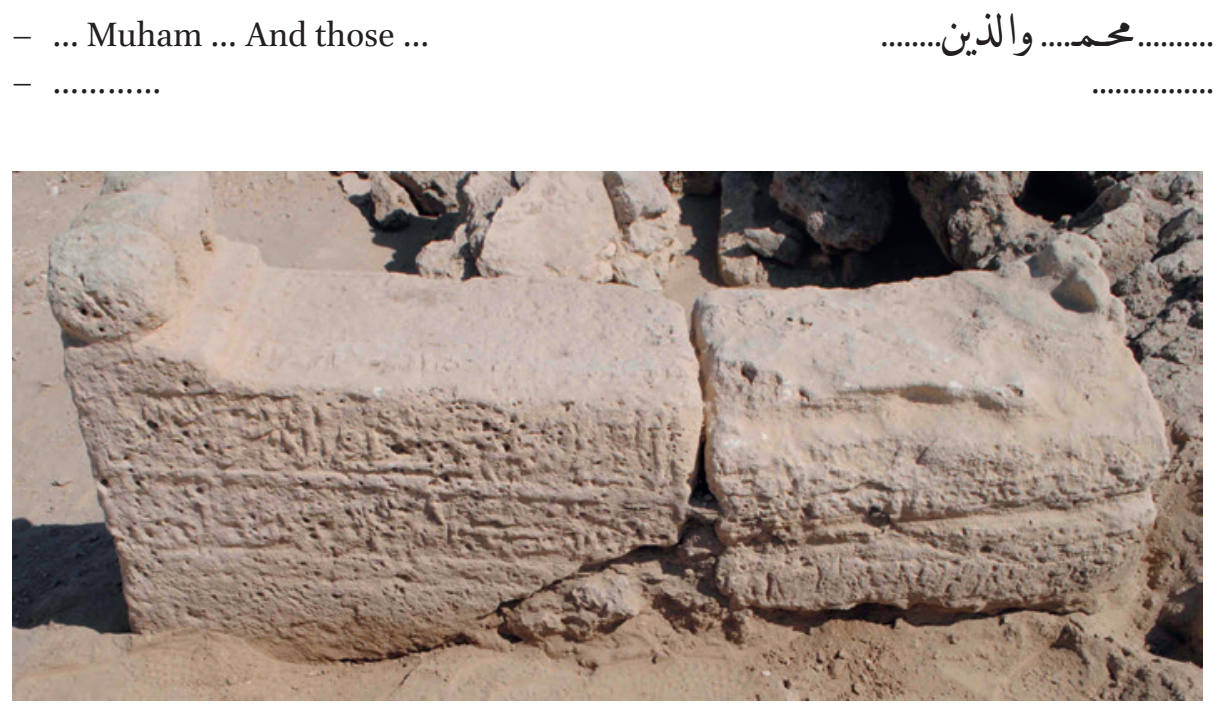

FIGURE 2.287 Surface A, KHA4

B:

- ... the Most Gracious, the Most Merciful. Allah, there is no deity but he, the Ever Living, the One Who sustains and protects all that exists. Neither slumber nor sleep overtakes Him. To Him belongs whatever is

- in the heavens and whatever is on the earth. Who is he that can intercede with Him except by His permission! He knows what happens to them in this world, and will happen to them in the Hereafter (2:255).

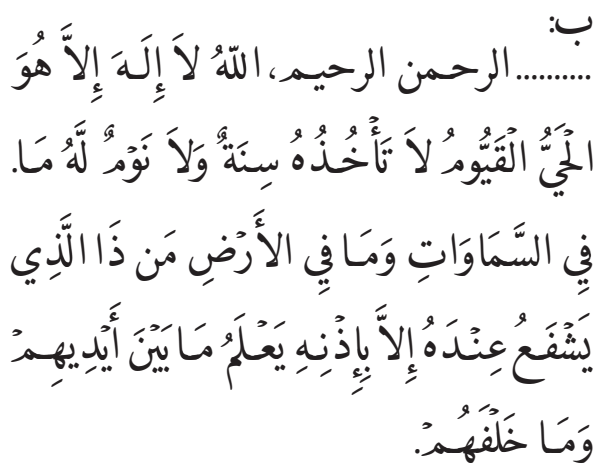




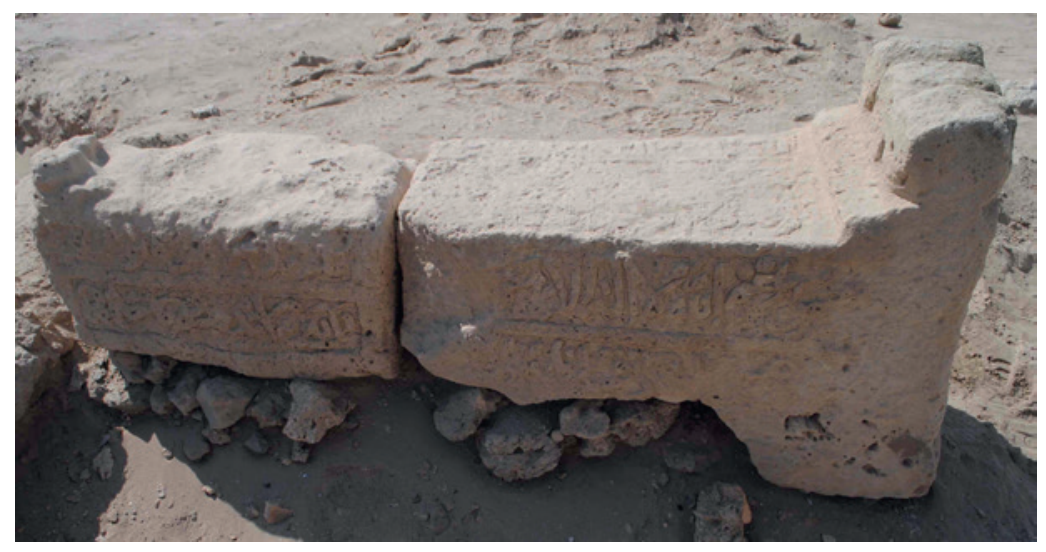

FIGURE 2.288 Surfaces B and E, KHA4

C:

- Grave of Shaikh Has ...

- Has ...

$-\mathrm{Al} \ldots$

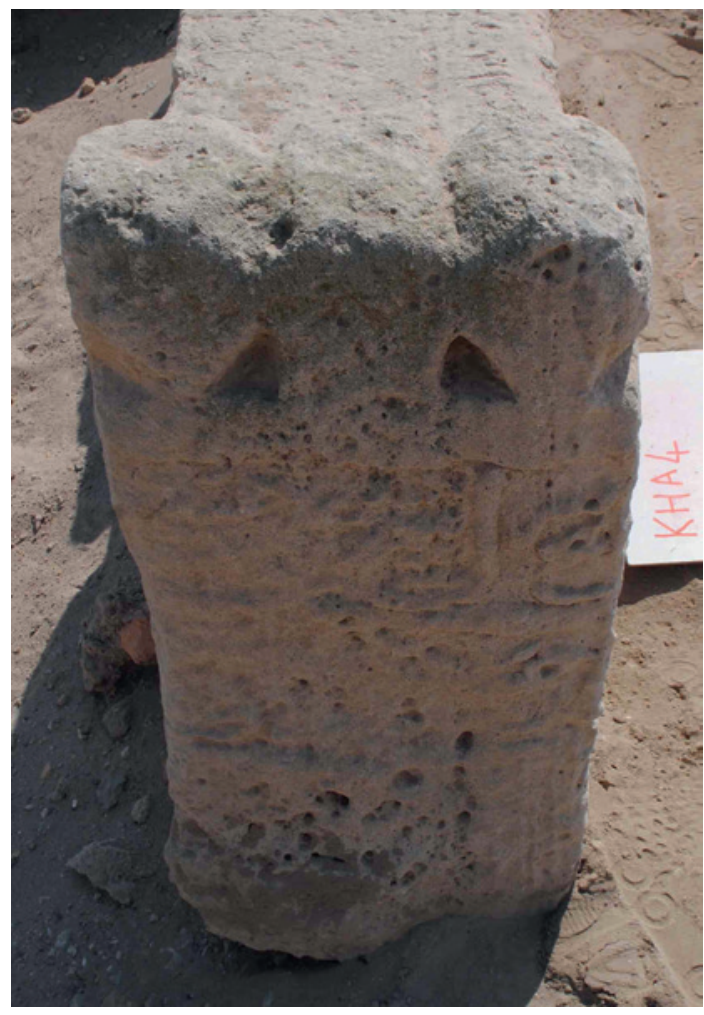

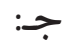
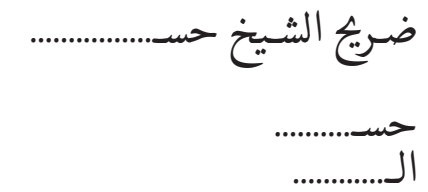
D:

- Very deteriorated. Unable to read.
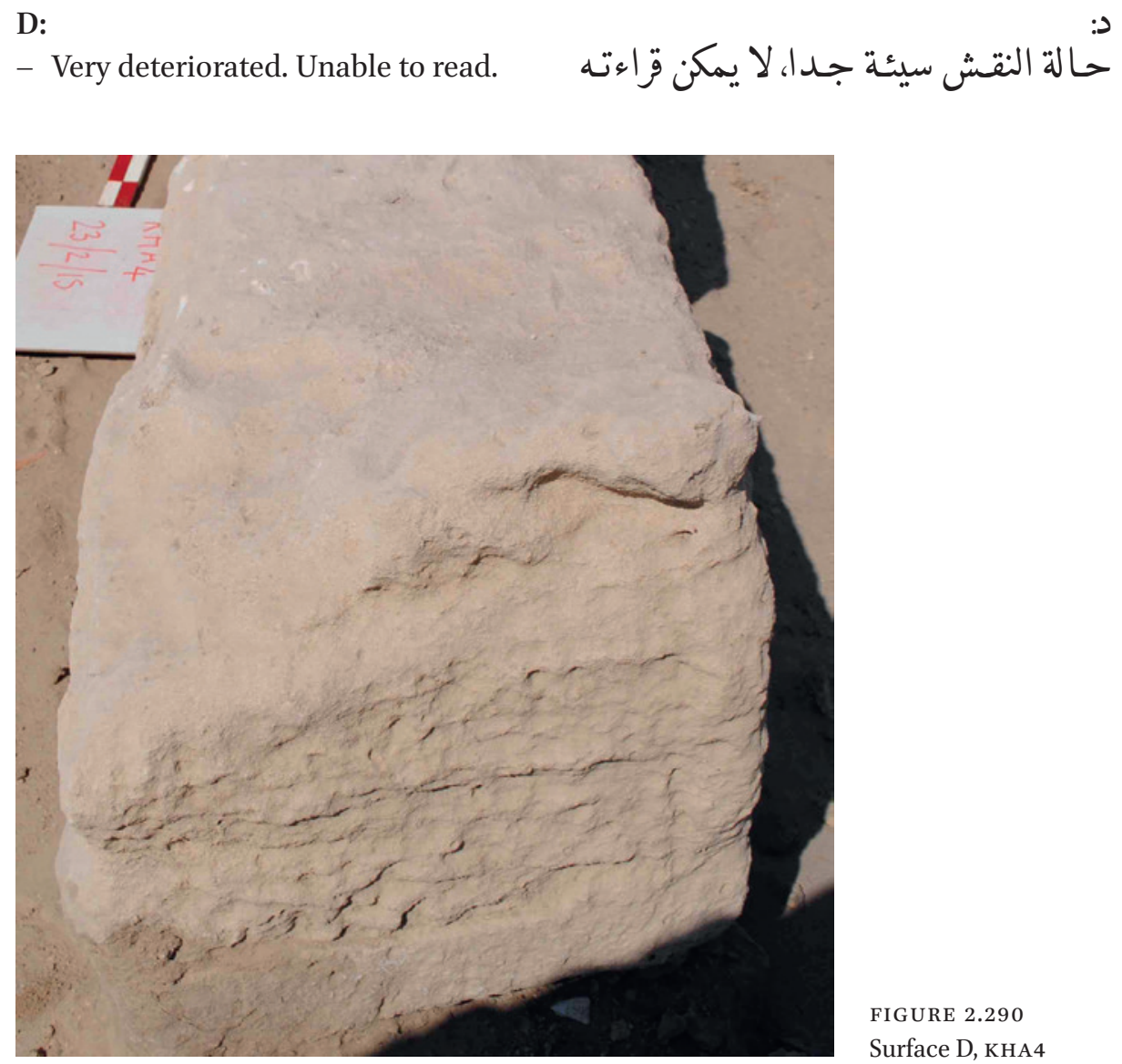

FIGURE 2.290

Surface D, KHA4

E:

- Very deteriorated. Unable to read.

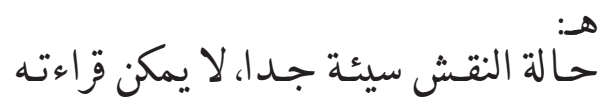

See Figure 2.288

Reference Number: KHA5

Co-ordinates: $26.20851^{\circ} \mathrm{N} 050.54845^{\circ} \mathrm{E}$

\section{Dimensions:}

Slab 1: $61 \mathrm{~cm}(\mathrm{l}) \times 24 \mathrm{~cm}(\mathrm{w}) \times 40 \mathrm{~cm}(\mathrm{~h})$

Slab 2: $70 \mathrm{~cm}(\mathrm{l}) \times 22 \mathrm{~cm}(\mathrm{w}) \times 40 \mathrm{~cm}(\mathrm{~h})$

Orientation: NNW-SSE 
Description: Gravestone formed of double limestone slabs. Unidentifiable three element raised decoration at both ends. Shallow carved rounded niche design on top surface (E). Red paint/pigment on the lettering on two surfaces. Inscriptions on four surfaces. Excavated within collapsed shrine.

\section{Arabic Transcription and Translation:}

A:

- May peace from Allah be upon Muhammad al-Mustafa and Imam 'Ali al-Murtada. Peace be upon alHasan al-Radi. Peace be upon the martyr at Karbala, al-Husayn bin 'Ali. Peace be upon Zayn al-'Ubad. Peace be upon Muhammad al-Baqir. Peace be upon Ja'far al-Sadiq.

- And Musa al-Kadhim ... upon 'Ali bin Musa al-Rida. Peace be upon Muhammad al-Naqi. Peace be upon 'Ali al-Taqqi. Peace be upon al-Hasan al-Askari. Peace be upon al-Hujjah al-Mahdi. May peace from Allah be upon all of them.
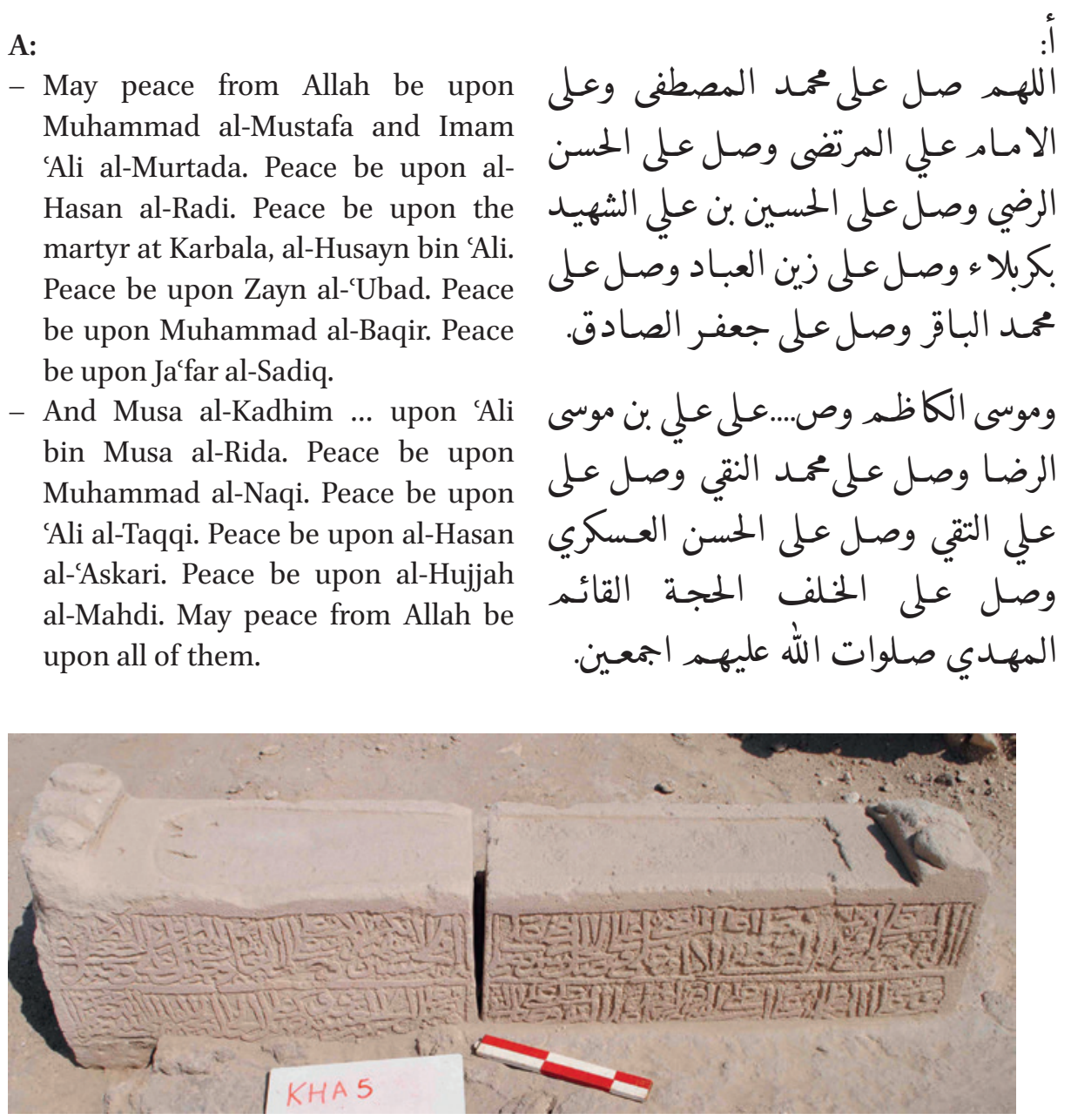

FIGURE 2.291 Surface A, KHA5 
B:

- Allah, none has the right to be worshipped but he, the Ever Living, the One Who sustains and protects all that exists. Neither slumber nor sleep overtakes Him. To Him belongs whatever is in the heavens and whatever is on the earth. Who is he that can intercede with Him except by His permission! He knows

- what happens to them in this world, and will happen to them in the Hereafter. And they will never compass anything of His Knowledge except that which He wills. His Seat extends over the heavens and the earth, and $\mathrm{He}$ feels no fatigue in guarding and preserving them. And $\mathrm{He}$ is the Most High, the Most Great (2:255). The angels will descend on them, saying: Fear not, nor grieve; but receive the glad tidings of Paradise which you have been promised (41:30).
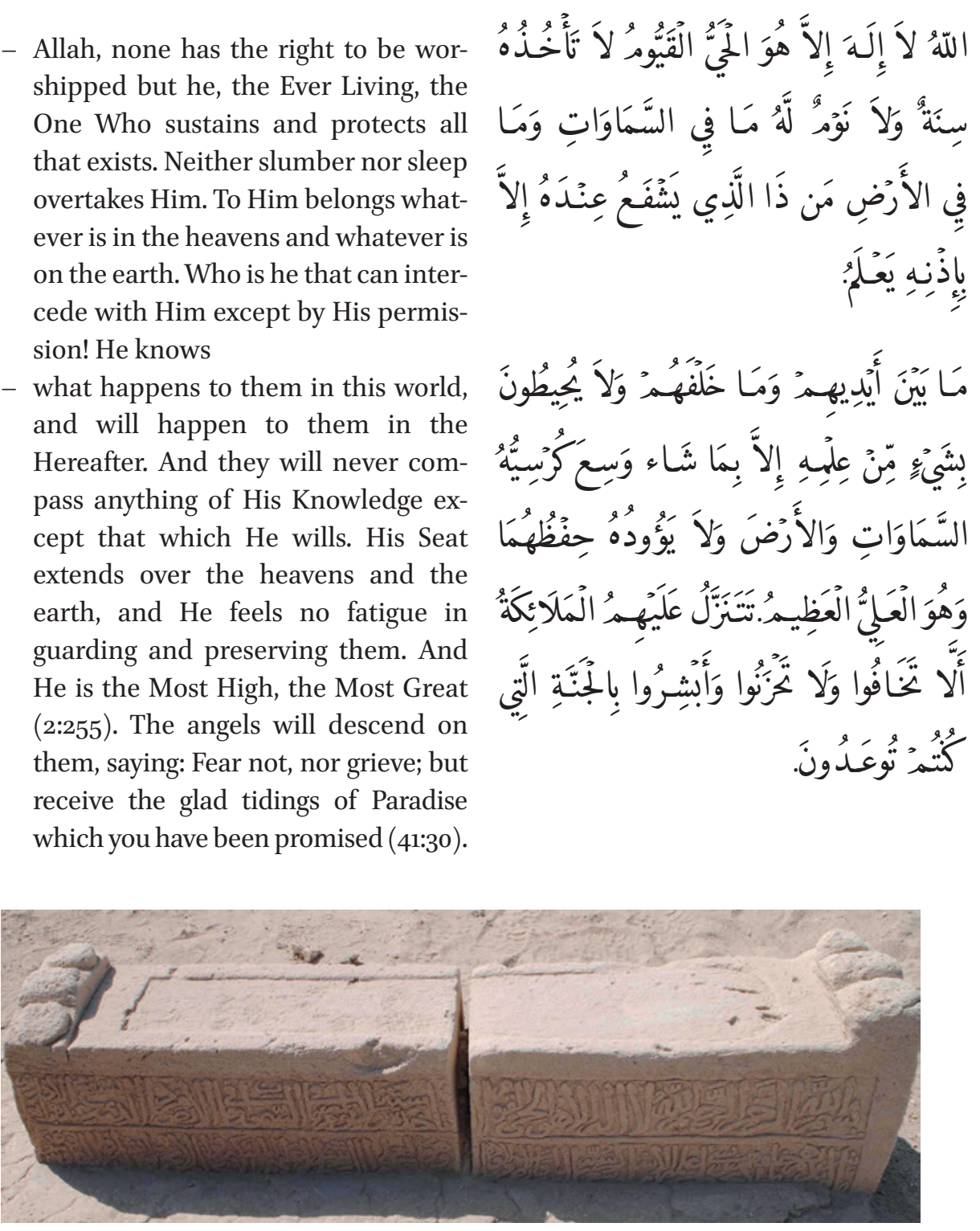

FIGURE 2.292 Surface B, KHA5

C:

- ... in the eleventh.

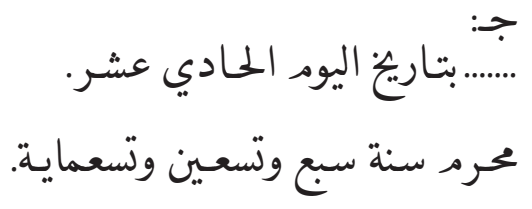

- Of Muharram, in nine hundred and ninety-seven. 


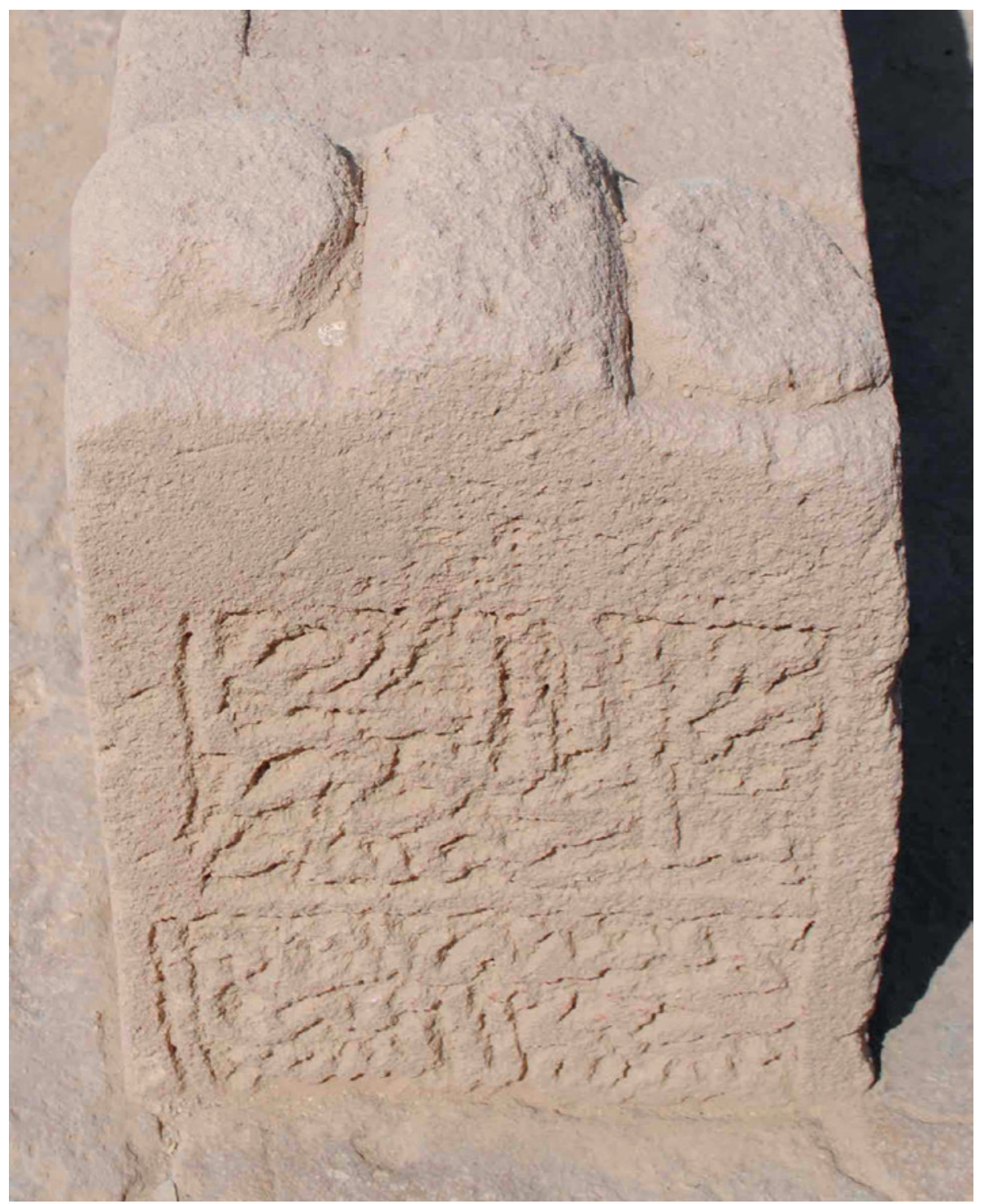

FIGURE 2.293 Surface C, KHA5

D:

- The noble and chaste lady,

- Muluk bint al-Sayyid 'Abd al-'Aziz, died.

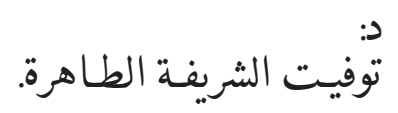

العفيفة مـاوك بنت السيد عبد العزيز. 


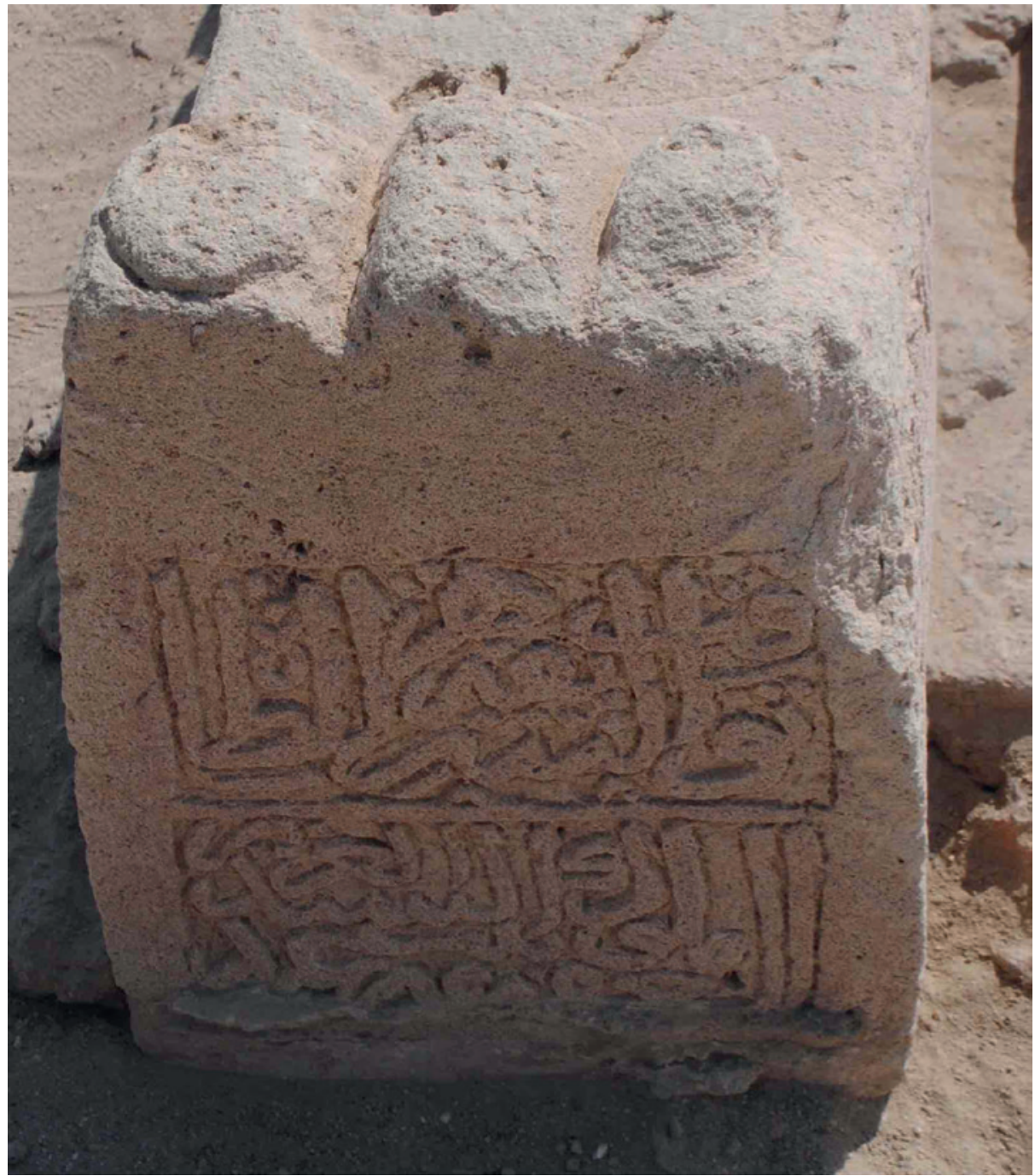

FIGURE 2.294 Surface D, KHA5

E:

- No carving or inscriptions.

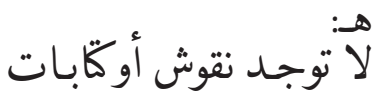




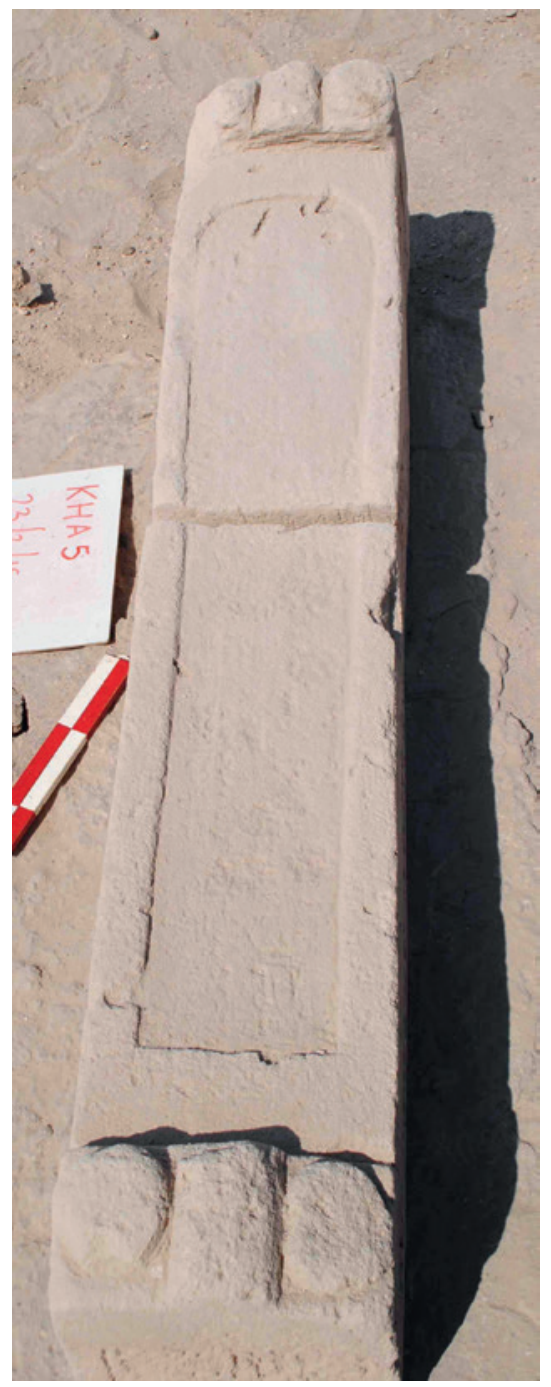

FIGURE 2.295

Surface E, KHA5

\section{Reference Number: KHA6}

Co-ordinates: $26.20850^{\circ} \mathrm{N} 050.54847^{\circ} \mathrm{E}$

Dimensions: $74.5 \mathrm{~cm}(\mathrm{~L}) \times 19 \mathrm{~cm}(\mathrm{~W}) \times 40 \mathrm{~cm}(\mathrm{H})$

\section{Orientation: NNW-SSE}

Description: Single limestone slab, part of a double slab gravestone. Cracked. Eroded and unidentifiable three element raised decoration set on a rectangular 
plinth at one end. Traces of shallow carved rectangular panel design on the top surface (E). Red paint/pigment on lettering on all three inscribed surfaces. Inscriptions on three surfaces. Excavated within collapsed shrine.

\section{Arabic Transcription and Translation:}

A:

- May peace from Allah be upon Muhammad al-Mustafa and ... upon 'Ali al-Murtada. Peace be upon $\mathrm{Al}$ Hasan.

- And Peace be upon Ja'far al-Sadiq and Musa al-Kadhim. Peace be upon 'Ali bin Musa al-Rida. Peace be upon Muhammad al ...
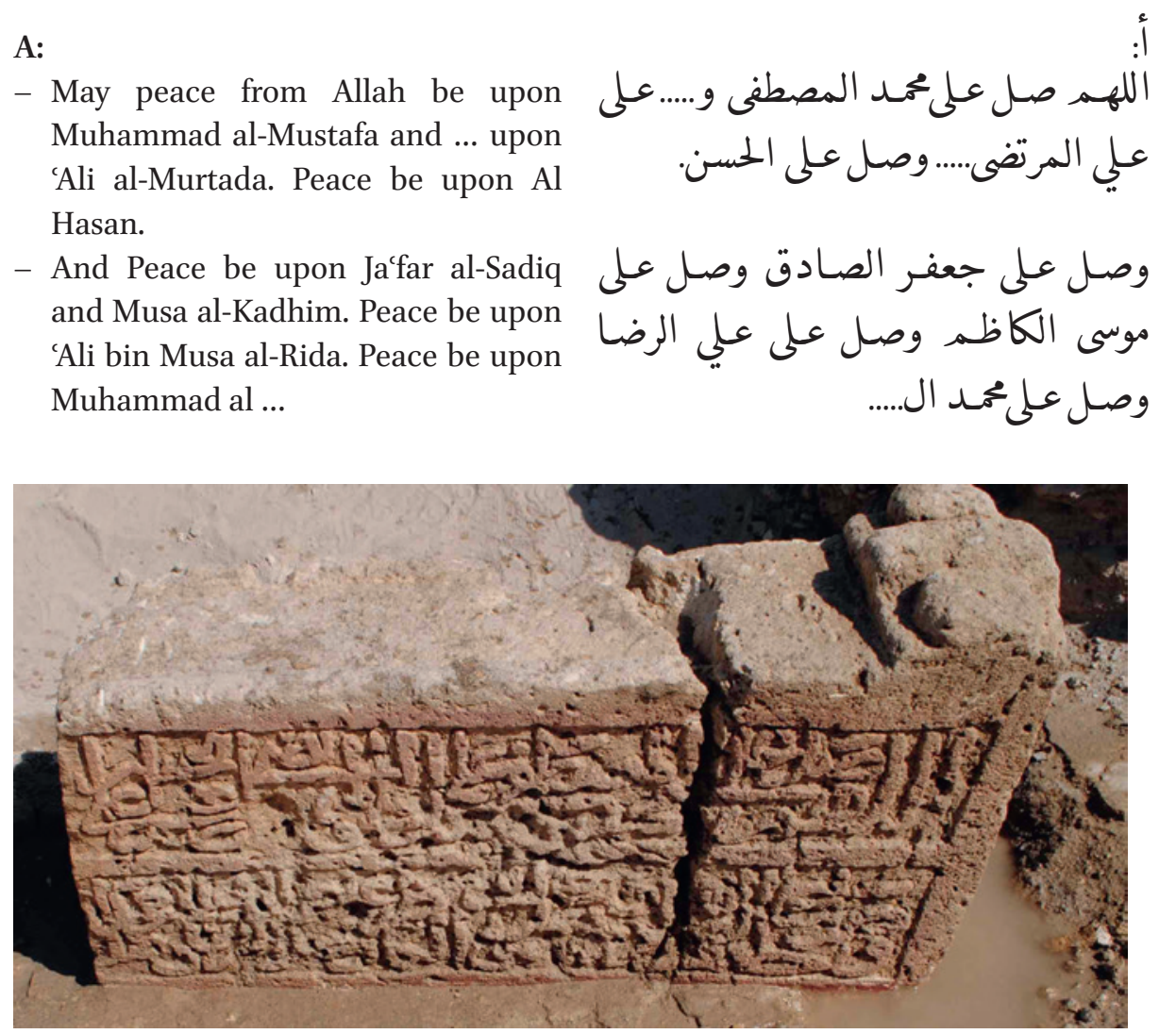

FIGURE 2.296 Surface A, KHA6

B:

- nor sleep overtakes Him. To Him belongs whatever is in the heavens and whatever is on the earth. Who is he that can intercede with Him except by His permission!

- His Seat extends over the heavens and the earth, and He feels no fatigue in guarding and preserving them. And He is the Most High, the Most

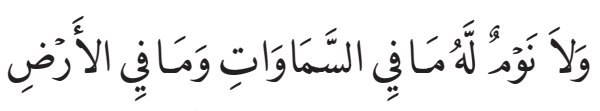

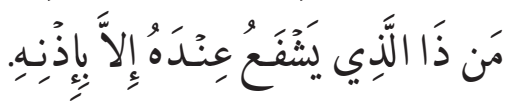

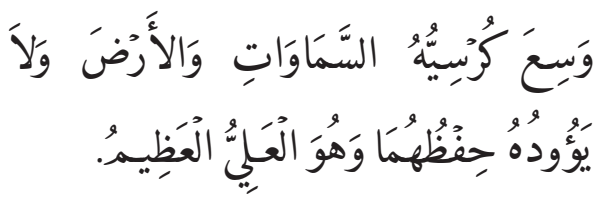
Great (2:255). 


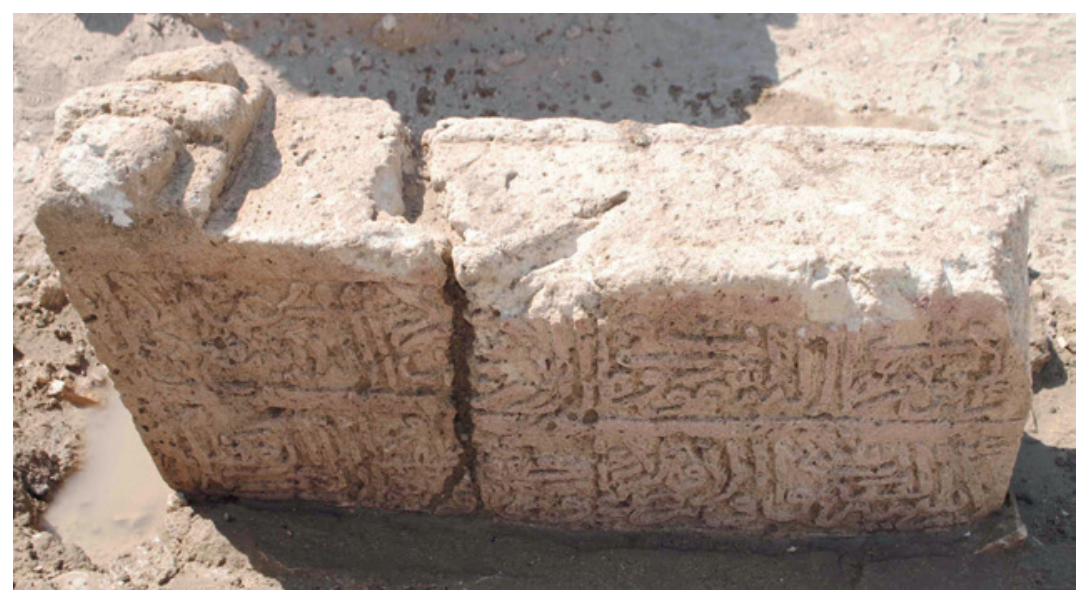

FIGURE 2.297 Surface B, KHA6

C:

- In the beginning of the month of

- Jumada al-awwal.

- In the year of four hundred and seven.

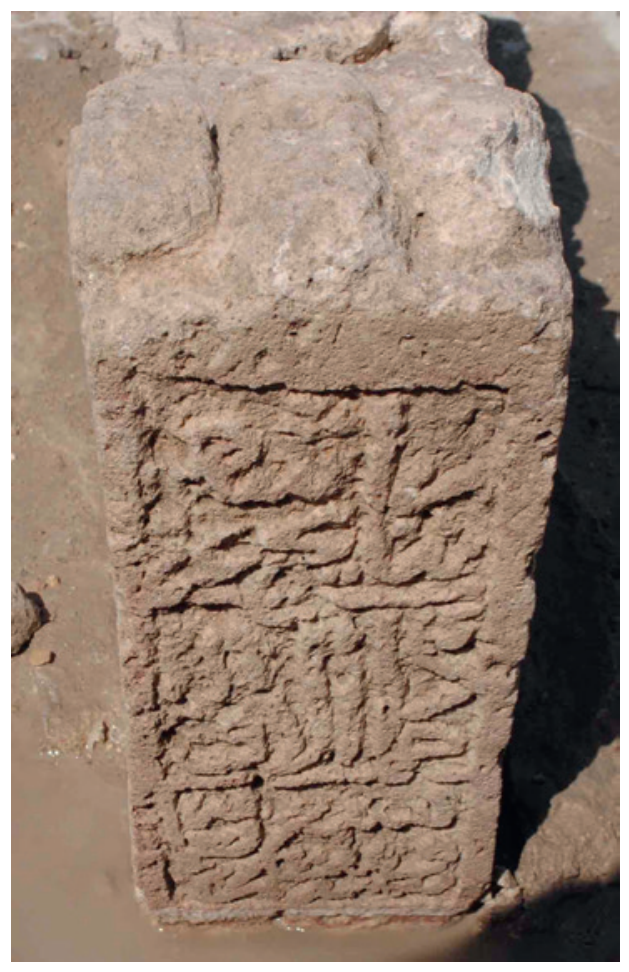

$$
\text { بتاريخ غرة شهر. }
$$

FIGURE 2.298

Surface C, KHA6 
D:

- No carving or inscriptions.

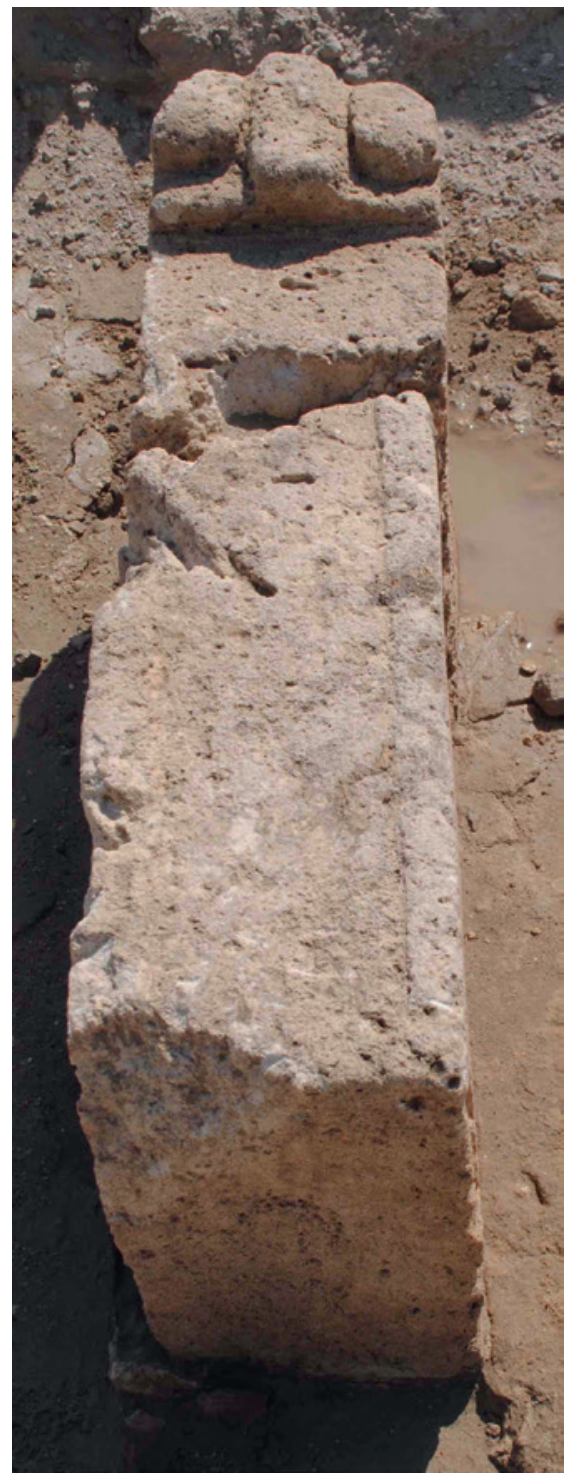

FIGURE 2.299

Surfaces D and E, KHA6

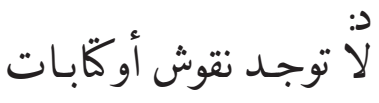

E:

- No carving or inscriptions.
لا تُوجــ نقوش أوكَبات

See Figure 2.299 


\section{Reference Number: KHA7}

Co-ordinates: $26.20843^{\circ} \mathrm{N} 050.54847^{\circ} \mathrm{E}$

Dimensions: $156 \mathrm{~cm}(\mathrm{l}) \times 29.5 \mathrm{~cm}(\mathrm{w}) \times 39 \mathrm{~cm}(\mathrm{~h})$

\section{Orientation: NNW-SSE}

Description: Single limestone slab gravestone. Cracked and broken on top where it was exposed above the ground surface. Possible traces of red paint/pigment on some of the lettering. Raised decoration, which was possibly set on rectangular plinths has been cut off each end. Inscriptions on five surfaces. Shallow carved rounded niche design on the top surface (E). Excavated inside the main room of a collapsed shrine. The gravestone states that the shrine was built for the person it commemorates, Shaikh Muhammad bin al-Mabrur Shaikh Majid.

\section{Arabic Transcription and Translation:}

A:

- Verily, those who say: Our Lord is Allah, and then they stand firm, The angels will descend on them, (saying:) 'Fear not, nor grieve; But receive the glad tidings of Paradise which you have been promised. We have been your friends in the life of this world and in the Hereafter. Therein you shall have all that your souls desire and all that you ask for.

- As hospitality from One, the Forgiving, the Most Merciful (41:30-32). Gardens of Eden whose gates will be opened for them. Therein they will recline, therein they will call for fruits in abundance and drinks. And beside them will be maidens of equal age with modest gaze. This is what you are promised on the Day of Reckoning. Verily, this is our Provision which will never finish (38:50-54).
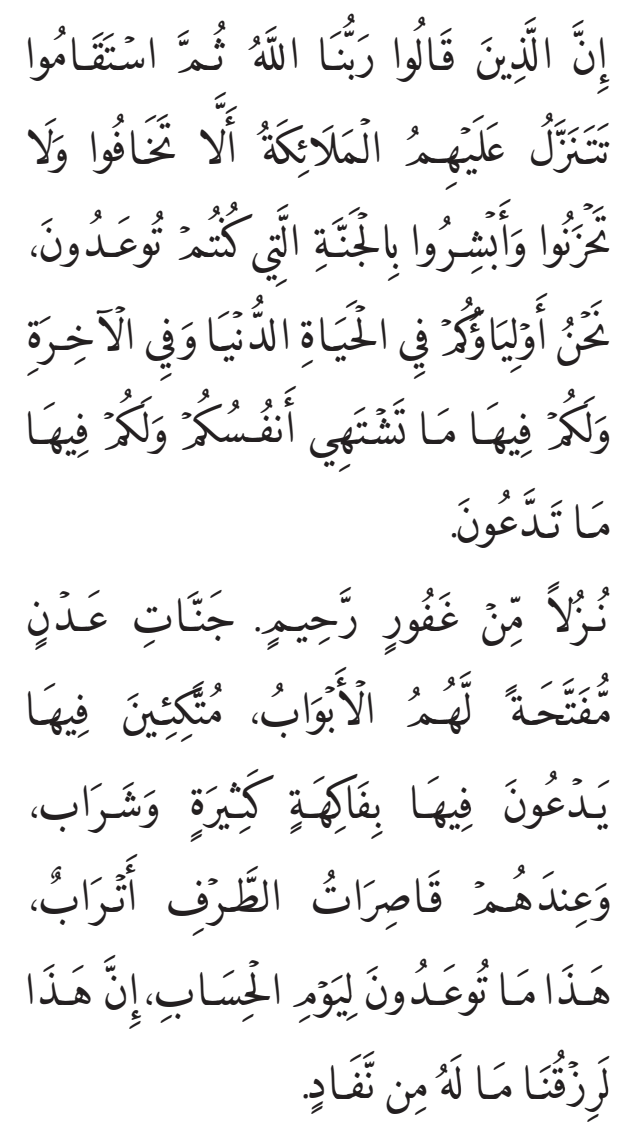


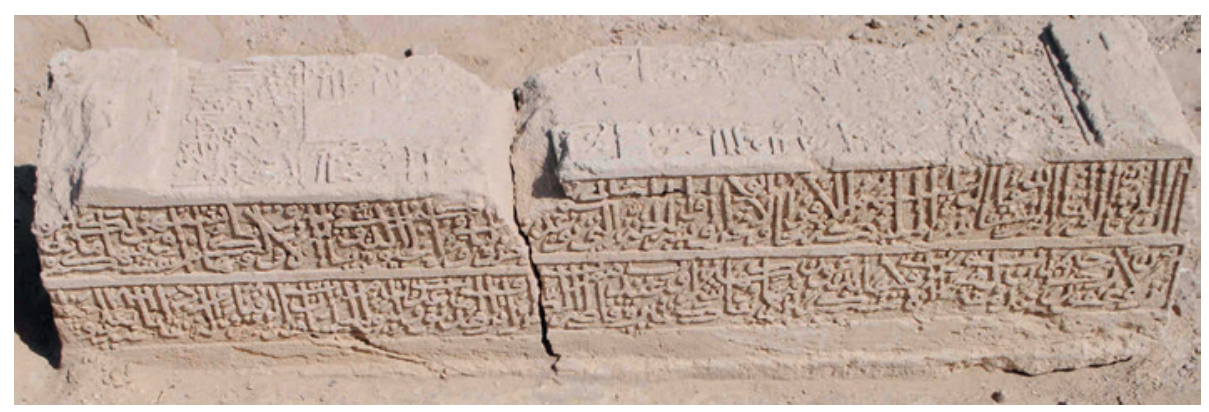

FIGURE 2.300 Surface A, KHA7

B:

- In the Name of Allah, the Most Gracious, the Most Merciful. Allah, none has the right to be worshipped but he, the Ever Living, the One Who sustains and protects all that exists. Neither slumber nor sleep overtakes Him. To Him belongs whatever is in the heavens and whatever is on the earth. Who is he that can intercede with Him except by His permission! He knows ... And they will never compass anything of His Knowledge except that which He wills. His Seat extends

- over the heavens and the earth, and He feels no fatigue in Guarding and preserving them. And $\mathrm{He}$ is the Most High, the Most Great. There is no compulsion in religion. Verily, the Right Path has become distinct from the wrong path. Whoever disbelieves in Allah, then has grasped the most trustworthy handhold that will never break. And Allah is All-Hearer AllKnower (2:255-256). Allah and His Great Prophet have spoken the truth.

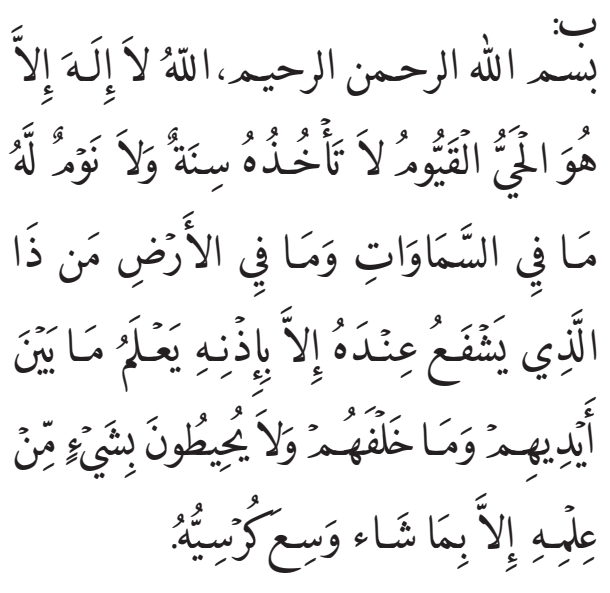

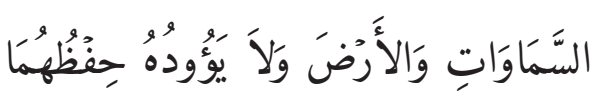

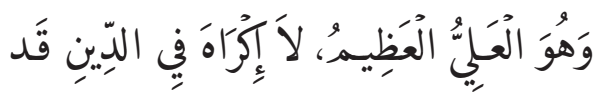

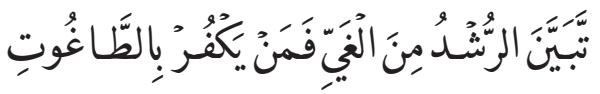

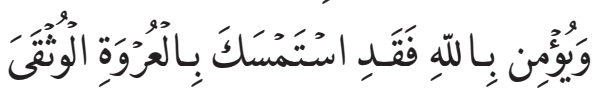

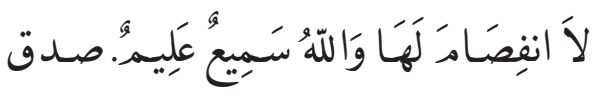
الله العظيـم وبلغ رسوله النبي الكيـم. 


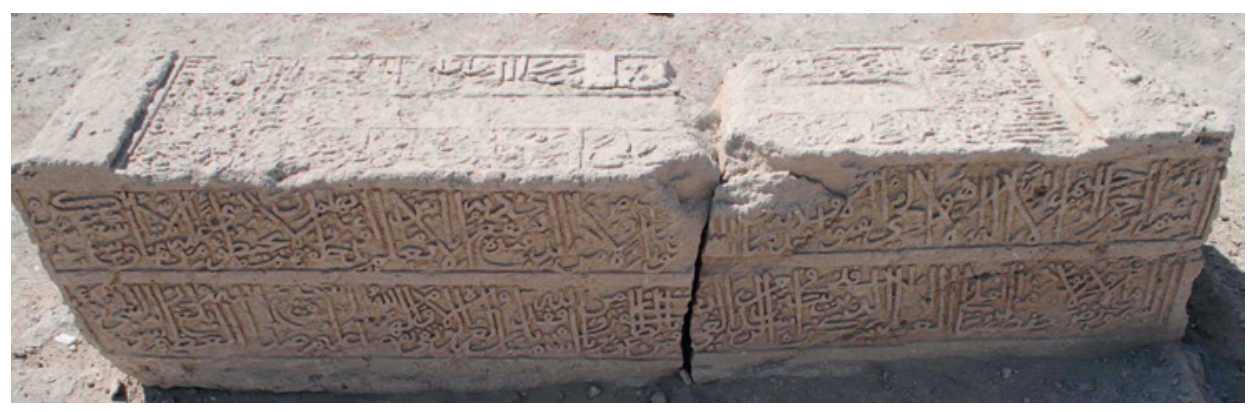

FIGURE 2.301 Surface B, KHA7

C:

- This is the shrine of the late Shaikh Muhammad bin al-Mabrur Shaikh Majid, may Allah be merciful to him, he died on Friday, nineteenth
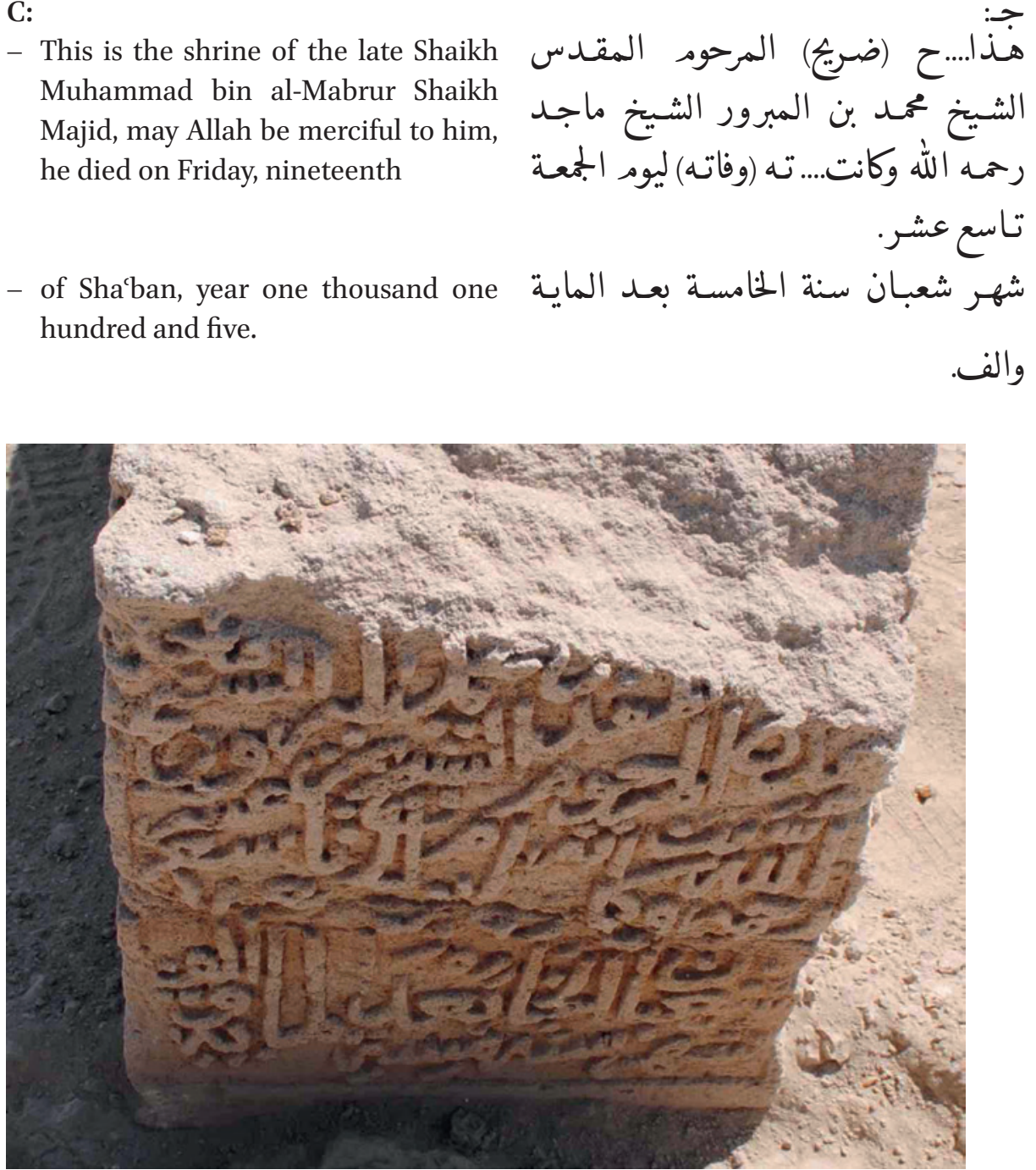

FIGURE 2.302 Surface C, KHA7 
D:

- Reading one part of the Book of God the Powerful, for fifteen Muhammadiyyah.

- From income of the al-Mahall palms which are located in the backyard of Mani in al-Bahrayn.

$$
\begin{aligned}
& \text { قراءة جرزء من كتاب الله العزيز.... }
\end{aligned}
$$

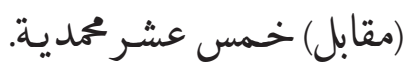

$$
\begin{aligned}
& \text { من حـاصل خغل المحل وتوابعـه موقعـ } \\
& \text { لسيحة ظهر مـني من البحرين }
\end{aligned}
$$

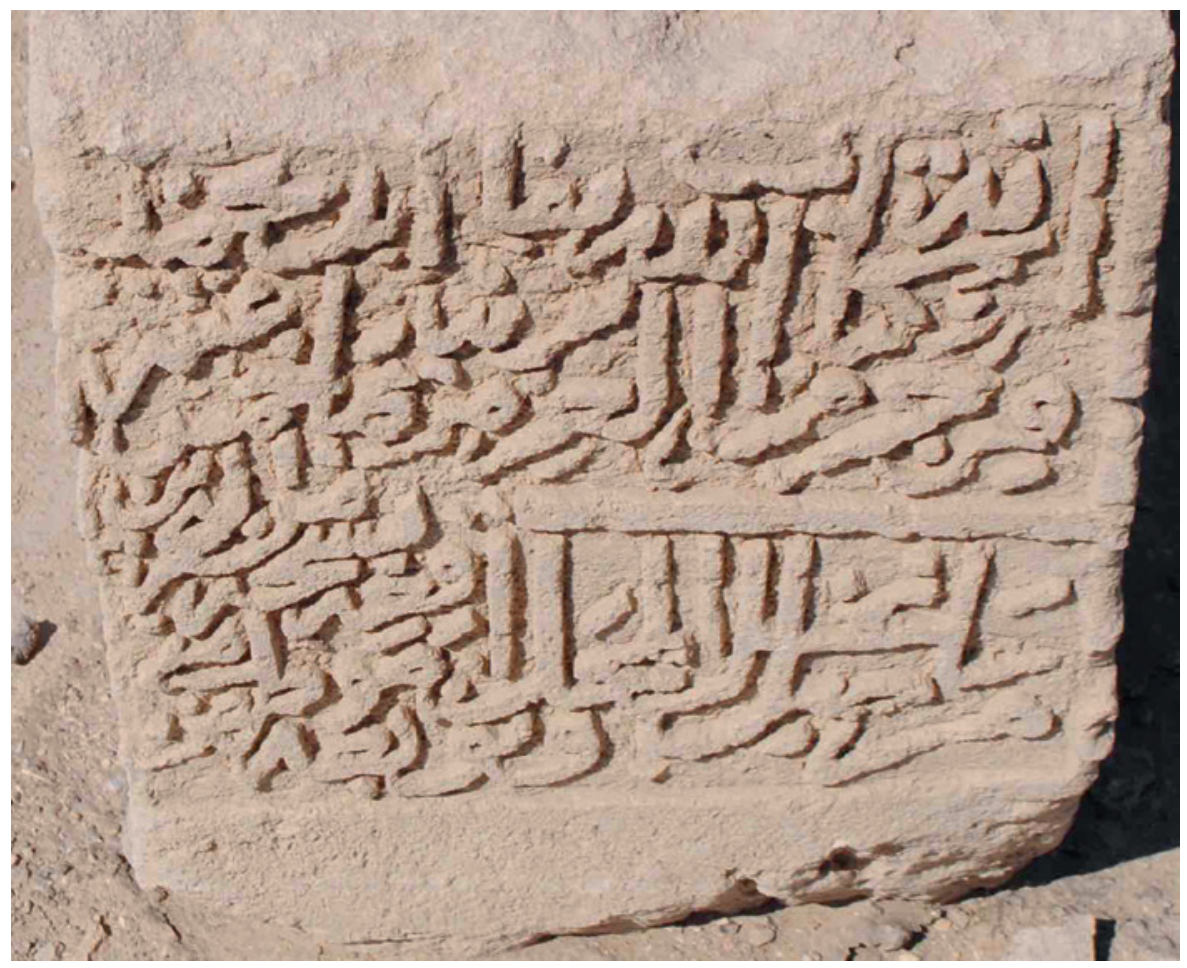

FIGURE 2.303 Surface D, KHA7

E:

- Engraved by al-Sayyid Naser Bin the late al-Sayyid Hashim al-Husayni, May Allah forgive them.

- Oh grave, be proud you embedded ... and illuminated ... sadness ...

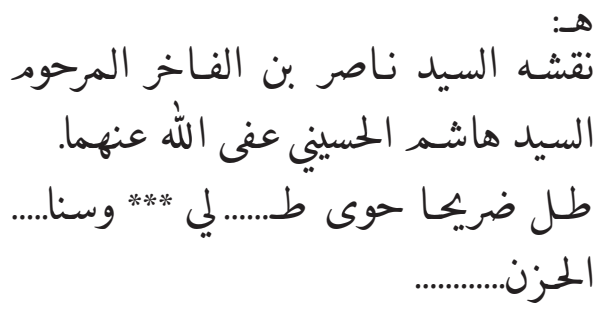

- ... paradise ... offered to me ... may be ... people

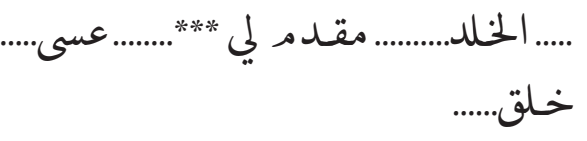

- ... them. 


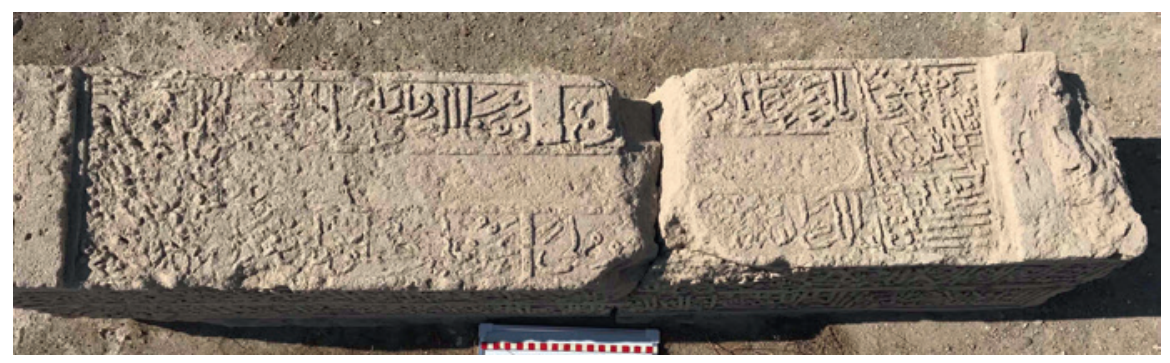

FIGURE 2.304 Surface E, KHA7

\section{Reference Number: KHA8}

Co-ordinates: $26.20837^{\circ} \mathrm{N} 050.54841^{\circ} \mathrm{E}$

Dimensions: $168 \mathrm{~cm}(\mathrm{l}) \times 36 \mathrm{~cm}(\mathrm{w}) \times 46 \mathrm{~cm}(\mathrm{~h})$

\section{Orientation: NNW-SSE}

Description: Single limestone slab gravestone. Very eroded except on one surface. Inscription on one surface, and partially legible inscription on another surface. Not in original position.

Previous Publication: Number 17, Kalus (1990: 48).

\section{Arabic Transcription and Translation:}

A:

- Gardens of Eden whose doors will be opened for them. Therein they will recline, therein they will call for fruits in abundance and drinks. And beside them will be chaste females restraining their glances and of equal ages $\left(38: 5^{0-52}\right)$. The angels will descend on them, (saying:) 'Fear not, nor grieve; But receive the glad tidings of Paradise which you have been promised. We have been your friends in the life of this world and in the Hereafter.
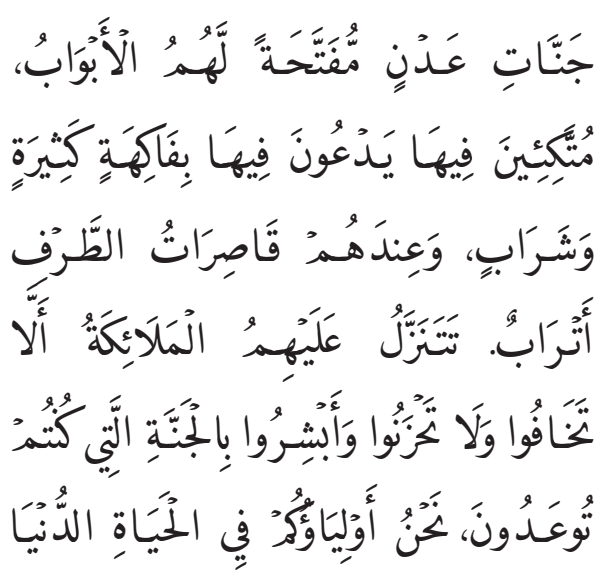

$$
\text { وَفِي الآخِرَة. }
$$


- Therein you shall have all that your souls desire and all that you ask for as hospitality from One, the Forgiving, the Most Merciful (41:30-32). Their Lord gives them glad tidings of Mercy from Him, and His being pleased and of gardens for them wherein are everlasting delights. They will dwell therein forever. Verily, with Allah is a great reward (9:21-22). Eden Gardens which they shall enter and also those who acted righteously from among their fathers, and their wives, and their offspring. And angels shall enter unto them from every gate (13:23).

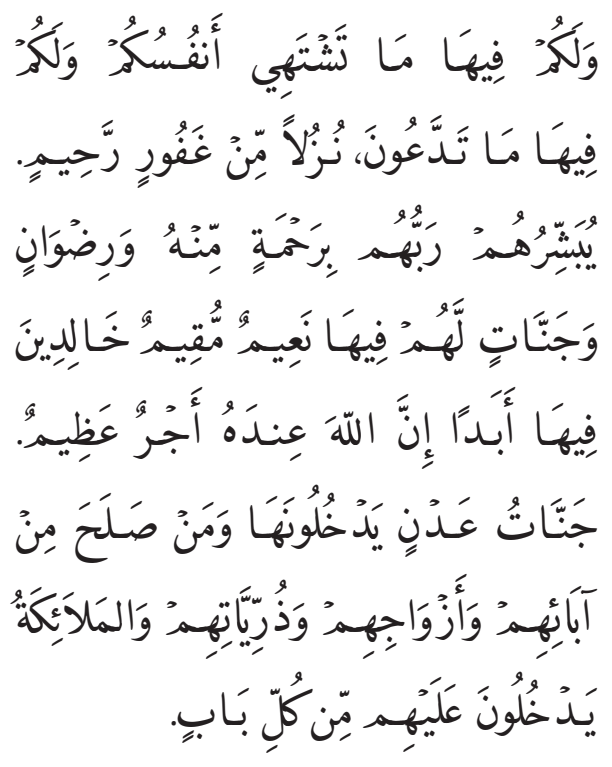

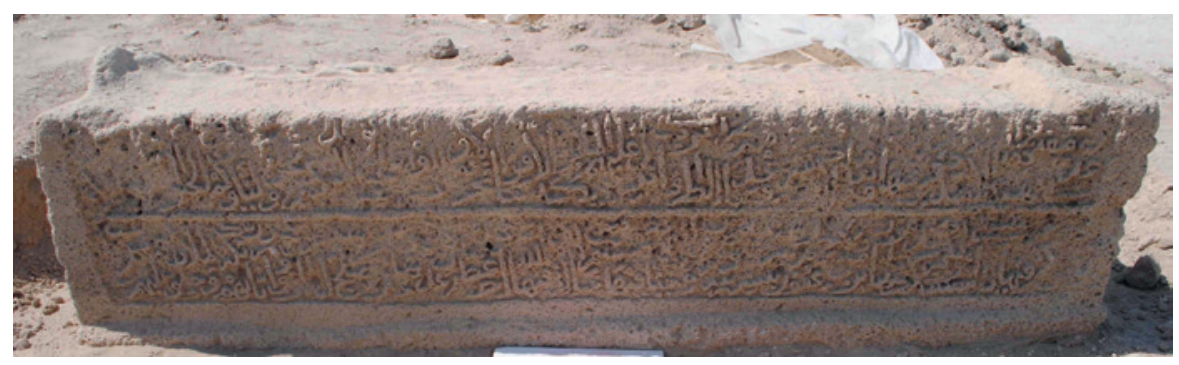

FIGURE 2.305 Surface A, KHA8

B:

- No carving or inscriptions.
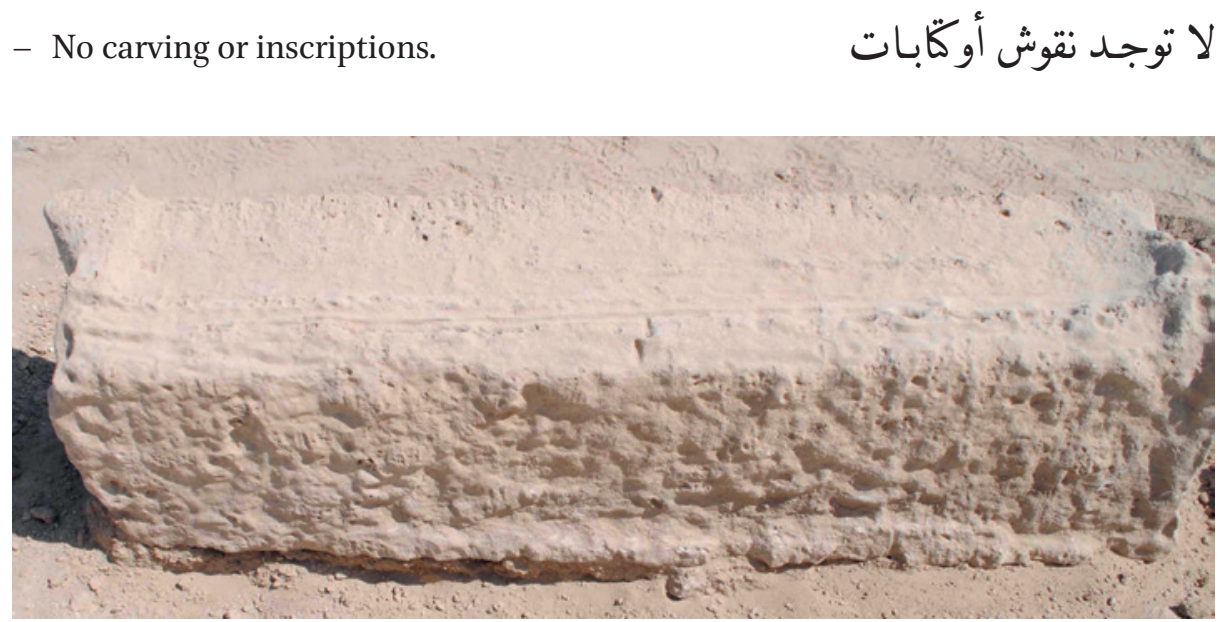

FIGURE 2.306 Surface B, KHA8 
C:

- No carving or inscriptions.

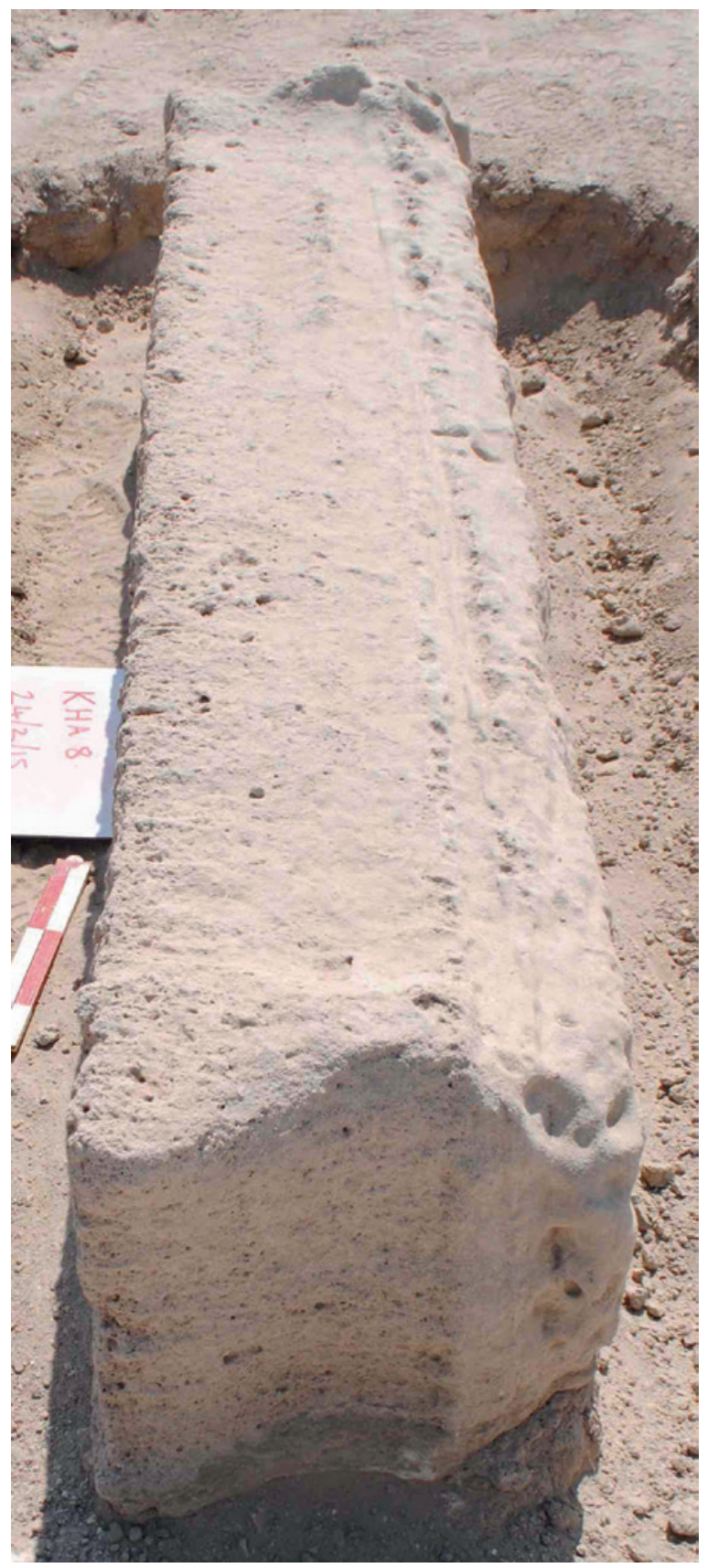

FIGURE 2.307

Surfaces $\mathrm{C}$ and E, KHA8 
D:

- Year ...

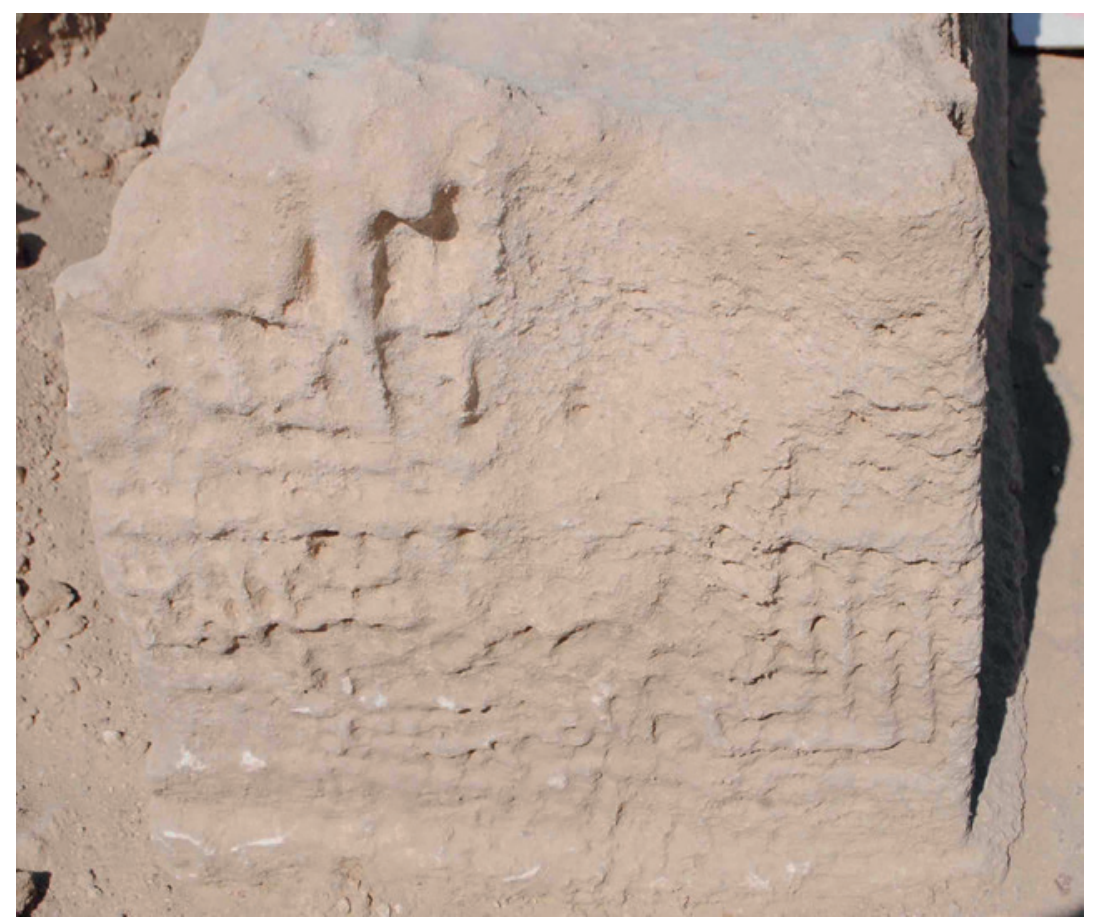

FIGURE 2.308 Surface D, KHA8

E:

- No carving or inscriptions.

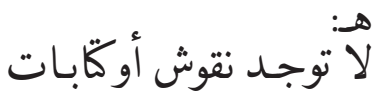

See Figure 2.307

Reference Number: KHA9

Co-ordinates: $26.20838^{\circ} \mathrm{N} 050.54844^{\circ} \mathrm{E}$

Dimensions: $141 \mathrm{~cm}(\mathrm{l}) \times 40 \mathrm{~cm}(\mathrm{w}) \times 60 \mathrm{~cm}(\mathrm{~h})$

\section{Orientation: NNW-SSE}

Description: Single limestone slab gravestone (Figure 2.309). It is roughed out and was probably left unfinished as it has been irregularly cut into shape on one side 
and thus is not the regular rectangular block usually found. Three element raised decoration formed of two facetted cubes and a central rounded arch at each end, but irregularly cut and of poor quality. Chisel marks can be seen on one side. Not in original position

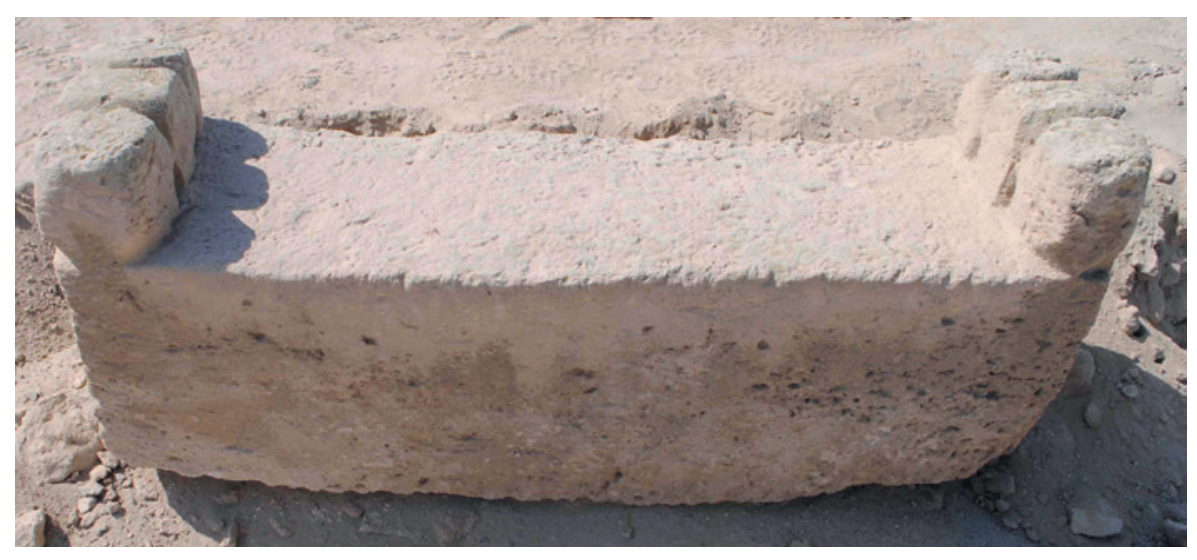

FIGURE 2.309 KHA9

Arabic Transcription and Translation: No inscriptions

\section{Reference Number: KHA10}

Co-ordinates: $26.20836^{\circ} \mathrm{N} 050.54842^{\circ} \mathrm{E}$

Dimensions: $157 \mathrm{~cm}(\mathrm{l}) \times 37 \mathrm{~cm}(\mathrm{w}) \times 53 \mathrm{~cm}(\mathrm{~h})$

\section{Orientation: NW-SE}

Description: Single limestone slab gravestone. Heavily eroded on top surface (E) and one side surface (A). Inscriptions on four surfaces. Raised decoration broken or cut off at one end and eroded or the other end, but with one facetted cube and a central rounded arch identifiable. Not in original position.

Previous Publication: Number 13, Kalus (1990: 37). The raised decoration from the one end has disappeared since it was recorded by Kalus (cf.199o: Pl. XV).

\section{Arabic Transcription and Translation:}


A:

- No carving or inscriptions.
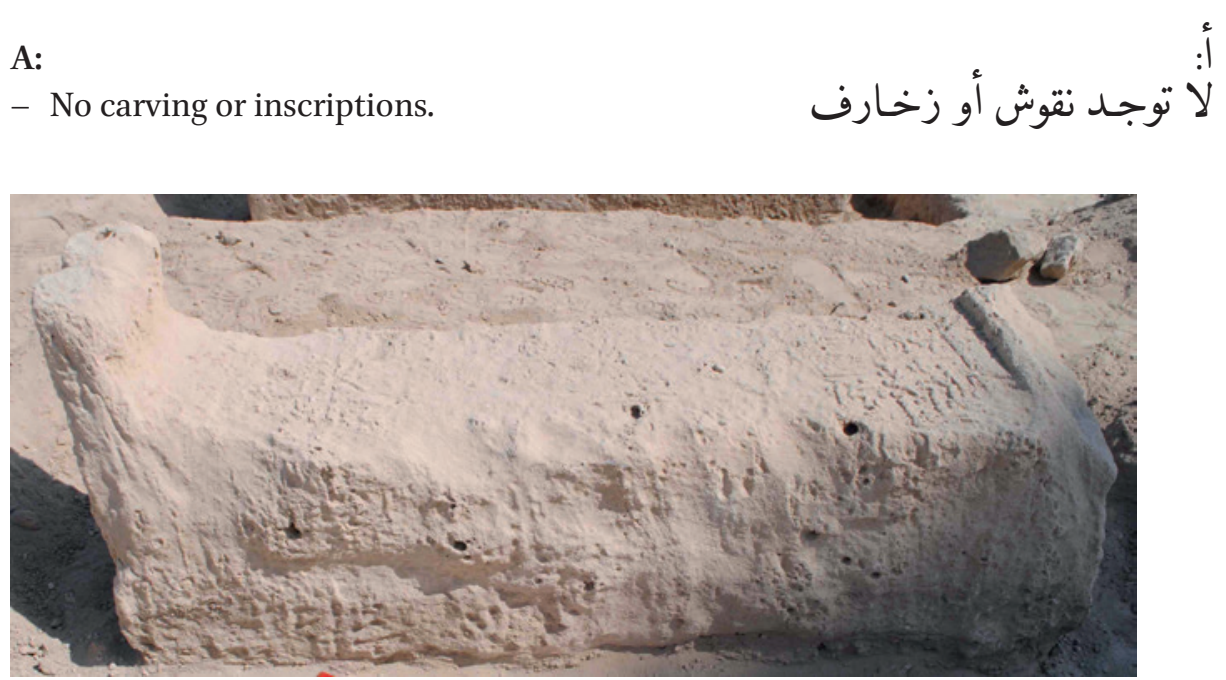

FIGURE 2.310 Surface A, KHA10

B:

- In the Name of Allah, the Most Gracious, the Most Merciful. Allah, none has the right to be worshipped but he, the Ever Living, the One Who sustains and protects all that exists. Neither slumber nor sleep overtakes Him. To Him belongs whatever is in the heavens and whatever is on the earth. Who is he that can intercede with Him except by His permission! He knows what happens to them in this world, and will happen to them in the Hereafter and they will never compass anything of His Knowledge except that which He wills. His Seat extends over the heavens.

- And the earth, and He feels no fatigue in guarding and preserving them. And He is the Most High, the Most Great. There is no compulsion in religion. Verily, the Right Path has become distinct from the wrong path. Whoever disbelieves in Taghut and believes

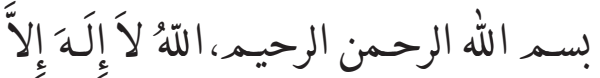

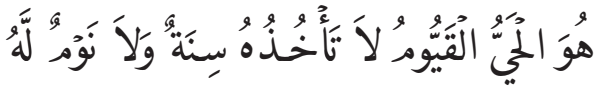

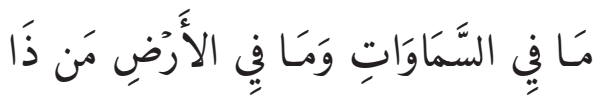

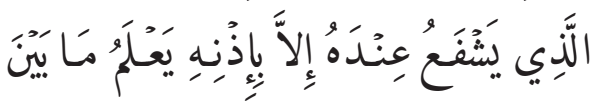

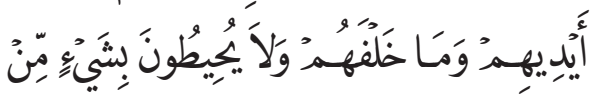

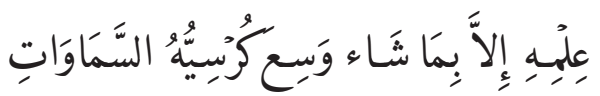

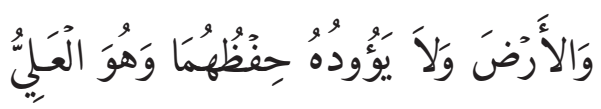

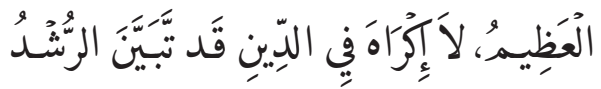

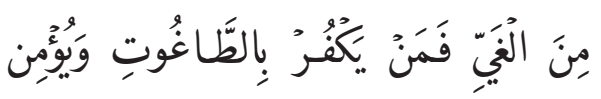

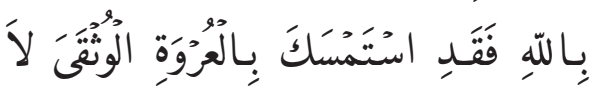


in Allah, then he has grasped the most trustworthy handhold that will never break. And Allah is All-Hearer, All-Knower. Allah is the Protector of those who believe. He brings them out from darkness into light. But as for those who disbelieve, their supporters are Taghut (2:255-257).
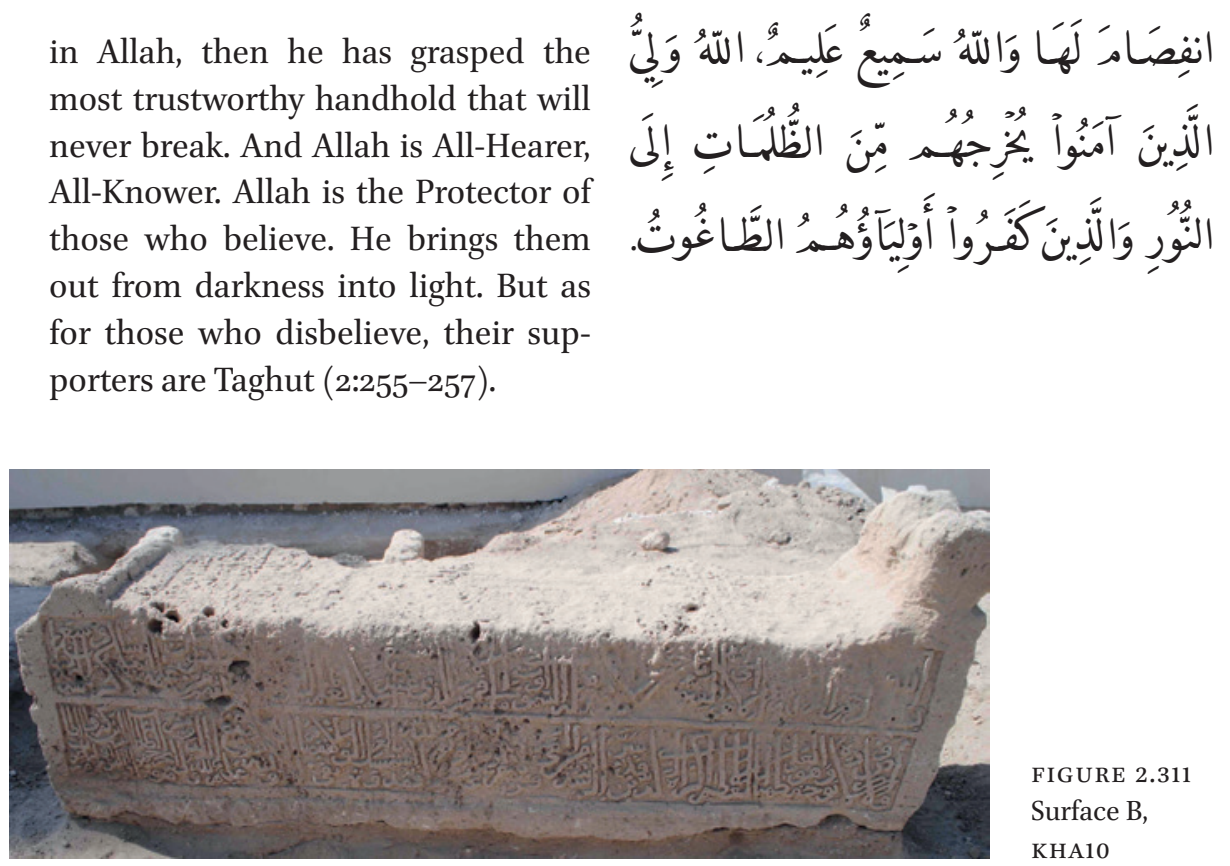

FIGURE 2.311

Surface B,

KHA10

C:

- ... unless ... Allah ... night between ... thirty-seven ...
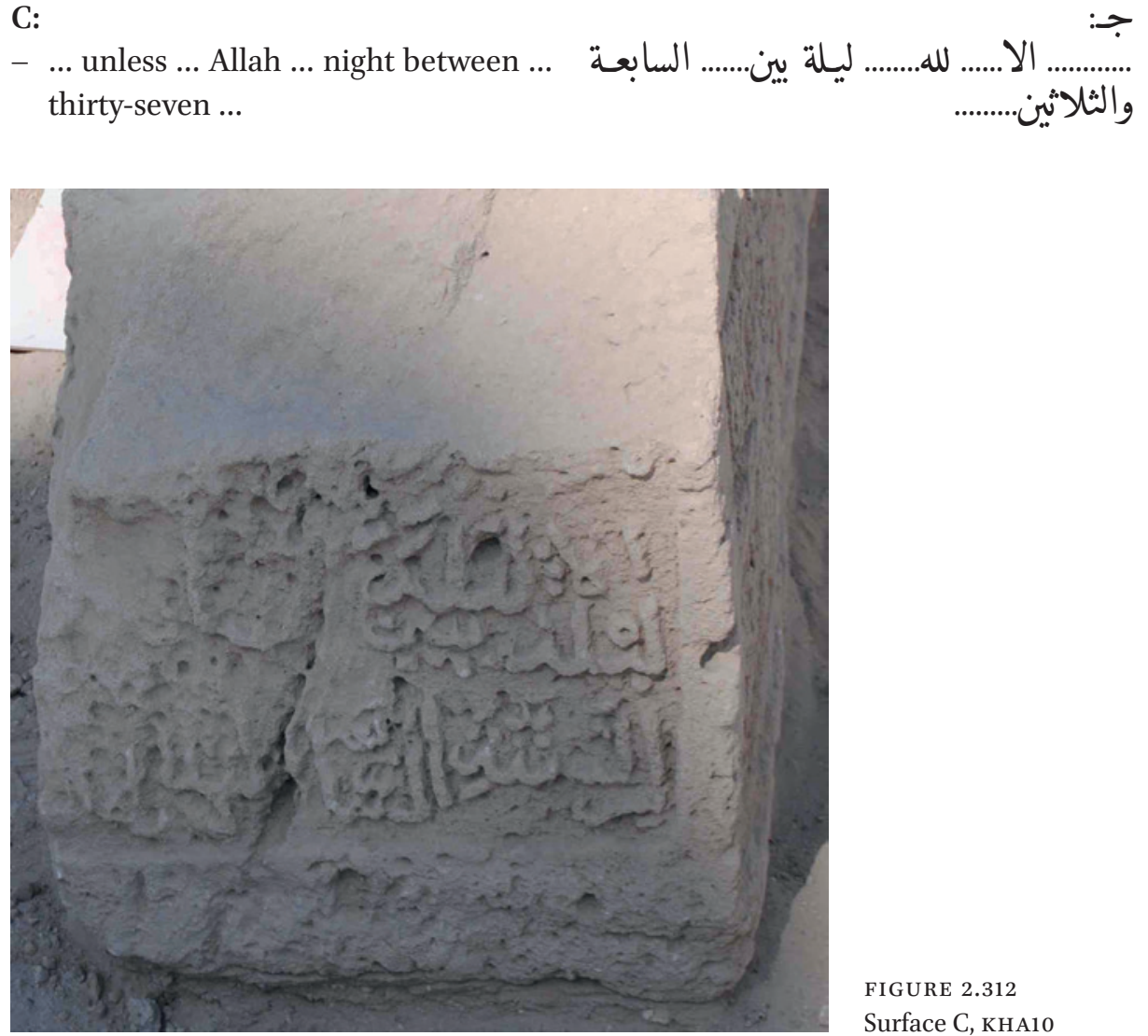
D:

- Grave of the late, the blessed, al-Sayyid Darwish bin

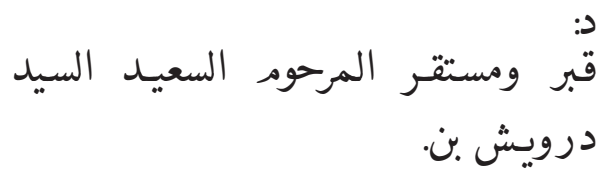

- al-Sayyid Naser Bin al-Mutawwaj alSayyid Sulayman.
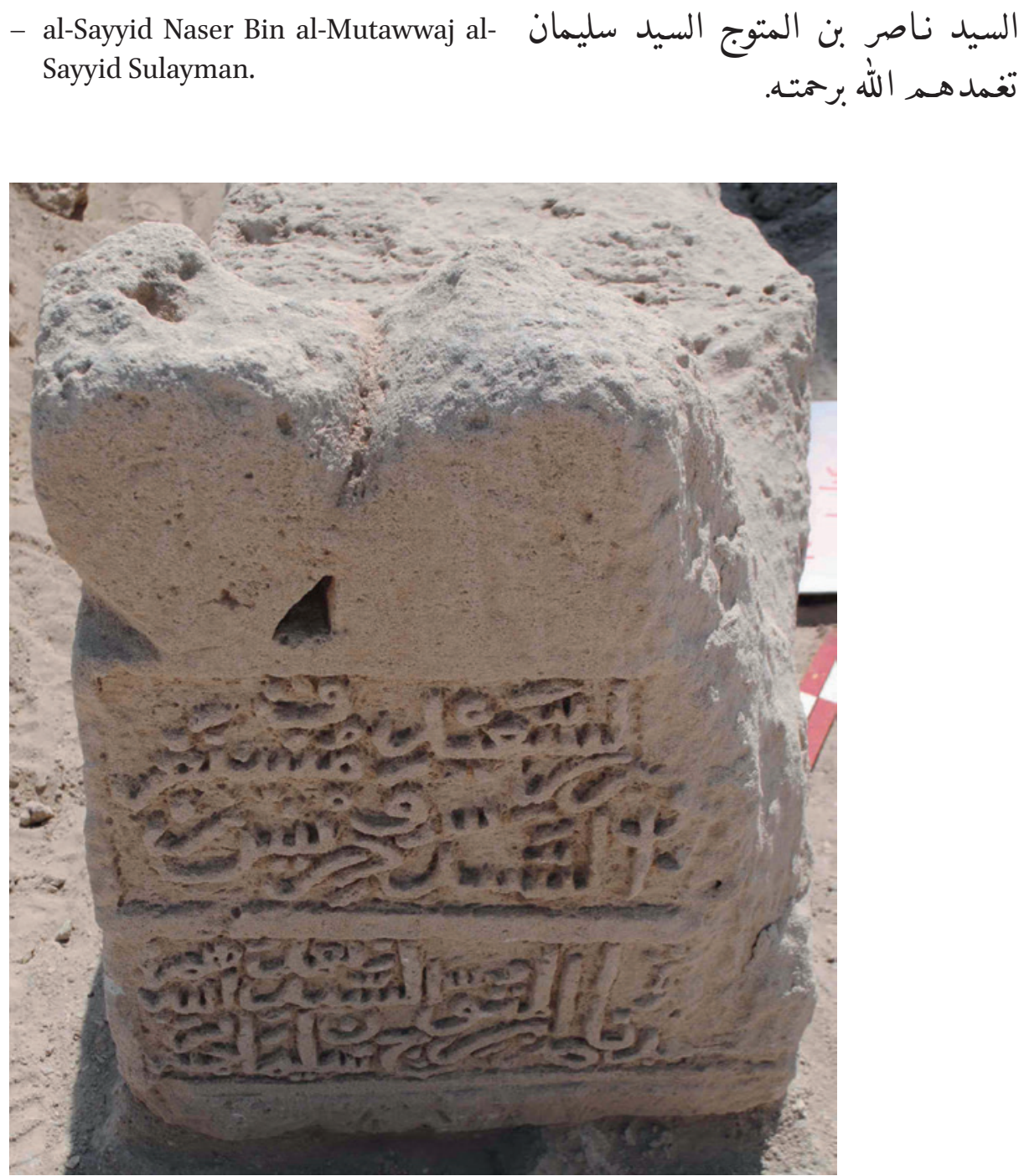

FIGURE 2.313 Surface D, KHA10

E:

- Inscribed by al-Sayyid Hashim ...

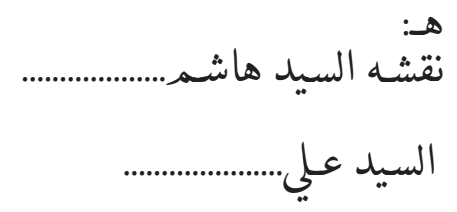

- al-Sayyid 'Ali ... 


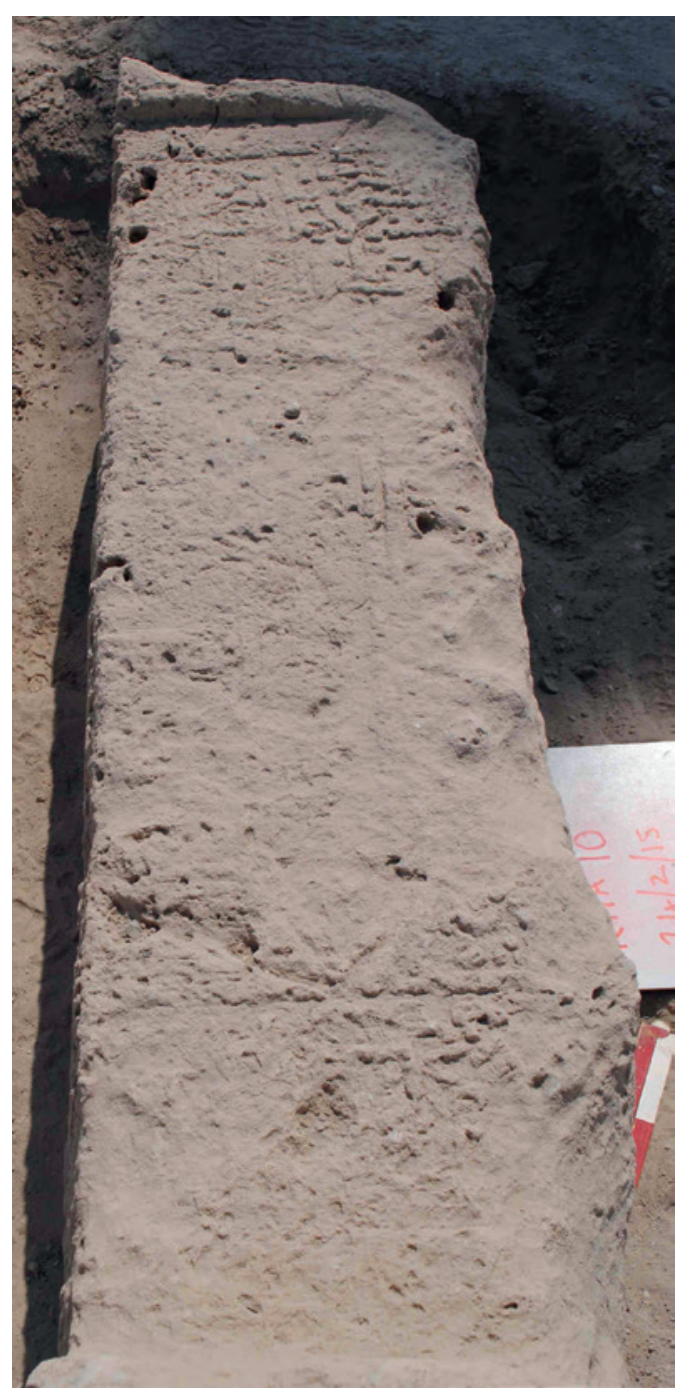

FIGURE 2.314

Surface E, KHA10

\section{Reference Number: KHA11}

\section{Co-ordinates: $26.20836^{\circ} \mathrm{N} 050.54845^{\circ} \mathrm{E}$}

Dimensions: $178 \mathrm{~cm}(\mathrm{l}) \times 33 \mathrm{~cm}(\mathrm{w}) \times 64 \mathrm{~cm}(\mathrm{~h})$

\section{Orientation: NA}

Description: Single hollow limestone slab gravestone. No inscriptions. Three element raised decoration at one end formed of two facetted cubes and a central 
rounded arch. At the other end the raised decoration has been cleanly cut off. The gravestone is unfinished and there are cut marks on the one side surface (A) where the stone has been roughly sawn into shape (Figure 2.315). The other side surface (B) has been broken recently but has a short carved raised plinth at its base (Figure 2.316). Not in original position.

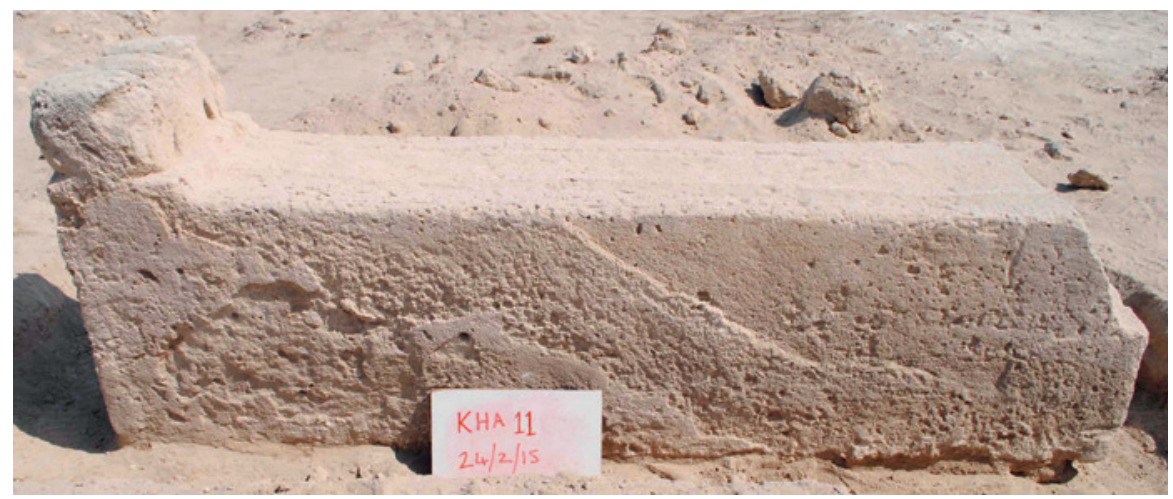

FIGURE 2.315 Surface A, KHA11

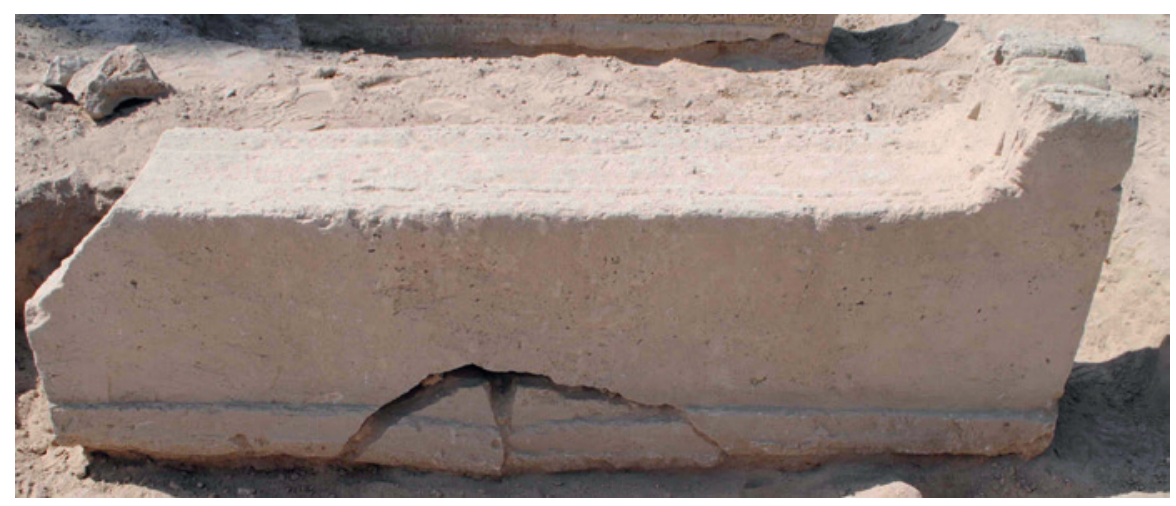

FIGURE 2.316 Surface B, KHA11

Arabic Transcription and Translation: No inscriptions

Reference Number: KHA12

Co-ordinates: $26.20834^{\circ} \mathrm{N} 050.54844^{\circ} \mathrm{E}$

Dimensions: Two slabs measured as one unit $-127 \mathrm{~cm}(\mathrm{l}) \times 34 \mathrm{~cm}(\mathrm{w}) \times 48 \mathrm{~cm}(\mathrm{~h})$

Orientation: NNW-SSE 
Description: Gravestone formed of double limestone slabs. Some erosion on top. Three element raised decoration formed of two facetted cubes and a central rounded arch all set on a rectangular plinth at each end. Possibly in original position close to mosque wall. Inscriptions on five surfaces. Excavated to expose whole gravestone.

\section{Arabic Transcription and Translation:}

A:

- And He is the Most High, the Most Great. There is no compulsion in religion. Verily, the Right Path has become distinct from the wrong path. Whoever disbelieves in Taghut and believes in Allah, then he has grasped the most trustworthy handhold that will never break.

- And Allah is All-Hearer, All-Knower. Allah is the Protector of those who believe. He brings them out from darkness into light. But as for those who disbelieve, their supporters are al-Taghut.
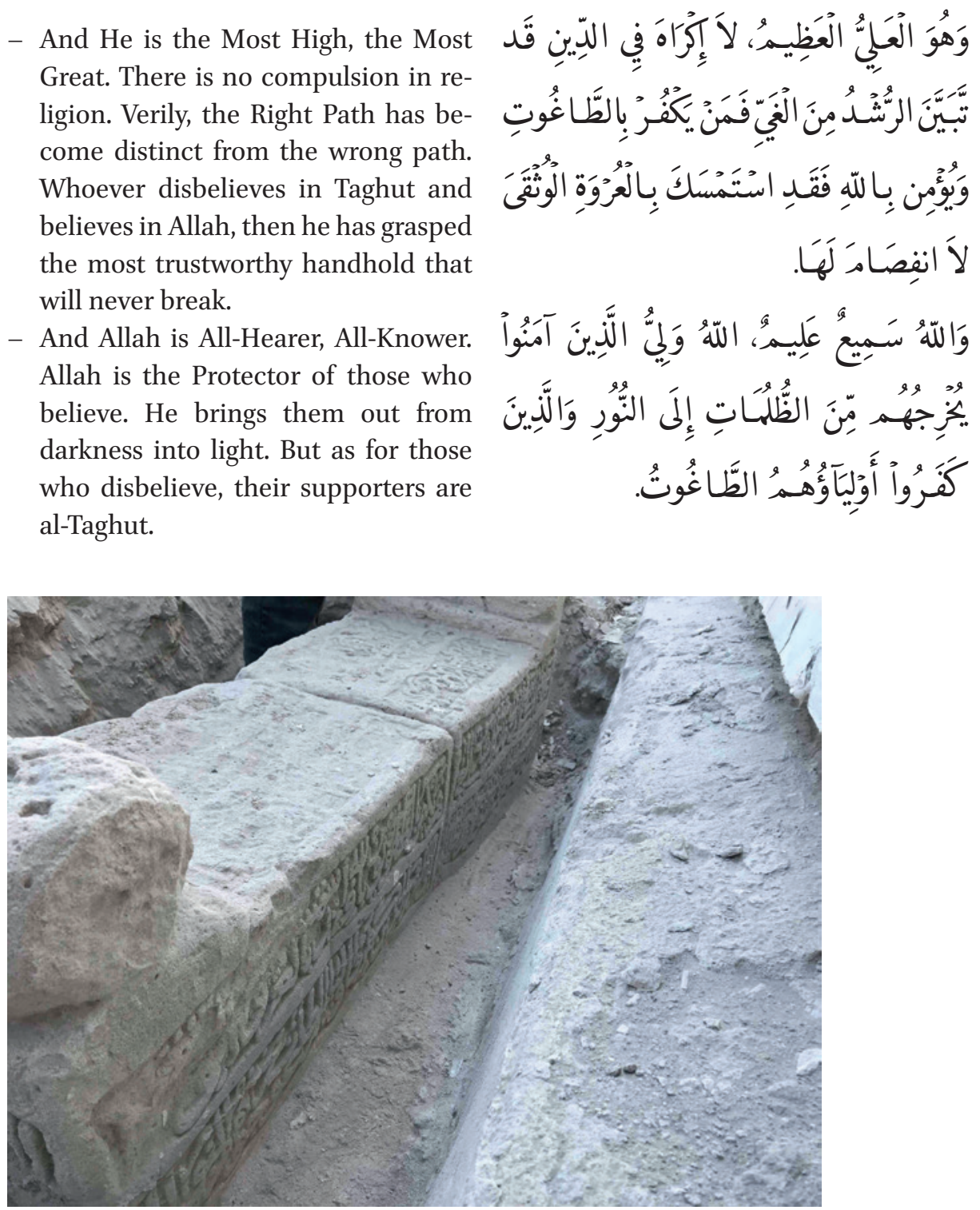

FIGURE 2.317 Surface A, KHA12 
B:

- In the Name of Allah, the Most Gracious, the Most Merciful. Allah, none has the right to be worshipped but he, the Ever Living, the One Who sustains and protects all that exists. Neither slumber nor sleep overtakes Him. To Him belongs whatever is in the heavens and whatever is on the earth. Who is he that can intercede with Him

- Except by His permission! He knows what happens to them in this world, and will happen to them in the Hereafter and they will never compass anything of His Knowledge except that which He wills. His Seat extends over the heavens and the earth, and He feels no fatigue in guarding and preserving them (2:255-257).

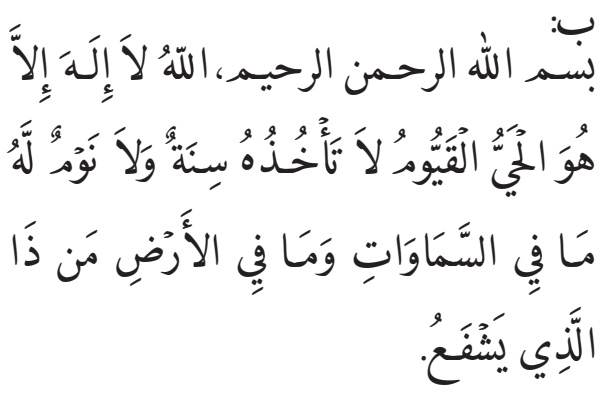

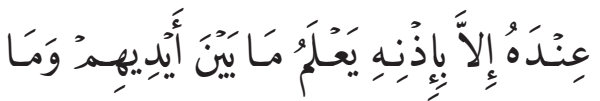

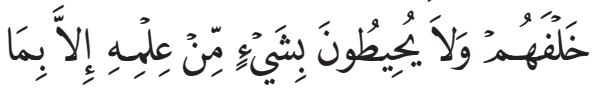

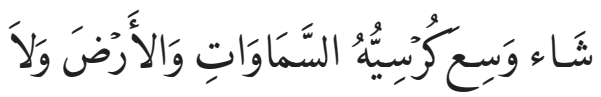

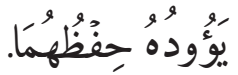

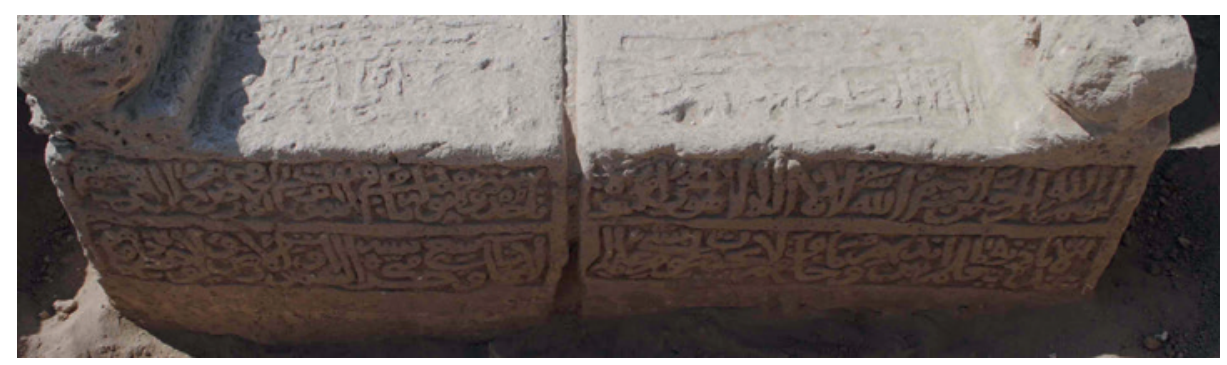

FIGURE 2.318 Surface B, KHA12

C:

- Glad Mercy from Him, and His being pleased with them, and of Paradise for them wherein are everlasting delights.

- They will dwell therein forever. Verily, with Allah is a great reward (9:21-22).
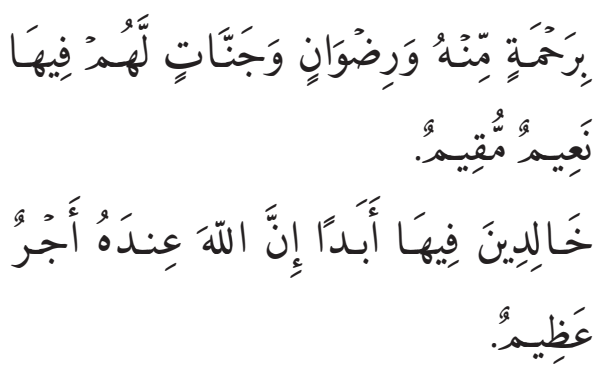


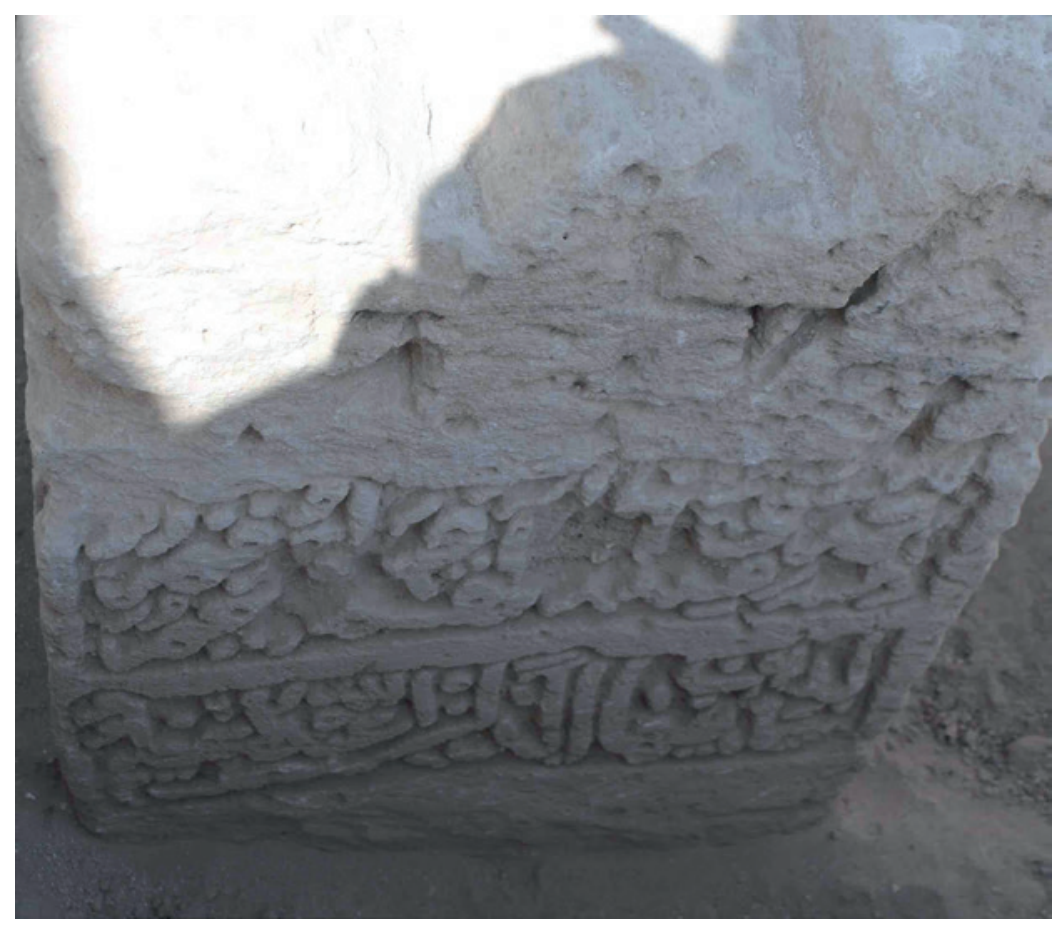

FIGURE 2.319 Surface C, KHA12

D:

- Darkness, those are the dwellers of the Fire.

- And they will abide therein forever (2:257). Their Lord gives them (9:21-22).
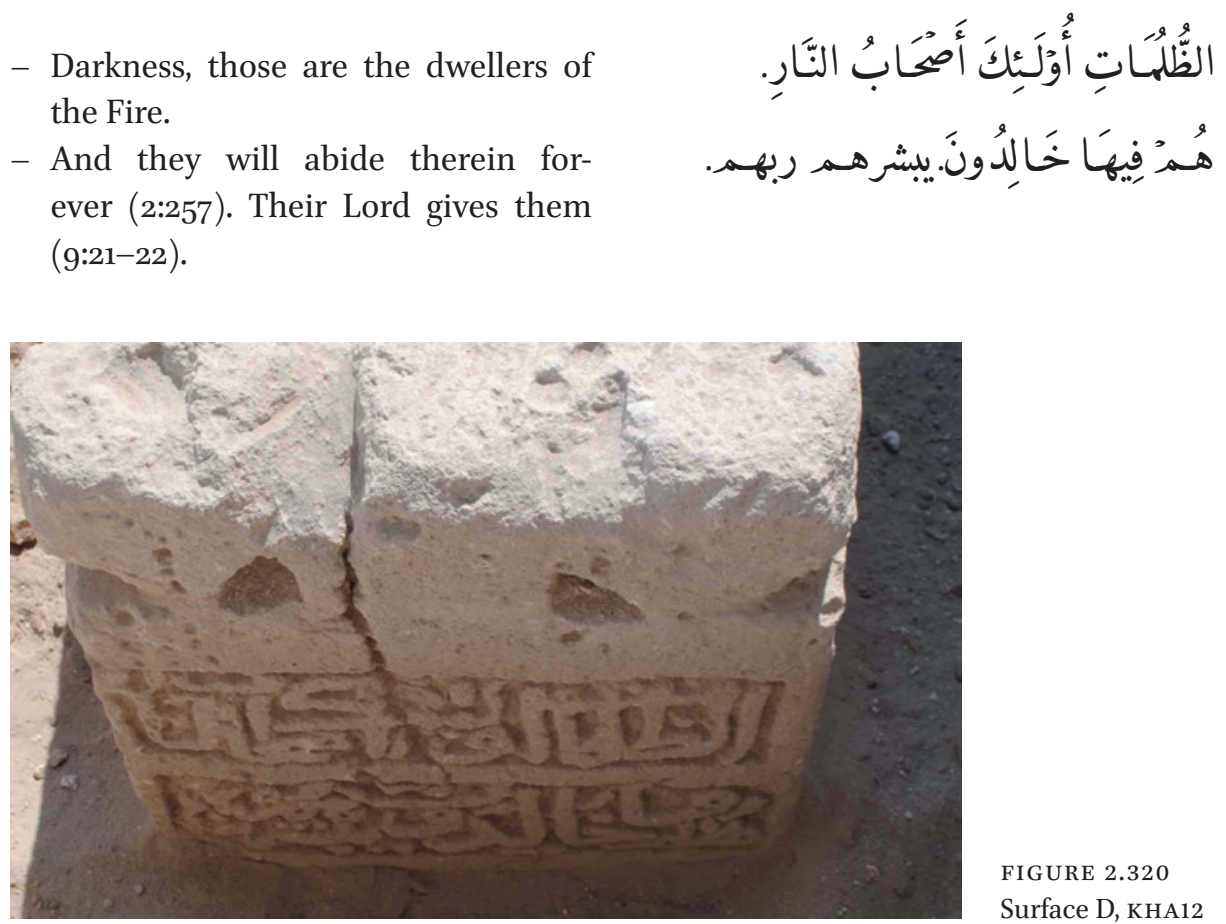
E:

- ... the soil and he is the moon of science and work.

- ... eighty-six, Awal Island.

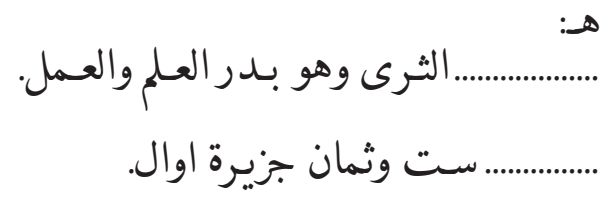

- ... blessed grave ... 'Ali leaves ...
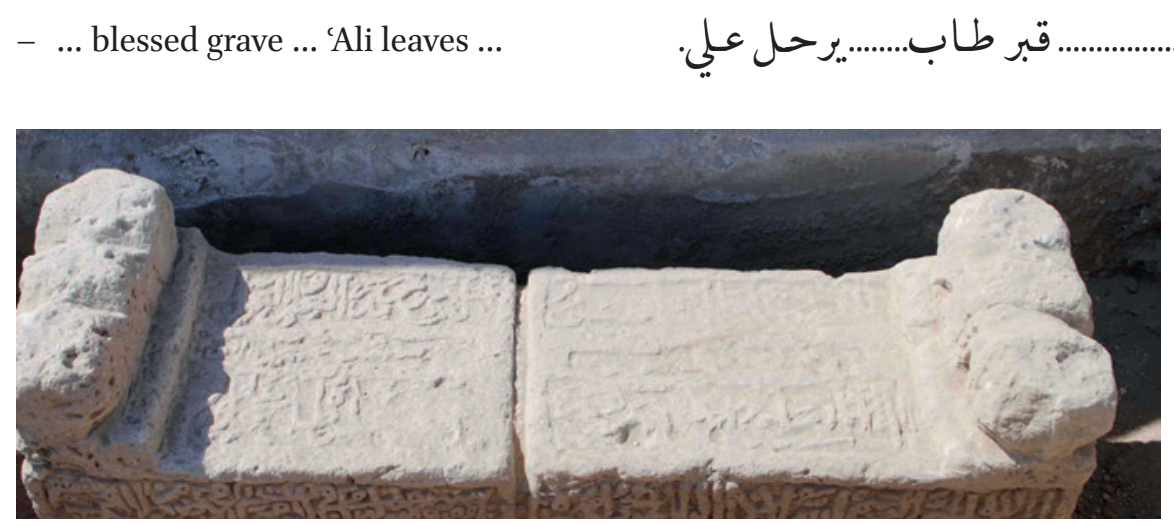

FIGURE 2.321 Surface E, KHA12

Reference Number: KHA13

Co-ordinates: $26.20835^{\circ} \mathrm{N} 050.54846^{\circ} \mathrm{E}$

Dimensions: $143 \mathrm{~cm}(\mathrm{l}) \times 30.5 \mathrm{~cm}(\mathrm{w}) \times 39.5 \mathrm{~cm}(\mathrm{~h})$

\section{Orientation: NNW-SSE}

Description: Single limestone slab gravestone. Top surface (E) eroded but a shallow carved rectangular panel design, probably a niche is identifiable. Inscriptions on five surfaces, two only partially legible. Raised decoration has been cut off at each end and these were set on rectangular plinths which remain. Not in original position.

Previous Publication: Number 19, Kalus (1990: 50)

\section{Arabic Transcription and Translation:}

A:

- Verily, those who say: Our Lord is Allah, and afterward are upright, the angels descend upon them, saying:

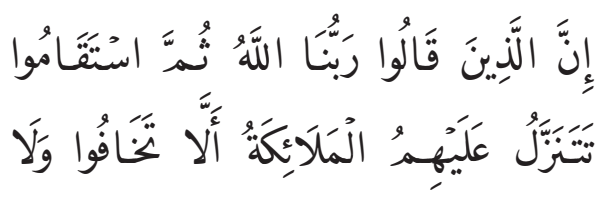


Fear not nor grieve, but receive the glad tidings of the paradise which you have been promised. We have been your friends in the life of this world and are in the Hereafter. Therein you shall have all that your inner-selves desire, and therein you shall have all for which you ask (41:30-31).

- Eden Paradise, whose doors will be opened for them. Therein they will recline, therein they will call for fruits in abundance and drinks. And beside them will be chaste females restraining their glances and of equal ages. This is what you are promised for the day of Reckoning. Verily, this is our provision which will never finish. This is so, and for the disobedient to Allah will be an evil final return (38:50-55).
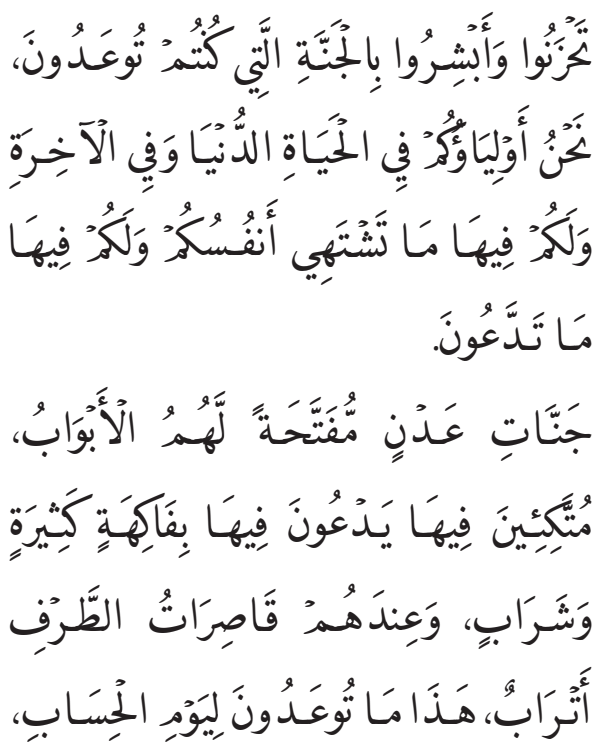

إِ

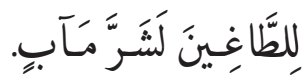

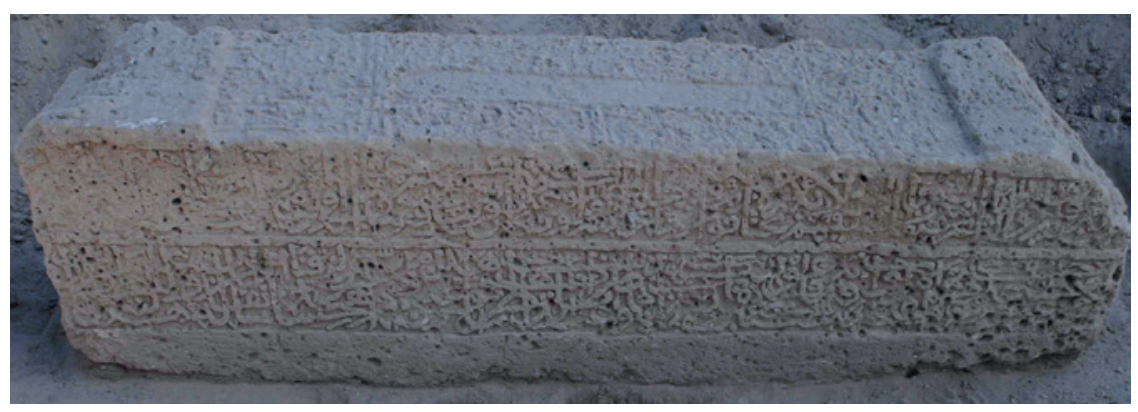

FIGURE 2.322 Surface A, KHA13

B:

- In the Name of Allah, the Most Gracious, the Most Merciful. Allah, none has the right to be worshipped but he, the Ever Living, the One Who sustains and protects all that exists. Neither slumber nor sleep overtakes Him. To Him belongs whatever is in

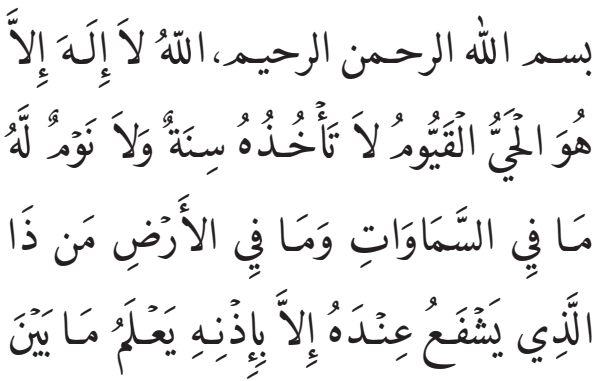


the heavens and whatever is on the earth. Who is he that can intercede with Him except by His permission! He knows what happens to them in this world, and will happen to them in the Hereafter and they will never compass anything of His Knowledge except that which He wills. His Seat extends over the heavens and the earth.

- And He feels no fatigue in guarding and preserving them. And $\mathrm{He}$ is the Most High, the Most Great. There is no compulsion in religion. Verily, the Right Path has become distinct from the wrong path. Whoever disbelieves in Taghut and believes in Allah, then he has grasped the most trustworthy handhold that will never break. And Allah is All-Hearer, All-Knower. Allah is the Protector of those who believe. He brings them out from darkness
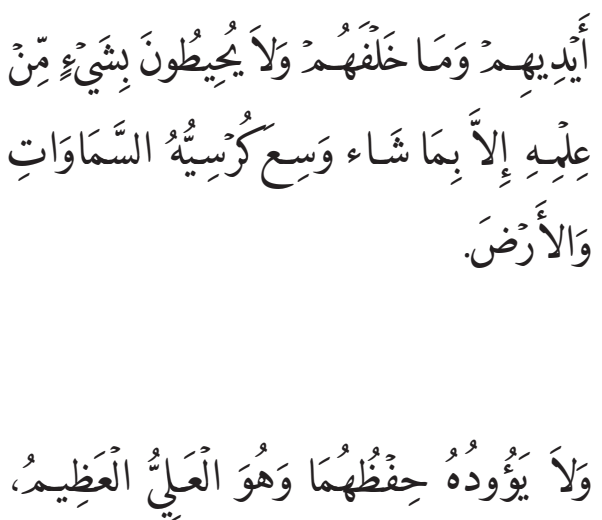

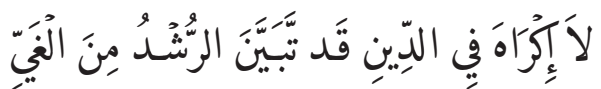

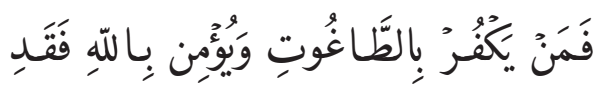

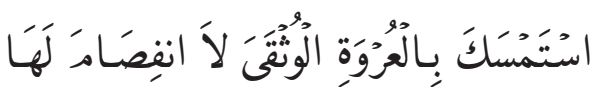

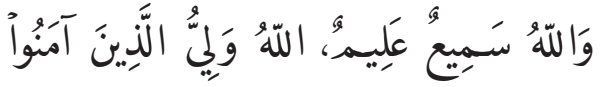

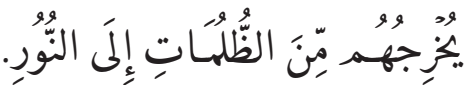
into light (2:255-257).

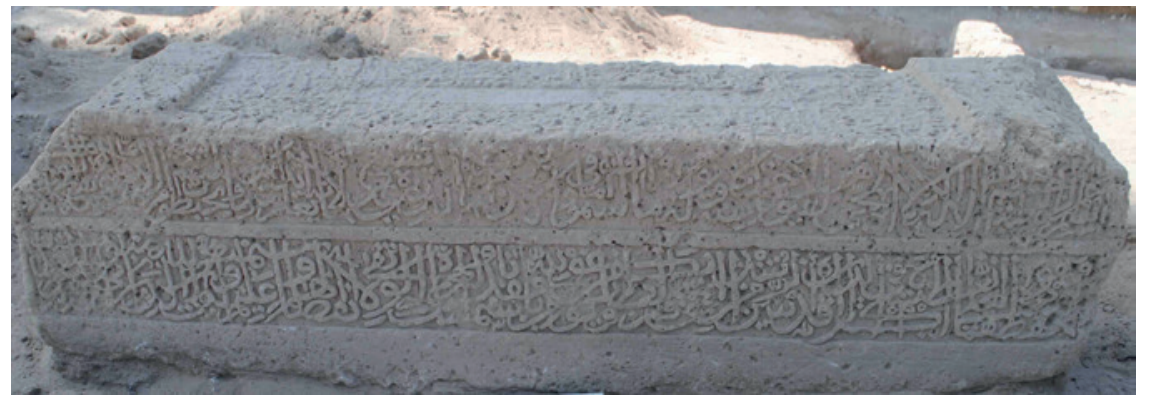

FIGURE 2.323 Surface B, KHA13

C:

- This is the grave of the blessed ... The Prophet ... Mercy on him ...

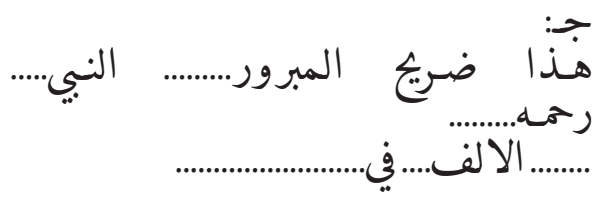

- ... Thousand ... in ... 


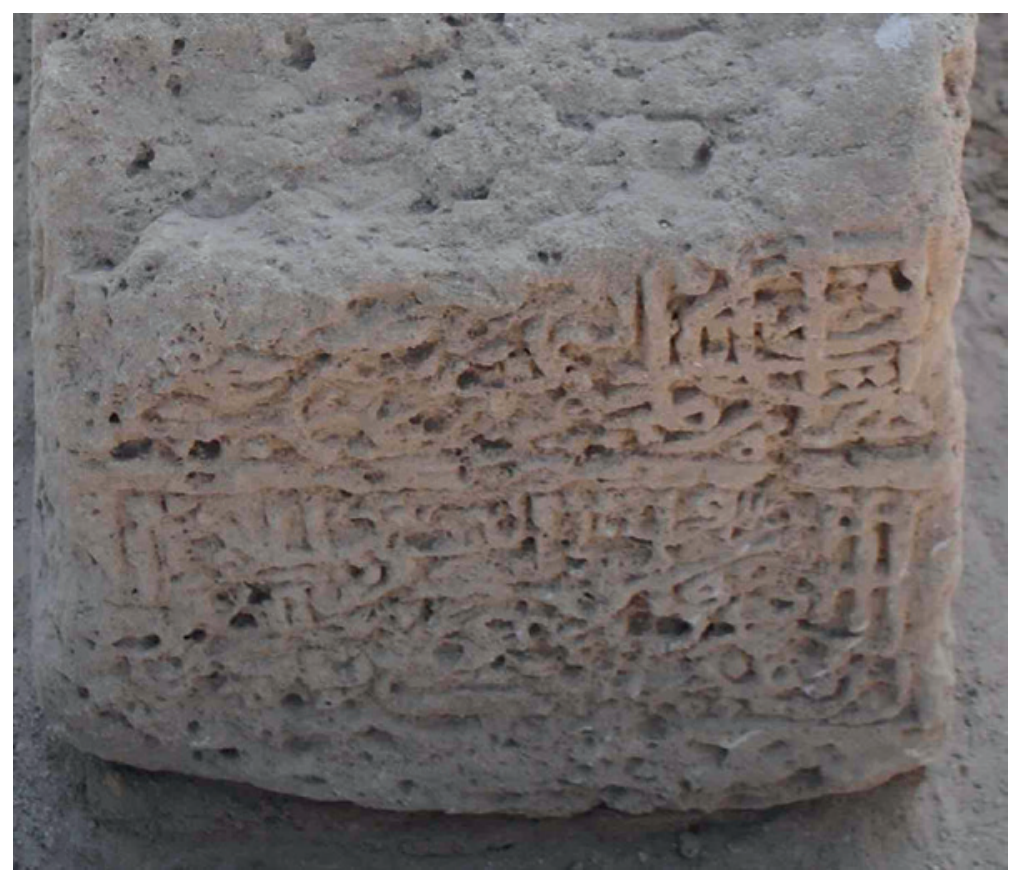

FIGURE 2.324 Surface C, KHA13

D:

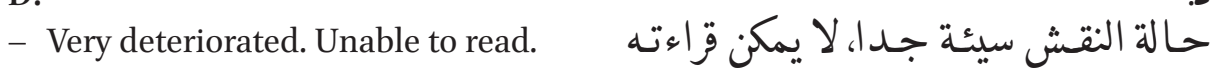

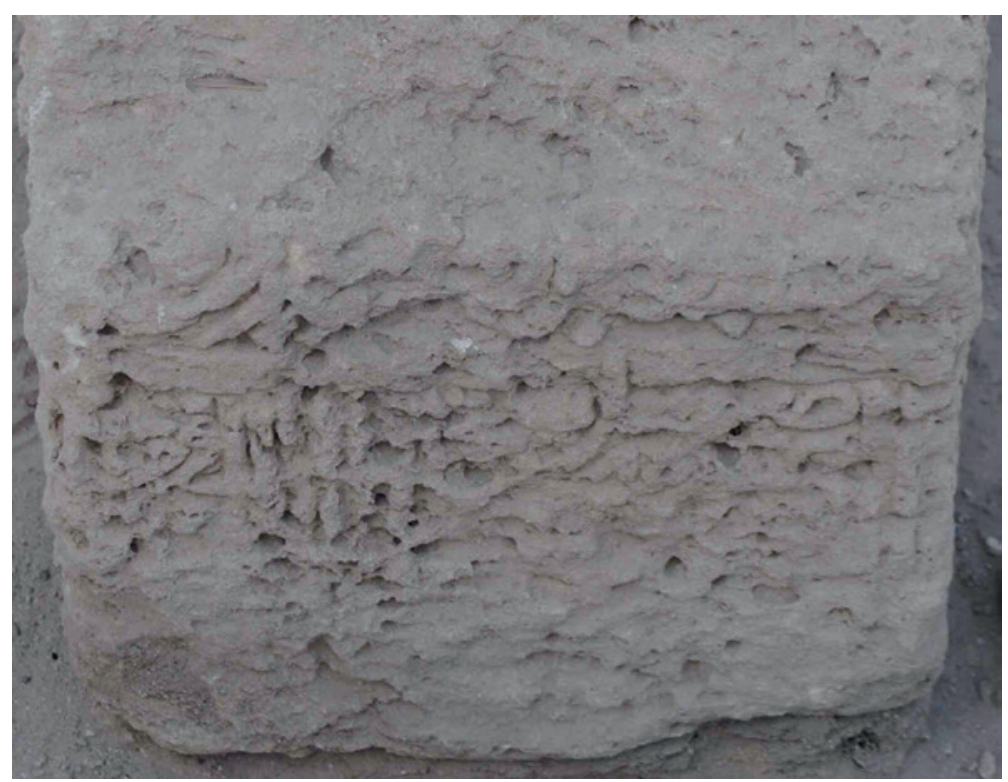

FIGURE 2.325 Surface D, KHA13 
E:

- Very deteriorated. Unable to read.

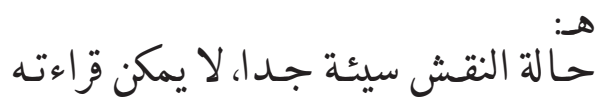

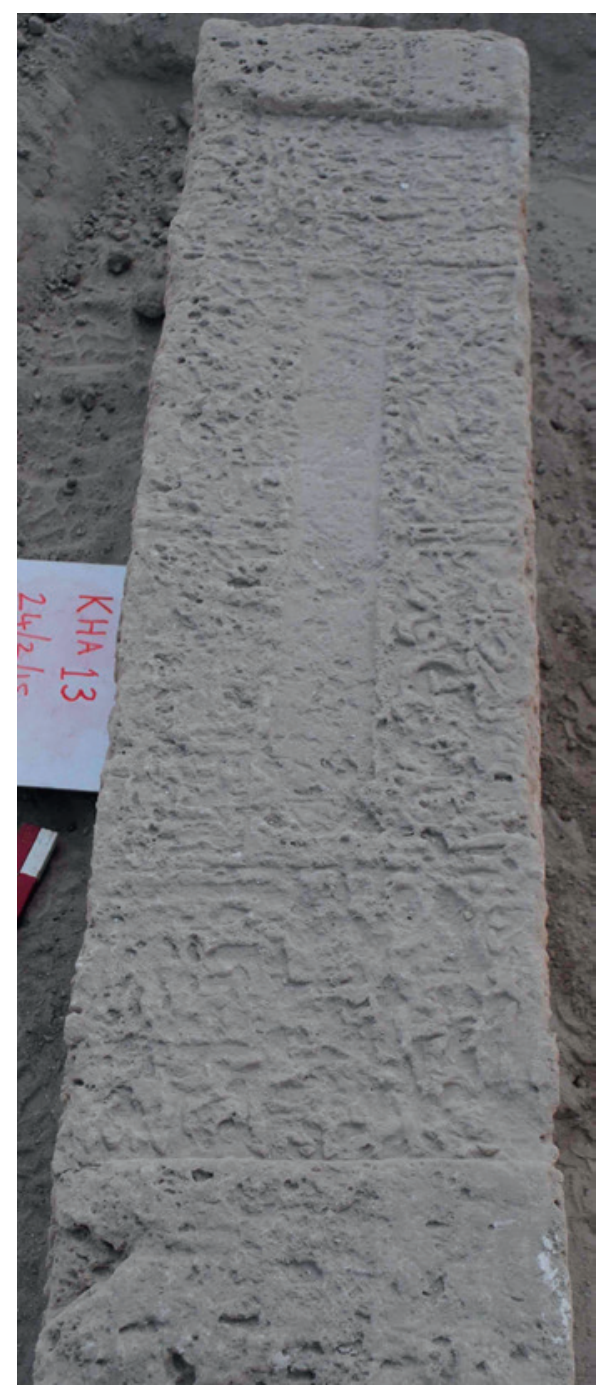

FIGURE 2.326

Surface E, KHA13

Reference Number: KHA14

Co-ordinates: $26.20833^{\circ} \mathrm{N} 050.54845^{\circ} \mathrm{E}$

Dimensions: $138 \mathrm{~cm}(\mathrm{l}) \times 37 \mathrm{~cm}(\mathrm{w}) \times 54.5 \mathrm{~cm}(\mathrm{~h})$

Orientation: NNW-SSE 
Description: Single limestone slab gravestone (Figure 2.327). No inscriptions. Rather than being due to erosion, the bad surface but relatively sharp lines of the different surfaces suggests the gravestone was left unfinished as the limestone was found to be of too poor quality to take inscriptions once the initial shape had been cut. Badly cut three element raised decoration formed of two facetted cubes and a central rounded arch at each end, one of which is eroded. Not in original position. Excavated to expose whole gravestone.

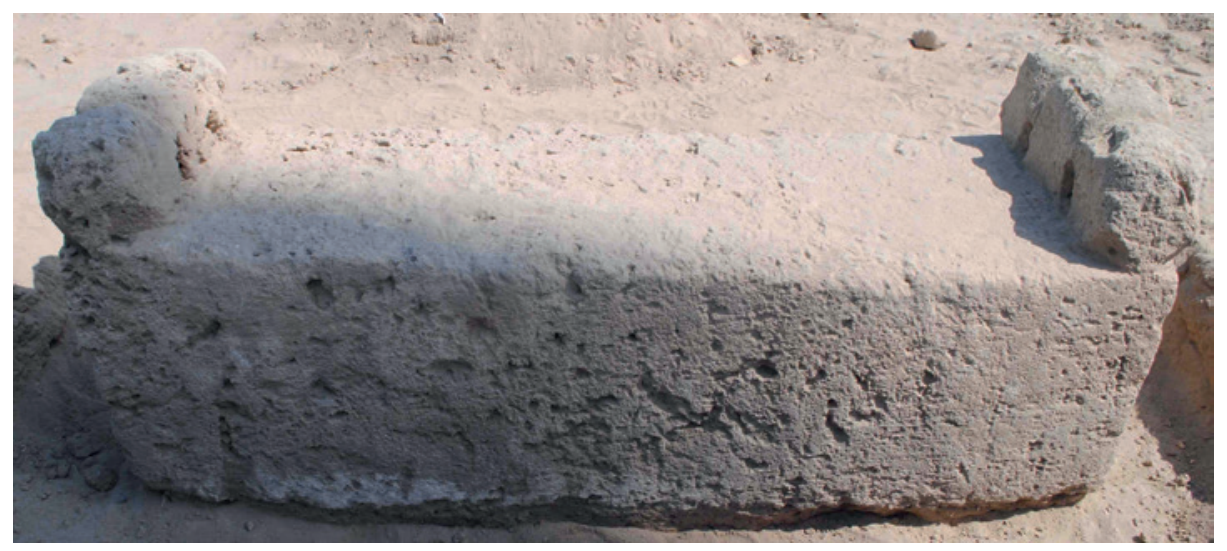

FIGURE $2.327 \quad$ KHA14

Arabic Transcription and Translation: No inscriptions

\section{Reference Number: KHA15}

Co-ordinates: $26.2083^{\circ} \mathrm{N} 050.54846^{\circ} \mathrm{E}$

Dimensions: $126.5 \mathrm{~cm}(\mathrm{l}) \times 33 \mathrm{~cm}(\mathrm{w}) \times 48 \mathrm{~cm}(\mathrm{~h})$

\section{Orientation: NNW-SSE}

Description: Single limestone slab gravestone. Some erosion at the base and at one end, suggesting it was upended and left exposed for some time. Not in original position. Three element raised decoration formed of two facetted cubes and a central thin rounded arch all set on a shallow rectangular plinth at each end. Shallow carved rounded riche design on upper surface (E). Hole drilled into one end surface (C). Inscriptions on five surfaces.

Previous Publication: Number 12, Kalus (1990: 35) 
Arabic Transcription and Translation:

A:

- Inscription cannot be read.
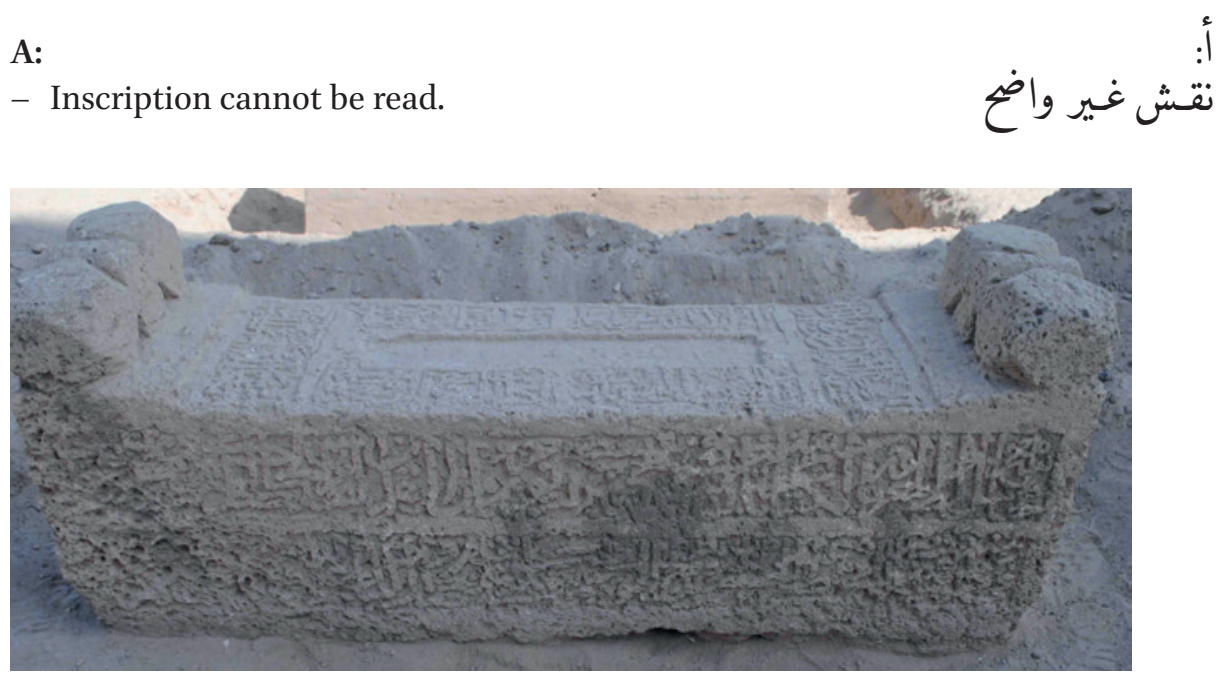

FIGURE 2.328 Surface A, KHA15

B:

- In the Name of Allah, the Most Gracious, the Most Merciful. Allah, none has the right to be worshipped but he, the Ever Living, the One Who sustains and protects all that exists. Neither slumber nor sleep overtakes Him. To Him belongs whatever is in the heavens and whatever is on the earth. Who is he that can intercede with Him

- ... His Seat extends over the heavens and the earth. And He feels no fatigue in guarding and preserving them. And He is the Most High, the Most Great. There is no compulsion in religion. Verily, the Right Path has become distinct from the wrong path. Whoever disbelieves in al-Taghut ... in Allah (2:255-256).

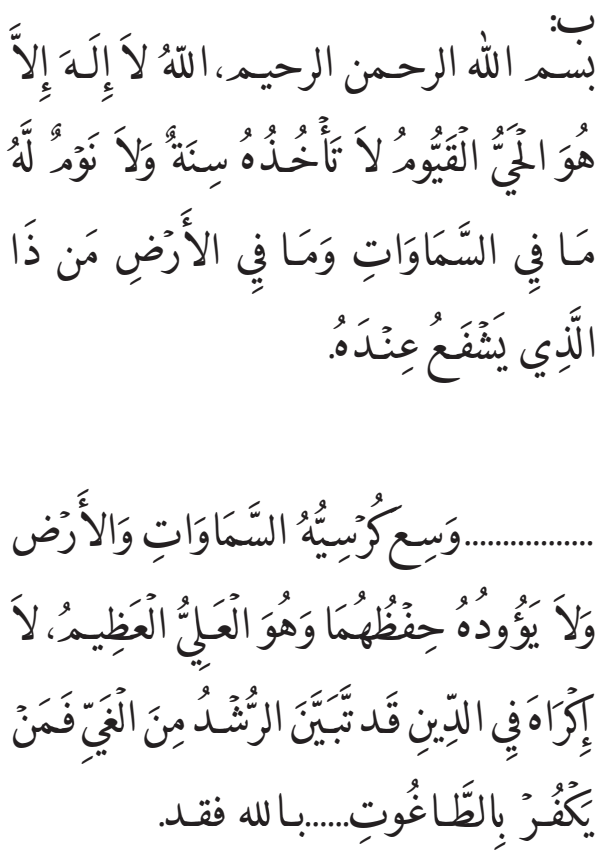

لّ

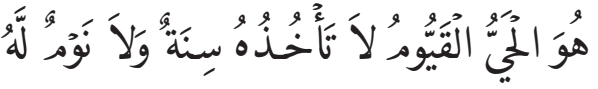

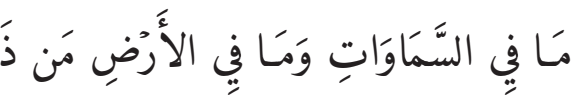
\&

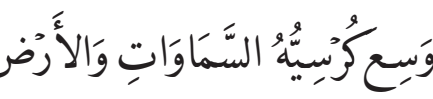
إكركا

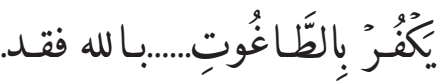




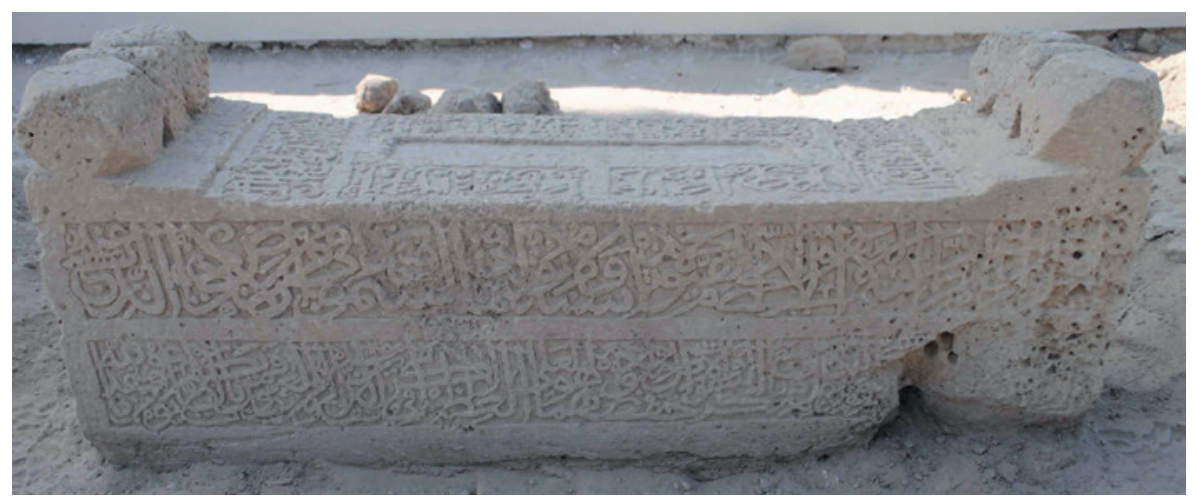

FIGURE 2.329 Surface B, KHA15

C:

- ... from proceeds...share ... known as ... located ... Katkatan ... everyday one part of the Quran should be read ...
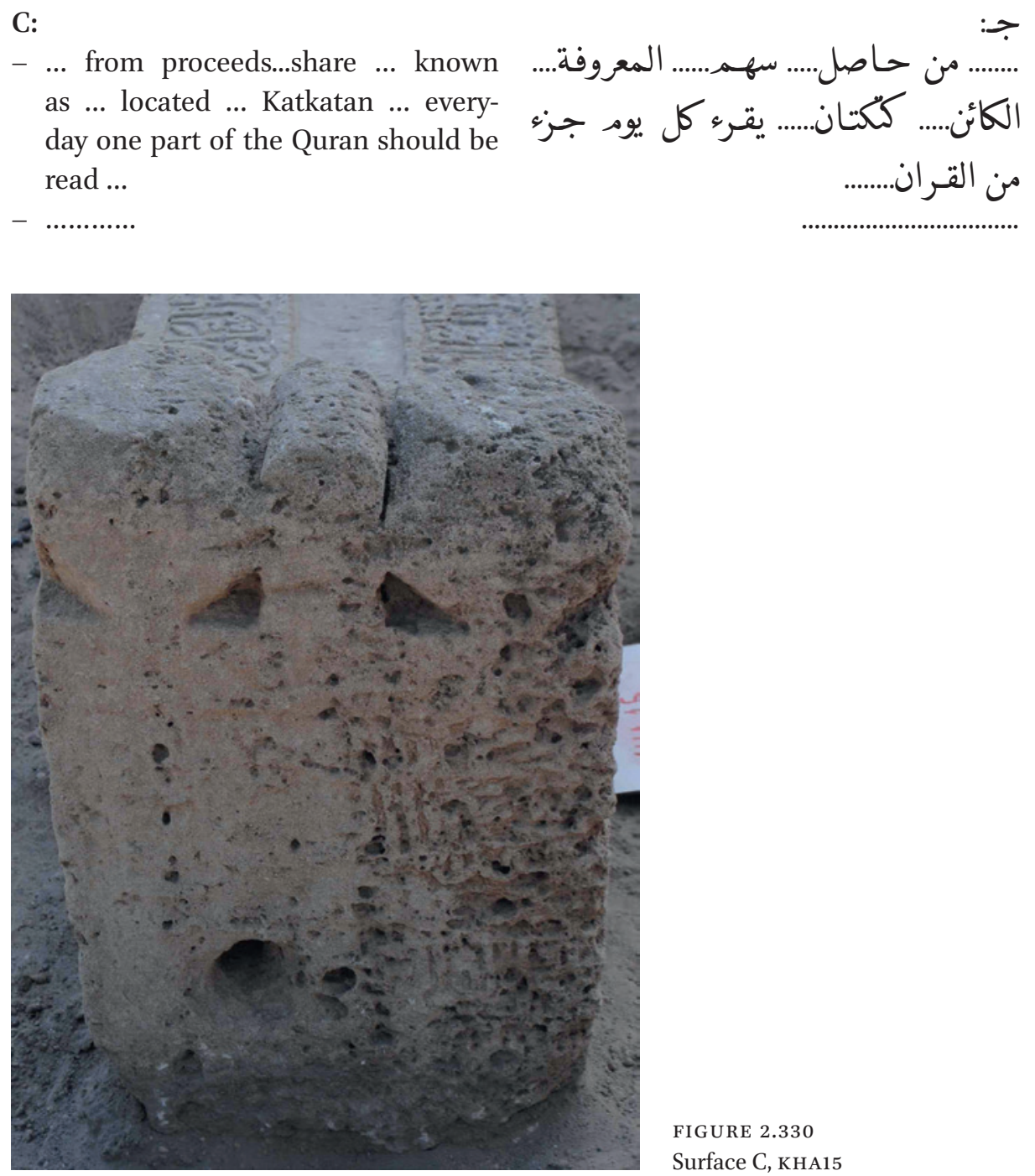

FIGURE 2.330

Surface C, KHA15 
D:

- ... six hundred and fifty-four ...

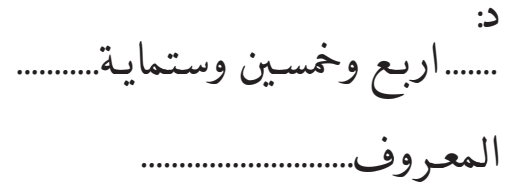

- Known as ...

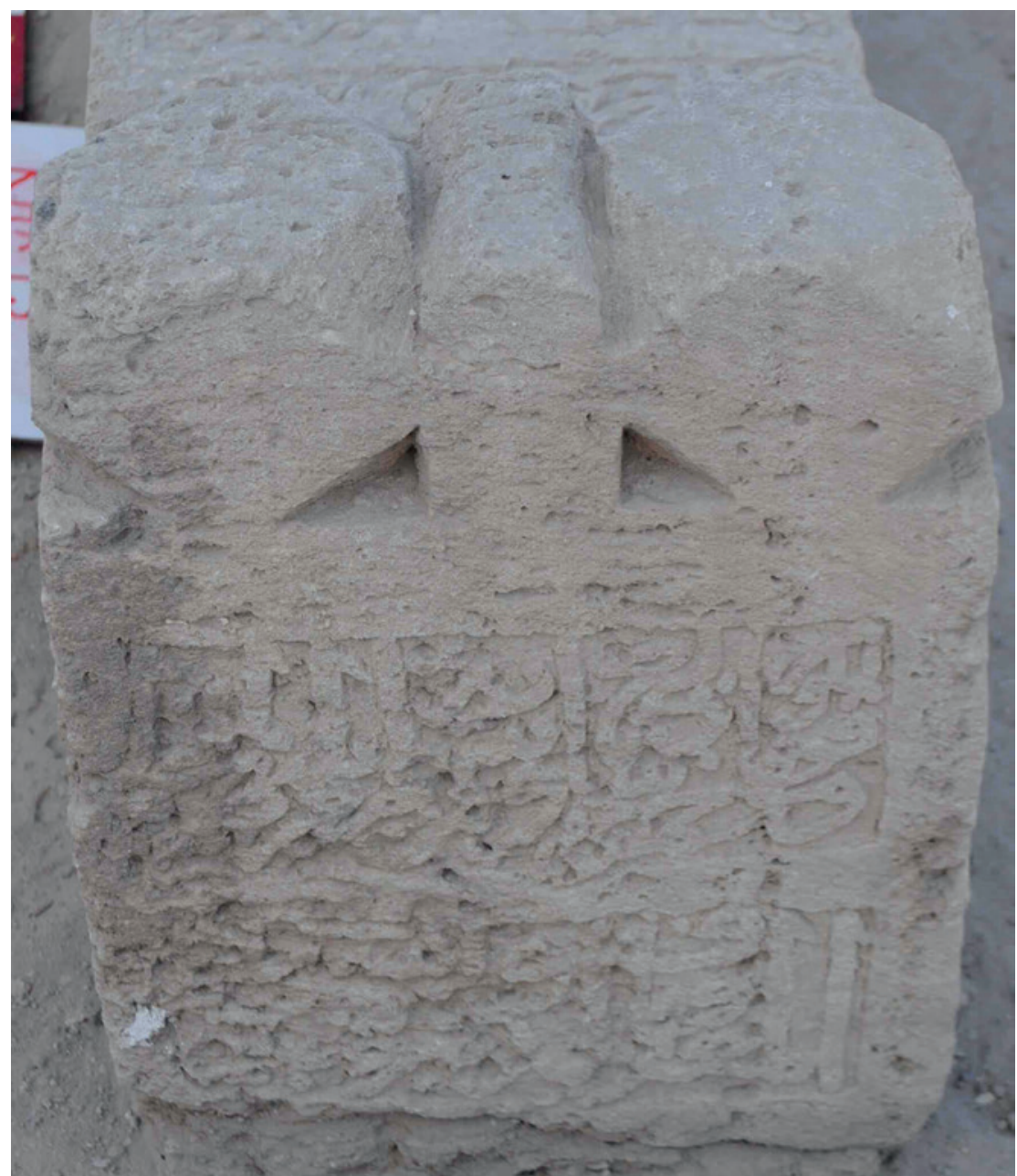

FIGURE 2.331 Surface D, KHA15

E:

- Engraved by Husayn bin 'Ali Bin نقشه الاقل حسين بن علي بن فردان Fardan al-Manami.

- Oh grave, you embedded Naser who يا قبر واريت المقـد نـاصر|*** ذات is great, dignified and polite 
- ... proud ... highclass ...

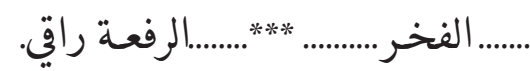

- Written by Husayn bin 'Ali bin Zayn كبه الاقل حسين بن علي .ن زن الدين al-Din, may Allah forgive him.
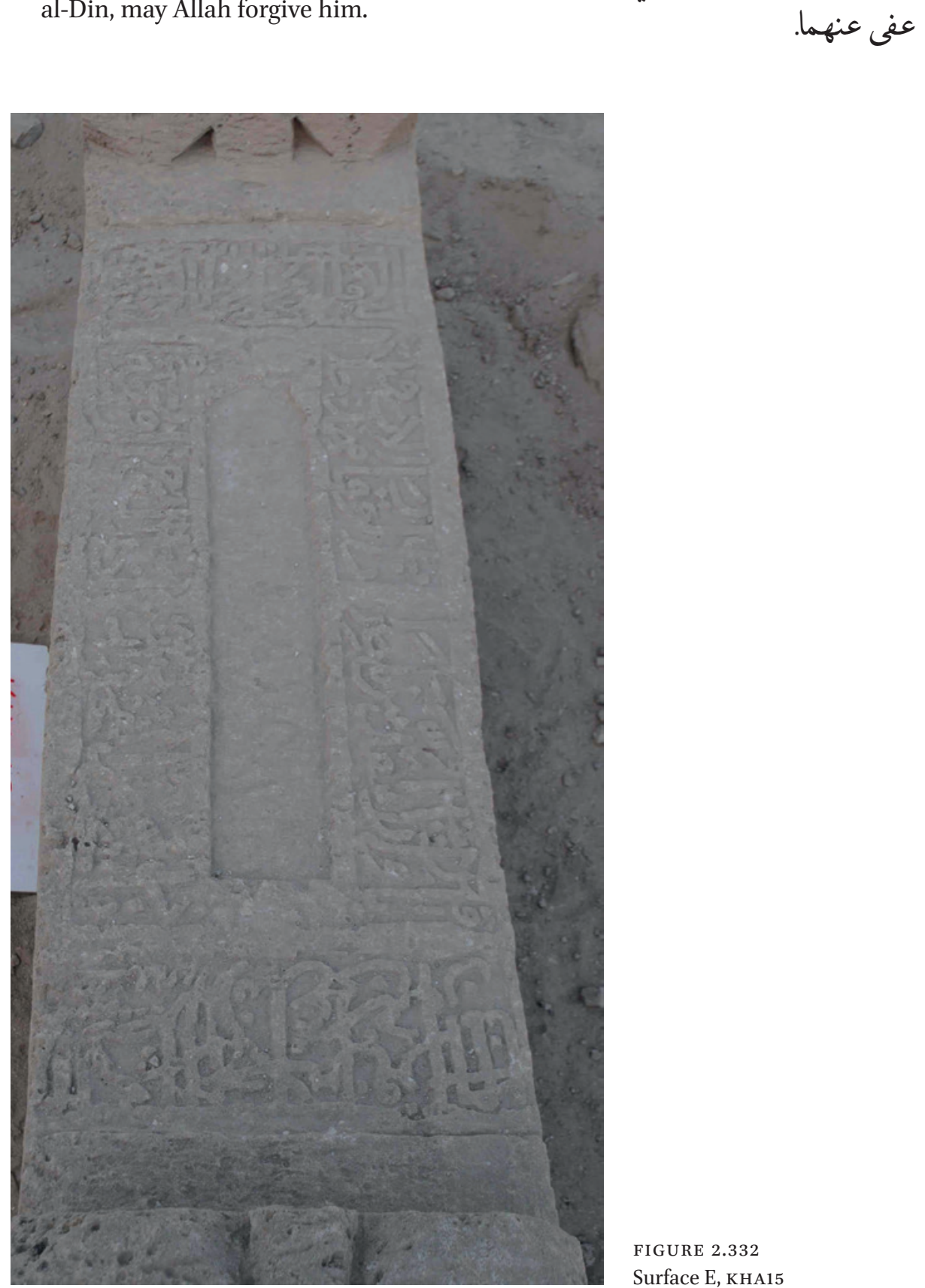

FIGURE 2.332

Surface E, KHA15 
Reference Number: KHA16

Co-ordinates: $26.20832^{\circ} \mathrm{N} 050.54847^{\circ} \mathrm{E}$

Dimensions: $138 \mathrm{~cm}(\mathrm{l}) \times 31.5 \mathrm{~cm}(\mathrm{w}) \times 51.5 \mathrm{~cm}(\mathrm{~h})$

\section{Orientation: NNW-SSE}

Description: Single limestone slab gravestone (Figure 2.333). No inscriptions. Roughed out unfinished gravestone which has been cut to size but left decoratively uncarved. A rectangular block for raised decoration is cut at one end with a shallow rectangular plinth below it. Chisel marks on the upper surface (E) indicate that the rectangular block that would have formed the raised decoration has been cleanly cut off, but the lower rectangular plinth step has been left. Three small circular cup marks are cut into the upper surface $(\mathrm{E})$. Not in original position.

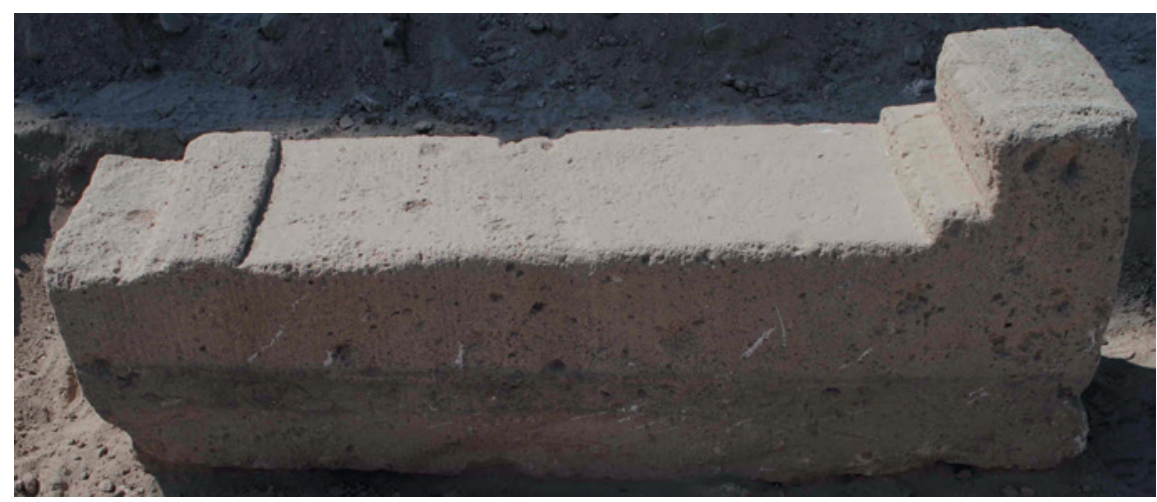

FIGURE $2.333 \quad$ KHA16

Arabic Transcription and Translation: No inscriptions

Reference Number: KHA17

Co-ordinates: $26.20829^{\circ} \mathrm{N} 050.54847^{\circ} \mathrm{E}$

Dimensions: $175 \mathrm{~cm}(\mathrm{l}) \times 33.5 \mathrm{~cm}(\mathrm{w}) \times 60 \mathrm{~cm}(\mathrm{~h})$

\section{Orientation: NW-SE}

Description: Single limestone slab gravestone. Eroded three element raised decoration with one facetted cube and central rounded arch identifiable at one end, decoration cut off at the other end. Inscriptions on four surfaces. Not in original position. 
Previous Publication: Number 18, Kalus (1990: 49)

\section{Arabic Transcription and Translation:}

A:

- In the Name of Allah, the Most Gracious, the Most Merciful. Allah, none has the right to be worshipped but he, the Ever Living, the One Who sustains and protects all that exists. Neither slumber nor sleep overtakes Him. To Him belongs whatever is in the heavens and whatever is on the earth. Who is he that can intercede with Him except by His permission! He knows what happens to them in this world.

- And will happen to them in the Hereafter and they will never compass anything of His Knowledge except that which He wills. His Seat extends over the heavens and the earth, and He feels no fatigue in guarding and preserving them. And He is the Most High, the Most Great. There is no compulsion in religion. Verily, the Right Path has become dis-
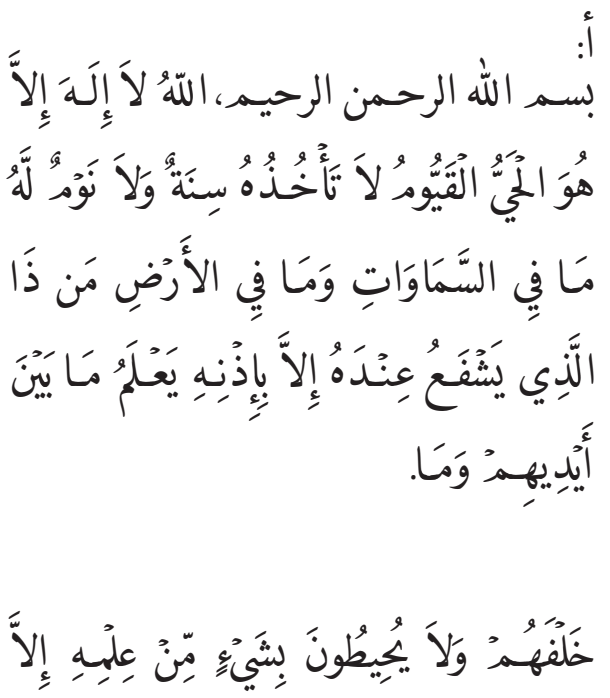

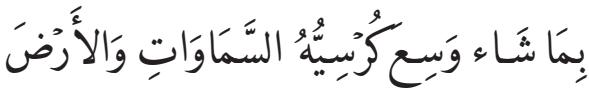

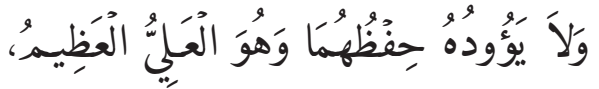

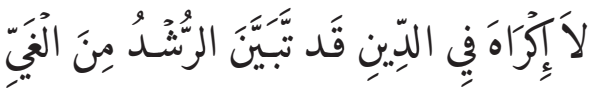
فَمَنْ. tinct from the wrong path. Whoever

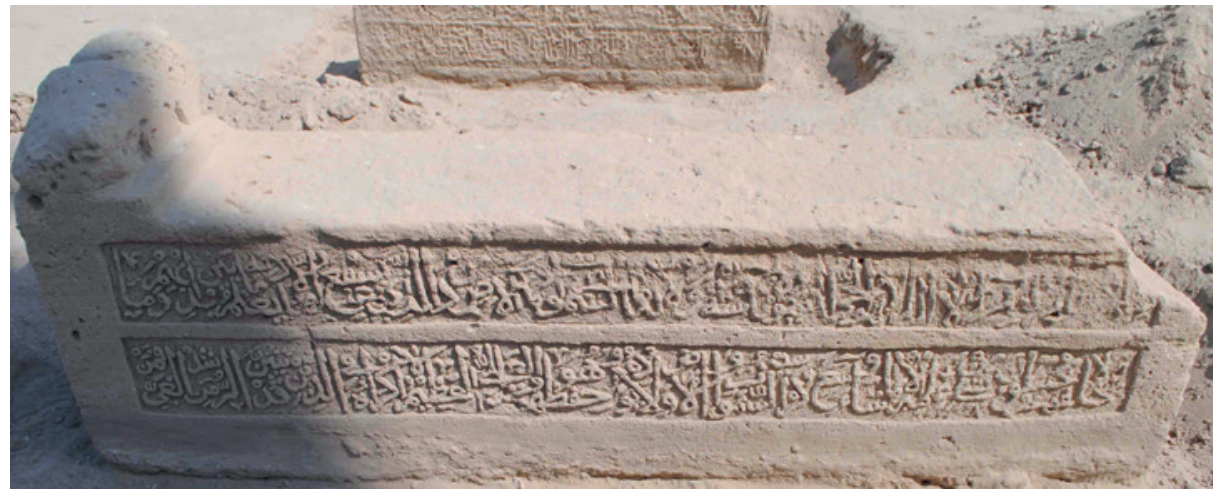

FIGURE 2.334 Surfaces A and E, KHA17 
B:

- Disbelieves in al-Taghut and believes in Allah, then he has grasped the most trustworthy handhold that will never break. And Allah is All-Hearer, All-Knower. Allah is the Protector of those who believe. He brings them out from

- Darkness into light. But as for those who disbelieve, their supporters are Taghut, they bring them out from light into darkness. Those are the dwellers of the Fire, and they will abide therein forever (2:255-257). Verily, those who say: Our Lord is Allah, and afterward are upright (41:30-32).
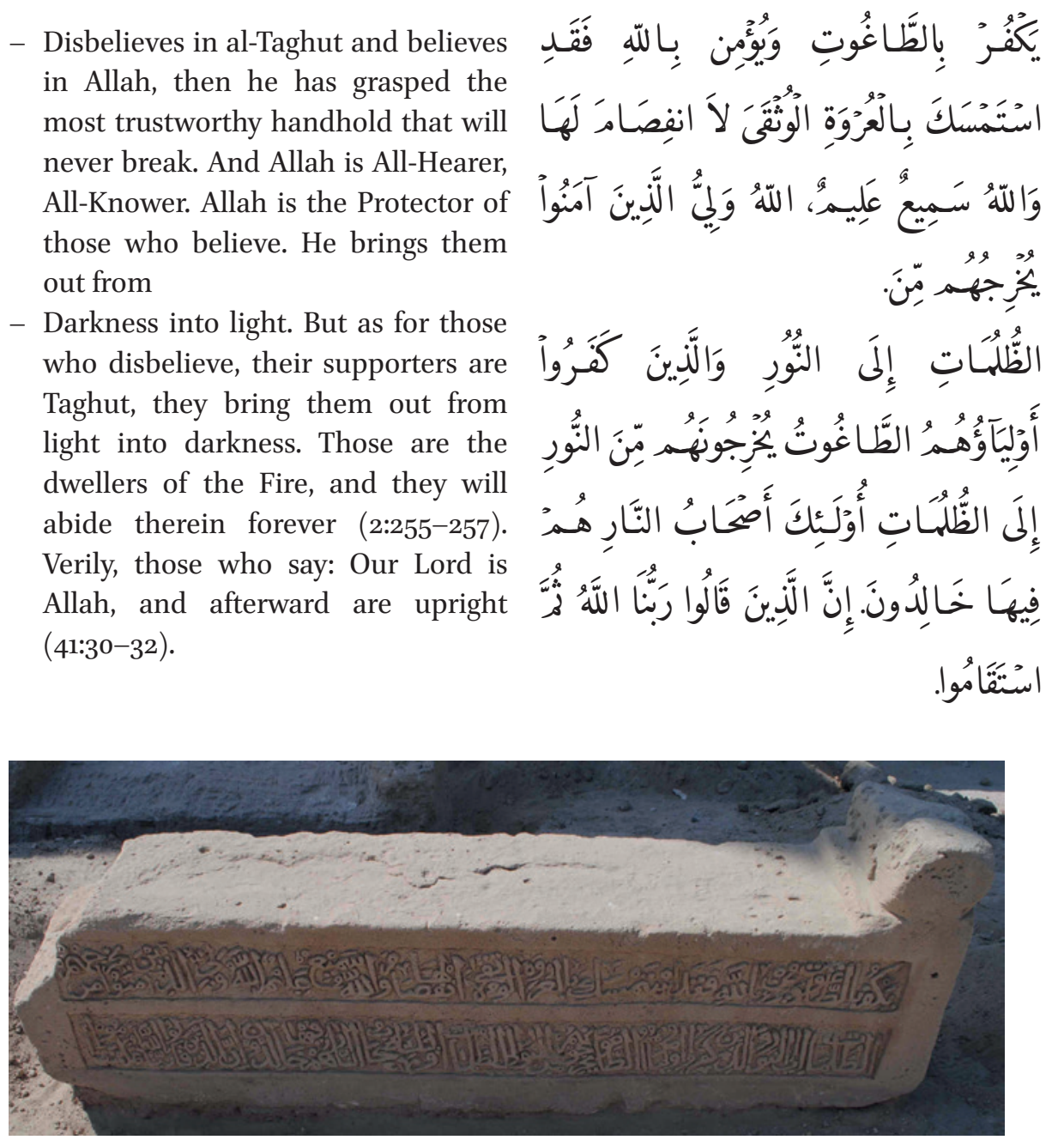

FIGURE 2.335 Surface B, KHA17

C:

- Fear not nor grieve, but receive the glad tidings of paradise 


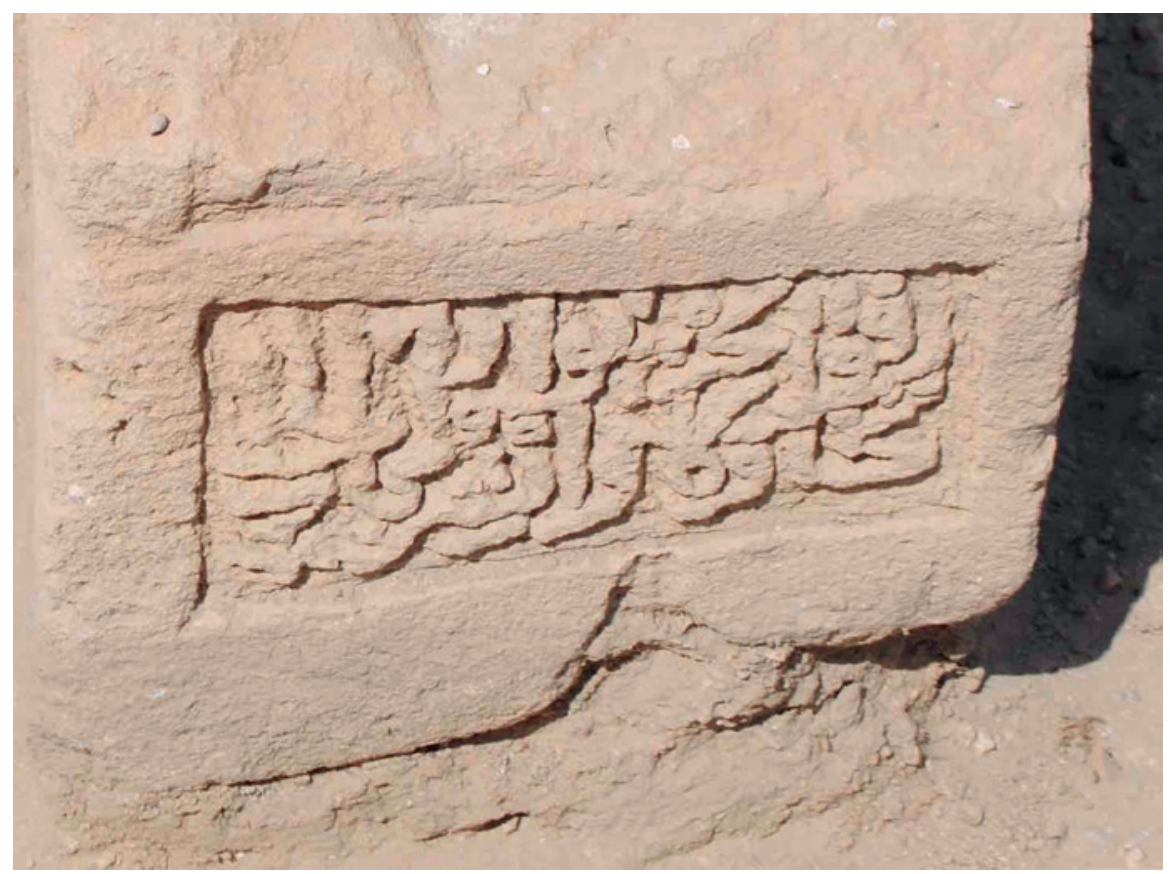

FIGURE 2.336 Surface C, KHA17

D:

- which you have been promised (41:30). We have been your friends in the life

- of this world and are in the Hereafter. Therein you shall have all that your inner-selves desire,

- And therein you shall have all for which you ask. An entertainment from the Oft-Forgiving, Most Merciful (41:31-32).
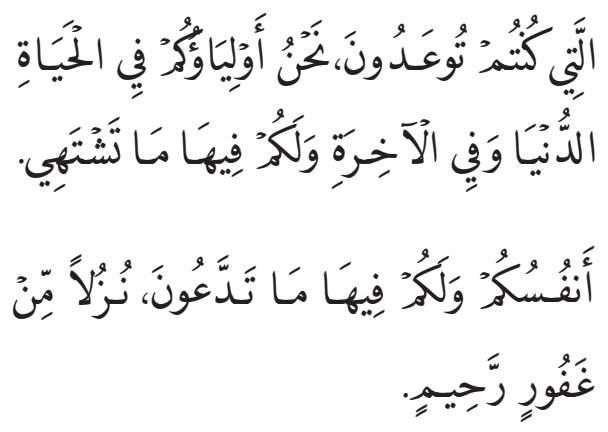


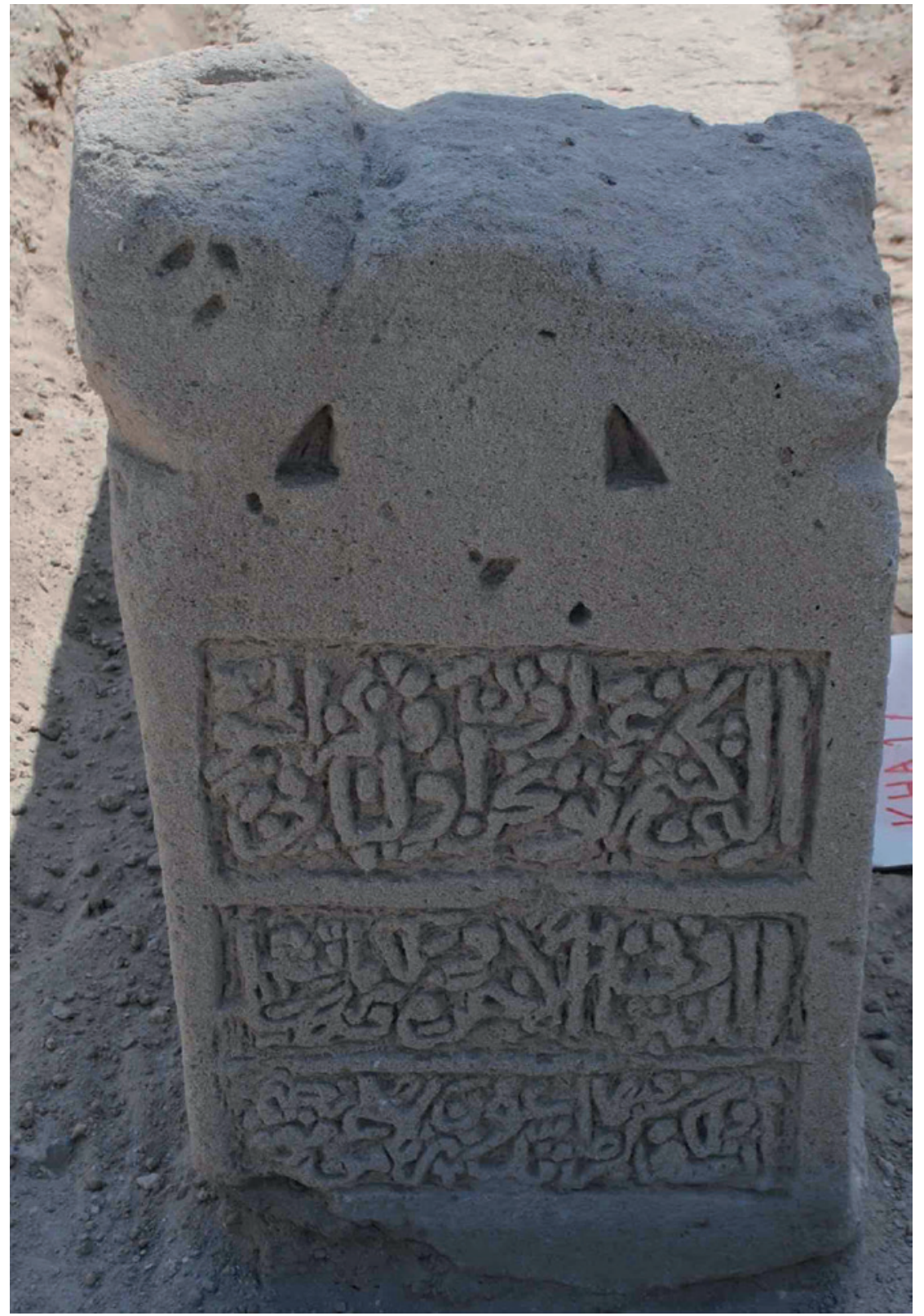

FIGURE 2.337 Surface D, KHA17

E:

- No carving or inscriptions.

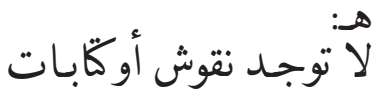

See Figure 2.334 


\section{Reference Number: KHA18}

Co-ordinates: $26.2083^{\circ} \mathrm{N} 050.54849^{\circ} \mathrm{E}$

Dimensions: $127 \mathrm{~cm}(\mathrm{l}) \times 22.5 \mathrm{~cm}(\mathrm{w}) \times 31 \mathrm{~cm}(\mathrm{~h})$

\section{Orientation: NNW-SSE}

Description: Single limestone slab gravestone. Heavily eroded. Raised decoration cut off at both ends. The gravestone has been deliberately recut on one surface (B) to remove the inscriptions except in the lower right corner where a fragment of the original inscribed surface remains. Partially legible inscriptions on four surfaces. Not in original position.

\section{Arabic Transcription and Translation:}

A:

- In the name of Allah ... none has the

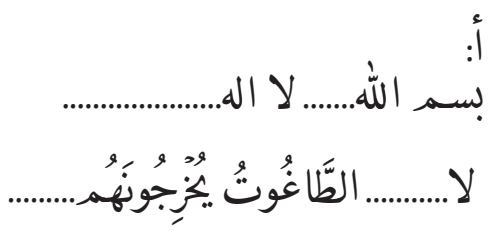

- No ... al-Taghut, they bring them out ... (2:257).

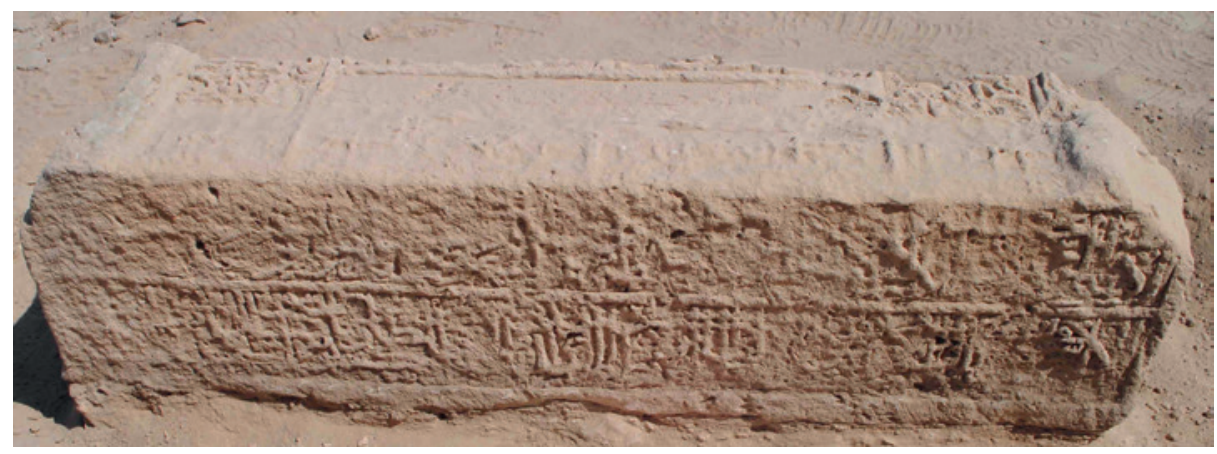

FIGURE 2.338 Surface A, KHA18

B:

- No legible inscriptions.

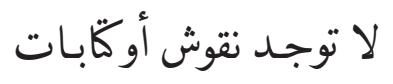




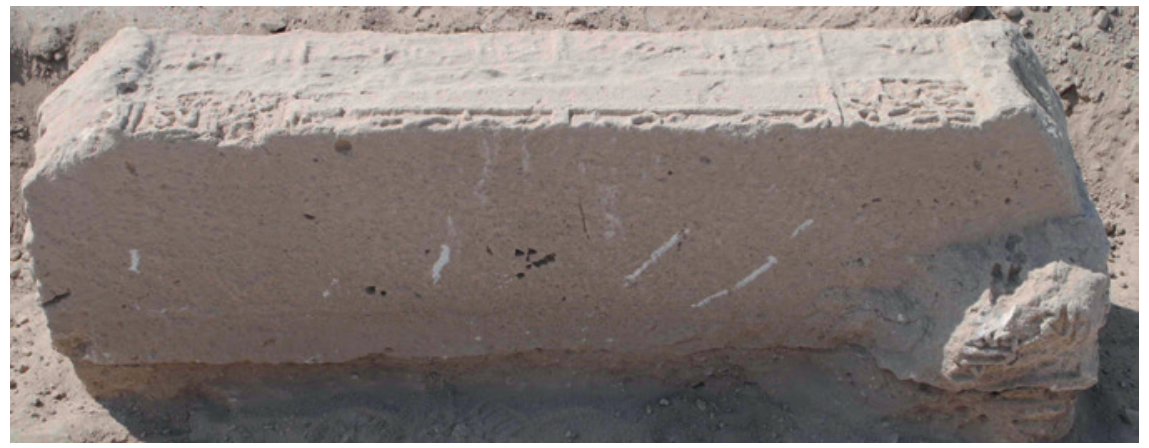

FIGURE 2.339 Surface B, KHA18

C:

- ... and the holy ...

(المقد................................

- Al-Firdawsi Shaikh Muhammad bin الفردوسي الشيخ محـد (احمد) بن الشَيخ Shaikh 'Abd a[1]......bin Hasan.

$$
\text { عبد ا.... (الله).بن حسن. }
$$

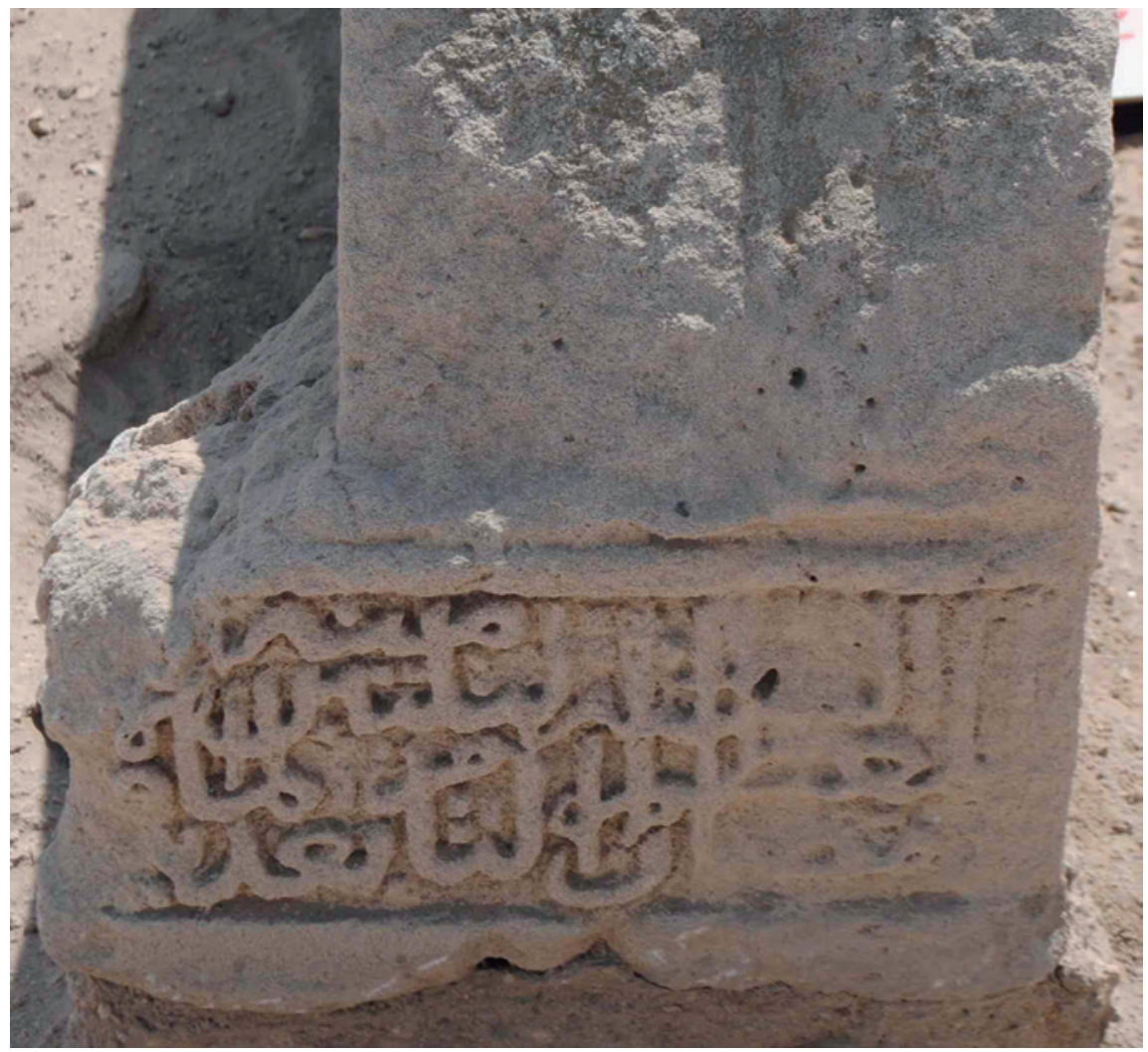

FIGURE $2.340 \quad$ Surface C, KHA18 
D:

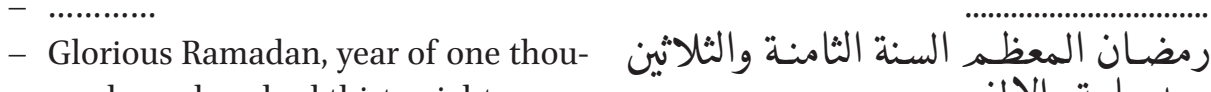
sand, one hundred thirty-eight.
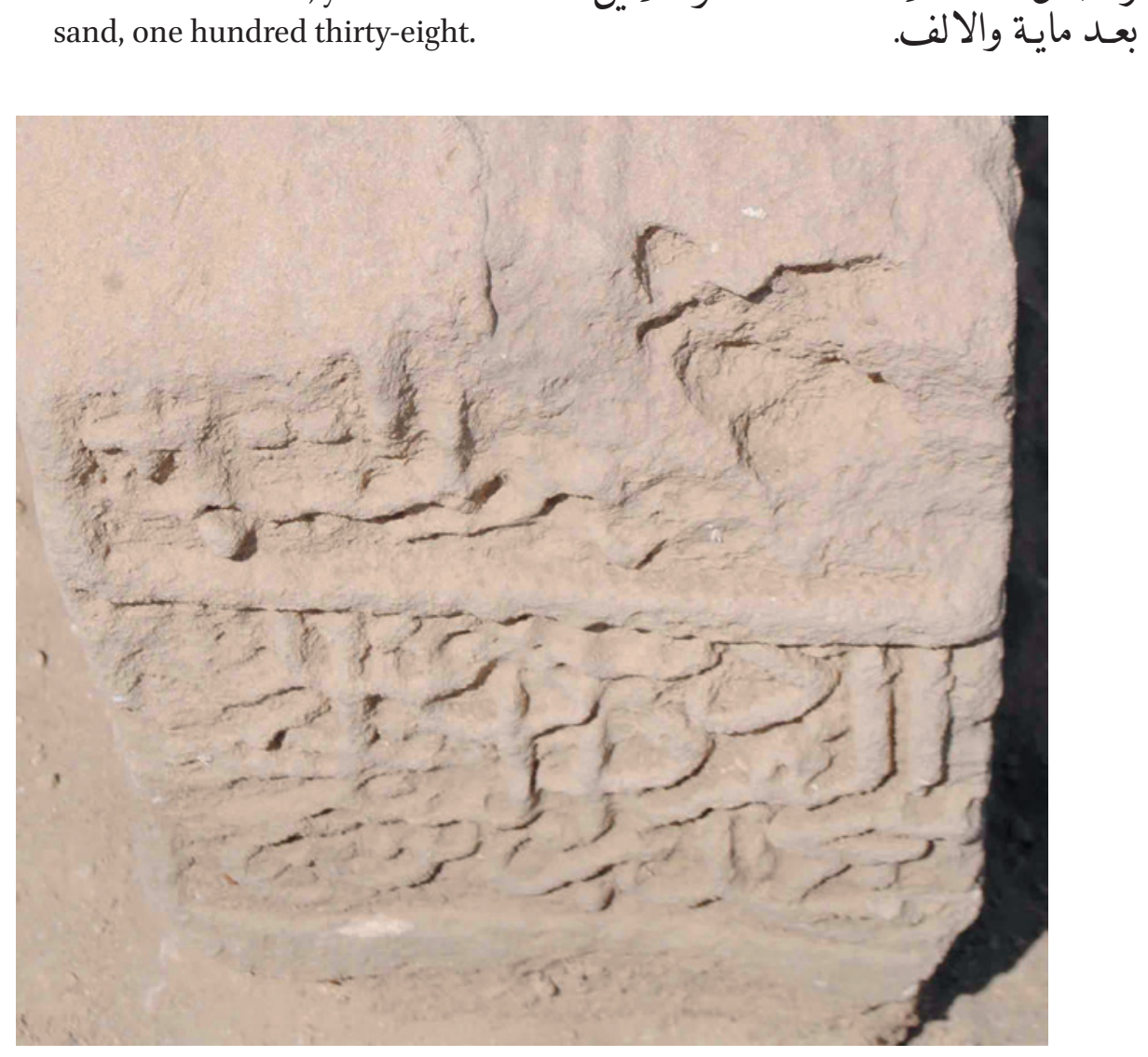

FIGURE 2.341 Surface D, KHA18

E:

- Engraved by ... al-Sayyid ...

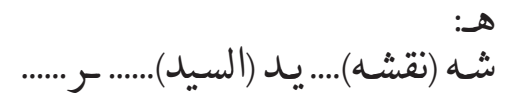




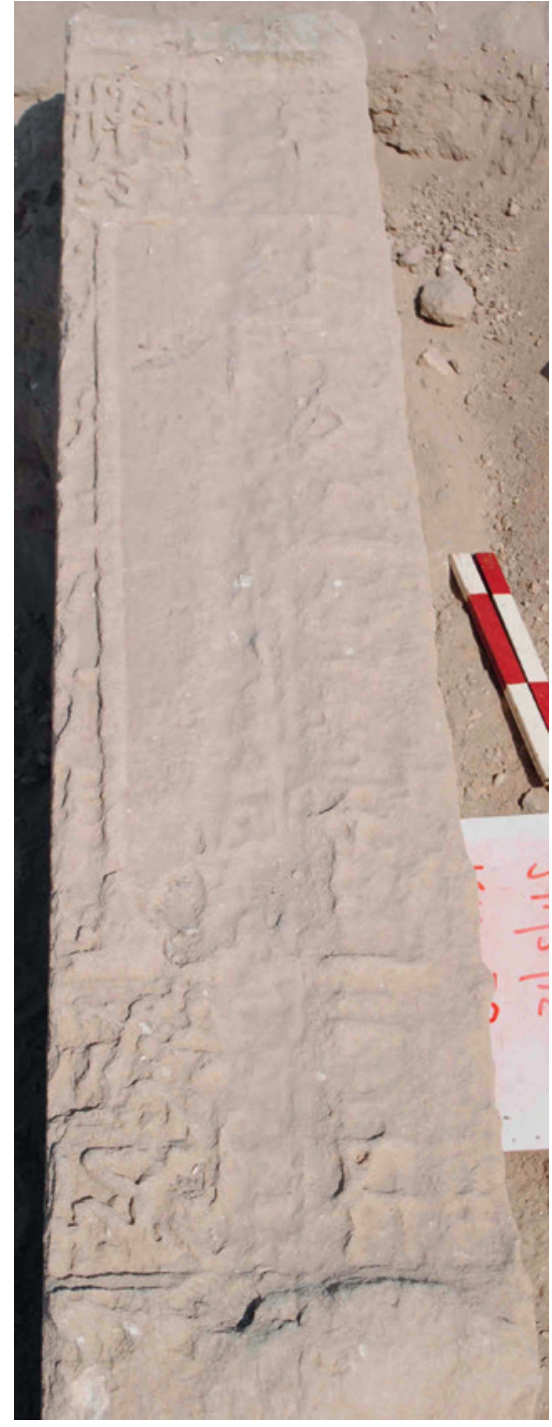

FIGURE 2.342

Surface E, KHA18

Reference Number: KHA19

Co-ordinates: $26.20828^{\circ} \mathrm{N} 050.54845^{\circ} \mathrm{E}$

Dimensions: $156 \mathrm{~cm}(\mathrm{l}) \times 44 \mathrm{~cm}(\mathrm{w}) \times 50 \mathrm{~cm}(\mathrm{~h})$

\section{Orientation: NW-SE}

Description: Single limestone slab gravestone (Figure 2.343). Possibly in original position near mosque wall. No inscriptions. Cut roughly into shape and with 
rectangular blocks at each end for raised decoration. The upper surface $(E)$ is badly shaped so that a downward sloping surface has been produced with clear chisel marks evident. This might be the reason the gravestone was left unfinished along with the poor quality of the stone which would have been evident once it had been cut into shape. Excavated to expose whole gravestone.

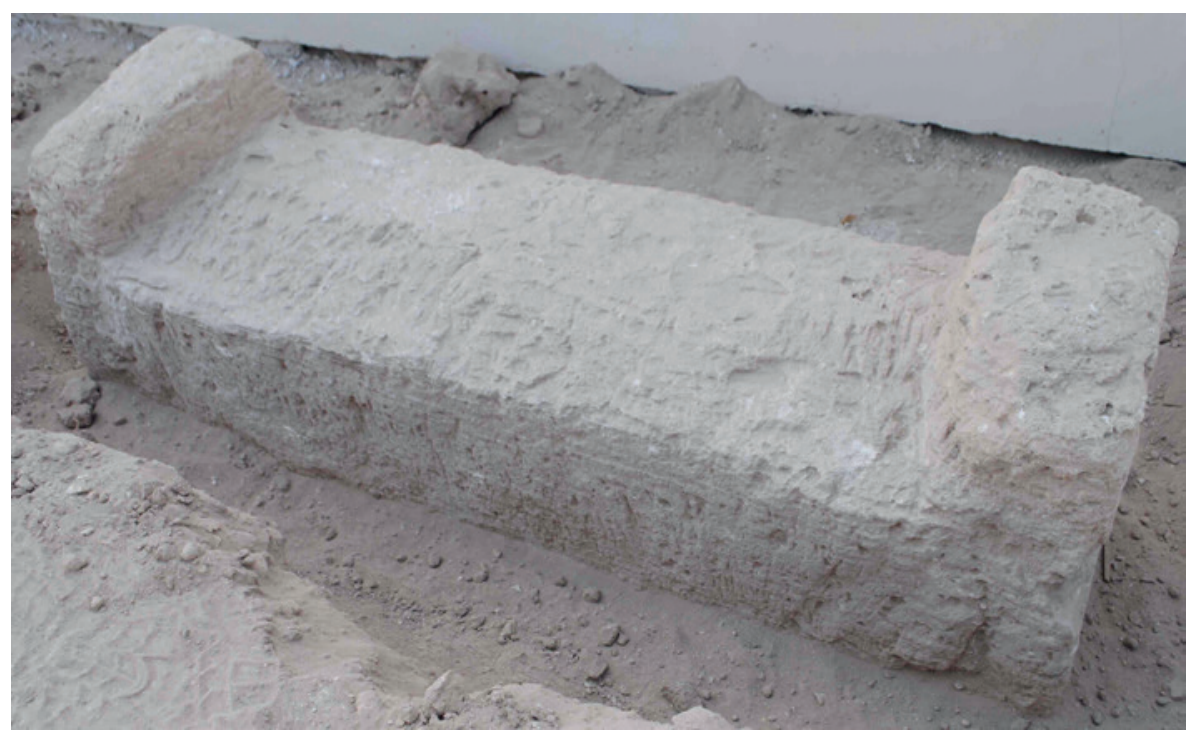

FIGURE $2.343 \quad$ KHA19

Arabic Transcription and Translation: No inscriptions

\section{Reference Number: KHA20}

Co-ordinates: $26.20828^{\circ} \mathrm{N} 050.54849^{\circ} \mathrm{E}$

\section{Dimensions:}

Slab 1: $73.5 \mathrm{~cm}(\mathrm{l}) \times 31 \mathrm{~cm}(\mathrm{w}) \times 40.5 \mathrm{~cm}(\mathrm{~h})$

Slab 2: $58 \mathrm{~cm}(\mathrm{l}) \times 30.5 \mathrm{~cm}(\mathrm{w}) \times 45 \mathrm{~cm}(\mathrm{~h})$

\section{Orientation: NNW-SSE}

Description: Gravestone formed of double limestone slabs. Damage on one side surface (A) and some erosion including surface flaking on the other (B). Three element raised decoration formed of two facetted cubes and a central rounded arch at one end, and remains of broken unidentifiable raised decoration at the other end. Inscriptions on four surfaces. Not in original position. 
Previous Publication: Number $\mathrm{S}_{5}$, Kalus (1995: 136-137), and Number $\mathrm{S}_{7}$, Kalus (1995: 138-139). It is unclear why Kalus separately catalogued the two halves of one gravestone (cf. Kalus 1995: Figures 2 and 4), presumably because they had been separated when Kalus was completing his recording.

\section{Arabic Transcription and Translation:}

A:

- In the Name of Allah, the Most Gracious, the Most Merciful. Verily, we have given you a manifest victory. That Allah may forgive you your sins of the past and the future.

- And complete His favour on you, and guide you on the straight path. And that Allah may help you with strong help (48:1-3). Eden Paradise, which they shall enter and also those who acted righteously
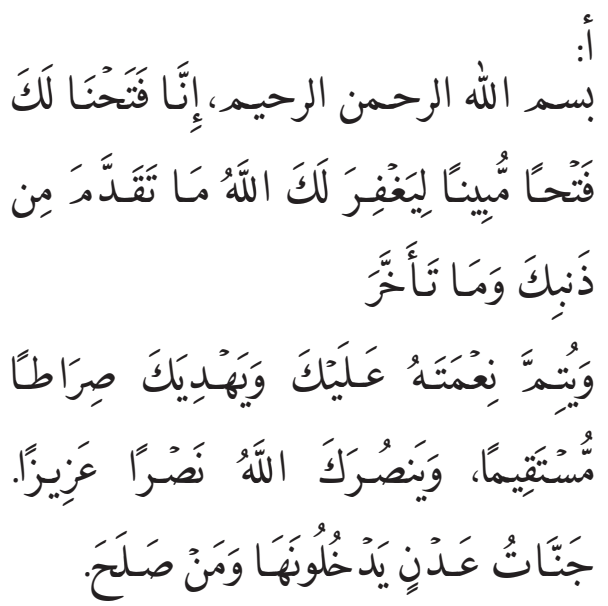

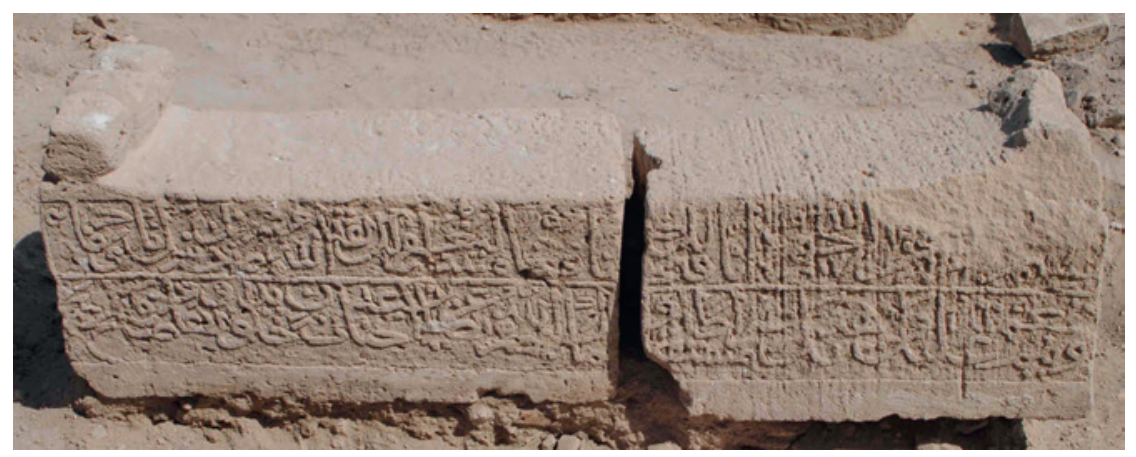

FIGURE 2.344 Surfaces A and E, KHA20

B:

- From among their fathers and their wives and their offspring. And angels shall enter unto them from every gate saying, peace be upon you, for you preserved in patience.

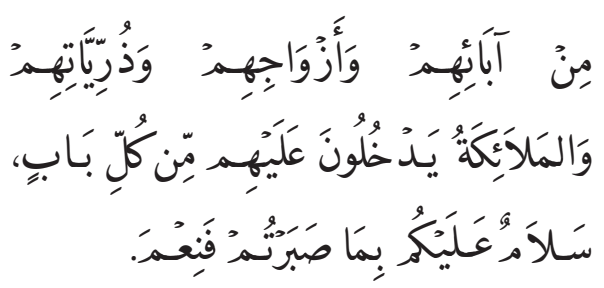


- Excellent indeed is the final home (13:23-24). Their Lord gives them glad tidings of Mercy from Him, and His being pleased with them, and of Paradise for them wherein are everlasting delights. They will dwell therein forever. Verily, with Allah is a great reward (9:21-22).
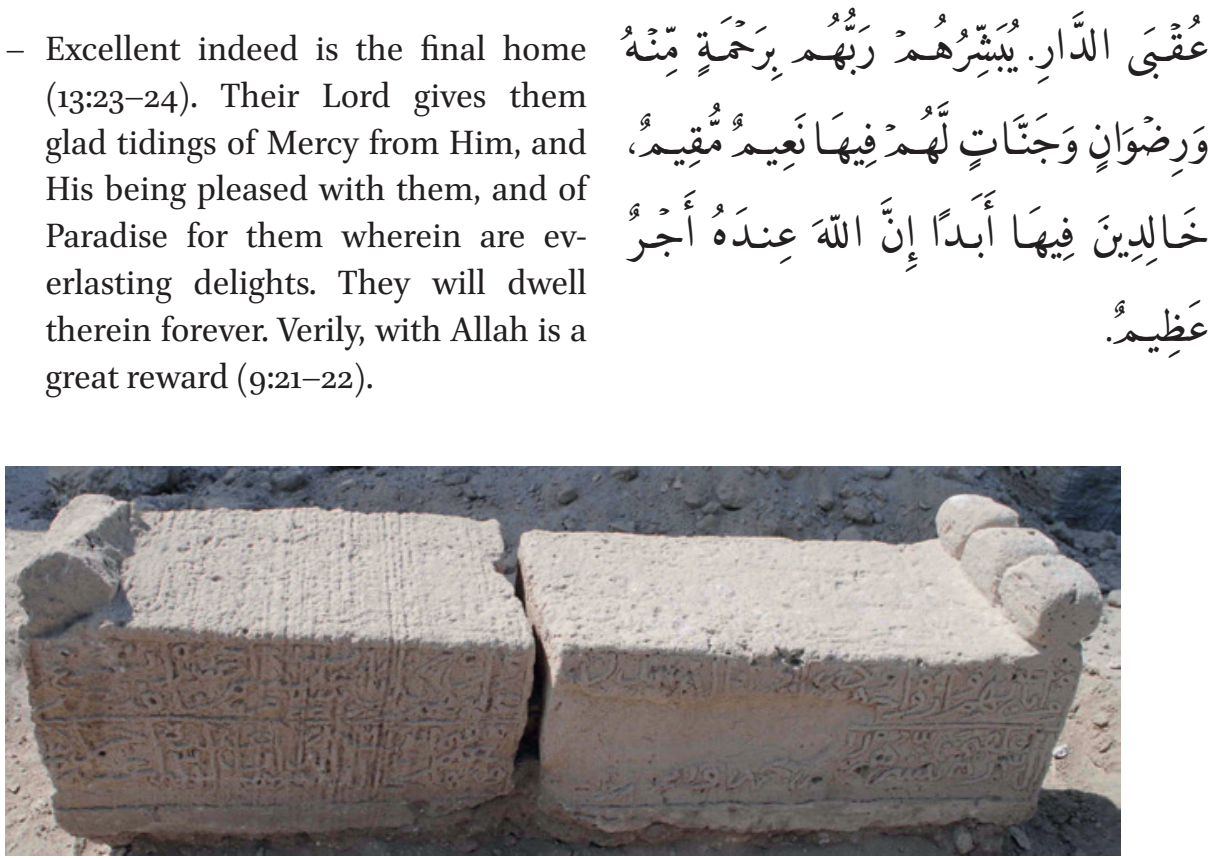

FIGURE 2.345 Surface B, KHA20

C:

- The late, the blessed Muhammad died ...

- ... al-Din ... bin Husayn bin Mubarak ...
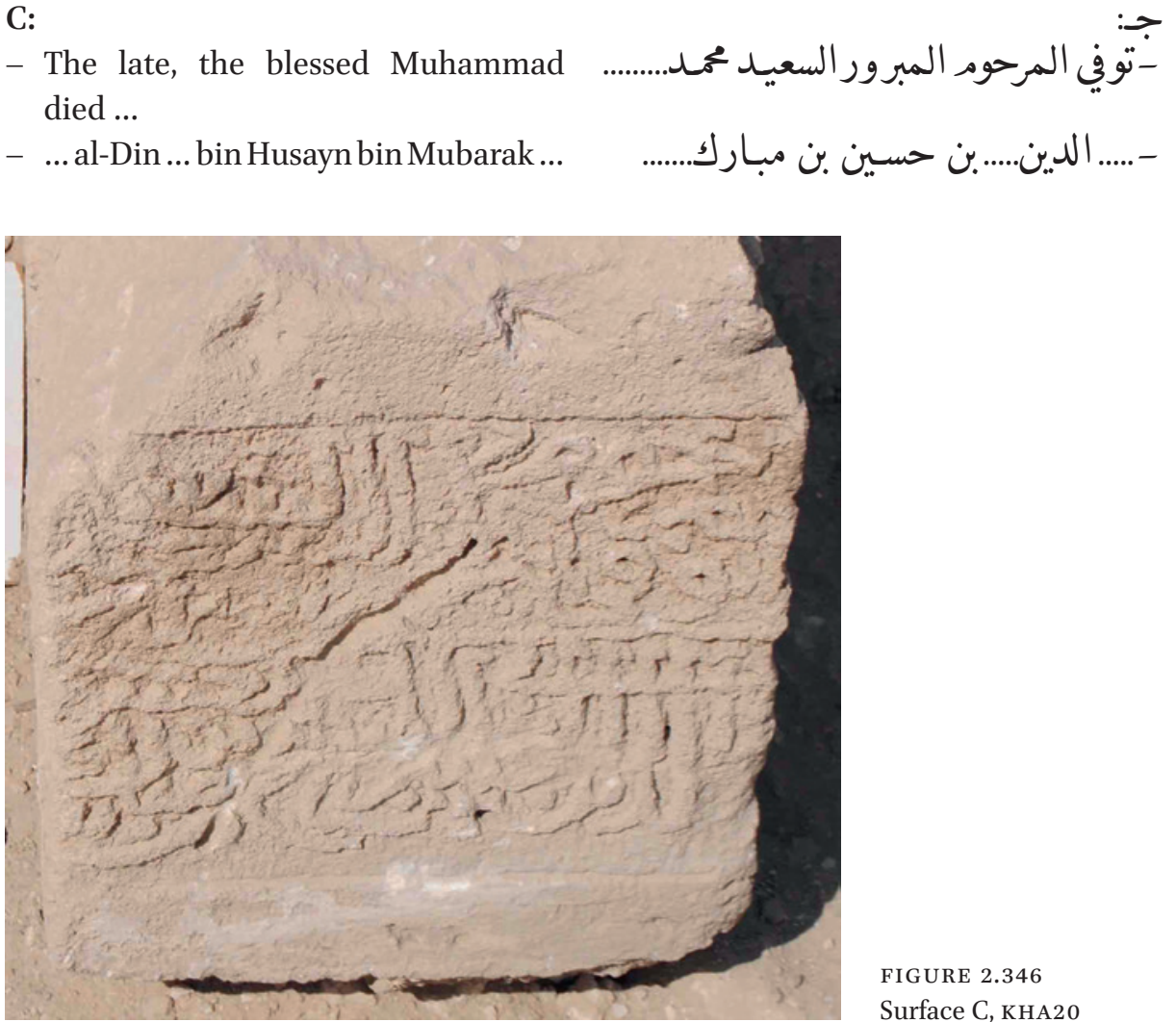
D:

- ...... In the Monday night, ninth of Jumada

- The first, year eight hundred and الاول سنة سـت واربعين وثمان مايـة forty-six

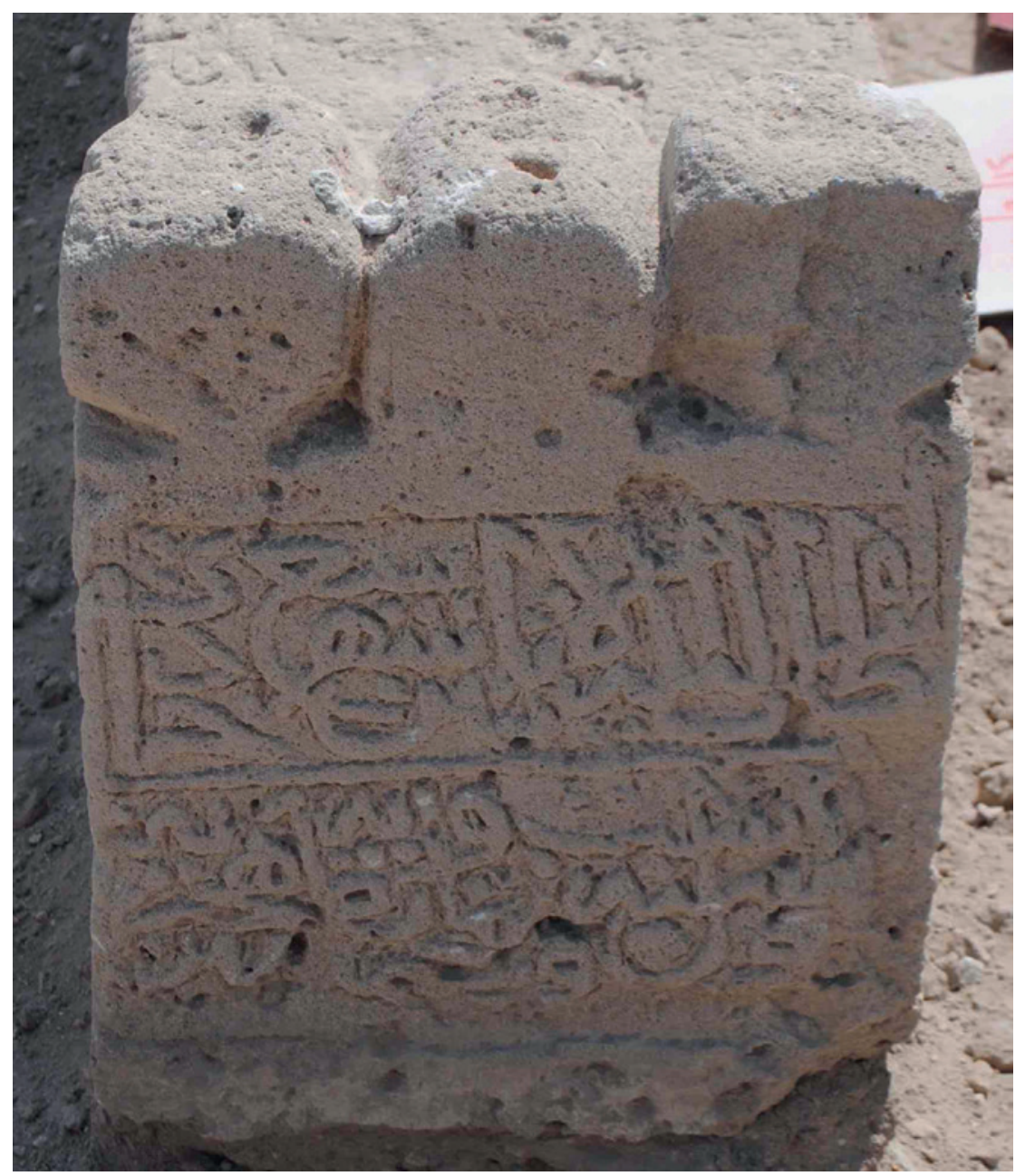

FIGURE 2.347 Surface D, KHA20

E:

- No carving or inscriptions.

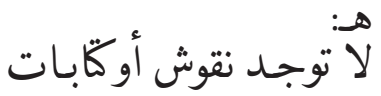

See Figure 2.344 


\section{Reference Number: KHA21}

Co-ordinates: $26.20829^{\circ} \mathrm{N} 050.54851^{\circ} \mathrm{E}$

\section{Dimensions:}

Slab 1: $96 \mathrm{~cm}(\mathrm{l}) \times 38 \mathrm{~cm}(\mathrm{w}) \times 53 \mathrm{~cm}(\mathrm{~h})$

Slab 2: $63 \mathrm{~cm}(\mathrm{l}) \times 35 \mathrm{~cm}(\mathrm{w}) \times 47 \mathrm{~cm}(\mathrm{~h})$

\section{Orientation: NW-SE}

Description: Gravestone formed of double limestone slabs. The smaller slab is very eroded and the raised decoration has been cut off and the area where it was subsequently eroded. The larger slab has the remains of raised decoration, likely formed of three elements, with one facetted cube identifiable. Traces of shallow carved rectangular panel design, probably a niche, on the upper surface (E) of the larger slab. Partially legible inscriptions on three surfaces of the smaller slab and two surfaces of the larger slab. Not in original position.

\section{Arabic Transcription and Translation:}

A:

- Very deteriorated. Unable to read.
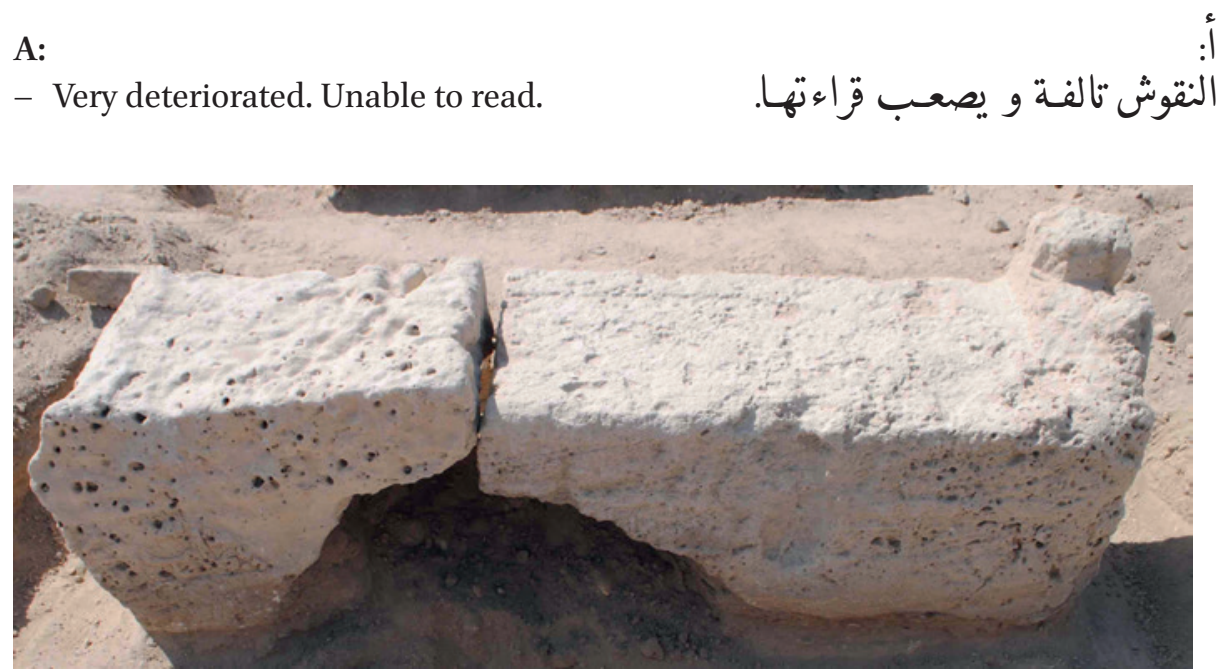

FIGURE 2.348 Surfaces A and E, KHA21

B:

- The heavens ...

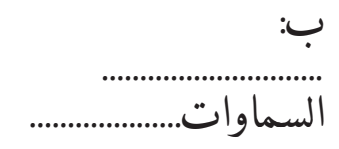




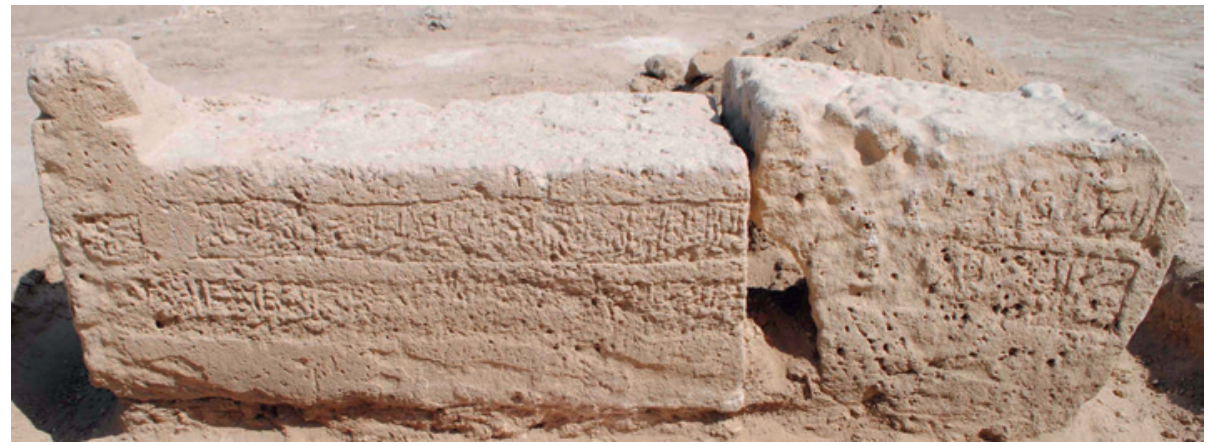

FIGURE 2.349 Surface B, KHA21

C:

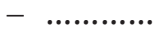

- ... the most merciful.
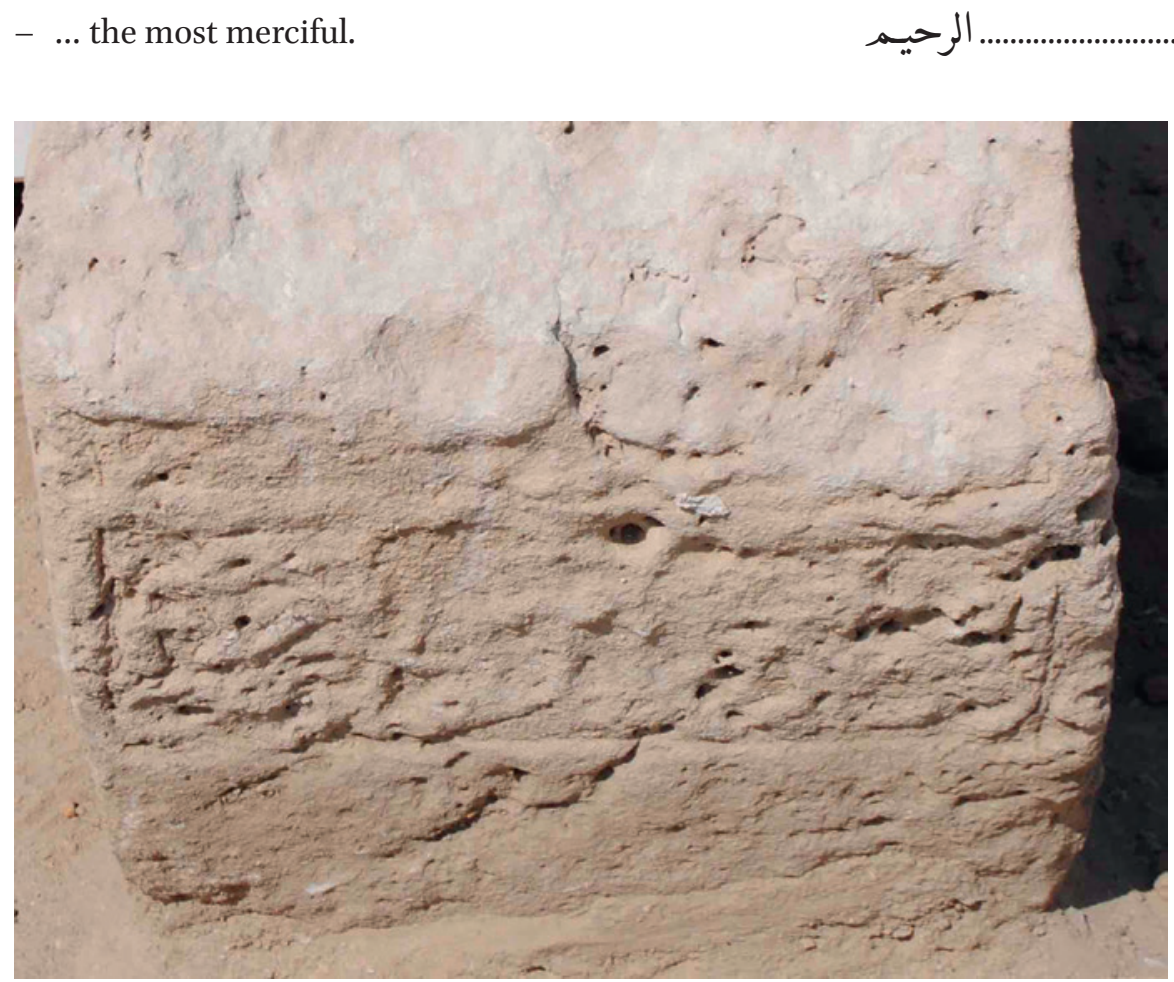

FIGURE 2.350 Surface C, KHA21 
D:

- This is the grave ... Ahmad ... alSaid ...
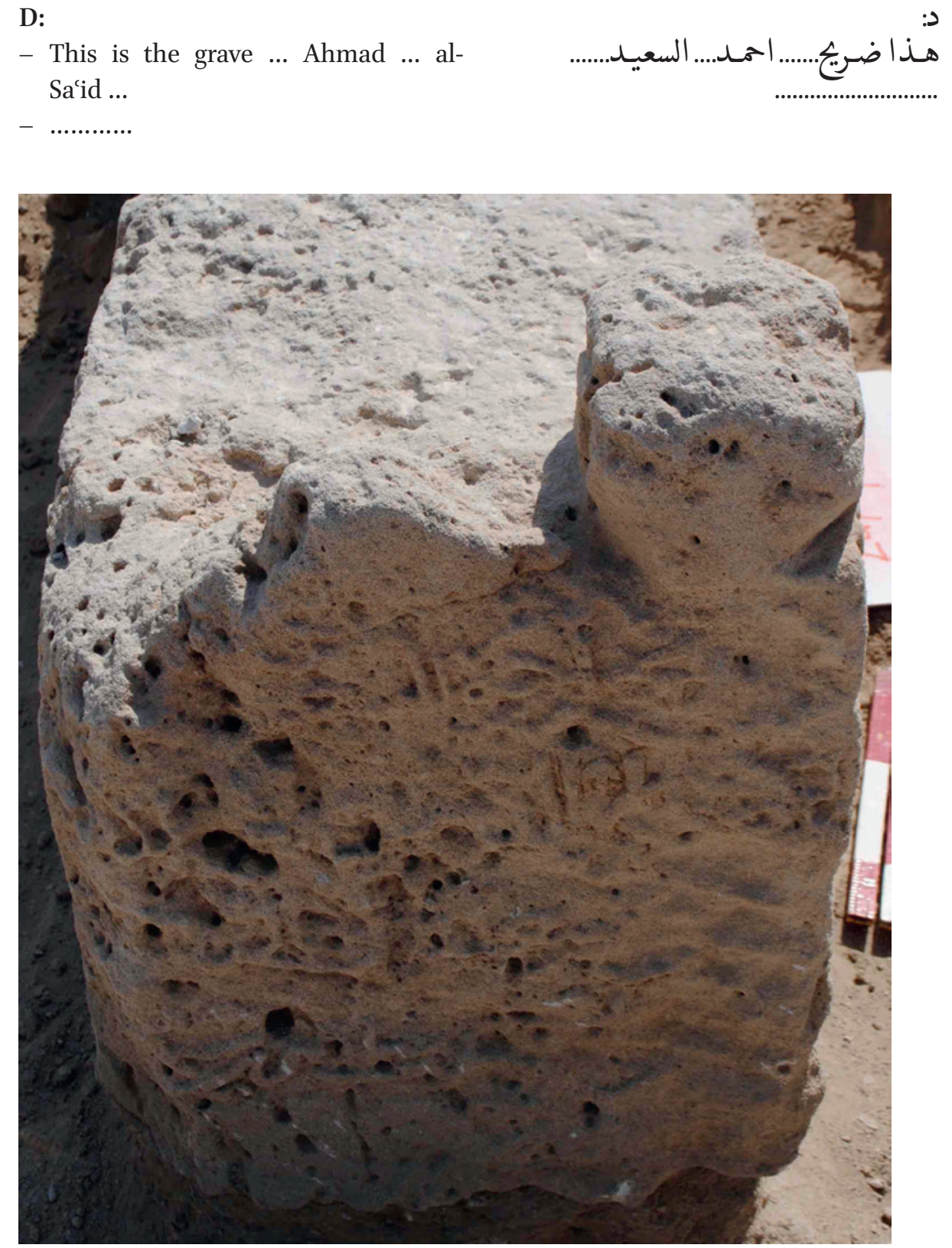

FIGURE 2.351 Surface D, KHA21

E:

- No carving or inscriptions.

لا تهـ: توجد نقوش أوكّابات

See Figure 2.348 
Reference Number: KHA22

Co-ordinates: $26.20851^{\circ} \mathrm{N} 050.54860^{\circ} \mathrm{E}$

\section{Dimensions:}

Slab 1: $77.5 \mathrm{~cm}(\mathrm{l}) \times 37 \mathrm{~cm}(\mathrm{w}) \times 37 \mathrm{~cm}(\mathrm{~h})$

Slab 2: $38.5 \mathrm{~cm}(\mathrm{l}) \times 37 \mathrm{~cm}(\mathrm{w}) \times 40 \mathrm{~cm}(\mathrm{~h})$

\section{Orientation: NA}

Description: Parts of a gravestone formed of double limestone slabs (Figure 2.352). The slabs were unfortunately moved by the workmen during excavation of the collapsed shrine and it appears that they are not connected. The smaller slab is eroded on the top and upper side surfaces and has partially legible inscriptions on two surfaces. The larger slab has no inscriptions. Not in original position.

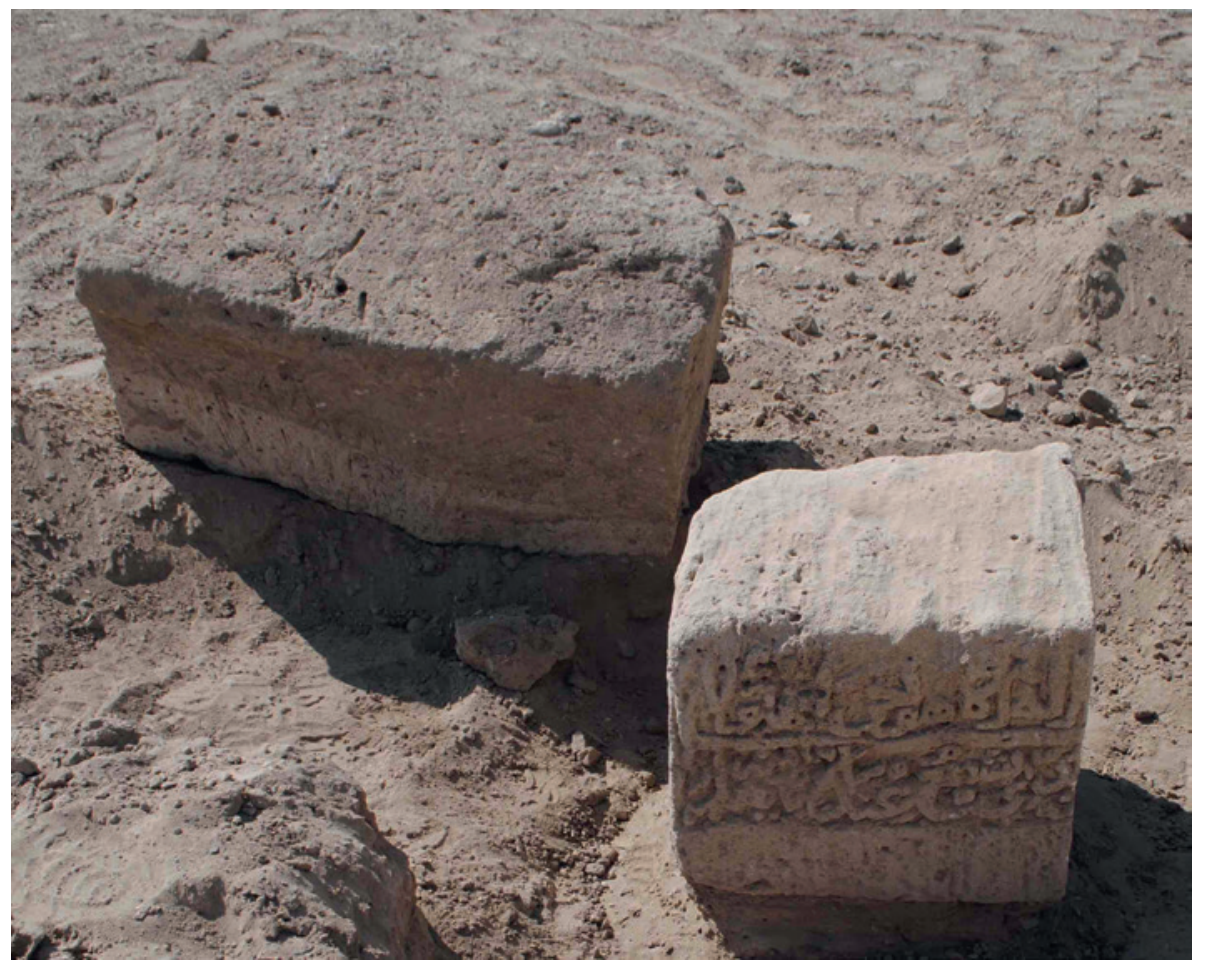

FIGURE $2.352 \quad$ KHA22

Previous Publication: Number 20, Kalus (1990: 52) 


\section{Arabic Transcription and Translation:}

A:

- Religion. Verily, the right path has become distinct from the wrong path

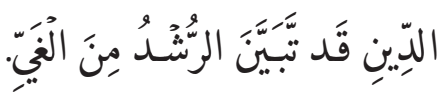
(2:256).

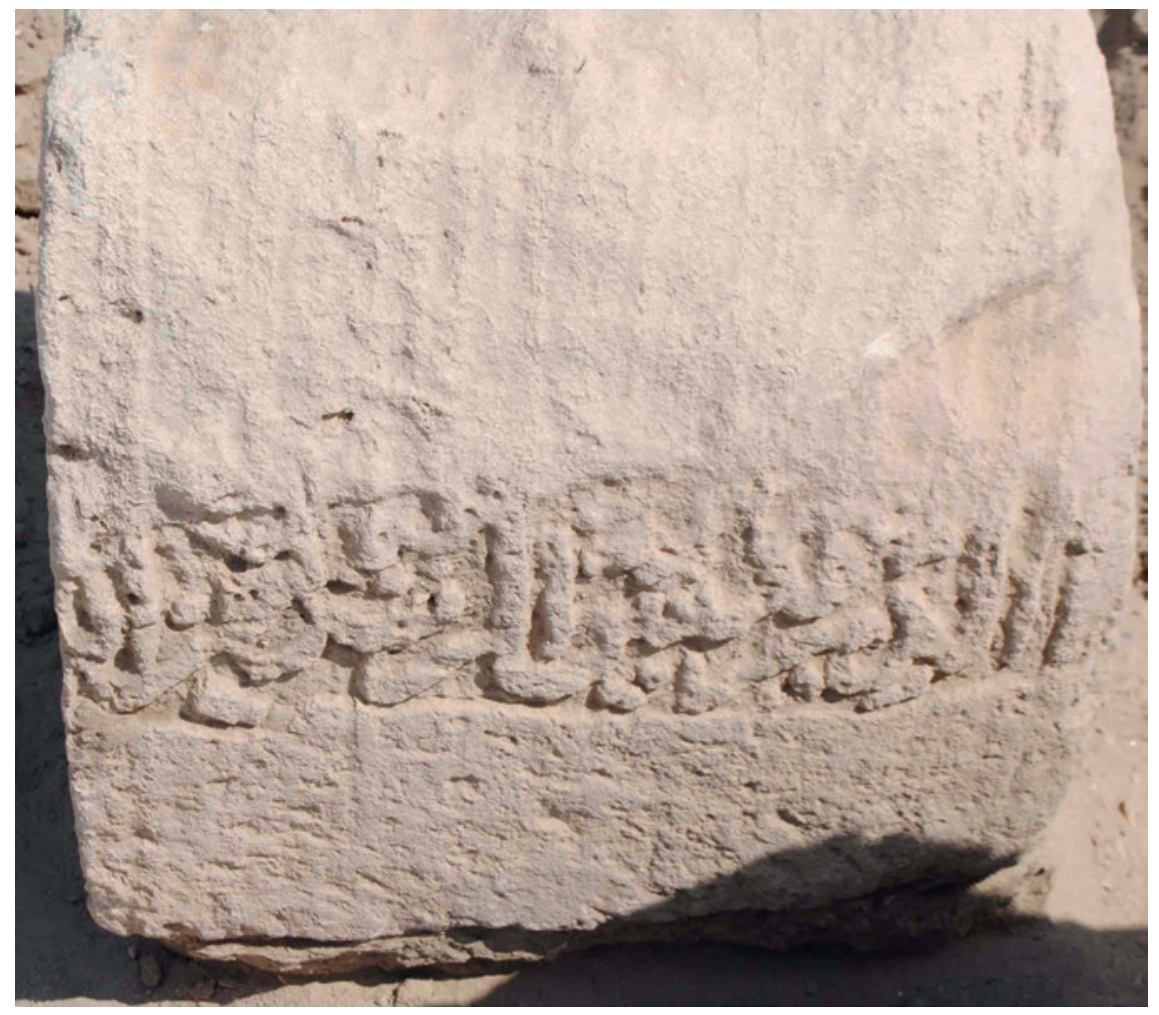

FIGURE 2.353 Surface A, small slab, KHA22

B:

- None has the right to be worshipped but Him, the Ever Living, the One who

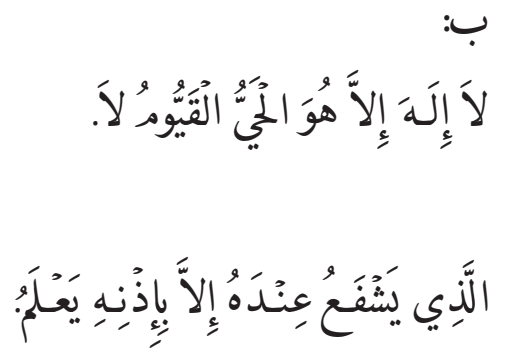
sustains and protects all that exists. Neither

- Intercede with Him except with His permission (2:255). 


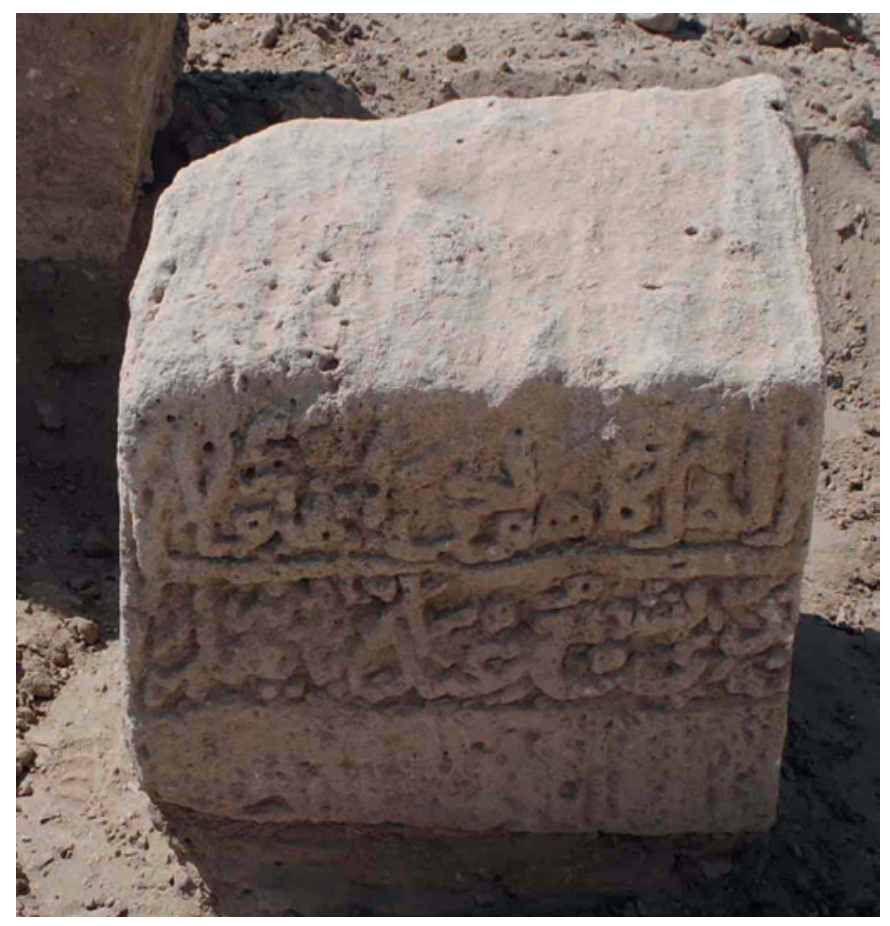

$\mathrm{C}:$

- No carving or inscriptions.

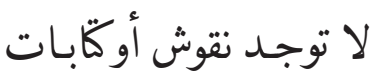

D:

- No carving or inscriptions. لا توجـد نقوش أوكّابـات

E:

- No carving or inscriptions.

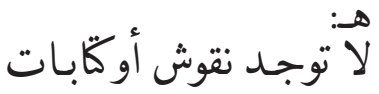

Reference Number: KHA23

Co-ordinates: $26.20839^{\circ} \mathrm{N} 050.54814^{\circ} \mathrm{E}$

Dimensions: $63 \mathrm{~cm}(\mathrm{l}) \times 30.5 \mathrm{~cm}(\mathrm{w}) \times 34 \mathrm{~cm}(\mathrm{~h})$

Orientation: NA 
Description: Single limestone slab from a double slab gravestone. Eroded. Traces of red paint/pigment on some of the lettering on one surface. Partially legible inscriptions on two surfaces and carved double interlocking circle decoration on the upper surface (E). Three element eroded raised decoration at one end formed of two facetted cubes each with a cupmark on top and a central rounded arch. Additional carved geometric patterns are on the external side surfaces and rear of the raised decorative blocks. Not in original position. Excavated to expose whole gravestone.

\section{Arabic Transcription and Translation:}

A:

- In the Name of Allah, the Most Gracious, the Most Merciful ...
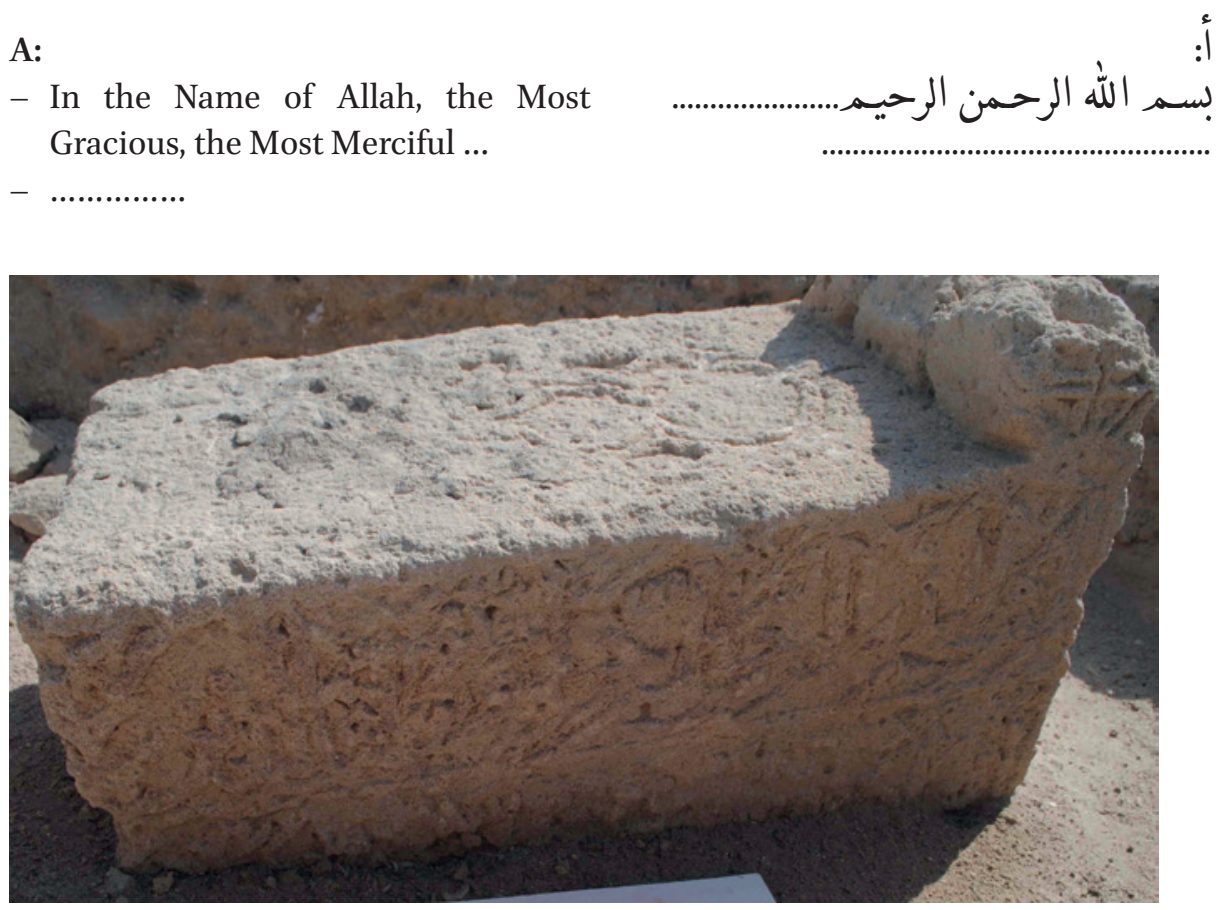

FIGURE 2.355 Surface A. KHA23

B:

- The inscription cannot be read.

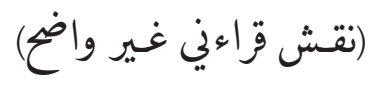




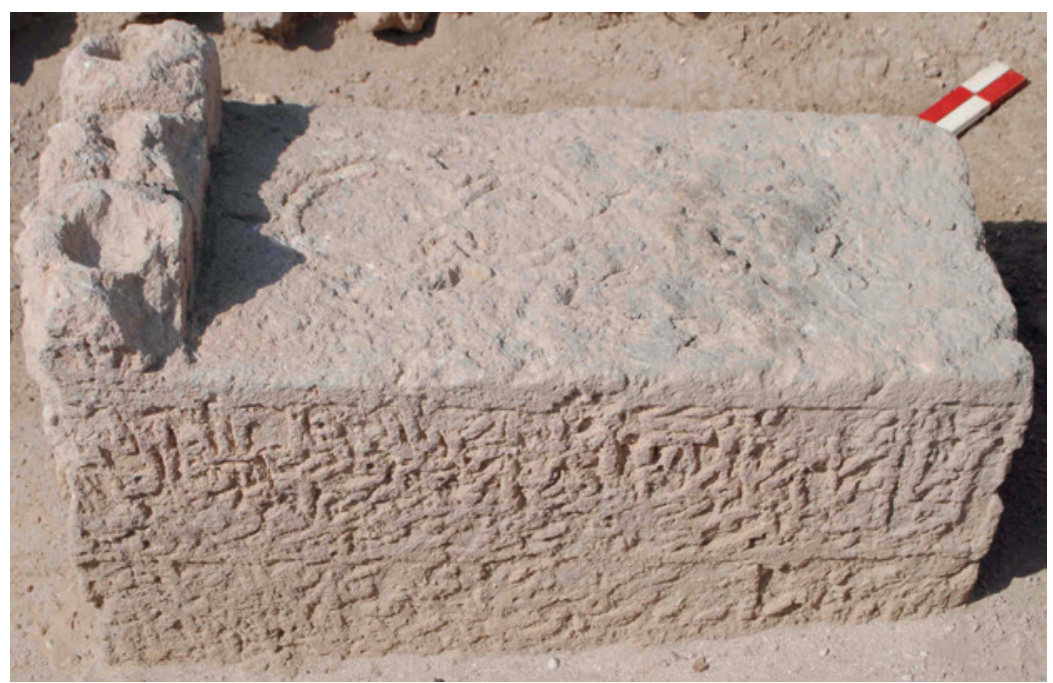

FIGURE 2.356 Surface B, KHA23

C:

- This is the grave of the Late al-Sayyid ... Naser ...

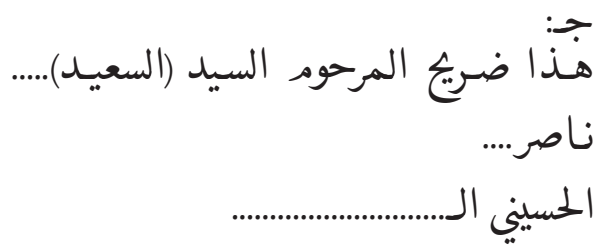

- al-Husayni ...

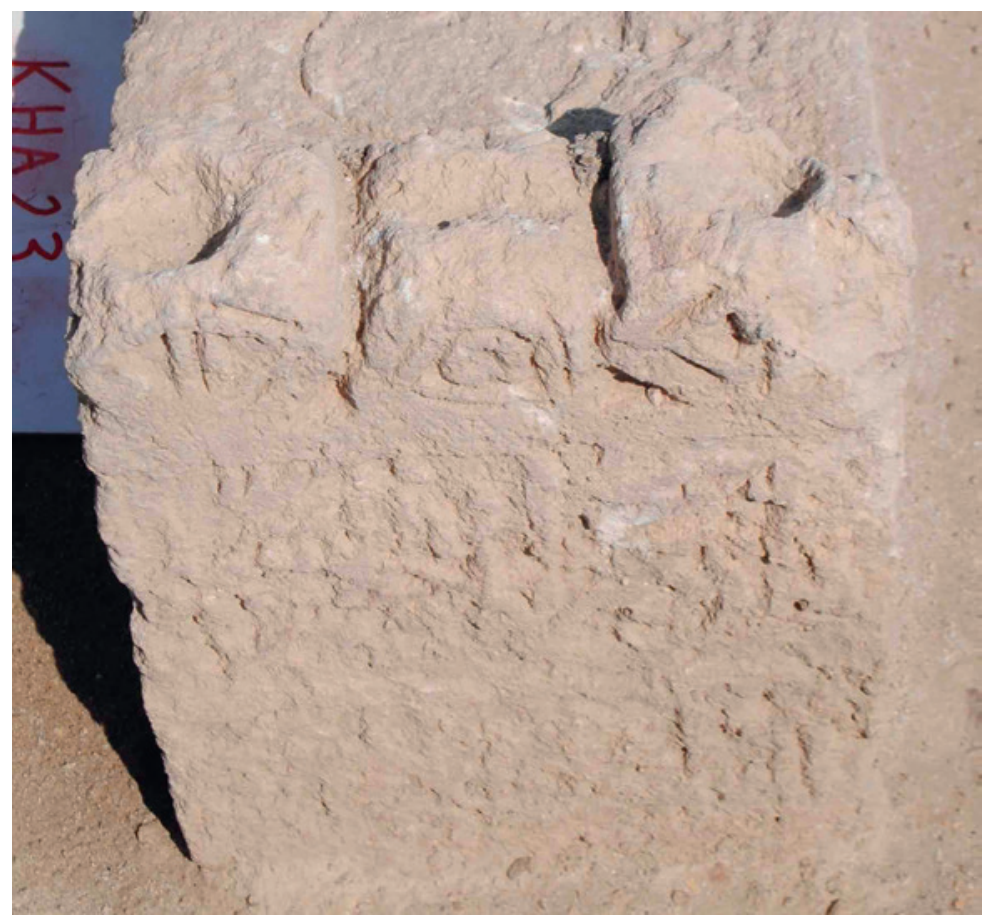

FIGURE 2.357

Surface C,

KHA23 
D:

- No carving or inscriptions.

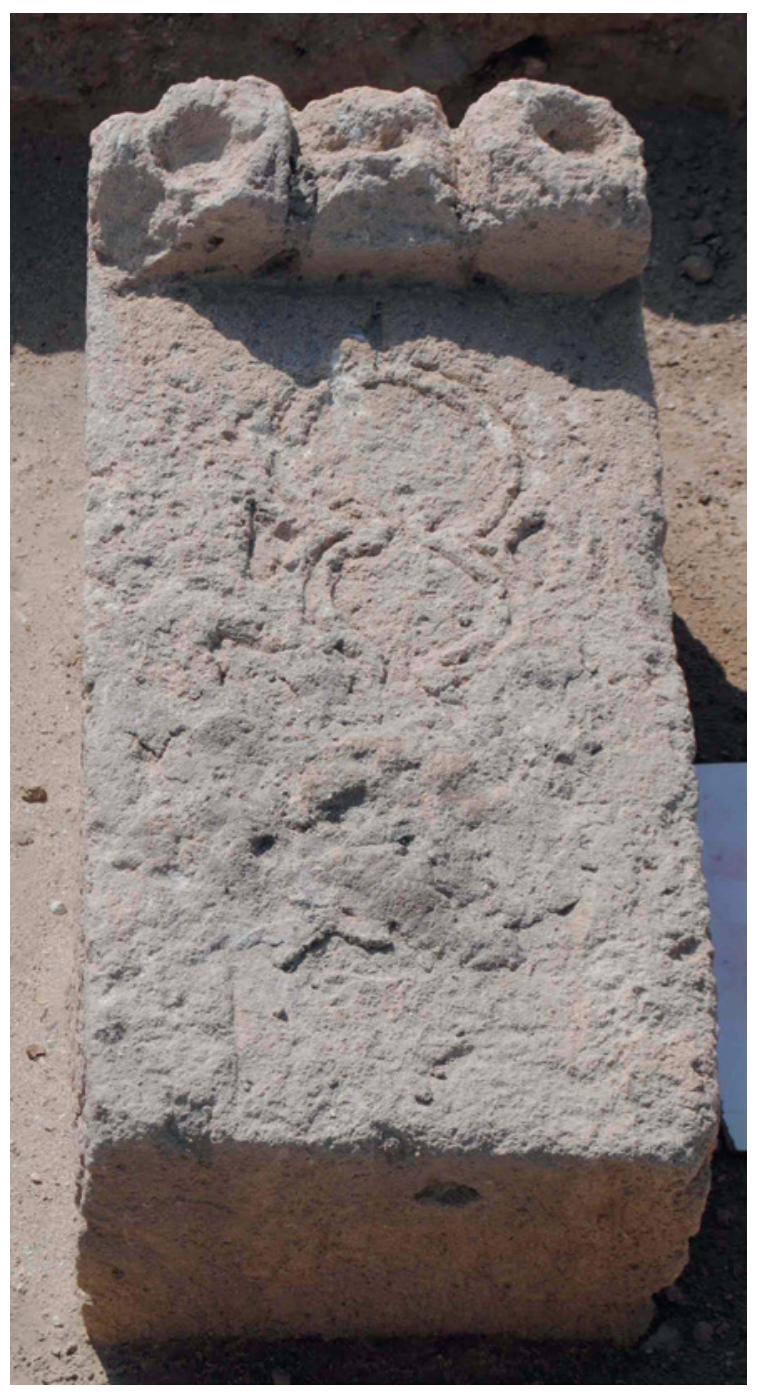

FIGURE 2.358

Surfaces D and E, KHA23

E:

- No inscriptions.

See Figure $2.35^{8}$
لا تّوجـد كَّات أو نقوش

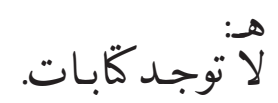


Reference Number: KHA24

Co-ordinates: $26.20839^{\circ} \mathrm{N} 050.54811^{\circ} \mathrm{E}$

Dimensions: $74.5 \mathrm{~cm}(\mathrm{l}) \times 22 \mathrm{~cm}(\mathrm{w}) \times 40 \mathrm{~cm}(\mathrm{~h})$

\section{Orientation: NA}

Description: Single limestone slab from a double slab gravestone. Eroded and with areas of damage. Eroded unidentifiable raised decoration at one end. Traces of shallow carved recessed rectangular panel on the top surface (E), probably a niche. Inscriptions on three surfaces. Not in original position. Excavated to expose whole gravestone.

\section{Arabic Transcription and Translation:}

A:

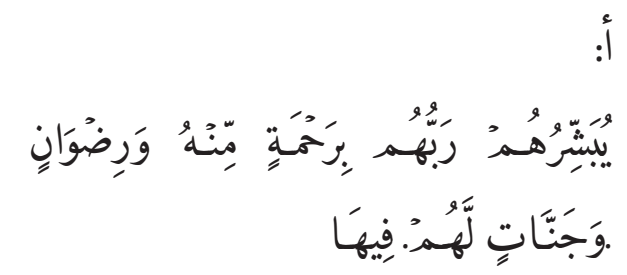
wherein are (9:21).
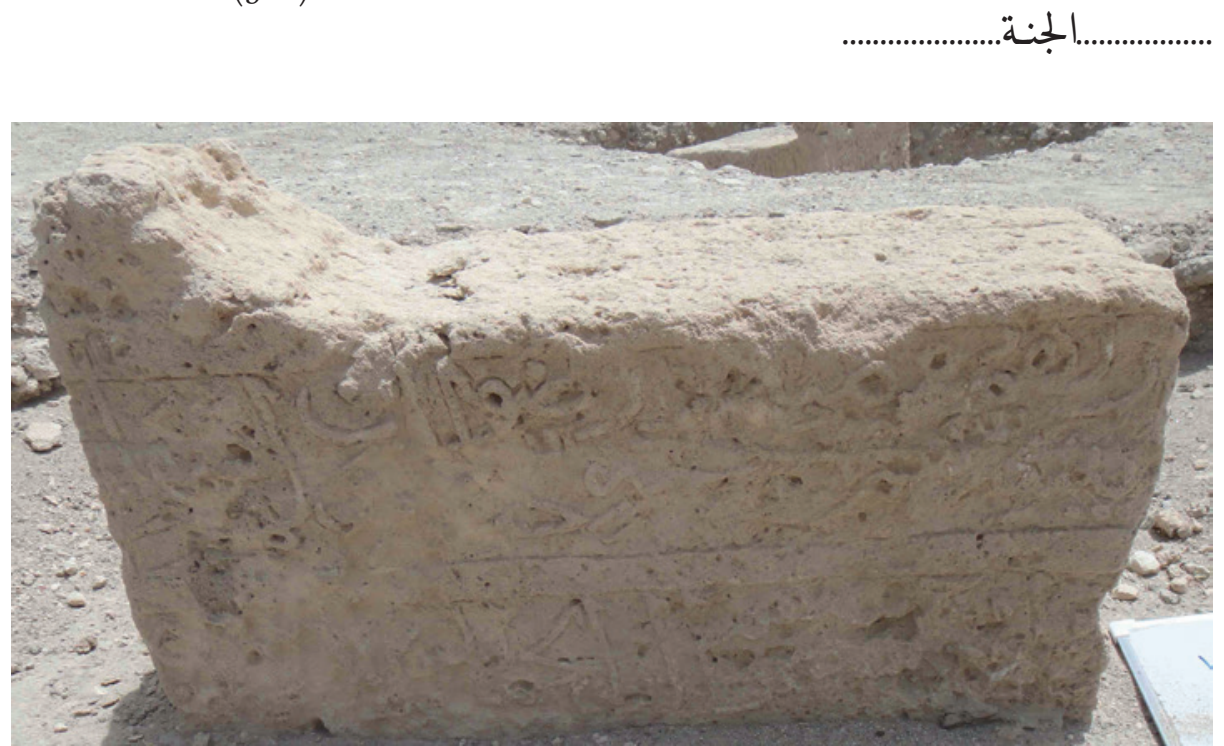

FIGURE 2.359 Surface A, KHA24 
B:

- In the Name of Allah, the Most Gracious, the Most Merciful. Their Lord gives them glad tidings.

- ... Allah has ... (9:21-22).

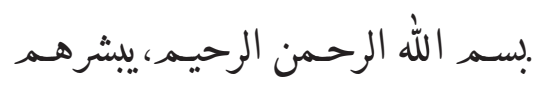

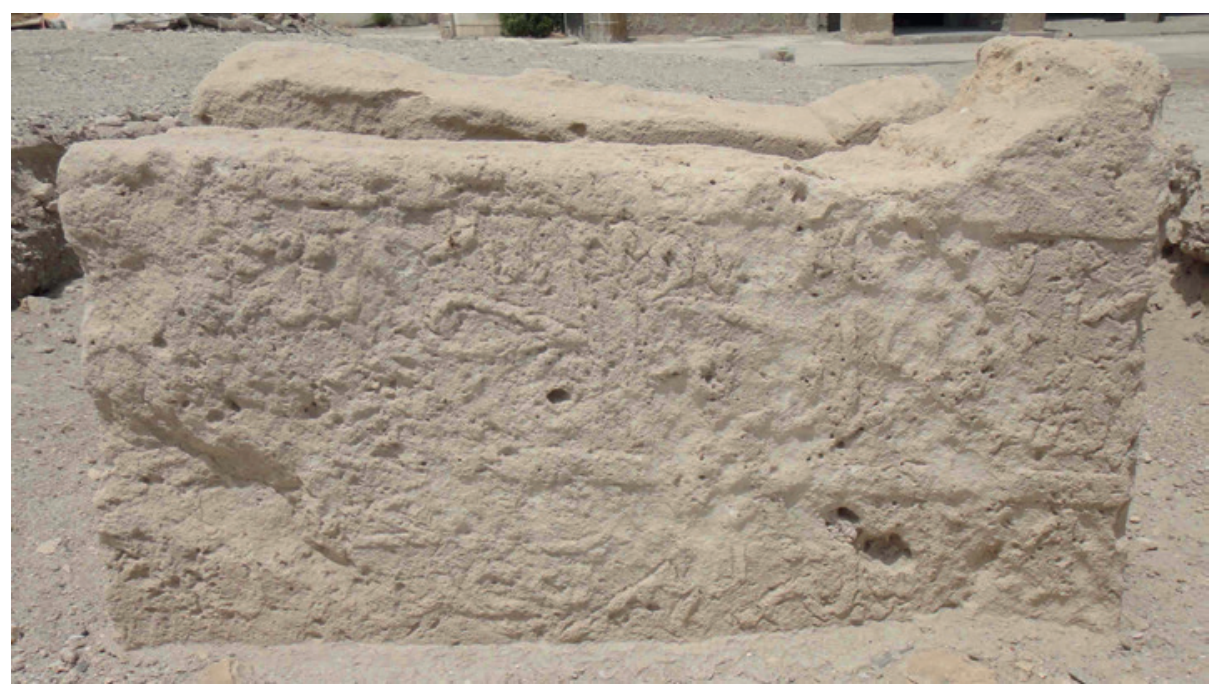

FIGURE 2.360 Surface B, KHA24

C:

- ... Grave of the Inviolable lady ...

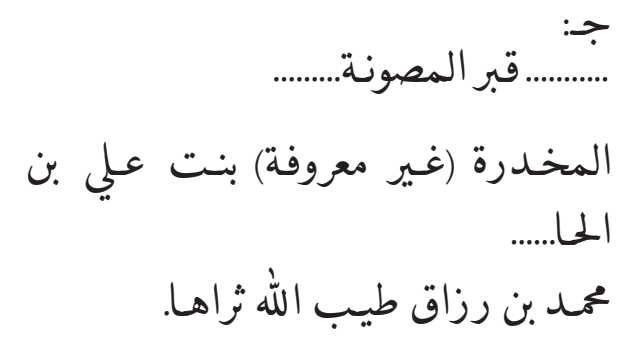

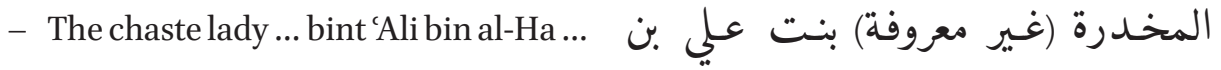

- Muhammad bin Razzak, May Allah have mercy on him 


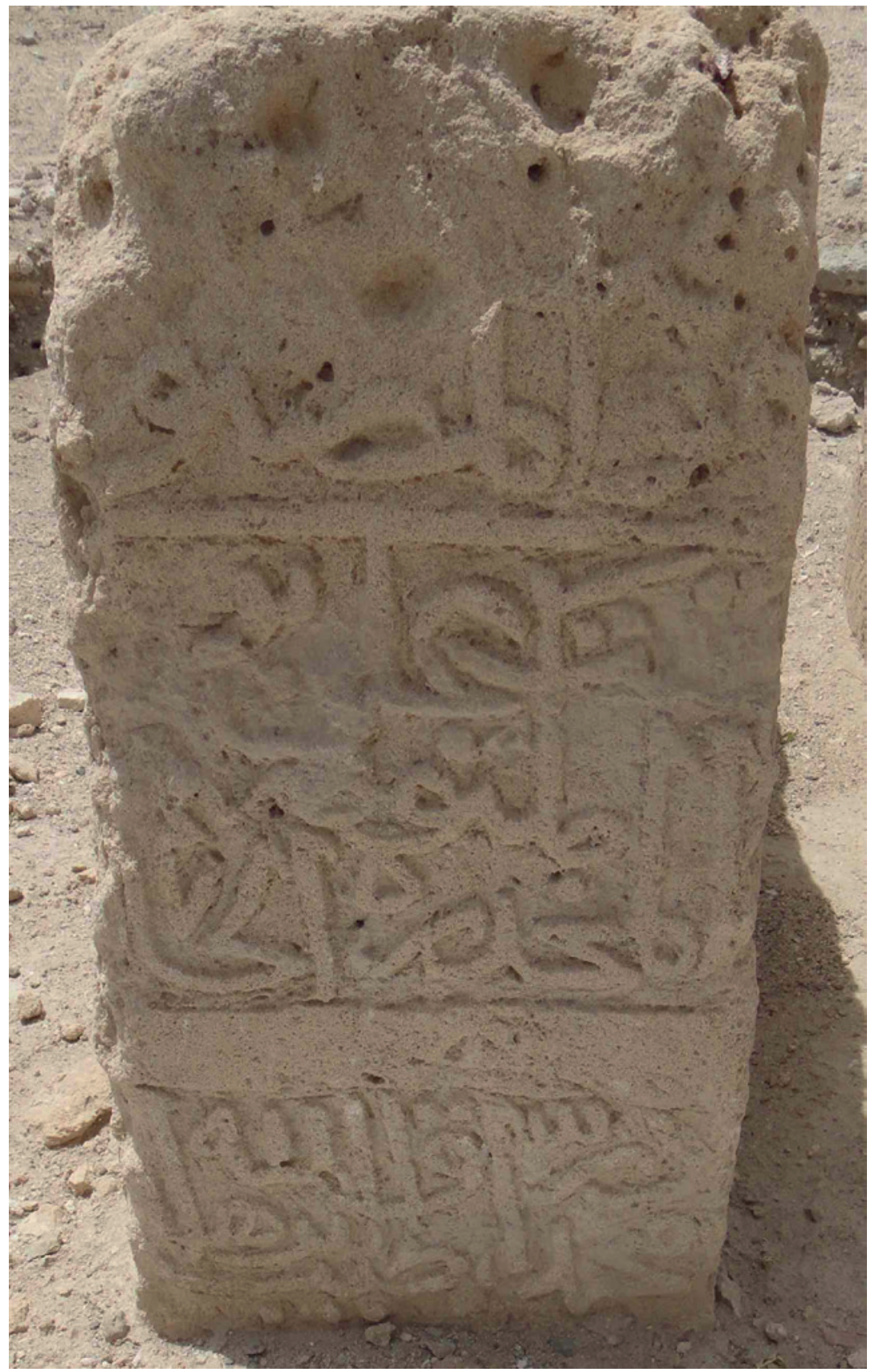

FIGURE 2.361 Surface C, KHA24

D:

- No carving or inscriptions.

لا توجـــ نقوش أوكَّاتات 


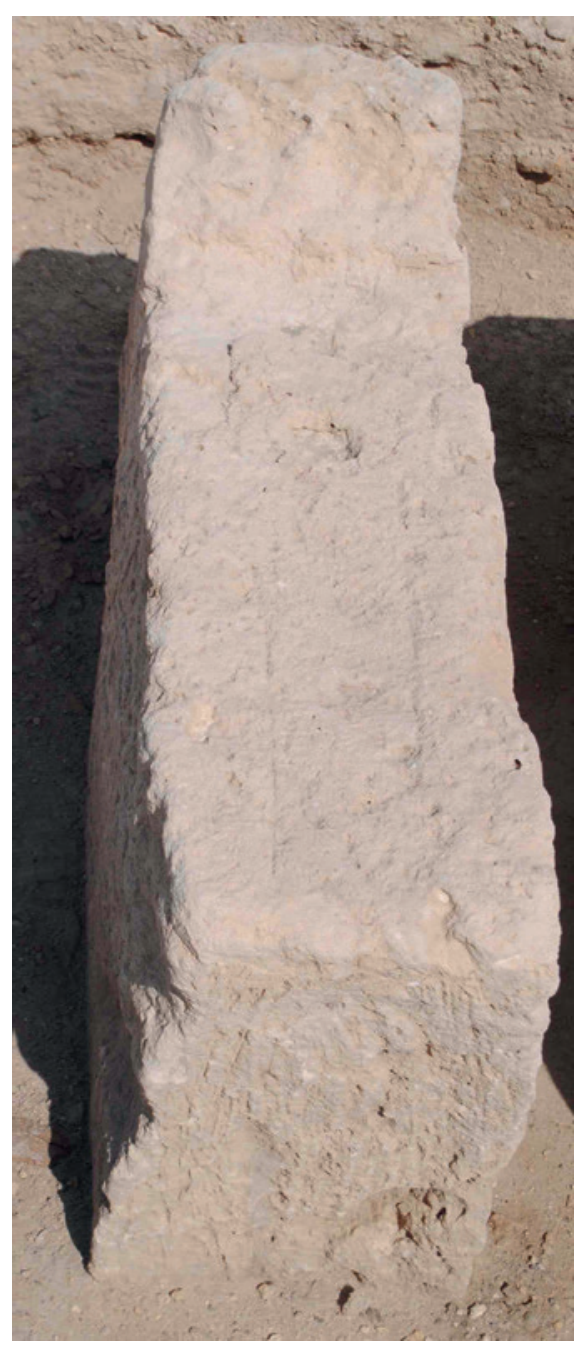

FIGURE 2.362

Surfaces D and E, KHA24

E:

- No carving or inscriptions.

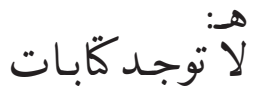

See Figure 2.362

\section{Reference Number: KHA25}

Co-ordinates: $26.20839^{\circ} \mathrm{N} 050.54811^{\circ} \mathrm{E}$

Dimensions: $77 \mathrm{~cm}(\mathrm{l}) \times 24 \mathrm{~cm}(\mathrm{w}) \times 38 \mathrm{~cm}(\mathrm{~h})$

Orientation: NA 
Description: Single limestone slab from a double slab gravestone. Eroded on the upper surface (E), on the upper side surfaces (A and B), and the bottom of one end surface (D). Inscriptions on three surfaces. Broken and eroded unidentifiable raised decoration at one end but with rectangular plinth present. Not in original position. Excavated to expose whole gravestone.

\section{Arabic Transcription and Translation:}

A:

- From among their fathers and their wives and their offspring, and angels shall enter (13:23).

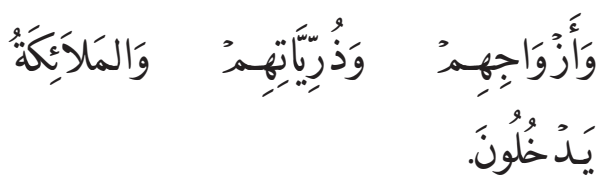

- Therein they will recline, therein they will call for fruits in abundance and drinks (38:51).
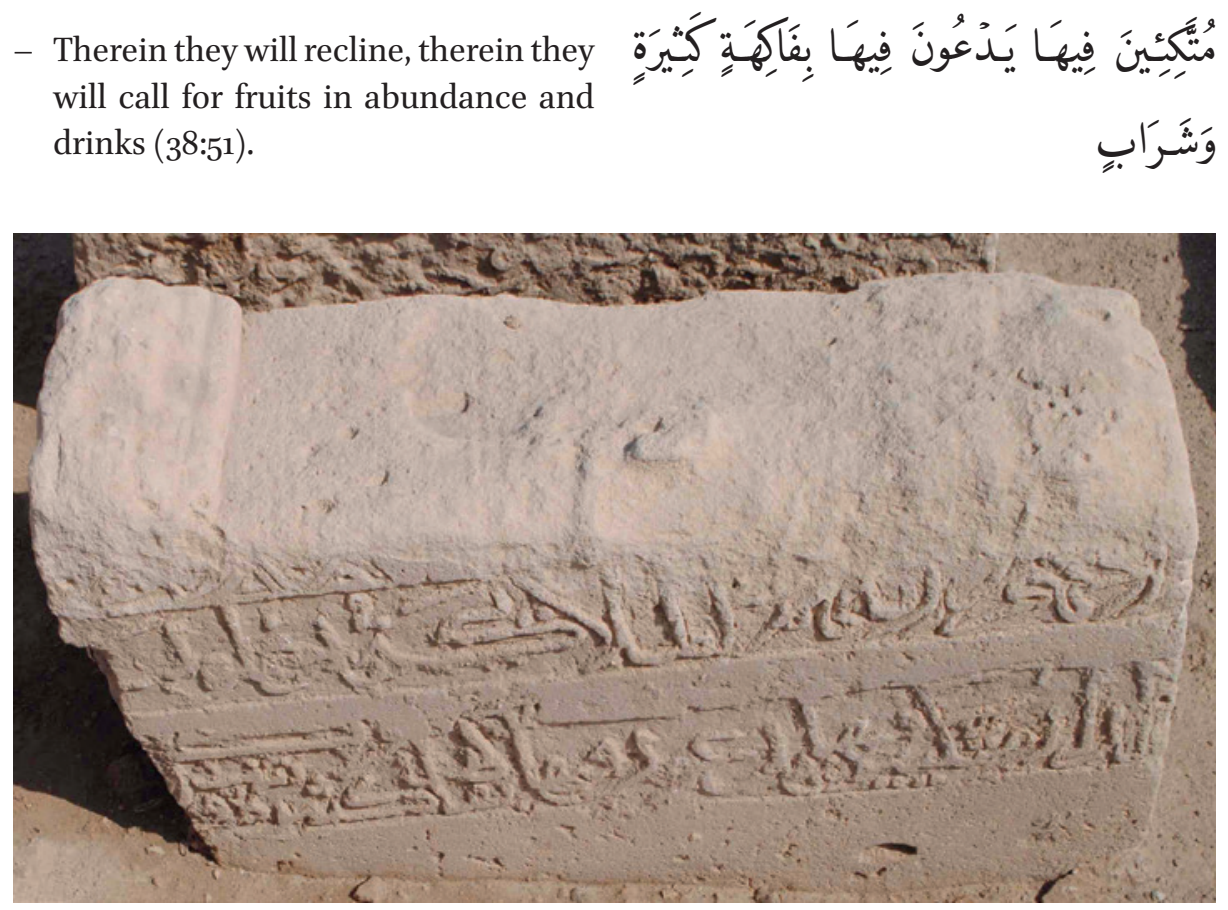

FIGURE 2.363 Surface A, KHA25

B:

- In the Name of Allah, the Most Gracious, the Most Merciful ... wherein are everlasting delights.

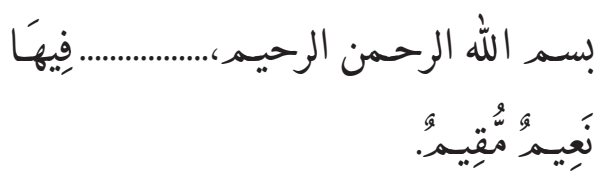

- ... therein ... (9:21-22) 


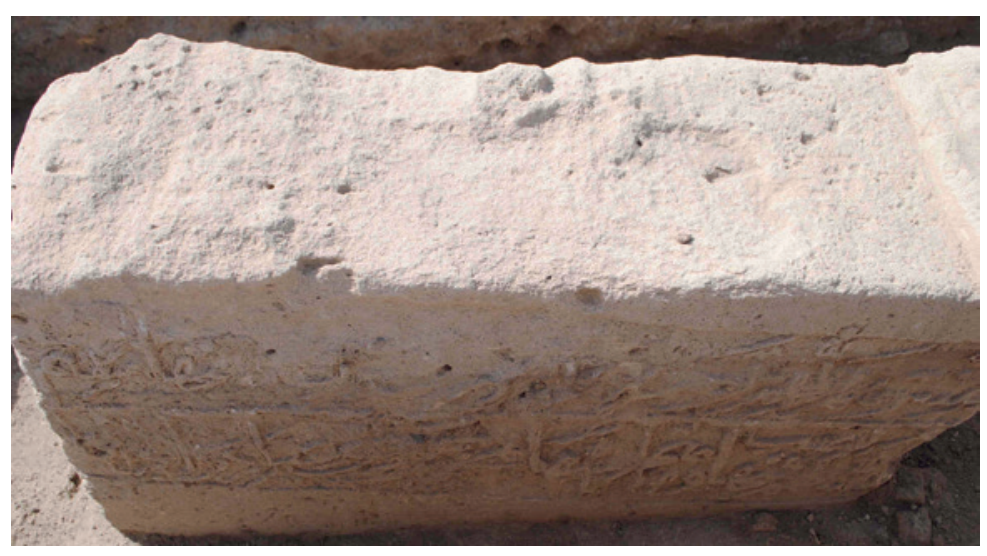

FIGURE 2.364

Surface B,

KHA25

C:

- No carving or inscriptions.
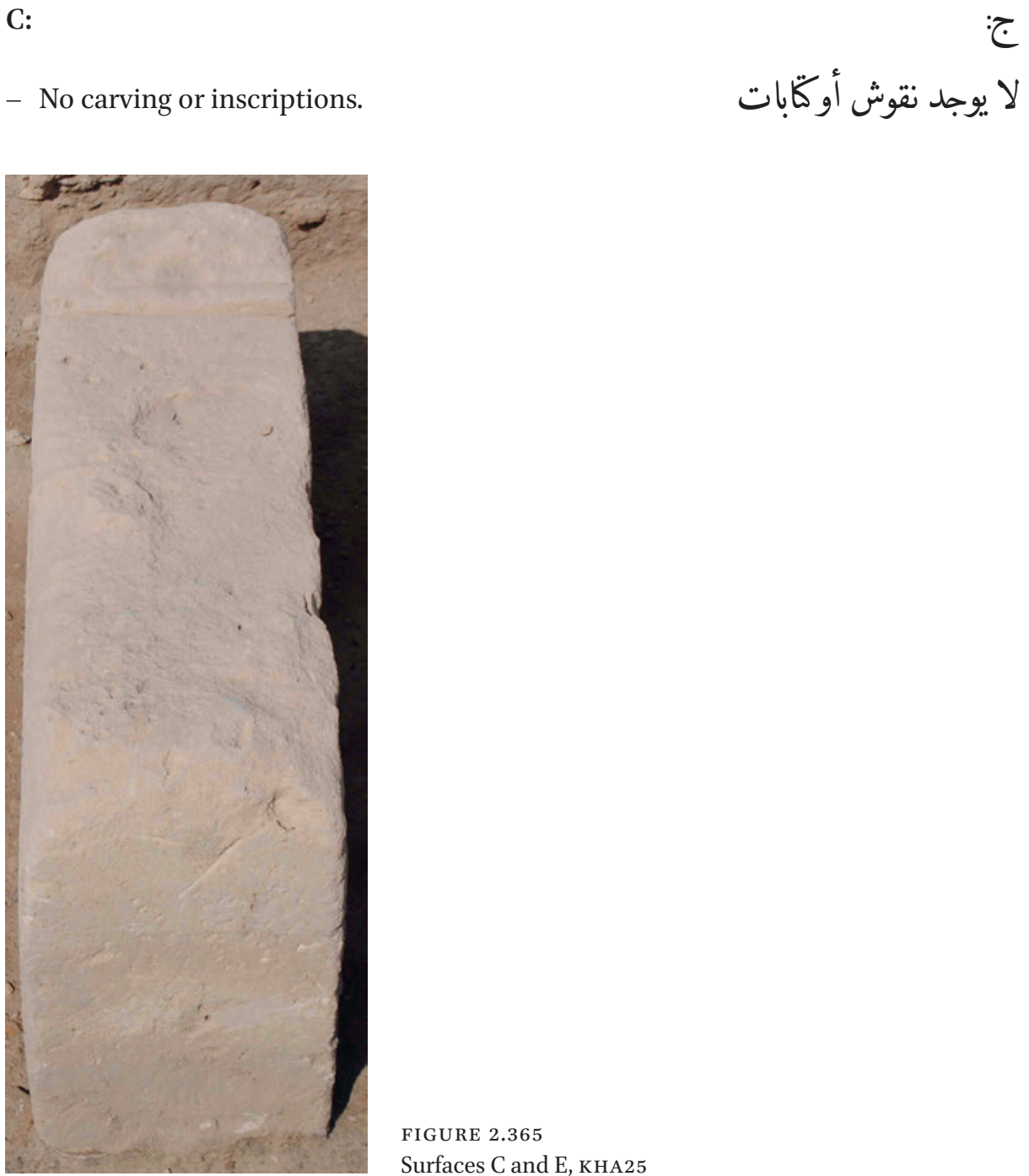

FIGURE 2.365

Surfaces C and E, KHA25 
D:

- Hasan Bin 'Abd Allah

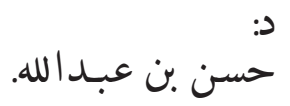

$-\ldots$ al ...

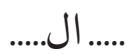

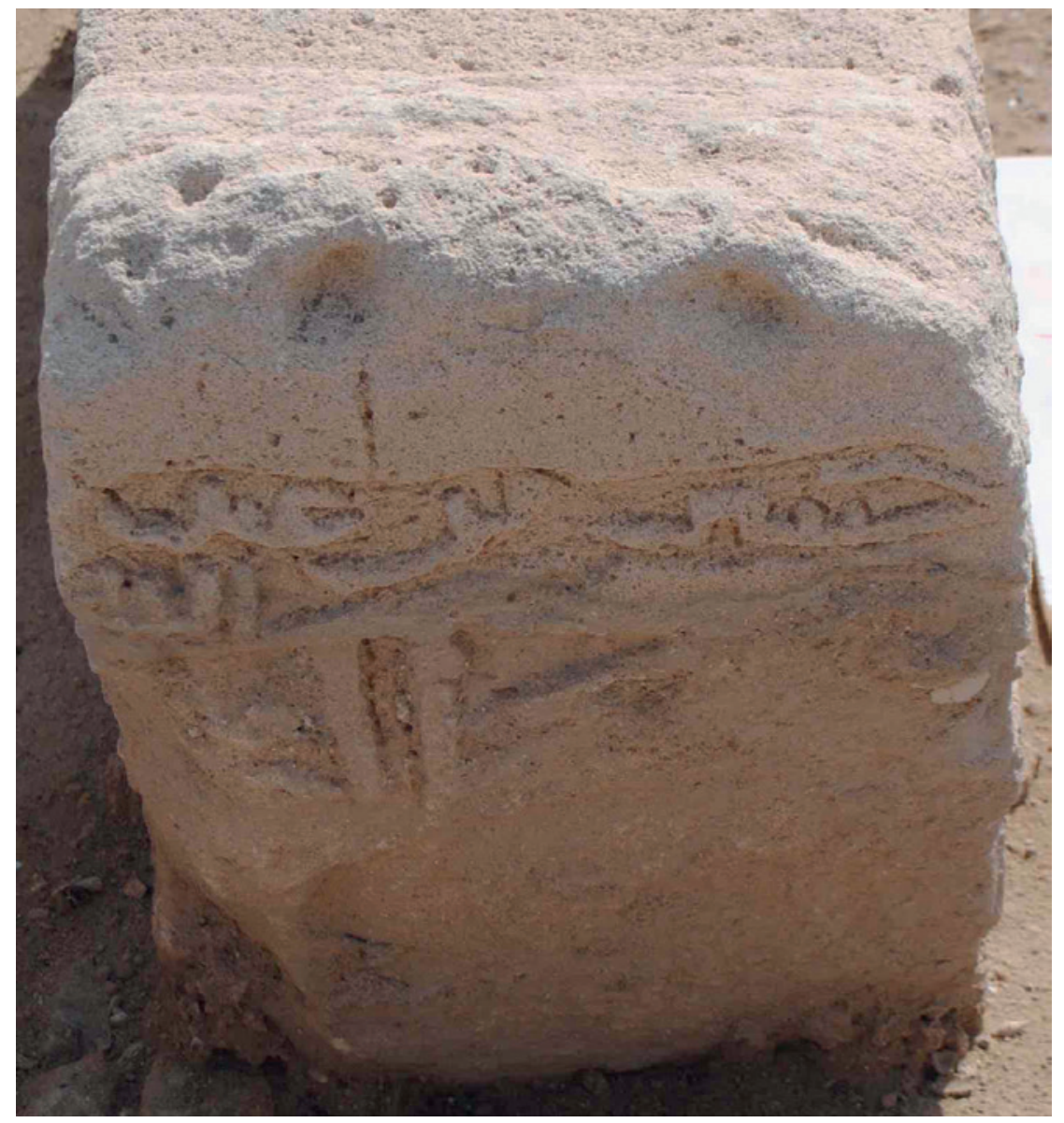

FIGURE 2.366 Surface D, KHA25

E:

- No carving or inscriptions.

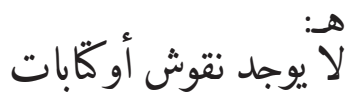

See Figure 2.365 
Location: Urban district cemetery in Manama containing a shrine within a mosque.

Reference Number: MAH1

Co-ordinates: $26.21069^{\circ} \mathrm{N} 050.58792^{\circ} \mathrm{E}$

Dimensions: $147 \mathrm{~cm}(\mathrm{l}) \times 30.5 \mathrm{~cm}(\mathrm{w}) \times 34 \mathrm{~cm}(\mathrm{~h})$

\section{Orientation: NW-SE}

Description: Single limestone slab gravestone. Roughed out, cut to shape and left unfinished. Eroded rectangular block at one end for raised decoration and stump of similar block at the other end. Saw marks visible on one side (Figure 2.367). No inscriptions. Located within a partially discernible small building that was visible only by fragments of wall stumps. The precise function of the building is unknown and a mihrab niche was not seen, but based on parallels with other structures recorded (e.g. ABN47), it was probably a small mosque, shrine, or tomb.

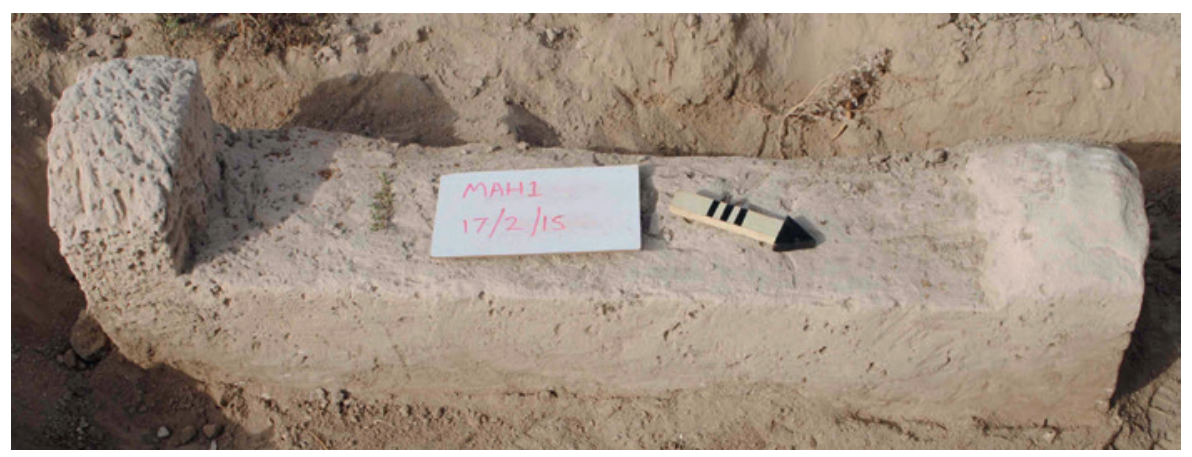

FIGURE 2.367 MAH1

Arabic Transcription and Translation: No inscriptions

Reference Number: MAH2

Co-ordinates: $26.21042^{\circ} \mathrm{N} 050.58794^{\circ} \mathrm{E}$

Dimensions: $155.5 \mathrm{~cm}(\mathrm{l}) \times 36.5 \mathrm{~cm}(\mathrm{w}) \times 35 \mathrm{~cm}(\mathrm{~h})$

Orientation: NW-SE 
Description: Single limestone slab gravestone housed inside a shrine within a mosque. The top surface and upper part of the side surfaces are rendered in cement covering a significant portion of the inscriptions. The gravestone is set within a modern aluminium and wooden cover with wooden grilles allowing a partial view of the gravestone within (Figure 2.368). It is a focus of devotion as indicated by the various 100 Fils coins that had been pushed through the grilles and were on the tiled floor next to the gravestone. Inscriptions on four surfaces but none could be read as their position made them impossible to read or photograph successfully.

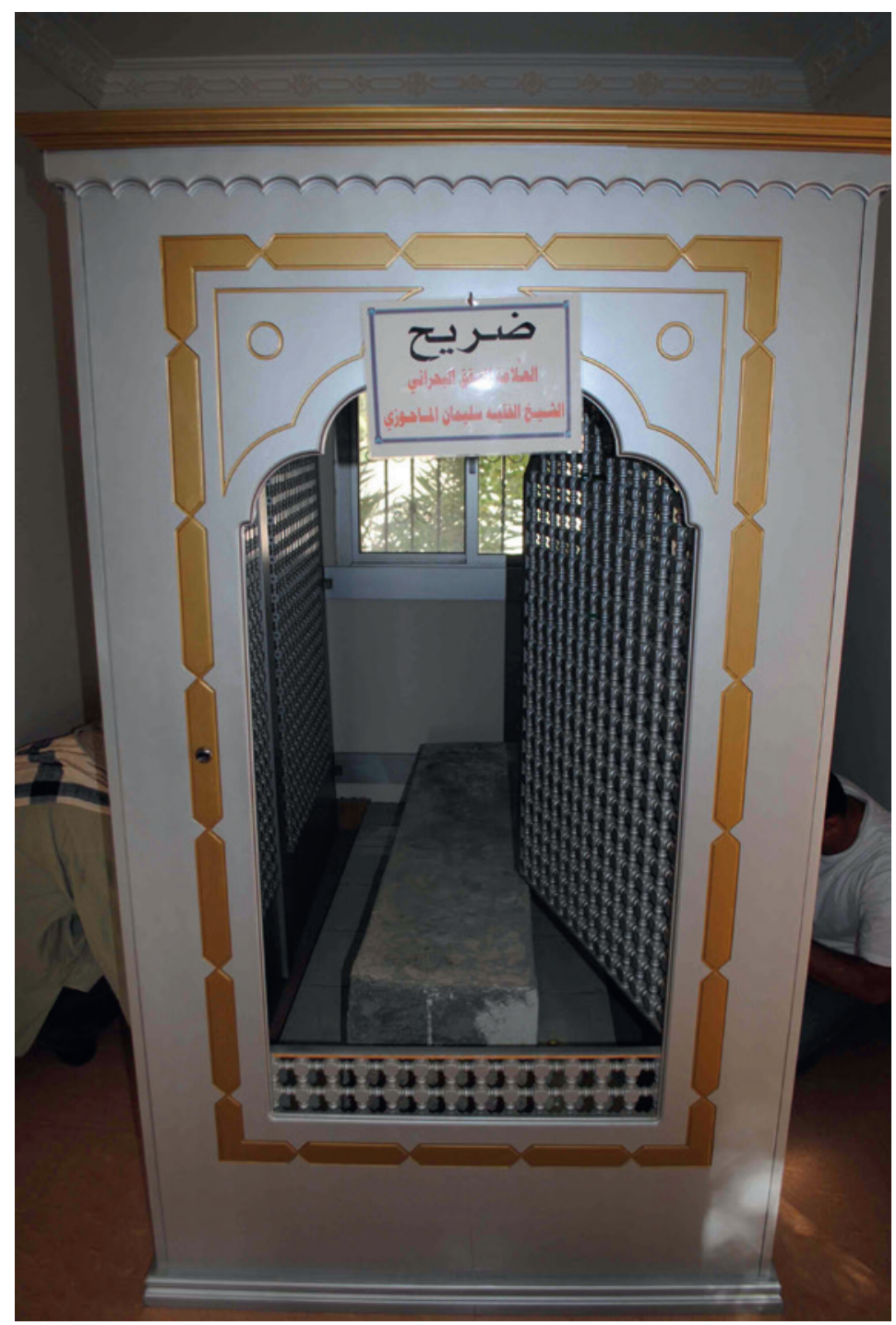

Arabic Transcription and Translation: No legible inscriptions 
Location: Shrine inside the Amir Zaid Mosque

Reference Number: MAL1

Co-ordinates: $26.09651^{\circ} \mathrm{N} 050.48169^{\circ} \mathrm{E}$

Dimensions: $181 \mathrm{~cm}(\mathrm{l}) \times 50 \mathrm{~cm}(\mathrm{w}) \times 48 \mathrm{~cm}(\mathrm{~h})$

\section{Orientation: NNW-SSE}

Description: Single limestone slab gravestone. Raised decoration at both ends formed of double square pillars with rounded tops (Figure 2.369). Some cracking and cement staining on the top surface (E). No inscriptions. Located inside a sunken room accessed by a staircase and partitioned off by a wooden screen from the rest of the mosque. A neighbouring door has various Arabic graffiti scribbled in marker pen on its interior surface. These are all personal names and were written there to invoke the help of the Saint. The gravestone is situated within a modern aluminium and glass canopy covered with cloth shrouds at the far end of the sunken room.

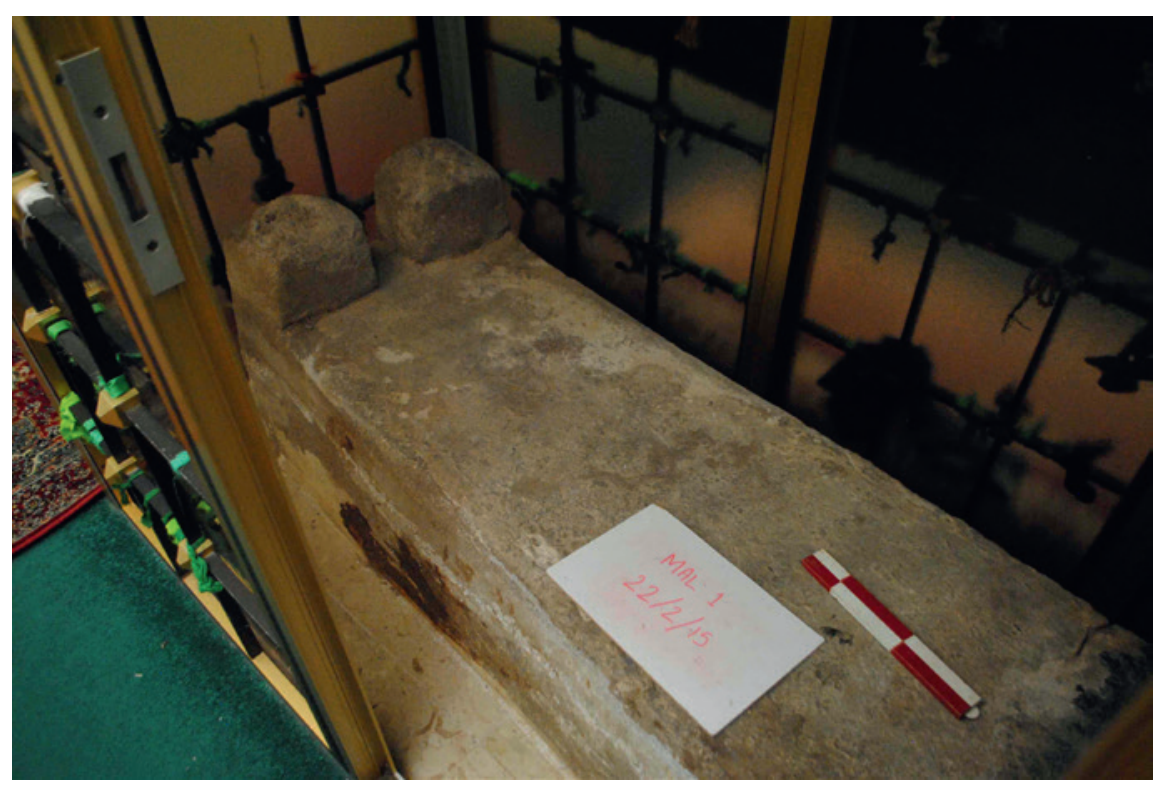

FIGURE 2.369 MAL1

Arabic Transcription and Translation: No inscriptions 
Location: Village cemetery

Reference Number: MAQ1

Co-ordinates: $26.22138^{\circ} \mathrm{N} 050.51798^{\circ} \mathrm{E}$

\section{Dimensions:}

Slab 1: $63 \mathrm{~cm}(\mathrm{l}) \times 20.5 \mathrm{~cm}(\mathrm{w}) \times 40 \mathrm{~cm}(\mathrm{~h})$

Slab 2: $73 \mathrm{~cm}(\mathrm{l}) \times 20 \mathrm{~cm}(\mathrm{w}) \times 46 \mathrm{~cm}(\mathrm{~h})$

\section{Orientation: NNW-SSE}

Description: Gravestone formed of double solid limestone slabs. Some erosion and, unusually, patches of green moss/algae on the upper surface indicating water exposure. Three element raised decoration formed of two facetted cubes and a central rounded arch at each end, but missing a section of the raised decoration and surface below at one end. The intact end has an unclear carved design on the rear of the central rounded arch. Inscriptions on three surfaces.

\section{Arabic Transcription and Translation:}

A:

- In the Name of Allah, the Most Gracious, the Most Merciful. Verily, those who say: Our Lord is Allah, ...

- ... Fear not nor grieve, but receive the glad tidings ... (41:30)
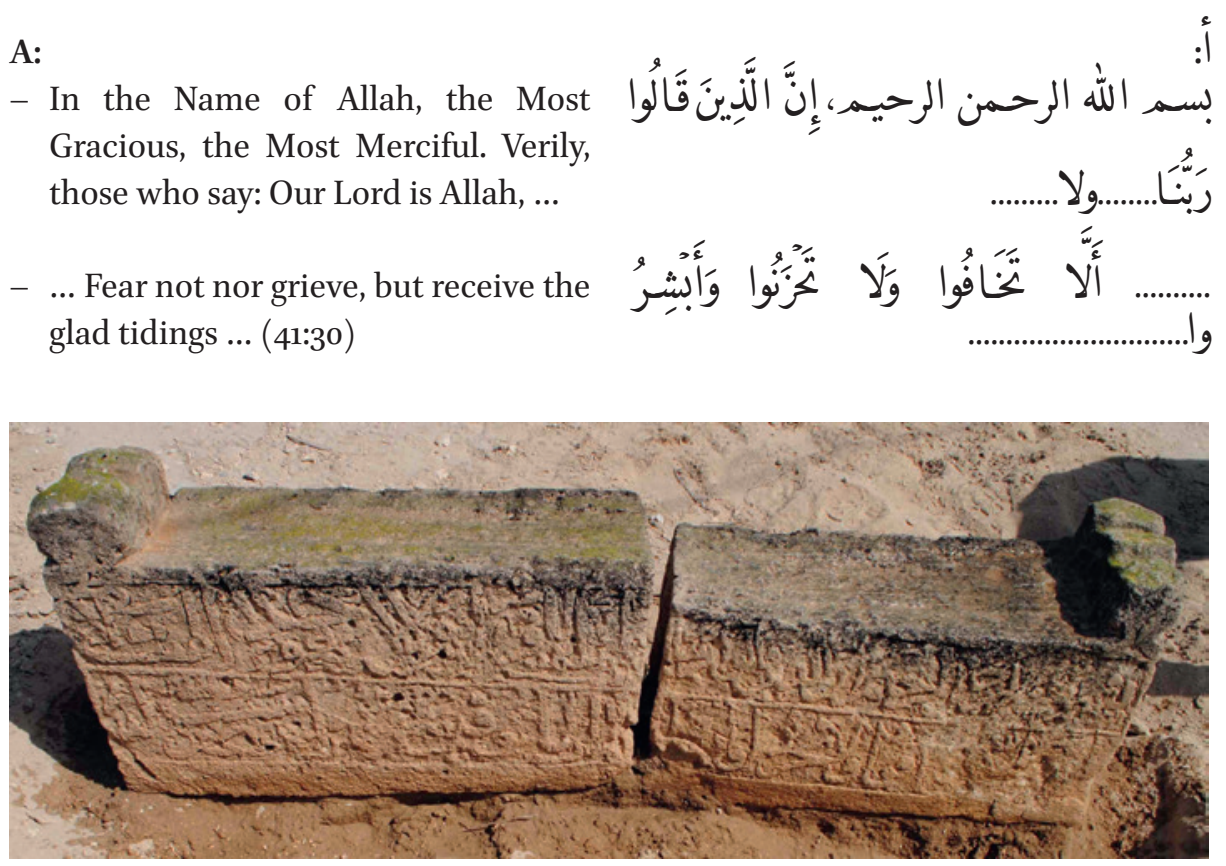

FIGURE 2.370 Surface A, MAQ1 
B:

- ... Hereafter ... therein ...

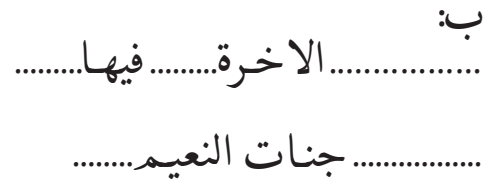

- ... paradise ...

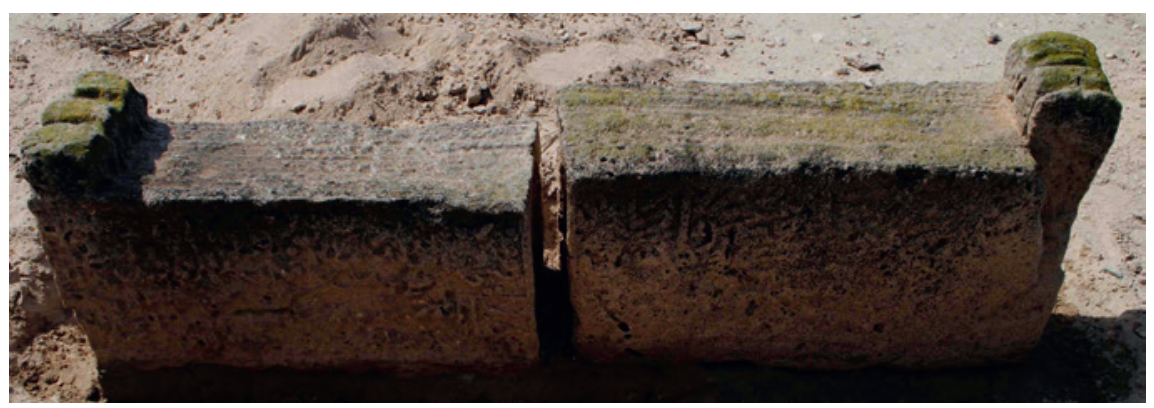

FIGURE 2.371 Surface B, MAQ1

C:

- Preserving them ...

- The good people ... the late lady ... the blessed ...

- ... the late ...
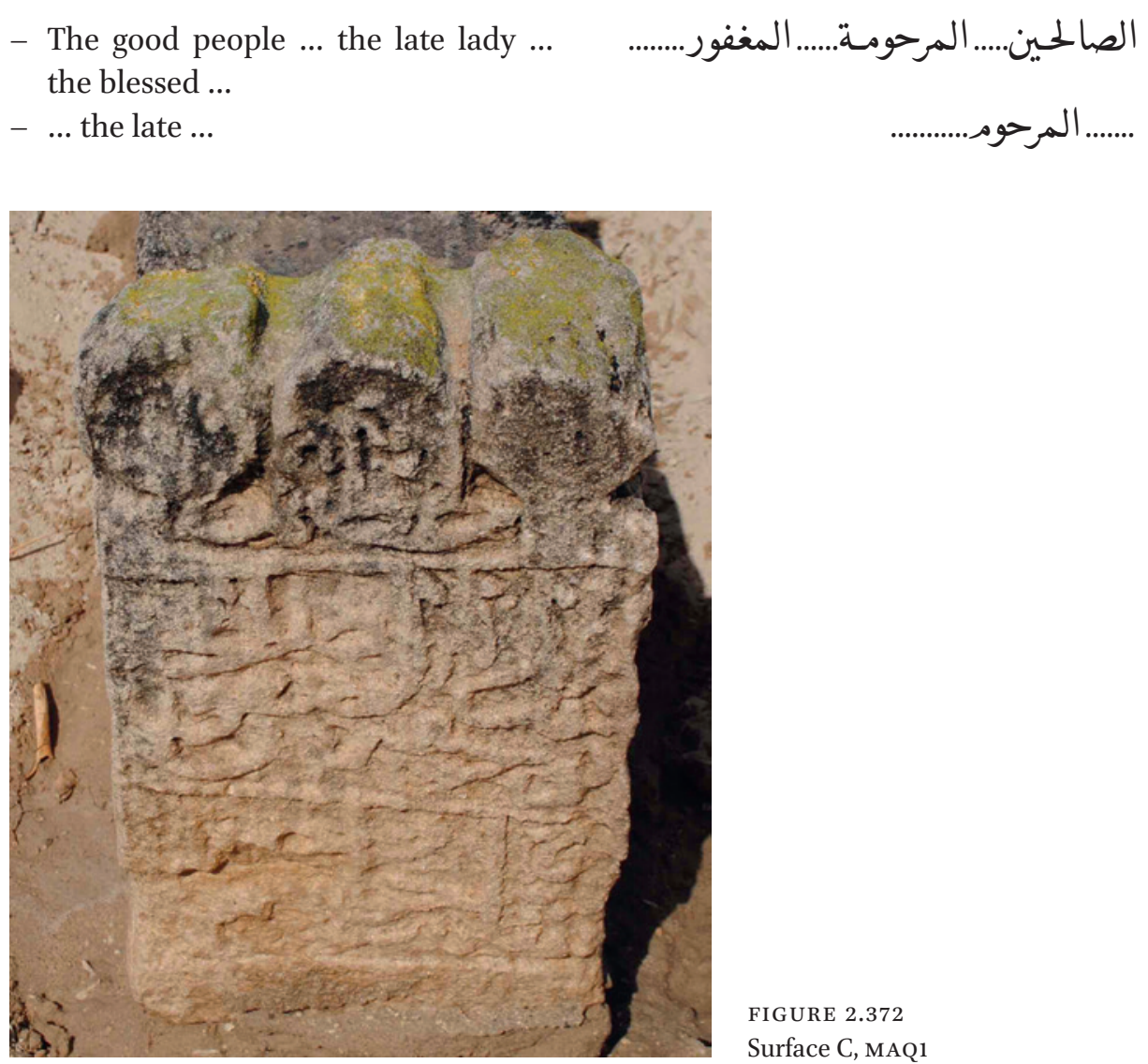
D:

- No carving or inscriptions.

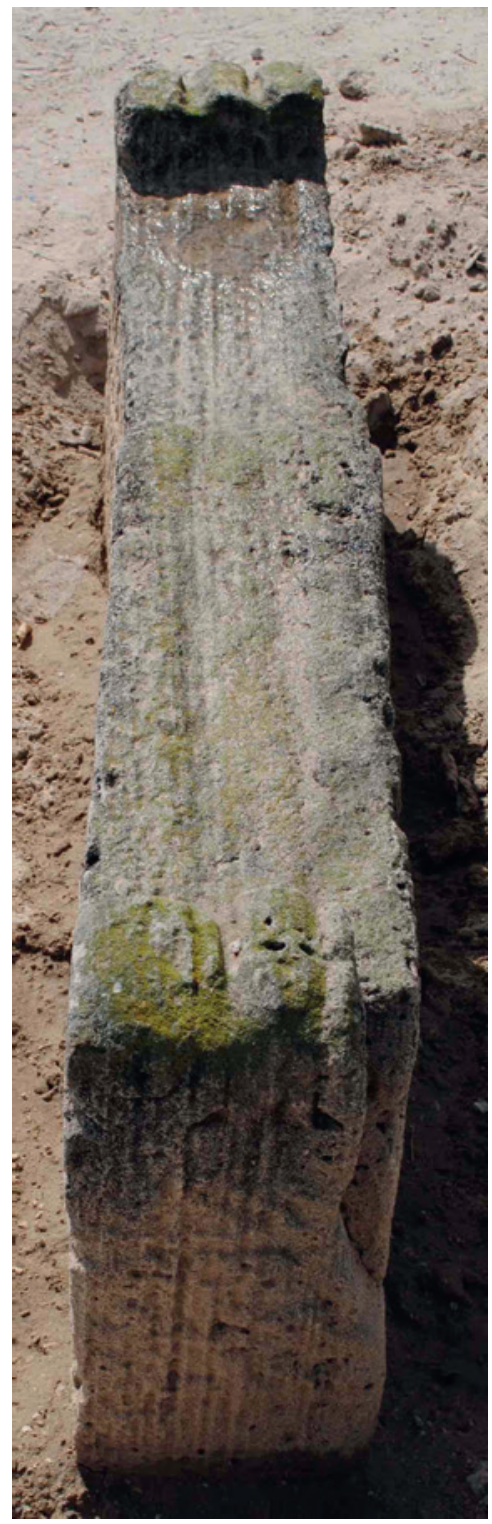

E:

- No carving or inscriptions.
لا تُوجــ نقوش أوكَّابـات

FIGURE 2.373

Surfaces D and E, MAQ1 
Reference Number: MAQ2

Co-ordinates: $26.22144^{\circ} \mathrm{N} 050.51812^{\circ} \mathrm{E}$

\section{Dimensions:}

Slab 1: $69 \mathrm{~cm}(\mathrm{l}) \times 24.5 \mathrm{~cm}(\mathrm{w}) \times 34.5 \mathrm{~cm}(\mathrm{~h})$

Slab 2: $85 \mathrm{~cm}(\mathrm{l}) \times 24.5 \mathrm{~cm}(\mathrm{w}) \times 31 \mathrm{~cm}(\mathrm{~h})$

\section{Orientation: N-S}

Description: Gravestone formed of double limestone slabs. Very well carved with inscriptions on five surfaces but only partially legible on three surfaces, and illegible on one surface. Severely damaged in places with the raised decoration cut off but with the rectangular plinth still present at each end and major patches of erosion on one side surface $(\mathrm{A})$.

\section{Arabic Transcription and Translation:}

A:

- They will be served by immortal boys ... from ... nor any intoxication. And fruit; that they may choose. And the flesh of fowls that they desire ...

- Like unto preserved pearls ... (56:17-23).
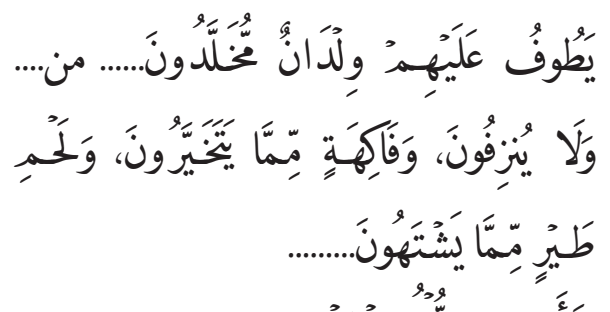

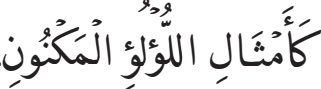

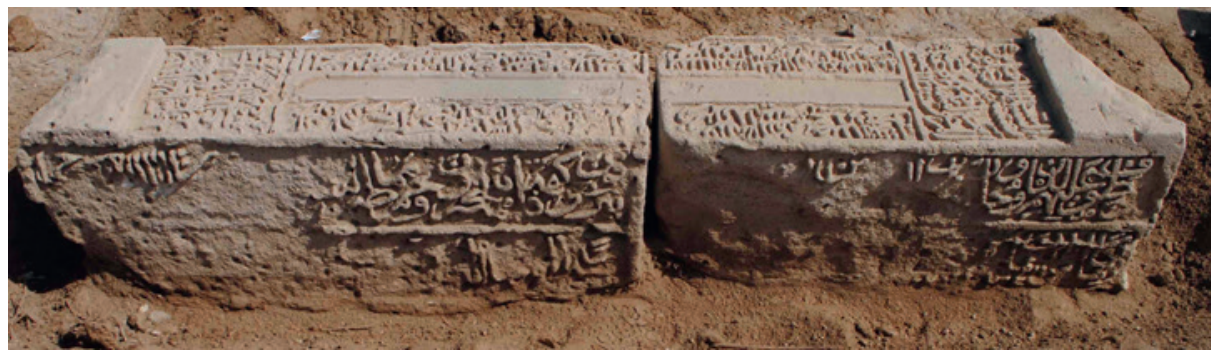

FIGURE 2.374 Surface A, MAQ2 
B:

- In the Name of Allah, the Most Gracious, the Most Merciful. Allah, none has the right to be worshipped but he, the Ever Living, the One Who sustains and protects all that exists. Neither slumber nor sleep overtakes Him. To Him belongs whatever is in the heavens and whatever is on the earth. Who is he that can intercede with Him except by His permission! He knows what happens to them in this world, and will happen to them in the Hereafter and they will never compass anything

- Of His Knowledge except that which He wills. His Seat extends over the heavens and the earth. And He feels no fatigue in guarding and preserving them. And He is the Most High, the Most Great. There is no compulsion in religion. Verily, the Right Path has become distinct from the wrong path. Whoever disbelieves in al-Taghut and believes in Allah, and then he has grasped the most trustworthy handhold that will never break. And Allah is All-Hearer, All-Knower $\left(2: 255^{-256) \text {. }}\right.$

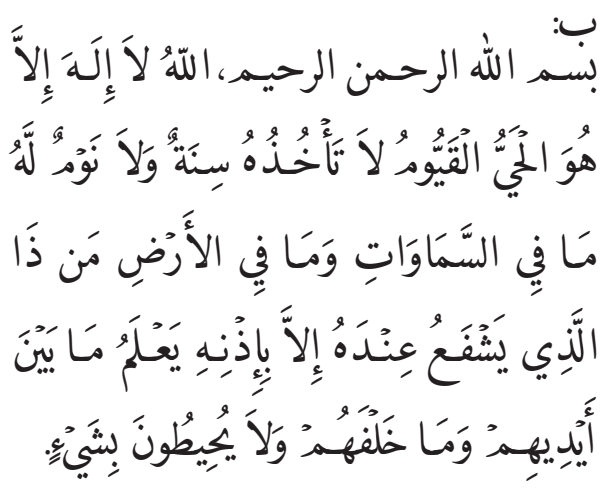

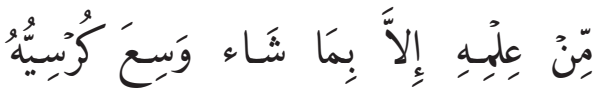

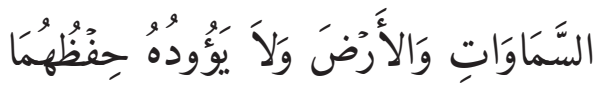

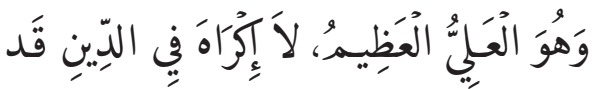

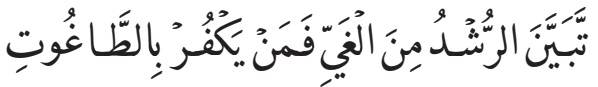

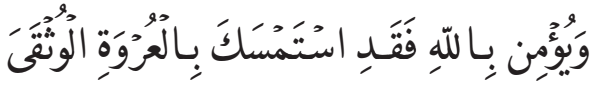

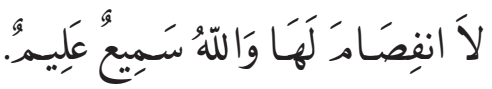

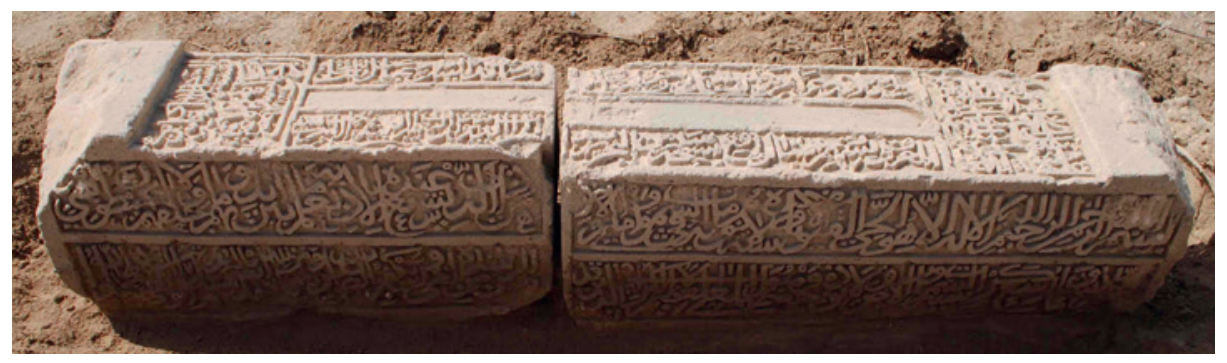

FIGURE 2.375 Surface B, MAQ2 
C: Ramadan.

المعظم

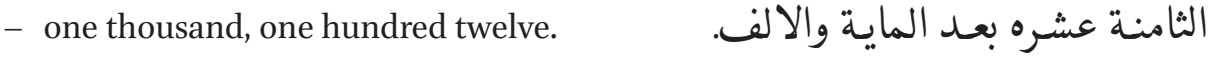

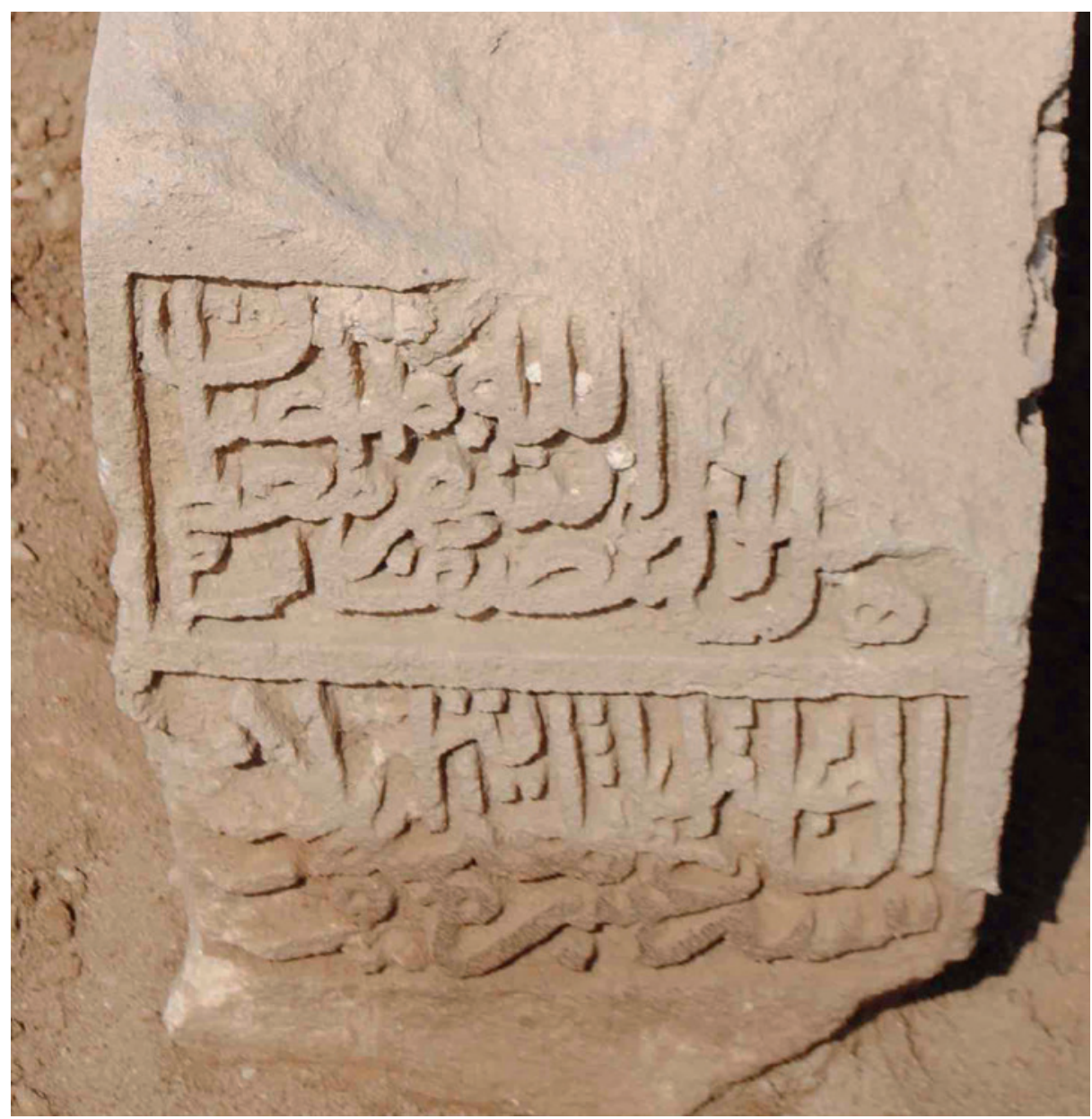

FIGURE 2.376 Surface C, MAQ2 
D:

- Very deteriorated. Unable to read.
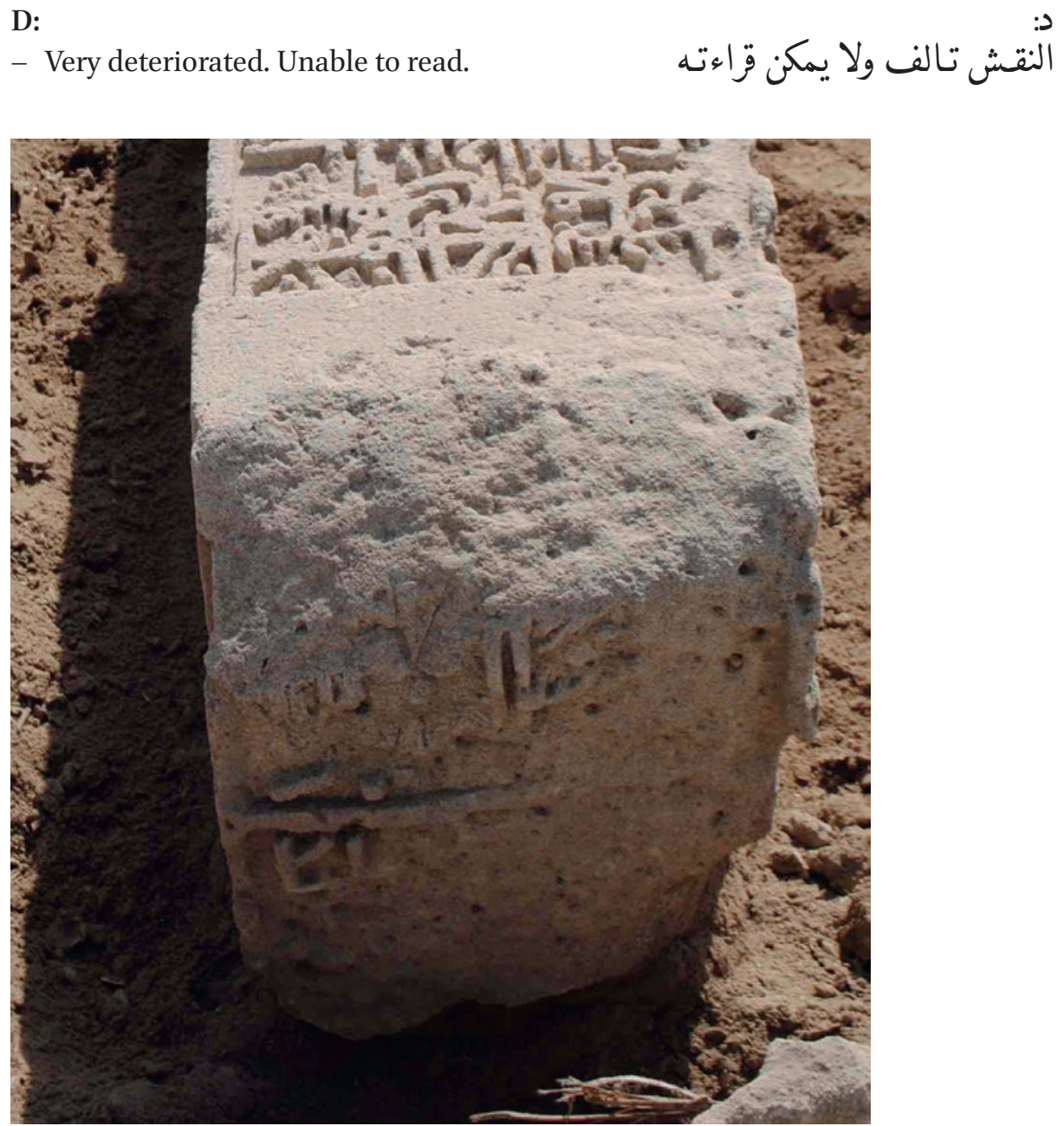

FIGURE 2.377 Surface D, MAQ2

E:

- Engraved by al-Sayyid 'Alawi bin alSayyid Naser al-Asbai, God bless them, 1121.

- Reading three parts of the Book of God the Very High ... tributes on the grave of the noble lady with a total of one third of the palms.

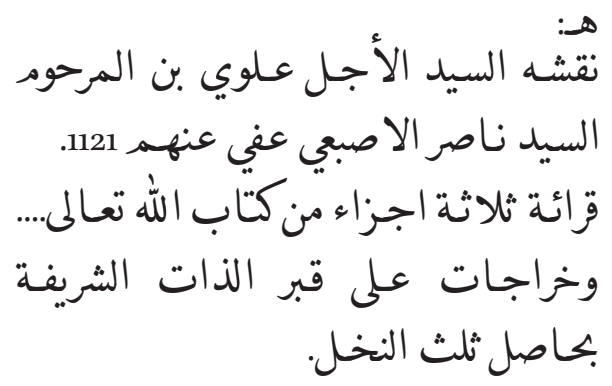

- Which are known as girl's part, which is located at Sar area in al-Bahrayn, after ploughing ... and cultivating it ... until God inherits the earth.

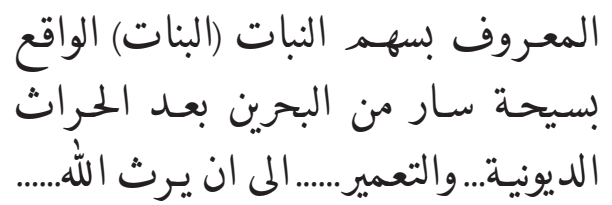


- ... The lowest Muhammad bin Sacid.

$$
\text { الاقل الجاني محمد بن سعيد. }
$$

- bin Muhammad bin 'Abd Allah alبن محمد بن عبدالله المقابي عني عنهم Muqabi, God bless all of them. أجمعين.

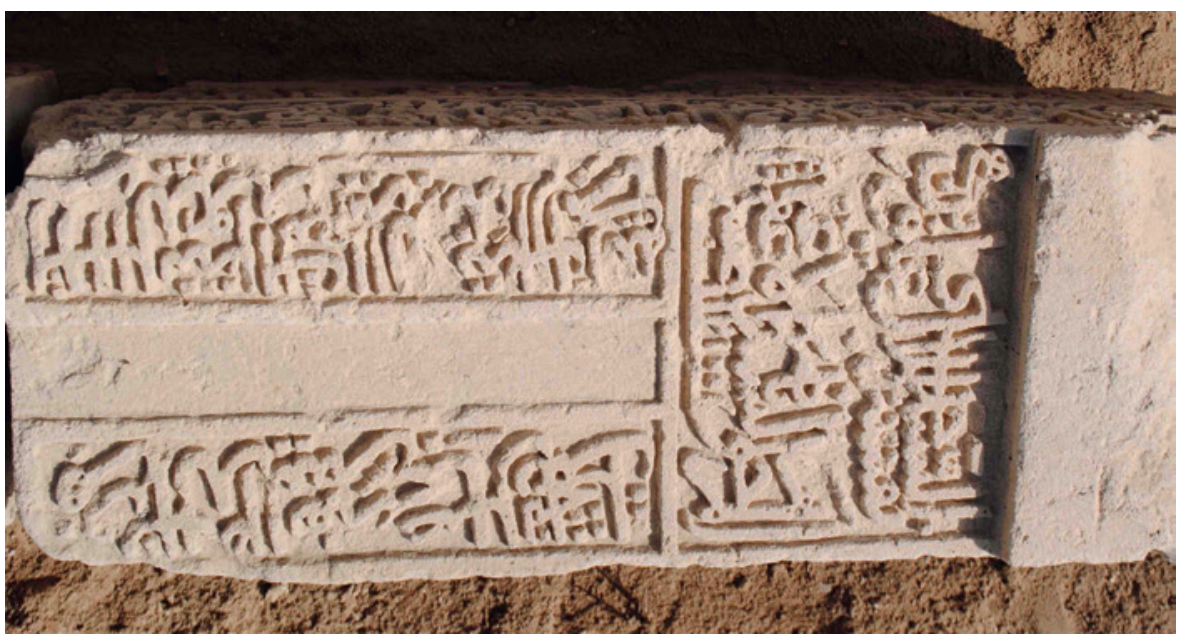

FIGURE 2.378 Surface E, part 1, MAQ2

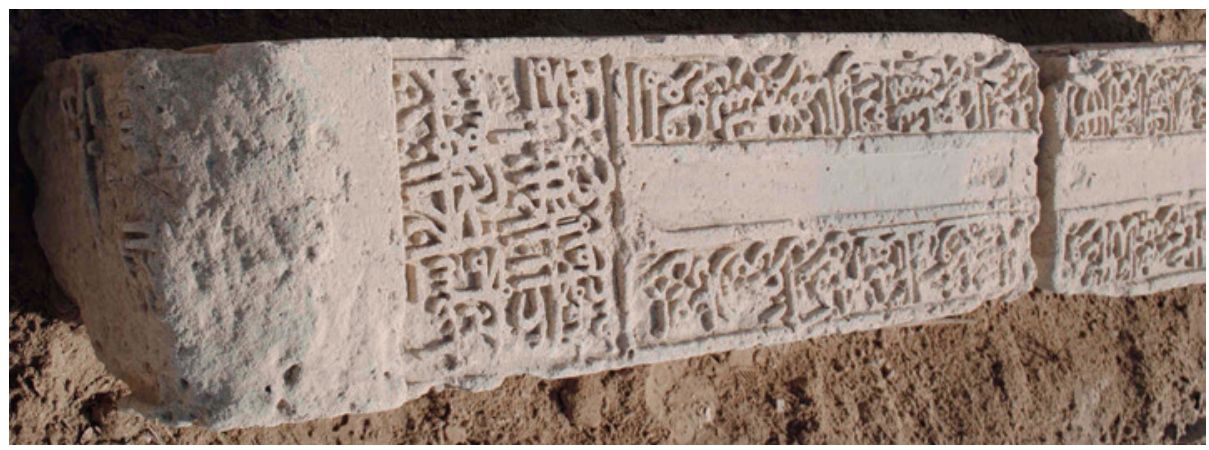

FIGURE 2.379 Surface E, part 2, MAQ2

Reference Number: MAQ3

Co-ordinates: $26.22166^{\circ} \mathrm{N} 050.51788^{\circ} \mathrm{E}$

Dimensions: $72.5 \mathrm{~cm}(\mathrm{l}) \times 21 \mathrm{~cm}(\mathrm{w}) \times 43 \mathrm{~cm}(\mathrm{~h})$

Orientation: N-S 
Description: Single hollow limestone slab from a double slab gravestone. Badly eroded on one side surface (B) where exposed above the ground surface. Poorly carved three element raised decoration formed of three rounded rectangular blocks. Inscriptions on two surfaces, but only one is partially legible. Excavated to expose whole gravestone.

\section{Arabic Transcription and Translation:}

A:

- In the Name of Allah, the Most Gracious, the Most Merciful. Verily, those who say: Our Lord is Allah, and afterward are upright, ... descend

- ... your friends in the life of this world and are in the Hereafter ... (41:30-31).
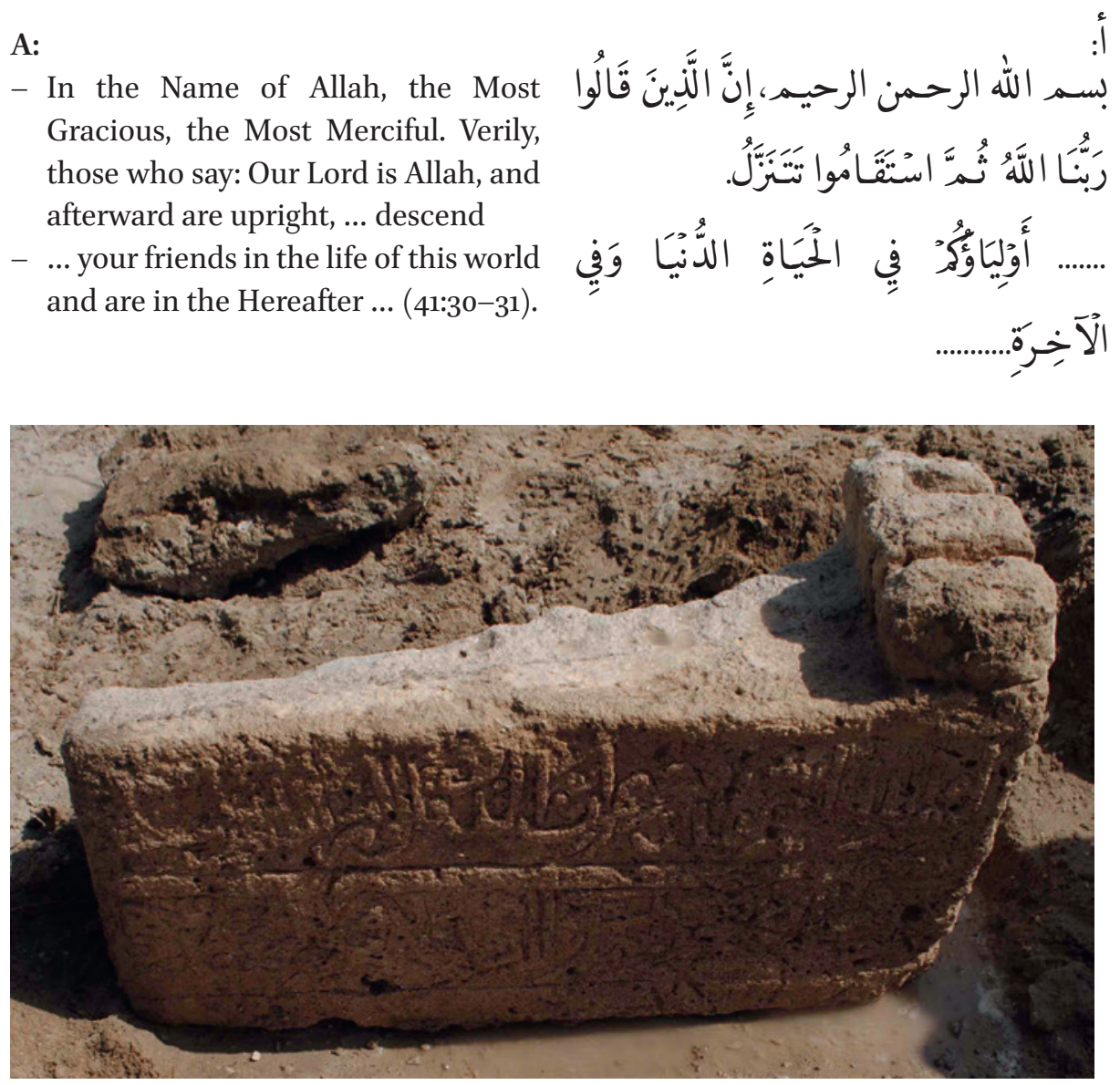

FIGURE 2.380 Surface A, MAQ3

B:

- No carving or inscriptions.

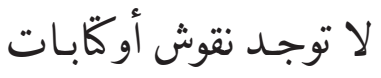




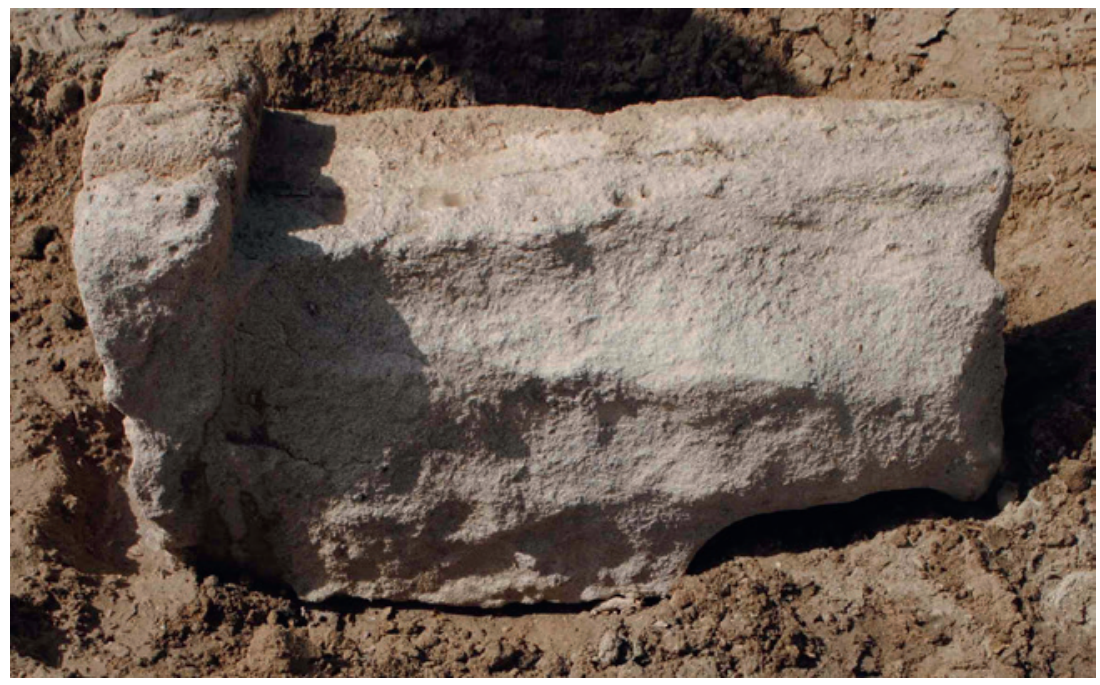

FIGURE 2.381 Surfaces B and E, MAQ3

C:

- Very deteriorated. Unable to read.

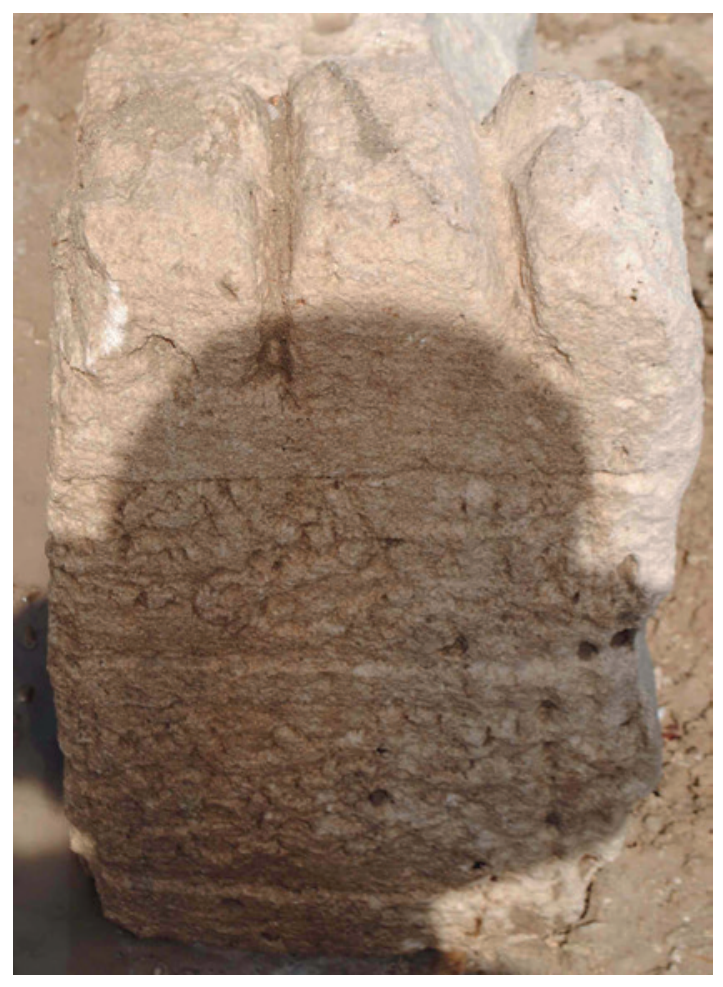

ج

النقش تالف ولا يمكن قواءتـه

FIGURE 2.382

Surface C, MAQ3 
D:

- No carving or inscriptions.

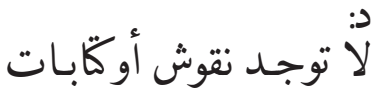

E:

- No carving or inscriptions.

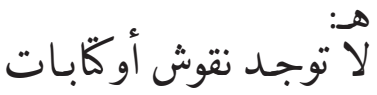

See Figure 2.381

20

\section{Bahrain National Museum (MUs)}

Location: Archaeological stores and Islamic archaeology gallery in the National Museum in Manama

Reference Number: MUS1

Co-ordinates: NA

Dimensions: $143 \mathrm{~cm}(\mathrm{l}) \times 34 \mathrm{~cm}(\mathrm{w}) \times 60 \mathrm{~cm}(\mathrm{~h})$

Orientation: NA

Description: Single limestone slab gravestone in the store at Bahrain National Museum. Partly damaged unusual thin and high raised decoration formed of two facetted cubes and a central rounded arch at one end, broken off at the other end. Shallow carved rectangular panel design on upper surface (E), probably a niche. Serious erosion in places. Inscriptions on four surfaces of which one is illegible and two partially legible.

\section{Arabic Transcription and Translation:}

A:

- In the Name of Allah, the Most Gracious, the Most Merciful. Allah, none has the right to be worshipped but he, the Ever Living, the One Who sustains and protects all that exists. Neither slumber nor sleep overtakes Him. To Him belongs whatever is in

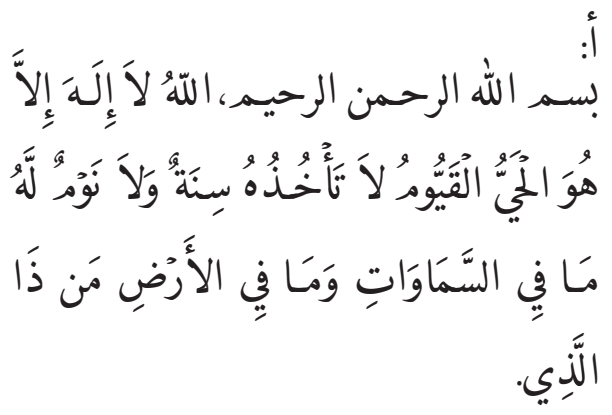
the heavens and whatever is on the earth. Who is he that 
- Can intercede with Him except by His permission! He knows what happens to them in this world, and will happen to them in the Hereafter and they will never compass anything of His Knowledge except that which He wills. His Seat extends over the heavens and the earth. And He feels no fatigue in guarding and preserving them (2:255).

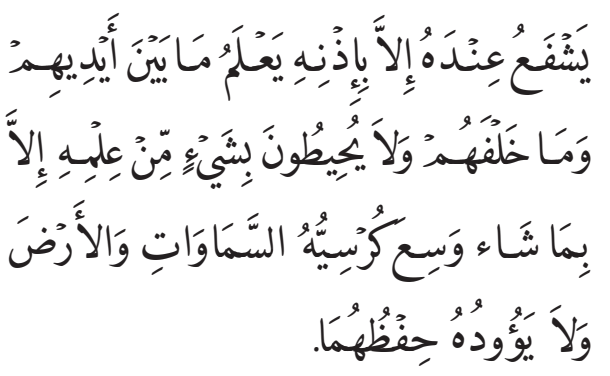

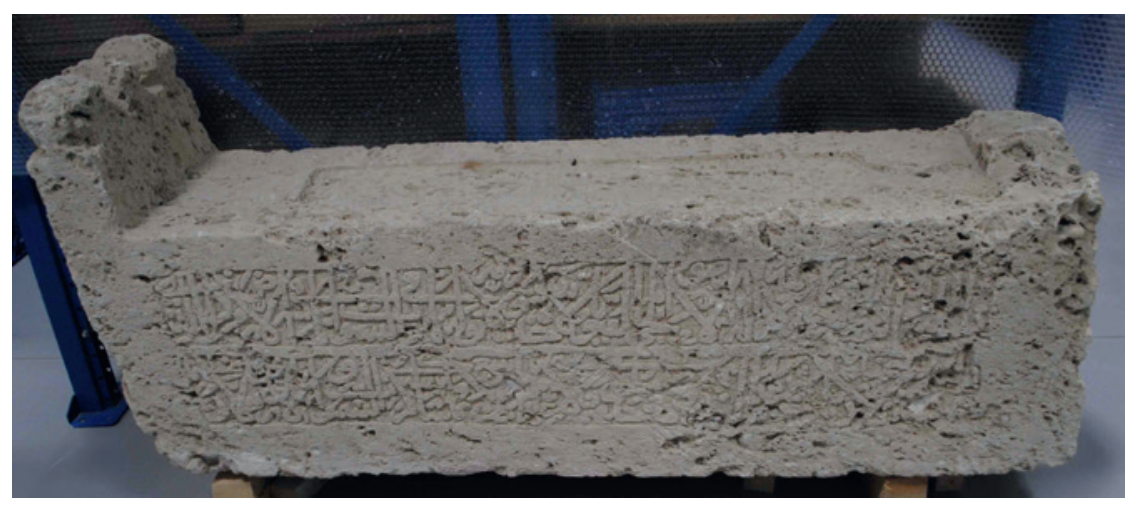

FIGURE 2.383 Surfaces A and E, MUS1

B:

- And He is the Most High, the Most Great. God's blessings upon Muhammad al-Mustafa, God's blessings upon 'Ali ... , God blessings upon al-Hasan, God blessings upon al-Husayn, God's blessings upon ... ,

- God's blessings upon al-Jawad ... God's blessings upon al-Hasan al-Askari, God's blessings upon al-Hujjah al-Qaim al-Mahdi bin al-Hasan ... Imams ... al-Jawad ... upon all of them.

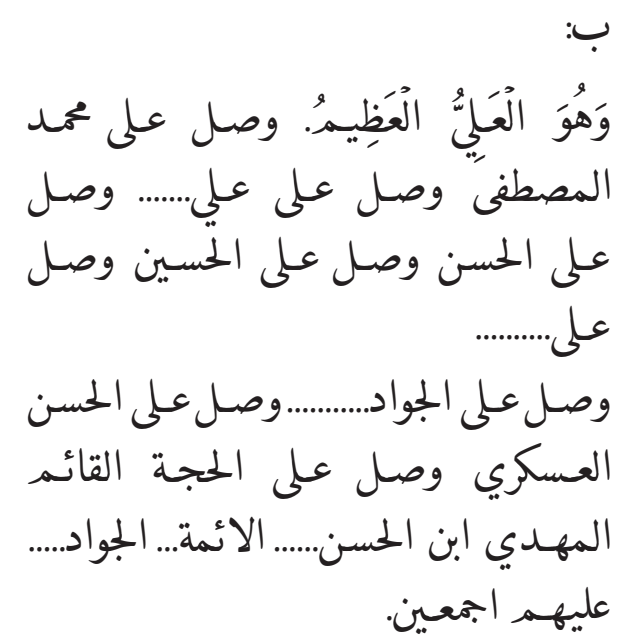




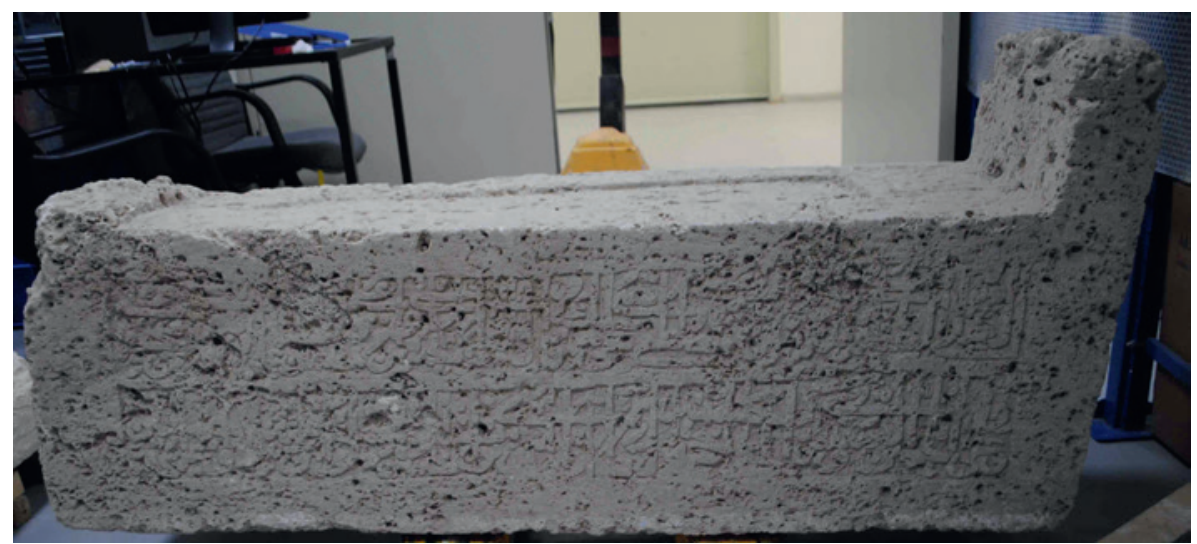

FIGURE 2.384 Surface B, MUS1

C:

$-\quad \ldots . . . . . . . .$.

- ... al-Rashid ...

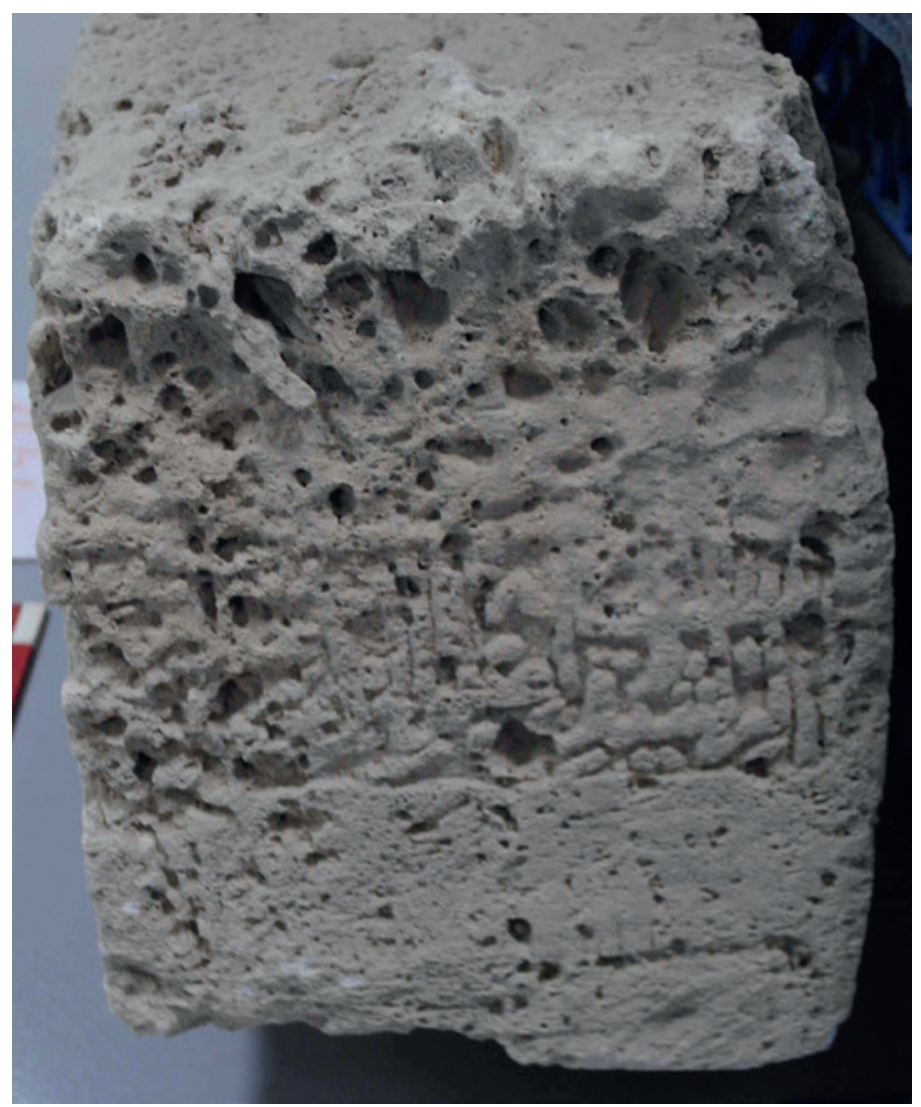

:

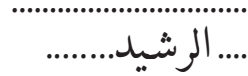

FIGURE 2.385

Surface C, MUS1 
D:

- Very deteriorated. Unable to read.
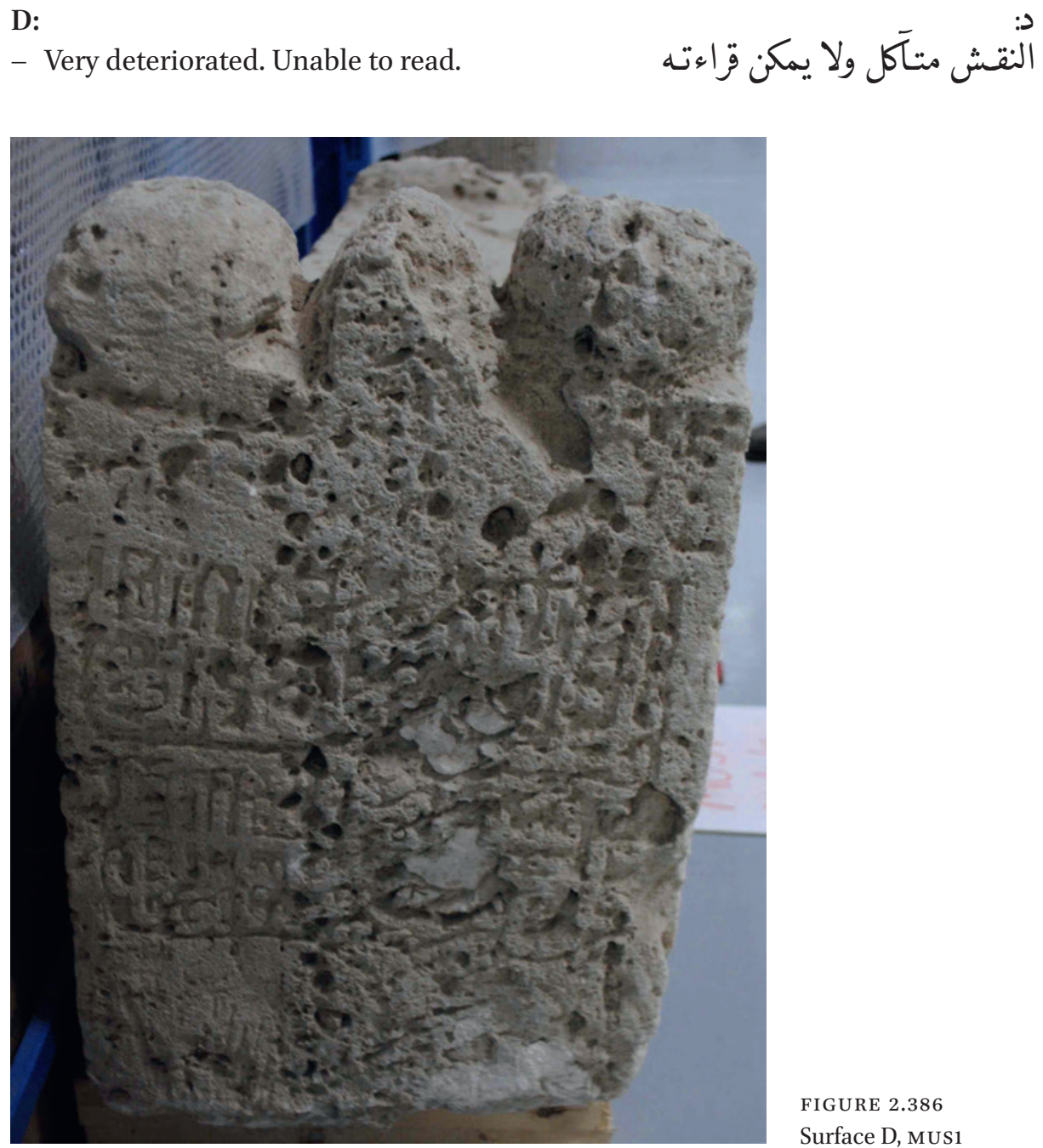

E:

- No carving or inscriptions.

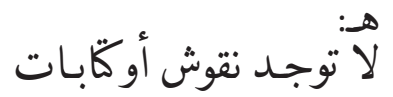

See Figure 2.383

\section{Reference Number: MUS2}

Co-ordinates: NA

Dimensions: $149.5 \mathrm{~cm}(\mathrm{l}) \times 35.5 \mathrm{~cm}(\mathrm{w}) \times 54 \mathrm{~cm}(\mathrm{~h})$

Orientation: NA 
Description: Single limestone slab gravestone. Originally from the Al-Khamis Mosque cemetery. When recorded it was in the store at the Bahrain National Museum, and was subsequently transferred to public display in the gallery at the Al-Khamis Mosque Visitor Centre. Three element raised decoration at both ends, formed of a central point and two triangles at one end and a central point and slightly rounded rectangle with the third element broken off at the opposite end. Inscriptions on four surfaces.

Previous Publication: Number 45, Kalus (1990: 81). The original location, where it is shown in-situ (cf. ibid: Pl. LXIV) is given as a small cemetery to the right of the Karbabad road.

\section{Arabic Transcription and Translation:}

A:

- In the Name of Allah, the Most Gracious, the Most Merciful. Allah, none has the right to be worshipped but he, the Ever Living, the One Who sustains and protects all that exists. Neither slumber nor sleep overtakes Him. To Him belongs whatever is in the heavens and whatever is on the earth. Who

- Is he that can intercede with Him except by His permission! He knows what happens to them in this world, and will happen to them in the Hereafter and they will never compass anything of His Knowledge except that which He wills. His Seat extends over the heavens and the earth (2:255).
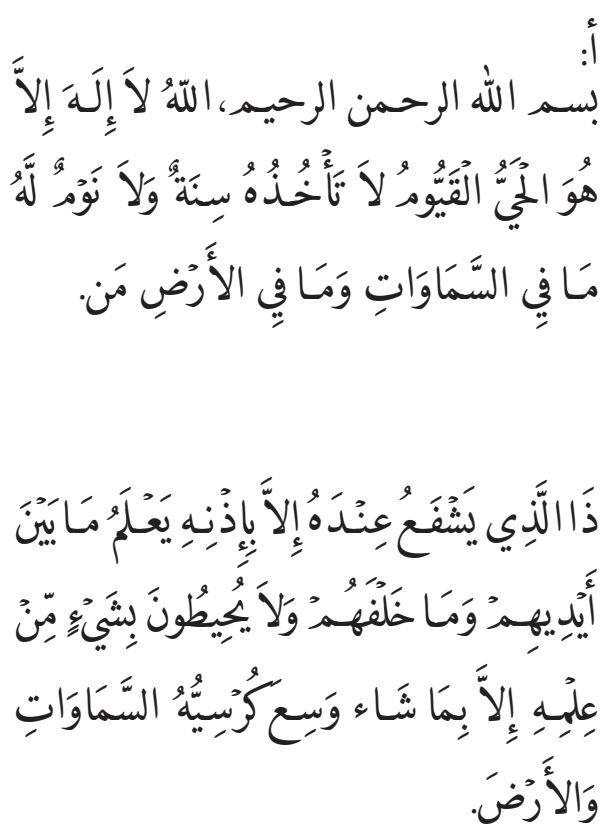

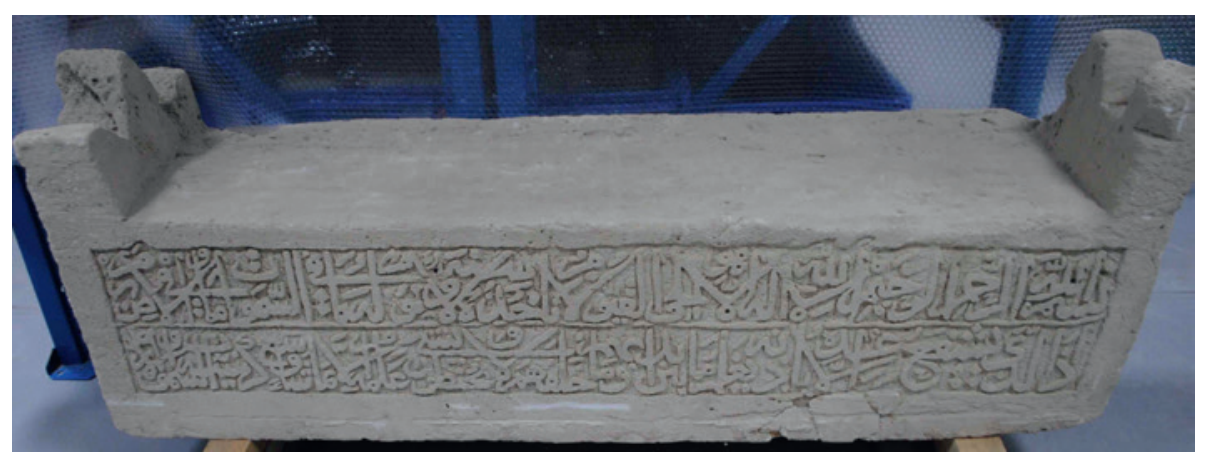

FIGURE 2.387 Surfaces A and E, MUS2 
B:

- And He feels no fatigue in guarding and preserving them. And $\mathrm{He}$ is the Most High, the Most Great. God's blessings upon Muhammad al-Mustafa, God's blessings upon 'Ali al-Murtada, Fatimah al-Zahra', al-

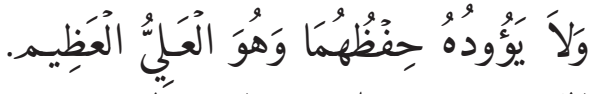

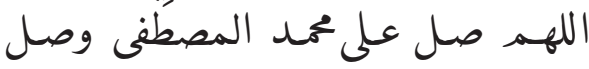
على على المرتضى وفاطمة الزهـراء والحسن والحسـين وعلي وممـل وجعفر. Hasan, al-Husayn, 'Ali, Muhammad, Ja'far,

- Musa, 'Ali, Muhammad, 'Ali, al-Hasan al-'Askari and al-Khalaf al-Hujjah al-Qa'im Muhammad bin al-Hasan. God's blessings and peace upon all of them.
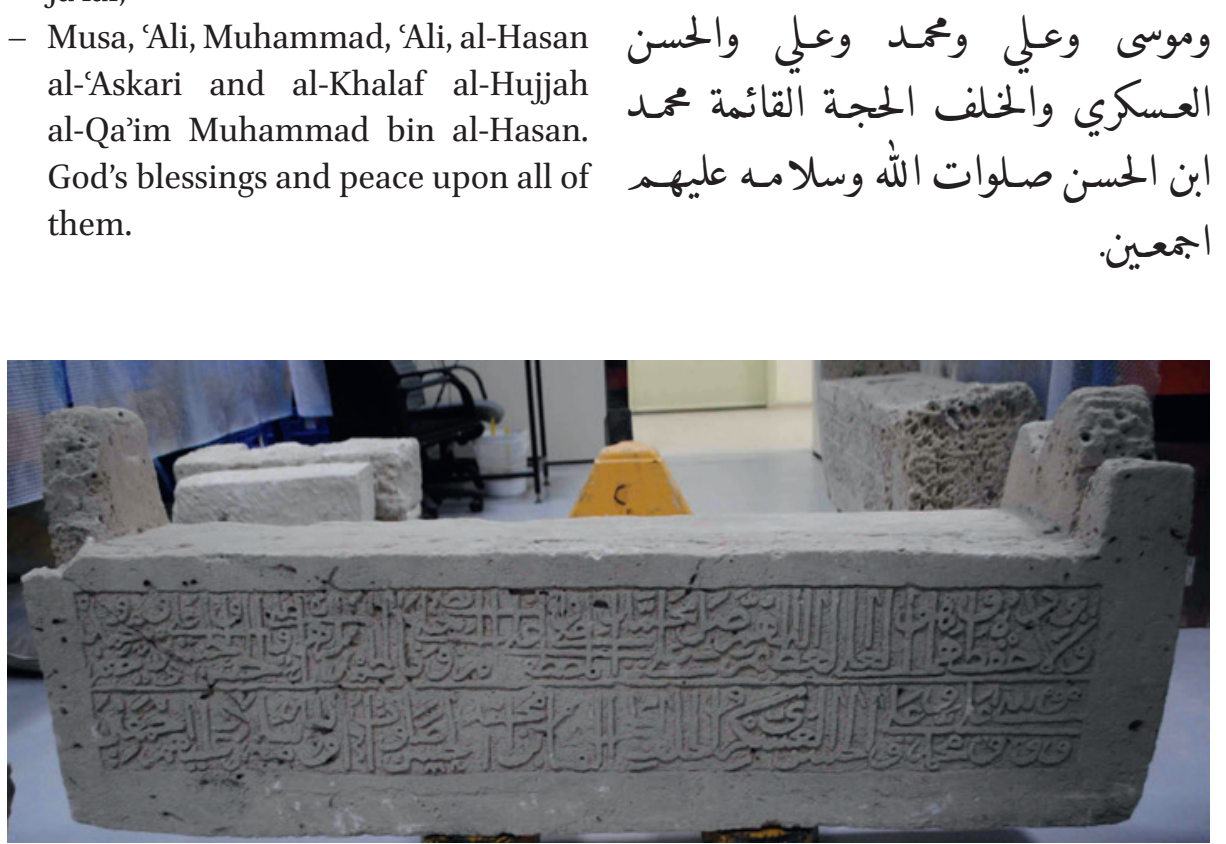

FIGURE 2.388 Surface B, MUS2

C:

- ... The one who shows the wonders, he will assist you during crisises.

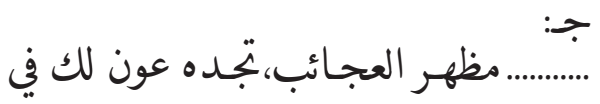

- Every grief and anxiety will go by the blessing of Muhammad and by loving 'Ali.

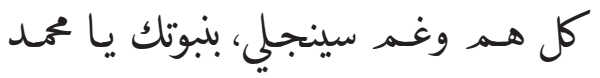
بولا يتك يا عـا فيل.

- He died in thirteenth of Muharram, year 1014 .

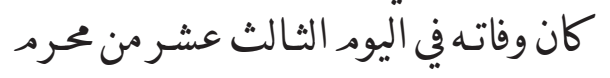




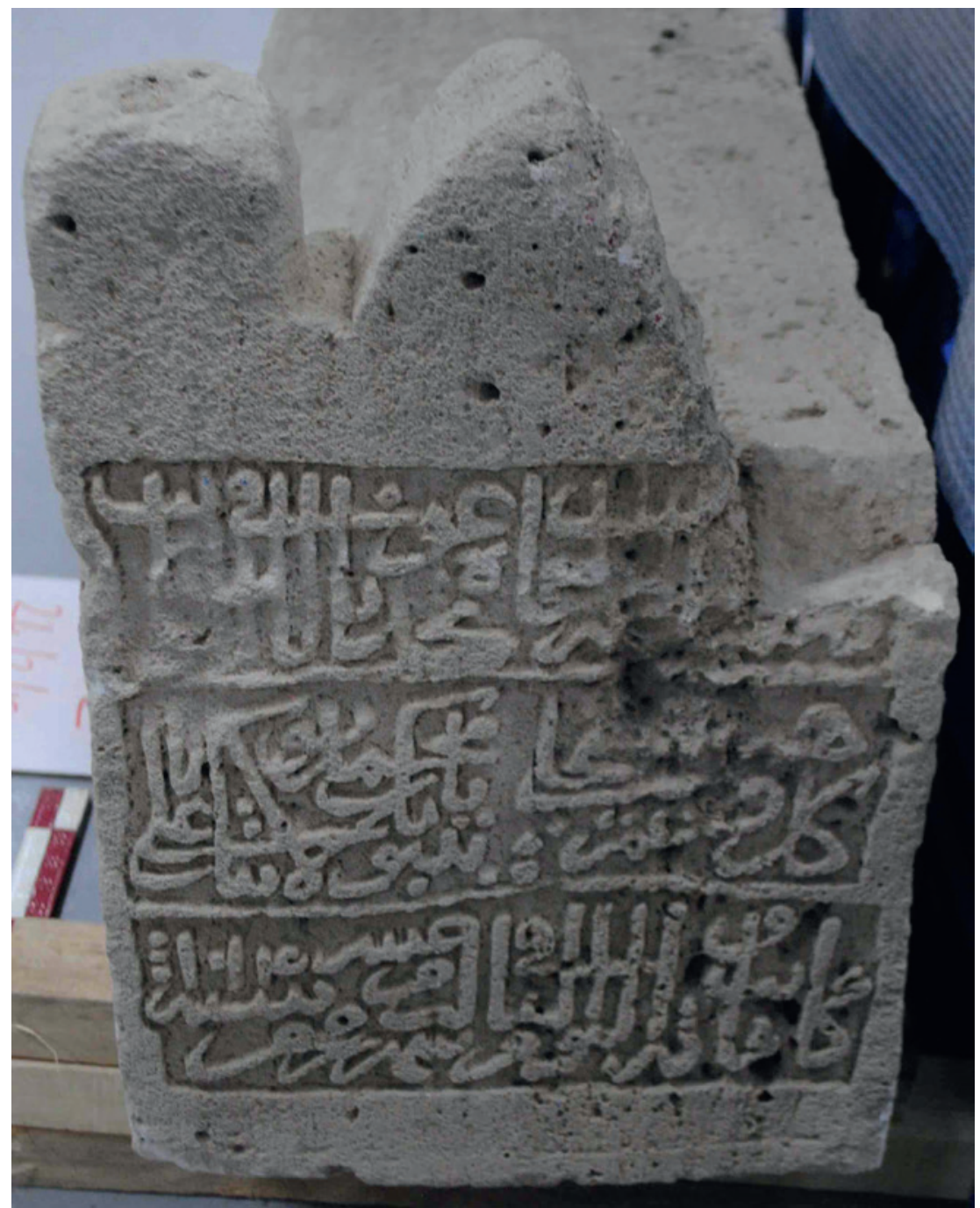

FIGURE 2.389 Surface C, MUS2

D:

- This is grave of the blessed late, the Innocent (possibly Wardi Abak)

- Brother of the greatest and generous ...

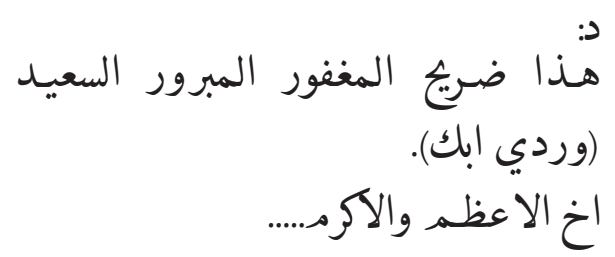




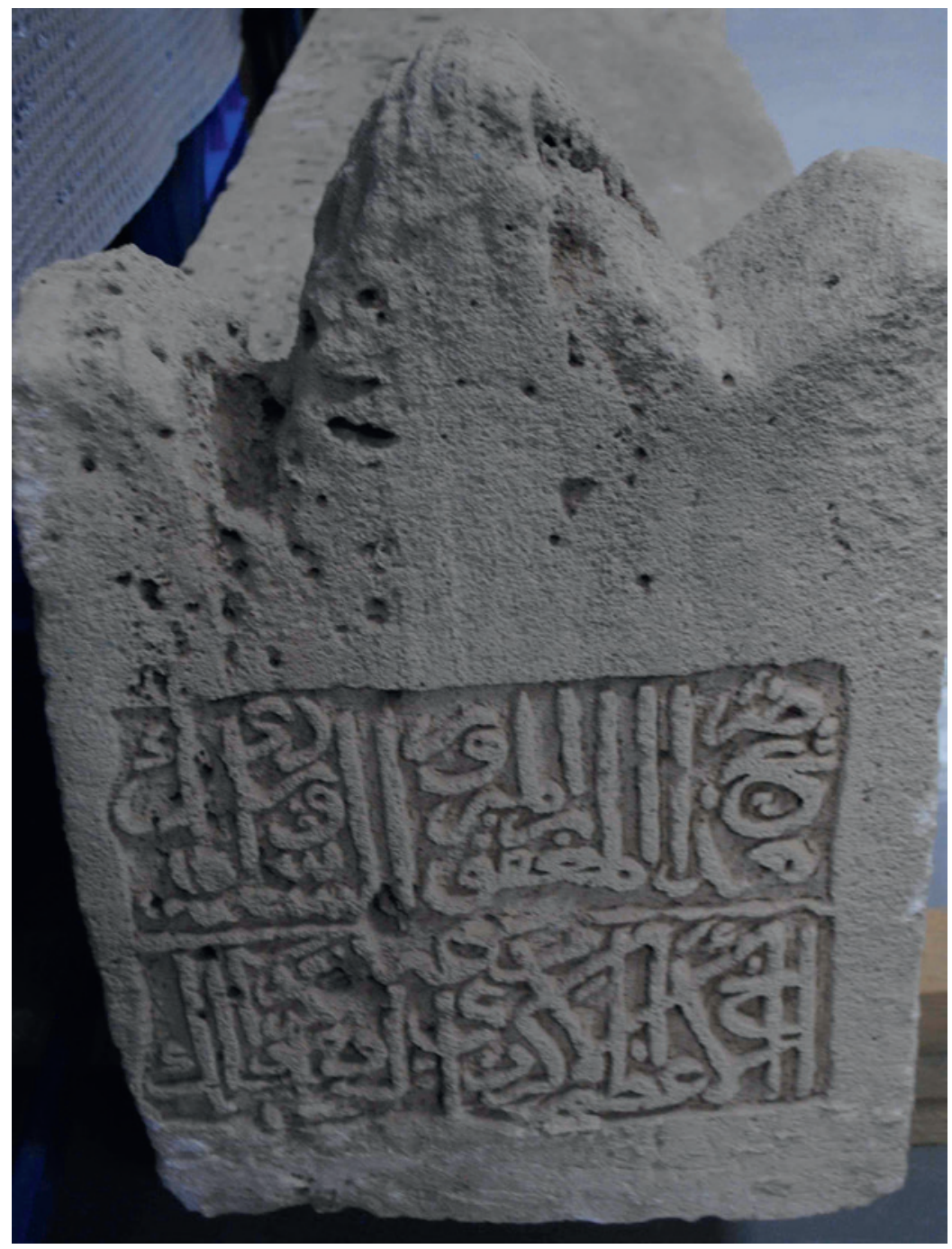

FIGURE $2.390 \quad$ Surface D, MUS2

E:

- No carving or inscriptions.

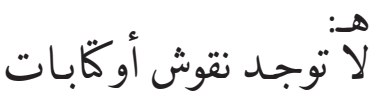

See Figure 2.387 
Reference Number: MUS3

Co-ordinates: NA

Dimensions: $66 \mathrm{~cm}(\mathrm{l}) \times 30 \mathrm{~cm}(\mathrm{w}) \times 45 \mathrm{~cm}(\mathrm{~h})$

Orientation: NA

Description: Single limestone slab from a double slab gravestone in the store at Bahrain National Museum. Impact damage on one side surface (A), and significant erosion in places. Inscriptions on two surfaces.

Previous Publication: Number 44, Kalus (1990: 80). The original location is given as found re-employed in Qala'at al-Bahrain (Bahrain Fort) presumably as spolia in construction. This would possibly explain the unusual impact damage perhaps sustained during its removal.

\section{Arabic Transcription and Translation:}

A:

- ... that Allah may forgive you your sins of the past and the future, and complete His Favour on you ... (48:2).

- ... none has the right to be worshipped but he, the Ever Living, the One Who sustains and protects all that exists. Neither slumber nor sleep

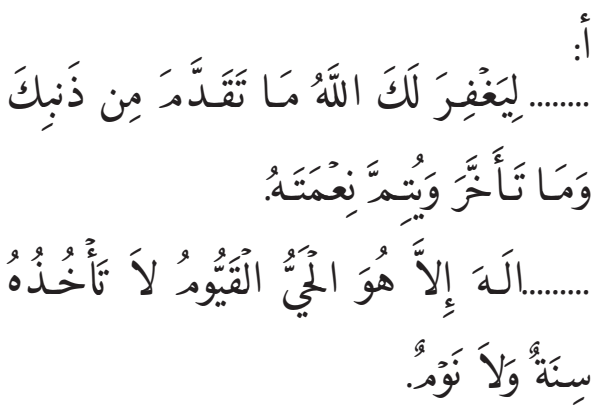
overtakes Him (2:255).

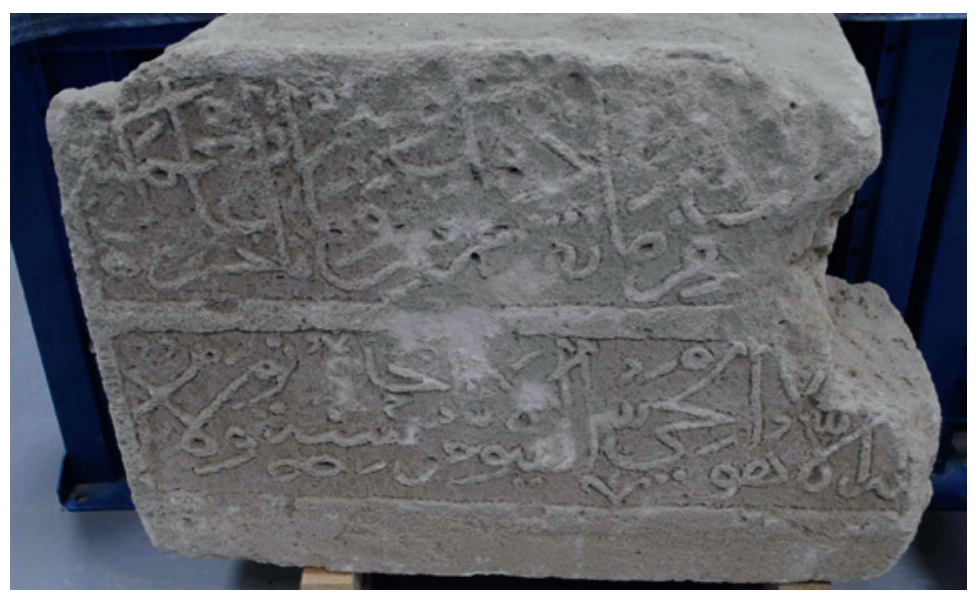


B:

- No carving or inscriptions.
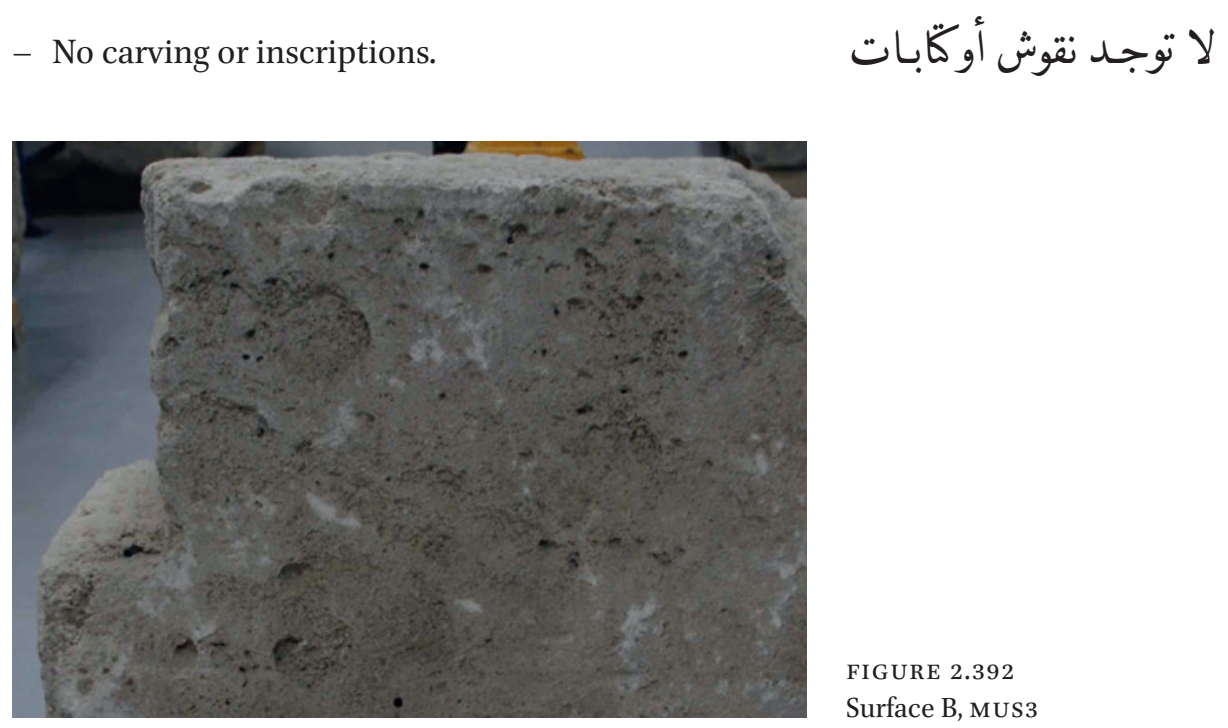

FIGURE 2.392

Surface B, MUs3

C:

- ..............

- Rabic al-thani, year of eight hundred ربيح الثاني لسنة اربح وخمسن وتمانمايـة. and fifty four.

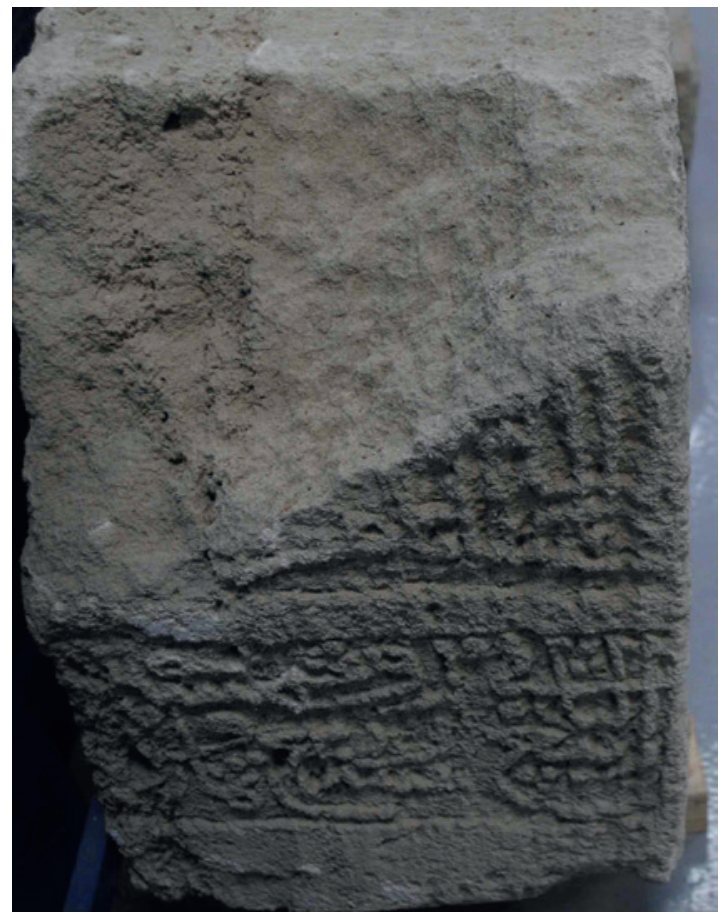

FIGURE 2.393

Surface C, MUs3 
D:

- No carving or inscriptions.

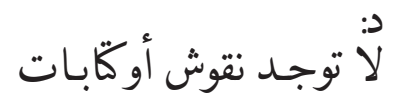

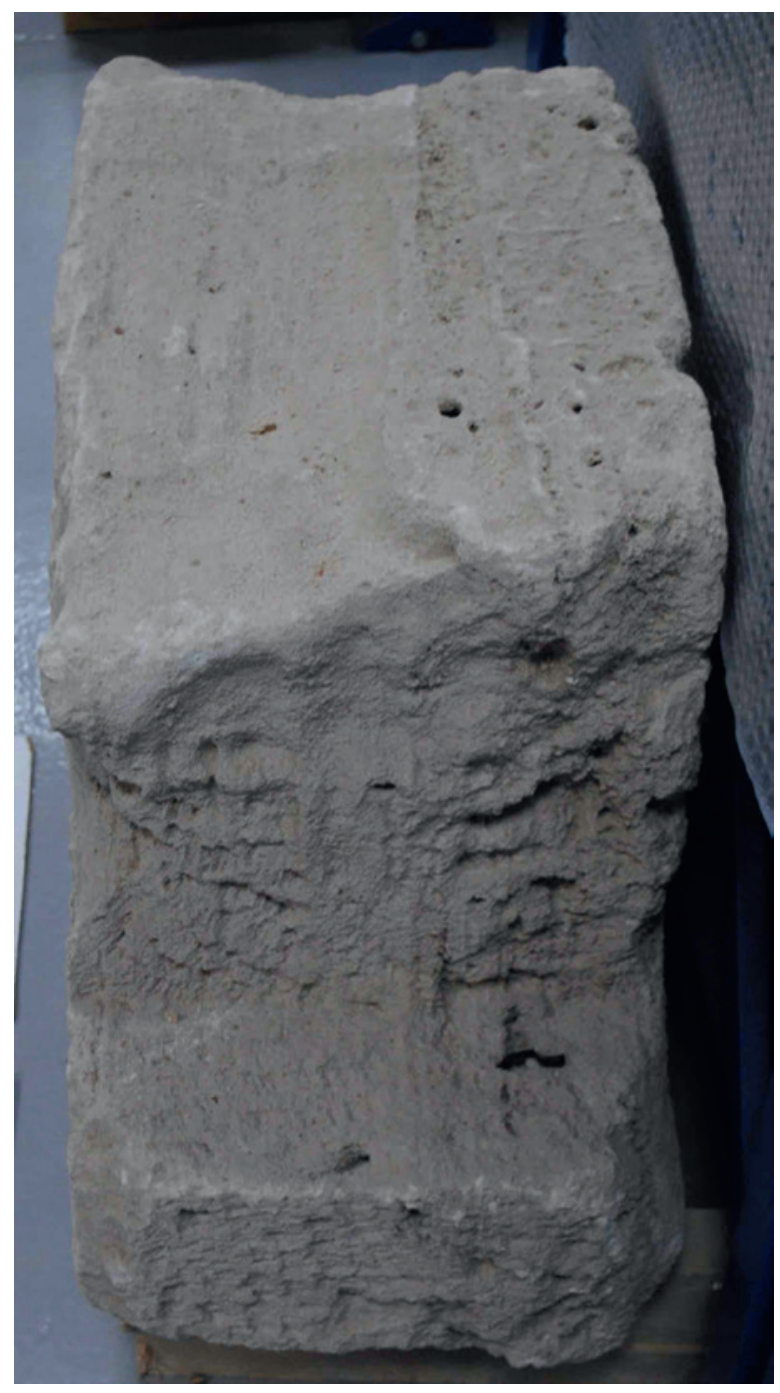

E:

- No carving or inscriptions.
FIGURE 2.394

Surface D, MUs3

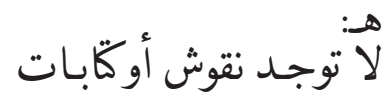




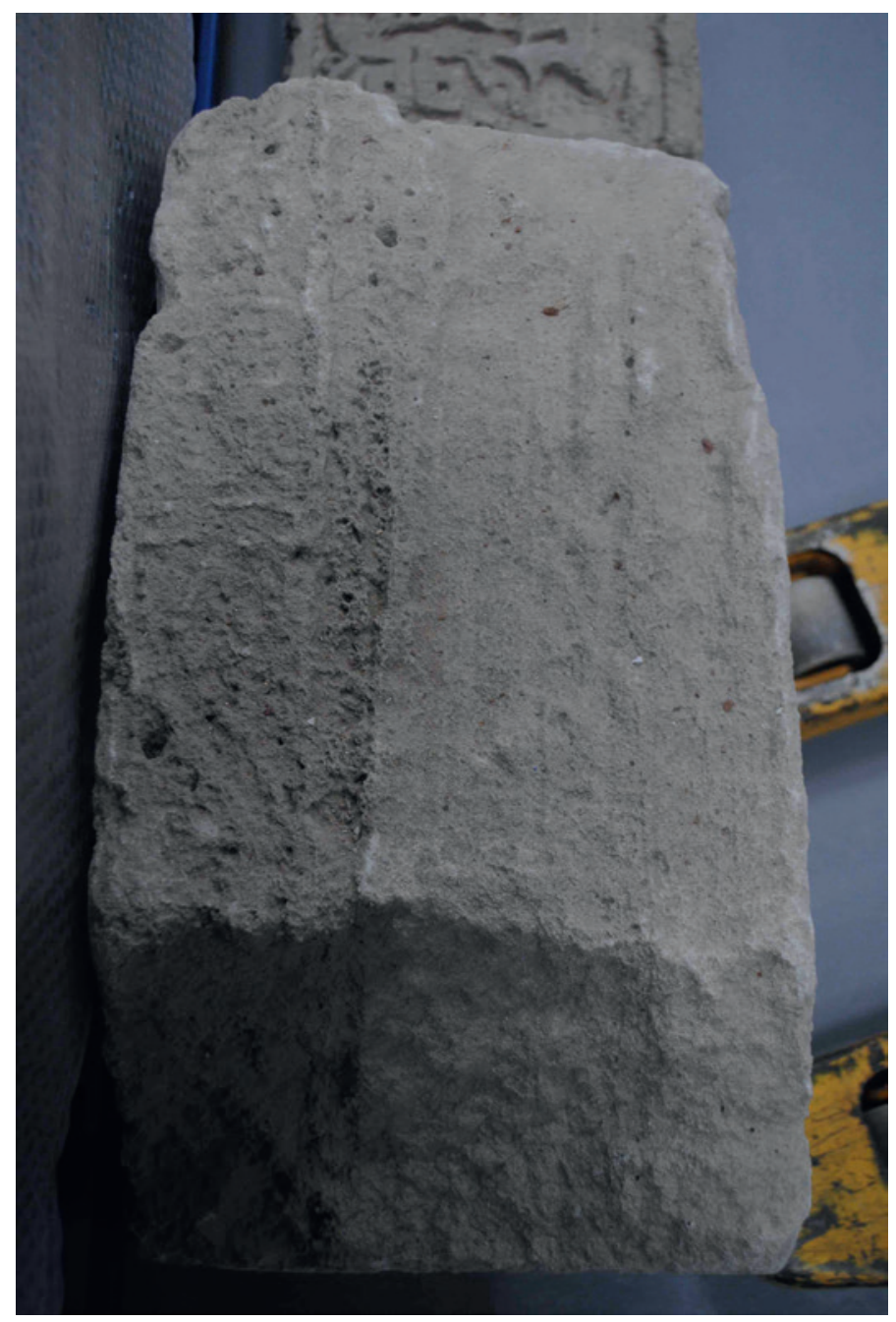

\section{Reference Number: MUS4}

\section{Co-ordinates: NA}

Dimensions: $150 \mathrm{~cm}(\mathrm{l}) \times 33.5 \mathrm{~cm}(\mathrm{w}) \times 64 \mathrm{~cm}(\mathrm{~h})$

\section{Orientation: NA}

Description: Single limestone slab gravestone. When recorded it was in the store at the Bahrain National Museum, and it was subsequently transferred to public display in the gallery at the Al-Khamis Mosque Visitor Centre. Three element raised 
decoration at both ends formed of two facetted cubes and a central rounded arch all set on a rectangular plinth. At one end the raised decoration is damaged with one of the three elements partially broken off. Shallow carved pointed niche design on the upper surface (E). Inscriptions on five surfaces.

Previous Publication: Number S13, Kalus (1990: 53$)$. Original location given as in a palm garden near Zallaq (ibid: 142).

\section{Arabic Transcription and Translation:}

A:

- In the Name of Allah, the Most Gracious, the Most Merciful. Allah, none has the right to be worshipped but he, the Ever Living, the One Who sustains and protects all that exists. Neither slumber nor sleep overtakes Him. To Him belongs whatever is in the heavens and whatever is on the earth.

- Who is he that can intercede with Him except by His permission! He knows what happens to them in this world, and will happen to them in the Hereafter and they will never compass anything of His Knowledge except that which He wills. His Seat extends over the heavens and the earth (2:255).
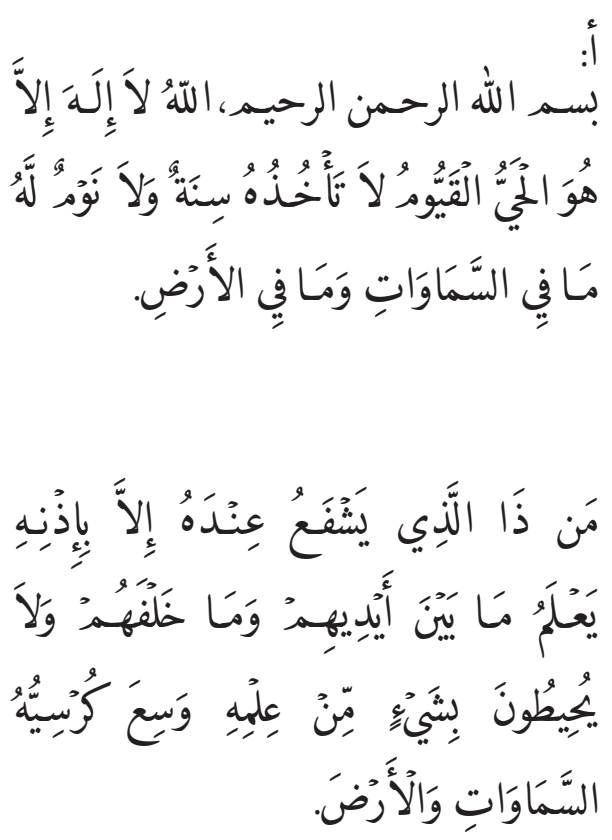

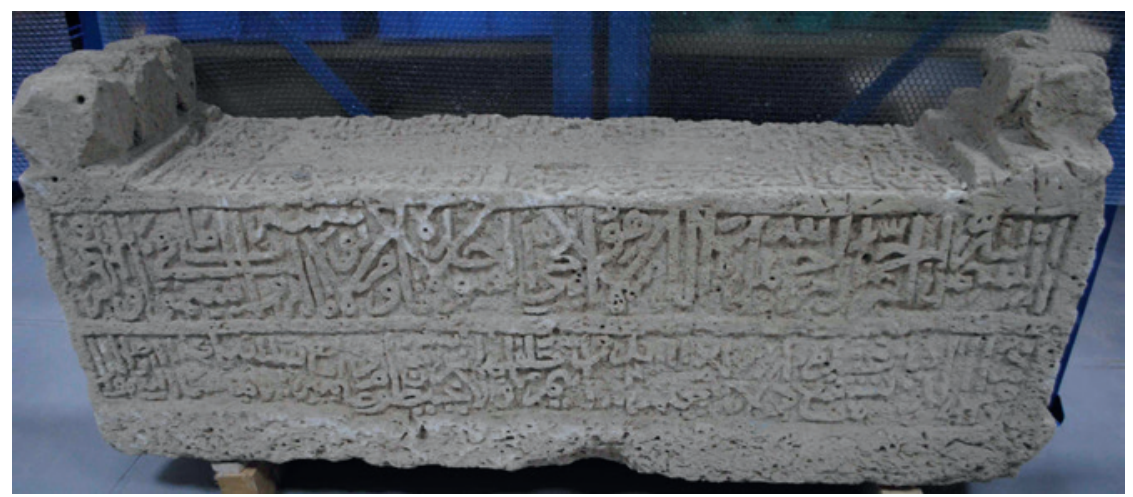

FIGURE 2.396 Surface A, MUS4 
B:

- Endowments of the late, Shaikh Husayn Bin Hurz al-Din for Imam al-Qa'im ... thirty-four shares, one share...

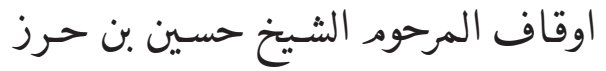

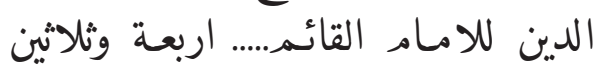

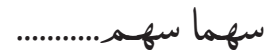

- From the garden of bin al-Zayid (possibly al-Din) for the reader at Hilal mosque, (possibly Shu'ayb) southern garden of al-Kharajat ... proceeds ... part of ...

منهـم في صرمـة ابن الرنايــ والذي (الدين) للد ارس في مسجد هلا لي صرمد (شعيب)

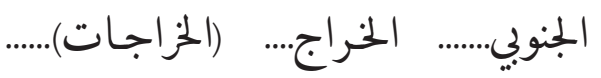

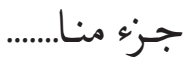

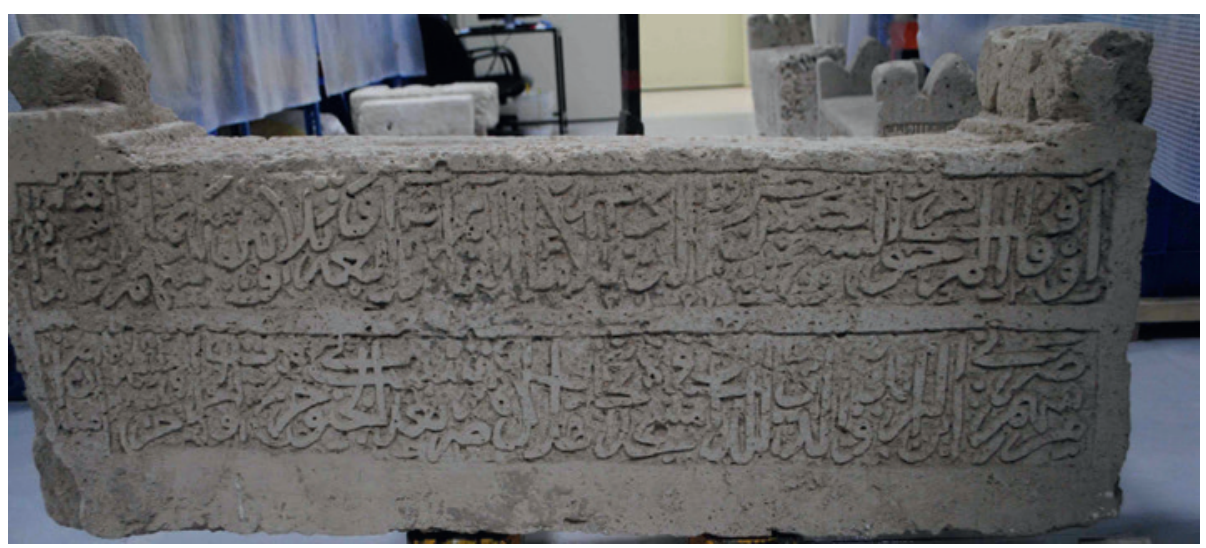

FIGURE 2.397 Surface B, MUS4

C:

- Grave ... 'Abd Allah ('Abd al-Samad) who died on tenth of Muharram (al-Husayn).

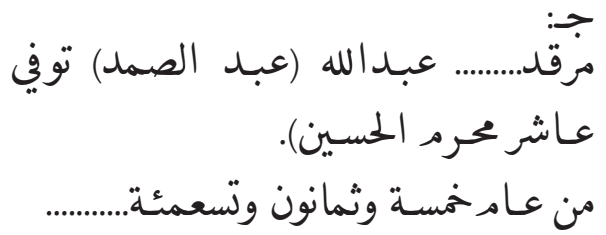

- Year nine hundred and eighty-five ... من عـامرخسـة وتمانون ورسعمئة.. 


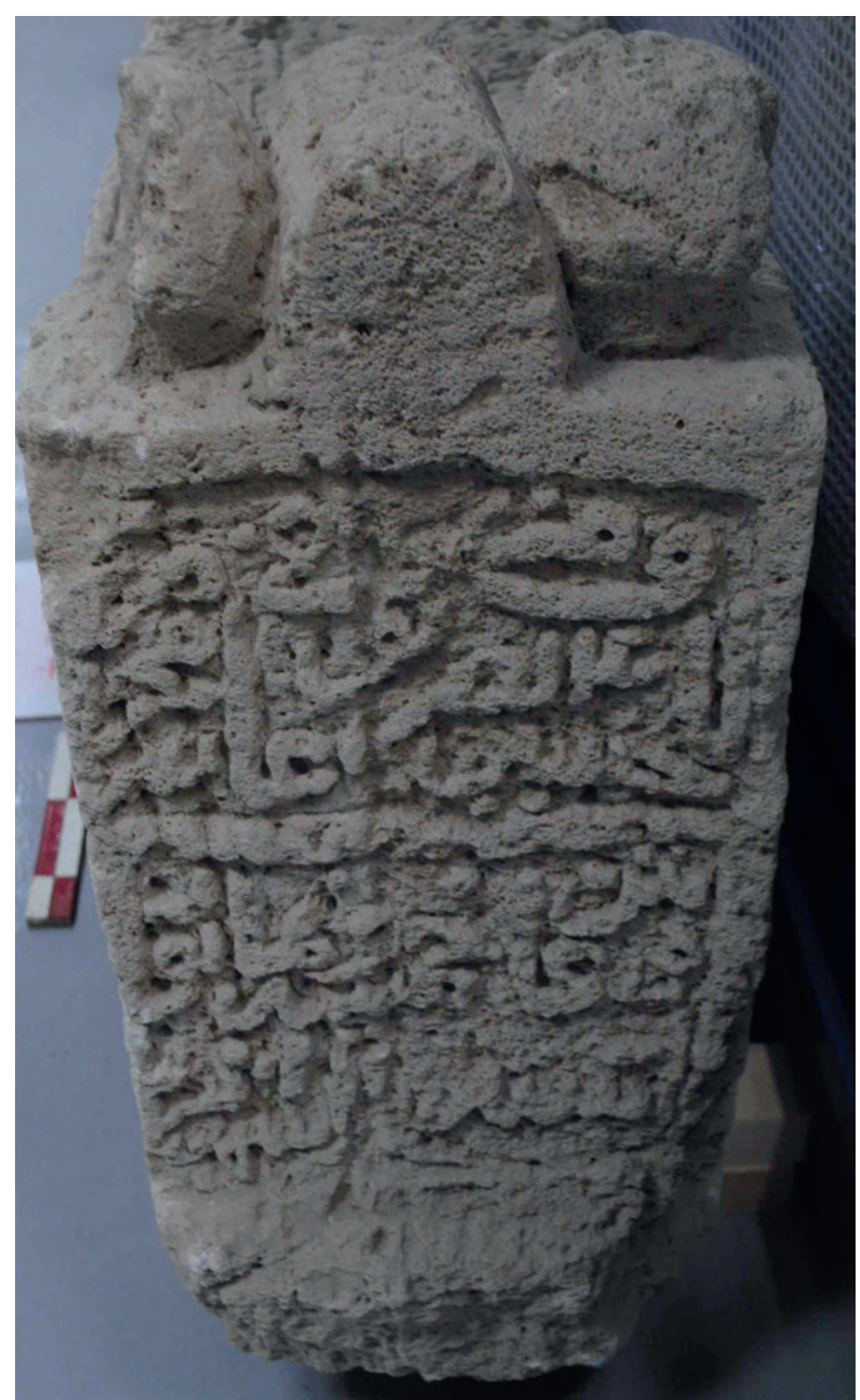

FIGURE 2.398

Surface C, MUS4
D:

- ... Month of Rabic, who was born in 1007 (possibly 1017).
د: ............. 


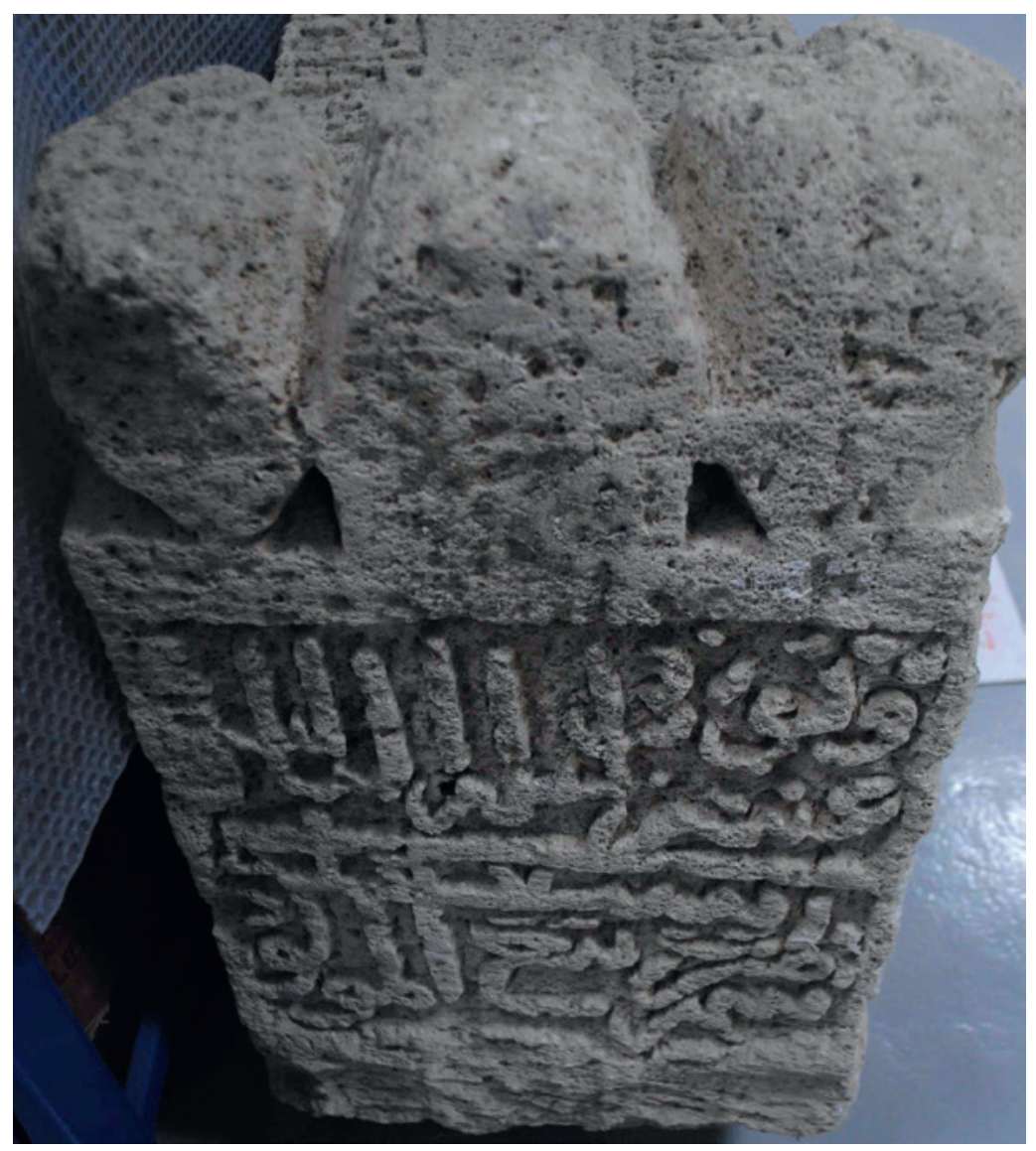

FIGURE 2.399 Surface D, MUS4

E:

- ... And reading for a quarter of income of ... Garden.

- Ibrahim bin Sinan after planting ...

- ... has got the happiness ...

- bin (bint) Sacd ...

- Written by Mas'ud, and engraved by

- al-Sayyid Hashim

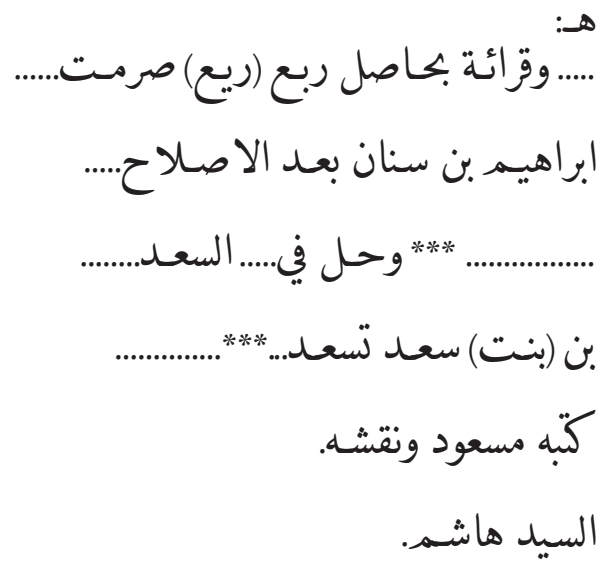




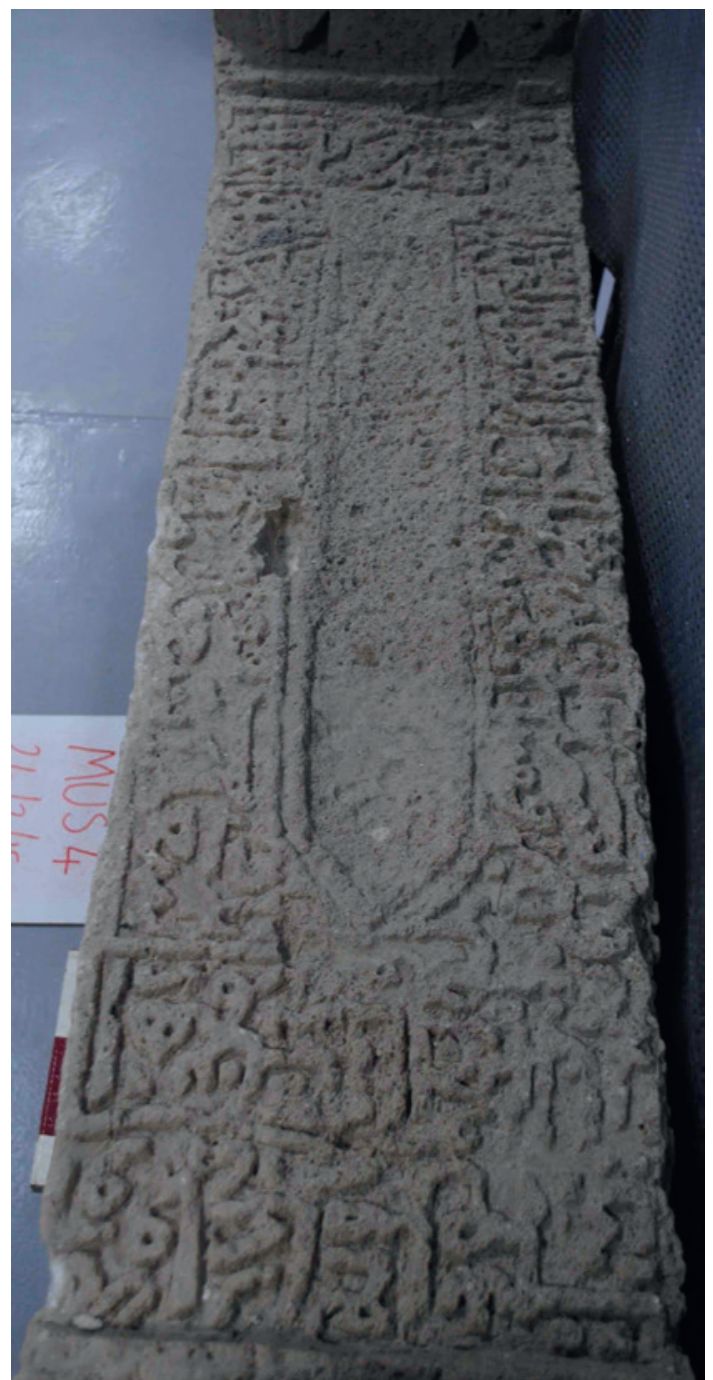

FIGURE 2.400

Surface E, MUS4

Reference Number: MUS5

Co-ordinates: NA

Dimensions: $131 \mathrm{~cm}(\mathrm{l}) \times 33 \mathrm{~cm}(\mathrm{w}) \times 49 \mathrm{~cm}(\mathrm{~h})$

\section{Orientation: NA}

Description: Single limestone slab gravestone in the store at Bahrain National Museum. Poorly carved three element raised decoration formed of two facetted cubes and a central rounded arch at each end. Erosion to upper surface (E) and parts of both the side surfaces (A and B). Partially legible inscriptions on five surfaces. 
Arabic Transcription and Translation:

A:

- In the Name of Allah, the Most Gracious, the Most Merciful. Allah, none has the right to be worshipped but he, the Ever Living, the One Who sustains and protects all that exists. Neither slumber nor sleep overtakes Him. To Him belongs whatever is in the heavens and whatever is on the earth. Who is he that can intercede with Him except by His permission! He knows what happens to them in this world, and will happen to them in the Hereafter and they will never compass.

- Anything of His Knowledge except that which He wills. His Seat extends over the heavens and the earth. And He feels no fatigue in guarding and preserving them. And He is the Most High, the Most Great. There is no compulsion in religion. Verily, the Right Path has become distinct from the wrong path. Whoever disbelieves in alTaghut and believes in Allah, then he has grasped the most trustworthy handhold that will never break. And Allah is All-Hearer, AllKnower (2:255-256).
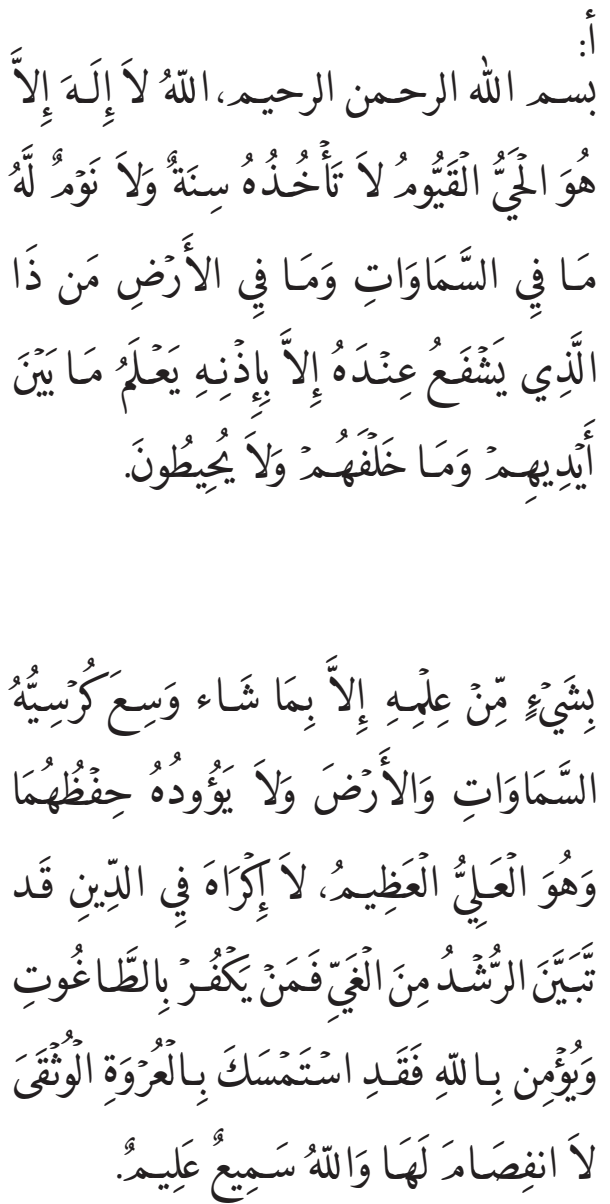

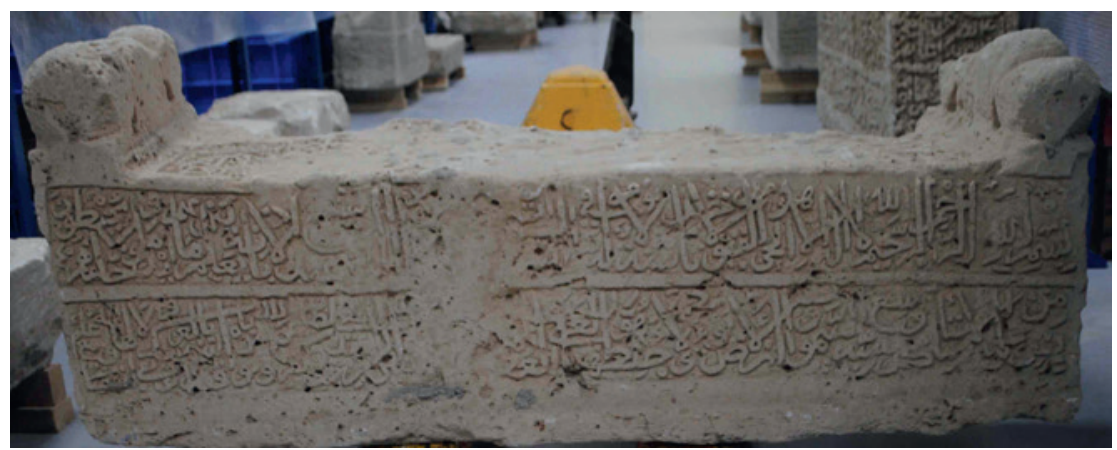

FIGURE 2.401 Surface A, MUS5 
B:

- ... whose doors will be opened for them. ... will recline, therein ... for fruits in abundance and drinks. And beside them will be chaste females restraining their glances and of equal ages. This is what you are promised ... (38:50-53).

- ... Therein forever. Verily, with Allah is a great reward (9:22). The angels descend upon them, saying: Fear not nor grieve, but receive the glad tidings of the paradise which you have been promised (41:30).

- Bequeathed for reading on ... the cherished, six ... half of palm garden ... the western ... and half on ...

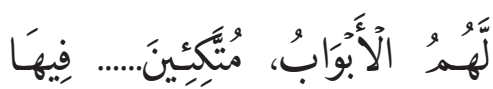

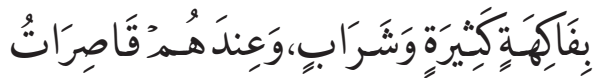

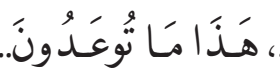
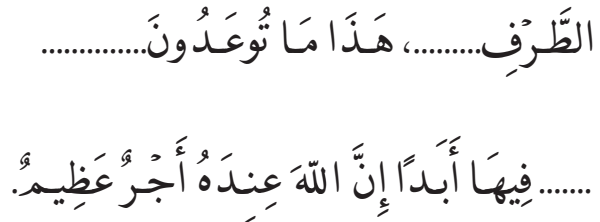

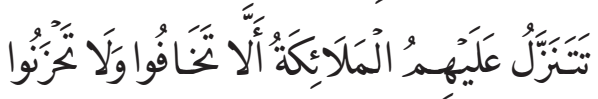

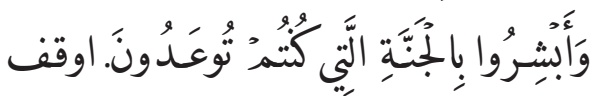
عنـده للقـراءة عـلى.... (ذا)..... العزيز سـت....نصفت صرمـة..... الغربية....... ونصف على...............

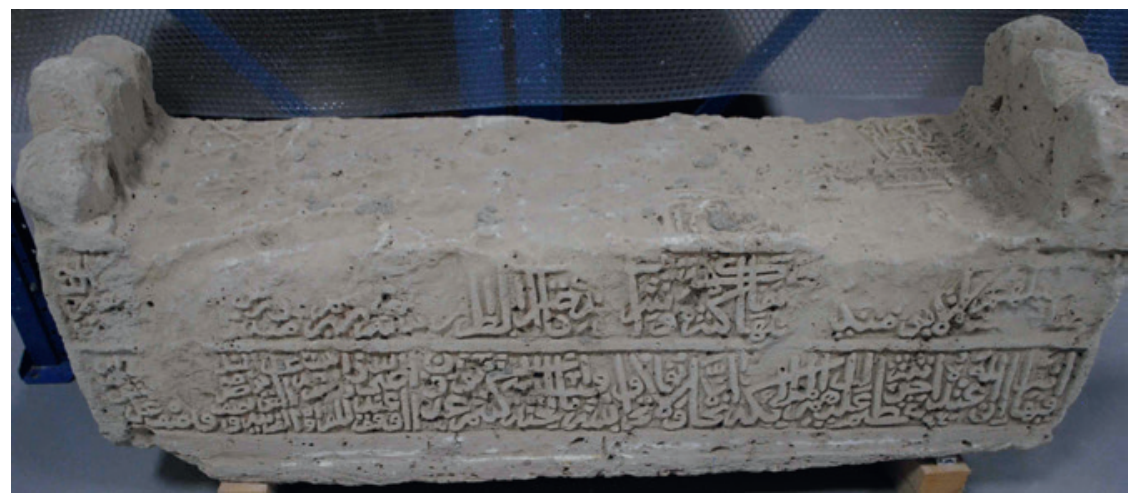

FIGURE 2.402 Surface B, MUS5

C:

- This is a grave of the one who went to the highest place

- Of paradise, Haji Najm bin 'Ali bin الجنان الحاجي بنم بن على بن (حز) (Hiz)... God forgive him.

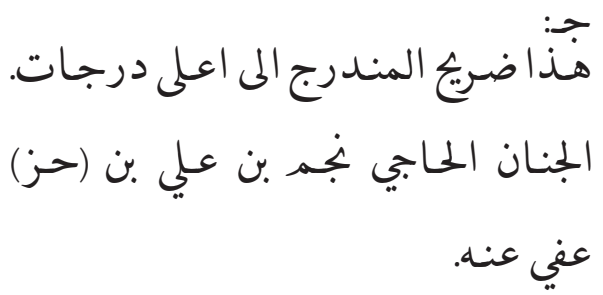




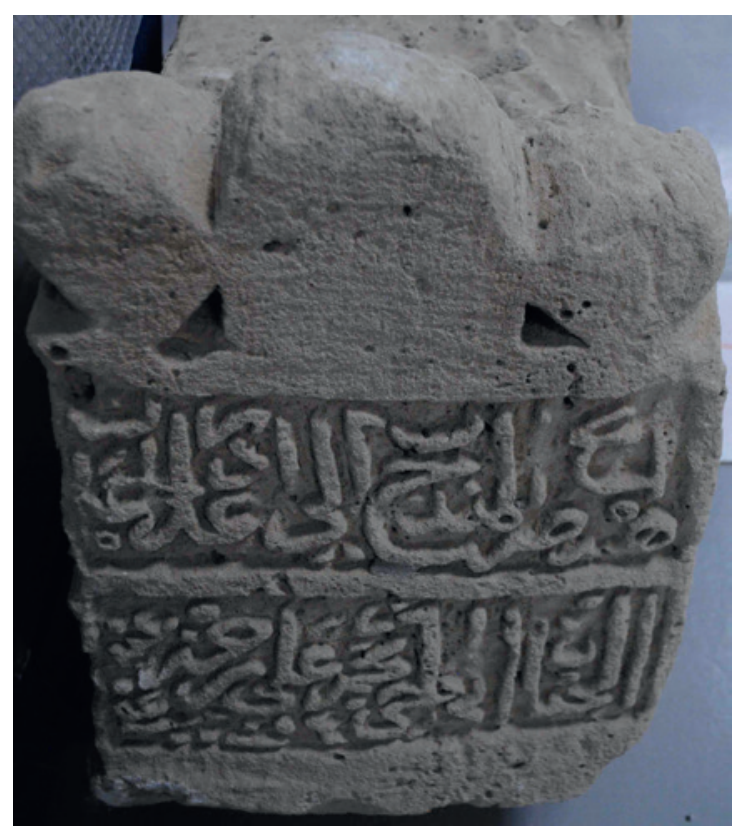

FIGURE 2.403

Surface C, MUS5

D:

- ... Muharram al-Haram, complete reading ... Muhammad.

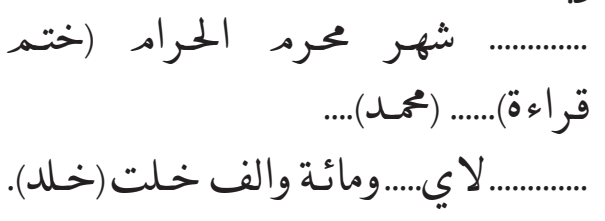

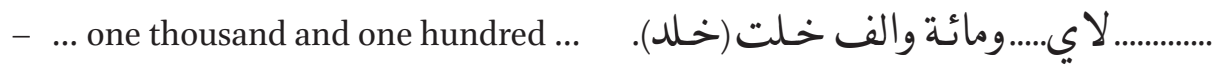

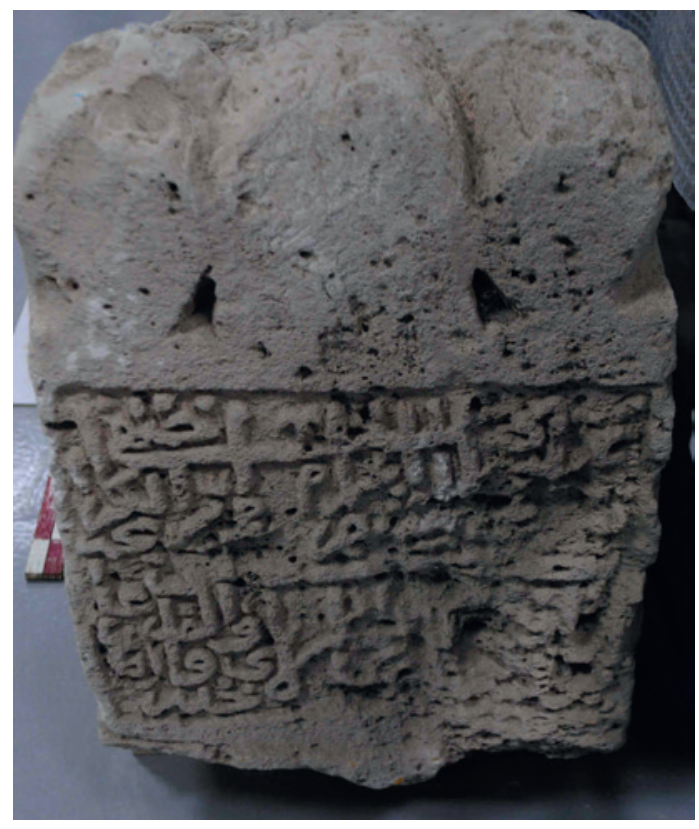


E:

- ... Hashim 'Ali al-Husayni ...

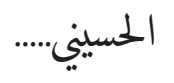

هاشم علي

هـ

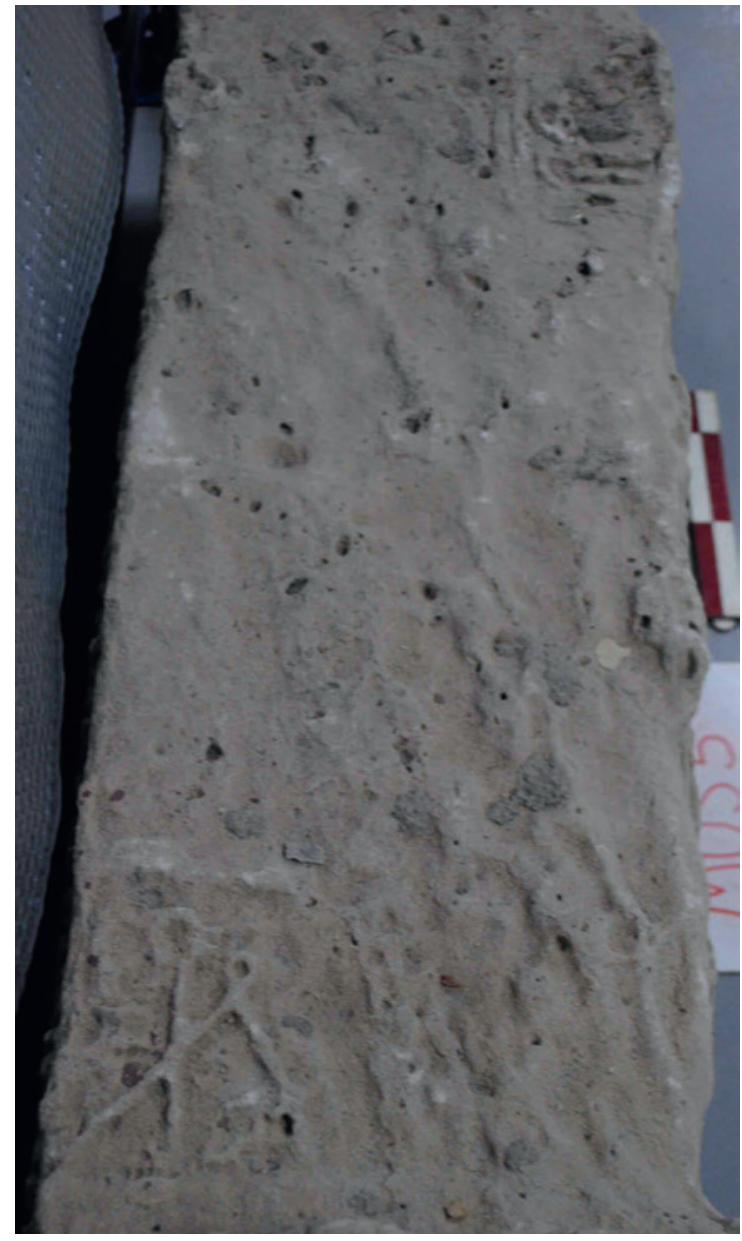

FIGURE 2.405

Surface E, MUS5

Reference Number: MUS6

Co-ordinates: NA

Dimensions: $142 \mathrm{~cm}(\mathrm{l}) \times 39.5 \mathrm{~cm}(\mathrm{w}) \times 39 \mathrm{~cm}(\mathrm{~h})$

\section{Orientation: NA}

Description: Single limestone slab gravestone. Originally from the Al-Khamis Mosque cemetery. When recorded it was in the store at the Bahrain National 
Museum, and it was subsequently transferred to public display in the gallery at the Al-Khamis Mosque Visitor Centre. Well carved. Some unusual damage on the top surface (E) that appears to have been made with a chisel and the raised decoration has been cleanly cut off at both ends. Circular hole drilled in one side surface (A), and damage to both end surfaces (C and D). Elaborate shallow carved pointed niche design with a double border and a flower or abstract symbol in the point of the niche on the upper surface (E). Inscriptions on five surfaces.

Previous Publication: Number 16, Kalus (1990: 45)

\section{Arabic Transcription and Translation:}

A:

- In the Name of Allah, the Most Gracious, the Most Merciful. Allah, none has the right to be worshipped but he, the Ever Living, the One Who sustains and protects all that exists. Neither slumber nor sleep overtakes Him. To Him belongs whatever is in the heavens and whatever is on the earth. Who is he that can intercede with Him except by His permission! He knows what happens to them in this world, and will happen to them in the Hereafter.

- And they will never compass. Anything of His Knowledge except that which He wills. His Seat extends over the heavens and the earth. And He feels no fatigue in guarding and preserving them. And $\mathrm{He}$ is the Most High, the Most Great. There is no compulsion in religion. Verily, the Right Path has become distinct from the wrong path. Whoever disbelieves in Taghut and believes in Allah, then he has grasped the most trustworthy handhold that will never break. And Allah is All-Hearer, All-Knower (2:255-256).
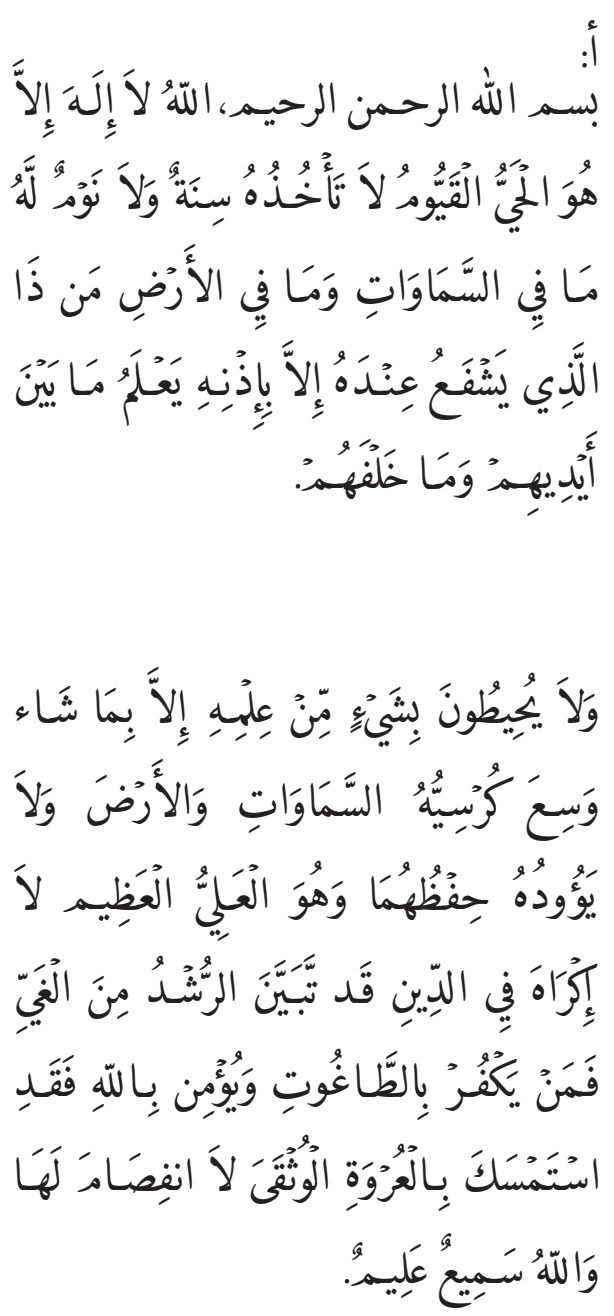


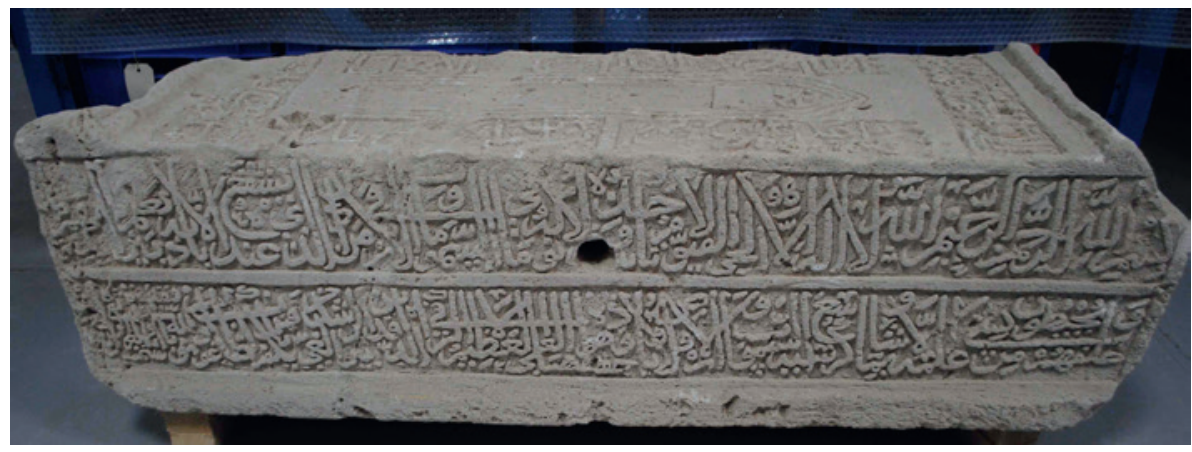

FIGURE 2.406 Surface A, MUS6

B:

- Eden Paradise, whose doors will be opened for them. Therein they will recline, therein they will call for fruits in abundance and drinks. And beside them will be chaste females restraining their glances and of equal ages (38:50-52). The angels descend upon them, saying: Fear not nor grieve, but receive the glad tidings of the paradise which you have been promised. We have been your friends in the life of this world and are in the Hereafter. Therein you shall have all that your inner-selves desire

- And therein you shall have all for which you ask. An entertainment from the Oft-Forgiving, Most Merciful (41:30-32). Their Lord gives them glad tidings of Mercy from Him, and His being pleased, and of Gardens for them wherein are everlasting delights. They will dwell therein forever. Verily, with Allah is a great reward (9:21-22). Eden Paradise, which they shall enter and those who acted righteously from among their fathers, and their wives, and their offspring. And angels shall enter unto them every gate (13:23). God Almighty has spoken the truth.
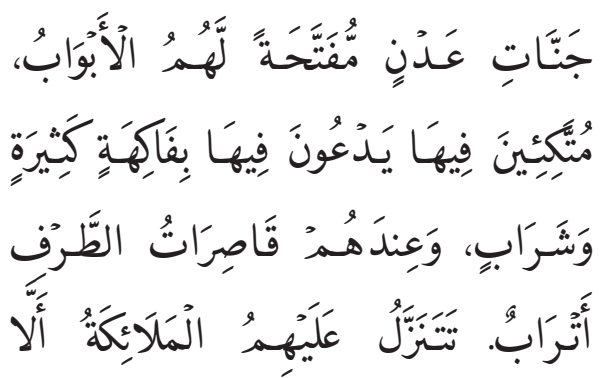

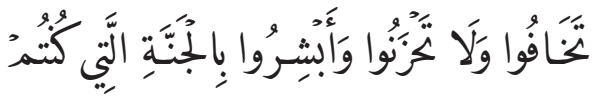

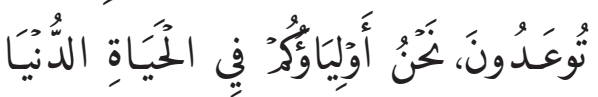

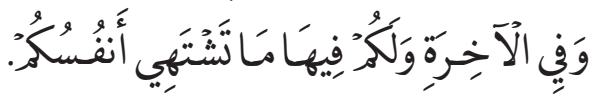

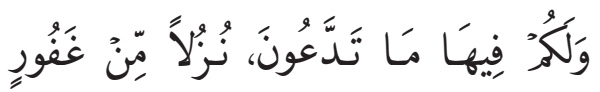

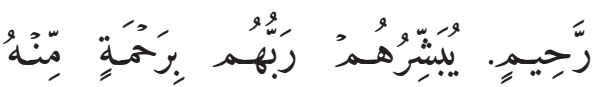

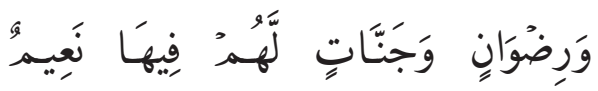

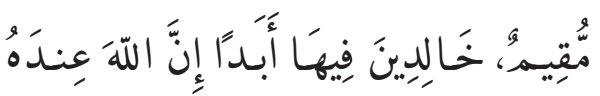

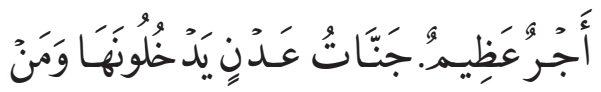

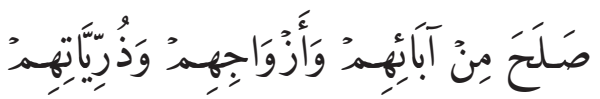

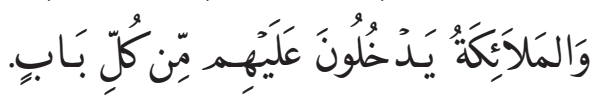
صـدق الله العظيـم. 


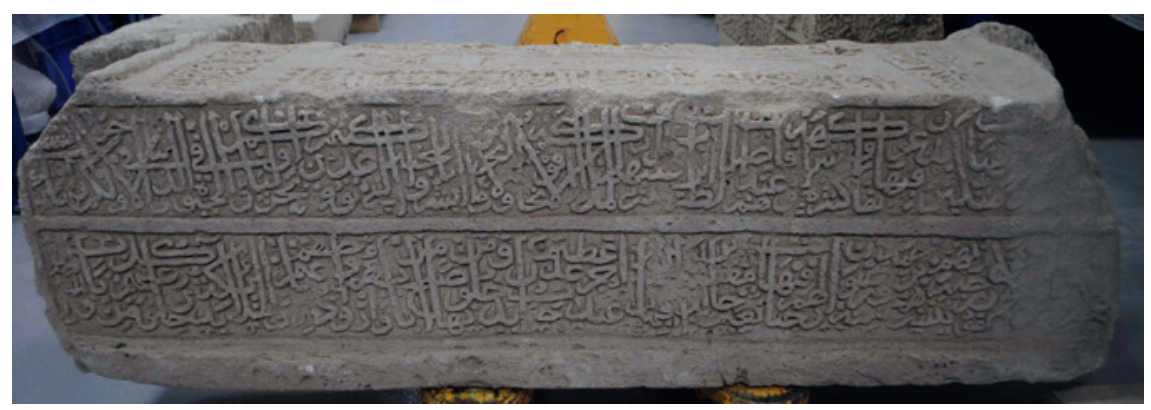

FIGURE 2.407 Surface B, MUS6

C:

- This is ... the blessed ...

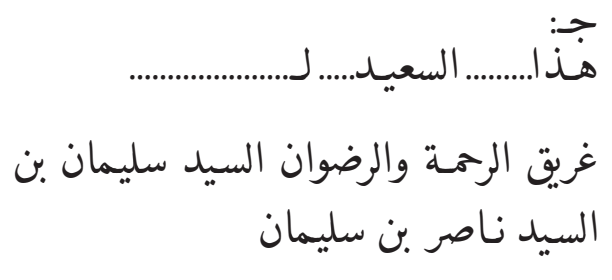

- The one who has got God's mercy and approval, al-Sayyid Sulayman bin alSayyid Naser bin Sulayman.

$$
\text { السيد ناصر .بن سليمان }
$$

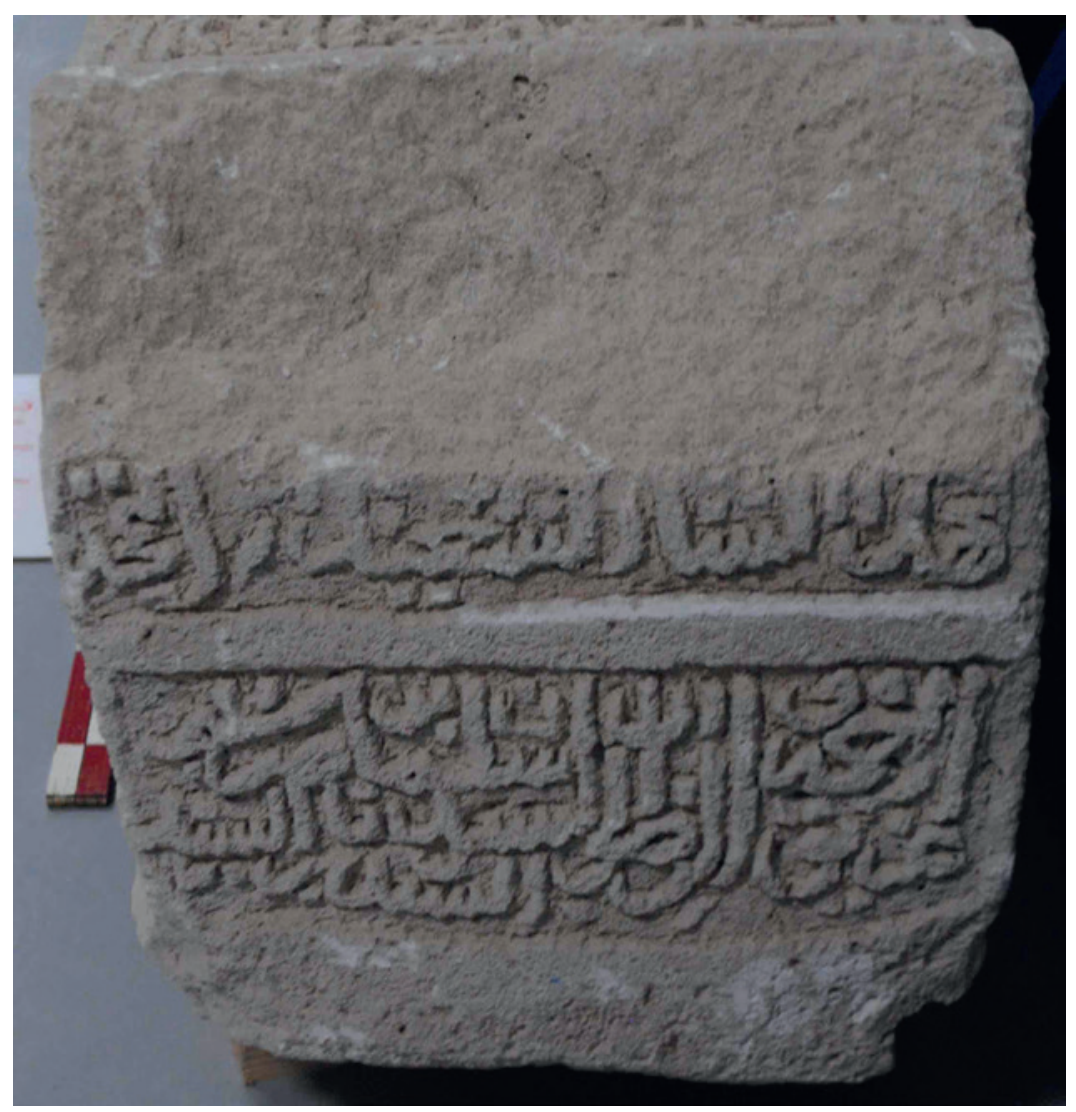

FIGURE 2.408 Surface C, MUS6 
D:

- Date...
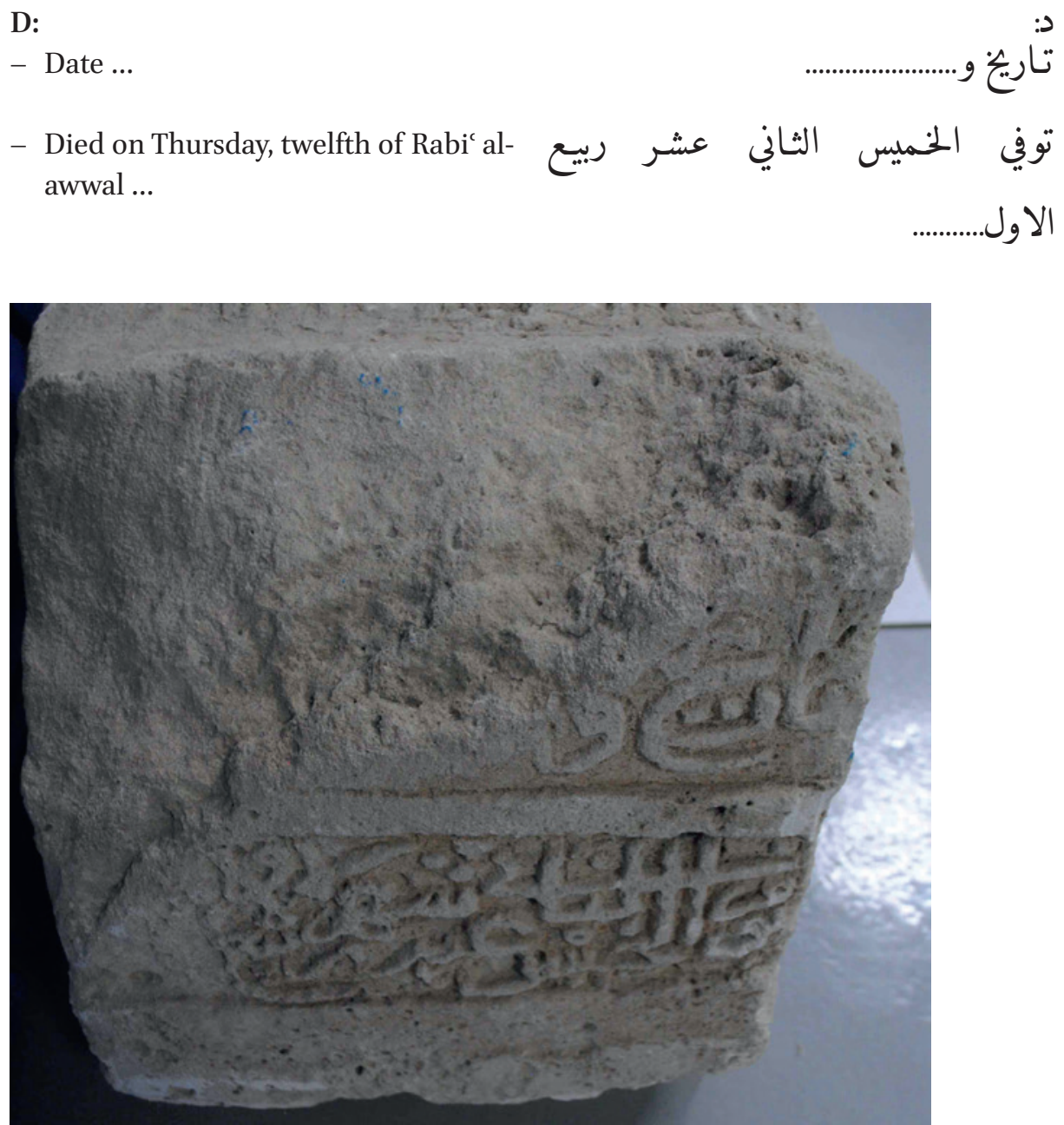

FIGURE 2.409 Surface D, MUS6

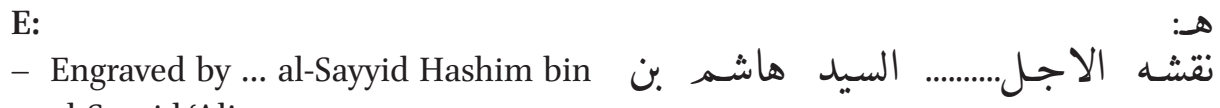
al-Sayyid 'Ali.

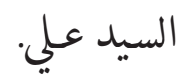

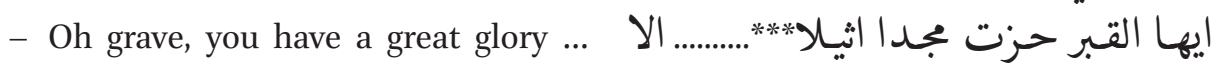
incomparable.

يضا.

- And you have a highness and pride more than the stars with Sulayman ...

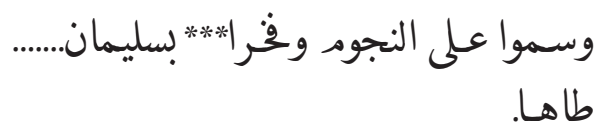

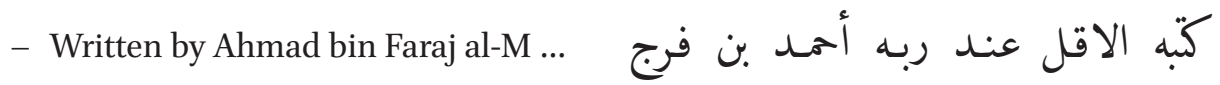




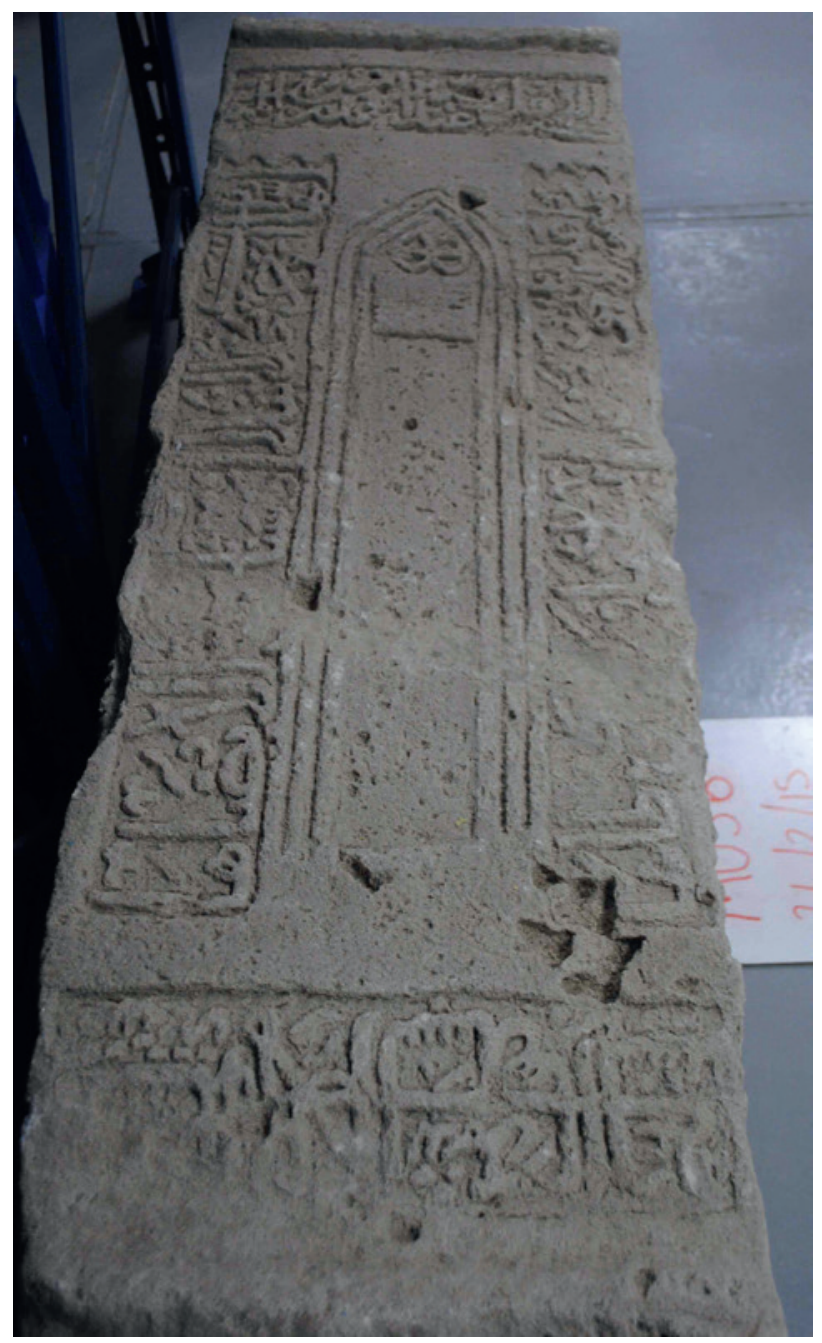

FIGURE 2.410

Surface E, MUs6

\section{Reference Number: MUS7}

\section{Co-ordinates: NA}

\section{Dimensions:}

Panel 1: $161 \mathrm{~cm}(\mathrm{l}) \times 22 \mathrm{~cm}(\mathrm{w})$

Panel 2: $164.5 \mathrm{~cm}(\mathrm{l}) \times 21 \mathrm{~cm}(\mathrm{w})$

\section{Orientation: NA}

Description: Two gypsum panels on display in the Islamic Gallery at the Bahrain National Museum (Figures 2.411 and 2.412). These are described in the gallery text 
panel as "dating from the 13th and 13th centuries, were found in the ruins of a Dilmun temple near Sar village. They bear Arabic inscriptions and floral decorations which had been carved in wood and pressed into the wet plaster, section by sections. The inscriptions on one were inverted".

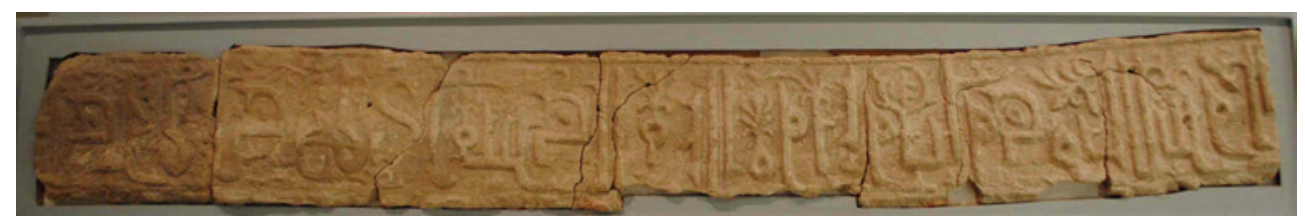

FIGURE 2.411 Surface A, MUS7

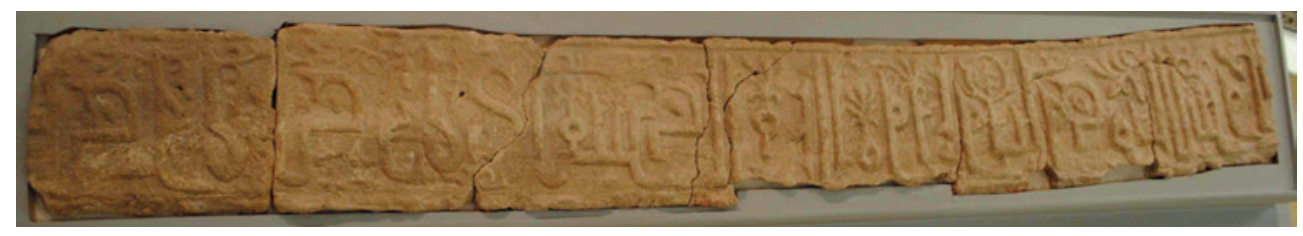

FIGURE 2.412 Surface B, MUS7

Previous Publication: Number 40, Kalus (1990: 75-76)

\section{Arabic Transcription and Translation:}

The inscriptions cannot be read

Reference Number: MUS8

\section{Co-ordinates: NA}

Dimensions: Double slabs measured as single slab. $134.5 \mathrm{~cm}(\mathrm{l}) \times 27.5 \mathrm{~cm}(\mathrm{w}) \times$ $52 \mathrm{~cm}(\mathrm{~h})$

\section{Orientation: NA}

Description: Double limestone slab gravestone on display in the Islamic Gallery at the Bahrain National Museum. Roughed out unfinished gravestone which has been cut to size but left decoratively uncarved (Figure 2.413). A rectangular block for raised decoration is cut at each end with a rectangular plinth below it. Cut marks evident on the side surfaces (A and B), and chisel marks on the lower rectangular plinth. Four shallow linear cup marks cut into the upper surface. No decorative carving or inscriptions. 


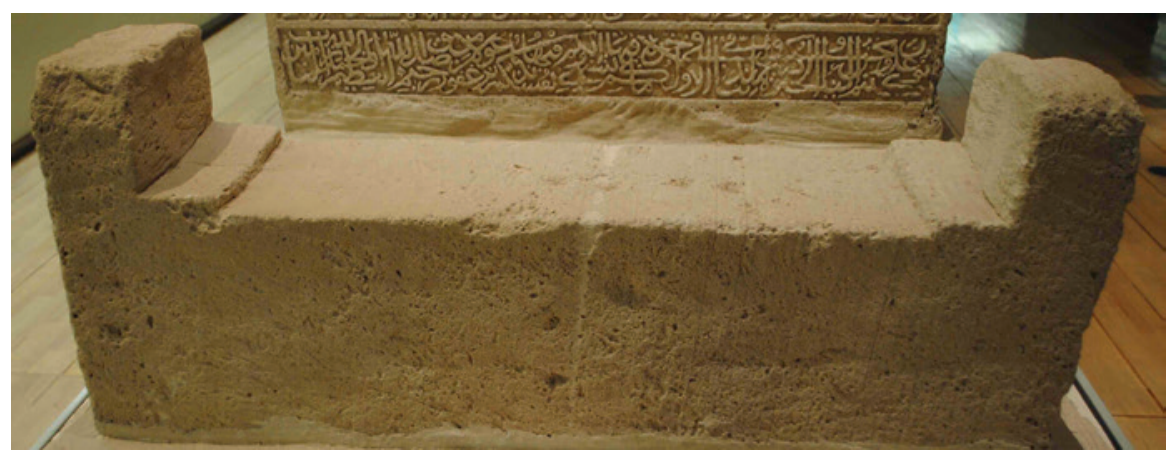

FIGURE 2.413 MUS8

\section{Arabic Transcription and Translation: No inscriptions}

\section{Reference Number: MUs9}

\section{Co-ordinates: NA}

Dimensions: $136.5 \mathrm{~cm}(\mathrm{l}) \times 3^{2} \mathrm{~cm}(\mathrm{w}) \times 50.5 \mathrm{~cm}(\mathrm{~h})$

\section{Orientation: NA}

Description: Single limestone slab gravestone on display in the Islamic Gallery at the Bahrain National Museum. Three element raised decoration formed of two facetted cubes and a central thin rounded arch all set on a rectangular plinth at each end. Shallow carved rounded niche design on upper surface (E). Some localised impact damage on sides of the upper surface (E), and on one side surface (B). Inscriptions on five surfaces.

Previous Publication: Number 14, Kalus (1990: 39). The original location is given as the caretaker's garden, cemetery, Suq al-Khamis.

\section{Arabic Transcription and Translation:}

A:

- In the Name of Allah, the Most Gracious, the Most Merciful. Allah, none has the right to be worshipped but he, the Ever Living, the One Who sustains and protects all that exists.

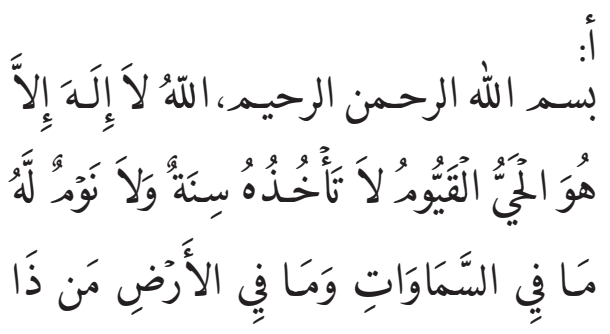


Neither slumber nor sleep overtakes Him. To Him belongs whatever is in the heavens and whatever is on the earth. Who is he that can intercede with Him except by His permission! He knows what happens to them in this world, and will happen to them in the Hereafter and they will never

- Compass anything of His Knowledge except that which He wills. His Seat extends over the heavens and the earth. And He feels no fatigue in guarding and preserving them. And He is the Most High, the Most Great. There is no compulsion in religion. Verily, the Right Path has become distinct from the wrong path. Whoever disbelieves in Taghut and believes in Allah, then he has grasped the most trustworthy handhold that will never break.

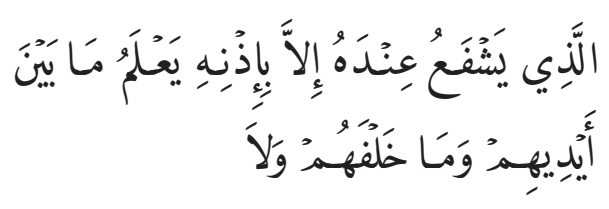

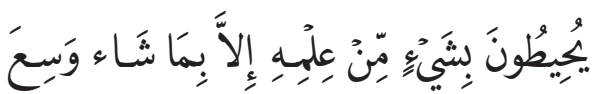

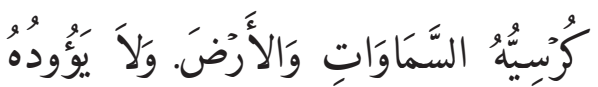

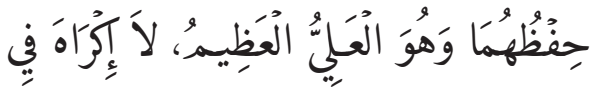

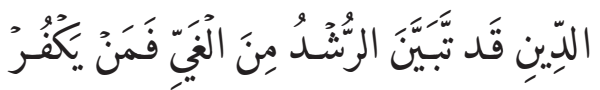

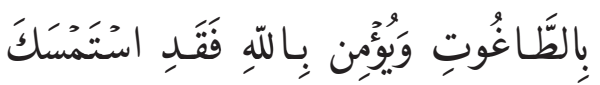

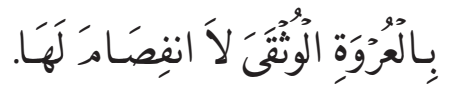

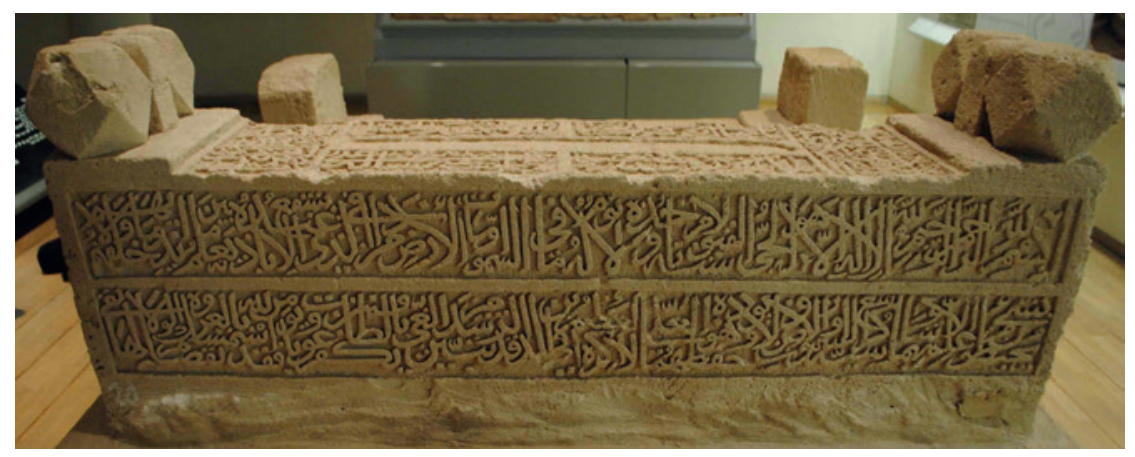

FIGURE 2.414 Surface A, MUs9

B:

- And Allah is All-Hearer, AllKnower (2:255-256). Their sides forsake their beds, to invoke their Lord in fear and hope, and they spend out of what We have

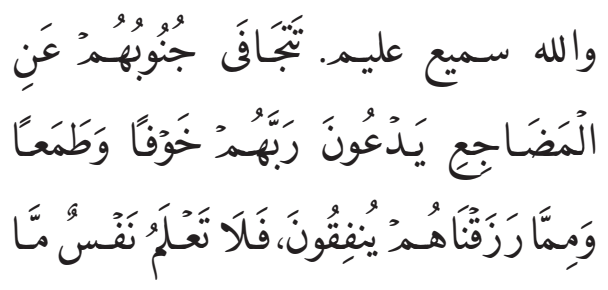


bestowed on them. No person knows what is kept hidden for them of joy as reward for what they used to do (32:16-17). The angels descend upon them, saying: Fear not nor grieve, but receive the glad tidings of the paradise

- Which you have been promised. We have been your friends in the life of this world and are in the Hereafter. Therein you shall have all that your inner-selves desire, and therein you shall have all for which you ask. An entertainment from the Oft-Forgiving, Most Merciful (41:30-32). God Almighty has spoken the truth. And praise be to Allah, Lord of the worlds.
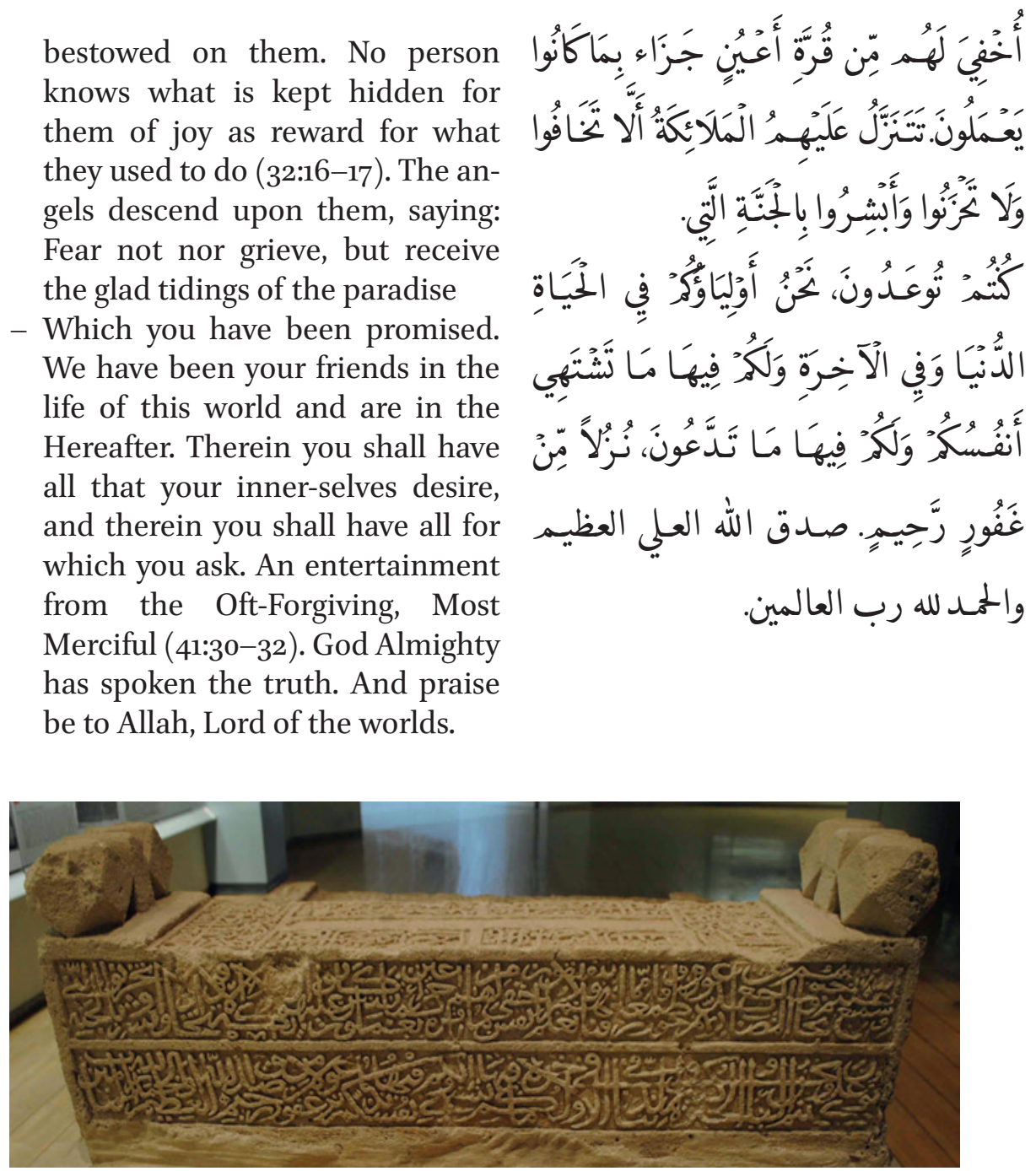

FIGURE 2.415 Surface B, MUS9

C:

- This is the grave of the late, al-Hajj 'Ali bin the late

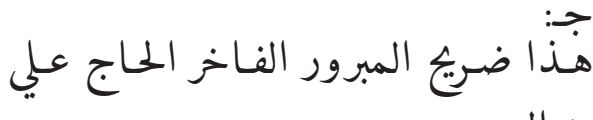

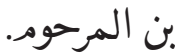

- Naser bin Iskandar. His death was on second of Jumada al-awwal, year 1106 .

ناصر بن اسكندر وكانت وفاته لليلتن خلتا من شـ...(شهر ) جمادى الاول سنة وكن 


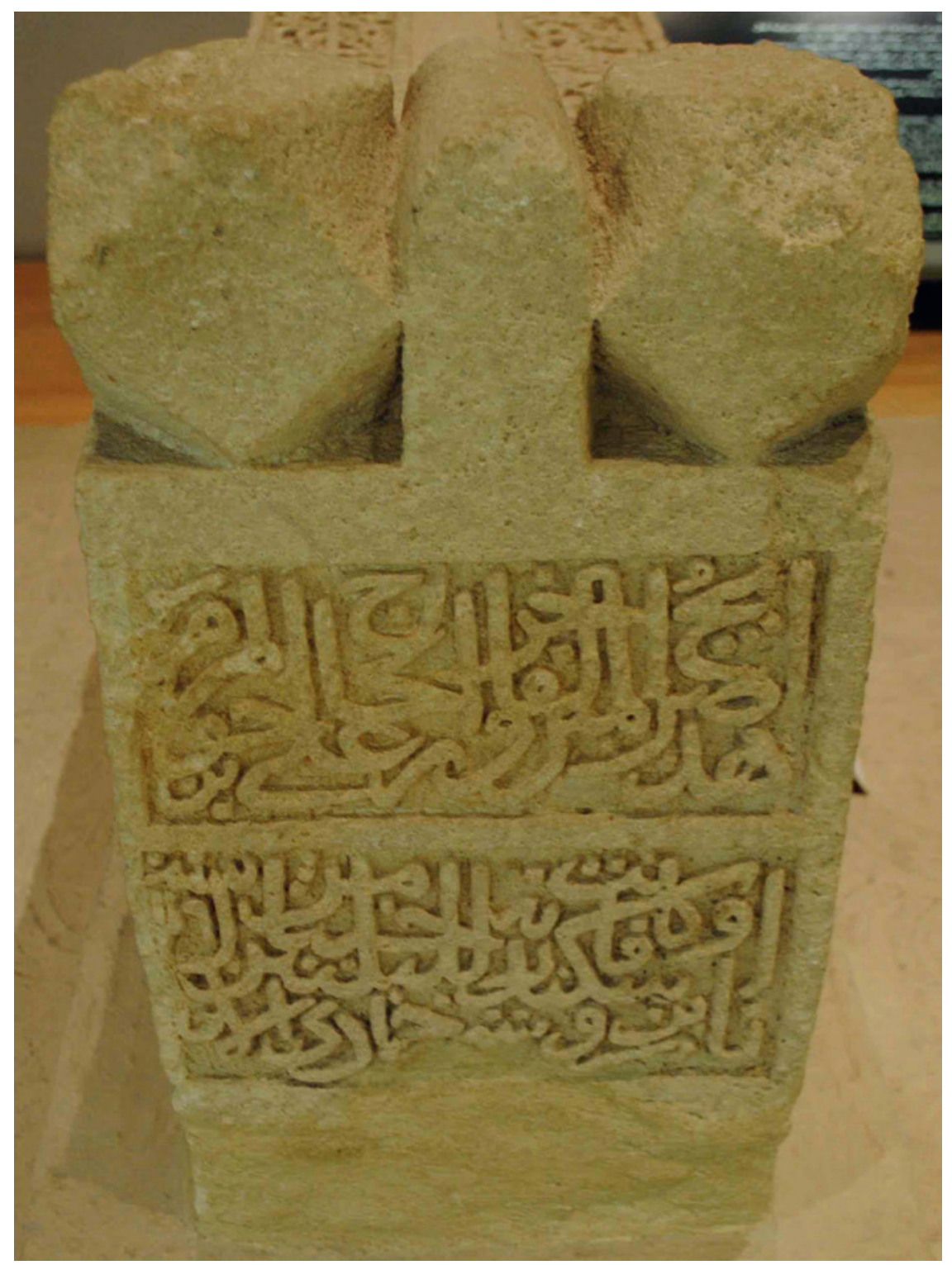

FIGURE 2.416 Surface C, MUS9

D:

- Reading one part of the Book of God every day, ... for twenty mann ... dates.

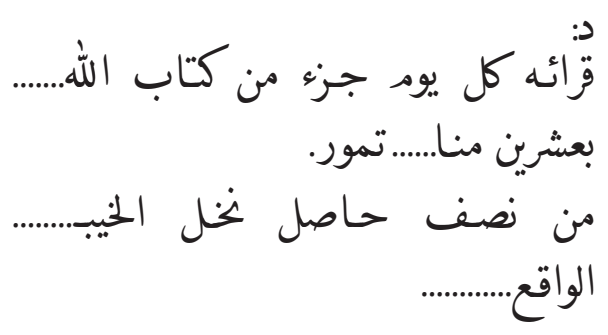

- From half of Alkhaieb ... crops ... located ... 


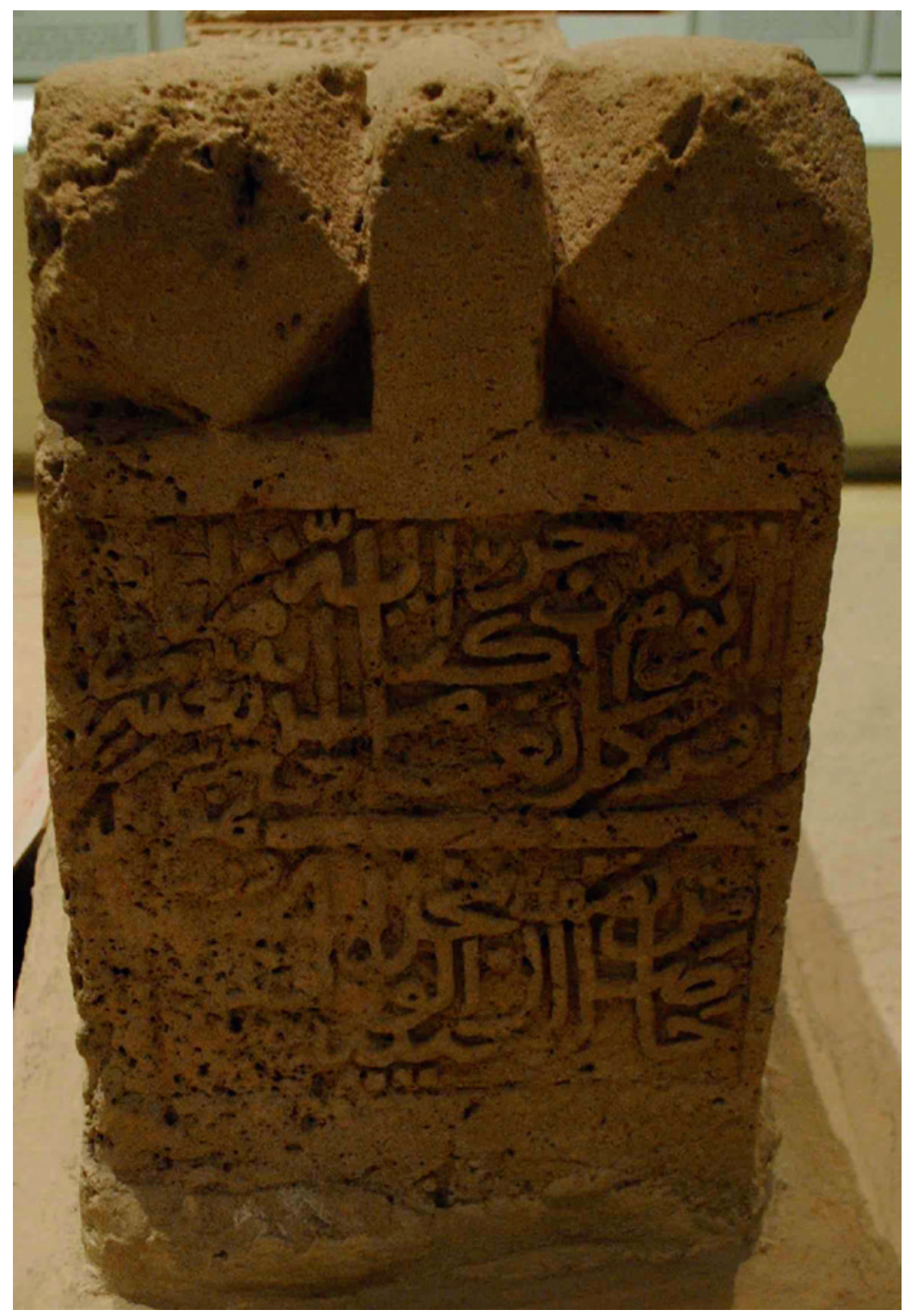

FIGURE 2.417 Surface D, MUS9

E:

- Engraved by al-Sayyid 'Alawi bin alSayyid Naser.

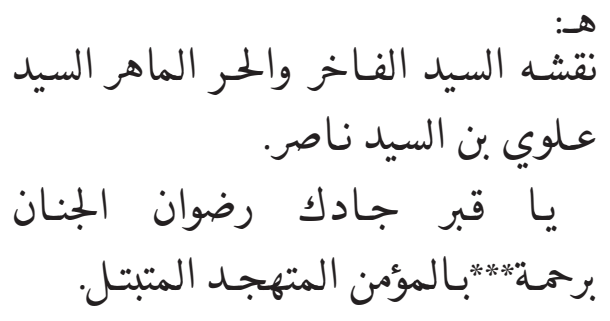

- Oh grave, the paradise guard gave you the mercy because you embedded a faithful person who was praying all the time. 
مـا انت الا روضـة في جنة ج*** طابت you embedded a good man his name is 'Ali.

- Written by 'Ali bin Abdullah ... al-Bahrani.

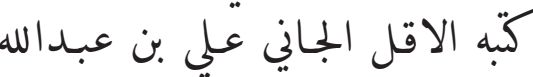
البحراني.

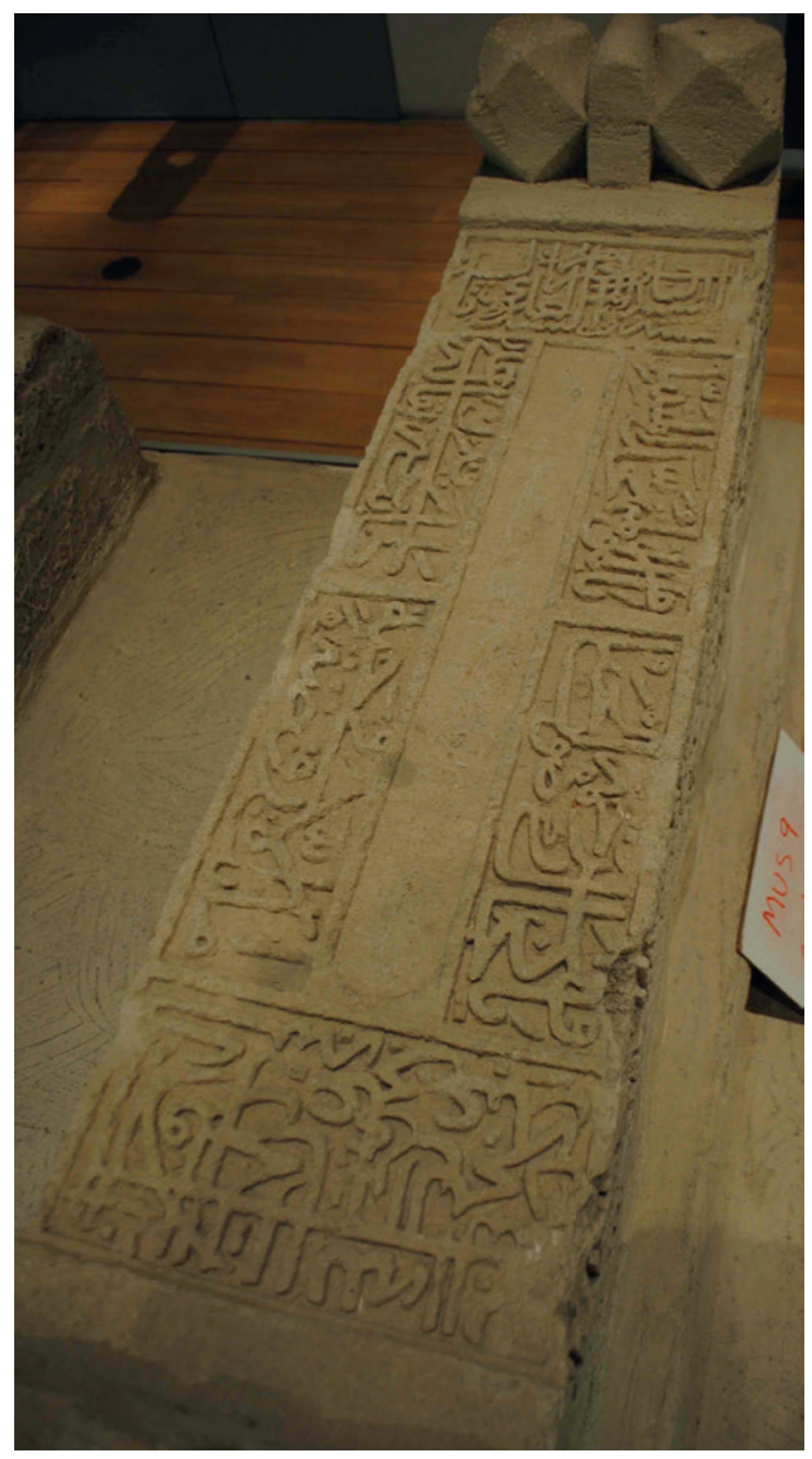

FIGURE 2.418

Surface E, MUs9 


\section{Reference Number: MUS10}

\section{Co-ordinates: NA}

Dimensions: $134 \mathrm{~cm}(\mathrm{l}) \times 30.5 \mathrm{~cm}(\mathrm{w}) \times 36 \mathrm{~cm}(\mathrm{~h})$

\section{Orientation: NA}

Description: Single limestone slab gravestone on display in the Islamic Gallery at the Bahrain National Museum. Some erosion. Raised decoration cut off at each end. Inscriptions on five surfaces.

Previous Publication: Number 15, Kalus (1990: 42). Number 14, Kalus (1990: 39). The original location is given as the caretaker's garden, cemetery, Suq al-Khamis.

\section{Arabic Transcription and Translation:}

A:

- In the Name of Allah, the Most Gracious, the Most Merciful. Allah, none has the right to be worshipped but he, the Ever Living, the One Who sustains and protects all that exists. Neither slumber nor sleep overtakes Him. To Him belongs whatever is in the heavens and whatever is on the earth. Who is he that can intercede with Him except by His permission! He knows what happens to them in this world, and will happen to them in the Hereafter

- And they will never Compass anything of His Knowledge except that which He wills. His Seat extends over the heavens and the earth. And He feels no fatigue in guarding and preserving them. And $\mathrm{He}$ is the Most High, the Most Great. There is no compulsion in religion. Verily, the Right Path has become distinct from the wrong path. Whoever disbelieves in Taghut and believes in Allah, then he has grasped the most trustworthy handhold (2:255-256).
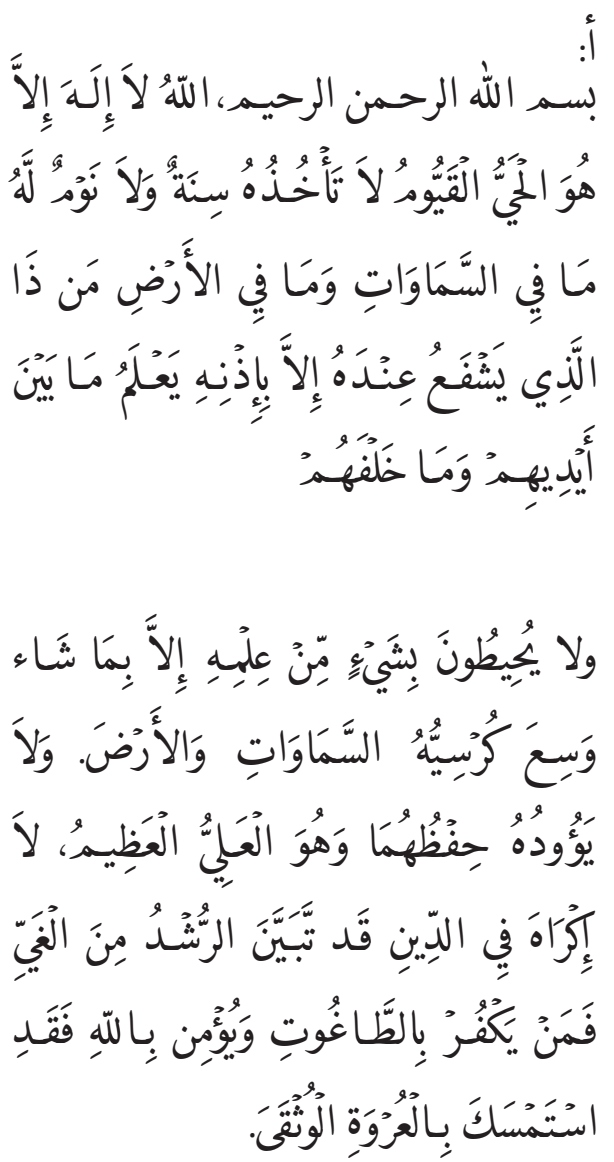


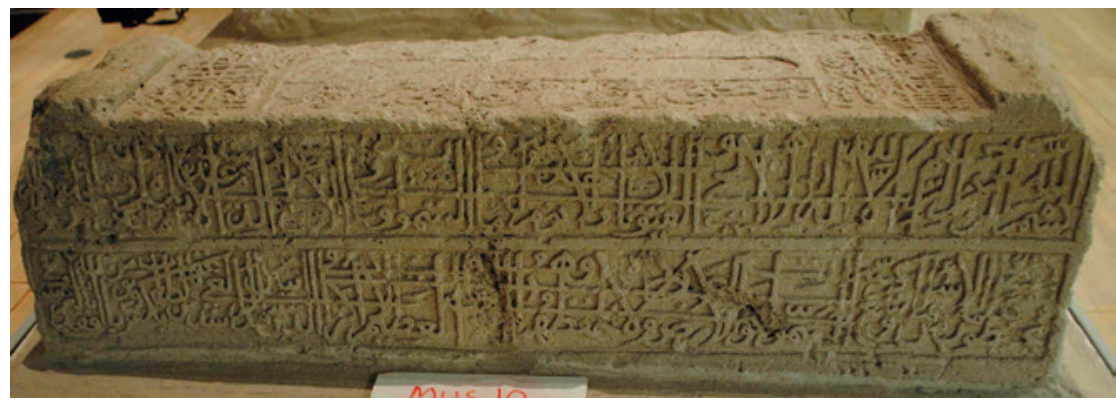

FIGURE 2.419 Surface A, MUS10

B:

- ... Their Lord gives them glad tidings of Mercy from Him, and His being pleased, and of Gardens for them wherein are everlasting delights. They will dwell therein forever (9:21-22)

- ... Fear not nor grieve, but receive the glad tidings of the paradise which you have been promised. We have been your friends in the life of this world and are in the Hereafter. Therein you shall have all that your inner-selves desire, and therein you shall have all for which you ask. An entertainment from the Oft-Forgiving, Most Merciful (41:30-32).
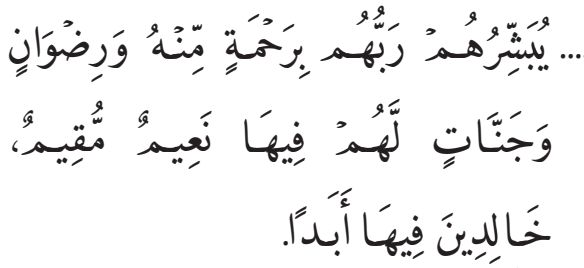

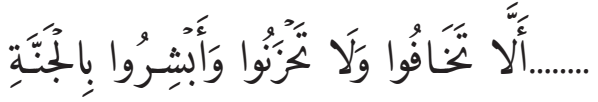
التّ

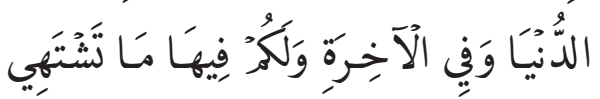

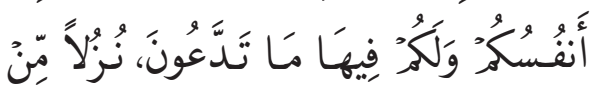
غَفْورِ رَّحِيـدِ.

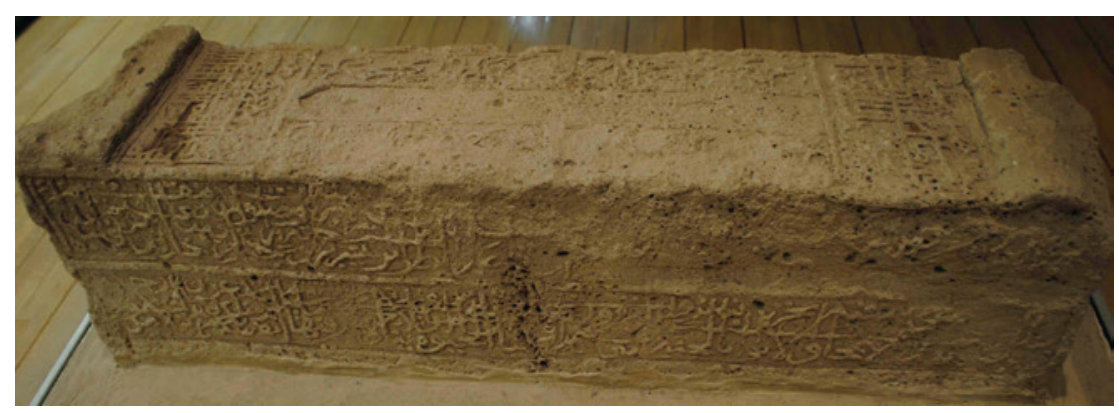

FIGURE 2.420 Surface B, MUS10 
C:

- ... in Rajab in the year of one thousand, one hundred and two, the Inviolable lady, Fa ... bint, died.

...... لشهر رجب الاصم للسنة الثانية.

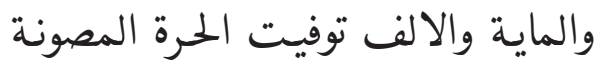

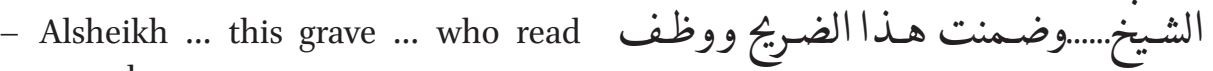
everyday ...

من يقـرآكل .يوم.......

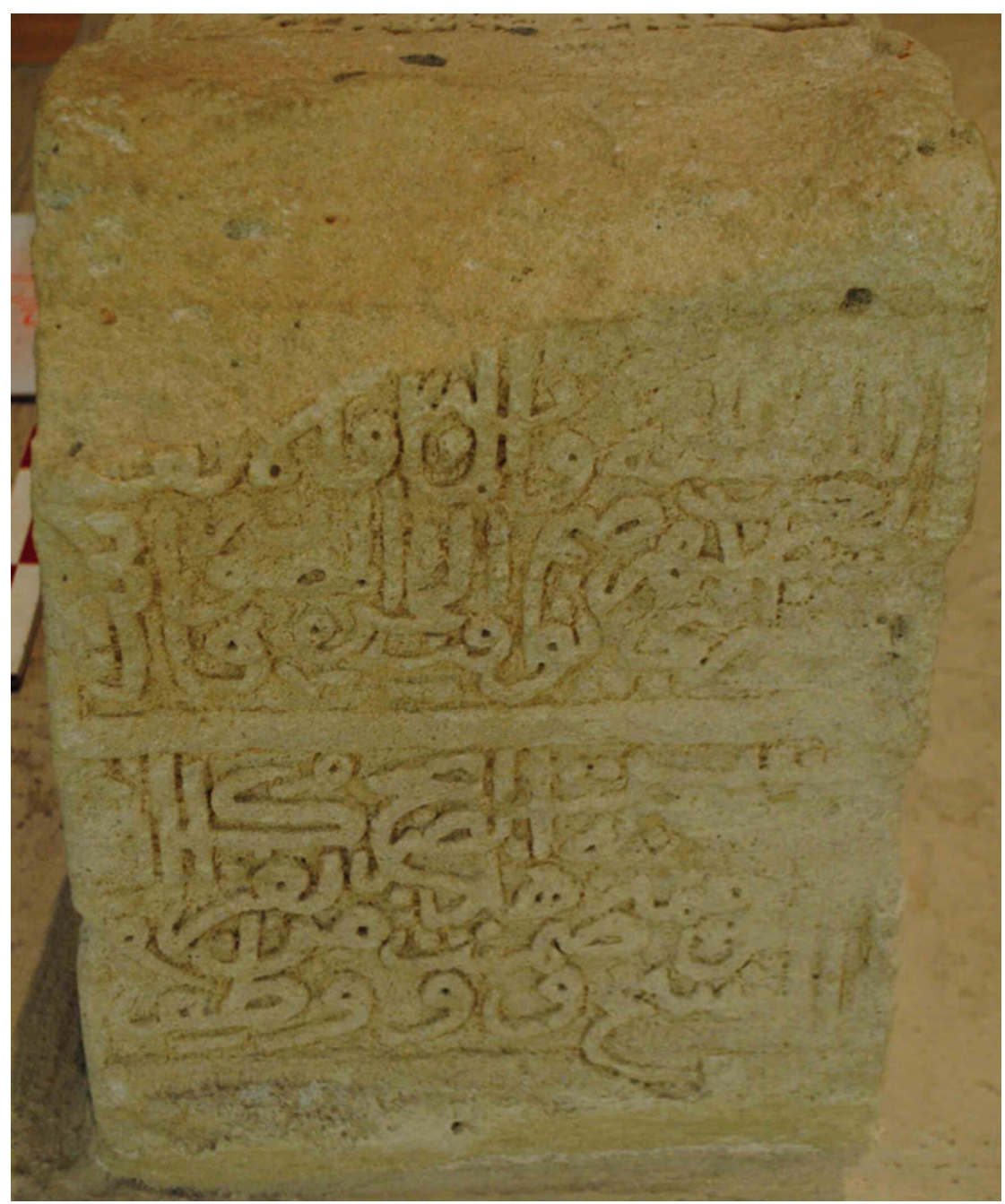

FIGURE 2.421 Surface C, MUS10 
D:

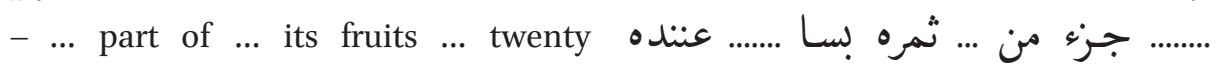
maan ... .

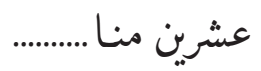

- Basanj at Awal, income of ... Alsahlan سنج من اوال حاصل ح.... السرلكان of Sakyah.

من الساقيه

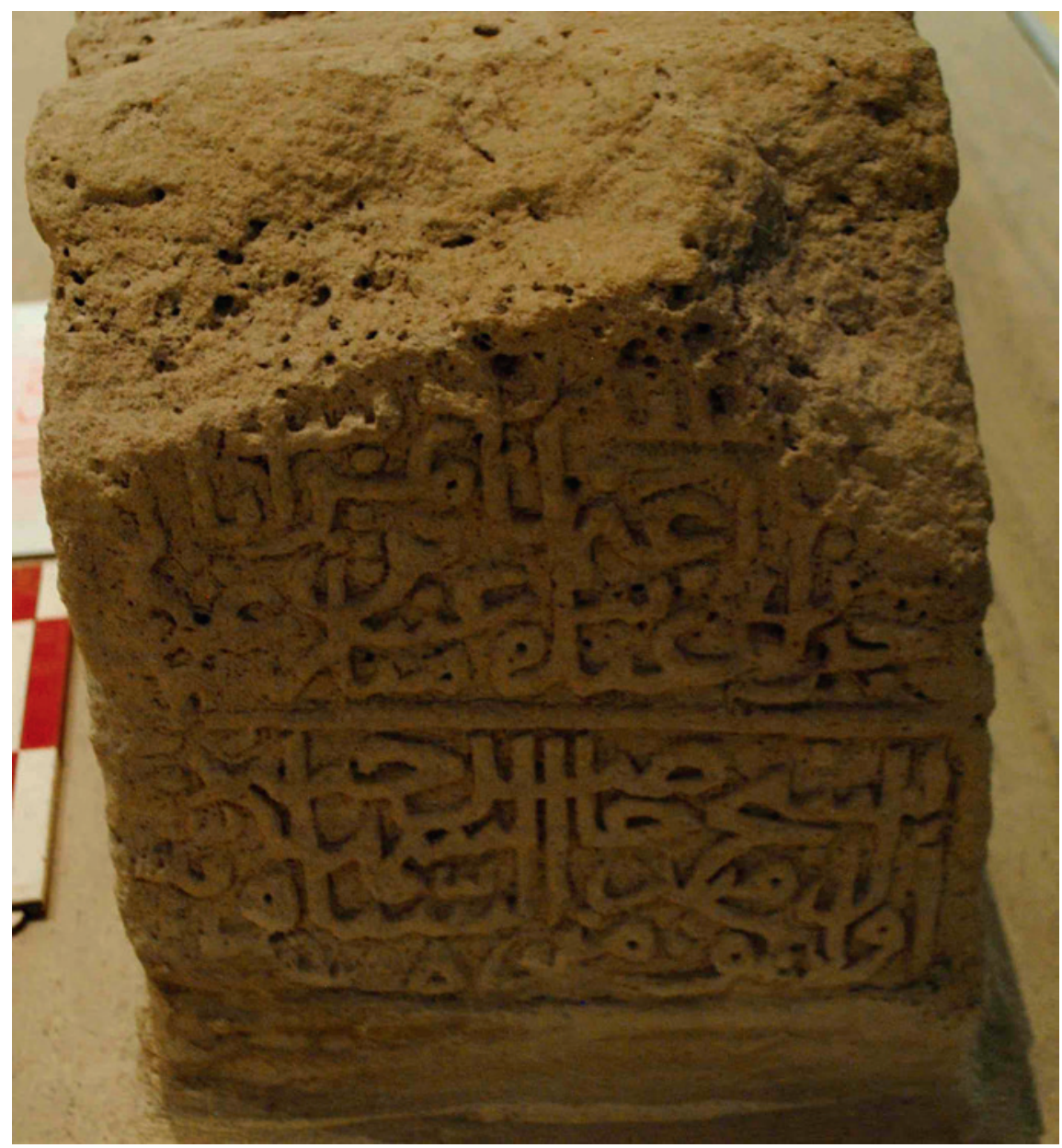

FIGURE 2.422 Surface D, MUS10 
E:

- Engraved by Sayed Hashem bin Sayed Naser Alhussaini Albahrani.

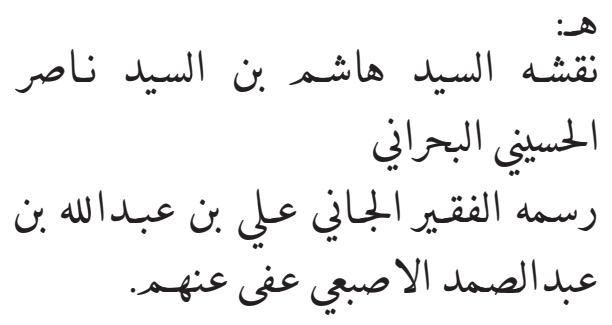
'Abd al-Samad Alosbai. May Allah forgive them.

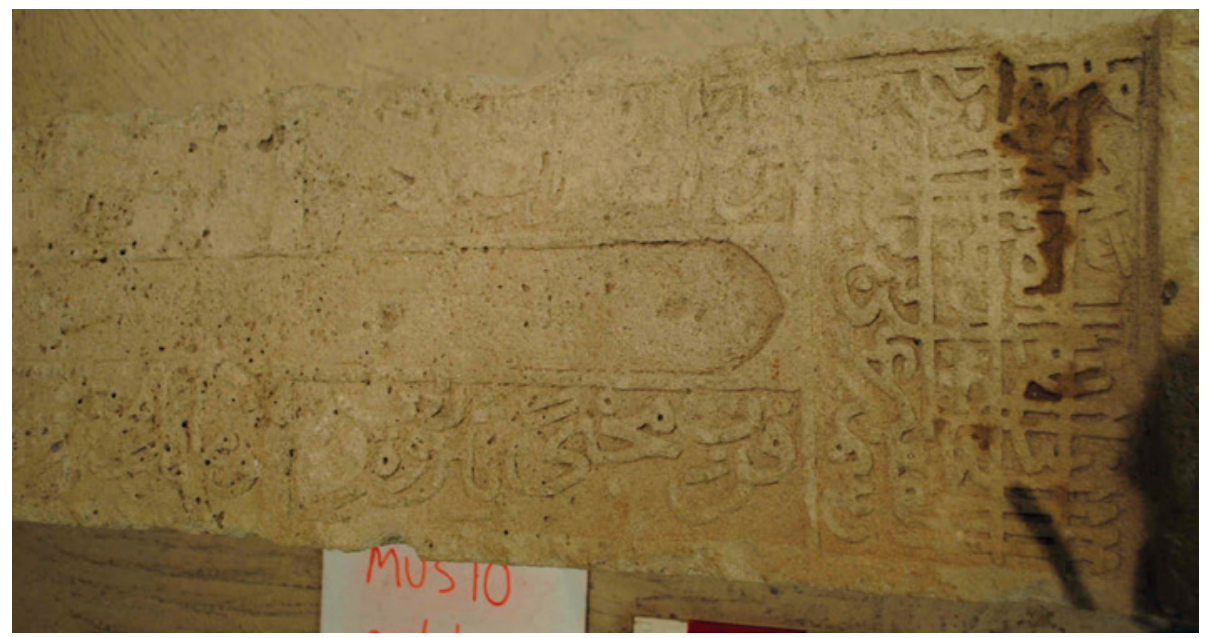

FIGURE 2.423 Surface E, part 1, MUS10

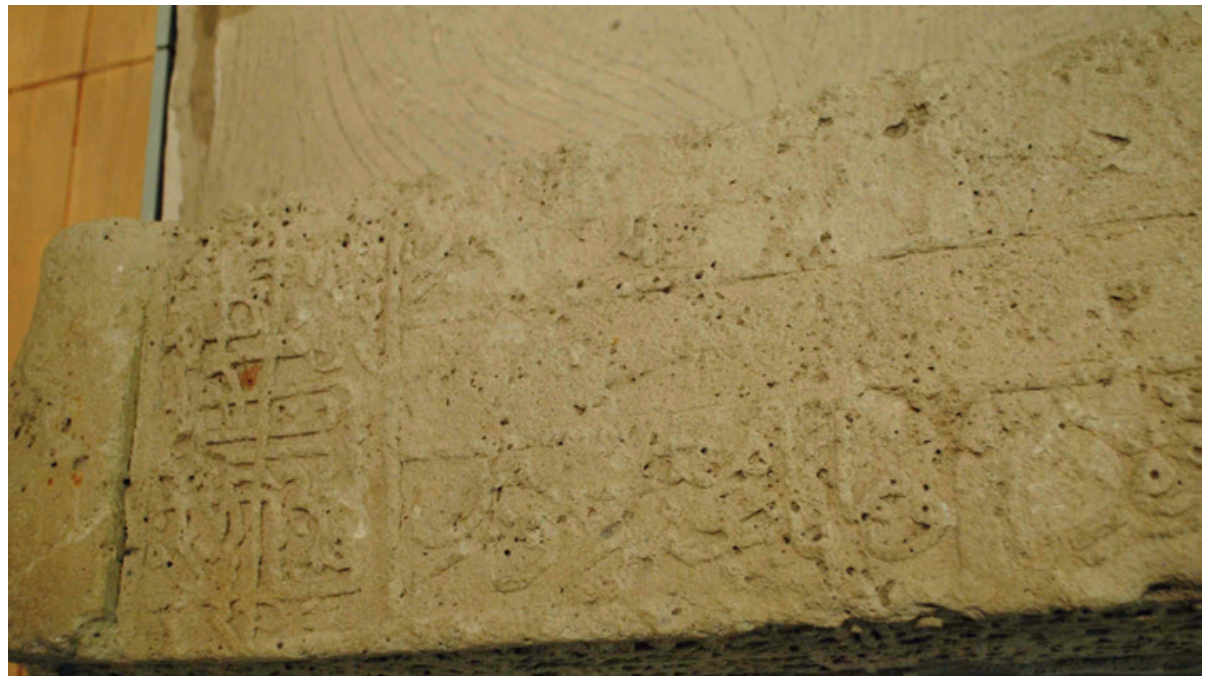

FIGURE 2.424 Surface E, part 2, MUS10 
Reference Number: MUS11

Co-ordinates: NA

Dimensions: $153 \mathrm{~cm}(\mathrm{l}) \times 18.5 \mathrm{~cm}(\mathrm{w}) \times 28 \mathrm{~cm}(\mathrm{~h})$

Orientation: NA

Description: Double limestone slab gravestone in the store at Bahrain National Museum. Badly damaged in places, particularly on the upper surface (E). Traces of red paint/pigment on some of the lettering on three surfaces. Inscriptions on three surfaces.

\section{Arabic Transcription and Translation:}

A:

- In the Name of Allah, the Most Gracious, the Most Merciful ... that Allah may forgive you your sins of the past and the future, and complete His Favour on you, and ...

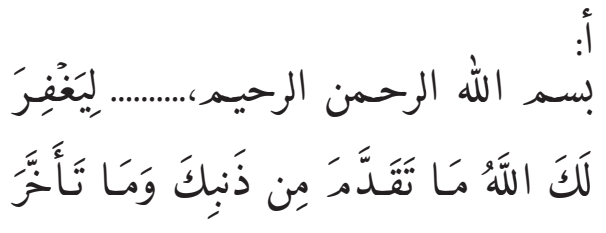

- the straight path. And that Allah may help you with strong help ... (48:2-3). The angels ... upon them, saying: Fear not nor grieve, but receive the glad tidings of the paradise

- Which you have been promised (41:31-32).

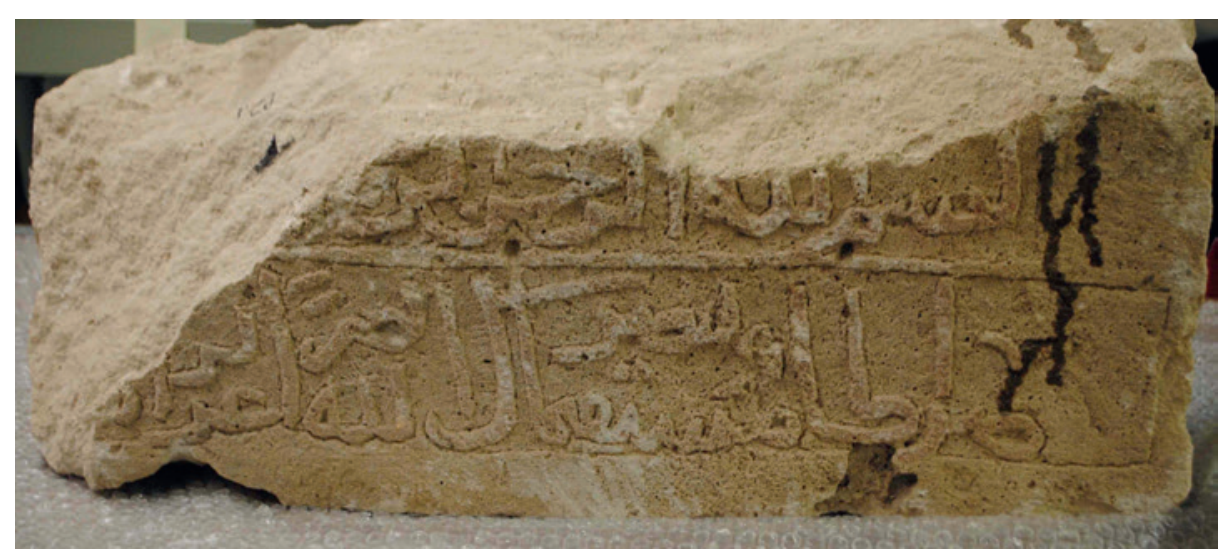

FIGURE 2.425 Surface A, part 1, MUS11 


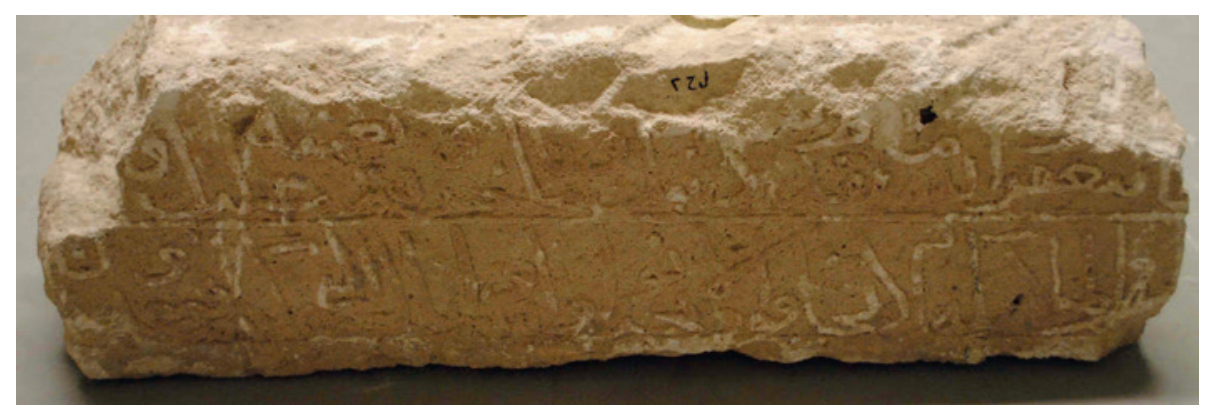

FIGURE 2.426 Surface A, part 2, MUS11

B:

- We have been your friends in the life of this world and are in the Hereafter. Therein you shall have all that your inner-selves desire, and therein you shall have all for which you ask. An entertainment from the OftForgiving, Most Merciful.

- Their Lord gives them glad tidings of Mercy from Him, and His being pleased, and of Gardens for them wherein are everlasting delights. They will dwell therein forever. Verily, with Allah is a great reward. Amin

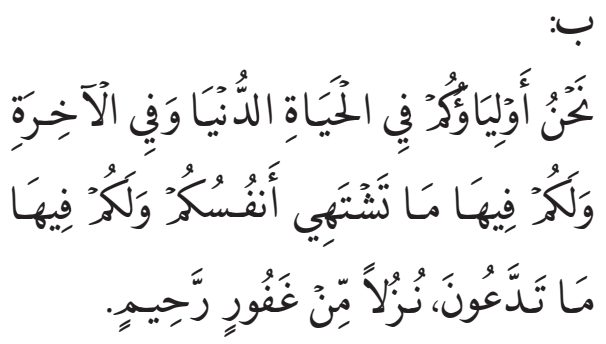
(9:21-22).

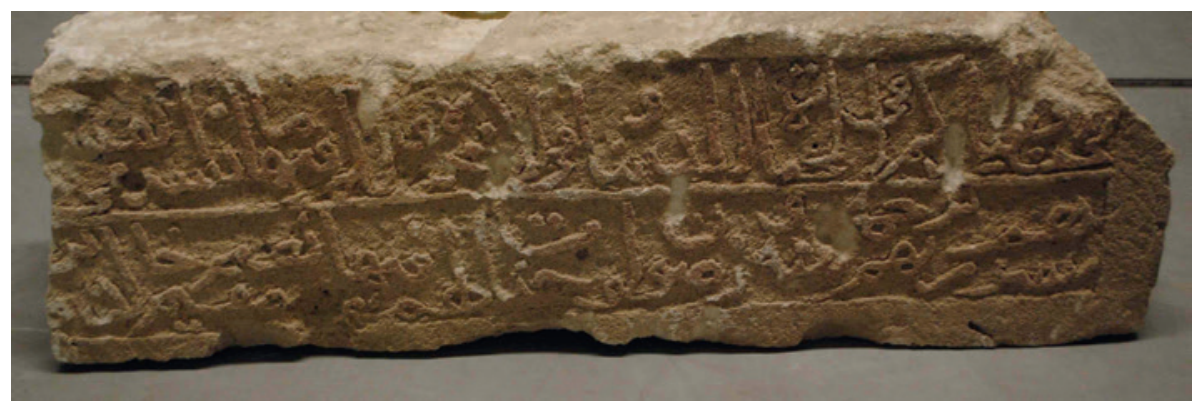

FIGURE 2.427 Surface B, part 1, MUS11

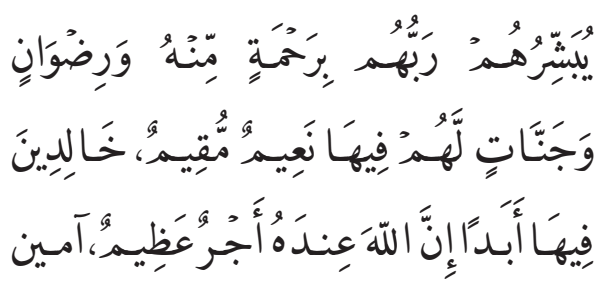




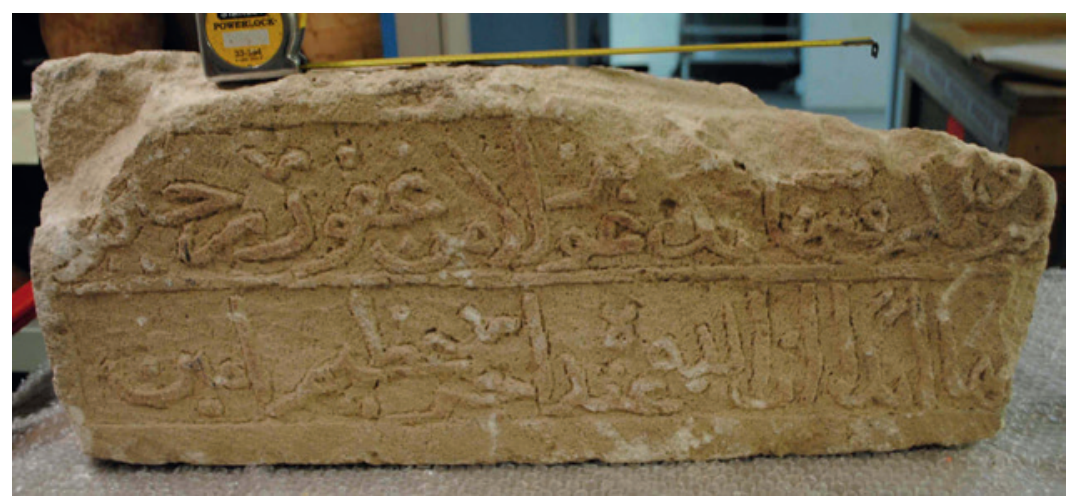

FIGURE 2.428 Surface B, part 2, MUS11

C:

- Grave of the Late, the Savant Shaikh

- Salman bin Husayn bin Majid

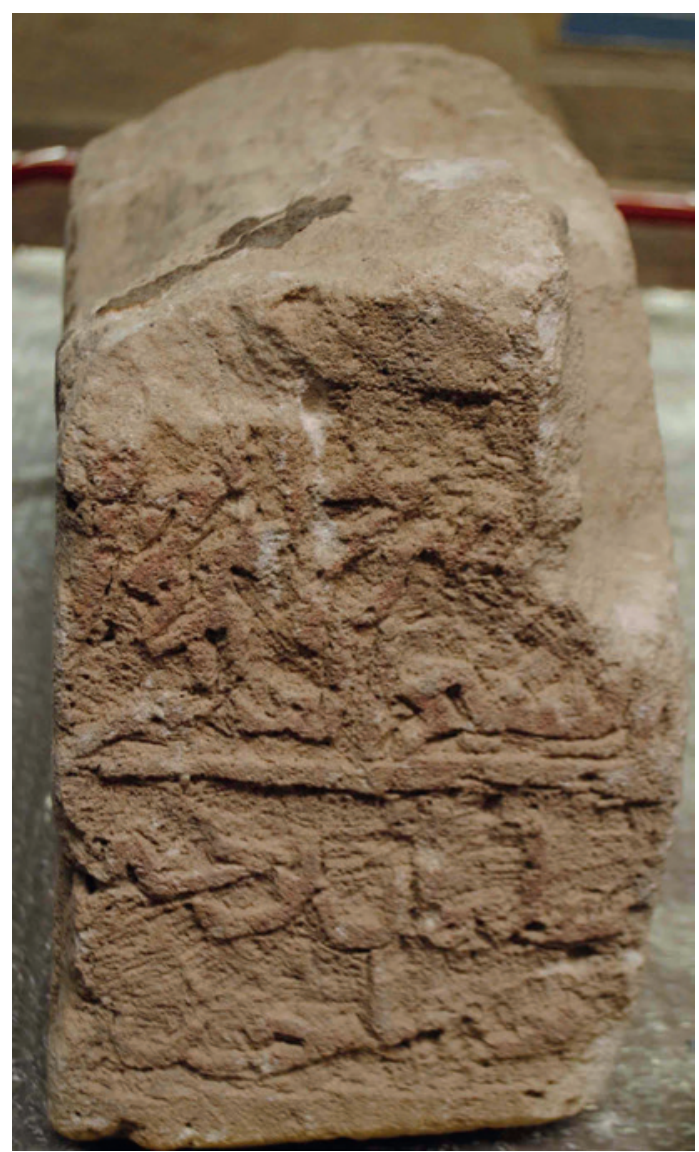

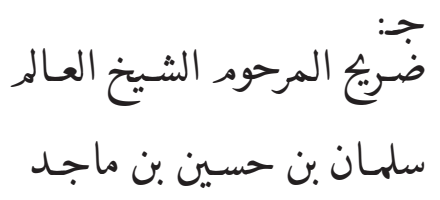

FIGURE 2.429

Surface C, MUS11 
D:

- Very deteriorated. Unable to read.
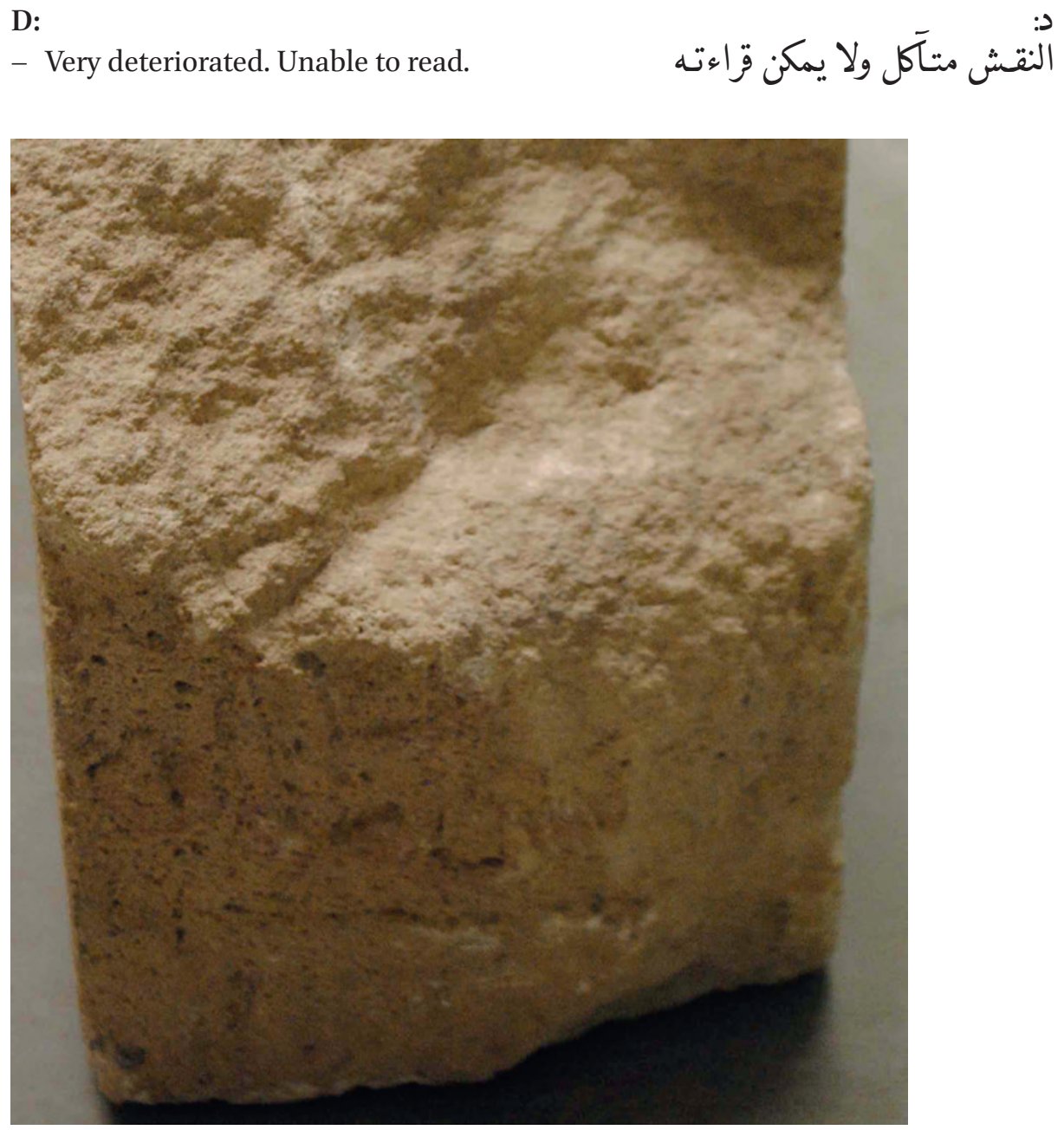

FIGURE 2.430 Surface D, MUS11

E:

- No carving or inscriptions.

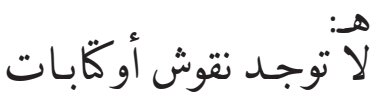

Reference Number: MUS12

Co-ordinates: NA

Dimensions: $76 \mathrm{~cm}(\mathrm{l}) \times 48 \mathrm{~cm}(\mathrm{~h}) \times 21 \mathrm{~cm}(\mathrm{w})$

\section{Orientation: NA}

Description: Single limestone slab from a double slab gravestone in the store at Bahrain National Museum. Eroded on one end surface (D), on one side surface (A), 
and on top surface (E). Possibly defaced on one side surface (B), which also has a circular hole drilled into it. Unusual raised decoration formed of a solid rectangular block that slopes downward to the upper surface (E). Partially legible inscription on one surface and illegible inscription on another.

\section{Arabic Transcription and Translation:}

A:

- ... in religion. Verily, the Right Path has become distinct from the wrong path. Whoever disbelieves in alTaghut and believes in Allah, then he has grasped the most trustworthy handhold that will never break. And Allah is All-Hearer, All-Knower
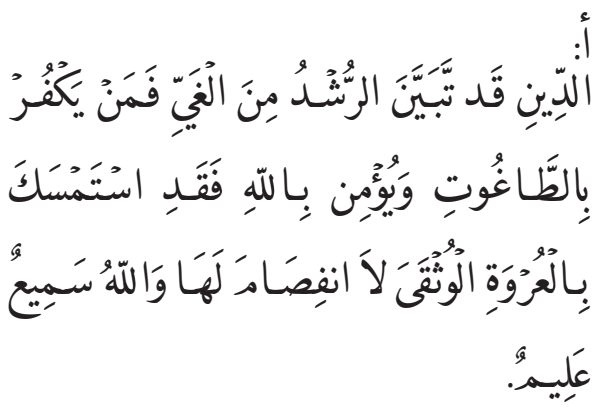
$\left(2: 25^{6}\right)$.

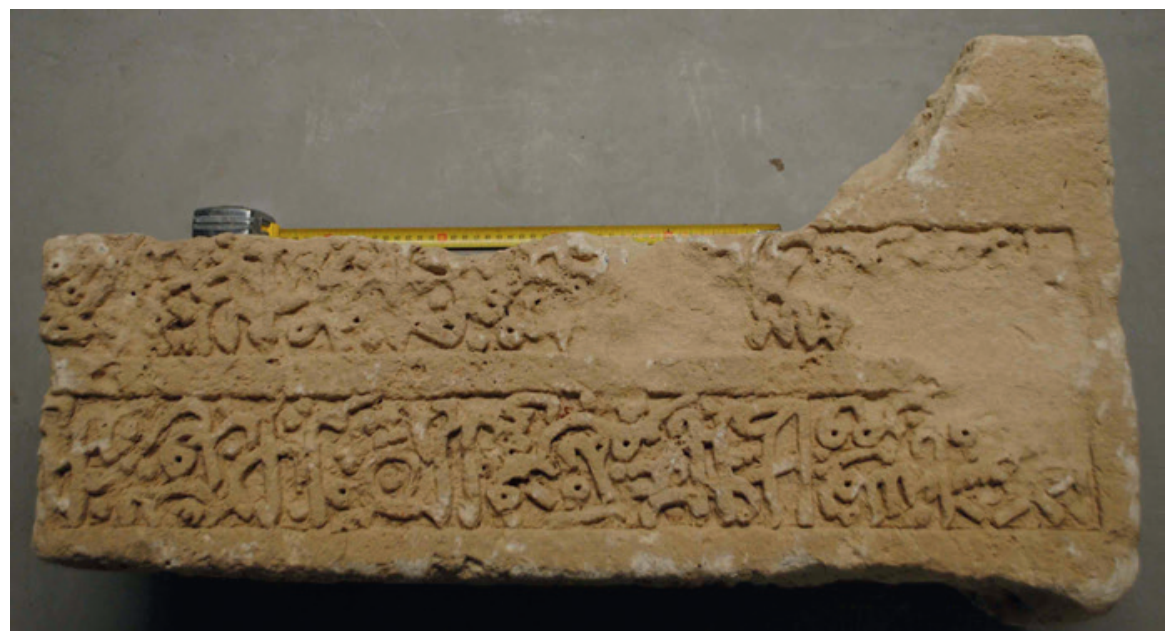

FIGURE 2.431 Surface A, MUS12

B:

- No carving or inscriptions.

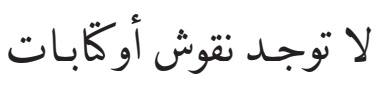




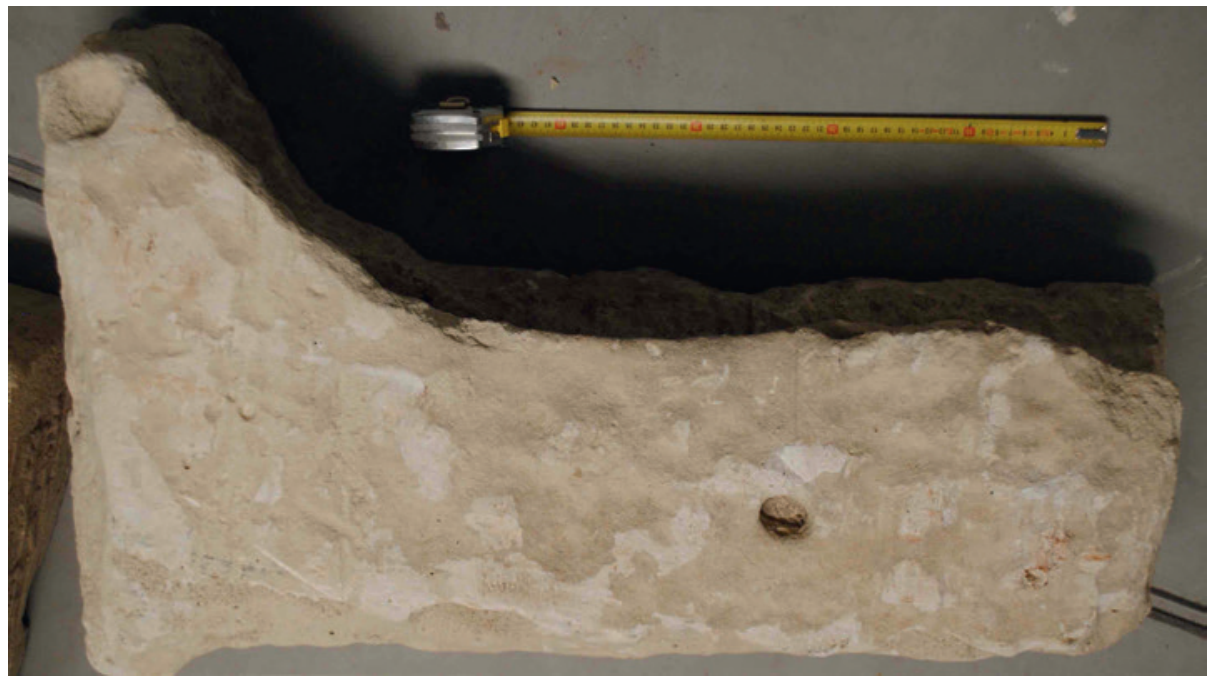

FIGURE 2.432 Surface B, MUS12

C:

- No carving or inscriptions.
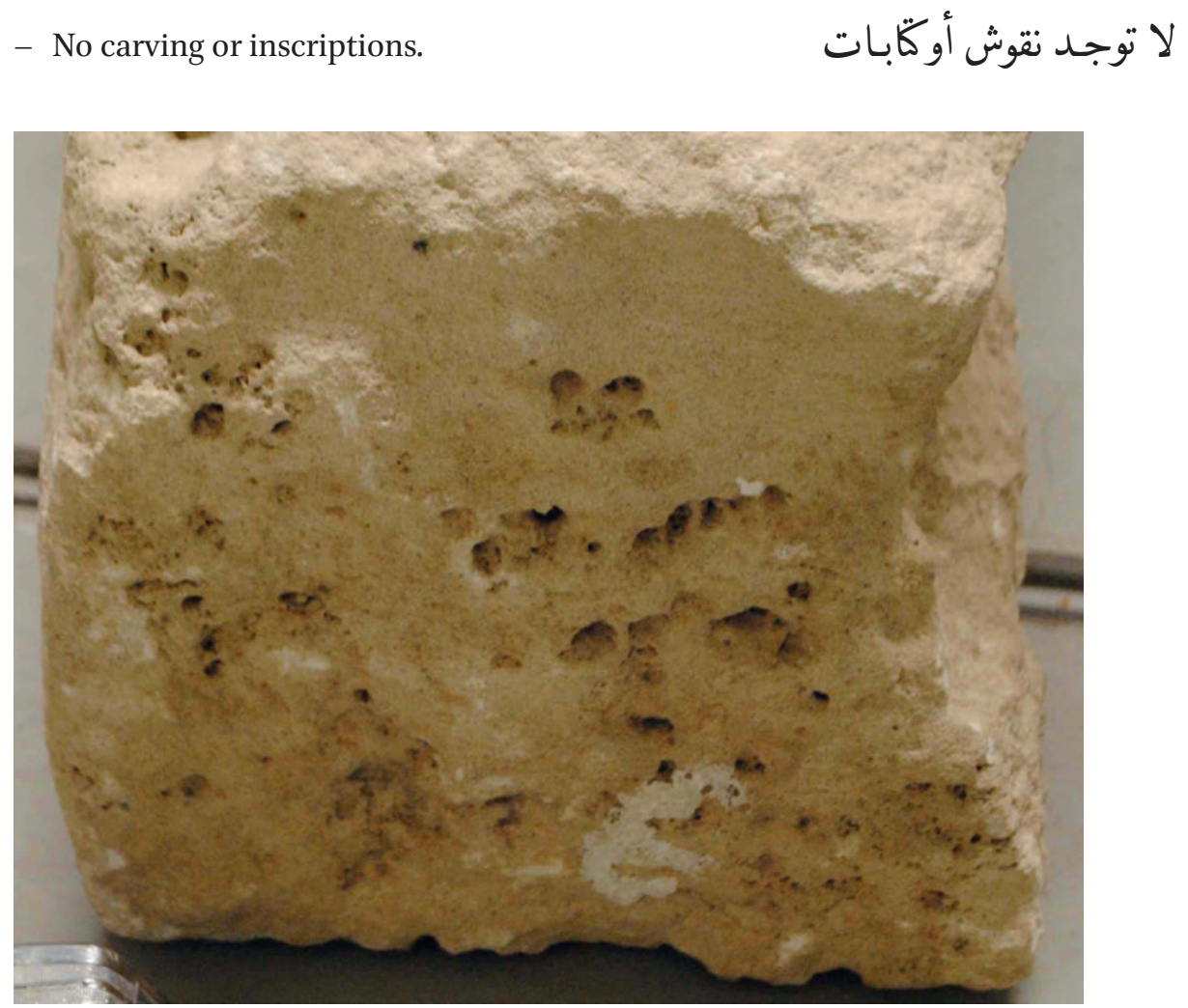

FIGURE 2.433 Surface C, MUS12 
D:

- No carving or inscriptions.

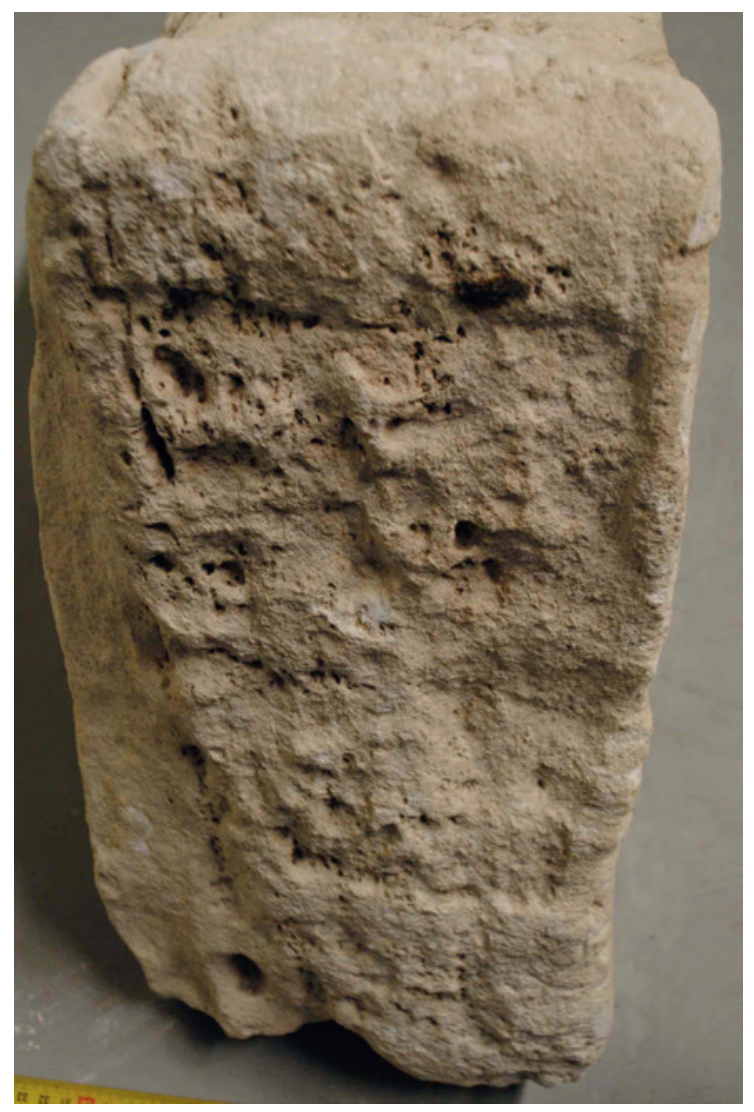

FIGURE 2.434

Surface D, MUS12

E:

- Very deteriorated. Unable to read.
لا توجــ نقوش أوكَّابـات

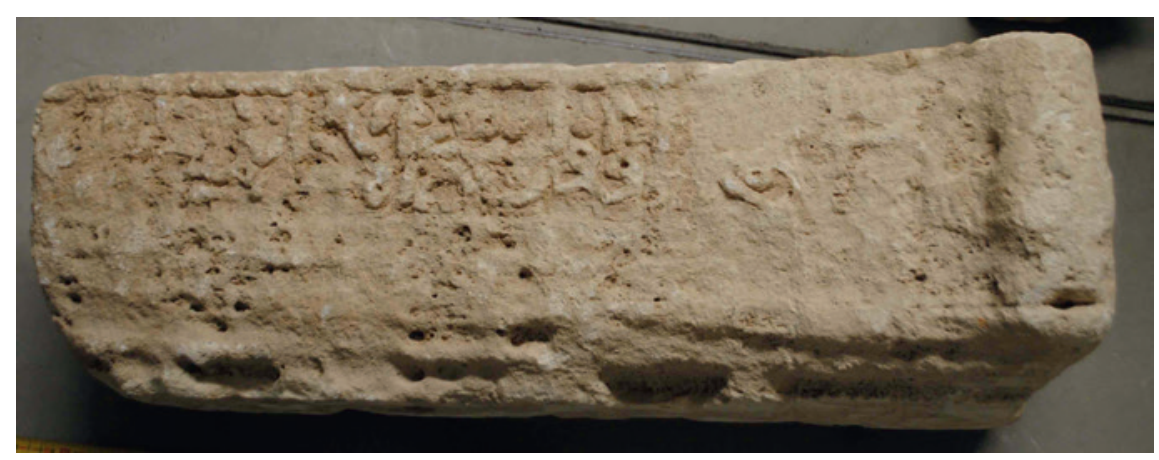

FIGURE 2.435 Surface E, MUS12 
Location: Urban cemetery in Manama

\section{Reference Number: NOA1}

Co-ordinates: $26.22611^{\circ} \mathrm{N} 050.56799^{\circ} \mathrm{E}$

Dimensions: $167 \mathrm{~cm}(\mathrm{l}) \times 30 \mathrm{~cm}(\mathrm{w}) \times 40 \mathrm{~cm}(\mathrm{~h})$

\section{Orientation: NNW-SSE}

Description: Single limestone slab gravestone. Three element raised decoration formed of two facetted cubes and a central thin rounded arch all set on a rectangular plinth at each end. Badly eroded on the top surface (E), on one side surface (A), and on one set of raised decoration. Traces of shallow carved rectangular panel design, probably a niche, on the top surface (E). Inscriptions on five surfaces.

Previous Publication: Number 43, Kalus (1990: 78)

\section{Arabic Transcription and Translation:}

A:

- The angels ... upon them, saying: Fear not nor grieve, but receive the glad tidings of paradise which you have been promised. We have been your friends in the life of this world and are in the Hereafter. Therein you shall have all that your inner-selves desire, and therein you shall have all for which you ask. An entertainment from the Oft-Forgiving ... (41:30-32). Paradise,

- Whose doors ... Therein they will recline, therein they will call for fruits in abundance and drinks. And beside them will be chaste females restraining their glances and of equal ages. This is what you are promised for the day of Reckoning. Verily, this
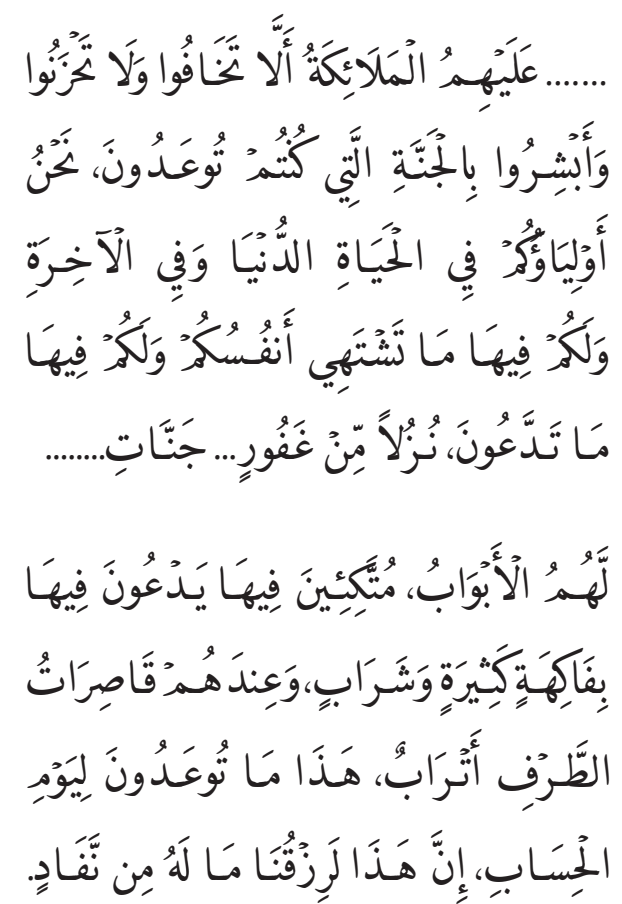
is our provision which will never finish (38:50-54). God Almighty and his Prophet have spoken the truth. Praise be to Allah, Lord of the worlds.

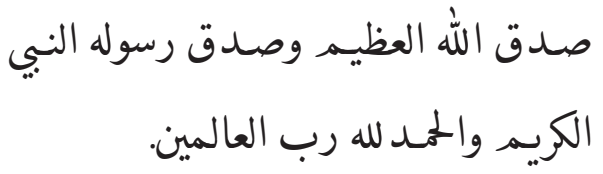

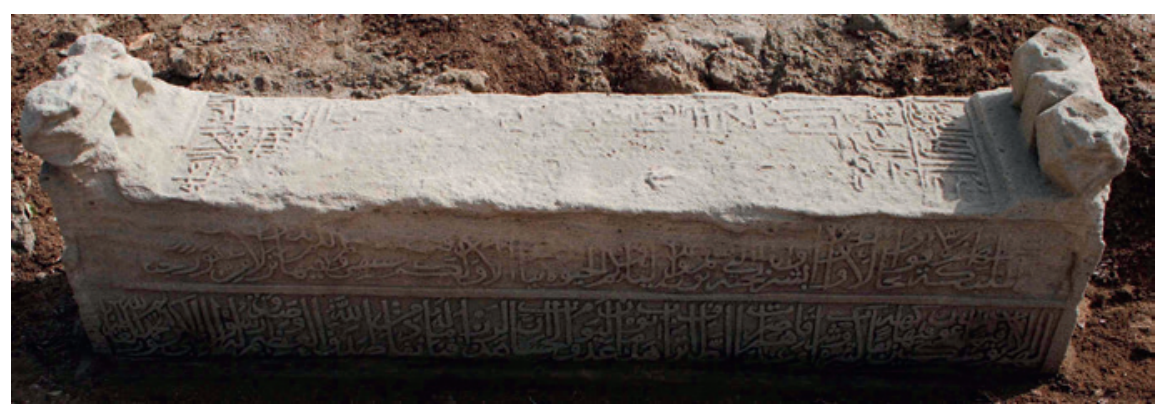

FIGURE 2.436 Surface A, NOA1

B:

- In the Name of Allah, the Most Gracious, the Most Merciful. Allah, none has the right to be worshipped but he, the Ever Living, the One Who sustains and protects all that exists. Neither slumber nor sleep overtakes Him. To Him belongs whatever is in the heavens and whatever is on the earth. Who is he that can intercede with Him except by His permission! He knows what happens to them in this world, and will happen to them in the Hereafter and they will never compass anything of His Knowledge.

- Except that which He wills. His Seat extends over the heavens and the earth. And He feels no fatigue in guarding and preserving them. And $\mathrm{He}$ is the Most High, the Most Great. There is no compulsion in religion. Verily, the Right Path has become distinct from the wrong path. Whoever disbelieves in Taghut and believes in Allah, then he has grasped the most trustworthy handhold that will never break. And Allah is All-Hearer, All-Knower (2:255-256).

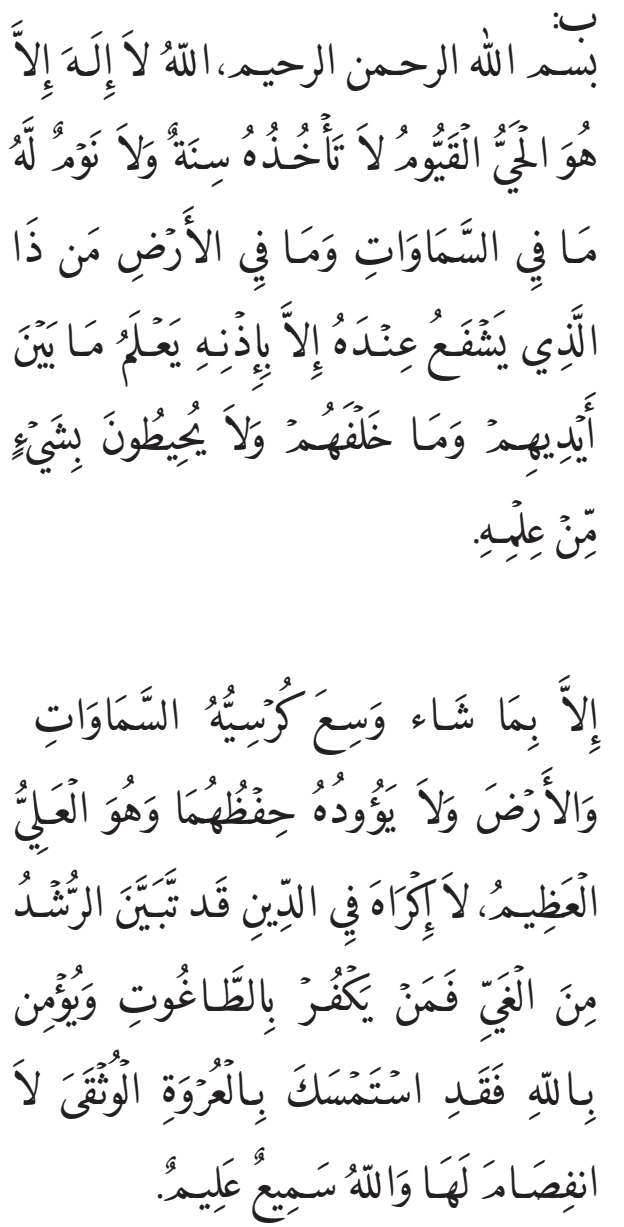




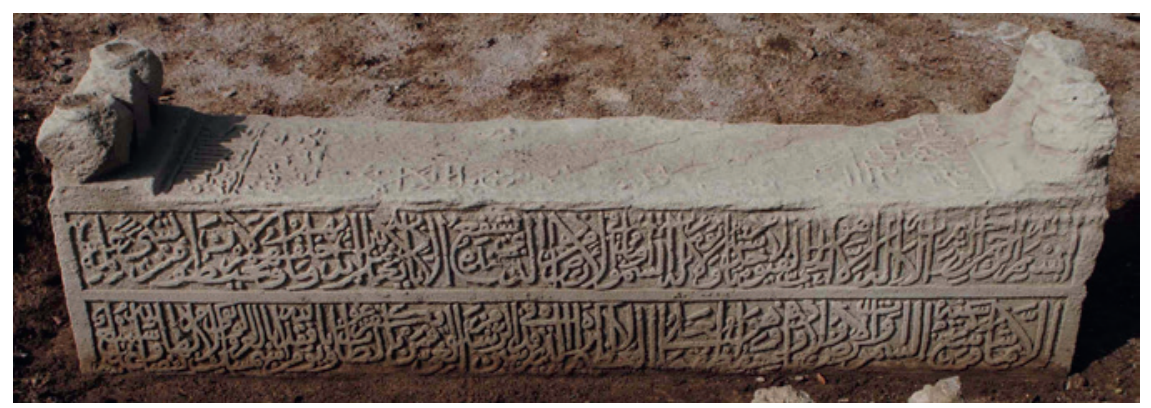

FIGURE 2.437 Surface B, NOA1

C:

- Reading parts of the Book of God the Powerful ... Shaikh.

قراءة اجزاء من كَّب الله العزيز....... Powerful ... Shaikh.

- Good dates from crops of the palms which is known as (possibly Barbaghi al-'Ayn) at Buqwah area.

تمرا سالما من الخزاجات من النخل

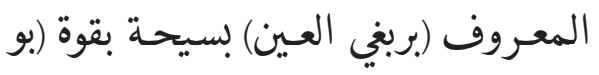

قوة).

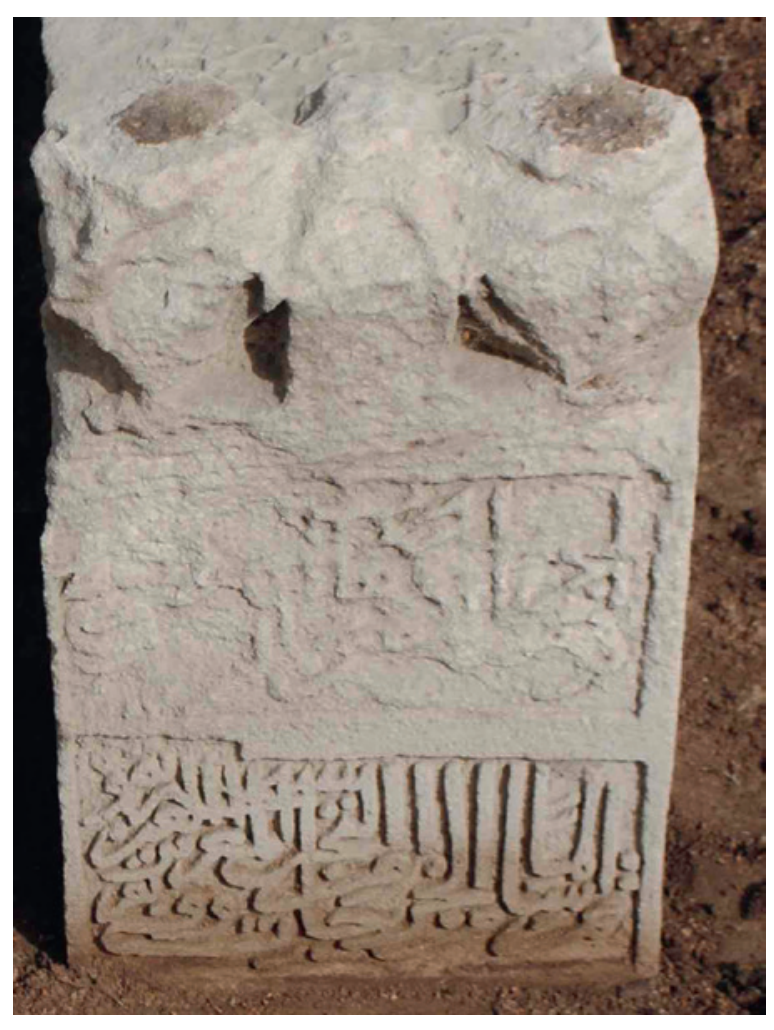

FIGURE 2.438

Surface C, NOA1 
D:

- The blessed late, al-Hajj Naser bin alHajj 'Abd al-Husayn, God bless them.

- Died in the eighth of Jumada al-thani, year one thousand and seventy-six.
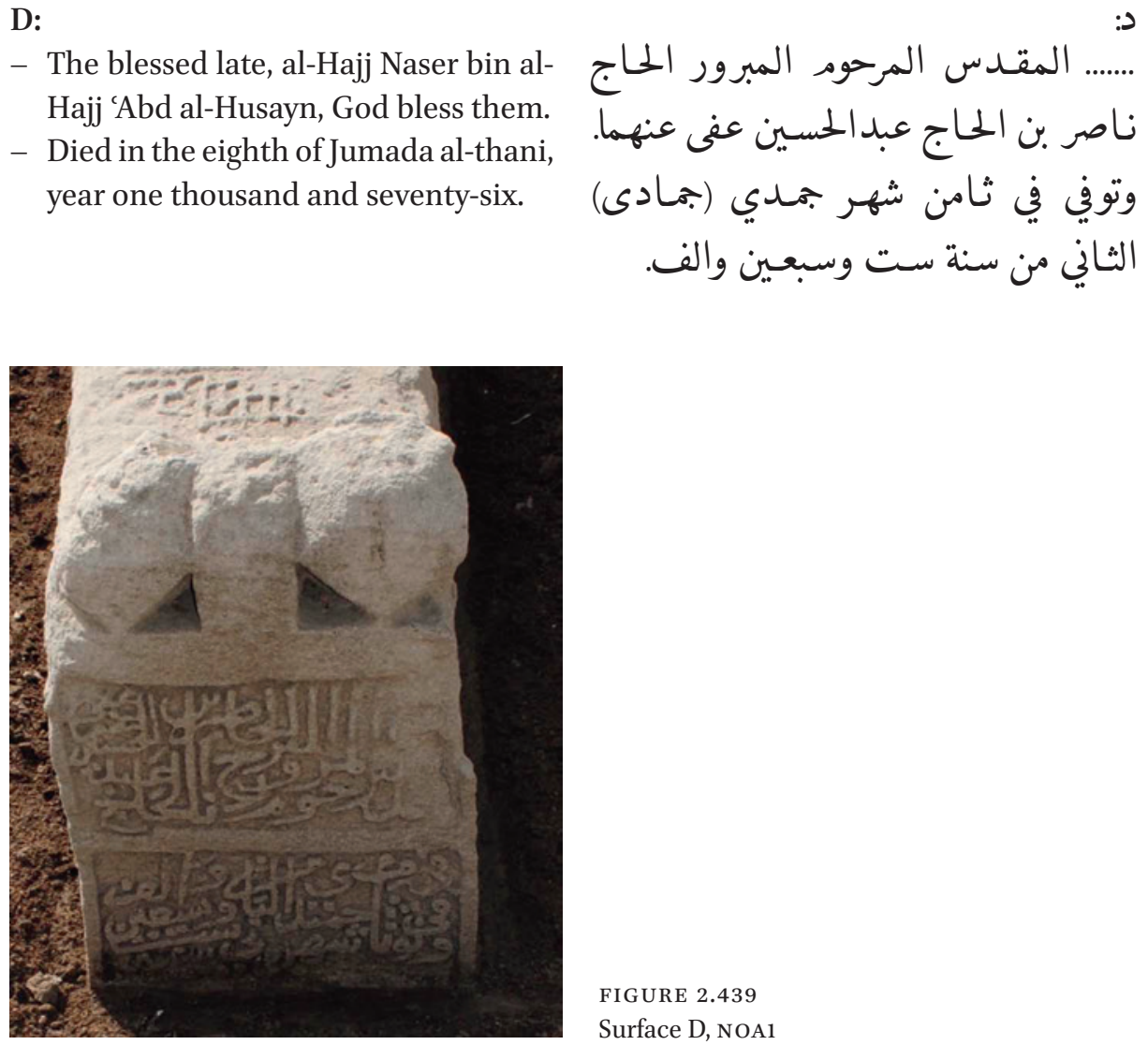

E:

- Written by the one who stands in need of the Only Owner of the Day of Reckoning ... 'Ali bin Husayn bin

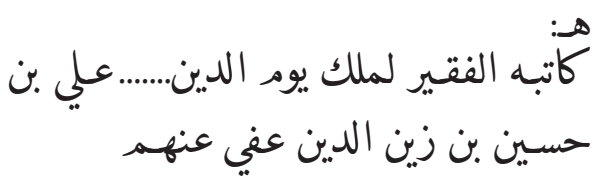
Zayn al-Din. God bless them.

- Engraved by al-Sayyid Hashim bin alSayyid Naser ...

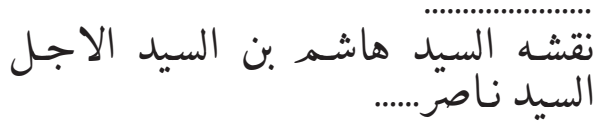




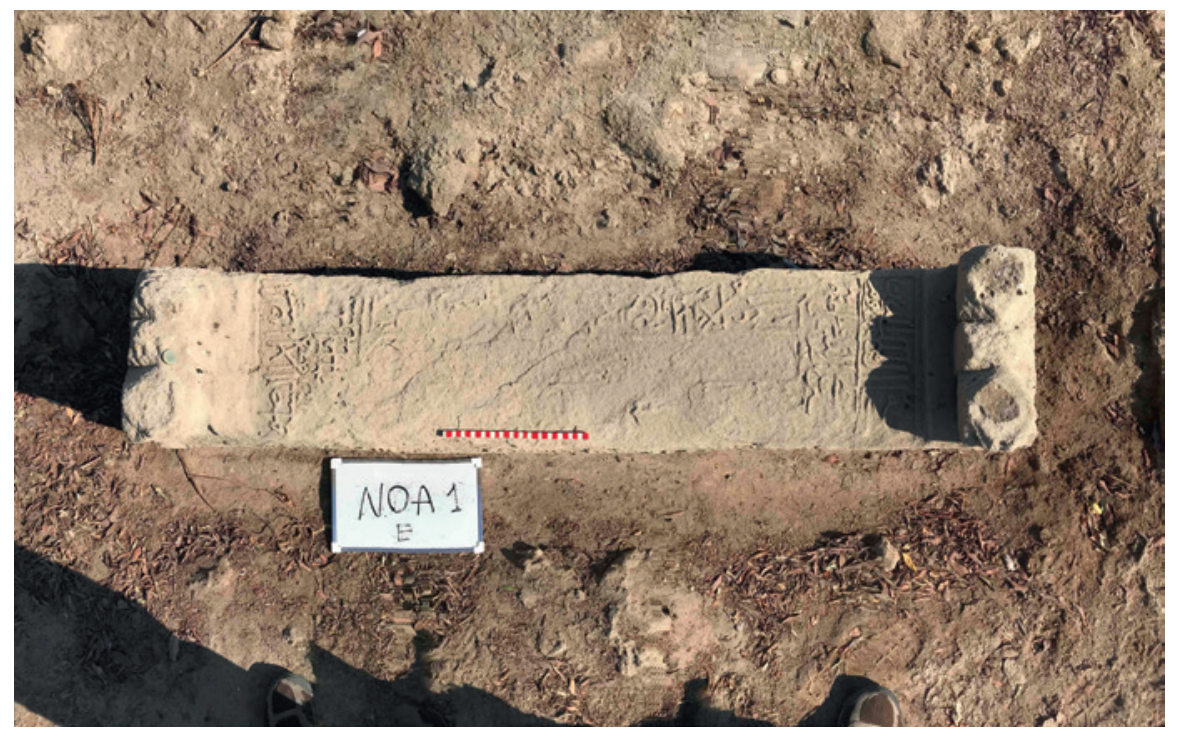

FIGURE 2.440 Surface E, NOA1

\section{Reference Number: NOA2}

Co-ordinates: $26.22606^{\circ} \mathrm{N} 050.56804^{\circ} \mathrm{E}$

Dimensions: $15^{2.5} \mathrm{~cm}(\mathrm{l}) \times 28.5 \mathrm{~cm}(\mathrm{w}) \times 63 \mathrm{~cm}(\mathrm{~h})$

\section{Orientation: NNW-SSE}

Description: Single limestone slab gravestone. Badly eroded in various areas and cracked and with a section missing on one side surface (B). Eroded three element raised decoration formed of two facetted cubes and a central rounded arch all set on a rectangular plinth at each end. Partially legible inscriptions on two surfaces and illegible inscriptions on the other three surfaces.

\section{Arabic Transcription and Translation:}

A:

- Inner-selves desire ... you ask ...

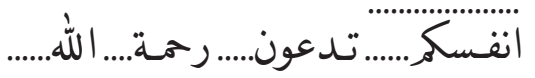
mercy ... Allah ... 


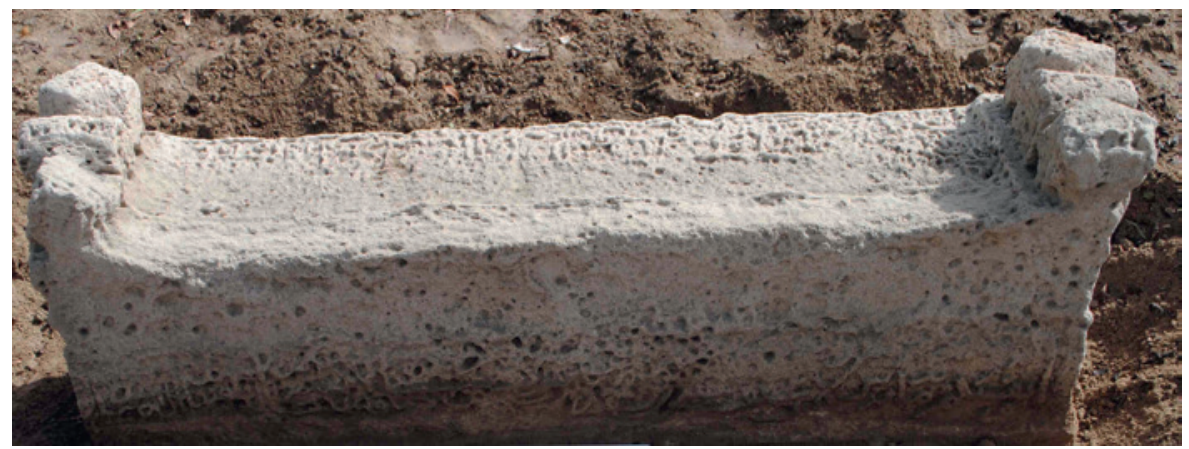

FIGURE 2.441 Surface A, NOA2

B:

- In the name of Allah ... whatever is in the heavens and whatever is on the earth. Who is he that can intercede with Him except by His permission! ...His Seat ... the heavens and the earth. And He feels no fatigue in guarding and preserving them. And He is the Most High, the Most Great (2:255).
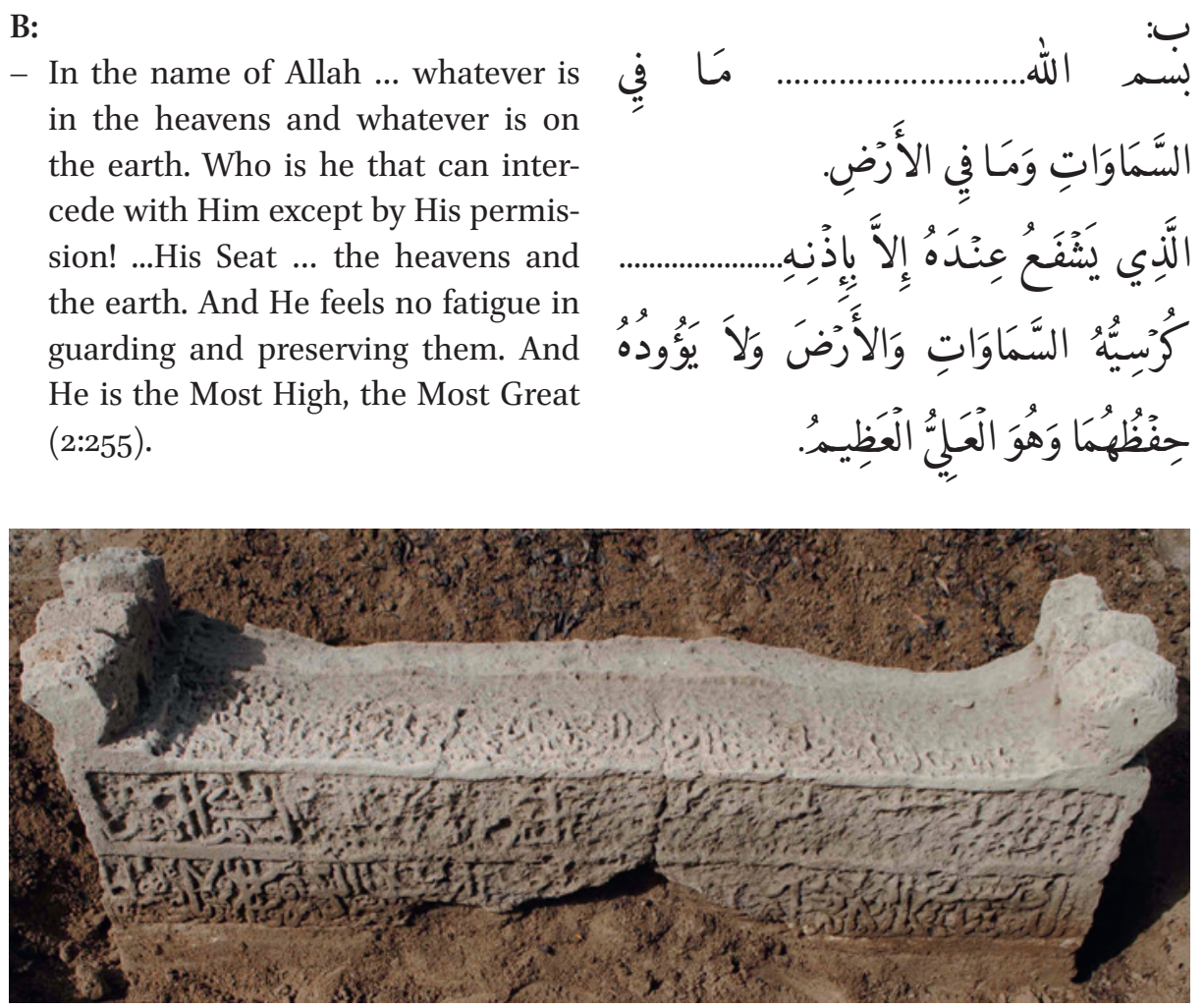

FIGURE 2.442 Surfaces B and E, NOA2 
C:

- Very deteriorated. Unable to read.

$$
\text { الكَبة متآكلة ولا يمكن قواءتها }
$$

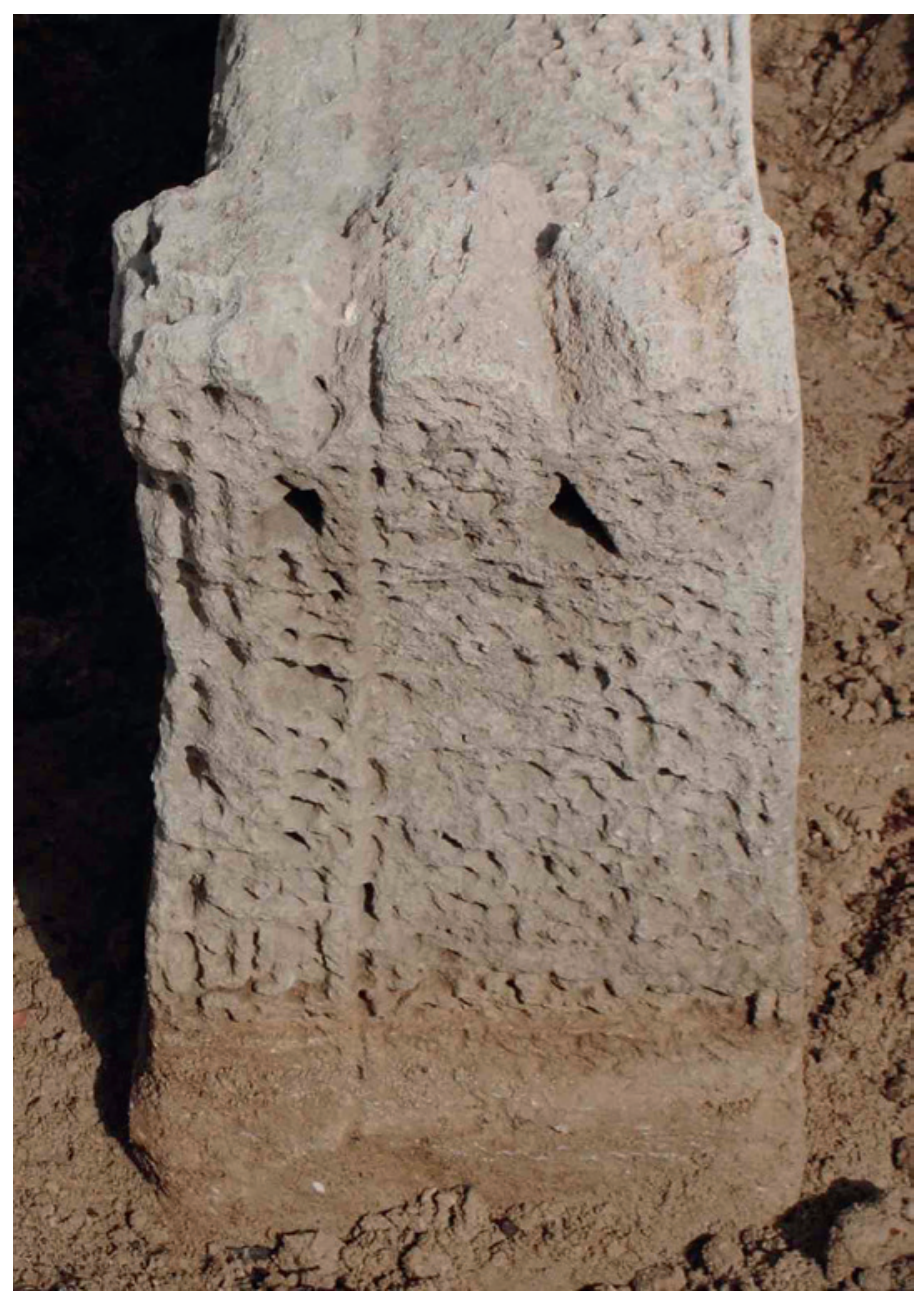

FIGURE 2.443 Surface C, NOA2 
D:

- Very deteriorated. Unable to read.
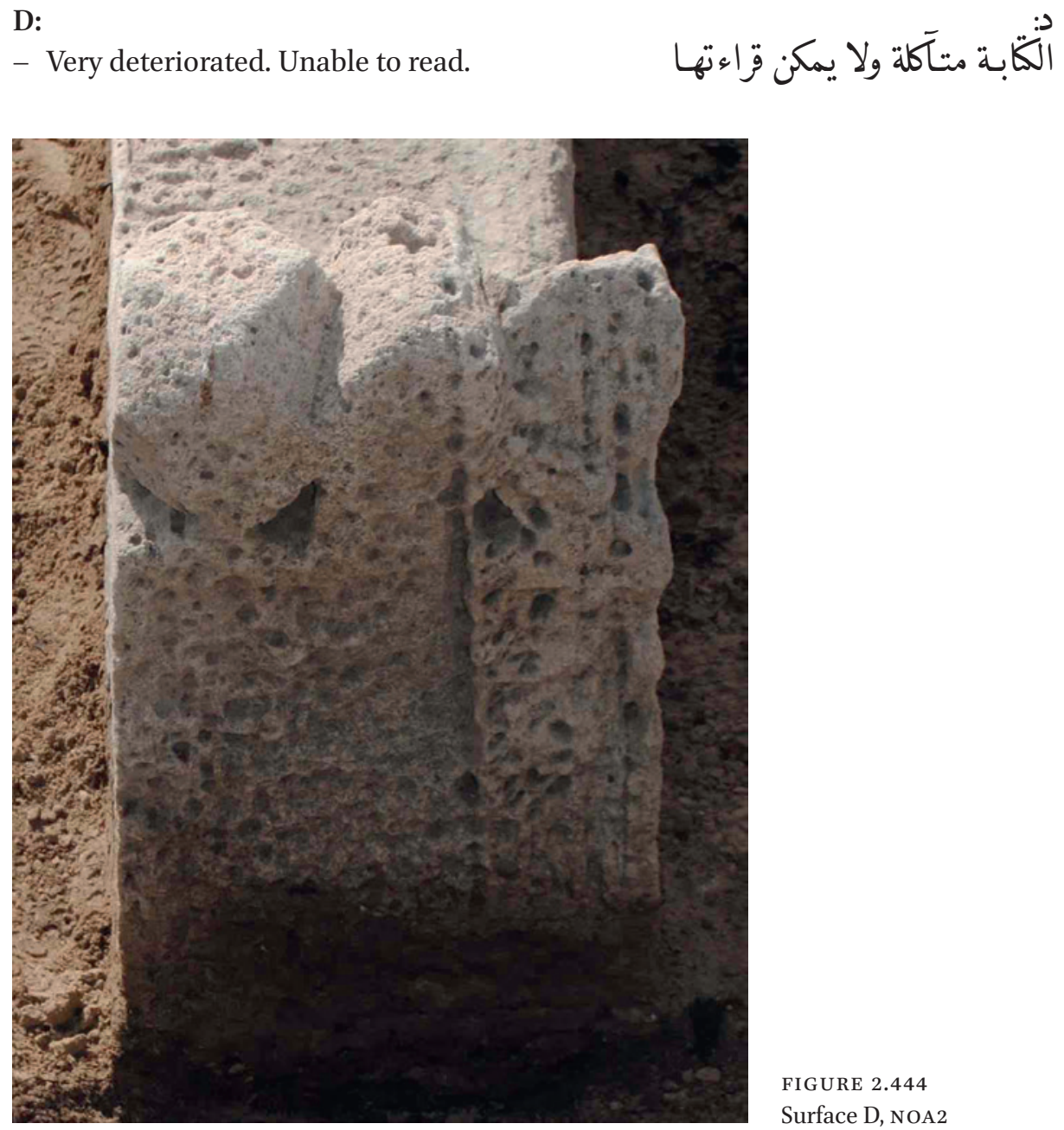

FIGURE 2.444

Surface D, NOA2

E:

- Very deteriorated. Unable to read. الكَابة متآتلة ولا يمكن قزاءتها

See Figure 2.442

Reference Number: NOA3

Co-ordinates: $26.22623^{\circ} \mathrm{N} 050.56821^{\circ} \mathrm{E}$

Dimensions: $139.5 \mathrm{~cm}(\mathrm{l}) \times 28.5 \mathrm{~cm}(\mathrm{w}) \times 5^{2} \mathrm{~cm}(\mathrm{~h})$

Orientation: NW-SE 
Description: Single limestone slab gravestone. Unfinished. The gravestone has been cut to size and the three element raised decoration formed of two facetted cubes and a central thin rounded arch all set on a rectangular plinth at each end has been finished, albeit crudely (Figure 2.445). No inscriptions or other decoration have been added. Some erosion to the upper parts of the raised decoration where it was above the ground surface. Fifteen rows of four shallow cup marks are cut into one corner of the top surface (E) (Figure 2.446). These are almost certainly connected with playing the Awari/Mancala type games discussed in relation to ABN46. Excavated to expose whole gravestone.

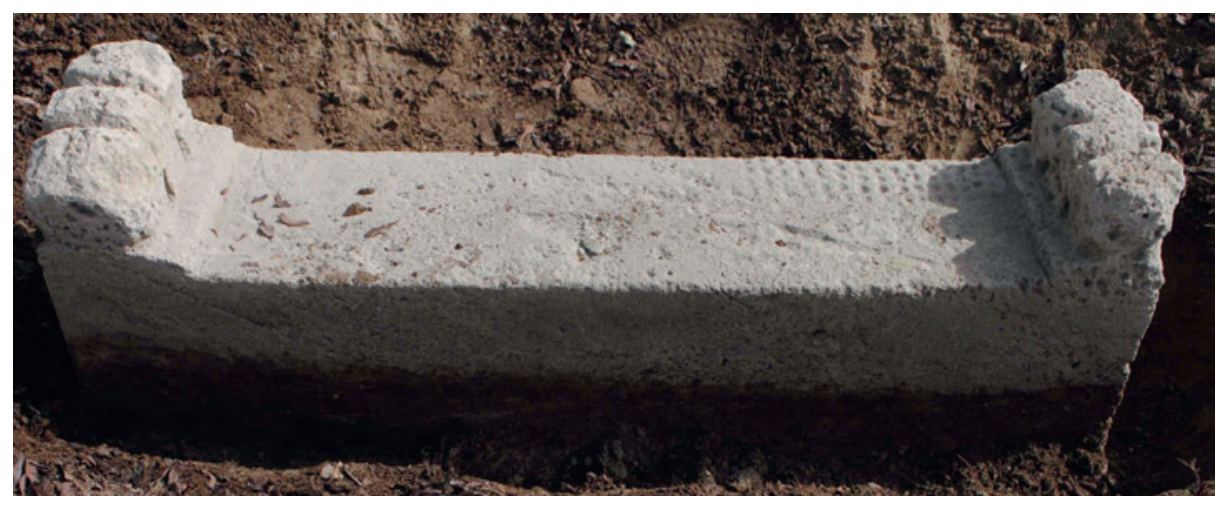

FIGURE 2.445 NOA3

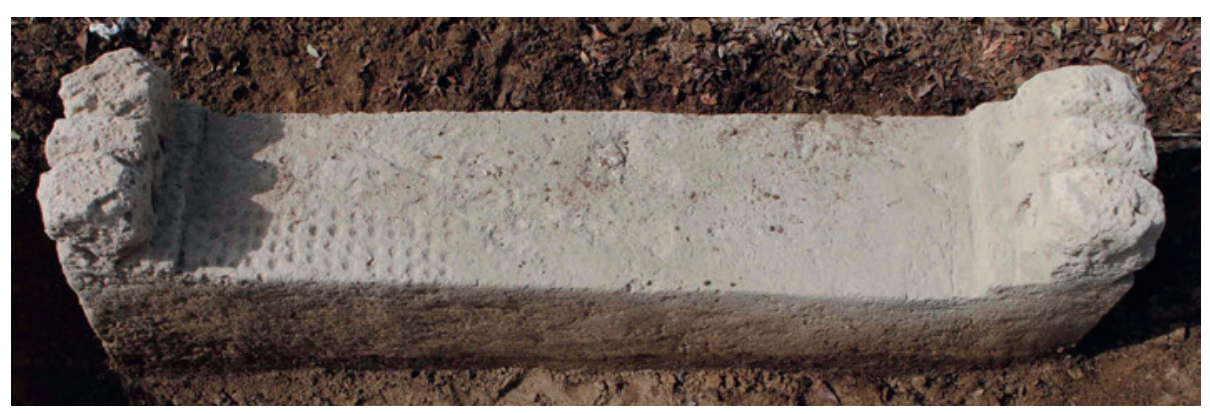

FIGURE 2.446 Fifteen rows of four shallow cup marks, likely Awari/Mancala type game, NOA3

\section{Arabic Transcription and Translation: No inscriptions}

\section{Reference Number: NOA4}

Co-ordinates: $26.2265^{\circ}{ }^{\circ} \mathrm{N} 05^{0.56711^{\circ} \mathrm{E}}$

Dimensions: $56 \mathrm{~cm}(\mathrm{l}) \times 28 \mathrm{~cm}(\mathrm{w}) \times 45 \mathrm{~cm}(\mathrm{~h})$ 
Orientation: NA

Description: Broken fragment from either a single or double limestone slab gravestone. Eroded on the inscribed surface. Hollow (Figure 2.447). Partial inscription on one surface.

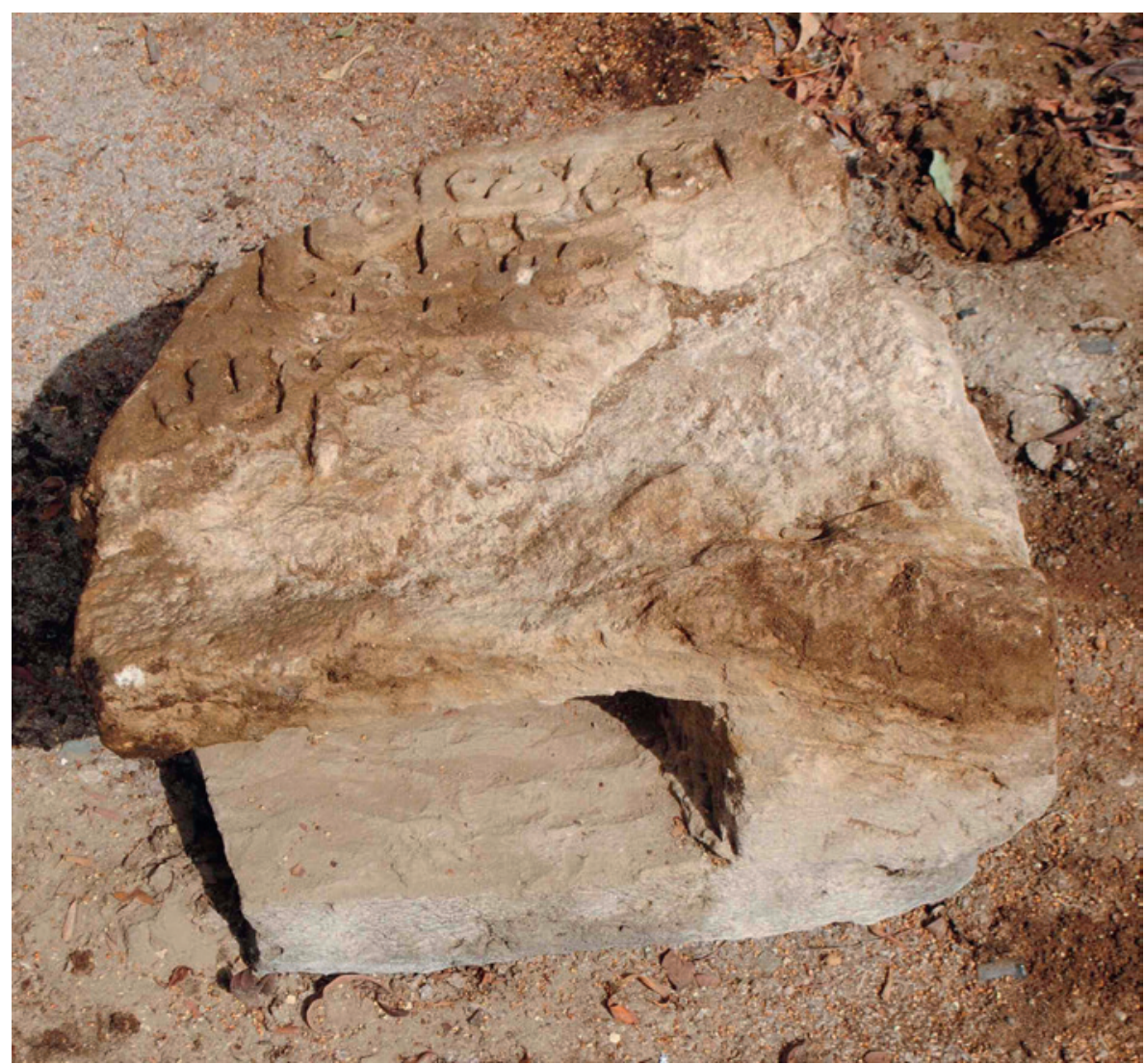

FIGURE 2.447 Hollow cavity, NOA4

\section{Arabic Transcription and Translation:}

- ... preserving them ... And He ...

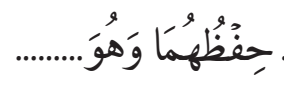

- ... Allah ... 


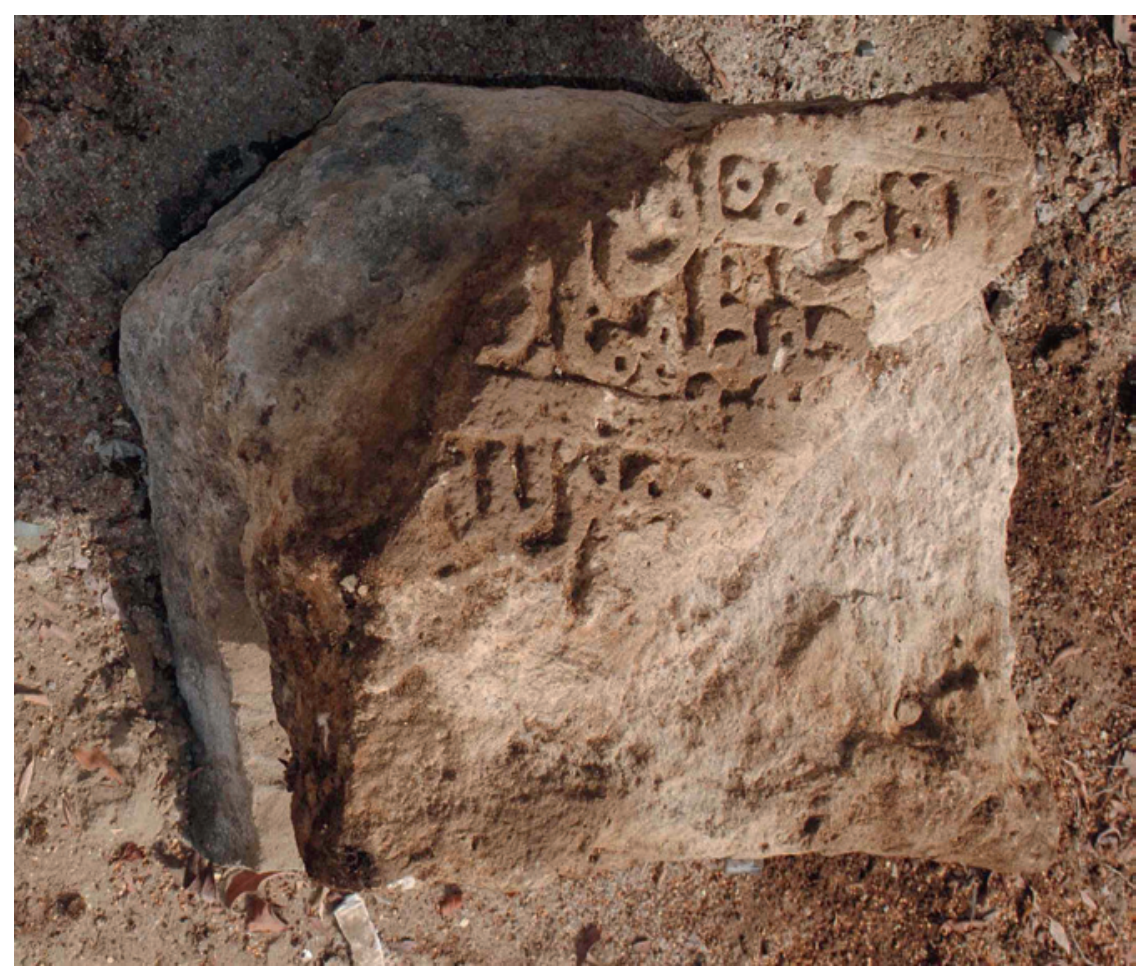

FIGURE 2.448 Inscription fragment, NOA4

22

$$
\text { Al-Qadem (QAD) }
$$

Location: Village cemetery containing a mosque

Reference Number: QAD1

Co-ordinates: $26.21629^{\circ} \mathrm{N} 050.51596^{\circ} \mathrm{E}$

Dimensions: $132 \mathrm{~cm}(\mathrm{l}) \times 25.5 \mathrm{~cm}(\mathrm{w}) \times 47 \mathrm{~cm}(\mathrm{~h})$

Orientation: NW-SE

Description: Single limestone slab gravestone. The carver has had to compensate for a fault formed of an indentation in the stone on one side surface (A). Three 
element raised decoration formed of two facetted cubes and a central rounded arch at each end. Inscriptions on five surfaces. The gravestone was covered with a recently made wooden green painted slatted canopy. Excavated to expose whole gravestone.

\section{Arabic Transcription and Translation:}

A:

- In the Name of Allah, the Most Gracious, the Most Merciful. Allah, none has the right to be worshipped but he, the Ever Living, the One Who sustains and protects all that exists. Neither slumber nor sleep overtakes Him. To Him belongs whatever is in the heavens and whatever is on the earth. Who is he that can intercede?

- With Him except by His permission! He knows what happens to them in this world, and will happen to them in the Hereafter and they will never compass anything of His Knowledge. Except that which He wills. His Seat extends over the heavens and the earth (2:255).

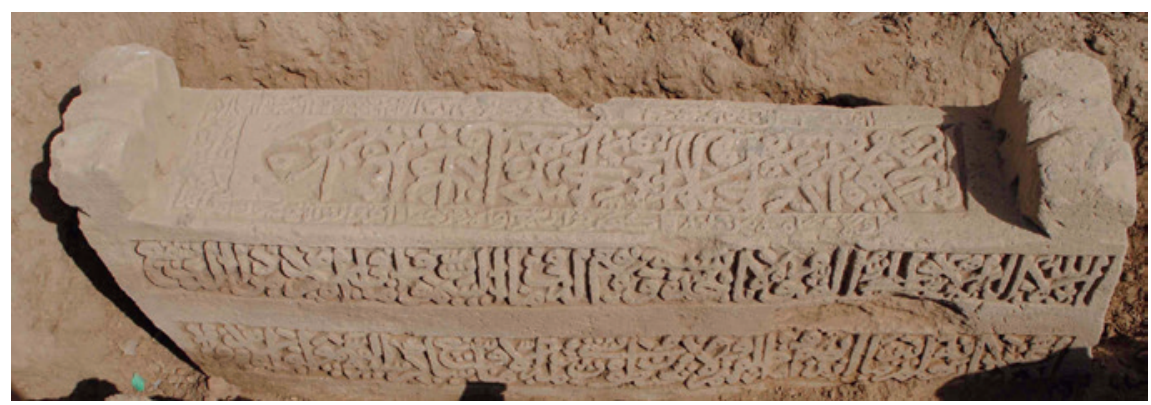

FIGURE 2.449 Side A, QAD1
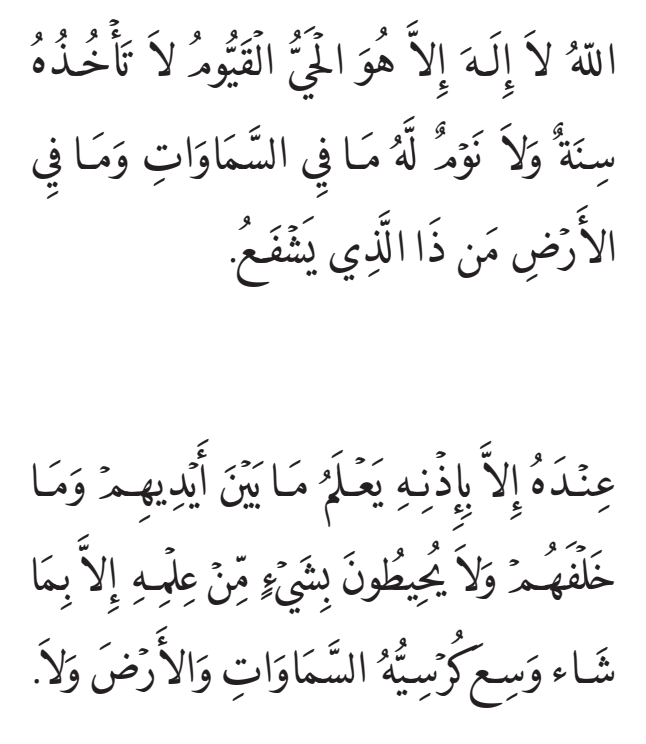

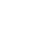


B:

- In the Name of Allah, the Most Gracious, the Most Merciful. Verily, your protector is none other than Allah, His Messenger, and the believers, those who establish regular prayers and regular charity, and they bow down humbly.

- And whosoever takes Allah, His Messenger, and the believers, it is the fellowship of Allah that must certainly triumph $\left(5: 55^{-5} 5^{6}\right)$.
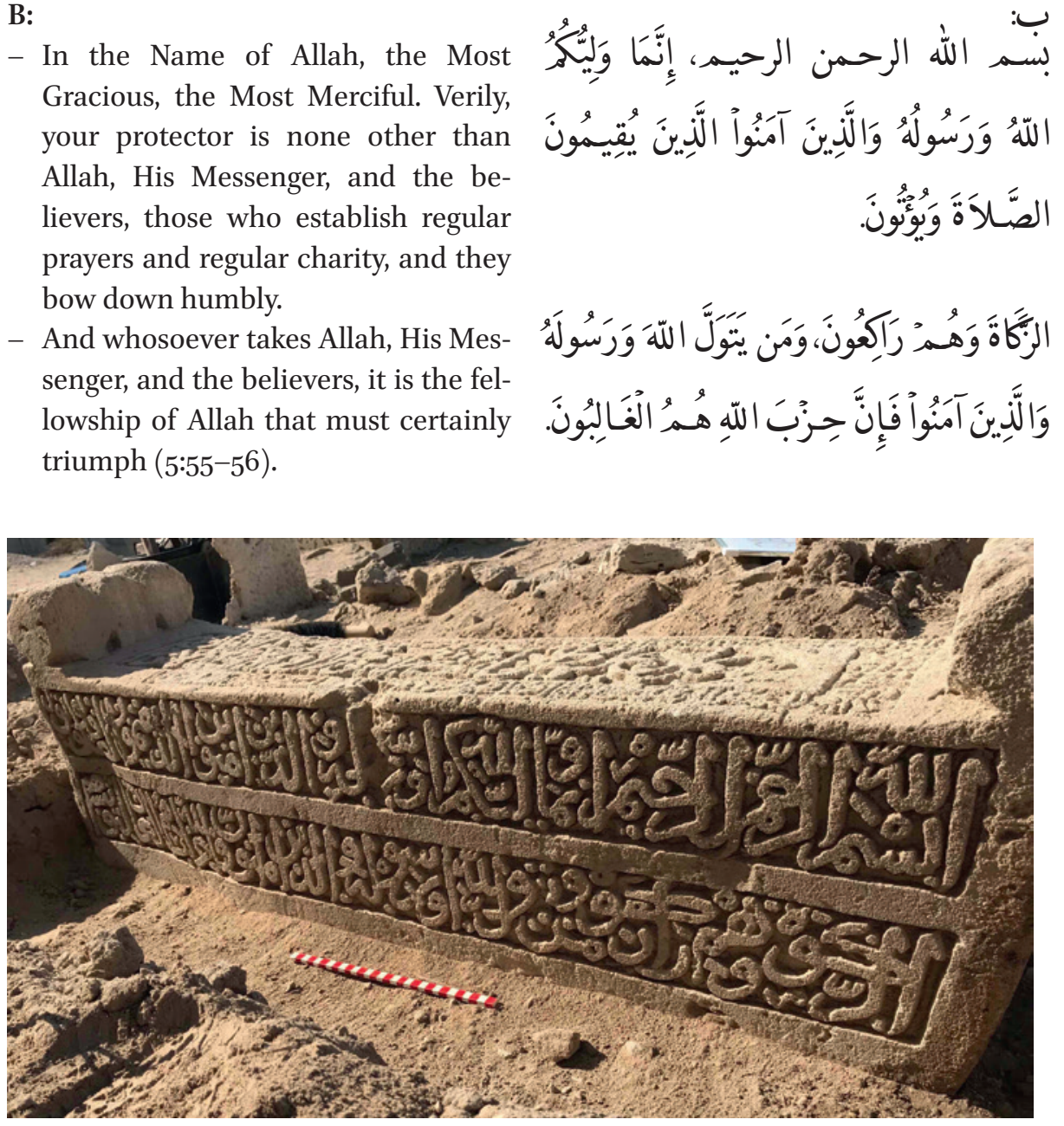

FIGURE 2.450 Side B, QAD1

C:

- It is the grave of Shaikh 'Ali

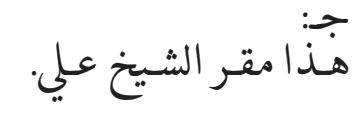

- bin 'Abd Allah al-Awali ...

.ن عبـداله الاواليى (جـا). 


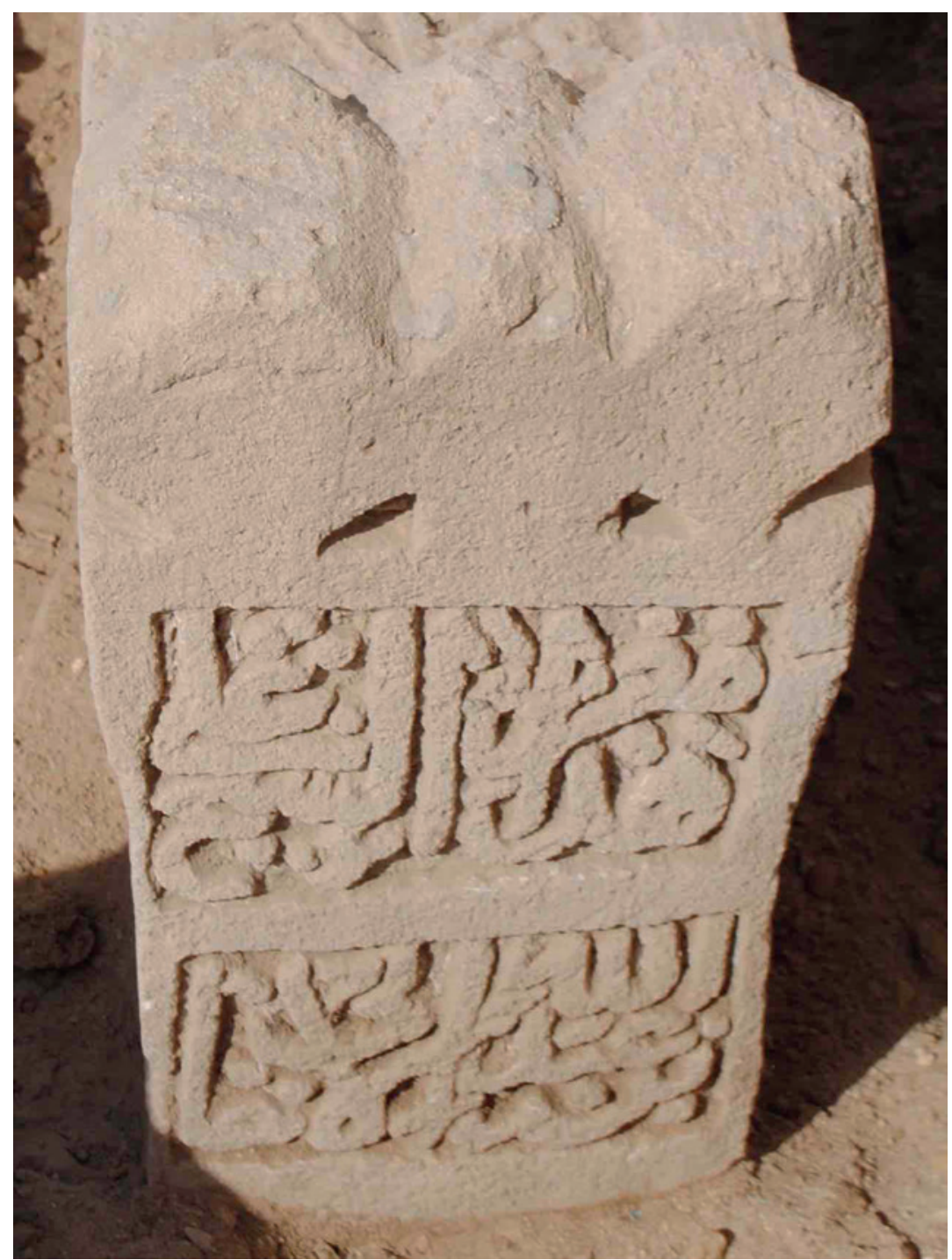

FIGURE 2.451 Side C, QAD1

D:

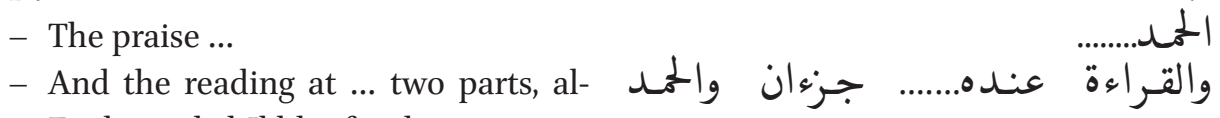
Fatiha and al-Ikhlas for three times.

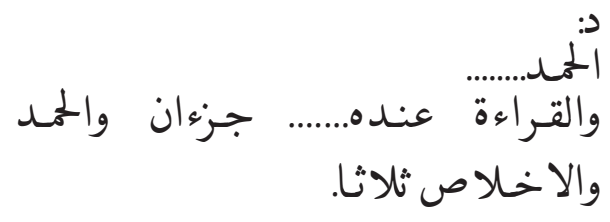

- And one part for him with his parents and his son Ibrahim and his wives.

$$
\begin{aligned}
& \text { وجزيء له مجع ولديـه وابنه ابراهيه } \\
& \text { وزوجاته. }
\end{aligned}
$$




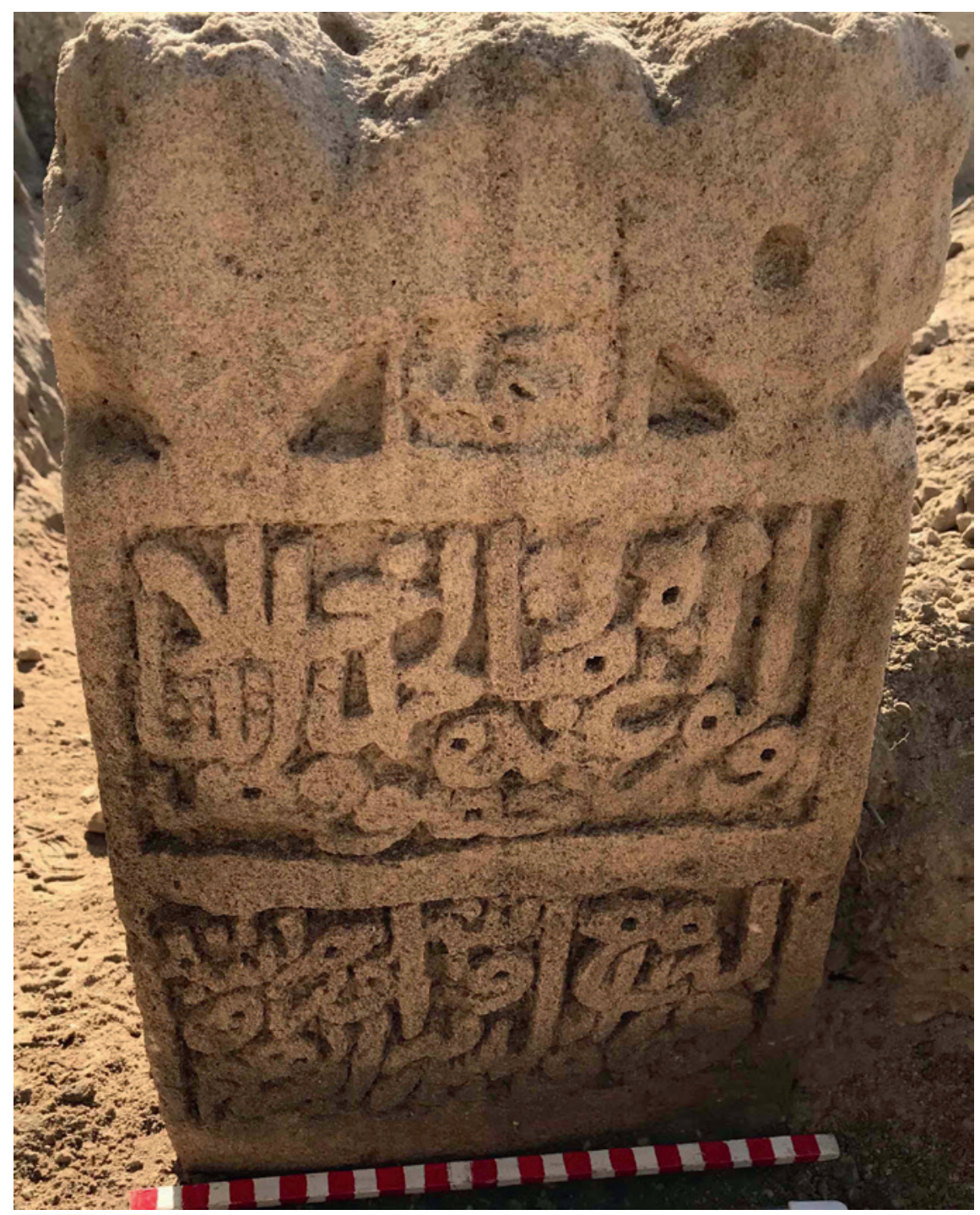

FIGURE 2.452 Side D, QAD1 
E:

- Whatsoever is on the earth will perish. And the Face of your Lord full of Majesty and Honour will remain forever (55:26-27). Peace be on you, a Word from the Lord, Most Merciful (36:58).

- This shrine embedded ... it is surrounded with real knowledge.
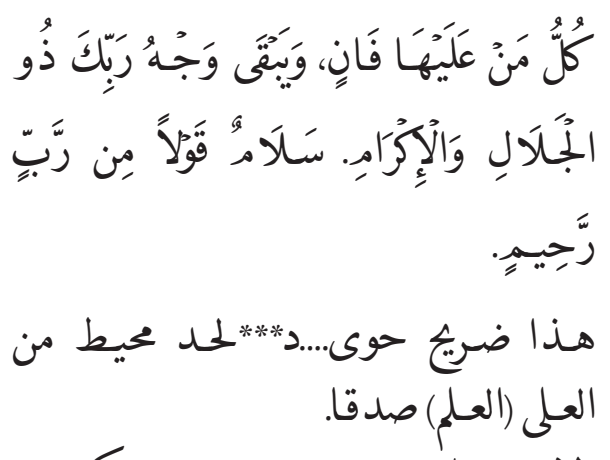

- ... his grave is as wide as the width of earths and skies.
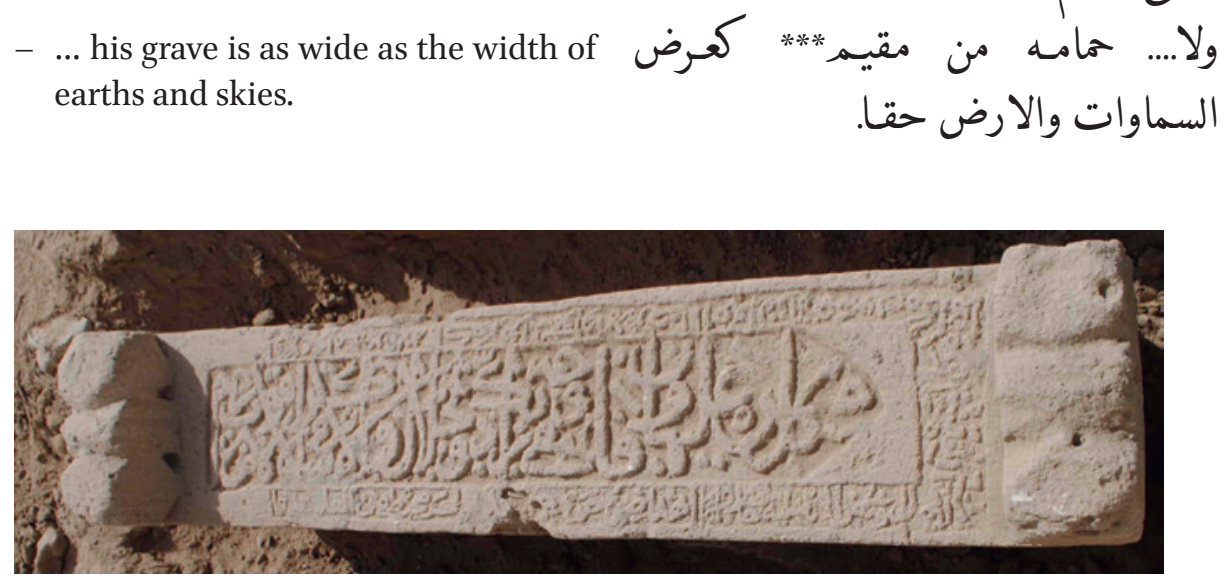

FIGURE 2.453 Side E, QAD1

Reference Number: QAD2

Co-ordinates: $26.21631^{\circ} \mathrm{N} 050.51609^{\circ} \mathrm{E}$

Dimensions: $142.5 \mathrm{~cm}(\mathrm{l}) \times 38 \mathrm{~cm}(\mathrm{w}) \times($ height not measurable $)$

\section{Orientation: NNW-SSE}

Description: Double limestone slab gravestone. An active shrine is centred around this gravestone which is sunk into the floor, cemented in place, and surrounded with green carpet. A moveable aluminium canopy has been placed over the gravestone. Coins (predominantly of 100 fils denomination), small glass perfume bottles, one dinar notes, stems of green or dried fragrant herbs (mashmoom, Basil, Ocimum basilcum) had been put through the canopy grille as offerings (Figure 2.454). The gravestone is exceptionally well carved with three element raised decoration formed of two facetted cubes and a central rounded arch at each end. This is finished with carved calligraphy on the rear of each element and carved geometric star 
patterns in the top of the facetted cubes (Figure 2.457). A shallow pointed niche design is carved on the upper surface (E) which incorporates a double scroll into the double border below the point of the niche. Inscriptions on five surfaces but only one is legible and two are partially legible because of the gravestone being partly buried in the shrine floor and covered with cement.

\section{Arabic Transcription and Translation:}

A:

- Covered with cement and cannot be read.
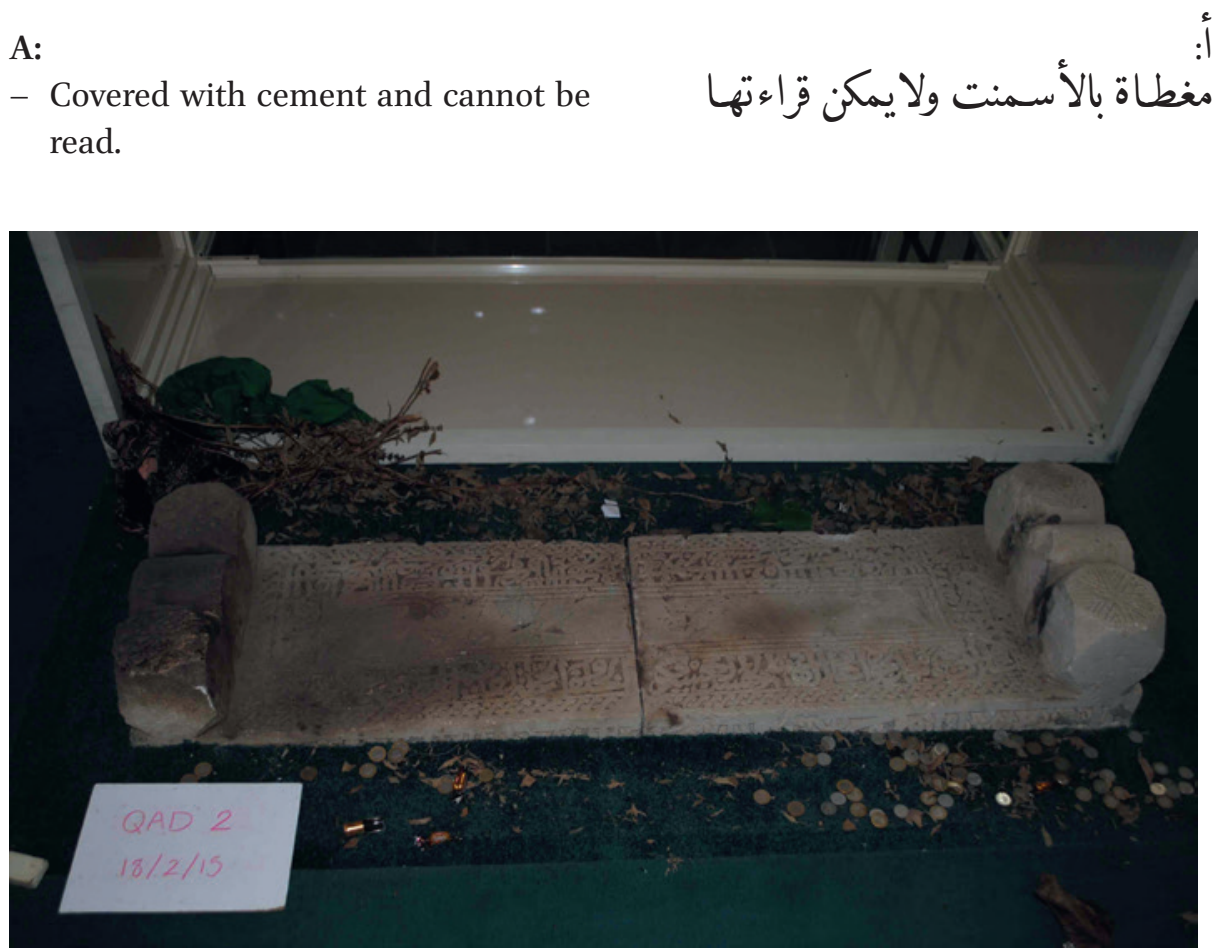

FIGURE 2.454 Surface A, QAD2

B:

- Covered with cement and cannot be read.

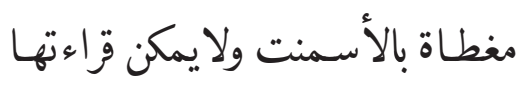

C:

- I put my trust in Allah.

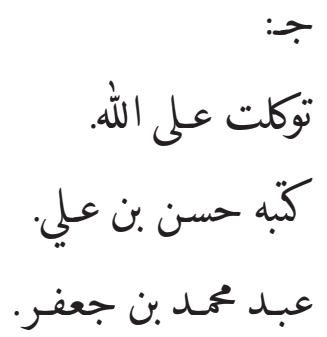

- Abd Muhammad bin Ja'far. 


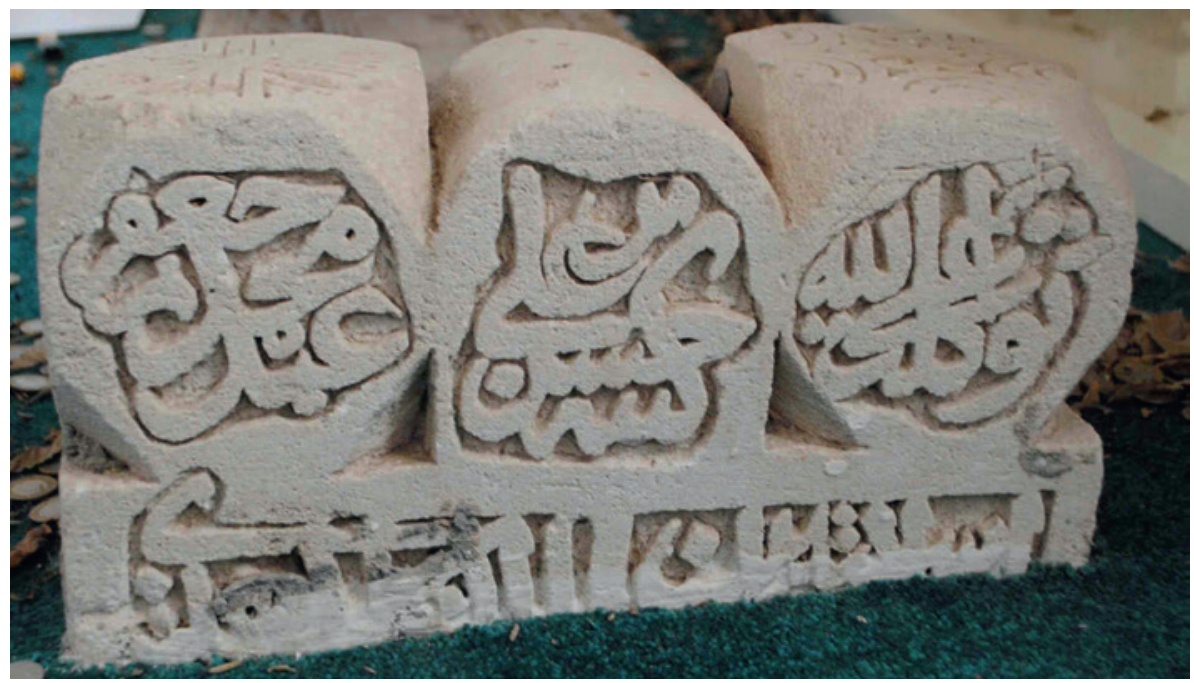

FIGURE 2.455 Surface C, QAD2

D:

- This is the grave of the chaste, the enlightened mind.

- The one who has got paradise.

$$
\text { دا: الثبر الا طهر الانور. }
$$

- Shaikh 'Ali bin Sulayman.

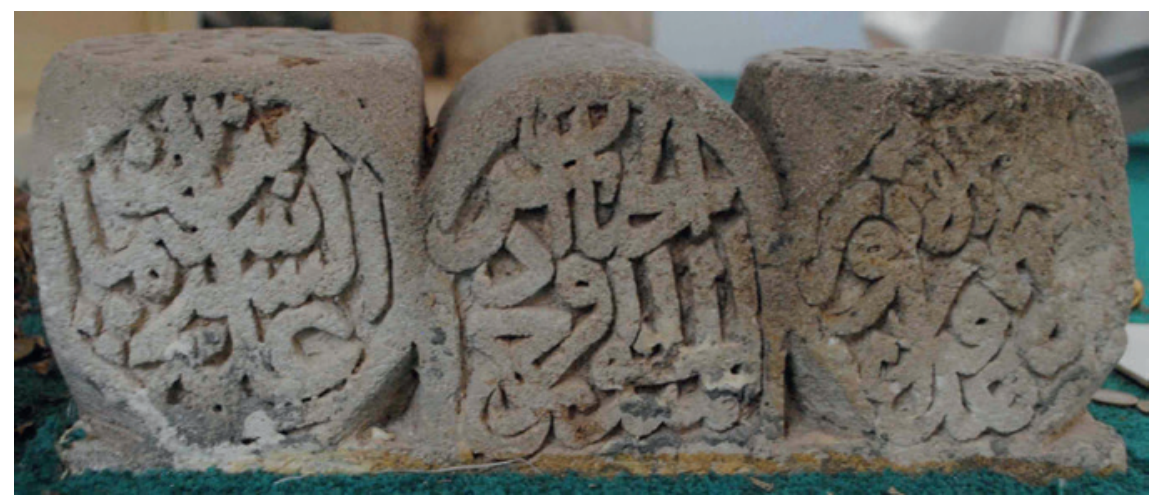

FIGURE 2.456 Surface D, QAD2 
E:

- May the blessing of Allah be upon Muhammad al-Mustafa, 'Ali alMurtada, Fatimah al-Zahra', Khadija al-Kubra, al-Hasan al-Zaki, al-Husayn al-Shahid, 'Ali, Muhammad, Ja'far alSadiq, Musa al-Kadhim, Ali al-Rida, Muhammad al-Jawad, 'Ali al-Hadi, al-Hasan al-'Askari, and al-Khalaf alHujjah al-Qa'im al-Mahdi. May the blessing of Allah be upon all of them.
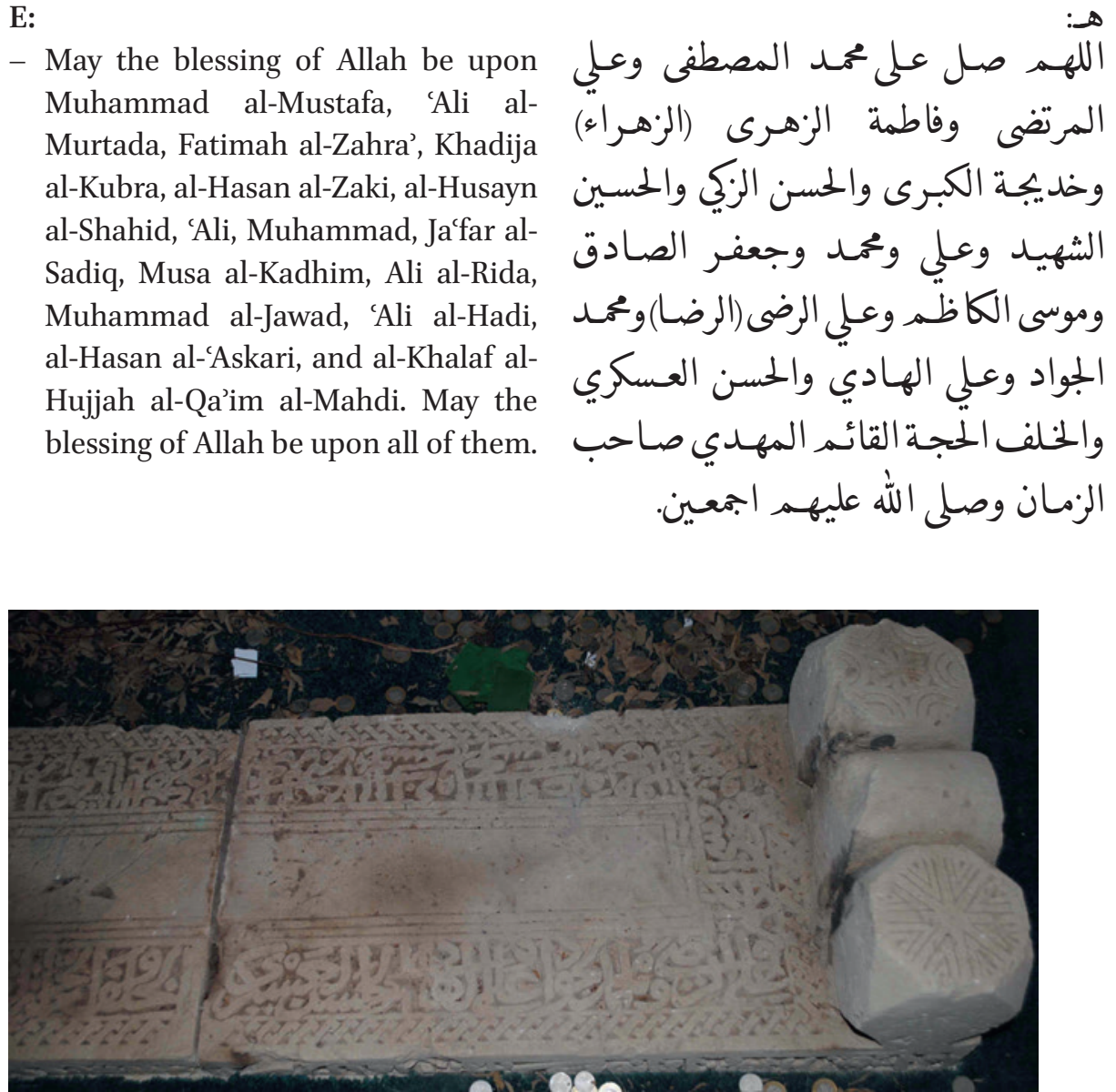

FIGURE 2.457 Surface E, part 1, QAD2

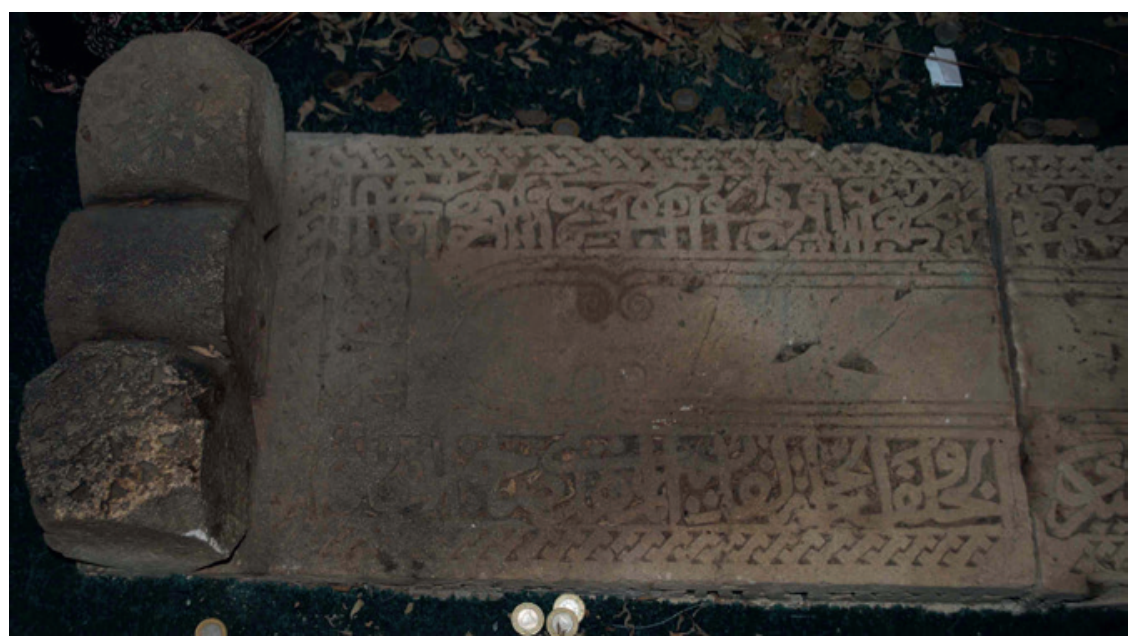

FIGURE 2.458 Surface E, part 2, QAD2 
Location: Mosque in Jidhafs village

Reference Number: Sh. AB1

Co-ordinates: $26.21703^{\circ} \mathrm{N} 050.53794^{\circ} \mathrm{E}$

Dimensions: $156 \mathrm{~cm}(\mathrm{l}) \times 33.5 \mathrm{~cm}(\mathrm{w}) \times 35 \mathrm{~cm}(\mathrm{~h})$

Orientation: NW to SE

Description: Single limestone slab gravestone. Eroded and with patches of cement on it. Partially buried in cement under a metal and glass canopy inside a shrine. Approximately $70 \mathrm{~cm}$ below current ground level suggesting it is in its original position (Figure 2.459). The only accessible legible inscription is on the upper surface (E). Two inscriptions can be seen but are not accessible for adequate reading or photography on the side surfaces (A and B). Three element raised decoration at one end formed of two facetted cubes and a central thin rounded arch, broken or cut off at the other end. Shallow carved rounded niche design on top surface (E).

\section{Arabic Transcription and Translation:}

A:

- Difficult to read.

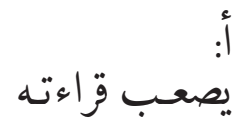

B:

- Difficult to read.

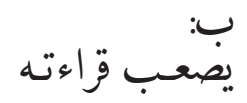

C:

Difficult to read.

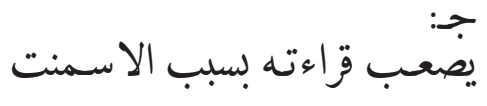

D:

- Difficult to read.

E:

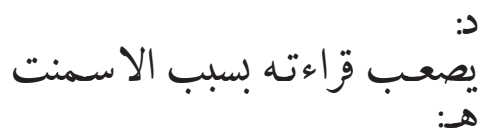

- Written by ... Sheikh ... Lutf Allah Lut Allah Bin Ali Lut Allah Aljedhafsi Albahrani, May Allah bless them.

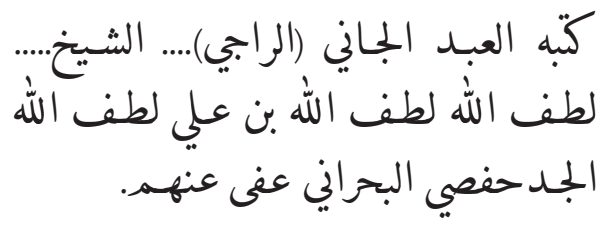

- Engraved by ... Ali Bin ...

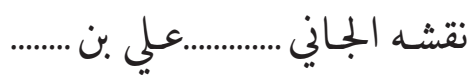




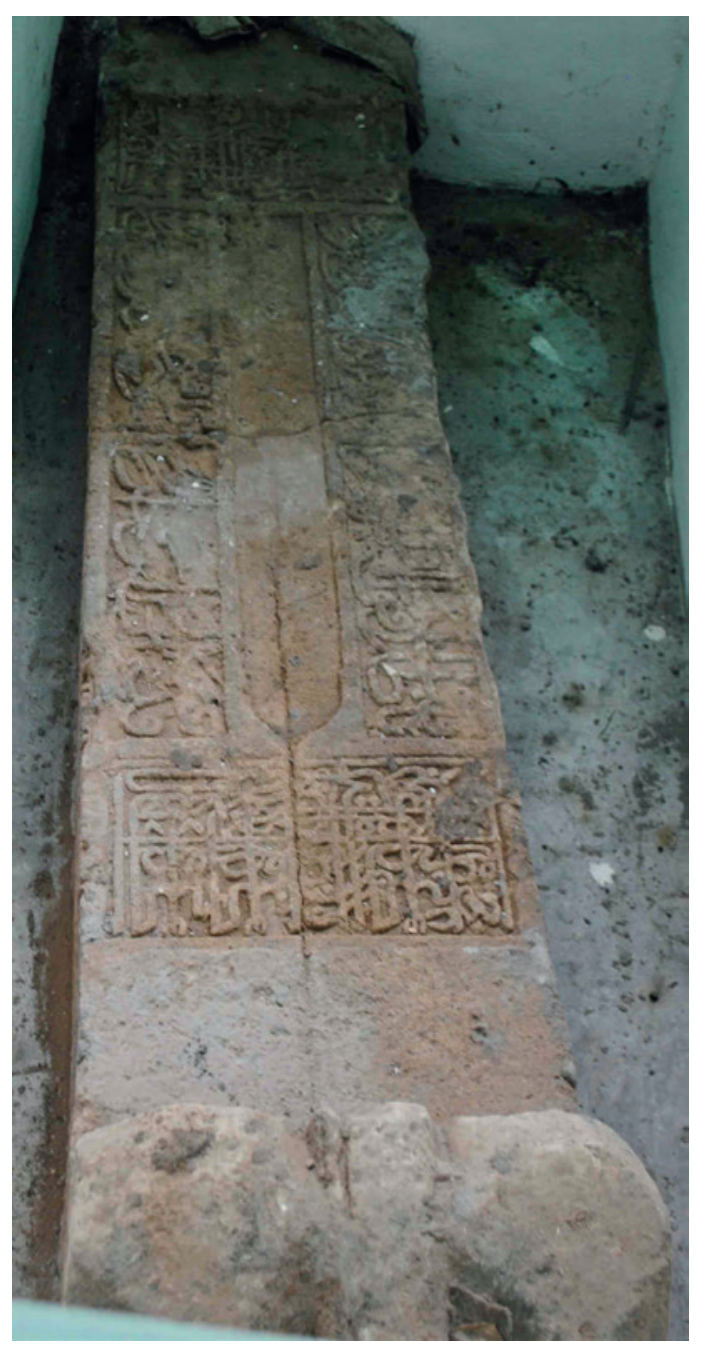

FIGURE 2.459

Surface E, Sh. AB1

24 Sh. Latfulla (Sh. LA)

Location: Mosque in Jidhafs village

Reference Number: Sh. LA1

Co-ordinates: $26.21703^{\circ} \mathrm{N} 050.53794^{\circ} \mathrm{E}$

Dimensions: $143 \mathrm{~cm}(\mathrm{l}) \times 32 \mathrm{~cm}(\mathrm{w}) \times 30.5 \mathrm{~cm}(\mathrm{~h})$

Orientation: NW to SE 
Description: Single limestone slab gravestone. Partly covered in modern green mosaic tiles. Flat rectangular slab, probably the plinth from which the raised decoration was removed, at each end. Accessible inscriptions only on two surfaces, and one of these (A) was only partially photographable (Figure 2.46o). Located in a metal and glass canopy inside a shrine. Approximately $100 \mathrm{~cm}$ below current ground level suggesting it is in its original position.

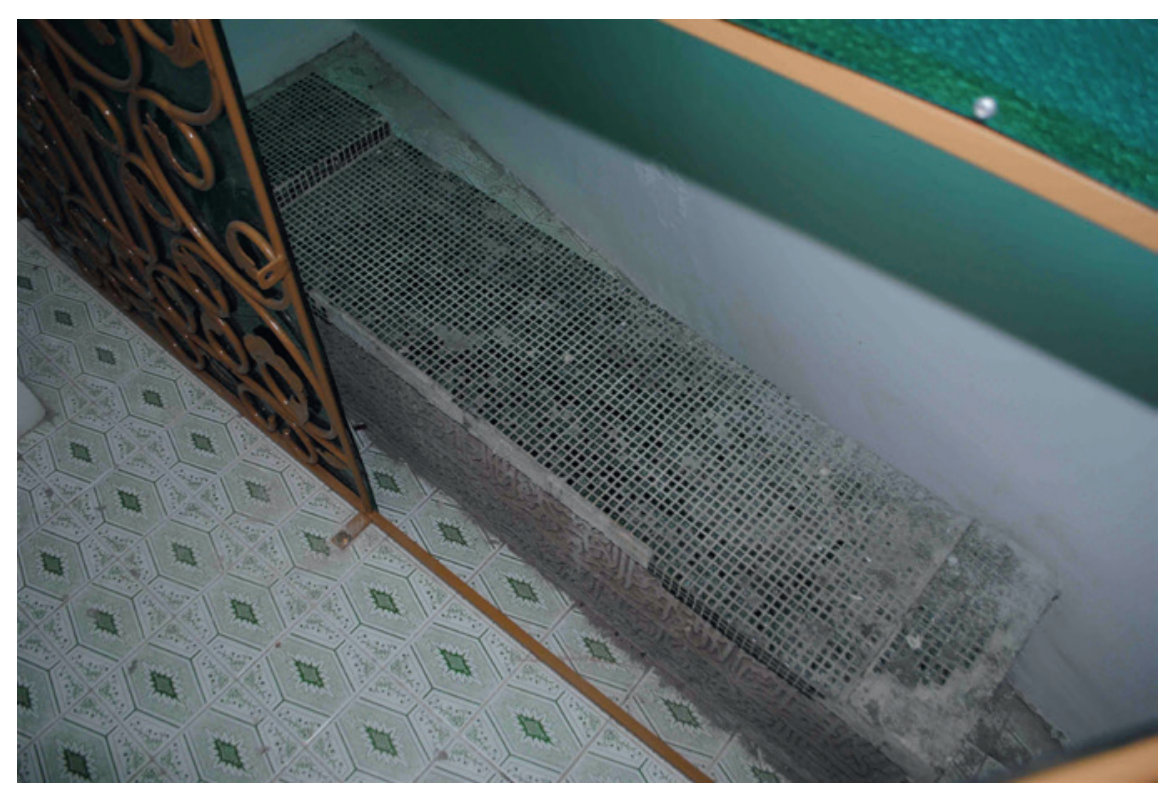

FIGURE 2.460 Sh. LA1

\section{Arabic Transcription and Translation:}

A:

- In the Name of Allah, the Most Gracious, the Most Merciful Allah, none has the right to be worshipped but he, the Ever Living, the One Who sustains and protects all that exists. Neither slumber nor sleep overtakes Him. To Him belongs whatever is in the heavens and whatever is on the earth. Who is he that can intercede with Him except by His permission! He knows what happens to them in this world, and will happen to them in the Hereafter.

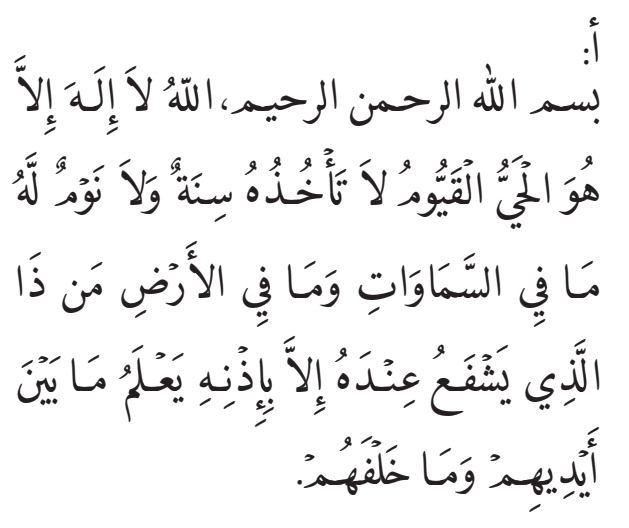


- And they will never compass anything of His Knowledge except that which He wills. His Seat extends over the heavens and the earth. And $\mathrm{He}$ feels no fatigue in guarding and preserving them. And $\mathrm{He}$ is the Most High, the Most Great. There is no compulsion in religion. Verily, the Right Path has become distinct from the wrong path. Whoever disbelieves in Taghut and believes in Allah, then he has grasped the most trustworthy handhold that will never break. And Allah is All-Hearer, All-Knower (2:255-256).
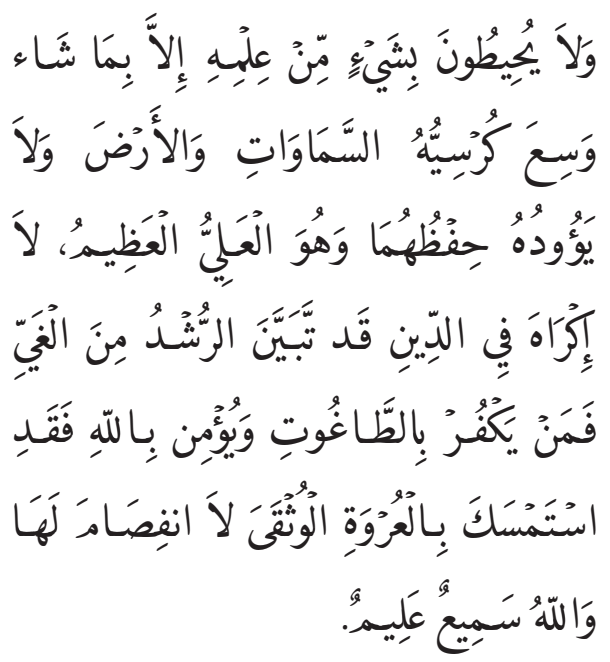

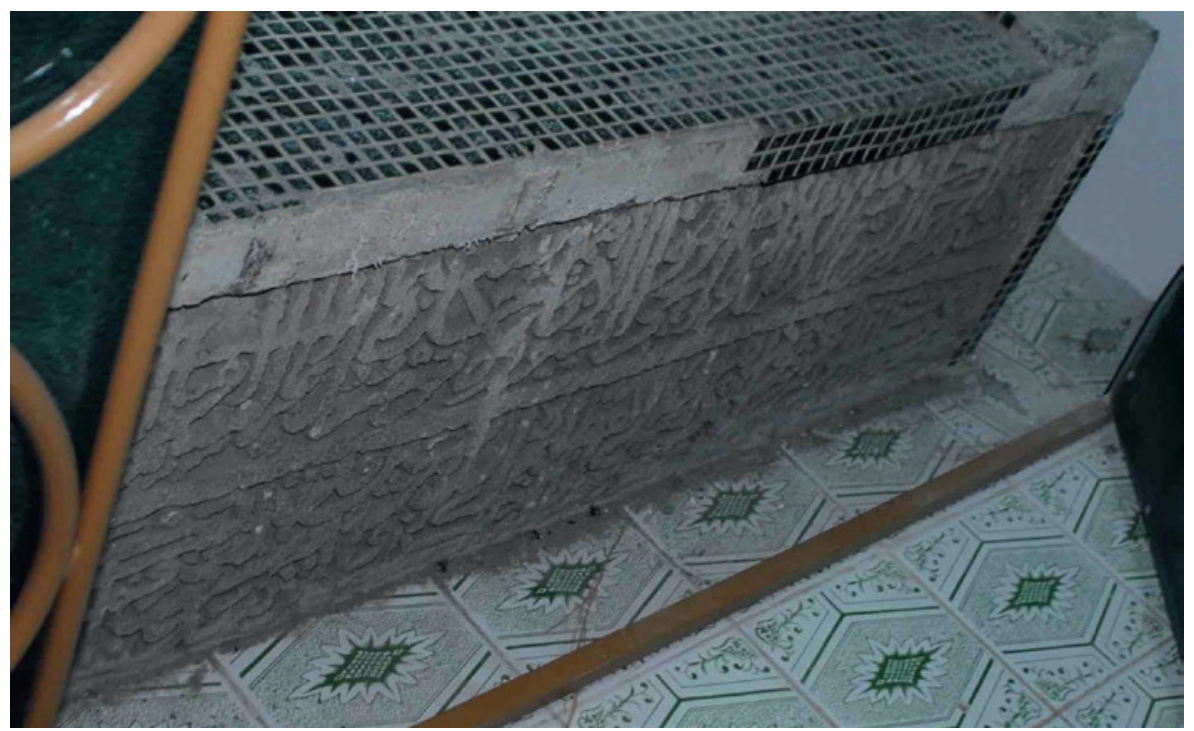

FIGURE 2.461 Partial view of surface A, Sh. LA1

B:

- Difficult to read.

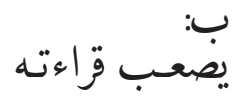


C:

- reading part of the Holy Quran every day, with a fare of 2 baskets of palm dates ... from the crop of palm garden ... known as ... Mani land in al-Bahrayn, 1150.

قراءة كل يوم جـزء من كتاب الله العزيز

بجلتين من تمر النخل...... من حـاصل صرمة النخل .... المعرووف ..... لسيحة منين من البحرين سنة 1150.

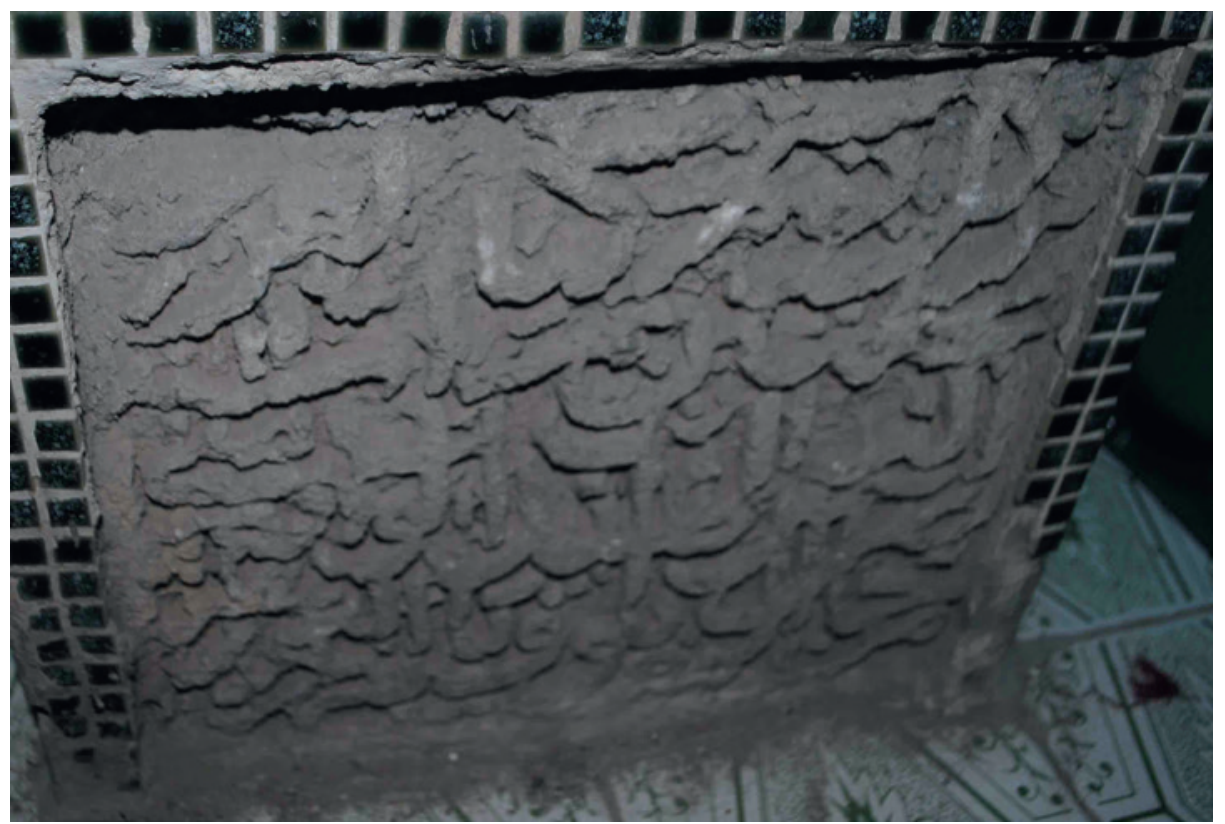

FIGURE 2.462 Surface C, Sh. LA1

D:

- Difficult to read.

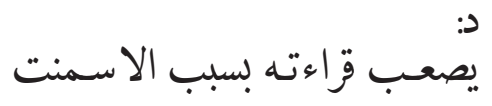

E:

- Difficult to read.

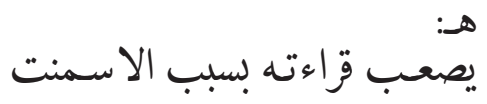


Location: Small walled plot in Manama containing the tomb of Sheikh Ahmed bin Muhammed Al-Khalifa.

Co-ordinates: $26.22725^{\circ} \mathrm{N} 050.58373^{\circ} \mathrm{E}$

Dimensions: $288 \mathrm{~cm}(\mathrm{l}) \times 153 \mathrm{~cm}(\mathrm{w}) \times 131 \mathrm{~cm}(\mathrm{~h})$ (maximum grave dimensions)

\section{Orientation: NNW-SSE}

Description: Upright flat marble headstone commemorating Al-Fattah es Sheikh Ahmed bin Muhammad Al-Khalifa, first Al-Khalifa ruler of Bahrain, d. 1209 AH, AD 1795. The inscription appears to be laser-etched onto the stone and was filled in with black paint, most of which has come off.

\section{Arabic Transcription and Translation:}

- In the Name of Allah, the Most Gracious, the Most Merciful. You, the one in rest and satisfaction. Come back to your Lord well-pleased and well-pleasing. Enter you then among My honoured slaves. And enter you My Paradise (89:27-30). God
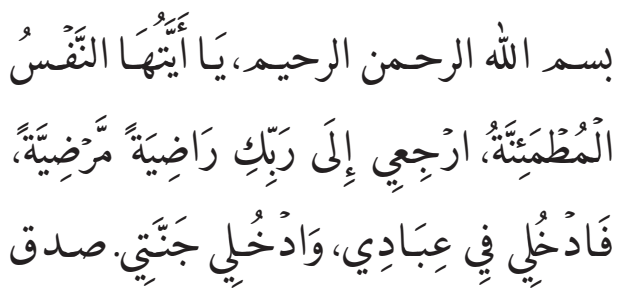
Almighty has spoken the truth.

- Al-Fatih, Shaikh Ahmad bin Muhammad al-Khalifa.

- Entered al-Bahrayn in 1198 AH-1783 $\mathrm{AD}$, died in 1209 AH-1795 AD. May Allah abide him in His spacious paradise.
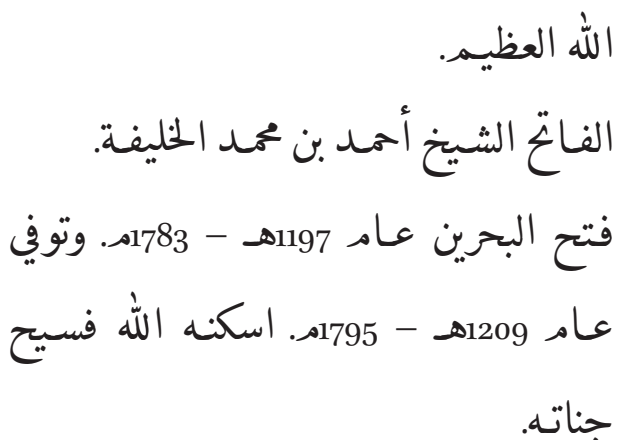


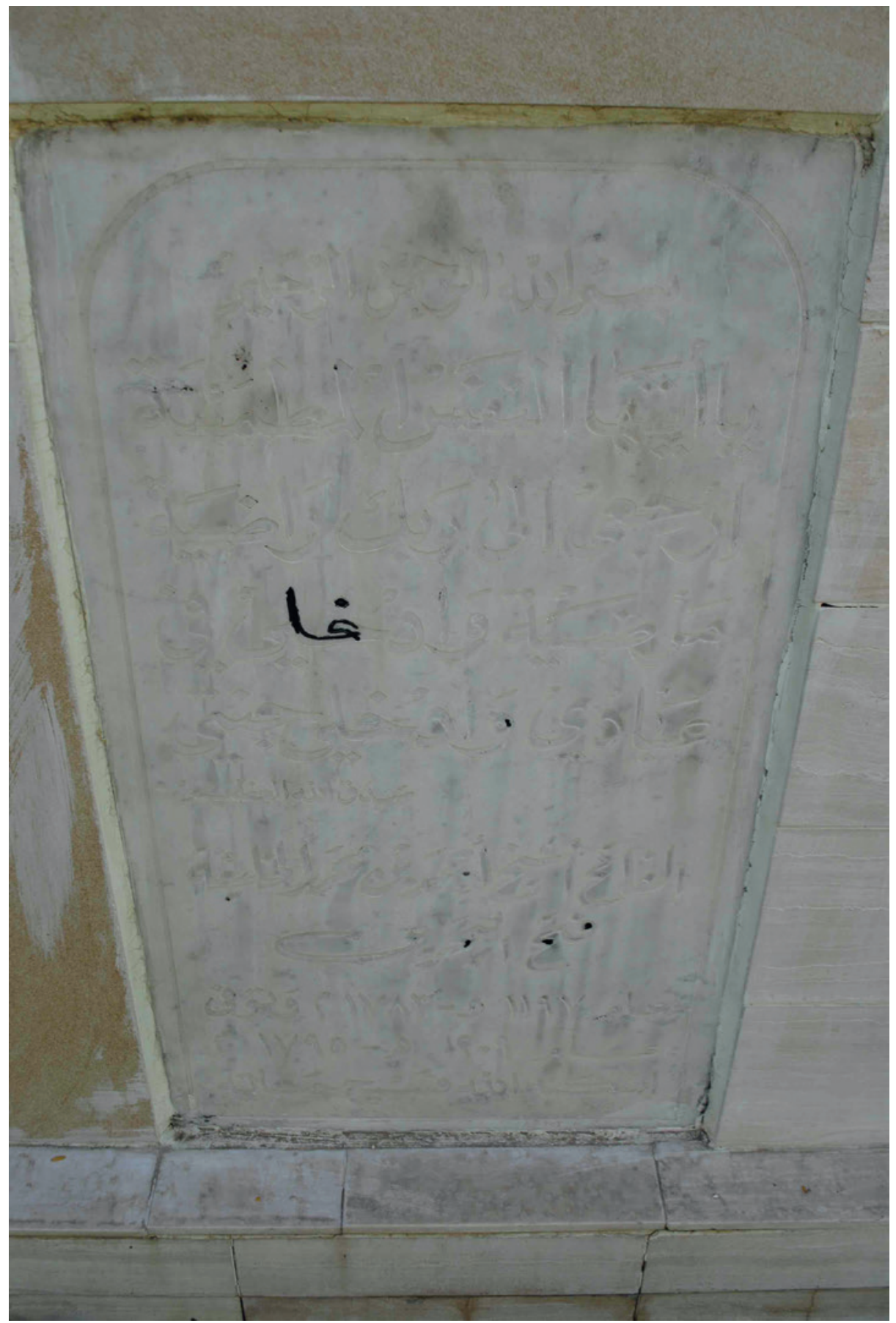

FIGURE 2.463 SHAM-ALK 
26

$$
\text { Sayed Yahya Al Husseini (sYA) }
$$

Location: Tomb next to a mosque in Al Musalla village

Reference Number: SYA1

Co-ordinates: $26.21202^{\circ} \mathrm{N} 050.54042^{\circ} \mathrm{E}$

Dimensions: $151 \mathrm{~cm}(\mathrm{l}) \times 33.5 \mathrm{~cm}(\mathrm{w}) \times 54 \mathrm{~cm}(\mathrm{~h})$

\section{Orientation: NW-SE}

Description: Single limestone slab gravestone inside a small modern domed shrine with a tiled interior. Some erosion and small patches of cement adhering to the surface. Three element raised decoration formed of two facetted cubes and central rounded arch all set on a rectangular plinth at each end. Eroded traces of shallow carved pointed niche design on the upper surface (E). Legible inscriptions on five surfaces, three of which were impossible to photograph (A, C, D), as although they could be read, they could not be accessed for adequate photography because of the position of the gravestone within the small shrine space (Figure 2.464).

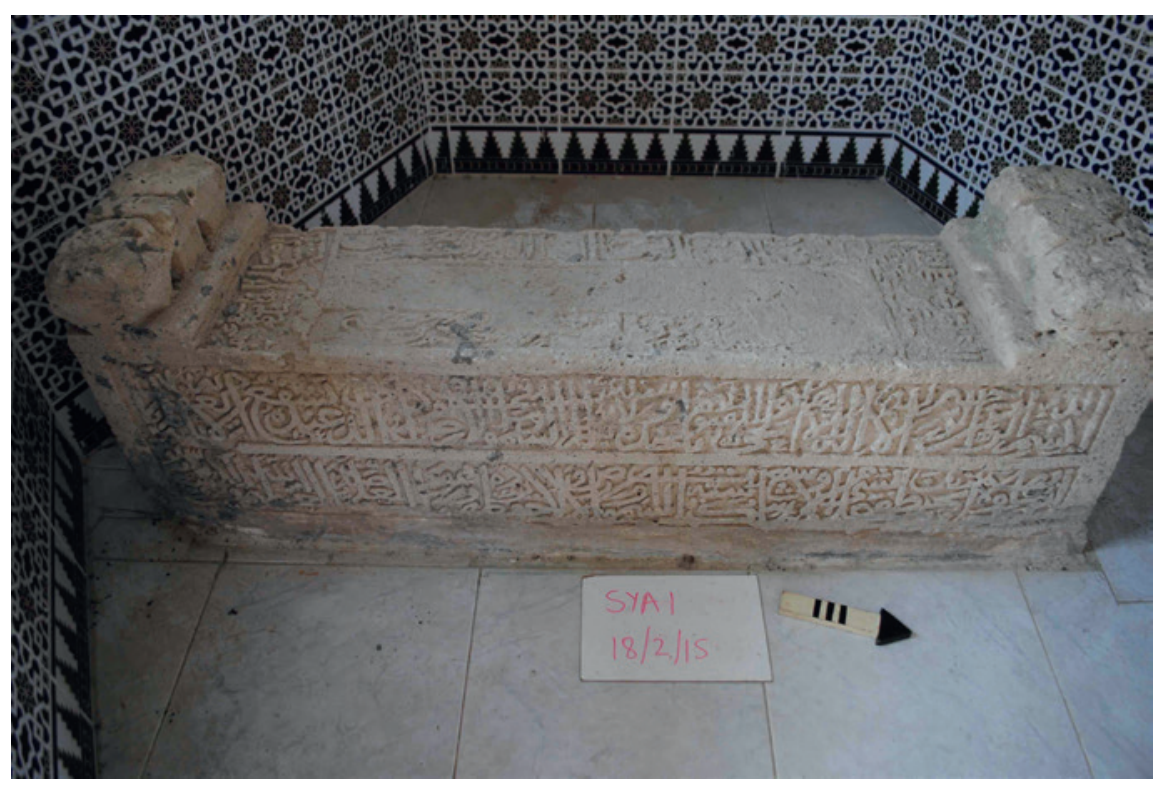

FIGURE 2.464 SYA1 


\section{Arabic Transcription and Translation:}

A:

- The angels descend upon them, saying: Fear not nor grieve, but receive the glad tidings of the paradise which you have been promised. We have been your friends in the life of this world and are in the Hereafter. Therein you shall have all that your inner-selves desire, and therein you shall have all for which you ask.

- An entertainment from the OftForgiving, Most Merciful (41:30-32). Whose doors will be opened for them. Therein they will recline, therein they will call for fruits in abundance and drinks. And beside them will be chaste females restraining their glances and of equal ages. This is what you are promised for the day of Reckoning. Verily, this is our provision which will never finish (38:50-54).

B:

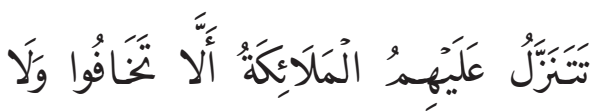

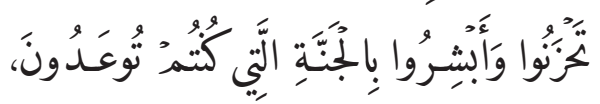

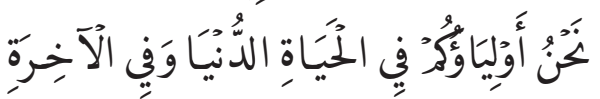

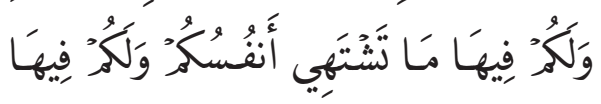

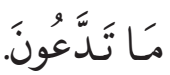
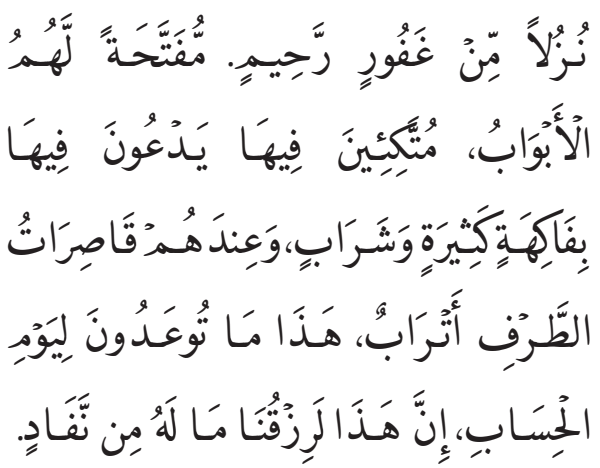

- In the Name of Allah, the Most Gracious, the Most Merciful. Allah, none has the right to be worshipped but he, the Ever Living, the One Who sustains and protects all that exists. Neither slumber nor sleep overtakes Him. To Him belongs whatever is in the heavens and whatever is on the

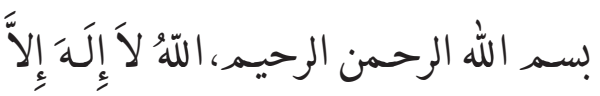

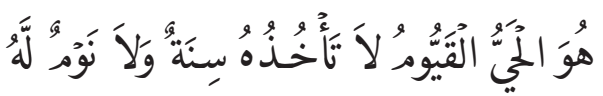

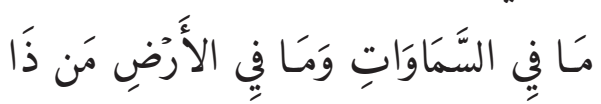

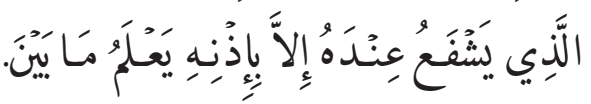
earth. Who is he that can intercede with Him except by His permission! He knows what happens to them in this world, 
- And will happen to them in the Hereafter and they will never compass anything of His Knowledge except that which He wills. His Seat extends over the heavens and the earth. And He feels no fatigue in guarding and preserving them. And He is the Most High, the Most Great

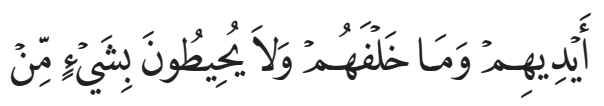

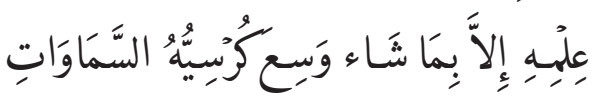

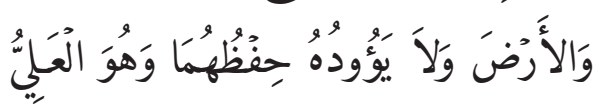
الُْظِيـمُو.صدق الله وصدق رسوله. (2:255). Allah and His Prophet have spoken the truth.

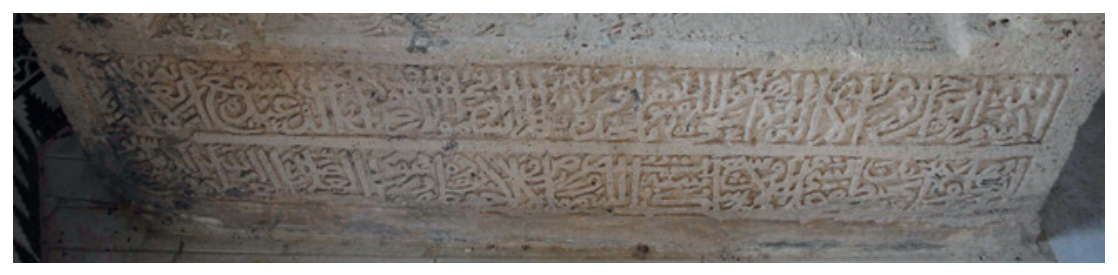

FIGURE 2.465 Surface B, SYA1

C:

- Reading two parts ... from dates ... at Sanj in al-Bahrayn, from crop of

- Al-Ghara ... palms which is located ... al-Bahrayn.

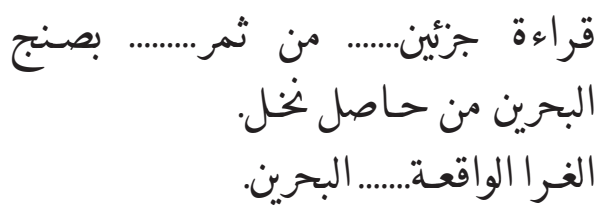

D:

- This is the grave of the late, al-Sayyid Yahya Bin al-Sayyid Muhammad.

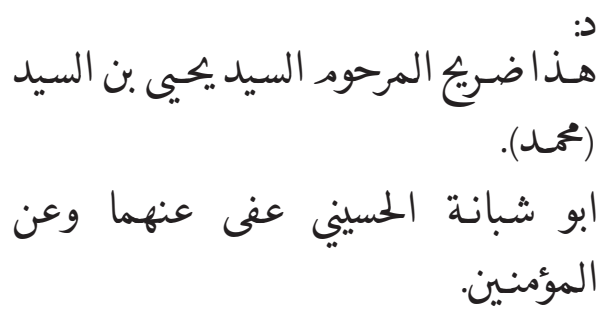

E:

- Engraved by al-Sayyid Salih bin alSayyid Hashim. May Allah forgive them.

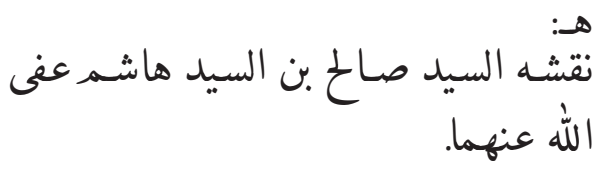

- O grave have a look on al-Husayni Yahya, the master of both the chandelier and the dust.

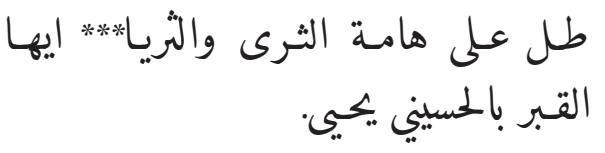


- ... his body ... paradise ...

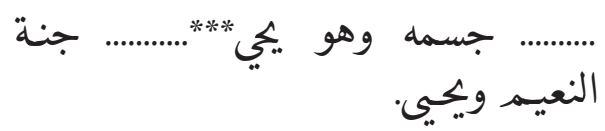

- ... written by 'Ali bin Husayn, May

Allah forgive them, in 1093.
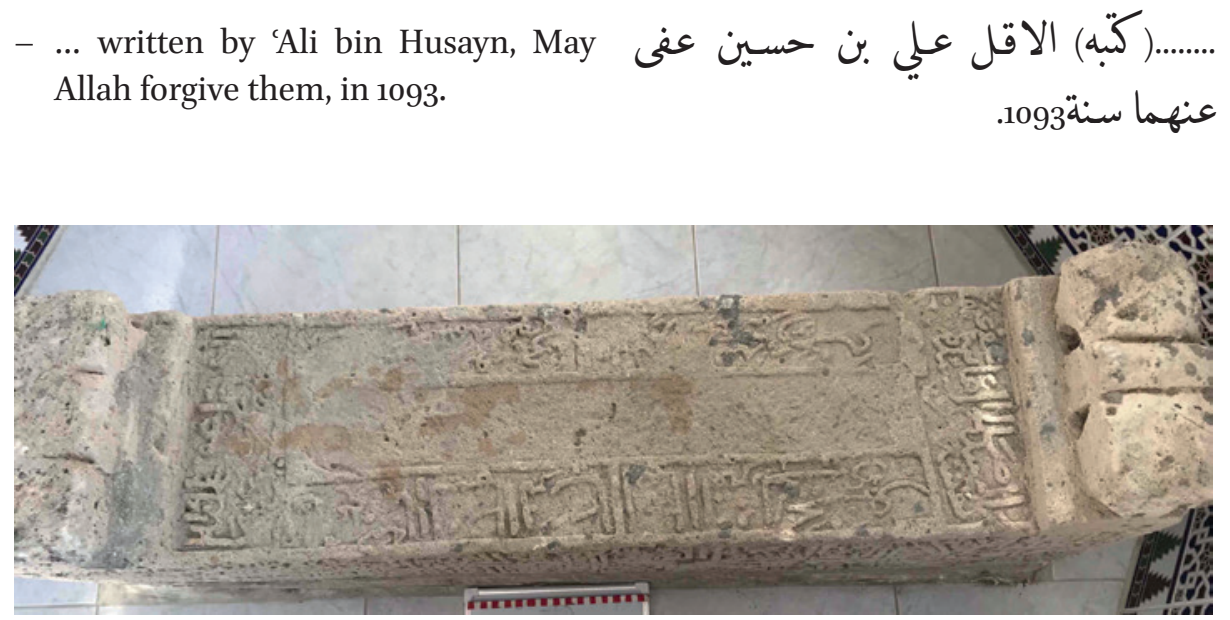

FIGURE 2.466 Surface E, SYA1

27 Tubli (TUB)

Location: Village cemetery in Tubli adjacent to the Sheikh Hashem El Tublah mosque

\section{Reference Number: TUB1}

Co-ordinates: $26.18412^{\circ} \mathrm{N} 050.54807^{\circ} \mathrm{E}$

Dimensions: $140 \mathrm{~cm}(\mathrm{l}) \times 26 \mathrm{~cm}(\mathrm{w}) \times 54.5 \mathrm{~cm}(\mathrm{~h})$

\section{Orientation: NW-SE}

Description: Single limestone slab gravestone in Tubli cemetery. Well-carved three element raised decoration formed of two facetted cubes and a central thin rounded arch all set on a rectangular plinth at each end. Delineated central uncarved rectangular panel on the top surface (E) which, unusually, is not a niche. Several small circular holes drilled in one side surface (A), and some surface pitting in places. Inscriptions on five surfaces. 


\section{Arabic Transcription and Translation:}

A:

- Verily, those who say: Our Lord is Allah, and afterward are upright; the angels descend upon them, saying: Fear not nor grieve, but receive the glad tidings of the paradise which you have been promised. We have been your friends in the life of this world and are in the Hereafter. Therein you shall have all that your inner-selves desire,

- And therein you shall have all for which you ask. An entertainment from the Oft-Forgiving, Most Merciful (41:30-32). Eden Paradise, whose doors will be opened for them. Therein they will recline, therein they will call for fruits in abundance and drinks. And beside them will be chaste females restraining their glances and of equal ages. This is what you are promised for the day of Reckoning. Verily, this is our provision which will never finish (38:5054). Praise be to Allah.
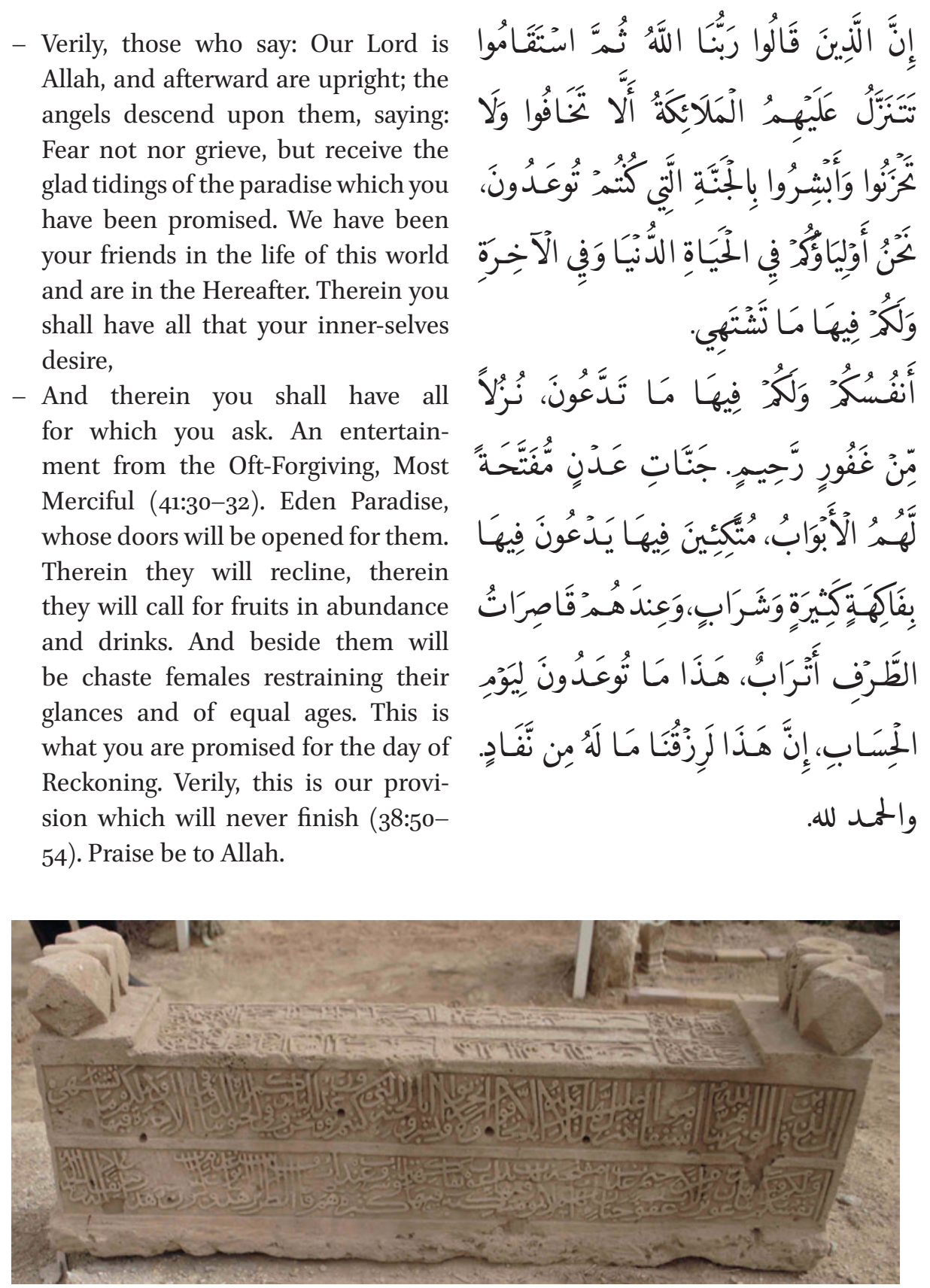

FIGURE 2.467 Surface A, TUB1 
B:

- In the Name of Allah, the Most Gracious, the Most Merciful. Allah, none has the right to be worshipped but he, the Ever Living, the One Who sustains and protects all that exists. Neither slumber nor sleep overtakes Him. To Him belongs whatever is in the heavens and whatever is on the earth. Who is he that can intercede with Him except by His permission! He knows what happens to them in this world, and will happen to them in the Hereafter and they will never

- Compass anything of His Knowledge except that which He wills. His Seat extends over the heavens and the earth.

- And He feels no fatigue in guarding and preserving them. And $\mathrm{He}$ is the Most High, the Most Great (2:255). God Almighty has spoken the truth. And His Messenger, the Generous Prophet proclaimed the message. And Ali, the commander of the faithful has spoken the truth.
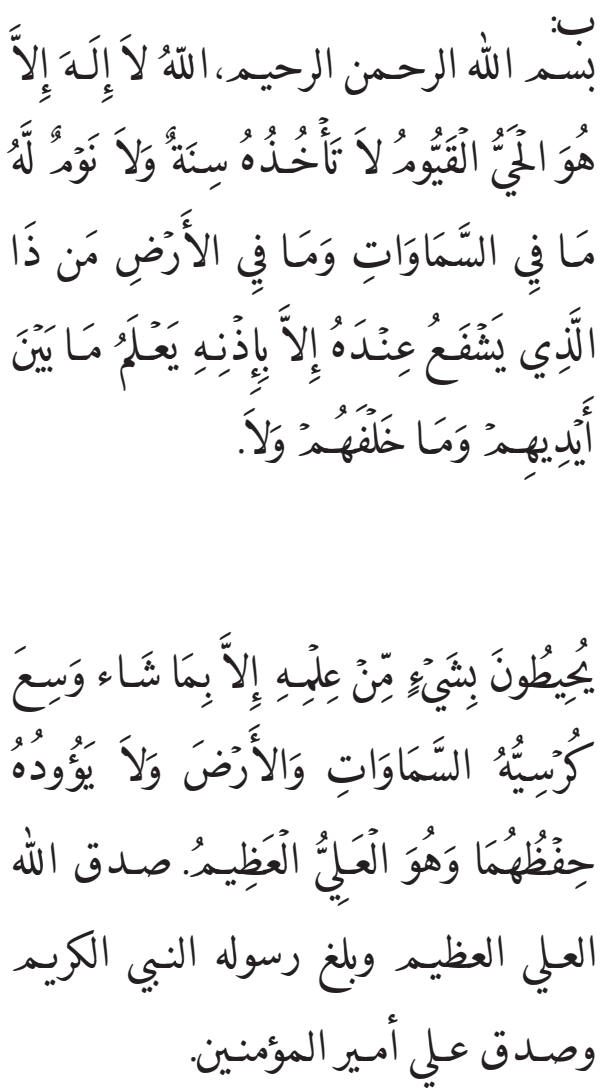

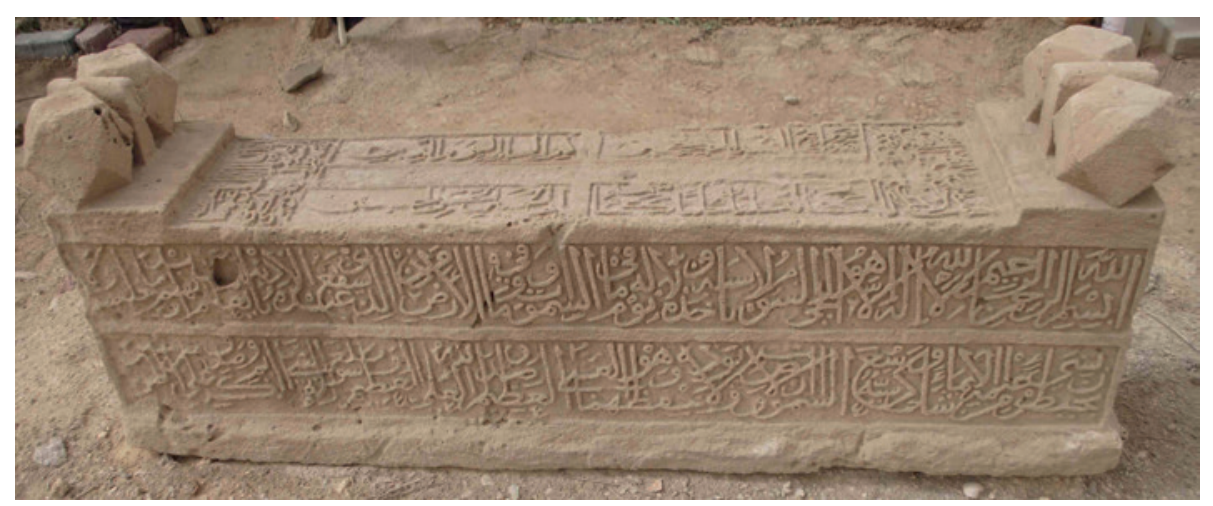

FIGURE 2.468 Surface B, TUB1 
C:

- Reading one part for twenty mann, al-Bahrayn's weight ... $\mathrm{n}$... from the crop of al-Ghara palms.
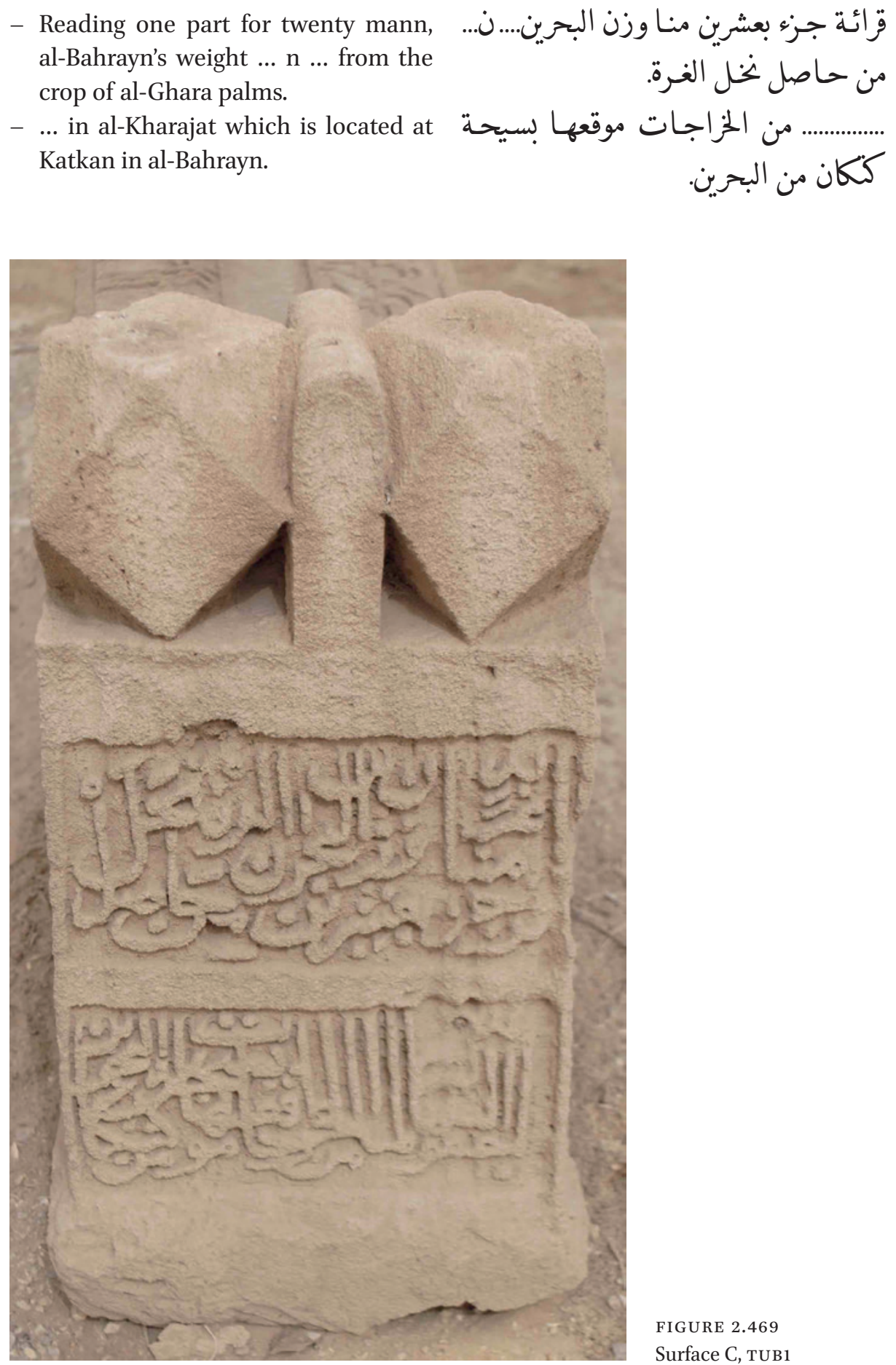
D:

- This grave of the noble, al-Sayyid Hasan bin al-Sayyid 'Ali bin al-Sayyid Muhammad.

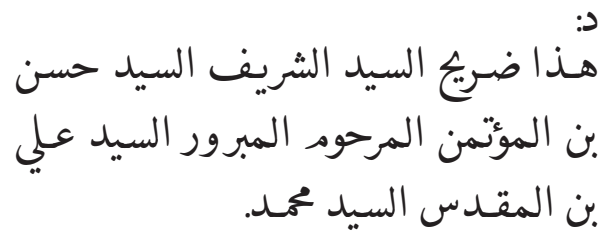

- Al-Qaruni al-Husayni who died seventh of Rajab, one thousand and ninety-five.
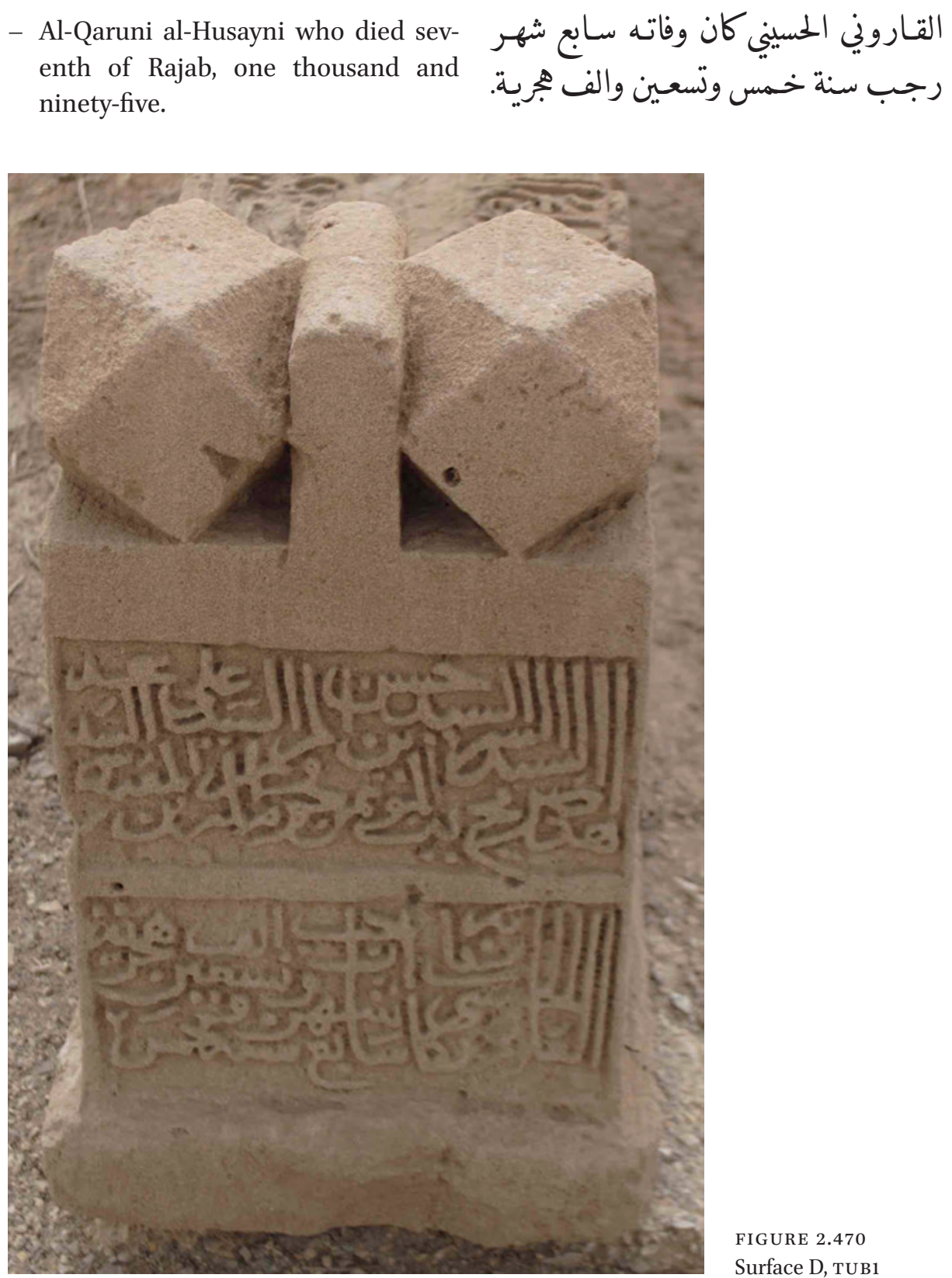

FIGURE 2.470

Surface D, TUB1 
E:

- Engraved by al-Sayyid Naser bin alSayyid Hashim al-Husayni. May Allah forgive them.

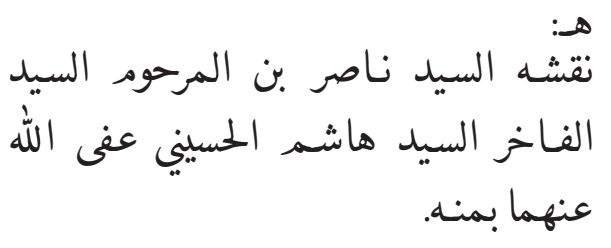

- This is a grave of prophet Muhammad's son, who is a viscount and saint.

هذا ضريه السيد المكين ***ز الفخار والتقى والدين.

- He was a good person and had a face as beautiful as his name $\mathrm{Abu}$ al-Husayn Hasan al-Husayni.

- Written by Husayn bin 'Ali bin Zayn al-Din. May Allah forgive them.
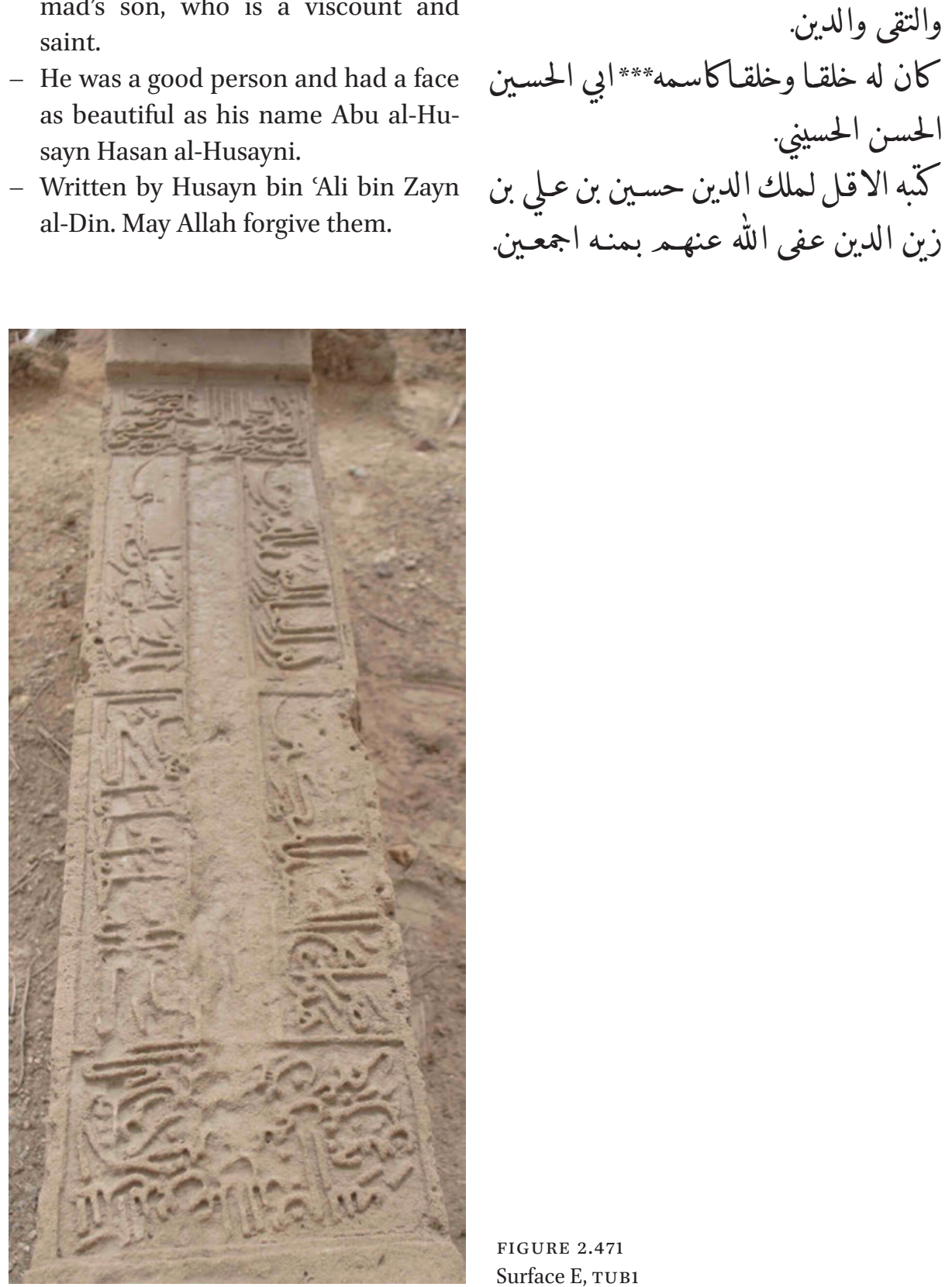
Reference Number: TUB2

Co-ordinates: $26.18419^{\circ} \mathrm{N} 050.54807^{\circ} \mathrm{E}$

\section{Dimensions:}

Slab 1: $60 \mathrm{~cm}(\mathrm{l}) \times 31 \mathrm{~cm}(\mathrm{w}) \times 33.5 \mathrm{~cm}(\mathrm{~h})$

Slab 2: $71 \mathrm{~cm}(\mathrm{l}) \times 35 \mathrm{~cm}(\mathrm{w}) \times 37 \mathrm{~cm}(\mathrm{~h})$

\section{Orientation: NW-SE}

Description: Double limestone slab gravestone in Tubli village cemetery. Cemented onto a modern concrete block base. Unfinished, mis-shapen and badly cut to size with saw and chisel marks evident (Figure 2.472). Roughed out but unfinished three element raised decoration at each end. No inscriptions or decorative carving.

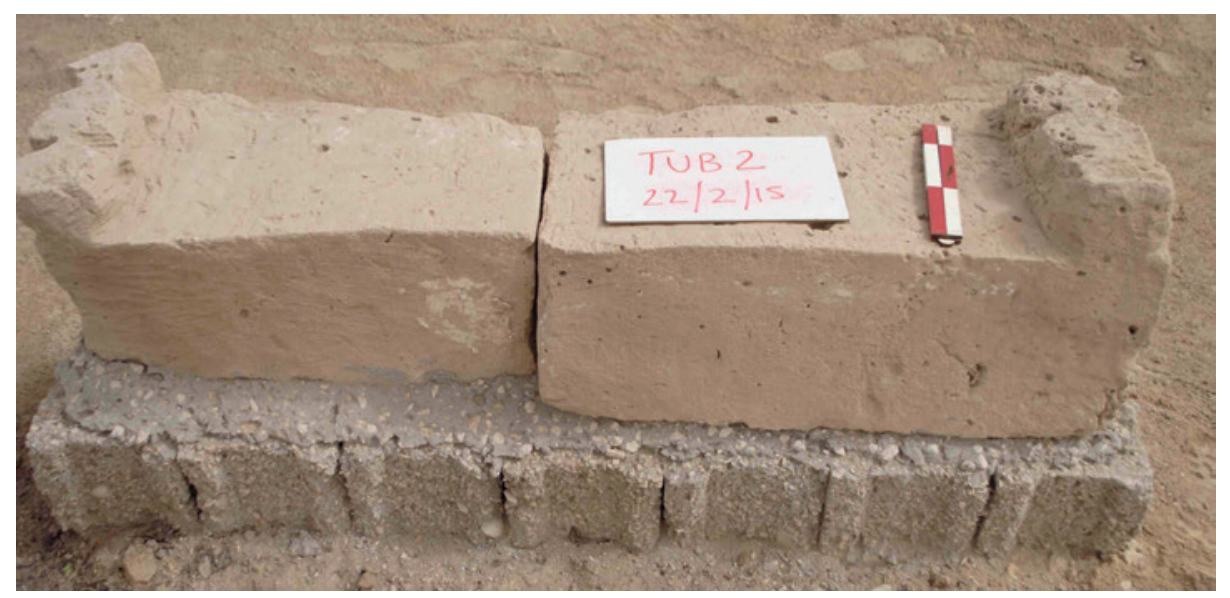

FIGURE 2.472 TUB2

Arabic Transcription and Translation: No inscriptions

Reference Number: TUB3

Co-ordinates: $26.18507^{\circ} \mathrm{N} 050.54725^{\circ} \mathrm{E}$

Dimensions: $120 \mathrm{~cm}(\mathrm{l}) \times 27 \mathrm{~cm}(\mathrm{w}) \times 33 \mathrm{~cm}(\mathrm{~h})$

Orientation: NW-SE 
Description: Single limestone slab gravestone set on a plaster slab on top of a marble plinth under a glass case in the Sheikh Hashem El Tublah mosque. Some erosion, surface pitting, and also a small rectangular cut mark on one side surface (B). Raised decoration broken or cut off at both ends. Inscriptions on five surfaces.

Previous Publication: Number S14, Kalus (1995: 147-148). Original location described as unknown but at the time of recording it was in the courtyard of a house in the village (ibid: 147).

\section{Arabic Transcription and Translation:}

A:

- In the Name of Allah, the Most Gracious, the Most Merciful. Allah, none has the right to be worshipped but he, the Ever Living, the One Who sustains and protects all that exists. Neither slumber nor sleep overtakes Him. To Him belongs whatever is in the heavens and whatever is on the earth.

- Who is he that can intercede with Him except by His permission! He knows what happens to them in this world, and will happen to them in the Hereafter and they will never compass anything of His Knowledge except that which He wills.
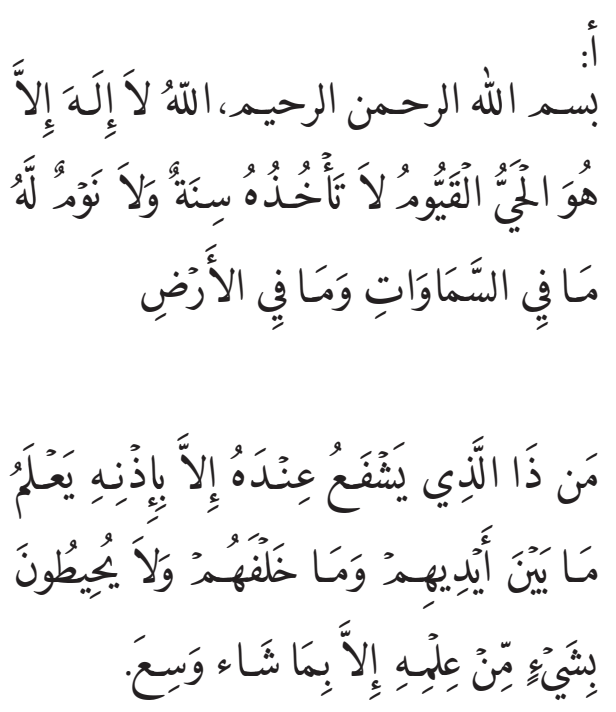

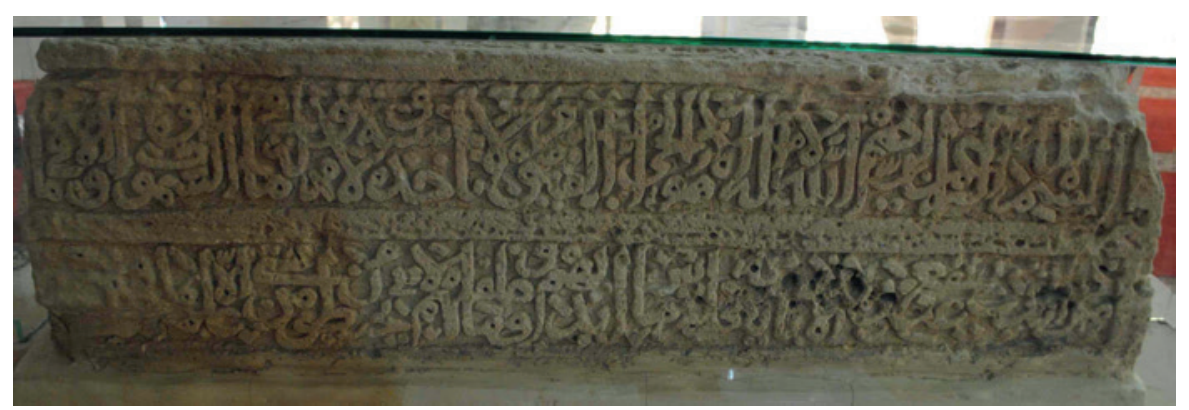

FIGURE 2.473 Surface A, TUB3 
B:

- His Seat extends over the heavens and the earth. And He feels no fatigue in guarding and preserving them. And He is the Most High, the Most Great. There is no compulsion in religion. Verily, the Right Path has become distinct from the wrong path. Whoever disbelieves in Taghut and believes in Allah, then he has grasped the most trustworthy handhold that will never break. And Allah is All-Hearer, AllKnower (2:255-256). Allah ...
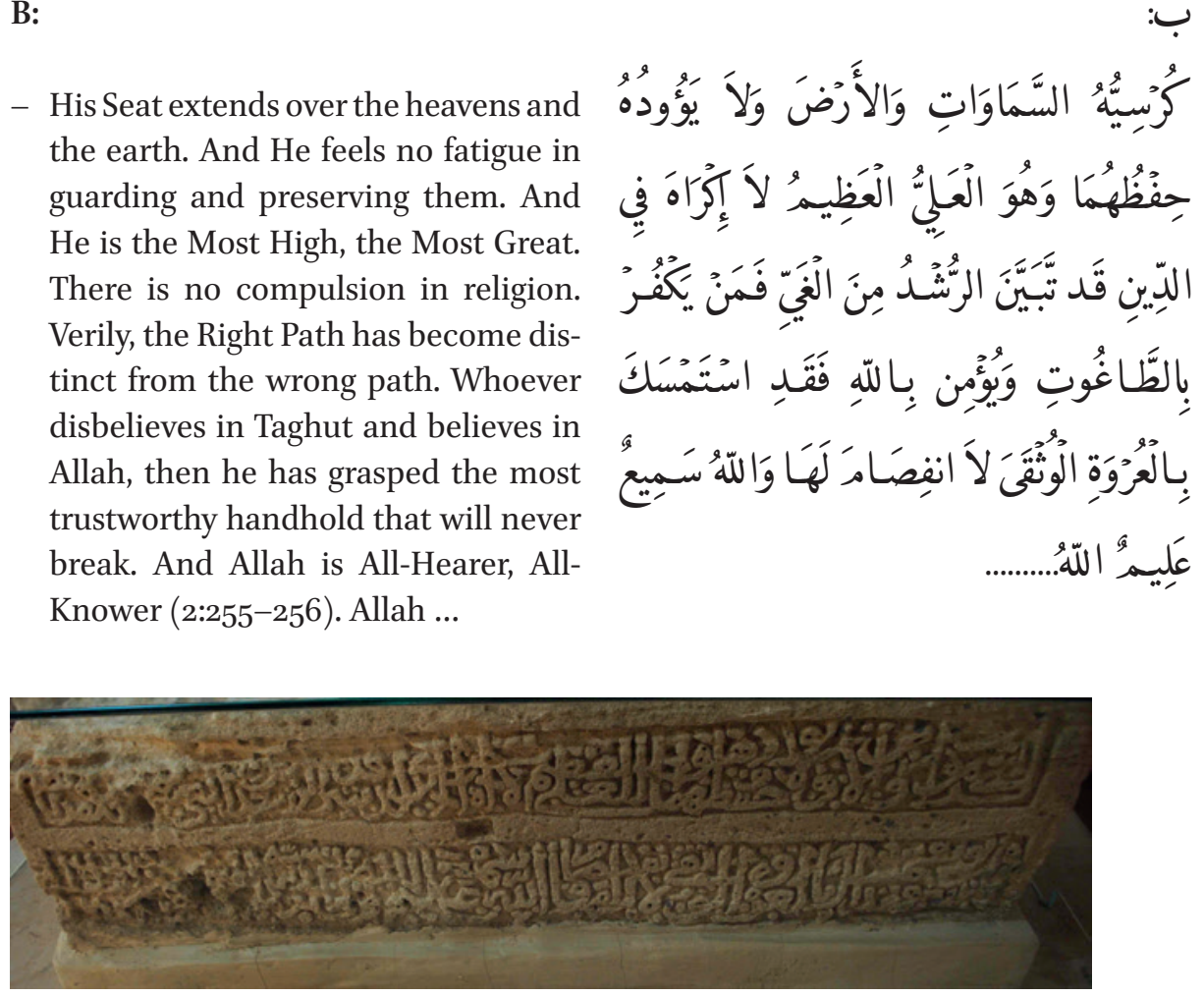

FIGURE 2.474 Surface B, TUB3

C:

- This is the grave of ... the blessed

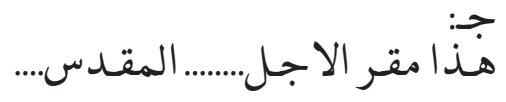

- al-Sayyid ... Muhamad bin ...

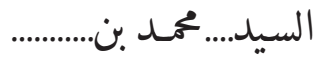




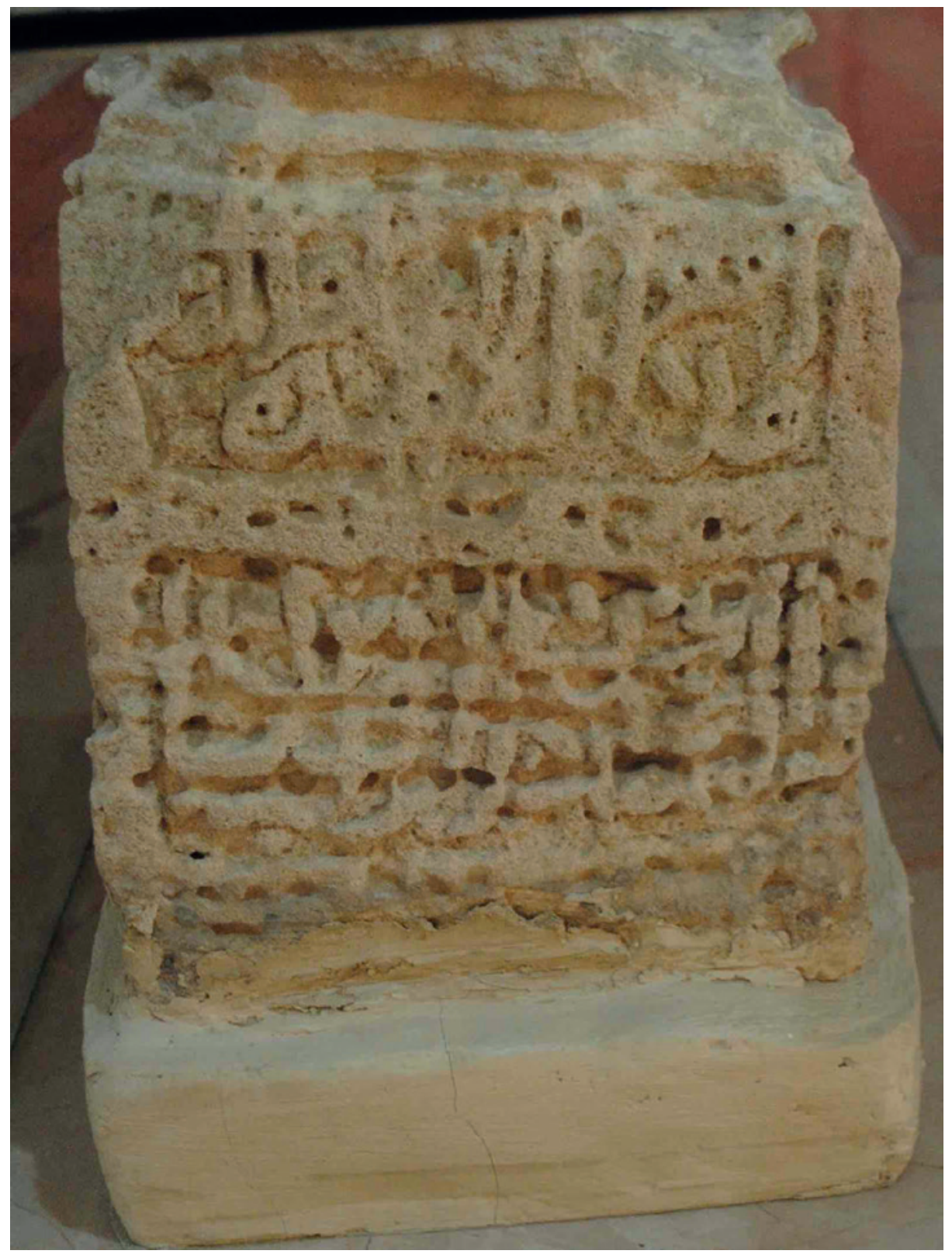

FIGURE 2.475 Surface C, TUB3 
D:

- ....................

- ... month ... year of one thousand and

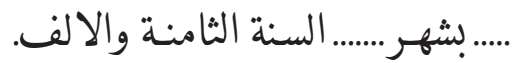
eight.

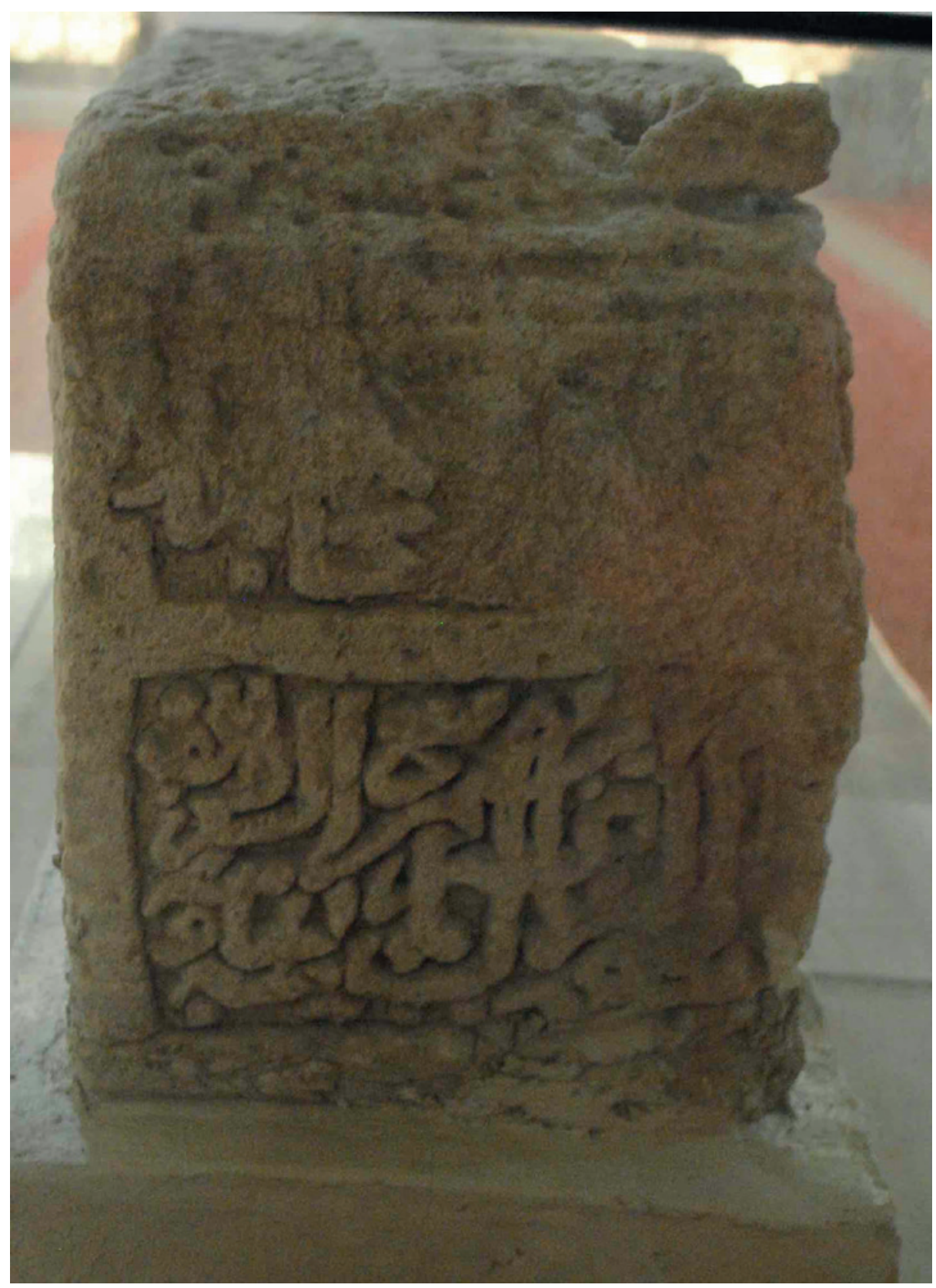

FIGURE 2.476 Surface D, TUB3 
E:

- ... between proudness and ...

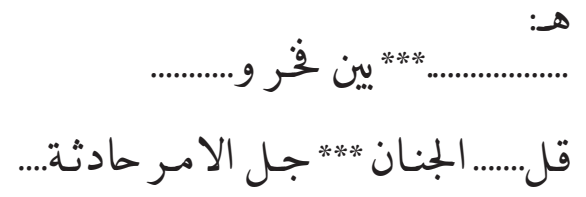

- ... paradise ... At the end it happens ... قل...... الجنـان ****جل الانـر حادثة....

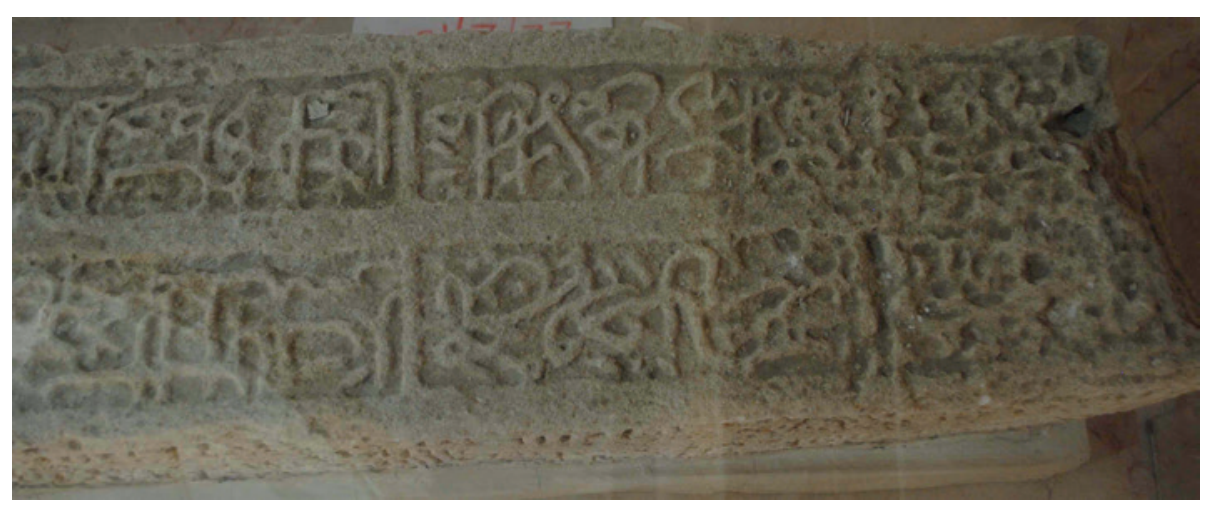

FIGURE 2.477 Surface E, part 1, TUB3

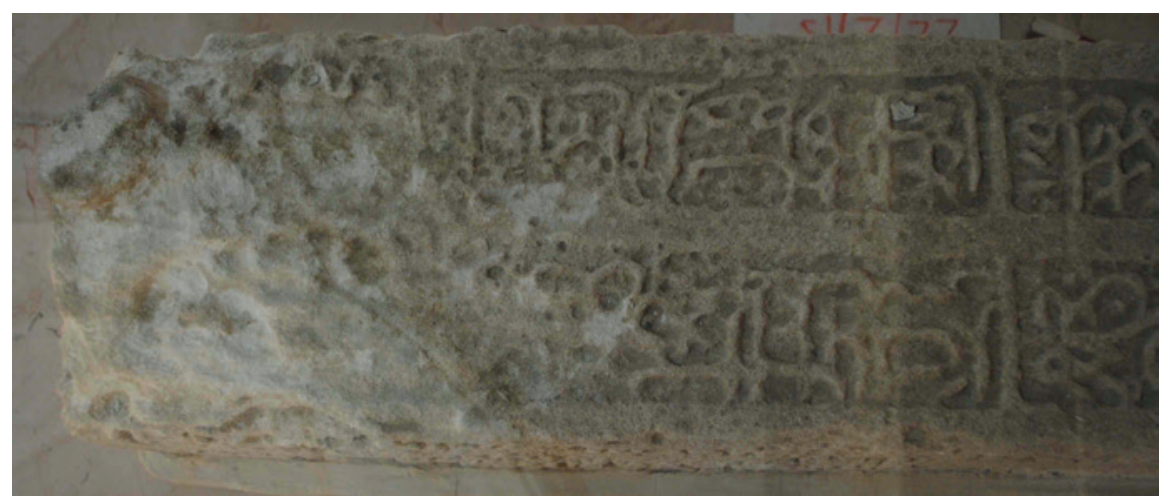

FIGURE 2.478 Surface E, part 2, TUB3

Reference Number: TUB4

Co-ordinates: $26.18503^{\circ} \mathrm{N} 050.5473^{\circ} \mathrm{E}$

Dimensions: $145 \mathrm{~cm}(\mathrm{l}) \times 29 \mathrm{~cm}(\mathrm{w}) \times 34 \mathrm{~cm}(\mathrm{~h})$

Orientation: NNW-SSE

Description: Single limestone slab gravestone set on a plaster slab on top of a marble plinth under a glass case in the Sheikh Hashem El Tublah mosque. Significant 
erosion on the top surface (E). Raised decoration broken or cut off at both ends. Inscriptions on five surfaces.

Previous Publication: Number S14, Kalus (1995: 145-147). Original location described as unknown but at the time of recording it was in the courtyard of a house in the village (ibid: 145 ).

\section{Arabic Transcription and Translation:}

A:

- The angels descend upon them, saying: Fear not nor grieve, but receive the glad tidings of the paradise which you have been promised. We have been your friends in the life of this world and are in the Hereafter. Therein you shall have all that your inner-selves desire, and therein you shall have all for which you ask. An entertainment ... (41:30-32)

- Eden Paradise, whose doors will be opened for them. Therein they will recline, therein they will call for fruits in abundance and drinks. And beside them will be chaste females restraining their glances and of equal ages. This is what you are promised for the day of Reckoning. Verily, this is our provision which will never finish (38:50-54). God Almighty has spoken the truth. And His Messenger, the Generous Prophet proclaimed the

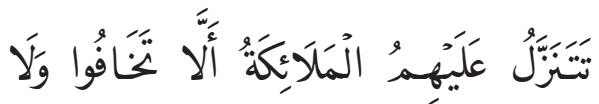

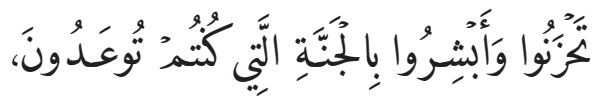

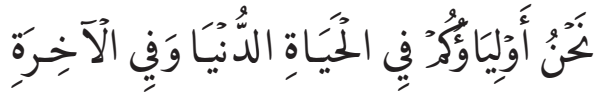

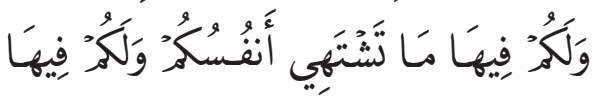

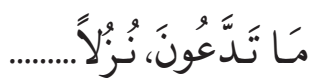

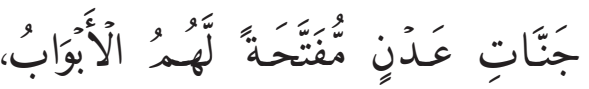

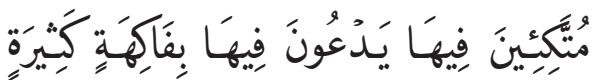

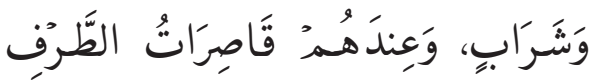

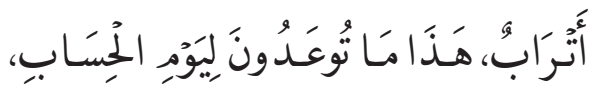

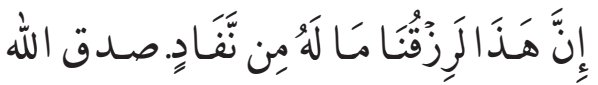
العلي العظيمه وبلغ رسوله الكريم. message.

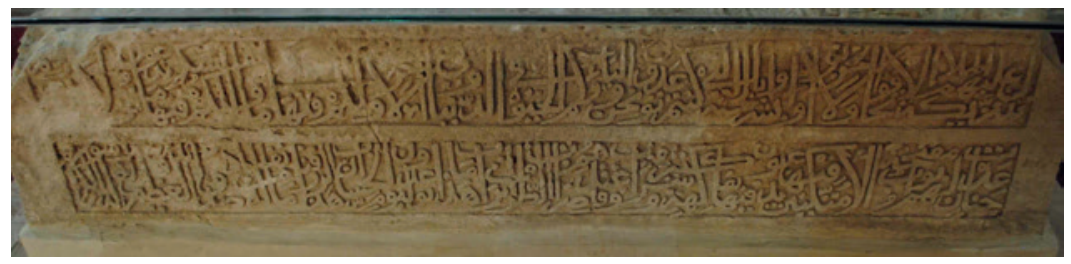

FIGURE 2.479 Surface A, TUB4 
B:

- In the Name of Allah, the Most Gracious, the Most Merciful. Allah, none has the right to be worshipped but he, the Ever Living, the One Who sustains and protects all that exists. Neither slumber nor sleep overtakes Him. To Him belongs whatever is in the heavens and whatever is on the earth. Who is he that can intercede with Him except by His permission! He knows what happens to them in this world, and will happen to them in the Hereafter and they will never compass anything of His Knowledge

- Except that which He wills. His Seat extends over the heavens and the earth.

- And He feels no fatigue in guarding and preserving them. And $\mathrm{He}$ is the Most High, the Most Great (2:255). God Almighty has spoken the truth. And His Messenger, the Generous Prophet proclaimed the message. And Ali, The commander of the faithful has spoken the truth. And Praise be to Allah, Lord of the worlds.

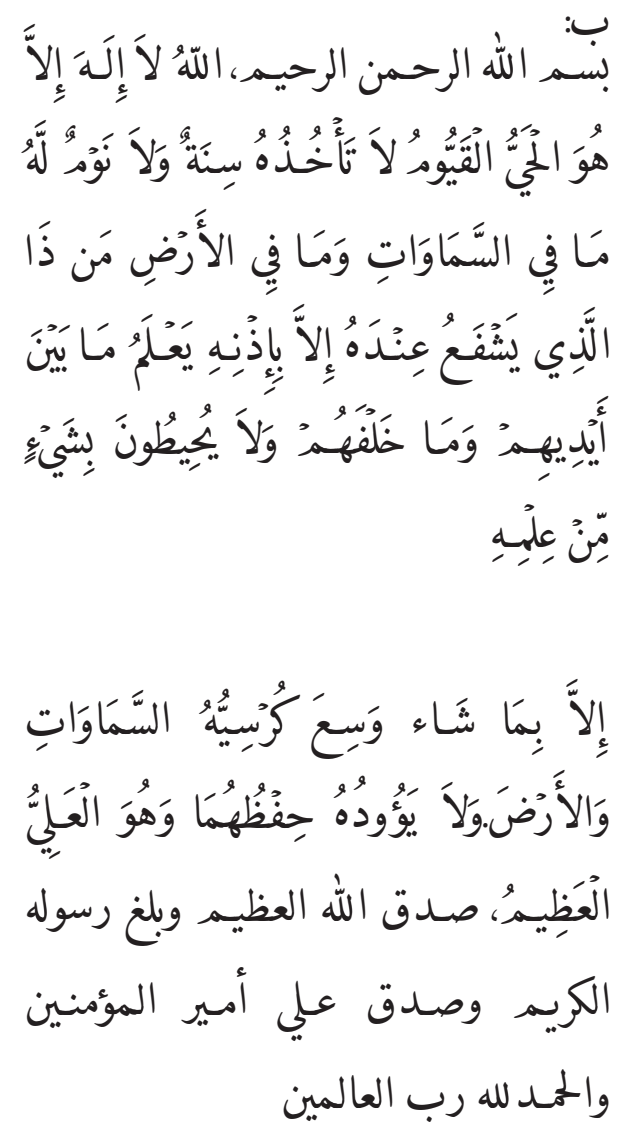

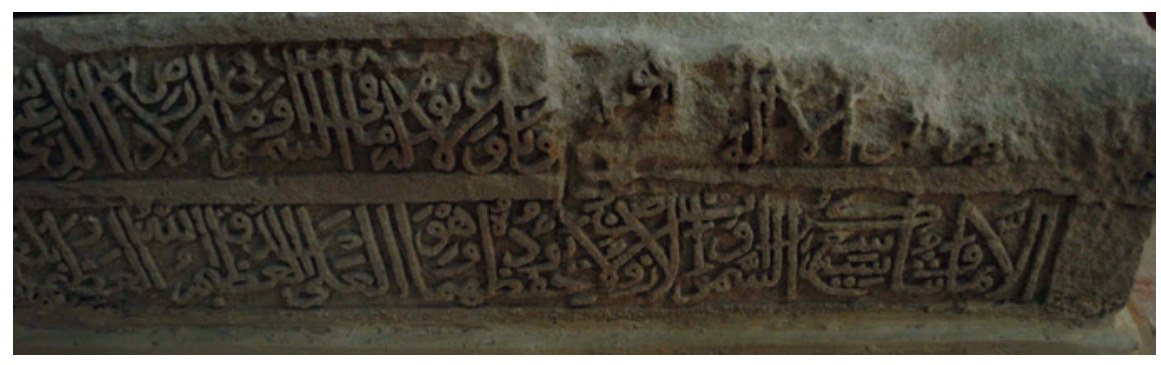

FIGURE 2.480 Surface B, part 1, TUB4 


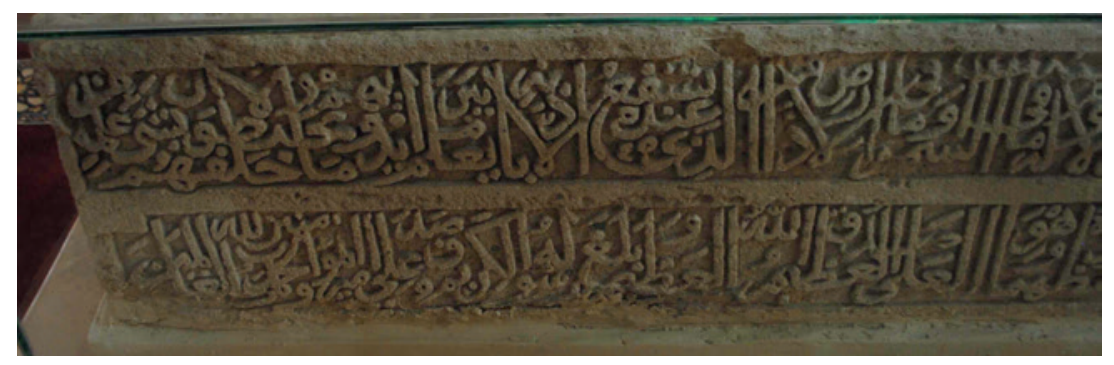

FIGURE 2.481 Surface B, part 2, TUB4

C:

- This is ... the late, al-Sayyid ...
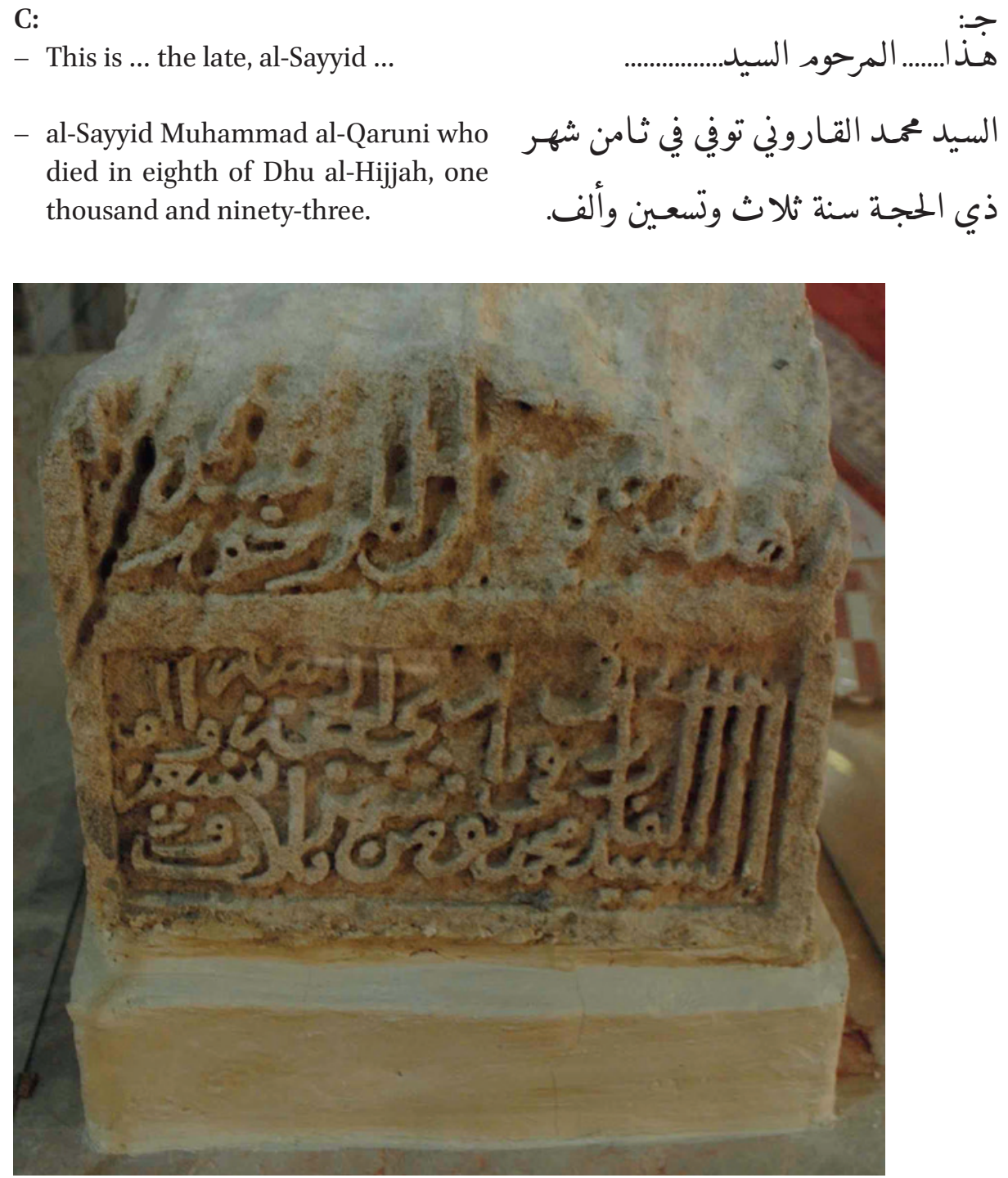

FIGURE 2.482 Surface C, TUB4 


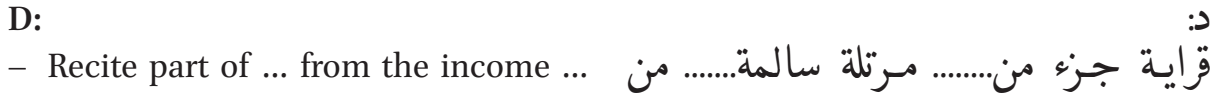
from al-Kharajat ... with

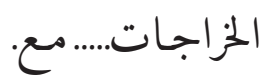

- Crop of palms known as al-shatib al- حاصل النخل المعروف بالشطيب kabir which is located at Katkan area nearby the sea.
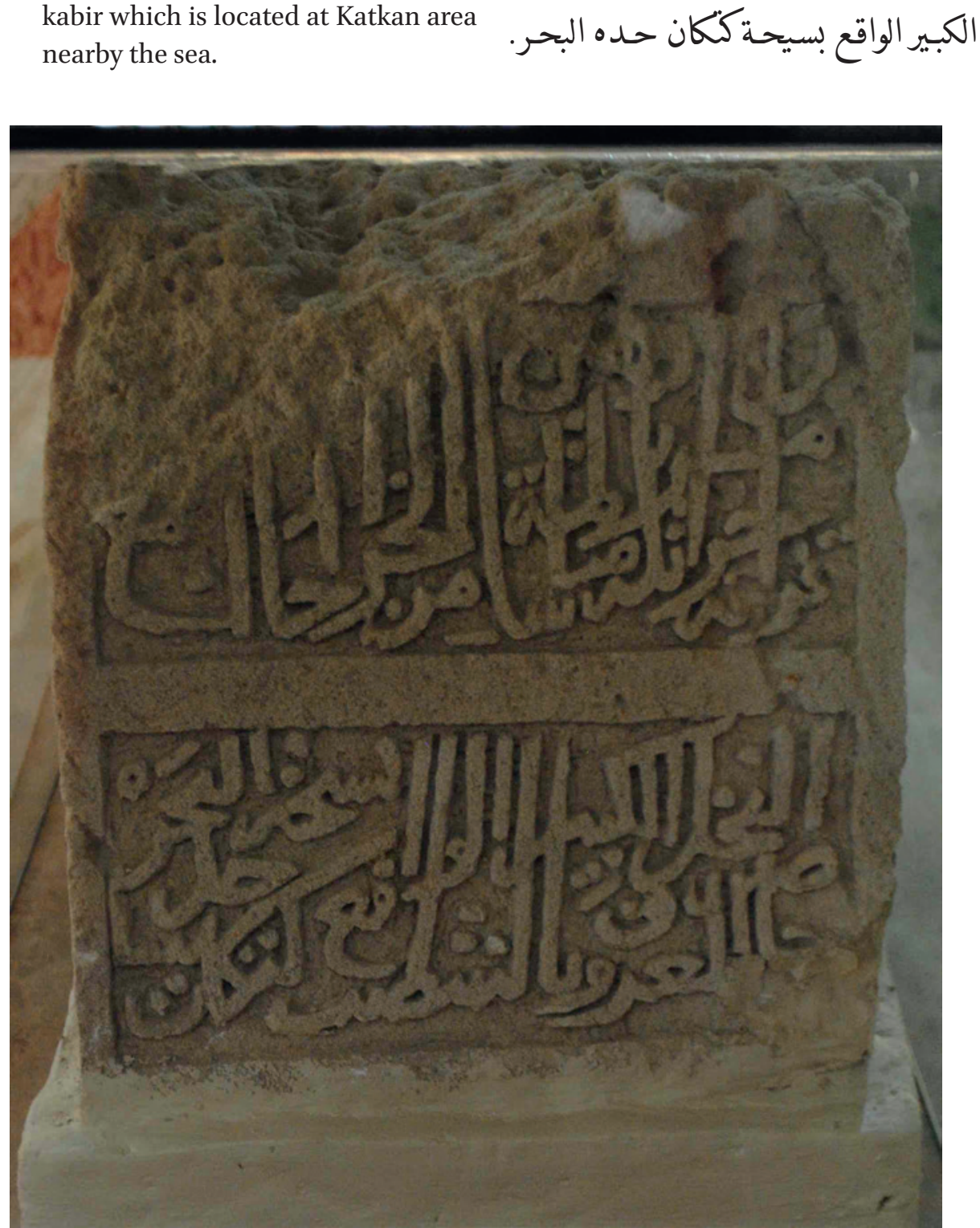

FIGURE 2.483 Surface D, TUB4 
E:

- Engraved by ... al-Sayyid Hashim ... may Allah forgive them.
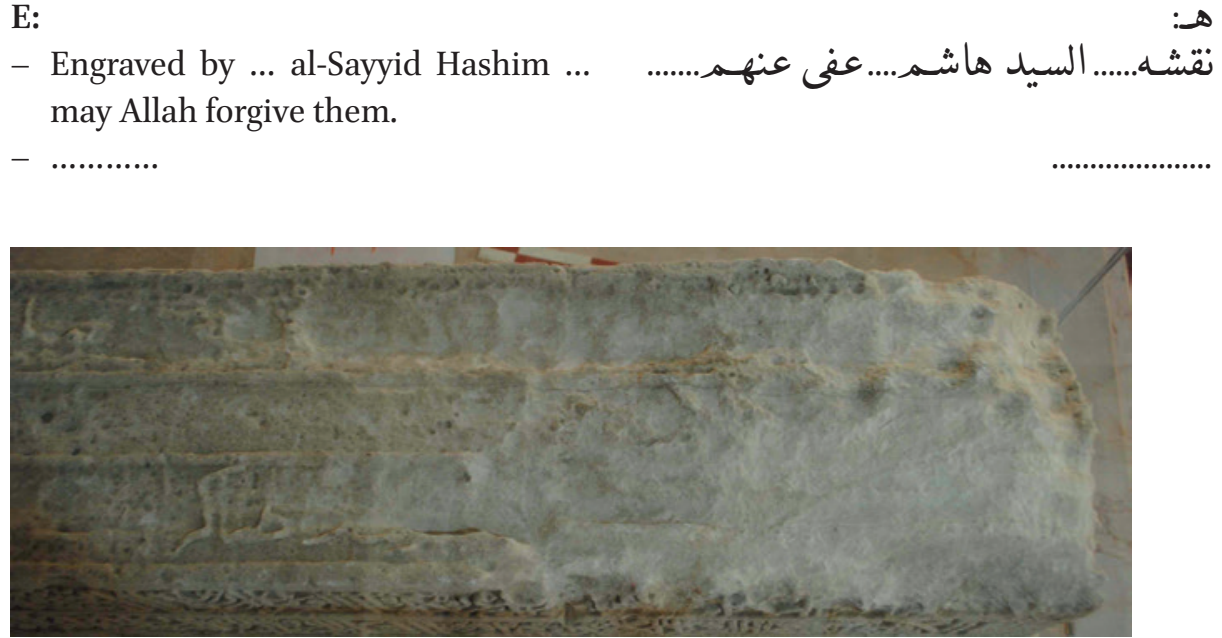

FIGURE 2.484 Surface E, part 1, TUB4

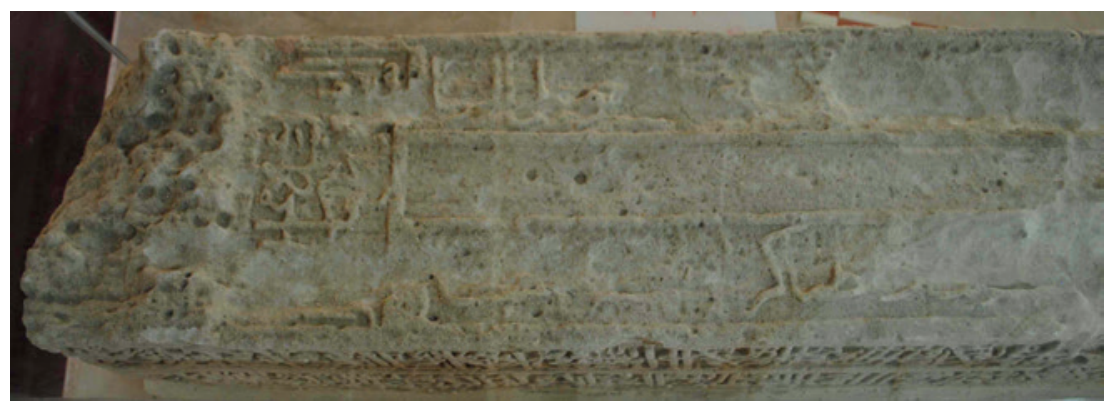

FIGURE 2.485 Surface E, part 2, TUB4 